\title{
The Supai Group of Grand Ganyon
}

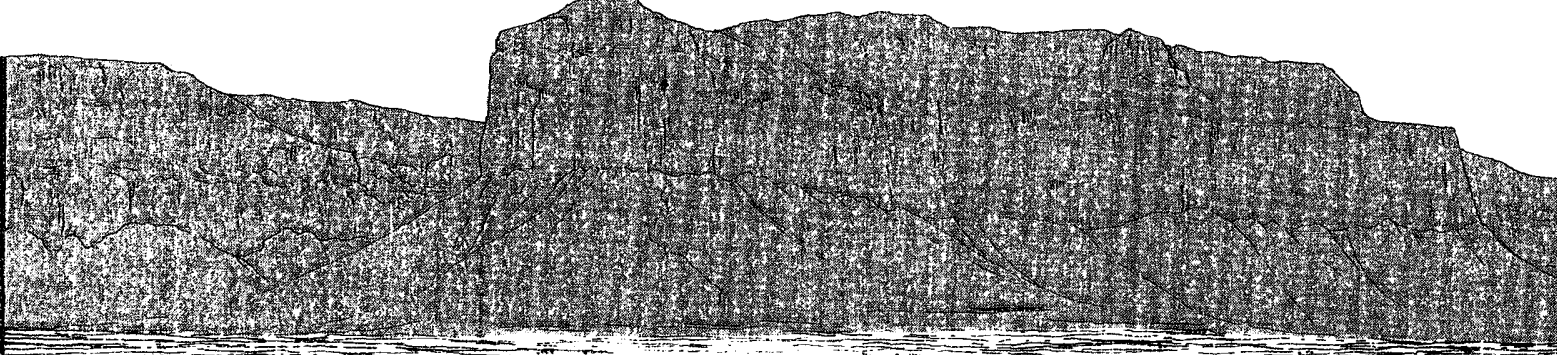

$2>1$.

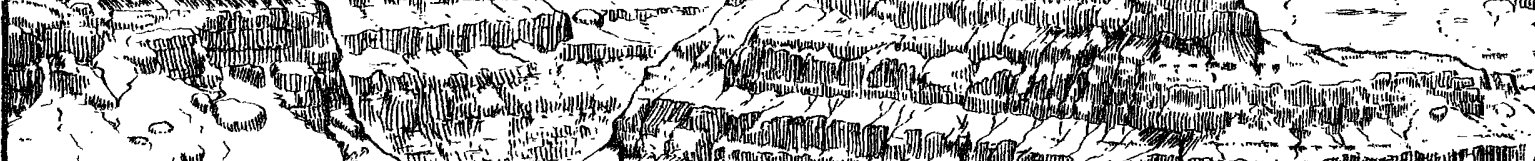
(3) 6

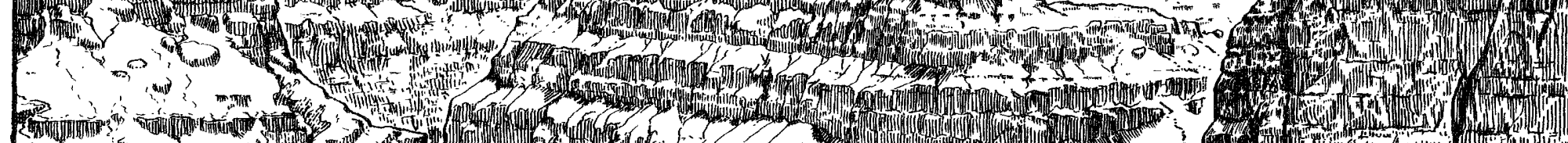

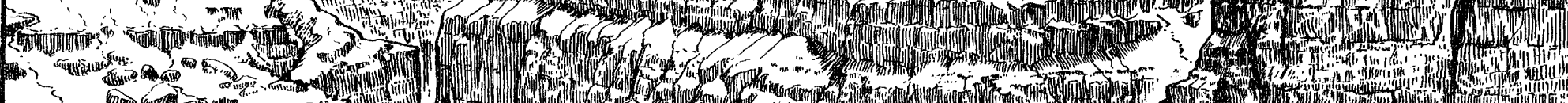

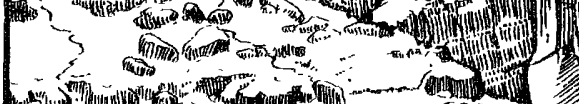

(1)

(1)

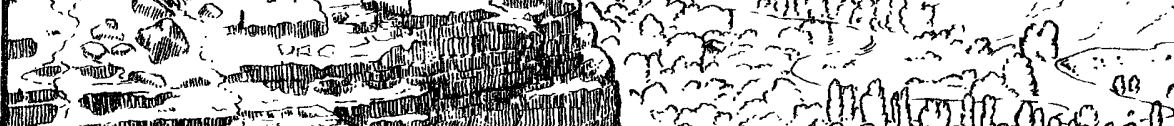

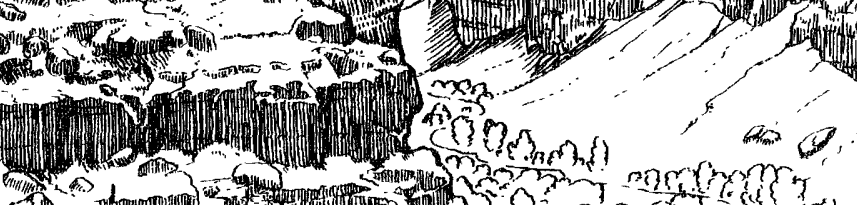

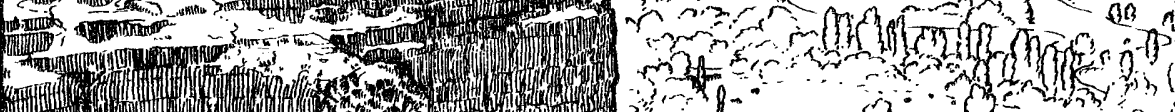

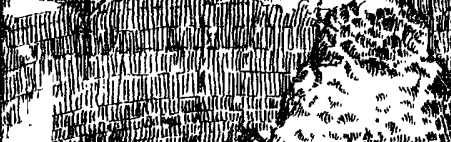

-

(1) (t)

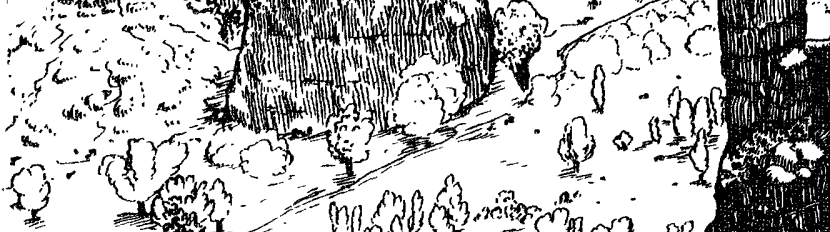

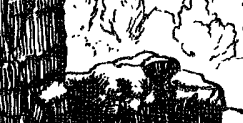

4 , the

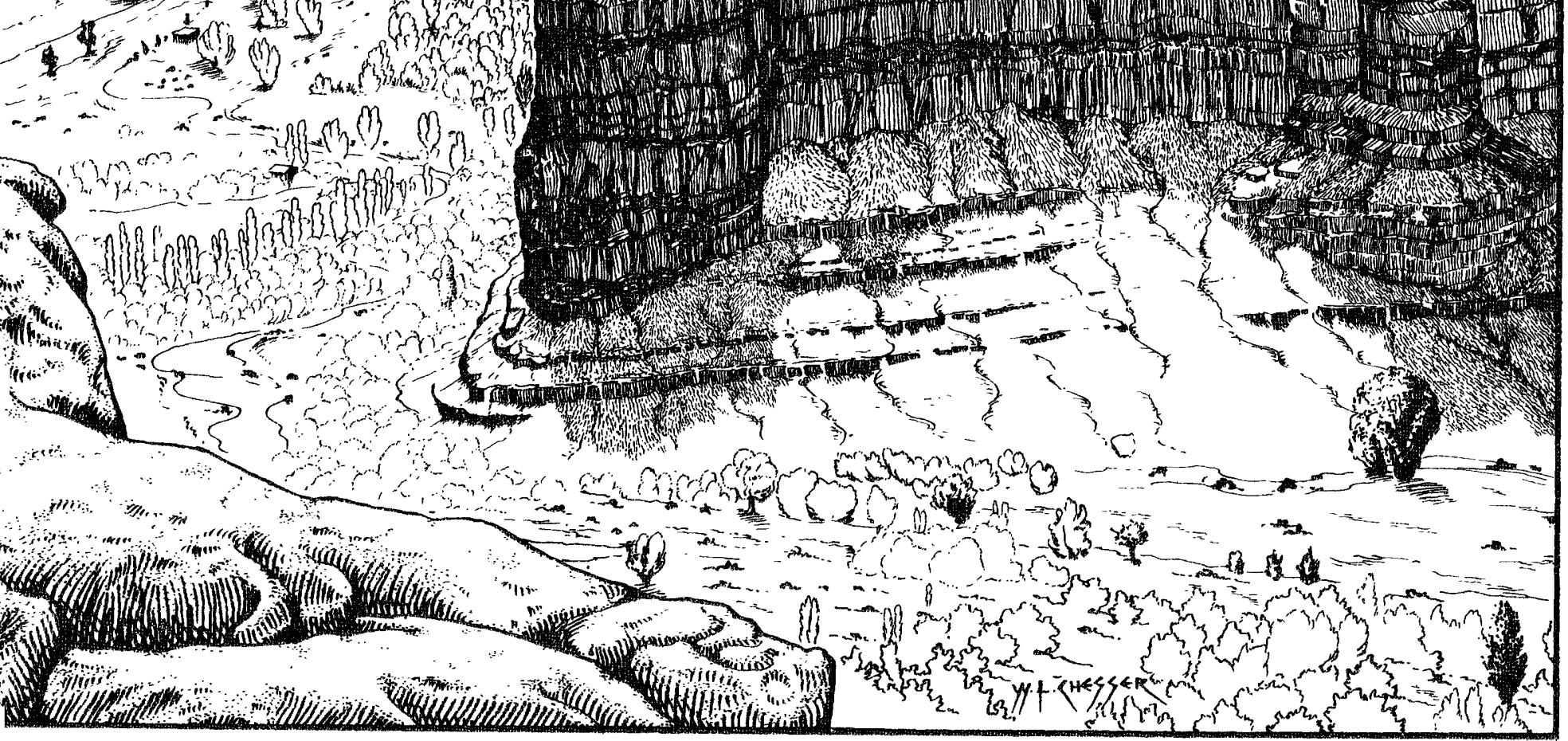

(n)

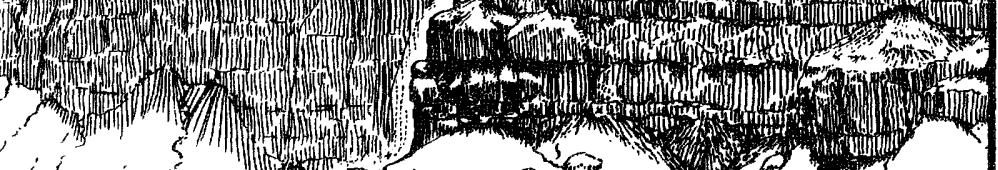

(2) s)

(6) .

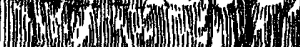




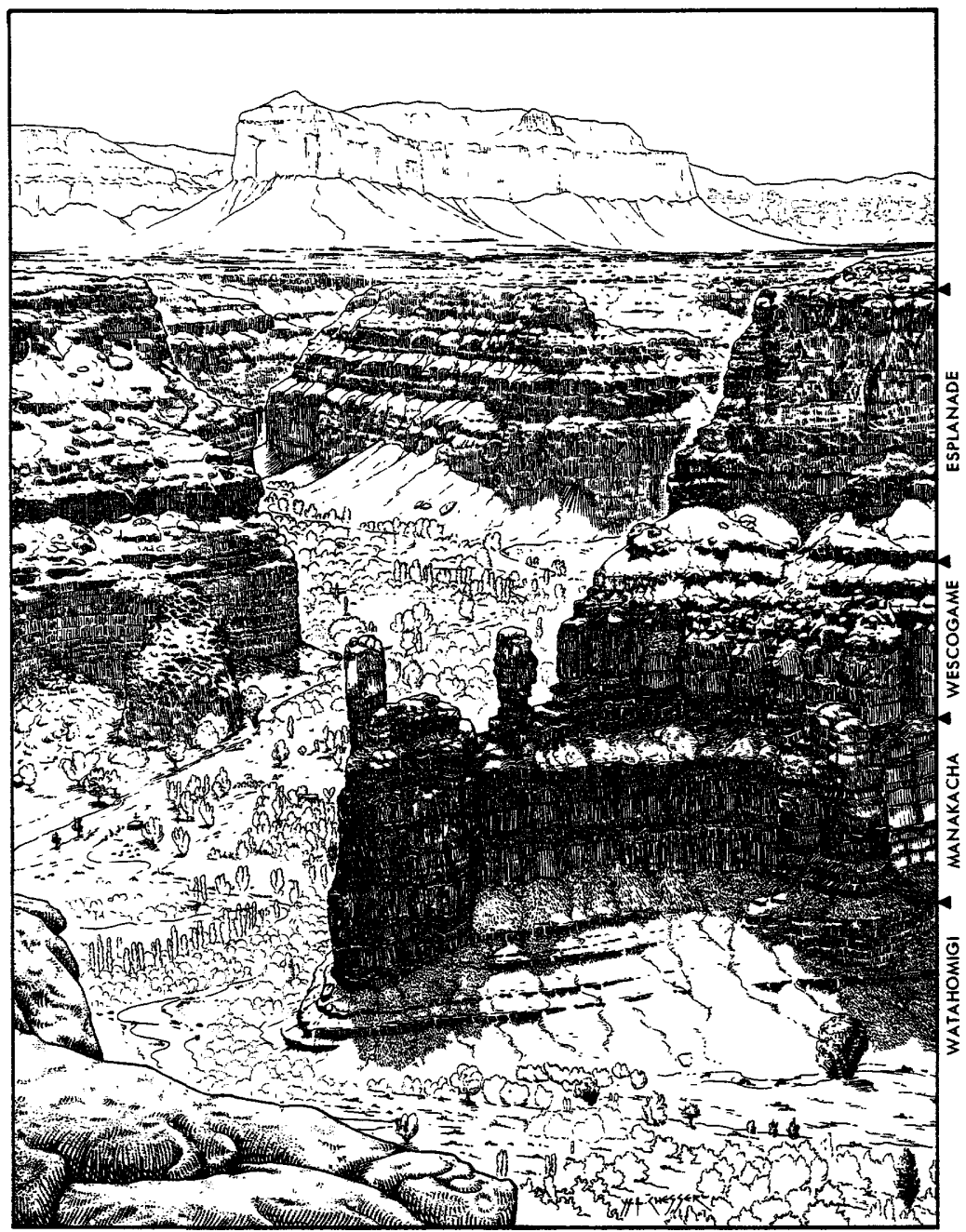

View south in Havasu Canyon, tributary of Grand Canyon, showing the four formations comprising the Supai Group near their type localities. The two sandstone monuments in the Wescogame Formation, center foreground, are referred to as Wigleeva in legends of the Havasupai Indians who consider them to be spirits or deities. Drawing by William L. Chesser, 1976. 


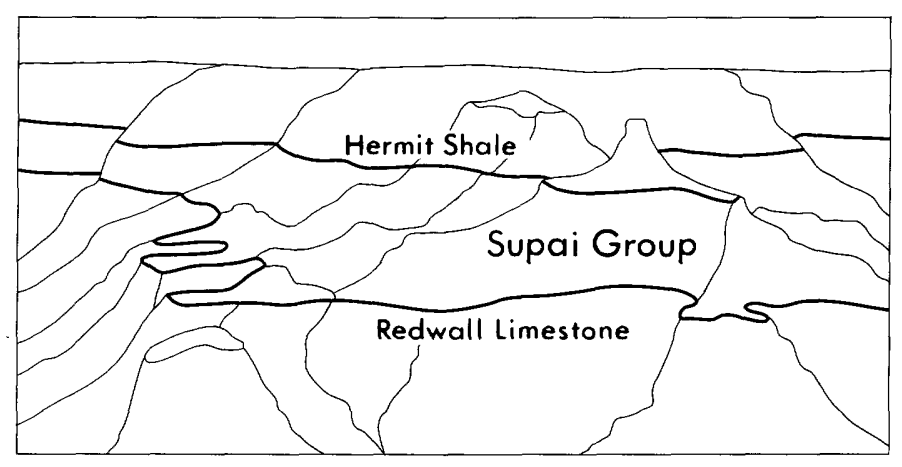

View in eastern Grand Canyon painted from Yavapai Point on the South Rim in 1936 by the famous Swedish artist Gunnar Widforss. The red strata in the middle part of the picture consist of the Hermit Shale and the four formations of the Supai Group. Only the central part of the original painting is reproduced here. 


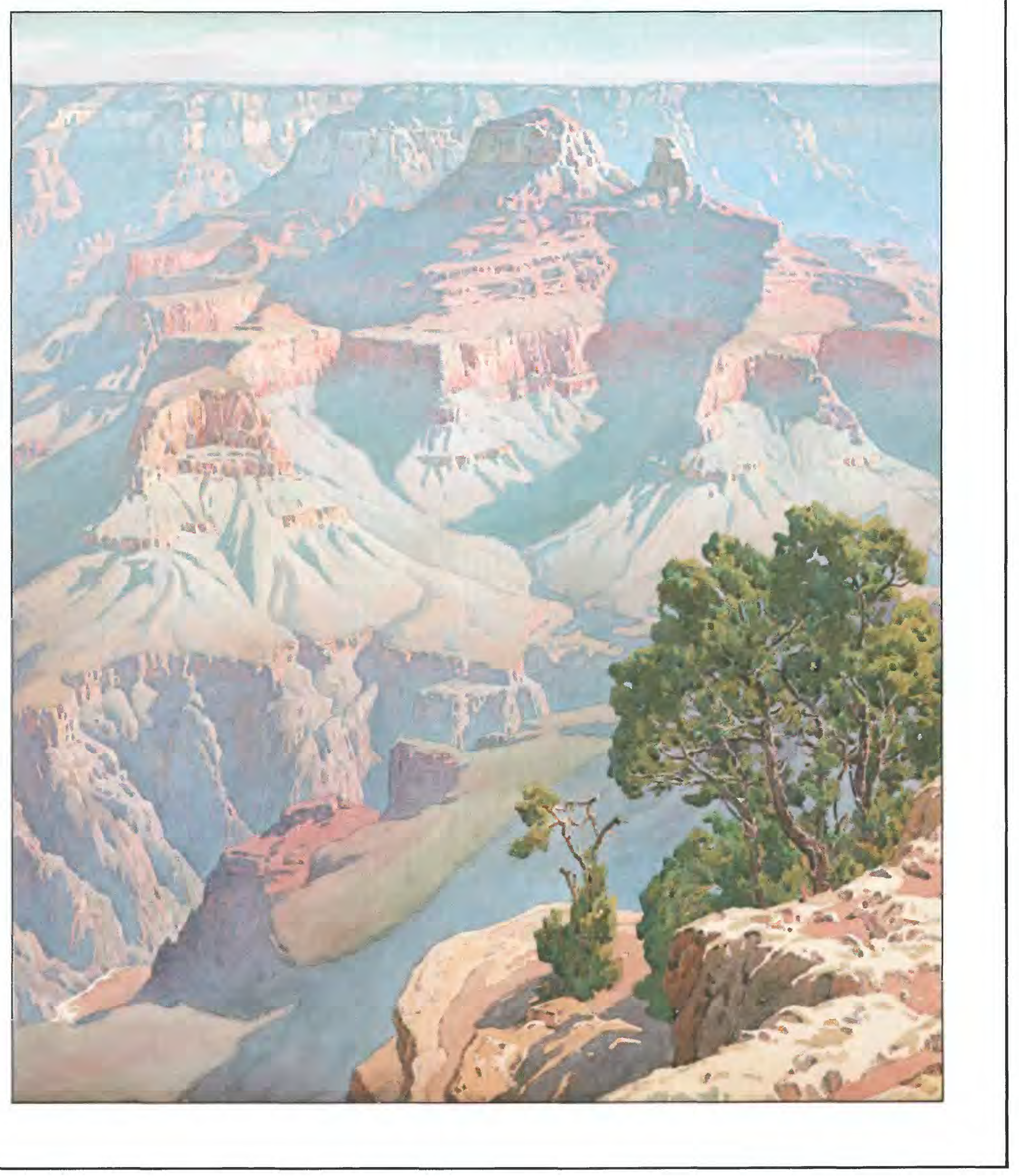





\section{The Supai Group of Grand Canyon}

By Edwin D. McKee

GEOLOGICAL SURVEY PROFESIONAL PAPER 1173

A study of the environment and history of four red bed formations, partly marine and partly continental, that comprise the Supai Group of Grand Canyon, Arizona

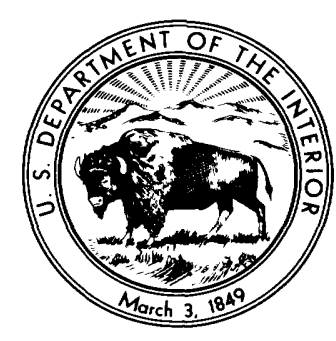




\section{UNITED STATES DEPARTMENT OF THE INTERIOR \\ WILLIAM P. CLARK, Secretary}

GEOLOGICAL SURVEY

Dallas L. Peck, Director

First printing 1983

Second printing 1983 


\section{The Supai Group of Grand Canyon}

\section{Contents}

[For convenience in cross-referencing, each chapter of this publication has a letter designation]

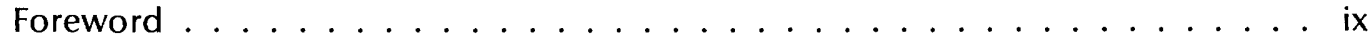

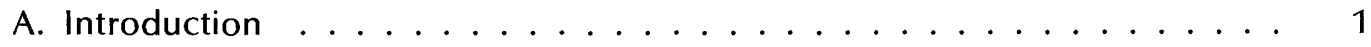

B. Introductory summary . . . . . . . . . . . . . . . 21

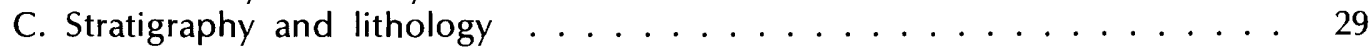

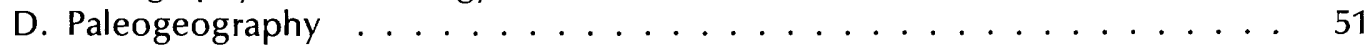

E. Distribution and age of fauna and flora ........... 75

F. Biostratigraphy of the Watahomigi Formation, by

Mackenzie Gordon, Jr. ................. . . 113

G. Pre-Supai buried valleys, by George H. Billingsley and

Edwin D. McKee . . . . . . . . . . . . . . . . . . . 137

H. Erosion surfaces . . . . . . . . . . . . . . . . . . 155

I. Transgressions and regressions . . . . . . . . . . . . . . . 177

J. Conglomerates . . . . . . . . . . . . . . . . . . 187

K. Sandstones . . . . . . . . . . . . . . . . . . . 205

L. Environment of deposition of sandstone bodies . . . . . . . . 245

M. Insoluble residue patterns, by Walter Pierce, A. J.

Gude, III, and Edwin D. McKee............... 263

N. Minor sedimentary features, contorted structures,

and homogeneous sedimentary rocks . . . . . . . . . . . . 273

O. Clay mineralogy, by Phoebe L. Hauff and Edwin D. McKee . . . . . . 287

P. Petrography of the Supai Group and Pakoon Limestone, by

Edwin D. McKee and Walter Pierce . . . . . . . . . . . . 333

Q. Stable isotope analyses ....................... 361

R. Aphanitic silica rock . . . . . . . . . . . . . . . . . 365

S. Evaporite deposits and magnesian carbonate rocks . . . . . . . . 375

Measured stratigraphic sections . . . . . . . . . . . . . 389 


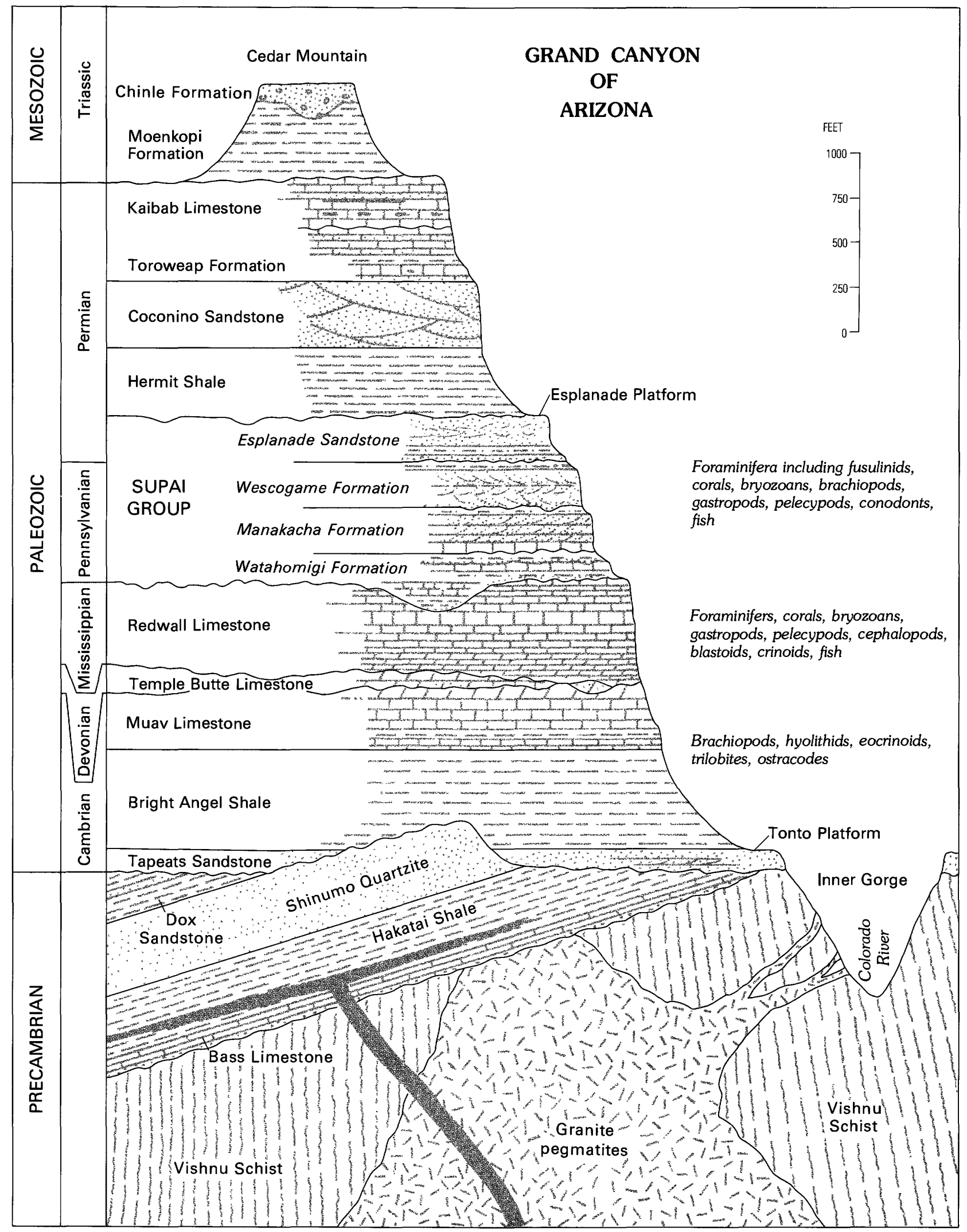




\section{Foreword}

This comprehensive geological monograph, definitive of the Supai Group of rocks in the Grand Canyon region, needs to be put into the proper personal and technical perspective and context for the reader. Edwin Dinwiddie McKee, Grand Canyon geologist and naturalist, has taken the initiative and dedication in his professional lifetime to document the Paleozoic stratigraphic rock sequence as part of the geological history of the Grand Canyon of Arizona-a monumental task and a truly remarkable record of achievement nearing completion after 50 years of devotion and effort!

The Grand Canyon has proved to be one of the World's finest laboratories for illustrating various geological principles, especially those related to the sedimentary history of stratified rocks. Clear, complete exposures of the strata as far as the eye can see and the general lack of structural disturbance offer nearly ideal conditions for study of these rocks. Opportunities are exceptionally good for applying geologic strategy (scientific method) in testing theories concerning natural processes and for demonstrating the detailed record of such phenomena as marine transgression and regression, cyclic sedimentation, marine-continental litho- and biofacies relationships, diastem and unconformities, and a spectrum of paleoenvironmental and paleoecological data. The Grand Canyon is a field laboratory of study in which McKee has contributed a wealth of ideas supported by extensive field observational and laboratory data for generations of students to come.

To appreciate the scope of McKee's program as a prelude and a foundation for the Supai study and to furnish the reader with background references to definitive contributions of this exceptional stratigraphic column, the following list gives McKee's major works in stratigraphic order from top to bottom. With this list, reference should be made to the generalized graphic section of the Grand Canyon on the opposite (facing) page. Fossil groups represented on the diagram call attention to detailed reports by specialists that are included in each monograph; McKee did the paleontology for the early studies. Innumerable other published works of McKee's studies related to the Grand Canyon are not included in this summary.

McKee, E. D., 1954, Stratigraphy and history of the Moenkopi Formation of Triassic age: Geological Society of America Memoir 61, 133 p.

1938, The environment and history of the Toroweap and Kaibab Formations of northern Arizona and southern Utah: Carnegie Institution of Washington Publication 492, 268 p. 1934, The Coconino Sandstone-its history and origin: Carnegie Institution of Washington Publication 440, p. 77-115, 14 pls. The Supai Group of Grand Canyon: Present Professional Paper.

McKee, E. D., and Gutschick, R. C., 1969, History of the Redwall Limestone of northern Arizona: Geological Society of America Memoir 114, 726 p.

McKee, E. D., and Resser, C. E., 1945, Cambrian history of the Grand Canyon region; Pt. 1. Stratigraphy and ecology of the Grand Canyon Cambrian; Pt. 2. Cambrian fossils of the Grand Canyon: Carnegie Institution of Washington Publication 563, $232 \mathrm{p}$.

McKee, E. D., 1969, Stratified rocks of the Grand Canyon-A history of stratigraphic investigation in the Grand Canyon region, in The Colorado River region and John Wesley Powell: U.S. Geological Survey Professional Paper 669-B, p. 23-58.

Not present on the above list are detailed reports on the Devonian Temple Butte Limestone and the Permian Hermit Shale. Observations were made on the Devonian 
from the first days that McKee stepped foot in the Grand Canyon as park naturalist, back in 1929; he has since examined it and measured sections in many places. As regards the Hermit Shale, McKee assisted Dr. David White in the canyon during some of his classic studies of that formation in 1928.

Accessibility to the rocks in the Grand Canyon is reflected in the chronology of McKee's reports. Early studies relate to rocks at or near the rim, followed by studies from river level up (Carnegie Institution boat trip in 1937), and lastly, studies of rocks that are least accessible, in the middle of the chasm walls.

Basic geologic research established from carefully made field observations and library and laboratory investigations-all done with scientific zeal and precision-is the lifeblood of our applied science. The present report on the Supai Group is an outstanding example of this ideal by a master field geologist and laboratory investigator. It represents an exhaustive treatment of the geologic history of these rocks with emphasis on the sedimentation, stratigraphy, paleontology, and paleogeography. McKee in his classical style presents a wide array of basic geologic data from which he makes logical interpretation of the genesis of this red bed-carbonate facies sequence. It fills a major gap between the Mississippian Redwall history and Permian Coconino-Toroweap-Kaibab history of the Grand Canyon area.

Proximity of the type area and type sections to the Havasupai Indian village of Supai in the bottom of Havasu (Cataract) Canyon and the affection McKee has for the gentle agrarian sun people (Supai) who live there account for the names of three of the four formations of the Supai Group and also for the pictures of Supai baskets used as chapter headings in this book. C. E. Dutton's (1882, U.S. Geological Survey Monograph 2) reference to the "Esplanade" as the majestic red bed-veneered expanse on top of the Supai Group is a natural designation for the uppermost formation.

Obstacles in most geologic studies of red-bed sequences are: (1) lack of traceable continuity of strata for correlation purposes, and (2) apparent absence of fossil faunas and floras from which to establish a detailed time-zonation framework. For Supai research, perceptive field observation proved successful in making possible recognition of key conglomerate beds and erosional unconformity surfaces for correlation of strata, the discovery of marine faunas that yielded close resolution of a succession of time units for zonation, and identification of marine and continental lithologic and faunal facies for interpretation of the environments of deposition. These are all hallmarks of the principles and models which McKee established through his earlier studies in the Grand Canyon.

A major contribution of this professional paper is the sedimentological analysis of the Supai Group. McKee has pioneered the study of sedimentary structures by field comparison of ancient examples in rocks with supposed modern analogs. For more than the past two decades, he has followed such field observations with laboratory experiments in order to understand the conditions and variable parameters critical for replication of each structure or combination of structures. This experience and information has been applied to the Supai Group. Large quantities of field data and collections were analyzed for the sedimentary attributes from 32 stratigraphic sections measured in an area of approximately 15,000 square miles in which the Supai Group varies in thickness from 700 to more than 1,000 feet.

The chapters of this book have been organized with excellent graphic illustrations for comparison of the quantitative data with geographic units and to similar examples in modern environments. Much of the analysis of the raw sedimentological data, interpretation of its environmental significance, and organization of the text was done by McKee during a lengthy siege of illness. In effect, adversity accelerated the completion of this professional paper even though the initial fieldwork started in 1936. Indeed, such a course illustrates that geological reports from extensive field data take a long time to complete. 
Contributions from paleontologists and other specialists are critical to and enhance the report with their resolution of dating and facies interpretation. The accounts of clay mineralogy, petrography, and stable isotope analysis have greatly sharpened the interpretation of environments both for the Supai Group and for pre-Supai history. Most useful fossils for recognition of geologic time and facies are the brachiopods, corals, small foraminifera and fusulinids and, to a smaller extent, the molluscs and other less common forms. Discovery by Billingsley of pre-Supai drainage valleys on the Redwall Limestone surface fits the regional paleogeography of pre-Chester age epeirogenesis and the Chester continental-marine sedimentary pattern of the northern and middle Rocky Mountains and eastern Great Basin to the north.

This foreword is a tribute to the wisdom, foresight, and energy of Edwin D. McKee and the outstanding contributions to Grand Canyon geology by the U.S. Geological Survey for more than a century. McKee follows in the footsteps and tradition of Marcou, Newberry, Powell, Gilbert, Marvine, Walcott, Dutton, Darton, Noble, and White. Students of earth history, the geological profession, and the public are richer for knowledge of the natural wonders and creation of the Grand Canyon, and we express our gratitude for the progress of geological science to these men.

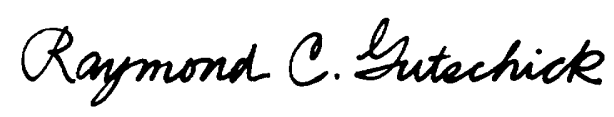

Research Geologist

Department of Earth Sciences

University of Notre Dame

Notre Dame, Indiana 46556 



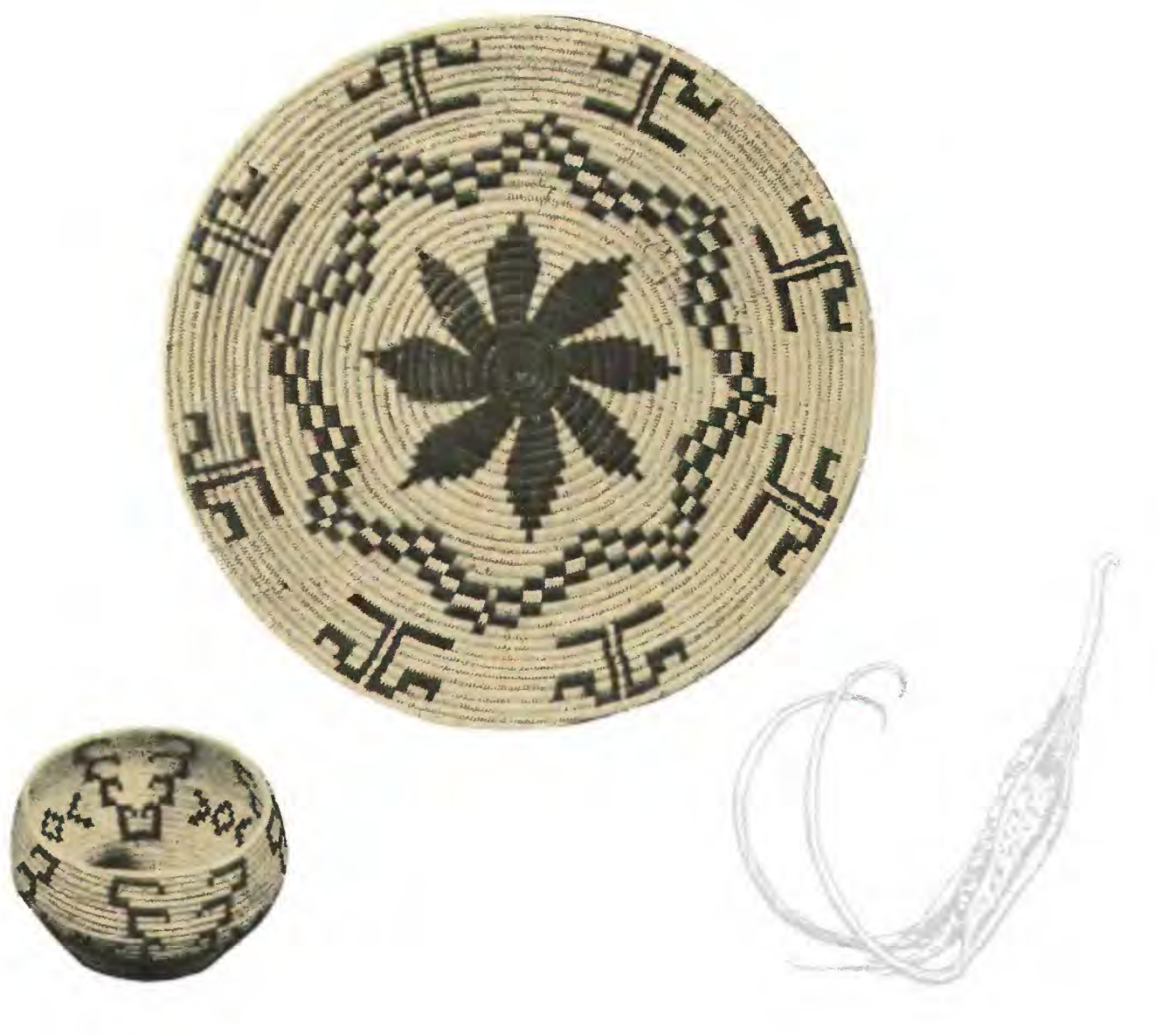

THE SUPAI GROUP OF GRAND CANYON

INTRODUCTION

Chapter A

By EDWIN D. McKEE

\section{Contents}

Scope of study

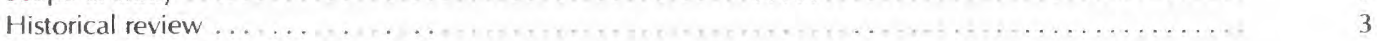

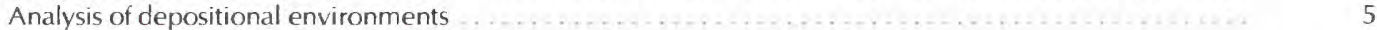

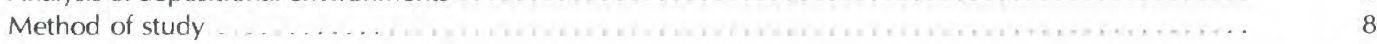

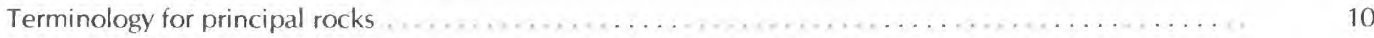

Acknowledgments . . . . . . . . . . .

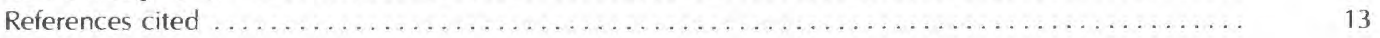




\section{Illustrations}

IGURE A1. Map showing localities of measured sections and principal lines of sections ............. A2-A8. Profiles of measured sections:

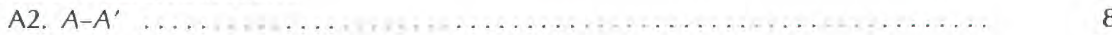

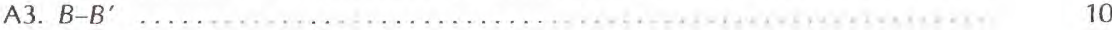

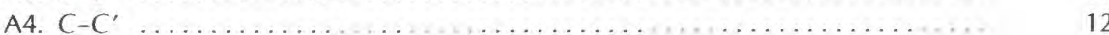

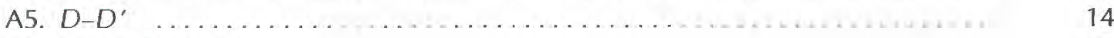

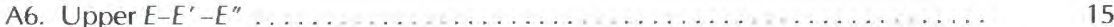

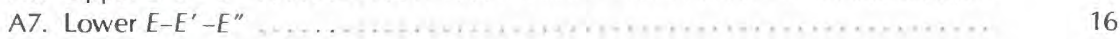
A8. $F-F^{\prime}+E^{\prime}-E^{\prime \prime} \cdot 18$

\section{Table}

TABLE

A1. Classifications of Carboniferous-Permian strata of Grand Canyon, Ariz. 


\section{SCOPE OF STUDY}

The present study of the Supai Group dates back to 1936. At that time the writer, while engaged in stratigraphic work on the Kaibab Limestone and Toroweap Formation and, later on the Cambrian strata of Grand Canyon, under the auspices of the Carnegie Institution of Washington, took the opportunity to examine red beds and to measure some Supai sections. As a result, the general character of the rocks and certain regional changes became familiar (McKee, 1937, p. 341; 1938, p. 358).

It was not until the late 1930 's, when systematic work on a statistical study of cross-strata dip directions was undertaken (McKee, 1940a), that the trends and the complexity of the Supai problem began to be apparent. Also, at about that time, discovery of an assemblage of invertebrate fossils in the basal slope unit (now Watahomigi Formation) of the Supai at Toroweap Valley and at Parashant Canyon stimulated interest in the age of the strata. Fossil collections sent to Dr. James Williams of the U.S. Geological Survey were determined to be not of Permian age as generally supposed at that time, but of Early Pennsylvanian age.

The "Stratigraphy of the Supai Formation and Hermit Shale of Grand Canyon" was made an official project of the U.S. Geological Survey in 1959, with E. D. McKee as project chief. A program of study was planned to get underway at that time and to be continued over a period of years, averaging about two months' study in the field each year. Meanwhile, chemical, mechanical, and other analyses of selected rock samples were made in the Denver laboratories and fossil determinations were obtained from specialists in Washington, D.C., as various stratigraphic sections were being completed.

\section{HISTORICAL REVIEW}

The earliest reference by a geologist to rocks now called the Supai Group was by Jules Marcou (1856) who, as a member of an exploration party for the U.S. Pacific Railroad under Lt. A. W. Whipple, traversed northern Arizona in 1853-54. Marcou did not see Grand Canyon, but examined several of its formations where they crop out at Partridge and Cedar Creeks, to the south. Marcou referred to "carboniferous sandstones-the equivalents of the coal measures," which apparently included both the Coconino Sandstone and Supai, beneath the "magnesian limestone" [Kaibab] and above the "mountain limestone" [Redwall].

Supai rocks in Grand Canyon were first examined and described by J. S. Newberry (1861, p. 42, 59, 63) who referred to them as "blood red calcareous sandstones and shales, which have an aggregate thickness of nearly 500 feet." They were reported to underlie cross-stratified sandstones and to be above Lower Carboniferous(?) limestone. Newberry found no fossils in them, but described the presence of gypsum and a stratum of cream-colored limestone.

Little mention of the Supai rocks was made by J. W. Powell (1875) in his classic report on the geology of Grand Canyon, based on the river expeditions of 1869 and 1871-72. The Supai was referred to only as "rocks of Carboniferous Age" (Powell, 1875, p. 212) and "Carboniferous formation" [including Kaibab and others] (p. 180). It was described as "beds of bright red sandstones, weathered to form shelves *** but in many places [broken] down in steep slopes" (p. 195).

The first formal name applied to the Supai strata (and the overlying Paleozoic formations) of the Grand Canyon was Aubrey Group (see chapter $C$ for formal abandonment of this name). This name was given by G. K. Gilbert (table A1) during the U.S. Geographic and Geologic Survey west of the 100th Meridian (Gilbert, 1875, p. 176-185) and was derived from exposures at Aubrey Cliffs bordering the Aubrey Valley south of Grand Canyon. Only the uppermost part of the Supai Group (McKee, 1975) is exposed at this locality; most of the red beds exposed in Aubrey Cliffs are Hermit Shale.

Subsequently, in a report on the Paleozoic groups of Kanab Canyon, on the north side of Grand Canyon, C. D. Walcott (1880, p. 221-225) subdivided the Aubrey ${ }^{1}$ Group into an upper Aubrey (consisting of the Kaibab Limestone and Toroweap Formation) and a lower Aubrey (Coconino Sandstone, Hermit Shale, Supai Group of McKee, 1975, in part) (table A1). Below the lower Aubrey Group is the "Red Wall Limestone"; together the three groups are referred to the "Carboniferous." They are described by Walcott $(1880$, p. 224) as having a fauna "of the coalmeasure type, except near the base [where there is] a much larger proportion of a Lower Carboniferous character." Based on descriptions and thicknesses given by Walcott, much or most of the Supai was included in the lower Aubrey.

The term lower Aubrey Group, as applied by C. E. Dutton in his monographic treatment of the Tertiary history of Grand Canyon (1882), differed considerably from the stratigraphic units and boundaries as used in adjacent areas by other geologists of the time. The term Aubrey Group was used by Dutton at Toroweap Valley (p. 89) (table A1, col. 3) for strata of the "outer" canyon, "from the summit [rim] to the plain below [Esplanade]." His upper Aubrey therefore consisted of the Kaibab, Toroweap, and Coconino of present usage, but his lower Aubrey was restricted to the Hermit Shale. This usage is shown in Dutton's figure 1, profile "at the foot of the Toroweap Valley," and in his statement (p. 88): "The walls of the inner gorge have at the summit about 325 feet of hard sandstone of a

\footnotetext{
"This name was incorrectly spelled "Aubry" throughout the report
} 
brown red color. Below the sandstone are about 1,800 feet of impure limestone in layers of the most massive description." From this statement, it seems certain that Dutton included all of the present Supai Group in his "Red Wall group," and only the Hermit Shale was assigned to the lower Aubrey.

Further confusion (table A1, col. 4) in the stratigraphic classification as used by Dutton (1882) is apparent in his Plate XXIV, "Key to the Panorama from Point SublimeLooking South." In this precise, detailed drawing, the unit marked 4 is labelled "Lower Aubrey sandstones"; it consists of the Hermit Shale, and all of the Supai Group, except for the lowest slope unit (Watahomigi Formation of the present publication). Unit number 5 in the "Panorama" is labelled the "Upper Red Wall sandstone" and is comprised of the Watahomigi only. Almost certainly the discrepancy (table A1) between the rock assignments in the lower Aubrey Group in Dutton's "Panorama from Point Sublime" and his "Toroweap Valley" description and profile (fig. 1) is the result of miscorrelation resulting from major differences in topographic expression of the same stratigraphic units in the two areas.
After a reconnaissance study by N. H. Darton (1910, p. 25) in parts of northwestern New Mexico and northern Arizona, he recommended that rocks of the Aubrey Group be separated into formations and that these be given formal status. In proposing the "Supai formation" Darton stated: "The red sandstones and shales constituting the lower portion of the Aubrey group in northern Arizona form a definite stratigraphic unit over a wide area. Accordingly, I propose that they be designated the Supai formation, from the Supai village on Cataract Creek, where they are very conspicuously exposed." Thus, Havasu (Cataract) Canyon, a tributary of Grand Canyon on its south side, is the type locality of the formation. It is overlain by the Coconino Sandstone and underlain by the Redwall Limestone (table A1, col. 5).

Because the "Supai formation" as originally defined by Darton included at its top a sequence of red shaly siltstones, separated from the main body of strata by an erosional unconformity, these upper beds were removed from the Supai by Noble (1922, p. 64) and made a separate formation called the "Hermit Shale" (table A1, col. 6). At the same time, Noble further redefined the Supai by adding to

TABLE A1.-Classifications of Carboniferous-Permian strata of Grand Canyon, Ariz.

\begin{tabular}{|c|c|c|c|c|c|c|c|c|c|}
\hline \multicolumn{8}{|c|}{ Reference } & \multirow{2}{*}{\multicolumn{2}{|c|}{ Age }} \\
\hline $\begin{array}{c}\text { Gilbert } \\
(1875, \text { fig. 82) }\end{array}$ & $\begin{array}{c}\text { Walcott } \\
(1880, \text { p. 222) }\end{array}$ & $\begin{array}{c}\text { Dutton } \\
\text { (1882, pl. XXVIII; } \\
\text { Point Sublime) }\end{array}$ & $\begin{array}{c}\text { Dutton } \\
\text { (1882, fig. 1; } \\
\text { Toroweap Valley) }\end{array}$ & $\begin{array}{c}\text { Darton } \\
(1910, \text { p. } 25)\end{array}$ & $\begin{array}{c}\text { Noble } \\
(1922, \text { p. } 60)\end{array}$ & & $\begin{array}{l}\text { Present } \\
\text { study }\end{array}$ & & \\
\hline \multirow{7}{*}{$\begin{array}{l}\text { Aubrey } \\
\text { Group }\end{array}$} & \multirow{2}{*}{$\begin{array}{l}\text { Upper } \\
\text { Aubry } \\
\text { Group }\end{array}$} & \multirow{3}{*}{$\begin{array}{l}\text { Upper } \\
\text { Aubrey } \\
\text { Group }\end{array}$} & \multirow{3}{*}{$\begin{array}{l}\text { Upper } \\
\text { Aubrey } \\
\text { Group }\end{array}$} & \multirow{2}{*}{$\begin{array}{c}\text { Kaibab } \\
\text { Limestone }\end{array}$} & \multirow{2}{*}{$\begin{array}{c}\text { Kaibab } \\
\text { Limestone }\end{array}$} & & $\begin{array}{c}\text { Kaibab } \\
\text { Limestone }\end{array}$ & \multirow{3}{*}{\multicolumn{2}{|c|}{ Leonardian }} \\
\hline & & & & & & & $\begin{array}{l}\text { Toroweap } \\
\text { Formation } \\
\end{array}$ & & \\
\hline & \multirow{5}{*}{$\begin{array}{l}\text { Lower } \\
\text { Aubry } \\
\text { Group }\end{array}$} & & & $\begin{array}{l}\text { Coconino } \\
\text { Sandstone }\end{array}$ & $\begin{array}{l}\text { Coconino } \\
\text { Sandstone }\end{array}$ & & $\begin{array}{l}\text { Coconino } \\
\text { Sandstone }\end{array}$ & $\frac{\frac{\pi}{\varepsilon}}{\varepsilon}$ & \\
\hline & & \multirow{4}{*}{$\begin{array}{l}\text { Lower } \\
\text { Aubrey } \\
\text { Group }\end{array}$} & $\begin{array}{c}\text { Lower } \\
\text { Aubrey Group }\end{array}$ & \multirow[t]{4}{*}{$\begin{array}{c}\text { Supai } \\
\text { Formation }\end{array}$} & $\begin{array}{l}\text { Hermit } \\
\text { Shale }\end{array}$ & & $\begin{array}{l}\text { Hermit } \\
\text { Shale }\end{array}$ & 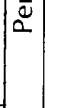 & \\
\hline & & & \multirow[t]{7}{*}{$\begin{array}{l}\text { Red Wall } \\
\text { Group }\end{array}$} & & \multirow[t]{5}{*}{$\begin{array}{c}\text { Supai } \\
\text { Formation }\end{array}$} & \multirow{5}{*}{$\begin{array}{l}0 \\
0 \\
0 \\
0 \\
0 \\
\overline{0} \\
0 \\
0 \\
\end{array}$} & $\begin{array}{l}\text { Esplanade } \\
\text { Sandstone }^{2}\end{array}$ & & Wolfcampian \\
\hline & & & & & & & $\begin{array}{c}\text { Wescogame } \\
\text { Formation }\end{array}$ & \multirow{4}{*}{ 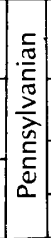 } & Virgilian \\
\hline & & & & & & & $\begin{array}{l}\text { Manakacha } \\
\text { Formation }\end{array}$ & & Des Moinesian(?) \\
\hline & \multirow[b]{4}{*}{$\begin{array}{l}\text { Red Wall } \\
\text { Limestone }\end{array}$} & \multirow[b]{4}{*}{$\begin{array}{l}\text { Red Wall } \\
\text { Group }\end{array}$} & & \multirow[b]{4}{*}{$\begin{array}{l}\text { Redwall } \\
\text { Limestone }\end{array}$} & & & \multirow{2}{*}{$\begin{array}{l}\text { Watahomigi } \\
\text { Formation }\end{array}$} & & Atokan \\
\hline & & & & & & & & & Morrowan \\
\hline & & & & & \multirow[b]{2}{*}{$\begin{array}{l}\text { Redwall } \\
\text { Limestone }\end{array}$} & & $\begin{array}{l}\text { Pre-Supai } \\
\text { sediment }^{3}\end{array}$ & & Chesterian \\
\hline $\begin{array}{l}\text { Red Wall } \\
\text { Limestone } \\
\text { Group }\end{array}$ & & & & & & & $\begin{array}{c}\text { Redwall } \\
\text { Limestone }\end{array}$ & & Mississippian \\
\hline
\end{tabular}

${ }^{1}$ Spelling used by Walcott.

${ }^{2}$ Lower part replaced by Pakoon Limestone (MCNair, 1951) in western Grand Canyon.

${ }^{3}$ In buried valleys. 
its base "about 25 feet of red sandy shale, purplish and gray limestone with red chert and reddish to buff calcareous sandstone of Pennsylvanian age that have heretofore been included in the Redwall limestone." The age of the "Supai formation" was believed to be Permian(?) and Pennsylvanian.

Following the detailed studies and the reclassification of the Supai by Noble, completed in 1922, work on rocks of this group in Grand Canyon was intermittent for the next three decades. The most notable contribution was a monographic study of the flora of the Hermit Shale by David White (1929); other publications were limited to a few scattered stratigraphic notes on plants by White (1927, 1928), on fossil trackways by Gilmore (1927, 1928), and on stratigraphy and paleogeography by McKee (1938, 1940a,b, 1947, 1951).

In the region south of Grand Canyon, several studies of the Supai and its lateral equivalents were made during the 1940 's. These were largely on stratigraphy, but included some paleontology and environmental interpretation (Huddle and Dobrovolny, 1945; Hughes, 1949, 1952; Winters, 1951, 1963; Jackson, 1951). Later investigations in the same region were by Lokke (1962), Brew (1965), Gerrard (1964), Peirce (1958, 1966), and Ross (1973).

The Supai and its correlatives in northwestern Grand Canyon and adjoining parts of Arizona, Nevada, and Utah did not receive much attention until the early 1950's when McNair (1951) proposed two new formations and reorganized the local stratigraphy. One of these formations, the Pakoon Limestone, is considered (in this report) to be a western equivalent of the lower part of the Esplanade Sandstone. For this reason and because much of the fossil evidence dating the upper part of the Supai comes from the Pakoon Limestone, it is included in sections of the northwestern Grand Canyon area even though not part of the Supai Group (figs. A2-A8).

The work of McNair was followed in the late 1950's and 1960 's by a series of stratigraphic studies north and west of Grand Canyon, some establishing zones and determining boundaries on the basis of fossils, others correlating rock units and unconformities between various areas (Steele, 1959; Welsh, 1959; Bissell, 1962, 1969; Brill, 1963; Heath, 1965; Langenheim and Langenheim, 1965; Cassity and Langenheim, 1966; Douglass, 1974).

During the 1960 's, the Supai and related rocks in northwestern Grand Canyon and neighboring areas also were the subject of numerous local petrographic and lithologic investigations. Studies along the north side of the canyon, involving detailed mapping and lithologic correlation, were made by Sorauf (1962), Fisher (1962), and Billingsley (1970). Studies that were principally petrographic were made in adjoining parts of Nevada by Lumsden (1965), Heath, Lumsden, and Carozzi (1967), and Lumsden, Ledbetter, and Smith (1973).
In northeastern Arizona beyond the Grand Canyon, correlative strata of the Supai in the San Juan Basin received considerable attention, especially from the standpoint of stratigraphy, during the late 1950's and 1960's. Under the stimulus of petroleum exploration, a great proliferation of publications occurred at this time. Some of the important studies were by Merrill and Winer (1958), Wengerd and Matheny (1958), Peterson (1959), Baars (1962), and Peterson and Ohlen (1963). Studies of the gypsum deposits were recorded in Sears (1956) and O'Sullivan (1965).

Investigations of the Supai Group have by no means been limited to stratigraphic, petrographic, and faunal studies. One of the most thoroughly studied subjects has been the paleogeography as represented by the structural framework in which the Supai was formed. Determination of the constantly fluctuating land and sea relations, and delineation of positive elements, basins, and troughs, have been the subjects of many papers during the past several decades. Since 1949, 17 systems of tectonic elements, together with sets of proposed terms for paleogeographic units, have been published; they are summarized in table D2. Isopach, lithofacies, and paleogeographic maps of these features are many.

\section{ANALYSIS OF DEPOSITIONAL ENVIRONMENTS}

The ultimate aim in the current investigations of the stratigraphy and sedimentology of the Supai Group has been to interpret the various environments of deposition represented by its components. Because the rocks of four formations, with a range in age from Early Pennsylvanian into the Early Permian, and with a geographical distribution equal to the entire Grand Canyon area are under consideration, a large variety of environments represented by many lithologic facies is to be expected.

The facies of the Supai Group clearly range from continental to normal marine and include a wide variety of intermediate types. End members in this sequence of facies are, in general, easy to recognize. Many of the siltstones and mudstones at one extreme are clearly of continental origin as indicated by the presence of land plants and such diagnostic minor structures as shrinkage cracks and rain pits. At the other extreme, limestones of several formspeloidal, bioclastic, accretal, and micritic-are recognized as definitely marine, especially where they contain such fossils as corals, brachiopods, and crinoids. Differences in the size and shape of clastic grains are attributed to various degrees of current energy.

Between the end members are many facies, the exact natures of which are difficult to establish either in terms of water salinity, of geographic position, or of transport and 
depositional processes. Some inferences as to salinity can be made on the basis of composition. Rocks such as gypsum and dolostone are indicators of depositional environment. Virtually all of the sandstones and many of the siltstones, however, contain no diagnostic fossils or any distinctive mineral or rock constituents that give evidence of genesis. Primary structures must be resorted to as the only reliable type of evidence available for interpreting the genesis of many parts of the Supai.

Numerous approaches have been used in this analysis of depositional environments. Even though conclusive evi- dence of genesis is not furnished by any single study, definite trends of various kinds collectively point to the most probable interpretations. Accordingly, the first and primary consideration has been a reconstruction of paleogeography to establish a framework on which all accumulations of data could be organized. By the development of isopach maps both for the area under study and also for a statewide region of which this area is a part, the basic relationships between negative and positive areas have been established. Furthermore, by detailed analysis of widespread erosional surfaces, using key conglomerate

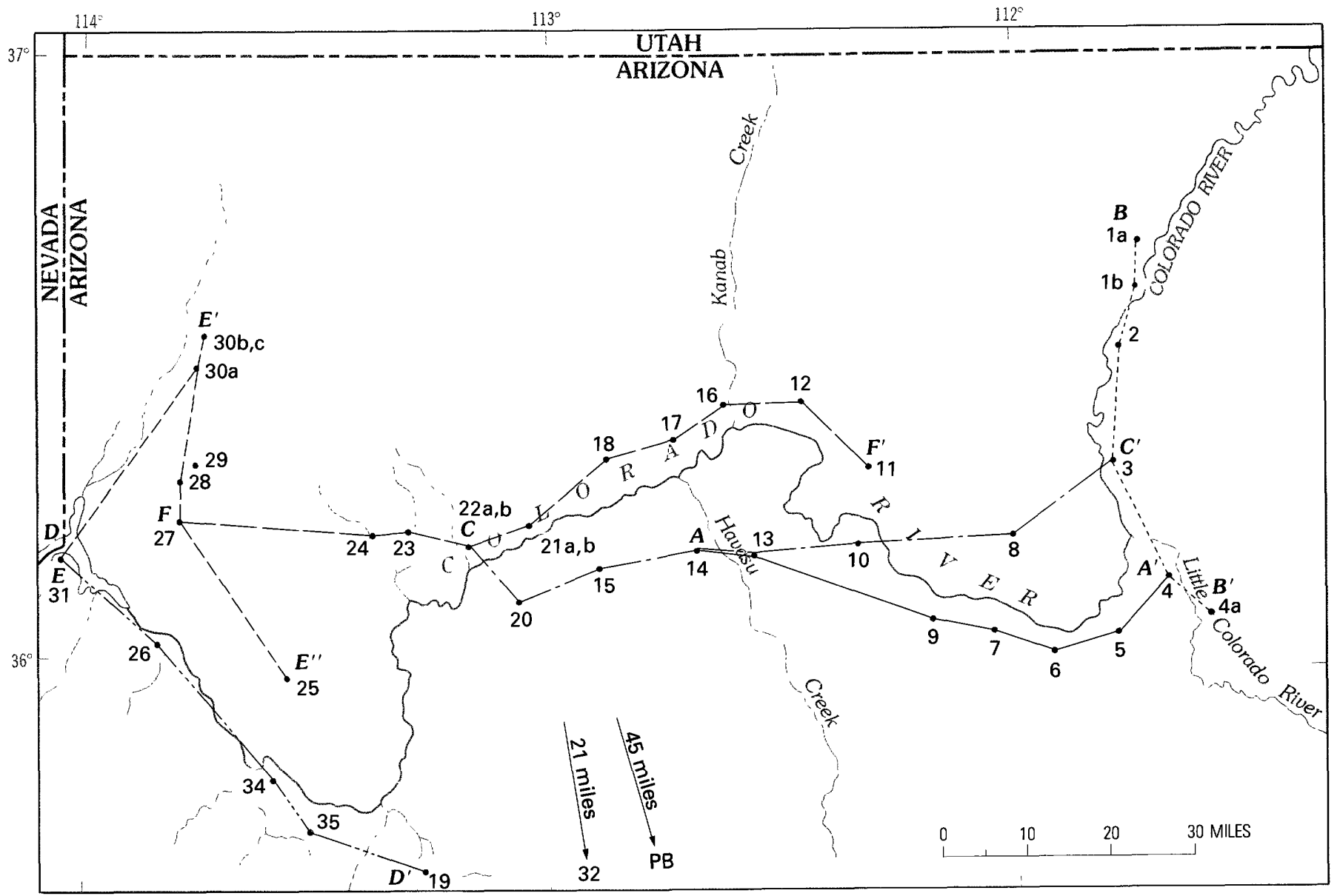

FIGURE A1.-Locality map of Grand Canyon region, Arizona, showing positions (solid circles) of measured stratigraphic sections (1-35) and principal lines of sections $\left(A-A^{\prime}\right.$ to $\left.F-F^{\prime}\right)$ referred to throughout text. Arrow and miles indicate direction and distance to actual locality of section.

\section{EXPLANATION}

MEASURED SECTIONS

\begin{tabular}{cl}
$\begin{array}{c}\text { Number } \\
1 \mathrm{a}\end{array}$ & \multicolumn{1}{c}{ Name } \\
$1 \mathrm{~b}$ & House Rock Canyon \\
& Near mile 22, Marble Canyon \\
2 & Twentynine Mile Canyon \\
3 & Eminence Fault \\
4 & Blue Spring
\end{tabular}

Location/Description

Partial section; basal conglomerate of Esplanade Sandstone at mile 16.5 in Marble Canyon, west wall

Partial section; upper part of section measured on west side of Colorado River near mile 23; basal conglomerate measured on east side of River at mile 22

Along northeast wall at Marble Canyon (section progresses up Twentynine Mile Canyon)

Along east side of Eminence Fault in Marble Canyon, east wall

Along the trail to Blue Spring 


\begin{tabular}{|c|c|}
\hline $4 a$ & Horsetrail Canyon \\
\hline 5 & Bunker Trail \\
\hline 6 & Grandview Trail \\
\hline 7 & Kaibab Trail, south \\
\hline 8 & Kaibab Trail, north \\
\hline 9 & Hermit Trail \\
\hline 10 & Bass Trail \\
\hline 11 & Shinumo Trail \\
\hline 12 & Thunder River Trail \\
\hline 13 & Topocoba Trail \\
\hline 14 & Havasu Canyon \\
\hline 15 & National Canyon \\
\hline 16 & Kanab Canyon \\
\hline 17 & S B Canyon \\
\hline 18 & Tuckup Canyon \\
\hline 19 & Blue Mountain Canyon \\
\hline 20 & Prospect Valley \\
\hline $21 \mathrm{a}$ & Toroweap Valley \\
\hline $21 b$ & do. \\
\hline $22 a$ & Whitmore Wash \\
\hline
\end{tabular}

Parashant Canyon

Andrus Canyon

Twin Springs Canyon

Guano Cave

Snap Canyon

Pigeon Wash

Grand Gulch Mine

Hidden Canyon

do.

do.

Iceberg Canyon

Seligman

Separation Canyon

Hindu Canyon
At Little Colorado River, 0.5 mile downstream from Waterhole Canyon

Along west side of Bunker Trail (locally called Tanner Trail) below Lipan Point

Along Grandview Trail on west side of main ridge; 1 mile south of Horseshoe Mesa

Along ridge extending north from Yaki Point

Slope and cliff units of Esplanade Sandstone measured on north side of Roaring Springs Canyon; lower part of group measured on south side

Measurement begins south of major slump area crossing trail on east side of canyon

On west side of Bass Canyon east of Mount Huethawali

Measured northeast of trail in Muav Canyon, western part of Shinumo Amphitheater

Measured in Fishtail Canyon about 3 miles from Thunder River Trail

Partial section; along south side of trail, 1 mile west of Topocoba Hilltop; lower part of Supai not measured

Watahomigi Formation measured on west side of canyon at Navajo Falls; upper part of group measured along Apache Trail, northeast of Supai Village

In National Canyon, Hualapai Indian Reservation. Watahomigi measured on west side above the gorge formed by the Redwall Limestone; from Manakacha to Esplanade, measured on east side; Esplanade measured on west side of canyon

On west side of Kanab Canyon, 2 miles north of Colorado River

In S B Canyon (Hundred and Fifty Mile Canyon)

Upper part measured in Cottonwood Canyon; lower part in Tuckup Canyon

In Blue Mountain Canyon, southwest side, T. 26 N., R. 9 W.; upper part measured on west side of Tower of Babylon

On east side of Prospect Valley, 6 miles south of Colorado River

Measured south of Toroweap Point, east of lava flows

Partial section; on west side of Toroweap Valley (measured at foot of valley to record fossil horizons)

On east side near the mouth of Whitmore Wash (lower part measured in narrow canyon normal to the wash)

Partial section; complete Esplanade section on east side of Whitmore Wash; measured north of section 22a, between major basalt cascades
East of Shivwits Plateau

Upper part measured on canyon wall about 2 miles southeast of Grassy Mountain; lower part on southwest side of canyon, west of fault zone about 9 miles southeast of Grassy Mountain

Lower part measured on west side of canyon; Esplanade Sandstone measured on east side

Measured at tram to Guano Cave (also called Bat Cave) on south side of Colorado River

Grand Wash Cliffs; measured in Snap Canyon about 5 miles south of Grand Gulch Mine

On north side of Pigeon Wash, Grand Wash Cliffs

Partial section; measured northeast of mine

Partial section; measured 3 miles south of Hidden Canyon; together with sections $30 \mathrm{~b}$ and $30 \mathrm{c}$, makes a complete section of Supai strata

Partial section; main part of Hidden Canyon section

Partial section; measured on east side of Jump Canyon, 0.5 mile from junction with Hidden Canyon

Measured on east side; regional dip $45^{\circ}$

Partial section; on Aubrey Cliffs, 4 miles west of Seligman

South side of Picacho Butte

Measured on south side of Colorado River at Separation Canyon east of Spencer Canyon

In eastern end of Hindu Canyon, south of Bridge Canyon, on small mesa at approximately sec. 24, T. 27 N., R. 12 E. and sec. 19, T. 27 N., R. 11 W. 


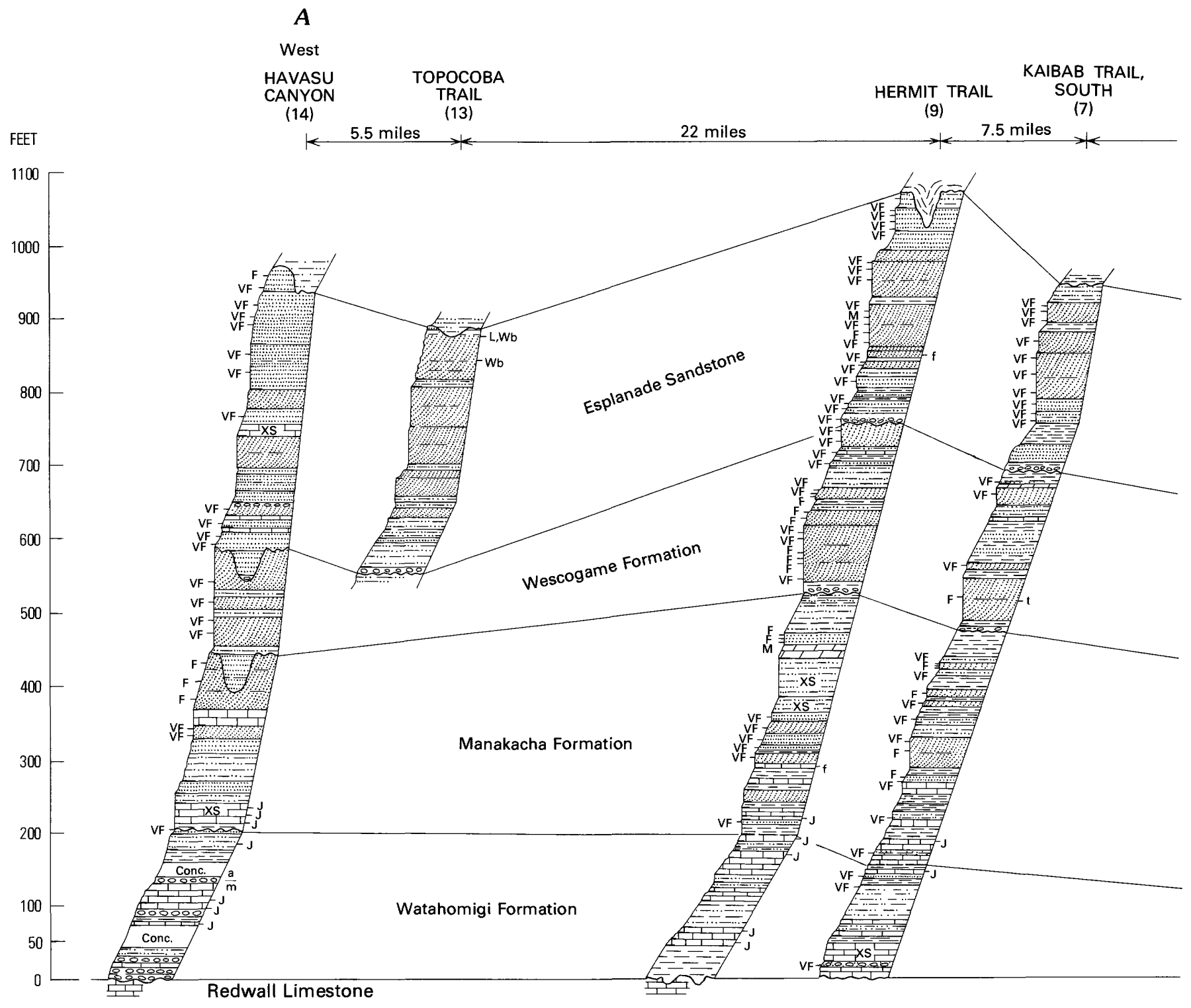

FIGURE A2.-Stratigraphic profiles of Supai Group along line $A-A^{\prime}$ (fig. A1)

beds for correlation, the locations of principal unconformities are established, thus subdividing the Supai Group in time as well as space.

Succeeding chapters of this volume are organized principally on the basis of lithology. For each rock type, consideration is given to such features as texture, structure, geometry, and fossils. This publication has been organized to permit easy comparisons, using tables, charts, and diagrams of various attributes such as grain size frequency, distribution of grain forms, direction of current movement, shape and percent of various types of grains, that lend themselves to quantitative measurement. Thus, it should be possible to directly compare these attributes within the principal geographic units-east, central, and western parts of the area-and, finally, between the ancient strata of the Supai and their various possible analogs as represented in selected models of modern environments.

\section{METHOD OF STUDY}

Plans for investigation of the Supai Group in Grand Canyon, like those for earlier studies of Paleozoic strata in that area, were designed to take full advantage of the excellent and nearly continuous exposures of the stratigraphic record. By using a network of carefully measured detailed 

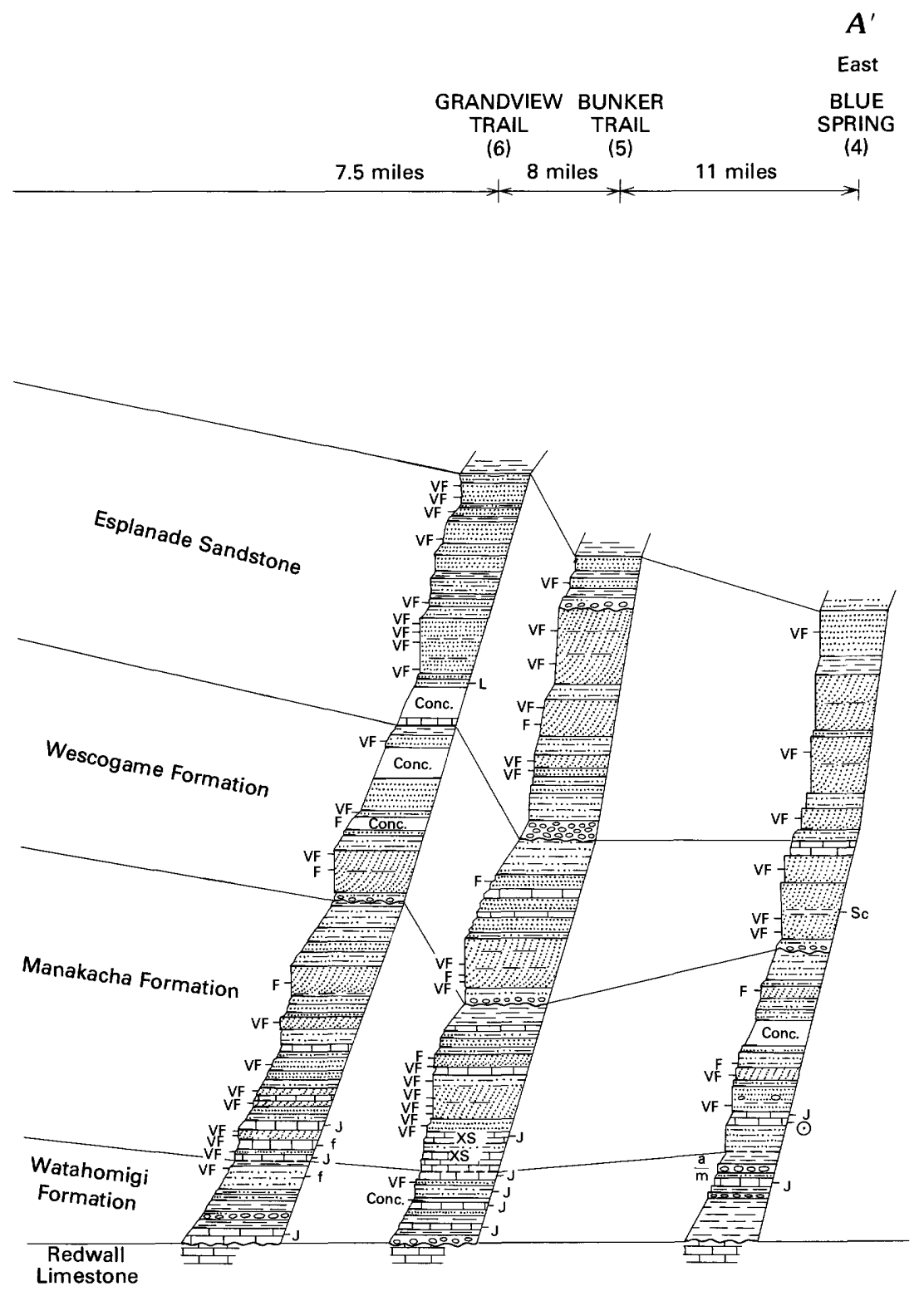

EXPLANATION

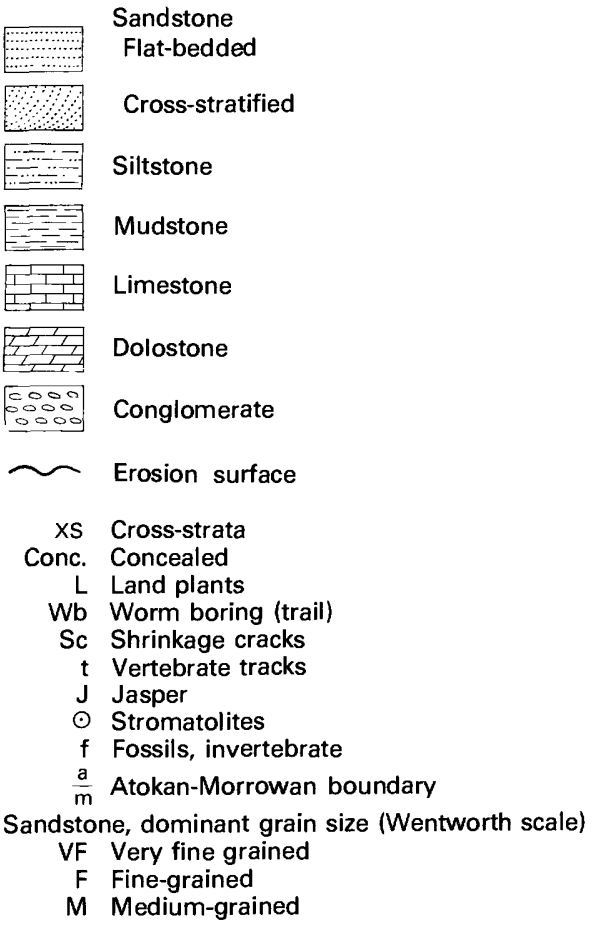

in Grand Canyon region, Arizona. Horizontal distance in miles is not to scale.

sections, the trends in lithologic and faunal change were determined and traced across an area approximately $150 \mathrm{mi}$ from east to west and $100 \mathrm{mi}$ from north to south (fig. A1).

Thirty-five sections of the Supai, distributed along the lines $A-A^{\prime} C-C^{\prime}$, and $F-F^{\prime}$ in a general east-west direction, and $B-B^{\prime}, D-D^{\prime}$, and $E-E^{\prime}-E^{\prime \prime}$ in a north-south direction (figs. A2-A8) were measured and described in detail. These sections record the principal lithologic units recognized in the field and give the all-important vertical dimension to the study. Various modifications of these stratigraphic columns were used as the bases on which to record, in three dimensions, such data as the distribution of fossils, the size and sorting of sand grains, directional vectors of cross-bedding, calcium-magnesium ratios, and various other features of each formation. In brief, the vertical sections became responsible for conclusions concerning the trends and interpretation of the geologic attributes of each formation.

In addition to field studies, in many of which a statistical approach was used, numerous laboratory investigations were undertaken. These included the petrographic examination of 970 thin sections, the study of more than 1,000 insoluble-residue samples, the compiling and interpreting of 524 calcium-magnesium ratios, and the plotting of 272 mechanical analyses (grain determinations by sieving) of sandstones. 


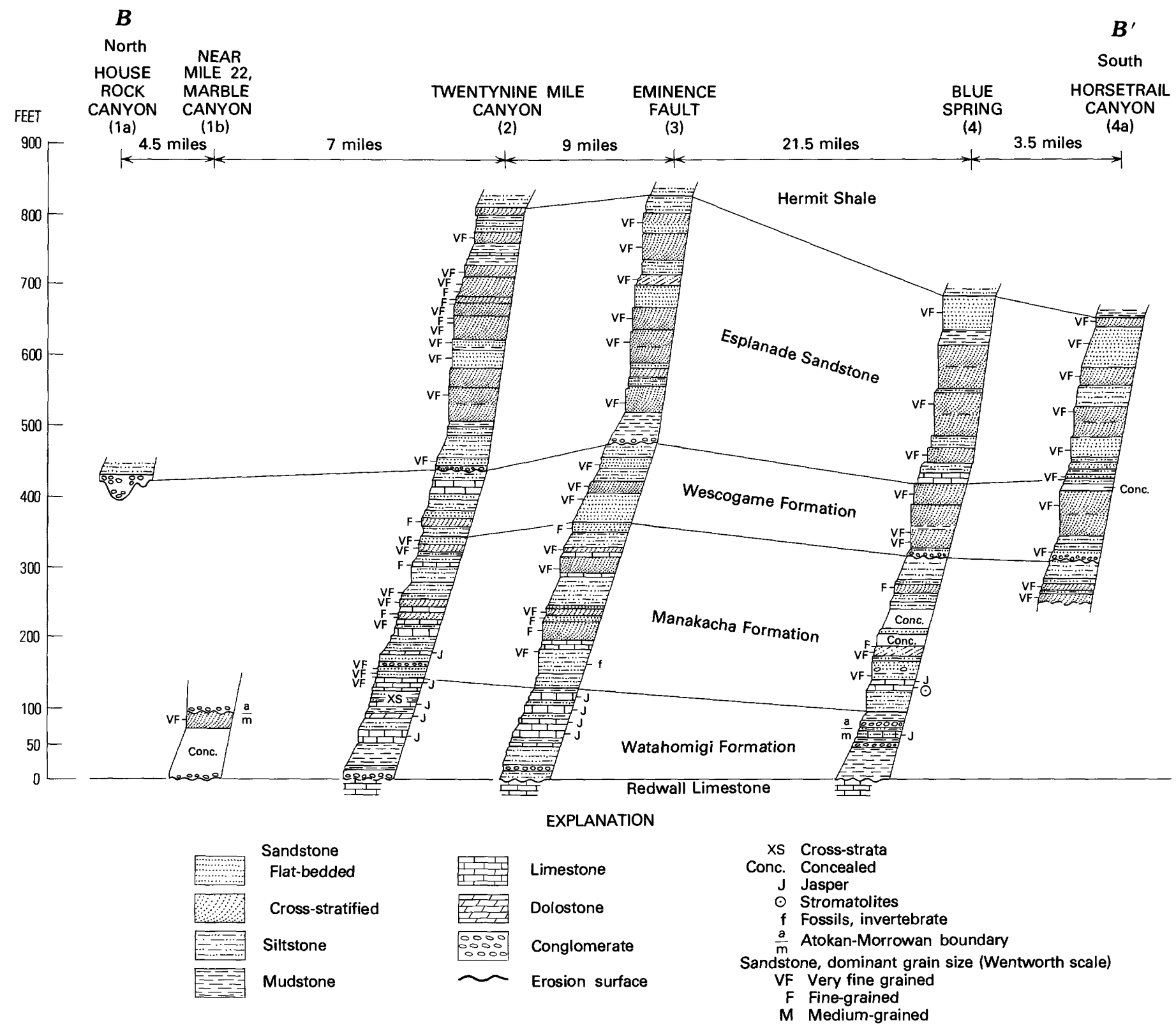

FIGURE A3.-Stratigraphic profiles of Supai Group along line $B-B^{\prime}$ (fig. A1) in Grand Canyon region, Arizona. Horizontal distance in miles is not to scale.

\section{TERMINOLOGY FOR PRINCIPAL ROCKS}

In general, standard terms for the basic rock types are used throughout this publication, but a few words in which usage is controversial or meaning is somewhat ambiguous are defined here for the sake of clarity.

For all detrital rocks the size grade scale of Wentworth (Wentworth, 1922) is used throughout, both for sediment (disaggregated grains) and for sedimentary rocks (consolidated sediment). Thus, in the largest size, four grades of gravel, ranging from $2 \mathrm{~mm}$ upward, are recognized; in the intermediate or sand size, five grades ranging from $1 / 16$ to $2 \mathrm{~mm}$ are recognized, and in the smallest size, consisting of silt and clay, two grades are recognized.

The name "shale" has been used by geologists in three different senses, referring to (1) fine grain size, (2) splitting property or fissility of rock, and (3) composition (argillaceous character). The term "shale" is here restricted to the second use: mudstone with splitting properties. Wherever it is desirable to distinguish mineralogic composition, the terms "argillaceous" or "carbonate" are used in conjunction with mudstone. Where the grain size has been determined, the rock is termed either "siltstone" $(1 / 16-1 / 256 \mathrm{~mm})$ or "claystone" $(<1 / 256 \mathrm{~mm})$, or "mudstone" if both occur in 
roughly equal proportions.

For carbonate rocks containing large proportions of quartz grains (as much as 50 percent), the term "arenaceous" is used to indicate the presence of quartz grains; the term "sandy" is used to indicate the size class, as opposed to "silty."

The term "limestone" designates all rocks dominantly composed of $\mathrm{CaCO}_{3}$; rocks with the $\mathrm{CO}_{3}$ radical, including both limestone and dolostone, are generally referred to as "carbonate rocks." The mineral $(\mathrm{Ca}, \mathrm{Mg}) \mathrm{CO}_{3}$ is referred to as "dolomite"; the rock formed of this mineral is termed "dolostone."

Limestone with very fine (aphanitic) texture is referred to as a "carbonate mudstone" or "micrite."

Sandstone with a high content of calcium carbonate (but less than 50 percent) is termed "calcareous sandstone," not limy sandstone.

Carbonate rocks for which $\mathrm{Ca}-\mathrm{Mg}$ ratios have been determined are classed as follows:

\begin{tabular}{|c|c|}
\hline & Molal ratio \\
\hline Dolostone & $1.0-1.20$ \\
\hline Calcitic dolostone & $1.20-\quad 2.85$ \\
\hline Dolomitic limestone & $2.85-17.67$ \\
\hline Magnesian limestone & $17.67-36.19$ \\
\hline imestone & $36.19-100.00$ \\
\hline
\end{tabular}

With the exception of the size grade scale, all measurements were made in inches, feet, or miles and are so reported. The following English-metric conversion scales are given for the convenience of the reader. They are for visual comparison only and do not represent actual units of measurement.

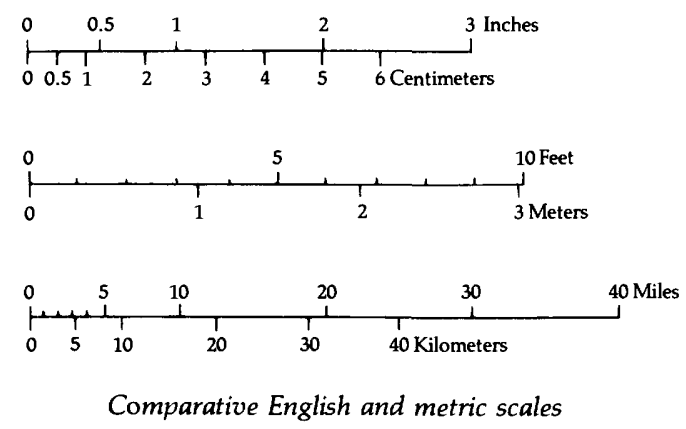

Conversion units from English to metric are as follows: 1 in. $=2.54 \mathrm{~cm} ; 1 \mathrm{ft}=0.3048 \mathrm{~m} ; 1 \mathrm{mi}=1.609 \mathrm{~km} ; 1 \mathrm{mi}^{2}$ $=2.6 \mathrm{~km}^{2}$.

\section{ACKNOWLEDGMENTS}

Field investigations of the Supai Group in Grand Canyon, carried on intermittently (1-3 months per year) over a period of about 14 years, were made with the assistance of numerous geologists. I wish to gratefully acknowledge the help of the following, each of whom accompanied me during one or more field seasons: Thomas A. Sterrett, James Mytton, Claude H. Baker, Donald C. Koenig, Joseph M. Barrett, John McDowell, Willard McCracken, and Kenneth Gardner. Thanks are also due numerous geologists not with the U.S. Geological Survey who contributed much help in the field on a voluntary basis. They are as follows: David Niev, William Breed, Carlos Renaldi, Manfred Hobbler, Kenneth Hamblin, and George Billingsley.

Laboratory work, supplementing the field investigations included preparation of mechanical analyses by sieving, insoluble-residue determinations and calcium-magnesium ratio analyses, all by Robert Gantner of the U.S. Geological Survey's Denver sedimentation laboratory. Compilation of textural data for sandstones, and determination of stratigraphic and distribution patterns for lithologic types were largely by Suzanne Rittenhouse and Kenneth Gardner. Thin-section studies and microfacies analyses of carbonate rocks were by Walter Pierce. Credit also is due Walter Pierce for compiling data on insoluble-residue analyses. The series of histograms in chapter $M$, illustrating the trends of these analyses, was prepared by James Gude III.

The determination of clay minerals, the study of their distribution patterns, and their interpretation were by Phoebe Hauff, who is largely responsible for chapter $O$. Assistance in the preparation of the clay samples for analysis was given by Walter Pierce and Kenneth Gardner.

Most figures were prepared from field sketches and measurements. Fossil-distribution charts and paleogeographic maps were drafted by Curt Mast; the cover portraying the type section of the Supai Group, the fence diagrams of each formation, and various drawings of unconformities and lithologic relations were by William Chesser. Profiles of measured stratigraphic sections were by Sarah Andrews; most other illustrations, including charts of the key conglomerate beds, of cross-bedding types and of lithologic distribution were drafted by Bruce Towsner, Leslie Anderson, Tony Vaccavello, and Robert Cull of the Boulder Vocational Technological Center.

Acknowledgment of much assistance and helpful suggestions in the preparation and editing of the manuscript is extended to Diane C. Schnabel, Paula Hansley, and Sigrid Asher-Bolinder of the U.S. Geological Survey. For a careful and accurate job of preparing the descriptions of "Measured Sections" that are basic to the study, sincere thanks are given Margery Cater, and for manuscript preparation in the early stages much credit is due Shirley Person, Helen Colburn, and Hyla Strickland of the U.S. Geological Survey.

Faunal determinations for each of the fossil groups represented in the Supai and related pre-Supai strata were by specialists as follows: 


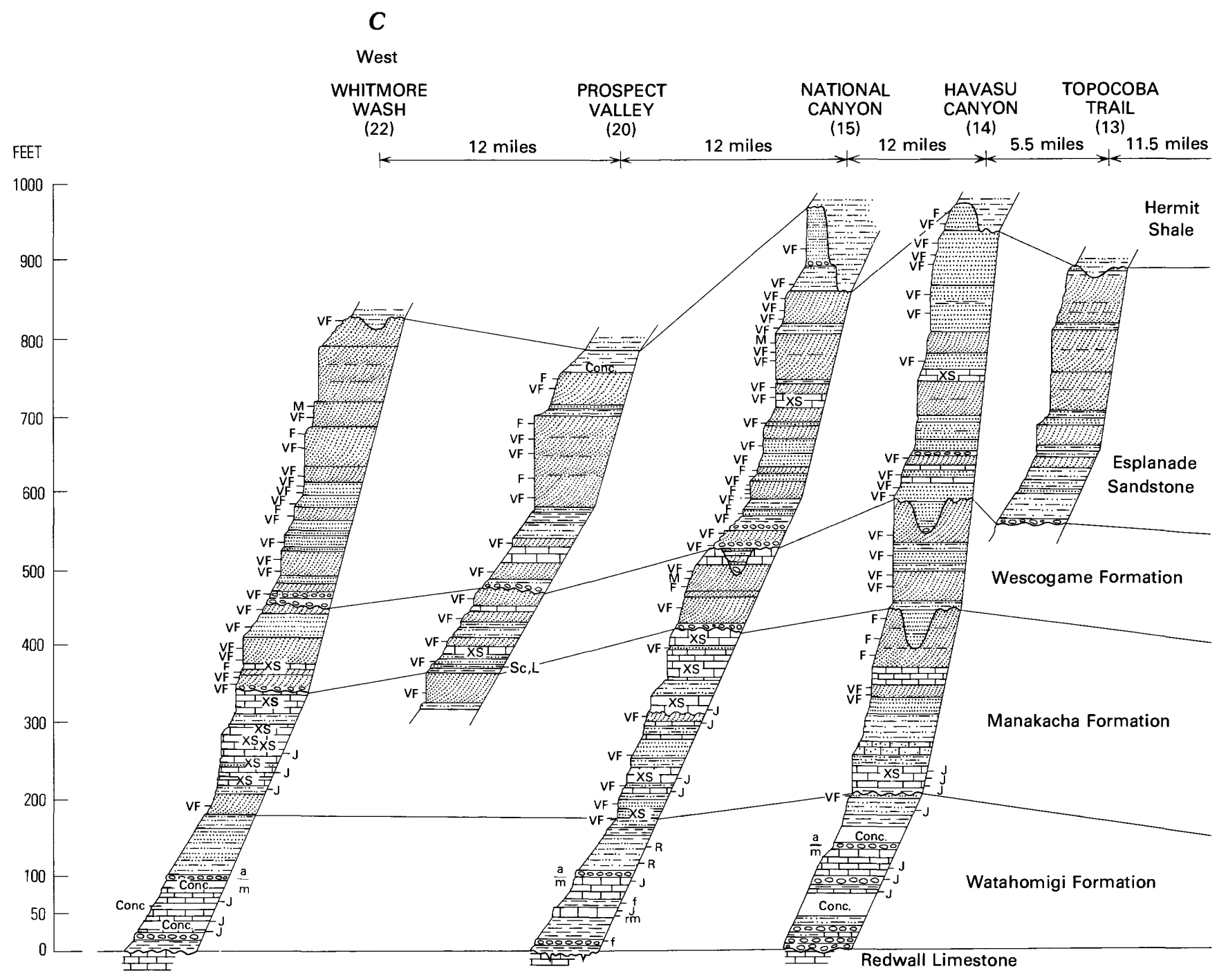

Small foraminifers ...... L. G. Henbest, retired.

Bernard Mamet, University of Montreal.

Endothyrids $\ldots \ldots \ldots$. Betty Skipp, USGS

(U.S. Geological Survey).

Fusulinids .......... Raymond C. Douglass, USGS.

Corals $\ldots \ldots \ldots \ldots \ldots$ W. J. Sando, USGS.

Bryozoans ............ Helen Duncan, USGS.

Brachiopods .......... Mackenzie Gordon, Jr., USGS.

R. E. Grant, USGS.

Gastropods .......... E. L. Yochelson, USGS.

Pelecypods .......... John Pojeta, Jr., USGS.

Conodonts . . . . . . . . John W. Huddle, USGS.

Fish . . . . . . . . . . . David H. Dunkle, USGS.

Two of these paleontologists, Sando and Douglass, visited critical fossil localities in the field; most of the paleontolo-

FIGURE A4.-Stratigraphic profiles of Supai Group along line $C-C^{\prime}$ (fig. A1)

gists also furnished valuable information on ecology and age determination for the specimens examined. Sincere thanks are extended to all of them for their assistance.

Chapter F, entitled "Biostratigraphy of the Watahomigi Formation," has been prepared by Mackenzie Gordon, Jr., based on collections made during fieldwork on the Supai Group. This study represents a detailed analysis of the megascopic invertebrate faunas of the Watahomigi, a stratigraphic analysis of their distribution patterns, and a discussion of broad correlation problems.

Chapter $\mathrm{G}$ on pre-Supai buried valleys is a description and discussion by George Billingsley and E. D. McKee of a part of the stratigraphic record immediately preceding and leading up to the beginning of Watahomigi history. It is based on the discovery by Billingsley of sediment-filled valleys within the Redwall and beneath the Supai in parts of western Grand Canyon. 


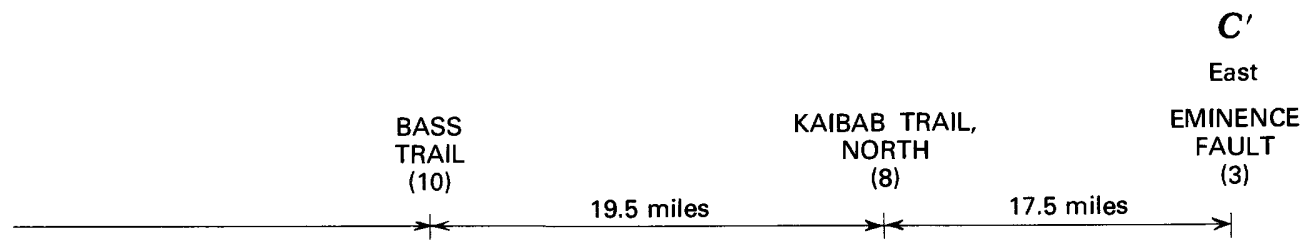

\section{EXPLANATION}

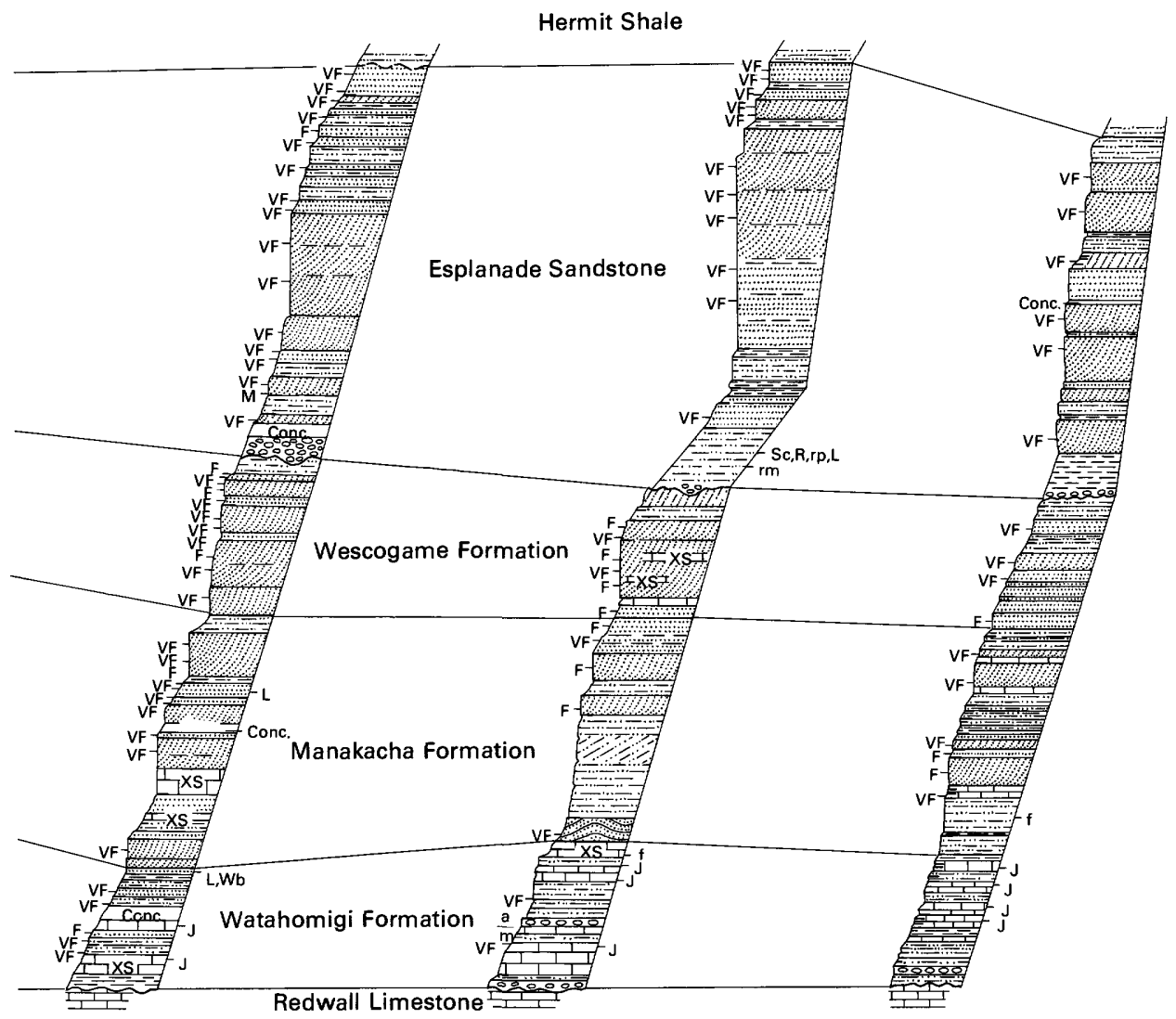

\begin{tabular}{|c|c|}
\hline$\ldots$ & $\begin{array}{l}\text { Sandstone } \\
\text { Flat-bedded }\end{array}$ \\
\hline & Cross-stratified \\
\hline 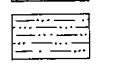 & Siltstone \\
\hline $\begin{aligned} E=-7 \\
=-7\end{aligned}$ & Mudstone \\
\hline 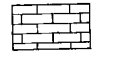 & Limestone \\
\hline $\begin{array}{l}000 \\
0000 \\
0000\end{array}$ & Conglomerate \\
\hline & Erosion surface \\
\hline $\begin{array}{r}\text { XS } \\
\text { Conc. }\end{array}$ & $\begin{array}{l}\text { Cross-strata } \\
\text { Concealed }\end{array}$ \\
\hline & Land plants \\
\hline $\begin{array}{l}\text { Wb } \\
S c\end{array}$ & Worm boring (trail) \\
\hline $\begin{array}{l}\mathrm{Sc} \\
\mathrm{rm}\end{array}$ & $\begin{array}{l}\text { Shrinkage cracks } \\
\text { Ripple marks }\end{array}$ \\
\hline $\begin{array}{l}r p \\
R \\
J \\
f\end{array}$ & $\begin{array}{l}\text { Rain pits } \\
\text { Rivularites sp. } \\
\text { Jasper } \\
\text { Fossils, invertebrate }\end{array}$ \\
\hline$\frac{a}{m}$ & $\begin{array}{l}\text { Atokan-Morrowan boundary } \\
\text { Sandstone, dominant grain size } \\
\text { (Wentworth scale) }\end{array}$ \\
\hline $\begin{array}{l}\text { VF } \\
F \\
M\end{array}$ & $\begin{array}{l}=\text { Very fine grained } \\
=\text { Fine-grained } \\
\end{array}$ \\
\hline
\end{tabular}

in Grand Canyon region, Arizona. Horizontal distance in miles is not to scale.

\section{REFERENCES CITED}

Baars, D. L., 1962, Permian system of Colorado Plateau: American Association of Petroleum Geologists Bulletin, v. 46, no. 2, p. 149-218.

Billingsley, G. H., Jr., 1970, General geology of Tuckup Canyon, central Grand Canyon, Mohave County, Arizona: Northern Arizona University, M.S. thesis, $115 \mathrm{p}$.

Bissell, H. J., 1962, Pennsylvanian and Permian rocks of Cordilleran area, in Pennsylvanian System in the United States-A symposium: American Association of Petroleum Geologists, p. 188-263.

1969, Permian and Lower Triassic transition from shelf to basin (Grand Canyon, Arizona to Spring Mountains, Nevada), in Geology and natural history of the Grand Canyon region: Four Corners Geological Society Guidebook, p. 135-169.

Brew, D. C., 1965, Stratigraphy of the Naco Formation (Pennsylvanian) in central Arizona: Cornell University, Ph. D. thesis, 230 p.

Brill, K. G., Jr., 1963, Permo-Pennsylvanian stratigraphy of western Colorado plateau and eastern Great Basin regions: Geological Society of America Bulletin, v. 74, no. 3, p. 307-330.
Cassity, P. E., and Langenheim, R. L., Jr., 1966, Pennsylvanian and Permian fusulinids of the Bird Spring Group from Arrow Canyon, Clark County, Nevada: Journal of Paleontology, v. 40, no. 4, p. 931-968.

Darton, N. H., 1910, A reconnaissance of parts of northwestern New Mexico and northern Arizona: U.S. Geological Survey Bulletin 435, $88 \mathrm{p}$.

Douglass, R. C., 1974, Fusulinids in the Basin and Range province in California, Nevada, and Utah: Journal of Paleontology, v. 48, no. 4 , p. 846-853.

Dutton, C. E., 1882, Tertiary history of the Grand Canyon district: U.S. Geological Survey Monograph 2, 264 p.

Fisher, W. L., 1962, Upper Paleozoic and Lower Mesozoic stratigraphy of Parashant and Andrus Canyons, Mohave County, northwestern Arizona: Kansas University, Ph. D. thesis, 345 p.

Gerrard, T. A., 1964, Environment studies of the Fort Apache Member, Supai Formation (Permian), east-central Arizona: Arizona University, Ph. D. thesis, $187 \mathrm{p}$.

Gilbert, G. K., 1875, Report on the geology of portions of Nevada, Utah, California, and Arizona, examined in the years 1871, 1872, and 1873: U.S. Geographical and Geological Surveys West of the 100th Meridian (Wheeler), v. 3, p. 17-187. 
D
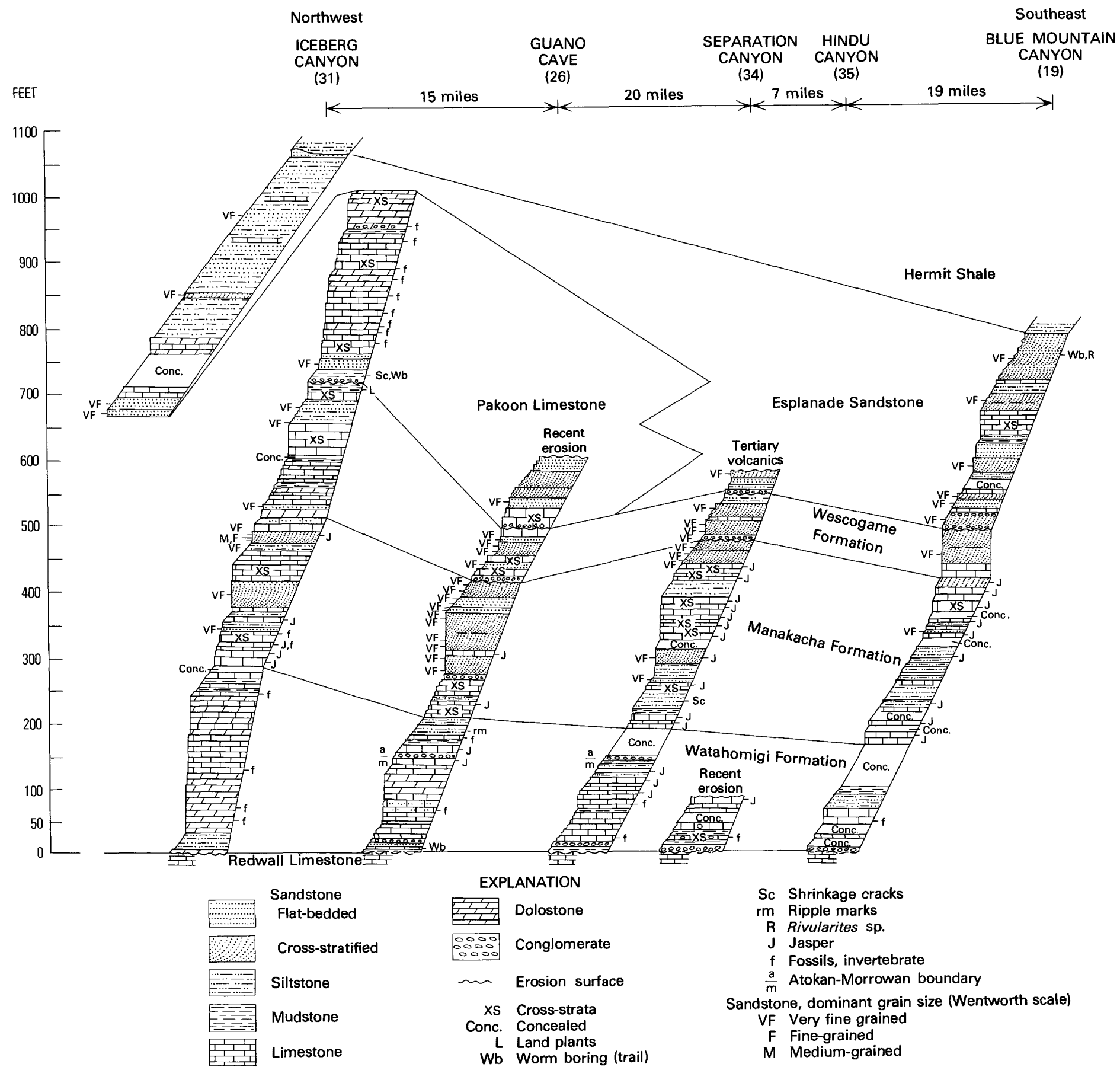

FIGURE A5.-Stratigraphic profiles of Supai Group and Pakoon Limestone (McNair, 1951; equivalent to lower part of Esplanade Sandstone in western Grand Canyon, Arizona) along line $D-D^{\prime}$ (fig. A1). Horizontal distance in miles is not to scale.

Gilmore, C. W., 1927, Fossil footprints from the Grand Canyon; second contribution: Smithsonian Miscellaneous Collection, v. 80, no. 3, $78 \mathrm{p}$.

1928, Fossil footprints from the Grand Canyon; third contribution: Smithsonian Miscellaneous Collection, v. 80, no. 8, 16 p.

Heath, C.P.M., 1965, Microfacies of the Lower Bird Spring Group (Pennsylvanian-Permian), Arrow Canyon Range, Clark County, Nevada: Illinois University, Ph. D. thesis, 163 p.
Heath, C.P.M., Lumsden, D. N., and Carozzi, A. V., 1967, Petrography of a carbonate, transgressive-regressive sequence-The Bird Spring Group (Pennsylvanian), Arrow Canyon Range, Clark County, Nevada: Journal of Sedimentary Petrology, v. 37, p. 377-400.

Huddle, J. W., and Dobrovolny, E., 1945, Late Paleozoic stratigraphy and oil and gas possibilities of central and northeastern Arizona: U.S. Geological Survey Oil and Gas Investigations Preliminary Chart 10. 


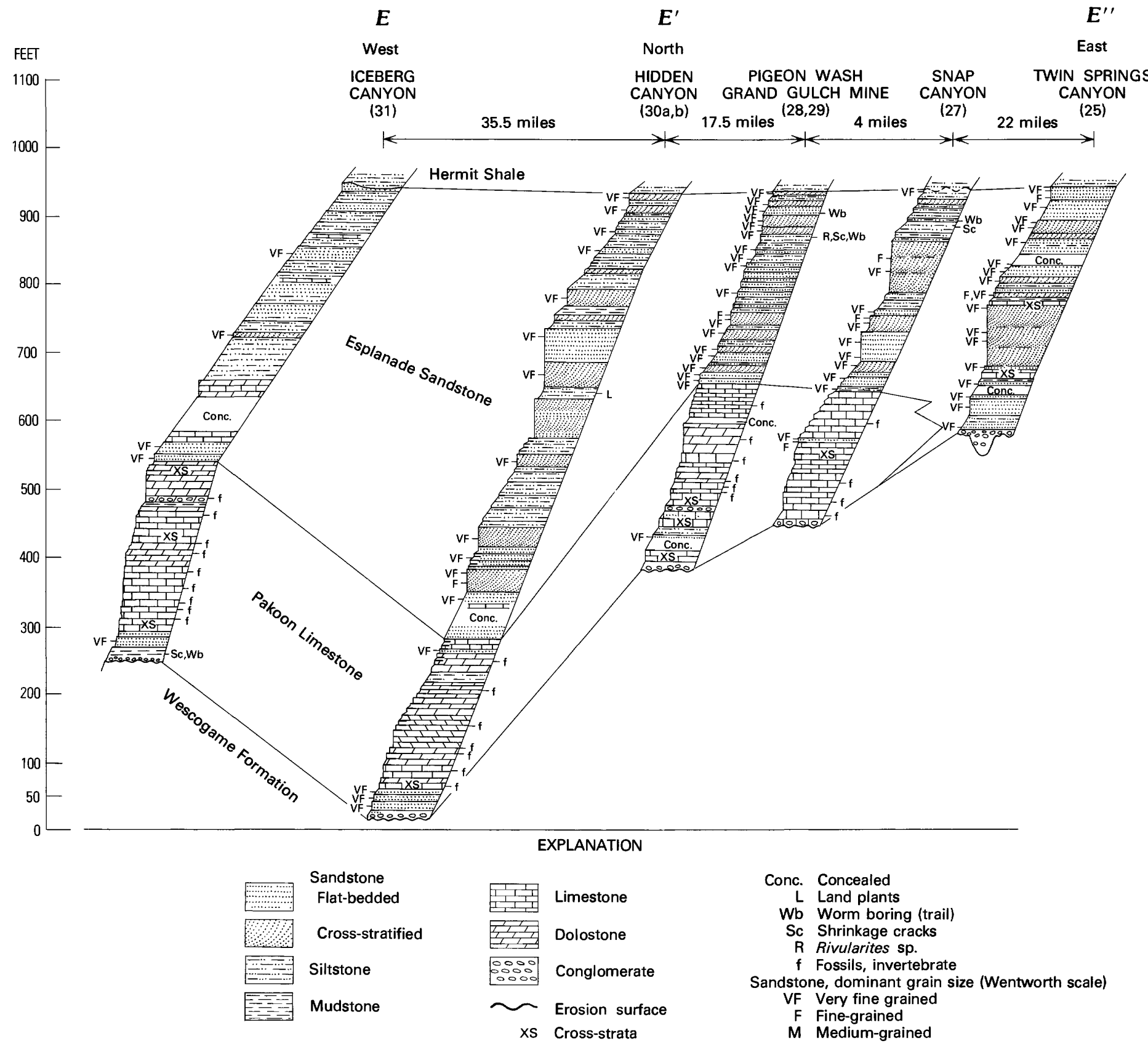

FIGURE A6.-Stratigraphic profiles of upper part of Supai Group and Pakoon Limestone (McNair, 1951; equivalent to lower part of Esplanade Sandstone in western Grand Canyon, Arizona) along line $E-E^{\prime}-E^{\prime \prime}$ (fig. A1). Horizontal distance in miles is not to scale.

Hughes, P. W., 1949, History of the Supai Formation in Black Mesa, Yavapai County, Arizona: Plateau, v. 22, no. 2, p. 32-36.

1952, Stratigraphy of Supai formation, Chino Valley area, Yavapai County, Arizona: American Association of Petroleum Geologists Bulletin, v. 36, no. 4, p. 635-657.

Jackson, R. L., 1951, The stratigraphy of the Supai Formation along the Mogollon Rim, central Arizona: Arizona University, M.S. thesis, $82 \mathrm{p}$.

Langenheim, V.A.M., and Langenheim, R. L., 1965, The Bird Spring Group, Chesterian through Wolfcampian at Arrow Canyon, Arrow Canyon Range, Clark County, Nevada: Illinois State Academy of Science Transactions, v. 58, p. 225-240.
Lokke, D. H., 1962, Paleontological reconnaissance of subsurface Pennsylvanian in southern Apache and Navajo Counties, Arizona: New Mexico Geological Society 13th Field Conference Guidebook, p. 84-86.

Lumsden, D. N., 1965, Microfacies of the Middle Bird Spring Group (Pennsylvanian-Permian), Arrow Canyon Range, Clark County, Nevada: Illinois University, Ph. D. thesis, 110 p.

Lumsden, D. N., Ledbetter, M. T., and Smith, G. T., 1973, Lithostratigraphic analysis of the Bird Spring-Callville Group and Pakoon Formation (Pennsylvanian-Lower Permian), southern Clark County, Nevada: Journal of Sedimentary Petrology, v. 43, no. 3, p. 655-671. 


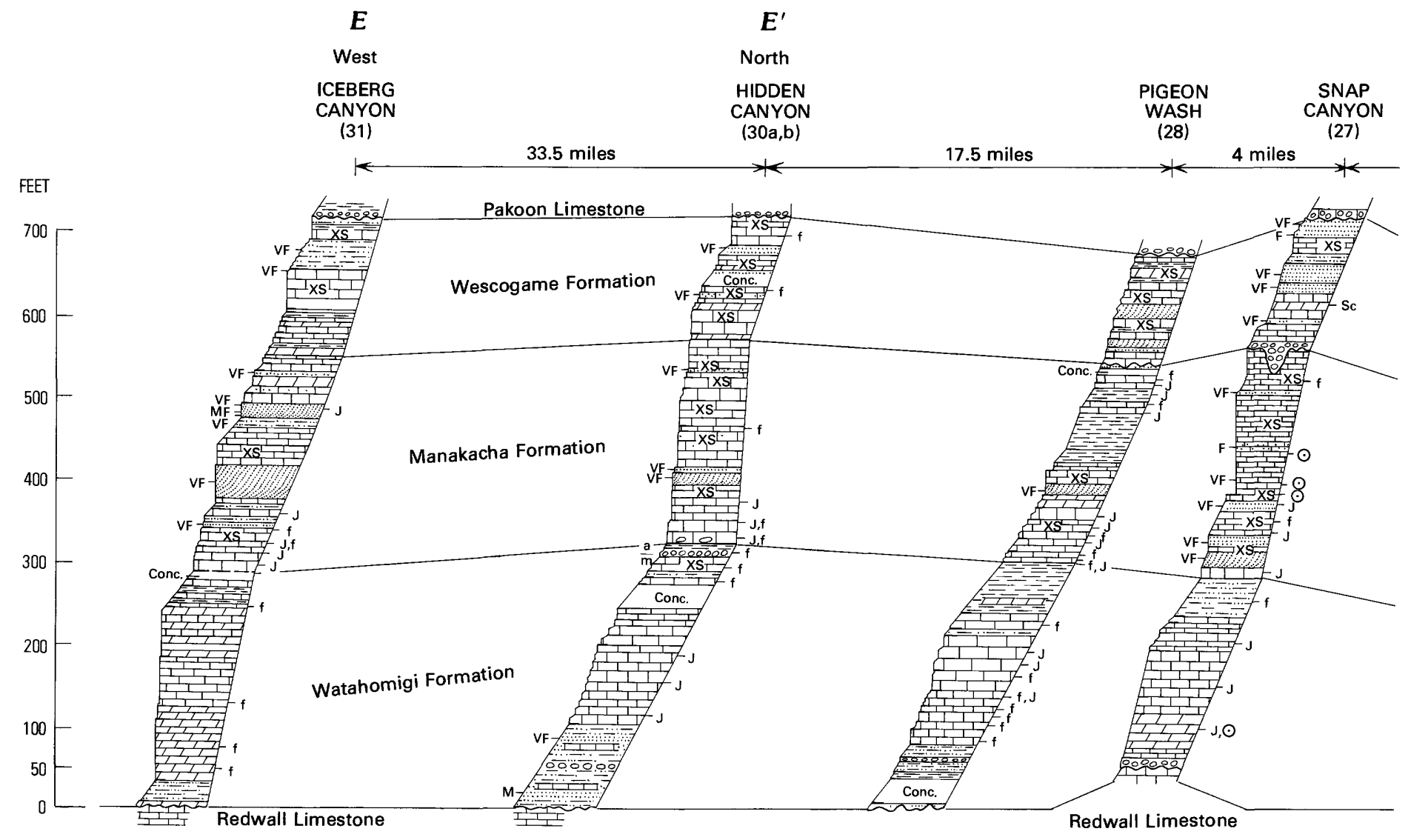

FIGURE A7,-Stratigraphic profiles of lower part of Supai Group and Pakoon Limestone (MCNair, 1951; in western Grand Canyon, Arizona) along line $E-E^{\prime}-E^{\prime \prime}$ (fig. A1). Horizontal

McKee, E. D., 1937, Researches on Paleozoic stratigraphy in western Grand Canyon: Carnegie Institution of Washington Year Book 36, p. 332-345.

1938, Researches on Paleozoic stratigraphy in Grand Canyon: Carnegie Institution of Washington Year Book 37 (1937-38), p. 358. 1940a, Three types of cross-lamination in Paleozoic rocks of northern Arizona: American Journal of Science, v. 238, no. 11, p. 811-824.

1940b, Studies on the history of Grand Canyon Paleozoic formations: Carnegie Institution of Washington Year Book 39 (1939-40).

1947, Paleozoic seaways in western Arizona: American Association of Petroleum Geologists Bulletin, v. 31, no. 2, p. 282-292.

1951. Sedimentary basins of Arizona and adjoining areas: Geological Society of America Bulletin, v. 62, no. 5, p. 481-505.

1975, The Supai Group-Subdivision and nomenclature: U.S. Geological Survey Bulletin 1395-J, p. J1-J11.

McNair, A. H., 1951, Paleozoic stratigraphy of part of northwestern Arizona: American Association of Petroleum Geologists Bulletin, v. 35, no. 3, p. 503-541.

Marcou, Jules, 1856, Resume and field notes, in U.S. Pacific Railroad Exploration: U.S. 33d Congress session, Senate Executive Document 78 and House of Representatives Executive Document 91, v. 3 . pt. 4, Geological Report, p. 165-171.

Merrill, W. M., and Winar, R. M., 1958, Molas and associated formations in San Juan basin-Needle Mountains area, southwestern Colorado: American Association of Petroleum Geologists Bulletin, v. 42, no. 9, p. 2107-2132.
Newberry, J. S., 1861, Geological report, in J. C. Ives, Report upon the Colorado River of the West: U.S. 36th Congress, 1st Session, Senate Executive Document and House Executive Document 90, p. 3, Geological Report, p. 59, 62-64.

Noble, L. F., 1922, A section of the Paleozoic formations of the Grand Canyon at the Bass Trail: U.S. Geological Survey Professional Paper 131-B, p. 23-73.

O'Sullivan, R. B., 1965, Geology of the Cedar Mesa-Boundary Butte area, San Juan County, Utah: U.S. Geological Survey Bulletin 1186, $128 \mathrm{p}$.

Peirce, H. W., 1958, Permian sedimentary rocks of the Black Mesa Basin area, in Guidebook of the Black Mesa Basin, northeastern Arizona; New Mexico Geological Society, 9th Field Conference, Oct. 1958: p. 82-87.

Peirce, H. W., and Gerrard, T. A., 1966, Evaporite deposits of the Permian Holbrook basin, Arizona, in Symposium on salt, $2 \mathrm{~d}-\mathrm{v} .1$, Geology, geochemistry, mining: Cleveland, Ohio, Northern Ohio Geological Society, p. 1-10.

Peterson, J. A., 1959, Petroleum geology of the Four Corners area: World Petroleum Congress, 5th, New York, 1959, Proceedings, sec. 1, p. 499-523.

Peterson, J. A., and Ohlen, H. R., 1963, Pennsylvanian shelf carbonates, Paradox basin, in Shelf carbonates of the Paradox basin, a symposium-Four Corners Geological Society, 4th Field Conference, 1963: Durango, Colo., Petroleum Information Corp., p. 65-79.

Powell, J. W., 1875, Exploration of the Colorado River of the West and its tributaries explored in 1869-1872: Smithsonian Institution, $291 \mathrm{p}$. 


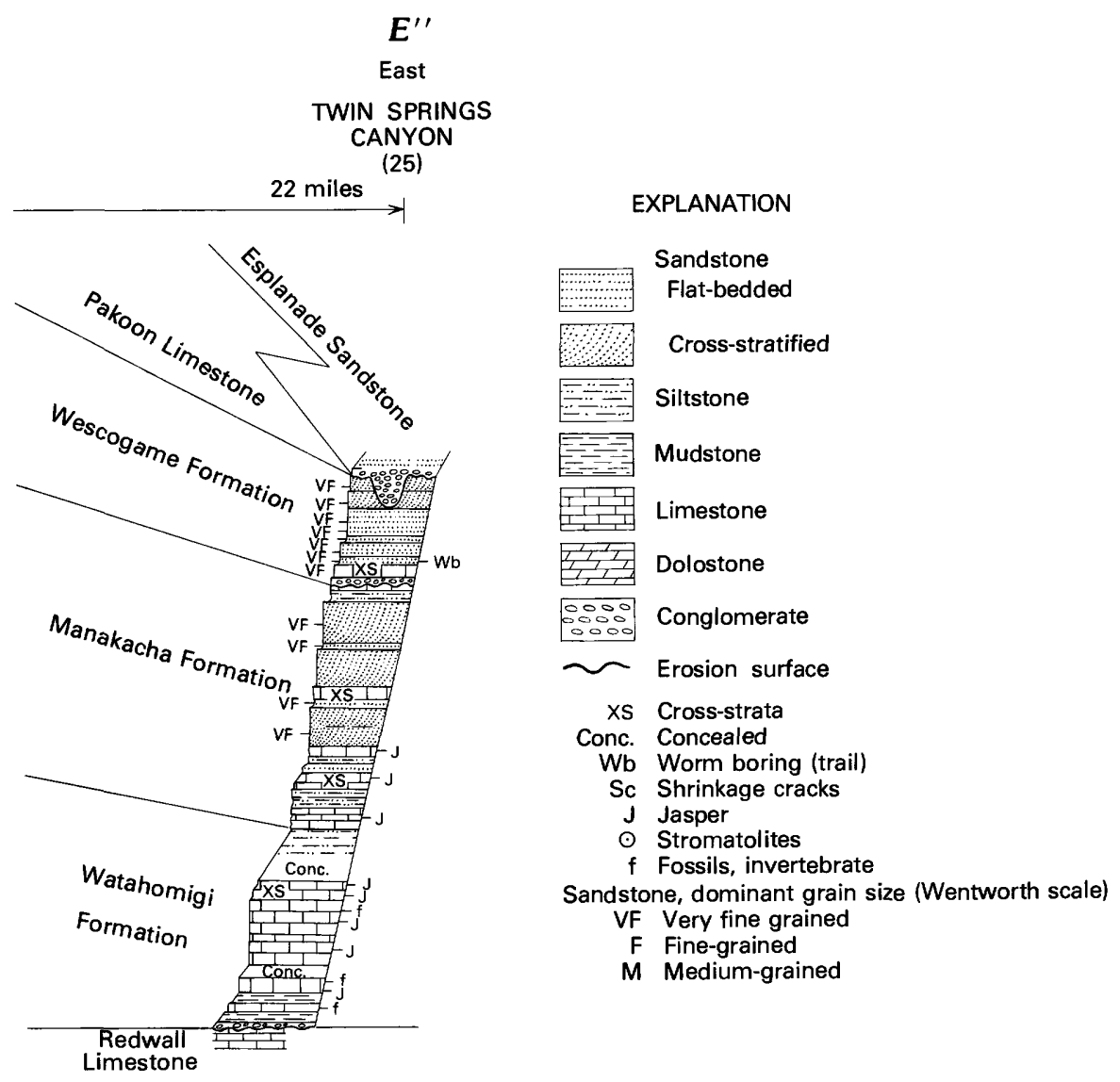

equivalent to lower part of Esplanade Sandstone distance in miles is not to scale.

Ross, C. A., 1973, Pennsylvanian and Early Permian depositional history, southeastern Arizona: American Association of Petroleum Geologists Bulletin, v. 57, no. 5, p. 887-912.

Sears, J. D., 1956, Geology of Comb Ridge and vicinity north of San Juan River, San Juan County, Utah: U.S. Geological Survey Bulletin 1021-E, p. 167-207.

Sorauf, J. E., 1962, Structural geology and stratigraphy of the Whitmore area, Mohave County, Arizona: Kansas University, Ph. D. thesis, $361 \mathrm{p}$.

Steele, G., 1959, Stratigraphic interpretation of the PennsylvanianPermian Systems of the eastern Great Basin: Washington University, $\mathrm{Ph}$. D. thesis, $294 \mathrm{p}$.

Walcott, C. D., 1880, The Permian and other Paleozoic groups of the Kanab Valley, Arizona: American Journal of Science, ser. 3, v. 20, p. 221-225.

Welsh, J. E., 1959, Biostratigraphy of the Pennsylvanian and Permian Systems of southern Nevada: Utah University, Ph. D. thesis, 106 p.
Wengerd, S. A., and Matheny, M. L., 1958, Pennsylvanian System of Four Corners region: American Association of Petroleum Geologists Bulletin, v. 42, no. 9, p. 2048-2106.

Wentworth, C. K., 1922, A scale of grade and class terms for clastic sediments: Journal of Geology, v. 30, no. 5, p. 377-392.

White, David, 1927, Study of the fossil flora in the Grand Canyon, Arizona: Carnegie Institution of Washington Year Book 26 (1926-27), p. 366-369.

1928, Study of the fossil floras in the Grand Canyon, Arizona: Carnegie Institution of Washington Year Book 27 (1927-28), p. 389-390.

1929, Flora of the Hermit Shale, Grand Canyon, Arizona: Carnegie Institution of Washington Publication 405, 221 p.

Winters, S. S., 1951, Permian stratigraphy in eastern Arizona: Plateau, v. 24 , no. 1 , p. 10-16.

1963, Supai formation (Permian) of eastern Arizona: Geological Society of America Memoir 89, $99 \mathrm{p}$. 


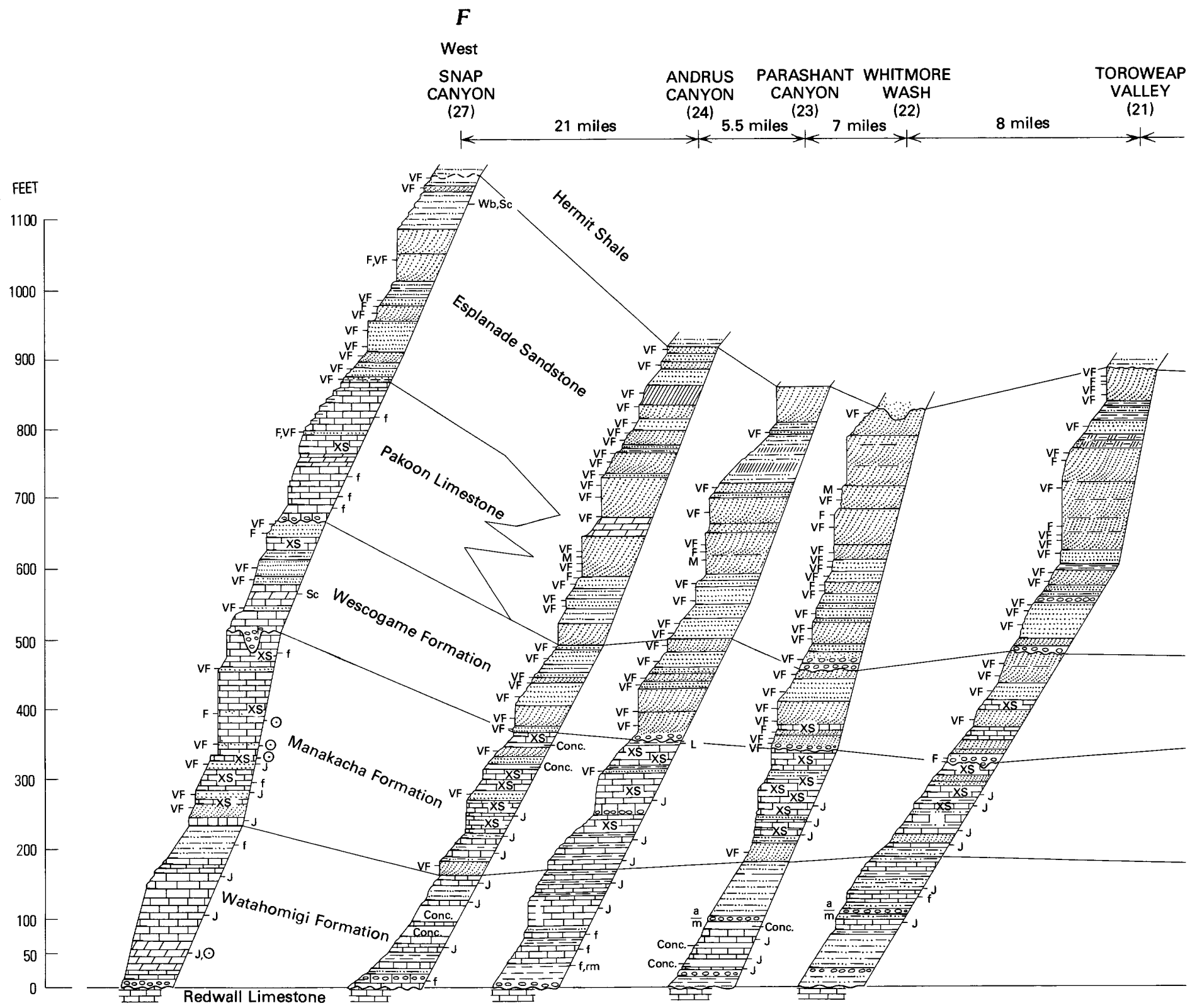

FIGURE A8.-Stratigraphic profiles of Supai Group and Pakoon Limestone (MCNair, 1951; equivalent to lower part of Esplanade Sandstone in western Grand Canyon) along line $F-F^{\prime}$ (fig. A1). Horizontal distance in miles is not to scale. 


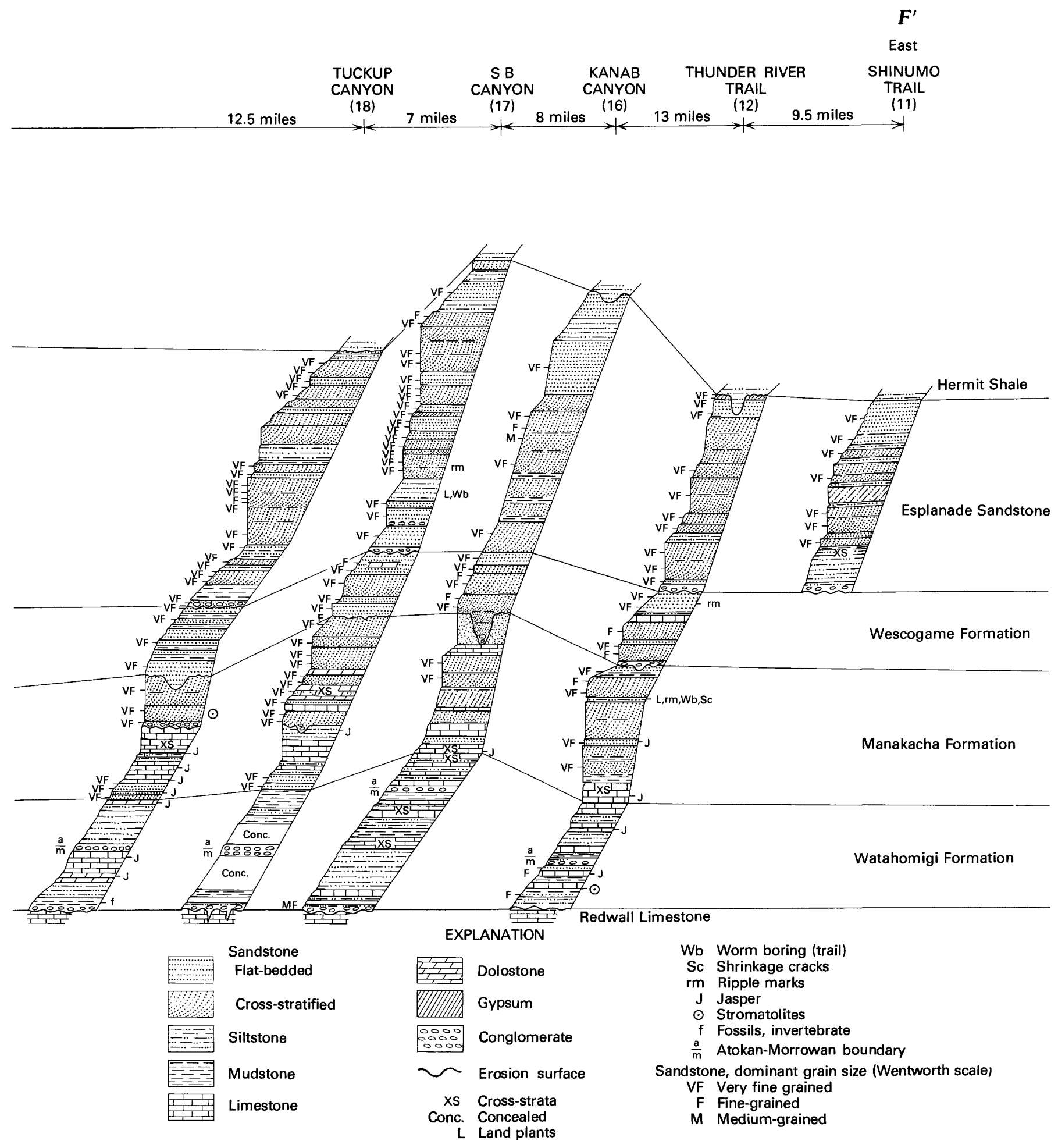




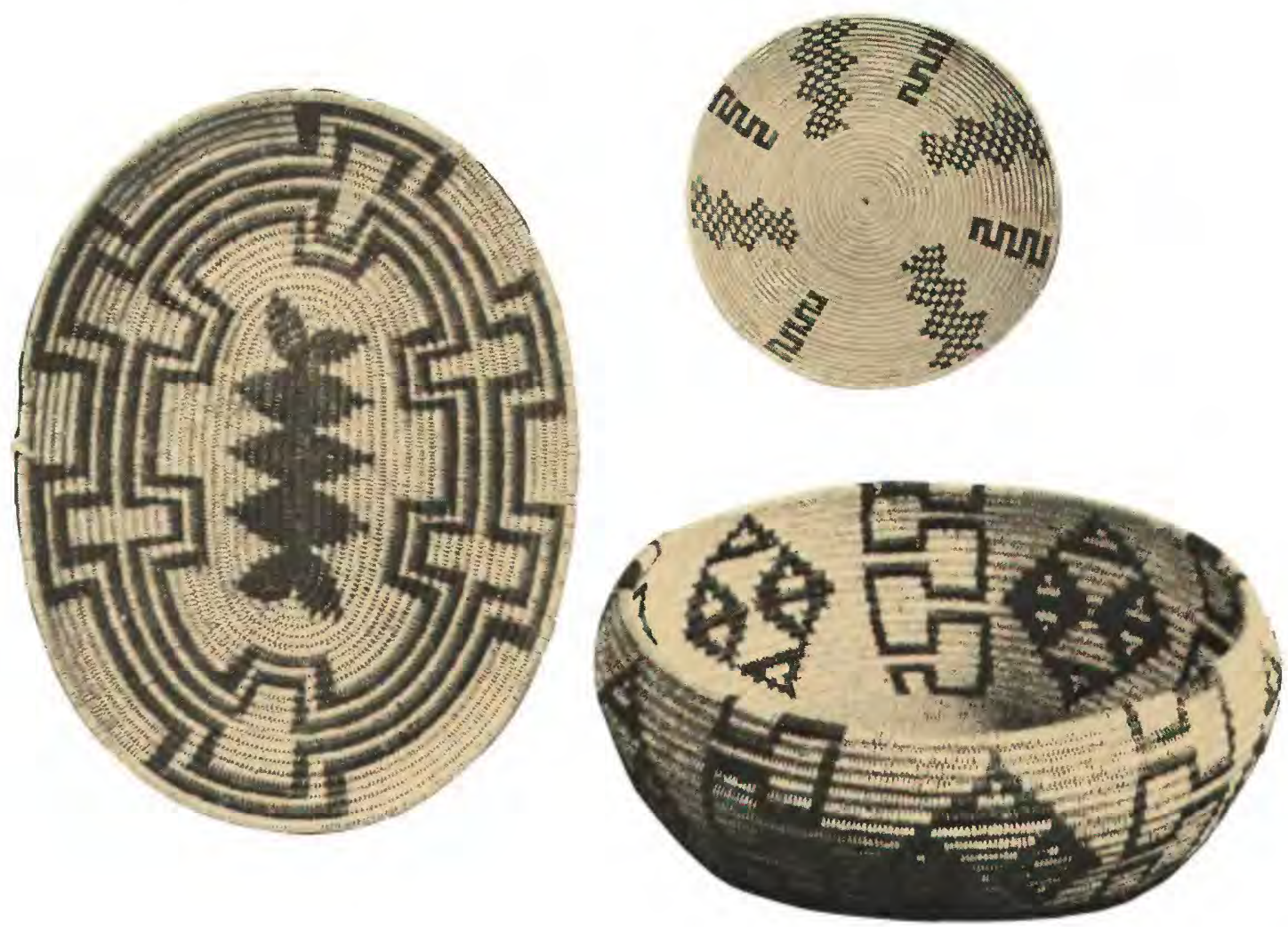

THE SUPAI GROUP OF GRAND CANYON

\section{INTRODUCTORY SUMMARY}

Chapter B

By EDWIN D. McKEE

\section{Contents}

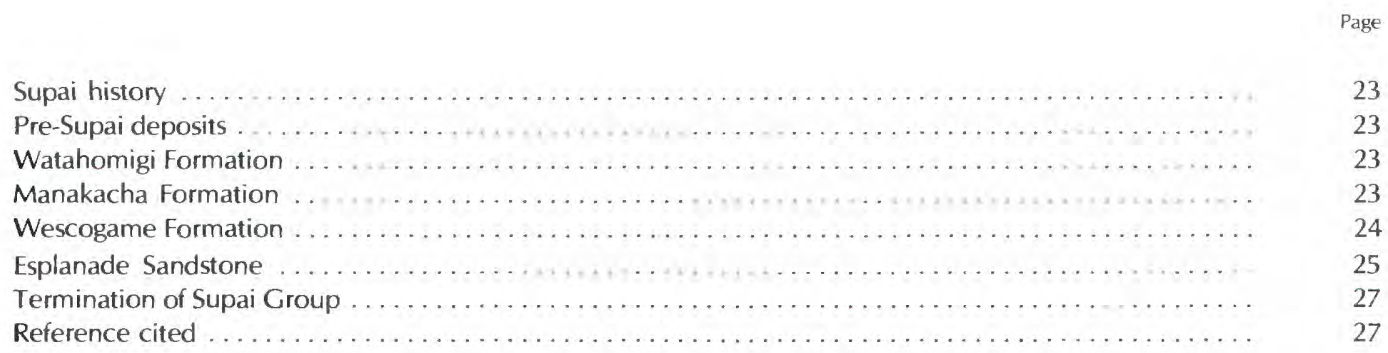





\section{SUPAI HISTORY}

The Pennsylvanian and Early Permian history of the Grand Canyon region consists principally of a series of four transgressions. Deposits of each transgression were more widespread than those of the preceding one, and included both marine and continental sediments. A period of nondeposition recorded by a widespread erosion surface marks the termination of each depositional cycle. The principal times of deposition are represented by the four formations of the Supai Group. Hiatuses between these formations, recorded by erosion surfaces, are of very different magnitudes, but all are of appreciable size.

\section{PRE-SUPAI DEPOSITS}

Events preceding deposition of the Supai and leading up to its evolutionary history consist of a regional uplift, probably epeirogenic, following retreat of the Redwall sea at the end of Early Mississippian time. The uplift amounted to at least several hundred feet in the Grand Canyon area as one or more narrow valleys, approximately $400 \mathrm{ft}$ deep, were carved by westward-flowing streams near its western margin. Following this tectonism, a change in relative sea level apparently caused the filling of these valleys with sediments, first with fluviatile deposits preserving land plants, and later with beds of carbonate sediments containing marine fossils of Late Mississippian (Chesterian) age.

\section{WATAHOMIGI FORMATION}

The history of the Watahomigi, the lowest formation of the Supai Group, began with an eastward transgression of the sea from the Cordilleran geosyncline into a restricted embayment in the Grand Canyon area. The sea advanced over a relatively flat but uneven surface, formed partly by karst topography at the top of the Redwall Limestone and partly by Chesterian strata that filled stream-cut valleys carved in the Redwall. A thin sheet of gravel, composed mostly of durable pebbles such as chert and flint, and locally containing brachiopods or other marine fossils, was spread over much of the area and was followed by layers of mud, silt, and eventually by carbonate deposits.

The Watahomigi Formation averages about $300 \mathrm{ft}$ thick in western Grand Canyon, about $200 \mathrm{ft}$ in the central area, and $100 \mathrm{ft}$ in the eastern part. The embayment was connected with the sea only along the west and northwest margins and, as determined by isopachs, probably was bordered by land in all other directions. Lithologic analyses indicate that the deposits in this embayment consisted mostly of carbonate sediment (60-90 percent) with some silt and argillaceous mud (10-40 percent) in the west, and dominantly of mud (50-85 percent) with relatively little carbonate sediment (15-35 percent) in the east. Sand was absent in the west and formed less than 15 percent in central and eastern localities.

The Watahomigi consists of three units, all of which are progressively thinner eastward. The lower two, as indicated by brachiopods, are of Morrowan age, whereas the upper is shown by fusulinids to be of Atokan age. Bioclastic debris, consisting of pelmatozoan, foraminifer, bryozoan, and bivalve fragments, occurs in all units and is common in many places in western Grand Canyon. However, this fossil debris is absent in all but a few localities in eastern Grand Canyon. Such distribution probably results from lack of marine connections at this time with seas to the northeast and to the southeast.

Clay minerals, like the fossils in the Watahomigi, show a relationship to environment; marine clays such as illite, chlorite, and corrensite are commonly associated with carbonate rocks of the western Grand Canyon, but kaolinite, which is considered nonmarine, probably deltaic, occurs in eastern Grand Canyon. The presence of some illite and corrensite, also in the eastern area, probably indicates local marine incursions that extended eastward beyond the main seaway at that time. A general lack of sand and accumulations of carbonate mud probably indicate a low-energy environment in most of the Grand Canyon embayment.

The amount of sandstone in the Watahomigi is very small compared with that in the other three formations of the Supai Group. It consists almost entirely of very fine grained sand, with only small amounts of coarser grains such as are common in the overlying formations. The proportion of sand to silt is about $1: 3$, whereas the overlying formations show between two and five times as much sand as silt. The percentage of samples that are skewed ( 25 percent) is low compared with that of the other formations. Large-scale cross-bedding is absent; small-scale, in the form of ripple laminae and climbing ripples, is only locally common. In brief, evidence furnished by the sandstone confirms evidence from other sources that a low-energy environment prevailed throughout the Grand Canyon embayment when the Watahomigi was being deposited.

\section{MANAKACHA FORMATION}

The Manakacha Formation, which is largely or entirely of Atokan age, is represented in the Grand Canyon region by several hundred feet of sediment, mostly marine, that filled an embayment much like that of the preceding Morrowan time. The principal difference in the paleogeography as recorded in these two formations is that during Atokan time the sea that transgressed from the southwest extended 
farther northeastward and connected with waters of the San Juan Basin in the Four Corners area of Arizona, New Mexico, Colorado, and Utah. The axis of maximum thickness as shown by an isopach map (fig. D10) confirms this trend, and illustrates why thickness of the Manakacha is essentially the same in western, central, and eastern Grand Canyon. A landmass, however, apparently still lay to the south and southeast.

Lithologically, the Manakacha differs greatly from the earlier Watahomigi. The Manakacha contains considerably more sandstone (10-30 percent in western Grand Canyon and 20-50 percent in eastern Grand Canyon) as compared to no sandstone in the west and only a few percent in the east for the Watahomigi. On the other hand, both mudstone and carbonate rock are mostly considerably less in the Manakacha than in the Watahomigi for corresponding areas. In the Manakacha, mudstone ranges from as much as 10 percent in the west to $30-60$ percent in the east; carbonate rock forms from 35-90 percent in the west, but only 5-20 percent in the east.

Faunal distribution in the Manakacha seems to be largely facies-controlled; however, it reflects to some degree the continuous passageway of the sea to the northeast. Three genera of fusulinids recorded from Atokan rocks of southern Nevada likewise occur in western Grand Canyon strata; two genera have also been found in eastern Grand Canyon. Although complete fossils of various other groups seem to be restricted to limestone facies of western Grand Canyon, numerous forms occur as bioclastic debris in strata of central and eastern, as well as western, Grand Canyon. Clasts of pelmatozoans, calcispherids, algae (Girvanella), and bivalves are recorded from various parts of central Grand Canyon, and all of these but the bivalves have been noted in eastern sections.

A large percentage of clays in the Manakacha are types considered to be marine. Illite is abundant in the northwestern part of the embayment where it probably is marine, as indicated at Andrus Canyon where 80 percent is associated with limestone. Some illite also occurs at scattered localities in eastern Grand Canyon. In that area, however, it is associated with continental sediments and is believed to have been derived from degraded detrital micas. For that reason, it probably does not constitute an indicator of depositional environment.

Corrensite, a clay of probably marine origin, has been recorded only from the western part of Grand Canyon. It is seldom, if ever, associated with sandstone in the Manakacha Formation and is believed to represent a low-energy, marine environment of restricted waters, especially in the vicinity of Toroweap Point and of Separation Canyon.

Eastward in Grand Canyon, from Havasu and Fishtail Canyons, marine deposits merge into continental, indicated by the presence of kaolinite as the common clay. In most places, the kaolinite is associated with silt and mud.
Principal areas in which these fine-grained detrital sediments are concentrated in the Manakacha are seen on the cross-section diagrams (fig. P8). They occur in (1) the southwestern part of the region where a probable source of terrigeneous material was farther south or southeast, and (2) the eastern and northeastern Grand Canyon region where waters from the western embayment merge with those from the San Juan Basin to the east, forming an area of shoals.

Although sandstone of the Manakacha is mostly very fine grained throughout the region, it contains fine sand as the dominant size grade in the east, three localities, and in the west, one locality. Likewise, in both east and west but not in the middle, maximum grain sizes consisting of very coarse sand and coarse sand occur at numerous localities, suggesting, by their distribution, dual directions of source. Good sorting is shown in 72 percent of samples; 28 percent show medium sorting. A high degree of roundness is a common attribute of nearly all the sand, in contrast to angular shapes of the silt grains. As with other formations of the Supai, probably roundness is a function of grain size and is not directly related to distance of transport or to genesis.

Cross-stratification in sandstone of the Manakacha is dominantly medium scale, but includes a considerable amount of large scale. It is mostly tabular-planar, although wedge-planar is common; trough type has not been recorded. Angles of foreset dips are about equally distributed above and below $20^{\circ}$ (high angle and low angle, respectively) and can be as high as $27^{\circ}-28^{\circ}$. Dip-direction vectors are southerly and have a spread of $71^{\circ}$, or less than one quadrant. All of these features of cross-strata are similar to those of the overlying Wescogame, except that in the Manakacha the dip directions are more restricted (smaller spread) and are more southerly.

\section{WESCOGAME FORMATION}

Deposition of the Wescogame Formation of Virgilian age in the Grand Canyon region followed a large hiatus in the stratigraphic record, representing most or all of Des Moinesian time and all of Missourian time. The unconformable surface on which deposition began is marked by numerous channels and depressions that are as much as $80 \mathrm{ft}$ in depth. Initial deposits in most places are rounded gravels of siltstone and limestone, probably derived from the underlying Manakacha Formation. These gravels partially fill channels and spread extensively to form a thin blanket conglomerate. In western Grand Canyon, most of the formation above the gravel is composed of carbonate rock (50-75 percent) and sandstone (10-50 percent), but in the east much sandstone (70-90 percent) and some mudstone (20-35 percent) overlie the conglomerate. 
An isopach map (fig. D11) of the Wescogame Formation resembles that of the underlying Manakacha except that the seaway is more extensive and a landmass to the south is missing. As in Atokan time, a connection between the Grand Canyon embayment and the San Juan Basin to the northeast is apparent. Thickness of deposits in the embayment ranges from $150 \mathrm{ft}$ in the west to about $100 \mathrm{ft}$ in the central and eastern parts.

The marine fauna of the Wescogame is largely restricted to the carbonate rock facies along the western margin of the formation. It consists mostly of fusulinids, pelecypods, gastropods, and pelmatozoans. These fossils do not occur, however, in the high-energy deposits of cross-stratified sandstone in middle and eastern Grand Canyon except in the form of bioclasts. Brachiopods have not been found in the formation and fusulinids are not known from the eastern part of the area.

Marine clays of the Wescogame are largely confined to the extreme western part of the embayment. Compared to the underlying formations, the amount of authigenic illite in the Wescogame is small. Among the sand deposits from Andrus Canyon eastward, minor amounts of illite seem to have developed in what probably were lagoons isolated from the sea by migrating sands. Near Kaibab Trail, north, one such deposit contains some possible corrensite with illite.

Kaolinite, here as in the other formations, is the second most common clay mineral and occurs exclusively among sands and silts. Its relative abundance, therefore, suggests an increase in the eastern part of the region in the percentage of continental deposits over those of the preceding formations, and its interface with the illite deposits marks shorelines of various stages. Chlorite occurs at scattered localities, but seems to be mostly detrital and probably contributes no information concerning the paleogeography.

The abundant sandstone foresets of eastern Grand Canyon contain well-preserved footprints of four-footed vertebrate animals-probably amphibians or reptiles-in a number of scattered localities. These tracks indicate the proximity of land and give a possible explanation for the dearth of skeletal accumulations derived from marine animals. Except for local accumulations of worn and comminuted fragments of pelmatozoans, bivalves, and a few other invertebrate animals that may have been transported from afar, faunal evidence favors the interpretation of a continental environment in eastern Grand Canyon.

Sand of the Wescogame has most of the features characteristic of sand in the underlying Manakacha, even though separated from it by a large stratigraphic break. The sand likewise is dominantly very fine grained, and, in scattered localities both in the east and in the west, contains coarse-grained maxima. In the northwest, some samples include very coarse grains. Such a distribution pattern, together with the orientation of cross-strata direction vectors pointing southward, seems to indicate that, as with the Manakacha, a sand source was to the north and northwest, and initial transportation routes were into the eastern and far western parts of the embayment, with lesser concentration in the middle area. The sorting of sand in most cases is good, but in a few areas it is only moderate. A large majority of grains are rounded, in contrast with the largely angular shapes of associated silt grains, suggesting that the rounding is a function of grain size.

Cosets of cross-strata in the Wescogame include the largest in the Supai Group-as much as $40 \mathrm{ft}$ thick-and the sets contain many large-scale tabular-planar and wedge-planar foresets. Medium-scale cross-strata are also common, but small-scale types are rare. The ratio of sand to silt is about $4: 1$, much greater than in the two underlying formations, and the percentage of skewed samples is moderately high. All of these features seem to indicate a depositional environment involving high energy and a progressively greater increase in current activity with each extension of the embayment following the beginning of Pennsylvanian time.

\section{ESPLANADE SANDSTONE}

Strata of the Esplanade Sandstone and its western correlative, the Pakoon Limestone (McNair, 1951), have the greatest thickness and are the most widespread of any formation in the Supai Group. These deposits extend through the entire Grand Canyon area, thickening toward the northeast, north, northwest, and west; probably also they once were continuous with thick deposits of similar age in southeastern Arizona. Only two small areas within the region-one to the east (Defiance positive element) and the other to the south-show positive trends. Thus, nearly the entire shelf was a surface of deposition. Thickest deposits, indicating belts of maximum sinking, extended outward in the form of troughs toward the San Juan Basin, the Cordilleran geosyncline, and the Sonoran geosyncline.

Deposition in Early Permian (Wolfcampian) time began on a relatively flat surface of the Wescogame Formation, dissected by numerous small channels from a few feet to a maximum of about $35 \mathrm{ft}$ in depth. These channels were incised by streams when the region was elevated slightly above sea level during the hiatus between Pennsylvanian and Permian time. Initial deposits on this surface probably represent a continental environment and consist mostly of conglomerate that fills or partly fills the channels and forms a sheet covering most of the interfluves. The conglomerate is composed of well-rounded gravels of siltstone and limestone apparently derived from the underlying Wescogame Formation and deposited by streams. Only in the extreme west are these basal deposits associated with marine fossils, indicating burial under the sea. 
The Esplanade Sandstone is readily divisible into two, and locally three, units based on lithology and topographic expression. The basal slope-forming unit consists of much mudstone or siltstone (17-81 percent) and a similar amount of fine to very fine sandstone (12-75 percent). In far western Grand Canyon the basal slope unit of the Pakoon Limestone, in which carbonate rocks occur in small amount (1-7 percent), occupies a similar position at the bottom. Uncommon fossils indicate that these units are at least partially continental.

The main cliff-forming unit of the Esplanade is a thick unit of cross-stratified sandstone (74-100 percent) that clearly indicates a high-energy environment within the central and eastern Grand Canyon areas at the time of deposition. In contrast, in the western part of the region this unit is represented by thick-bedded carbonate rocks (90-98 percent), mostly dolostone (Pakoon Limestone), that intertongue with sandstone of the Esplanade within a short distance to the east.

The uppermost cliff-slope unit of the Esplanade, represented only in the northern and western parts of the region, consists largely of fine- or very fine grained detrital sediment. In some areas to the northwest, it includes beds of gypsum and gypsiferous sandstone. In areas where this unit is well developed, an appreciable additional amount of sediment adds to the thickness of the formation, and the implication is that increased basin sinking in these areas was responsible. The sea apparently was withdrawing at this time, leaving its record of residual-type sediments and concentrating the water.

The Pakoon along the western margin contains an abundance of marine fossils including corals, pelmatozoans, and bivalves; farther east the sandstones of the Esplanade apparently represent an environment that was inhospitable to most forms of life. Except for a few scattered fusulinids, the faunal record consists of bioclasts only. Fossil fragments that have been recorded include bivalves, pelmatozoans, bryozoans, and foraminifers. These bioclasts occur throughout the region in limited numbers but are more common in the western than in the central or eastern parts of Grand Canyon.

Distribution of clay minerals in the Esplanade Sandstone differs in several important respects from that in the other formations of the Supai Group. Especially noteworthy is the relative scarcity of illite-a mineral largely confined to the carbonate rocks in this formation. Illite, believed to be authigenic, occurs in dolostone at Hidden and Iceberg Canyons on the western margin of the area; it is in calcareous or dolomitic lenses where associated with sandstone. At Andrus Canyon, illite is among evaporitic deposits in the gypsum facies. No illite has been recorded east of Toroweap Point in this area.

Corrensite, which, like illite, commonly develops in a marine environment, is uncommon in the Esplanade, al- though it also is present in the gypsum facies at Andrus Canyon and seems to reflect quiet-water conditions. Chlorite, associated with sand, silt, and mud, is confined to the upper cliff-slope unit and is believed to be of detrital origin. The most abundant clay in the formation, except the random mixed-layer type, is kaolinite. This clay is primarily in the sandstones. Because it is considered of continental origin and is especially abundant east of Andrus Canyon and Prospect Valley, its western boundary probably marks a continental-marine interface in the formation. Kaolinite probably represents an oxidizing environment where iron oxides are present and where feldspar-bearing rocks furnish a source.

Analyses of sand composing the Esplanade Sandstone show that, like sand in the underlying formations of the Supai, it is composed largely of very fine grains and in most places is well sorted (75 percent, good sorting; 25 percent, medium sorting). Unlike sands of the Wescogame and Manakacha Formations, however, those of the Esplanade are coarsest in the central part of the Grand Canyon region where very coarse grains are recorded from five localities. In this part of the region, mean size grades were determined to be medium sand at a few localities and fine sand at many others. As in the earlier formations, grains of all sand sizes show good rounding, but the silt-size grains are angular. The proportion of sand to silt (5:1) is greater than in any of the earlier Supai formations.

Cross-strata of the Esplanade Sandstone constitute what is probably its outstanding characteristic. Like cross-strata of the underlying Wescogame, about half the sets are of the tabular-planar type and half are of the wedge-planar type; trough cross-strata are rare. Also similar are the angles of dip of foresets, because in both formations the number of high-angle examples $\left(>20^{\circ}\right)$ and the number of low-angle examples $\left(<20^{\circ}\right)$ are about equal. Maximum dip degrees of foresets are about $27^{\circ}$ or $28^{\circ}$ in both units.

Despite certain similarities between cross-stratification in the Esplanade and that in the Wescogame, some major differences are apparent. Analyses of directional vectors of foreset dip surfaces indicate that the mean regional direction was considerably more toward the east during Esplanade deposition (southeast) than for the older Supai formations (south). Further, the average spread of dip directions is more restricted in Esplanade cross-beds $\left(57^{\circ}\right)$ than in the underlying formations.

The thickness of cosets that consist of successions of planar cross-strata tends to be greater in the Wescogame (maximum $40 \mathrm{ft}$ ) than in the Esplanade (maximum $27 \mathrm{ft}$ ). This probably is because of larger scale foresets included; however, the number of sets represented in a coset commonly is greater in the Esplanade where a repetition of medium-scale foresets seems to be normal in contrast to fewer but larger sets in the Wescogame. 


\section{TERMINATION OF SUPAI GROUP}

Deposition of the Supai Group in the Grand Canyon region ended with the development of a widespread surface of erosion near sea level. Small stream channels (as much as $55 \mathrm{ft}$ deep) dissected this surface in many places, but otherwise it apparently was extremely flat and even. Basal units of the Hermit Shale that overlie the Supai and fill the channels across the region consist of shaly silt and other fine detrital sediments; they contain land plants of xero- phytic types and sedimentary structures of many varieties. Conglomerates are absent, and therefore a relatively short hiatus is probably represented suggesting that consolidation of the underlying Supai sediments had not been attained before deposition of the basal units of the Hermit Shale.

\section{REFERENCE CITED}

McNair, A. H., 1951, Paleozoic stratigraphy of part of northwestern Arizona: American Association of Petroleum Geologists Bulletin, v. 35 , no. 3, p. 503-541. 


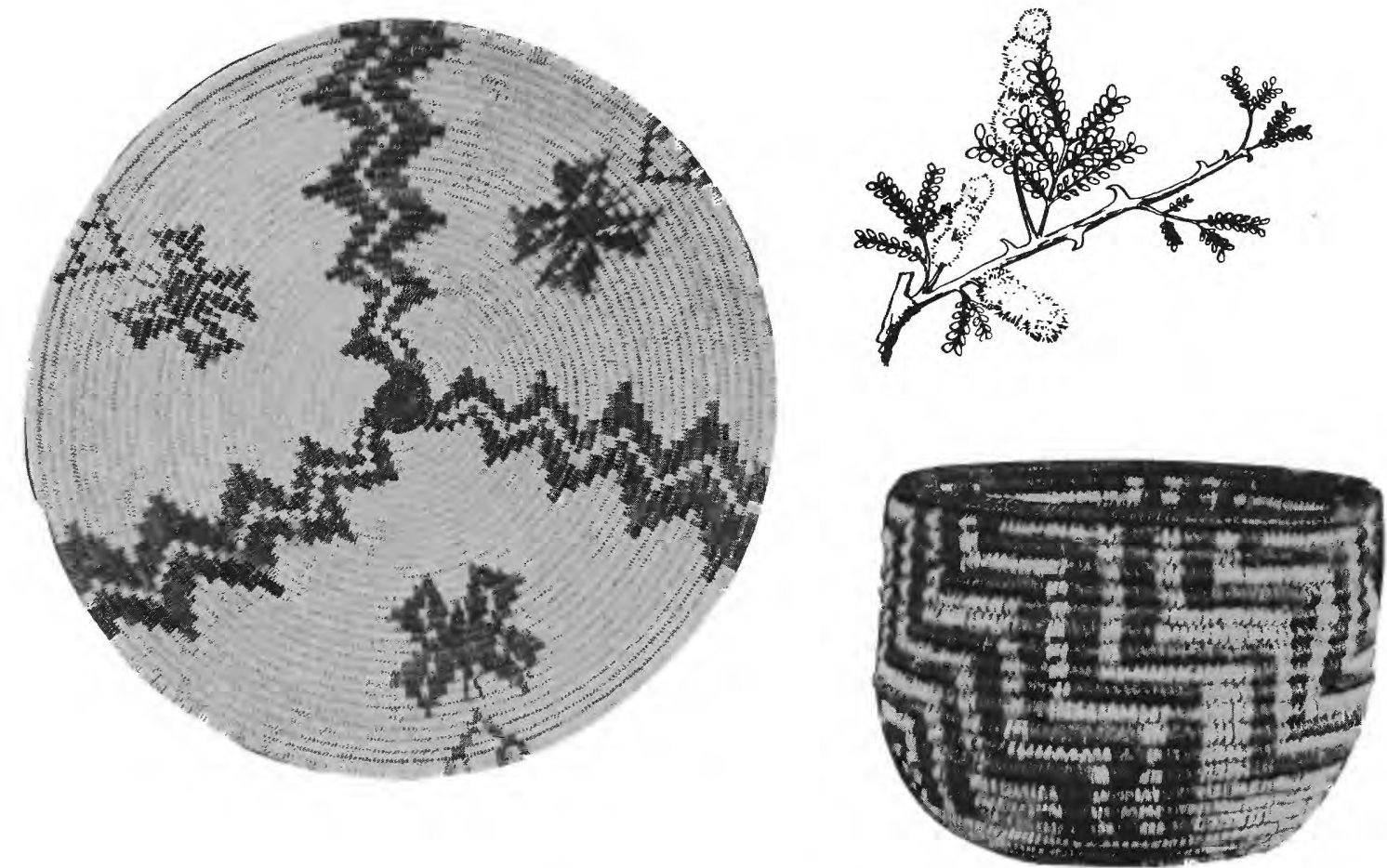

THE SUPAI GROUP OF GRAND CANYON

\title{
STRATIGRAPHY AND LITHOLOGY
}

\author{
Chapter C
}

By EDWIN D. McKEE

\section{Contents}

Stratigraphy . . . . . . . . . . . . . . . . . . . 31

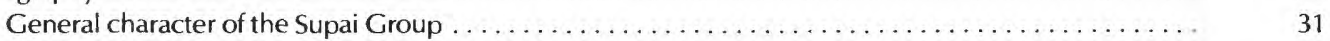

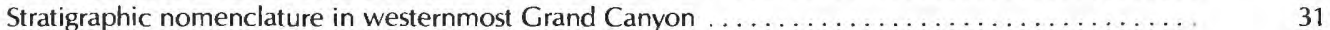

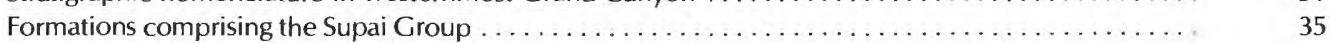

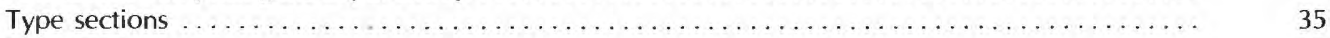

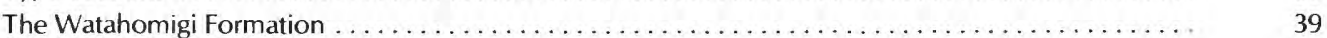

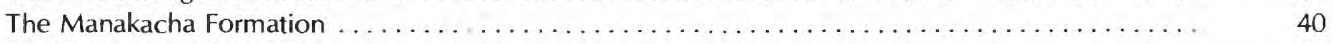

The Wescogame Formation . . . . . . . . . . . . . . . . . . . . . . . . . . . . . . . 40

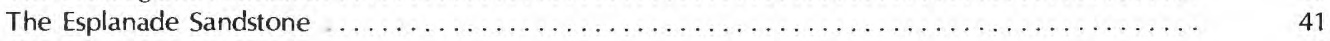

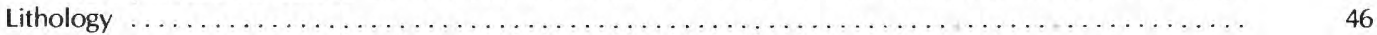

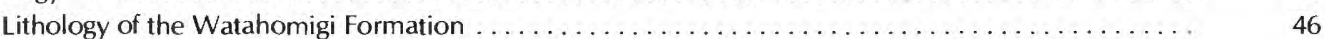

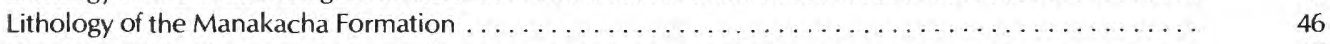

Lithology of the Wescogame Formation . . . . . . . . . . . . . . . . . . . . . . . . . . . . 47

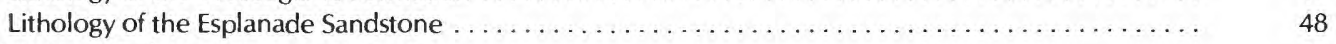

References cited $\ldots \ldots \ldots \ldots \ldots \ldots \ldots \ldots \ldots \ldots \ldots \ldots$ 


\section{Illustrations}

FIGURE C1. Generalized Supai profile showing formations, their subdivisions, and key conglomerate beds

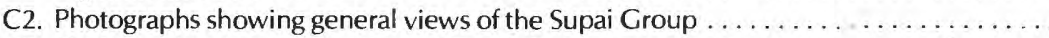

C3. Photographs showing section of Supai Group exposed in various areas of western

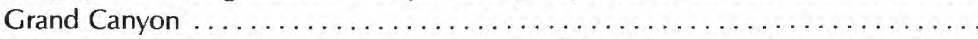

C4. Map of Havasu Canyon, Arizona, showing localities of type sections of the Watahomigi, Manakacha, and Wescogame Formations and the Esplanade Sandstone .....

C5. Photographs of the Watahomigi and Manakacha Formations . . . . . . . . . . .

C6. Maps showing thickness distribution of Supai formations $\ldots \ldots \ldots \ldots \ldots \ldots \ldots$

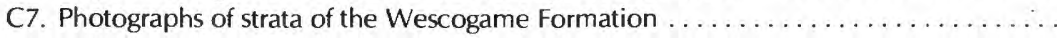

C8. Columnar sections showing principal rock types of Esplanade Sandstone ..........

C9. Photographs of the Esplanade Sandstone . . . . . . . . . . . . . . . . .

C10-C13. Bar graphs showing proportion of rock types in the:

C10. Watahomigi Formation ............................ 47

C11. Manakacha Formation ................................ 48

C12. Wescogame Formation ............................ 49

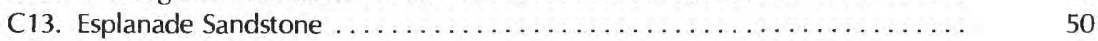

\section{Tables}

TABLE

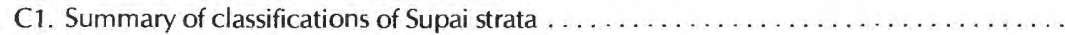

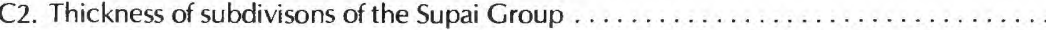


STRATIGRAPHY

\section{General character of the Supai Group}

The unifying features of the Supai Formation as originally defined by Darton (1910, p. 25) were its characteristic red-bed components, consisting largely of sandstone and sandy shale. On this basis, it was considered distinctive and was clearly separable from the white Coconino Sandstone above and from the dominantly massive gray limestone of the Redwall below. At that time the Redwall, as defined, included in its upper part units of red silty mudstone, alternating with beds of limestone. The Supai was redefined by Noble (1922, p. 59) some years later after he examined in detail and measured stratigraphic sections along the Hermit and Bass Trails in Grand Canyon. Instead of using lithology and color to determine its boundaries, he delineated the formation on the basis of breaks in the stratigraphic sequence. Thus, the upper limit of the Supai was placed at an erosional surface a few hundred feet below the former top, and its base was lowered to an erosional surface separating the massive limestone of the Redwall cliff from the alternating red mudstones and thinbedded limestones above.

Slope-forming beds of red shaly siltstone that overlie the uppermost erosional surface recognized by Noble in the Supai were assigned by him (Noble, 1922, p. 59) to a new formation, which he named Hermit Shale.

The lower boundary of the Supai was established by Noble (1922, p. 59) to conform with the concept that a stratigraphic break marked a meaningful and logical formation boundary. "Alternating sandstones and compact limestones, 200-500 feet" thick, formerly included in the underlying Redwall, were transferred to the Supai as its basal division. This change in assignment was justified, partly on the grounds that the red beds concerned resembled more closely the Supai strata than the massive limestone beds of the Redwall, but also because they were considered of Pennsylvanian age, whereas the Redwall was Mississippian, and a hiatus occurred between.

The stratigraphic approach in the present study has followed to a considerable extent the methods and procedure developed by Noble, but a principal difference is that this investigation has been extended across a much greater area. By establishing 32 control points, with a detailed measured section at each, the trends and changes in lithology and fauna have been established across an area roughly 150 by $60 \mathrm{mi}$ (fig. A1). Reliable key conglomerate beds have permitted the tracing of rock units for great distances and the recognition of time-equivalent lithologic and faunal facies throughout a wide area.

The key beds that have been recognized and used as stratigraphic markers in this study are thin conglomerate units that are distinctive lithologically (fig. $\mathrm{C} 1$; table $\mathrm{H} 1$ ). As described in an earlier publication (McKee, 1975, p. J2), they occur at four principal horizons and have widespread distribution in the Grand Canyon region. The uppermost conglomerate was recognized in 25 of 31 sections examined, the next lower conglomerate in 19 of 27 sections, and the third in 14 of 25 sections. The fourth conglomerate bed, at or near the base of the Supai, occurs at 22 localities.

The key conglomerate beds mark hiatuses, probably of considerable magnitude, within the sequence of red-bed deposits known as the Supai, therefore they constitute a major reason for subdividing the Supai formation, as defined by Noble (1922), into four formations. In 1975, as a result of the present investigation, the original formation was raised in rank to Supai Group and, as a result, removed from the Aubrey Group.

It is recommended that the Aubrey Group be abandoned as a result of the adoption of the name Supai Group for the lowermost part of the Aubrey Group in the Grand Canyon area, which includes Aubrey Cliffs, type locality for the Aubrey Group (see chapter A, this volume, pages 3-4, for a discussion of the history of the Aubrey Group).

Four formations are recognized within the Supai Group (oldest to youngest): Watahomigi, Manakacha, and Wescogame Formations and Esplanade Sandstone (McKee, 1975, p. J2). These formations (figs. C2, C3) are mappable units because the strata included in each form topographically distinct features as a result of characteristic lithology. Thus, informal field terms for various rock units, based on topographic expression, as suggested to me in 1930 by F. E. Matthes of the U.S. Geological Survey, and followed throughout the present investigation can readily be converted into both rock units (formations of this paper) and time-equivalents (table C1). The type section in Havasu Canyon, near Supai village, illustrates well (fig. MS2) the succession of red sandstone, limestone, and mudstone strata of the Supai Group.

\section{Stratigraphic nomenclature in westernmost Grand Canyon}

Equivalents of the Supai Group in extreme southeastern Nevada are the Callville and Pakoon Limestones, and the Queantoweap Sandstone. The Callville Limestone was described by Longwell (1921, p. 46-47) from southeastern Nevada (Muddy Mountains) as a limestone with interbedded shale in the upper part. As originally defined, it included rocks of Late Mississippian, Pennsylvanian, and Early Permian age and the type locality was designated as Callville Mountain, Clark County, Nev. Later, the formation was restricted by McNair (1951) to Pennsylvanian limestones below Permian dolostones (Pakoon) near the Arizona-Nevada boundary in the Lake Mead region. In westernmost Grand Canyon (Grand Wash Cliffs, Iceberg 


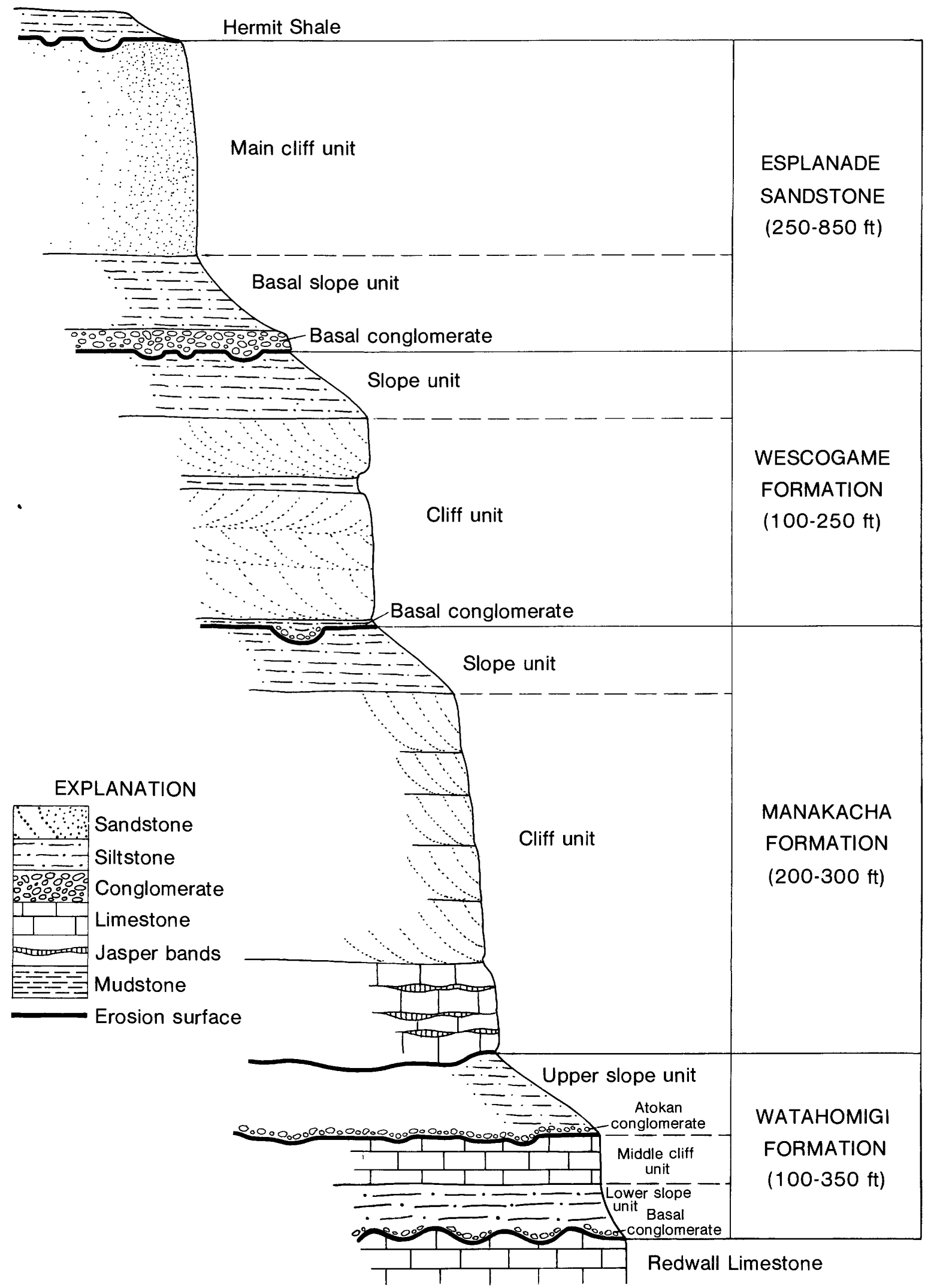

FIGURE C1.-Generalized Supai profile showing formations, their subdivisions, and key conglomerate beds at bases of Esplanade Sandstone, Wescogame Formation, upper slope unit of Watahomigi Formation, and base of Watahomigi. 

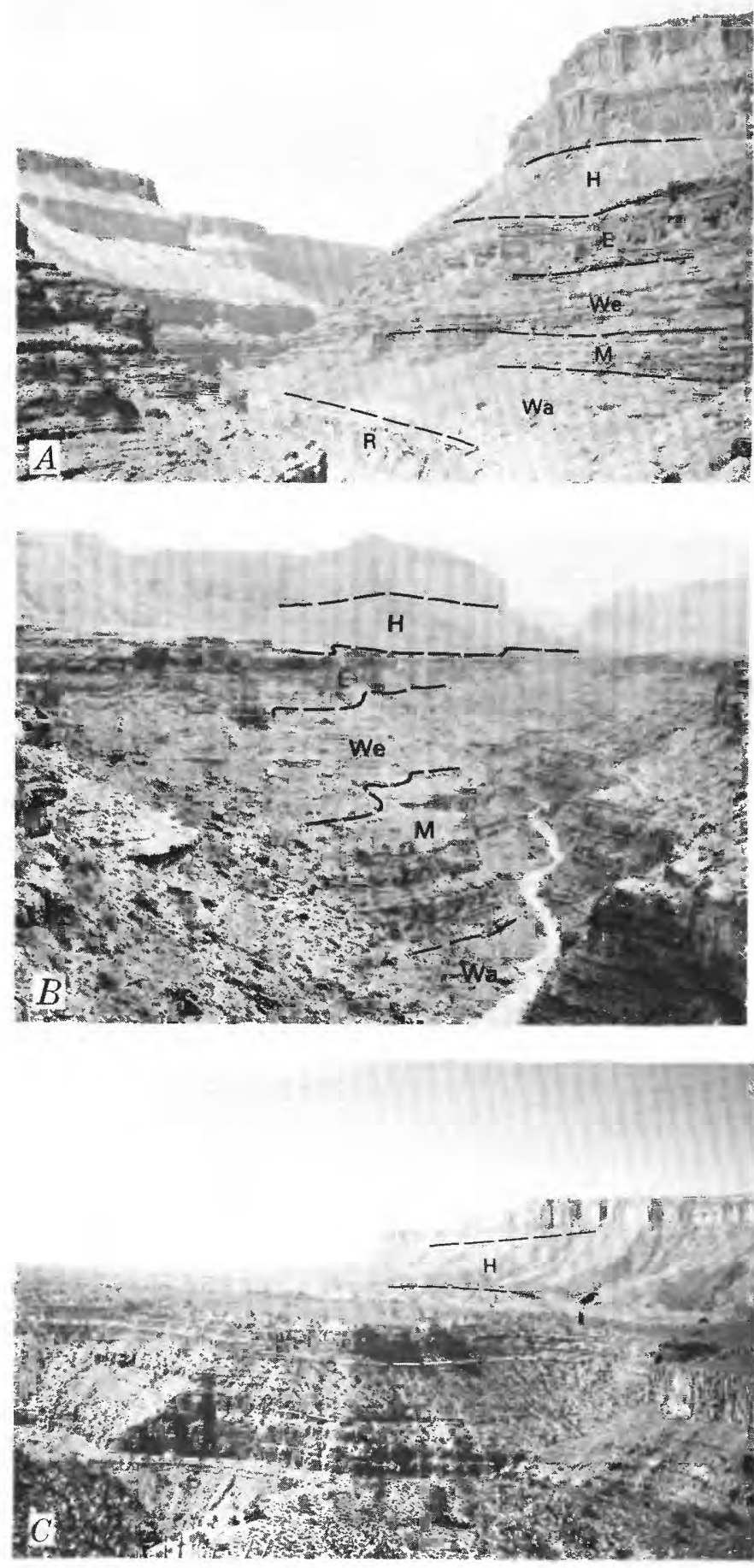

Canyon), strata formerly referred to the Callville Limestone are included in the lower part of the Supai Group. The name Callville is now not used in the Grand Canyon area and is restricted to the carbonate-rock facies equivalents of the Watahomigi, Manakacha, and Wescogame Formations to the west. The Callville may also include some Chester-age limestones equivalent to those filling pre-Supai valleys in Grand Canyon.

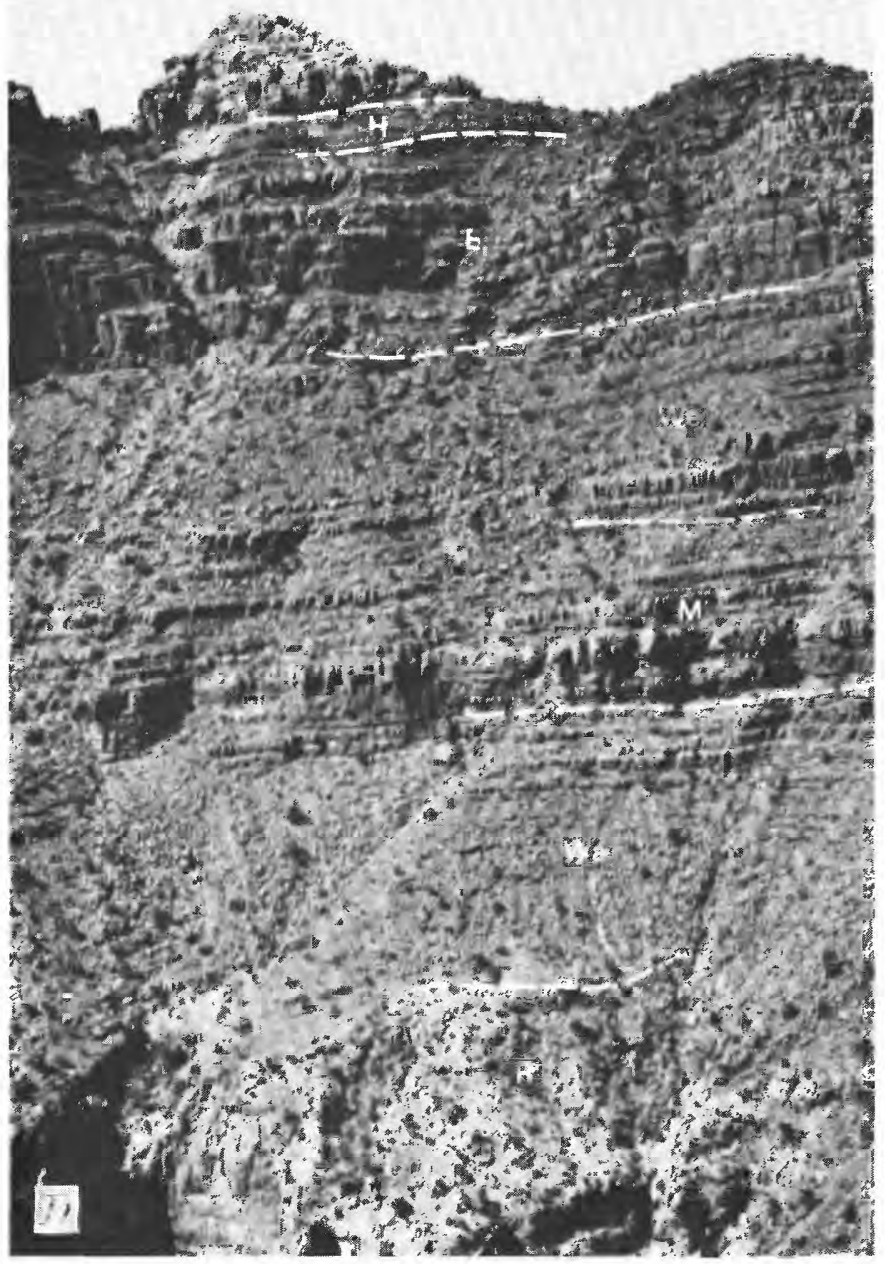

FIGURE C2.-General views of the Supai Group in various parts of the Grand Canyon region, Ariz. A, Marble Canyon at Vasey's Paradise, view south; $B$, view south toward Hualapai Plateau, looking up $\mathrm{Na}$ tional Canyon; $C$, view west toward Shivwits Canyon, across Twin Springs Canyon; and D, west of Bunker Trail, eastern Grand Canyon. R, Redwall Limestone. Supai Group: Wa, Watahomigi Formation; M, Manakacha Formation; We, Wescogame Formation; E, Esplanade Sandstone. H, Hermit Shale. The Supai Group ranges from 800 to $1,050 \mathrm{ft}$ thick in these photographs.

The Pakoon Limestone was defined by McNair (1951, p. 524) as "a wedge of dolomitic limestones that lie between the upper member of the Callville limestone and the 'Supai' redbeds." The type section is at Pakoon Ridge, Mohave County, Ariz., approximately T. 35 N., R. 16 W., where the formation is $688 \mathrm{ft}$ thick, according to McNair. On the "north Grand Wash Cliffs" (probably near Pigeon Wash or Snap Canyon), McNair (1951, p. 525) measured a section, almost entirely of dolomitic limestone that was $305.5 \mathrm{ft}$ thick. It contained a fusulinid zone of Permian (Wolfcampian) age. In westernmost Grand Canyon the Pakoon is now thought, in the opinion of the author, to be equivalent to the lower part of the Esplanade Sandstone because it contains limestone tongues (Pakoon-equiva- 

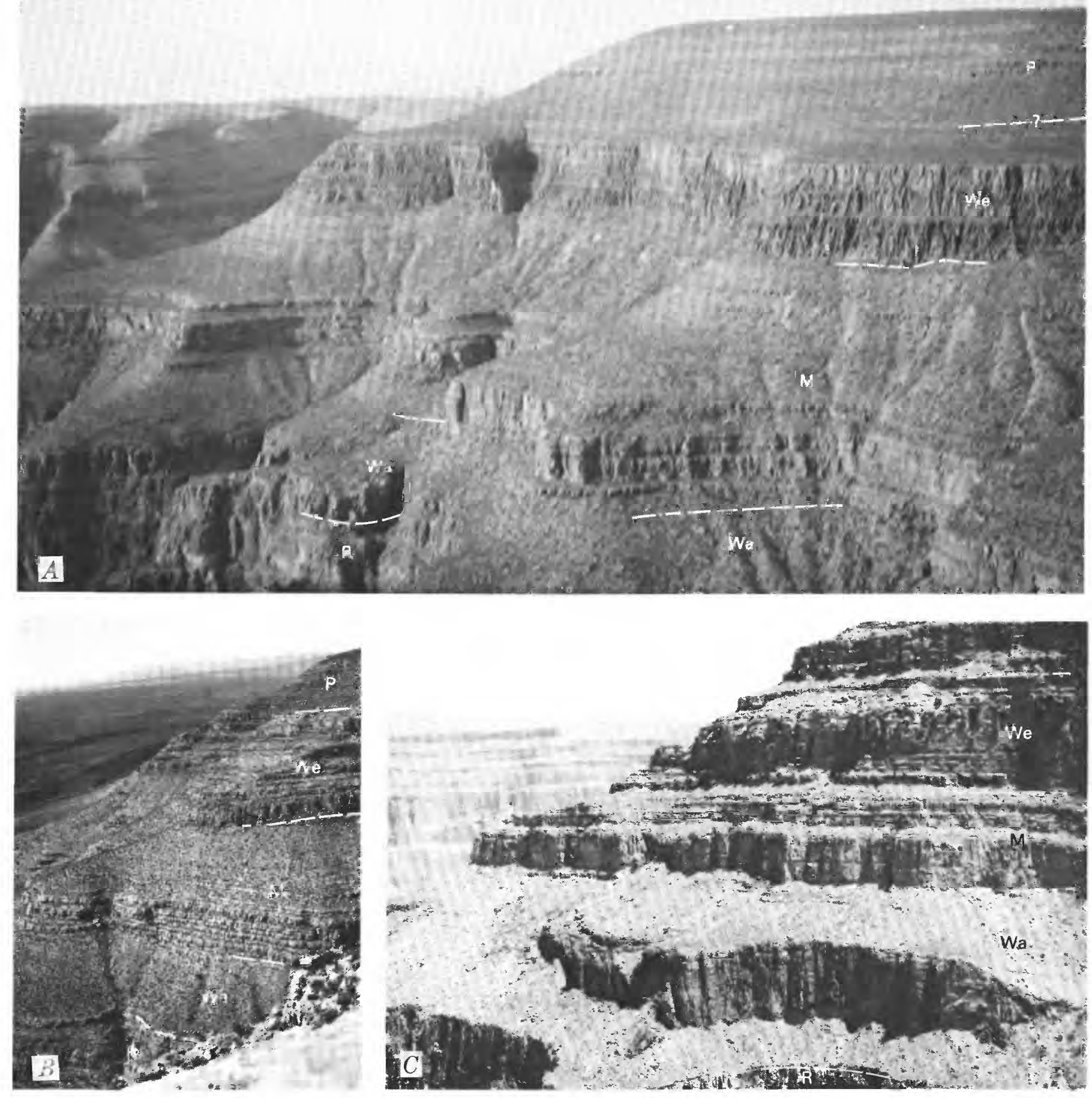

FIGURE C3.-Section of Supai Group as exposed in various areas of western Grand Canyon, Ariz. A, North side of Pigeon Wash, in Grand Wash Cliffs; $B$, view north along Grand Wash from near Hidden Canyon; and C, west side of promontory, east of Guano Cave locality. R, Redwall Limestone. Supai Group: Wa, Watahomigi Formation; M, Manakacha Formation; We, Wescogame Formation. P, Pakoon Limestone (McNair, 1951). The Manakacha is $210-260 \mathrm{ft}$ thick in these photographs. 
TABLE C1.-Summary of past and present classifications of Supai strata

\begin{tabular}{|c|c|c|c|}
\hline $\begin{array}{c}\text { Subdivisions } \\
\text { of Noble } \\
(1922, \text { p. } 61)\end{array}$ & $\begin{array}{l}\text { Informal field } \\
\text { terms for } \\
\text { rock units }\end{array}$ & $\begin{array}{l}\text { New formal } \\
\text { terminology of } \\
\text { Supai Group }\end{array}$ & Age \\
\hline A & Esplanade cliff & \multirow{2}{*}{$\begin{array}{l}\text { Esplanade } \\
\text { Sandstone }\end{array}$} & Wolfcampian \\
\hline \multirow{5}{*}{ B } & Upper slope & & - Erosion- \\
\hline & & \multirow{2}{*}{$\begin{array}{l}\text { Wescogame } \\
\text { Formation }\end{array}$} & \multirow[t]{2}{*}{ Virgilian } \\
\hline & Middle cliff & & \\
\hline & Middle slope & \multirow{2}{*}{$\begin{array}{c}\text { Manakacha } \\
\text { Formation }\end{array}$} & $\begin{array}{c}\text { Erosion } \\
\text { Des } \\
\text { Moinesian(?) }\end{array}$ \\
\hline & Lower cliff & & Atokan \\
\hline C & Lower slope & $\begin{array}{l}\text { Watahomigi } \\
\text { Formation }\end{array}$ & $\begin{array}{l}\text { Erosion } \\
\text { Morrowan }\end{array}$ \\
\hline
\end{tabular}

lents?) farther to the east in west-central Grand Canyon.

The "Queantoweap sandstone" is the name applied by McNair (1951, p. 525) to the "cliff-forming, cross-bedded sandstones which rest on the Pakoon and upper Callville limestones." His type section was "on the east side of Queantoweap Valley [Whitmore Wash] between the upper and lower lava flows," where it "forms a set of conspicuous ledges and cliffs below the easily eroded Hermit redbeds." This formation seems to be the same as the Esplanade Sandstone of the Supai Group, so the name Queantoweap is not recognized in this publication. Furthermore, the Pakoon does not occur below this (Esplanade) sandstone in Whitmore Wash, and probably is represented by the main cliff unit of the Esplanade Sandstone as shown by intertonguing elsewhere. If this correlation is correct, the Queantoweap of McNair at its type locality is a time-equivalent of the Pakoon farther west.

\section{Formations comprising the Supai Group}

The four formations of the Supai Group-the Watahomigi, Manakacha, and Wescogame Formations and the Esplanade Sandstone-not only are mappable units because of distinctive topographic expression (McKee, 1975), but also are readily divisible into informal units for the same reason. The formations and most of the units are remarkably widespread (table C2), forming persistent slopes or cliffs for great distances. Indeed, most of them retain somewhat the same lithographic and topographic character, changing primarily in thickness, from eastern to western Grand Canyon, about $150 \mathrm{mi}$ and in a north-south direction approximately $60 \mathrm{mi}$.

The boundaries between formations, with the single exception of the Watahomigi-Manakacha contact, coincide with various key conglomerate beds that probably are approximate time planes. The boundaries between most of the units, in contrast, are surfaces between different rock types and, therefore, bear no relation to planes of time. The various sandstones, mudstones, and limestones thicken or thin in different directions, but most of them change facies very gradually. Only through a study of facies distribution, as discussed in chapter $P$, are many of these subtle differences detected.

Major trends in thickening and thinning of rock units and changes in facies commonly are attributed to distance from shore in marine deposits and to rates of sinking and changes in environment along the shore or inland from it. Most thickness and lithic changes in formations of the Supai Group can be explained by changes in the land-sea relations as shown on successive paleogeographic maps of the region (figs. D3, D4, D7, and D8). The Supai strata were deposited in an embayment bordering on a geosyncline to the west but periodically were connected with a seaway to the southeast and at other times with a seaway to the northeast. Thus, the embayment and its coastline were constantly changing shape and position.

\section{Type sections}

The type locality of the Supai Formation, now the Supai Group, was designated by N. H. Darton (1910, p. 25) as Havasu (Cataract) Canyon in the vicinity of Supai village. This locality, on the south side of Grand Canyon, includes excellent exposures of the red sandstone, limestone, and mudstone beds that constitute this group.

When strata of the Supai Formation were raised in rank to the Supai Group, the type section remained unchanged (McKee, 1975, p. J2), but the group was divided into four formations, each of which had its type section in the same general area (fig. C4).

The lowermost, or Watahomigi Formation, was named for Watahomigi Point on the west side of Havasu Canyon, about $1.5 \mathrm{mi}$ northwest of Supai village; its type section is along the Hualapai Trail. The second formation above the base of the group, the Manakacha, was named from Manakacha Point on the east side of Havasu Canyon and directly above Supai village; its type section is along the Apache Trail. The third, or next to highest of the formations, was named the Wescogame from the point of that name on the west side of Havasu Canyon, about $3 \mathrm{mi}$ southwest of the village, and it has its type section along 


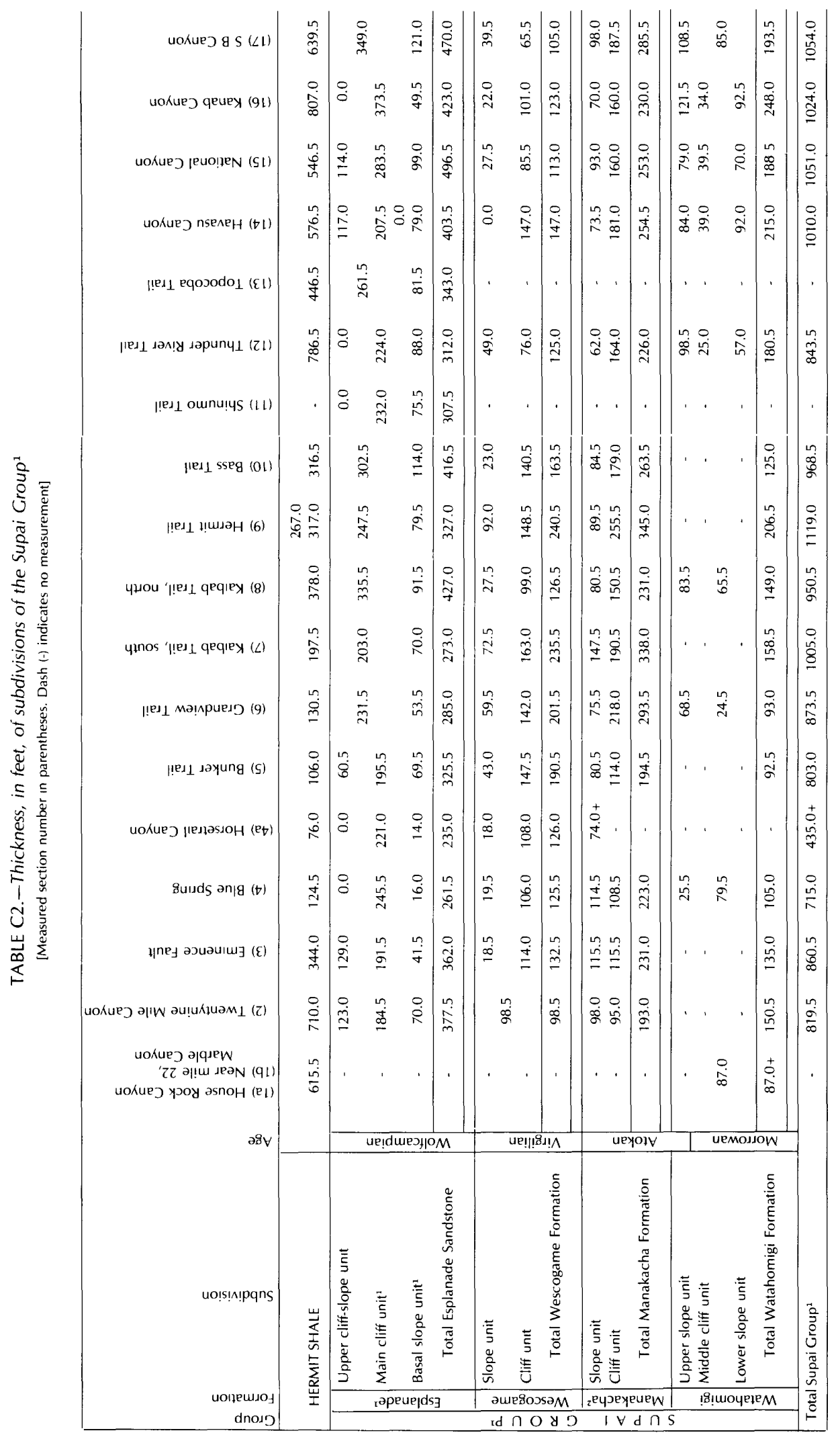




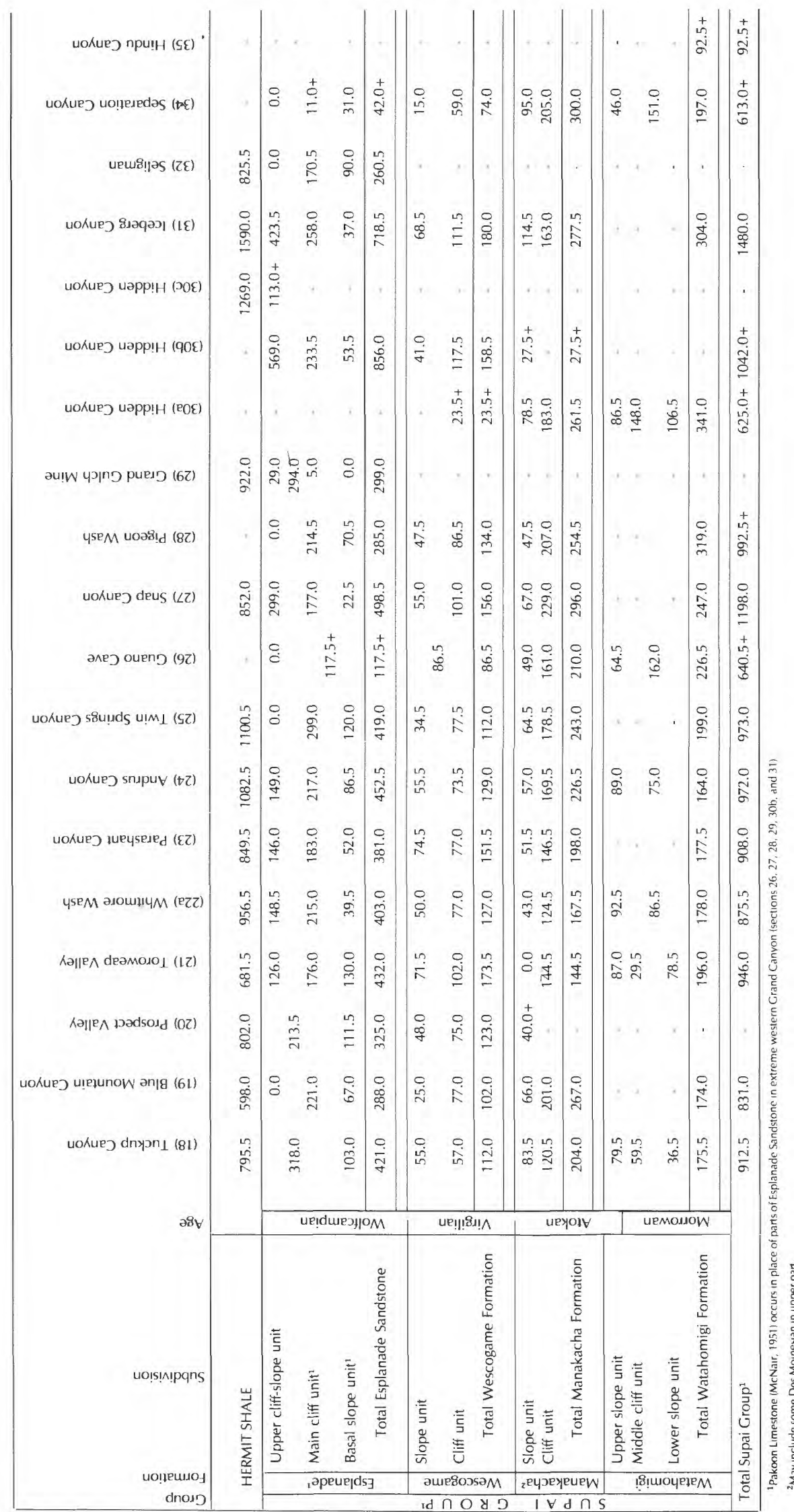




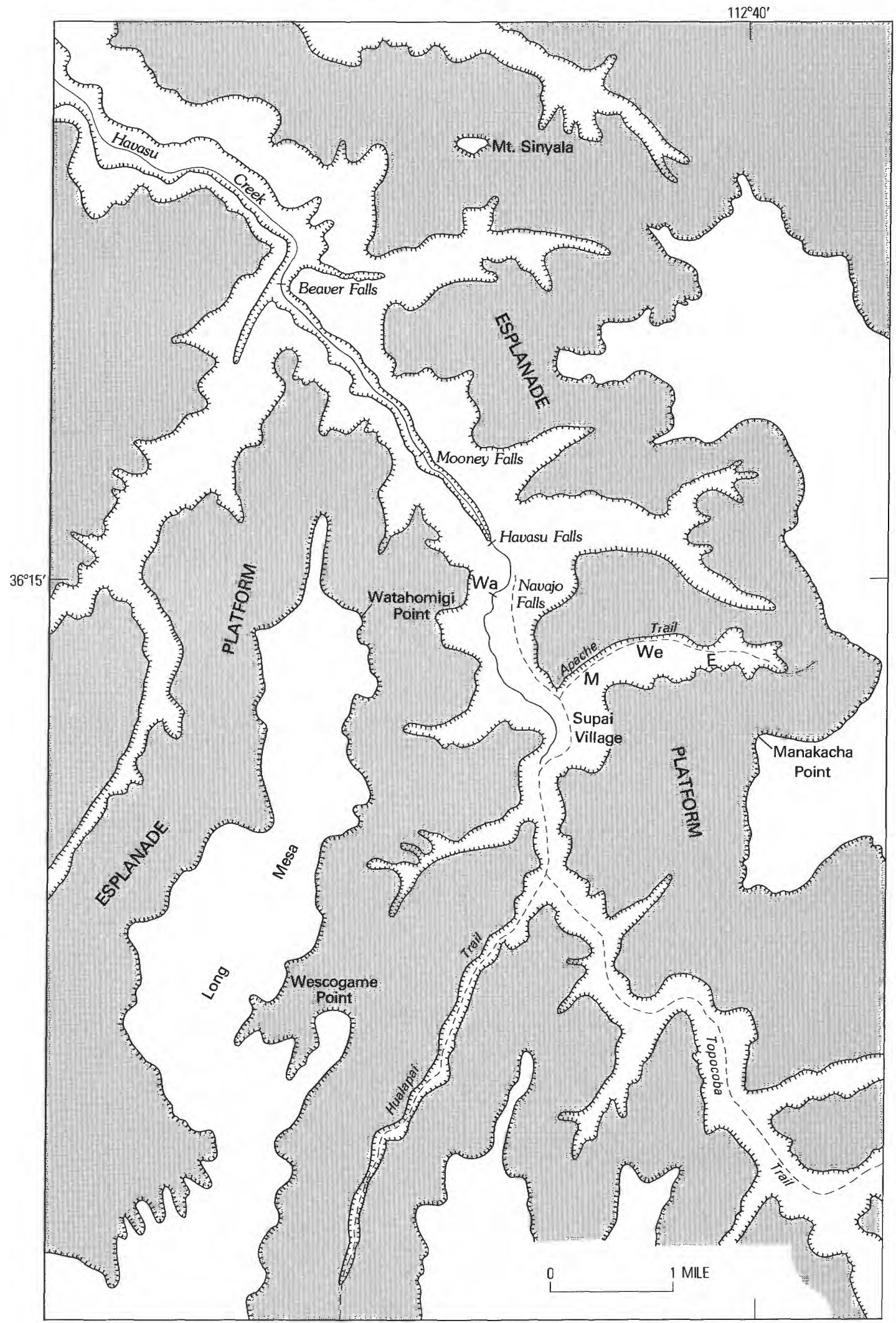

FIGURE C4.-Havasu Canyon, Ariz., showing localities of type sections and geographic features used in naming the Watahomigi (Wa), Manakacha (M), and Wescogame (We) Formations and the Esplanade Sandstone (E). 
the Hualapai Trail. The uppermost formation was called the Esplanade Sandstone after the Esplanade Platform, a prominent bench that the formation forms in the walls of Havasu Canyon. The type section of the Esplanade was described from the east side of the Havasu Canyon, along the Apache Trail above Supai village (measured sec. 14).

\section{The Watahomigi Formation}

The Watahomigi is composed of three informal units: a lower slope unit, a middle cliff unit, and an upper slope unit (fig. C5). The characteristic lithologic features and boundaries of each are described below.

The lower slope unit of the Watahomigi is dominantly red argillaceous mudstone and siltstone with a few thin units of aphanitic to granular limestone (peloidal wackestone and bioclastic wackestone). Beds of conglomerate at the base and within this unit include angular chert gravels of olive, gray, and brown, within a dark red-brown silt or sand matrix. The lower slope and middle cliff units probably intertongue or grade laterally from one to the other; the upper part of the lower slope mudstone of eastern

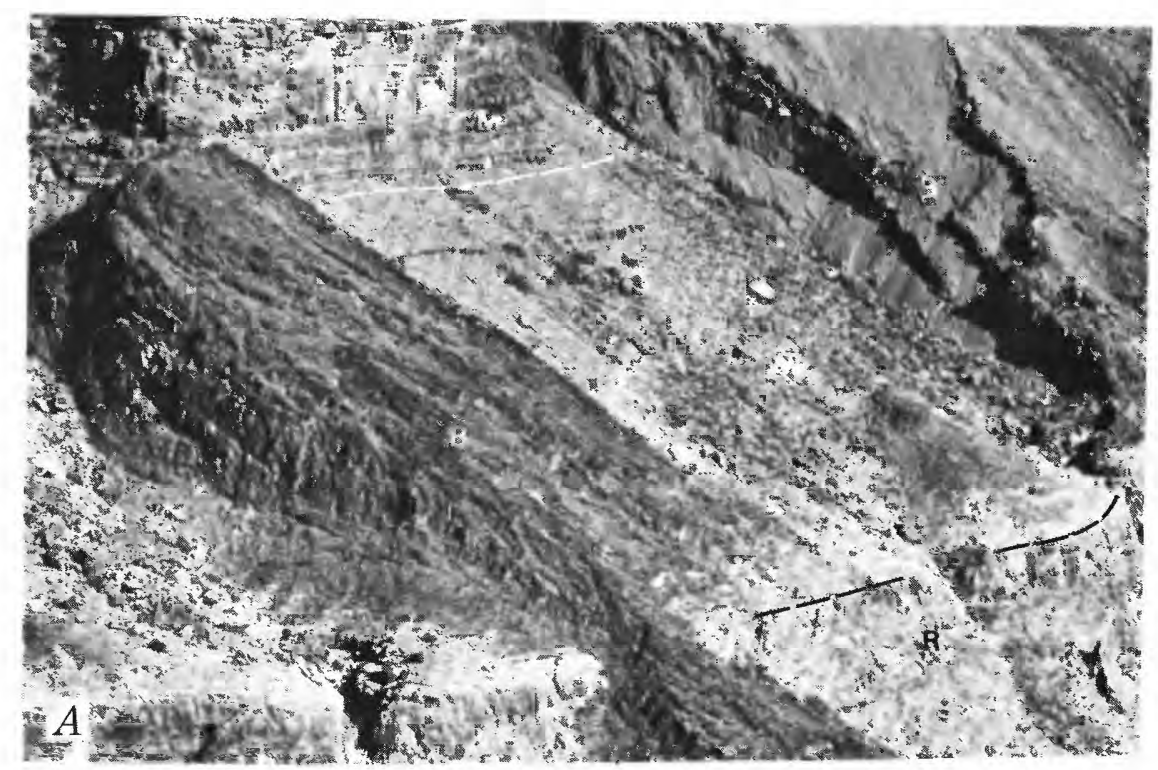

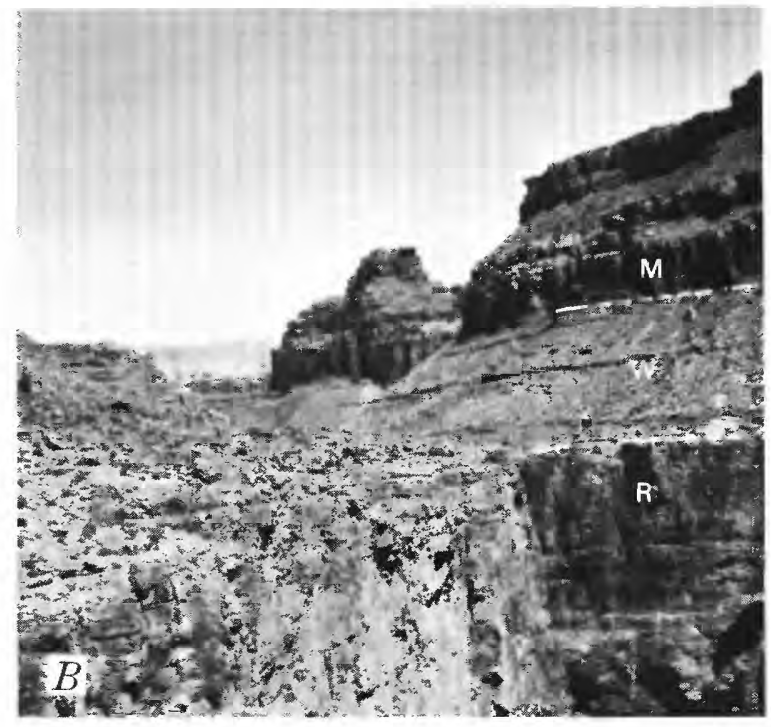

FIGURE C5.-The Watahomigi and Manakacha Formations in Grand Canyon region, Arizona. A, Slope of Watahomigi, $196 \mathrm{ft}$ thick, exposed in window formed by Holocene basalt flows, foot of Toroweap Valley; cliff of Redwall Limestone at bottom. B, Watahomigi slope between cliffs of Manakacha, above, and Redwall, below; Havasu

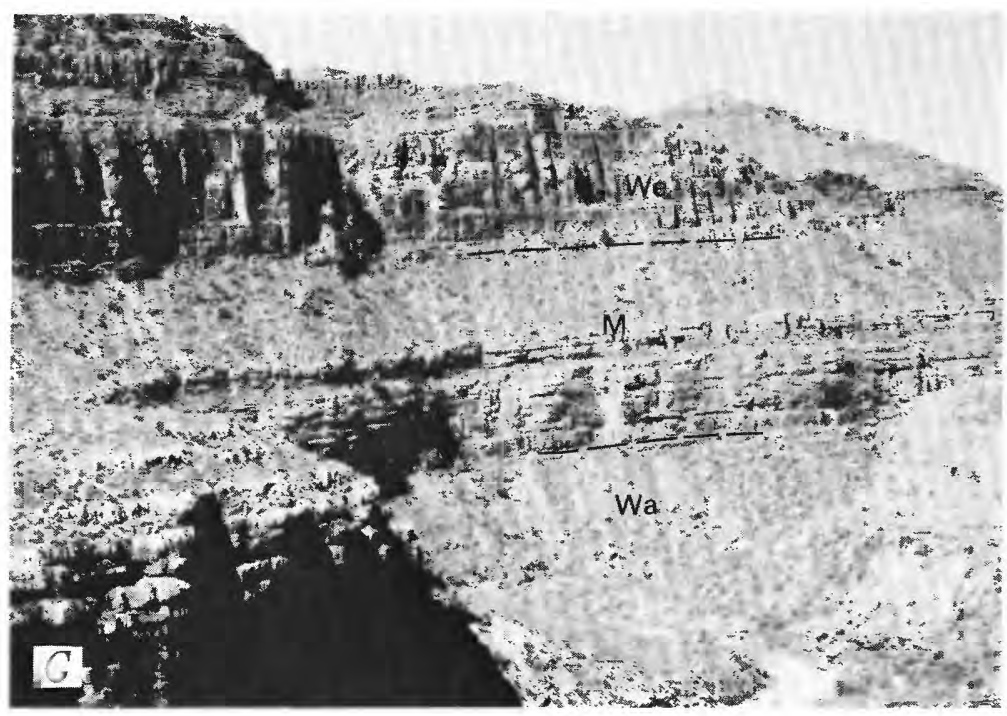

Canyon. C, Slope of Watahomigi (bottom) overlain by cliff and slope units of Manakacha (center) and Wescogame cliff above; Snap Canyon. We, Wescogame Formation; M, Manakacha Formation; B, Holocene basalt flow; Wa, Watahomigi Formation; R, Redwall Limestone. 
Grand Canyon seems to be a facies-equivalent of the middle cliff limestone of western Grand Canyon.

The middle cliff unit of the Watahomigi is a tongue of limestone that thins eastward and southeastward through Grand Canyon, and is absent in the Blue Springs area east of Grand Canyon. This thinning may have resulted from any of several factors: (1) a lateral facies change from limestone to red argillaceous mudstone that occurred progressively farther east with passage of time; (2) a thicker accumulation of limestone toward the deeper water in the west; or (3) progressively greater bevelling in the east, resulting from emergence of the land and westward regression of the sea. The upper contact of the middle cliff unit is flat and even in most places.

The upper slope unit of the Watahomigi has at its base the conglomerate informally referred to as the Atokan conglomerate because it is the lowest stratum of Atokan age. This conglomerate has been found in 14 of 25 measured sections. At the type section of the Watahomigi Formation this conglomerate contains fragments of jasper, associated with aphanitic limestone (lime mudstone) pebbles. In many localities, the upper slope unit of the Watahomigi is covered with talus from the cliff unit of the overlying Manakacha Formation, but, in general, this part of the Watahomigi can be recognized by its topographic expression, with a major cliff above. It consists largely of alternating beds of limestone and shaly siltstone or mudstone.

In eastern Grand Canyon, where limestone beds in the Watahomigi Formation are thin or absent, the middle cliff unit is not well developed, and the upper boundary of the formation is placed at the base of the first major cliff above the Redwall Limestone. Farther west, where the middle part of the Watahomigi forms a cliff, the upper boundary of the formation occurs at the bottom of the second major cliff. In addition to these topographic criteria, contact between the Watahomigi and the Manakacha commonly can be recognized by the occurrence of the first conspicuous sandstone beds; sandstone is characteristic of the lower part of the Manakacha Formation, but not of the Watahomigi.

Within the Grand Canyon region the Watahomigi Formation ranges in thickness from less than $100 \mathrm{ft}$ in the southeast (Bunker Trail, Grandview Trail) to more than $300 \mathrm{ft}$ in the west (Iceberg Canyon, Hidden Canyon, Pigeon Wash). Differences in thickness of adjacent sections, as recorded (figs. $\mathrm{C} 6 \mathrm{~A} ; \mathrm{A} 2-\mathrm{A} 8$ ), may be, in part, the result of relief at the base, but also at some localities may be due to difficulties in recognizing the upper boundary.

In general, directions of thinning in the various units, especially the middle carbonate rock unit, seem to reflect the configuration of the embayment in which deposition occurred. Because the embayment was open only to the west (figs. D3, D9), a shoreward thinning to the south, east, and north resulted; mostly red siltstone and mudstone accumulated around the shoreward margins.

\section{The Manakacha Formation}

Unlike other formations of the Supai Group, the Manakacha attains its maximum thickness in the eastern part of Grand Canyon (figs. C6B; A2-A8) where strata are more than $300 \mathrm{ft}$ thick at Kaibab and Hermit Trails. From this area, the formation thins in all directions, as indicated on the paleogeographic map (fig. D4). At the time (Atokan) of deposition the embayment seems to have been part of a passageway connecting the Cordilleran geosyncline to the west with the Paradox basin to the northeast and an absence of shorelines existed in both of these directions. The area of maximum deposition had shifted eastward from that of the preceding epoch.

The Manakacha consists of two units (figs. C3, C5): a (lower) cliff unit that is dominantly cross-bedded, calcareous sandstone and sandy limestone and an (upper) slope unit composed largely of shaly mudstone with minor amounts of limestone and sandstone. In northeastern Grand Canyon the two units have approximately the same thickness (table C2), but westward the cliff unit is progressively thicker at the expense of the slope unit above. From Kaibab Trail west to National Canyon, the cliff unit is about twice as thick as the slope unit, and still farther west it averages approximately three times as thick. Thus, the proportion of limestone and sandstone to mudstone is relatively much greater in the west than in the east.

The lower boundary of the Manakacha Formation is placed at the bottom of the sheer cliff formerly referred to as the lower cliff unit of the Supai (table C1). This is a readily recognizable topographic feature, hence contributes to the formation being a mappable unit. Furthermore, sandstone beds commonly occur directly above this contact, but not in the Watahomigi slope below, so the sandstone constitutes a useful guide to the boundary. Irregular surfaces of erosion occur at the boundary on the Kaibab Trail, north, and in Havasu Canyon. Elsewhere the contact seems to be a flat, even surface.

The top of the Manakacha Formation is a widespread erosion surface characterized by many small to moderately deep channels. This channeled surface has been recognized in numerous places throughout the Grand Canyon region. The position of this upper boundary of the Manakacha can, in most places, be readily determined for mapping purposes as it is near the base of a major cliff (middle cliff unit, table $\mathrm{C} 1$ ).

\section{The Wescogame Formation}

The Wescogame Formation is a tabular rock unit, ranging between 100 and $200 \mathrm{ft}$ in thickness throughout most of the Grand Canyon area (fig. C7). Only in the southwestern part, at Guano Cave and at Separation Canyon, is its thickness less than $100 \mathrm{ft}$ (figs. C6C; A2-A8). It is bounded 

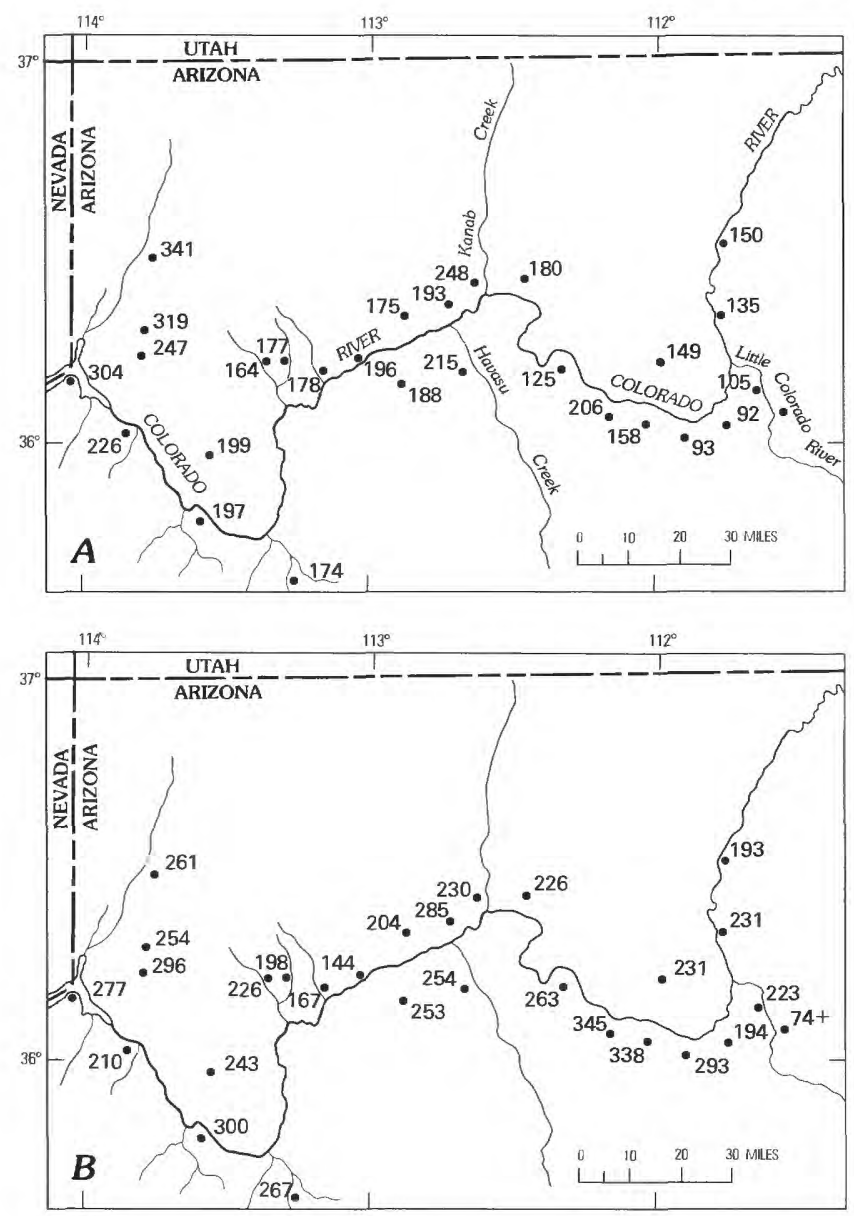
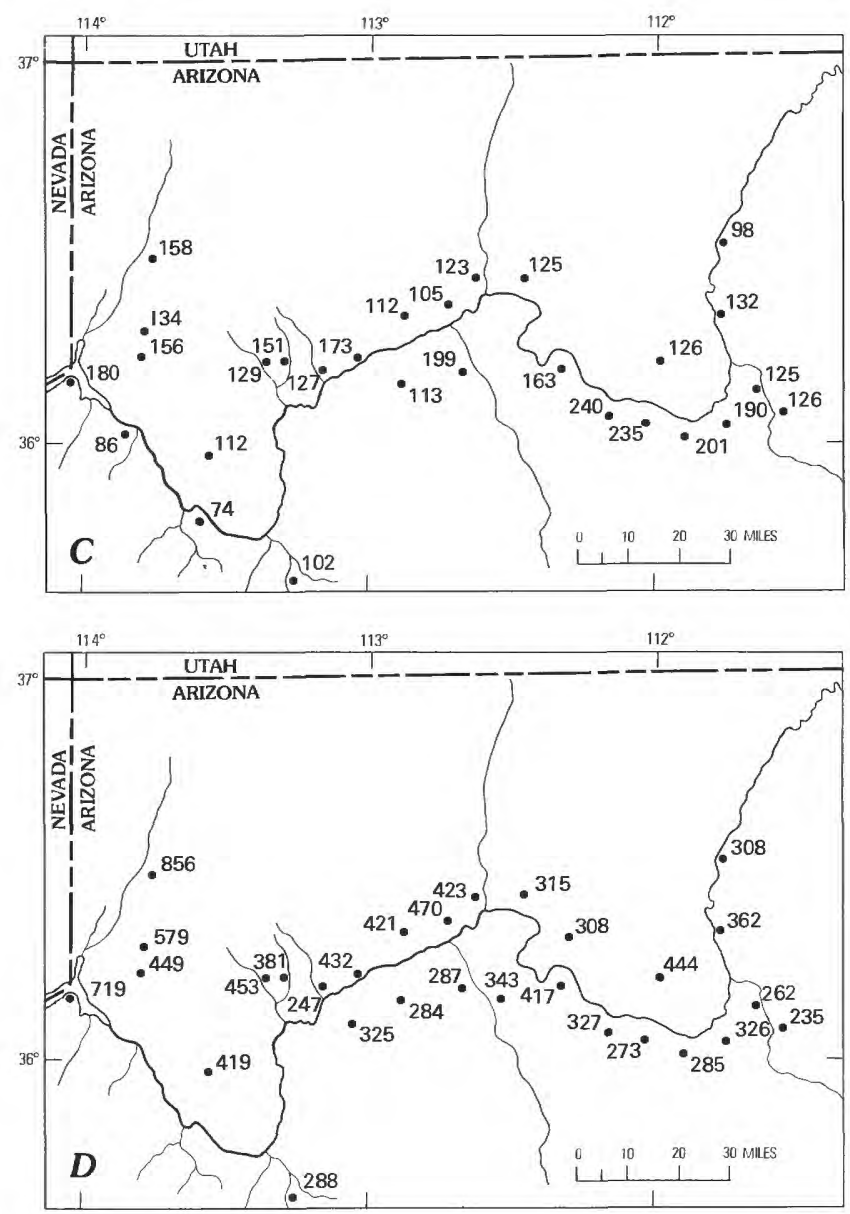

FIGURE C6.--Thickness distribution (in feet) of formations in Supai Group, Grand Canyon region, Arizona. A, Watahomigi; B, Manakacha; C, Wescogame; and D, Esplanade (including tongues of Pakoon Limestone of McNair, 1951).

both on top and bottom with surfaces of erosion in which channels are partly or entirely filled with conglomerates (table $\mathrm{H} 1$ ).

The basal conglomerate of the Wescogame Formation has been recorded in 14 measured sections. Although it forms a regular even bed, a few feet thick in most places, it fills channels to depths of 10,11, and $15 \mathrm{ft}$ at Bunker Trail, Toroweap Valley, and Thunder River Trail, respectively (figs. H7, H8, H10, J3). At some localities, neither channels nor conglomerate seem to be present at the base of the Wescogame, probably because of originally high terrane in interfluve areas.

Two units are recognized in the Wescogame, distinguished by composition and topographic expression. The lower, thicker unit is here referred to as the cliff unit and in earlier descriptions of the Supai was called (McKee, 1975) the middle cliff unit (table C1). It is composed largely of cross-stratified, very fine grained sandstone. The upper unit is referred to in this publication as the slope unit, and in an earlier classification of the Supai was designated as the lower part of the upper slope unit (table C1). It is composed mostly of alternating red-brown siltstone or mudstone beds and cross-stratified sandstone.
The cliff unit of the Wescogame ranges in thickness between 100 and $150 \mathrm{ft}$ throughout most of eastern Grand Canyon (table C2). It is between 70 and $100 \mathrm{ft}$ thick nearly everywhere in central and central western Grand Canyon, but more than $100 \mathrm{ft}$ in the extreme western part.

The thin slope unit in the upper part of the Wescogame ranges in thickness betwen 20 and $70 \mathrm{ft}$ throughout most of the region, but in sections of the northeast is slightly less than $20 \mathrm{ft}$ thick.

An isopach map of the Wescogame Formation (fig. D11) shows that the basin of accumulation was connected with seaways both to the west and the southeast. Current direction vectors (fig. $\mathrm{K} 15 A, B$ ) suggest a principal source of detritus to the north.

\section{The Esplanade Sandstone}

Throughout the Grand Canyon region, the Esplanade Sandstone consists of two readily recognizable units; in many places, a third unit can be distinguished (fig. P12). From bottom to top these units are referred to by the informal terms of (1) basal slope unit, (2) main cliff unit, and 

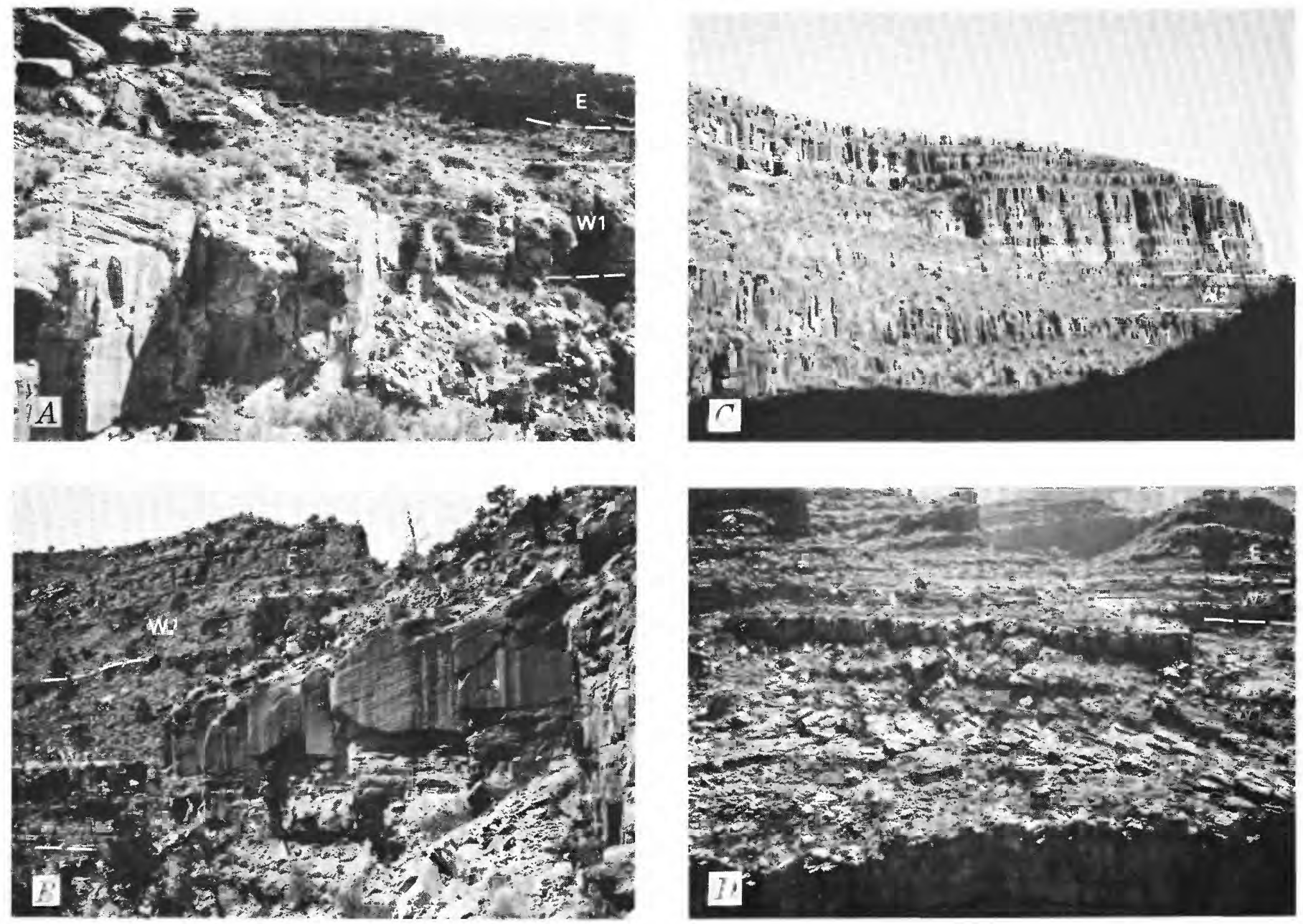

FIGURE C7.-The Wescogame Formation in Grand Canyon, Arizona. A, Large-scale tabular-planar cross-strata at top of cliff unit; slope unit above and main cliff of Esplanade Sandstone beyond; Thunder River Trail. B, Massive unit of large-scale cross-strata with thinner beds below forming cliff unit of formation, slope unit above; Esplanade Sandstone cliff in upper left, Kaibab Trail, south. C, Cliff unit

(3) upper slope and ledge unit or upper cliff-slope unit. The bottom two are continuous throughout the region; the upper unit, recognized by alternating slopes and small cliffs, or receding ledges, is conspicuous along both eastern and western margins of the outcrop area and in the north-central part (figs. C8; P12). In the extreme western Grand Canyon region most of the lower part of the main cliff unit is represented by thick beds of carbonate rock, mostly dolostone, known as the Pakoon Limestone (McNair, 1951).

The basal slope unit of the Esplanade consists of alternating layers of sandstone and siltstone or mudstone, with limestone at a few localities (table C3). The thickness ranges from about $14 \mathrm{ft}$ to a maximum of $130 \mathrm{ft}$, but across most of the area is between 50 and $100 \mathrm{ft}$ (table C2). Much of the difference in thickness from place to place results from irregularities of the channeled erosion surface upon

and slope unit of Wescogame overlain by cliff formed by tongue of Pakoon Limestone of McNair (1951), Snap Canyon. D, Planar crossstrata, large-scale, in upper part of cliff unit; near Apache Trail to Havasu Canyon. W1, Wescogame cliff unit; W2, Wescogame slope unit; E, Esplanade Sandstone; P, Pakoon Limestone.

which deposition occurred. Channels $50 \mathrm{ft}$ deep at Soap Creek, $47 \mathrm{ft}$ at Havasu Canyon, and $45 \mathrm{ft}$ at National Canyon indicate extremes in this erosion (table H1). Because the deep channels are mostly in the central part of the region, maximum thicknesses of the unit are also in this area.

Most channels at the base of the formation are largely or entirely filled with gravel known as the basal conglomerate of the Esplanade. This conglomerate is the most persistent one within the Supai Group, and has been recorded from 28 localities. Conglomerate beds, $15-17 \mathrm{ft}$ thick, occur at four localities examined, and an erosion channel $35 \mathrm{ft}$ deep was measured at Twin Springs Canyon. Characteristics and diagnostic features of this conglomerate are described and tabulated in chapter $J$.

A somewhat similar but less extensive and thinner conglomerate occurs higher in the basal slope unit at Havasu, National and S B Canyons and at Toroweap Valley, all in 

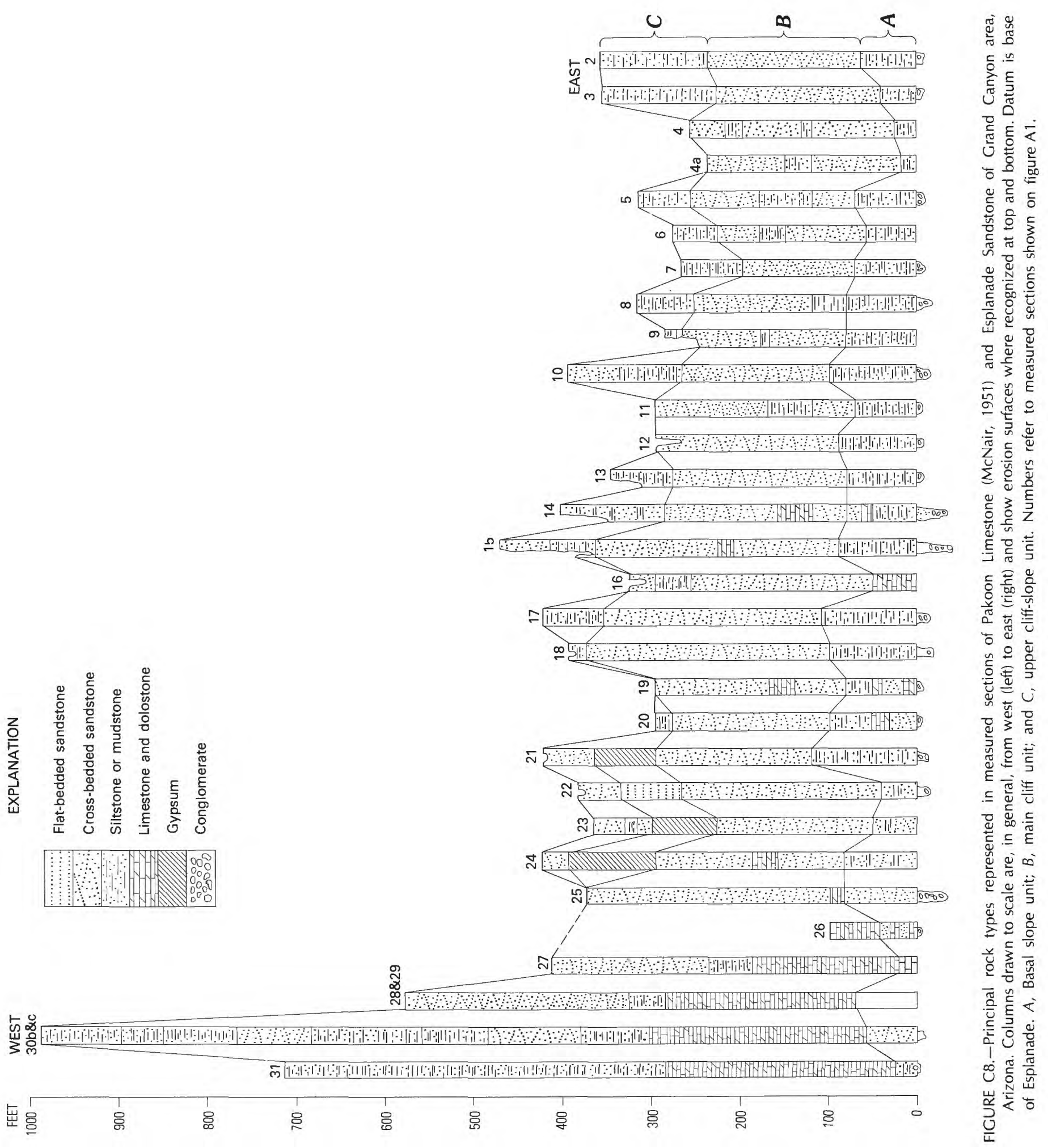
TABLE C3.-Percentages of sandstone, mudstone, and carbonate rocks in principal units of Esplanade Sandstone ${ }^{1}$

[ss, sandstone; sh, mudstone; Is, limestone; dol, dolostone. Leaders (--) indicate not present]

\begin{tabular}{|c|c|c|c|c|c|c|c|c|c|c|}
\hline \multirow{2}{*}{$\begin{array}{l}\text { Sec. } \\
\text { No. }\end{array}$} & \multirow[t]{2}{*}{ Locality } & \multicolumn{3}{|c|}{ Basal slope } & \multicolumn{3}{|c|}{ Main cliff } & \multicolumn{3}{|c|}{ Upper cliff-slope } \\
\hline & & SS & sh & |s-dol & SS & sh & Is-dol & SS & sh & |s-dol \\
\hline 2 & Twentynine Mile Canyon .... & 43 & 56 & 1 & 96 & 2 & 2 & 60 & 40 & -- \\
\hline 3 & Eminence Fault $\ldots \ldots \ldots \ldots$ & -- & 100 & --- & 89 & 11 & -- & 64 & 36 & -- \\
\hline 4 & Blue Spring $\ldots \ldots \ldots \ldots \ldots$ & -- & 100 & -- & 83 & 17 & -- & - & - & -- \\
\hline $4 a$ & Horsetrail Canyon ......... & 47 & 53 & -- & 84 & 16 & -- & --- & - & -- \\
\hline 5 & Bunker Trail . . . . . . . . . & 18 & 82 & -- & 80 & 20 & -- & 64 & 36 & -- \\
\hline 6 & Grandview Trail .......... & -- & 98 & 2 & 74 & 26 & -- & --- & - & --- \\
\hline 7 & Kaibab Trail, south ........ & 41 & 59 & -- & 76 & 24 & - & -- & - & -- \\
\hline 8 & Kaibab Trail, north . . . . . . . . & 38 & 62 & -- & 83 & 17 & -- & -- & -- & -- \\
\hline 9 & Hermit Trail . . . . . . . . . & 18 & 72 & 10 & 84 & 16 & -- & --- & -- & -- \\
\hline 10 & Bass Trail . . . . . . . . . . & 42 & 58 & -- & 85 & 15 & -- & -- & -- & -- \\
\hline 11 & Shinumo Trail .......... & 63 & 37 & -- & 79 & 21 & $\ldots$ & --- & -- & -- \\
\hline 12 & Thunder River Trail . . . . . . . . & 85 & 15 & -- & 100 & 0 & - & --- & -- & $-\cdots$ \\
\hline 14 & Havasu Canyon ........... & 87 & 13 & -- & 100 & 0 & --- & 100 & --- & --- \\
\hline 15 & National Canyon . . . . . . . . & 67 & 35 & -- & 87 & 6 & 7 & -- & -- & -- \\
\hline 16 & Kanab Canyon ............ & 100 & -- & -- & 90 & 10 & --- & -- & -- & -- \\
\hline 17 & S B Canyon . . . . . . . . . . & 68 & 32 & $\ldots$ & 91 & 9 & -- & -- & -- & - \\
\hline 18 & Tuckup Canyon ........... & 66 & 34 & -- & 87 & 13 & --- & -- & -- & -- \\
\hline 19 & Blue Mountain Canyon ...... . & 21 & 73 & 6 & 70 & 12 & 18 & --- & -- & -- \\
\hline 20 & Prospect Valley ........... & 36 & 43 & 21 & 100 & -- & -- & -- & -- & -- \\
\hline 21 & Toroweap Valley .......... & 86 & 14 & -- & 100 & -- & - & 59 & 41 & --- \\
\hline 22 & Whitmore Wash ......... & 84 & 16 & -- & 100 & --- & -- & 83 & 17 & --- \\
\hline 23 & Parashant Canyon ......... & 58 & 42 & -- & 100 & -- & --- & 41 & 59 & --- \\
\hline 24 & Andrus Canyon $\ldots \ldots \ldots \ldots$ & 55 & 45 & -- & 85 & 2 & 13 & 67 & 33 & -- \\
\hline 25 & Twin Springs Canyon ....... & 65 & 35 & -- & 81 & 13 & 6 & --- & -- & -- \\
\hline 27 & Snap Canyon ............ & --- & --- & -- & 2 & $\cdots$ & 198 & 75 & 25 & -- \\
\hline 28 & Pigeon Wash . . . . . . . . . . & 4 & 72 & 24 & -- & 6 & 194 & \multicolumn{3}{|c|}{ (Not measured) } \\
\hline 29 & Grand Gulch Mine ........ & \multicolumn{3}{|c|}{ (Not measured) } & \multicolumn{3}{|c|}{ (Not Measured) } & 71 & 28 & 1 \\
\hline 30 & Hidden Canyon . . . . . . . . & 89 & -- & -- & -- & 10 & 190 & 56 & 44 & $\cdots$ \\
\hline 31 & Iceberg Canyon ........... & 52 & 48 & -- & 3 & 2 & 195 & 12 & 81 & 7 \\
\hline
\end{tabular}

${ }^{1}$ Includes Pakoon Limestone (McNair, 1951) where present.

central Grand Canyon, and at Whitmore Wash, Blue Mountain and Snap Canyons in the west. The significance of this upper conglomerate is not apparent, but probably marks the position of a local hiatus.

The main cliff unit of the Esplanade is the thickest and most distinctive unit of the formation as its name suggests (fig. C9). The thickness ranges from about 200 to $350 \mathrm{ft}$. This sandstone is characteristically thick bedded and crossstratified, but locally, especially in eastern Grand Canyon, it appears structureless in some sections. Everywhere it forms a massive, reddish-brown cliff of well-sorted quartz sandstone.

In the extreme western part of the Grand Canyon region, most of the main cliff unit, including all of its lower part, is represented by thick beds of carbonate rock, mostly dolomitic, known as the Pakoon Limestone (McNair, 1951) (fig. P12). The Pakoon, according to McNair (1951, p. 524), might be interpreted as a wedge of carbonate rock, older than the Esplanade and thinning eastward under the Esplanade so that in measured sections along the east side of the Shivwits Plateau, as at Andrus Canyon, Parashant Canyon, Whitmore Wash, and other localities, it is absent through nondeposition. Such an explanation probably is not correct, however, because sections farther southeastward at Twin Springs Canyon, Blue Mountain Canyon, and elsewhere, show tongues of Pakoon-like rock within the massive sandstone cliff. Furthermore, much of the sandstone of the Esplanade directly east of the Pakoon outcrops is very dolomitic, suggesting the continuation of an environment of concentrated marine waters into the area of sand deposition. Thus, the Pakoon is here considered to be an intertonguing facies equivalent to the lower part of the Esplanade Sandstone.

The uppermost unit (upper cliff-slope unit) of the Esplanade Sandstone is present in many stratigraphic sections (fig. P12). It contains a series of slope-forming siltstone or mudstone tongues or lenses within beds of massive sandstone and characteristically forms receding ledges or small cliffs separated by slopes and benches. The contact between this unit and the underlying main cliff unit is arbitrarily placed at the top of the massive sandstone or the base of the lowermost prominent slope. Because sedimentation apparently was continuous through this sequence of strata (main cliff-uppermost unit) and because no evidence of unconformity can be recognized between the two, 

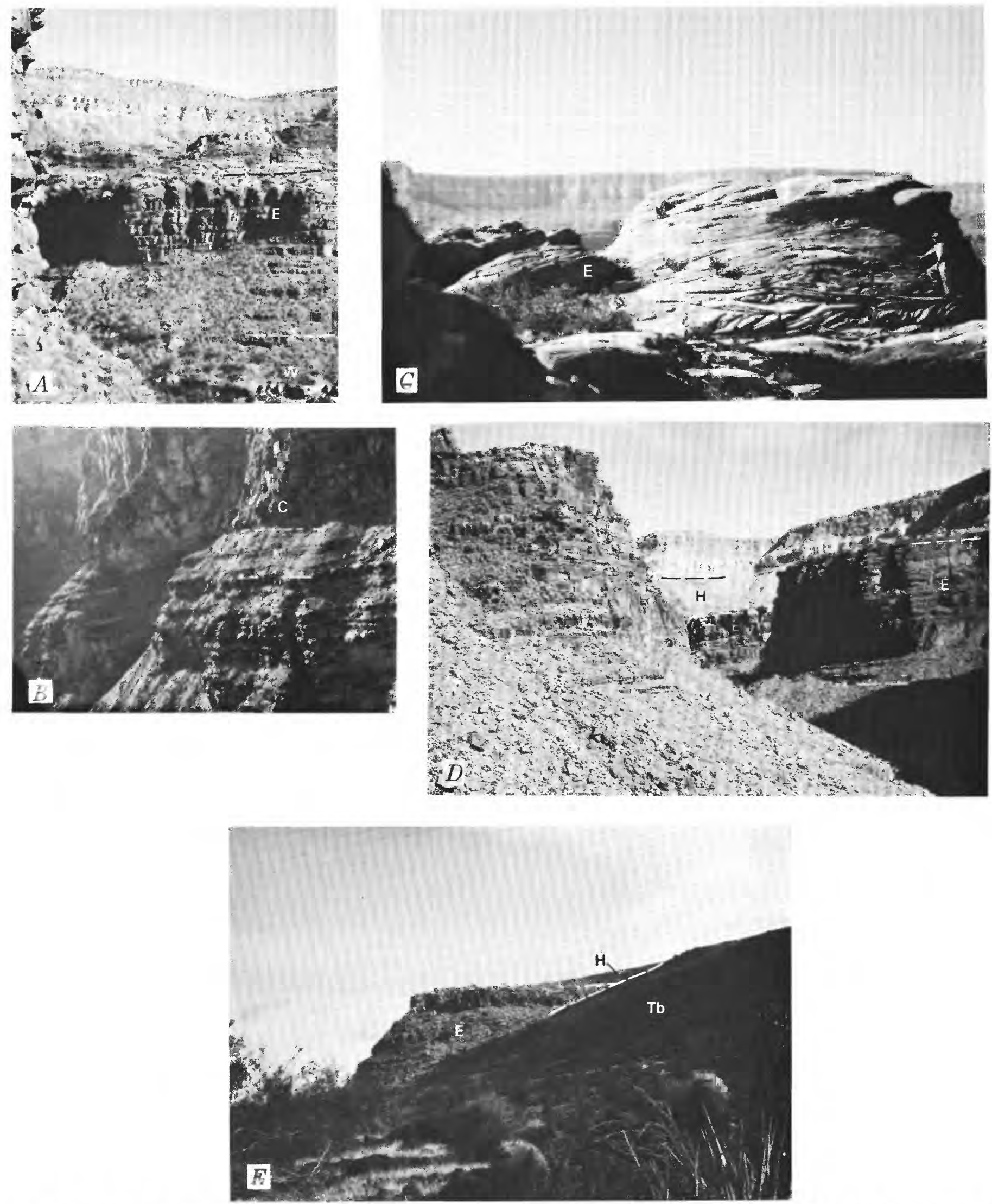

FIGURE C9.-The Esplanade Sandstone in Grand Canyon, Ariz. A, Fishtail Canyon near Thunder River Trail; B, Little Colorado River canyon at Blue Spring; C, along west trail to Thunder River; $D$, Parashant Canyon, view north; $E$, east side of Whitmore Wash, basalt flow to right. E, Esplanade Sandstone; W, Wescogame Formation; H, Hermit Shale; C, Coconino Sandstone; Tb, Tertiary basalt. 
accurate extension of this boundary throughout the region cannot be made with any degree of certainty.

On the Shivwits Plateau in the northwestern part of the region (fig. P12) a gypsiferous facies consisting of bedded gypsum and gypseous fine-grained sandstone occurs above the massive sandstone of the main cliff unit, forming a weak unit between two resistant cliffs. These gypsiferous beds extend from Andrus and Parashant Canyons on the west to Toroweap Valley on the east and are considered a facies of the upper cliff-slope unit.

Fine-grained detrital rocks of the upper cliff-slope unit that are dominantly siltstones and mudstones overlie the carbonate rocks of the Pakoon Limestone in westernmost sections of the Grand Canyon area. These fine-grained strata apparently grade eastward or intertongue with relatively pure sandstone in the upper part of the Esplanade. The change in facies is well illustrated by comparing the section at Iceberg Canyon, where the upper cliff-slope unit is 12 percent sandstone and 81 percent siltstone and mudstone, with the Snap Canyon section to the east with 75 percent sandstone and 25 percent siltstone and mudstone (table C3). A similar contrast exists in a north-south sequence of sections from Hidden Canyon to Snap Canyon, with ratios of 56-44 percent and 75-25 percent, respectively.

The combined thickness of the Esplanade Sandstone and Pakoon Limestone increases from east to west. Westward from Snap Canyon to Iceberg Canyon-a distance of 50 $\mathrm{mi}$-the thickness increases from $498.5 \mathrm{ft}$ to $718 \mathrm{ft}$. Northwestward from Twin Springs Canyon to Hidden Canyon, approximately $45 \mathrm{mi}$, an increase from $419 \mathrm{ft}$ to $856 \mathrm{ft}$ is recorded (fig. C8). The most likely explanation for this marked thickness change at the outer edge of the northwestern Arizona embayment is an increased rate of downwarping with consequent greater deposition along the margin of a basin or geosyncline to the west. A decreasing degree of erosion from east to west at the termination of Esplanade deposition might also account for increasing westward thickening. However, the coincidence of a marked change in sediment type from chiefly sandstone of the Esplanade into carbonate rock of the Pakoon on the western edge of the area of thickening lends strong support to the former concept. To the east, high-energy crossbedded sands indicative of a high-energy environment contrast with the western low-energy carbonate deposits overlain by silts, representative of relatively quiet waters.

The upper boundary of the Esplanade is a surface of erosion and in many places contains narrow channels, of considerable depth, as noted by Noble (1922, p. 63-64). This eroded surface at the upper boundary is nowhere overlain by a conglomerate. Although this contact is conspicuous in most parts of eastern Grand Canyon, it has not been recognized in sections of the far west, such as those near Grand Wash Cliffs. The Esplanade Sandstone is covered by the Hermit Shale throughout the region.

\section{LITHOLOGY}

\section{Lithology of the Watahomigi Formation}

Rocks of the Watahomigi Formation in the Grand Canyon region are distinctive in that they consist almost entirely of mudstone and carbonate rock and include very little sandstone. Red mudstone is more common here than in any other formation of the Supai Group; the amount of carbonate rock ranges from about 15 percent in the east to as much as 90 percent locally in the west. The proportions of these rock types in the Grand Canyon region (fig. C10) are shown by the following generalized percentages (figures show range in percent for each area):

$\begin{array}{llccc} & & \text { West } & \text { Central } & \text { East } \\ \text { Sand } \ldots \ldots \ldots \ldots \ldots \ldots \ldots \ldots & 0 & 5-15 & 0-5 \\ \text { Mud } \ldots \ldots \ldots \ldots \ldots \ldots \ldots & 20-40 & 25-60 & 50-85 \\ \text { Carbonates } \ldots \ldots \ldots \ldots \ldots \ldots & 60-90 & 30-40 & 15-35\end{array}$

Vertical sections of the Watahomigi Formation are readily divisible into three units in most localities of western Grand Canyon. The upper and lower divisions form slopes that are separated by a cliff in canyon profiles. Each slope consists largely of detrital beds-mostly red mudstones and red siltstones-and the cliff is formed largely of carbonate rock. Because the proportion of mudstone increases eastward as that of limestone decreases, the middle cliff unit becomes progressively smaller and weaker in that direction until it is a negligible topographic feature in most localities of eastern Grand Canyon.

Conglomerate forming thin beds and lenses constitutes a small but prominent part of the Watahomigi. In many places a distinctive conglomerate bed of durable pebbles and granules occurs at or near the bottoms of the lower and upper slope units, and in some places other conglomerate beds occur in the section, as at Toroweap Valley and at Havasu Canyon. The gravels are of resistant rock types such as flint and jasper and they commonly include indigenous marine fossils.

\section{Lithology of the Manakacha Formation}

The lithology of the Manakacha Formation differs greatly both from that of the underlying Watahomigi and from that of the overlying Wescogame. Considerably more sand, but somewhat less silt and mud, is contained in the Manakacha than in the Watahomigi as shown by figures $\mathrm{C} 10$ and C11. Limestone is common in both, especially in 


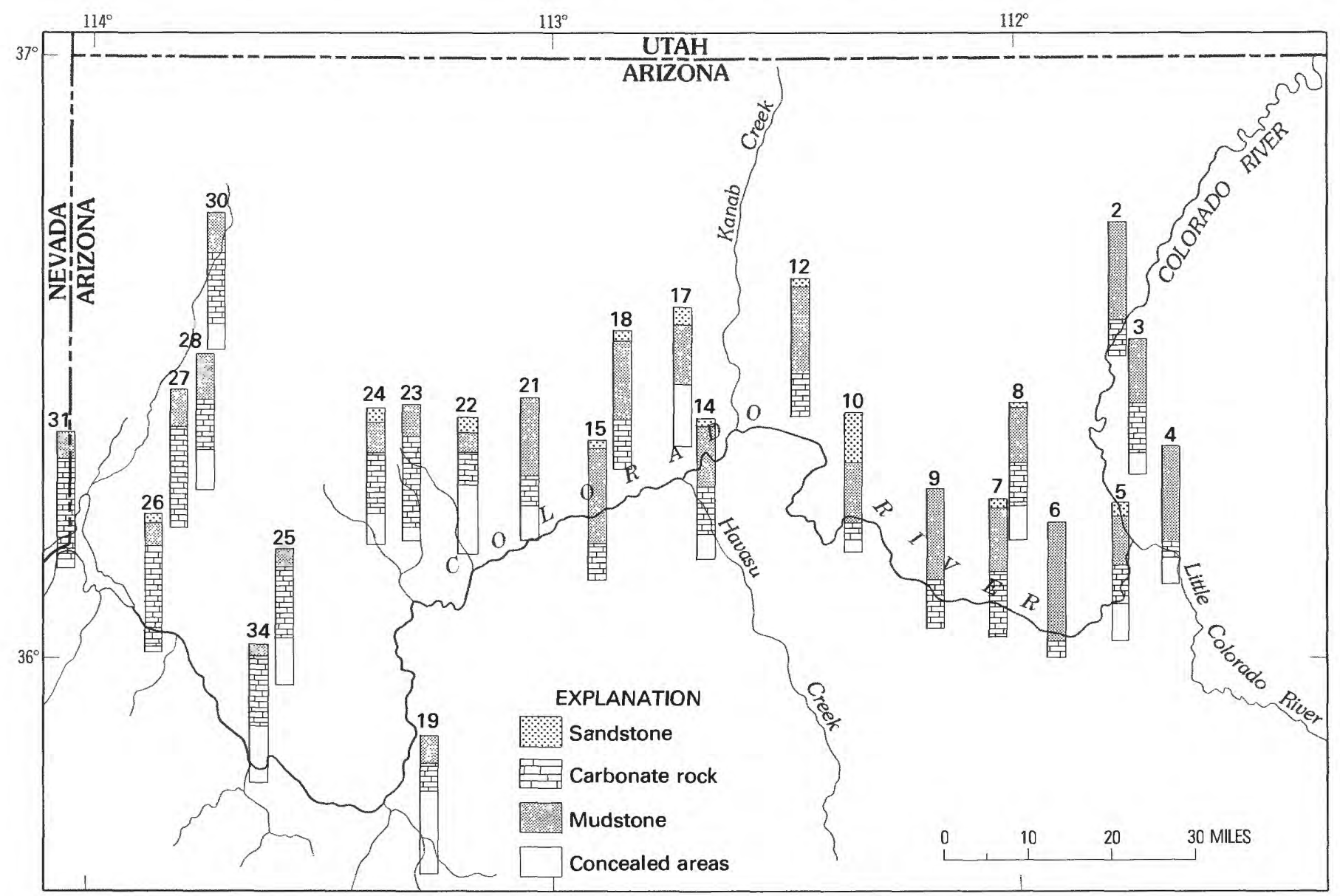

FIGURE C10.-Vertical bar graphs indicating the proportion of sandstone, mudstone, carbonate rock, and concealed areas in measured sections of the Watahomigi Formation, Grand Canyon area, Arizona. The graphs show only the proportion of major rock types; no stratigraphic position is indicated. Numbers are those of measured sections (fig. A1).

the western sections. Much more carbonate sediment and less mud occurs in the Manakacha than in the Wescogame Formation (fig. C12). Sandstone, although common in both formations, constitutes nearly all of many Wescogame sections. Approximate proportions of each main type of sediment in the Manakacha are as follows (figures show range in percent for each Grand Canyon area):

\begin{tabular}{|c|c|c|c|}
\hline & West & Central & East \\
\hline Sand & $10-30$ & $5-60$ & $20-50$ \\
\hline$\ldots \ldots$ & $0-10$ & $5-30$ & $30-60$ \\
\hline Carbonates & $35-90$ & $15-75$ & $5-20$ \\
\hline
\end{tabular}

Distinction of carbonate rock from sandstone in the Manakacha Formation is difficult in many places as a complete gradation occurs from sandy limestone to calcareous sandstone. Accurate determination of a rock's classification in such places can be made only through mechanical analysis. Sandstone comprises most of the upper part of the unit, whereas a large proportion of carbonate rock is in the lower half. These lithologic differences between upper and lower parts of the unit may be indicative of a major environmental change and, near the midpoint in at least four sections-S B, Tuckup, Parashant, and Snap Canyons-a conglomerate overlying an erosion surface occurs in that stratigraphic position.

Mudstone is most abundant in the eastern localities and, to a lesser extent, in central localities; limestone is dominant in the west, but is also common through much of the central area.

\section{Lithology of the Wescogame Formation}

Lithofacies of the Wescogame Formation differ considerably from east to west across the Grand Canyon region (fig. C12). Although sandstone, mudstone, and carbonate rock are represented in most sequences their proportions are very different from place to place as shown below (figures show range in percent for each Grand Canyon area): 


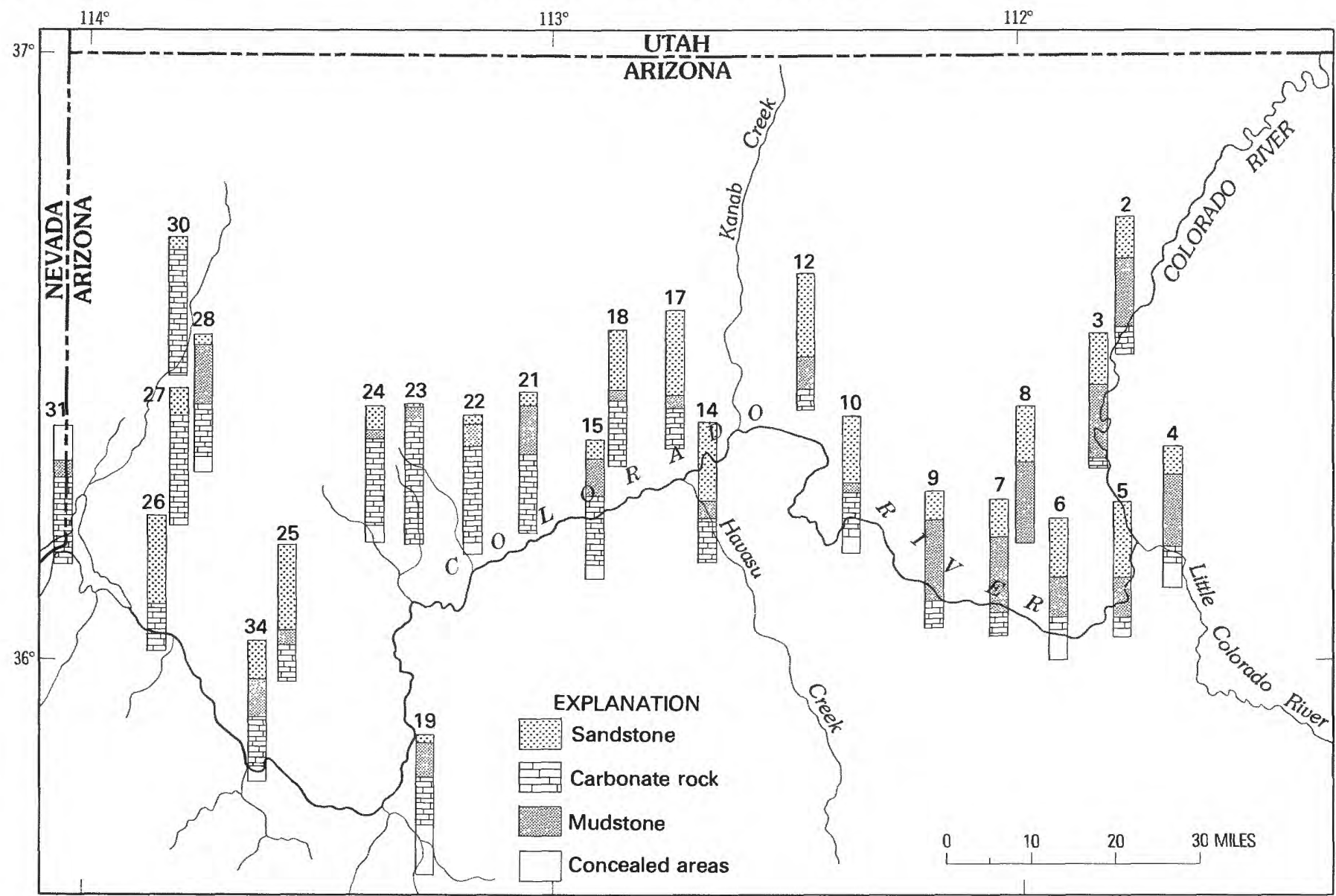

FIGURE C11.- Vertical bar graphs indicating the proportion of sandstone, mudstone, carbonate rock, and concealed areas in measured sections of the Manakacha Formation, Grand Canyon area, Arizona. The graphs show only the proportion of major rock types; no stratigraphic position is indicated. Numbers are those of measured sections (fig. A1).

\begin{tabular}{lrccr} 
& West & West-central & East-central & \multicolumn{1}{c}{ East } \\
Sand $\ldots \ldots \ldots \ldots$ & $10-50$ & $70-100$ & $75-90$ & $50-65$ \\
Mud $\ldots \ldots \ldots \ldots$ & $0-10$ & 0 & $10-25$ & $20-35$ \\
Carbonates .... $50-75$ & $0-30$ & Trace & $0-10$
\end{tabular}

Except in the extreme west where carbonate rock prevails, sandstone is the dominant rock, forming more than 50 percent of the measured sections. In some parts of central Grand Canyon, the Wescogame is exclusively sandstone. Farther east, considerable amounts of mudstone are present, whereas toward the west higher proportions of limestone occur. Limestone occurs in moderate amounts in a few eastern sections and may have been deposited in a seaway from the northeast (fig. D7) or have accumulated in local ponded areas, with no connection to the western sea.

Limestones and sandstones intertongue in rock sequences at Snap Canyon, Pigeon Wash, and Hidden Canyon along the Grand Wash Cliffs. At each locality, three or four cross-bedded sandstone units occur between thicker units of cross-bedded limestone. Eastward from this area of intertonguing, as at Twin Springs Canyon, only one thin unit of limestone occurs. Westward from this area, at Iceberg Canyon, little sandstone is present.

\section{Lithology of the Esplanade Sandstone}

The Esplanade Sandstone throughout most of the Grand Canyon region is composed dominantly of uniform, very fine grained sandstone (fig. C13). This lithology represents from 60 to 90 percent of the formation; siltstone and mudstone forms most of the remainder. At many localities in central and eastern Grand Canyon, mudstone forms a large part of the basal slope unit above a pre-Permian erosion surface; farther west, and also northeast, mudstone occurs above the main massive sandstone cliff as well. The percentage of mudstone in these areas ranges from 10 to 35. At Andrus and Parashant Canyons and at Toroweap Valley, numerous beds of gypsum occur within the sandstone-mudstone sequence of the upper cliff-slope unit. 


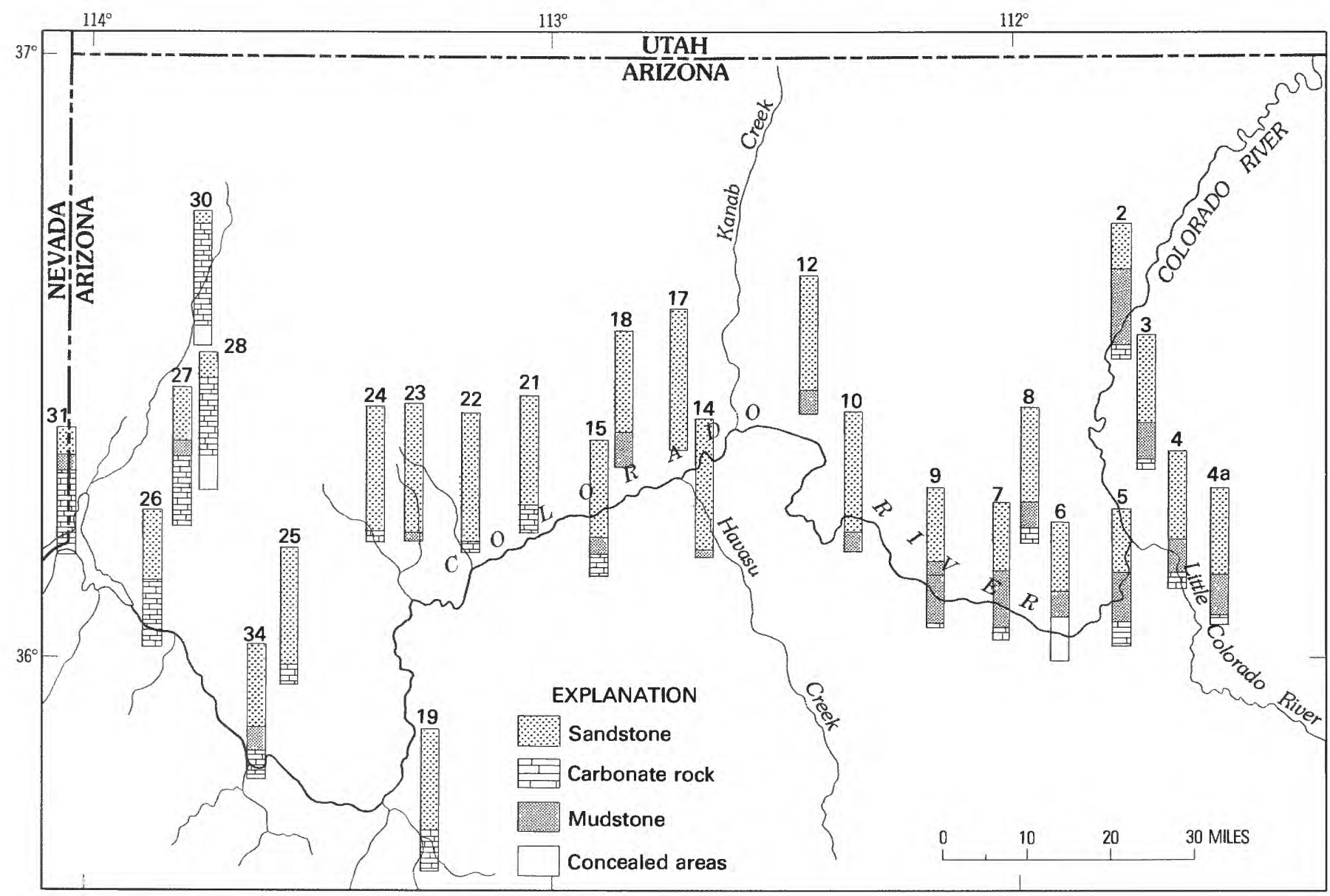

FIGURE C12.-Vertical bar graphs indicating the proportion of sandstone, mudstone, carbonate rock, and concealed areas in measured sections of the Wescogame Formation, Grand Canyon area, Arizona. The graphs show only the proportion of major rock types; no stratigraphic position is indicated Numbers are those of measured sections (fig. A1).

In all sections along the Grand Wash Cliffs of extreme western Grand Canyon and in Iceberg Canyon farther west, the position of the lower half of the Esplanade is occupied by dolomitic carbonate rock of the Pakoon Limestone. Apparently an abrupt lateral change westward in lithologic facies takes place through intertonguing of the Pakoon with the Esplanade. It occurs in a relatively short distance between sections at Twin Springs Canyon, Andrus Canyon, and others in westernmost Grand Canyon where the Pakoon is present.

A few thin tongues of carbonate rock, apparently from the Pakoon, extend far eastward through the Esplanade Sandstone of west-central and central Grand Canyon. These limestone tongues are recognized at Twin Springs Canyon in both the basal slope and main cliff units of the Esplanade and occur at Blue Mountain Canyon, Whitmore Wash, National, and Havasu Canyons near the base of the main cliff unit. In most, if not all, of these places, however, the limestone tongues represent less than 5 percent of the total lithology of the Esplanade.

Intertonguing of sandstone and mudstone is well devel- oped in the area of east-central and eastern Grand Canyon. Through much of this area, thin mudstone units occur in the basal slope unit. At Hermit, Kaibab, south, and Grandview Trails, and at some other localities in the eastern area, mudstone beds alternate with sandstone beds in the upper part of the main cliff unit and in the basal slope unit of the Esplanade, apparently the result of interfingering between two facies. The main part of the formation in this area is a massive cross-bedded sandstone with little or no mudstone.

Very fine grained sandstone composes most of the sets and cosets throughout the formation, including the main cliff unit (fig. C8, table C3). A considerable amount of siltsize quartz is distributed throughout the region, mostly as siltstones in the upper and lower units or mixed with mud in beds of mudstone. Quartz sand of fine grain size has been determined for one or two samples from each of 15 localities and sand of medium grain size for 7 localities. Sand particles of the larger sizes are mostly concentrated in a relatively few strata, indicating that sorting is good throughout the formation. 


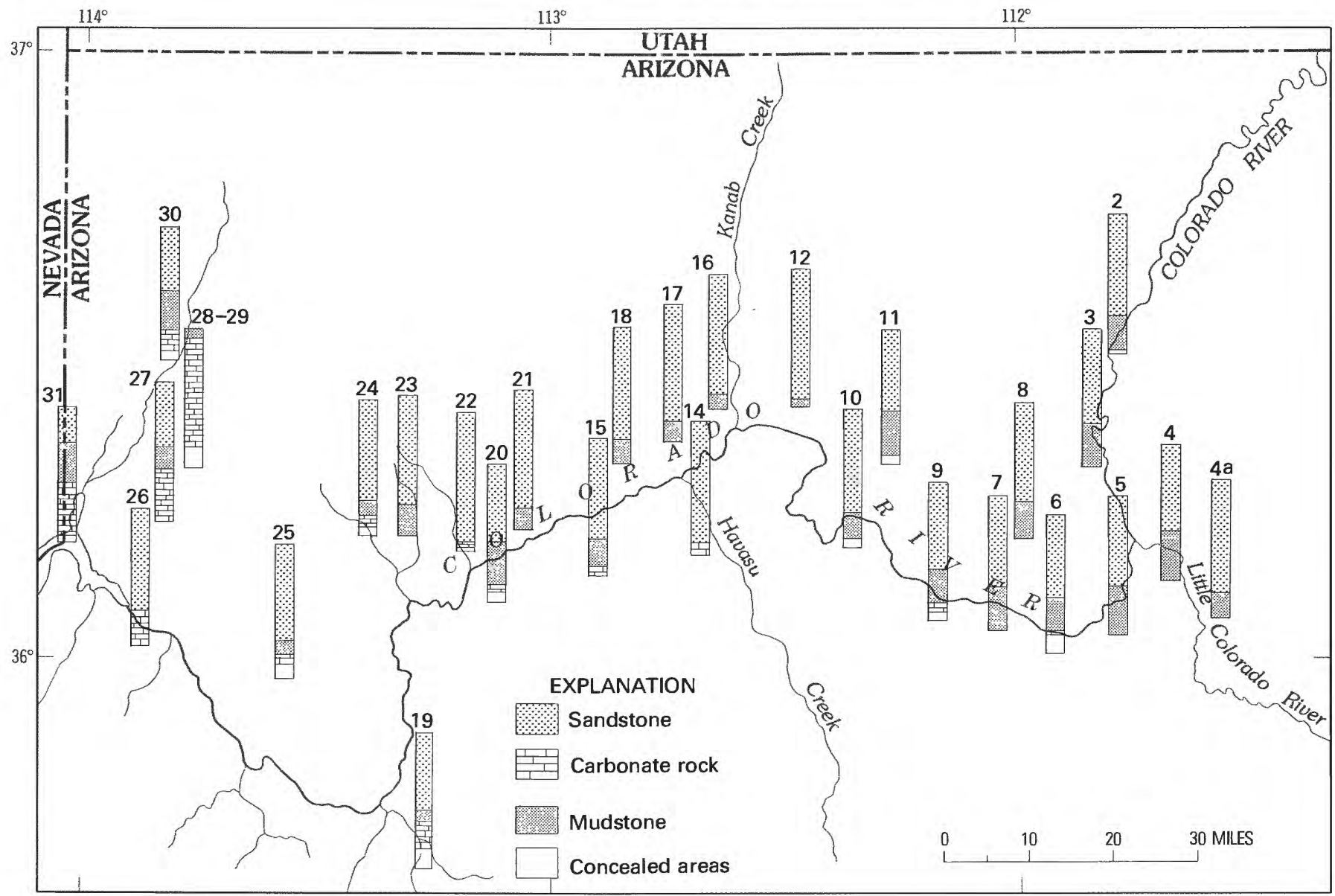

FIGURE C13.-Vertical bar graphs indicating the proportion of sandstone, mudstone, carbonate rock, and concealed areas in stratigraphic sections of the Esplanade Sandstone and Pakoon Limestone (McNair, 1951). The graphs show only the proportion of major rock types; no stratigraphic position is indicated. Numbers are those of measured sections (fig. A1).

The Pakoon Limestone in the far west contains both relatively pure limestones and relatively pure dolostones, but some intermediate mixtures of calcium and magnesium carbonate are present. In marginal areas bordering the Esplanade Sandstone on the west, however, dolostone is the dominant rock type in the Pakoon.

\section{REFERENCES CITED}

Darton, N. H., 1910, A reconnaissance of parts of northwestern New Mexico and northern Arizona: U.S. Geological Survey Bulletin 435, $88 \mathrm{p}$.
Longwell, C. R., 1921, Geology of the Muddy Mountains, Nevada, with a section to the Grand Wash Cliffs in western Arizona: American Journal of Science, 5th ser., v. 1, no. 1, p. 39-62.

McKee, E. D., 1975, The Supai Group-Subdivision and nomenclature, in Contributions to stratigraphy: U.S. Geological Survey Bulletin 1395-J, p. J1-J11.

McNair, A. H., 1951, Paleozoic stratigraphy of part of northwestern Arizona: American Association of Petroleum Geologists Bulletin, v. 35 , no. 3, p. 503-541.

Noble, L. F., 1922, A section of the Paleozoic formations of the Grand Canyon at the Bass trail: U.S. Geological Survey Professional Paper 131, p. 23-73. 

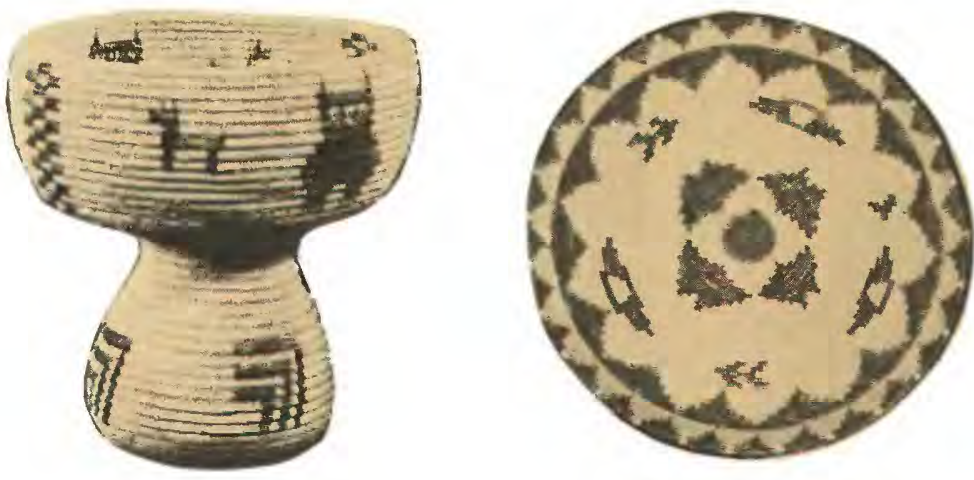

THE SUPAI GROUP OF GRAND CANYON

\title{
PALEOGEOGRAPHY
}

\author{
Chapter D
}

By EDWIN D. McKEE

\section{Contents}

\begin{tabular}{|c|}
\hline \\
\hline$\ldots \ldots$ \\
\hline 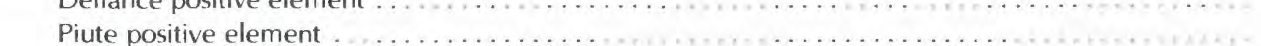 \\
\hline 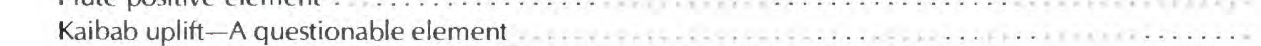 \\
\hline 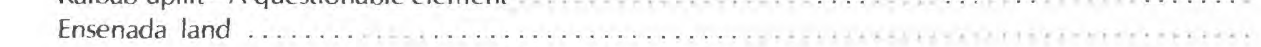 \\
\hline Cordilleran negative belt $\ldots \ldots \ldots \ldots \ldots \ldots \ldots \ldots \ldots \ldots \ldots \ldots$ \\
\hline 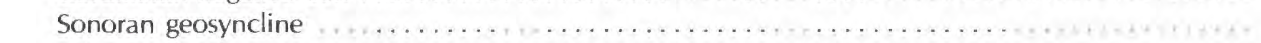 \\
\hline Arizona sag \\
\hline Paradox basin \\
\hline 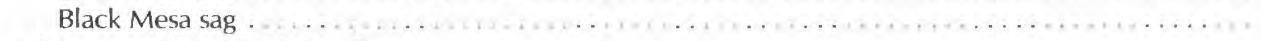 \\
\hline 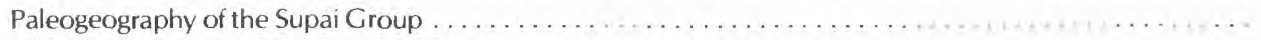 \\
\hline 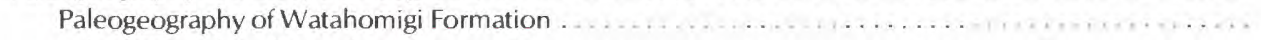 \\
\hline 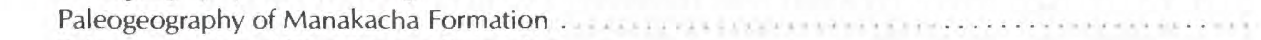 \\
\hline 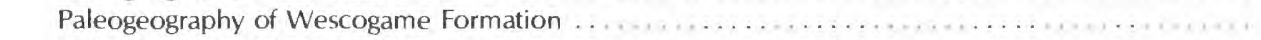 \\
\hline 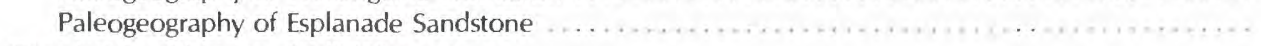 \\
\hline 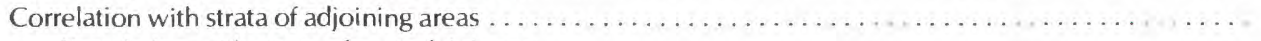 \\
\hline Correlation with strata of central Arizona \\
\hline Correlation with strata to west and northwest of Grand Canyon $\ldots \ldots \ldots \ldots \ldots \ldots \ldots$ \\
\hline Correlation with strata of the Four Corners area .. \\
\hline leferences cited \\
\hline
\end{tabular}




\section{Illustrations}

FIGURE D1. Map showing general tectonic provinces in the Arizona region during Pennsylvanian

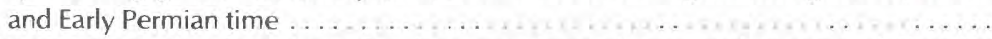

D2. Cross-sections showing alternative interpretations of ages and extents of Permian strata, Fort Defiance area, Arizona and New Mexico .................. 54

D3-D8. Regional paleogeographic maps for:

D3. Morrowan time .................................... 59

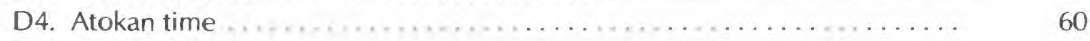

D5. Des Moinesian time ................................ 61

D6. Missourian time .............................................. 62

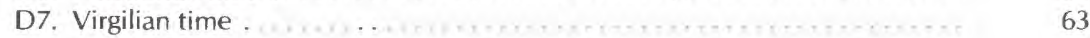

D8. Wolfcampian time ................................... 64

D9-D12. Isopach maps, Grand Canyon region, of:
D9. Watahomigi Formation

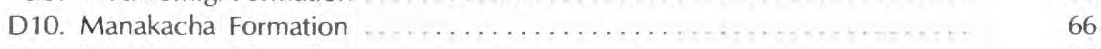

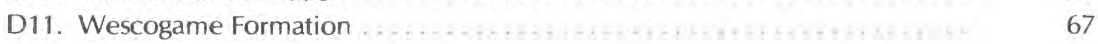

D12. Esplanade Sandstone .............................. 68

D13. Map of fossil localities in Mogollon Rim area, south and southeast of Grand Can-

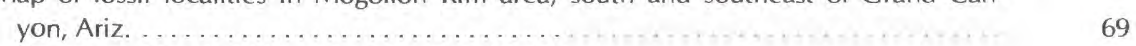

D14. Index map of fusulinid localities cited in table D4 ..................................... 71

\section{Tables}

TABLE D1. Terminology that has been applied to the Defiance, Defiance-Zuni, and related

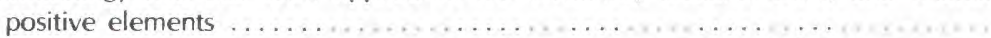

D2. List of paleogeographic maps showing area of Supai Group and related features .......

D3. Faunal assemblages from Pennsylvanian well samples in Four Corners area ..........

D4. Comparison of fusulinids of Grand Canyon with those of southern Nevada and

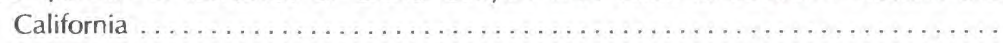




\section{STRUCTURAL FRAMEWORK FOR THE SUPAI GROUP}

Throughout Pennsylvanian and Early Permian time the region of Arizona and adjoining states consisted of three, possibly four, areas that were consistently positive, two negative belts or geosynclines, one roughly circular basin, and two intermittently negative connecting passages or sags (fig. D1). These features largely controlled the distribution of lands and seas, with constantly fluctuating positive or negative trends.

\section{Defiance positive element}

A positive element, located in the northeastern part of Arizona near Fort Defiance on the New Mexico border, probably was the most persistent elevated area within the state and certainly the most widely recognized through the Paleozoic. Its structural characteristics were first noted by Gregory (1917, p. 18), who described an outcrop in Quartzite Canyon as "a monadnock of a pre-Cambrian erosion surface-an elevated mass which outlived its contemporaries through Cambrian, Silurian, Devonian and early Carboniferous time, only to be itself buried by the streams of Permian time." The irregular surface of quartzite was covered by Permian "chocolate-colored and red arenaceous shales" (Gilbert, 1917, p. 17).

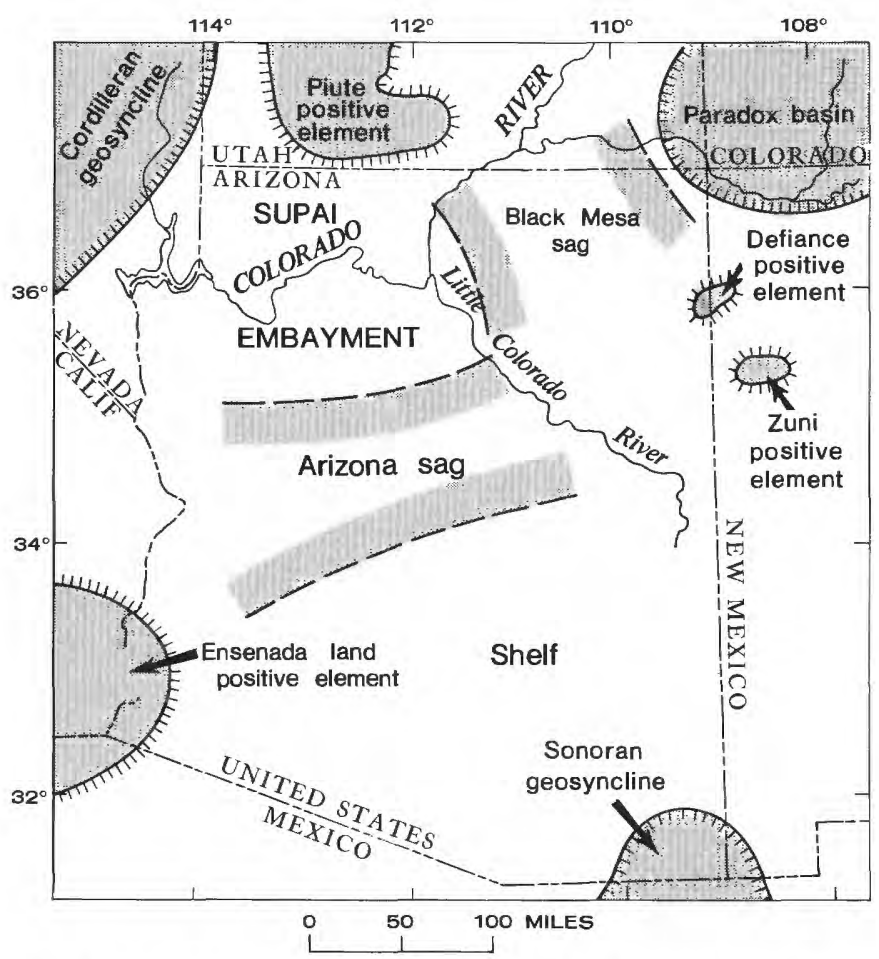

FIGURE D1.-General tectonic provinces in the Arizona region during Pennsylvanian and Early Permian time. Note position of Supai embayment.
Further description of the physical character of the Defiance uplift at the time of its initial burial in the Permian is furnished by Darton (1925, p. 85-86), who stated that the old quartzite surface contains "depressions and knobs, some of them $50 \mathrm{ft}$ or more in height" that in some places are overlain directly by red sandy shale, but elsewhere are covered by "local masses of conglomerate ${ }^{* * *}$ consisting of angular masses of quartzite and a few boulders of limestone in a red sandy matrix."

The Zuni uplift to the southeast, as described by Darton (1925, p. 86) also exhibits an onlapping relation between the Precambrian basement and the covering of Permian red beds. This contact is similar to that near Fort Defiance, Ariz., but at Zuni the Precambrian rocks are granite and the overlying Permian contains near its base a limestone with "many Manzano fossils." Although the Defiance and Zuni uplifts are separated by an area of upper Paleozoic sediments, they have similar histories and are both relatively small, so they are commonly referred to by a compound name as though parts of a single positive element.

The Defiance or the Defiance-Zuni area, although recognized as a positive element by nearly all geologists concerned with the paleogeography of the region, has been described under a myriad of names. This lack of consistency is illustrated by a compilation from the literature (table D1) that shows three variations in terminology for Defiance, two for Zuni, and nine for the combination of Defiance, Zuni, and other elements supposed to be parts of a single original feature.

Various opinions have developed concerning the time of burial and the nomenclature of onlapping Paleozoic strata on the Defiance positive element. This is primarily because, with a different sequence of formation names in the basin on each flank of the positive element, multiple correlations and different age assignments have been proposed. Whether the highest parts of the Precambrian surface were finally buried in Wolfcampian or in Leonardian time has been interpreted in more than one way as shown in northsouth sections (fig. D2). In any event, the positive element does not seem to have been "elevated as a highland or mountain area" at any part of the Pennsylvanian or Permian and few conglomerates or arkoses developed from it (McKee, 1951, p. 488). The general lack of relief or elevation during this time was discussed by Brew (1965, p. 102) and by Havenor and Pye (1958, p. 78, 79).

\section{Piute positive element}

Positive elements seem to have prevailed throughout much of southern Utah during Pennsylvanian and Early Permian time. Localized positive elements comparable to the Defiance in Arizona have been postulated in various parts of this area. Among these are the Emery uplift of central Utah (Eardley, 1962, p. 74, fig. 6.7; Wengerd and 
TABLE D1.-Terminology that has been applied to the Defiance, Defiance-Zuni, and related positive elements

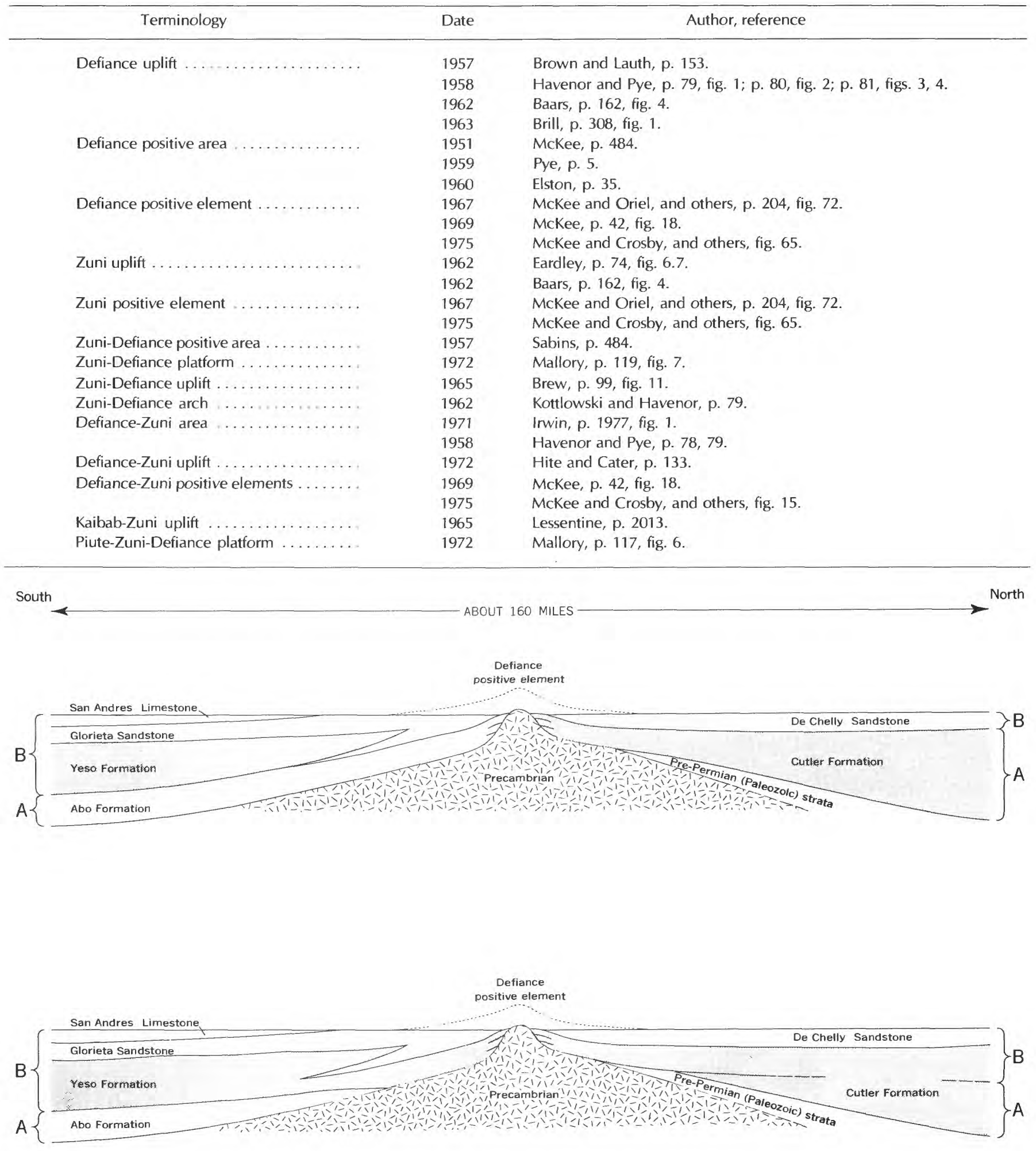

FIGURE D2.-Alternative interpretations of ages and extents of Permian strata in Fort Defiance area, Arizona and New Mexico. A, Wolfcampian age; B, Leonardian age. Modified from McKee and Oriel, and others (1967, fig. 77). 
Matheny, 1958, fig. 17; Baars, 1962, p. 162, fig. 4; Brill, 1963 , p. 308 , fig. 1; Rich, 1971, p. 446, fig. 11; Hite and Cater, 1972, p. 133) and the Circle Cliffs uplift farther south in central southern Utah (Eardley, 1962, p. 74, fig. 6.7; Heylmun, 1958, p. 1798, fig. 3). A third localized positive element, referred to as the Sevier uplift (Brill, 1963, p. 308 , fig. 1), is shown questionably in west-central Utah.

A broad weakly defined positive area covering much of southwestern Utah and including some or all of the three elements just described is apparent on most isopach maps of the region. This entire area, bordered by the Cordilleran geosyncline on the west and the strongly negative Paradox basin on the east, has variously been referred to as the west-central Utah uplift (Steele, 1959, p. 3-7), the central Utah high (Brill, 1963, p. 308, fig. 1), the western Utah high (Coogan, 1964, p. 488, fig. 1), the (southwestern Utah) platform (McKee and Oriel, and others, 1967, p. 204, fig. 72), the Piute platform (Mallory, 1972, p. 115, 126, figs. 4, 9), and the Piute positive element (McKee and Crosby, and others, 1975, fig. 15).

\section{Kaibab uplift- A questionable element}

The name "Kaibab uplift" seems to the writer to be an unfortunate choice of name for a positive element in Pennsylvanian time, despite the fact that a number of authors have used it. Some geologists (Havenor, 1958; Baars, 1962, fig. 4; Hite and Cater, 1972, p. 133) have applied it to a supposed positive element located during the Pennsylvanian in the position of the present Kaibab uplift (fig. A1, near sec. 8). This concept seems untenable, however, in view of the amount of sediment deposited in that area during Morrowan, Atokan, Virgilian, and Wolfcampian time, shown in isopach maps of formations in the Supai Group (figs. D9-D12). This area did not exhibit positive tendencies like those of the Defiance and Zuni uplifts, during Pennsylvanian and Early Permian time, and apparently sank at least as much as several adjacent shelf areas.

Some authors, on the other hand, have used the name Kaibab uplift for areas well removed from the present geographic position of the Kaibab Plateau, and this usage likewise seems misleading. The name has been applied to an area in the middle part of southern Utah (Brill, 1963, fig. 1; Rich, 1971 , p. 446 , fig. 11), to the eastern part of southern Utah, northeast of Kanab, Utah (Heylmun, 1958, p. 18011802, fig. 3), and to an area in southern Utah northwest of the present Kaibab uplift (Brew, 1965, p. 99, fig. 11). That movements in these areas may have been ancestral to the present Kaibab uplift does not seem to be supported by their geographic positions, which show no relation to those structures that control the Kaibab uplift of today.

\section{Ensenada land}

The name Ensenada land was used by Schuchert (1910) for a supposed landmass in or near the southwestern corner of Arizona. Rather scant evidence, consisting of thickness trends from northeast and east across southern Arizona, is available to support this concept of a Paleozoic positive element. A thinning of Pennsylvanian rocks toward that area suggested to McKee (1951, p. 485, pl. 1-2) that a persistent landmass probably existed. Little evidence concerning the position, extent, or elevation of this positive element has become available with subsequent work on Pennsylvanian strata of the region (McKee and Oriel, and others, 1967; McKee, 1969, p. 42, fig. 18; McKee and Crosby, and others, 1975, figs. 15, 65), but it still seems likely that a landmass existed during the time of deposition of the Supai Group.

\section{Cordilleran negative belt}

In southern Nevada and westernmost Utah, the strongly negative belt, commonly referred to as the Cordilleran miogeosyncline, had pronounced negative tendencies in various places during late Paleozoic time (Brill, 1963, p. 312). The region west and northwest of the Grand Canyon area, therefore, has been variously referred to as the Cordilleran geosyncline (McKee, 1951, p. 490; Havenor and Pye, 1958, p. 78; Pye, 1959, p. 5; Brew, 1965, p. 99, fig. 11; McKee and Oriel, and others, 1967, p. 204, fig. 72; Irwin, 1971, p. 1977, fig. 1), the Cordilleran trough (McKee, 1969, p. 42, fig. 18), and the miogeosyncline (Welsh, 1959, p. 87, fig. 12; Bissell, 1960, p. 1426; Coogan, 1964, p. 487; McKee and Crosby, and others, 1975, figs. 15, 65).

Because during Pennsylvanian and Permian time the areas of rapid sinking were more localized and less uniform than in earlier parts of the Paleozoic, some geologists have considered the Cordilleran negative belt to be divisible into two or more basins separated periodically by less negative or by positive areas. The southernmost basin or basinswest of the area of Supai deposition-have been referred to as the Pioche basin (Brill, 1963, p. 308, fig. 1), the Ely basin and Bird Spring basin (Coogan, 1964, p. 488, fig. 1), the Hogan basin (Rich, 1971, p. 446, fig. 11), the Ely-Bird Spring basin (McKee and Crosby, and others, 1975, fig. 15), and simply the basin (Welsh, 1959, figs. 8, 9, 10).

The southern Nevada basins probably were not continuously active throughout Pennsylvanian-Permian time; the Ely basin, for example, subsided principally in Early Pennsylvanian (late Morrowan) time, according to Coogan (1964, p. 488), but during the Late Pennsylvanian much of that area was included in the western Utah high. Thus, the conclusion is reached by Coogan that "both 
basinal and mildly positive elements of less than systemic duration appear to have existed in the same part of the Cordilleran miogeosyncline during the Late Paleozoic."

An attempt to delineate within narrow limits a boundary between the "basin" with thick sections and the adjoining "platform" or shelf with relatively thin sections has been made by Welsh (1959, figs. 1, 12). This line of demarcation he has termed the "Las Vegas Hinge Line" (1959, p. 88). As pointed out by Brill (1963, p. 312), however, "this relatively rapid change in thickness and facies may be an illusion created through shortening caused by Cretaceous thrust faulting." Numerous examples of thrusting and consequent shortening of magnitudes ranging from 20 miles (Longwell, 1949, p. 924) to 40 miles (Misch, 1957) have been recorded and were summarized by Brill for various areas along the Las Vegas line.

The part of southern Nevada, directly west of the Supai depositional area and southeast of the Cordilleran basins, has been referred to as the Callville shelf by Coogan (1964, fig. 1) and the Bird Spring carbonate shelf by Rich (1971, fig. 11).

\section{Sonoran geosyncline}

A negative belt persisted in southeastern Arizona during all of Paleozoic time, but was especially active in the Pennsylvanian. It appears as a prominent feature on isopach maps of the region and is generally recognized as the northern end of a geosyncline that trended northwestward into Arizona from Mexico (fig. D1). Commonly it is referred to as the Sonoran geosyncline (McKee, 1951, p. 485; Wengerd and Matheny, 1958, fig. 14; Pye, 1959, p. 5; McKee and Crosby, and others, 1975, p. 5, fig. 65), but it has also been called the Mexican geosyncline (Havenor and Pye, 1958, p. 80) and the Sonoran trough (McKee, 1969, p. 42, fig. 18).

The Arizona part of the Sonoran geosyncline is considered a basin by some geologists and is called the Pedregosa basin by Brew (1965, p. 99, fig. 11) and by McKee and Oriel, and others (1967, p. 204, fig. 72). It is referred to as the Quemado-Cuchillo basin by Irwin (1971, p. 1977, fig. 1).

\section{Arizona sag}

The record of epeirogenic activity in central Arizona during Paleozoic time has long been a matter of controversy. Uncertainty concerning this activity has been caused partly because the sedimentary record is sparse, Paleozoic strata having been largely removed by erosion, and partly because the region apparently fluctuated between positive and negative movements. The history of this area has necessarily been deduced largely by projection of isopach trends and other data from adjacent areas.
To the northwest and southeast were geosynclines, and to the northeast an extensive basin, all of which sank considerably during Pennsylvanian and Early Permian time. Positive elements that remained constantly above sea level, though they were not elevated to great heights during this time, were to the north, east-northeast, and probably also southwest. However, the central Arizona area had neither the strongly negative tendencies of the geosynclines and basins, nor the consistently positive character of the positive elements.

Because of its intermediate character, central Arizona at times formed a barrier to adjacent seas and at other times was covered by shallow water, so it has been considered a positive area by some geologists and negative by others. Periods of elevation in this area were emphasized by Stoyanow (1936, p. 462; 1942, p. 1273-1274), and by Huddle and Dobrovolny (1945) who referred to it as Mazatzaland during Paleozoic time. Evidence of submergence and connecting seaways across this area have caused others (McKee, 1951, p. 485-486; 1969, p. 42; Eardley, 1951, pls. 7, 8, 9; 1962, figs. 6.7, 6.8) to minimize its positive character. Accordingly, it has been referred to as the Arizona sag (fig. D1), periodically connecting seas of the Cordilleran and Sonoran geosynclines.

The Arizona sag seems to have been a marine barrier during Early Pennsylvanian (Morrowan) and Middle Pennsylvanian (Atokan) time, as illustrated by isopach lines on figures D3 and D4. During all of this time, the seaway occupying the Sonoran geosyncline probably was cut off from the embayment of the Cordilleran geosyncline that covered the Grand Canyon area. Not until Late Pennsylvanian (Virgilian) time is there good evidence that the sea extended completely across Arizona from northwest to southeast (fig. D7). Thickness trends on both sides (fig. D8) indicate that seas of two geosynclines probably connected across the Arizona sag again in Early Permian (Wolfcampian) time, but evidence for this event is not conclusive.

\section{Paradox basin}

Northeast of the area of Supai deposition in the Grand Canyon region, the Paradox basin of southwestern Colorado and southeastern Utah was actively sinking during much of Pennsylvanian and Early Permian time. The basin axis paralleled the southwest side of the Uncompahgre uplift in Colorado, and the basin margins extended southwestward into Arizona and New Mexico. The basin was about 360 miles from northwest to southeast and 180 miles at right angles.

The Paradox basin began to develop in Atokan time (fig. D4), when deposits a few hundred feet thick accumulated in both southwestern Colorado and southeastern Utah (Wengerd and Matheny, 1958, fig. 14) on a karst surface of 
Mississippian rocks. Maximum subsidence of the Paradox basin was reached during Des Moinesian time, when several thousand feet of sediment were deposited and thick salt deposits accumulated in evaporitic seas. The depositional area at that time was widespread and connected westward across central Utah with the Cordilleran geosyncline and southward through western New Mexico with the Sonoran geosyncline (fig. D5).

Later in Pennsylvanian time sediments accumulated at a relatively slow rate and evaporitic deposition ceased, but the basin margins continued to be widespread. In Virgilian time connections with the Grand Canyon area, as well as in other directions, resulted from further submergence. By Wolfcampian time the basin configuration had greatly changed and the term "San Juan Basin" commonly is applied to the negative parts of this area.

\section{Black Mesa sag}

Black Mesa sag is the name used by Wengerd and Matheny (1958, p. 2082, fig. 17) for a marine embayment, extending southwestward from the Paradox basin, that subsided during Missourian time. This area in northeastern Arizona, roughly between Kayenta and Chinle, apparently was submerged also during parts of Atokan (fig. D4), Virgilian (fig. D7), and Wolfcampian times (fig. D8), and at those times formed a strait connecting with marine waters of the Grand Canyon region. Relatively thin deposits of sediment were accumulated in the Black Mesa sag, suggesting that the term "sag" is much more appropriate than "Black Mesa basin," which has commonly been used (for example, Lessentine, 1965, fig. 12).

\section{PALEOGEOGRAPHY OF THE SUPAI GROUP}

Because strata of the Supai Group range in age from Early Pennsylvanian into Early Permian and were formed during a number of widely separated intervals of time, they represent numerous distinct combinations of land-sea relationships. Generalizations regarding marine distribution are, therefore, difficult to make, although throughout this time some features remained constant, as indicated by the preceding discussion of the structural framework.

A general agreement occurs in the recognition of a continuously positive element east of the Grand Canyon embayment, along the Arizona-New Mexico border, and in the existence of major negative areas to the west in Nevada, to the northeast in the Paradox basin area, and in southeastern Arizona. Interpretations of minor physiographic features, however, differ greatly. As shown in table D2, more than 40 different paleographic maps of this region, mostly isopach and lithofacies, have been published during the period between 1949 and 1978. These maps represent a wide variation in viewpoints.

In connection with the present investigation, a series of maps showing land-sea relations within Arizona and parts of adjoining states has been prepared for Pennsylvanian and Early Permian time (figs. D3-D8). These maps are largely derived from the isopach maps of the Pennsylvanian and Permian volumes of the Paleotectonic Map series, U.S. Geological Survey (McKee and Oriel, and others, 1967; McKee and Crosby, and others, 1975). Details of the Supai embayment, in which the Supai Group was formed, however, were established directly from stratigraphic section measurements obtained at the 35 control stations studied in connection with this project.

Maps showing, in detail, configuration of the Supai embayment during development of each of the four formations of the Supai Group have been prepared as isopach maps (figs. D9-D12). Actually these maps delimit the boundaries of areas, both continental and marine, in which deposition occurred and are not strictly representative of land-sea margins; their isopachs indicate thicknesses of continental and marine deposits combined. As will be shown later, however, the proportion of continental sediments to that of marine apparently was so small that for general considerations the depositional limits, as established, serve to indicate approximate boundaries of the seaways.

\section{Paleogeography of Watahomigi Formation}

Paleogeography of the Watahomigi Formation is reconstructed primarily from the record of land-sea relationships in the Grand Canyon region during Morrowan time, and a small part of Atokan time. Throughout this interval the environment of deposition apparently was relatively constant in the area. The nearest main seaway was to the west in the Cordilleran miogeosyncline of Nevada. The Grand Canyon area was a shallow embayment with landmasses on three sides, as indicated by isopachs (fig. D3).

To the northeast of the Grand Canyon area, along the southern margin of the Paradox basin, no fossils of certain Morrowan age have been reported from Pennsylvanian rocks (table D3). Apparently at that time the Paradox sea was much restricted and was limited to areas farther east and north in Colorado and Utah; no marine connections from those directions to the Watahomigi embayment could have existed.

Eastward from the Grand Canyon area was the Defiance positive element with its center along the New Mexico boundary (McKee, 1951, p. 491). It, like the region farther north, seems to have been an area of nondeposition during 
TABLE D2.-Paleogeographic maps that show area of Supai Group and related features

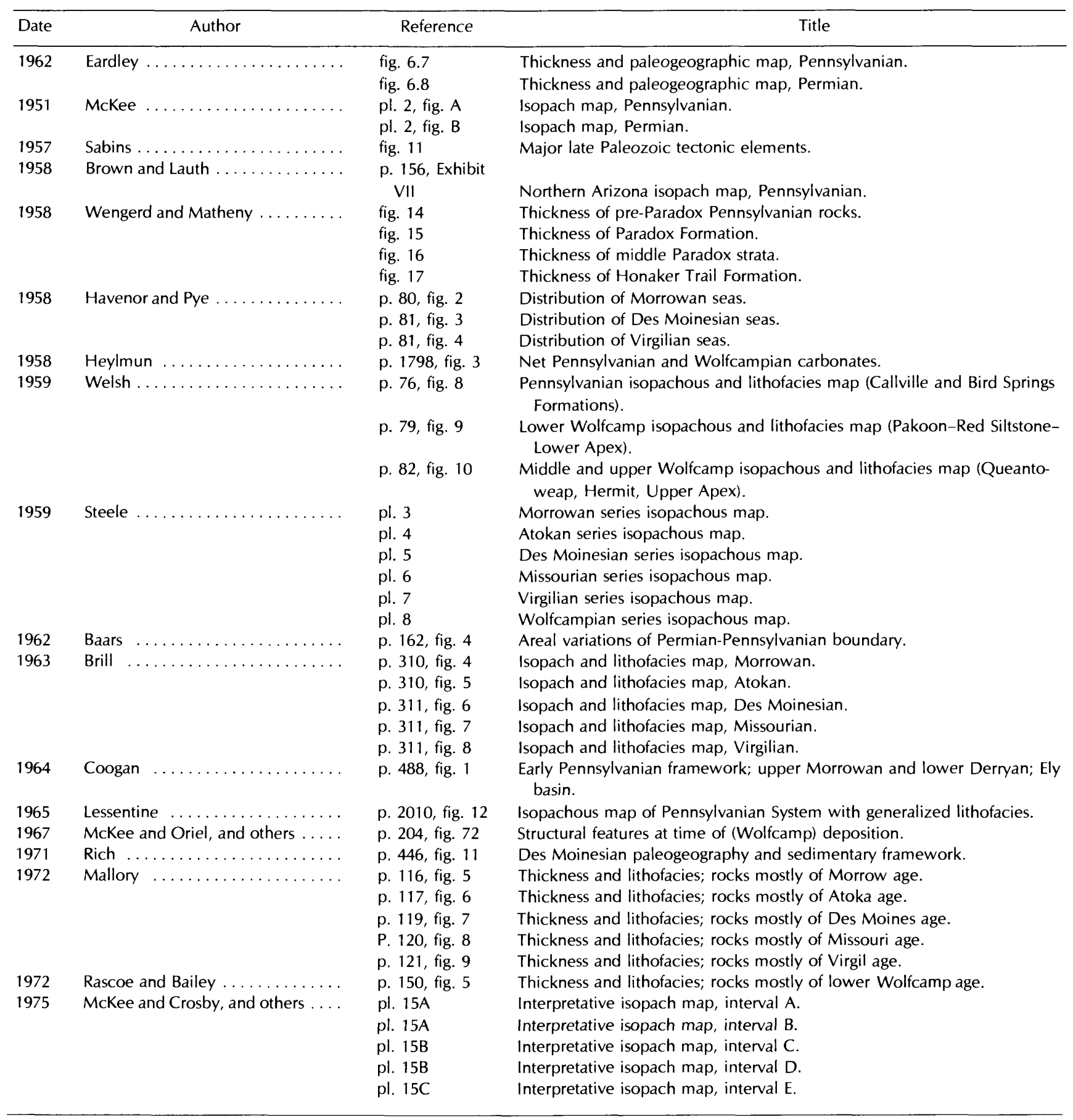

Morrowan time, for no diagnostic fossils and no deposits considered of Morrowan age have been recognized in that part of Arizona.

South and southeast of the Grand Canyon area, the closest recorded deposits of Morrowan age are in the extreme southeastern corner of Arizona. In the thick Paleozoic sections of that area, occupying the northern end of the Sonoran geosyncline, rocks of Morrowan age have been recognized in many places (Sabins, 1957; Tyrell, 1957; Nations, 1963). Along the Mogollon Rim in central Arizona and elsewhere southeast of Grand Canyon, however, the entire sequence of Pennsylvanian strata, as represented by the Naco Group, apparently is younger than Morrowan. The Sonoran seas, therefore, could not have 


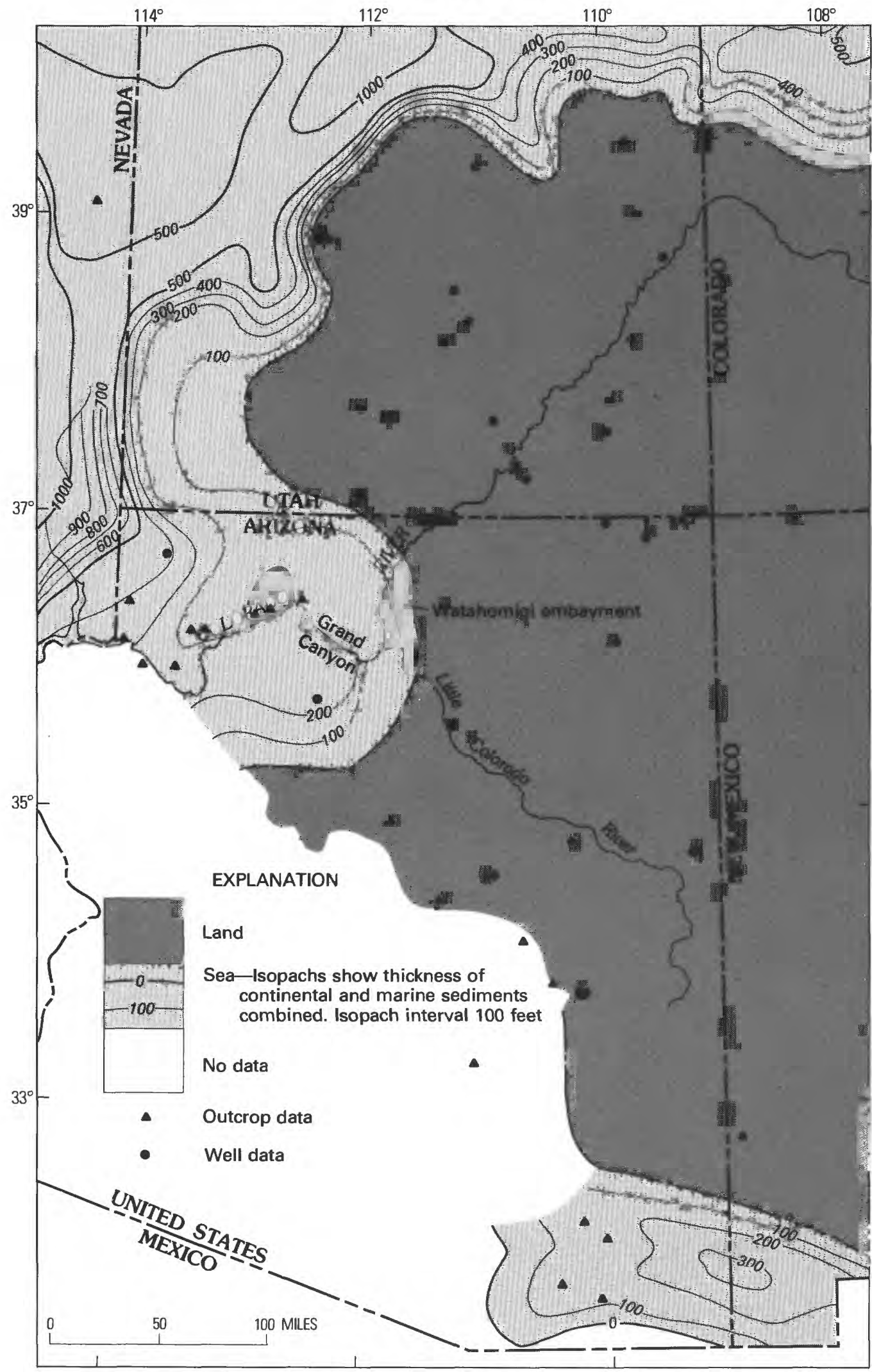

FIGURE D3.-Regional paleogeographic map for Morrowan time. Isopach interval $100 \mathrm{ft}$. 


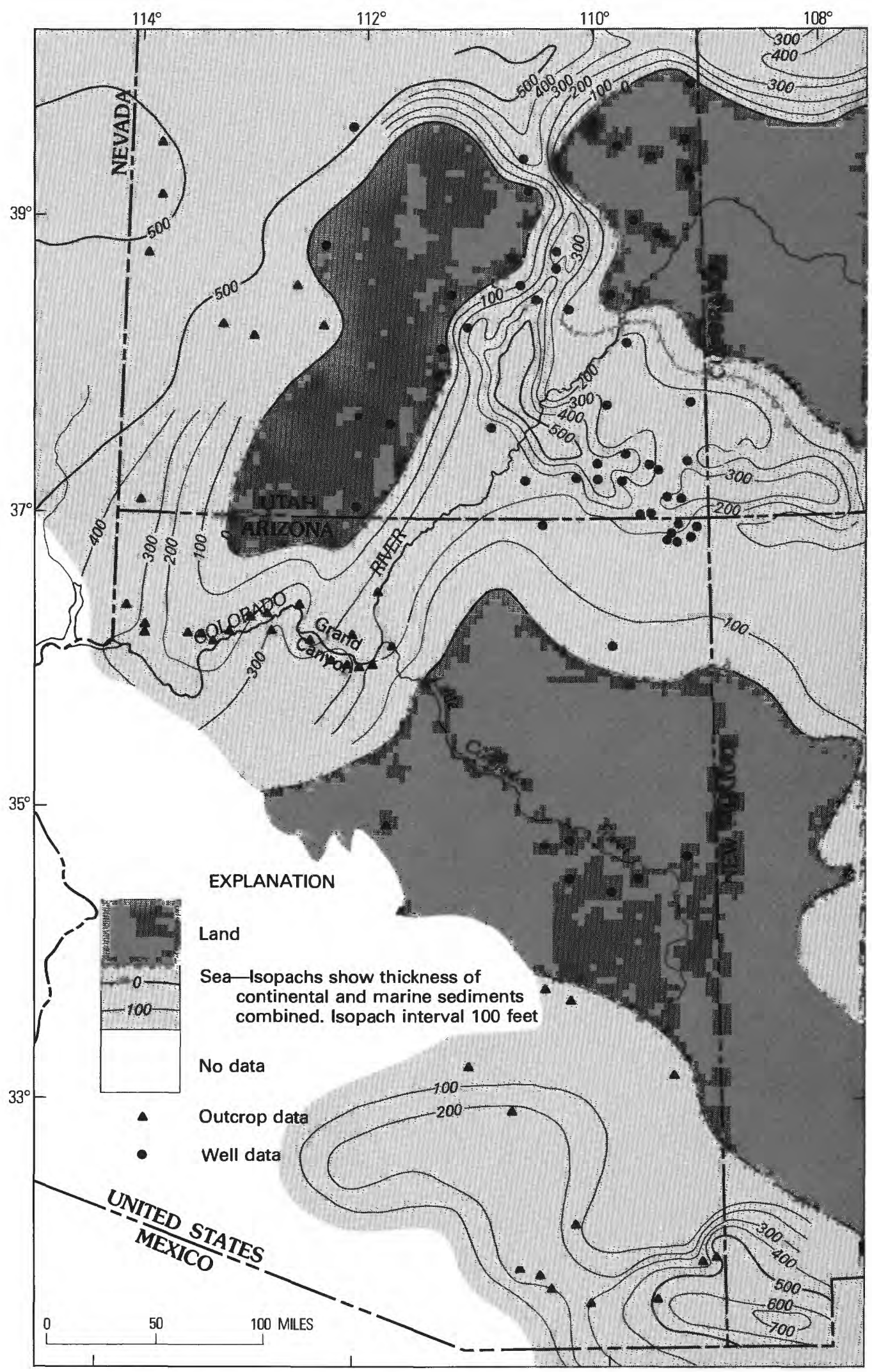

FIGURE D4.- Regional paleogeographic map for Atokan time. Isopach interval $100 \mathrm{ft}$. 


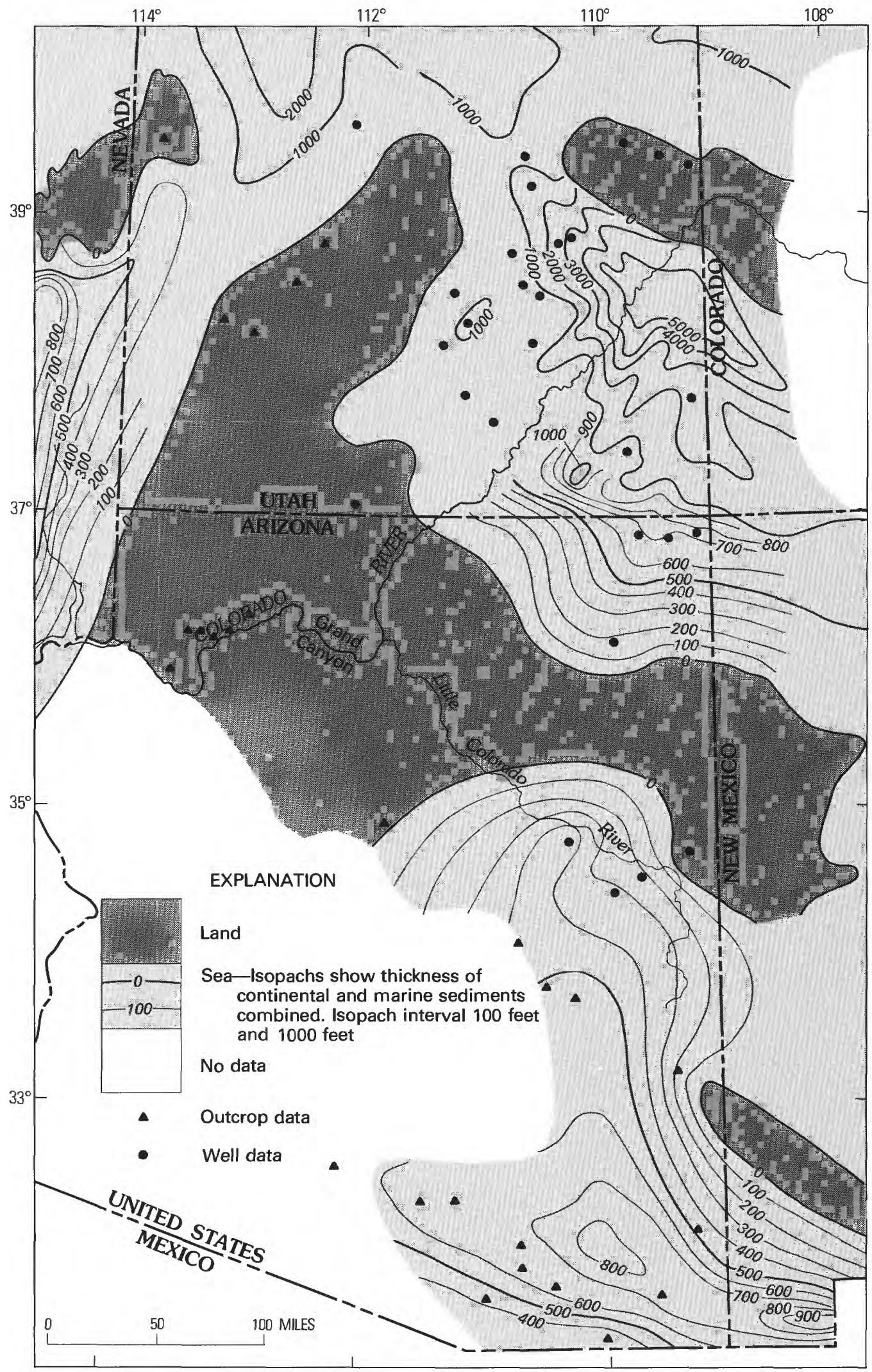

FIGURE D5.-Regional paleogeographic map for Des Moinesian time. Isopach interval $100 \mathrm{ft}$ and $1000 \mathrm{ft}$. 


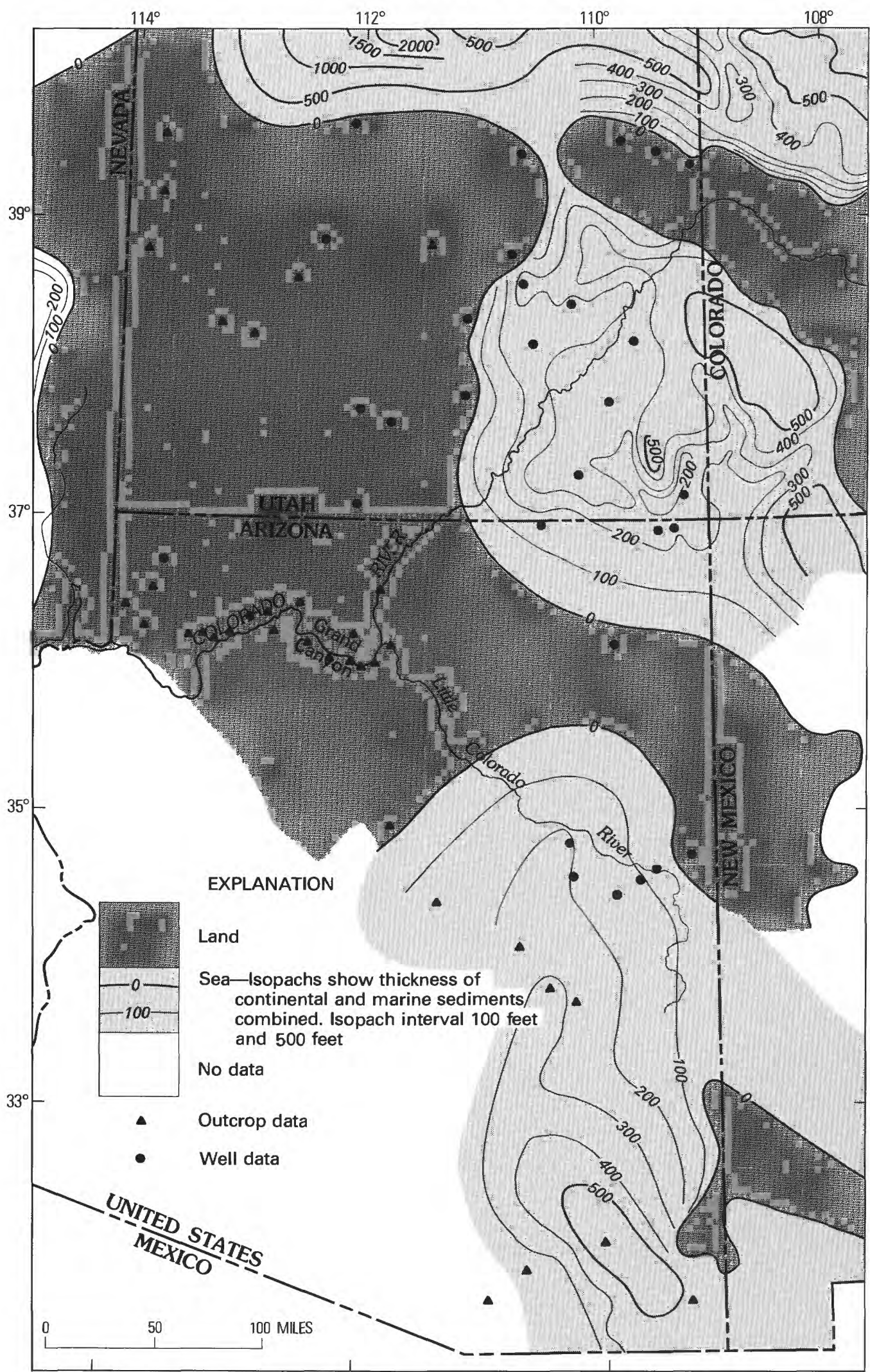

FIGURE D6.-Regional paleogeographic map for Missourian time. Isopach interval $100 \mathrm{ft}$ and $500 \mathrm{ft}$ 


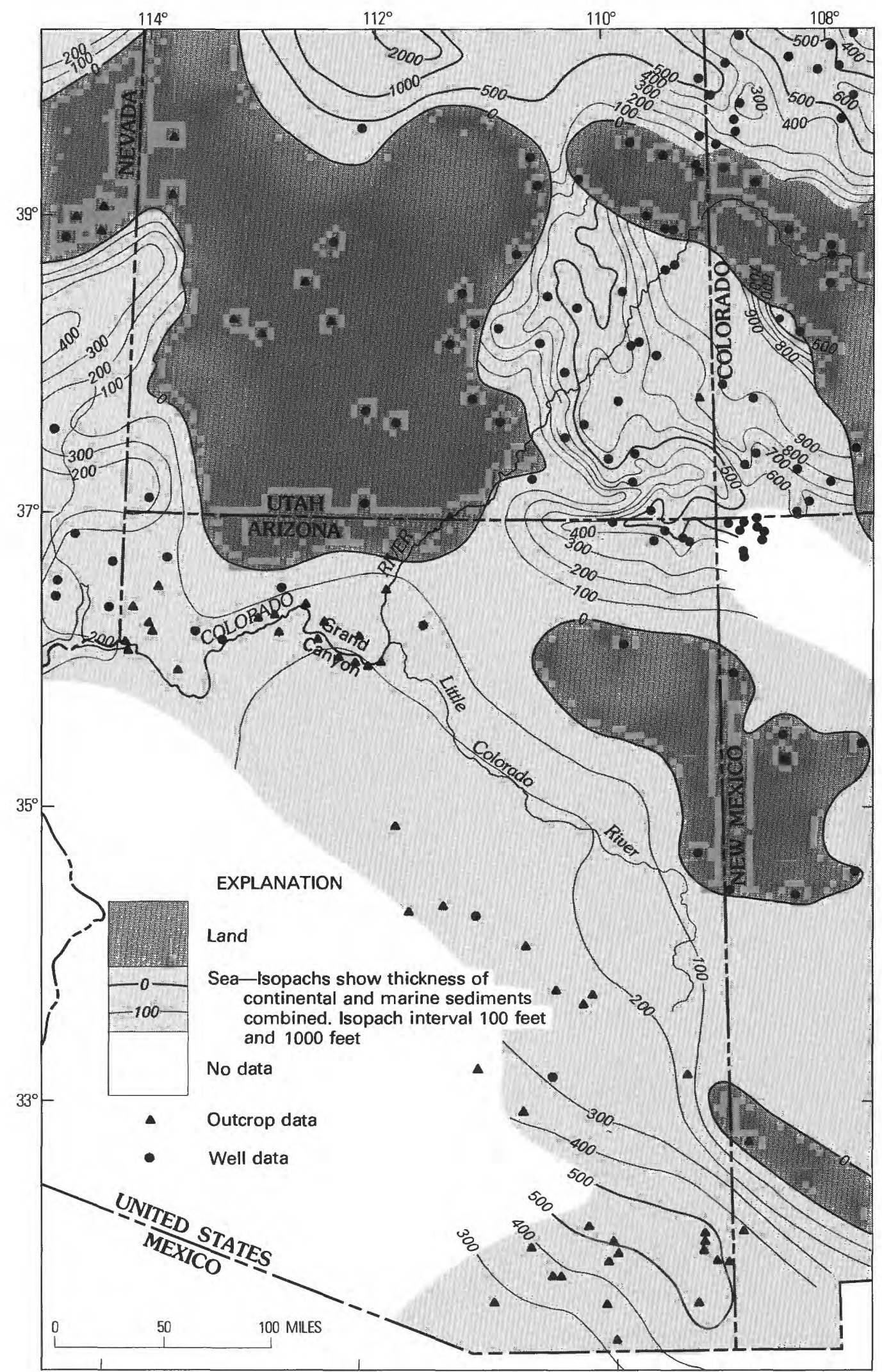

FIGURE D7.-Regional paleogeographic map for Virgilian time. Isopach interval $100 \mathrm{ft}$ and $1000 \mathrm{ft}$. 


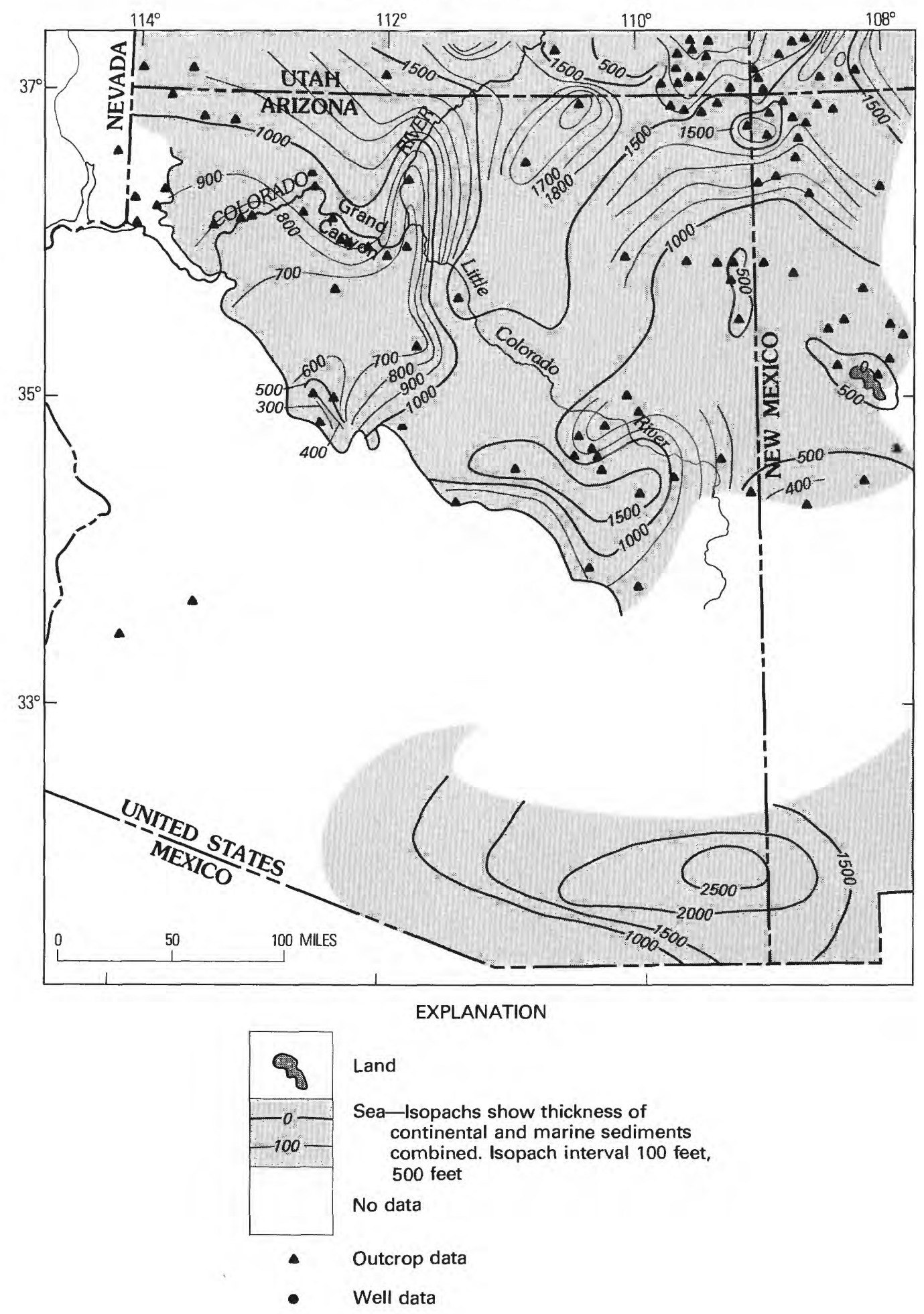

FIGURE D8.-Regional paleogeographic map for Wolfcampian time. Isopach interval $100 \mathrm{ft}$ and $500 \mathrm{ft}$.

connected across central Arizona with the Watahomigi embayment at that time.

The thickest sections of strata $(250$ and $300 \mathrm{ft})$ in the Watahomigi (Morrowan) marine embayment of the Grand Canyon region, as delineated by isopachs (fig. D9), roughly parallel the western margin of the Colorado Plateau and are normal to the trend of Grand Canyon. The zero isopach or inner margin of the Watahomigi embayment is not far east of Grand Canyon's eastern end.

Deposits within the Morrowan embayment furnish no 
TABLE D3.-Faunal assemblages from Pennsylvanian well samples in Four Corners area showing distribution and age assignments by John Chronic

[Figures in columns refer to number of collections]

Morrowan Atokan Des Moınesian Missourian Virgilian

\begin{tabular}{|c|c|c|c|c|c|}
\hline Northeastern Arizona. . . & 11 & 2 & 5 & 0 & 0 \\
\hline County ............ & 0 & 5 & 9 & 0 & 1 \\
\hline $\begin{array}{l}\text { Utah, southern San } \\
\text { Juan County (T. } 39 \text { S.- } \\
\text { T. } 43 \text { S.) .......... }\end{array}$ & 0 & 2 & 19 & ${ }^{1} 1$ & 1 \\
\hline $\begin{array}{l}\text { Utah, middle San Juan } \\
\text { County (T. } 32 \text { S.-T. }\end{array}$ & & & & & \\
\hline $\begin{array}{l}38 \text { S.) ........... } \\
\text { Utah, northern San } \\
\text { Juan County (T. } 27 \text { S.- }\end{array}$ & 0 & 1 & 9 & 1 & 5 \\
\hline T. 31 S.) ........ & 0 & 4 & 10 & 3 & 6 \\
\hline
\end{tabular}

${ }^{1}$ Age assignment uncertaın.

evidence that surrounding landmasses were elevated. Except for a thin basal conglomerate, locally developed, and scattered lenses of consolidated gravel at a few higher horizons, the sediments are very fine grained and consist mostly of carbonate rock and argillaceous mudstone. Compared with the overlying formations of the Supai Group, sandstone is conspicuously scarce and crossstratification is rare.

The megafauna of this embayment is restricted largely to the western and central parts. Nearly all of the large diagnostic brachiopods are in the area delineated by the $250-\mathrm{ft}$ isopach, where carbonate rocks are relatively thick bedded and form a major part of the formation. Several other faunal assemblages range eastward nearly as far as the limit of the 200-ft isopach line. Apparently all marine animals entered the embayment from the Cordilleran sea to the west.

\section{Paleogeography of Manakacha Formation}

The Manakacha Formation, composed mostly or entirely of strata of Atokan age, represents a time of dominantly marine deposition in the Grand Canyon area. These rocks were shown as strata of Des Moinesian age on

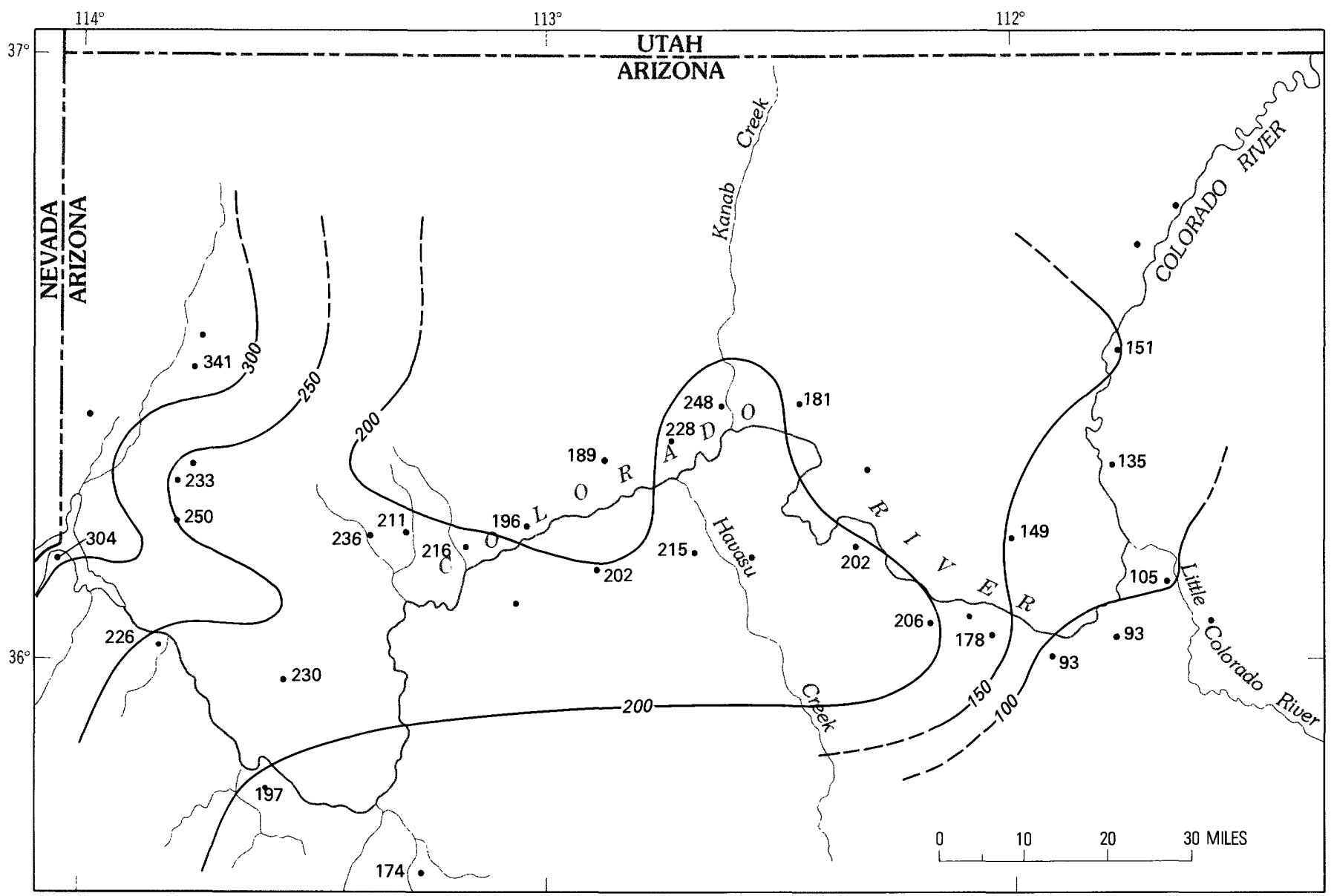

FIGURE D9.-Isopach map of Watahomigi Formation (Morrowan and Atokan), Grand Canyon region, Arizona. Dots are locations of measured sections (fig. A1). Number next to dot is thickness, in feet, of formation in that section. Isopach interval $50 \mathrm{ft}$. Isopach dashed in area of poor control. 
paleotectonic maps prepared some years ago but only recently published (McKee and Crosby, and others, 1975), because at that time fossils diagnostic of Atokan time had not been discovered in the rocks. Correlation with areas farther west has proved to be faulty.

An isopach map prepared from thicknesses of the Manakacha recorded in the Grand Canyon area is shown in figure D10. A general thickening from north to south occurs in a belt roughly parallel to the course of the Colorado River in Grand Canyon. The thinnest or landward margin of the deposit extends in a north-south direction at the western end of the Grand Canyon area and trends northsouth near the eastern end of the area. Midway between is an embayment that extends 30-60 mi northward. Isopach trends (fig. D10) indicate that a land area existed to the north in southern Utah during Atokan time, probably the physiographic feature referred to as the Piute positive element (McKee and Crosby, and others, 1975, fig. 15). This element apparently was not high at the time because detrital sediment in the Manakacha south of the land area consists largely of uniformly fine grained sand with much silt (table K7). Cross-bedding directional vectors indicate a consistent southerly direction of sediment transport (fig. M2) away from the shore.

Westward from the Piute landmass was the Cordilleran miogeosyncline (Bird Spring-Ely basin) where thick deposits, largely of carbonate sediment, accumulated during Atokan time (fig. D4). To the southeast in the Grand Canyon area (figs. D4, D10) a southward thickening indicated by isopachs strongly suggests that the seaway may once have connected with the Sonoran geosyncline in southeastern Arizona, but such connection cannot be proved at present because the record of Pennsylvanian rocks has been removed by late erosion across much of central Arizona.

\section{Paleogeography of Wescogame Formation}

The Wescogame Formation of probable Virgilian age was formed at a time when the seas were exceptionally widespread in Arizona. It developed at the convergence of three principal transgressive seaways (fig. D7). The seas entered from the Bird Spring-Ely basin, to the west or

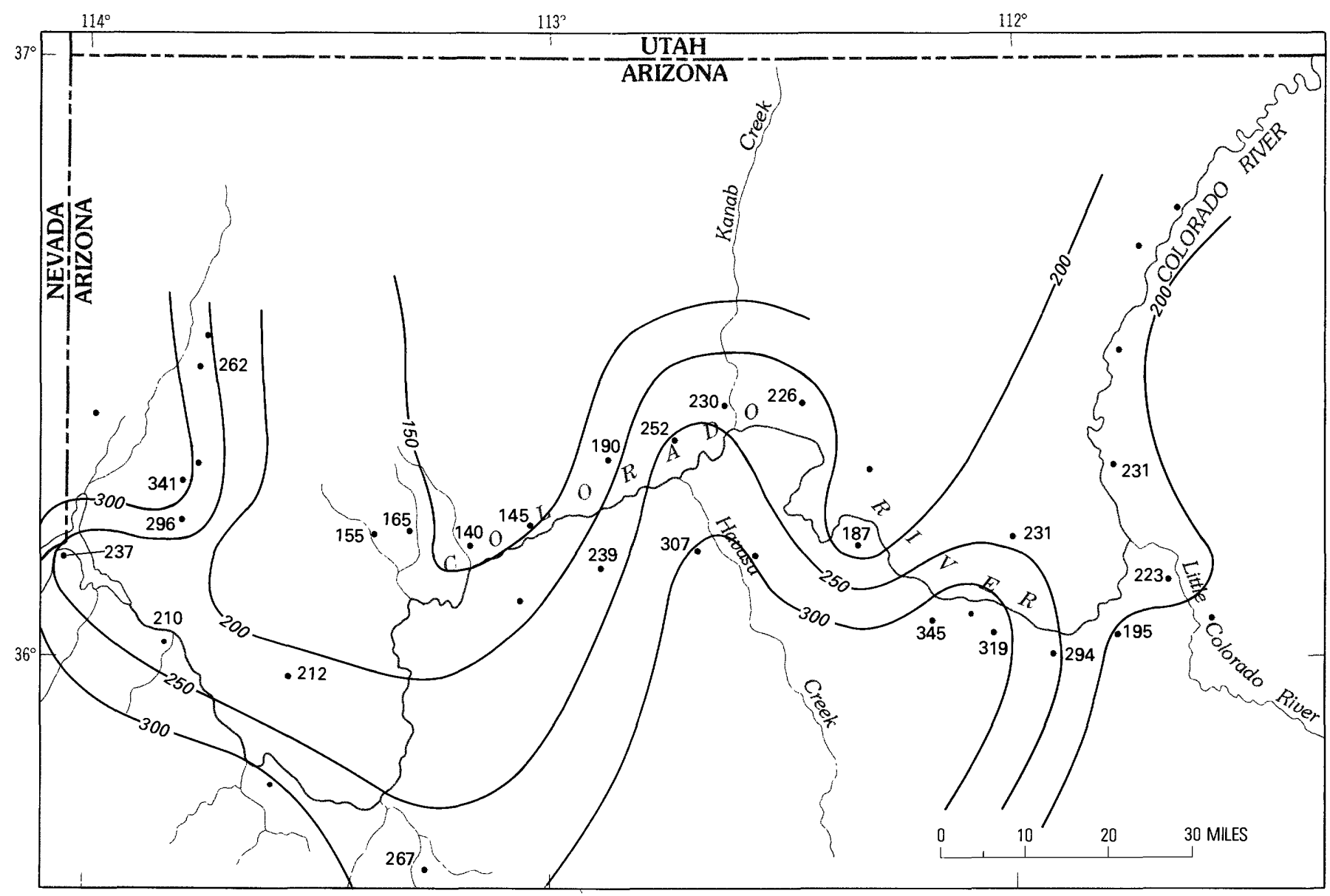

FIGURE D10.-Isopach map of Manakacha Formation (Atokan and Des Moinesian? age), Grand Canyon region, Arizona. Dots are locations of measured sections (fig. A1). Number next to dot is thickness, in feet, of formation in that section. Isopach interval $50 \mathrm{ft}$. 
northwest, at the south end of the Cordilleran geosyncline; from the greatly expanded Paradox basin of Colorado and Utah to the northeast; and from the northern end of the Sonoran geosyncline, to the southeast.

Isopachs portraying thickness trends in the Wescogame Formation of the Grand Canyon region (fig. D11) show a southeastward thickening. This trend, together with the occurrence of Virgilian-type fusulinids both in western Grand Canyon and along the Mogollon Rim of central Arizona (table E4), indicate that the Sonoran sea almost certainly connected from the south with the Wescogame embayment at that time; similar isopach and faunal evidence to the west suggests a connection between the Wescogame and Cordilleran seas. To the northeast, isopach trends provide less convincing evidence of a connection (fig. D11), but a connecting strait may have existed also in this area, for Virgilian-type Triticites are recorded from subsurface in the Four Corners area (table D3), and the nearest Upper Pennsylvanian rocks of the Paradox basin extension are in close proximity to the Wescogame (fig. D7).

As in earlier parts of Pennsylvanian time the principal positive elements controlling the distribution of life and the accumulation of sediments were the Defiance element, east of the Grand Canyon area, the Piute to the north in southern Utah, and probably an area to the southwest, as indicated by trends of thickening in isopachs (fig. D7). Because most of the Paleozoic record in southwestern Arizona has been destroyed by late erosion, however, the features in that direction are very poorly known.

\section{Paleogeography of Esplanade Sandstone}

The Esplanade Sandstone and its carbonate equivalent, the Pakoon Limestone (McNair, 1951), in the western Grand Canyon are of Early Permian (Wolfcampian) age. Because of the intertonguing relationship between these two formations, they are combined on the isopach map (fig. D12). To the west beyond the Grand Canyon area, their exact equivalents are not known and, as a result, their correlatives in adjoining areas and their relations to surrounding paleogeographic features are difficult to establish. Deposition began on a widespread erosion surface on

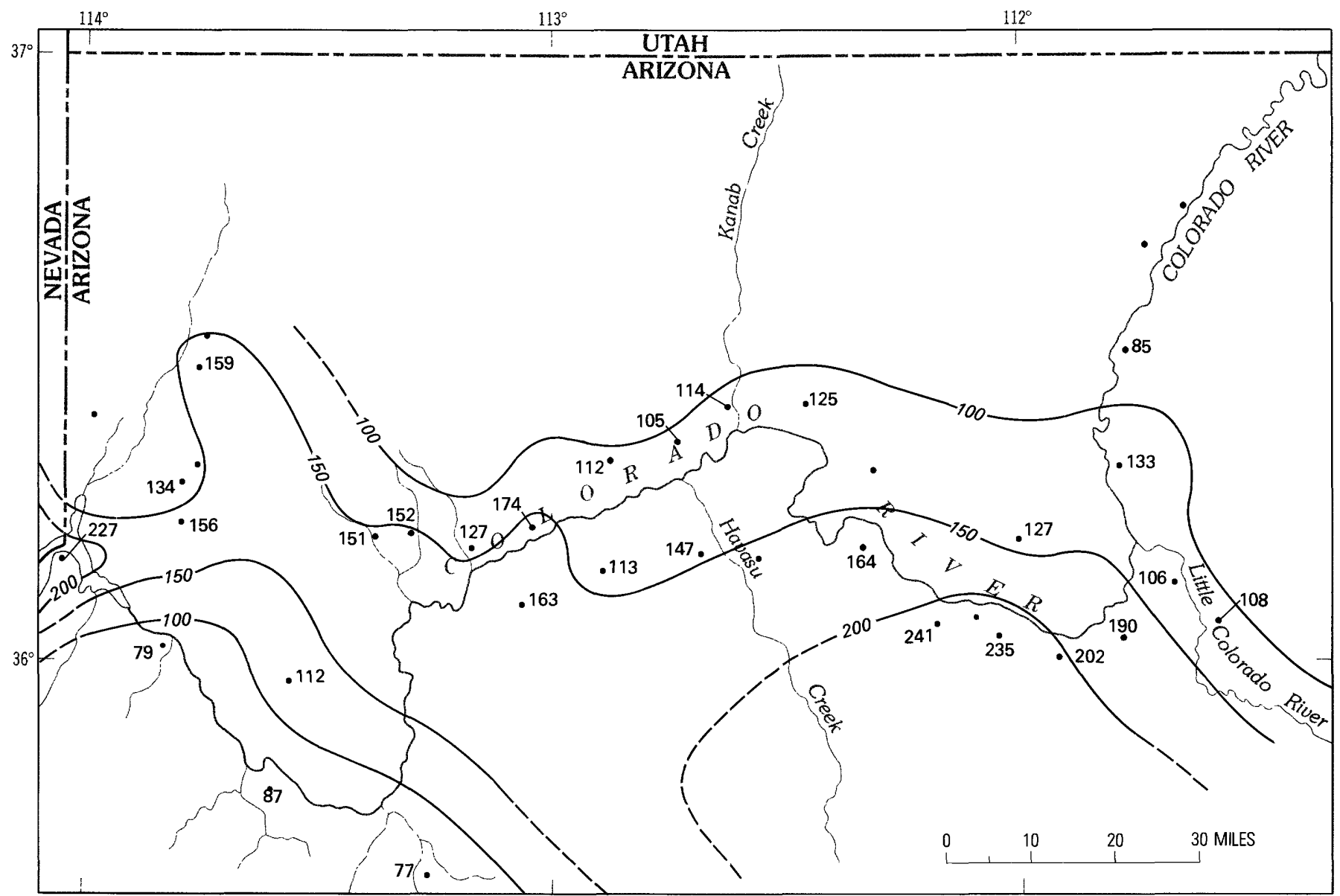

FIGURE D11.- Isopach map of Wescogame Formation (Virgilian age), Grand Canyon region, Arizona. Dots are locations of measured sections (fig. A1). Number next to dot is thickness, in feet, of formation in that section. Isopach interval $50 \mathrm{ft}$. Isopach dashed in area of poor control. 
strata of late Pennsylvanian age; it was followed by another interval of erosion, which preceded deposition of the Hermit Shale. The hiatus marked by this second unconformity probably was not great and the Hermit is believed (White, 1929, p. 39) to be "near the top of the Lower Permian". Neither the Hermit nor the Esplanade is recognized lithologically in areas to the northeast or southeast of Grand Canyon, so these units either change facies or are absent in those directions.

Some concept of the regional setting in which the Esplanade formed can be gained by reference to an isopach map of the combined formations of Wolfcampian age, prepared for Arizona and surrounding areas (fig. D8). As during deposition of the older formations in the Supai Group, the Defiance and Zuni positive elements formed a strongly stable area in northeastern Arizona and adjacent New Mexico.

North of this positive element was the Paradox basin of Utah and Colorado, including numerous small sinking basins that accumulated much sediment. A second but less well-defined positive element was west of the Paradox basin. The persistent Sonoran geosyncline in southeastern Arizona and the southern part of the Cordilleran geosyncline in southern Nevada, adjacent to northwestern Arizona, were major negative areas during Wolfcampian time.

An isopach map of the Esplanade Sandstone including tongues of the Pakoon Limestone in the western Grand Canyon area shows trends in thickening (fig. D12) almost opposite to those of the two underlying formations of the Supai Group (figs. D10, D11). In general, thickening is from south to north in the Esplanade, except in the extreme western part of the area where it is from east to west. In contrast, the Manakacha and Wescogame Formations have directions of thickening from north to south.

On the basis of isopach trends and the location of positive and negative elements shown on the regional map of Wolfcampian deposits (fig. D8), the probability that seas in the Grand Canyon area transgressed from both northwest and northeast seems likely. On the other hand, waters of the Sonoran geosyncline may not have extended into northern Arizona at that time. A likely source of the extensive clean sand deposits in the Esplanade was to the

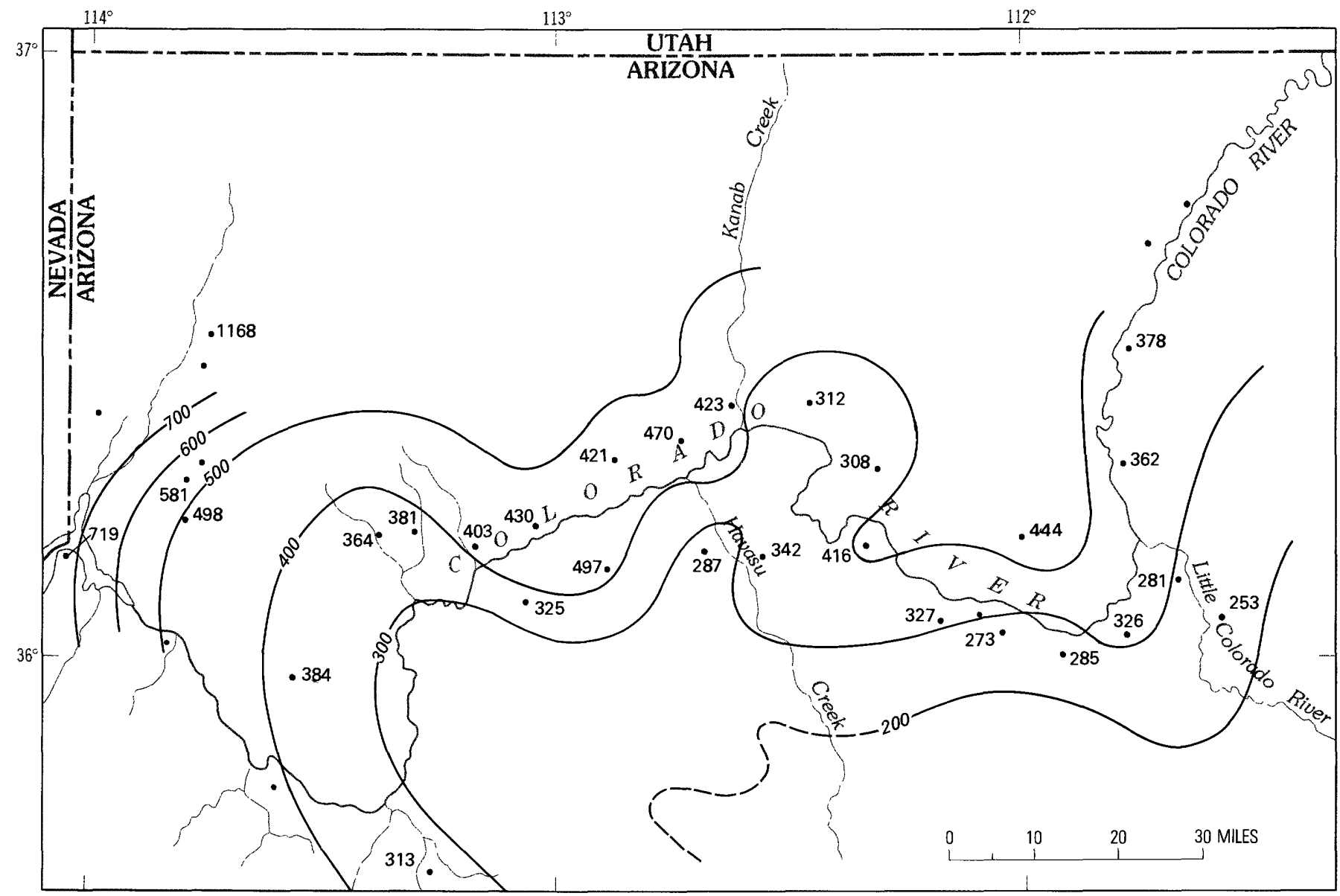

FIGURE D12.-Isopach map of Esplanade Sandstone (Wolfcampian age) including tongues of Pakoon Limestone (McNair, 1951) to the west; Grand Canyon region, Arizona. Dots are locations of measured sections (fig. A1). Number next to dot is thickness, in feet, of formation in that section. Isopach interval $100 \mathrm{ft}$. Isopach dashed in area of poor control. 
north in a positive area in the central or western part of southern Utah, as indicated by cross-bedding dip-directions in the sand (figs. M2, D5).

The Pakoon Limestone that interfingers with the lower part of the Esplanade and marks an abrupt change from quartz sand to calcium carbonate near the western end of Grand Canyon seems to indicate an area of barrier buildup and contains an abundance of coral mounds. Along this belt, isopachs are close together, indicating an abrupt increase in rate of deposition seaward, and perhaps a hinge or the margin of an area of more rapid subsidence to the west. East of the barrier and within the Esplanade, extensive beds of gypsum perhaps indicate areas of concentrated sea water, cut off from the western sea.

\section{CORRELATION WITH STRATA OF ADJOINING AREAS}

\section{Correlation with strata of central Arizona}

Correlation of formations in the Supai Group of Grand Canyon with the nearest Pennsylvanian-Permian strata to the south, at Oak Creek and Sycamore Creek (fig. D13), can be made only on the basis of lithologic similarities, for as yet no diagnostic fossils have been found at those locali- ties. The nearest recorded fossil-bearing sites in a southerly direction (fig. D13) are along the Mogollon Rim at Fossil Creek (Jackson, 1952; Brew, 1965), and East Verde River, Tonto Creek, and Kohls Ranch (Brew, 1965). Farther south and east from the Mogollon Rim at Big Spring Canyon, Carrizo Creek, and Black River (Brew, 1965) fossils are progressively more numerous and varied and represent a greater time range.

The lower part of the Watahomigi Formation in Grand Canyon contains brachiopods of Early Pennsylvanian (early Morrowan) age and, about midway in the formation, Linoproductus nodosus of late Morrowan age occurs. None of these fossils (discussed under "Age of the Supai Group," chapter E) occurs in sections along the Mogollon Rim, and apparently no strata of Morrowan age are present there. In contrast, rocks dated as Morrowan are reported from southeastern Arizona (Gilluly and others, 1954; Sabins, 1957; Tyrell, 1957; Nations, 1961, 1963). Thus, in Early Pennsylvanian time the shelf seas of the Grand Canyon area had no direct connection with waters of the Sonoran geosyncline to the southeast.

The uppermost part of the Watahomigi and most, if not all, of the overlying Manakacha Formation contain fusulinids considered to be of Atokan age as described under "Age of the Supai Group" (chapter E). Of these fossils, Fusulinella sp. and Pseudostaffella sp. that are associated at several localities in eastern Grand Canyon and Eoschubertella sp. that has been found at many sites

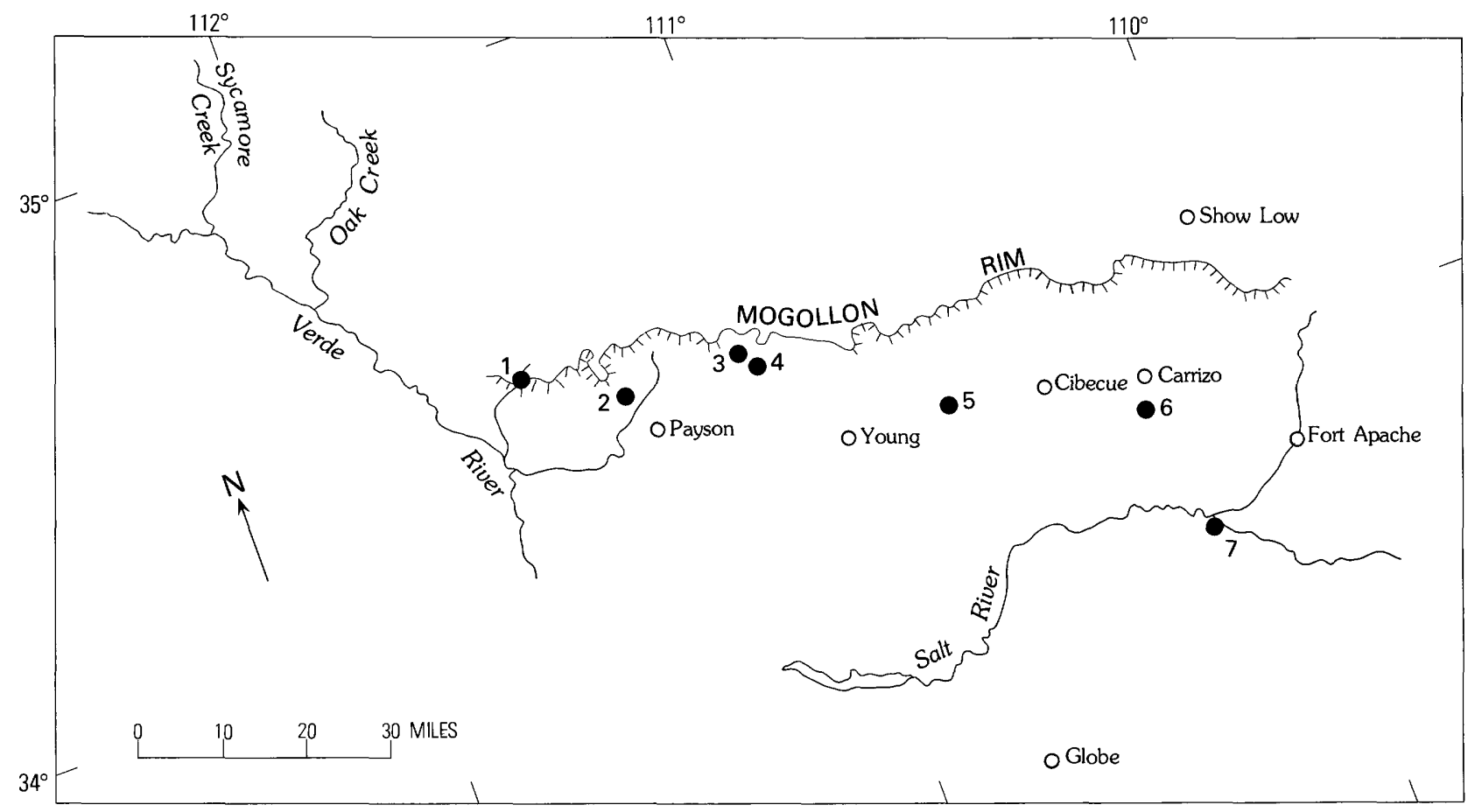

FIGURE D13.-Stratigraphic sections including fossil localities (solid circles) referred to in Mogollon Rim area, south and southeast of Grand Canyon, Ariz. (Modified from Jackson, 1952, and from Brew, 1965). 1, Fossil Creek; 2, East Verde River; 3, Tonto Creek; 4, Kohls Ranch; 5, Big Spring Canyon; 6, Carrizo Creek; and 7, Black River. 
in western Grand Canyon are not reported from the Mogollon Rim area south of Grand Canyon.

The lowest fusulinid zones reported from sections along the Mogollon Rim contain Fusulina sp. and Wedekindellina sp., both indicators of Des Moinesian age (Brew, 1965, p. 69, table 4). This evidence supports the concept (Brew, 1965, fig. 10) that transgressive seas from the Sonoran geosyncline had not advanced far north by the end of Atokan time (table E4).

Because neither Fusulina sp. nor Wedekindellina sp. has yet been found in the Grand Canyon sections $50-60 \mathrm{mi}$ north of the Mogollon Rim in central Arizona, correlation at this time level cannot be established. A strong probability exists, therefore, that the Des Moinesian age is not represented in Grand Canyon rocks.

Rocks of Missourian age are recognized in the east-central Arizona area on the basis of four species of Triticites and one chonetid (Brew, 1965, table 4). None of these species occur as far north as the Mogollon Rim sections, but the fauna is recorded by Brew (1965, p. 62) from Carrizo Creek and Big Spring Canyon sections (fig. D13) $40-80 \mathrm{mi}$ farther south and east. No fossils identified as of Missourian age have yet been recognized in the Supai of Grand Canyon and probably the time interval is represented within the hiatus at the base of the Wescogame Formation.

The Wescogame Formation of the Supai Group probably can be correlated with upper parts of the Naco Formation in east-central Arizona. Several species of Triticites and one of Dunbarinella are used by Brew (1965, table 4) in zonation of the Naco Formation in sections from Black River to Big Spring Canyon (fig. D13).

North from Black River, Virgilian Triticites are recorded by Lokke $(1962$, p. 84, 85) in the subsurface Naco Formation of Navajo County (Lockhart No. 1 Aztec Land and Cattle Co. well) and of Apache County (Pan American 1B New Mexico and Arizona Land Co. well). However, thinning of Pennsylvanian strata northward from these localities and progressive elimination of many fusulinid-bearing beds in that direction (Lokke, 1962, p. 85) suggest that the southern seaway did not connect with that of the Paradox basin across eastern Arizona during Virgilian time.

In western Grand Canyon at Hidden Canyon, species of Virgilian-type Triticites, as recognized by $\mathrm{R}$. C. Douglass (written communs., 1966, 1973), indicate a Virgilian age for the Wescogame Formation. Although in both eastern Arizona and central Arizona fossil-bearing strata of Virgilian age have also been reported, a direct marine connection at that time between these areas and the western Grand Canyon region is questionable. In the intermediate area of eastern Grand Canyon no marine fossils have been found in the Wescogame. Isopach trends suggest connections from the south and the west to the western part of the canyon area (fig. D11).

The Pakoon Limestone in extreme western Grand Can- yon, believed on the basis of intertonguing relationships to be a lateral equivalent of the Esplanade, contains abundant fusulinids. Among these are the characteristic Wolfcampian genera of Schwagerina, Pseudoschwagerina, Schubertella, Triticites, and others. This assemblage apparently does not occur in the upper Paleozoic strata of the Mogollon Rim south of Grand Canyon. In that area no Wolfcampian fusulinids have been recorded.

Farther southeast, at Carrizo Creek, Big Spring Canyon, and elsewhere, some species of Dunbarinella and Triticites, the age of which is doubtful, are assigned a "post-Virgil" age (Brew, 1965, p. 63). Absence of diagnostic Wolfcampian fusulinids in the central Arizona area makes correlation with the Pakoon-Esplanade strata impossible. Wolfcampian time apparently is represented in the Mogollon Rim sections by barren red beds commonly referred to as the Supai formation.

\section{Correlation with strata to west and northwest of Grand Canyon}

Most Pennsylvanian-Permian sections in parts of Nevada and Utah that are adjacent to the Grand Canyon area contain an abundance of fossils that have been the subject of three principal investigations (Steele, 1959; Welsh, 1959; Brill, 1963). As a result, the various taxa can be directly compared with fossils in the Supai Group and tentative correlations between the Grand Canyon formations and their lateral equivalents to the west and northwest can be established. A summary of recorded sites compiled by Douglass (1974, p. 846) is given in table D4 and figure D14.

The lower two-thirds of the Watahomigi Formation, considered to be of Morrowan age chiefly on the basis of several diagnostic brachiopods, represents the oldest Pennsylvanian strata in the Grand Canyon area. In the Nevada and Utah sections, rocks of Morrowan age likewise are recorded, but the diagnostic brachiopods recognized in the Watahomigi, including the very common Anthrocospirifer occiduus and the marker form, Linoproductus nodosus, are not listed either by Welsh $(1959$, tables 1,2$)$ or by Brill (1963, p. 313). On the other hand, Rhipidomella nevadensis, Hustedia miseri, and a few other species that are cited by both geologists as indicators of the earliest Morrowan zone in Nevada have not been found in Grand Canyon sections, possibly because deposition did not begin in the Grand Canyon area until later in Morrowan time.

Some taxa that are recorded in the "Lowermost Pennsylvanian: Lower Morrow" in the basin sections of Nevada (Welsh, 1959, table 1), but also occur in the lower part of the Watahomigi, are the coral Michelinia sp. (fig. E5), the brachiopods Derbyia sp., Orbiculoidea sp., Punctospirifer sp., Buxtonia sp., Schizophoria sp. (fig. E1), and the foraminifer Millerella sp. 
TABLE D4.-Comparison of fusulinid genera of Grand Canyon and those listed by R. C. Douglass (1974) from southern Nevada and California. Localities shown in figure D14

\begin{tabular}{|c|c|c|c|c|c|c|c|c|c|c|c|c|}
\hline \multirow[b]{2}{*}{ Formation } & \multirow[b]{2}{*}{ Genus } & \multicolumn{7}{|c|}{$\begin{array}{c}\text { Grand Canyon area } \\
\text { (Recorded in this paper) }\end{array}$} & \multicolumn{3}{|c|}{$\begin{array}{l}\text { Southern Nevada } \\
\text { (Recorded by Douglass, }\end{array}$} & \multirow{2}{*}{$\begin{array}{c}\text { Calif. } \\
\text { 1974) } \\
\begin{array}{c}\text { Southeast } \\
\text { of } \\
\text { Baker }\end{array}\end{array}$} \\
\hline & & $\begin{array}{l}\text { Eastern } \\
\text { Grand } \\
\text { Canyon }\end{array}$ & $\begin{array}{l}\text { Parashant } \\
\text { Canyon }\end{array}$ & $\begin{array}{l}\text { Twin } \\
\text { Springs } \\
\text { Canyon }\end{array}$ & $\begin{array}{c}\text { Snap } \\
\text { Canyon }\end{array}$ & $\begin{array}{l}\text { Pigeon } \\
\text { Wash }\end{array}$ & $\begin{array}{l}\text { Hidden } \\
\text { Canyon }\end{array}$ & $\begin{array}{l}\text { Iceberg } \\
\text { Canyon }\end{array}$ & $\begin{array}{l}\text { Arrow } \\
\text { Canyon }\end{array}$ & $\begin{array}{l}\text { Lee } \\
\text { Canyon }\end{array}$ & $\begin{array}{l}\text { Mountain } \\
\text { Springs } \\
\text { Summit }\end{array}$ & \\
\hline \multirow[t]{5}{*}{ Pakoon Limestone } & Triticites & --- & -- & -- & $x$ & --- & $x$ & $\mathrm{X}$ & $X$ & $X$ & --- & $x$ \\
\hline & Schubertella ....... & --- & --- & --- & --- & --- & $x$ & $x$ & --- & --- & -- & $x$ \\
\hline & Schwagerina ...... & --- & --- & --- & $x$ & $x$ & $\mathrm{X}$ & $x$ & $x$ & $x$ & $-\cdots$ & $x$ \\
\hline & Pseudoschwagerina . & -- & -- & $\cdots$ & --- & $x$ & $x$ & $x$ & $\mathrm{x}$ & $x$ & --- & $x$ \\
\hline & Monodiexodina .... & --- & --- & --- & --- & --- & $x$ & -- & --- & $x$ & -- & $x$ \\
\hline Wescogame Formation & Triticites . . . . . . . & --- & --- & --- & -- & --- & $x$ & --- & $x$ & $x$ & --- & --- \\
\hline \multirow[t]{5}{*}{ Manakacha Formation } & Eoschubertella ..... & -- & $x$ & $\mathrm{X}$ & $x$ & $x$ & $x$ & $x$ & $x$ & --- & $x$ & --- \\
\hline & Staffella ......... & -- & $\cdots$ & --- & -.. & $x$ & -- & -- & --- & --- & $x$ & --- \\
\hline & Pseudostaffella ..... & $x$ & --- & --- & --- & --- & --- & --- & --- & $\mathrm{x}$ & $x$ & --- \\
\hline & Profusulinella ...... & --- & -- & --- & -- & $x$ & --- & -- & $\mathrm{X}$ & $x$ & $x$ & -- \\
\hline & Fusulinella ....... & $x$ & -- & -- & --- & $x$ & $x$ & --- & $x$ & $X$ & $x$ & -- \\
\hline $\begin{array}{l}\text { Watahomigi Formation } \\
\text { (lower part). }\end{array}$ & Millerella. & -- & --- & --- & --- & -- & $\cdots$ & --- & $x$ & $x$ & $x$ & --- \\
\hline
\end{tabular}

${ }^{1}$ Of MCNair (1951); Esplanade Sandstone-equivalent in western Grand Canyon.

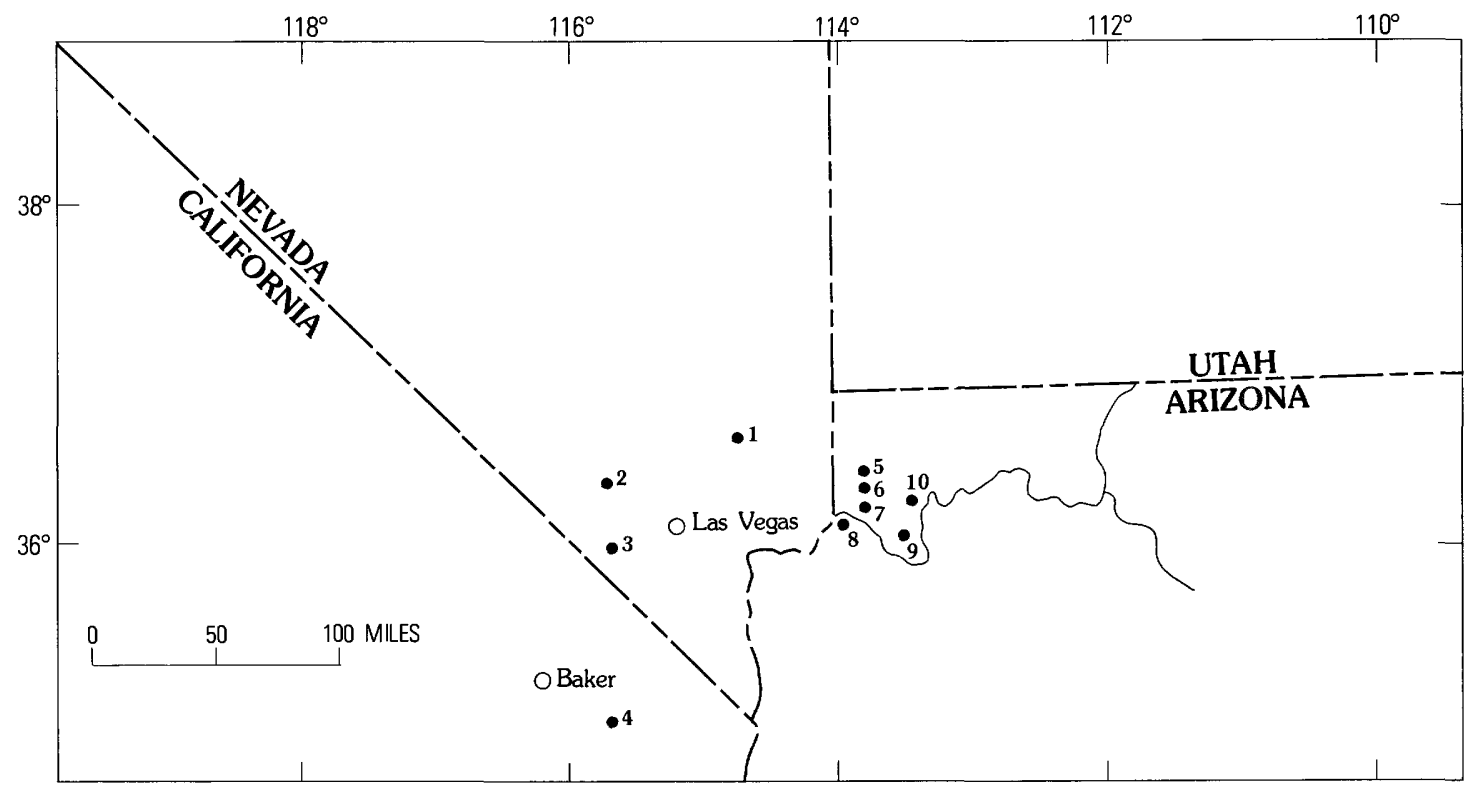

FIGURE D14.-Fusulinid localities cited in table D4, discussed by Douglass (1974) (loc. 1-4), and recorded in Grand Canyon (this paper) (loc. 5-10). 1, Arrow Canyon; 2, Lee Canyon; 3, Mountain Springs Summit; 4, Southeast of Baker, Calif.; 5, Hidden Canyon; 6, Pigeon Wash; 7, Snap Canyon; 8, Iceberg Canyon; 9, Twin Springs Canyon; and 10, Parashant Canyon.

Strata of Virgilian age, recognized by distinctive types of Triticites at Hidden Canyon in western Grand Canyon (fig. E13), are also found at Pakoon Ridge, Arizona, and Frenchman Mountain, Nevada, according to Welsh (1959, p. A-12, A-61). Seas of this age are believed to have occupied much of the southern Nevada and northwestern Ari- zona region (Brill, 1963, p. 316), but the diagnostic forms of Triticites have not been recorded from sections other than those previously noted.

A locally common fusulinid fauna of Wolfcampian age including such characteristic genera as Schwagerina, Pseudoschwagerina, and Triticites (fig. E15) occurs in the 
Pakoon Limestone at various places in the western part of Grand Canyon. Westward from there, Schwagerina is recorded at Frenchman Mountain, Bird Spring Range, Mormon Mountains, and elsewhere in southern Nevada (Welsh, 1959, p. A-33, A-61, A-74) and in southern California (table D4, fig. D14).

The fusulinid genera Fusulina and Wedekindellina that are believed restricted to and characteristic of Des Moinesian time have not been recorded from the Grand Canyon area, although they occur in many ranges not far to the west. Wedekindellina is reported from Frenchman Mountain and the Virgin Mountains of Nevada (Welsh, 1959, p. A-61, A-21) and from Pakoon Ridge, Arizona (Welsh, 1959, p. A-12), and Fusulina is listed from the last two of these localities. Thus, the absence of these genera in the Grand Canyon sections suggests that rocks of Des Moinesian age are either lacking in the Supai or limited to the uppermost part of the Manakacha Formation, the age of which is poorly established.

No fossils of Missourian age have as yet been recognized in the sections of Grand Canyon. Their occurrence there seems unlikely because fusulinids of Virgilian-type of the genera Ozawainella and Triticites are recorded from not far above the widespread erosion surface and conglomerate at the base of the Wescogame Formation (fig. E13). Furthermore, no faunas of Missourian age are recognized by either Welsh (1959) or Brill (1963) in adjoining sections to the west and northwest. Missourian seas of the Great Basin area were restricted to the Pioche and Oquirrh Basins to the west according to Brill (1963, p. 315). The section that is nearest to Grand Canyon on the west, reported to have Missourian fossils, is at Frenchman Mountain, Nevada. In this range Triticites aff. $T$. plicatulus has been recorded by Steele (1959, p. 72).

\section{Correlation with strata of the Four Corners area}

Throughout Pennsylvanian time a marine environment prevailed in the Paradox basin of eastern Utah and western Colorado. Seas periodically were greatly restricted, but at other times they expanded and their waters extended southward past the Four Corners into Arizona and New Mexico (McKee and Crosby, and others, 1975).

Correlation between formations of the Supai Group of the Grand Canyon area and rocks of PennsylvanianPermian age in the Four Corners area is difficult because sections in the Four Corners area are known mainly from subsurface data and reliable dating is restricted mostly to sparse fusulinid records. On this basis, however, certain times have been determined when faunas of the two areas probably had easy intercommunication as shown by distinctive fossil forms common to both. A chart showing dis- tribution of faunal assemblages in Pennsylvanian well samples from the Four Corners area has been prepared (table D3).

Strata of Morrowan age probably did not extend south of the Utah-Arizona state line from the Paradox basin area, as shown in table D3. Beds of Atokan age in the Four Corners area, recognized by species of Fusulinella (John Chronic, oral commun., 1974), may correlate with the upper part of the Watahomigi or the Manakacha Formation or both, of the Grand Canyon area, where Atokan forms of this genus occur in both formations. Strata of Des Moinesian age containing Wedekindellina and Fusulina are represented in many collections from Four Corners localities, but these genera are unrecorded from Grand Canyon strata. Nevertheless, rocks of Des Moinesian age may possibly be represented in Grand Canyon by the barren uppermost part of the Manakacha. Strata of Missourian age apparently were restricted to the area north of Arizona, but rocks of Virgilian age containing distinctive species of Triticites occur both in Four Corners and in Grand Canyon areas and permit correlation of the Wescogame Formation with strata of similar age at Four Corners.

\section{REFERENCES CITED}

Baars, D. L., 1962, Permian System of Colorado Plateau: American Association of Petroleum Geologists Bulletin, v. 46, no. 2, p. 149-218.

Bissell, H. J., 1960, Eastern Great Basin Permo-Pennsylvanian strataPreliminary statement: American Association of Petroleum Geologists Bulletin, v. 44, no. 8, p. 1424-1435.

Brew, D. C., 1965, Stratigraphy of the Naco Formation (Pennsylvanian) in central Arizona: Cornell University, Ph. D. thesis, 201 p.

Brill, K. G., Jr., 1963, Permo-Pennsylvanian stratigraphy of western Colorado Plateau and eastern Great Basin regions: Geological Society of America Bulletin, v. 74, no. 3, p. 307-330.

Brown, S. C., and Lauth, R. E., 1958, Oil and gas potentialities of northern Arizona, in Guidebook of the Black Mesa basin, northeastern Arizona: New Mexico Geological Society 9th Field Conference Guidebook, p. 153-160.

Coogan, A. H., 1964, Early Pennsylvanian history of Ely basin, Nevada: American Association of Petroleum Geologists Bulletin, v. 48, no. 4, p. 487-495.

Darton, N. H., 1925, A resume of Arizona geology: Arizona Bureau of Mines Bulletin 119, 298 p.

Douglass, R. C., 1974, Fusulinids in the Basin and Range Province in California, Nevada, and Utah: Journal of Paleontology, v. 48, no. 4, p. 846-853.

Eardley, A. J., 1949, Paleotectonic and paleogeologic maps of central and western North America: American Association of Petroleum Geologists Bulletin, v. 33, no. 5, p. 655-682.

1951, Structural geology of North America, 1st edition: New York, Harper and Brothers, $624 \mathrm{p}$.

1962, Structural geology of North America, 2d edition: New York, Harper and Row, 738 p.

Elston, Wolfgang E., 1960, Structural development and Paleozoic stratigraphy of Black Mesa basin, northeastern Arizona, and surrounding areas: American Association of Petroleum Geologists Bulliten, v. 44 , no. 1, p. 21-36. 
Gilluly, J., Cooper, J. R., and Williams, J. S., 1954, Late Paleozoic stratigraphy of central Cochise County, Arizona: U.S. Geological Survey Professional Paper 266, 49 p.

Gregory, H. E., 1917, Geology of the Navajo Country-A reconaissance of parts of Arizona, New Mexico, and Utah: U.S. Geological Survey Professional Paper 93, $161 \mathrm{p}$.

Havenor, K. C., 1958, Pennsylvanian framework of sedimentation in Arizona: Arizona University, M.S. thesis, 73 p.

Havenor, K. C., and Pye, W. D., 1958, Pennsylvanian paleogeography of Arizona, in Guidebook of the Black Mesa basin, northeastern Arizona: New Mexico Geological Society 9th Field Conference Guidebook, p. 78-81.

Heylmun, E. B., 1958, Paleozoic stratigraphy and oil possibilities of the Kaiparowits region, Utah: American Association of Petroleum Geologists Bulletin, v. 42, no. 8, p. 1781-1811.

Hite, R. J., and Cater, F. W., 1972, Pennsylvanian rocks and salt anticlines, Paradox basin, Utah and Colorado, in Geologic atlas of the Rocky Mountain region: Denver, Rocky Mountain Association of Geologists, p. 133-137.

Huddle, J. W., and Dobrovolny, E., 1945, Late Paleozoic stratigraphy and oil and gas possibilities of central and northeastern Arizona: U.S. Geological Survey Oil and Gas Investigations Preliminary Chart No. 10.

Irwin, C. D., 1971, Stratigraphic analysis of upper Permian and lower Triassic strata in southern Utah: American Association of Petroleum Geologists Bulletin, v. 55, no. 11, p. 1976-2007.

Jackson, R. L., 1952, Pennsylvanian-Permian facies of the Supai Formation in central Arizona, in Guidebook for southern Arizona: Arizona Geological Society, p. 143-146.

Kottlowski, F. E., and Havenor, K. C., 1962, Pennsylvanian rocks of the Mogollon Rim area, Arizona, in Guidebook of the Mogollon Rim region, east-central Arizona, New Mexico Geological Society, 13th Field Conference, 1962: Socorro, New Mexico Bureau of Mines and Mineral Resources, p. 77-83.

Lessentine, R. H., 1965, Kaiparowits and Black Mesa basins-Stratigraphic synthesis: American Association of Petroleum Geologists Bulletin, v. 49, no. 11, p. 1997-2019.

Lokke, D. H., 1962, Paleontological reconnaissance of subsurface Pennsylvanian in southern Apache and Navajo Counties, Arizona, in Guidebook of the Mogollon Rim region, east-central Arizona, New Mexico Geological Society, 13th Field Conference, 1962: Socorro, New Mexico Bureau of Mines and Mineral Resources, p. 84-86.

Longwell, C. R., 1949, Structure of the northern Muddy Mountains area, Nevada: Geological Society of American Bulletin, v. 6, no. 5, p. 923-968.

McKee, E. D., 1951, Sedimentary basins of Arizona and adjoining areas: Geological Society of America Bulletin, v. 62, no. 5, p. 481-506. 1969. Stratified rocks of the Grand Canyon, in The Colorado River region and John Wesley Powell: U.S. Geological Survey Professional Paper 669-B, p. 23-58.

McKee, E. D., and Crosby, E. J., and others, 1975, Paleotectonic investigations of the Pennsylvanian System in the United States; Part I, Introduction and regional analyses of the Pennsylvanian System: U.S. Geological Survey Professional Paper 853, 349 p. [1976].
McKee, E. D., and Oriel, S. S., and others, 1967, Paleotectonic investigations of the Permian System in the United States: U.S. Geological Survey Professional Paper 515, $271 \mathrm{p}$.

McNair, A. H., 1951, Paleozoic stratigraphy of part of northwestern Arizona: American Association of Petroleum Geologists Bulletin, v. 35 , no. 3, p. 503-541.

Mallory, W. W., Bachman, G. O., Maughan, E. K., and others, 1972, Regional synthesis of the Pennsylvanian System, in Geologic atlas of the Rocky Mountain region: Denver, Rocky Mountain Association of Geologists, p. 111-127.

Misch, P. H., 1957, Magnitude and interpretation of some thrusts in northeast Nevada [abs.]: Geological Society of America Bulletin, v. 68 , no. 12 , pt. 2 , p. $1854-1855$.

Nations, J. D., 1961, The Black Prince Limestone (Mississippian or Pennsylvanian) of southeastern Arizona: Arizona University, M.S. thesis, $52 \mathrm{p}$.

1963, Evidence for a Morrowan age for the Black Prince Limestone of southeastern Arizona: Journal of Paleontology, v. 37, no. 6, p. $1252-1264$.

Pye, W. D., 1959, Marine sedimentation in southern Arizona, in Southern Arizona guidebook II: Tucson, Ariz., Arizona Geological Society, p. 5-11.

Rascoe, Bailey, Jr., and Baars, D. L., 1972, Permian System, in Geologic atlas of the Rocky Mountain region: Denver, Rocky Mountain Association of Geologists, p. 150.

Rich, Mark, 1971, Middle Pennsylvanian rocks of eastern Great Basin: American Association of Petroleum Geologists Bulletin, v. 55, no. 3, p. $432-453$.

Sabins, F. F., 1957, Stratigraphic relations in Chiricahua and Dos Cabezas Mountains, Arizona: American Association of Petroleum Geologists Bulletin, v. 41, no. 3, p. 466-510.

Schuchert, Charles, 1910, Paleogeography of North America: Geological Society of America Bulletin, v, 20, p. 427-606.

Steele, G., 1959, Stratigraphic interpretation of the Pennsylvanian-Permian Systems of eastern Great Basin: Washington University, Ph. D. thesis, $294 \mathrm{p}$.

Stoyanow, A. A., 1936, Correlation of Arizona Paleozoic formations: Geological Society of America Bulletin, v. 47, no. 4, p. 459-540.

1942, Paleozoic paleogeography of Arizona: Geological Society of America Bulletin, v. 53, no. 9, p. 1255-1282.

Tyrrell, W. W., Jr., 1957, Geology of the Whetstone Mountain area, Cochise and Pine Counties, Arizona: Yale University, Ph. D. thesis, $64 \mathrm{p}$.

Welsh, H. E., 1959, Biostratigraphy of the Pennsylvanian and Permian Systems of southern Nevada: Utah University, Ph. D. thesis, 106 p.

Wengerd, S. A., and Matheny, M. L., 1958, Pennsylvanian System of Four Corners region: American Association of Petroleum Geologists Bulletin, v. 42, p. 2048-2106.

White, David, 1929, Flora of the Hermit Shale, Grand Canyon, Arizona: Carnegie Institution of Washington Publication 405, 221 p. 


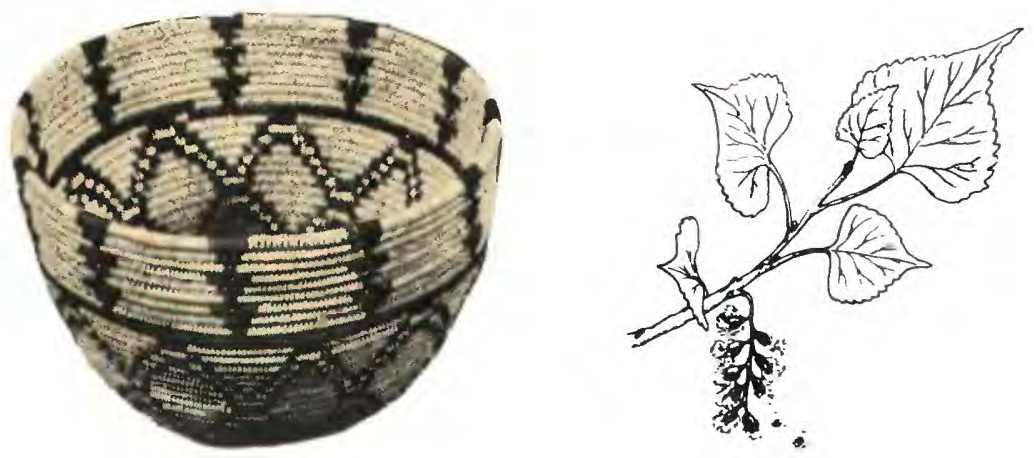

THE SUPAI GROUP OF GRAND CANYON

\title{
DISTRIBUTION AND AGE OF FAUNA AND FLORA
}

\author{
Chapter E
}

By EDWIN D. McKEE

\section{Contents}

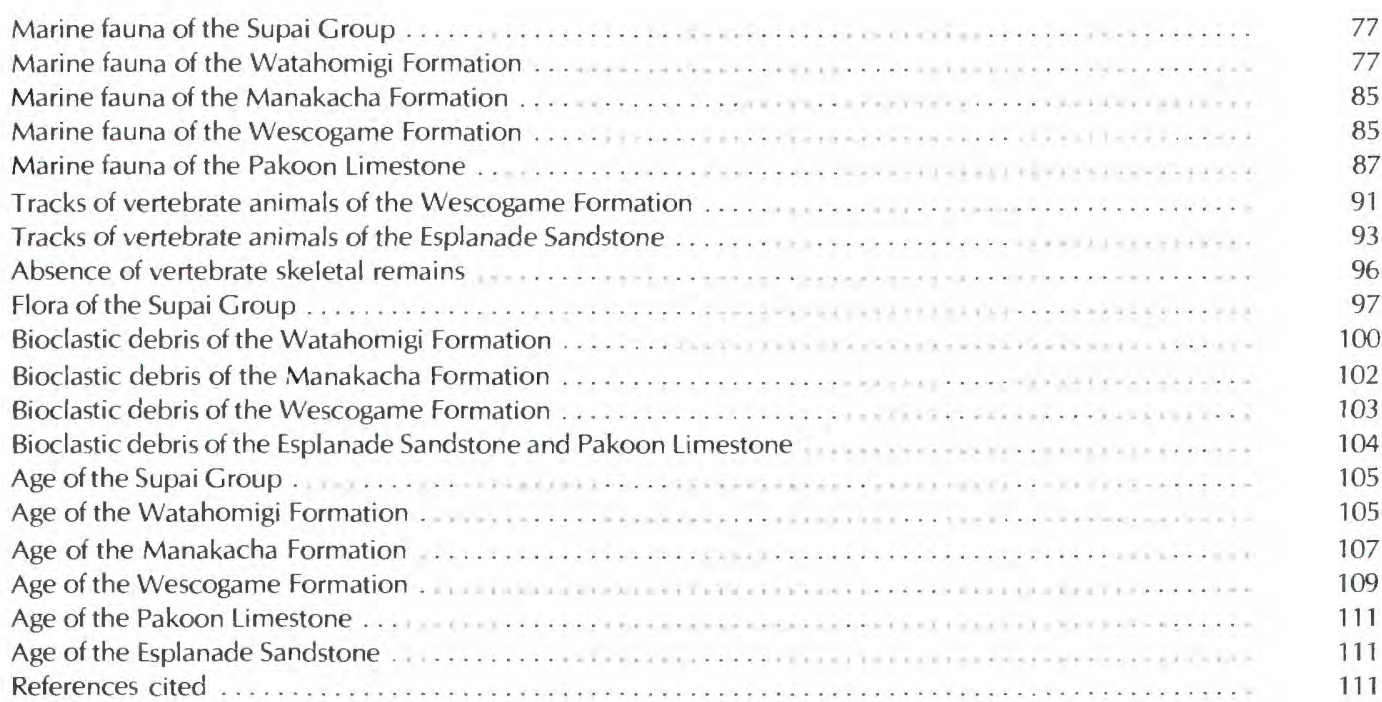




\section{Illustrations}

FIGURES E1-E8. Diagrams showing distribution of:

E1. Brachiopods of the Watahomigi Formation .....................

E2. Gastropods of the Watahomigi Formation $\ldots \ldots \ldots \ldots \ldots \ldots \ldots \ldots$.

E3. Pelecypods of the Watahomigi Formation $\ldots \ldots \ldots \ldots \ldots \ldots$

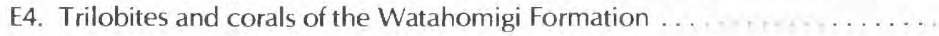

E5. Conulariids and nautiloids of the Watahomigi Formation ...................

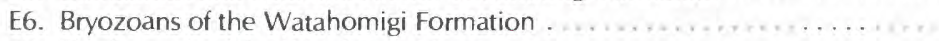

E7. Sharks teeth of the Watahomigi Formation ......................

E8. Principal invertebrate megafossils of the Manakacha Formation ..........

E9. Photographs of Bellerophon (Bellerophon) n. sp. from the Manakacha Formation .

E10. Map showing distribution of fusulinids of Atokan age in upper part of Watahomigi

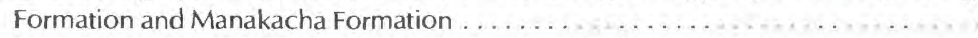

E11. Diagram showing horizons of fusulinids of Atokan age in Grand Canyon sections ....

E12. Map showing distribution of Endothyra media and E. teres in upper part of the Manakacha Formation and lower part of the Wescogame Formation ............

E13. Diagram showing distribution of principal marine fossils of the Wescogame

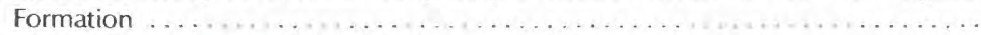

E14. Photographs of pelecypods from the Wescogame Formation . . . . . . . . . . . .

E15. Map showing measured sections from which clasts of marine fossils have been obtained in the Wescogame Formation . . . . . . . . . . . . . . . . . . . . . . . .

E16. Map showing measured sections from which clasts of marine fossils have been obtained in the Esplanade Sandstone and Pakoon Limestone . . . . . . . . . . . . . . .

E17. Diagram showing distribution of corals, bryozoans, gastropods, and sharks teeth

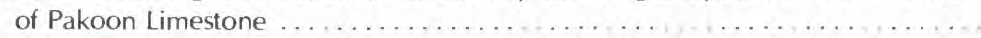

E18. Diagram showing distribution of fusulinids of the Pakoon Limestone and Espla-

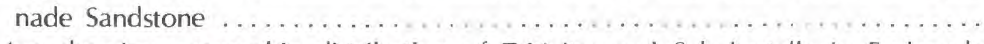

E19. Map showing geographic distribution of Triticites and Schubertella in Esplanade

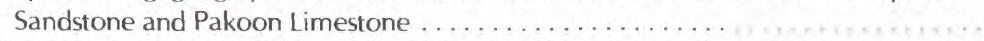

E20. Diagram showing distribution of brachiopods of the Pakoon Limestone .............. E21-E23. Photographs of:

E21. Trackways of vertebrate animals in the Wescogame Formation and

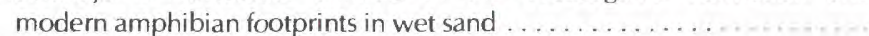

E22. Trackways of vertebrate animals in the Wescogame Formation ..........

E23. Trackways of vertebrate animals in Esplanade Sandstone

E24. Map showing localities of continental flora in the Manakacha Formation ........... 100

E25-E30. Maps showing distribution of:

E25. Bioclastic debris containing pelmatozoans, Watahomigi Formation .... 102

E26. Bioclastic debris containing foraminifers, Watahomigi Formation ........ 103

E27. Bioclastic debris containing bryozoans, Watahomigi Formation .......... 104

E28. Bivalves in bioclastic limestone, Watahomigi Formation . . 105

E29. Various marine fossils in bioclastic debris of the Manakacha Formation .... 106

E30. Bivalve fragments in bioclastic limestones of the Manakacha

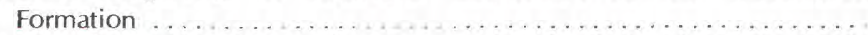

E31. Maps showing relative abundance of various marine fossils in bioclastic debris,

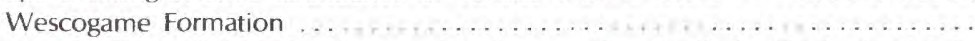

E32. Maps showing relative abundance of various marine fossils in bioclastic debris,

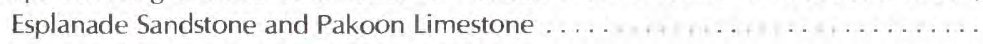

79

80

81

82 99 . .

(1)

106

\section{Tables}

TABLE

E1. Foraminifers and associated microorganisms of the Supai Group . . . . . . . .

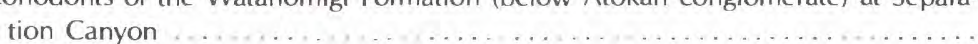

E3. Land plants, animals, and minor structures in formations of the Supai Group . ........

E4. Fusulinids of the Supai Group and Pakoon Limestone in Grand Canyon area compared with those reported from areas to the northwest and southeast .......... 


\section{MARINE FAUNA OF THE SUPAI GROUP}

Each of the four formations comprising the Supai Group in Grand Canyon locally contains a faunal assemblage represented by numerous individuals, but relatively few genera and (or) species. Of the 11 animal groups included, the brachiopods have the greatest variety with a total of 27 genera and (or) species. Next in order of abundance (number of genera and (or) species) are pelecypods with 23 , gastropods with 20 , and corals with 11 . Among the megafossils the brachiopods are the most common from the standpoint of individuals and are most widespread.

The distribution and concentration of individuals within each formation clearly seem to have been controlled by environmental factors that reflect geographic position and age. Seventeen of the 18 genera of brachiopods, for instance, are found in the Watahomigi Formation, whereas only 2 are in the Manakacha and 4 in the Esplanade (fig. E1). Also, most of the gastropods (18) and pelecypods (21) are in the Watahomigi, and trilobites are most widespread in it (10 localities) (figs. E4, E8). This formation consists largely of argillaceous mud and carbonate sediment and, unlike the younger formations, includes little sand. In contrast, the Lower Permian Pakoon Limestone (McNair, 1951), which intertongues with the Esplanade in western Grand Canyon, consists almost entirely of limestone and dolostone and contains most of the fusulinids (7 genera) and corals (9 genera) (figs. E13, E15).

Types of marine animals, other than those indicated above, that occur in one or more divisions of the Supai Group are as follows: Bryozoans are in general uncommon, but are represented by seven genera in the Watahomigi (fig. E6), and only locally by one or two in younger formations (figs. E8, E17). Crinoids and echinoids occur as bioclastic detritus - in many places large and only slightly worn fragments, elsewhere much comminuted-in all formations of the Supai. Conodonts are recorded from the Separation Canyon area in western Grand Canyon where four genera have been recognized in the Watahomigi Formation. They have not been noted elsewhere. Conulariids were found at two localities (fig. E5) in the Watahomigi.

A review of the microorganisms, exclusive of fusulinids, made by Bernard Mamet in 1972 (table E1) shows a total of 38 taxa. Included in this list are four types of algae and two or more foraminiferal species included in several genera. These organisms are concentrated largely, but not exclusively, in areas with a high proportion of carbonate strata, in western Grand Canyon; they occur in all the formations of the Supai Group, although only a few were collected from the Pakoon Limestone.

An obvious problem in interpreting the microfauna of the Supai, including the foraminifers, is that many of the animals are in sediments that represent high-energy conditions and, in at least some specimens, considerable transportation and erosion are represented. Thus, conclusions concerning the environment of life and the age of the enclosing sediment may be open to question. Two convincing illustrations of the reworking of faunas have been noted.

First, a specimen of Fusulinella found in the Wescogame Formation at Whitmore Wash probably was derived from the Manakacha. Its age almost surely is not younger than Des Moinesian, yet it is preserved in rocks considered of Virgilian age and occurs as eroded fragments forming clastic grains. The second example is from Toroweap Valley where fusulinellids, considered by R. C. Douglass (written commun., 1973) to be of late Atokan or early Des Moinesian age, are found in strata of the Wescogame Formation. The specimens occur as clastic grains in sand, and probably were transported into Wescogame strata from the underlying formation.

\section{MARINE FAUNA OF THE WATAHOMIGI FORMATION}

The Watahomigi Formation contains a moderately varied and locally abundant brachiopod fauna throughout most of the western Grand Canyon region (fig. E1). The fauna consists of 17 genera, which are distributed largely within three general zones: (1) at or near the base, (2) in thickbedded limestone that forms a resistant cliff at about the middle, and (3) in the uppermost carbonate rock ledges. A majority of the brachiopods belong to either of two groups-the productids and the spiriferids-each of which is represented by a number of genera and species.

The most abundant brachiopod species doubtless is a small form of Composita, referred to C. gibbosa, but two other species of Composita are also numerous (fig. E1). This genus has been found in the formation at 15 sites, ranging east as far as Havasu Canyon, and is extremely common at many of these localities. Near the bottom of the Watahomigi, Composita commonly occurs in or near the basal conglomerate where individual ovoid shells are scattered among chert or quartz pebbles of similar size (fig. J1B, $E$ ). Locally, however, species of Composita form a majority of the particles within a conglomeratic bed. In many places they seem to have been rolled about and abraded and are not buried in life positions. Although they occur largely in the basal 10-12 ft of the formation, at some localities they are common at $40-60 \mathrm{ft}$ above the base and at a few places, in the extreme west, they occur about $150 \mathrm{ft}$ above the base (fig. E1).

Anthrocospirifer, probably the second most common genus in the formation, is represented by at least four species and has been collected at 14 localities including 
TABLE E1.-Foraminifers and associated microorganisms from the Supai Group and the Pakoon Limestone ${ }^{1}$ showing distribution by formations, occurrence in microfacies, and age assignments

[Compiled from data furnished by Bernard Mamet]

\begin{tabular}{|c|c|c|c|c|c|c|c|c|c|c|}
\hline & \multirow[b]{3}{*}{$\begin{array}{l}\text { Mamet age } \\
\text { indicators } \\
\text { and } \\
\text { assignments }^{3}\end{array}$} & \multicolumn{4}{|c|}{ Rock unit } & \multicolumn{4}{|c|}{ Microfacies ${ }^{2}$} & \multirow[t]{3}{*}{ Class } \\
\hline & & & & & & 1 & 2 & 3 & 4 & \\
\hline & & 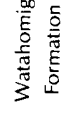 & 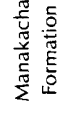 & 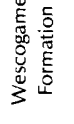 & 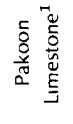 & $\begin{array}{l}\text { Lacks mud; } \\
\text { pelletoidal } \\
\text { grain } \\
\text { support }\end{array}$ & $\begin{array}{l}\text { Coarse- } \\
\text { graıned; } \\
\text { grains } \\
\text { bound }\end{array}$ & $\begin{array}{l}\text { Grains } \\
\text { not } \\
\text { bound } \\
\text { together }\end{array}$ & $\begin{array}{l}\text { Attached } \\
\text { forams }\end{array}$ & \\
\hline Ammovertella sp $\ldots \ldots \ldots \ldots \ldots$ & & 0 & 0 & 1 & $\ldots$ & -- & $\cdots$ & $X$ & --- & \\
\hline Apterrinellids $\ldots \ldots \ldots \ldots \ldots$ & & 7 & 14 & 10 & -- & $x$ & $x$ & $x$ & $\mathrm{x}$ & \\
\hline Archaediscidae $\ldots \ldots \ldots \ldots \ldots$ & & 2 & 0 & 0 & $\ldots$ & $x$ & $\ldots$ & -- & -- & \\
\hline Asteroachaediscus sp .......... & A & 2 & 0 & 0 & $\cdots$ & $\mathrm{X}$ & $\ldots$ & $\ldots$ & -- & \\
\hline Asphaltina $\mathrm{sp} \ldots \ldots \ldots \ldots \ldots$ & B & 1 & 1 & 0 & $\cdots$ & --- & $x$ & --- & $\cdots$ & Algae. \\
\hline Biseriamminds $\ldots \ldots \ldots \ldots \ldots$ & & 0 & 0 & 0 & 1 & $x$ & $x$ & $x$ & $\mathrm{X}$ & \\
\hline Biseriella sp . . . . . . . . . & A & 3 & 2 & 2 & -- & $x$ & --- & --- & $\cdots$ & \\
\hline Bradyina sp . . . . . . . . . . & & 0 & 0 & 2 & $\cdots$ & --- & --- & $x$ & -- & \\
\hline Calcisphaera sp . . . . . . . . . . & & 0 & 8 & 1 & $\cdots$ & $x$ & $x$ & $x$ & $x$ & Insertae sedis. \\
\hline Calcisphaera laevis . . . . . . . . & & 2 & 0 & 0 & $\ldots$ & $X$ & $x$ & --- & --- & Do. \\
\hline Dasyclad algae $\ldots \ldots \ldots \ldots \ldots$ & & 1 & 0 & 0 & -- & $x$ & --- & -- & --- & Algae. \\
\hline Diplosphaerina sp . . . . . . . . . & & 0 & 0 & 0 & 1 &.-- & --- & -- & $x$ & \\
\hline 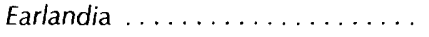 & & 1 & 4 & 0 & $\cdots$ & $\mathrm{x}$ & $\mathrm{X}$ & $\mathrm{X}$ & --- & \\
\hline Endothyridae $\ldots \ldots \ldots \ldots \ldots$ & & 4 & 5 & 1 & -- & $\mathrm{x}$ & $x$ & $x$ & $x$ & \\
\hline Endothyra sp ............. & & 0 & 4 & 1 & 2 & $\ldots$ & $x$ & $\mathrm{X}$ & $x$ & \\
\hline E. bowmani Brown emend Brady . & & 0 & 2 & 2 & -- & --- & $x$ & $\mathrm{X}$ & --- & \\
\hline E. media $\ldots \ldots \ldots \ldots \ldots \ldots$ & $\mathrm{C}$ & 4 & 10 & 4 & -.. & -- & $x$ & $x$ & --- & \\
\hline E.teres .............. & $\mathrm{C}$ & 0 & 6 & 3 & -- & -- & --- & $x$ &.-- & \\
\hline Eolasiodiscus sp . . . . . . . . & & 1 & 1 & 0 & $\cdots$ & --- & $\mathrm{x}$ & -- & $\cdots$ & \\
\hline cf. Eoschubertella sp . . . . . . . . . & B & 2 & 3 & 2 & $\ldots$ & --- & $x$ & $x$ & $\ldots$ & Fusulinid. \\
\hline Eotuberitina sp $\ldots \ldots \ldots \ldots \ldots$ & & 1 & 0 & 3 & -- & -- & $x$ & $x$ & --- & \\
\hline Eovolutina $\mathrm{sp} \ldots \ldots \ldots \ldots \ldots$ & & 0 & 1 & 0 & $\cdots$ & -- & $\cdots$ & $x$ & --- & \\
\hline Globivalvulina? sp . . . . . . . . . & A & 3 & 3 & 2 & 1 & $x$ & --- & --- & -- & \\
\hline G. bulloides . . . . . . . . . . & A & 0 & 0 & 4 & -- & $\mathrm{X}$ & --- & --- & --- & \\
\hline Neoarchaediscus incertus ........ & A & 1 & 0 & 0 & $\cdots$ & $x$ & -- & --- & --- & \\
\hline N. parvus $\ldots \ldots \ldots \ldots \ldots \ldots$ & A & 1 & 0 & 0 & -- & $x$ & -- & -- & -- & \\
\hline Orthovertella sp ............ & & 1 & 0 & 0 & -- & --- & $\mathrm{X}$ & --- & --- & \\
\hline Osagia sp $\ldots \ldots \ldots \ldots \ldots \ldots \ldots$ & & 1 & 0 & 0 & --- & -- & $\cdots$ & $x$ & -.- & Algae. \\
\hline Palaeonubicularia sp .......... & & 1 & 2 & 0 & $\cdots$ & --- & $x$ & $\mathrm{x}$ & -- & \\
\hline Palaeotextulariidae $\ldots \ldots \ldots \ldots$ & & 0 & 1 & 0 & $\cdots$ & --- & --- & --- & $\mathrm{X}$ & \\
\hline Polytaxis sp $\ldots \ldots \ldots \ldots \ldots \ldots$ & & 0 & 1 & 0 & $\cdots$ & $\cdots$ & $-\overline{1}$ & $x$ & -- & \\
\hline Priscella sp $\ldots \ldots \ldots \ldots \ldots \ldots$ & & 2 & 1 & 2 & -- & --- & $x$ & $x$ & -- & \\
\hline cf. Profusulinella? sp . . . . . . . . . & & 0 & 0 & 2 & -.. & -- & -- & $\mathrm{X}$ & -- & Fusulinid. \\
\hline Pseudocornuspira sp . . . . . . . & & 1 & 0 & 1 & -- & $x$ & --- & $\mathrm{X}$ & -- & \\
\hline Pseudoendothyra sp . . . . . . . . & & 0 & 0 & 1 & 2 & -- & -- & $x$ & $x$ & \\
\hline Spongiostramids . . . . . . . . & & 2 & 0 & 0 & $\cdots$ & --- & $x$ & --- & -- & Algae. \\
\hline Tetrataxis sp $\ldots \ldots \ldots \ldots \ldots \ldots$ & & 1 & 4 & 2 & $\cdots$ & $x$ & $x$ & $x$ & $x$ & \\
\hline Tuberitina sp . . . . . . . . . . . & & 0 & 0 & 2 & $\cdots$ & --- & -- & $x$ & -- & \\
\hline Volvotextularia sp . . . . . . . . . & & 1 & 0 & 0 & -- & -.- & $x$ & $-\cdots$ & -- & \\
\hline Wetheredella sp ............ & & 3 & 0 & 0 & -- & --- & $\mathrm{x}$ & $\mathrm{x}$ & -- & \\
\hline
\end{tabular}

${ }^{1}$ Or MCNair (1951); equivalent of Esplanade Sandstone in western Grand Canyon.

${ }^{2}$ Microfacies as recognized by Bernard Mamet (written commun., Nov. 16, 1972):

1. "A basal unit composed of pelletoidal-oncolithic-botryolitıc grainstone with a sieved microfauna."

2. "*** * coarse grained oncolithic-botryolitic grainstone-boundstone (birdseye bahamite) * * *"

3. "*** * composed mostly of silty to sandy pelletoidal fine-grained wackestones, packstones and graınstones. Calcareous silts are also abundant."

4. "** * *identified on the abundance of mud-filled small fusulinids, while the small forams are almost exclusively attached forms."

3 Indicators and probable age by Bernard Mamet (written commun., Nov. 16, 1972):

A. Suggest Morrowan-Atokan equivalent (microfacies 1 ).

B. Not younger than Middle Pennsylvanıan (microfacies 2).

C. Des Moinesian equivalent or slightly younger (microfacies 3 ).

most of those studied in western Grand Canyon. A large form of this genus (fig. E1), identified by Mackenzie Gordon, Jr., as $A$. occiduus, occurs in middle and upper lime- stones of the formation. It is considered by Dunbar and Condra (1932, p. 325) to indicate "Lower Pennsylvanian age." The species has been found in the Supai Group only 
NORTH

Hidden

Canyon

(30)

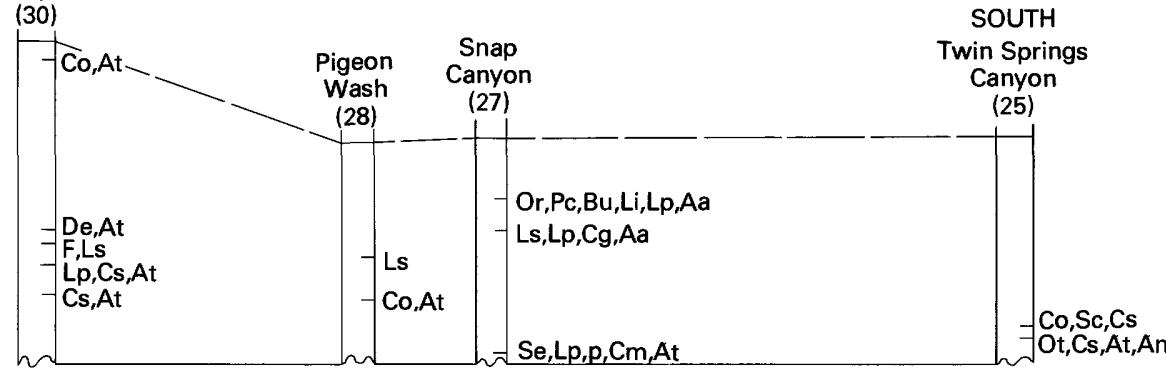

NORTHWEST

Iceberg

Canyon

(31)

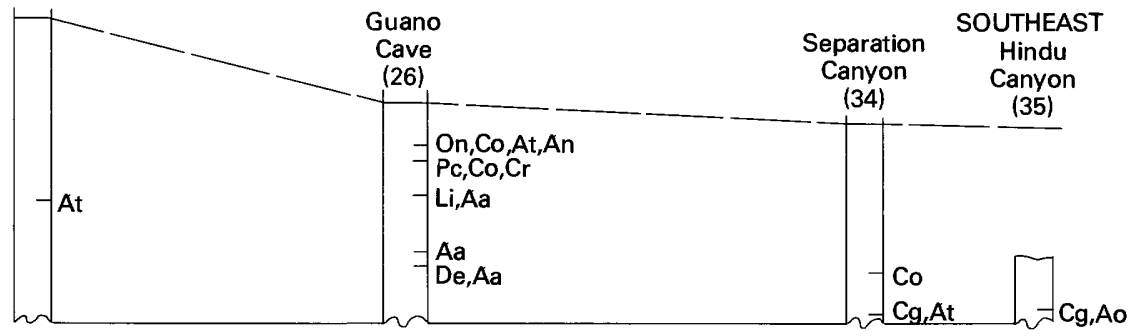

EXPLANATION

L Lingula sp.

Or Orbiculoidea sp.

Om Orbiculoidea meekana

Sc Schizophoria altirostris

Ot Orthotetes sp. A

De Derbyia sp.

on Orthotetacean

$\mathrm{Li}$ Linoproductus nodosus

Ls Linoproductus sp. A

Lp Linoproductus pumilus

p Productoid

$r$ Rhynchonelloid

A aff. Anteridocus n. sp.

$\mathrm{Cg}$ Composita gibbosa

Co Composita ovata

Cs Composita subtilita

$\mathrm{Cm}$ Composita sp.

$\mathrm{Cr}$ Crurithyris planoconvexa

Ao Anthrocospirifer of A. opimus

At Anthrocospirifer tanoensis

An Anthrocospirifer newberryi

Aa Anthrocospirifer occiduus

$\mathrm{Pu}$ Punctospirifer transversus

Re Reticulariina gonionota

di Dielasmid

Pc Pulchratia? sp.

$\mathrm{F}$ Flexaria? sp.

Bu Buxtonia sp.
FEET

$\left.\begin{array}{r}400- \\ 300- \\ 200- \\ 100- \\ - \\ 0\end{array}\right]$

SOUTHWEST

Iceberg

Canyon

(31)

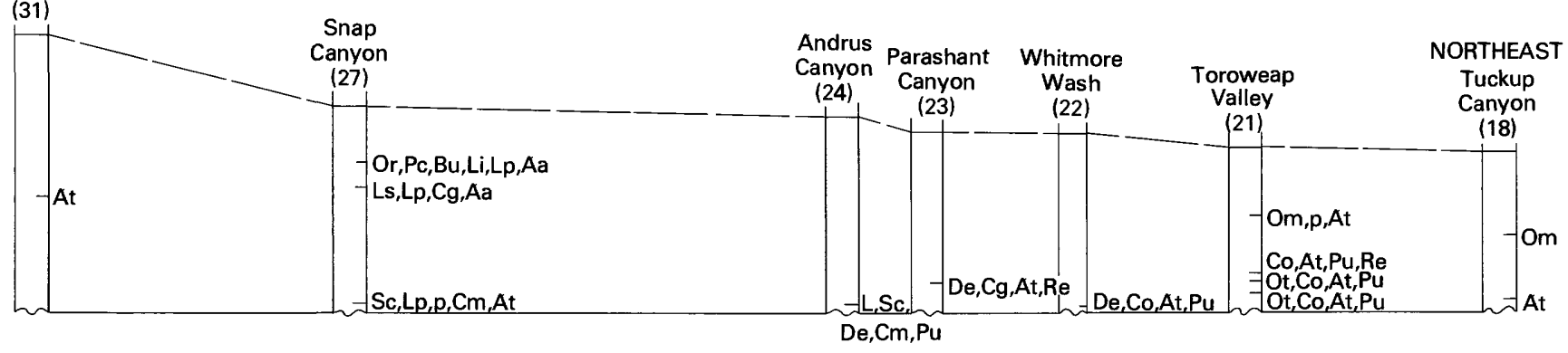

WEST

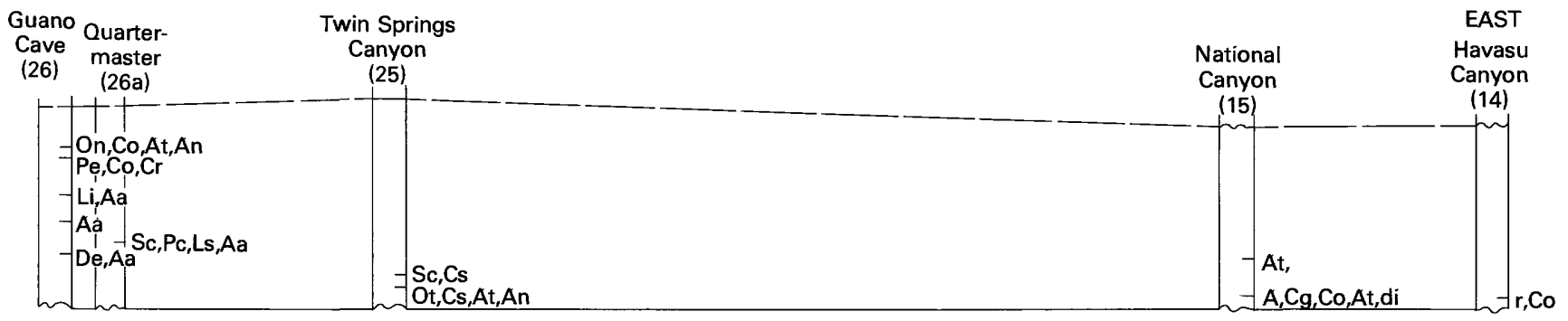

$\stackrel{0}{\perp} \quad \stackrel{10}{\perp} \quad 20$ MLES

FIGURE E1.-Brachiopods of the Watahomigi Formation, western Grand Canyon region, Arizona. Numbers in parentheses are those of measured sections. Fossil determinations by Mackenzie Gordon, Jr., and R. E. Grant. 
in the Watahomigi Formation; it is recorded from four localities (fig. E1), the easternmost of which is Pica, about 10 miles southeast of the Blue Mountain section.

A small species of Anthrocospirifer, referred to the species $A$. tanoensis, is very common in the Watahomigi Formation and mostly occurs lower in the section than the larger form, $A$. occiduus. Considerable numbers of the small species are associated with Composita, Derbyia, and other braciopods in the lower half of the formation at nine of the localities examined (fig. E1). Other species of $A n$ throcospirifer in the formation are $A$. newberryi and $A$. cf. opimus (Hall) (fig. E1).

Linoproductus nodosus is recorded from two localities, in the middle third of the formation. Because its stratigraphic range is believed limited to the uppermost part of the Morrowan, it is a significant time indicator. A closely related form $L$. sp. A has been recorded from two additional localities at a slightly lower horizon.
Other genera and (or) species of brachiopods found only in the Watahomigi Formation are Linoproductus pumilus, Punctospirifer transversus, and Schizophoria altirostris sp. Two genera of inarticulate brachiopods also occur in the Watahomigi. These are Orbiculoidea and a linguloid form. They are found in the middle part of the formation, the Orbiculoidea ranging from central to western Grand Canyon (fig. E1). The genera Derbyia, at four localities, and Orthotetes, at three localities, among the largest and most prominent of the brachiopods, are also widespread, having been collected in moderate numbers from Toroweap in central Grand Canyon westward to the Grand Wash Cliffs.

Many kinds of gastropods occur in the Watahomigi Formation, especially in the central part of Grand Canyon from where specimens representing 15 genera have been determined by E. L. Yochelson and associates (fig. E2). Farther west in the region, on and near the Grand Wash
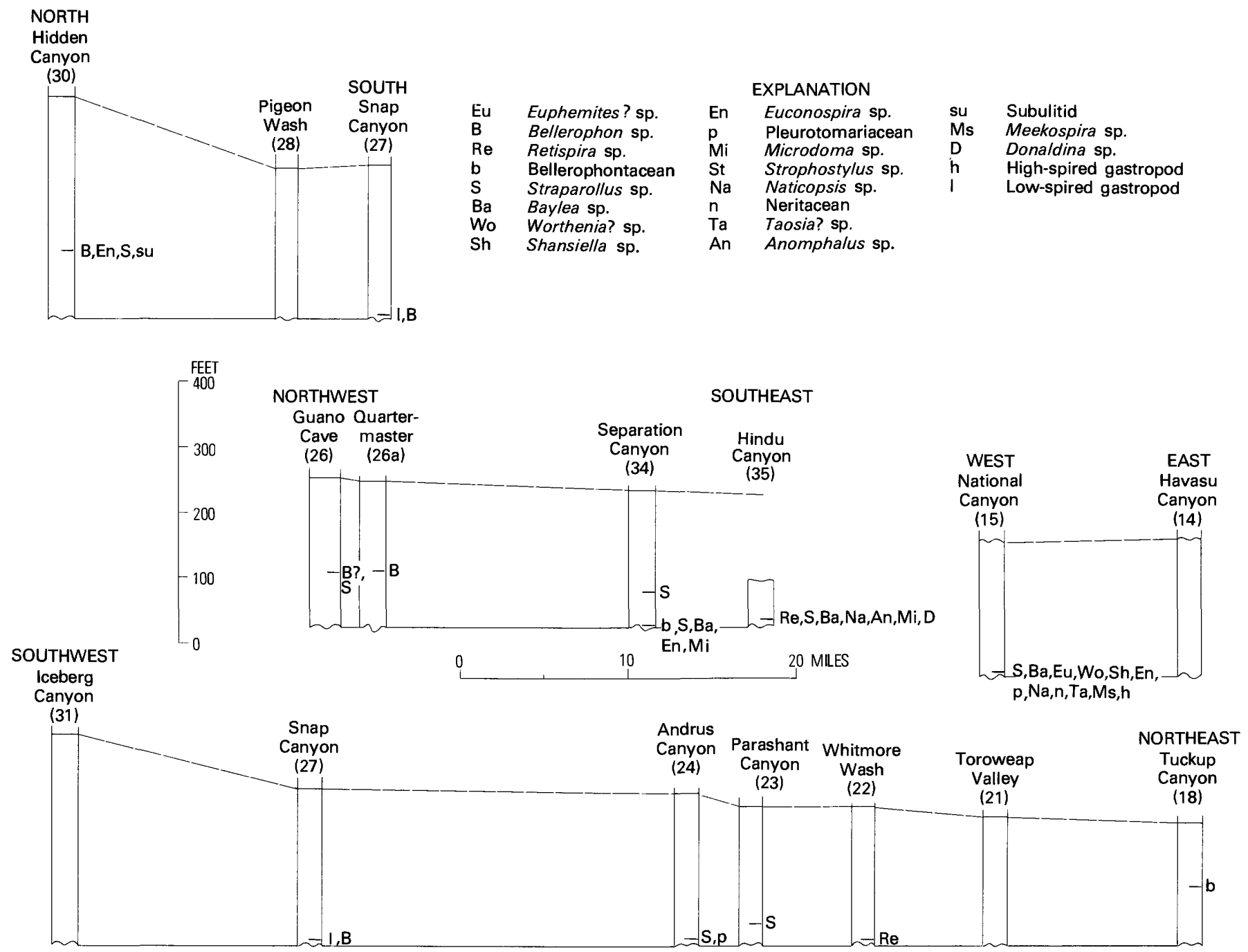

FIGURE E2.-Gastropods of the Watahomigi Formation, Grand Canyon region, Arizona. Numbers in parentheses are those of measured sections. Fossil determinations by E. L. Yochelson. 
Cliffs, some additional genera have been recognized as well as a few of those of the central area, but, in general, gastropods are less numerous in western than in central Grand Canyon. Most numerous and also most conspicuous in the thick beds of limestone in western sections is Bellerophon sp.

Pelecypods, represented by nearly as many genera as

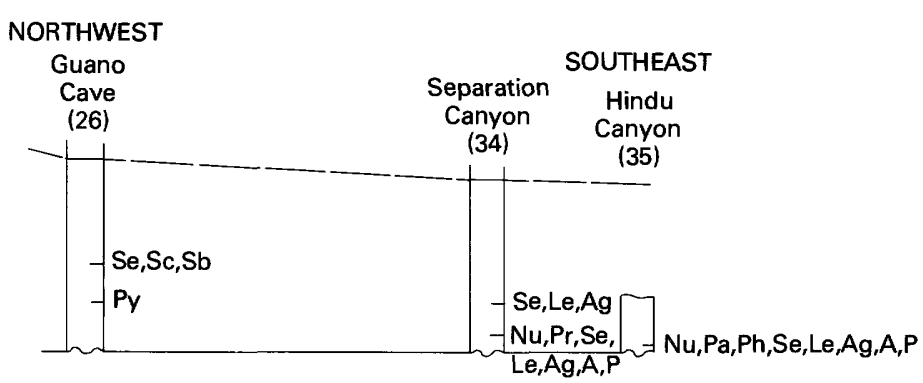

the gastropods, probably are equally common in the Watahomigi Formation of central and western Grand Canyon (fig. E3). Myalina, Aviculopecten, and Schizodus are most widespread and apparently flourished in the same near-shore, shallow-water environment as that occupied by the gastropods and certain of the brachiopods.

Pelecypods of a faunal assemblage from $12 \mathrm{ft}$ above

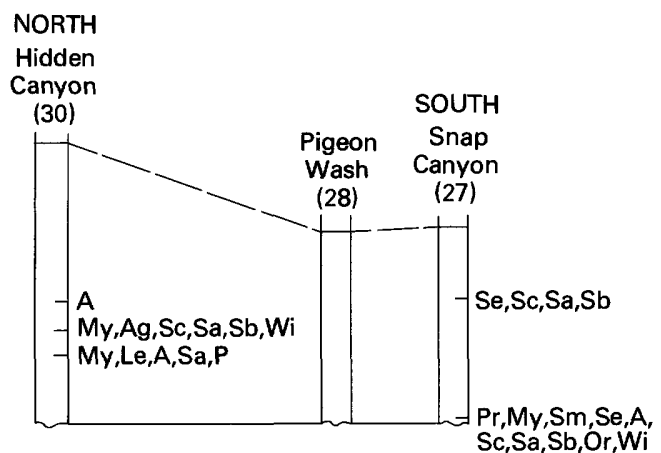

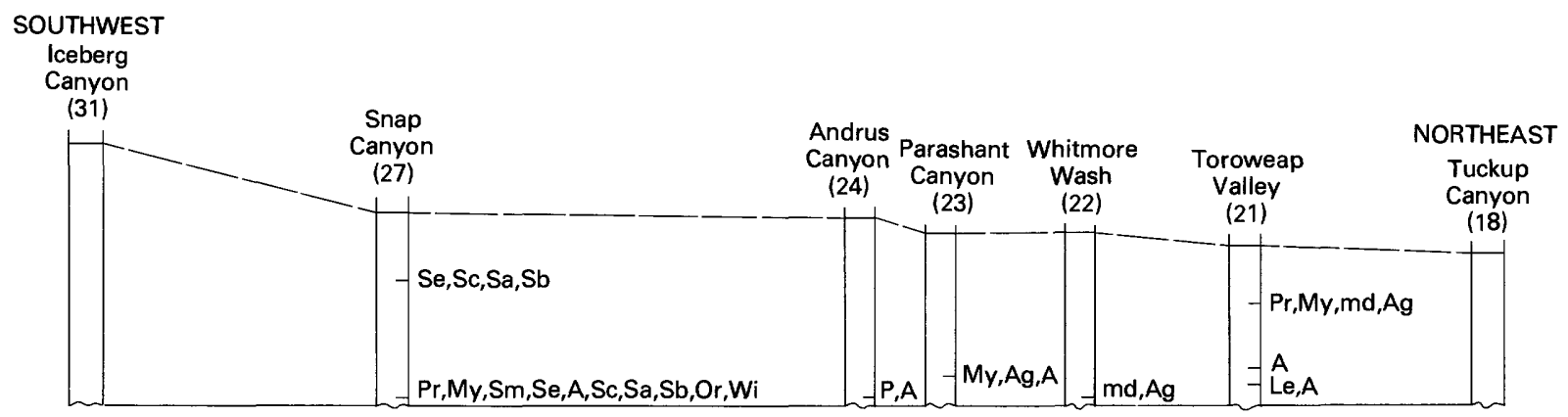
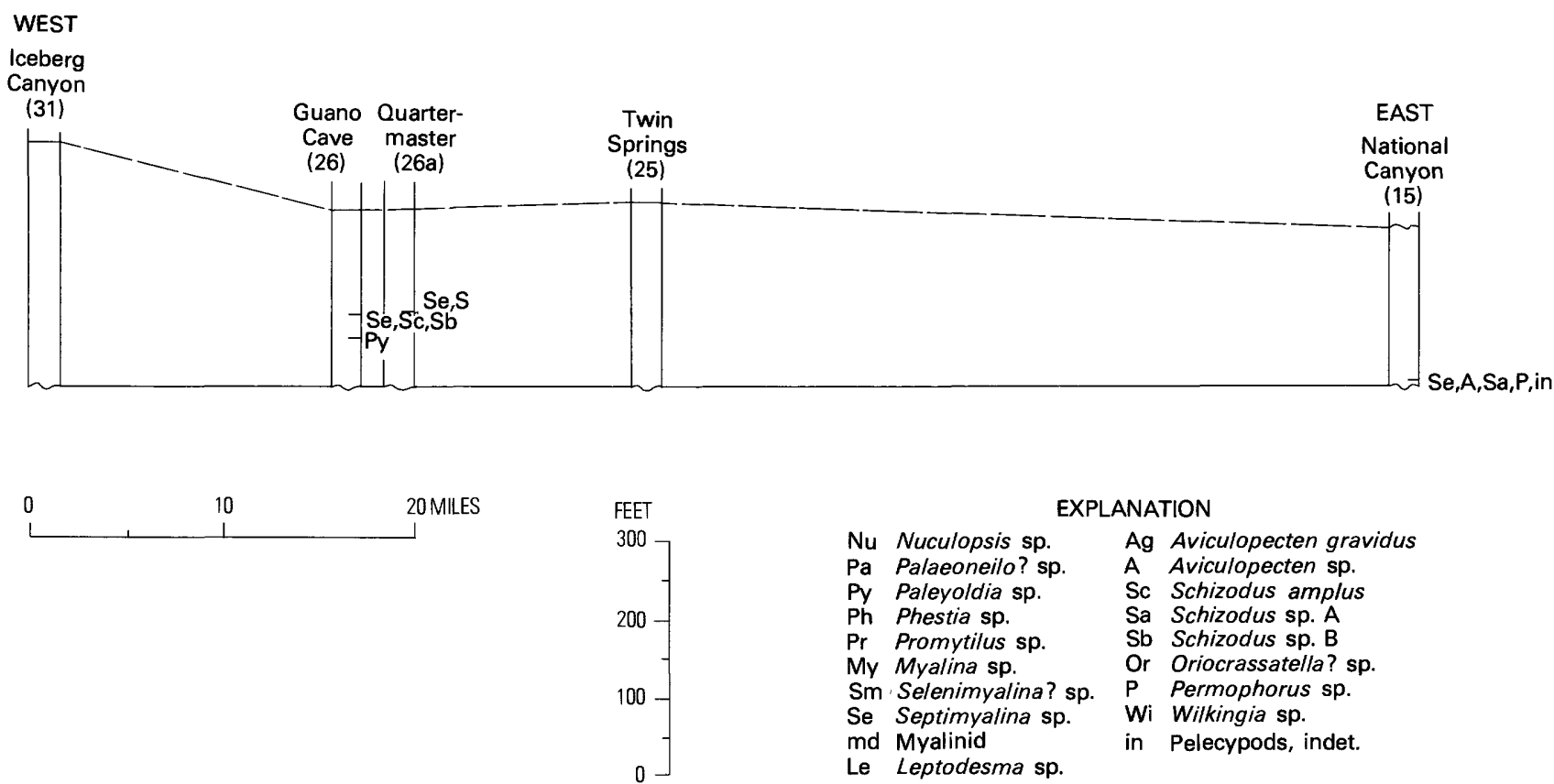

FIGURE E3.-Pelecypods of the Watahomigi Formation, Grand Canyon region, Arizona. Numbers in parentheses are those of measured sections. Fossil determinations by John Pojeta, Jr., and Mackenzie Gordon, Jr. 
the base of the Watahomigi at National Canyon have been examined by John Pojeta, Jr. who recognized six taxa. On the basis of his study, several conclusions on the paleoecology were reached (John Pojeta, Jr., written commun., 1971) as follows: (1) "the assemblage is overwhelmingly dominated by the byssally-attached, suspension-feeding genus Septimyalina" of which more than 80 specimens were included; (2) the second most numerous form (10 specimens) was Aviculopecten, which likewise was an epifaunal, byssate, suspension feeder; (3) the other genera represented-“Schizodus, Sphenotus?, Edmondia?, and Permophorus - were all shallow infaunal burrowing suspension feeders."

Fragments of echinoderms, especially crinoids and echinoids, are very common in some bioclastic rocks of the
Watahomigi Formation, but complete specimens of these animals have not been reported. Corals, although common in some of the upper formations of the Supai Group, seem to be lacking in the Watahomigi, except at Toroweap where a Michelinia was found and at Parashant with a Syringopora (fig. E4). Conulariids are recorded from two localities and nautiloids from one (fig. E5).

Associated with assemblages of brachiopods in the central parts and, to a less extent, the western part of Grand Canyon are bryozoans, represented in the Watahomigi by seven genera (fig. E6). Individual specimens are relatively uncommon in the formation, but at Toroweap five different forms were recognized at one horizon.

Trilobites seem to be relatively common in the Watahomigi Formation of central and western Grand Canyon,
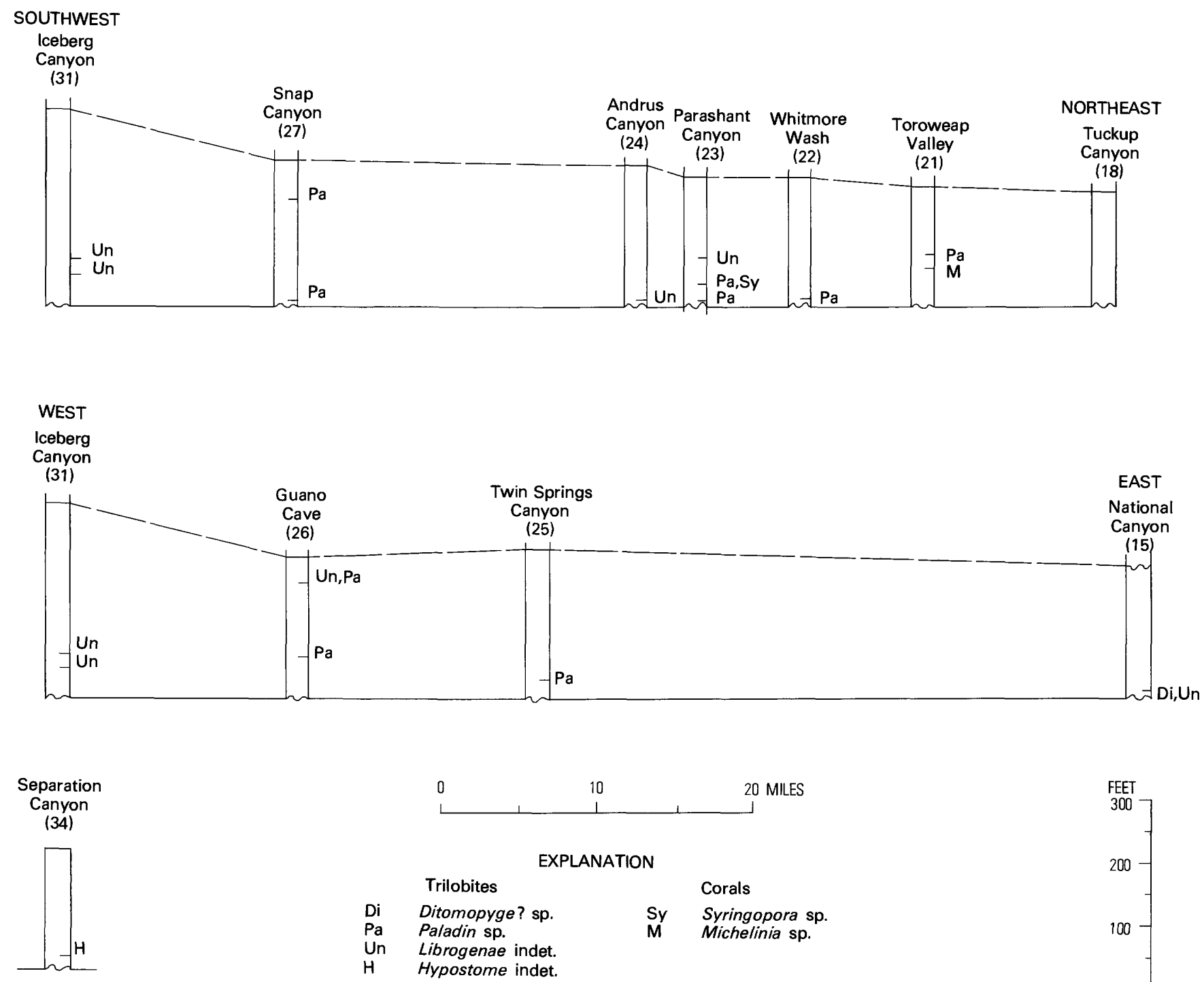

FIGURE E4.-Trilobites and corals of the Watahomigi Formation, Grand Canyon region, Arizona. Numbers in parentheses are those of measured sections. Trilobite determinations by R. E. Grant and others; coral determinations by W. J. Sando. 


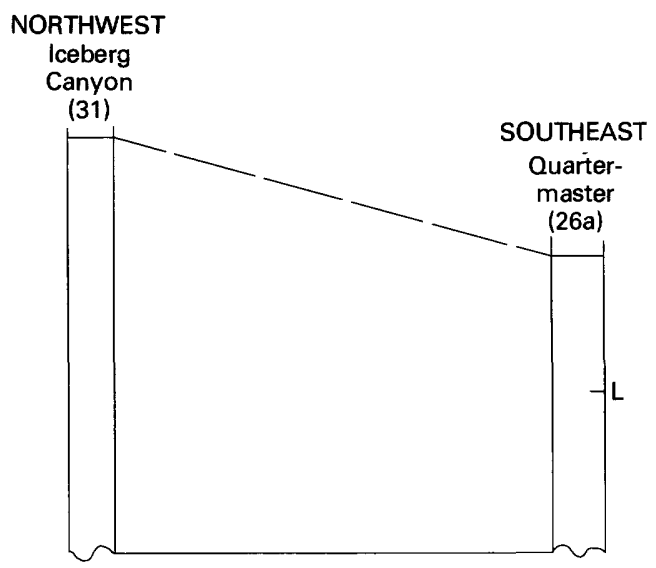

FEET
$400-$
$300-$
200
$100-$
-
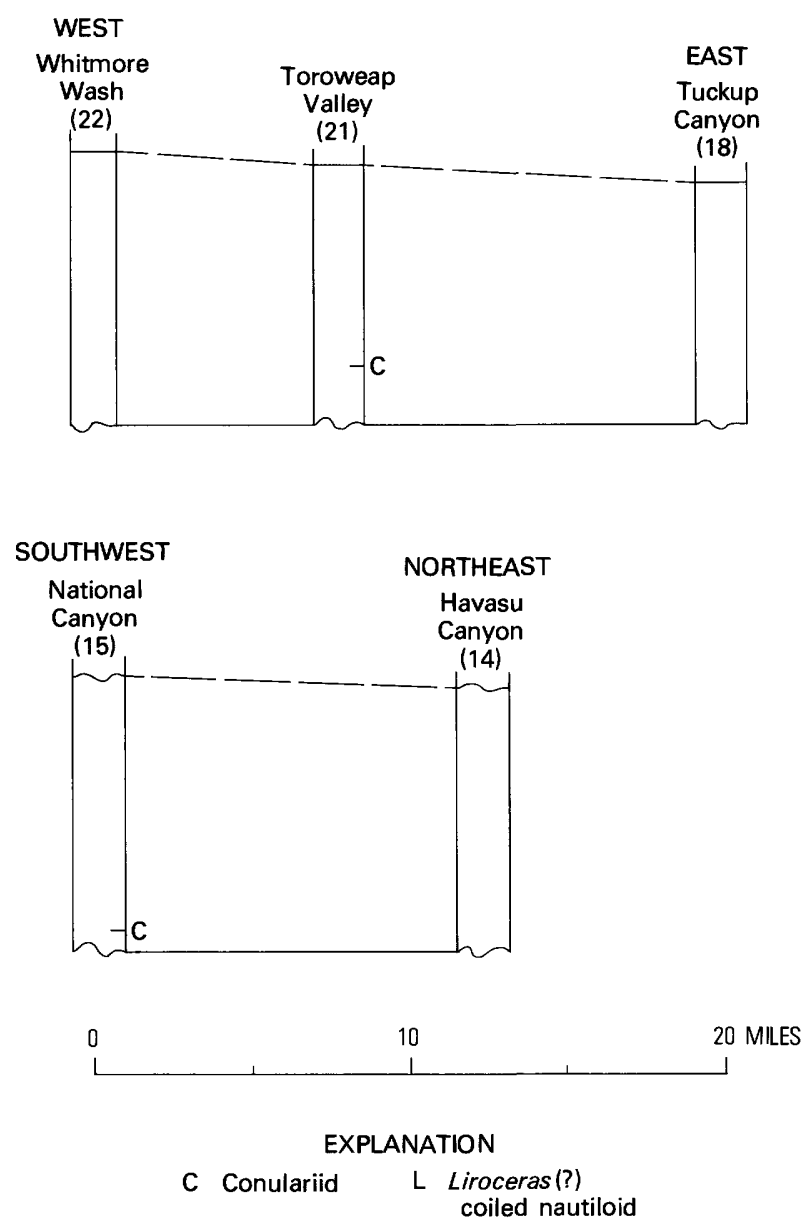

FIGURE E5.-Conulariids and nautiloids of the Watahomigi Formation, Grand Canyon region, Arizona. Numbers in parentheses are those of measured sections.

in contrast to their rarity or absence in overlying formations of the Supai. At 10 localities (fig. E4) they have been collected and two genera are recognized.

The only marine vertebrate represented in the Watahomigi Formation is the shark Deltodus. Isolated teeth of

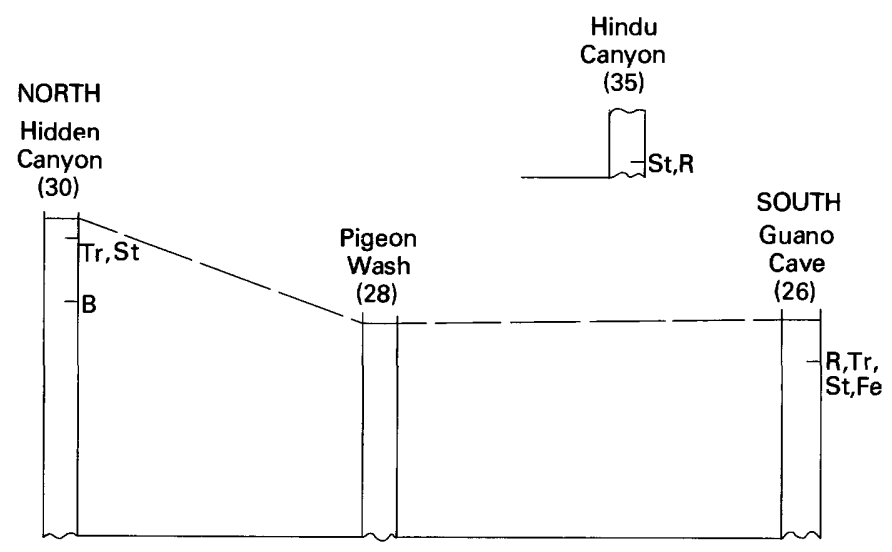

WEST

Andrus

Canyon Parashant Whitmore EAST

(24) Canyon Wash Toroweap
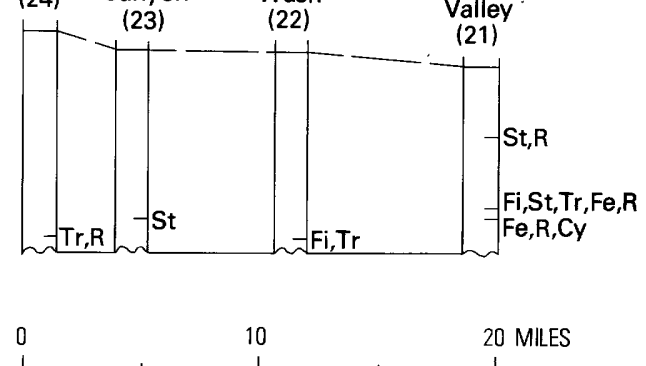

20 MLES
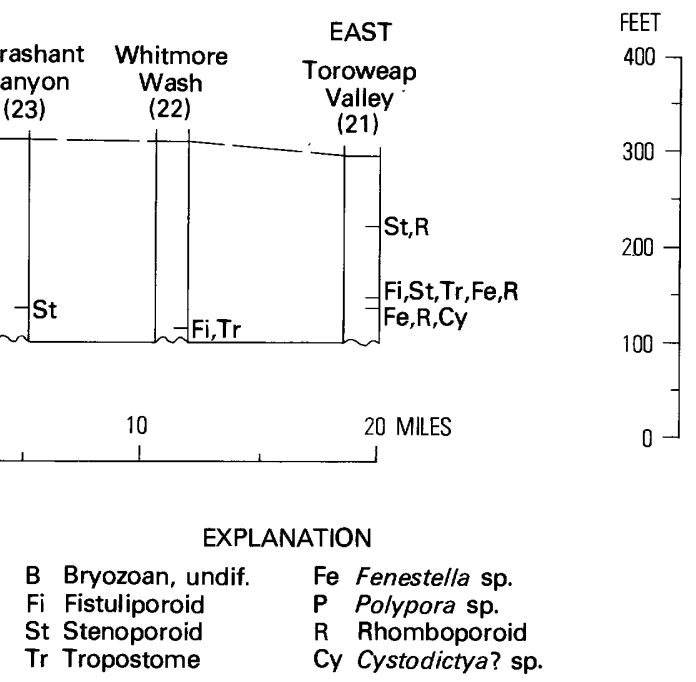

FIGURE E6.-Bryozoans of the Watahomigi Formation, Grand Canyon region, Arizona. Numbers in parentheses are those of measured sections.

this animal have been found at the Parashant Canyon, Guano Cave, and Separation Canyon sections and a spine fragment at Toroweap Valley (fig. E7).

The microfauna of the Watahomigi Formation has been examined and studied by Bernard Mamet at the University of Montreal. He recognized 17 kinds of small forams, associated with four types of algae (table E1). Eleven of the foraminifers have been found in younger units of the Supai but 6 have not.

Of particular interest among the microfossils reported on by Bernard Mamet are the forms Neoarchaediscus parvus, $N$. incertus, and Asteroarchaediscus sp., all of which occur exclusively in the lower half of the Watahomigi Formation in a distinctive pelletoidal-oncolithic facies and, according to Mamet (written commun., 1972), are suggestive of a Morrowan to Atokan age.

Conodonts of this formation have been recorded in Grand Canyon thus far only from the Separation Canyon 
NORTHWEST
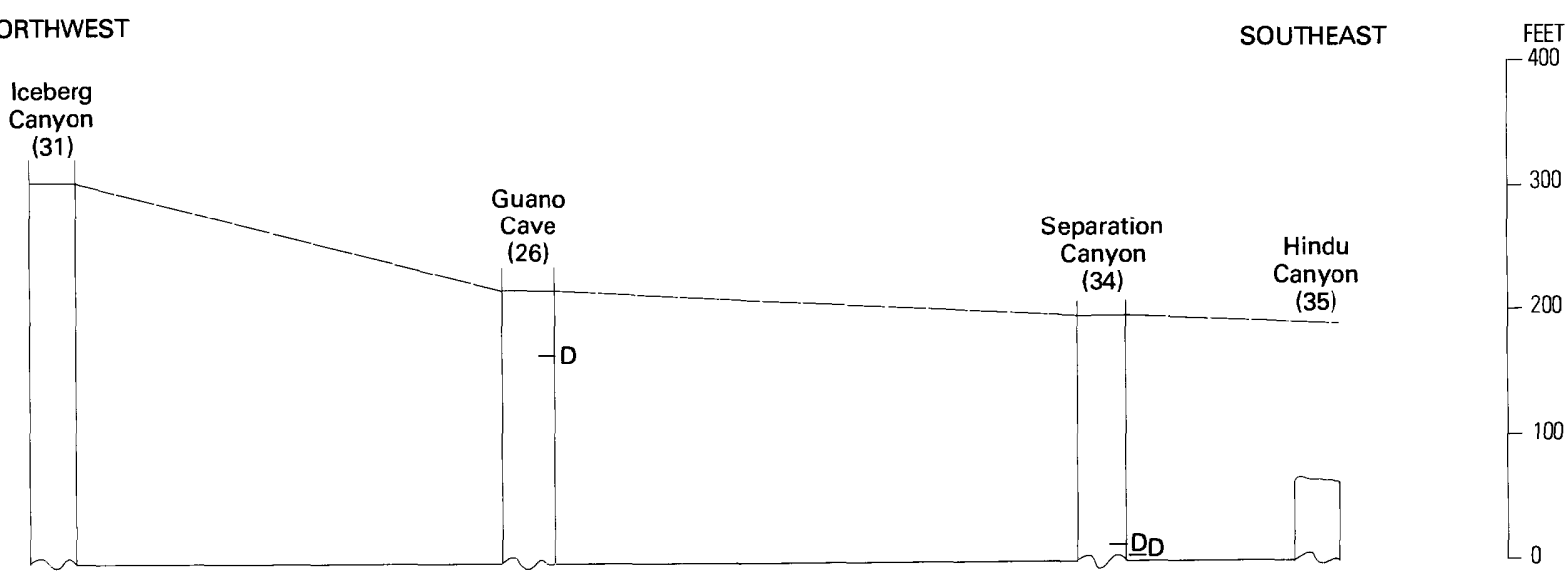

WEST

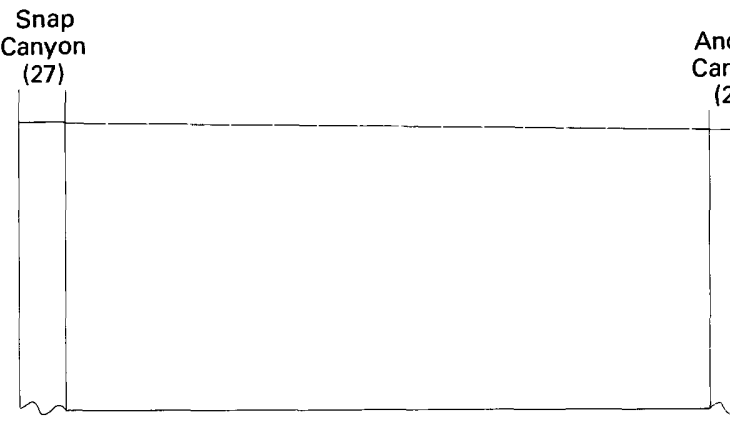

0 10 20 MILES

EXPLANATION

D Deltodus sp.

FIGURE E7.-Sharks teeth and spine fragments of the Watahomigi Formation, Grand Canyon region, Arizona. Numbers in parentheses are those of measured sections. Fossil determinations by D. H. Dunkle.

locality. There they have been noted at three horizons-32, 68 , and $104 \mathrm{ft}$ above the base - and are represented by four genera (table E2). Probably they occur elsewhere in the area, but as yet have not been observed in any collections. Concerning the Separation Canyon assemblage, J. W. Huddle (written commun., 1970) stated: "The only significant species is Cavusgnathus gigantus, which ranges from Late Mississippian to Permian. An Early Pennsylvanian age is reasonable."

West of the Grand Canyon region-at Lime Ridge and Pakoon Ridge-conodonts have been collected by Walter Pierce (written commun., 1976) at various horizons that he considered to be correlatable with the lower and middle parts of the Watahomigi. These specimens were examined by George J. Vervile who recognized 15 different genera, including the 5 recorded by Huddle from Separation Canyon. The collections by Pierce were assigned a Morrowan age by Vervile (Walter Pierce, written commun., 1976).

The abundance of certain brachiopod groups and various molluscs and the near absence of corals and many types of foraminifers probably is, at least in part, related to
TABLE E2.-Conodonts of the Watahomigi Formation (below Atokan conglomerate) at Separation Canyon

[Determined by J. W. Huddle]

\begin{tabular}{|c|c|c|}
\hline $\begin{array}{l}\text { Horizon (feet } \\
\text { above base) }\end{array}$ & Determination & $\begin{array}{l}\text { No. of } \\
\text { specimer }\end{array}$ \\
\hline \multirow[t]{3}{*}{32} & Cavusgnathus gigantus Gunnell & 4 \\
\hline & C. sp. (broken specimens) & 5 \\
\hline & Bar fragments & 10 \\
\hline \multirow[t]{2}{*}{68} & Cavusgnathus sp. (broken specimen) & 1 \\
\hline & Bar fragments .... & 4 \\
\hline \multirow[t]{6}{*}{104} & Cavusgnathus sp. & 1 \\
\hline & C.? sp. .... & 1 \\
\hline & Hindeodella sp. ................. & 2 \\
\hline & Spathognathodus of. S. minutus Ellison . . . . . . . . . . & 1 \\
\hline & Synprioniodina sp. . . . . . . . . . . & 1 \\
\hline & 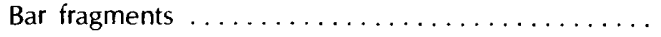 & 5 \\
\hline
\end{tabular}

the lithofacies. As shown in figure $\mathrm{C} 10$, this formation, unlike those higher in the Supai Group, consists of much mudstone and limestone but contains very little sandstone. The general lack of cross-bedding and the relative abun- 
dance of fine sediments suggest that low-energy conditions prevailed.

A synthesis of the distribution and abundance of fossils in the Watahomigi Formation of Grand Canyon emphasizes certain major differences between assemblages in this formation and those of younger units in the Supai. Brachiopods of several groups are numerous and both gastropods and pelecypods are locally abundant, whereas these faunal groups are relatively uncommon in the overlying formations.

\section{MARINE FAUNA OF THE MANAKACHA FORMATION}

Invertebrate fossils of all types are sparse in the Manakacha Formation. This is in contrast to the relatively abundant marine assemblage of the underlying Watahomigi Formation where numerous species and many individuals occur. Six groups of megafossils, all of them from western Grand Canyon, are represented in the Manakacha collections made during this study. Included in these groups are three genera of brachiopods, two of bryozoans, two of pelecypods, and a single genus each of gastropod, trilobite, and coral (fig. E8).

Among the brachiopods of the Manakacha is a small form of Anthrocospirifer that is very numerous in the upper part of the slope unit of the formation at Pigeon Wash (fig. E8). Probably the most common and widespread of the megafossils, however, is a large species of Bellerophon found in all sections along the Grand Wash Cliffs (figs. E8, E9).

Most diagnostic and also most widespread of the marine invertebrate fossils in the Manakacha Formation are the fusulinids, distributed throughout most of the Grand Canyon area (fig. E10). Although individuals are not extremely common, the group is represented by the following five genera (fig. E11): Fusulinella, Profusulinella, Staffella, Pseudostaffella, and Eoschubertella. These fusulinids are the principal means of establishing an Atokan age for the formation. Representatives of these genera have been found in the Manakacha at Hidden Canyon, Pigeon Wash, and Parashant Canyon in the west and at Hermit Trail, Grandview Trail, and Eminence Fault in the east.

The presence of Fusulinella sp. at Kaibab Trail, north, and at Grandview Trail and of Pseudostaffella sp. at Kaibab Trail, north (fig. E11), at an horizon seemingly below the lower boundary of the formation, suggests that rocks of Atokan age begin in the Watahomigi Formation.

Small foraminifera seem to be widely distributed in the formation, and are most common in the western part of Grand Canyon. They have been examined by Bernard Mamet who recognized (written commun., 1972) 13 genera including a number of endothyrid species (table E1). These various foraminifers have been assigned by Mamet to four principal microfacies and he stated that these facies are readily distinguished by their petrographic characteristics. The various small foraminifers, however, do not seem to be restricted to single time-rock units, but commonly occur in two or more formations as seen on Grand Canyon profiles. Associated with them in some places are calcispheres and other algae, and some fusulinids.

The presence of Endothyra media Waters and "E." teres St. Jean among the foraminifers is said by Mamet (written commun., 1972) to indicate a Des Moinesian (or slightly younger) age. These species are numerous in the Manakacha Formation, but also occur in the Wescogame (fig. E12). In the latter formation they may have been introduced as detrital grains.

\section{MARINE FAUNA OF THE WESCOGAME FORMATION}

The Wescogame Formation, like the underlying Manakacha, contains an impoverished fauna (fig. E13), but one that is widely distributed (fig. E14). This probably is the result of a high-energy depositional environment, dominated by highly cross-stratified, limy sand that was hostile to most marine life. Brachiopods have not been found in the Wescogame Formation, bryozoans are not recorded, and corals, except for two forms from Hidden Canyon, are not represented.

Most numerous of the megafossils, at least locally, are the pelecypods (fig. E15). In limestone of the Guano Cave section they are represented by six genera (fig. E13). Gastropods, especially large bellerophontidae, are common in aphanitic limestone at Hidden Canyon. None of these mollusks are in the sandy cross-bedded limestones or calcareous sandstones, however, and they apparently favored a quiet-water environment.

Sharks teeth, referred to Deltodus sp. by D. H. Dunkle, are recorded from two localities-Hidden Canyon and Iceberg Canyon (fig. E13). Their presence in a sandy environment is not surprising as they represent swimming animals. Likewise, the occurrence of fusulinids and numerous smaller foraminifers may be at least partially accounted for by the ease with which they could be transported in high-energy waters inferred from the crossbedded detrital sand in which they occur.

A Late Pennsylvanian (Virgilian) age has been assigned to rocks of the Wescogame Formation in Grand Canyon on the basis of the fusulinid Triticites sp. and the corals Syringopora multattenuata McChesney and Canina sp. (W. J. Sando, written commun., 1964). Further support of this assignment is furnished by the presence of Ozawainella? sp. from three collections made at $49 \mathrm{ft}$ below the top of the formation at Hidden Canyon. "A considerable number of shells are present," according to L. G. Henbest (written commun., 1964). 


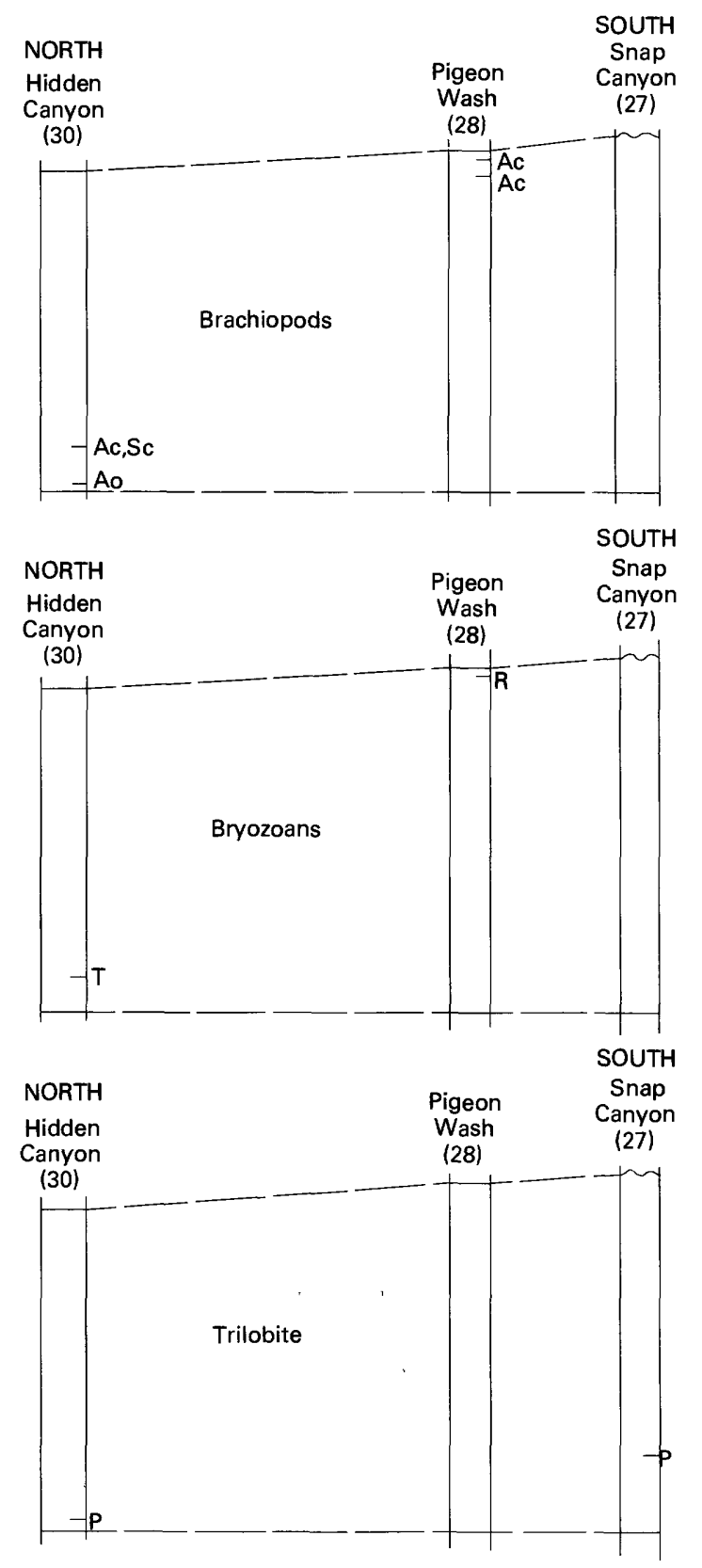

0

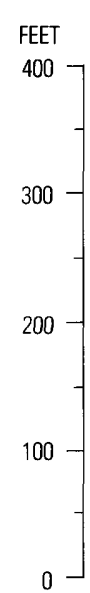

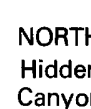

Canyon

(30)

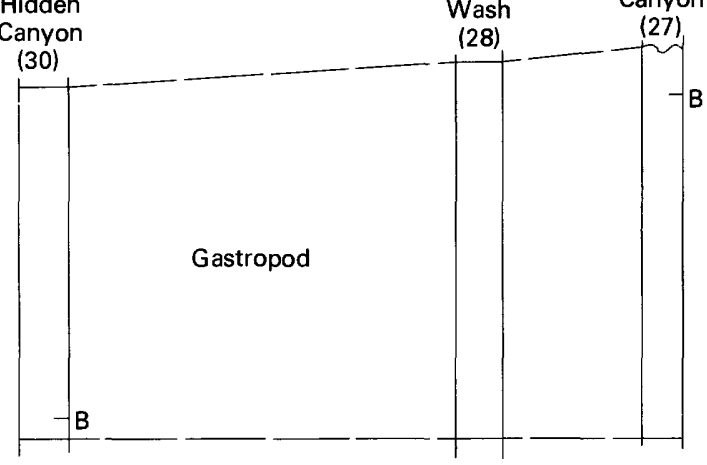

NORTH

Hidden

Canyon

(30)

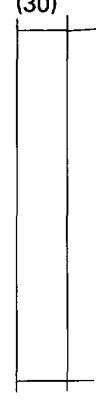

NORTH

Hidden
Canyon

(30)

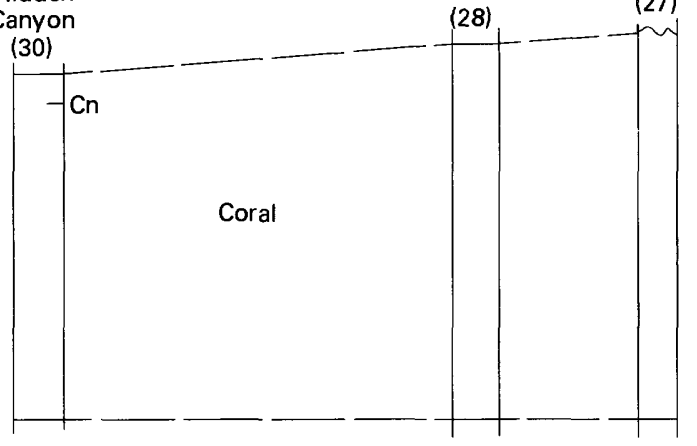

20 MILES

EXPLANATION

$\begin{array}{ll}\text { Brachiopods: } & \text { Ao Anthrocospirifer occiduus } \\ & \text { Ac Anthrocospirifer tanoensis } \\ & \text { Sc Schizophoria sp. } \\ \text { Bryozoans: } & \text { R Rhomboporoids, etc. } \\ & \text { T Tabulipora sp. } \\ \text { Trilobite: } & \text { P Paladin } \\ \text { Gastropod: } & \text { B Bellerophon (Bellerophon) n. sp. } \\ \text { Pelecypods: } & \text { S Schizodus sp. } \\ & \text { N Nuculopsis sp. } \\ \text { Coral: } & \text { Cn Caninia sp. }\end{array}$

FIGURE E8.-Principal invertebrate megafossils of the Manakacha Formation, western Grand Canyon, Arizona. Numbers in parentheses are those of measured sections. Fossil determinations as follows: brachiopods by Mackenzie Gordon, Jr.; bryozoans by Helen Duncan; gastropods by $\mathrm{E}$. L. Yochelson; pelecypods by John Pojeta, Jr.; corals by W. J. Sando. 


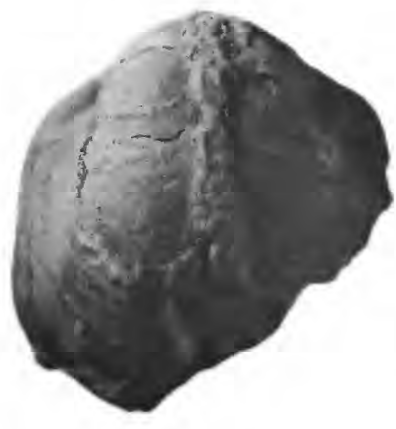

$A$

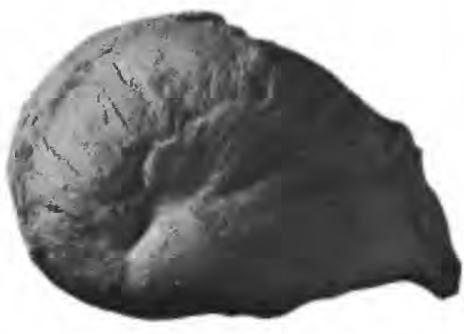

$B$
FIGURE E9.-Bellerophon (Bellerophon) n. sp. dorsal (A) and side (B) view of large specimen, natural size. Manakacha Formation, USCS colln. 22272-FC, from Snap Canyon section, Grand Canyon, Ariz. Photograph by Mackenzie Gordon, Jr.
Small (nonfusulinid) foraminifers of which 14 species, including 4 Endothyridae, have been recognized by Bernard Mamet (table E1), seem to have had their distribution determined by microfacies rather than by age factors. Thus, many of the genera represented in the Wescogame Formation likewise are found in other formations of the Supai Group where similar microfacies occur.

\section{MARINE FAUNA OF THE PAKOON LIMESTONE}

The uppermost formation of the Supai Group, the Esplanade Sandstone, is largely barren; however, its lateral equivalent to the west, known as the Pakoon Limestone (McNair, 1951), is a relatively pure carbonate rock and is highly fossiliferous. The Pakoon is exposed along the

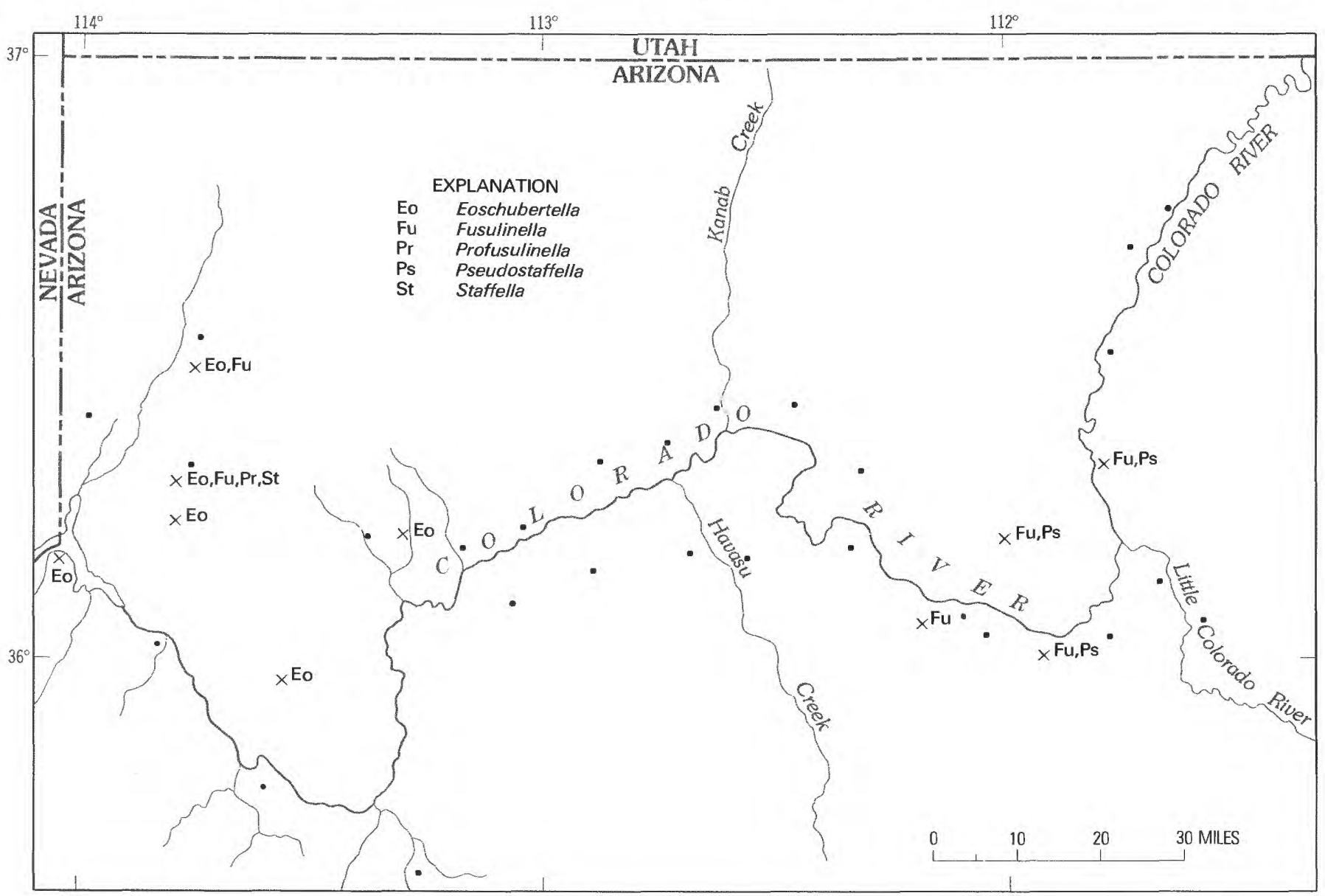

FIGURE E10.-Distribution of fusulinids of Atokan age (Manakacha Formation and upper part of the Watahomigi Formation), Grand Canyon region, Arizona. Fossil determinations by R. C. Douglass. 

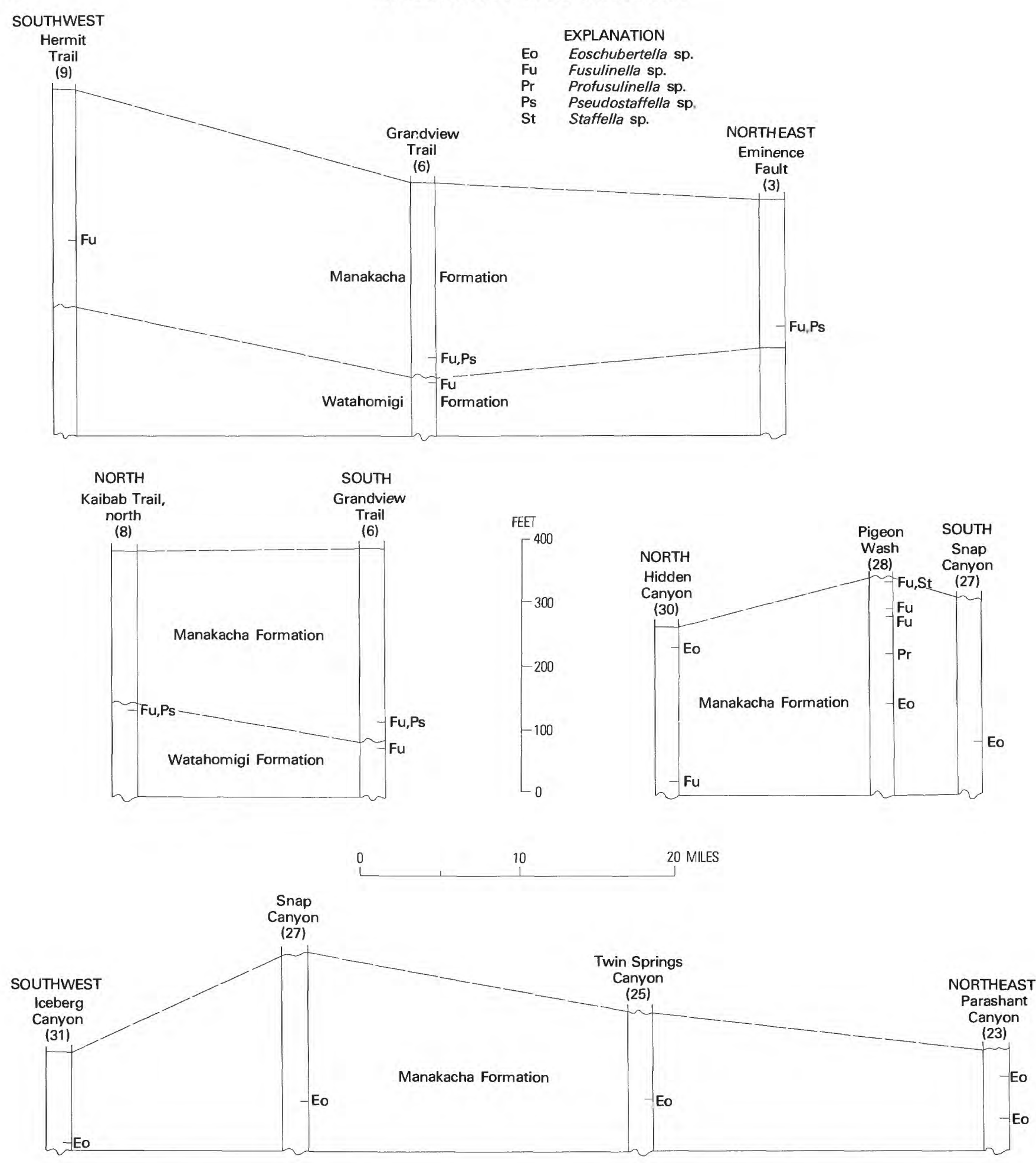

FIGURE E11.- Horizons of fusulinids of Atokan age in Grand Canyon measured sections, Arizona. Numbers in parentheses are those of measured sections. Fossil determinations by R. C. Douglass.

Grand Wash Cliffs at the western end of Grand Canyon; it was studied in this area at Hidden Canyon, Pigeon Wash, and Snap Canyon, and to the southwest at Iceberg Can- yon. A partial section was examined at the Guano Cave locality, south of the Colorado River. At all of these sections large faunas were collected. 


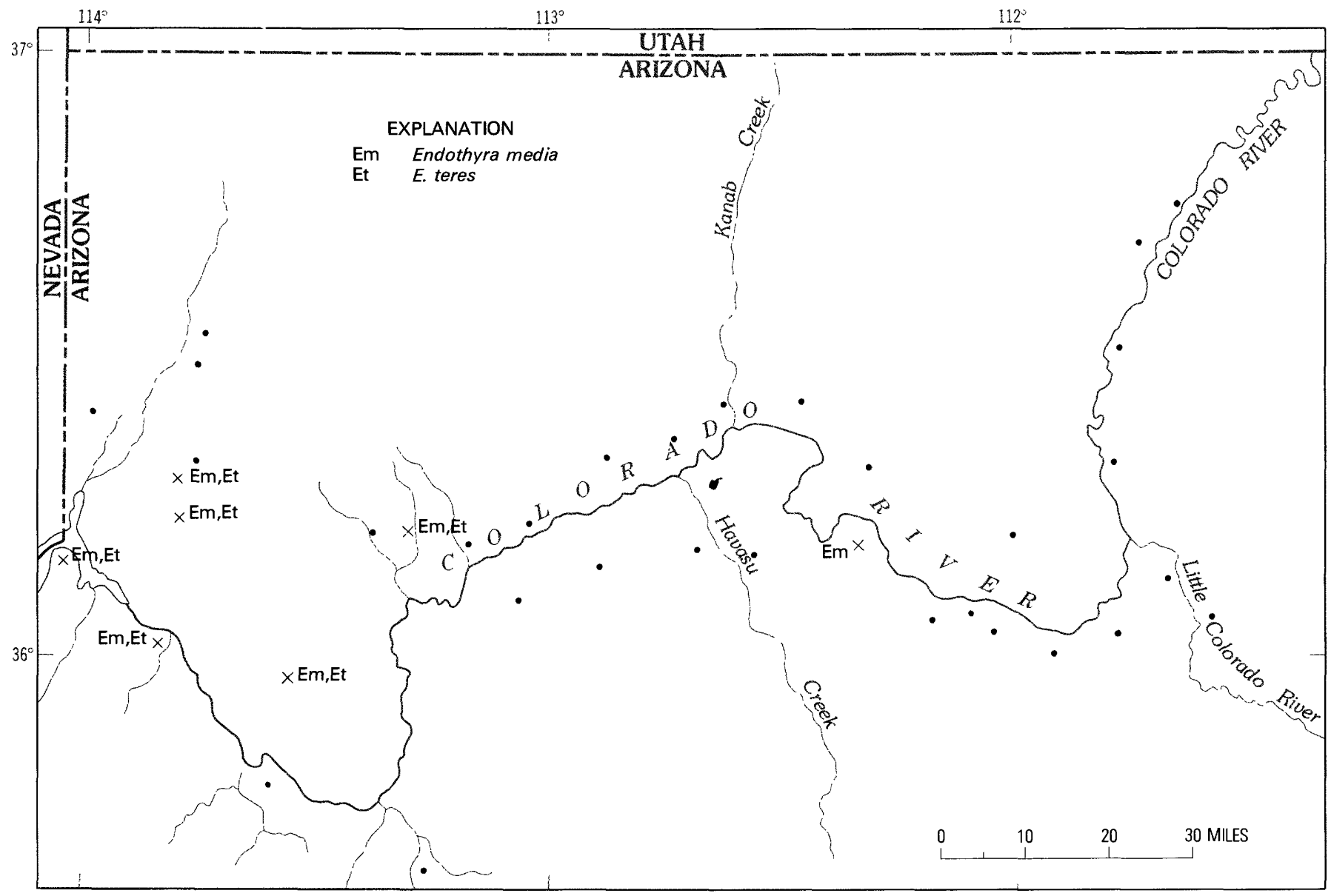

FIGURE E12.-Distribution of Endothyra media and E. teres in upper part of the Manakacha Formation and lower part of the Wescogame Formation, Grand Canyon region, Arizona. Fossil determinations by Bernard Mamet.

Eastward in the Grand Canyon area the carbonate rocks of the Pakoon are represented only by the thin tongues of limestone that extend into highly cross-stratified sandstones of the Esplanade. The only fossils that have been found in these strata of sandstone are bioclasts (fig. E16) that cannot be identified specifically.

The fauna of the Pakoon consists chiefly of corals, fusulinids, and smaller foraminifers. These were abundant and varied at all of the localities examined, and were accompanied by some brachiopods, gastropods and fragments of echinoderms. Sharks teeth were found at two places (fig. E17) and an unidentified bryozoan at one (fig. E17).

The coralline material in the Grand Canyon collections was studied by W. J. Sando (written commun., March 26, 1964) who recognized nine genera among 40 specimens from four localities (fig. E17). The colonial corals form small mounds or bioherms scattered through thick limestone beds at various horizons. They "show affinities to the Lower Permian faunas ${ }^{* *}$ from the Ely area,
Nevada," according to Sando.

Six genera of fusulinids (fig. E18) have been identified in rocks of this formation, and they include some, such as Schwagerina and Pseudoschwagerina, that serve to establish the Wolfcampian age of the strata, and others, including Triticites and Schubertella (fig. E19), that are common in Lower Permian rocks elsewhere in the region. As yet no fusulinids have been found in the Esplanade to establish whether or not it is precisely equivalent in age to the Pakoon; apparently the cross-bedded sand represents an environment unfavorable to most marine life.

A collection of small foraminifers of the Pakoon Limestone at Iceberg Canyon was examined by L. G. Henbest (written commun., 1964) who recognized the following forms of Early Permian or probable Early Permian age: Geinitzina? sp., Spandelinoides? sp., and Calcivertella sp. All of these were from $24 \mathrm{ft}$ above the base of the Pakoon Limestone.

Microfacies of type 4 of Bernard Mamet (written com- 


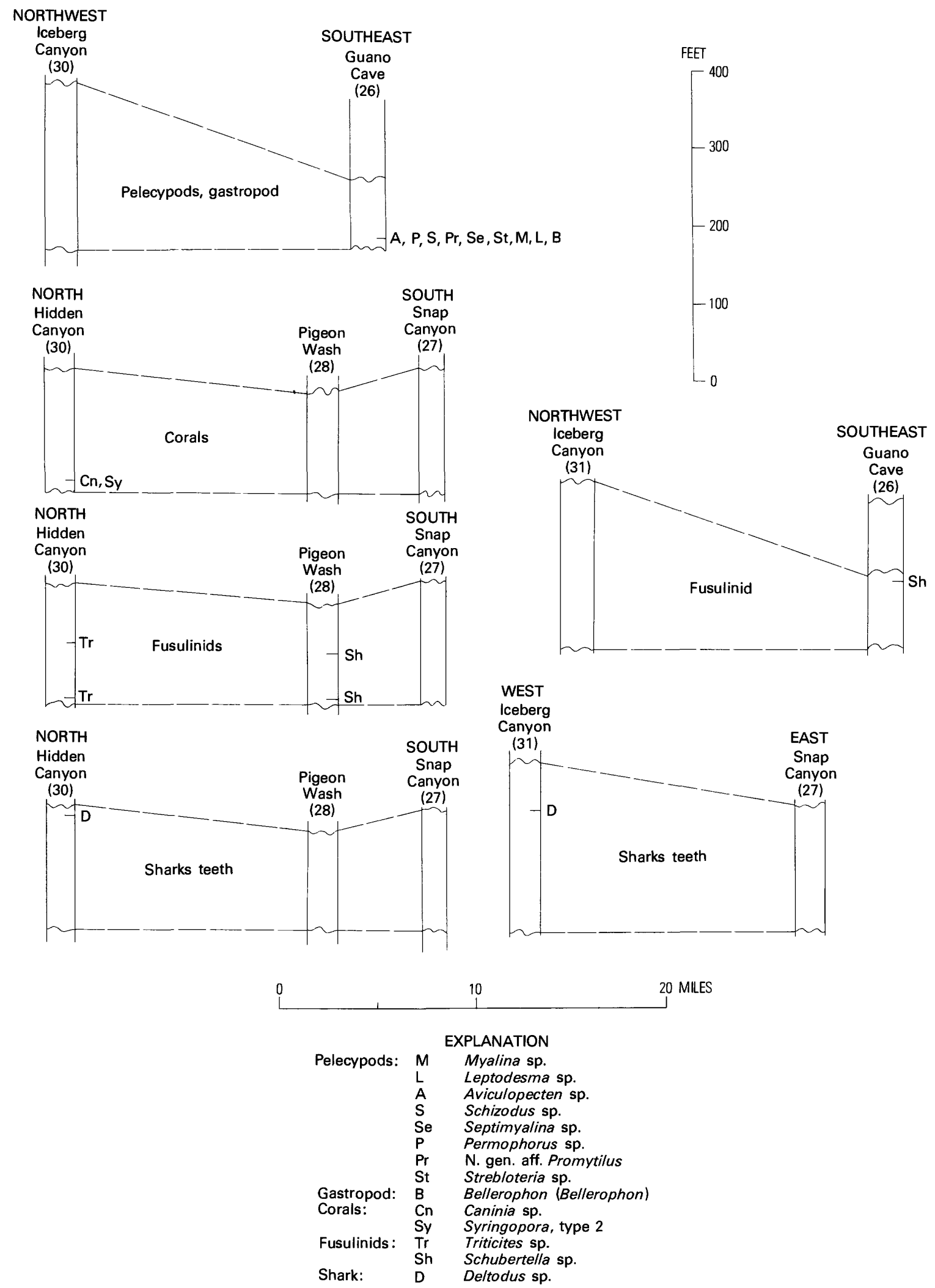

FIGURE E13.-Principal marine fossils of the Wescogame Formation, Grand Canyon region, Arizona. Numbers in parentheses are those of measured sections. Fossil determinations as follows: pelecypods by John Pojeta, Jr.; corals by W. J. Sando; fusulinids by R. C. Douglass; sharks teeth by D. H. Dunkle. 

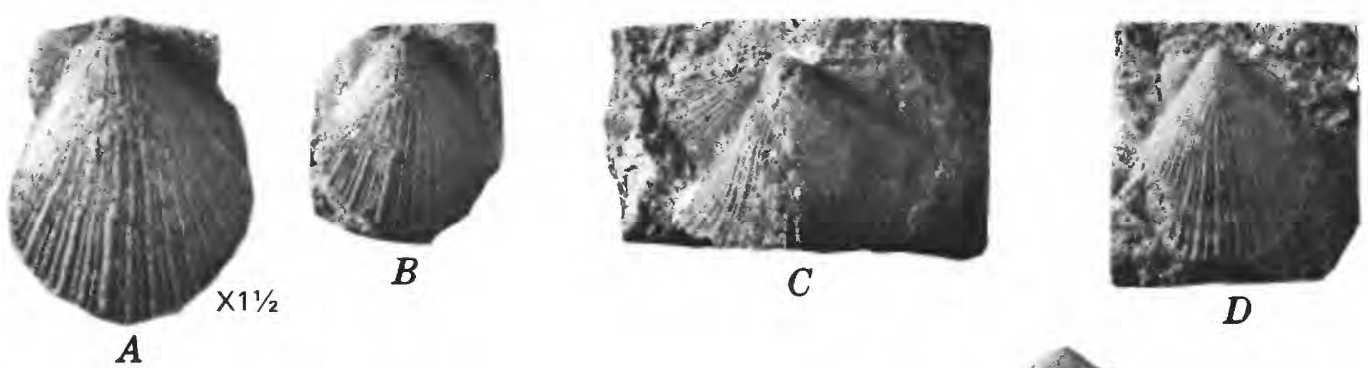

D

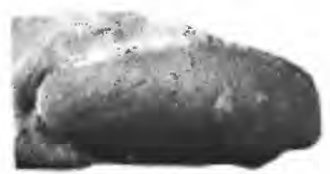

E

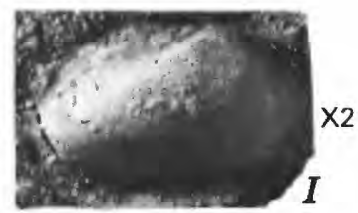

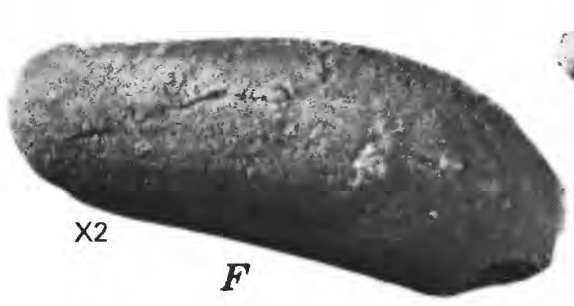

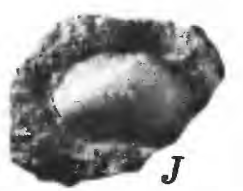

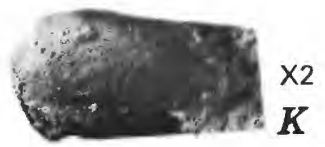

$\mathrm{X} 2$
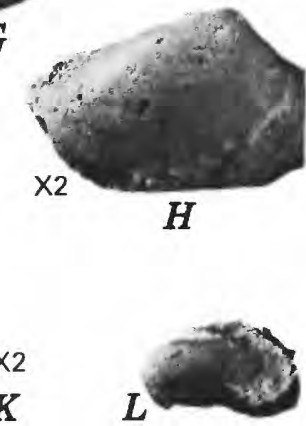

FIGURE E14.-Pelecypods from the Wescogame Formation: A-D, Aviculopecten sp., enlarged view and view natural size of left valve (USNM 256853) and views of two other left valves (USNM 256854 and USNM 256855); E, F, N. gen. aff. Promytilus, n. sp., views natural size and enlarged of left valve (USNM 256856); G-L, Permophorus sp., views natural size and enlarged of two right valves (USNM 256857 and USNM 256858) and one left valve (USNM 256859). All specimens from USGS colln. 24774, Guano Cave measured section, Grand Canyon, Ariz. Photographs by Mackenzie Gordon, Jr.

mun., 1972) is "identified on the abundance of mud-filled small fusulinids, and small forams that are almost exclusively attached forms." This microfacies, where it occurs in the Pakoon Limestone, contains the following foraminifers: Biseriamminds, Diplosphaerina sp., Endothyra sp., and Pseudoendothyra sp.

Four genera of brachiopods have been recognized in the Pakoon Limestone of the western Grand Canyon area. Two of these-Composita sp. and a chonetid-are numerous at several localities, but the only other brachiopods recorded are a species of Derbyia and one of Linoproductus (fig. E20). Mollusca are represented by four genera, all from a single zone at the Guano Cave locality (fig. E17).

\section{TRACKS OF VERTEBRATE ANIMALS OF THE WESCOGAME FORMATION}

In at least four localities in the eastern end of Grand Canyon, tracks and trails of vertebrate animals are preserved on foreset beds of the Wescogame Formation. The original discovery, in 1915, was by Charles Schuchert (1919, p. 357) at a site about one-half mile below Santa Maria Spring on the Hermit Trail. Subsequently, fossil footprints were found at a lower horizon, "below Breezy Point," on Hermit Trail and also near O'Neill Butte on the Kaibab Trail, south (figs. E21A, B, E22B) (Gilmore, 1927, p. 8). Still later, tracks were discovered by G. E. Sturdevant in the Supai along the Bright Angel Trail (Gilmore, 1927, p. 9) and at about the same horizon on the Kaibab Trail, north (Gilmore, 1928, p. 3).

During the course of fieldwork in central and western Grand Canyon conducted during the 1950's, trackways of small vertebrate animals were found by the writer in slabby sandstones of the Wescogame Formation at several localities. In the Parashant Canyon section a series of seven or eight footprints preserved on the surface of a slab from a very limy cross-bedded sandstone was photographed (fig. E22A); tracks also were recorded in this formation in Andrus Canyon and S B Canyon. At Andrus they were on a ripple-marked surface.

The Supai (Wescogame) trackways, according to Gilmore (1927, p. 73) represent "an ichnite fauna new to North America." He stated that it is uncertain whether the animals that made them were reptiles or amphibians, but they were quadrupedal creatures whose tracks show no close relationship to those from any other known locality, and are "Carboniferous in aspect." Not a single genus or species found in the Supai also occurs in the Hermit Shale or Coconino Sandstone-doubtless because those formations represent very different environments. 


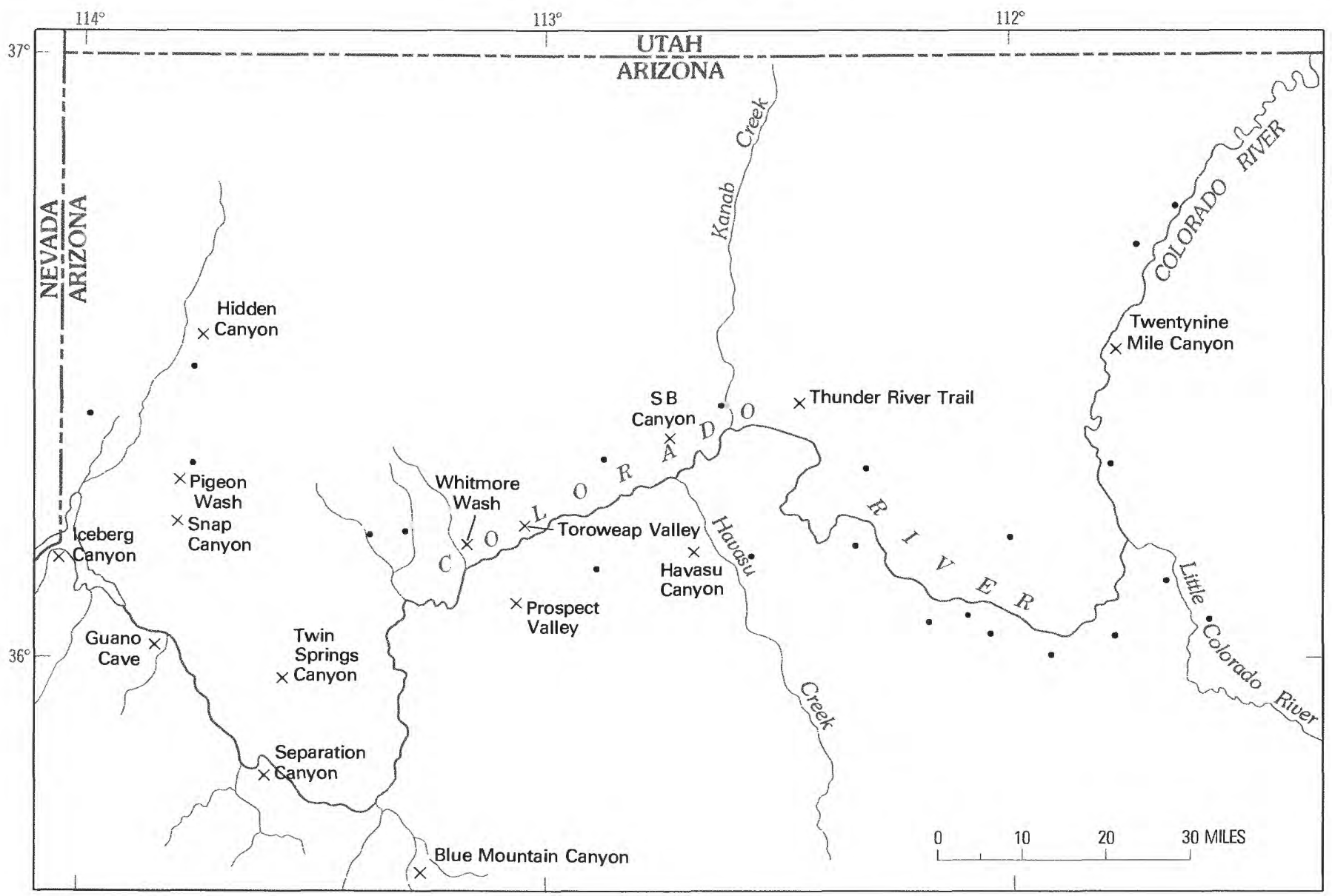

FIGURE E15.-Measured sections from which clasts of marine fossils have been obtained in the Wescogame Formation, Grand Canyon region, Arizona.

The known ichnite fauna of the Wescogame as described and named by Gilmore (1927, p. 8, 10) consists of four genera and species of vertebrates as follows:

Anomalopus sturdevanti ...... Stenichnus yakiensis.......... Tridentichnus supaiensis .....

Kaibab (Yaki) Trail, south. Kaibab (Yaki) Trail, south. Hermit Trail, Kaibab Trail, south. Bright Angel Trail.

The trailways of two varieties of invertebrate animals from the Kaibab Trail, south, were described and illustrated (Gilmore, 1928, p. 10-13, pl. 4, 5) but not named.

Recent studies by Haubold (1975, p. 131) of tetrapod footprints have indicated that "the stratigraphically important evolution of amphibians and reptiles universal in the late Paleozoic" is illustrated by identical evolutionary sequences in fossil faunas of many isolated and widely separated sections in central Europe and in North America. In this connection, Haubold $(1975$, p. 121) briefly referred to the track fauna of the Supai with its distinctive characteristics, its associated flora, and its relation to the European sequence.
In ichnological studies made of footprints from the Lower Permian Cutler Formation of southwestern Colorado, Baird (1965, p. C48-C49) referred one form to "Genus indet., cf. Brachydactylopus Toepelman and Rodeck, 1936," and stated that it is similar to Tridentichnus supaiensis Gilmore (which he considered synonymous with Ammobatrachus turbatans Gilmore, also from the Supai). These forms, together with species described from the "Permo-Carboniferous Fountain formation of the Colorado Front Range" and the "Upper Pennsylvanian (Rock Lake formation, Virgilian) of Garnett, Kansas" were referred by Baird to the form-family Korynichniidae. The Korynichniid footprints were correlated by Nopcsa (1923) and by Lotze (1928) with diadected cotylosaurs, and Baird (1965, p. C49) presented evidence in support of this correlation.

The nature of the animals that made the Wescogame tracks is unknown, for not a single bone or skeletal fragment has yet been found in the formation. In an attempt to identify some of the tracks in terms of vertebrate skeletons from other regions, Gilmore (1927, p. 73) made tracings 


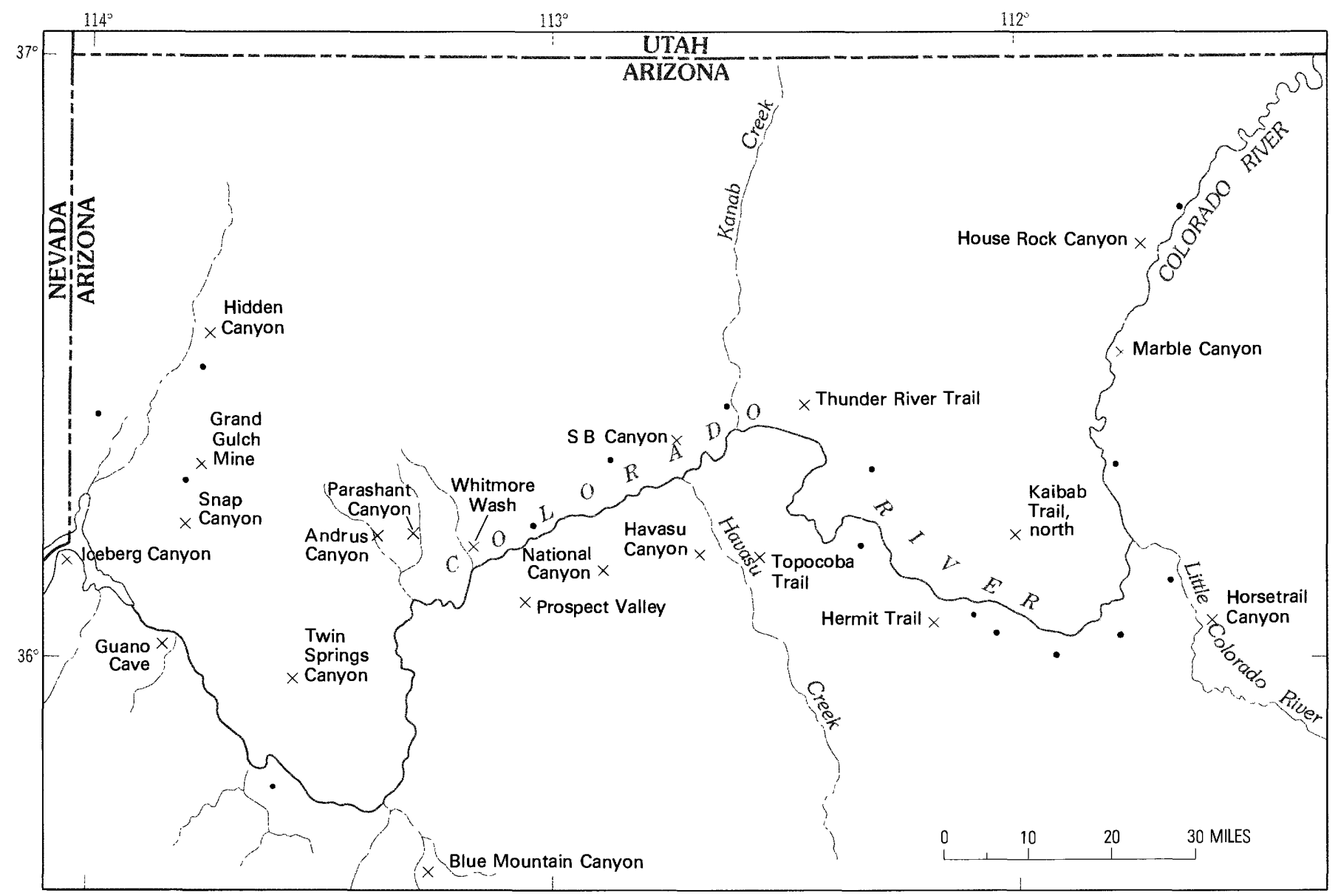

FIGURE E16.-Measured sections in the Grand Canyon region, Arizona, from which clasts of marine fossils have been obtained in the Esplanade Sandstone and intertonguing Pakoon Limestone (MCNair, 1951).

"of the fore- and hind feet of animals" to compare with the Supai tracks, but results were unrewarding.

The species Anomalopus sturdevanti apparently had a heavy body and very short legs, for the footprints are close together. A specimen described by Gilmore (1927, p. 70, pl. 20) shows "portions of the forefoot track *** destroyed by the hindfoot partially stepping upon it." The same feature is illustrated by a set of tracks in situ along the Kaibab Trail, below and east of $O^{\prime}$ Neill Butte, where many Grand Canyon visitors see it today (fig. E22B). This trackway, like most of those in the Wescogame Formation, is "ascending the slope of cross-bedding," which has a steep dip and apparently caused the animal to walk slowly and deliberately, leaving deeply impressed and clearly defined prints (Gilmore, 1927, p. 20).

In experiments conducted in the mid-1970's by Leonard Brand of Loma Linda University, California (written commun., 1977), footprints made under water by a large amphibian showed many of the same features displayed in some of the Wescogame trackways. In a photograph (fig. E21C) kindly furnished by Brand, the prints are seen to be overlapping each other and to display various degrees of clarity or sharpness depending on the state of saturation or lack of cohesiveness of the sand at different positions on the slope.

\section{TRACKS OF VERTEBRATE ANIMALS OF THE ESPLANADE SANDSTONE}

Some peculiar tracklike markings having "superficial resemblance to tracks made by horses hoofs" were recorded by Gilmore (1926, p. 37) from "a massive sandstone of the Supai formation [Esplanade Sandstone] in that part of Grand Canyon known as 'Fossil Bay'" northeast of Havasu Canyon. These markings are illustrated, described in some detail, and discussed by Gilmore who stated that the Supai Indians "regarded them as tracks made by a band of horses."

The similarity to the imprints of horse's hoofs noted in the markings at Fossil Bay, with their semi-oval forms, posterior extremities prolonged backward, and their round 


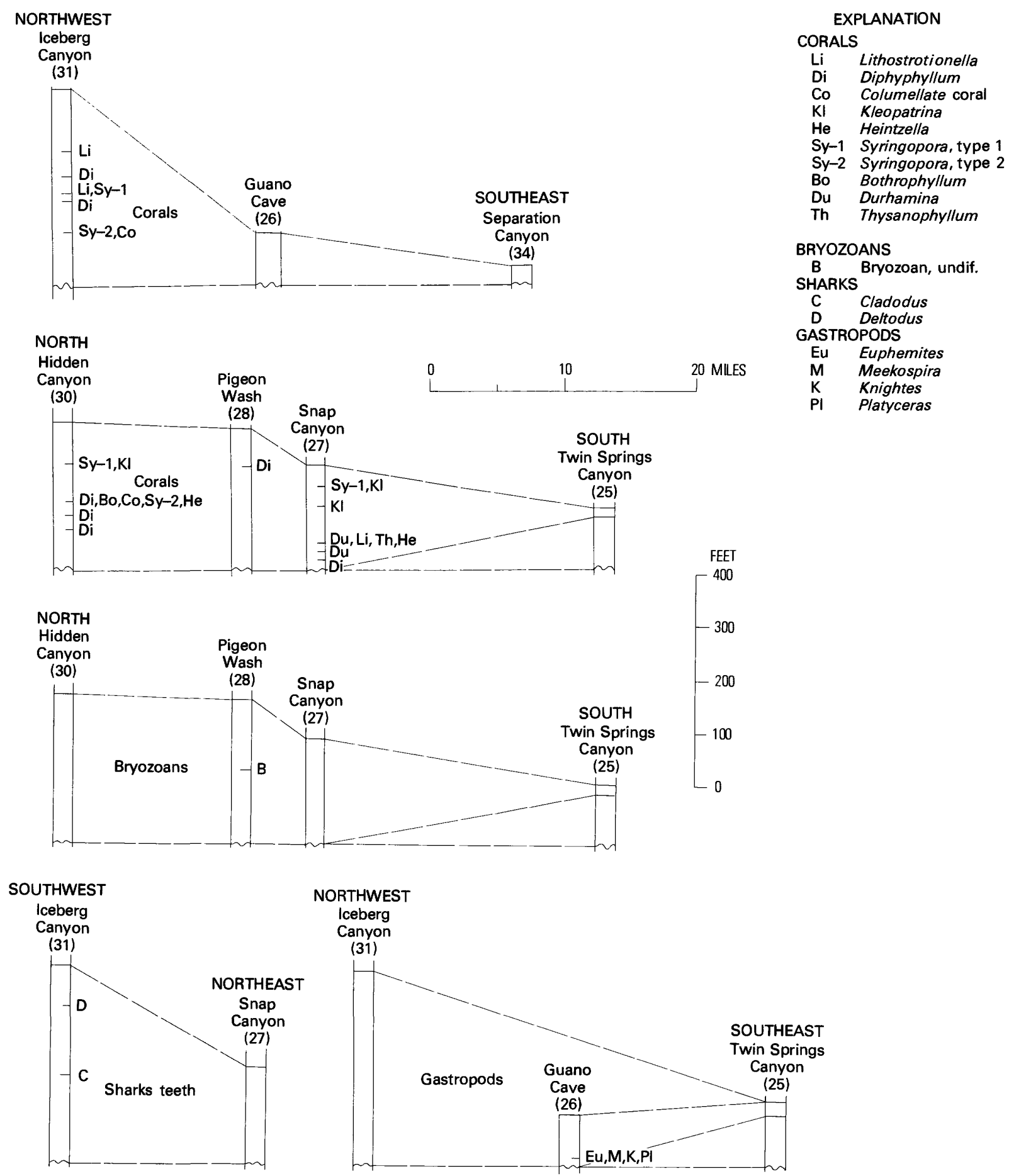

FIGURE E17.-Corals, bryozoans, gastropods, and sharks teeth of Pakoon Limestone (McNair, 1951), Grand Canyon region, Arizona. Numbers in parentheses are those of measured sections. Fossil determinations as follows: corals by W. J. Sando; bryozoans by Helen Duncan; gastropods by E. L. Yochelson; sharks teeth by D. H. Dunkle.

or oval ends all pointing in a common direction, caused Gilmore (1926, p. 38-39) to search the literature for records of other markings of comparable type. Tracks described as Hoplichnus equus from the Triassic of Connecticut, described by Hitchcock (1858, p. 134), and hooflike prints named Choliohnus gigas, from the New Red Sandstone of Scotland, described by Jardine (1853, p. 9, H.1) were discussed by Gilmore.

During the course of the present investigation, impressions similar in size and general form (fig. E23A, B) to those 


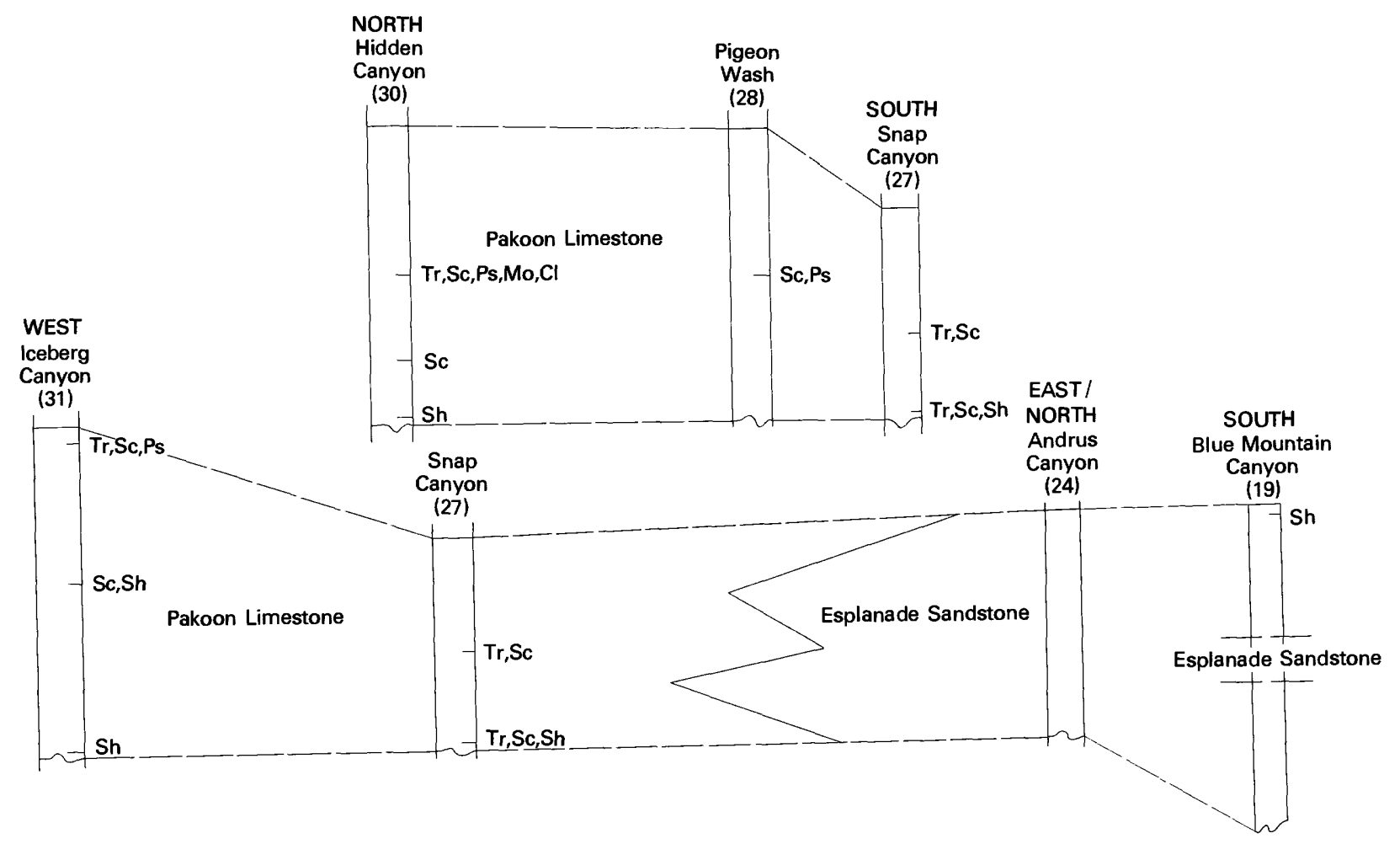

SOUTHWEST

NORTHEAST

Twin Springs

SB

Canyon

Canyon

(25)

EXPLANATION

Triticites sp.

Schwagerina sp.

Pseudoschwagerina sp.

Monodiexodina sp.

Climacammina sp.

Schubertella sp.

Wash

Esplanade Sandstone

Esplanade

Sandstone

$\operatorname{Tr}$

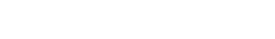

$\sim \mathrm{Tr}$

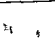

0

10

20 MILES

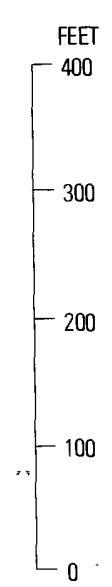

FIGURE E18.-Fusulinids of the Pakoon Limestone (MCNair, 1951) and Esplanade Sandstone, Grand Canyon region, Arizona. Numbers in parentheses are those of measured sections. Fossil determinations by R. C. Douglass. 


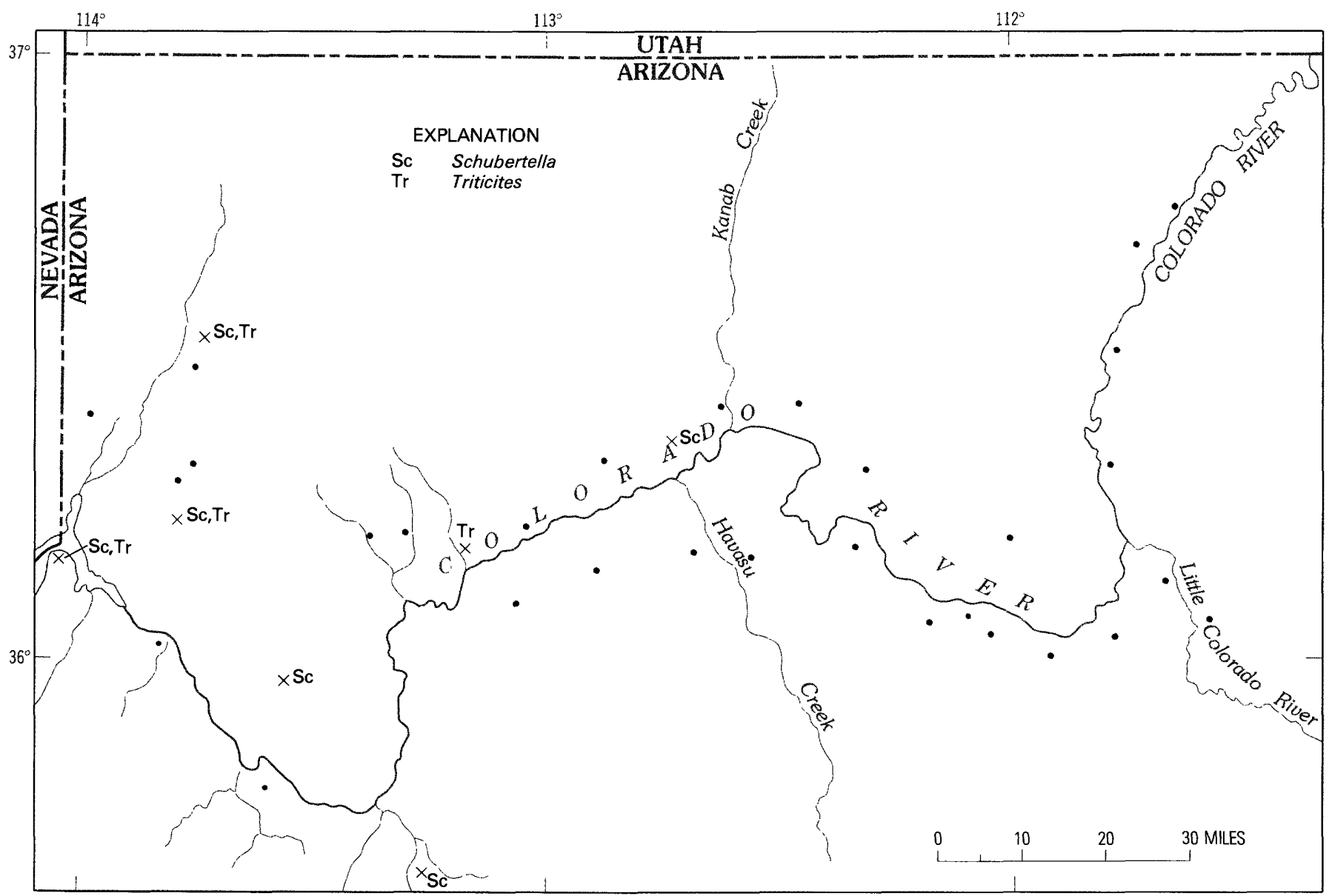

FIGURE E19.-Geographic distribution of Triticites and Schubertella in Esplanade Sandstone and Pakoon Limestone (McNair, 1951), Grand Canyon region, Arizona. Fossil determinations by R. C. Douglass.

of the Fossil Bay locality were observed on sandstone surfaces of the Esplanade at Hidden Canyon in the extreme western part of the region. No information is available on the type of animal represented, but the pairing of the impressions, the common directions of orientation, and the uniformity of shape, all suggest an origin as trackways of a quadrupedal animal.

\section{ABSENCE OF VERTEBRATE SKELETAL REMAINS}

Although some red beds of Pennsylvanian and Permian age, similar at least superficially to those of the Supai Group, have produced vertebrate faunas, no skeletal material has yet been found in the Supai of Grand Canyon. Even in parts of the Wescogame Formation of Virgilian age where numerous trackways of vertebrates occur, no record of the makers is known.

In red beds of the Cutler Formation in the Monument Valley area northeast of Grand Canyon, sizeable vertebrate faunas are found in both the Halgaito and Organ Rock Tongues as described by Vaughn $(1962,1964)$. The Halgaito is believed to be of early Wolfcampian age, so probably is the time equivalent of the Esplanade Sandstone; the Organ Rock is considered by Vaughn (1964, p. 581) on the basis of faunal elements to be probably of earliest Leonardian age.

In both the Halgaito and the Organ Rock Tongues, fossils "are restricted, with rare exceptions, to streamchannel deposits" and "occur in conglomerates and in cross-bedded sandstones immediately above, below, and at the lateral edges of the conglomerate" (Vaughn, 1964, p. 568). In the formations of the Supai Group, probably a general lack of stream channels and associated conglomerates precludes the likelihood of finding strata of 

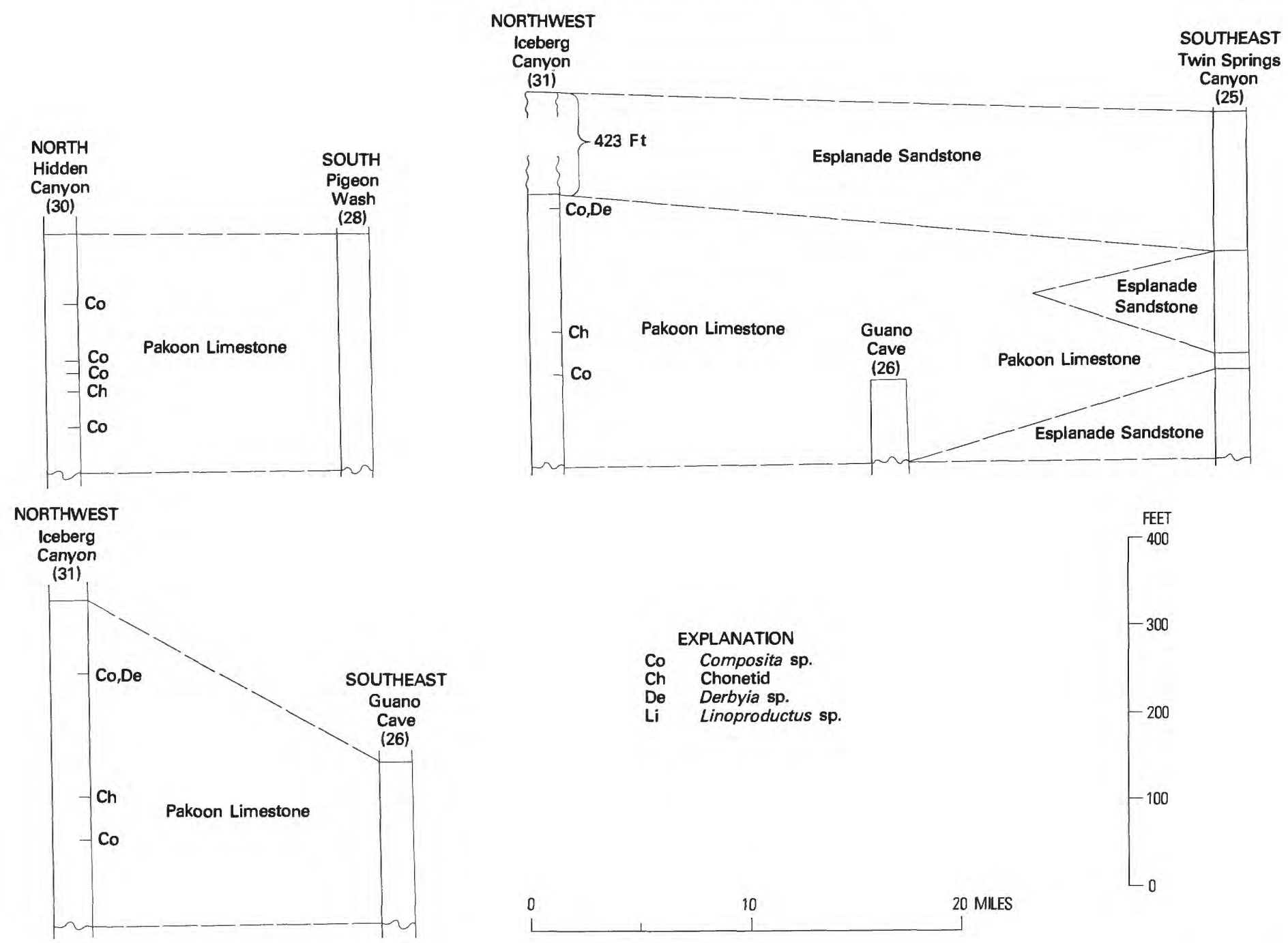

FIGURE E20.-Brachiopods of the Pakoon Limestone (MCNair, 1951), western Grand Canyon area, Arizona. Numbers in parentheses are those of measured sections. Fossil determinations by Mackenzie Gordon, Jr., and R. E. Grant.

comparable depositional environments. Most channels in the Supai probably mark times of regional hiatus rather than intraformational stream erosion, and at least some of the associated conglomerates are marine as shown by brachiopods within them.

\section{FLORA OF THE SUPAI GROUP}

Fragments of land plants are preserved in red-brown siltstones and mudstones, scattered through all formations of the Supai Group. Along the Kaibab Trail, south, these fossils occur in the "lower and middle portions" of the Supai, as well as in the Hermit Shale above. They are referred to (White, 1929, p. 10) as "traces of plants including
Walchia and Rivularites ${ }^{* *}$ at several levels" in the redbed sequence.

In the lowest formation-the Watahomigi-an assemblage of land plants consisting of "Walchia, Toeniopteris, Neuropteris, Cordarites and Calamites," in fragmentary form, is recorded from about 25 feet above the base along the Yaki (Kaibab, south) Trail (White, 1929, p. 10). Likewise near the base of the Watahomigi, but along the Hermit Trail "rain pittings and fillings of suncracks," which commonly are associated with land plants in the redbrown mudstones, were noted by Schuchert (1918, p. 357). Farther west in Grand Canyon, however, at comparable horizons in the lower part of the formation, brachiopods and other marine fossils constitute the principal traces of depositional environment. 

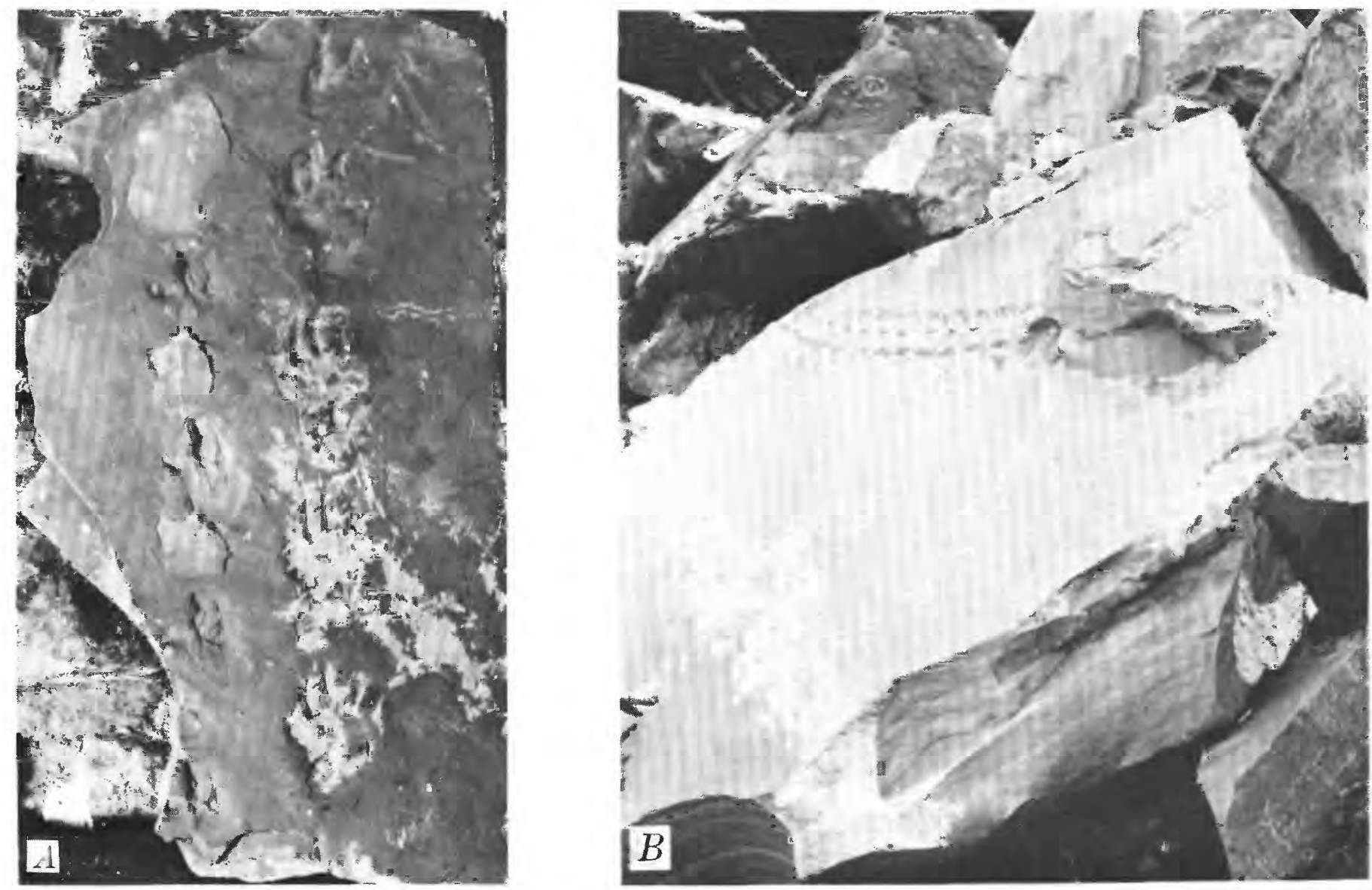

FIGURE E21 (above and facing page).-Trackways of vertebrate animals in sand and fine-grained sandstone. A, Footprints (each about 4 in. long) with long toe marks, on slab from foreset beds of sandstone, Wescogame Formation, south section of Kaibab Trail. B, Set of overlapping footprints (each about $4 \mathrm{in}$. long; compare with $\mathrm{C}$ )

In the Manakacha Formation, marine fossils of various types constitute a large majority of all organic remains, but at some horizons and in a few localities, land plants characteristic of Pennsylvanian types have been found (fig. E24). Continental fossils recorded from the Manakacha of Grand Canyon to date include the conifer Walchia and some indeterminate ferns and plant stems, preserved in red-brown shaly mudstone. They are reported from Thunder River Trail, Bass Trail, and Parashant Canyon (table I1).

In the Wescogame Formation, as in the Manakacha, land plants are sparse. A few have been found in redbrown shaly mudstones near the top. At Iceberg Canyon they occur associated with ripple marks in the upper part of the formation. From strata near the base of a red sandyshale slope near the Hermit Trail, which probably represents the top of the Wescogame but may be the basal slope member of the Esplanade, plant remains are recorded of short-legged quadruped moving up $24^{\circ}$-foreset bed, sandstone of Wescogame, south section of Kaibab Trail. C, Footprints of amphibian made underwater in modern sand deposit with steep surface dip. Photograph by Leonard Brand, Loma Linda University, California.

by Schuchert (1918, p. 357). The strata are described as "thin, flaggy beds with some sun-crack fillings and an abundance of rain prints of the mammillary kind." The plants are stated to be "midribs of either ferns or cycadofilices." No other fossil plants are known from the Wescogame or Esplanade. Perhaps a strongly oxidizing environment, as suggested by the red beds in which they are preserved, explains their general scarcity in mudstones of the formation.

The Esplanade Sandstone contains plant stems, leaves, and other fragments at numerous localities, both in the shaly basal slope unit and in muddy beds and lenses within the main cliff unit above. They have been recorded from the Kaibab Trail, north, Topocoba Trail, S B Canyon, Grand Gulch Mine, and Hidden Canyon sections of Grand Canyon (table E3).

Land plants in shaly siltstones and mudstones of the Supai Group commonly are associated with both sedimen- 


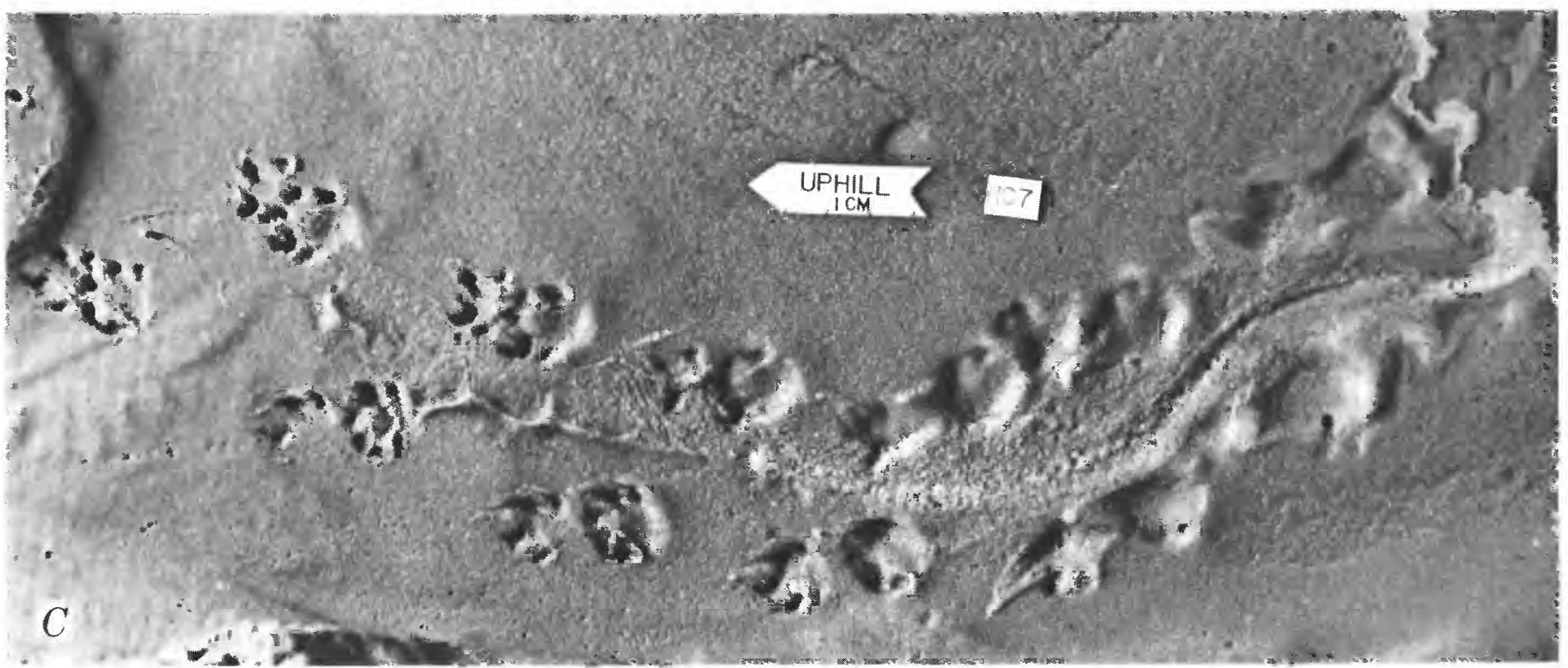

tary and organic structures of types that strongly suggest a continental environment of deposition. Shrinkage cracks and molds, rain pits, and cuspate ripple marks occur together with plant impressions at some localities; wormlike tubes or borings are recorded with them at numerous places.

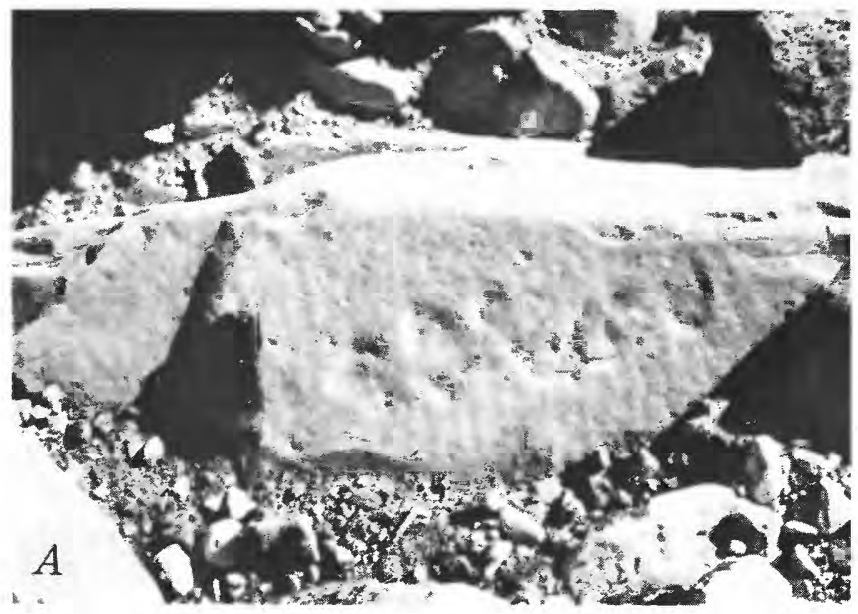

FIGURE E22.-Trackways of vertebrate animals in fine-grained sandstone of Wescogame Formation. A. Set of poorly preserved tracks made by quadruped; surface of unoriented sandstone slab, Parashant Canyon. B, Tracks of short-legged quadruped on $25^{\circ}$-slope of foreset bed in sandstone of the Wescogame, near Kaibab Trail, south. Toe marks point uphill; heel marks in each overlapping print show sand squeezed outward. Photograph by National Park Service.
The algal form known as Rivularites is moderately common in the Supai. It is considered to represent colonies of blue-green algae (Cyanophyceae) forming somewhat flexible carpets that floated or pulsated in water (White, 1929, p. 43). This type of algae is believed by White to have lived in streams and "was adapted to survive occa-

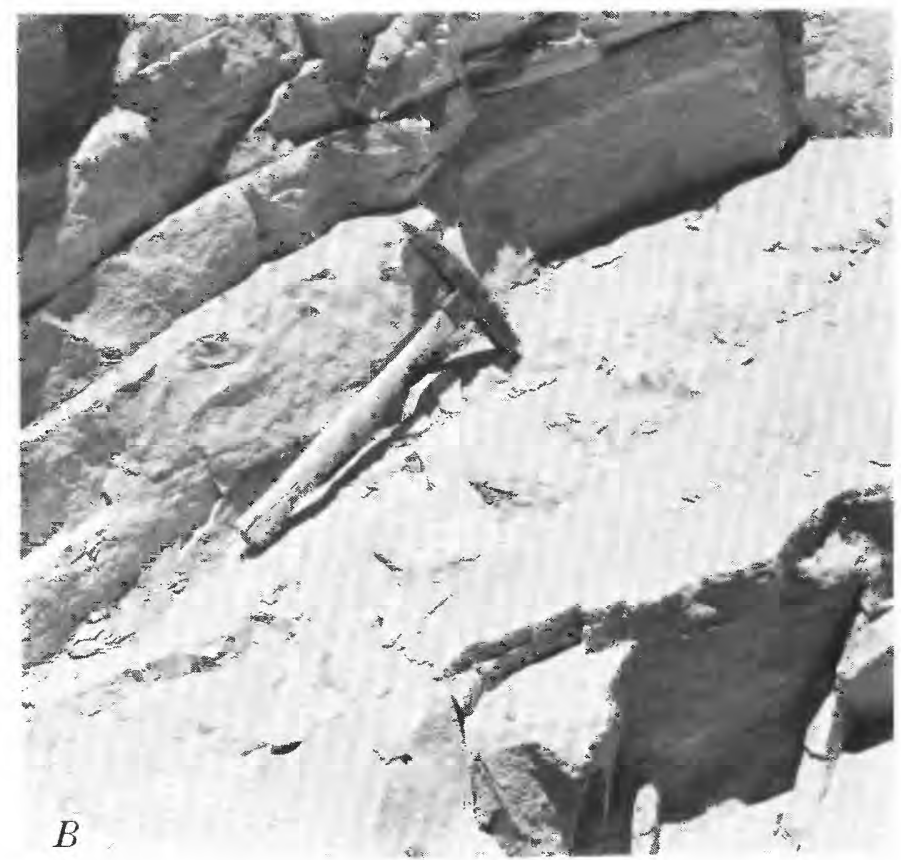



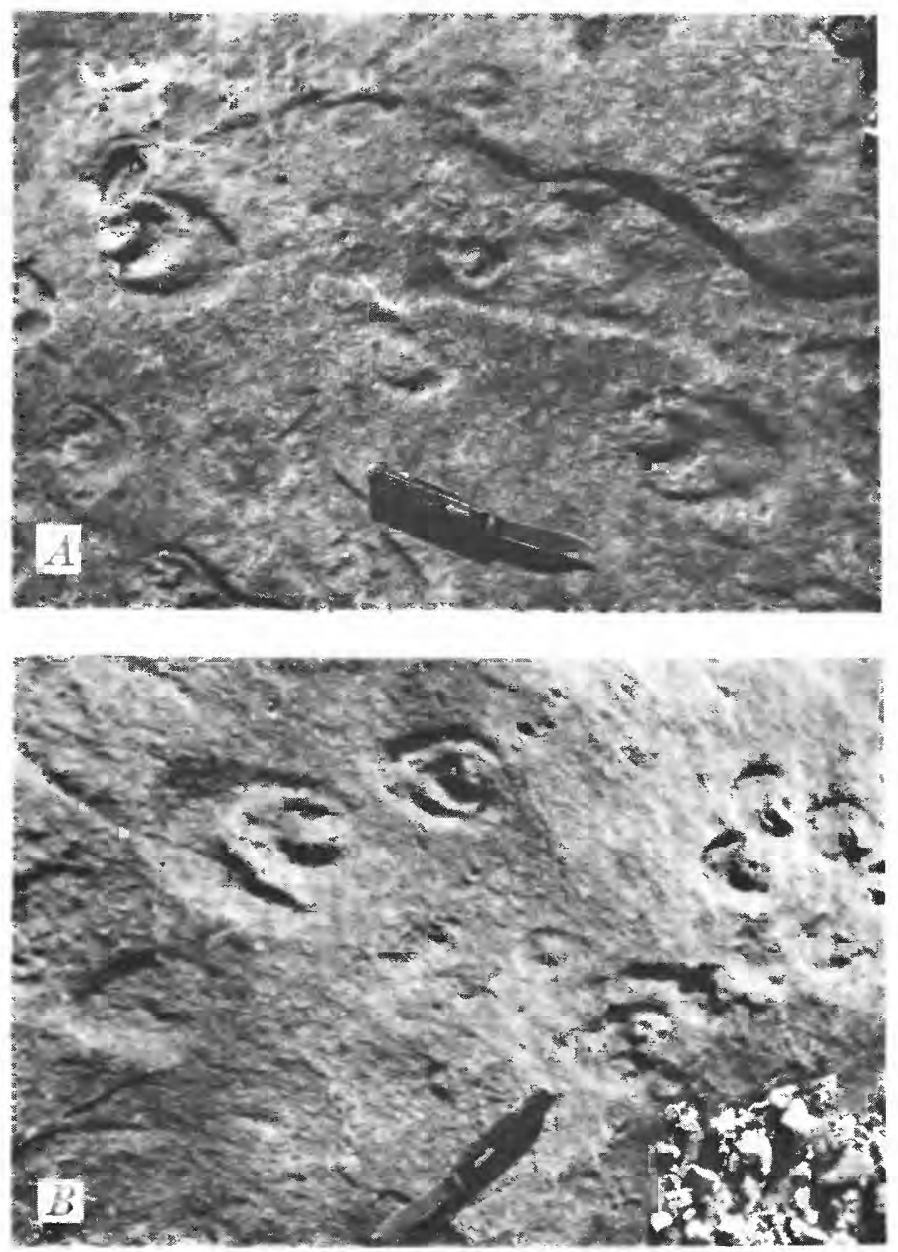

FIGURE E23.-Tracks (A, B) of vertebrate animal in the Esplanade Sandstone at Hidden Canyon in western Grand Canyon, Ariz.
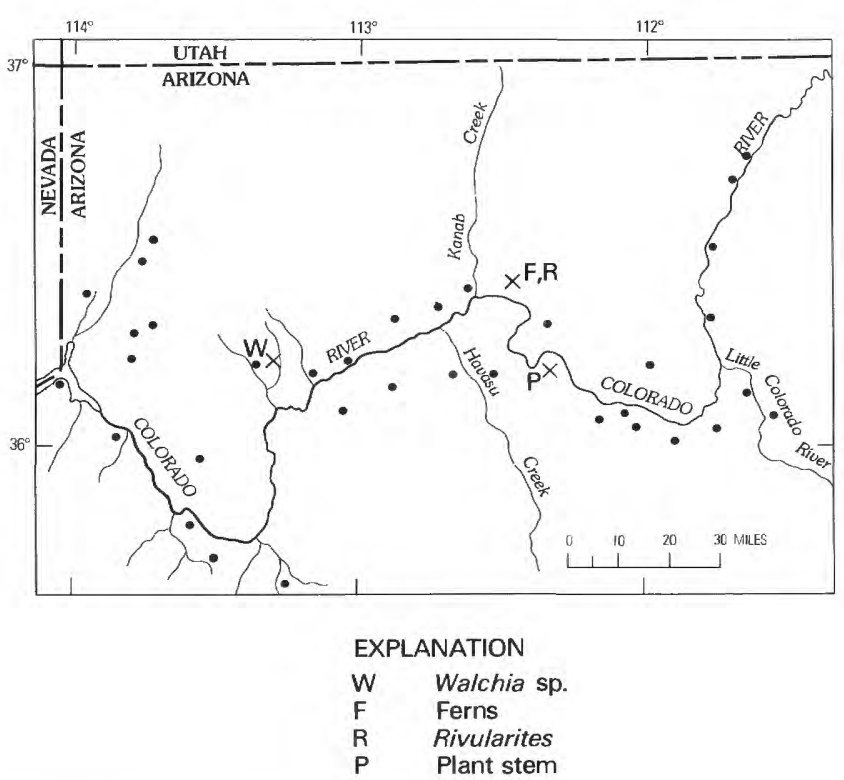

FIGURE E24.-Localities of continental flora in the Manakacha Formation, Grand Canyon region, Arizona. sional periods of exposure to the air and drying." Rivularites is recorded from nine localities in Grand Canyon and from all formations of the Supai Group (table E3). It is a smaller form than that called Rivularites permiensis in the overlying Hermit Shale, according to White (1929, p. 43). Associated with Rivularites at three places in the Esplanade and at one each in the Watahomigi and Manakacha, were wormlike tubes or borings of a type described by White $(1929$, p. 115) from the Hermit Shale and named Scoyenia gracilis.

Although the land plants of the Supai Group, largely because of their fragmentary nature and poor preservation, furnish no precise information on the ages of various stratigraphic units, they indicate times and places of sea withdrawal. They establish the concept that broad fluctuations in marine-continental environments controlled deposition of the Supai Group. For many lithologic units in the Supai as with the Hermit Shale, the land plants establish the probable existence of wide flood plains developed during times of regressing seas and the likelihood of semiarid to arid climates.

\section{BIOCLASTIC DEBRIS OF THE WATAHOMIGI FORMATION}

An analysis of the bioclastic debris as represented in thin sections of the Watahomigi Formation illustrates a number of significant features relative to distribution of marine life and tends to confirm conclusions regarding paleogeography as described in chapter $D$. The principal faunal groups recognized in the bioclastic sediment of the formation are pelmatozoans (largely crinoids), small foraminifers, bryozoans, and bivalves (brachiopods and pelecypods, undifferentiated). The relative abundance of these groups in each of the three principal parts of the formation-slope at base, cliff in middle, slope at top-is shown in figures E25-E28. In comparing faunal distributions, it must be realized that (1) the lower two groups are of Morrowan age, the upper of Atokan age, and (2) the middle cliff is largely carbonate rock and therefore is especially favorable to a marine fauna, whereas the upper and lower slopes contain much mudstone and a correspondingly smaller amount of limestone.

Pelmatozoans are almost entirely restricted to the western half or seaward part of the Grand Canyon embayment, where they are widespread and common as shown in figure E25. The main exception in the east is at Hermit Trail where they are numerous in the upper slope of Atokan age. Small foraminifers make a distribution pattern (fig. E26) much like that of the pelmatozoans although the two mostly are not associated. In the western half of Grand Canyon foraminifers are numerous to abundant in many sections, but they are largely lacking farther east. The occurrence of these animals in the upper part of the formation at 
DISTRIBUTION AND AGE OF FAUNA AND FLORA
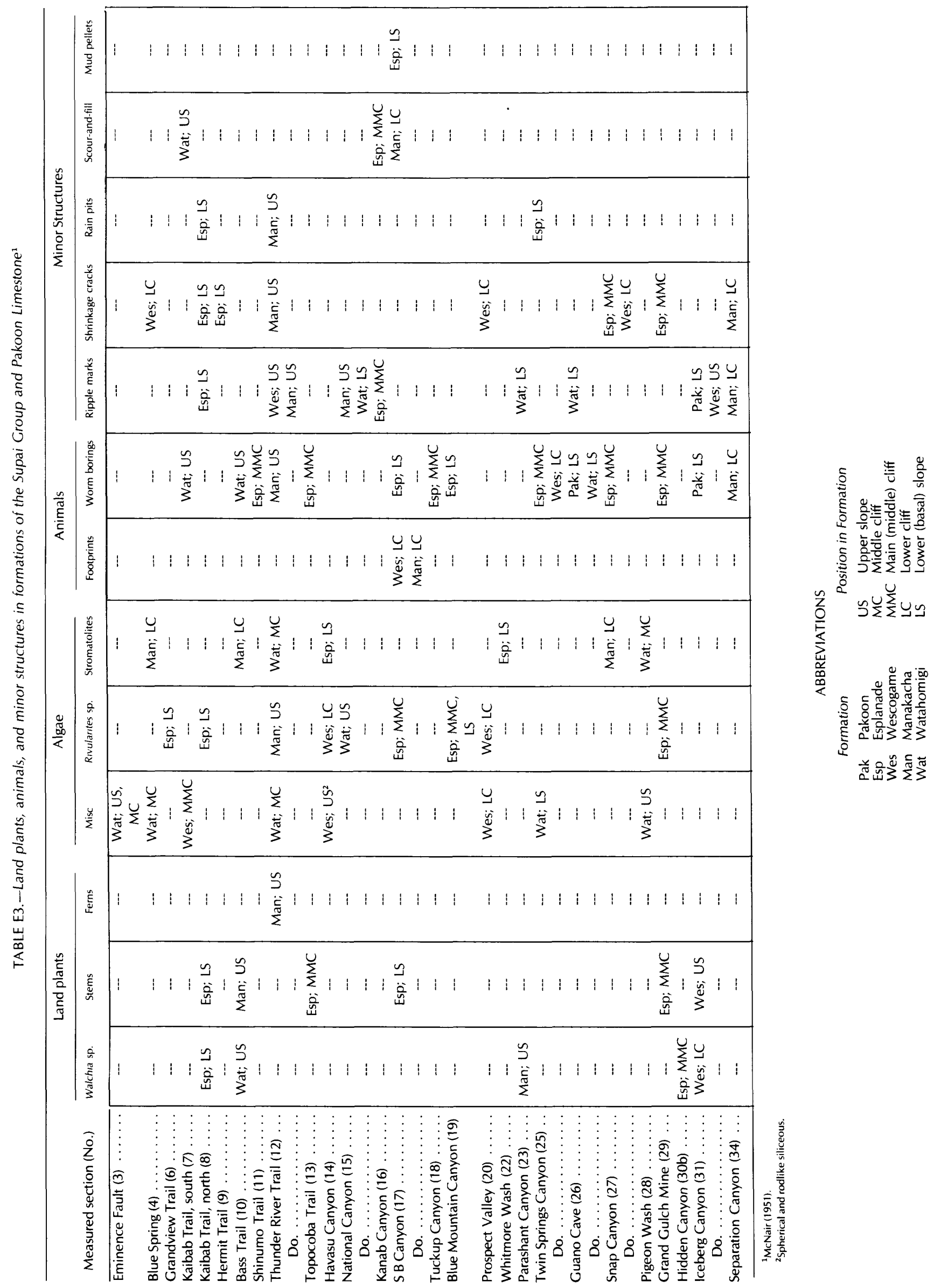

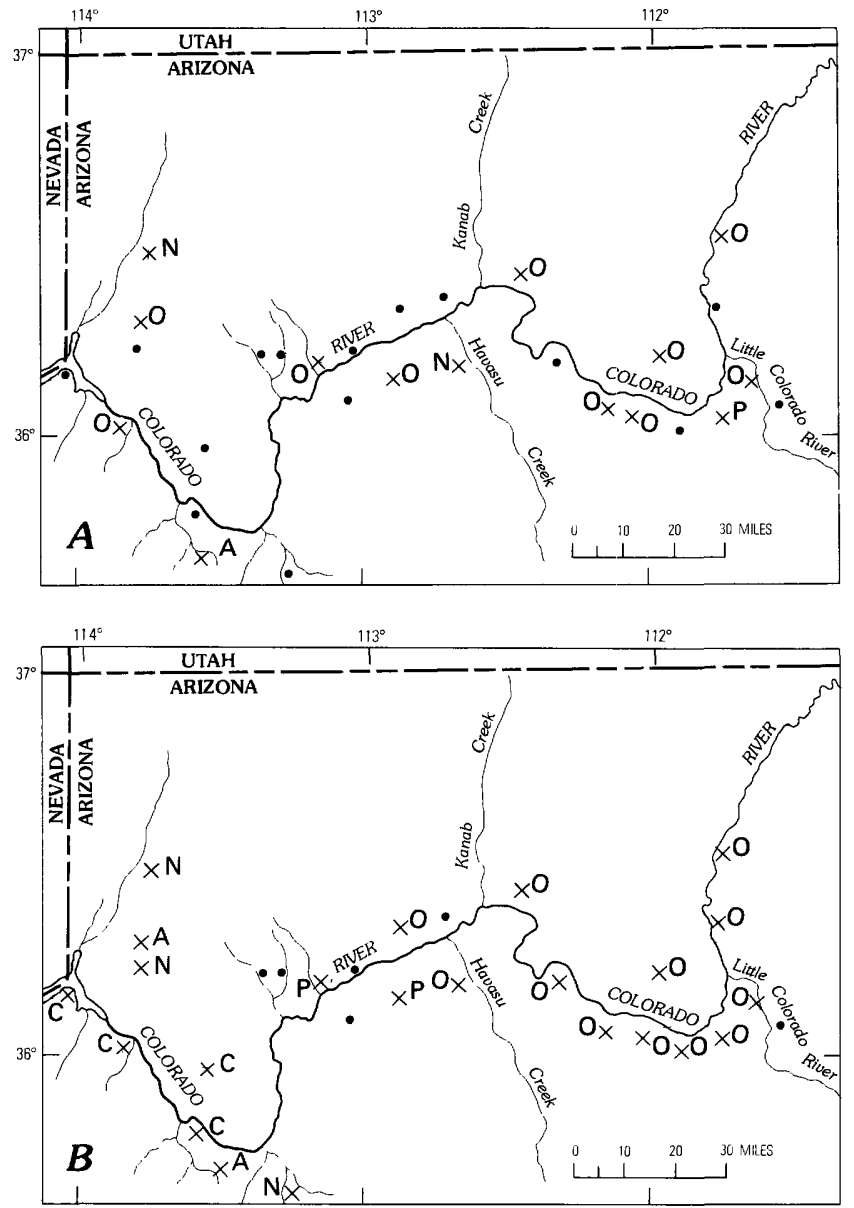

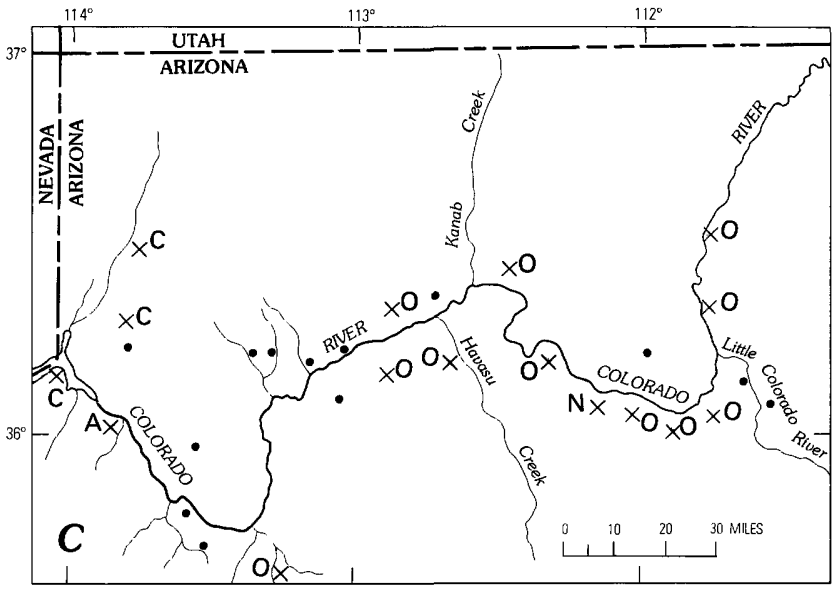

EXPLANATION

$\begin{array}{cc}\begin{array}{c}\text { Percent of } \\ \text { thin sections }\end{array} & \text { Abundance } \\ 0 & \text { O None } \\ 1-25 & \text { P Present } \\ 26-50 & \text { N Numerous } \\ 51-75 & \text { C Common } \\ 76-100 & \text { A Abundant }\end{array}$

FIGURE E25.-Distribution of bioclastic debris containing pelmatozoans, Watahomigi Formation, Grand Canyon region, Arizona: A, lower slope unit; $B$, middle cliff unit; $C$, upper slope unit.

Thunder River, Grandview, and Bunker Trails (fig. D4) in eastern Grand Canyon may be because at the time of deposition (Atokan), the seaway at Grand Canyon connected with the Paradox basin farther east.

The Watahomigi Formation, especially in the middle cliff unit that is largely carbonate rock, contains the debris of bryozoans (fig. E27) and of bivalves, either brachiopods or pelecypods (fig. E28). Some large concentrations of these skeletal materials occur in the limestones.

\section{BIOCLASTIC DEBRIS OF THE MANAKACHA FORMATION}

Carbonate rocks of the Manakacha Formation include a considerable amount of bioclastic debris in sections widely scattered throughout the Grand Canyon. Numerous types of animals and plants are represented by skeletal fragments in this debris, the most common forms being pelmatozoans, bryozoans, foraminifers, bivalves (pelecypods and (or) brachiopods), calcispherids, and Girvanella-type algae (fig. E29A-F).

The presence of bioclastic debris in many sections of eastern Grand Canyon, as well as farther west, suggests a marine passage across the Black Mesa sag in Atokan time, connecting the Cordilleran seaway in the west with waters of the Paradox basin to the northeast (fig. D4). This extension of the marine environment apparently caused a general expansion of sea life. The isopach map of Atokan rocks (fig. D4) indicates the pattern of seaways in Arizona at this time, and a comparison of this map with one of Morrowan rocks (fig. D3) shows the great change in configuration of landmasses that developed from Early to Middle Pennsylvanian time.

A comparison of distribution and abundance of the bioclastic debris, dominated by fragments of bivalves, is shown in figures $\mathrm{E} 30 A, B$. Figure $\mathrm{E} 30 \mathrm{~A}$ illustrates the lower part (cliff unit) and figure E30B the upper part (slope unit). Both parts show a wide distribution of bivalves in the Grand Canyon area, with eastern as well as western sections represented. The lower and older part shows greater 

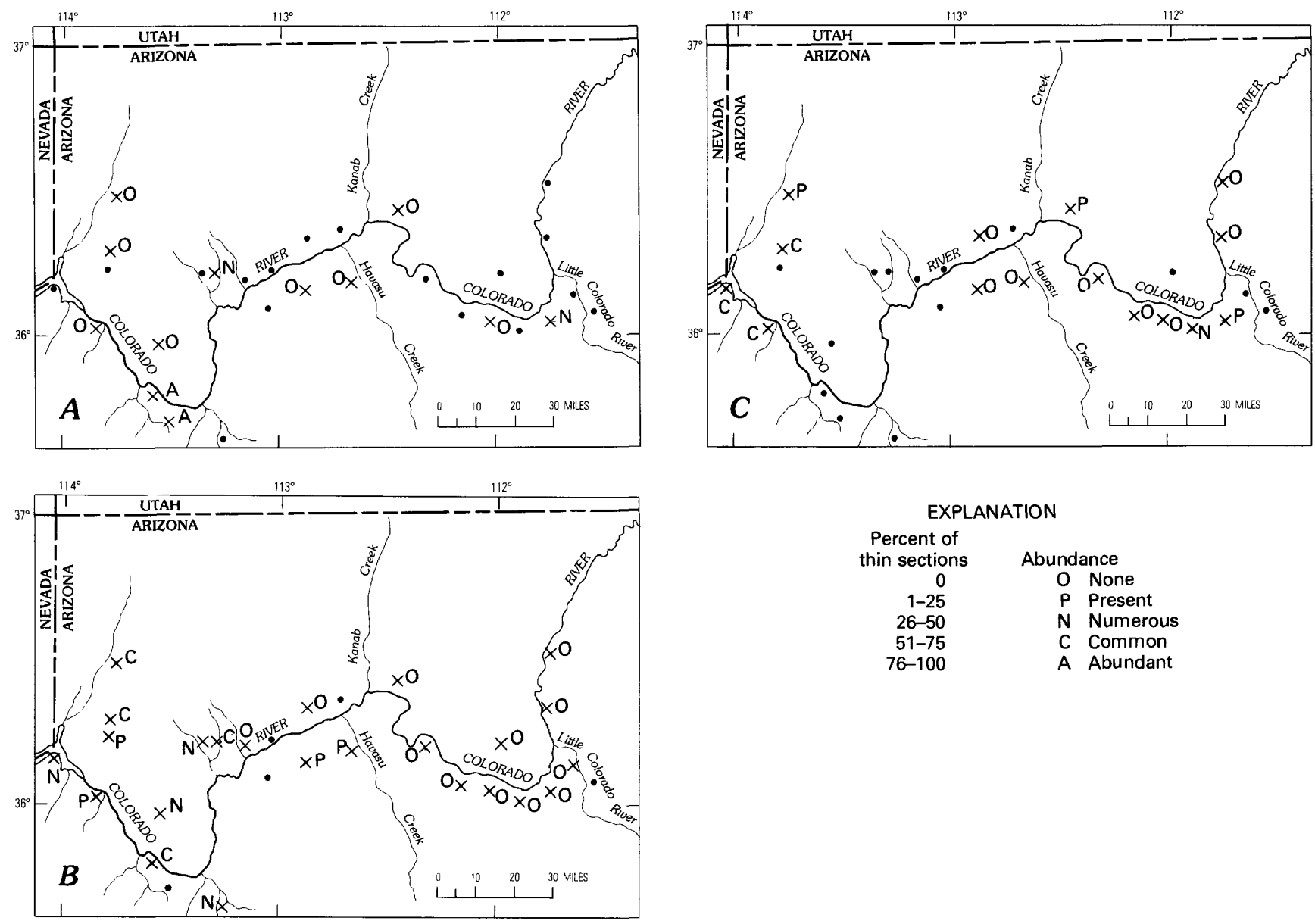

FICURE E26.-Distribution of bioclastic debris containing foraminifers, Watahomigi Formation, Grand Canyon region, Arizona: A, lower slope unit; $B$, middle cliff unit; $C$, upper slope unit.

density than the upper and younger, possibly because the lower part is thicker and contains more carbonate rock, but, in general, the concept of a relatively stable environment in this area throughout Atokan time is supported.

\section{BIOCLASTIC DEBRIS OF THE WESCOGAME FORMATION}

Bioclastic debris constitutes a moderate proportion of the carbonate material in limestone of the Wescogame, but it is less common than in the underlying Manakacha. Skeletal grains consist mainly of foraminifers, and fragments of pelmatozoans (crinoids and sea urchins), bryozoans, and bivalves, including unidentifiable pelecypods and brachiopods. In general, bioclastic debris is far more abundant in the western than in the eastern part of the Grand Canyon region (fig. E31).

Isopach maps of the Wescogame (Virgilian time), constructed both for the Grand Canyon embayment (fig. D11) and for Arizona and adjacent states (fig. D7), show thickening of deposits westward toward the Cordilleran geosyncline and southeastward toward the Sonoran. The smallscale map (fig. D7) also shows a possible marine connection with the Paradox basin toward the northeast, although no conclusive proof of this connection (Black Mesa sag) is available from well-log data of the area.

Evidence from the distribution of bioclastic debris (fig. E31) suggests that the possible northeasterly marine connection did not exist in Virgilian time, as bryozoan and foraminiferal fragments have not been observed in eastern Grand Canyon sections, and both bivalve and pelmatozoan grains are uncommon in them. Thus, most of the skeletal fragments probably were derived from the Cordilleran seaway to the west as shown by the relative abundance of many animal forms in the western area and the absence of all but a few bivalve and crinoid fragments in the east. Possibly some of these eastern carbonate grains were derived from the southeast, but direct evidence is lacking. 

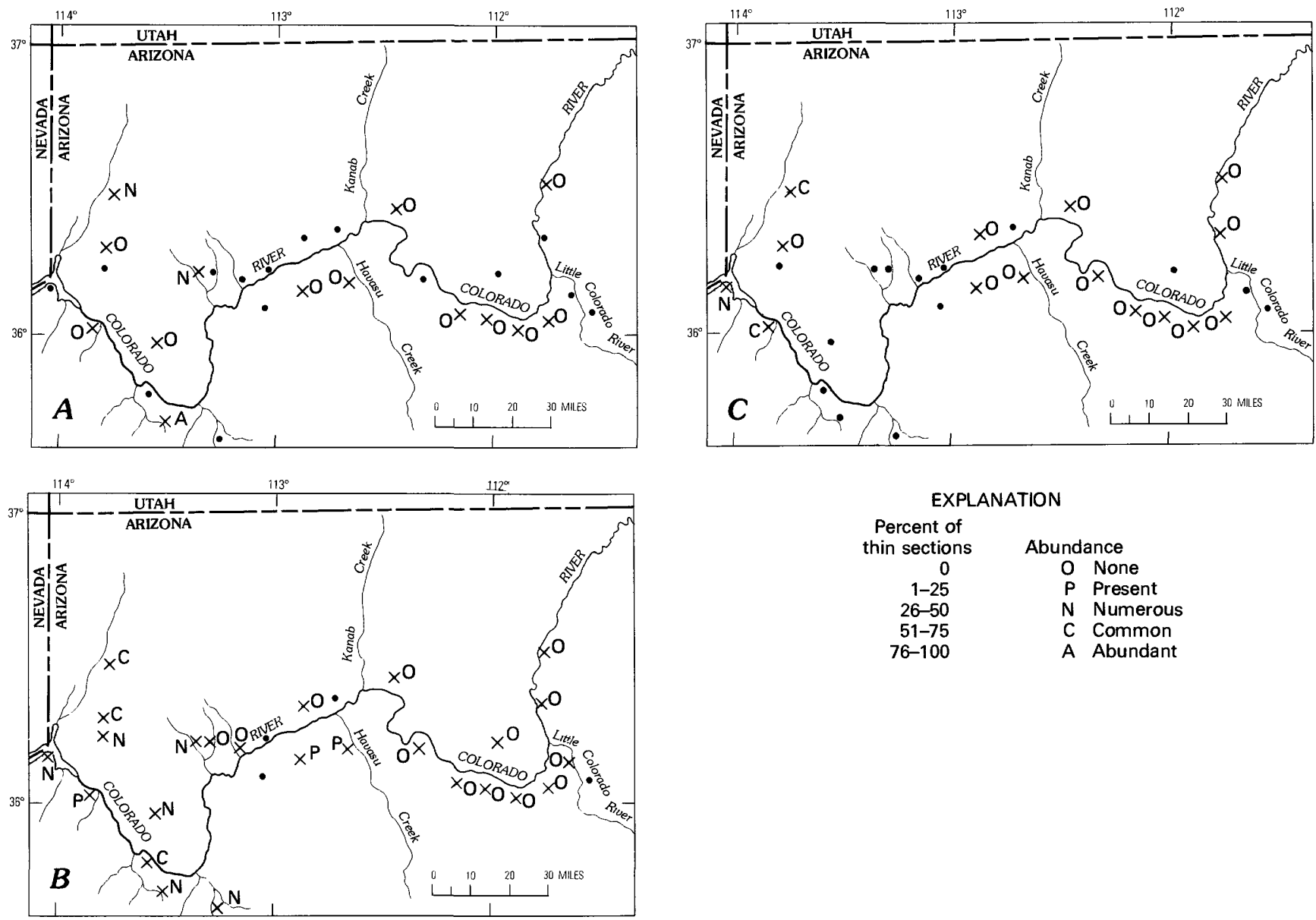

FIGURE E27.-Distribution of bioclastic debris containing bryozoans, Watahomigi Formation, Grand Canyon region, Arizona: A, lower slope unit; $B$, middle cliff unit; $C$, upper slope unit.

\section{BIOCLASTIC DEBRIS OF THE ESPLANADE SANDSTONE AND PAKOON LIMESTONE}

The environments of deposition in the Grand Canyon region during Early Permian (Wolfcampian) time, as represented by the Esplanade Sandstone and its western equivalent, the Pakoon Limestone, were different in several important respects from those of the older Supai formations in the same region. The area of sedimentation, instead of being a relatively restricted embayment along the eastern margin of the Cordilleran seaway and periodically connected with the main water bodies to the northeast and southeast, apparently was in Early Permian time part of a broad marine shelf extending across most of northern Arizona (fig. D8).

The Esplanade Sandstone, throughout most of the Grand Canyon area, is composed almost exclusively of quartz sand, whereas its western equivalent, the Pakoon Limestone, is a sequence of dominantly carbonate rock. The lateral change from one rock type to the other is abrupt, and is accomplished by intertonguing within a narrow belt. Thus, the Esplanade of eastern and central Grand Canyon seems to represent a water body of high energy where extensive cross-bedding developed, whereas the Pakoon to the west had a relatively quiet-water environment in which a large and varied fauna, including sessile forms such as corals and bryozoans, lived.

Examination of bioclastic debris in thin sections from throughout the region (fig. E32), shows that a limited amount of skeletal material of various types is included nearly everywhere, but that the amount of bioclasts increases greatly toward the western area of carbonate deposition (Pakoon). Further, coral and bryozoan fragments are nearly restricted to the western area where they presumably lived, whereas grains derived from foraminifers, crinoids, echinoids, brachiopods, and others are numerous to common in areas far removed, to the east, in presumably inhospitable sandy environments.

How far various bioclasts were transported cannot be determined from available information, but the broad distribution and the progressively farther northeastward 

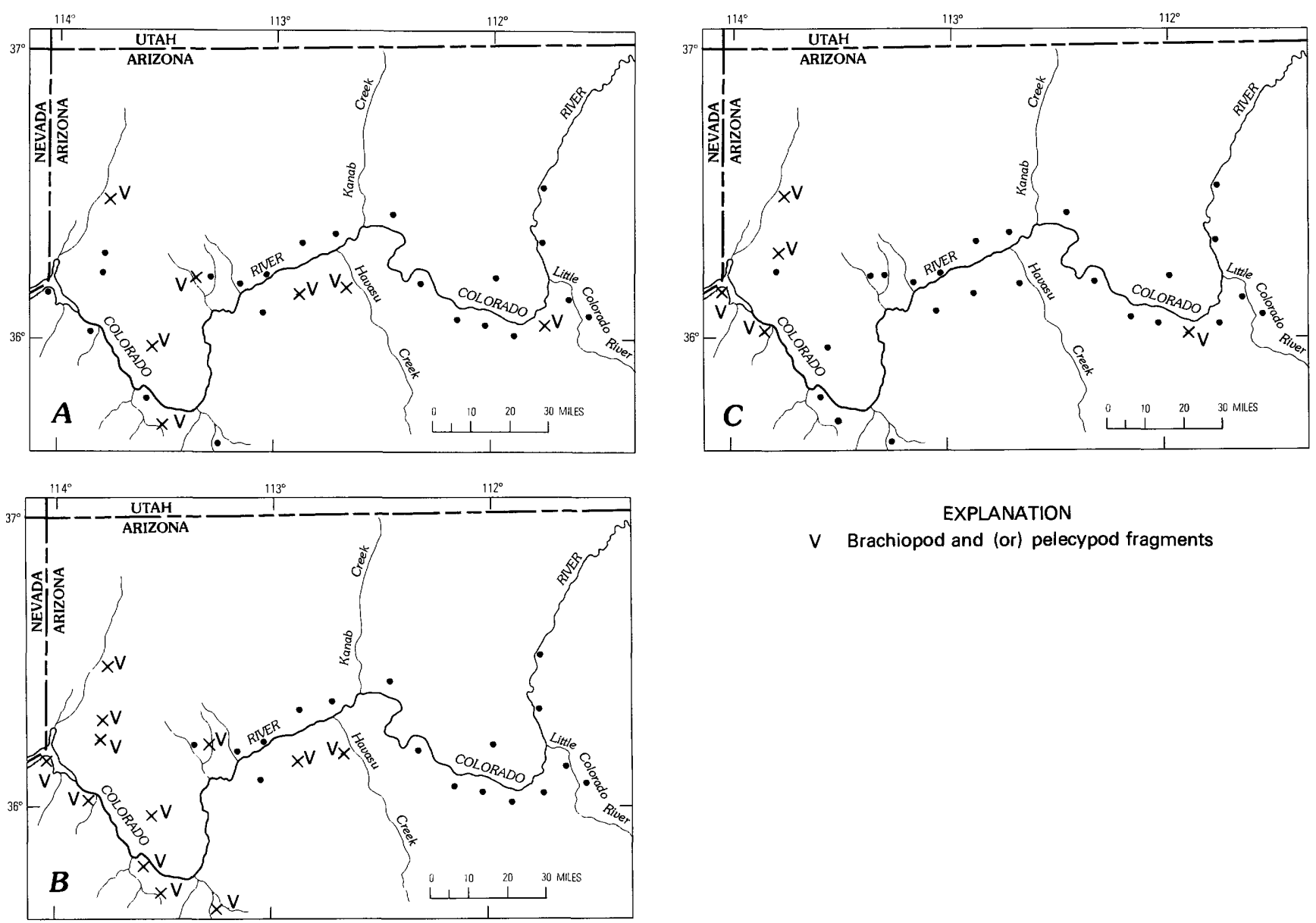

EXPLANATION

$\checkmark$ Brachiopod and (or) pelecypod fragments

FIGURE E28.-Distribution of bivalves in bioclastic limestone, Watahomigi Formation, Grand Canyon region, Arizona: $A$, lower slope unit; $B$, middle cliff unit; $C$, upper slope unit.

extension of bivalve, foraminifer, and pelmatozoan skeletons suggest that at least some of these skeletal remains may have been locally derived, rather than transported one hundred or more miles from the western (Pakoon) localities.

\section{AGE OF THE SUPAI GROUP}

The formations of the Supai Group are difficult to date precisely because of the general scarcity or lack of fossils in most parts of the area and because a majority of those fossils recorded either are long-ranging or their zonal distribution is not well known. Nevertheless, systematic collecting during the past 20 years has gradually assembled enough material to establish that the general age range extends from Morrowan into Wolfcampian time with, however, numerous hiatuses included, some of them probably of considerable duration.

The most important fossils in the determination of age in the Supai Group are fusulinids and brachiopods - the fusulinids showing a surprisingly wide distribution throughout the Grand Canyon region at certain horizons. Brachiopods are restricted to the central and western parts of the region and mostly to the lower half of the Supai Group. Small nonfusulinid foraminifers have furnished information on some problems, although, in general, their distribution seems to be more facies-controlled than time-controlled. Corals have contributed some stratigraphic data in the dominantly carbonate-rock sections of westernmost Grand Canyon.

\section{AGE OF THE WATAHOMIGI FORMATION}

The Watahomigi Formation is believed to be largely of Morrowan age, but probably includes strata of Atokan age in the upper one-third. Several genera of brachiopods from limestone ledges in the lowermost slope of the formation help to establish the age of those beds. The diagnostic brachiopods are Punctospirifer transversus and Raticulariina campestris which, according to Mackenzie Gordon, 

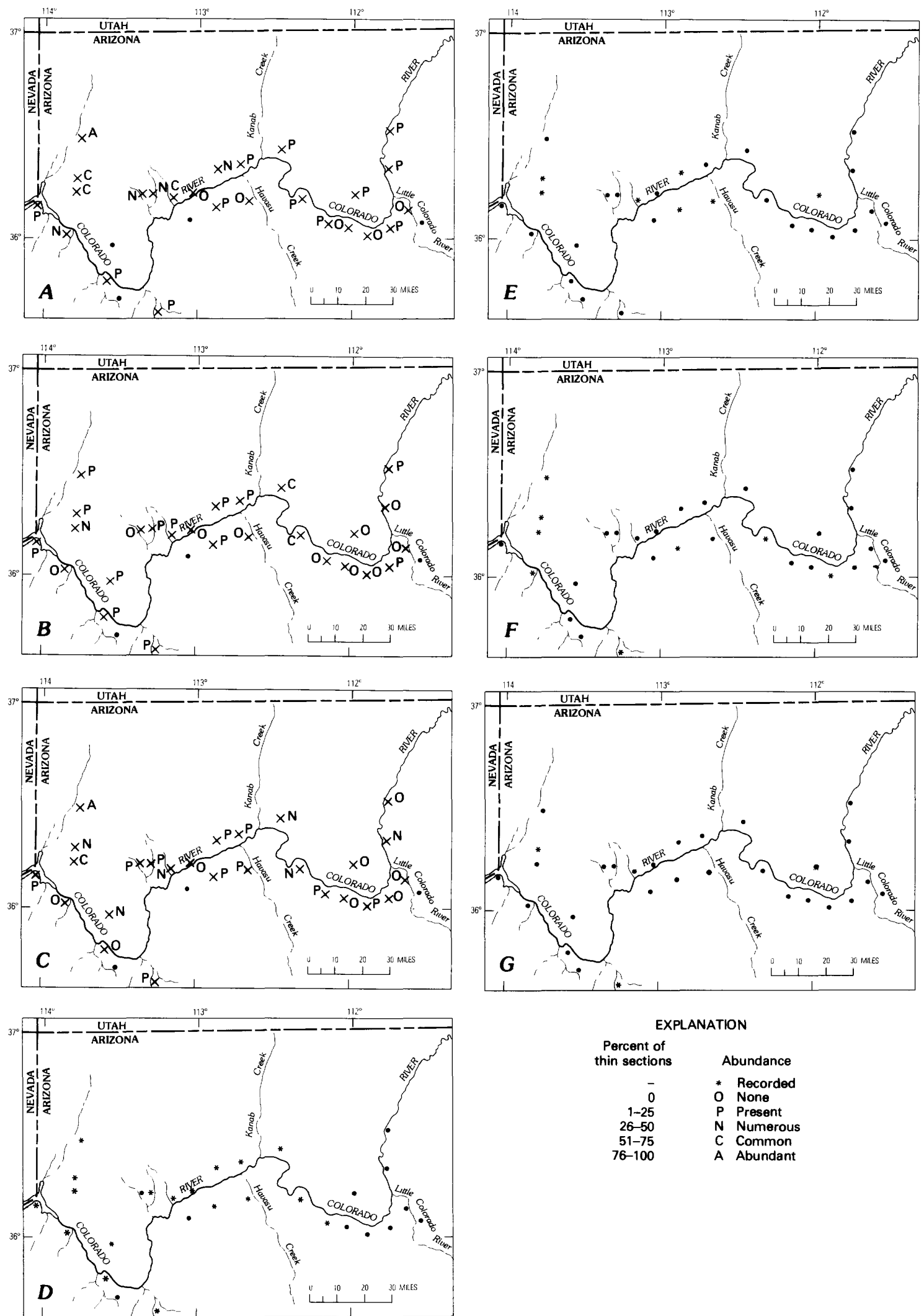

FIGURE E29.-Distribution of various marine fossils in bioclastic debris of the Manakacha Formation, Grand Canyon region, Arizona: $A$, pelmatozoans; $B$, bryozoans; $C$, foraminifers; $D$, bivalves (pelecypods and (or) brachiopods); $E$, calcispherids; F, algae (Girvanella); and G, ostracods. 

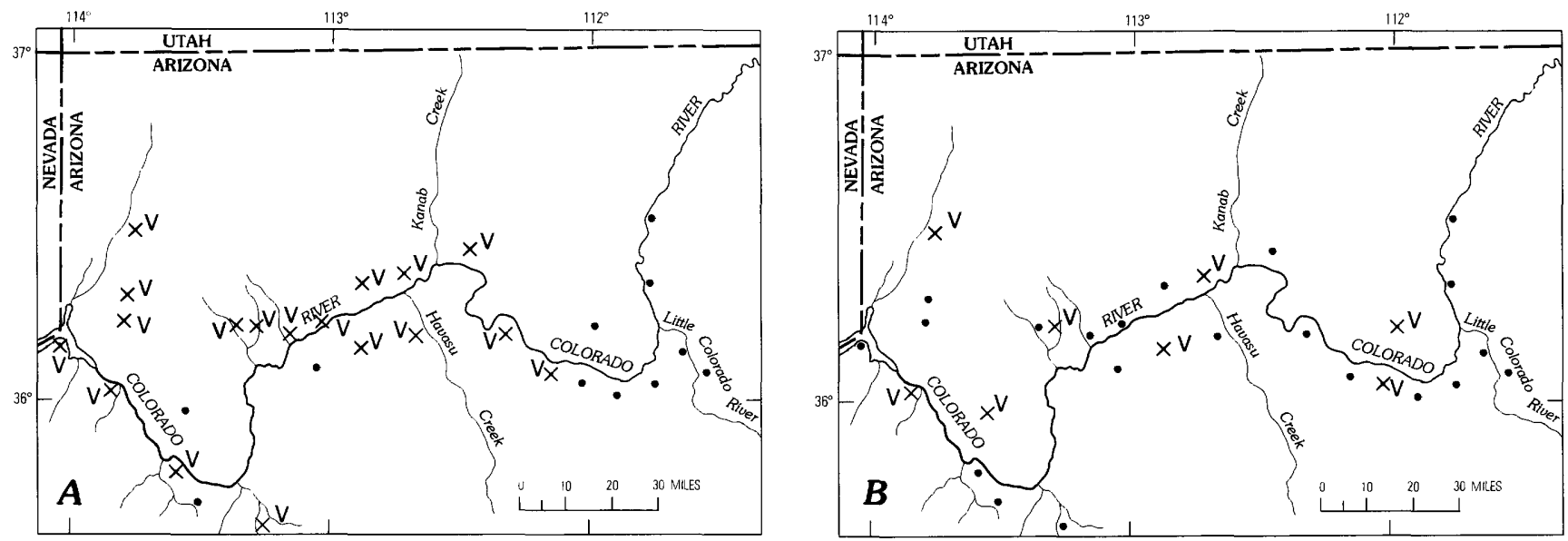

EXPLANATION

$\checkmark$ Brachiopod and (or) pelecypod fragments

FIGURE E30.-Distribution of bivalve fragments in bioclastic limestones of the Manakacha Formation, Grand Canyon region, Arizona: A, cliff unit; $B$, slope unit.

Jr. (written commun., 1972) are restricted to Chesterian (Late Mississippian) and Morrowan time, and Derbyia sp., representing a genus that does not occur below the Pennsylvanian. Thus, an early Morrowan age is indicated for the lower part of the Watahomigi.

In the relatively massive limestone cliff unit that occurs in the middle part of the formation, Anthracospirifer occiduus, considered a "Lower Pennsylvanian indicator" (Dunbar and Condra, 1932, p. 325), occurs in abundance at numerous places in western Grand Canyon. Also in the middle part of the formation and commonly associated with $A$. occiduus is Linoproductus nodosus, found at eight localities in northwestern Arizona. This species is a very important time indicator for, according to Mackenzie Gordon, Jr. (written commun., 1974), it is restricted to the uppermost part of the Morrowan in other parts of the United States. It apparently delineates within narrow age limits this part of the Watahomigi.

Further evidence of age is furnished in the lower part of the formation by a microfacies including the small foraminifers Asteroarchaediscus sp., Neoarchaediscus parvus, and $N$. incertus. These fossils occur at several localities and suggest a Morrowan-Atokan age, according to Bernard Mamet (written commun., 1972).

In the upper one-third of the Watahomigi, strata probably are of Atokan age as indicated both by the stratigraphic position of the Linoproductus nodosus Zone which indicates the youngest Morrowan age rocks, and by evidence of a widespread erosion surface marked by a conglomerate bed at numerous localities in central Grand Canyon. This conglomerate occurs near the base of the slope unit that forms the upper third of the formation (fig. J2). Principal faunal evidence of a probable Atokan age for these strata is the presence near Kaibab Trail, north, and on Grandview Trail of the fusulinid genera Fusulinella and Pseudostaffella, both of which have age ranges extending from Atokan into the Des Moinesian.

\section{AGE OF THE MANAKACHA FORMATION}

All or most of the Manakacha, as well as the upper third of the Watahomigi Formation, is believed to be of Atokan age both because of a position above the Linoproductus nodosus Zone and because of certain distinctive fusulinids that are also well represented in dated sections to the west and northwest of the Grand Canyon area (tables E4, D4). Probably the most diagnostic fusulinid for the Atokan age of these rocks is Profusulinella. The "Profusulinella fauna" of the Great Basin is given an Atokan age by Steele (1959, p. 37). The "zone of Profusulinella" is described (Welsh, 1959 , p. 30) "as geographically widespread" and a key to stratigraphic study in the Great Basin region. It is listed as being of "Atokan and Morrowan Ages" by Welsh (1959, table 2).

In the Grand Canyon area, Profusulinella sp. is found in the middle of the Manakacha Formation at Pigeon Wash (fig. E11). It is reported by Douglass (1974) from three localities in southern Nevada, and by Steele (1959, p. 37) from the Beaver Dam Mountains, Utah, and at Frenchman Mountain, Nevada, to the north and west, respectively. Other fusulinids in Grand Canyon sections that are considered to be Atokan and occupy stratigraphic positions between Linoproductus nodosus and Profusulinella sp. are Fusulinella sp. and Pseudostaffella sp., commonly found together, and Eoschubertella sp. In both the Beaver Dam 

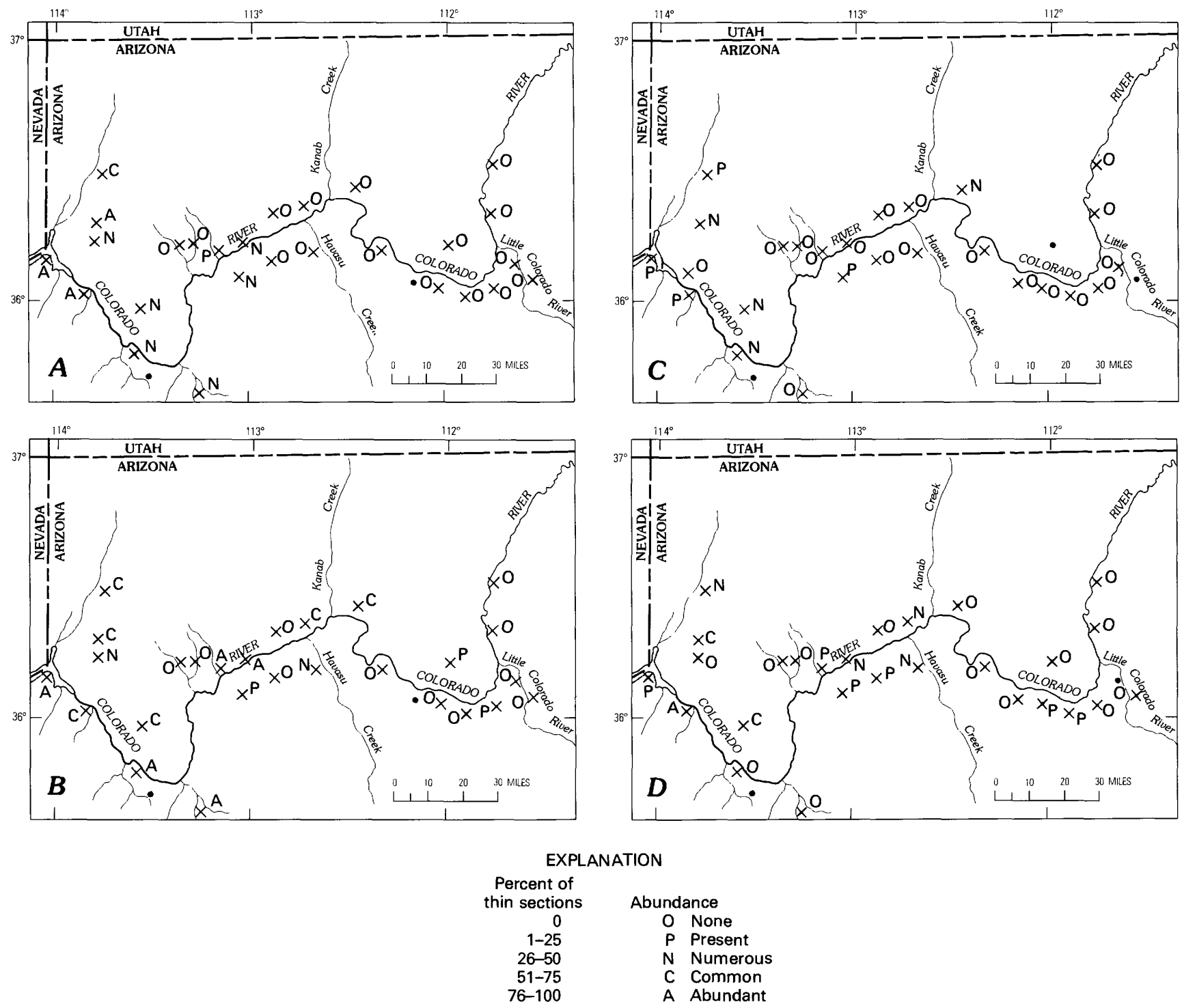

FIGURE E31.- Relative abundance of various marine fossils in bioclastic debris, Wescogame Formation, Grand Canyon region, Arizona: $A$, foraminifera; $B$, pelmatozoan plates and spines; $C$, bryozoans; and $D$, bivalves (pelecypods and brachiopods).

Mountains, Utah, and the Frenchman Mountain, Nevada, Fusulinella sp. is associated with Profusulinella sp. (Steele, 1959) and Fusulinella is shown by Brill (1963, fig. 9) in Atokan rocks of the Beaver Dam Mountains and by Douglass (1974) from three southern Nevada localities (table D4).

Eoschubertella sp., generally considered as of AtokanDes Moinesian age, is recorded from six localities in western Grand Canyon (figs. E11, E10). This genus is listed from North Virgin Mountains, Nevada, and from Pakoon Ridge, Arizona, by Welsh (1959, p. A12) who lists it as being of Des Moinesian age. In those places it is shown associated with or above Wedekindellina sp. and Fusulina sp. so it may be a younger species than that from Grand Canyon. Eoschubertella sp. is recorded from Arrow Canyon and Mountain Spring Pass, Nevada, by Douglass (table D4).

The erosional surface at the top of the Manakacha Formation may represent a stratigraphic break representing both Des Moinesian and Missourian ages. No fusulinids of Des Moinesian or Missourian age have been found in the Grand Canyon area though they are reported from both south and west of the Canyon (table E4). To the south both Fusulina (probably Beedeina) and Wedekindellina were reported from East Verde River, Kohls Ranch, and Black River (Brew, 1965), and to the west one or both were re- 

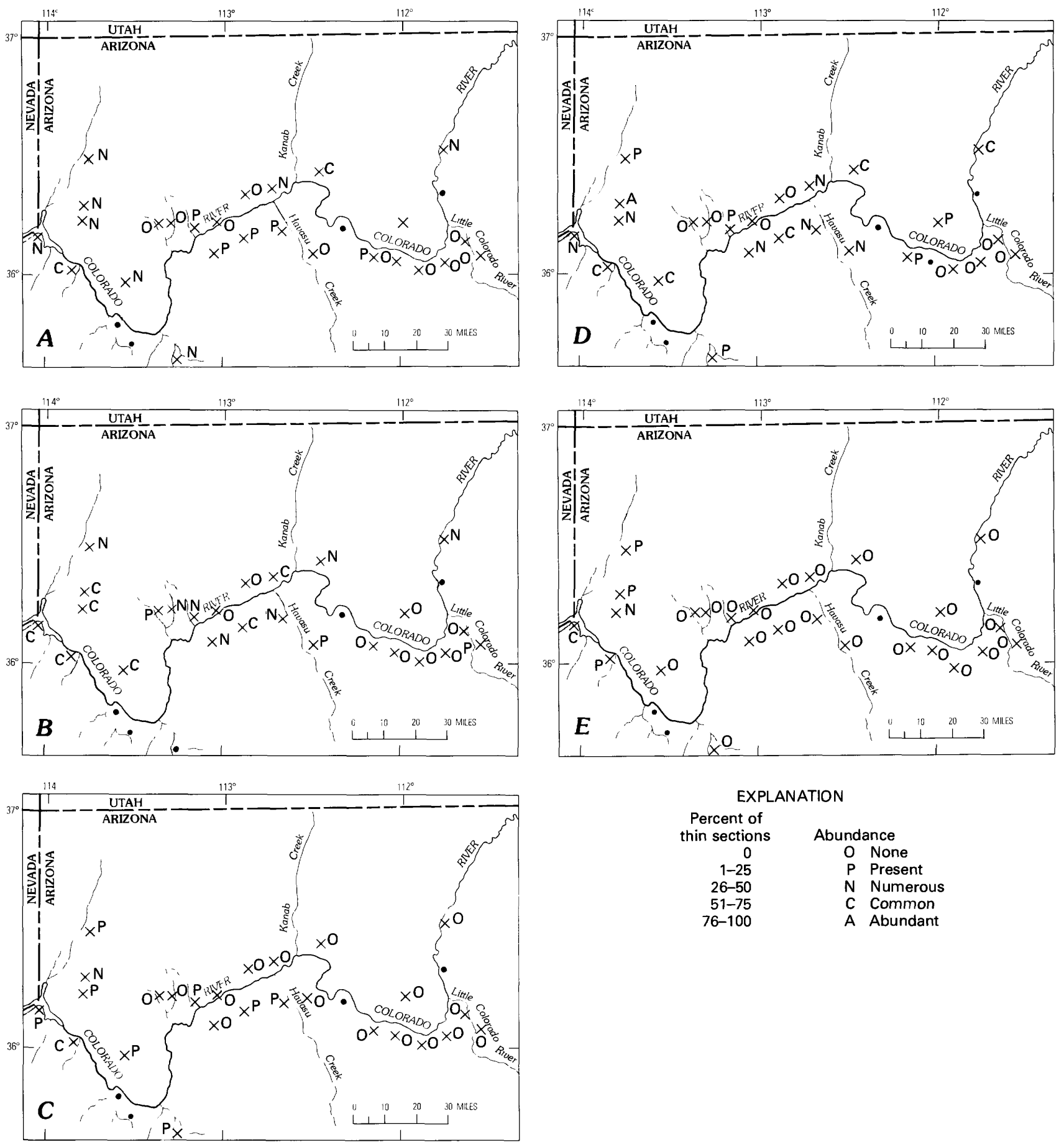

FIGURE E32.- Relative abundance of various marine fossils in bioclastic debris, Esplanade Sandstone and Pakoon Limestone, Grand Canyon region, Arizona: $A$, foraminifera, including fusulinids; $B$, pelmatozoan plates and spines; $C$, bryozoans; $D$, bivalves (pelecypods and (or) brachiopods); and $E$, corals.

ported from Frenchman Mountain (Welsh, 1959; Steele, 1959), Pakoon Ridge (McNair, 1951; Welsh, 1959), and Virgin Mountains (Welsh, 1959). Triticites sp. of Missourian age was reported from the south of Big Spring and at Carrizo Creek (Brew, 1965) and from the west at Frenchman Mountain (Steele, 1959).

\section{AGE OF THE WESCOGAME FORMATION}

The Wescogame Formation is separated from the Manakacha Formation by a widespread surface of erosion, containing channels that in some places are $30 \mathrm{ft}$ or more deep, 


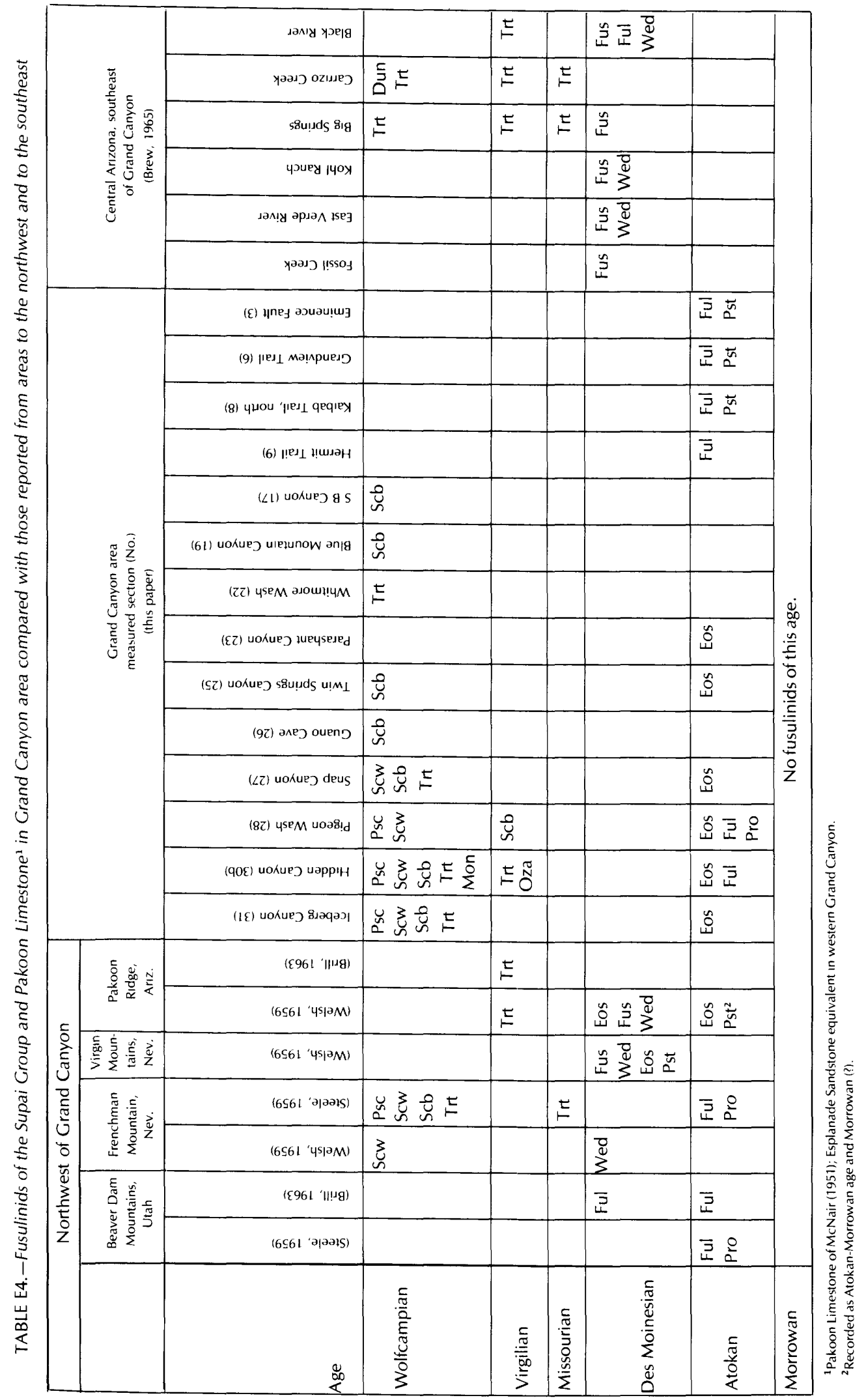
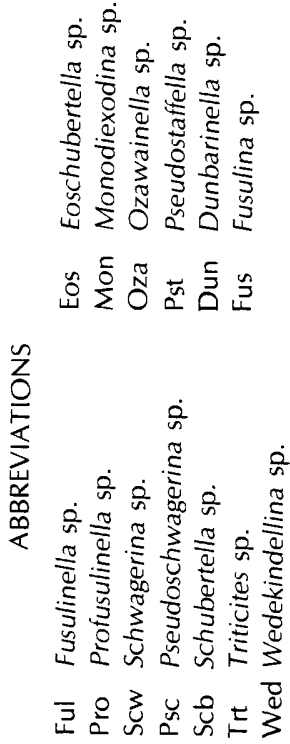
and covered in many places with a blanket of conglomerate. The magnitude of the hiatus represented by this erosion surface is not known but, as mentioned already, probably includes at least Des Moinesian and Missourian equivalents. The sea apparently withdrew completely to allow the widespread dissection cited and to permit a complete change of fauna.

The earliest fusulinids found in the Wescogame Formation are Triticites ssp. of probable Virgilian age from near the base in the Hidden Canyon section (fig. E13). Specimens of the genus Ozawainella are common higher in the section at Hidden Canyon.

Two coral species from the upper part of the Wescogame Formation at Hidden Canyon have been examined by W. J. Sando. These corals were determined as Syringopora multattenuata McChesney and Caninia sp., considered compatible with a Late Pennsylvanian age.

\section{AGE OF THE PAKOON LIMESTONE}

The Pakoon Limestone (McNair, 1951, p. 524) is considered to be the lateral equivalent of the lower part of the Esplanade Sandstone. The Pakoon occurs in western Grand Canyon and intertongues eastward into the Esplanade. McNair (1951) determined the age of the Pakoon as Wolfcampian on the basis of characteristic fusulinids from the type locality at Pakoon Ridge in northwestern Arizona. Faunal evidence from the present study corroborates this assignment.

Because the Pakoon or equivalent Esplanade is separated from the underlying Wescogame Formation by an erosion surface and a blanket of conglomerate throughout the Grand Canyon region, a significant hiatus seems to have preceded its deposition. As the Wescogame is believed to be of Virgilian age, the time represented by the unconformity probably includes the last part of the Virgilian, the early part of the Wolfcampian, or both.

Most important faunal evidence of Wolfcampian age is the presence of Schwagerina sp. at Hidden Canyon, Pigeon Wash, Snap Canyon, and Iceberg Canyon (fig. E15) and of Pseudoschwagerina sp. at all of those localities except Snap Canyon. Other fusulinids, common in rocks of Wolfcampian age, and associated with the preceding are Triticites sp. and Schubertella sp.

Further evidence of age is furnished by small (nonfusulinid) foraminifers among which Calcivertella sp., Spandelinoids? sp., and Geinitzina sp. were recognized by L. G. Henbest (written commun., 1964) from the Iceberg Canyon collections. These genera are believed to be characteristic of Late Pennsylvanian and Early Permian time according to Henbest.
Corals, which are abundant and varied in the Pakoon Limestone (fig. E17), give supporting evidence for the Wolfcampian age of this formation. Those "from the middle and basal part of the upper cliff member are firmly dated as Early Permian" according to W. J. Sando (written commun., 1964), and they are similar to the Lower Permian faunas from the area of Ely, Nev.

An upper limit for the age assignment of Pakoon Limestone and Esplanade Sandstone is furnished in eastern Grand Canyon by the flora near the base of the overlying Hermit Shale. The fossil plants in this formation were collected extensively in eastern Grand Canyon along the Hermit and Kaibab Trails and have been analyzed with respect to age by White $(1929$, p. 28-40). A conclusion that the Hermit Shale "belongs well up in the upper Rothliegendethe upper part of the Lower Permian" was reached by White (1929, p. 40). Characteristic plants of the Hermit have subsequently been found far to the west at Parashant Canyon (McKee, 1937, p. 341); therefore, the Esplanade Sandstone below the Hermit must be restricted to an early part of the Permian throughout much of the region.

A Leonardian age for the Hermit Shale is further suggested by a specimen of the species, Callipteris arizonae, found in the Hermit that has also been collected by Humble Oil Co. geologists from the Bone Spring Limestone, of Leonardian age in southeastern New Mexico (McKee and Oriel, and others, 1967, p. 215).

\section{AGE OF THE ESPLANADE SANDSTONE}

Direct evidence, based on fossils, for the age of the Esplanade Sandstone, is lacking. Because its lower part intertongues with the Pakoon Limestone of Wolfcampian age to the west, however, the Esplanade must be, at least in part, of this age. Whether the upper part, which changes to a fine-grained detrital facies and extends westward above the Pakoon, is also Wolfcampian is not known. An early Leonardian age has been suggested for it by Walter Pierce (written commun., 1976) on the basis of a fusulinid that he collected from the upper part of the Pakoon at Grand Gulch. The specimen was identified as Schwagerina linearis and interpreted as "Upper Wolfcampian" by George J. Verville.

\section{REFERENCES CITED}

Baird, Donald, 1965, Footprints from the Cutler Formation, in Early Permian vertebrates from the Cutler Formation of the Placerville area, Colorado: U.S. Geological Survey Professional Paper 503-C, p. C47-C50.

Brew, D. C., 1965, Stratigraphy of the Naco Formation (Pennsylvanian) in central Arizona: Cornell University, Ph. D. thesis, $201 \mathrm{p}$. 
Brill, K. G., Jr., 1963, Permo-Pennsylvanian stratigraphy of western Colorado Plateau and eastern Great Basin regions: Geological Society of America Bulletin, v. 74, p. 307-330.

Douglass, R. C., 1974, Fusulinids in the Basin and Range Province in California, Nevada, and Utah: Journal of Paleontology, v. 48, no. 4, p. 846-853.

Dunbar, C. O., and Condra, G. E., 1932, Brachiopoda of the Pennsylvanian system in Nebraska: Nebraska Geological Survey $2 d$ ser. Bulletin $5,377 \mathrm{p}$.

Gilmore, C. W., 1926, Fossil footprints from the Grand Canyon: Smithsonian Miscellaneous Collections, v. 77, no. 9, 41 p.

1927. Fossil footprints from the Grand Canyon; second Contribution: Smithsonian Miscellaneous Collections, v. 80, no. 3, 78 p.

1928, Fossil footprints from the Grand Canyon; third Contribution: Smithsonian Miscellaneous Collections, v. 80, no. 8, 16 p.

Haubold, von Hartmut, and Katzung, Gerhard, 1975, Die position der Autun/Saxon-Grenze (Unteres Perm) in Europa und Nordamerika: Schriftenreihe fur Geologische Wissenshaften, Berlin, v. 3, p. 87-138.

Hitchcock, Edward, 1858, Ichnology of New England; A report on the sandstone of the Connecticut Valley, especially its footmarks: Boston, W. White, $220 \mathrm{p}$.

Jardine, William, 1853, The ichnology of Annadale, or illustrations of footmarks impressed on the New Red Sandstone of Corncockle Muir: Edinburgh, 17 p., 13 pls.

Lotze, F. 1928, Die Tambacher Sphaerodactylum-Fahrten: Pälaontologische Zeitschrift, v. 9, p. 170-175.
McKee, E. D. 1937, Researches on Paleozoic stratigraphy in western Grand Canyon: Carnegie Institution of Washington Year Book 36 for 1936-1937, p. 332-345.

McKee, E. D., Oriel, S. S., and others, 1967, Paleotectonic investigations of the Permian System in the United States: U.S. Geological Survey Professional Paper 515, $271 \mathrm{p}$.

McNair, A. H., 1951, Paleozoic stratigraphy of part of northwestern Arizona: American Association of Petroleum Geologists Bulletin v. 35 , no. 3 , p. $503-541$.

Nopcsa, Franz, 1923, Die Familien der Reptilien: Geologic 2nd Pälaeontologic Fortschrift. 1st, no. 2, 210 p.

Schuchert, Charles, 1918. On the Carboniferous of the Grand Canyon of Arizona: American Journal of Science, 4th ser., v. 45, no. 267, p. $347-361$

Steele, G., 1959, Stratigraphic interpretation of the Pennsylvanian-Permian Systems of the eastern Great Basin: Washington University, Ph. D. thesis, $294 \mathrm{p}$.

Vaughn, P. P., 1962, Vertebrates from the Halgaito tongue of the Cutler formation, Permian of San Juan County, Utah and Arizona: Journal of Paleontology, v. 36, p. 529-539.

1964, Vertebrates from the Organ Rock Shale of the Cutler Group, Permian of Monument Valley and vicinity, Utah and Arizona: Journal of Paleontology, v. 38, no. 3, p. 567-583.

Welsh, H. E., 1959, Biostratigraphy of the Pennsylvanian and Permian System of southern Nevada: Utah University, Ph. D. thesis, p. 1-106, A-1-A-12.

White, David, 1929, Flora of the Hermit Shale, Grand Canyon, Arizona: Carnegie Institution of Washington Publication 405, 221 p. 

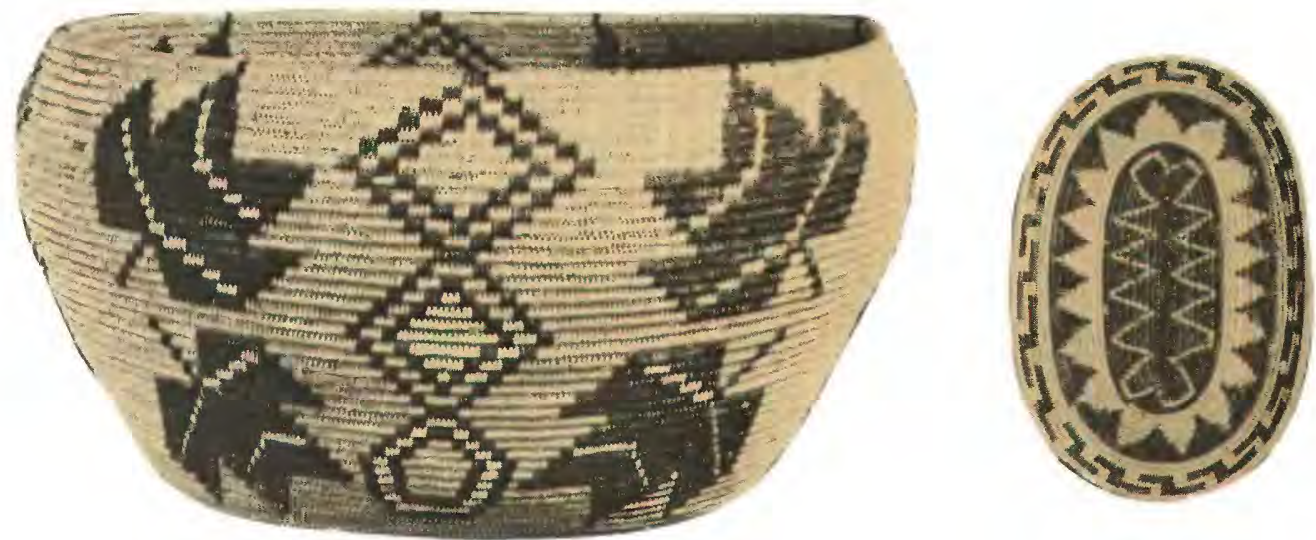

THE SUPAI GROUP OF GRAND CANYON

\section{BIOSTRATIGRAPHY OF THE WATAHOMIGI FORMATION}

Chapter $\mathrm{F}$

By MACKENZIE GORDON JR.

\section{Contents}

\begin{tabular}{|c|}
\hline troduction \\
\hline 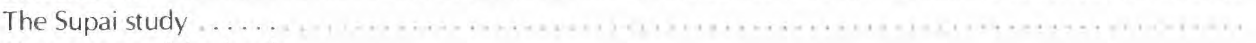 \\
\hline 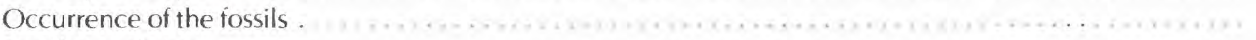 \\
\hline 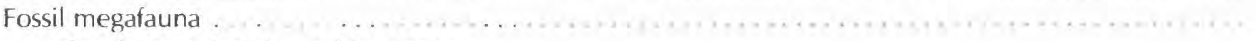 \\
\hline Corals, conulariids, and bryozoans \\
\hline Brachiopods \\
\hline 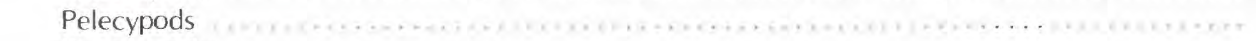 \\
\hline 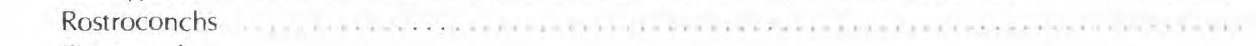 \\
\hline 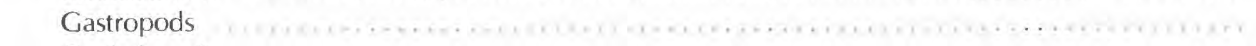 \\
\hline 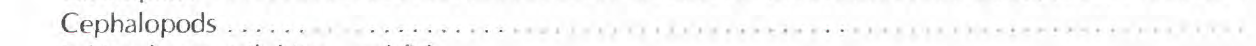 \\
\hline 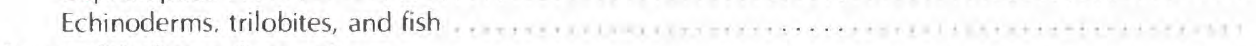 \\
\hline 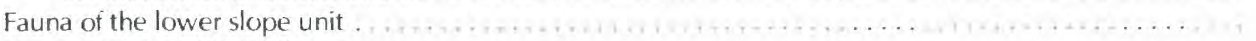 \\
\hline 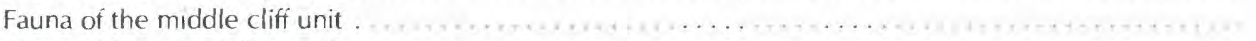 \\
\hline 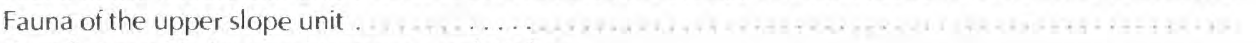 \\
\hline Correlation with the type Morrowan and Atokan $\ldots \ldots \ldots \ldots \ldots$ \\
\hline Correlation with other western American formations $\ldots \ldots \ldots \ldots \ldots \ldots \ldots$ \\
\hline 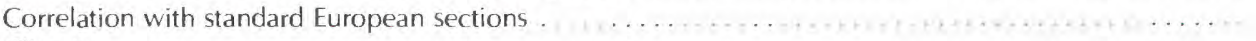 \\
\hline 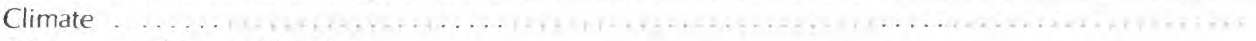 \\
\hline aleogeographic c \\
\hline erences cited \\
\hline
\end{tabular}




\section{Illustrations}

FIGURE F1. Correlation of Lower and lower Middle Pennsylvanian formations in the south-central and southwestern United States

PLATES F1-F3. Brachiopods .

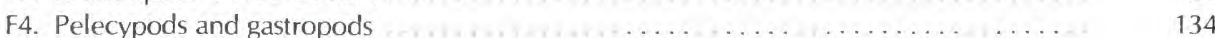

\section{Tables}

TABLE

F1. Megafauna of the Watahomigi Formation -118

F2. Major life-habit groups of Watahomigi pelecypods . . . . . . . . . . . . . . . . 120 


\section{INTRODUCTION}

The Watahomigi Formation contains the largest and most varied invertebrate fauna of any of the formations of the Supai Group. More than 85 species of megafossils have been recognized in this fauna, including remains of corals, bryozoans, brachiopods, pelecypods, gastropods, echinoids, and trilobites. The fossils indicate a middle to late Morrowan (Early and Middle Pennsylvanian) age for the greater part of the formation. Foraminiferal evidence from the upper part, however, suggests that this part is early Atokan in age.

McKee (chapter C) has recognized three informal divisions of the Watahomigi Formation. A lower slopeforming unit is succeeded by a middle cliff-forming limestone unit, and this limestone by an upper slope-forming unit. The base of the upper unit is marked by a conglomerate bed of wide lateral extent, which delineates the base of the Atokan part of the formation.

The Watahomigi Formation is the lowest division of the Supai Group and rests unconformably upon an erosion surface of highly resistant chert beds and softer limestone beds, probably representing the Horseshoe Mesa Member of the Redwall Limestone (McKee, 1963, p. C21). In Havasu Canyon, the cherts contain fossils of early to middle Meramecian (early Late Mississippian) age, including the brachiopods Orthotetes kaskaskiensis (McChesney), Torynifer setiger (Hall), and Anthracospirifer bifurcatus (Hall). This faunule can be no younger than St. Louis (Late Mississippian) in age. The presence of these resistant beds overlain and surrounded by the basal beds of the Watahomigi Formation does not necessarily imply a total lack of deposition within the time span represented by the unconformity. On the contrary, a $6.5-\mathrm{ft}$ limestone bed at Bright Angel Trail has been reported to contain fossils of Chesterian age (McKee and Gutschick, 1969, p. 74). More recently, large buried valleys cutting the Redwall Limestone in western Grand Canyon have been found to contain upper Chesterian strata, as described by Billingsley and McKee in chapter G. This would indicate that some deposition took place in northern Arizona during the Late Mississippian, and that these deposits were removed by erosion over large areas during the latest Mississippian and Early Pennsylvanian.

\section{THE SUPAI STUDY}

The study of the megafossils of the Supai Group has occupied several paleontologists intermittently over a period of approximately 15 years, as the fossil collections accumulated. Corals were studied by W. J. Sando, brachiopods by R. E. Grant, pelecypods by John Pojeta, Jr., gastropods by E. L. Yochelson, and fish remains by D. H.
Dunkle. In addition to the megafauna, fusulinids were studied by R. C. Douglass and smaller foraminifera and algae by Bernard Mamet. The writer came into the study in 1973 (after R. E. Grant took over administrative duties with the National Museum of Natural History) and was asked to complete the work on the Supai material. Part of the collections had been dissipated and turned over by McKee to two northern Arizona museums. Wishing to see all of the collections together, the writer asked that they be reassembled and McKee very kindly complied. Opportunity was thus provided to study the fauna as a whole and additional fossil preparation also yielded a number of previously unrecorded species. Publication of the Sutherland and Harlow (1973) study of Pennsylvanian brachiopods and biostratigraphy in the southern Sangre de Cristo Mountains, New Mexico, provided names for part of the brachiopod fauna. Conferences with T. W. Henry, who was studying the brachiopods of the Morrowan Provincial Series in Arkansas and Oklahoma, also were helpful in providing a basis for correlating the Watahomigi beds with the type Morrowan section. The Supai study has been time consuming, but has yielded considerable information and a better understanding of the Pennsylvanian history of the Grand Canyon region.

\section{OCCURRENCE OF THE FOSSILS}

Most of the Watahomigi Formation collections are from rather coarse gray limestone, much of it a granular organic detritus. Fossils are scattered through the matrix, locally in considerable numbers. Some fossils occur in rather resistant limestone or in chert, and a few in calcareous sandstone beds. None seem to have come from the red beds. Despite the relatively restricted types of lithology of the fossiliferous strata, considerable variation exists between individual beds and it often is possible to recognize the matrix as coming from a certain bed or geographic locality. For instance, USGS collection 25127-PC, from $12 \mathrm{ft}$ above the base of the formation in National Canyon, is from a reddish-brown conglomeratic limonitic sandstone not seen in other sections. USGS collection 27031-PC, from $10 \mathrm{ft}$ above the base, near Bridge Canyon, combines a light-gray granular limestone with small pellets of limonitic material; this also seems distinctive to the locality.

Fossils from the east side of Toroweap Valley include large Orbiculoidea and myalinid pelecypods in a matrix of near-white to dirty gray or dark brownish-gray sandstone. Specimens from the cliff-forming middle part of the formation are generally preserved in gray limestone and the collections are not so easily distinguished one from the other by lithology. 
The preservation of the fossils ranges from good to poor, but the poor end of the spectrum is much more in evidence. Well-preserved specimens are a great rarity and very few fossils are complete, or even nearly so. Much of this is due to the crumbly nature of the coarse granular limestone and the fact that most of the fossils are calcareous, rather than silicified.

\section{FOSSIL MEGAFAUNA}

Table F1 shows the distribution of the Watahomigi megafauna. The sections are listed in geographic succession from west to east and the fossils are arranged systematically. The occurrence of each species is recorded as to distance above the base of the formation in each measured section. The abundance of each species in each collection is indicated by the following symbols in the table:

A-Abundant (more than 50 specimens).

C-Common (15-20 specimens).

$X$-Well-represented (4-14 specimens).

$\mathrm{R}-$ Rare (1-3 specimens).

Such a key is only approximate, owing to such factors as personal bias in collecting, vicissitudes of preservation, and the fact that it was made not by the collectors but by those making the identifications. Nevertheless, it provides a far better picture of the distribution of the fauna than does merely recording the occurrence of species at a given locality.

The following discussion of the fossil megafauna is arranged according to the major categories shown in table F1. As a large proportion of the species are not yet described and as some of the specimens are too poorly preserved for specific identification, it is hoped that the following discussion of criteria for identification and remarks as to the distribution will be helpful.

\section{Corals, conulariids, and bryozoans}

No solitary corals are present in our collections. Two small fragments, each assignable to a different genus of colonial corals, constitute the entire coelenterate record from the Watahomigi. These occur in the lower slope unit of the formation.

A poorly preserved conulariid fragment, not identifiable as to genus, was found in each of two collections in the lower slope unit of the formation.

Remains of bryozoans are nowhere abundant but are present in 11 collections, mainly in the eastern half of the outcrop belt, as indicated in table F1. The most common of these are small rhomboporoid bryozoans, present in 6 collections; in one of these they are fairly numerous. The next most common form is a thin stenoporoid bryozoan incrusted on brachiopods such as Anthracospirifer, Composita, or Orthotetes. A single massive stenoporoid was collected in Parashant Canyon, in the lower part of the formation. A bifoliate fistuliporoid and an incrusting fistuliporoid are rare at each of two localities in the lower slope part of the formation. A ramose treptostomatous bryozoan, two to three times the diameter of the rhomboporoid, is present in five collections, including the most westerly occurrence of a bryozoan at Hidden Canyon. Fenestrate bryozoans probably are assignable to Fenestella and to Polypora, but are not common. A poorly preserved ribbonlike bryozoan fragment, having linear grooves along which the zooecia occur, is referred with question to Cystodictya.

\section{Brachiopods}

Among the inarticulate brachiopods, a single incomplete valve of Lingula is present. Although resembling $L$. carbonaria Swallow in size and shape, it is not complete enough to identify positively. Two species of Orbiculoidea also occur. One of these, identified as $O$. meekana (Whitfield) (pl. F1, figs. 1, 2) is common on the east side of Toroweap Valley at a stratigraphic level regarded as early Atokan in age. It is a large subcircular form having an eccentric apex, mature specimens ranging in length from 22 to $26 \mathrm{~mm}$. The other, from Snap Canyon, resembles O. missouriensis (Shumard) and is based upon a single incomplete brachial valve. The Entletacea are represented by a single species, Schizophoria altirostris (Mather), (pl. F1, figs. 3-5), at scattered localities in the lower part of the formation.

Three species of orthotetaceans are recognized. Orthotetes sp. A (pl. F1, figs. 6, 7) has a sharp-pointed umbo, a moderately low interarea at an angle of about $45^{\circ}$ to the plane of the pedicle valve, and the hinge line slightly shorter than the greatest width; the surface is parvicostellate, consisting of intercalating costellae of which 9 to 11 occur in the space of $5 \mathrm{~mm}$. The median septum forks narrowly near the umbo, enclosing a narrow matrix-filled space between two barely diverging dental plates, the delthyrium being very narrow. The brachial valve has its greatest convexity near mid-valve and is somewhat flattened near the umbo.

Derbyia sp. A (pl. F1, figs. 8-10) has a low blunt umbo, the interarea at an angle of $70^{\circ}$ to the plane of the pedicle valve. The brachial valve has its greatest convexity considerably posterior to mid-valve. The sculpture is parvicostellate but commonly approaches multicostellate, 13 to 16 costellae occurring in the space of $5 \mathrm{~mm}$. The median septum does not split and within the umbo the palintrope is filled with secondary shell deposit. Derbyia sp. A and Orthotetes sp. A have overlapping stratigraphic ranges in the lower and middle parts of the formation. 
A single large incomplete pedicle valve appears identical to material from the Amsden Formation of Wyoming identified as Derbyia cf. D. robusta (Hall) by Gordon (1975, p. D31).

Productacea are represented by only five genera in the Watahomigi fauna and, except for Linoproductus, are rare. They include characteristic middle and upper Morrowan species. Linoproductus sp. A, a precursor of $L$. nodosus in Arkansas, occurs in the lower middle part of the Watahomigi Formation. It is recognized by a double row of alternating spines ornamenting the middle zone of the pedicle valve, beginning near the umbo. An illustration of a well-preserved specimen of this species, from the Brentwood Limestone Member of the Bloyd Shale in Arkansas, appeared in a paper by Henry and Sutherland (1977, pl. 2, fig. 5). Linoproductus pumilis Sutherland and Harlow (pl. F1, figs. 20-22) occurs in the lower and middle parts of the Watahomigi and the small Buxtonia? sp. (pl. F1, figs. 11, 17-19) comes from the lower part of the middle cliff unit. Buxtonia sp. (pl. F1, figs. 23-25), Pulchratia? picuris Sutherland and Harlow (pl. F1, figs. 26-32), and Linoproductus nodosus (Newberry), shown in plate F1, figures 12-16, occur in the upper part of the middle cliff unit. P.? picuris also occurs in the lower middle part.

Rhynchonellaceans occur at three localities in the eastern part of the outcrop belt. At two of them, a species resembling Cupularostrum is rare and represented by poorly preserved specimens. Near the base of the formation, in National Canyon, a tiny rhynchonellacean (pl. F2, figs. 7-16) that superficially resembles the stenoscismatacean genus Coledium, but has a rhynochonellacean interior, occurs abundantly. R. E. Grant, who initially examined this material, believes it may represent an undescribed genus.

Athyridaceans, all of them belonging in the genus Composita, are common to abundant in the Watahomigi and three species have been recognized. Small- to medium-size, moderately narrow to moderately broad shells, having the greatest width at the middle of the valve and the anterior commisure exhibiting a broad shallow deflection, are referred to C. ovata Mather (pl. F2, figs. 17-31). Similar, but smaller, narrower, and more inflated shells are referred to C. gibbosa Mather (pl. F2, figs. 32-41). Subtriangular shells, having the greatest width well anterior to the middle of the valves are referred to C. subtilita (Hall), as shown in plate F3, figures 6,7 . A closely related, possibly conspecific, large transverse Composita occurs with it in the middle cliff unit in the Guano Cave section (pl. F3, figs. 1-5).

The cyrtiacean Crurithyris planiconvexa (Shumard) is shown on plate F2, figures 1-6; abundant in many Pennsylvanian formations, it is rare in the Watahomigi. Only three specimens are present in the collections studied, and these are from the upper slope (Atokan) part of the formation.

Four species of Anthracospirifer make up the rather abundant spiriferacean population of this formation. The most common and widely distributed of these is $A$. tanoensis Sutherland and Harlow (pl. F3, figs. 17-19), which occurs throughout the Morrowan part of the formation and is present in the Atokan part as well. This is a moderately small species, normally having 3 costae in the sulcus and 9 to 11 on each lateral slope. Some specimens have as many as 5 costae in the sulcus and some show a tendency for 1 or 2 of the lateral costae to bifurcate. These more highly costate specimens are regarded as advanced forms of $A$. tanoensis approaching $A$. chavezae Sutherland and Harlow. At Bridge Canyon, in the basal part of the formation, is an Anthracospirifer having 3 costae in the sulcus and 8 rather broad costae on each lateral slope. This has been identified as $A$. cf. A. opimus (Hall) in this report, as it closely resembles Hall's Midcontinent Middle Pennsylvanian species. The possibility exists, however, that this form is merely a variant of $A$. tanoensis, which occurs at the same level in the formation elsewhere.

A. newberryi Sutherland and Harlow (pl. F3, figs. 20, 21) has been recognized at a few localities, generally in association with $A$. tanoensis. This is an alate form having a low fold and sulcus, with 3 costae in the sulcus and as many as 15 simple costae on each lateral slope. A variant of this species, having the third and fourth costae on either side of the sulcus splitting toward the sulcus as in A. occiduus, was recorded at two localities.

A. occiduus Sadlick (pl. F3, figs. 8-16) occurs abundantly in the lower and middle parts of the formation in the vicinity of Guano Cave. Some variation is exhibited in these shells with regard to the splitting patterns of the lateral costae, but they include specimens that agree closely with the primary types from Idaho. This is the largest of the Watahomigi anthracospirifers.

Spiriferaceans were found in three measured sections, all of them in the lower half of the formation, in several canyons adjacent one to the other. The most common species is Punctospirifer transversus (McChesney), shown in plate F3, figures 22-24. Complete pedicle valves have as many as 15 costae on each lateral slope. At first it was thought that two punctospirifers might be present: those in limestone beds generally having 11 to 15 costae on each lateral slope, and those in shale layers commonly having 8 to 11 costae in the same area (a number typical of $P$. morrowensis Sutherland and Harlow). However, a few specimens in shale layers were found to have as many as 13 costae on either lateral slope, so it is concluded that the punctospirifers belong in one variable species.

Two poorly preserved specimens from two localities were identified as ?Reticulariina gonionota (Meek). These have four to five plications at either side of the sulcus and although surface spines cannot be discerned clearly, local knobby surfaces suggest that worn spine bases are present.

Lastly, a small unidentifiable terebratuloid brachiopod (pl. F2, figs. 42-46) was found in the lower of two collections from National Canyon. 
TABLE F1.-Megafauna of the Watahomigi Formation

[A, abundant (more than 50 specimens); C, common (15-50 specimens); X, well-represented (4-14 specimens); R, rare (1-3 specimens)]

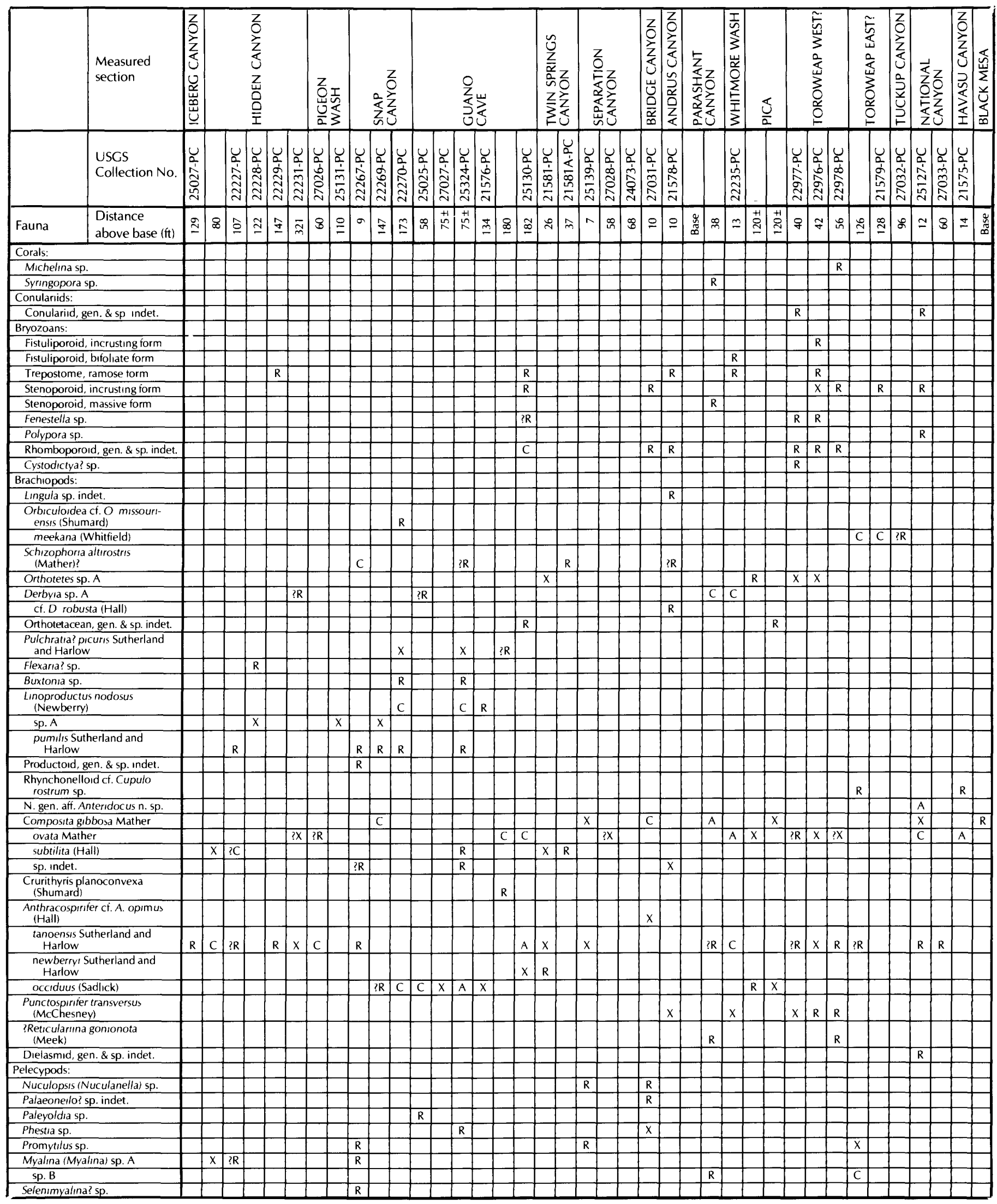


BIOSTRATIGRAPHY OF THE WATAHOMIGI FORMATION

TABLE F1.-Megafauna of the Watahomigi Formation-Continued

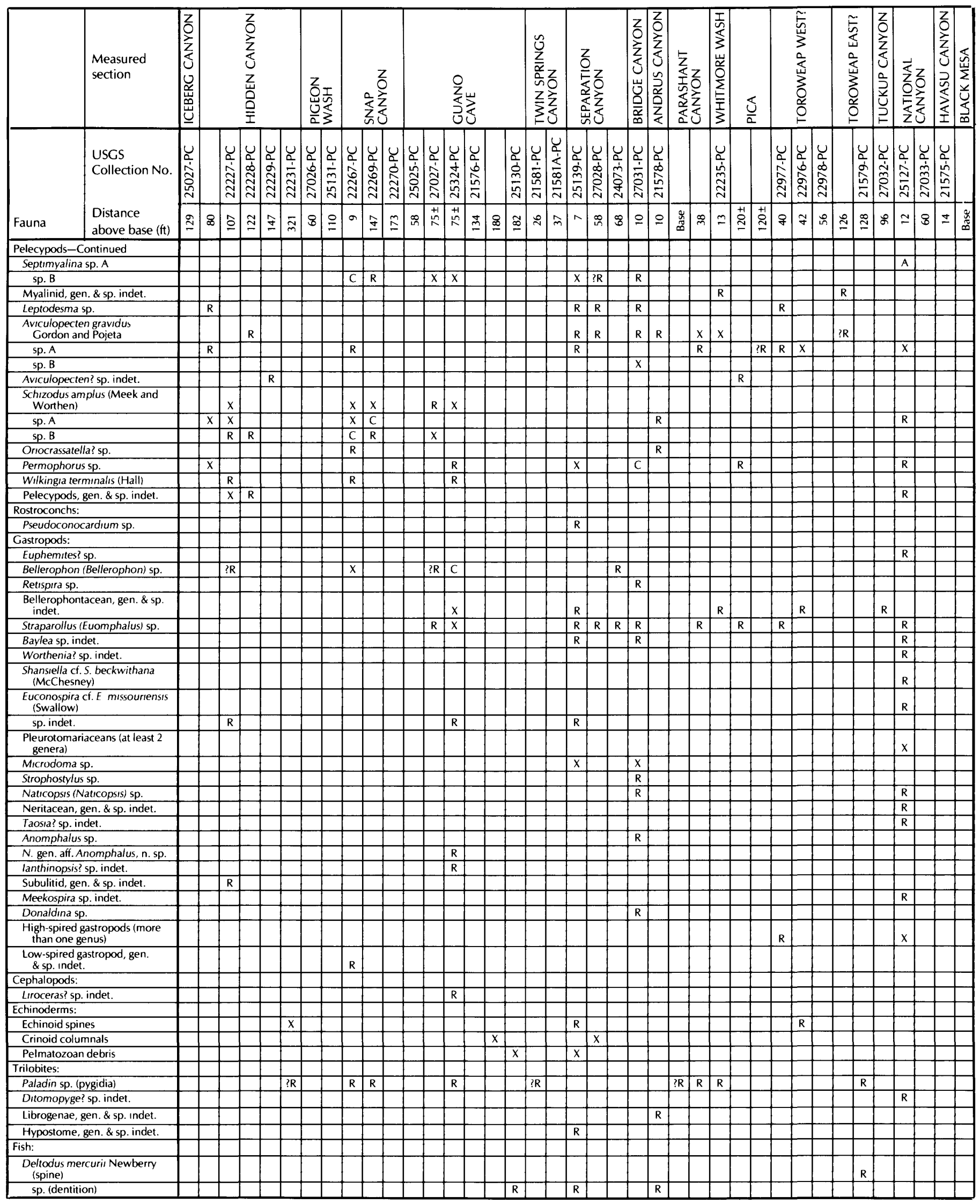




\section{Pelecypods}

Myalinids and, to a lesser extent, aviculopectenids, myophoriids, and permophorids are the dominant elements of the pelecypod fauna of the Watahomigi. Taxodont genera are rare: those recognized in the formation include $\mathrm{Nucu}$ lopsis (Nuculanella) (pl. F4, figs. 2, 3), Palaeoneilo?, Paleyoldia, and Phestia (pl. F4, figs. 1, 4), the whole group represented by only a few specimens. The mytilacean Promytilus (pl. F4, fig. 11) and pteriacean Leptodesma are likewise represented in our collections at few localities and generally by only one or two specimens at a locality.

The myalinids include five recognizable forms. Common in calcareous sandstone beds of the upper slope unit on the east side of Toroweap Valley is a strongly prosocline species, Myalina (Myalina) sp. A (pl. F4, figs. 9, 10). More common in limestone beds, particularly in Snap Canyon, is a more steeply inclined species, M. (Myalina) sp. B (pl. F4, fig. 12). In addition, a single specimen has the configuration of Selenimyalina. Septimyalina sp. A (pl. F4, figs. 7,8 ), having an acutely subangular diagonal ridge extending from the umbo is abundant near the base of the formation in National Canyon. Owing in part to its preservation in fairly hard limonite, the plate covering the umbonal cavity can be seen in several of our specimens. Septimyalina sp. B (pl. F4, fig. 13) includes those forms apparently lacking an anterior lobe and having a rounded, rather than a subangular, diagonal ridge. Because of preservation in soft limestone that is easily weathered, no umbonal plate was visible, hence the identification of the second Septimyalina is somewhat tentative.

The Watahomigi Aviculopectenidae consist entirely of members of the genus Aviculopecten. The most common species, but nowhere represented by more than a few specimens, is $A$. gravidus Gordon and Pojeta (pl. F4, fig. 17), having a radially lirate right valve of low convexity and an inflated semiovate left valve ornamented by radial and concentric lirae that form a finely reticulate pattern. Aviculopecten sp. A, which occurs at several localities, is a typical aviculopectenid, represented exclusively by left valves that bear several ranks of radiating costae. A very similar form, from the Wescogame Formation, is shown in figure E14. A rare form, Aviculopecten sp. B (pl. F4, figs. 5,6$)$, known from a single left valve from each of two localities, has approximately 12 major costae, bearing short nodelike spines on one of the specimens. Completing the roster of aviculopectenids is a large fragment of a valve that bears radiating costae crossed by concentric striae and identified here as Aviculopecten? sp. indet.

The myophoriids include three species of Schizodus in the Watahomigi Formation. The largest of these and the only one identified with a previously described species is Schizodus amplus Meek and Worthen (pl. F4, figs. 20-22), a rather inflated, suboval to subcircular species having a raised internal ridge in front of the posterior adductor muscle scar. Schizodus sp. A (pl. F4, fig. 19) is a shallow elongate form that reaches a length of $7 \mathrm{~cm}$, but normally is smaller. Schizodus sp. B (pl. F4, fig. 18) is a similar elongate species having an exterior subangular ridge directed posteriorly from the umbo.

Associated with the myophoriids is a telliniform pelecypod, its surface ornamented by concentric lirae. This species bears a superficial resemblance to Oriocrassatella, to which it is referred with question. As the hinge and dentition have not been seen, no assurance exists that it is a crassatellacean.

Permophorus is fairly common, represented in the Watahomigi Formation at five localities by what seems to be the same rather short species (pl. F4, figs. 15, 16). Tentatively referred to Edmondia (pl. F4, fig. 14) is a specimen from the section south of Pica. American shells having this configuration are commonly referred to this genus, although they have a less excentric beak and a smoother shell than the British type species. Finally, a few shells and fragments of Wilkingia terminalis (Hall), shown on plate F4, figure 28, have been found at Hidden and Snap Canyons and in the Guano Cave section.

In table F2, the genera to which the Watahomigi pelecypods have been referred are arranged according to lifehabit. A similar arrangement of pelecypod genera from the Amsden Formation of Wyoming appeared in a report by Gordon and Pojeta (1975, p. E3).

TABLE F2.-Major life-habit groups of Watahomigi pelecypods

\begin{tabular}{lll}
\hline \multicolumn{1}{c}{$\begin{array}{c}\text { Infaunal libial } \\
\text { palp deposit } \\
\text { feeders }\end{array}$} & \multicolumn{1}{c}{$\begin{array}{c}\text { Attached } \\
\text { suspension } \\
\text { feeders }\end{array}$} & $\begin{array}{c}\text { Infaunal burrowing } \\
\text { suspension } \\
\text { feeders }\end{array}$ \\
\hline $\begin{array}{l}\text { Nuculopsis (Nuculanella) } \\
\text { Palaeoneilo }\end{array}$ & $\begin{array}{l}\text { Promytilus } \\
\text { Phestia }\end{array}$ & $\begin{array}{l}\text { Schizodus } \\
\text { Paleyolida }\end{array}$ \\
& $\begin{array}{l}\text { Selenimyalina } \\
\text { Septimyalina }\end{array}$ & Oriocrassatella \\
& Peptodesma & Wilkingia \\
& Aviculopecten & \\
\hline
\end{tabular}

\section{Rostroconchs}

The only rostroconch noted in the collections is a small incomplete Pseudoconocardium collected near the base of the formation in Separation Canyon.

\section{Gastropods}

The number of gastropod species recognized in the formation approximates the number of pelecypod species, but 
the gastropods are more restricted in stratigraphic range and geographic distribution and are represented by fewer specimens. Only three collections contain a significantly diverse gastropod fauna. These occur in Separation, Bridge, and National Canyons at levels 7-12 ft above the base of the formation. Unfortunately, the gastropods from National Canyon were misplaced and never were seen by the writer.

Among the bellerophontaceans, Bellerophon (Bellerophon) sp. is a fairly widespread form, occurring in five collections and rather common locally in the Anthracospirifer occiduus coquinoid bed in the middle cliff unit in the Guano Cave section. The shell material at all the localities is coarsely recrystallized and the writer cannot be sure that only one species is present. Euphemites was recognized at National Canyon and Retispira at Bridge Canyon, near the base of the lower slope unit at both localities.

The euomphalacean Straparollus (Euomphalus) sp. was recognized at nine localities, represented generally by less than three specimens at each. Seven species of pleurotomariaceans are assigned to Baylea, Worthenia?, Shansiella, Euconospira, and at least two unrecognized and probably new genera; all of them occur very sparsely.

\section{Cephalopods}

The platyceratacean Strophostylus sp. is represented by a single specimen at Bridge Canyon. Microdoma sp. (pl. F4, figs. 23-27), a distinctive subconical species having a subdued middle row of nodes on each whorl, is well represented in collections from the Separation and Bridge Canyon sections. Anomphalus sp. is rare at Separation Canyon and a much larger species, listed as N. gen. aff. Anomphalus n. sp. is represented by two specimens from the middle cliff unit in the Guano Cave section.

The neritaceans include Naticopsis (Naticopsis) sp. recognized at two localities, one of which has also yielded another form that cannot be identified as to genus and may or may not be a neritacean. Higher-spired gastropods include one questionably referred to Taosia and others assigned to Meekospira and Donaldina, and to unidentified genera. A single fragment of a nautiloid resembling Liroceros and assigned to that genus with question was found in the middle cliff unit in the Guano Cave section.

\section{Echinoderms, trilobites, and fish}

All of the echinoderm remains are fragmental, but clearly both crinoids, represented by columnals, and echinoids, by spines, were present in the fauna.

The most common trilobite remains are pygidia found at eight localities and referred with various degrees of con- fidence to Paladin sp. One, from National Canyon, was identified by E. L. Yochelson as Ditomopyge? sp. indet. Several unidentified librogenae (but probably belonging to Paladin) and an incomplete hypostome were also noted.

D. H. Dunkle has identified a fish spine from the east side of Toroweap Valley in beds of probable Atokan age as Deltodus sp., mercurii Newberry. Moreover, he assigned a fish dentition also from the upper slope unit in the Guano Cave section to Deltodus sp., as well as other specimens from fairly low in the lower slope unit in the Parashant, Separation, and Andrus Canyon sections.

\section{FAUNA OF THE LOWER SLOPE UNIT}

An overall abundance of Composita, particularly those referred to C. gibbosa Mather and C. ovata Mather, and of Anthracospirifer, especially $A$. tanoensis Sutherland and Harlow, characterize the fauna of the lower slope unit of the Watahomigi Formation. No productoid brachiopods have been recorded from this unit. This brachiopod assemblage is similar in composition to the rather monotonous fauna that occurs in the middle part of an equivalent section of Morrowan age in the Great Basin, which also is dominated by Composita and Anthracospirifer, except that there the predominant spiriferoid is Anthracospirifer occiduus (Sadlick). A. occiduus appears in the upper part of the lower slope unit in the vicinity of the Guano Cave section, but has a rather limited lateral distribution in that area. Punctospirifer transversus (McChesney) has a similarly limited lateral distribution. It is very abundant in the middle part of the lower slope unit, but restricted to the eastern part of the area studied, in several canyons flanking Toroweap Valley (see table F1).

One striking feature of the lower $13 \mathrm{ft}$ of the formation at several localities is the diversity of small pelecypods and gastropods. This considerable diversity was noted at Bridge, Separation and National Canyons. By far the greatest number of gastropod species in the Watahomigi Formation occur at these localities. Another characteristic of the fauna of the lower slope unit is that it is composed of species that do not exceed $2.5 \mathrm{~cm}$ in long dimension; many of the shells are much smaller.

In summary, the following features characterize the fauna of the lower slope unit: (1) predominance of Composita and Anthracospirifer, (2) absence of productoid brachiopods, (3) high diversity locally of molluscs and brachiopods in the lower 13 feet but rather monotonous assemblage of relatively few species throughout most of the unit, and (4) scarcity of large shells. 


\section{FAUNA OF THE MIDDLE CLIFF UNIT}

In contrast to that of the lower slope unit, the fauna of the middle cliff unit is composed of species that generally grow to a size greater than $2.5 \mathrm{~cm}$. This coincides with a predominance of shallow water limestone, indicating optimum conditions for the development of shelf-dwelling organisms. Anthracospirifer occiduus is by far the most abundant species, at least in the vicinity of Guano Cave, where a virtual coquina of these shells occurs locally. Productoid brachiopods are fairly common in some beds and at least five species have been recognized. The unit can be divided roughly into two parts stratigraphically by the larger Linoproductus species. L. sp. A occurs in the lower half and L. nodosus (Newberry) is restricted to the upper half. Molluscan species in this unit also tend to be larger than those in the lower slope unit.

In summary, the middle cliff unit is characterized by (1) fairly large brachiopods and mollusks, (2) presence of several species of productoids, (3) great abundance locally of Anthracospirifer occiduus (Sadlick), and (4) moderate diversity of species.

\section{FAUNA OF THE UPPER SLOPE UNIT}

Beds assigned to the upper slope unit of the Watahomigi Formation (see table C2) have yielded fossils at three localities: in the Hidden Canyon and Guano Cave sections (USGS collns. 22231-PC, 25130-PC, and one numbered) and on the east side of Toroweap Valley (USGS colln. 21579-PC). The fossils from these localities are listed on table F1, but it might be helpful to list them separately here. A composite list of the fossils identified in the five collections is as follows:

Trepostomatous bryozoan, ramose form

Stenoporoid, incrusting form

Fenestella? sp. indet.

Rhomboporoid bryozoan

Orbiculoidea meekana (Whitfield)

Orthotetacean, gen. \& sp. indet.

Pulchratia? picuris Sutherland and Harlow

Rhynchonelloid cf. Cupulorostrum sp.

Composita ovata Mather

Crurithyris planoconvexa (Hall)

Anthracospirifer tanoensis Sutherland and Harlow

A. newberryi Sutherland and Harlow

Promytilus sp.

Myalina (Myalina) sp. B
Myalinid, gen. \& sp. indet.

Aviculopecten gravidus Gordon and Pojeta?

Echinoid spines

Crinoid columnals

Paladin sp.

Deltodus mercurii Newberry

Deltodus sp.

It is clear from the foregoing list of fossils, many of which occur also in lower beds, that the megafauna is of little use to distinguish beds of Atokan age from those of Morrowan age. Only when distinctive restricted species, such as Linoproductus nodosus, are present is this possible. The dating of the upper slope unit as Atokan has had to rely on fusulinid evidence.

\section{CORRELATION WITH THE TYPE MORROWAN AND ATOKAN}

The lower slope and middle cliff units of the Watahomigi Formation contain typical Morrowan brachiopods including Schizophoria altirostris (Mather), Pulchratia? picuris Sutherland and Harlow, Linoproductus nodosus (Newberry), L. sp. A, L. pumilis Sutherland and Harlow, Composita gibbosa Mather, C. ovata Mather, Anthracospirifer tanoensis Sutherland and Harlow, A. newberryi Sutherland and Harlow, A. occiduus Sadlick, and Punctospirifer transversus (McChesney). Although some of these have ranges that extend either above or below the Morrowan, their occurrence in association is typical of a fauna of Morrowan age.

Among the species restricted to rocks of Morrowan age are Linoproductus nodosus (Newberry) and L. sp. A. These are part of continuum, in the opinion of T.W. Henry (oral commun., 1976), who has been studying the Morrowan brachiopod faunas in Arkansas and Oklahoma. This evolutionary line began with $L$. eastoni Gordon in the lower Morrowan Hale Formation. L. eastoni was originally described by Gordon (1975, p. D51) from the Cameron Creek Member of the Tyler Formation of Montana and the Amsden Formation of Wyoming; T. W. Henry (oral commun., 1976) has recognized it in the Hale Formation. The three species in this continuum have convex ventral areas that bear coarse spines. In $L$. eastoni, the coarse spines of the ventral area are accompanied by finer spines ornamenting the flanks.

In the Brentwood Limestone Member, which constitutes the lower part of the Bloyd Shale in the type Morrowan section, $L$. eastoni is replaced by $L$. sp. A, which bears a zigzag row of coarse spines on the venter, forming a band 1 
$\mathrm{cm}$ wide; no spines are present on the flanks (Henry and Sutherland, 1977, pl. 2, fig. 5).

In the upper Morrowan Dye Shale, Kessler Limestone, and Trace Creek Shale Members of the Bloyd Shale $L$. sp. A has evolved into $L$. nodosus, which bears a linear median row of coarse spines. The upper Morrowan beds are Middle Pennsylvanian in age and this stratigraphic interval coincides approximately with the range zone of $L$. nodosus, the name bearer of the Linoproductus nodosus Zone (Sutherland and Henry, 1975, p. 274; Henry and Sutherland, 1977, p. 110).

In the Watahomigi Formation, L. nodosus is confined to the upper part of the middle cliff unit, where it has been found at two localities. $L$. sp. A occurs lower down in the middle cliff at three localities; it is a late form of this species, having the spine band roughly $0.5 \mathrm{~cm}$ wide.

The lower $13 \mathrm{ft}$ of the formation contains faunas of considerable diversity in the Snap, Separation, Bridge, and National Canyon sections. The writer has observed that the greatest faunal diversity in Morrowan rocks in the type region (Arkansas) is found in the Brentwood Limestone Member of the Bloyd Shale. The considerable faunal diversity of these lower Watahomigi collections, the absence of species known to be restricted to the Hale Formation, and the relatively advanced development of Anthracospirifer tanoensis in this lower part of the formation lead the writer to conclude that the lower slope unit of the Watahomigi Formation should be correlated principally with the Brentwood Limestone Member of the Bloyd Shale and that no Hale equivalents are present.

To summarize, the lower slope unit of the Watahomigi and the lower part of the middle cliff unit are middle Morrowan and correlate with the Brentwood-Woolsey part of the type Morrowan section in Arkansas (see fig. F1). The upper part of the middle cliff unit, containing Linoproductus nodosus, is late Morrowan in age. The relatively minor thickness of these late Morrowan beds in the Watahomigi and the presence of the widely distributed conglomerate bed above suggest that a hiatus is present and that part of the Morrowan is missing.

The presence of Profusulinella and Fusulinella in collections from the upper slope unit of the Watahomigi, identified by Douglass, indicates an early Atokan age for this unit. However, as these are reworked (R. C. Douglass, oral commun., 1978) and occur virtually together, it is entirely possible that the Profusulinella Zone actually is not represented and the upper part of the Watahomigi begins in the Fusulinella Zone. Profusulinella is not known in the Atoka Formation in Arkansas, but has been reported from the Barnett Hill Formation, the lowest unit of Atokan age in Coal County, Oklahoma. As Fusulinella has been found in the Atoka Formation in Crawford County, Arkansas, as low as the Winslowoceras henbesti Ammonoid Zone, roughly $590 \mathrm{ft}$ above the base, the earlier zone of Pro- fusulinella should be sought in older parts of the formation. It should coincide with part of the Diaboloceras varicostatum Zone and occur in the basal few hundred feet of the formation (Gordon and Sutherland, 1975).

\section{CORRELATION WITH OTHER WESTERN AMERICAN FORMATIONS}

Other western strata that were deposited at about the same time as the Watahomigi Formation include the following (see fig. F1): the middle part of the Ely Limestone in eastern Nevada and western Utah, the upper and thicker part of the Lake Point Limestone in the northern Oquirrh Mountains, Utah, and the upper part of the West Canyon Limestone of the Oquirrh Group, and also the basal part of the overlying Butterfield Peaks Formation in the central and southern Oquirrh Mountains. Eastward, the equivalents of the Watahomigi include the lower part of the La Pasada Formation of north-central New Mexico. In the northern Arbuckle Mountains of Oklahoma, the Wapanucka Limestone and overlying Barnett Hill Formation are Watahomigi equivalents and, in the southern Arbuckle Mountains, the Golf Course Formation (excluding the lower part of the Primrose Sandstone Member), as well as the overlying Bostwick Conglomerate Member of the Lake Murray Formation. In the nearby Ouachita Mountains region, the Johns Valley Shale and the overlying basal part of the Atoka Formation are Watahomigi equivalents and, as stated earlier, the Bloyd Shale and basal part of the Atoka Formation in the southern part of the Ozark region.

\section{CORRELATION WITH STANDARD EUROPEAN SECTIONS}

The ammonoids of the type Morrowan section permit correlation with the standard European Carboniferous succession. A recent comparison of the Arkansas succession with that of Europe (Saunders and others, 1977) indicates that the ammonoids of the Bloyd Shale have their equivalents in the Westphalian A and lower part of Westphalian $B$ Substages. The lower and middle units of the Watahomigi are probably of Westphalian A age. The upper beds of Atokan age within the Watahomigi Formation would probably be Westphalian B equivalents (fig. F1).

Correlations by means of ammonoids with stratigraphic sections in the European part of the Soviet Union indicate that the Arkansas beds equivalent to the Watahomigi Formation are correlative to the Bashkirian Provincial Stage 


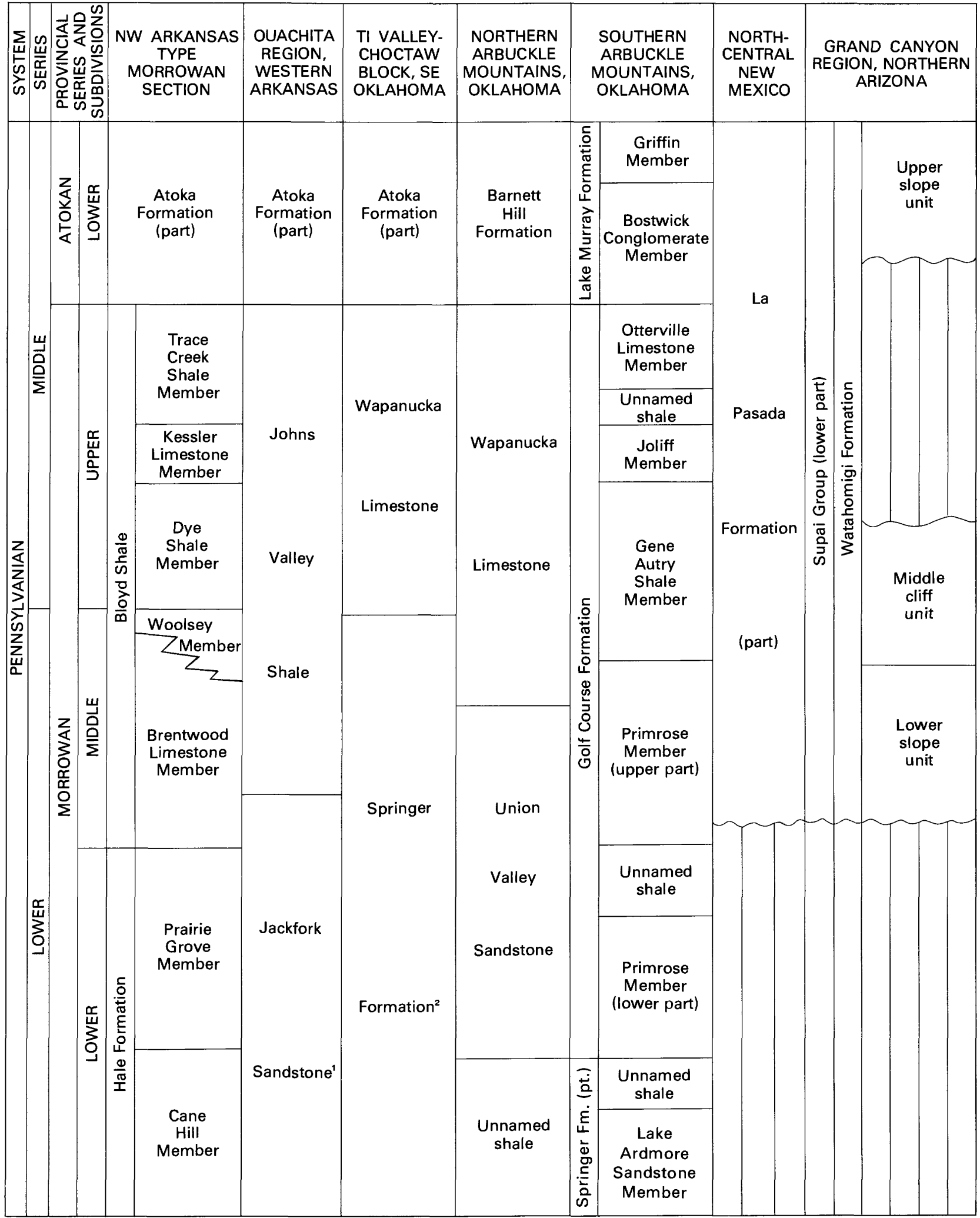




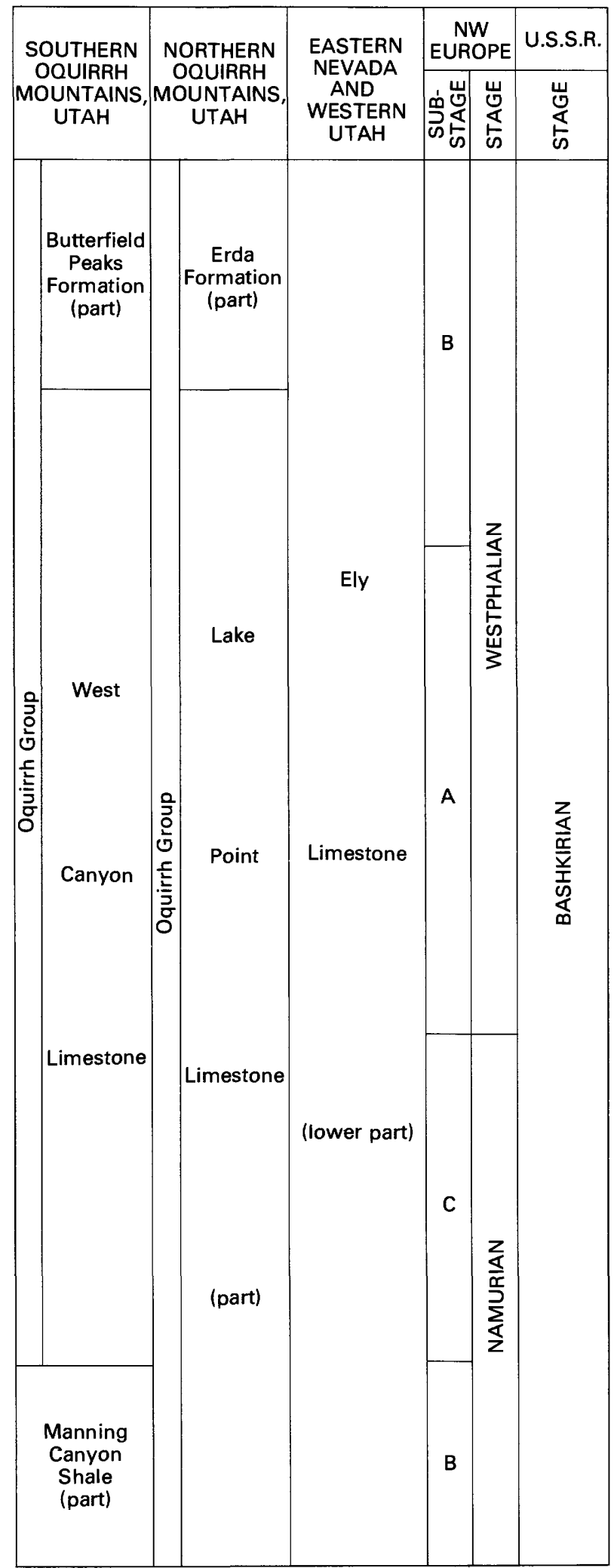

south-central and southwestern United States. of the southern Ural Mountains, as originally defined. In 1974, the base of the Bashkirian was officially lowered to coincide with the base of the middle Carboniferous (same as the base of the Pennsylvanian System in the United States). The new Bashkirian Stage includes equivalents of the Hale Formation, as well as the higher beds (fig. F1). Thus, the lower part of the Bashkirian Stage as presently defined includes beds older than the base of the Watahomigi, but the top of the Bashkirian and top of the Watahomigi are roughly equivalent.

\section{CLIMATE}

The presence in the Watahomigi Formation of numerous myalinid pelecypods as well as fusulinids suggests that the waters of the Early and early Middle Pennsylvanian seas in this region were shallow and fairly warm. In this regard, the total absence of rugose solitary corals and the scarcity of colonial corals is puzzling, but may have been due to local high-energy conditions and to excessive amounts of silt and sand being deposited along with the carbonates.

\section{PALEOGEOGRAPHIC CONSIDERATIONS}

The fossil evidence permits one to draw several relatively firm conclusions as to the sequence of geologic events in the Grand Canyon region during the period of Watahomigi deposition. The beginning of the Pennsylvanian found the Grand Canyon region a positive area, elevated above sea level. Watahomigi marine deposition probably commenced in Brentwood (middle Morrowan) time on a deeply eroded surface mainly of Meramecian, but also of Chesterian, rocks. This submergence and beginning of deposition correlates with a period of intense tectonic activity in the Ouachita trough in southeastern Oklahoma, when many huge erratic blocks derived from earlier formations were loosened by the development of growth faults along the Ouachita frontal belt and slid into the trough (Gordon and Stone, 1977).

The presence in the Watahomigi of species such as Aviculopecten gravidus Gordon and Pojeta, previously known only from the Amsden Formation of Wyoming, and Schizodus amplus Meek and Worthen, a characteristic Midcontinent pelecypod, indicates that links were established at that time with seas on both sides of the transcontinental arch that divided the waters of the great Cordilleran sea in the West from the even larger eastern interior sea, which lay between the arch and the Appalachian highland and at times covered much of the American Midcontinent. 
How long a time the Grand Canyon region remained above sea level, during the depositional hiatus marked by the conglomerate at the base of the upper slope unit of the Watahomigi, is not clear. As stated earlier, a considerable part of the upper Morrowan probably is missing; also, the fusulinid evidence indicates that beds of earliest Atokan age may likewise be absent. Nevertheless, at some moment early in the Atokan, the region was again shallowly submerged and deposition of the upper part of the Watahomigi as well as the entire Manakacha Formation took place without further interruption.

\section{REFERENCES CITED}

Gordon, Mackenzie, Jr., 1975, Brachiopoda of the Amsden Formation (Mississippian and Pennsylvanian) of Wyoming: U.S. Geological Survey Professional Paper 848-D, 86 p.

Gordon, Mackenzie, Jr., and Pojeta, John, Jr., 1975, Pelecypoda and rostroconchia of the Amsden Formation (Mississippian and Pennsylvanian) of Wyoming: U.S. Geological Survey Professional Paper 848-E, $24 \mathrm{p}$.

Gordon, Mackenzie, Jr., and Stone, C. G., 1977, Correlation of the Carboniferous rocks of the Ouachita trough with those of the adjacent foreland, in Symposium on the geology of the Ouachita Mountains, v. 1, Stratigraphy, sedimentology, petrography, tectonics, and paleontology: Arkansas Geological Commission, p. 70-91.
Gordon, Mackenzie, Ir., and Sutherland, P. K., 1975, Ammonoids of the upper Wapanucka Limestone and their bearing on the MorrowanAtokan boundary in Oklahoma [abs.]: American Association of Petroleum Geologists and Society of Economic Paleontologists and Mineralogists, Annual Meeting Abstracts, v. 2, p. 30.

Henry, T. W., and Sutherland, P. K., 1977. Brachiopod biostratigraphy of Morrowan Series (Pennsylvanian) in northwestern Arkansas and northeastern Oklahoma in P. K. Sutherland and W. L. Manger, eds., Mississippian-Pennsylvanian boundary in northeastern Oklahoma and northwestern Arkansas: Oklahoma Geological Survey Guidebook 18, p. 107-115.

McKee, E. D., 1963, Nomenclature for lithologic subdivisions of the Mississippian Redwall Limestone, Arizona in Geological Survey Research, 1963: U.S. Geological Survey Professional Paper 475-C, p. C28-C29.

McKee, E. D., and Gutschick, R. C., 1969, History of the Redwall Limestone of northern Arizona: Geological Society of America Memoir $114,726 \mathrm{p}$

Saunders, W. B., Manger, W. L., and Gordon, Mackenzie, Jr., 1977, Upper Mississippian and Lower and Middle Pennsylvanian ammonoid biostratigraphy of northern Arkansas, in P. K. Sutherland and W. L. Manger, eds., Mississippian-Pennsylvanian boundary in northeastern Oklahoma and northwestern Arkansas: Oklahoma Geological Survey Guidebook 18, p. 117-132.

Sutherland, P. K., and Harlow, F. H., 1973, Pennsylvanian brachiopods and biostratigraphy in southern Sangre de Cristo Mountains, New Mexico: New Mexico Bureau of Mines and Mineral Resources Memoir 27, $173 \mathrm{p}$

Sutherland, P. K., and Henry, T. W., 1975, Brachiopod zonation of the Lower and Middle Pennsylvanian System in the United States of America [abs.]: International Congress on Stratigraphy and Carboniferous Geology, 8th, Moscow, 1975, Abstracts of Papers, p. 274-275. 



\section{PLATE F1}

Brachiopods

[Figures natural size unless otherwise indicated on plate]

FIGURES 1, 2. Orbiculoidea meekana (Whitfield)

Ventral and side views of ventral valve internal mold showing patches of shell (USNM 256803), east side of Toroweap Valley, USGS colln. 21579-PC, upper slope unit.

3-5. Schizophoria altirostris (Mather)?

Side and dorsal views of poorly preserved brachial valve (USNM 256804) and ventral view of pedicle valve (USNM 256805), Guano Cave section, USGS colln. 25324-PC, middle cliff unit.

6, 7. Orthotetes sp. A

Ventral view and interarea of pedicle valve (USNM 256806) from Twin Springs Canyon, USGS colln. 21581-PC, lower slope unit.

8-10. Derbyia sp. A

Dorsal view of one specimen and side and ventral views of another (Grand Canyon Museum, nos. 4714 and 20595) Parashant Canyon, lower slope unit.

11, 17-19. Buxtonia? sp.

Side, ventral, enlarged ventral, and posterior views of a pedicle valve (USNS 256807) from Hidden Canyon, USGS colln. 22228-PC, middle cliff unit.

12-16. Linoproductus nodosus (Newberry)

12-14. Posterior, ventral, and side views of pedicle valve (USNM 256812) from Guano Cave section, USGS colln. 21576-PC, middle cliff unit.

15, 16. Ventral and side views of pedicle valve (USNM 256813) from Snap Canyon, USGS colln. 22270-PC, same unit.

20-22. Linoproductus pumilis Sutherland and Harlow

Enlarged ventral, anterior, and side views of pedicle valve (USNM 256814) from Guano Cave section, USGS colln. 25324-PC, middle cliff unit.

23-25. Buxtonia sp.

23. Ventral view of brachial valve (USNM 256808) from Guano Cave section, USGS colln. 25324-PC, middle cliff unit.

24,25 . Side and ventral views of incomplete pedicle valve attached to brachial valve (USNM 256809) from Snap Canyon, USGS colln. 22270-PC, same unit.

26-32. Pulchratia? picuris Sutherland and Harlow

26-29. Posterior, ventral, anterior, and side views of pedicle valve (USNM 256810) from Guano Cave section, USGS colln. 25324-PC, middle cliff unit.

30-32. Ventral, side, and enlarged ventral views of another pedicle valve (USNM 256811) from Snap Canyon, USGS colln. 22270-PC, same unit. 
GEOLOGICAL SURVEY

PROFESSIONAL PAPER 1173 PLATE F1
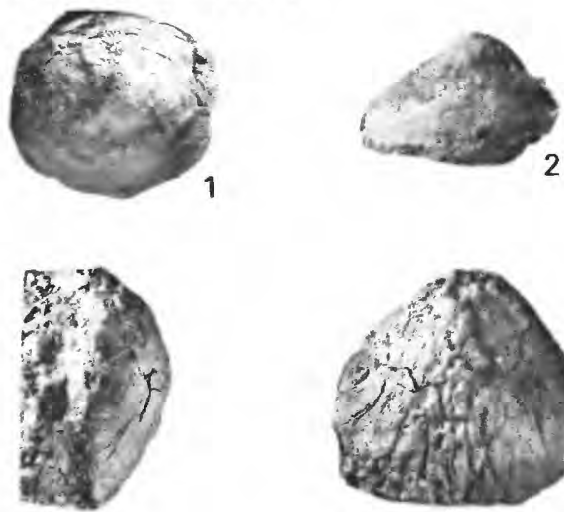

3
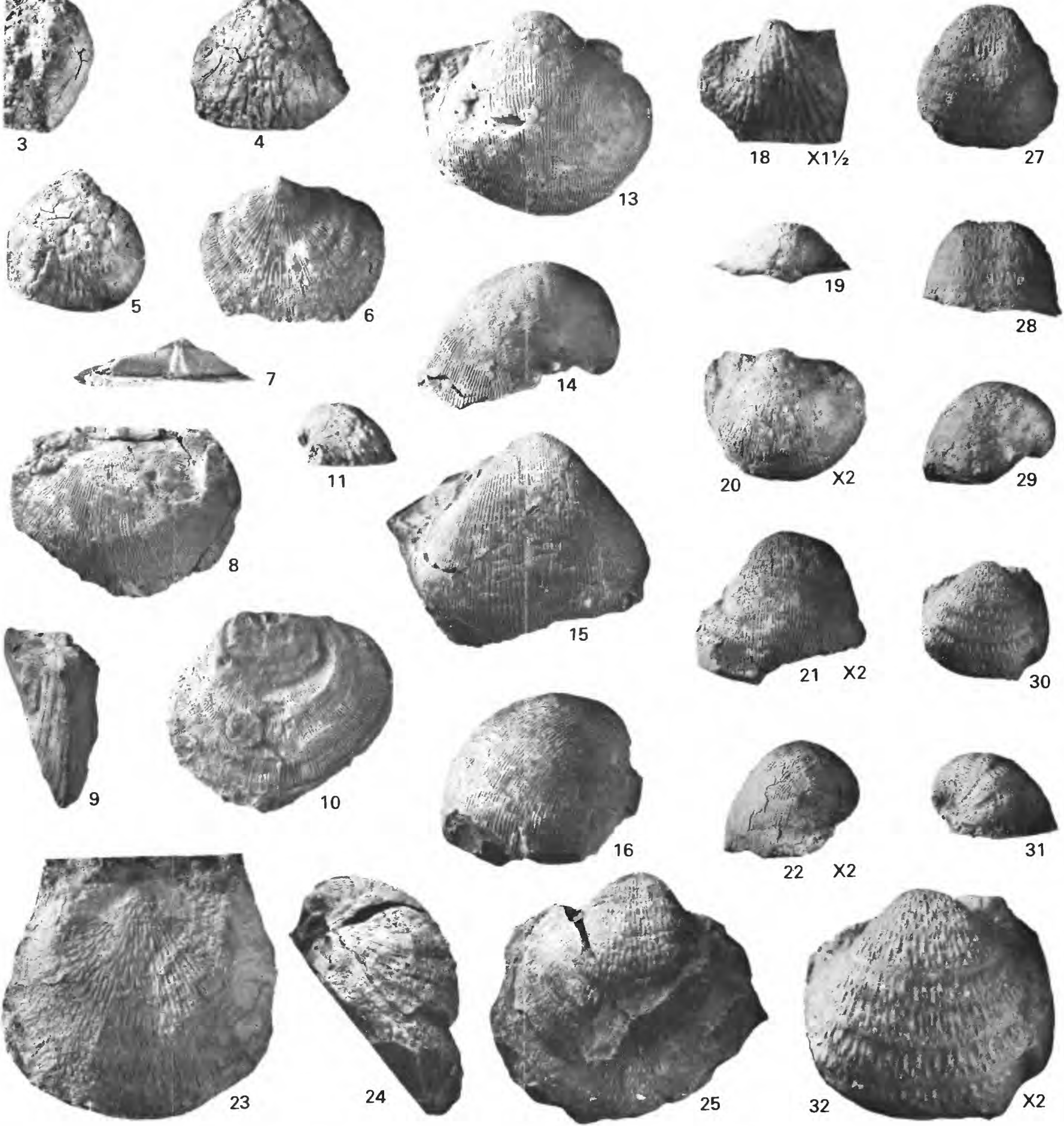

ORBICULOIDEA, SCHIZOPHORIA, ORTHOTETES, DERBYIA, BUXTONIA, LINOPRODUCTUS, AND PULCHRATIA 


\section{PLATE F2 \\ Brachiopods \\ [Figures natural size unless otherwise indicated on plate]}

FIGURES 1-6. Crurithyris planoconvexa (Shumard)

Enlarged posterior, dorsal, enlarged dorsal, side, ventral, and anterior views of well-preserved specimen (Grand Canyon Museum GC-224A) from Guano Cave section, upper slope unit.

7-16. N. gen. aff. Anteridocus, n. sp.

Enlarged posterior, dorsal, side, ventral, and anterior views of one specimen (USNM 256815) and enlarged dorsal, posterior, side, anterior, and ventral views of another (USNM 256816) from National Canyon, USGS colln. 25127-PC, lower slope unit.

17-31. Composita ovata Mather

Dorsal, posterior, ventral, side, and anterior views of two specimens (USNM 256817, 256818) from Whitmore Wash, USGS colln. 22235-PC, lower slope unit.

Enlarged dorsal, posterior, ventral, side, and anterior views of an immature specimen (USNM 256819) from west side of Toroweap Valley, USGS colln. 22976-PC, lower slope unit.

32-41. Composita gibbosa Mather

Enlarged dorsal, posterior, ventral, side, and anterior views of two specimens (Grand Canyon Museum, nos. 15244, 15252) from Parashant Canyon, lower slope unit.

42-46. Dielasmoid, gen. and sp. indet.

Enlarged dorsal, posterior, ventral, side, and anterior views of a specimen (USNM 256833) from National Canyon, USGS colln. 25127-PC, lower slope unit. 

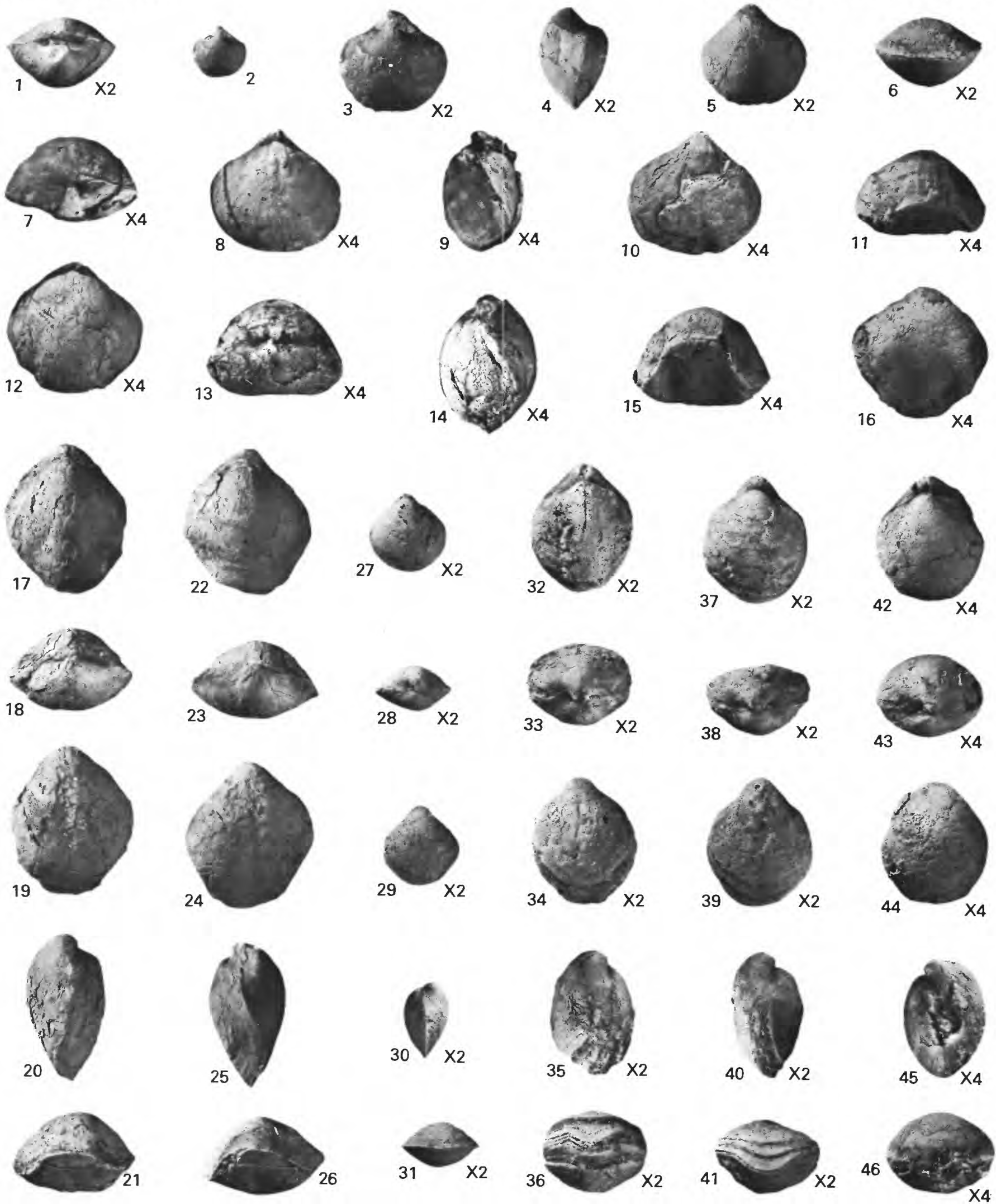


\section{PLATE F3 \\ Brachiopods \\ [Figures natural size unless otherwise indicated on plate]}

FIGURES 1-5. Composita sp. (transverse form)

Dorsal, posterior, ventral, anterior, and side views of a large individual (USNM 256820) from Guano Cave section, USGS colln. 25324-PC, middle cliff unit.

6, 7. Composita subtilita (Hall)

Ventral and side views of pedicle valve (USNM 256821) from same collection as last.

8-16. Anthracospirifer occiduus (Sadlick)

Ventral view of one specimen, dorsal, ventral, anterior, and side views of another specimen, dorsal and anterior views of a third, and anterior and ventral views of a fourth (USNM 256822-256825, inclusive) from Guano Cave section, USGS colln. 25324-PC, middle cliff unit.

17-19. Anthracospirifer tanoensis Sutherland and Harlow

Anterior and ventral views of pedicle valve (USNM 256826) from Hidden Canyon, USGS colln. 22226-PC (float); unit not known.

Dorsal view of brachial valve, (USNM 256827) from west side of Toroweap Valley, USGS colln. 22976-PC, lower slope unit.

20, 21. Anthracospirifer newberryi Sutherland and Harlow

Pedicle valve (USNM 256828) from Guano Cave section, USGS colln. 25130-PC, upper slope unit.

Brachial valve (USNM 256829) from same collection as last.

22-24. Punctospirifer transversus (McChesney)

Enlarged views of brachial and pedicle valves (USNM 256830, 256831) from Whitmore Wash, USGS colln. 22235-PC, lower slope unit.

Slab (USNM 256832) from west side of Toroweap Valley (enlarged), USGS colln. 22978-PC, lower slope unit. 
GEOLOGICAL SLRVEY
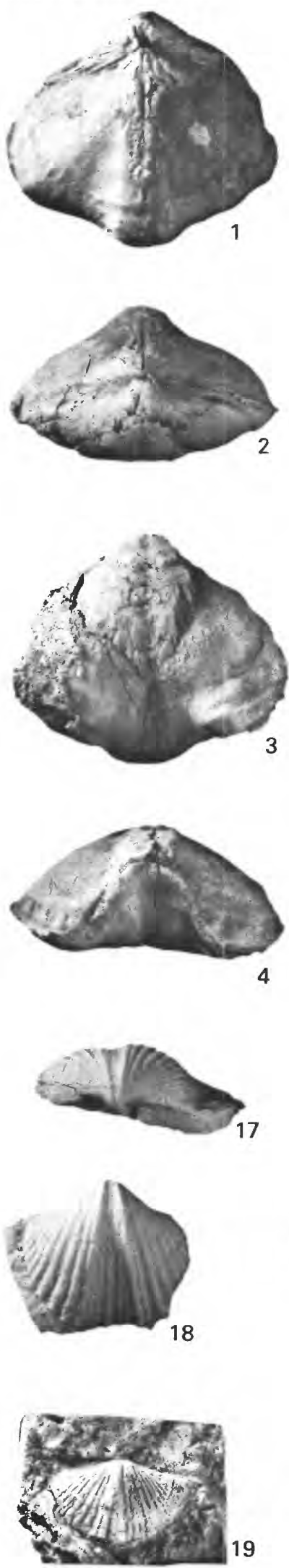

19
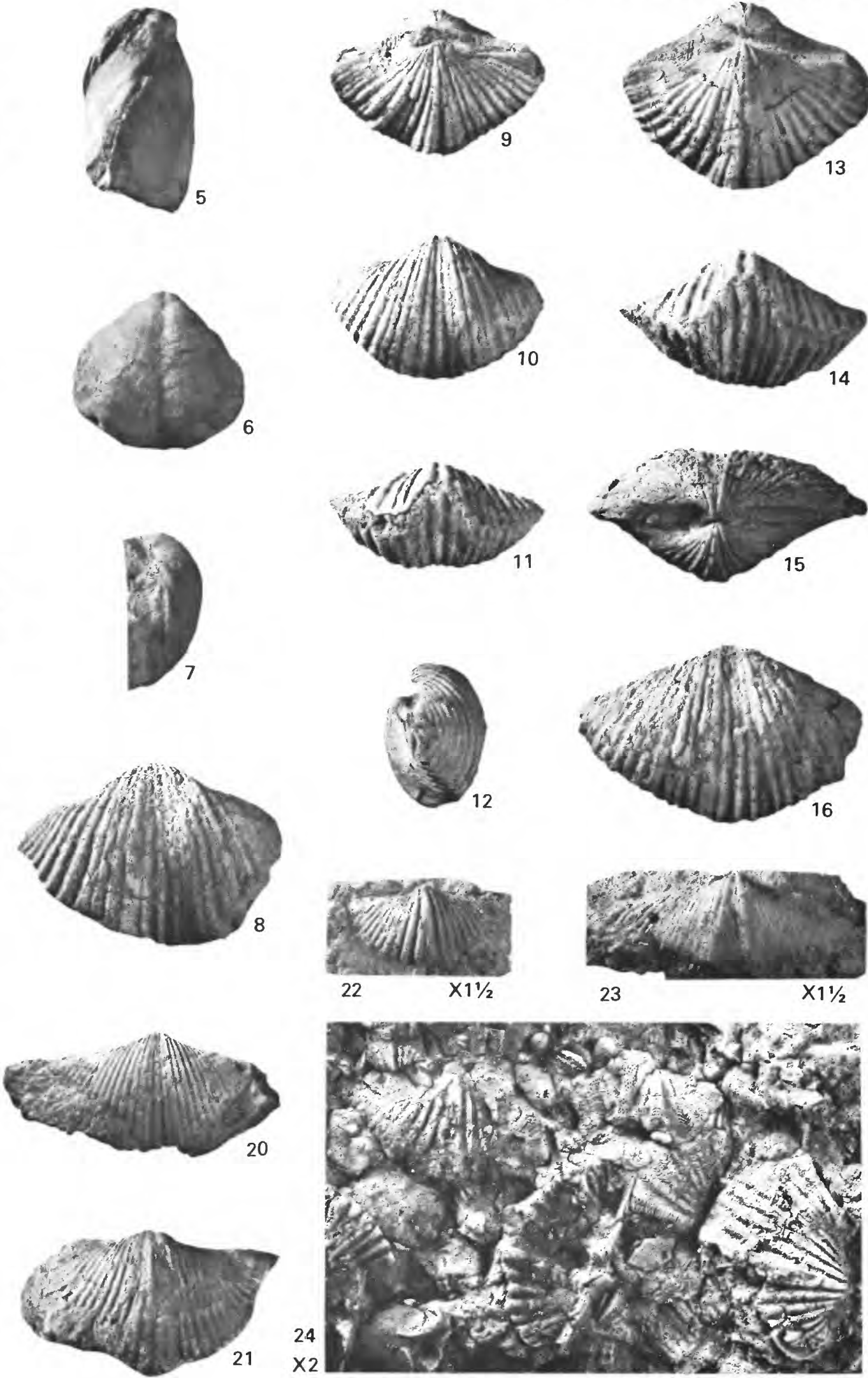


\section{PLATE F4}

Pelecypods and gastropods

[Figures natural size unless otherwise indicated on plate]

FIGURES 1, 4. Phestia sp.

Left valve of moderately large specimen (USNM 256836) from Guano Cave section, USGS colln. 25324-PC, middle cliff unit.

Left valve of small juvenile specimen (USNM 256835) from Bridge Canyon section, USGS colln. 27031-PC, lower slope unit.

2, 3. Nuculopsis (Nuculanella) sp.

Enlarged views of left valve and dorsum of a specimen (USNM 256834) from same collection as last.

5, 6. Aviculopecten sp. B

Left valve and enlarged view of same (USNM 256841) from Snap Canyon section, USGS colln. 22267-PC, lower slope unit.

7, 8. Septimyalina sp. A

Enlarged views of right valve and dorsum of same specimen (USNM 256839) from National Canyon, USGS colln. 25127-PC, lower slope unit.

9, 10. Myalina (Myalina) sp. A

Top view of paired valves and view of left valve of same specimen (Grand Canyon Museum, no. 11212) from east side of Toroweap Valley, McKee locality FS44, upper slope unit.

11. Promytilus sp.

Enlarged view of right valve (USNM 256837) from Bridge Canyon section, USGS colln. 27031-PC, lower slope unit.

12. Myalina (Myalina) sp. B

Left valve (USNM 256838) from Snap Canyon, USGS colln. 22267-PC, lower slope unit.

13. Septimyalina sp. B

Left valve (USNM 256840) from Guano Cave section, USGS colln. 25324-PC, middle cliff unit.

14. Edmondia? sp.

Right valve in chert (Museum of Northern Arizona, no. G2 6734) from section south of Pica, bed 5, lower slope unit.

15, 16. Permophorus sp.

Right valve and enlargement of same (USNM 256848) from Separation Canyon, USGS colln. 25139-PC, lower slope unit.

17. Aviculopecten gravidus Gordon and Pojeta

Enlarged view of left valve (USNM 256842) from Bridge Canyon section, USGS colln. 27031-PC, lower slope unit.

18. Schizodus sp. B

Left valve (USNM 256847) from Hidden Canyon section, USGS colln. 22227-PC, lower slope unit.

19. Schizodus sp. A

Left valve (USNM 256846) from Snap Canyon section, USGS colln. 2267-PC, lower slope unit.

20-22. Schizodus amplus Meek and Worthen

Left valve (USNM 256843) from Snap Canyon section, USGS colln. 2267-PC, lower slope unit.

Right valve (USNM 256844) from Guano Cave section, USGS colln. 25324-PC, middle cliff unit.

Internal mold of right valve, showing impression of internal ridge alongside posterior adductor muscle scar (USNM 256845) from Hidden Canyon section, USGS colln. 22227-PC, middle cliff unit.

23-27. Microdoma n. sp.

Enlarged top, bottom, and apertural views of specimen (USNM 256850) from Bridge Canyon section, USGS colln. 27031-PC, lower slope unit.

Enlarged side and top views of another specimen (USNM 256851) from same collection.

28. Wilkingia terminalis (Hall)

Left valve (USNM 256849) from Guano Cave section, USGS colln. 25324-PC, middle cliff unit. 
GEOLOGICAL SURVEY
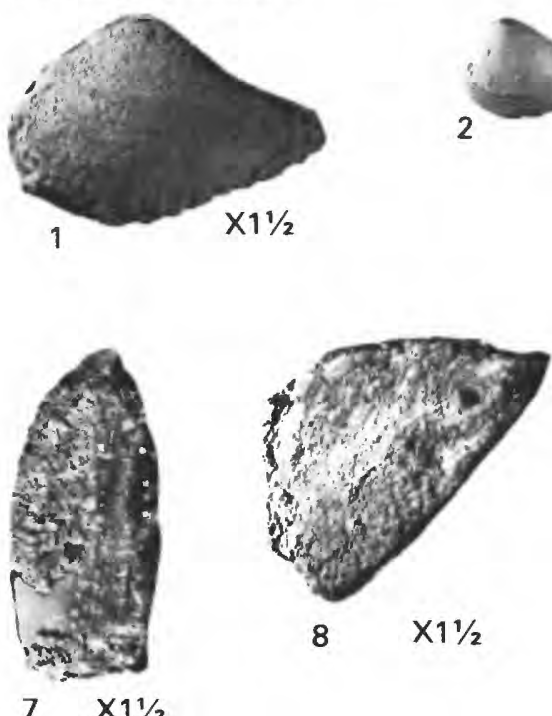
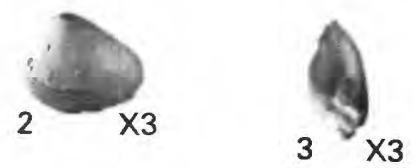

PROFESSIONAL PAPER 1173

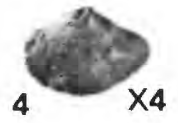

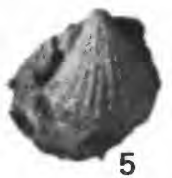

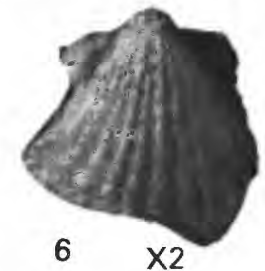

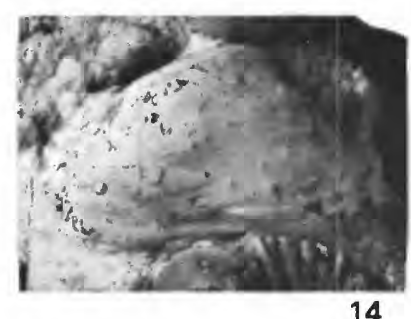
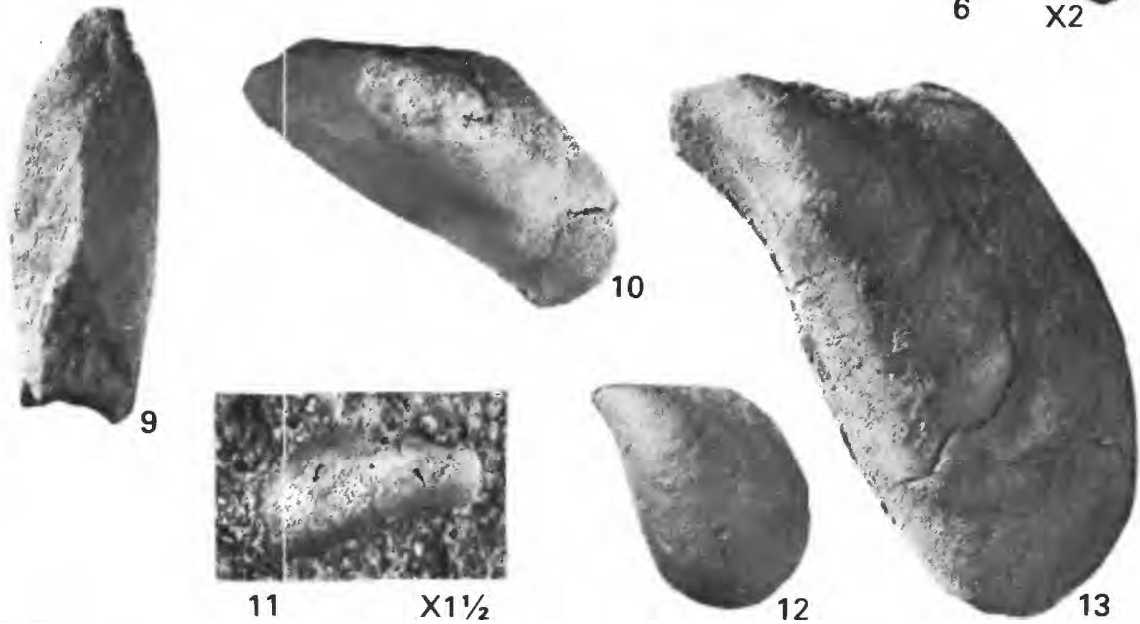

11

$\mathrm{X} 1 \mathrm{1} / 2$
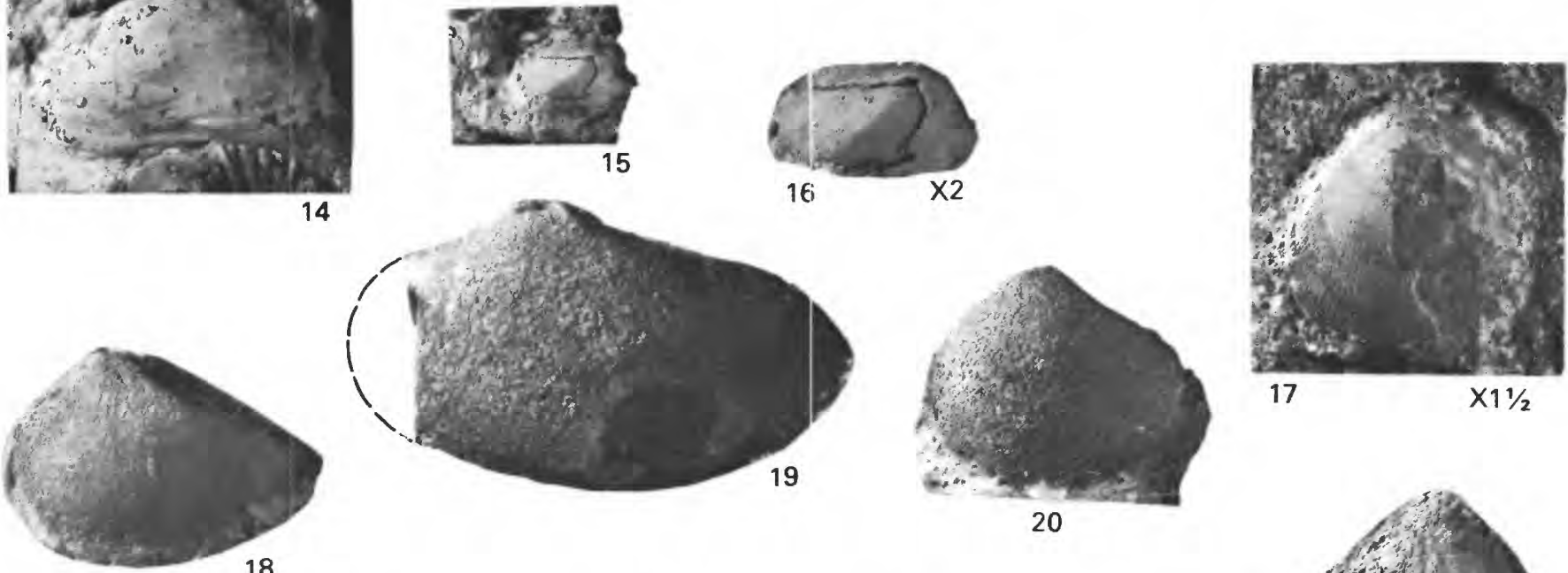

17

$X 11 / 2$
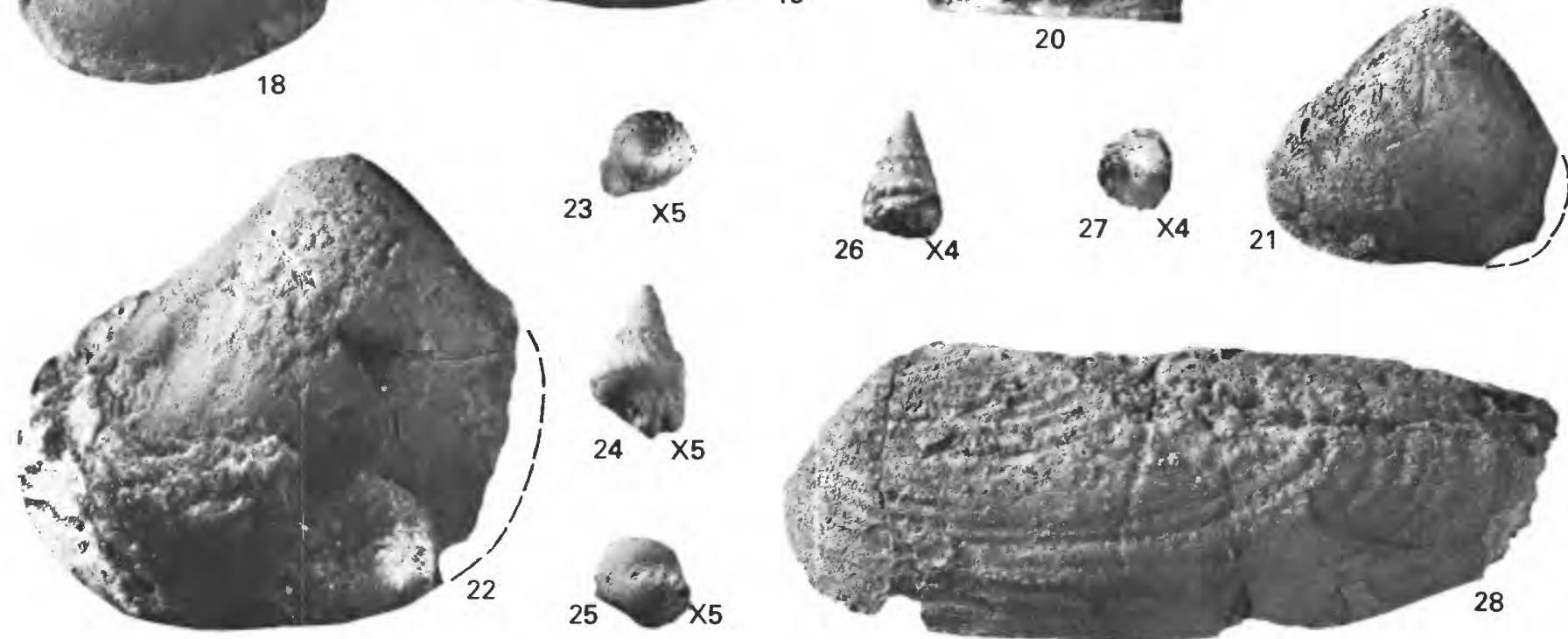

PHESTIA, NUCULOPSIS, AVICULOPECTEN, SEPTIMYALINA, MYALINA, PROMYTILUS, EDMONDIA , PERMOPHORUS, SCHIZODUS, MICRODOMA, AND WILKINGIA 


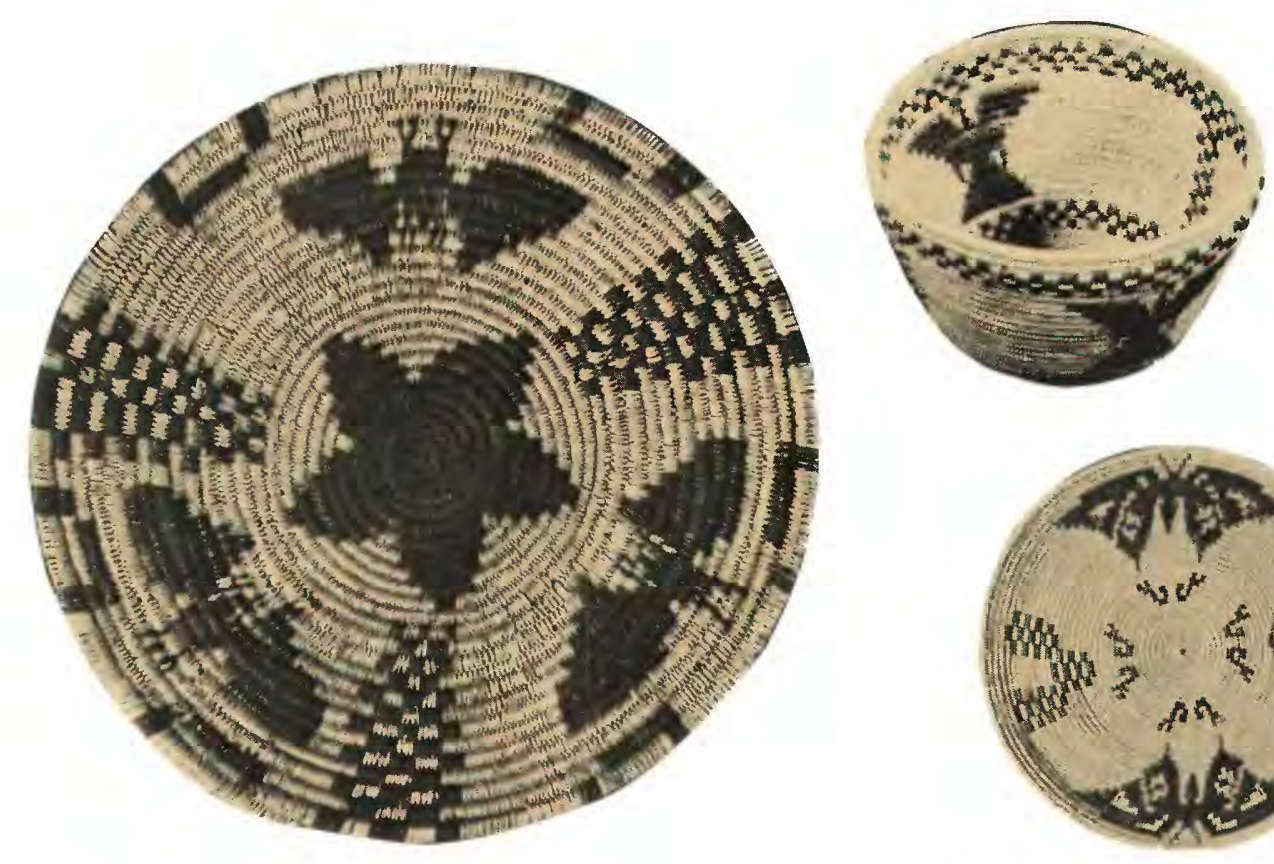

THE SUPAI GROUP OF GRAND CANYON

\section{PRE-SUPAI BURIED VALLEYS}

Chapter G

By GEORGE H. BILLINGSLEY and EDWIN D. McKEE

\section{Contents}

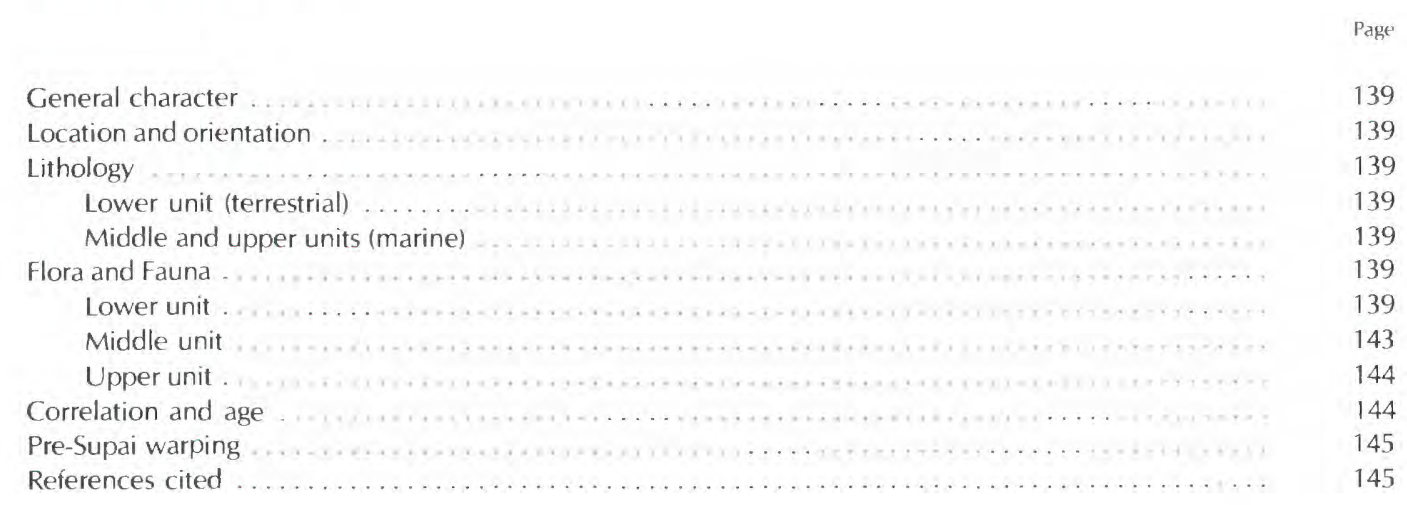




\section{Illustrations}

FIGURE G1. Photograph of buried valley deposits below Watahomigi Formation near Quartermaster Canyon.

G2. Photograph of buried valley deposits below Watahomigi Formation at 217 Mile Canyon . .

G3. A map of western part of Grand Canyon showing localities of principal pre-Supai valleyfill outcrops .................................. 141

G4. Generalized stratigraphic sections of principal pre-Supai valley deposits $\ldots \ldots$

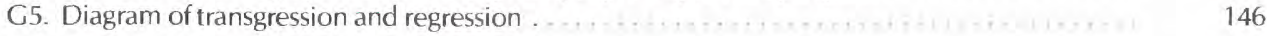

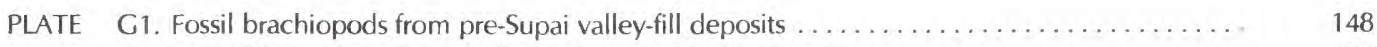

G2. Assemblage of small invertebrates in coquinoid limestone . . . . . . . . . . . . . . . . . . 150

G3. Foraminifera in the upper unit of pre-Supai valley fill deposits . . . . . . . . . . . . . . 152

\section{Tables}

TABLE G1. Depth and width of pre-Supai buried valleys . 


\section{GENERAL CHARACTER}

In much of the Grand Canyon region, basal deposits of the Watahomigi Formation of the Supai Group rest upon a relatively flat and even surface at the top of the Redwall Limestone, as described in chapter C. Mostly the surface is formed on limestone strata of Early Mississippian age (Osagian and Merimecian); features of karst topography and also shallow channels are characteristic.

Recent observations by G. H. Billingsley, made while mapping in western Grand Canyon, have revealed in many places the presence of buried valleys in the Redwall below the conglomerate at the base of the Watahomigi. These valleys average about $1,000 \mathrm{ft}$ in width and $280 \mathrm{ft}$ in depth with a maximum depth of $401 \mathrm{ft}$ near Quartermaster Canyon. Apparently the valleys are parts of an extensive drainage system formed after Redwall deposition had ceased; they were completely filled with sediment, partly marine and partly continental, by the close of Late Mississippian (Chesterian) time.

Implicit in the observed relations of erosion and sedimentation in the pre-Watahomigi valleys are certain tectonic events. The area must have been uplifted more than $400 \mathrm{ft}$ above sea level in the vicinity of Quartermaster Canyon about the middle of Mississippian time to have permitted dissection to that depth. Following uplift and erosion, relative sea level must have changed frequently during Chesterian time, causing first fluvial deposits and later marine deposits to accumulate and fill the valleys. By Early Pennsylvanian (Morrowan) time, the valleys of Chesterian age had been completely filled with sediment and the western sea had transgressed the broad level surface to begin Supai deposition.

\section{LOCATION AND ORIENTATION}

Buried-valley profiles are exposed in the walls of western Grand Canyon (figs. G1, G2) from the towers above Guano Cave, herein called Bat Tower, in the west to Diamond Creek in the east, approximately 40 river miles, and from Diamond Creek in the south to Granite Park in the north, approximately 16 river miles. The seven principal exposures that have been examined are listed with depth and with width (where measured) (table G1), and they are shown on the regional map (fig. G3).

Valley-fill deposits have been correlated from section to section on the basis of lithology, fossils, and rock color. They show lithologic continuity, but considerable variation in thickness. Drainage patterns, pebble imbrication, and the distribution of the fluvial detrital sediments at the base all indicate a westward-flowing drainage system that apparently consisted of two major streams. These streams joined in the vicinity of the present Surprise Canyon to form a single main stream. The northern tributary valley is referred to as the Granite Park valley; the southern tributary valley as Separation valley. Both apparently had small tributaries of their own and contain essentially the same sequence of strata filling them.

\section{LITHOLOGY}

\section{Lower unit (terrestrial)}

The basal unit in most of the valley-fill sequences (fig. G4) consists of detrital sediment considered to be fluvial and composed largely of pebble and cobble conglomerate, and calcareous sandstone.

The conglomerate is composed largely of rounded to subrounded chert pebbles and cobbles, ranging in diameter from 0.25 to 5 in. They are red, yellow, gray, and white, and occur in a matrix of poorly sorted, relatively coarse quartz sand with various types of cement. The cement differs from place to place and includes siliceous, calcareous, and ferrugineous types. The conglomerate is associated with and overlain by pale-yellow and dark-gray calcareous sandstone that is medium to coarse grained and locally cross-stratified. Quartz grains are generally rounded. These deposits contain petrified wood, leaf imprints, spores, and other plant remains. Locally, the color of the sandstone may be dark gray or black because of the abundance of carbonaceous plant fragments.

\section{Middle and upper units (marine)}

The upper part of the buried-valley deposits generally consists of three lithologic units: (1) massive, cliff-forming, thin-bedded, brown to purple limestone; (2) calcareous red-brown sandstone and siltstone; overlain by (3) cliff of an upper, relatively thin, gray limestone (fig. G4). This sequence generally weathers into two weak cliffs separated by a slope. Both limestone units contain marine fossils; the sandstone and siltstone between contain many worm trails and cuspate ripple marks. These marine units together range from about 150 to $300 \mathrm{ft}$ in thickness and, in most places, are thicker than the underlying fluviatile unit.

\section{FLORA AND FAUNA}

\section{Lower unit}

The basal unit of the valley-fill deposits that underlie the Watahomigi Formation locally contains poorly preserved plant remains in its sandstone facies. A collection from these rocks, examined by S. H. Mamay, contained two 


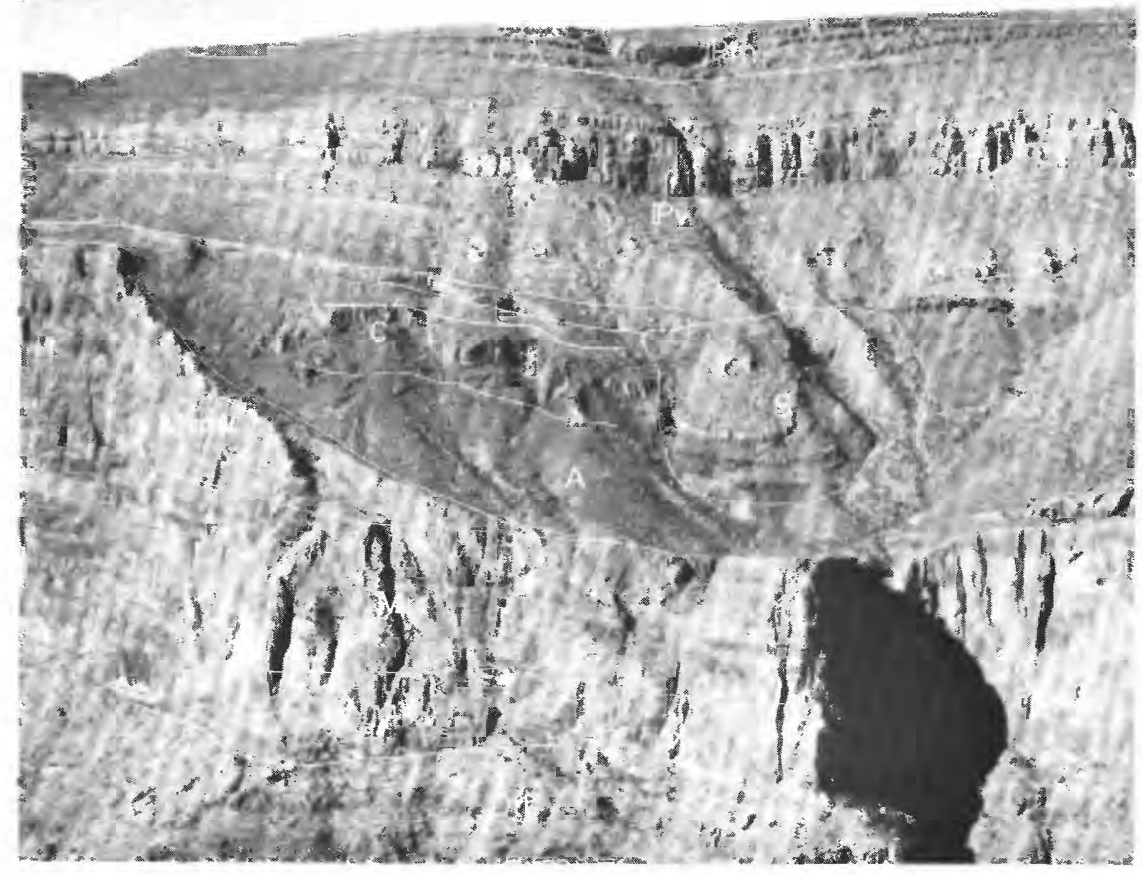

FIGURE G1.-Buried valley deposits below Watahomigi Formation near Quartermaster Canyon, western Grand Canyon, Ariz. Valley width, 1,250 ft; valley depth, $401 \mathrm{ft}$.

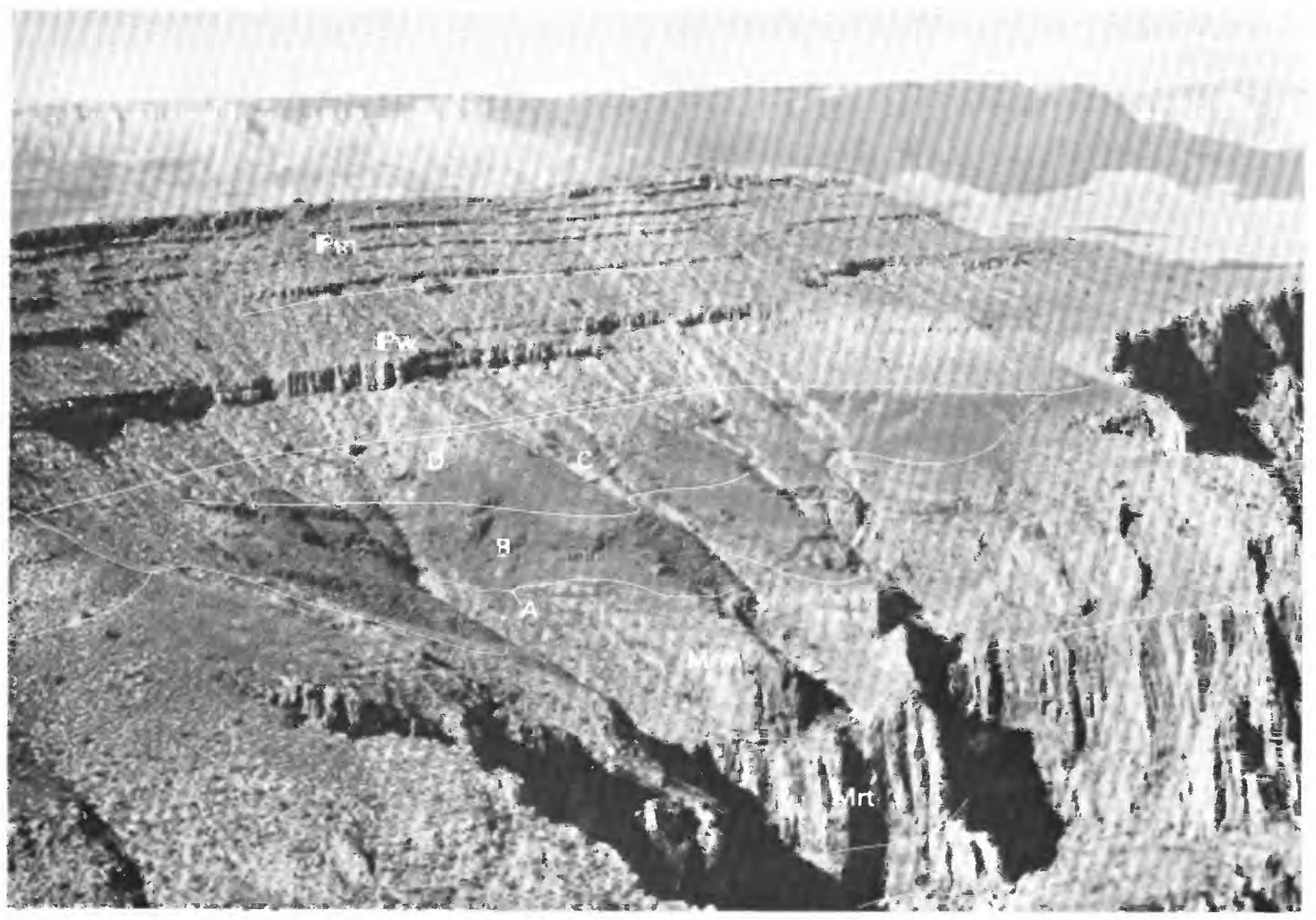

FIGURE G2.-Buried valley below Watahomigi Formation at 217 Mile Canyon, western Grand Canyon, Ariz. Valley depth, $212 \mathrm{ft}$; valley width, $1,050 \mathrm{ft}$. Refer to figure G1 for explanation of symbols. 
EXPLANATION

Buried valley deposits

D Upper unit (limestone cliff)

C Upper unit (sandstone slope)

B Lower limestone Middle unit (limestone cliff)

A Lower unit (sandstone and conglomerate slope)

S Slump block

Pm Manakacha Formation

Pw Watahomigi Formation

Redwall Limestone

Mrm Mooney Falls Member

Mrt Thunder Springs Member

Mrw Whitmore Wash Member

Dtb Temple Butte Limestone

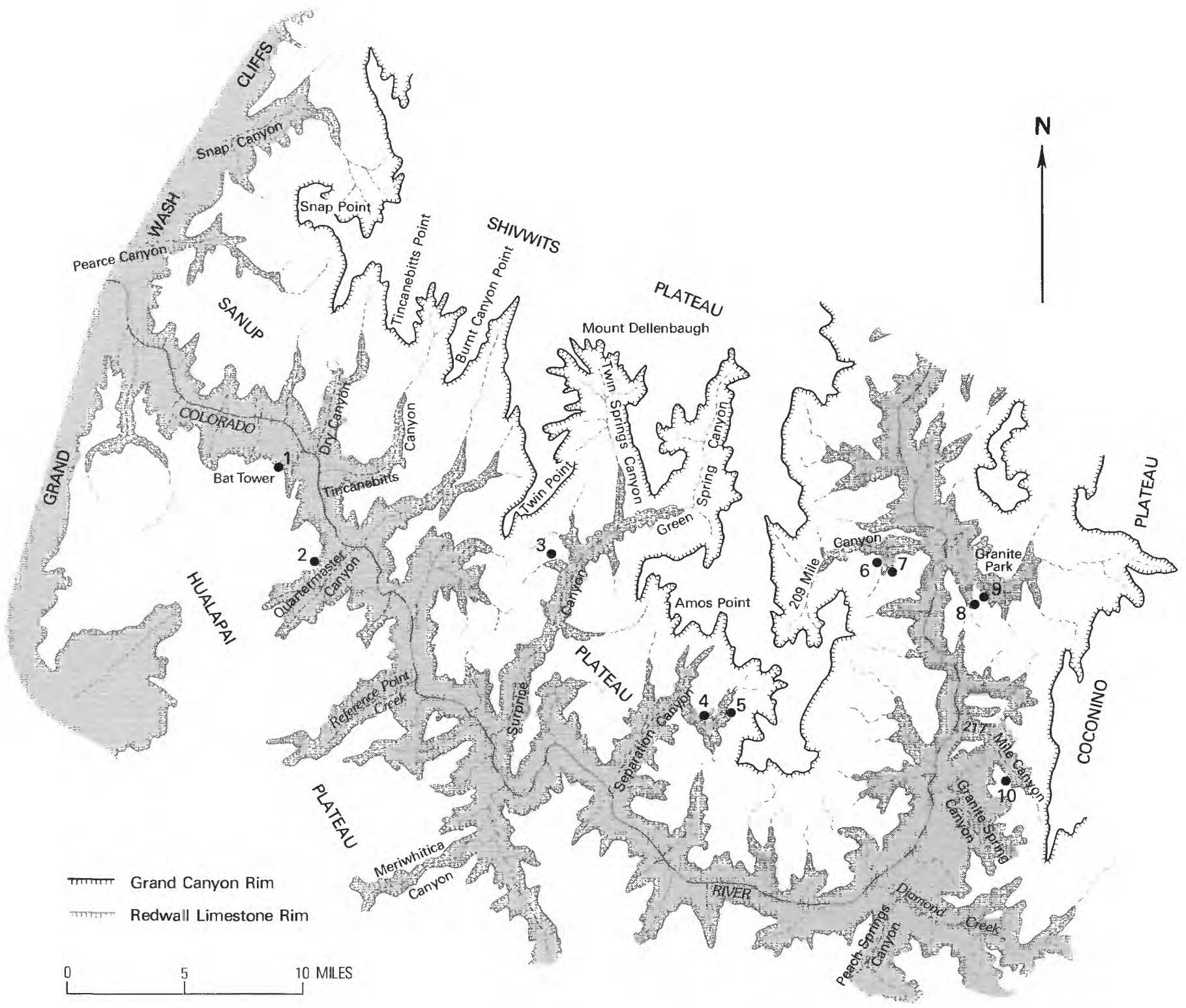

TABLE G1.-Pre-Supai buried valleys

[Leaders (-) indicate not measured]

\begin{tabular}{|c|c|c|c|}
\hline \multicolumn{2}{|c|}{ Outcrop No. and locality } & \multirow{2}{*}{$\frac{\text { Depth (ft) }}{267}$} & \multirow{2}{*}{$\frac{\text { Width }(\mathrm{ft})}{---}$} \\
\hline 1 & Bat Tower ............ & & \\
\hline 2 & Quartermaster Canyon .... & 401 & 1,205 \\
\hline 3 & Suprise Canyon . . . . . . . & 201 & 1,000 \\
\hline 4,5 & Separation Canyon ....... & $221-254$ & -- \\
\hline 6,7 & 209 Mile Canyon . . . . . . . & $283-331$ & --- \\
\hline 8,9 & Granite Park .......... & $197-226$ & -- \\
\hline 10 & 217 Mile Canyon ..... . . . & 212 & 1,050 \\
\hline
\end{tabular}

specimens of fern, five sphenopsids, and several unidentifiable axial scraps. The fern was described by Mamay (written commun., 1978) as "a very delicate, small-pinnuled sphenopterid or pecopterid." The "sphenopsid fragments are parts of the fruiting organs of a phyllothecoid plant;

FIGURE G3.-Western part of Grand Canyon, Ariz., showing principal pre-Supai valley-fill outcrops (solid circles): 1, Bat Tower; 2, Quartermaster Canyon; 3, Surprise Canyon; 4 and 5, Separation Canyon; 6 and 7, 209 Mile Canyon; 8 and 9, Granite Park; 10, 217 Mile Canyon. 


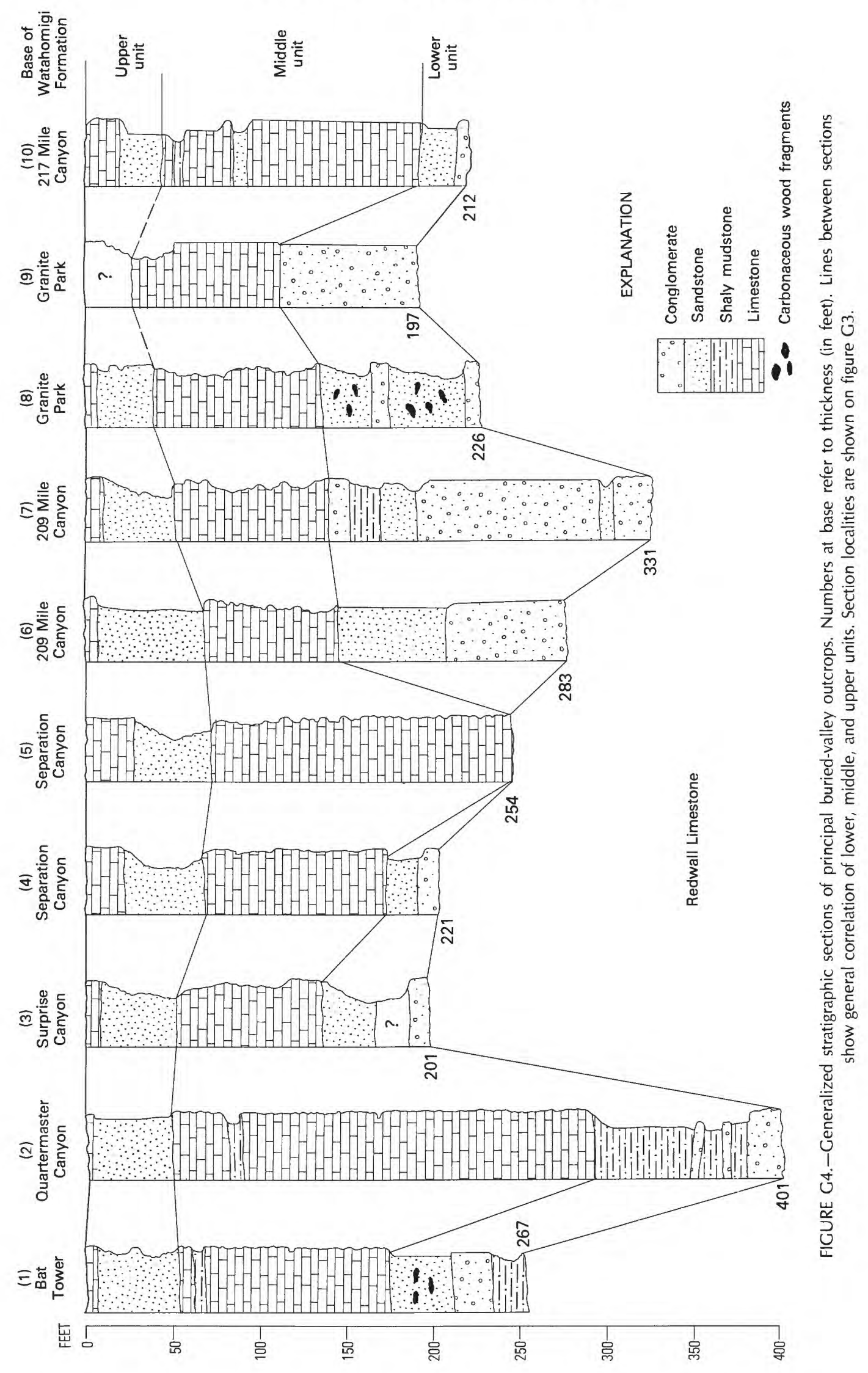


some of these are relatively slender, but others have stout axes, short internodes and short narrow bracts."

Samples also from the basal unit have been prepared and examined for palynomorphs. Two collections from the Granite Park locality were determined by R. M. Kosanke (written commun., 1978) to contain "abundant organic matter including fragments of fusinite, semifusinite, spores and pollen grains." The following palynomorphs were identified:

\author{
Anapiculatisporites concinnus Playford \\ Anaplanisporites globulus (Butterworth and Williams) \\ Smith and Butterworth \\ Auroraspora solisortus Hoffmeister, Staplin, and Malloy \\ Calamospora sp. \\ Convolutispora florida Hoffmeister, Staplin, and Malloy \\ C. sp. \\ Dictyotriletes cf. D. clatriformis (Artuz) Sullivan \\ Granulatisporites granulatus Ibrahim \\ G. sp. \\ Hadrohercos stereon Felix and Burbridge \\ Knoxisporites triradiatus Hoffmeister, Staplin, and Malloy \\ Lycospora spp. \\ Punctatisporites cf. P. heterofiliferous Felix and Burbridge \\ $P$. cf. P. nitidus Hoffmeister, Staplin, and Malloy \\ $P$. pseudolevatus Hoffmeister, Staplin, and Malloy \\ P. solidus Hacquebard \\ $P$. validus Felix and Burbridge \\ P. spp. \\ Recticulatisporites sp. \\ Schulzospora rara Kosanke \\ Triquitrites sp. \\ Monosaccates \\ Unassigned (? algal)
}

\section{Middle unit}

A fauna consisting of 187 specimens of invertebrate megafossils has been collected from the lower massive limestone (middle unit) of the valley-fill deposits below the Supai Group. The specimens have been examined by Mackenzie Gordon, Jr. (written commun., 1978), who has listed from the collections "one coral, eleven brachiopods, ten mollusks, remains of blastoids and crinoids, one trilobite, and a shark dentition" (table G2; pl. G1). Gordon further stated that the most common form is a small Inflatia (pl. G2) that resembles I. clydensis (Girty) of the Fayetteville Shale of Arkansas and Oklahoma, but is not identical with that species.

A zone of corals occurs in the middle unit (massive limestone) of the valley-fill sequence at Granite Park in Grand Canyon (fig. G3). A collection of 16 poorly preserved specimens was submitted to $W$. J. Sando who made the following determinations:

\section{Michelinia sp. \\ Barytichisma sp.}

The corals are not specifically identifiable. Michelinia ranges from Devonian to Permian and is little help for age determination. Barytich-
TABLE G2.-Invertebrate fossils from lower limestone unit of valley-fill deposits below Watahomigi Formation, western Grand Canyon, Ariz.

[Identifications by Mackenzie Gordon, Jr.]

\begin{tabular}{|c|c|c|}
\hline \multicolumn{2}{|c|}{$\begin{array}{l}\text { Locality and } \\
\text { USGS collection No. }\end{array}$} & $\begin{array}{c}\text { No. of } \\
\text { specimens }\end{array}$ \\
\hline \multicolumn{3}{|c|}{217 Mile Canyon, Coconino Co. } \\
\hline \multirow[t]{2}{*}{ 27422-PC } & Inflatia aff. I. clydensis (Girty) & 25 \\
\hline & Composita subquadrata (Hall)? & 1 \\
\hline \multirow[t]{2}{*}{ 27423-PC } & Paladin sp. & 1 \\
\hline & shark dentition & 1 \\
\hline \multicolumn{3}{|c|}{ Granite Park, Coconino Co. } \\
\hline 27424-PC & Coral & \\
\hline \multirow[t]{19}{*}{ 27425-PC } & Michelinia sp. & 1 \\
\hline & Inflatia aff. I. clydensis (Girty) & 11 \\
\hline & Diaphragmus? sp. & 1 \\
\hline & Ovatia sp. & Fragment \\
\hline & Pugnoides sp. & 2 \\
\hline & Torynifer setiger (Hall)? & 1 \\
\hline & Nuculopsis? sp. indet. & 1 \\
\hline & Aviculopecten sp. & 1 \\
\hline & Schizodus sp. indet. & 1 \\
\hline & Cypricardinia sp. & 1 \\
\hline & Plagioglypta sp. & 4 fragments \\
\hline & Retispira sp. & 2 \\
\hline & Clabrocingulum cf. G. & \\
\hline & quadrigatum Sadlick \& Nielson & 1 \\
\hline & Neilsonia sp. & 1 \\
\hline & Anematina & 1 \\
\hline & Microdoma sp. & 1 \\
\hline & $\begin{array}{l}\text { Pentremite ambulacrum } \\
\text { crinoidal debris }\end{array}$ & Fragment \\
\hline & Paladin sp. & 3 \\
\hline \multicolumn{3}{|c|}{ Separation Canyon, Mojave Co. } \\
\hline \multirow[t]{3}{*}{$27426-P C$} & Schizophoria sp. & Fragment \\
\hline & Inflatia aff. I. clydensis (Girty) & 35 \\
\hline & Anthracospirifer sp. A & 8 \\
\hline \multicolumn{3}{|c|}{ Surprise Canyon, Mojave Co. } \\
\hline \multirow[t]{11}{*}{$27427-\mathrm{PC}$} & Michelinia sp. & 1 \\
\hline & Orthotetoid, gen. \& sp. indet. & Fragment \\
\hline & Inflatia aff. I. clydensis (Girty) & 57 \\
\hline & Ovatia sp. (small) & 1 \\
\hline & Pugnoides sp. & 6 \\
\hline & Torynifer setiger (Hall)? & 1 \\
\hline & Anthracospirifer sp. A & 7 \\
\hline & Beecheria sp. & 1 \\
\hline & Pectenoid, gen. \& sp. indet. & Fragment \\
\hline & Pelecypod indet. & Fragment \\
\hline & Bellerophon (Bellerophon) sp. & 3 \\
\hline \multicolumn{3}{|c|}{209 Mile Canyon, Mojave Co. } \\
\hline \multirow[t]{2}{*}{ 27428-PC } & Brachiopod shell detritus & \\
\hline & $\begin{array}{l}\text { Straparollus (Straparollus?) sp. indet. } \\
\text { Pelmatozoan detritus }\end{array}$ & 1 \\
\hline
\end{tabular}

isma is a relatively rare horn coral. Species have been described from the Morrowan of Texas, Arkansas, and Colorado and from the late Chesterian of Wyoming (Mamet Zone 18 or 19). I have also identified this genus in beds of late Chesterian (Zone 17) age in Idaho. The possible age range indicated by the corals is late Chesterian (Zone 17) to Morrowan. 
Sandy limestone from the coral zone in the middle unit at Granite Park, examined in thin section by Betty Skipp, contains abundant bryozoan and pelmatozoan debris, and lesser amounts of ostracode, trilobite, and brachiopod detritus. The alga, Asphaltina sp., is present, along with a tubular calcareous foraminifer, Pseudoglomospira sp.

A thin-section of the lower limestone (middle unit) from the Bat Tower section (sec. 1, fig. G4) contains ostracodes, gastropods, and some pelmatozoan debris.

\section{Upper unit}

The highest limestone (upper unit) of the valley-fill deposits, like the lower limestone, contains a marine invertebrate fauna. The number and variety of species, however, is much more limited. Collections of megafossils from three localities were examined by Mackenzie Gordon, Jr., who reported the following forms:

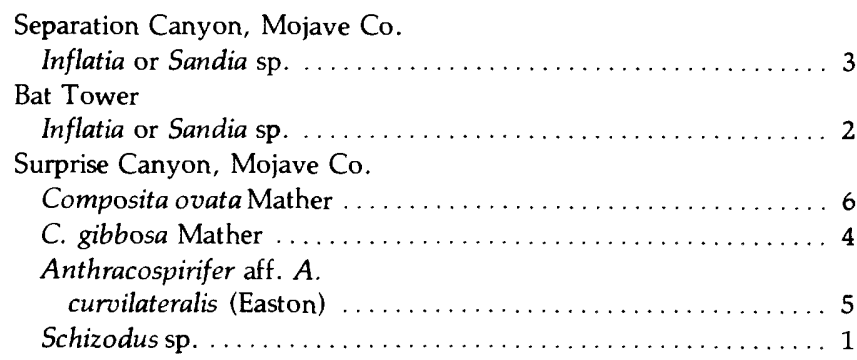

Gordon stated (written commun., 1978) that these species "are not as definitive" as those in the lower limestone. "The Compositas"** resemble the species found in the Watahomigi Formation" and "the Anthracospirifer is not the same species as that found in the lower limestone" (middle unit) of the valley-fill deposits.

Foraminifera and algae from limestone of the upper unit, representative of Mamet foraminiferal Zone 19 (Mamet and Skipp, 1970), uppermost Mississippian (uppermost Chesterian), have been identified by Betty Skipp (written commun., 1978), from the Granite Park and Bat Tower sections. The following genera and species are present:

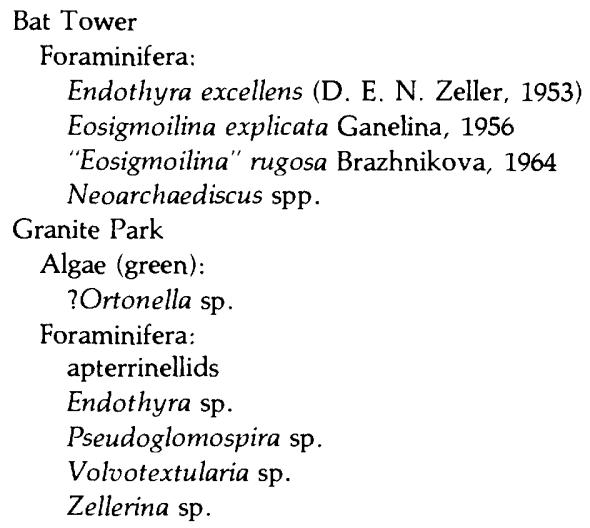

\section{CORRELATION AND AGE}

Evidence from three sources-brachiopods, foraminifers, and spores-indicates a Late Mississippian age for the lower, middle, and upper units of the valley-fill deposits.

Brachiopod evidence of a Late Mississippian age for the valley-fill deposits is furnished by the "predominance of Inflatia and the presence of Torynifer" in the lower limestone unit and by a specimen of Glabrocingulum, said to be almost identical with a late Chesterian species from the Chainman Shale of Utah (Mackenzie Gordon, Jr., written commun., 1978).

Evidence of Late Mississippian age supplied by spores in the basal sandstone unit is discussed by R. M. Kosanke (written commun., 1978) as follows:

Convolutispora florida and Knoxisporites triradiatus were originally described from the Hardinsburg Formation of Illinois. They were [later] reported by Felix and Burbridge (1967, p. 362) as occurring in the Goddard, Springer, and Morrow Formations of Oklahoma. Punctatisporites solidus was originally described from the Horton group (Mississippian) of Nova Scotia ${ }^{\star \star}[$ and has been reported] occurring throughout the Springer Formation of Oklahoma.

The spore taxon Hadrohercos stereon of the Grand Canyon sequence also occurs in Oklahoma, in the Goddard Shale Member, and in shales overlying the Rod Club and Overbrook Sandstone Members (formerly considered Pennsylvanian) of the Springer Formation. These three members and overlying shales have recently been assigned a Chesterian age. Thus, the known upper occurrence of $H$. stereon is now within the Upper Mississippian according to Gordon (1976).

A summary of the floral evidence concerning age is as follows: Three taxa are considered indicative of the Upper Mississippian:

\section{Anaplanisporites globulus Auroraspora solisortus \\ Hadrohercos stereon}

The following taxa occur in Upper Mississippian rocks, but also may be found in older Mississippian rocks:

\section{Anapiculatisporites concinnus \\ Dictyotriletes cf. $D$. clatriformis}

The balance of the taxa identified occur in both Mississippian and Pennsylvanian rocks.

The most important foraminifers for age determination in the upper unit are the eosigmoilinids (Betty Skipp, written commun., 1978). Eosigmoilina explicata Ganelina is considered to occur exclusively within Zone 19 as understood by this author. "Eosigmoilina" rugosa Brazhnikova (= Quasiarchaediscus of Mamet) may have a more extensive range (Mamet, 1975; Brenckle and others, 1977; P. L. 
Brenckle, oral commun., 1977). Plate G3 illustrates both forms from the upper limestone in the Bat Tower section. Eosigmoilina explicata Ganelina has been reported from the type Chesterian region in southern Illinois (Brenckle and others, 1977), and from Arkansas (Brenckle, 1977). "Eosigmoilina" rugosa Brazhnikova has been reported from Nevada (Brenckle, 1973, identified as Eosigmoilina and Quasiarchaediscus), and the Alaskan Cordillera (Armstrong and Mamet, 1977), in addition to the occurrences listed above for E. explicata. Eosigmoilinids also are known to occur in other parts of the Midcontinent and Cordilleran regions of the United States (Hewitt and Conil, 1969; Sando, Mamet, and Dutro, 1969; Mamet and others, 1971; Mamet, 1975).

Study of calcareous foraminifera west of the Grand Canyon area in the Battleship Wash Formation (Langenheim and Langenheim, 1965) and Indian Springs Formation (Webster and Lane, 1967) ${ }^{1}$ of the Arrow Canyon Range, Nevada, in conjunction with the discovery of the preSupai valleys, led to the construction of the correlation chart of figure G5. Correlation of foraminiferal faunas from Nevada east to the western Grand Canyon area suggests that uplift of the Redwall Limestone and erosion that preceded the deposition of the sediments in the pre-Supai valleys occurred in early Chesterian time. A faunal gap representing foraminiferal Zone $16 \mathrm{~s}$ is present within the Battleship Wash Formation. This gap is interpreted to represent a regression of the Redwall epeiric sea, followed by a transgression during the time of F.Z. (foraminiferal Zone) 17-18, another regression that corresponds in general to F.Z. 18 time, and then another transgression that spread eastward into the Grand Canyon area. The F.Z. 19 faunas of the upper limestone of the pre-Supai valleys were deposited during the latter transgression. It is not known for certain whether the lower limestone of the valleys also represents F.Z. 19 time or may be a remnant of the older (F.Z. 17-18) transgression. It is Betty Skipp's opinion, based on available faunal data, that at least some of the pre-Supai valley deposits probably were laid down during the F.Z. 17-18 transgression (fig. G5).

\section{PRE-SUPAI WARPING}

Evidence of regional warping in strata underlying the Supai was first noted in the area of eastern Grand Canyon. Near the Bunker (Tanner) Trail, the contact between the Redwall Limestone and Supai Group is an angular unconformity (McKee and Gutschick, 1969, p. 79, fig. 32a). "Forty feet of eastward-dipping thin beds of the Horseshoe Mesa Member are bevelled from east to west and overlain by red, shaly mudstone." Farther north, "westwarddipping strata of Redwall are bevelled along one-half mile of exposure."

${ }^{1}$ Includes lower part of Bird Spring Formation of Hewitt (1931)
In Snap Canyon in the Grand Wash Cliffs, which form the western end of Grand Canyon, further evidence of crustal uplift, probably by warping, in pre-Supai strata was recorded during the measuring of Supai sections by E. D. McKee during the 1960's. The measured section at that locality (fig. A6, sec. $E-E^{\prime}$, profile 27) shows the middle or cliff unit of the Watahomigi Formation resting on the Redwall Limestone. The bottom unit of the Watahomigi is missing. Presumably, this absence of the unit is due to nondeposition in an area that was relatively high or upwarped at the time of initial marine transgression at the start of Supai time.

In addition to evidence of epirogenic movement furnished in the two areas cited above, confirmation that widespread uplift of Redwall strata occurred prior to Watahomigi time is found in the presence of the buried valleys discussed in this chapter. The valley at Quartermaster Canyon in western Grand Canyon, cut to a depth of $401 \mathrm{ft}$, gives a figure for the magnitude of uplift in that area. Depths of buried valleys farther east at Granite Park, 217 Mile Canyon, and elsewhere show that base level in those areas was probably between 200 and $300 \mathrm{ft}$ below the general land surface.

The valley-fill deposits containing a flora and fauna of late Chesterian age indicate that an uplift with warping of the Grand Canyon region must have taken place in late Meramecian or early Chesterian time, followed by a gradual rising of sea level as the valleys were filled, first with continental and then with marine sediments, prior to a major transgression of the sea at the beginning of Watahomigi deposition during Morrowan time.

\section{REFERENCES CITED}

Armstrong, A. K., and Mamet, B. L., 1977, Carboniferous microfacies, microfossils, and corals, Lisburne Group, Arctic Alaska: U.S. Geological Survey Professional Paper 849, 144 p. [1978]

Brazhnikova, N. E., 1964, Studying Eosigmoiline from the Lower Carboniferous of the greater Donetz Basin [in Russian]: Akad. Nauk Ukrain. SSR, Ser. Strat. Paleont., no. 48, p. 3-15.

Brenckle, P. L., 1973, Smaller Mississippian and Lower Pennsylvanian calcareous foraminifers from Nevada: Cushman Foundation for Foraminiferal Research Special Publication 11, 82 p.

1977, Foraminifers and other calcareous microfossils from Late Chesterian (Mississippian) strata of northern Arkansas: Oklahoma Geological Survey Guidebook 18, p. 73-88.

Brenckle, P. L., Lane, H. R., Manger, W. L., and Saunders, W. B., 1977, The Mississippian-Pennsylvanian boundary as an intercontinental biostratigraphic datum: Newsletters on Stratigraphy, v. 6, no. 2, p. $106-116$.

Felix, C. J., and Burbridge, P. P., 1967, Palynology of the Springer Formation of southern Oklahoma, U.S.A.: Palaeontology, v. 10, no. 3, p. 349-425.

Ganelina, R. A., 1956, Foraminifera of the Visean sediments of the northwest region of the Moscow syncline [in Russian]: Vses. Neft. Nauchno-Issled. Geol.-Razved. Inst. Trudy 98, Mikrofauna SSSR no. 8, p. 31-159. 


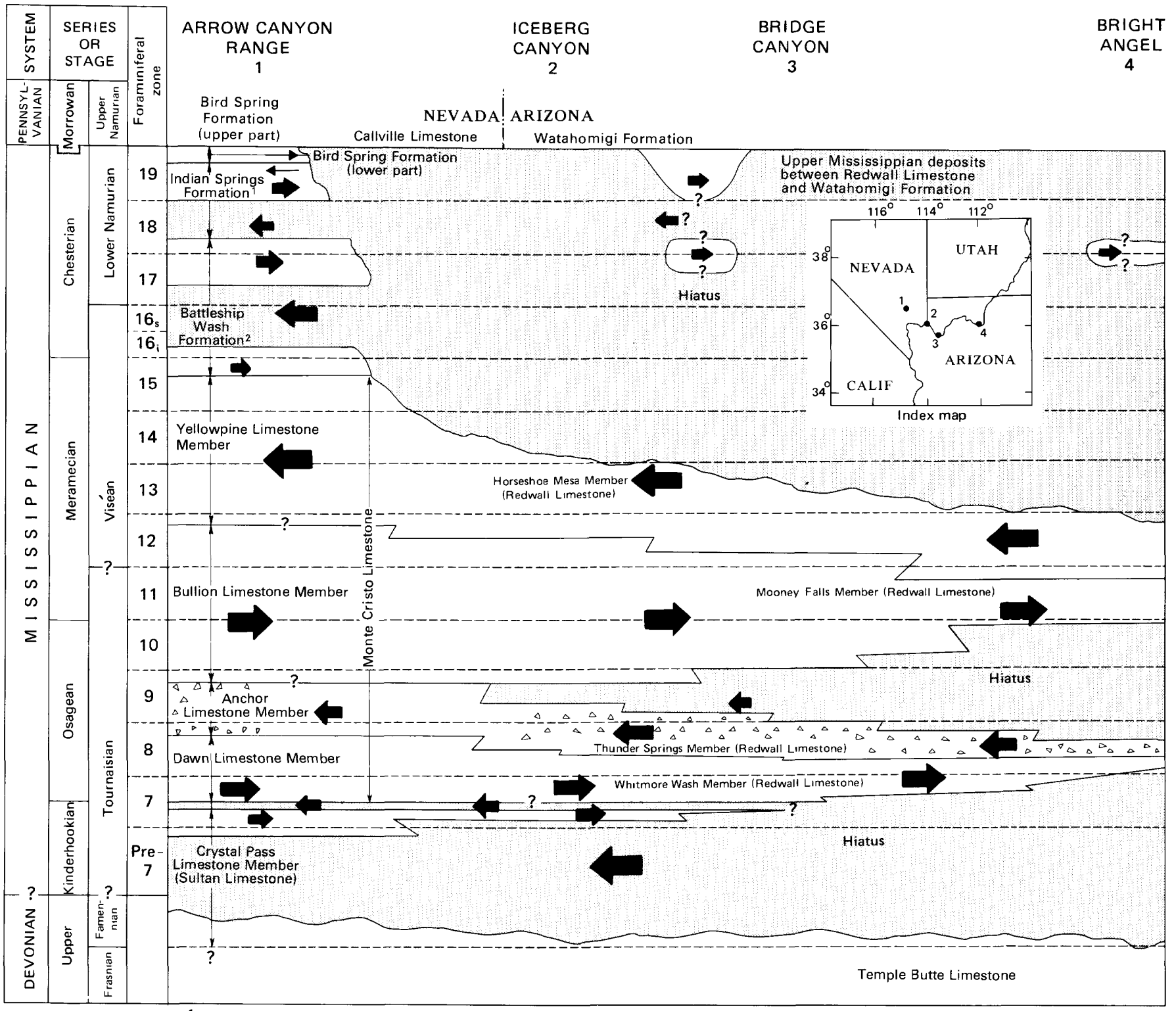

${ }_{2}^{1}$ Webster and Lane (1967); includes lower part of Bird Spring Formation of Hewitt (1931)

${ }^{2}$ Langenheim and Langenheim (1965).

FIGURE G5.-Diagram of the transgressions and regressions of the Mississippian seas across southern Nevada and northern Arizona based on time lines represented by the foraminiferal zones of Mamet (Mamet and Skipp, 1970). Microfaunal studies of Brenckle (1973; written commun., 1977), and Skipp in the Arrow Canyon Range, Nevada, and Skipp (1969) in northern Arizona, form the basis for zonal ranges

Gordon, Mackenzie, Jr., 1976, Correlation chart of carboniferous rocks in Arkansas and Oklahoma, in G. V. Cohee and W. B. Wright, Changes in stratigraphic nomenclature by the U.S. Geological Survey, 1975: U.S. Geological Survey Bulletin 1422-A, p. A54, A56-A57.

Hewett, D. F., 1931, Geology and ore deposits of the Goodsprings quadrangle, Nevada: U.S. Geological Survey Professional Paper 162, $172 \mathrm{p}$.

Hewitt, P. C., and Conil, R., 1969, Foraminiferes du Meramecien et du Chesterien des Etats-Unis (Tennesse): Bulletin de la Societe Belge de Geologie, de Paleontologie, et d' Hydrologie, v. 78, p. 175-185. of the formations. The pattern of transgressions and regressions of the Redwall sea is modified from McKee and Gutschick (1969, fig. 26). Large arrows indicate major transgressions and regressions. Smaller arrows indicate inferred minor transgressions and regressions. Modified from Skipp (1978).

Langenheim, V.A.M., and Langenheim, R. L., Jr., 1965, The Bird Spring Group, Chesterian through Wolfcampian, at Arrow Canyon, Arrow Canyon Range, Clark County, Nevada: Illinois State Academy of Science Transactions, v. 58 , no. 4, p. 225-240.

McKee, E. D., and Gutschick, R. C., 1969, History of the Redwall Limestone of northern Arizona: Geological Society of America Memoir $114,726 \mathrm{p}$.

Mamet, B. L., 1975, Carboniferous foraminifera and algae of the Amsden Formation (Mississippian and Pennsylvanian) of Wyoming: U.S. Geological Survey Professional Paper 848-B, p. B1-B18. 
Mamet, B. L., and Skipp, Betty, 1970, Preliminary foraminiferal correlations of Early Carboniferous strata in the North American Cordillera: Les Congres et Colloques de 1'Universite de Liege, v. 55, p. $327-348$.

Mamet, B. L., Skipp, Betty, Sando, W. J., and Mapel, W. J., 1971, Biostratigraphy of Upper Mississippian and associated Carboniferous rocks in south-central Idaho: American Association of Petroleum Geologists Bulletin, v. 55, no. 1, p. 20-33.

Sando, W. J., Mamet, B. L., and Dutro, J. T., Jr., 1969, Carboniferous megafaunal and microfaunal zonation in the northern Cordillera of the United States: U.S. Geological Survey Professional Paper 613-E, p. E1-E29.
Skipp, Betty, 1969, Foraminifera, Chapter 5, in McKee, E. D., and Gutschick, R. C., History of the Redwall Limestone of northern Arizona: Geological Society of America Memoir 114, p. 173-256.

1978, Great Basin Region, Chapter P, in Craig, L. C., Conners, C. W., and others, Mississippian System of the conterminous United States: U.S. Geological Survey Professional Paper 1010, Part 1, p. 273-328.

Webster, G. D., and Lane, N. G., 1967, Mississippian-Pennsylvanian boundary in southern Nevada, in Essays in paleontology and stratigraphy-Raymond C. Moore commemorative volume: Kansas University Department of Geology Special Publication 2, p. 503-522.

Zeller, D.E.N., 1953, Endothyroid foraminifers and ancestral fusulinids from the type Chesterian (Upper Mississippian): Journal of Paleontology, v. 27, p. 183-199. 


\section{PLATE G1}

Fossil brachiopods from pre-Supai valley-fill deposits, western Grand Canyon, Ariz.

[Natural size unless otherwise indicated. Photographs provided by Mackenzie Gordon, Jr.]

FIGURES 1-6. Inflatia aff. I. clydensis (Girty). Lower limestone unit.

$1,3,6$. Ventral, enlarged oblique (to show diagonal auricular spine row) and side views of a typical specimen (USNM 265888) from USGS colln. 27427-PC, Surprise Canyon.

2, 4, 5.Enlarged oblique, ventral, and side views of another specimen (USNM 265889) from the same collection.

7-9. Anthracospirifer cf. A. curvilateralis (Easton). Upper limestone unit.

Enlarged posterior, ventral, and enlarged ventral views of a specimen (USNM 265895) from USGS colln. 27421-PC, Surprise Canyon.

10-14. Cranaena? sp. Lower limestone unit.

10-12.Dorsal, anterior, and side views of a brachial valve (USNM 265896) from USGS colln. 27220-PC, Surprise Canyon.

13, 14.Ventral and side views of a pedicle valve (USNM 265897) from USGS colln. 27427-PC, Surprise Canyon.

15-18. Torynifer cf. T. setiger (Hall). Lower limestone unit.

15, 17.Views, enlarged and natural size, of a pedicle valve (USNM 265892) from USGS colln. 27425-PC, Granite Park.

16, 18.View and enlarged view of another pedicle valve (USNM 265893) from USGS colln. 27427-PC, Surprise Canyon.

19-21. Composita cf. C. ovata Mather. Upper limestone unit.

Dorsal view and enlarged dorsal and anterior views of a specimen (USNM 265890) from USGS colln. 27421-PC, Surprise Canyon.

22-26. Composita cf. C. elongata Dunbar and Condra. Upper limestone unit.

Dorsal view and enlarged posterior, ventral, anterior, and side views of a specimen (USNM 265891) from the same collection as the last.

27-29. Anthracospirifer sp. A. Lower limestone unit.

Enlarged ventral, ventral, and posterior views of an incomplete pedicle valve (USNM 265894) from USGS colln. 27427-PC, Surprise Canyon. 
GEOLOGICAL SURVEY

PROFESSIONAL PAPER 1173 PLATE G1
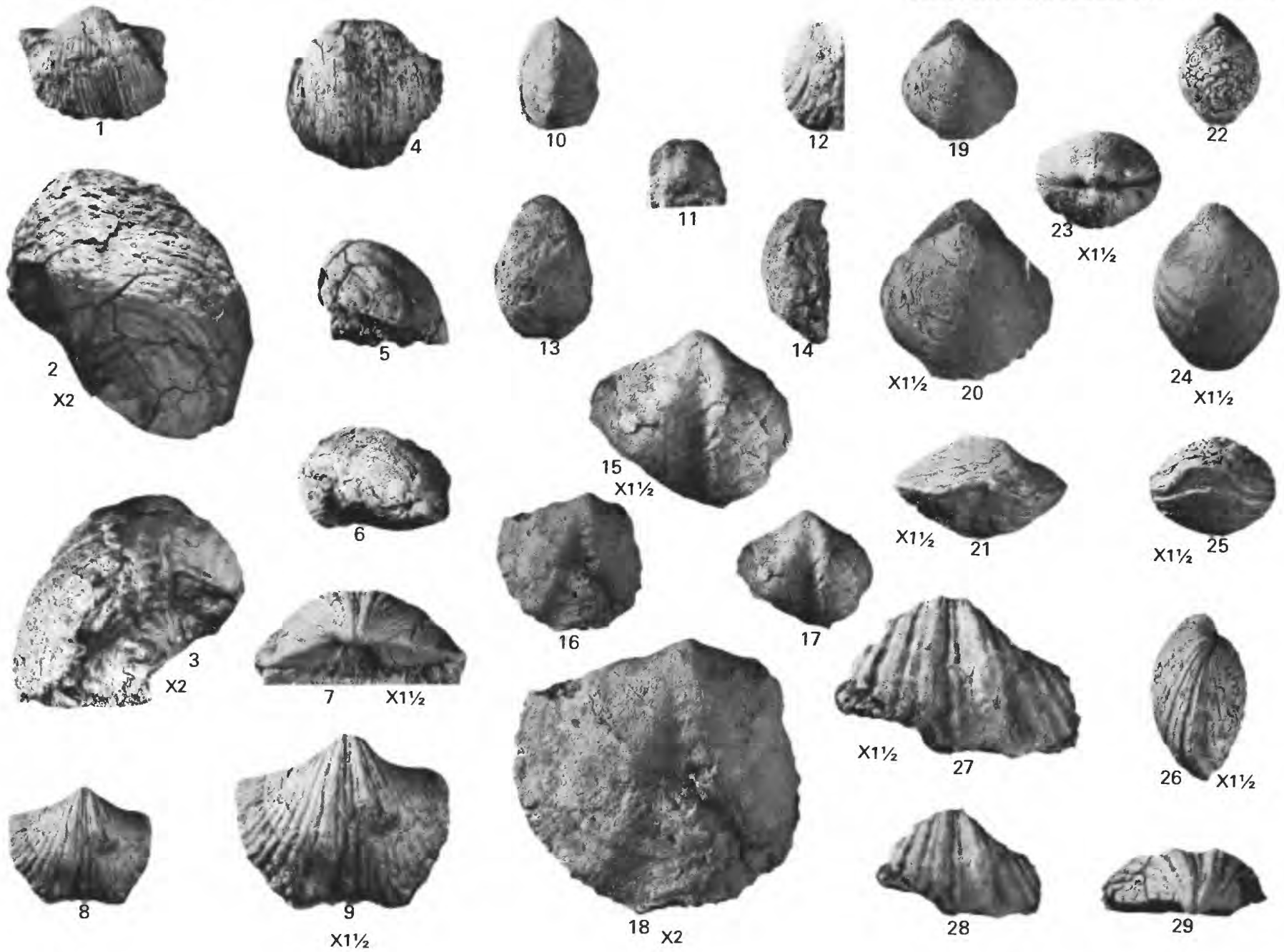


\section{PLATE G2}

Assemblage of small invertebrates (X 3) in coquinoid limestone from the lower limestone (middle unit) of a valley fill, USGS colln. 27425-PC, Granite Park, Coconino County, Ariz.

[Photograph provided by Mackenzie Gordon, Jr.]

FIGURE 1. Inflatia aff. I. clydensis (Girty), fragment

2. Ovatia sp., fragment

3. Composita sp., fragment

4. Glabrocingulum (Glabrocingulum) cf. G. (G.) quadrigatum Sadlick and Nielsen

5. Neilsonia sp.

6. Anematina sp.

7. Paladin sp.: A, librigena (free cheek), B, pygidium 


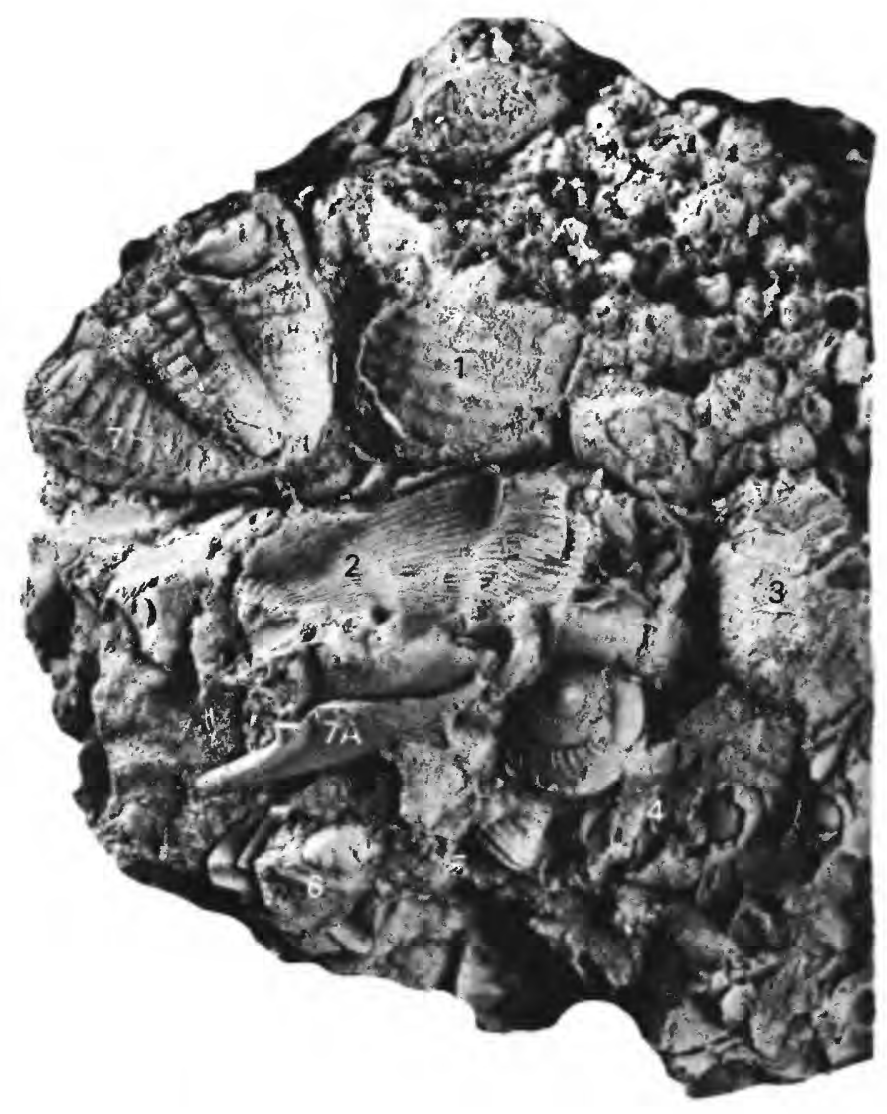




\section{PLATE G3}

Foraminifera in the upper unit of pre-Supai valley-fill deposits, western Grand Canyon, Ariz.

[Identification and photographs by Betty Skipp. All figures $\times 200$ ]

FIGURES 1-4. Eosigmoilina rugosa Brazhnikova, 1964. Bat Tower section, upper limestone, Mamet foraminiferal Zone 19 (uppermost Chesterian).

1. Axial section, USNM 258929.

2. Axial section, USNM 258930.

3. Transverse section, USNM 258931.

4. Transverse section, USNM 258932.

5-9. Eosigmoilina explicata Ganelina, 1956. Bat Tower section, upper limestone, Mamet foraminiferal Zone 19 (uppermost Chesterian).

5. Axial section, USNM 258933.

6. Sagittal section, USNM 258934.

7. Near-sagittal section, USNM 258935.

8. Near-sagittal section, USNM 258936.

9. Near-sagittal section, USNM 258937.

10. Pseudoglomospira sp. Bat Tower section, upper limestone, Mamet foraminiferal Zone 19 (uppermost Chesterian), USNM 258938. 

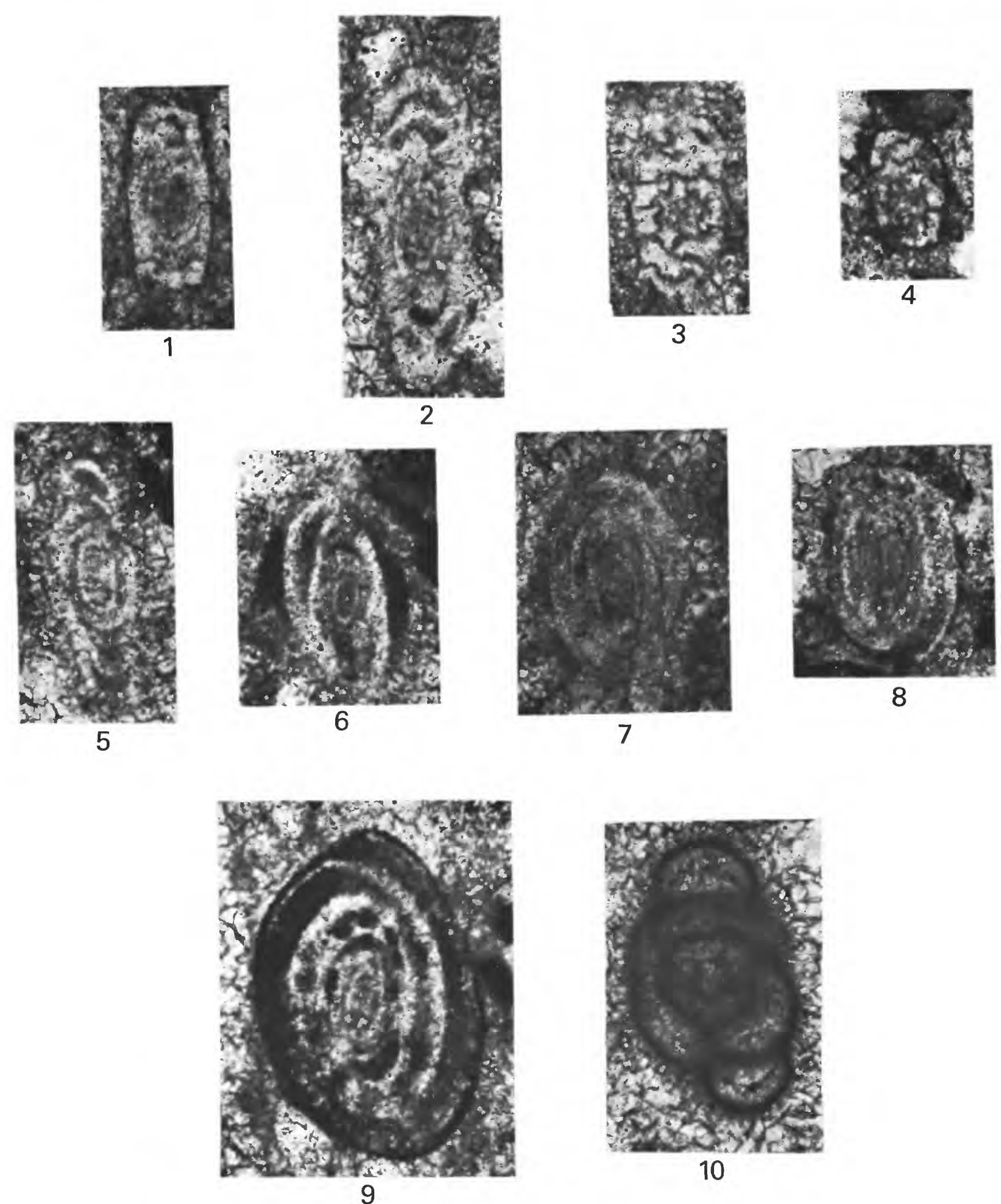

EOSIGMOILINA, AND PSEUDOGLOMOSPIRA 



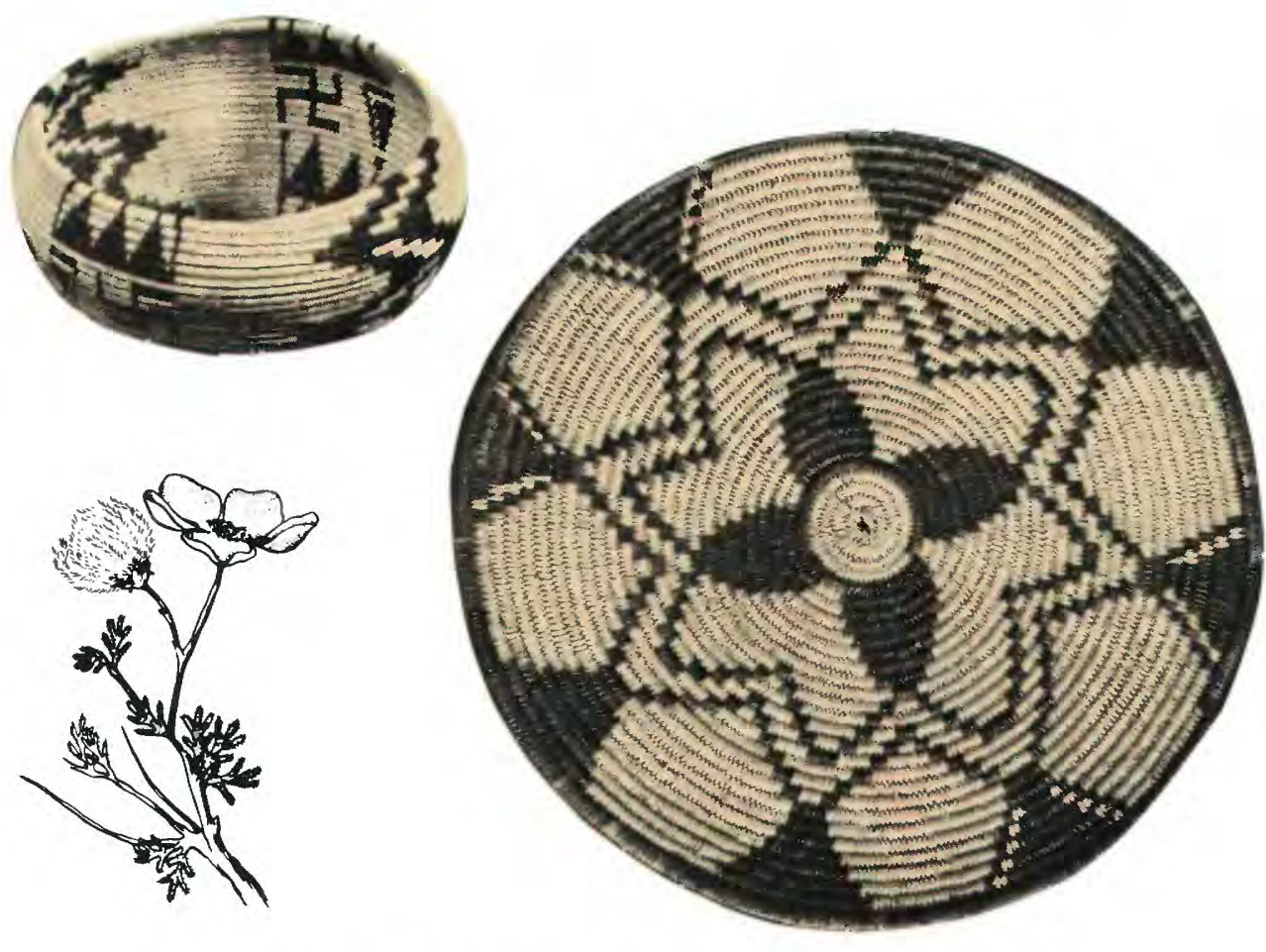

THE SUPAI GROUP OF GRAND CANYON

\title{
EROSION SURFACES
}

\author{
Chapter $\mathrm{H}$
}

By EDWIN D. McKEE

\section{Contents}

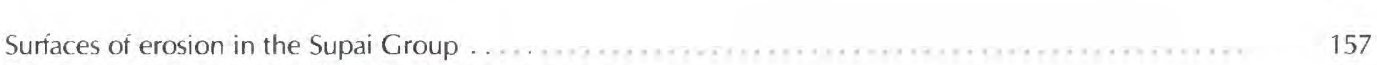

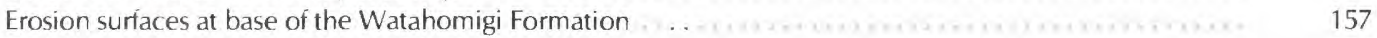

Probable erosion surface at base of Atokan-age rocks . . . . . . . . . . 159

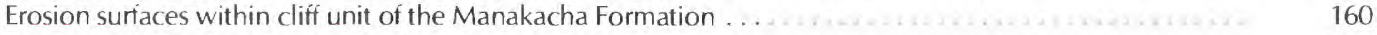

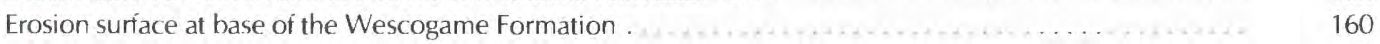

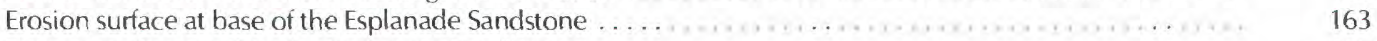

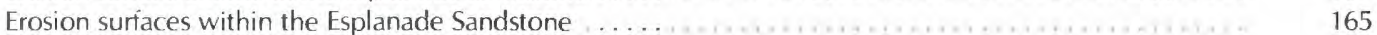

Erosion surface at contact of Esplanade Sandstone and Hermit Shale . . . . . . . . . . . . . . . . . . . . . . . 169

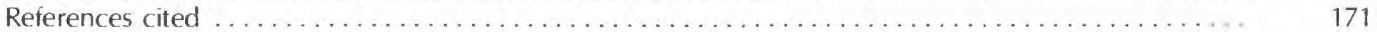




\section{Illustrations}

FIGURES H1-H4. Sketches of:

H1. East-west cross-section showing principal lithologic units, surfaces of erosion, hiatuses, and key conglomerate beds, Supai Group .

H2. Erosion surface at contact of Redwall Limestone and Watahomigi Formation

H3. Erosion surfaces within Manakacha Formation ....................... 163

H4. Erosion surface at $61 \mathrm{ft}$ above base of cliff unit, Manakacha Formation $\quad 164$

H5. Photographs of channels on erosion surfaces within Manakacha Formation . . . . . . 165

H6. Photographs of erosion surfaces at top of Manakacha, base of Wescogame . . . . . . 166

H7. Sketches of channeled surface, base of Wescogame . . . . . . . . . . . . . . . . . 167

H8. Sketches of channeled surface, base of Wescogame (cliff unit) . . . . . . . . . . . . 168

H9. Photographs of unconformable surface between Manakacha and Wescogame ...... 169

H10. Sketches of channeled surface at base of Wescogame Formation . . . . . . . . . . . . 170

H11. Photographs of surface erosion at top of Wescogame . . . . . . . . . . . . . . . . 172

H12. Sketches of channeled surface, top of Wescogame ... . . . . . . . . . . . . 173

H13. Sketches of channeled surface, top of Wescogame overlain by Esplanade Sandstone

H14. Photographs of unconformable surface between Esplanade Sandstone and Hermit Shale

H15. Sketches of erosional unconformity between Hermit and Esplanade .

\section{Tables}

TABLE H1. Thickness of conglomerate and relief on erosion surface at principal uncon-

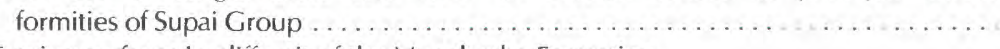

H2. Erosion surfaces in cliff unit of the Manakacha Formation . . . . . . . . . . . . . . . .

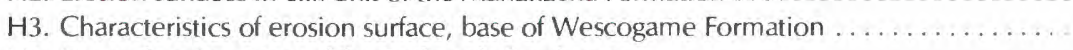

H4. Unconformity at top of the Esplanade Sandstone 


\section{SURFACES OF EROSION IN THE SUPAI GROUP}

Strata of the Supai Group are superficially alike because they are generally reddish brown and they weather into certain characteristic topographic forms that are repeated numerous times in each stratigraphic section. Detailed studies in a large area, however, clearly indicate that these strata do not constitute a single unified unit, but form a sequence of distinctive deposits. Furthermore, each major stratigraphic unit is separated from the underlying and overlying sequences by a well-marked boundary consisting of a surface of erosion and (or) a blanket of conglomerate (fig. H1).

Widespread surfaces of erosion separate both the Manakacha and Wescogame Formations and the Wescogame Formation and Esplanade Sandstone of the Supai Group; erosion surfaces also occur at the bottom and the top of the group. All of these surfaces are irregular and include channels. The basal contact of Atokan-age strata probably also represents a time of nondeposition, but no scouring has been noted there. All of these erosion surfaces except at the Hermit-Supai boundary are overlain by conglomerates. The surface at the top of the Supai is overlain by, and most of its channels are filled with, fine detrital rocks.

The basal conglomerates of the formations in the Supai are distinctive and widespread (chapter J), and have proved very useful in correlating strata within the Supai Group. Most of the unconformities in the Supai represent significant hiatuses as confirmed by fossils from above and below (chapter E). Unconformities within the Manakacha Formation and the Esplanade Sandstone are apparently only locally developed.

\section{EROSION SURFACES}

\section{AT BASE OF THE WATAHOMIGI FORMATION}

The irregular basal contact of the Watahomigi is the record of a long period of erosion. The existence of this widespread unconformity was noted by Darton (1910, p. 13) and by Noble (1922, p. 61). Noble stated, "I have presented evidence that this surface is a plane of unconformity by erosion," and he justified revision of the Redwall-Supai boundary on the presence of this feature. The character and extent of the erosion surface have been described and illustrated in an earlier publication by the author (McKee and Gutschick, 1969, p. 74), and will be summarized here.

In most places the hiatus between the Watahomigi Formation and the Redwall Limestone represents all of Late
Mississippian time and the earliest part of Morrowan or Early Pennsylvanian time. Generally, in the Grand Canyon region, the uppermost strata of the Redwall Limestone are of Early Mississippian age. Rocks of Late Mississippian (Chesterian) age have been reported from eastern Grand Canyon only at Bright Angel Trail, but, from western Grand Canyon, in several recently recognized pre-Supai valleys described in chapter G. In the overlying Supai Group, the oldest known fossils are from the base of the Watahomigi; their age has been determined by Mackenzie Gordon, Jr. (chapters E and F) as younger than earliest Morrowan.

During early stages in development of the unconformity between the Redwall Limestone and the Watahomigi Formation, the region of western Grand Canyon must have been moderately elevated, for stream-cut valleys dissect the upper Redwall surface in that area to depths in excess of $400 \mathrm{ft}$. These valleys, as described in chapter G, must have been eroded soon after Redwall deposition ceased for they were subsequently filled with fluvial, followed by marine, deposits of Chesterian age. Later, by the time this region was being inundated by a broad advance of the Morrowan sea, with basal Watahomigi strata being deposited, the regional surface again was flat and low.

The surface on which the basal conglomerate of the Supai accumulated, as seen in the walls of Grand Canyon, had very little relief with only shallow depressions and low ridges or mesas interrupting its evenness. The valleys of Late Mississippian age had been filled and the topography, in general, was determined by the resistance of the Redwall Limestone, which was eroded into ledges and steps forming the sides of channels (fig. $\mathrm{H} 2 \mathrm{C}, D, E$ ) or the margins of low mesas (fig. $\mathrm{H} 2 A, B$ ). Elsewhere erosion has formed sink holes and related karst features. In table 11 of McKee and Gutschick (1969, p. 74), the amount of relief on this surface is summarized. Channels as much as $40 \mathrm{ft}$ deep occur at Toroweap Valley and $30 \mathrm{ft}$ at Whitmore Wash.

The lithology of the basal beds of the Watahomigi Formation seems to reflect the amount of relief on the upper surface of the Redwall Limestone. In the bottoms of channels and other depressions, the lowest beds of the Watahomigi generally consist of conglomerate, red mudstone, or both. Higher in the channels or on the flat surfaces bordering them, shaly red mudstone is most common. Still higher in the sequence, and on the tops of low buried plateaus, the rocks consist of thin-bedded limestone. Typically, the lower part of the Watahomigi is composed of conglomerate, mudstone, and limestone, in ascending order.

The evidence of karst topography on the upper surface of the Redwall Limestone in this region consists of mudand breccia-filled depressions, and red mud along the bedding planes and in the solution holes, of the limestone. 


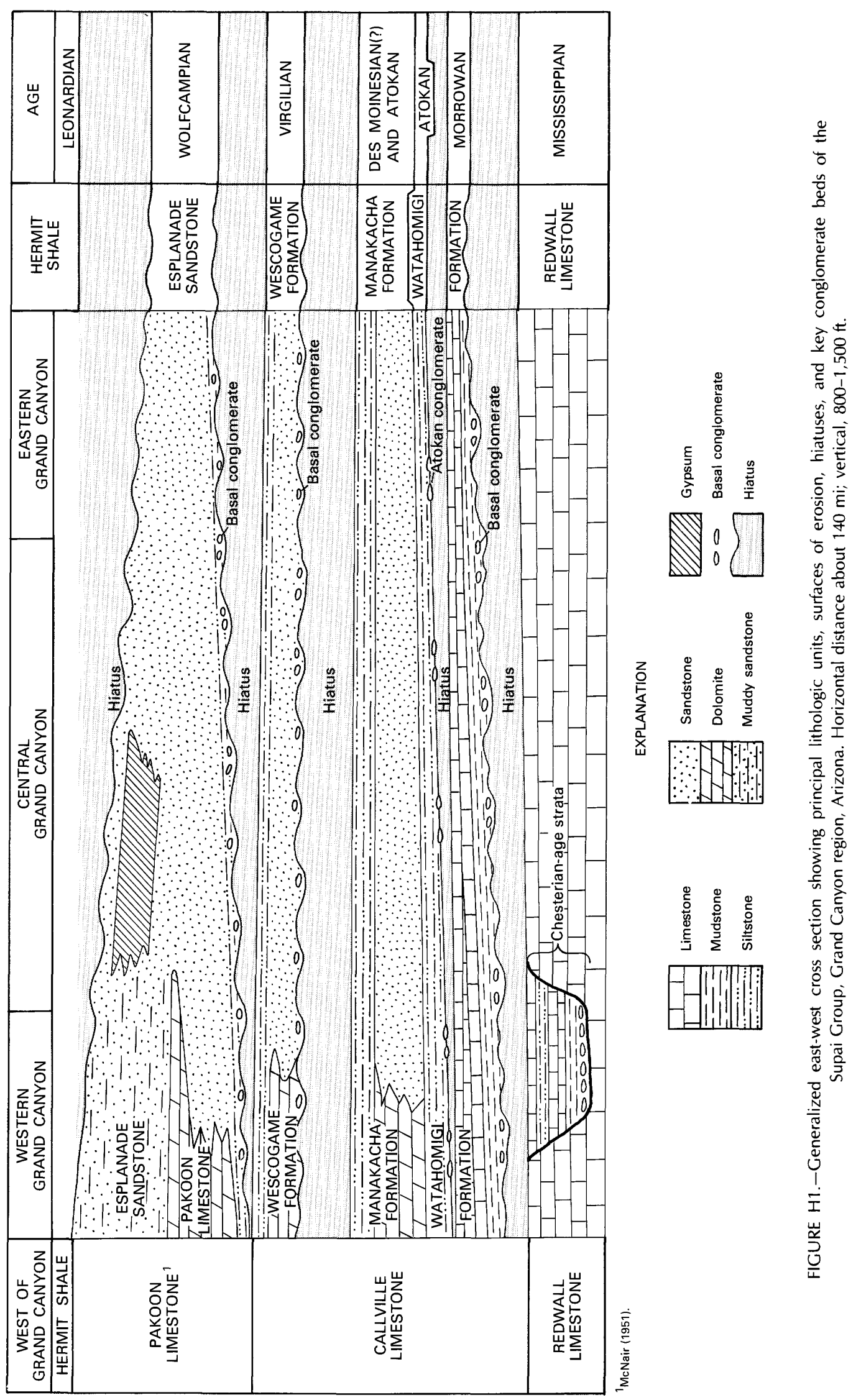



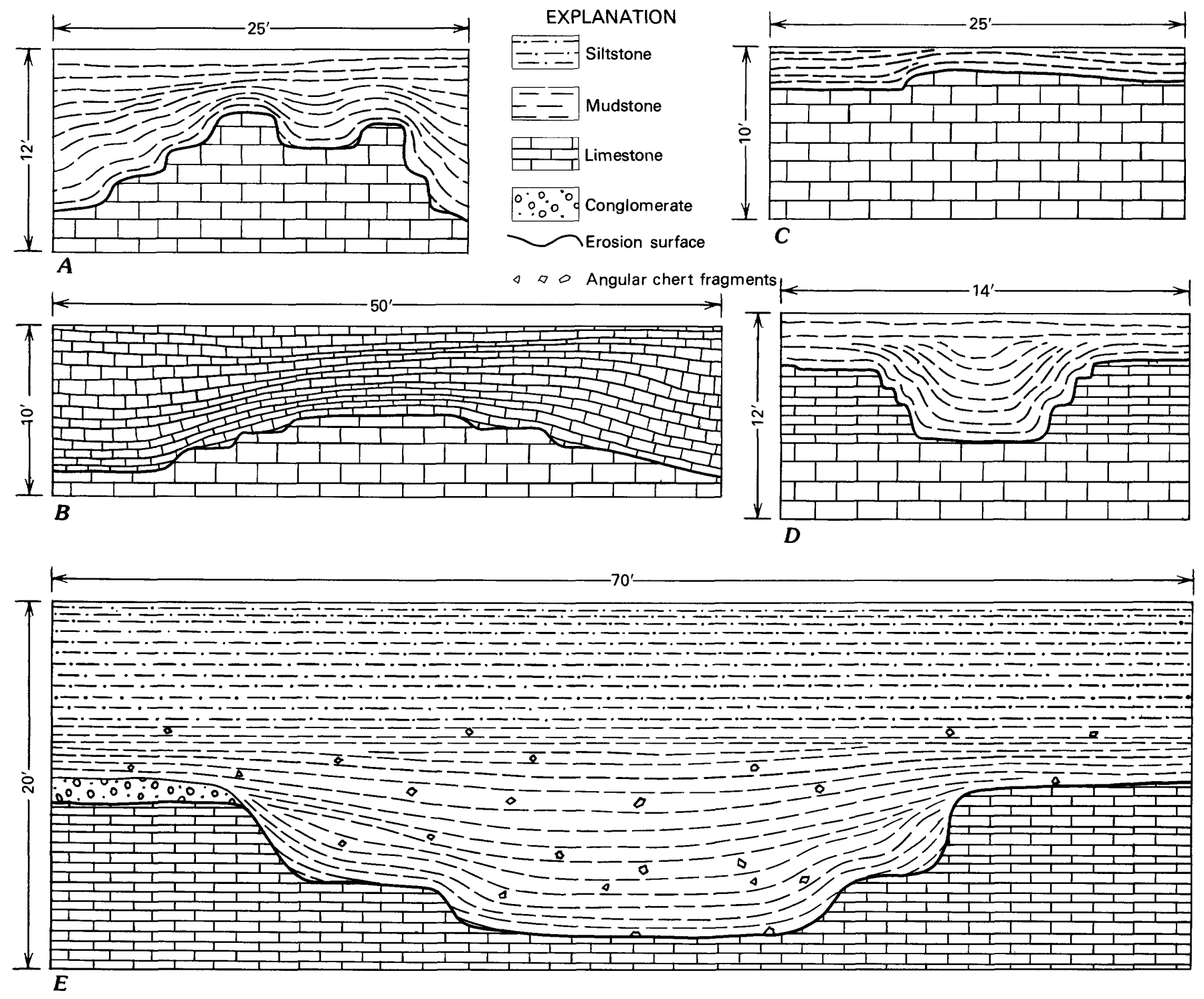

FIGURE H2.-Erosion surfaces at contact of the Redwall Limestone (R) and Watahomigi Formation (W), Grand Canyon, Ariz. A, Residual mounds at Thunder River Trail section; $B$, relief at top of Redwall, east side of Havasu Canyon near Navajo Falls; $C$, unconformity at

These features are depicted in figure 31 of McKee and Gutschick (1969). In general, the intensity of solution illustrated by the ancient karst surface and the thickness of Mississippian strata removed by solution are much less in the Grand Canyon region than farther south in the Mogollon Rim area of central Arizona. Many excellent examples are in both places.

The environment of deposition represented by the overlying basal beds of the Watahomigi Formation apparently was marine. The basal strata consist of conglomerate that in many areas contains brachiopods and other marine fossils among the pebbles and in other areas contains relatively continuous beds of limestone. Cherty rubble, which
Fishtail Canyon, near Thunder River Trail; $D$, channel at S B Canyon; and $E$, conglomerate and channel at Tuckup Canyon. Vertical and horizontal distances in feet.

locally includes large blocks of Redwall Limestone and contorted layers of reddish-brown mudstone, probably accumulated within the karst topography during pre-Supai time, possibly pre-Pennsylvanian, before transgression of the Watahomigi sea.

\section{PROBABLE EROSION SURFACE AT BASE OF ATOKAN-AGE ROCKS}

The contact of the middle cliff unit and the upper slope unit of the Watahomigi Formation in the Grand Canyon 
region probably is an unconformity. It is the boundary between rocks of Morrowan age and Atokan age as determined from fossils collected in the region (chapter E).

The contact of the middle and upper units of the Watahomigi is generally concealed by talus and does not provide evidence of channeling or dissection. A surface of erosion can be inferred, however, from the persistent basal (Atokan) conglomerate of the upper slope unit (fig. J1) that consists largely of angular and closely packed pebbles of jasper and chert, and has been found at 17 scattered localities in the region. No appreciable relief has been noted below this gravel of the Atokan conglomerate in Grand Canyon (table H1). Apparently, therefore, a very even, flat surface forms the contact between the marine deposits of Morrowan and Atokan age, indicating that no appreciable uplift of the area occurred during Early Pennsylvanian time. Certainly no narrow channels of 20- to $50-\mathrm{ft}$ depth, such as occur in stratigraphic breaks above and below, have been found at this horizon.

\section{EROSION SURFACES WITHIN CLIFF UNIT OF THE MANAKACHA FORMATION}

These unconformities and conglomerate beds at 11 localities in the Grand Canyon have been recognized within the cliff unit of the Manakacha Formation. The evidences of erosion occur at various horizons ranging from the bottom to the top of the cliff unit (table $\mathrm{H} 2$ ) and so cannot represent parts of a single surface of erosion. At 5 localities they were found at or near the base of the cliff unit (fig. H3); at 3 localities they were found from 50 to $70 \mathrm{ft}$ above the base; and at 3 other localities, they were found in the upper part of the cliff unit, more than $100 \mathrm{ft}$ above the base.

Channels on erosion surfaces of the cliff unit of the Manakacha Formation range in depth from 6 to $30 \mathrm{ft}$ (table H2) and are as much as $200 \mathrm{ft}$ wide in central Grand Canyon. Thin beds or lenses of gravel, 1 to $2 \mathrm{ft}$ thick, lie on the bottom or along the sides of some channels. At other places, the channels are filled with reddish-brown, shaly mudstone (figs. H4, H5). The gravel consists largely of chert or jasper pebbles, but at Grandview Trail it is composed of limestone clasts.

The erosion surfaces are at several stratigraphic positions and seem to be discontinuous, which may be the result of local origin and intermittent development. The composition of the gravels indicates that the conglomeratic rocks probably were derived from nearby sources. During Atokan time, sedimentation probably was interrupted periodically and in various places, with local erosion and redeposition leaving its record. The possibility must be entertained, however, that any or all of the three groups of erosion surfaces recorded in table $\mathrm{H} 2$ may represent traces or remnants of more widespread unconformities.

Because most of these local unconformities and conglomerates are within carbonate rock sequences, a marine origin seems likely. Scouring and the concentration of gravel on the sea floor is postulated, but changes in sea level accompanied by subaerial erosion and deposition may have been responsible for some of the stratigraphic breaks.

\section{EROSION SURFACE AT BASE OF THE WESCOGAME FORMATION}

A prominent unconformity, characterized by conspicuous channels in many places, occurs at the contact of the Manakacha and Wescogame Formations throughout most of the Grand Canyon region (fig. H6). This unconformity represents a hiatus that extends from Atokan or, possibly, early Des Moinesian time to Virgilian time, as determined from fossils (chapter E) collected both above and below the contact in western Grand Canyon.

This post-Manakacha erosion surface is especially conspicuous in exposures of central Grand Canyon where it occurs locally as an irregular and undulating surface, and elsewhere as narrow rounded channels between low ridges or platforms (figs. H7, H8). These features are especially well displayed in Havasu Canyon, the type locality of the Supai (figs. H9 and H10), but also in National, Tuckup, and Kanab Canyons, Thunder River Trail, and in other localities of this area (fig. H6).

As indicated in table $\mathrm{H} 3$, channels on the erosion surface dissect several different types of rock in the region, but they are mostly in flat-bedded siltstone and mudstone in the eastern Grand Canyon, and in cross-bedded sandstone and limestone in the central and western parts of the canyon area. The channels are commonly from 5 to $20 \mathrm{ft}$ deep, but are as much as $80 \mathrm{ft}$ deep in Havasu Canyon. Other deep channels were observed in Tuckup, S B, and Snap Canyons (table H1).

The hiatus between the Manakacha and Wescogame Formations, which probably involves most of Des Moinesian and Missourian time, seems to be of regional extent. In Nevada, "at Mountain Spring and at North Bird Spring Range a thin conglomerate separates the two systems" (Atokan and Virgilian) according to Welsh (1959, p. 59). At Beaver Dam Mountains in Utah, most of the Des Moinesian Series is missing and at Frenchman Mountain, Nevada, all of it is absent according to Steele (1959, table 2). This "regional widespread unconformity between lower and upper Pennsylvanian sediments throughout the entire 


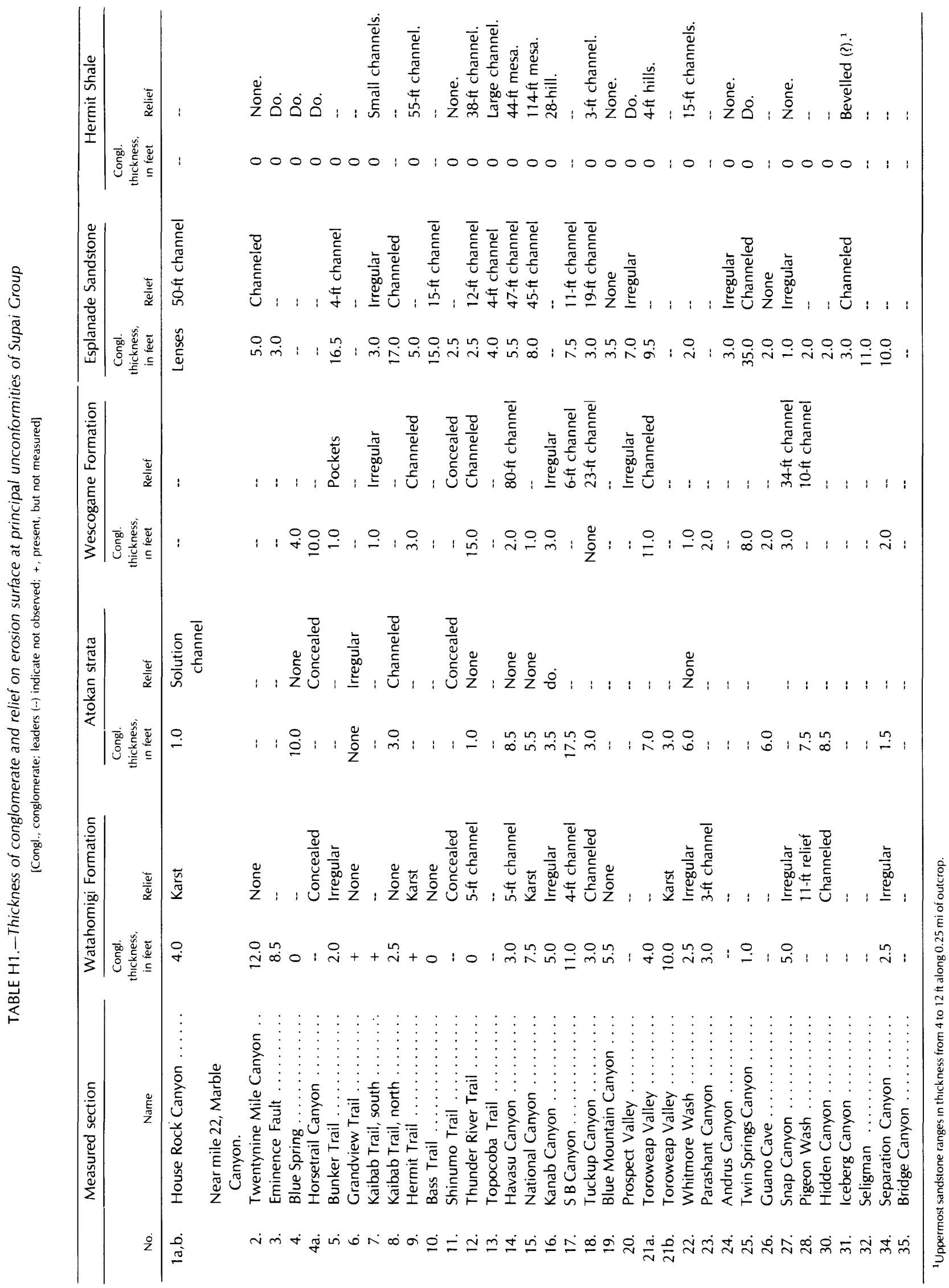


THE SUPAI GROUP OF GRAND CANYON

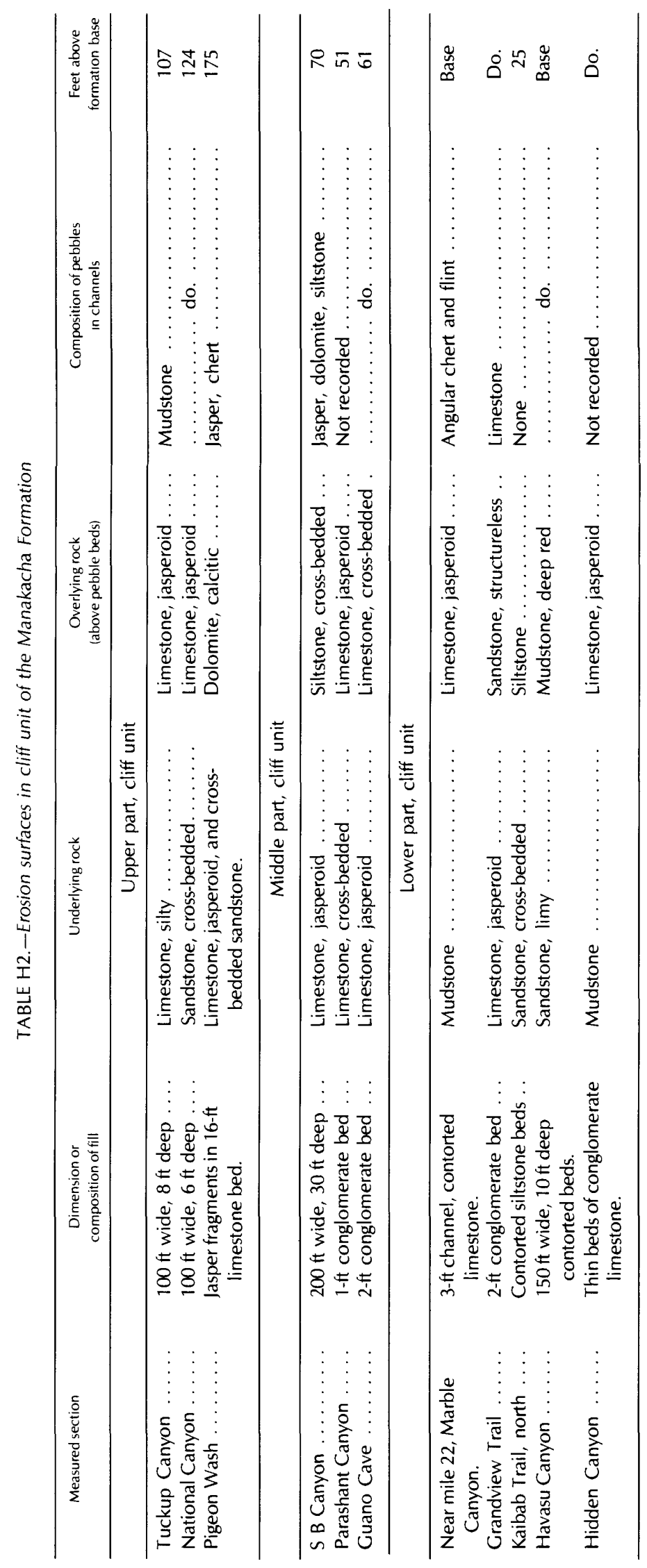



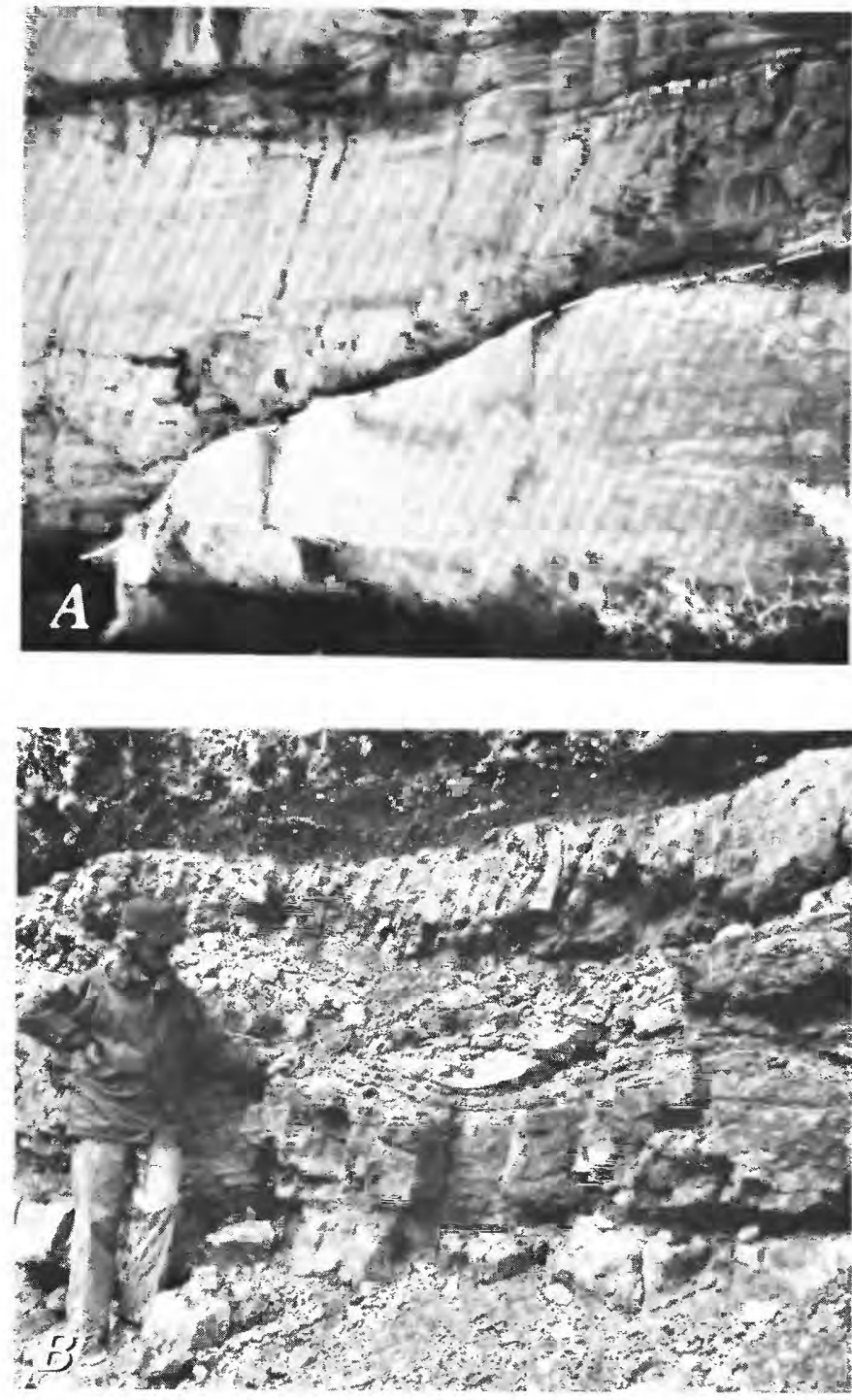

FICURE H3.-Channels on erosion surfaces within the Manakacha Formation, Grand Canyon, Ariz. A, Trough in jasper-banded limestone filled with sandy limestone, near base of formation, S B Canyon; B, wavy surface of erosion at base of Manakacha cliff unit, near Twentyseven Mile Rapids in Marble Canyon.

eastern Great Basin, has caused more confusion in understanding the stratigraphy of the area than any other single factor" (Steele, 1959, p. 52).

\section{EROSION SURFACE AT BASE OF THE ESPLANADE SANDSTONE}

The most conspicuous and widespread of the various erosion surfaces that delineate formations of the Supai Group in Grand Canyon is the one that underlies the Esplanade Sandstone and marks the top of the Wescogame
Formation. This surface includes many channels of different sizes and shapes, interfluve surfaces consisting of small rounded hills, and broad flat plains (table $\mathrm{H} 1$ ). This unconformity occurs at the boundary between the Pennsylvanian and Permian Systems.

Most channel profiles at the Wescogame-Esplanade contact are semicircular (fig. H11), some only a few feet deep, but others as much as $47 \mathrm{ft}$ (Havasu Canyon) and $45 \mathrm{ft}$ (National Canyon). Widths of the larger channels are as much as $500 \mathrm{ft}$. In profile, many channels are asymmetrical or irregular (figs. H12 and H13).

The record of unconformity between the Wescogame Formation and Esplanade Sandstone is locally complex. Rather than a single irregular surface of erosion at the top of the Wescogame and one basal conglomerate in the Esplanade, a zone consisting of two or more irregular surfaces of erosion and more than one conglomerate bed or lens occurs at some places. At six localities (S B Canyon, Havasu Canyon, National Canyon, Toroweap Valley, Whitmore Wash, and Blue Mountain Canyon) conglomerate beds occur at two horizons above the unconformable surface suggesting the repetition of a degradationaggradation cycle. Furthermore, in at least three localities conglomerate deposits are cut by channels of a younger erosion surface. Thus, more than one stage of erosion and deposition seems to be represented by unconformities associated with the basal part of the Esplanade Sandstone. On the other hand, this boundary was described as "gradational" by Fisher (1963, p. 153) and attributed to "extensive and continuous marine sedimentation in northwestern Arizona."

Before the close of Virgilian time and development of the post-Wescogame erosion surface, withdrawal of marine waters from the Grand Canyon region apparently took place. This is indicated by imprints of land plants in uppermost reddish-brown mudstones of the Wescogame. The conifer Walchia has been found in the upper part of the Wescogame at two localities (Hidden Canyon, Iceberg Canyon), together with shrinkage cracks, borings like those of worms, and other trace fossils, which are evidence of continental, probably alluvial, deposition prior to the time of unconformity.

The Grand Canyon region was elevated above sea level and an intricate pattern of drainage channels was eroded in the upper surface of the Wescogame before the Esplanade was deposited. Later, during transgression of the Permian sea, sediments of the Pakoon Limestone (McNair, 1951) accumulated in the western part of the region and sand of the Esplanade was deposited farther east.

A distinctive conglomerate, referred to as basal conglomerate of the Esplanade Sandstone, overlies the postWescogame surface of erosion in a majority of the localities (28 of 32) examined. This conglomerate consists mainly of well-rounded pebbles and cobbles of limestone 


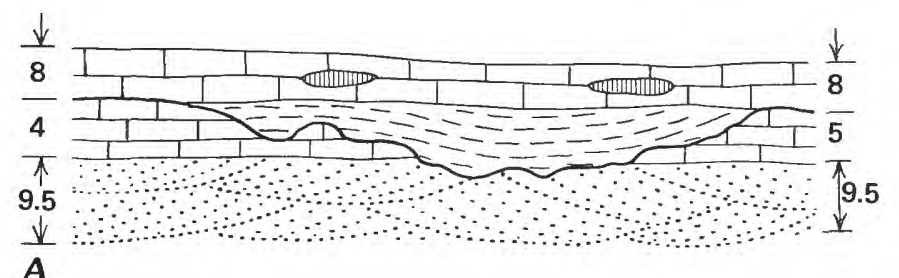

A
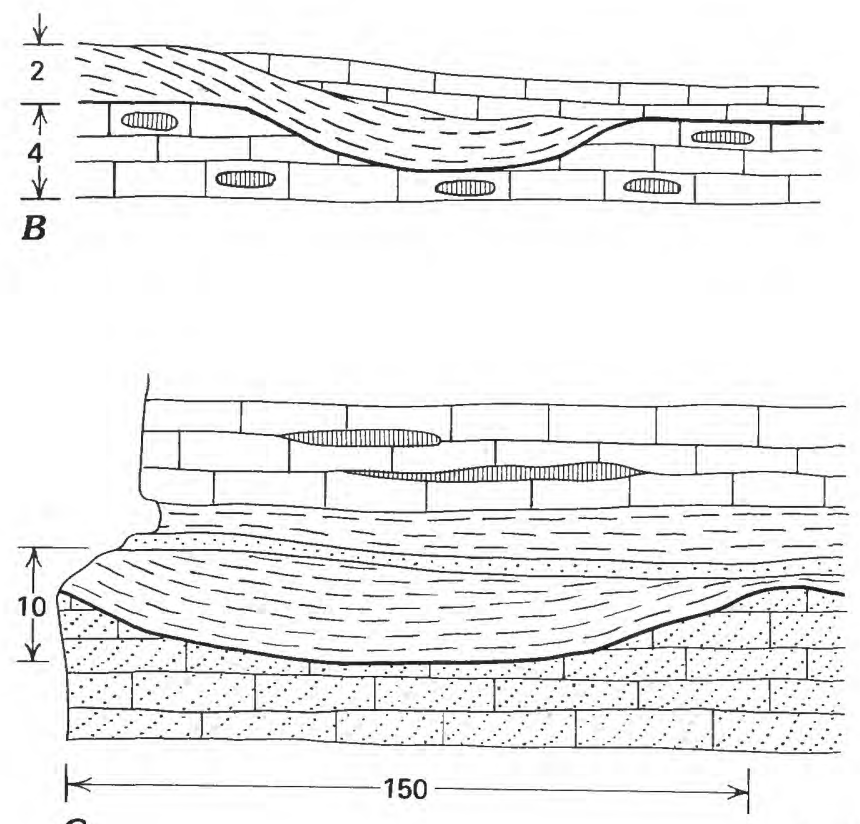
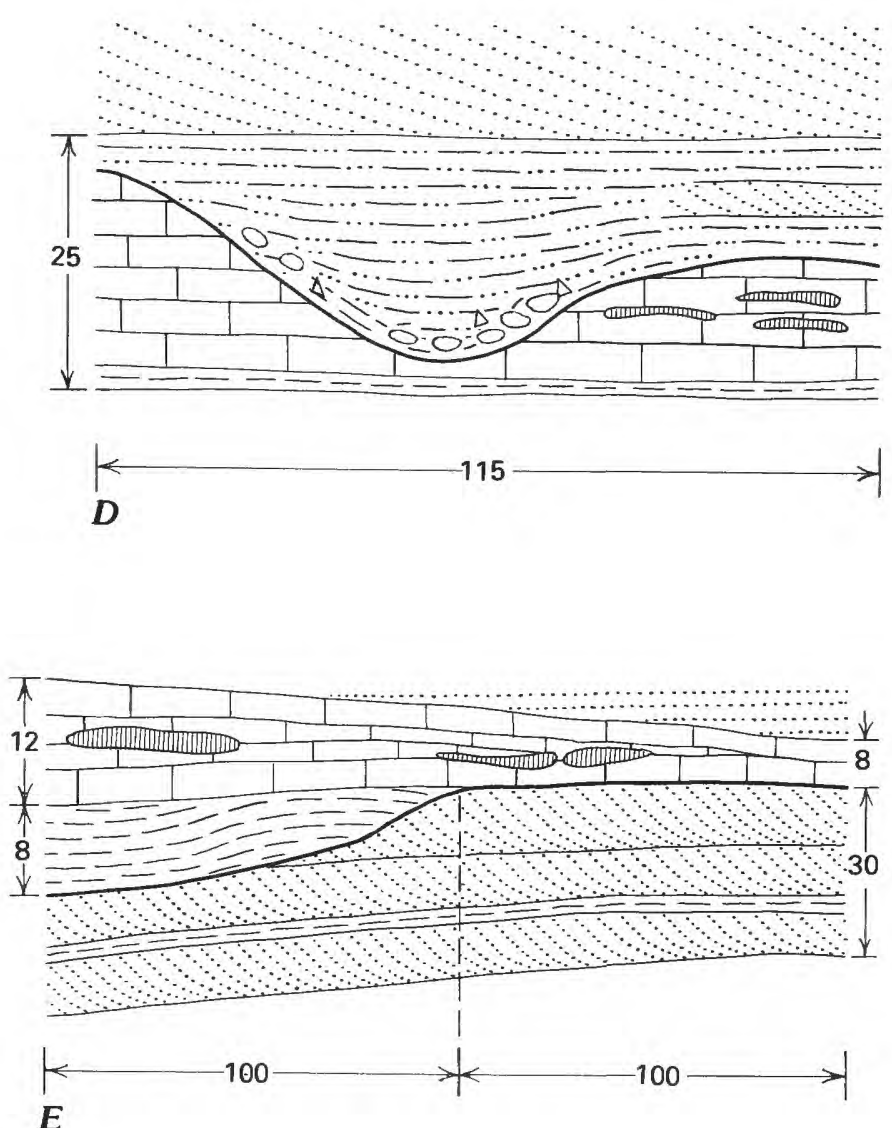

EXPLANATION

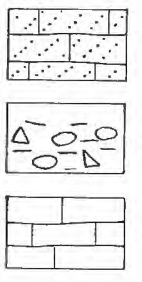

Cross-bedded sandy limestone

Conglomerate

Limestone

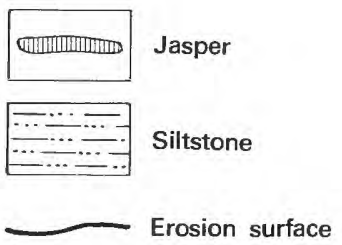

FIGURE H4.-Erosion surfaces in the Manakacha Formation. A, Channel $100 \mathrm{ft}$ wide and $6 \mathrm{ft}$ deep, near top and $124 \mathrm{ft}$ above base of formation, National Canyon. B, Shallow channel at base of cliff of Manakacha Formation near Mile 23 Rapid in Marble Canyon. C, Shallow channel at base of cliff unit of Manakacha Formation, near Hualapai Trail to Supai village. D, Twenty-foot deep channel cut in

and siltstone, but includes a very few clasts of chert or other durable rocks. The pebbles and cobbles are in thin layers on the bottoms and sides of channels and in lenses within the channel fill (table J3). In most places the conglomerate does not exceed a few feet in thickness, but near Bunker Trail it is $16.5 \mathrm{ft}$ thick and on Kaibab Trail, north, it fills a pocket that is $17 \mathrm{ft}$ deep.

In addition to conglomerate, the channel-fill in many places includes reddish-brown mudstone or siltstone (at Kaibab Trail, north, Topocoba Trail, Havasu Canyon, Tuckup Canyon, and other localities) and cross-bedded jasper-banded limestone at middle of cliff unit of Manakacha Formation; pebble layer in bottom, S B Canyon. E, East half of 8-ft channel in silty limestone; channel contains pebbles of reddish-brown mudstone and is $107 \mathrm{ft}$ above formation base, Tuckup Canyon. Horizontal and vertical distances in feet.

sandstone (at Topocoba Trail, Kanab Canyon, and Twin Springs Canyon).

Whether initial deposition, including the filling of channels, was by continental or marine processes is difficult to determine in most parts of the region. In the western part of the region where fossiliferous marine limestone of the Pakoon occurs as the equivalent of the lower part of the Esplanade Sandstone, the probability seems great that deposition began with marine sediments. The Pakoon Limestone has a basal conglomerate equivalent to the Esplanade basal conglomerate to the east. 


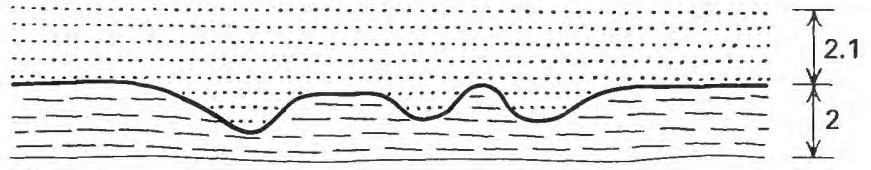

A

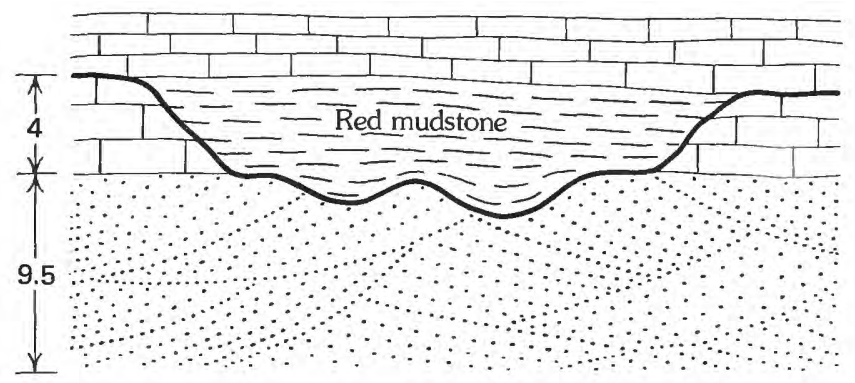

$B$
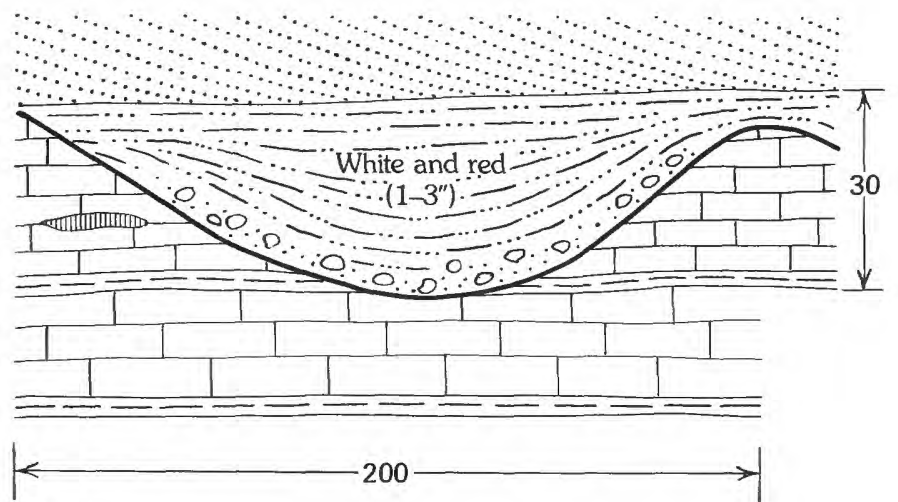

C

FIGURE H5.-Erosion surfaces in cliff unit of Manakacha Formation, Grand Canyon, Ariz. A, Base of cliff unit near Hualapai Trail to Supai village. B, Channels near top of cliff unit, National Canyon. C, 30-ft deep channel, filled with jasperoid limestone that contains blocks of

Evidence of likely marine deposition is furnished at Guano Cave section by concentrations of large pelecypod shells among limestone pebbles, and at $1 \mathrm{mi}$ farther east, where echinoid spines, crinoid joints, and brachiopods are in siltstone and limestone beds directly above the basal conglomerate. In a channel at Hidden Canyon, the basal strata of the Pakoon, about $6 \mathrm{ft}$ thick, consist of thin granular limestone beds overlain by conglomerate.

The basal conglomerate of the Esplanade Sandstone in central and eastern parts of Grand Canyon, in contrast, seems to be devoid of fossils and the accumulations of uniformly well-rounded gravel furnish no diagnostic evidence of depositional environment. Some of the reddish-brown mudstone and siltstone that overlies the

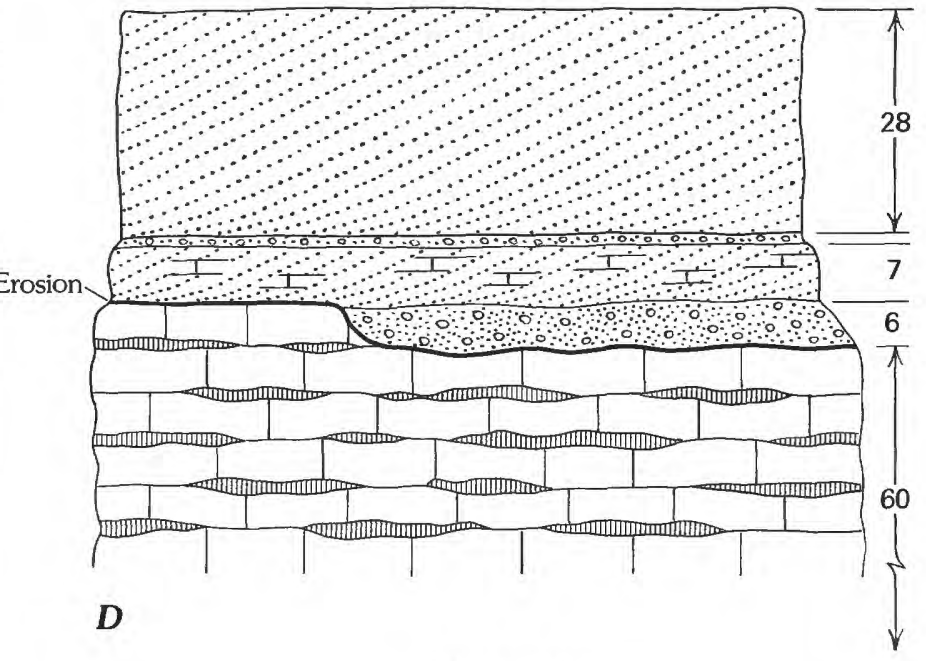

EXPLANATION

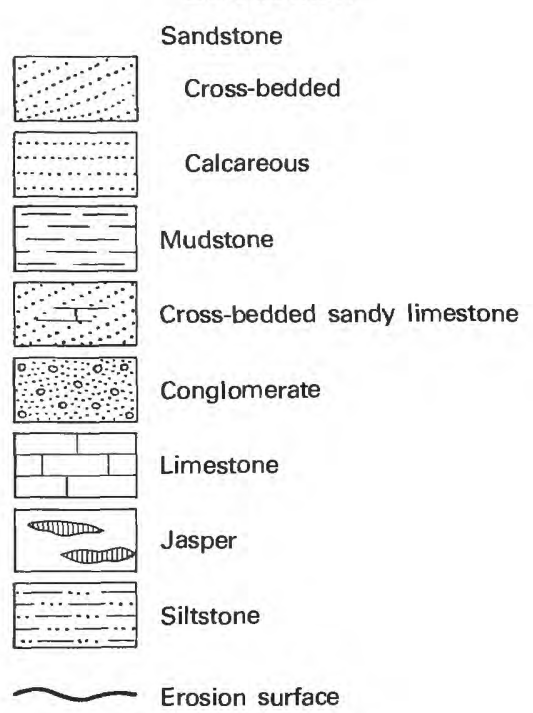

jasper and pebbles of dolomite and siltstone, $70 \mathrm{ft}$ above base of formation, S B Canyon. D, At $61 \mathrm{ft}$ above base of cliff unit at Guano Cave outcrop section; conglomerate about $6 \mathrm{ft}$ thick at middle right. Vertical and horizontal distances in feet.

conglomerate in this region may be of continental (fluvial?) origin. Rain pits in shaly siltstone occur about 7 $\mathrm{ft}$ above a channel top at Twin Springs Canyon, and fragments of plant stems were found in basal strata at House Rock Rapids (Mile 17.5 in Marble Canyon).

\section{EROSION SURFACES WITHIN THE ESPLANADE SANDSTONE}

The Esplanade Sandstone in the Grand Canyon region is generally composed of two easily recognizable units-a lower slope unit and a main cliff unit-but an upper cliffslope unit overlies the cliff unit in some areas. The upper 

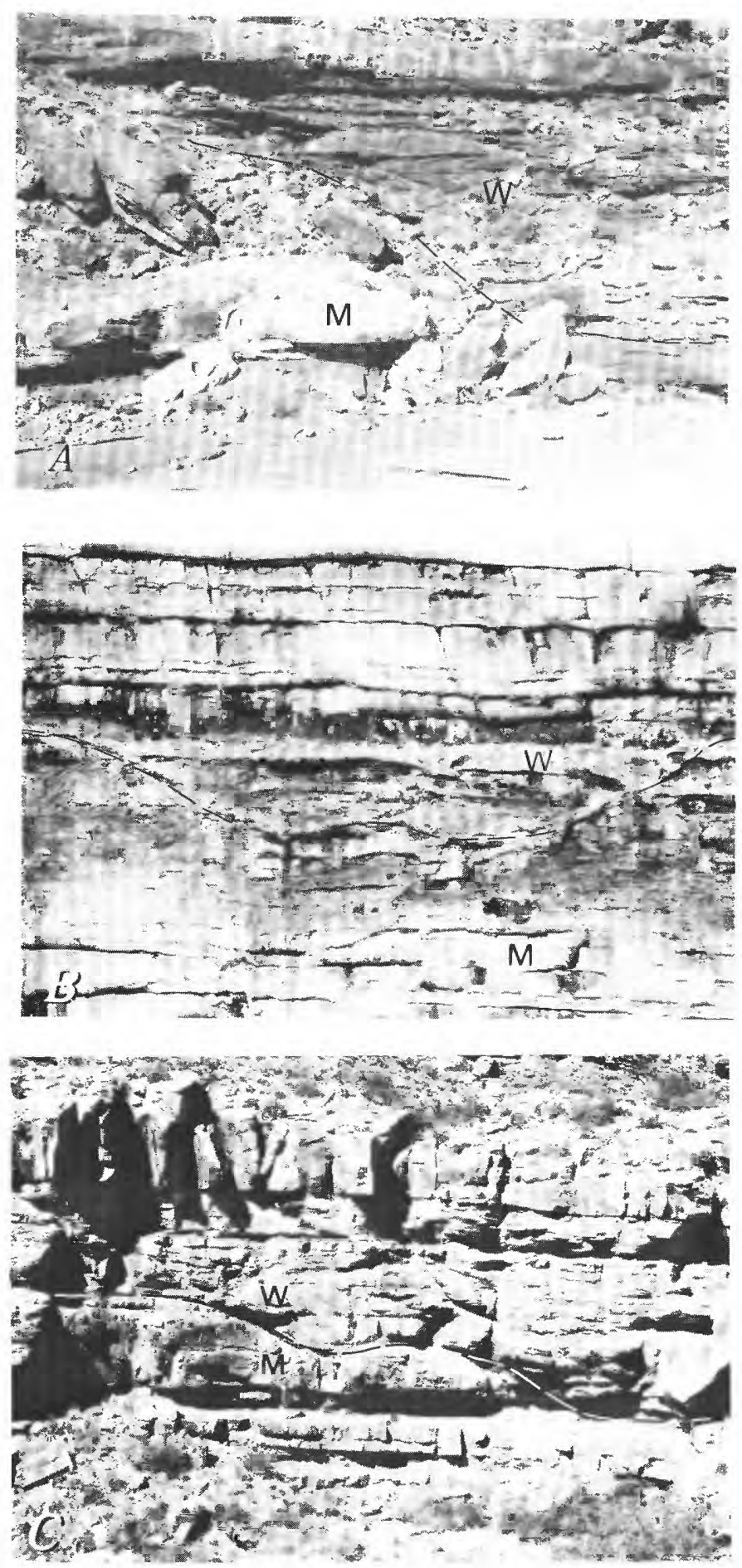

unit may be subdivided locally into gypsum beds, below, and alternating sandstone and siltstone, above.

Whether this upper unit represents local variations in sedimentation during essentially continuous deposition, or reflects two periods of accumulation and an intervening period of erosion, has not been determined.

Evidence of erosion within the Esplanade Sandstone has been detected at only two localities; near Bunker Trail in
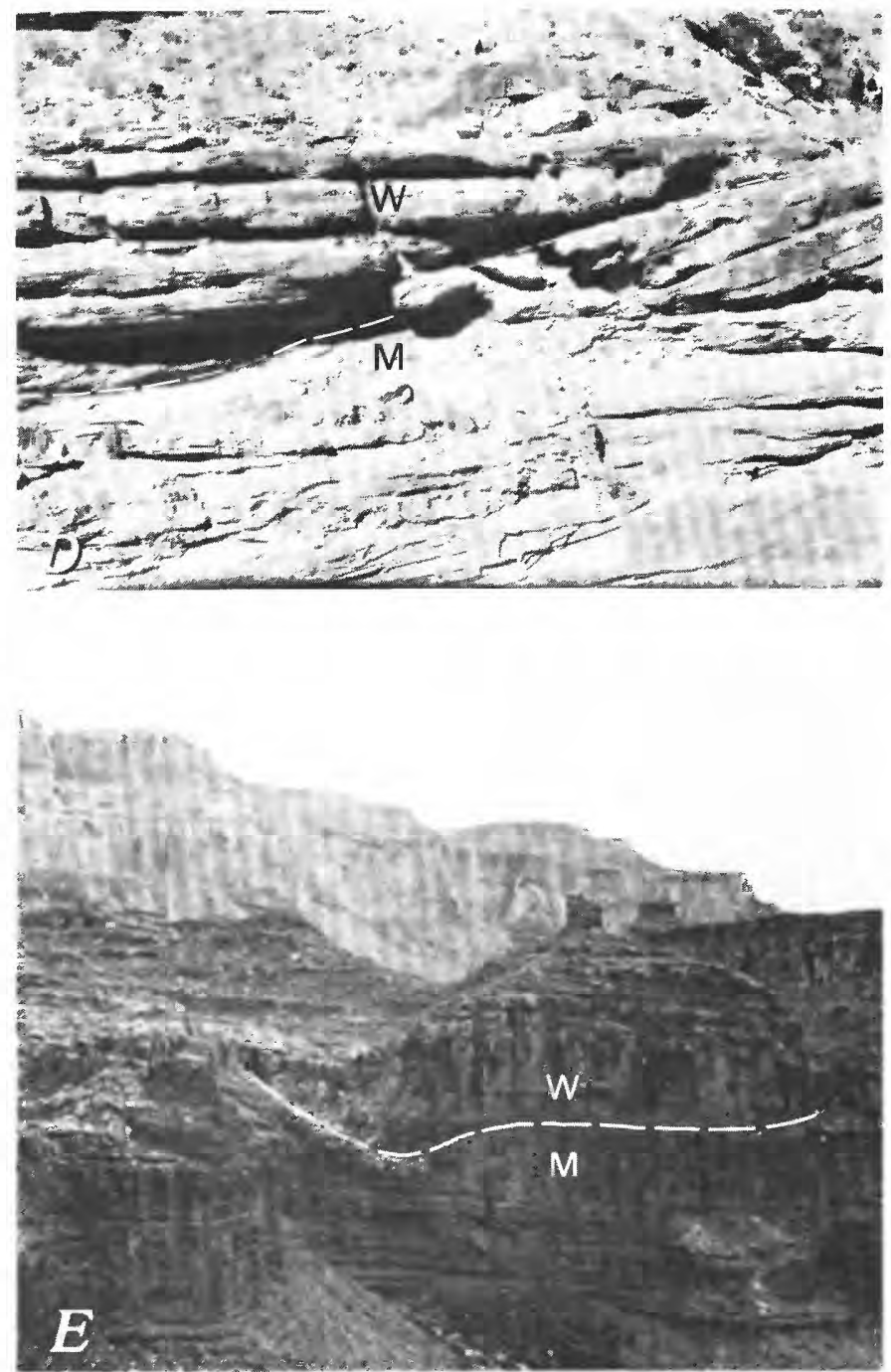

FIGURE H6. - Erosion surface at top of the Manakacha Formation, at the contact of the Manakacha (M) and Wescogame (W) Formations, Grand Canyon region, Arizona. A. Channel near Topocoba Trail; $B$, channel filled with basal conglomerate of the Wescogame, between Horsetrail and Waterhole Canyons on the Little Colorado River Gorge; $C$, channel in the Manakacha filled with conglomerate, base of Wescogame cliff unit, Fishtail Canyon; $D$, flat sandstone beds of the Wescogame, which fill a shallow swale on the upper surface of the Manakacha, S B Canyon; E, east wall of canyon above Supai village, channel about $50 \mathrm{ft}$ deep, in slope unit of Manakacha, filled with reddish-orange mudstone and scattered pebbles of Wescogame.

eastern Grand Canyon and in Andrus Canyon in the northwestern part of the region. At both localities, surfaces containing small channels and exhibiting low relief occur in the upper part of the formation.

The erosion surface near Bunker Trail is about $60 \mathrm{ft}$ below the top of the Esplanade Sandstone and is readily located by an overlying conglomerate of rounded limestone pebbles that fill channels to as much as $3 \mathrm{ft}$ in depth. 

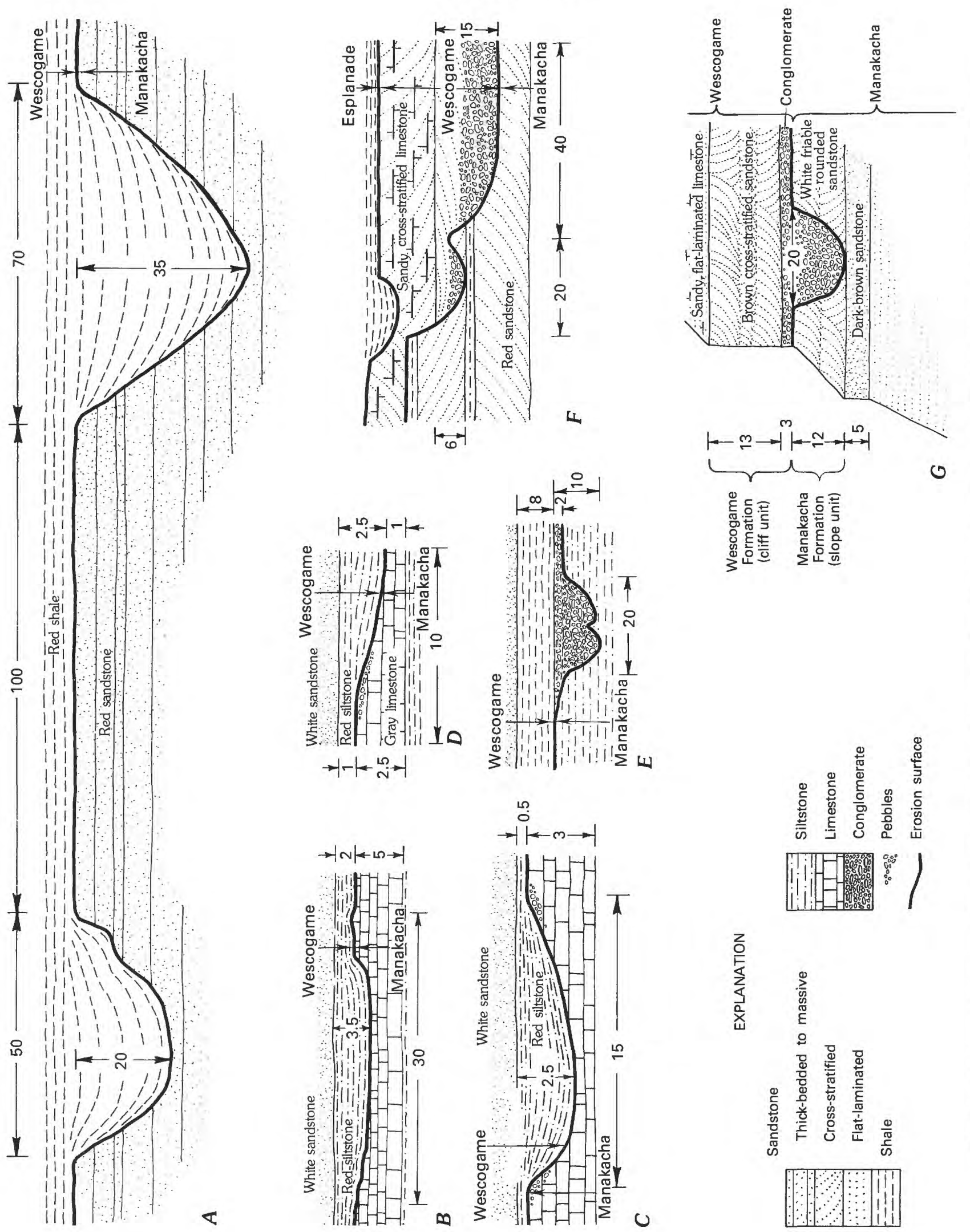

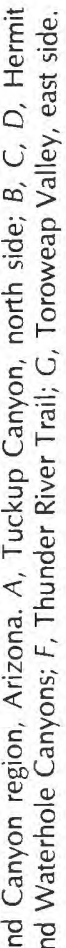

บำ

돈

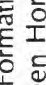

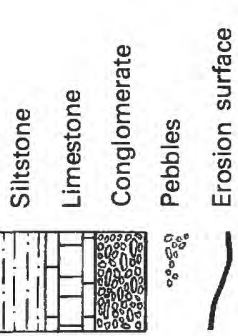

ह

Оू

30

离

递

ก 8.5

을

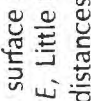

을 잉

暿?

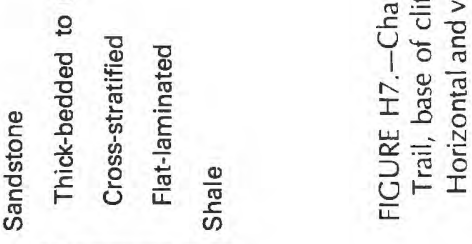



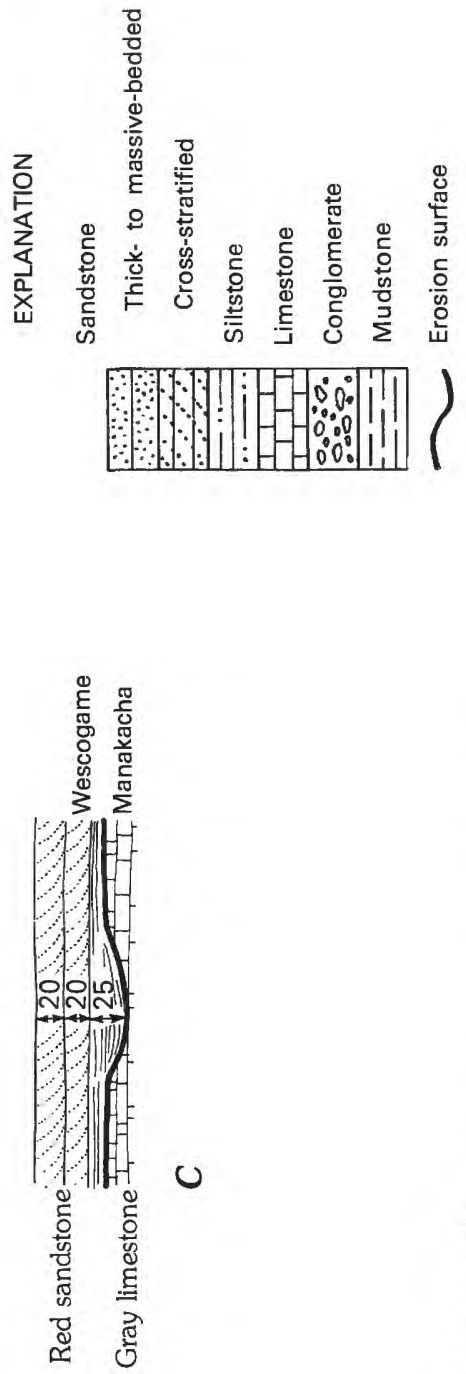

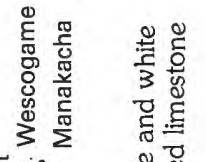

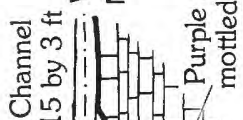

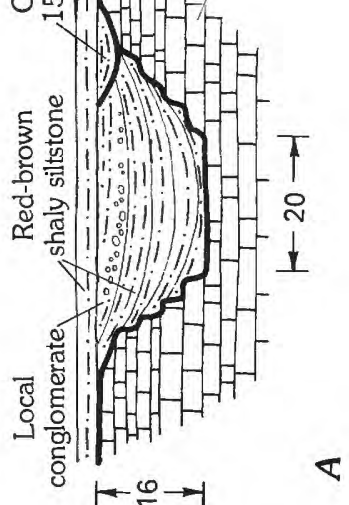

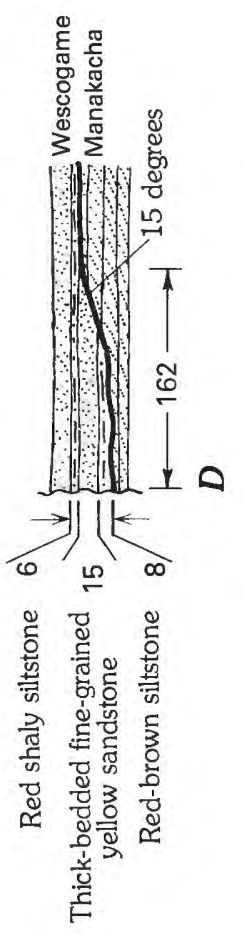

옹
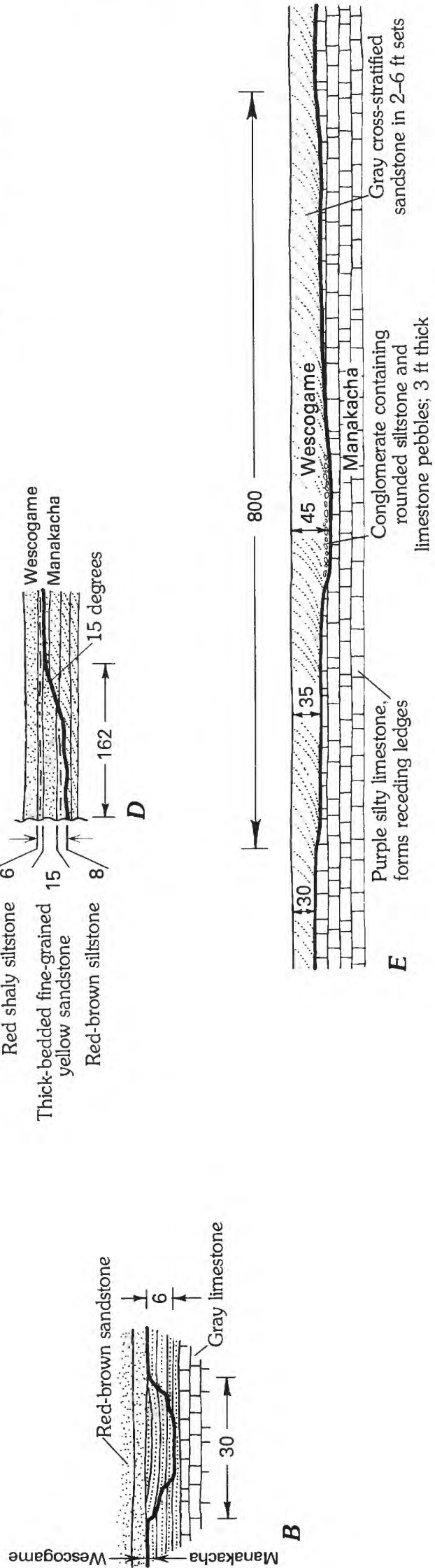

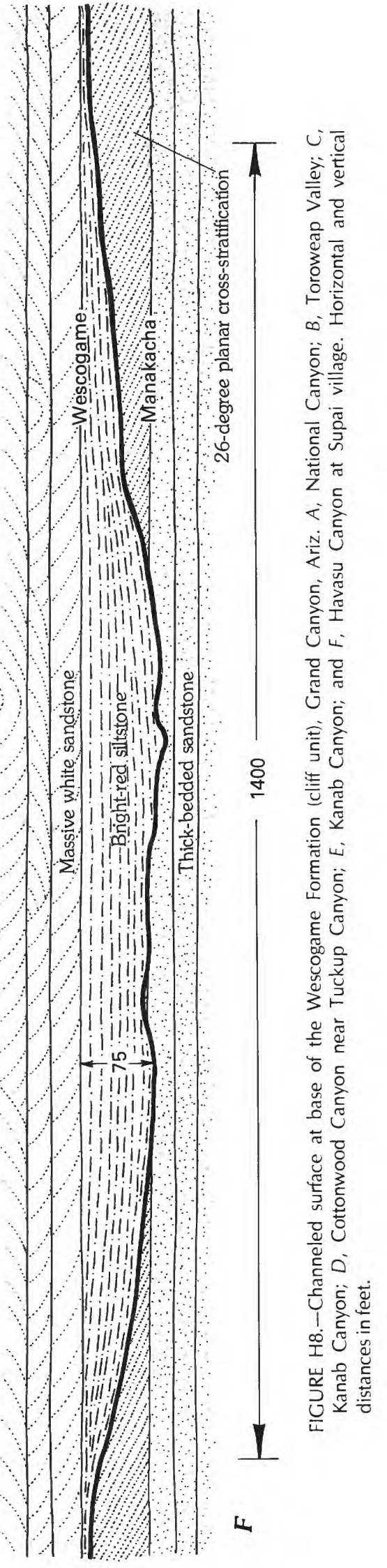



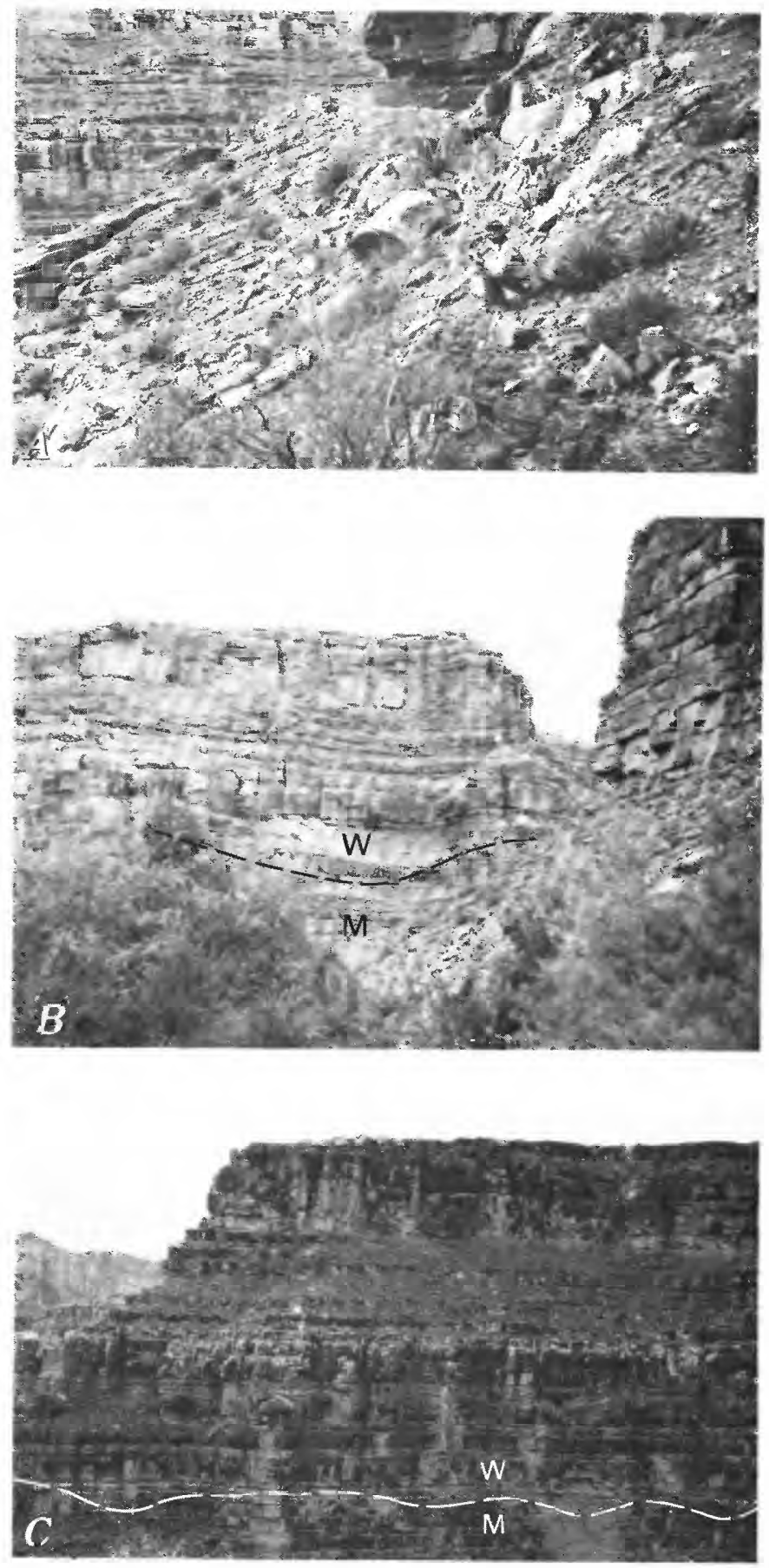

FIGURE H9. - Unconformable surface between the Manakacha $(M)$ and Wescogame (W) Formations in Havasu Canyon, Grand Canyon region, Arizona. A, Channel in cross-stratified sandstone of Wescogame Formation filled with red-brown mudstone, Apache Trail; $B$, channel 60-ft deep at base of cliff unit of Wescogame, west of Navajo Falls; $C$, irregular erosion surface with amplitude of about $1,000 \mathrm{ft}$ in west side of Havasu Canyon near Supai village.

This surface of erosion is at the top of the massive, main sandstone cliff and underlies minor cliffs of similar sandstone, alternating with slopes of mudstone. Neither the conglomerate nor the erosion surface has yet been observed at any other locality in the area.

The erosion surface in the upper Esplanade at Andrus Canyon occurs in an area where the formation is unusually thick and where a gypsiferous facies and an upper sandstone cliff comprise the upper cliff-slope unit above the main sandstone cliff (sec. 24, fig. C8). This intraformational erosion surface is very uneven and contains channels about $2 \mathrm{ft}$ deep and 5 or more feet wide. It is located at the contact of the gypsiferous facies and the upper sandstone cliff. Although the gypsiferous facies extends eastward at least as far as Toroweap Valley, the erosion surface at its top has been located only at Andrus Canyon, so must be considered local.

Neither an erosional surface nor a blanket of conglomerate has been found between the Pakoon Limestone and overlying units of the Esplanade Sandstone in any of the sections examined in far western Grand Canyon or in Iceberg Canyon. Probably the change in depositional environment represented by the limestone and the overlying sandstone did not cause a hiatus in the sequence.

\section{EROSION SURFACE AT CONTACT OF ESPLANADE SANDSTONE AND HERMIT SHALE}

An exhumed erosion surface at the top of the Esplanade, which is beautifully displayed in the walls of Hermit Canyon, consists of numerous depressions or channels carved in massive sandstone. The channels are filled with shaly mudstone and siltstone of the overlying Hermit Shale. This unconformity was the first of several widespread unconformities of erosion to be recognized within red beds of the Supai-Hermit sequence. It was discovered in 1916 by Noble (1922, p. 63), and subsequently reported by Schuchert (1918, p. 356). Because of this discovery, Noble (1922, p. 64) redefined the Supai Formation and placed its upper contact at the unconformity. He proposed the name Hermit Shale for the shaly mudstones and siltstones above.

A regional extent of considerable magnitude was recognized by Noble (1922, p. 63) for the erosional surface because he noted its occurrence below Havasupai Point, $11 \mathrm{mi}$ northwest of Hermit Trail, and also along Bright Angel Trail, $5 \mathrm{mi}$ to the southeast. Continuation of the same unconformable surface northwestward to the junction of Kanab Canyon and Hack Canyon was later demonstrated by Gregory and Noble (1923) who reported that "the unconformity is coincident with the great bench or platform that Dutton has named the 'Esplanade' [suggesting] the possibility that the Esplanade is an exhumed surface of Carboniferous time." 

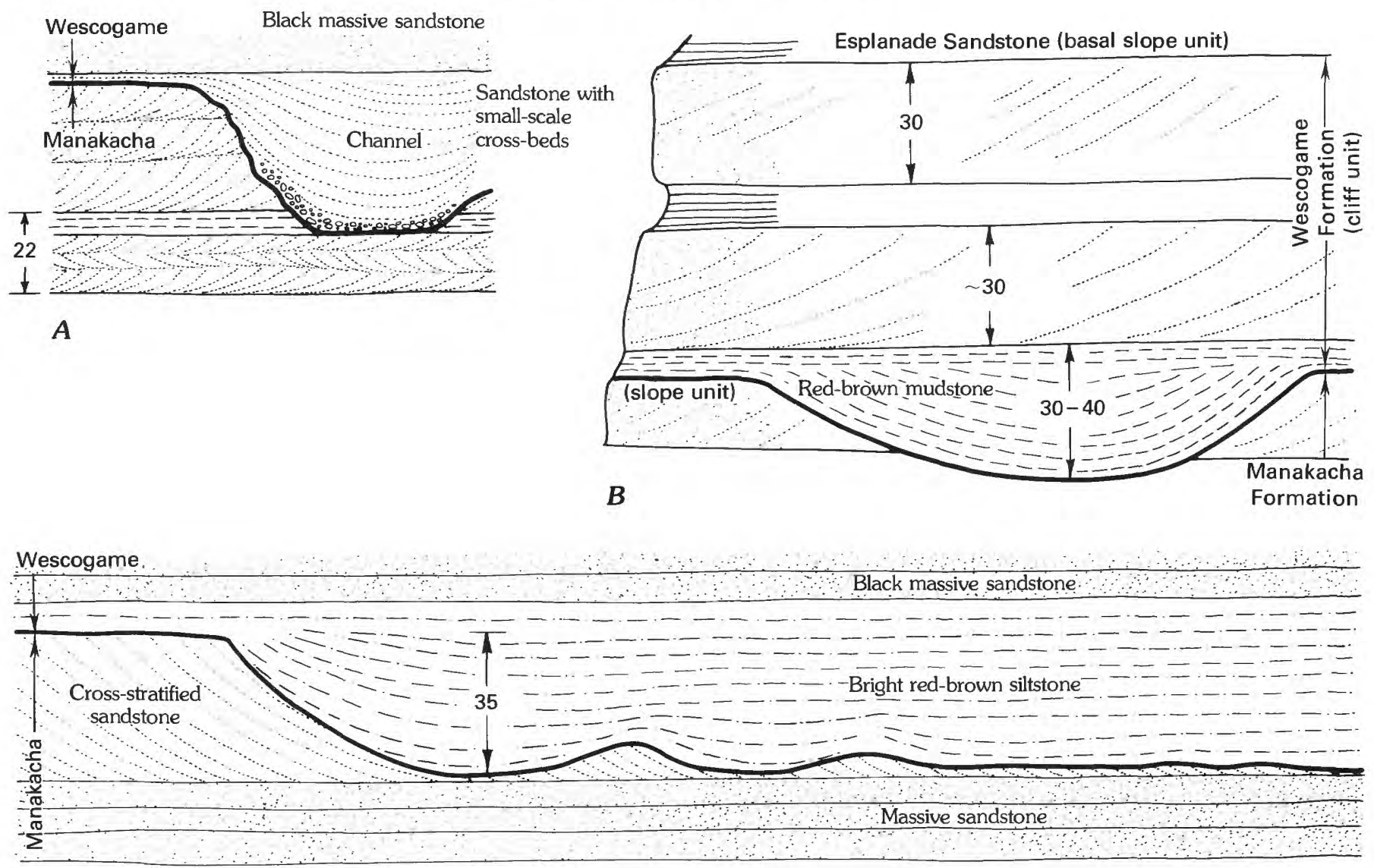

\section{$C$}
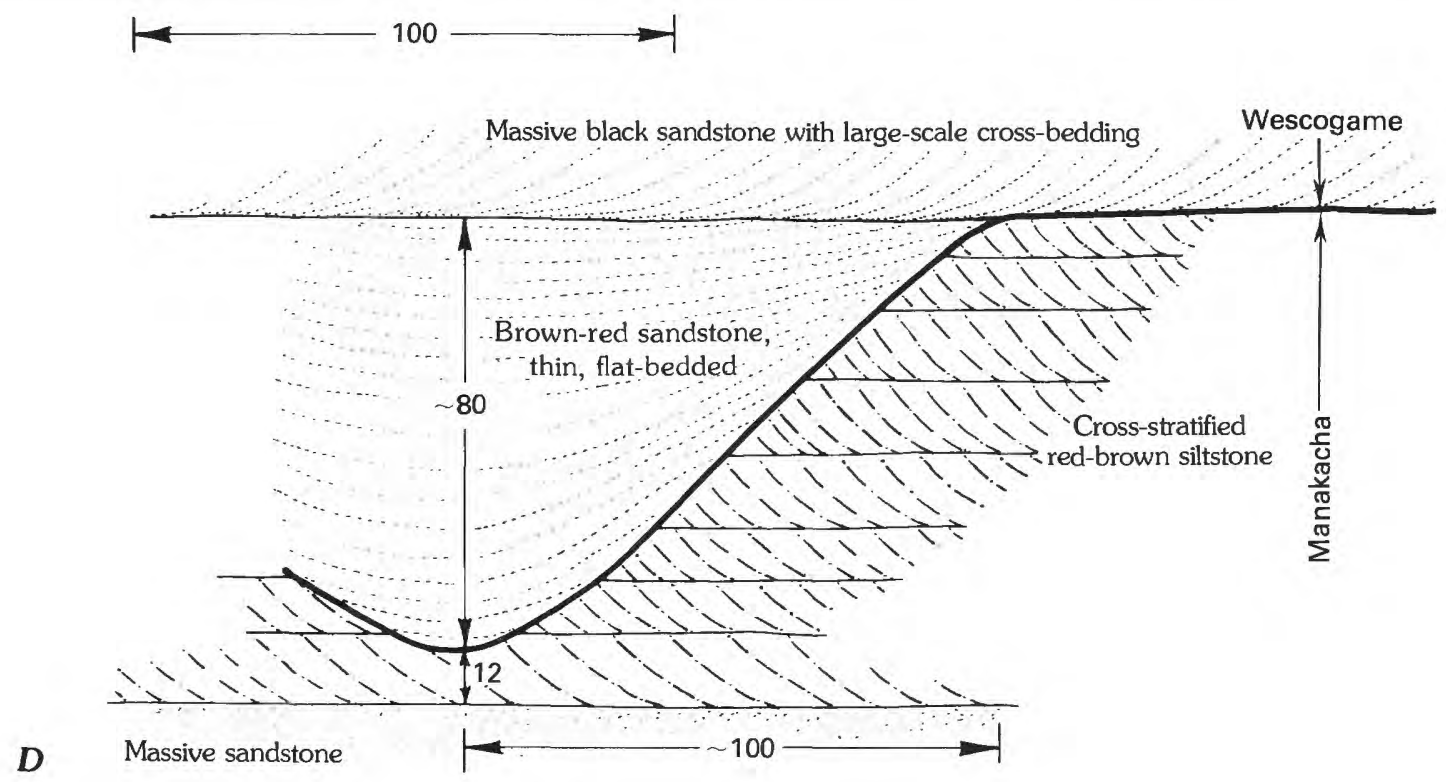

FIGURE H10 (above and right).-Channeled surface at base of the Wescogame Formation in Havasu Canyon, Ariz. A, Near Apache Trail above Supai village; $B$, along Hualapai Trail to Supai village; $C$, west side of channel exposed in canyon wall east of Supai village; $D$, in canyon wall opposite $C$ section along Apache Trail; $E$, at Supai village; $F$, along Apache Trail near Supai village; $C$, near Hualapai Trail to Supai village.

The erosional surface at the top of the Esplanade Sandstone forms hills and valleys (table H4, fig. H14) at numerous localities, in addition to those cited by Noble. Many of these occurrences are described in the measured stratigraphic sections included in this publication. Hills and valleys of the erosional surface were observed to the east of 

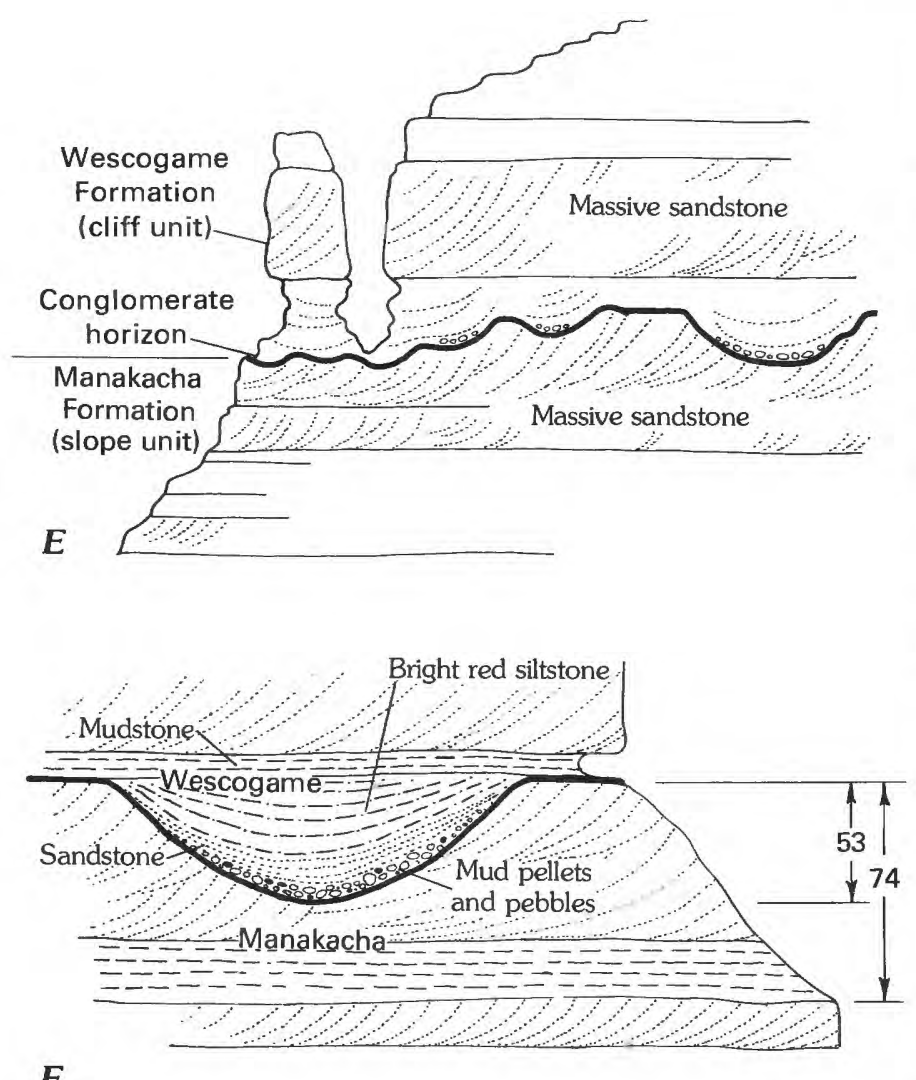

$\boldsymbol{F}$

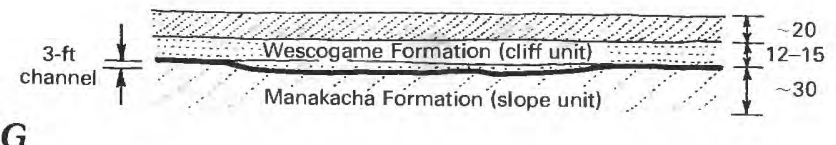

G

EXPLANATION

\begin{tabular}{|c|c|}
\hline & Sandstone \\
\hline & Thick-bedded to massive \\
\hline & Cross-stratified \\
\hline & Flat-laminated \\
\hline & Mudstone \\
\hline$-\infty$ & Siltstone \\
\hline :00: & Conglomerate \\
\hline & Erosion surface \\
\hline
\end{tabular}

Hermit Canyon, at Badger Canyon, near Bunker Trail and Kaibab Trail, south, and to the west or northwest of Hermit Trail, at Topocoba Trail, Havasu Canyon, Thunder River Trail, National and Tuckup Canyons, Toroweap Valley, and Whitmore Wash. Thus, the pre-Hermit channeled and eroded upper surface of the Esplanade extends at least from Marble Canyon and the eastern end of Grand
Canyon, westward to Whitmore Wash in middle western Grand Canyon.

In many of the areas studied, in which exposures were reasonably good, the unconformity is not represented by any obvious relief. Massive beds of sandstone in the Esplanade are overlain by shaly siltstone or mudstone of the Hermit with an even, flat contact. Principal areas in which the upper surface of the Esplanade seems to be planar and lacking in either channels or hills, are at Twentynine Mile Canyon, Eminence Fault, Blue Spring, Horsetrail Canyon, Shinumo, S B Canyon, Blue Mountain Canyon, Prospect Valley, and Andrus, Twin Springs, and Snap Canyons. At some of these localities, the contact is largely concealed by talus and might have very local relief.

In most parts of the region, the post-Esplanade erosion surface includes relatively shallow channels which range in depth from 10 to $40 \mathrm{ft}$ and have rounded sides and flat bottoms. Typical channels occur at Hermit Canyon (table H1; fig. H15), however, notable exceptions are in two areas west of Hermit Trail. Along the Apache Trail (in Havasu Canyon) and in National Canyon, the surface includes residual mesas of Esplanade-type sandstone, which are 44 $\mathrm{ft}$ and $114 \mathrm{ft}$, respectively, higher than the generally flat upper surface of the Esplanade (fig. H15). Thus, in these areas the amount of truncation in the massive sandstone beds at the top of the Esplanade seems to be greater than it is in areas to the east or west. Apparently, the postEsplanade upwarping and channeling was greatest in the central Grand Canyon area.

The general lack of conglomerate on the erosion surface at the Esplanade-Hermit contact is notable. A small lens of conglomerate, which consists of rounded limestone pebbles, was found in a channel at Bunker Trail and a sequence of limestone and conglomerate, a few feet thick, occurs at a place near Thunder River Trail, but elsewhere it is scarce or absent. Possibly the scarcity of conglomerate is the result of the hiatus being so short that the Esplanade did not become lithified prior to Hermit Shale deposition.

The basal beds of the Hermit Shale generally consist of platy or shaly mudstone and siltstone that probably were deposited in stream channels and on flood plains, as described by White $(1929$, p. 13). Evidence that this environment of deposition extended across most of the Grand Canyon region is furnished by the discovery of land plants, especially Walchia, the algal genus Rivularites, rain pits, shrinkage cracks, and amphibian trackways in basal deposits near Kaibab Trail, south, Hermit Trail, Whitmore Wash, and Parashant Canyon.

\section{REFERENCES CITED}

Darton, N. H., 1910, A reconnaissance of parts of northwestern New Mexico and northern Arizona: U.S. Geological Survey Bulletin 435, $88 \mathrm{p}$. 
TABLE H3.-Characteristics of erosion surface at base of the Wescogame Formation, Grand Canyon, Ariz.

[Leaders (--) indicate no data]

\begin{tabular}{|c|c|c|c|c|}
\hline Measured section & Channel depth & Channel width & Underlying strata & $\begin{array}{l}\text { Overlying conglomerate } \\
\text { distribution }\end{array}$ \\
\hline Blue Spring . . . . . . . & None ..... & None ..... & Structureless siltstone . . . . . . & 3-ft gravel bed. \\
\hline Horsetrail Canyon .. & $4 \mathrm{ft} \ldots \ldots$ & $20 \mathrm{ft} \ldots \ldots$ & $\begin{array}{l}\text { Thin- to thick-bedded } \\
\text { siltstone. }\end{array}$ & $\begin{array}{l}\text { Forms bed and fills channel } \\
\text { below. }\end{array}$ \\
\hline Bunker Trail ....... & $1 \mathrm{ft} \ldots \ldots \ldots$ & $3-4 \mathrm{ft} \ldots \ldots$ & Irregular-bedded mudstone .. & $\begin{array}{c}\text { Fills pockets; includes scat- } \\
\text { tered mud balls and pellets. }\end{array}$ \\
\hline Grandview Trail ... . & \multicolumn{2}{|c|}{ Small-scale irregularities .... } & Structureless siltstone ....... & $\begin{array}{l}\text { Limestone pellets in mud } \\
\text { matrix. }\end{array}$ \\
\hline Kaibab Trail, south .. & \multicolumn{2}{|c|}{$\ldots \ldots \ldots$ do. $\ldots \ldots \ldots$} & $\ldots \ldots \ldots$ do. $\ldots \ldots \ldots$ & $\begin{array}{l}\text { Pebbles scattered in } \\
\text { mudstone. }\end{array}$ \\
\hline Hermit Trail . . . . . . & $2-3 \mathrm{ft} \ldots \ldots$ & $15-30 \mathrm{ft} \ldots$ & Fine-grained limestone ...... & $\begin{array}{l}\text { Local pebble concentrates in } \\
\text { structureless mudstone. }\end{array}$ \\
\hline Thunder River Trail . & $0.5-15 \mathrm{ft} \ldots$ & $20-60 \mathrm{ft} \ldots$ & $\begin{array}{l}\text { Thin mudstone on cross- } \\
\text { stratified sandstone. }\end{array}$ & $\begin{array}{l}\text { Fills lower and middle parts of } \\
\text { channels. }\end{array}$ \\
\hline Havasu Canyon .... & $80 \mathrm{ft} \ldots \ldots$ & $1,400 \mathrm{ft} \ldots$ & Cross-stratified sandstone .... & $\begin{array}{l}\text { Scattered pebbles and pellets } \\
\text { along channel sides and } \\
\text { bottom. }\end{array}$ \\
\hline National Canyon ... & $16 \mathrm{ft} \ldots \ldots$ & $50+\mathrm{ft} \ldots$ & Cross-stratified limestone .... & $\begin{array}{l}\text { 1- } \mathrm{ft} \text { bed at bottom and thin } \\
\text { lens at top of sandstone. }\end{array}$ \\
\hline Kanab Canyon ..... & $18 \mathrm{ft} \ldots \ldots$ & $800 \mathrm{ft} \ldots \ldots$ & Thick-bedded limestone ..... & 3-ft bed at channel bottom. \\
\hline S B Canyon ........ & $2-6 \mathrm{ft} \ldots \ldots$ & $\ldots$ & Cross-stratified sandstone .... & $\begin{array}{l}\text { Flat-bedded sandstone fill } \\
\text { without gravel. }\end{array}$ \\
\hline Tuckup Canyon .... & $20-35 \mathrm{ft} \ldots$ & $50-70 \mathrm{ft} \ldots$ & , $\ldots \ldots$ do. $\ldots \ldots \ldots$ & $\begin{array}{l}\text { Sandstone and siltstone } \\
\text { without gravel. }\end{array}$ \\
\hline Toroweap Valley ... & $11 \mathrm{ft} \ldots \ldots$ & $20 \mathrm{ft} \ldots \ldots$ & $\ldots \ldots \ldots$ do. $\ldots \ldots \ldots$ & $\begin{array}{l}\text { Locally fills channel; some } \\
\text { channels contain sand only. }\end{array}$ \\
\hline Whitmore Wash ... & Small-scale irreg & gularities .... & Cross-stratified limestone .... & 1-ft gravel bed. \\
\hline Parashant Canyon ... & $\ldots \ldots$ do & $\ldots \ldots \ldots$ & Structureless siltstone . . . . . . & 2-ft gravel bed. \\
\hline Twin Springs Canyon & $\ldots \ldots$ do & $\ldots \ldots \ldots$ & Limestone and siltstone...... & $\begin{array}{l}\text { Pebbles scattered through } \\
\text { cross-stratified sandstone. }\end{array}$ \\
\hline Guano Cave ...... & $\ldots \ldots \ldots$ do & . & Cross-stratified sandstone .... & 2-ft gravel bed. \\
\hline Snap Canyon ...... & $34 \mathrm{ft} \ldots \ldots$ & -- & Cross-stratified limestone .... & $\begin{array}{l}\text { 3-ft pebble bed above channel } \\
\text { rim. }\end{array}$ \\
\hline Pigeon Wash ...... & $10 \mathrm{ft} \ldots \ldots$ & $30-40 \mathrm{ft} \ldots$ & Cross-stratified sandstone .... & $\begin{array}{l}\text { No conglomerate; clayey } \\
\text { limestone fill. }\end{array}$ \\
\hline Separation Canyon & None ..... & None ..... & $\ldots \ldots \ldots$ do. $\ldots \ldots \ldots$ & 2-ft gravel bed. \\
\hline
\end{tabular}

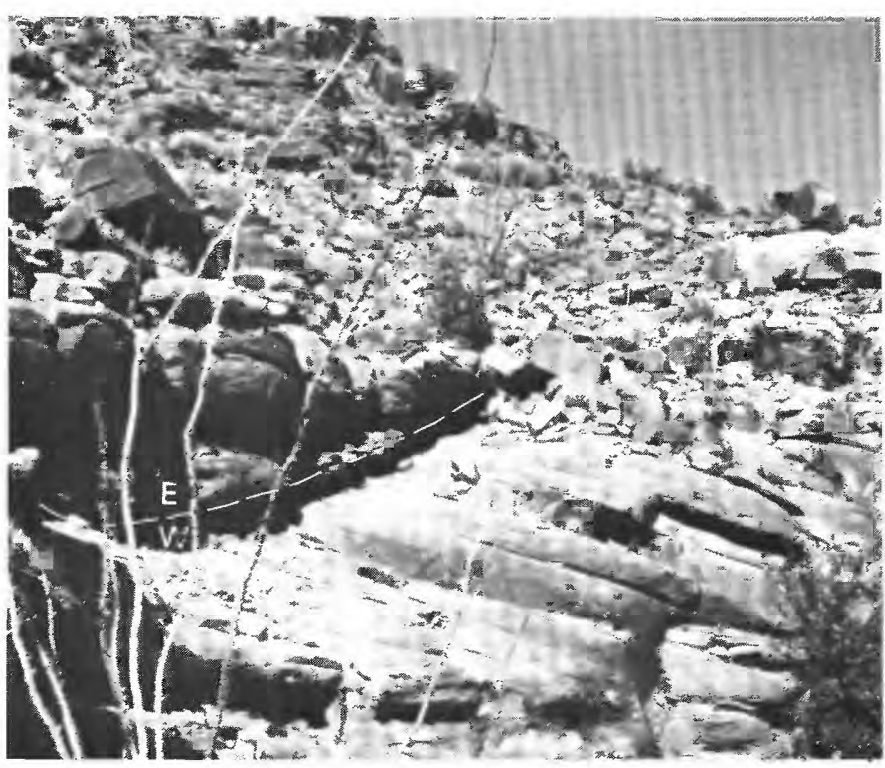

Fisher, W. L., 1963, Formation boundaries in the western Grand Canyon area [abs.]: Geological Society of America Special Paper 73. p. 153.

Gregory, H. E., and Noble, L. F., 1923, Notes on a geological traverse from Mohave, California, to the mouth of San Juan River, Utah: American Journal of Science, 5th ser., v. 5, p. 229-238.

McKee, E. D., and Gutschick, R. C., 1969, History of the Redwall Limestone of northern Arizona: Geological Society of America Memoir $114,726 \mathrm{p}$.

McNair, A. H., 1951, Paleozoic stratigraphy of part of northwestern Arizona: American Association of Petroleum Geologists Bulletin, v. 35, no. 3, p. 503-541.

Noble, L. F., 1922, A section of the Paleozoic formations of the Grand Canyon at the Bass Trail: U.S. Geological Survey Professional Paper 131-B, p. 23-73.

FIGURE H11.-Surface of erosion at top of Wescogame Formation and base of Esplanade Sandstone: A channel at Twin Springs Canyon, Ariz. cut in light-colored cross-stratified sandstone of the Wescogame and filled with brown limy sandstone and conglomerate of the Esplanade. The channel is $35 \mathrm{ft}$ deep and $500 \mathrm{ft}$ wide. 

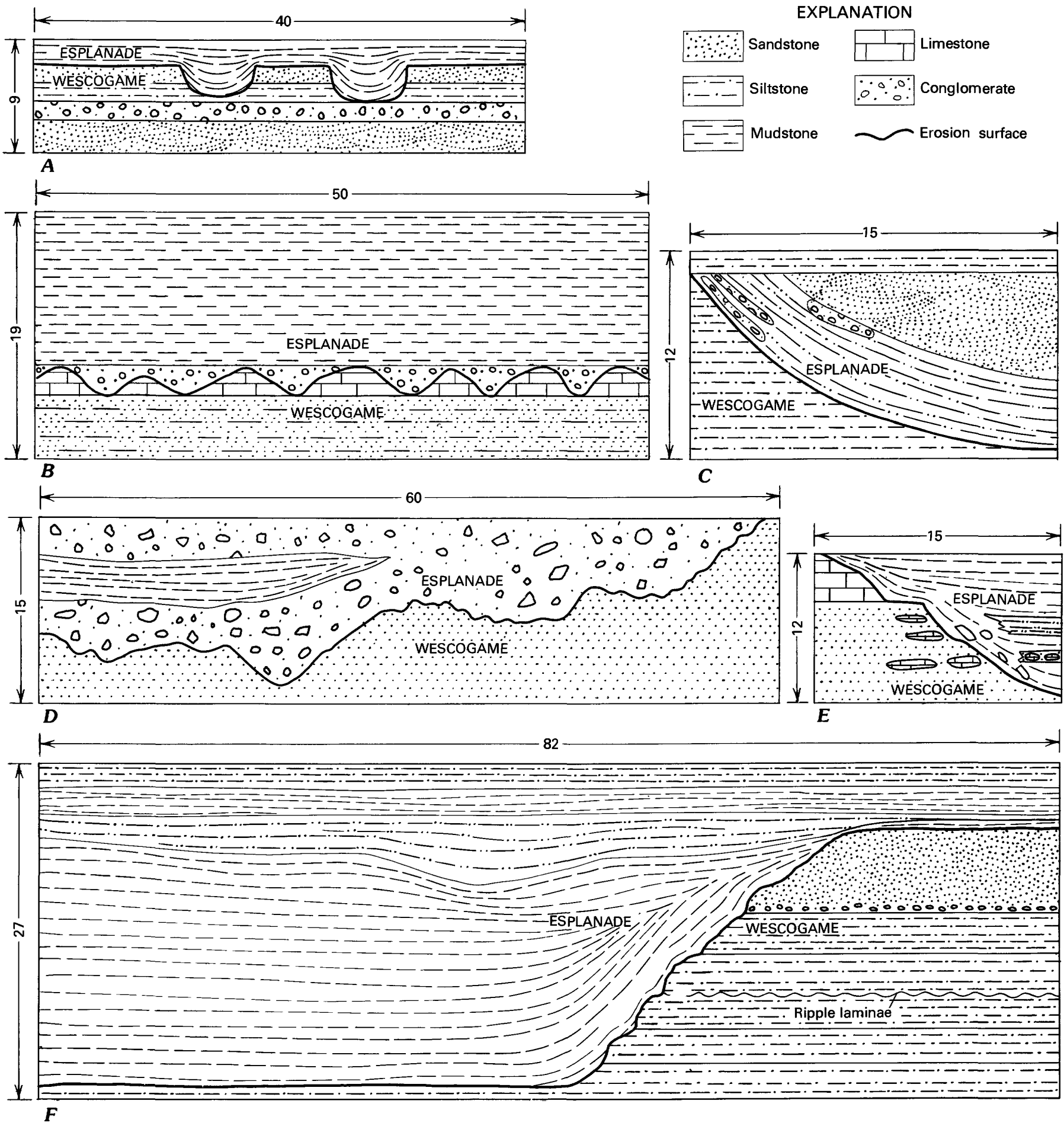

FIGURE H12.-Channeled surface at top of the Wescogame Formation, overlain by basal conglomerate of the Esplanade Sandstone in most places, Grand Canyon, Ariz. A, Mile 17.5, Marble Canyon; B, near Kaibab Trail, south section; $C$, margin of 240 -ft-wide channel,

Schuchert, Charles, 1918, On the Carboniferous of the Grand Canyon of Arizona: American Journal of Science, 4th ser., v. 45, p. 347-361. Steele, G., 1959, Stratigraphic interpretation of the Pennsylvanian-Permian Systems of the eastern Great Basin: Washington University, Ph. D. thesis, 294 p.
Bass Trail; $D$, near Bunker (west Tanner) Trail; and $E$, Thunder River Trail-note angular blocks of limestone conglomerate in channel; $F$, near Hualapai Trail to Supai village. Horizontal and vertical distances in feet.

Welsh, H. E., 1959, Biostratigraphy of the Pennsylvanian and Permian System of southern Nevada: Utah University, Ph. D. thesis, $106 \mathrm{p}$.

White, David, 1929, Flora of the Hermit Shale, Grand Canyon, Arizona: Carnegie Institution of Washington Publication 405, 221 p. 

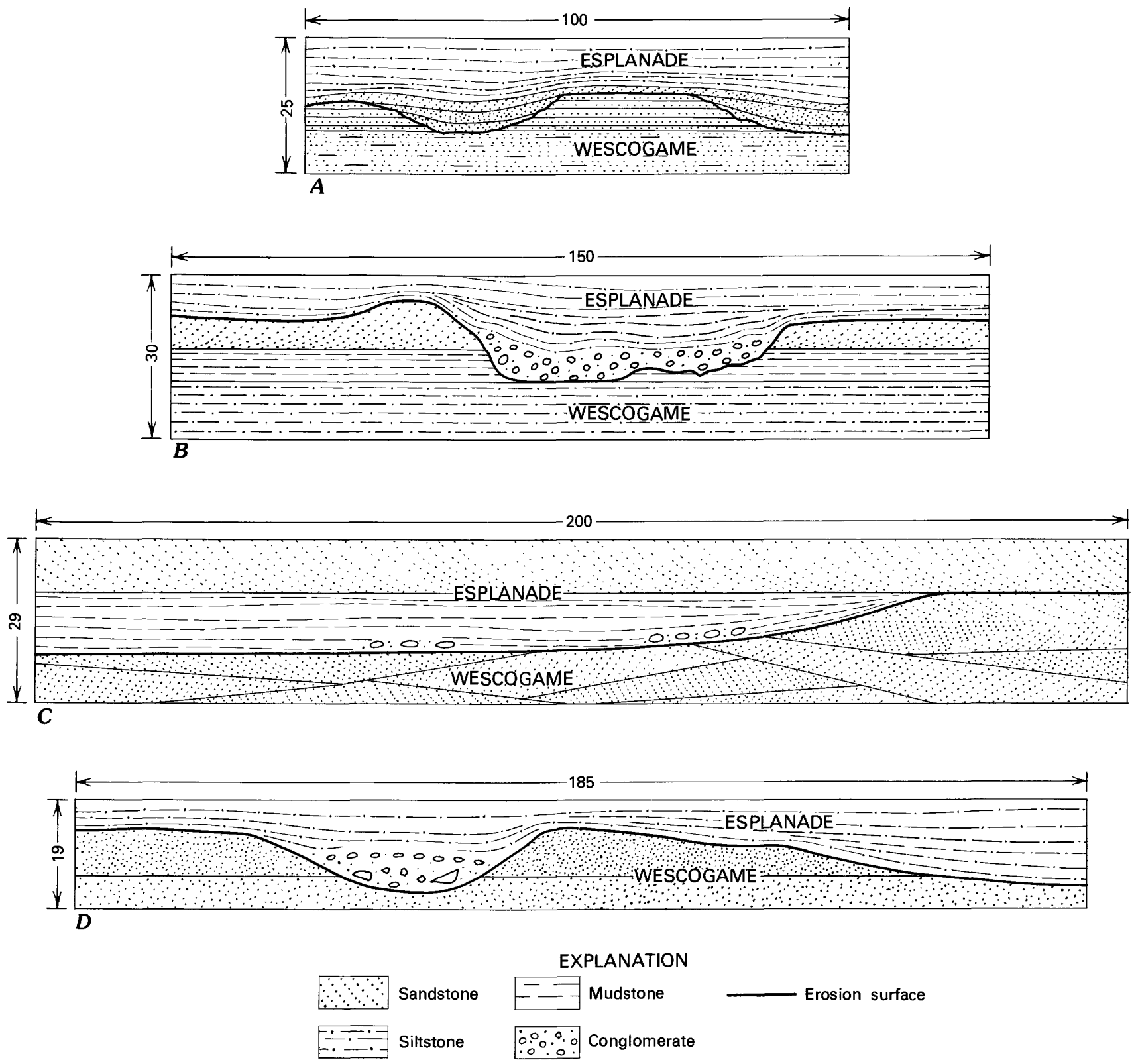

FIGURE H13.-Channeled surface at top of Wescogame Formation overlain by Esplanade Sandstone, Grand Canyon region, Arizona. A, Section at Andrus Canyon; B, Topocoba Trail to Havasu Canyon; C, Apache Trail to Havasu Canyon; and D, S B Canyon. Horizontal and vertical distances in feet. 
TABLE H4.-Unconformity at top of the Esplanade Sandstone

[Leaders (---) indicate no data]

\begin{tabular}{|c|c|c|c|c|c|}
\hline \multirow[b]{2}{*}{ Locality } & \multicolumn{3}{|c|}{ Local relief, in feet } & \multirow[b]{2}{*}{$\begin{array}{l}\text { Composition of } \\
\text { channel fill }\end{array}$} & \multirow{2}{*}{$\begin{array}{l}\text { Environmental } \\
\text { indicators in } \\
\text { fill }\end{array}$} \\
\hline & $\begin{array}{l}\text { Channel } \\
\text { depth }\end{array}$ & $\begin{array}{c}\text { Hill } \\
\text { height }\end{array}$ & $\begin{array}{l}\text { Channel } \\
\text { width }\end{array}$ & & \\
\hline Badger Canyon ...... & 70 & -- & 300 & -- & \\
\hline Bunker Trail ........ . & $\cdots$ & 3 & -- & Shaly siltstone and conglomerate lens. & \\
\hline Kaibab Trail, south .... & 46 & -- & 100 & Shaly siltstone $\ldots \ldots \ldots \ldots \ldots \ldots$ & Land plants, rain pits, shrinkage cracks. \\
\hline Hermit Trail . . . . . . . . & 40 & -- & 75 & $\ldots \ldots \ldots$ do. $\ldots \ldots \ldots \ldots$ & Do. \\
\hline Topocoba Trail ...... & 35 & --- & $60-80$ & $\ldots \ldots \ldots \ldots$ do. $\ldots \ldots \ldots \ldots$ & \\
\hline Havasu Canyon ..... . . & -- & 44 & $80-100$ & -- & \\
\hline Thunder River Trail . . . & 38 & -- & $150+$ & Limestone with conglomerate bed. & \\
\hline Kanab Canyon ....... & -- & 28 & 400 & Shaly siltstone $\ldots \ldots \ldots \ldots \ldots \ldots$ & \\
\hline National Canyon ..... . & -- & 114 & 1,000 & -- & \\
\hline Tuckup Canyon ...... . & -. & 3 &.- & Shaly siltstone . . . . . . . . . . . & \\
\hline Toroweap Valley ... . . . & - & 4 & -- & $\ldots \ldots \ldots \ldots$ do. $\ldots \ldots \ldots \ldots$ & \\
\hline Whitmore Wash .... & 15 & -- & $\square 100$ & $\ldots \ldots \ldots \ldots$ do. $\ldots \ldots \ldots \ldots$ & Land plants, borings, Rivularites. \\
\hline
\end{tabular}
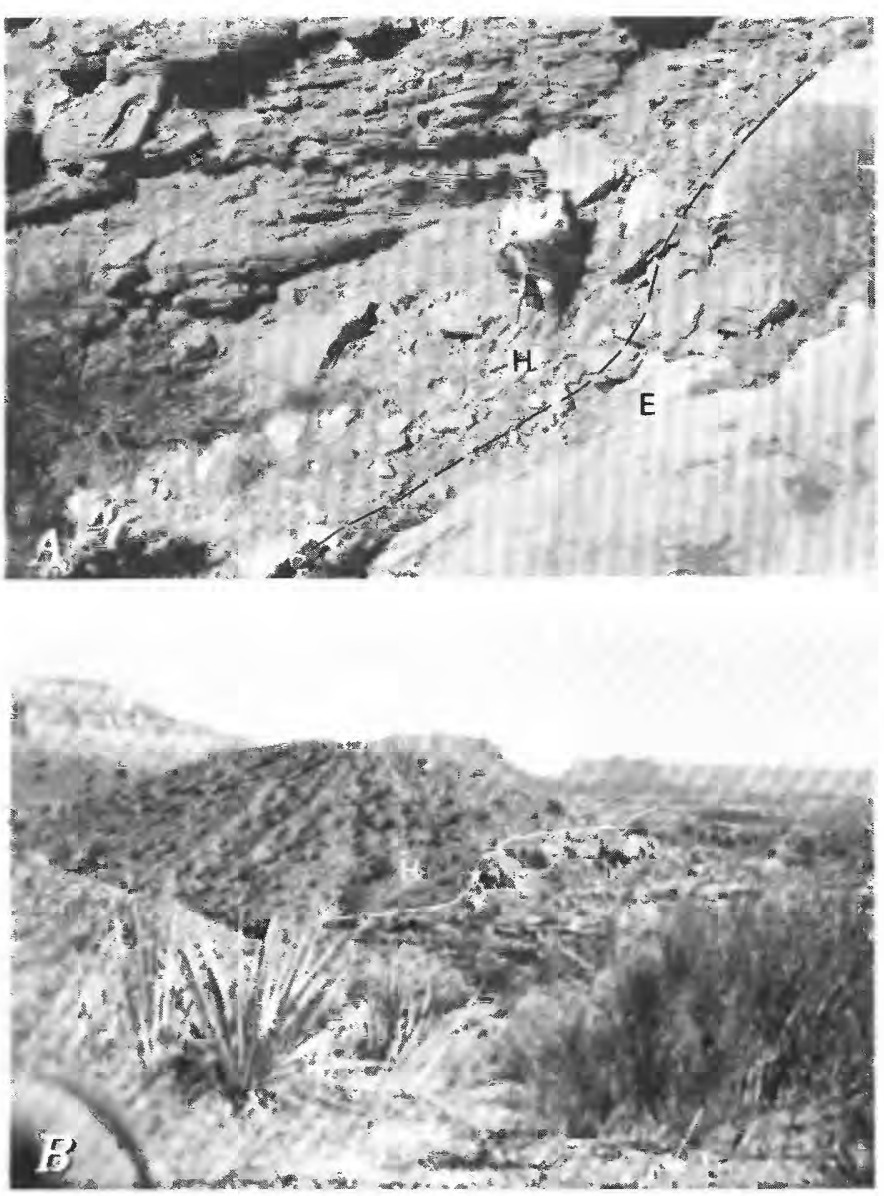

FIGURE H14.-Unconformable surface between Esplanade Sandstone (E) and Hermit Shale $(\mathrm{H})$, Grand Canyon region, Arizona. A, Side of channel carved in massive Esplanade Sandstone, filled with shaly red-brown mudstone of Hermit Shale, Whitmore Wash; $B$, channel at top of Esplanade Sandstone, containing shaly mudstone of Hermit Shale, Thunder River Trail near Fishtail Canyon; C, mudstone of Hermit Shale filling scour in massive sandstone of Esplanade on Hermit
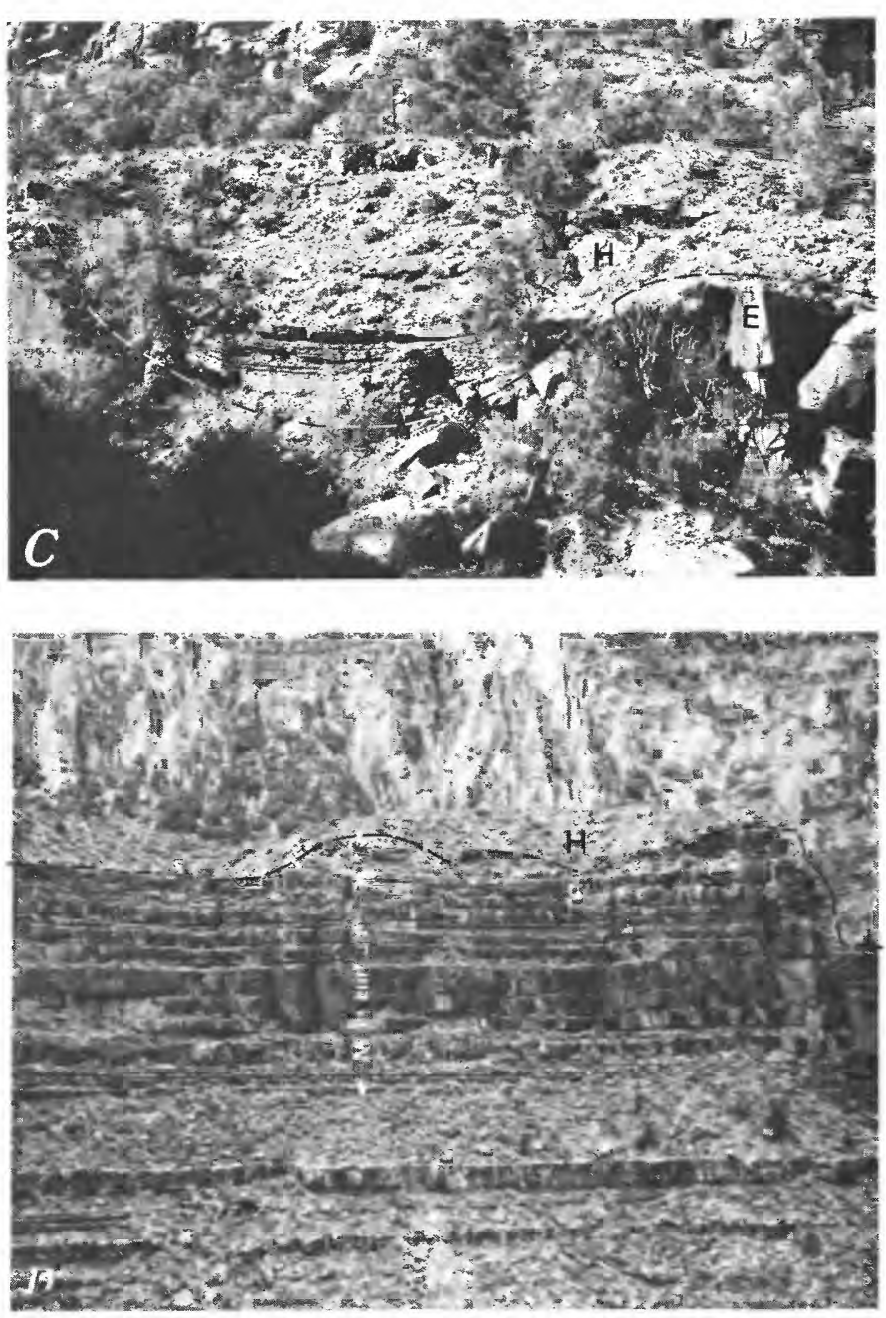

Trail; $D$, erosion surface with small hills or mesas between flat areas at top of Esplanade covered by Hermit Shale, section on west side of Hermit Canyon. Main cliff unit of Esplanade below unconformity is $250 \mathrm{ft}$ thick. Photograph $D$ by E. Tad Nichols. 


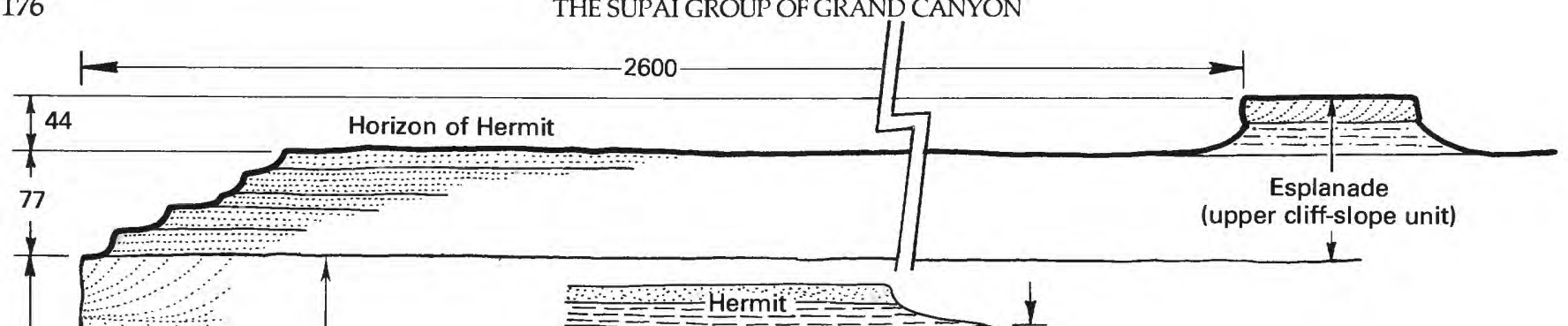

EXPLANATION
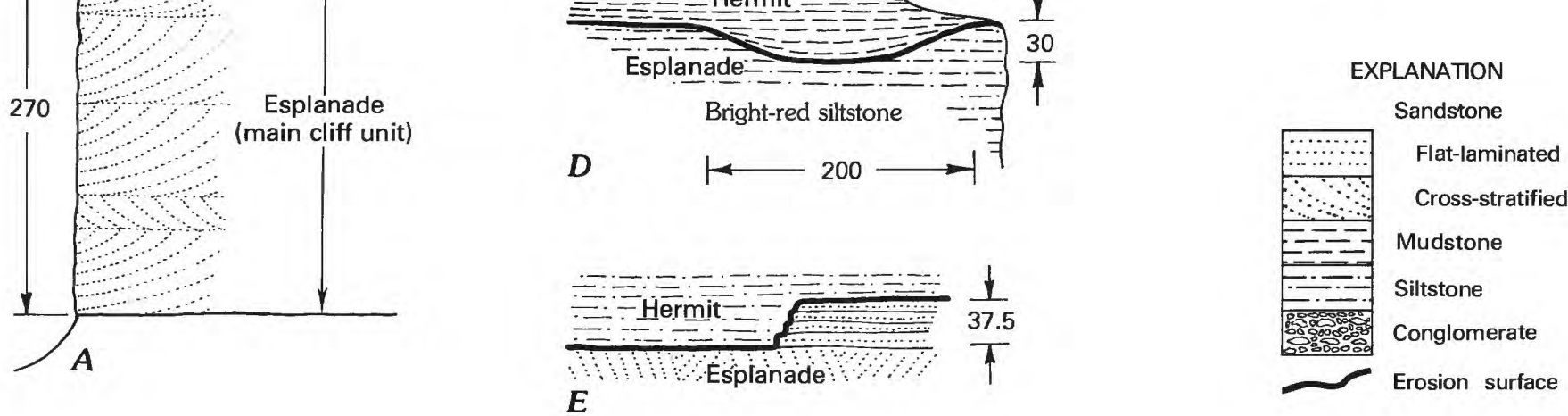

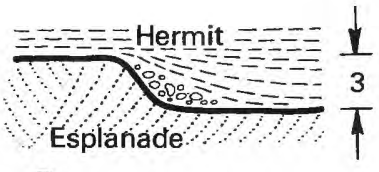

B
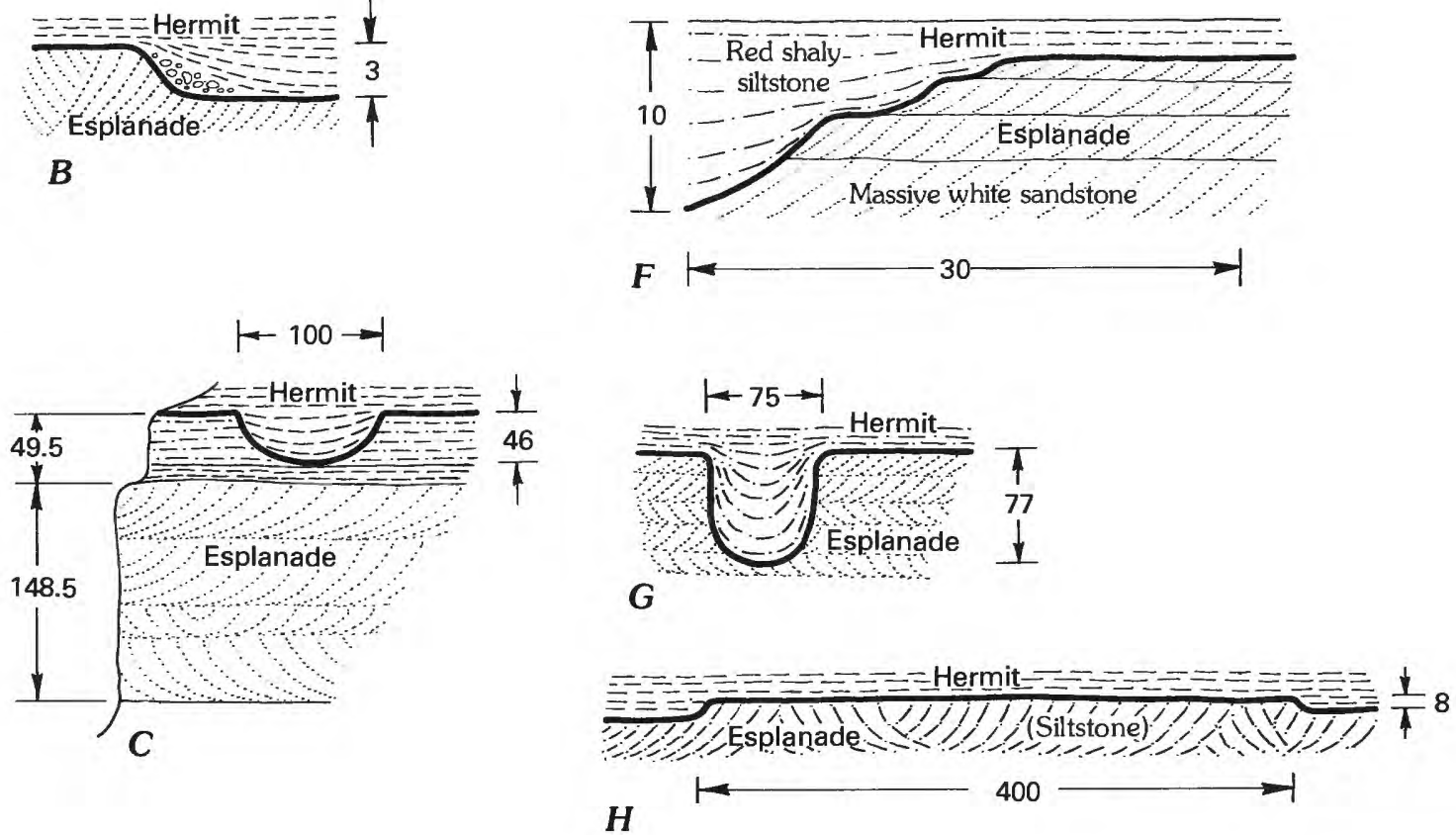

Conglomerate lens, thickest in center

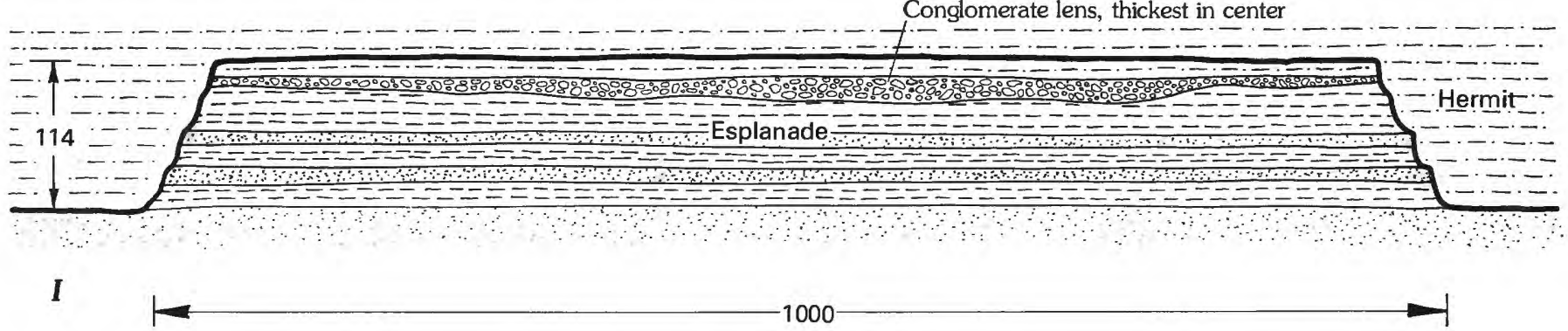

FIGURE H15.-Erosional unconformity between Hermit Shale and Esplanade Sandstone, Grand Canyon region, Arizona. A, Near Apache Trail, east side Havasu Canyon; $B$, Bunker Trail; $C$, Kaibab Trail, south section; $D$, Twin Springs Canyon; $E$, Thunder River Trail; $F$, Whitmore Wash; $G$, Hermit Canyon; $H$, Kanab Canyon; and I, National Canyon. Horizontal and vertical distances in feet. 

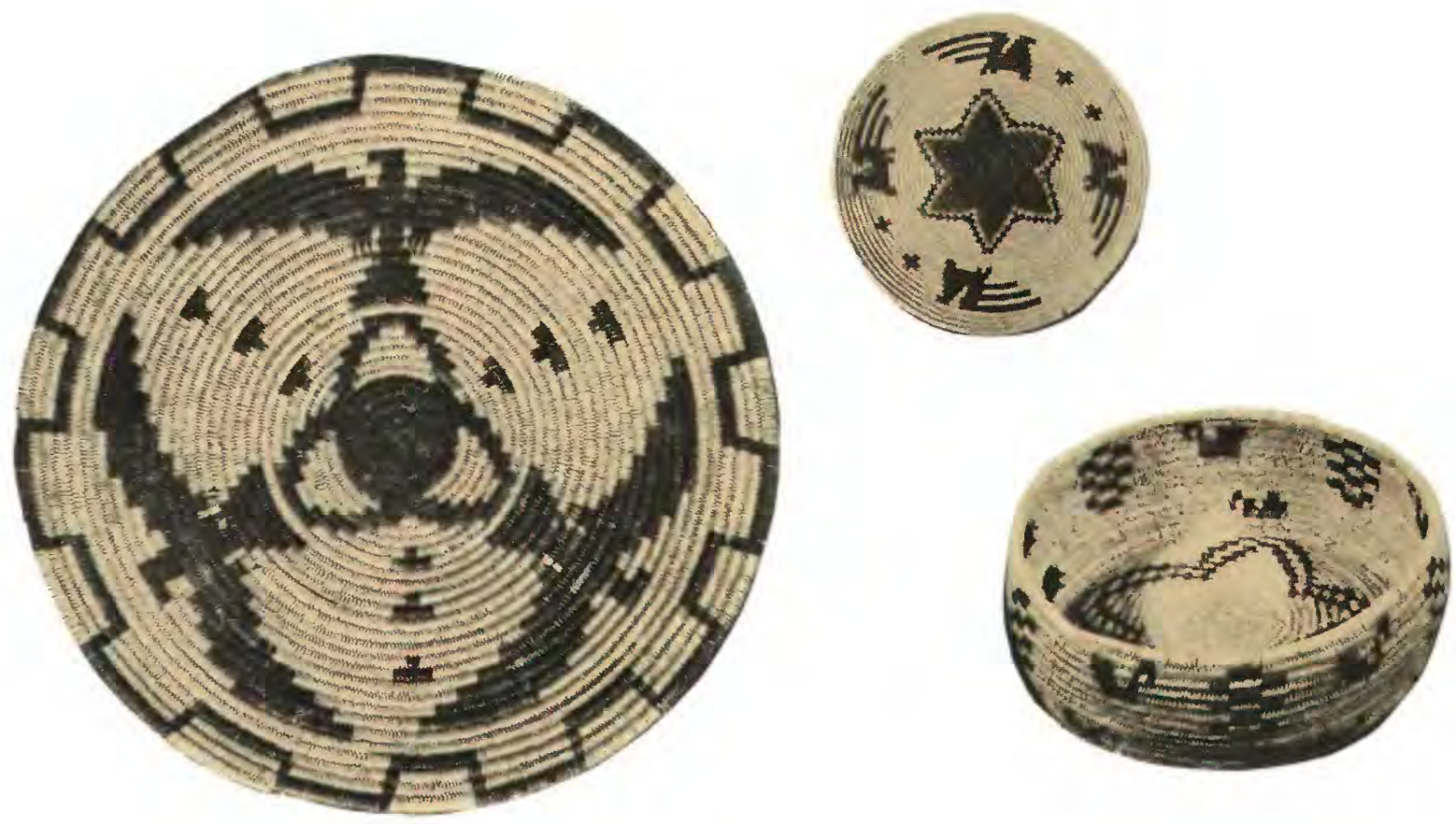

THE SUPAI GROUP OF GRAND CANYON

\section{TRANSGRESSION AND REGRESSION}

Chapter I

By EDWIN D. McKEE

\section{Contents}

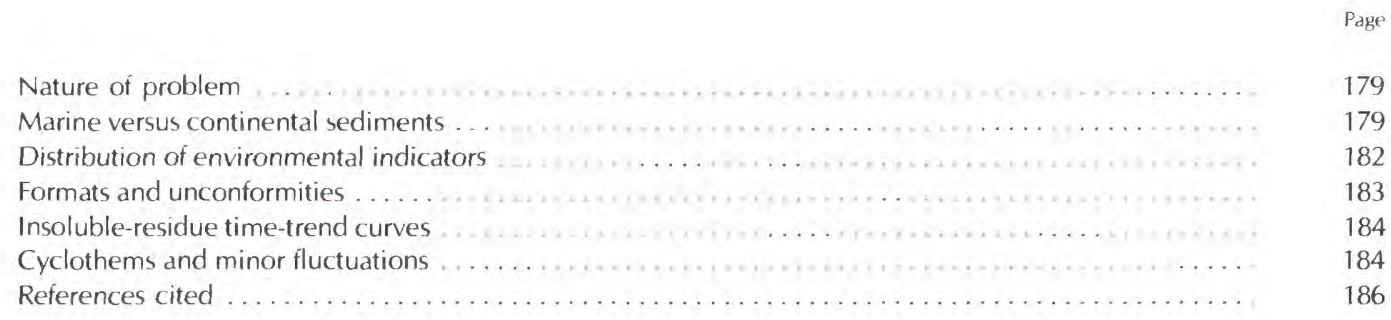




\section{Illustrations}

FIGURE 11. Distribution of nonmarine fossils and sedimentary structures in Supai Group and Pakoon Limestone

12. Comparison of transgression-regression determinations by insoluble residue curves of Lumsden (1974) and by lithofacies-unconformity measurements of the present study .

\section{Tables}

TABLE I1. Faunal, floral, and inorganic sedimentary structure indicators of continental environ-

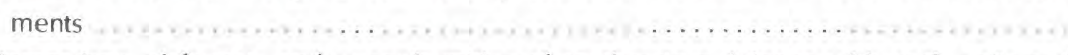

12. Comparison of formats and unconformities of southeastern Arizona with rock units and key conglomerate beds of $\mathrm{Grand}$ Canyon region . . . . . . . . . . . . . . . . . 


\section{NATURE OF PROBLEM}

The Grand Canyon embayment during Pennsylvanian and Early Permian time was the site of repeated advances and retreats of the sea. Following Late Mississippian (Chesterian) time, during which transgressive waters from a western seaway were restricted to narrow valleys carved in the Redwall Limestone and confined to the western part of the region (chapter $G$ ), successively broader marine incursions left their record in rocks of this region.

The first major advance of the sea, near the beginning of Pennsylvanian (Morrowan) time, followed a period of erosion, karst development, and accumulation of a gravel blanket, informally referred to as the basal conglomerate of the Watahomigi Formation (chapter J). Three subsequent major transgressions occurred (1) during Atokan time, as recorded by strata of the upper part of the Watahomigi Formation and the Manakacha Formation, (2) during Virgilian time as illustrated by the Wescogame Formation, and finally (3) during Early Permian (Wolfcampian) time when the Esplanade Sandstone and Pakoon Limestone were deposited. Each of these four main transgressions was initiated by the development of a regionally widespread gravel sheet. They were terminated by regression, followed by subaerial erosion, doubtless the result of relative changes in sea level or of regional uplift. In at least three of these sequences (Watahomigi, Wescogame, Esplanade-Pakoon) channeled surfaces were produced prior to the following major marine incursion.

A wide disparity exists both in the length of time between successive transgressive or regressive sequences in the Supai and in the duration of events represented by these sequences. The time represented by each major erosional unconformity that is recognized as a formation boundary, for example, ranges from a large hiatus between the Manakacha and Wescogame Formations that may have spanned all of Des Moinesian and Missourian time (table C2), to the boundary above, between the Wescogame and Esplanade, which represents only a small time interval at the end of Virgilian and perhaps earliest Wolfcampian time. Such lack of consistency probably is typical of all the unconformities and rock sequences in the Supai Group.

Within the limits of these major transgressions and regressions, many minor fluctuations doubtless occurred; the lateral extent and the duration of these fluctuations were relatively small and the physical records are correspondingly obscure. In the Grand Canyon area, some evidence of such events is furnished by "local" erosion surfaces and "scattered" conglomerates preserved in various places within both the Manakacha Formation and the Esplanade Sandstone as described in chapter $\mathrm{H}$.

Principal methods applied to the recognition of transgressive and regressive strata consist of the following:
1. Determination of the marine or nonmarine genesis of various deposits by fauna, flora, and sedimentary structures, thus demonstrating stages in the advances and retreats of the strandline for a particular locality (fig. I1).

2. Ascertaining the boundaries between transgressive and regressive sequences by tracing widespread erosion surfaces and (or) key conglomerate beds of regional extent.

3. Recognition within rock sequences of "formats" or thin marker-defined units through determination of diagnostic fossils (mostly fusulinids).

4. Construction of curves to record percentages of insoluble residues in systematically collected samples of the carbonate rocks in stratigraphic sequences.

5. Analysis and delineation of cyclothems as indicators of minor fluctuations in advance and retreat of depositional units as a result of eustatic changes in sea level.

The first and second methods listed above are applied in the current study of the Supai in the Grand Canyon embayment. Methods three and four have been used for rocks of similar age in adjacent regions to the southeast (Ross, 1973), and to the west (Lumsden, 1974). Results of their studies are compared with those from Grand Canyon. The fifth method is considered to have good potential, but has not been pursued in detail in this study.

\section{MARINE VERSUS CONTINENTAL SEDIMENTS}

Alternations of continental and marine sediments throughout the Supai Group testify to constant oscillations in sea level and (or) to warping of the land surface. The assignment of either land or sea environment to a specific deposit depends largely on included plants and animals, and on associated sedimentary structures considered to be diagnostic.

Strata of the Supai that are attributed with reasonable certainty to deposition in streams, ponds, or other continental environments consist mostly of shaly red-brown siltstones or mudstones (table I1). In numerous places such strata contain plant assemblages that may include fragments of various seed ferns, the conifer Walchia sp. and (or) colonies of blue-green algae known as Rivularites sp. Commonly associated with these plants are diagnostic sedimentary structures, especially rain pits and shrinkage (mud) cracks. Other structures common to this association but not restricted to a continental environment, are cusptype ripple marks and convolute laminae. Narrow curving tubelike molds with plumose surfaces, considered to be probable worm trails (White, 1929, p. 117), are also numerous among continental deposits of the Supai. 

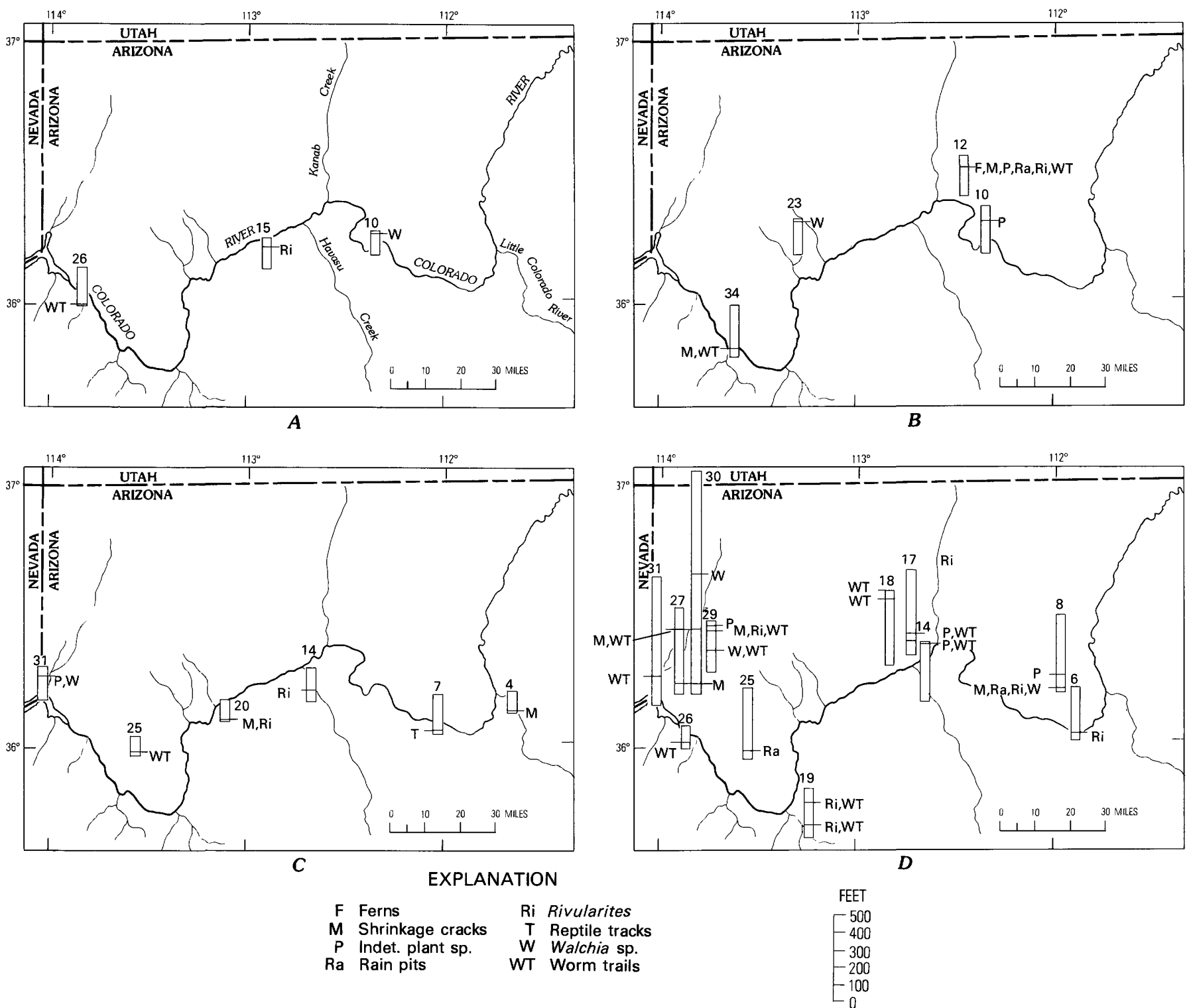

FIGURE I1.-Distribution of nonmarine fossils and sedimentary structures, Supai Group, Grand Canyon region, Arizona. A, Watahomigi Formation; B, Manakacha Formation; C, Wescogame Formation; D, Esplanade Sandstone. Numbers are those of measured sections (see fig. A1). Tick on bar indicates position in section of fossil or structure.

The algal genus Rivularites, represented by small thalli or colonies in at least nine localities and at various horizons, is considered by White $(1929$, p. 43) to have been a plant "adapted to survive occasional periods of exposure to the air and drying, as is the case with the algae in the mud playas of Nevada." A large species of Rivularites in the Hermit Shale of Grand Canyon apparently grew in currents of water as shown by strong rippling of associated sandy silts and by the "drag deformation" in one direction of all protuberances. In some specimens the colony carpet seems to have "floated or possibly pulsated in the water" (White, 1929, p. 43). Thus, the common impressions of the distinctive, horizontally spreading colonies of Rivularites sp., found in all formations of the Supai Group, are believed to be good evidence of nonmarine deposition.

A second type of organic structure, commonly associated with plant remains of the shaly red-brown siltstones in the Supai, is a slender ropelike form, probably a mold, that resembles worm trails and borings and is referred to a type of "Vermes?" by White (1929, p. 127). This wormlike form, as represented in the Hermit Shale, constitutes the species Scoyenia gracilis. Specimens from many parts of the Supai are similar if not identical, so are considered indicators of a comparable -nntinental environment. The mudstones and siltstones in which they occur probably are fluvial deposits. 
TABLE 11.-Faunal, floral, and inorganic sedimentary structure indicators of continental environments [Leaders (--) indicate no data]

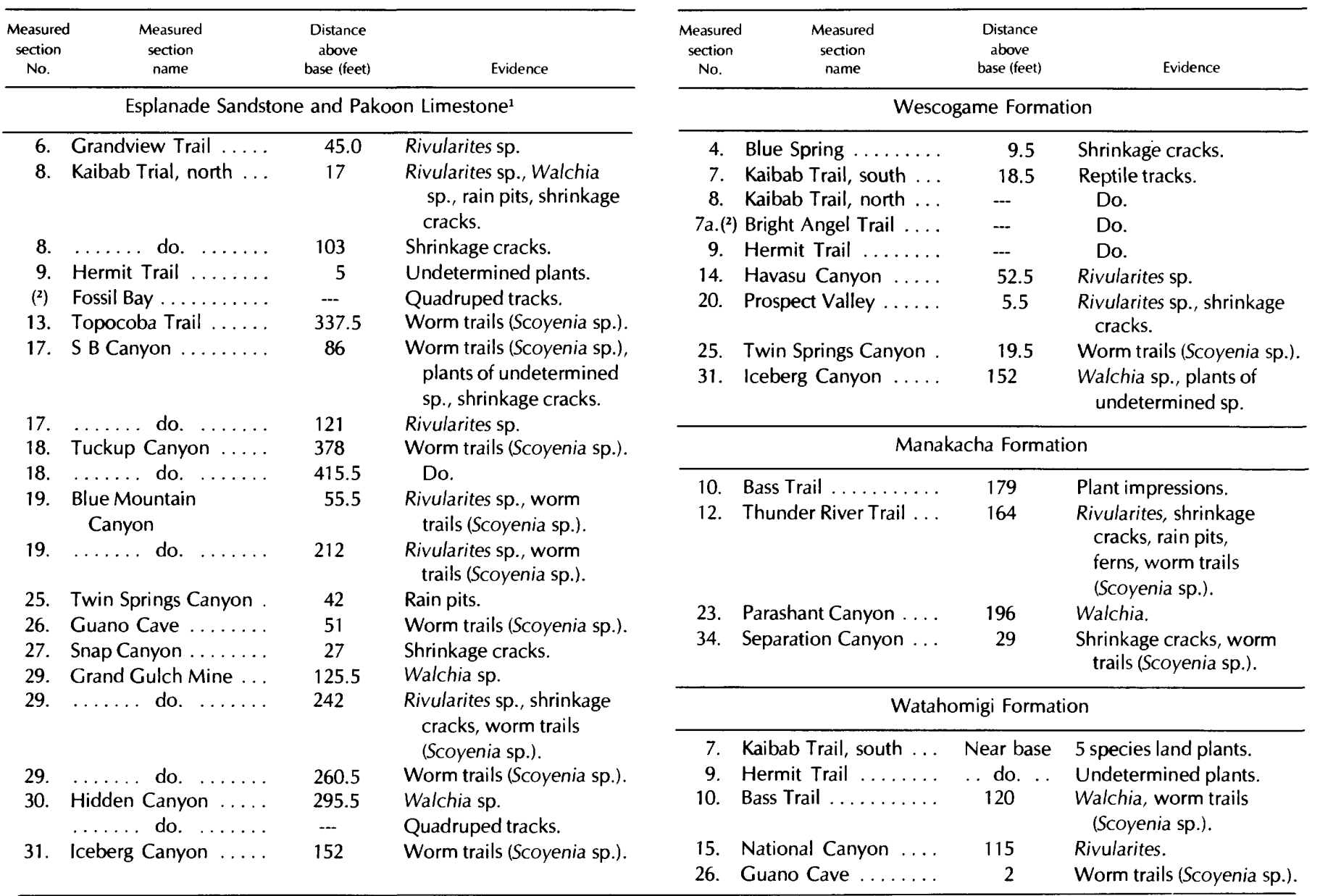

${ }^{1}$ McNair (1951).

${ }^{2}$ Not a numbered measured section.

Strata of definite marine origin in the Supai Group include virtually all types of limestone and dolostone. This contention of origin in the sea is supported by inclusion within these strata of a large array of invertebrate fossils, representing 14 major groups, that are generally believed to have inhabited marine environments; some, however, may also have dwelt in brackish waters. Scattered hard parts, consisting of the teeth and bones, of sharks and other vertebrate marine animals also occur in the carbonate rocks. Finally, evidence of marine habitat is furnished by an abundance of the marine alga known as Osagia sp. that forms grain coatings in various localities. The marine plants and animals are, in general, most abundant in western parts of the formations in the Supai Group, but there are exceptions. The distribution pattern supports the contention that normal marine waters not only entered the Grand Canyon embayment largely from the Cordilleran seaway in Nevada, but also locally through connections to the northeast or southeast.
Between lithologic facies extremes of the Supai, represented at one end by red-brown shaly siltstones and mudstones that are largely or entirely continental, and at the other end by various types of marine limestones and dolostones, are the abundant, uniformly very fine grained, cross-stratified sandstones that contain both continental and marine fossils and sedimentary structures. At places, the sandstones contain the well-preserved footprints of land-dwelling quadrupeds; elsewhere these sandstones incorporate the tests of foraminifers or the skeletal fragments from shells of various marine animals.

Based on faunal distribution within the various sandstone bodies and their geographic and stratigraphic positions with regard to bodies of both mudstone and carbonate rocks, deposition of the sandstone beds must have been controlled by a shallow-water, nearshore environment. In brief, the sandstones probably represent transitional stages of depositional cycles with features characteristic of both continental and marine environments. 


\section{DISTRIBUTION OF ENVIRONMENTAL INDICATORS}

A synthesis of the paleoenvironmental evidence based on characteristic animals, plants, and sedimentary structures from each unit and formation of the Supai Group follows. Where these fossils and structures are considered diagnostic of either a continental or a marine environment, their value in determining the stage of advance or retreat of the sea at a particular time is considerable.

The three units of the Watahomigi Formation (fig. P6) all contain marine fossils, including brachiopods, molluscs, trilobites, and foraminifers. The greatest concentrations of these fossils, however, are in the middle cliff unit, which is largely carbonate rock. This unit probably represents the maximum advance during the first major transgression of Supai time.

The lower slope unit of the Watahomigi, which contains some limestone, but consists largely of red mudstone and siltstone, probably represents early stages of the first transgression because marine invertebrates of several types occur in scattered limestone beds throughout its western or seaward parts, and foraminifers are recorded as far east as Grandview Trail. Some brachiopods occur even among pebbles in the basal conglomerate of the Watahomigi at localities in western Grand Canyon. Continental fossils are sparse, but five species of land plants are recorded (White, 1929, p. 10) from the lower red siltstones near the Kaibab Trail, south, and sedimentary structures, including rain pits and shrinkage cracks, are reported from basal strata near Hermit Trail (Schuchert, 1918, p. 357).

The upper slope unit of the Watahomigi (fig. P6), like the bottom unit, contains much red siltstone, but, especially in the west, also includes numerous beds of carbonate rock. This unit is of Atokan age and begins with a basal conglomerate, so it probably represents an early stage of the second major transgression. Because no land fossils or structures have been found associated with this basal conglomerate of Atokan age, and no marked evidence of channeling underlies it, the Grand Canyon region was probably not above sea level when deposition began. Thus, Atokan sediments of this embayment likely started to accumulate in a marine environment. Marine fossils including brachiopods, trilobites, and pelecypods are recorded from some of the western sections and foraminifers from as far east as Grandview Trail.

The cliff unit of the Manakacha probably represents the time of maximum marine advance during the second major transgression of the region. Marine fossils have been found at various horizons at nine localities including four in eastern Grand Canyon (fig. E8). Seven groups of invertebrate animals are represented, but most numerous by far are foraminifers including five genera of fusulinids (fig. E10). At this time (Atokan), the transgressing sea advanced northeastward through the Black Mesa sag to connect with the Paradox basin as indicated by isopach lines (fig. D4).

The overlying slope unit of the Manakacha includes much red siltstone and mudstone, in addition to limestone, especially in the eastern Grand Canyon region (fig. P8), and this is interpreted as the result of regression with a large increase of detrital sediment. The biota of this unit contains a few marine forms, especially fusulinids (fig. E11), but also such land plants as Walchia sp., various species of indeterminate ferns and Rivularites sp., in scattered localities of central Grand Canyon (fig. E24).

The Wescogame Formation begins with a sheet of conglomerate, but unlike the two widespread conglomerates below, it probably represents a continental environment and it overlies a much channeled erosion surface that apparently resulted from being elevated above sea level. A few marine fossils occur near the base in far western sections (fig. E13), but continental plants and structures occur at various localities farther east. Shrinkage cracks at Snap Canyon, Walchia sp. at Parashant Canyon, and Rivularites sp. in Havasu Canyon, all near the formation base, testify to a continental environment during initial stages of deposition. Fossils higher in the cliff unit of the Wescogame are, in general, scarce, and consist largely of fusulinids and other foraminifers (fig. E15). At several localities in eastern Grand Canyon, in contrast, the wellpreserved tracks of quadrupeds, possibly amphibians, occur on the surfaces of dipping cross-strata (figs. E21, E22). The character and relative scarcity of the Wescogame fauna probably reflects a depositional environment unfavorable to life. The environment is dominated by much very fine, even-grained, quartz sand and is cross-stratified throughout.

The overlying slope unit of the Wescogame seems clearly to represent a regressive stage, following the third major transgression. Like other regressive deposits of the Supai Group, it contains much red mudstone and siltstone and includes some characteristic land plants. Such plants, associated with shrinkage cracks and rain pits, have been recorded at this horizon near Hermit Trail (table E3) and in Iceberg Canyon where they occur in association with cusptype ripples.

The Esplanade Sandstone and its western equivalent, the Pakoon Limestone (McNair, 1951) (fig. P12), constitute the record of a fourth and still younger major transgression and regression within the Supai Group. The record begins with a widespread erosional surface including channels of 
30- to 40 -foot depth similar to those underlying the subjacent Wescogame. The erosion surface indicates a relative change in sea level sufficient to permit fluvial downcutting and it marks the end of a transgressive-regressive cycle. A broad but thin conglomerate layer overlying the surface constitutes the beginning of the next transgressive stage. This conglomerate, which fills many channels, probably is nonmarine, like the basal conglomerate of the Wescogame.

The basal slope unit of both the Esplanade and Pakoon consists largely of shaly red mudstone and siltstone, and resembles most of the older regressive units of the Supai Group. Furthermore, it likewise contains many of the fossils and structures characteristic of continental deposits found elsewhere. These include the plants Walchia sp., Rivularites sp., and others, the worm trails called Scoyenia sp., and such surface structures as shrinkage cracks, rain pits, and cusp ripple marks (table I1). These indicators of a continental environment occur at many localities from eastern Grand Canyon westward to Iceberg Canyon. Only at Hidden Canyon and Whitmore Wash have marine indicators, represented by foraminifers, been found in this unit.

The cliff unit of the Pakoon Limestone that occurs on the western edge of the Grand Canyon embayment is composed mostly of carbonate rocks and contains many forms of marine animals that serve to document the environment. These fossils consist of corals, bryozoans, gastropods, sharks teeth, and fusulinids (figs. E17, E18).

The eastward lateral equivalent of the Pakoon cliff unit, at least in part, is the lower part of the main cliff unit of the Esplanade. The transition from the facies of one formation to the other apparently is within a very short distance, because only a few relatively thin tongues of limestone extend far eastward into the Esplanade. Most of the main cliff unit of the Esplanade consists of fine cross-stratified sandstone in which fossils are sparse and poorly preserved. These fossils consist largely of two types: (1) the comminuted clasts of marine invertebrates, which occur in numerous sections as far east as Hermit Trail and House Rock Canyon (fig. E16); and (2) the uncommon tests of fusulinids that have been found at Twin Springs and S B Canyons, and at Whitmore Wash (fig. E18), but not in any eastern sections.

In the upper cliff slope unit of the Esplanade, evidence is recorded of a final regression within the Supai Group. Not only do the slopes contain much red siltstone and mudstone, but also, in numerous places, they contain indicators in the form of continental-type fossils and structures. At Tuckup Canyon occur two zones of worm trails (Scoyenia sp.); at Snap Canyon, beds containing Walchia sp. and shrinkage cracks; at Hidden Canyon, Walchia sp.; and at Pigeon Wash, Scoyenia sp., ripple marks, shrinkage cracks, and Walchia sp. (table I1). Thus, the youngest deposits of the Esplanade Sandstone are continental.

\section{FORMATS AND UNCONFORMITIES}

The term "format" as proposed by Forgotson (1957) for marker-defined, vertically segregated rock units was applied by Ross (1973, p. 893) in subdividing thick lithologic units of Pennsylvanian and Lower Permian strata in southeastern and central Arizona. Although the term has no formal status with the American Commission on Stratigraphic Nomenclature, Ross considered it a useful unit for local correlation. He used unconformities that "commonly are marked by thin conglomeratic beds, red siltstone or sandstone, or well-sorted, shallow water calcarenites," to separate the strata under study in that region. He recognized 15 unconformities, on the basis of which he subdivided the rocks into 14 formats which were designated by the letters A-N (table I2).

An attempt to correlate the unconformities and formats listed by Ross for central Arizona with corresponding features in the Grand Canyon region is shown in table I2. The five key conglomerate beds and underlying erosion surfaces in the Grand Canyon area seem to match unconformities 1, 2, 10, 13, and 15 of central Arizona (Mogollon Rim), assuming age determinations based on fusulinids (table E4) are correct in both areas. This correlation suggests that formats A, B, J, M, and N described by Ross are represented in strata of the Supai Group and that formats C-I and unconformities 3-9 of central Arizona probably are missing in the Grand Canyon region, because no fossils of unequivocal Des Moinesian age or of Missourian age have been recorded there. Sufficient information on the age of the Wescogame is not available to determine whether formats J, K, or L, or all three, are represented in it. No indication of an unconformity above the basal conglomerate of the Wescogame has been recorded from that formation.

Because of the relatively weak correlations of minor unconformities within the Pennsylvanian and Lower Permian strata between central Arizona and the Grand Canyon region, formats have not proven useful in this study involving the recognition of transgressive and regressive units. Times of advance and retreat of the sea during middle parts of the Pennsylvanian (Des Moinesian? and Missourian time) are unrecorded because of nondeposition; however, in both upper and lower parts of the Supai major advances and retreats are already well established on the basis of lithology, widespread erosion surfaces, and other features previously discussed. 
TABLE I2.-Comparison of formats and unconformities of southeastern Arizona with rock units and key conglomerate beds of Pennsylvanian to Permian age in Grand Canyon region

\begin{tabular}{|c|c|c|c|c|c|}
\hline \multicolumn{4}{|c|}{$\begin{array}{l}\text { Subdivisions in southeastern Arizona } \\
\text { (modified from Ross, 1973, p. 888) }\end{array}$} & \multicolumn{2}{|c|}{$\begin{array}{l}\text { Subdivisions of Grand Canyon } \\
\text { in the present study }\end{array}$} \\
\hline Unconformity & Format & Formation & Age & Key conglomerate bed & Formation \\
\hline 15 & & & & Basal conglomerate & Hermit \\
\hline 13 & $M, N$ & Supai & Wolfcampian & Basal conglomerate & Esplanade and Pakoon ${ }^{1}$ \\
\hline 11 & $K, L$ & Earp & Virgilian & & Wescogame(?) \\
\hline 10 & 1 & Horquilla & Virgilian & Basal conglomerate & Wescogame(?) \\
\hline 8 & $\mathrm{H}, \mathrm{I}$ & Horquilla & Missourian & & Not recognized \\
\hline 3 & $\mathrm{C}-\mathrm{G}$ & Horquilla & Des Moinesian & & Not recognized \\
\hline 2 & B & Horquilla & Derryan & Atokan conglomerate ${ }^{2}$ & Watahomigi-Manakacha \\
\hline 1 & A & Black Prince & Morrowan & Basal conglomerate & Watahomigi \\
\hline & & Escabrosa & Mississippian & & Redwall \\
\hline
\end{tabular}

${ }^{1}$ MCNair (1951).

${ }^{2}$ Conglomerate at base of Atokan-age rocks.

\section{INSOLUBLE-RESIDUE TIME-TREND CURVES}

Based on the thesis that the amount of insoluble residue in carbonate rocks should increase shoreward or toward the supposed source, time-trend curves were prepared by Lumsden (1974, fig. 1) for a series of sections of Permian and Pennsylvanian strata in southern Nevada. The 500 specimens studied "were dominantly fine-sand to silt size, angular quartz with variable minor quantities of fine brown to reddish clay." All samples containing visible authigenic chert were eliminated and not processed.

The time-trend curve of Lumsden for the Iceberg Canyon measured section is reproduced on the left side of figure I2. It shows four tongues (or times) of major increase in insoluble-residue content and these are interpreted as being times of major regression. Using the same vertical scale, the Iceberg Canyon measured section of the present study and two others located eastward in the Grand Canyon embayment, have been plotted to show zones of transgression and regression determined on the basis of lithology and unconformities. In the eastern sections, facies consist of far more detrital rock than in equivalent units in Iceberg Canyon where most of the rock is carbonate.

Measured sections at Iceberg Canyon, Pigeon Wash, and Parashant Canyon show zones of regressive-type sediment at five levels (fig. R1). The ultimate plane of regression, where the trend in strandline movement reverses and transgression begins, is commonly marked by a surface of erosion, a blanket of conglomerate, or both. Such markers within the Supai Group occur within stratigraphic units that consist largely of red shaly beds of siltstone and mudstone, and may contain the imprints of land plants and subaerial structures such as rain pits and shrinkage cracks.

\section{CYCLOTHEMS AND MINOR FLUCTUATIONS}

Cyclothems constitute one of the most characteristic and distinctive features of the Pennsylvanian System in many parts of the world. The term "cyclothem," as used by Weller (1930, p. 99) for rock sequences of Pennsylvanian age in the eastern and central United States, implies "recurrence, repetition, or a return to the starting point," in contrast to the term "rhythm," which has a time connotation for recurring events or deposits.

The nature of cyclothems and attempts to interpret their genesis have been the basis of a voluminous literature. Principal concepts explaining their origin are the diastrophic control theory of Weller (1930, 1931, 1956) and the glacial control theory of Wanless and Shepard (1936). Both diastrophism and glacial cycles are causes of eustatic shifts in sea level. Where the floor of the sea has been alternately above and below wave base, the principle of base-level control has been invoked as a mechanism to explain the frequent repetition of similar depositional sequences (Wanless, 1950, p. 25; Wheeler and Murray, 1957).

Complete cyclothems, as described from the midcontinent region, commonly consist of eight rock units or 


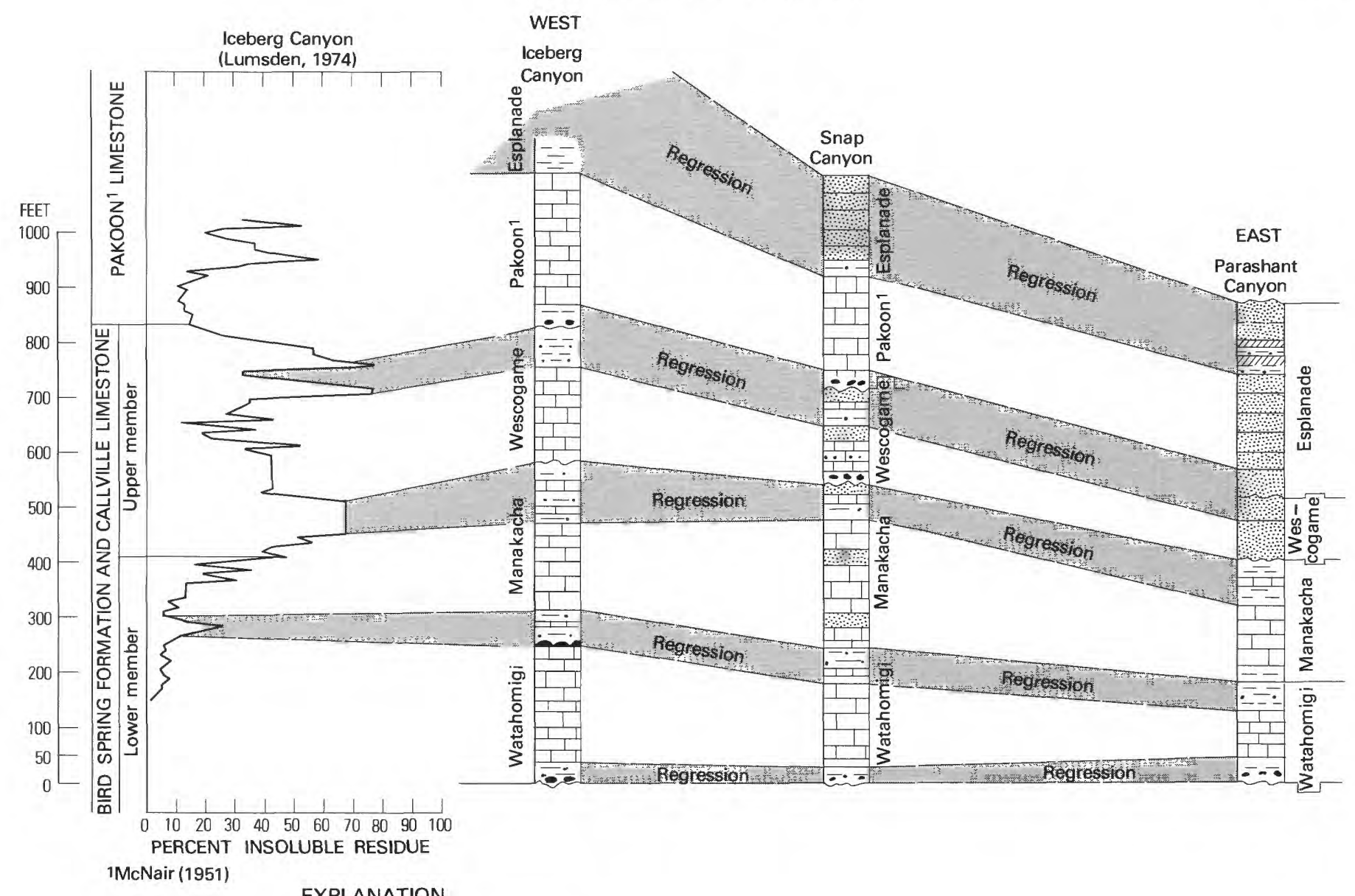

McNair (1951)

EXPLANATION

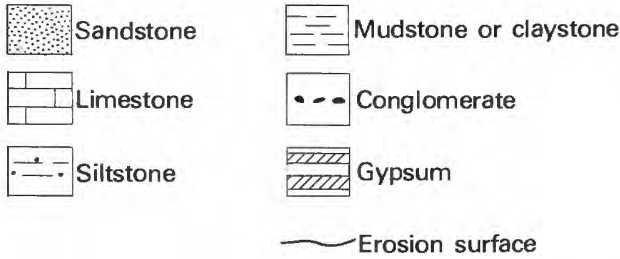

layers-the lower four being continental, the upper four marine (Weller, 1930, p. 101). In each cyclothem two relative changes in sea level are recognized: one was a sinking that terminated continental deposition and caused marine transgression; the other ended marine deposition by uplift and initiated erosion. Each cyclothem has been considered a formation (Weller, 1930, p. 101) with an erosion surface separating it from the superjacent formation.

Cyclic sedimentation similar to that in the midcontinent is represented throughout large areas in southwestern United States (Wanless and Patterson, 1951, p. 662). In places, much of this deposition was remote from areas of diastrophic activity. The inference is made, therefore, that variations in depth resulted from eustatic sea-level changes during Pennsylvanian and Early Permian time (Wanless and Patterson, 1951, p. 655).

In the Supai Group of western Grand Canyon, the presence of cyclothems was noted long ago (McKee, 1937,
FIGURE 12.-Comparison of transgression-regression determinations by insoluble-residue curves of Lumsden (1974) and by lithofacies-unconformity measurements of the present study, western Grand Canyon, Ariz.

p. 341) where a typical cycle was described as consisting of "(1) red beds; (2) cross-laminated sandy limestones; (3) flat-bedded, sandy limestones; (4) crystalline, fossiliferous limestones; (5) flat-bedded, sandy limestones; (6) crosslaminated, sandy limestones; (7) red beds." The following are locations where later observations have been made on cyclothems in the Supai and in formations of similar age in adjoining regions: numerous sections in southern Arizona (Wanless and Patterson, 1951); mechanically deposited Pennsylvanian limestones of northeastern Nevada (Dott, 1958); and southern Nevada sections directly west of Grand Canyon (Lumsden, Ledbetter, and Smith, 1973, p. 663).

In the present investigation of the Supai Group, no systematic study of its cyclothems was made, largely because time did not permit, but cyclothems were observed to be well developed in the carbonate rocks of the Wescogame Formation and, to a lesser extent, in the 
Manakacha of western Grand Canyon. They are conspicuous, especially in sections along the Grand Wash Cliffs and at Iceberg Canyon, where they weather with a characteristic step-like or cliff-slope topography.

In central and eastern Grand Canyon, where limestone is less abundant than in the west and where sandstone is progressively more common, repeated alternations of cliffforming sandstone and slope-forming mudstone or siltstone may be landward equivalents of dominantly limestone cyclothems farther from shore. In any event, these alternating sequences seem to represent fluctuations in areas of deposition resulting from minor advances and retreats of the sea within the limits of the major transgressions and regressions as determined by key conglomerate beds and widespread erosion surfaces.

\section{REFERENCES CITED}

Dott, R. H., Jr., 1958, Cyclic patterns in mechanically deposited Pennsylvanian limestones of northeastern Nevada: Journal of Sedimentary Petrology, v. 28, no. 1, p. 3-14.

Forgotson, J. M., Jr., 1957, Nature, usage, and definition of markerdefined vertically segregated rock units: American Association of Petroleum Geologists Bulletin, v. 41, no. 9, p. 2108-2113.

Lumsden, D. N., 1974, Relationships among insoluble residue, dolostone and limestone facies: Journal of Sedimentary Petrology, v. 44, no. 2 . p. $450-455$.

Lumsden, D. N., Ledbetter, M. T., and Smith, G. T., 1973, Lithostratigraphic analysis of the Bird Spring-Callville Group and Pakoon Formation (Pennsylvanian-lower Permian), southern Clark County, Nevada: Journal of Sedimentary Petrology, v. 43, no. 3, p. 655-671.
McKee, E. D., 1937, Researches on Paleozoic stratigraphy in western Grand Canyon: Carnegie Institution of Washington Year Book 36 for 1936-1937, p. 340-341.

McNair, A. H., 1951, Paleozoic stratigraphy of part of northwestern Arizona: American Association of Petroleum Geologists Bulletin, v. 35, no. 3 , p. 503-541.

Ross, C. A., 1973, Pennsylvanian and Early Permian depositional history, southeastern Arizona: American Association of Petroleum Geologists Bulletin, v. 57, no. 5, p. 887-912.

Schuchert, Charles, 1918, On the Carboniferous of the Grand Canyon of Arizona: American Journal of Science, 4th ser., v. 45, no. 267, p. 347-361.

Wanless, H. R., 1950, Late Paleozoic cycles of sedimentation in the United States: International Geologic Congress, 18th, Great Britain, 1948, Report, pt. 4, p. 17-28.

Wanless, H. R., and Patterson, J., 1952, Cyclic sedimentation in the marine Pennsylvanian of the southwestern United States: Cong. Av. Frudes de Stratigraphie et de Géologie du Carbonifère, 3d, Heerlen, June 25-30, 1951, compte rendu, v. 2, p. 655-664.

Wanless, H. R., and Shepard, F. P., 1936, Sea level and climatic changes related to late Paleozoic cycles: Geological Society of America Bulletin, v. 47, no. 8, p. 1177-1206.

Weller, J. M., 1930, Cyclical sedimentation of the Pennsylvanian period and its significance: Journal of Geology, v. 38, no. 2, p. 97-135. 1931, Sedimentary cycles in the Pennsylvanian strata-A reply: American Journal of Science, 5th ser., v. 21, p. 311-320.

1956, Argument for diastrophic control of late Paleozoic cyclothems: American Association of Petroleum Geologists Bulletin, v. 40 , no. 1, p. 17-50.

Wheeler, H. E., and Murray, H. H., 1957, Base-level control patterns in cyclothemic sedimentation: American Association of Petroleum Geologists Bulletin, v. 41, no. 9, p. 1985-2011.

White, David, 1929, Flora of the Hermit Shale, Grand Canyon, Arizona: Carnegie Institution of Washington Publication 405, 221 p. 


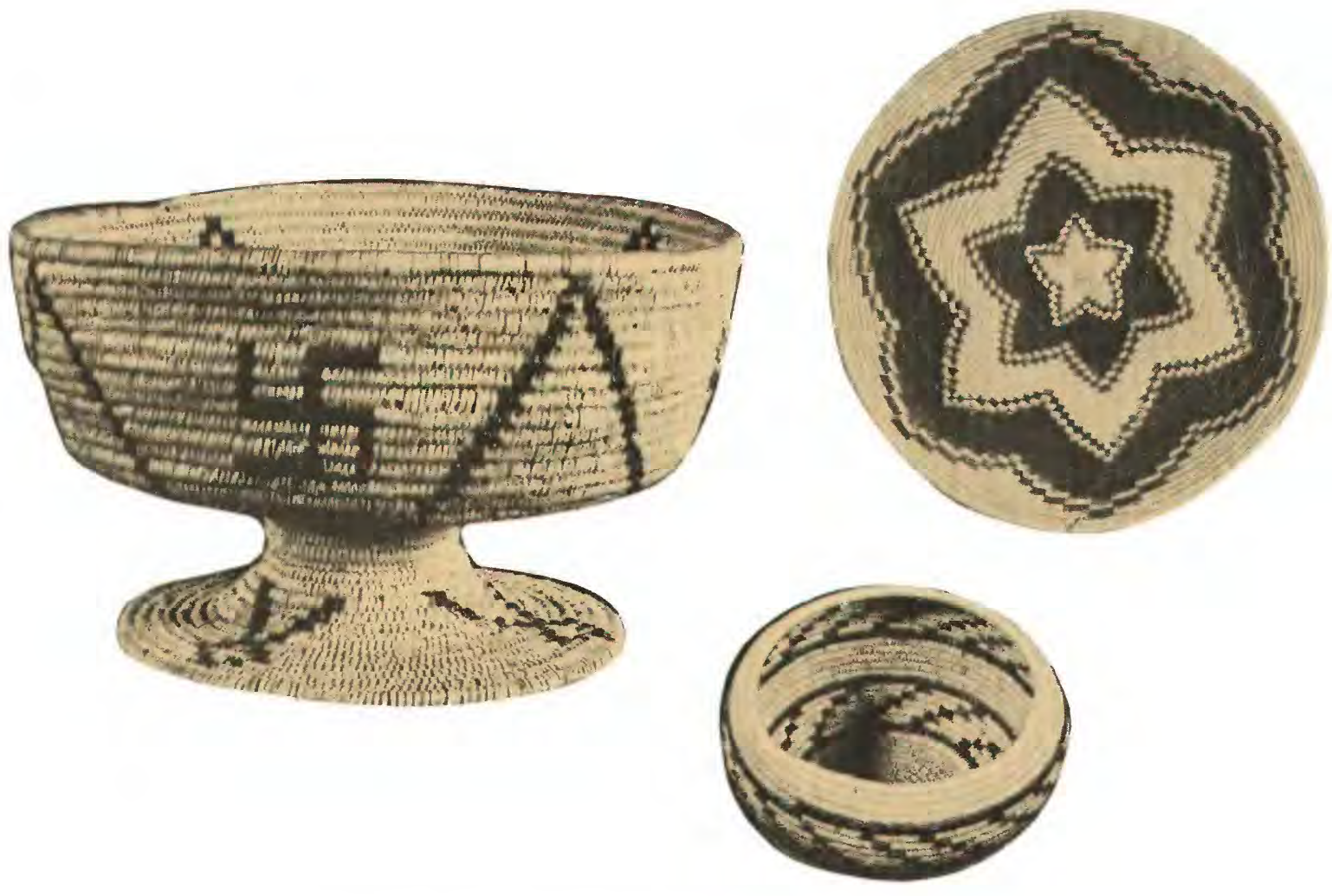

THE SUPAI GROUP OF GRAND CANYON

\title{
CONGLOMERATES
}

\author{
Chapter J
}

By EDWIN D. McKEE

\section{Contents}

\begin{tabular}{|c|}
\hline Introduction \\
\hline Conglomerates of the Watahomigi Formation .................... \\
\hline 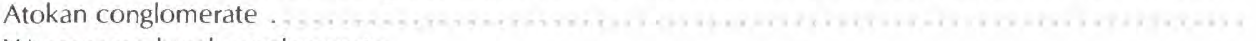 \\
\hline 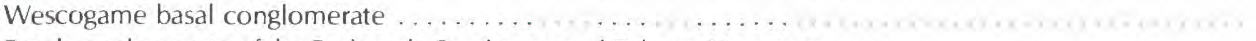 \\
\hline 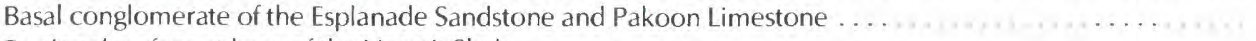 \\
\hline 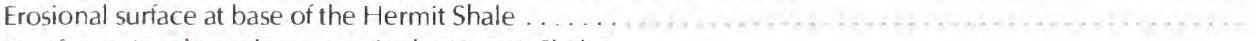 \\
\hline 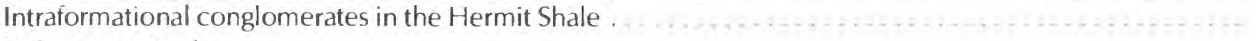 \\
\hline - \\
\hline
\end{tabular}




\section{Illustrations}

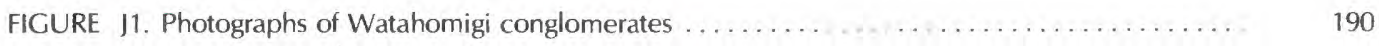

J2. Photographs of Atokan conglomerate . . . . . . . . . . . . . . . . . . . . . 194

13. Photographs of Wescogame basal conglomerate ....................... 196

14. Sketches showing channel forms and composition in the Esplanade . . . . . . . . . . . . 197

J5. Photographs of Esplanade conglomerate . . . . . . . . . . . . . . . . . . . . . . . . 200

\section{Tables}

TABLE 11. Occurrence, composition, and physical properties of Atokan conglomerate ............

J2. Occurrence, composition, and physical properties of Wescogame basal conglomerate ......

13. Characteristics of Esplanade Sandstone and Pakoon Limestone basal conglomerate and

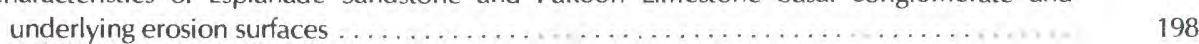

J4. Characteristics of the surface of relief at the base of the Hermit Shale ............ 202

J5. Stratigraphic position of buried channels and local conglomerates above base of Hermit

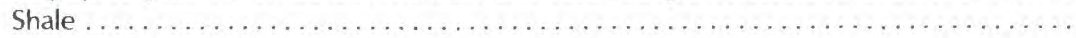




\section{INTRODUCTION}

Four widespread thin conglomerate beds have been recognized throughout most of the Grand Canyon region and serve as key beds in tracing the boundaries of lithologic units (fig. H1). The conglomerates occur as sheet-like or blanket deposits, for the most part, but in places they either completely or partly fill channels or depressions in the underlying strata so that locally they may attain considerable thickness.

The four conglomerate beds are believed to mark the positions of unconformities. Three of them form the basal deposits of formations - the Watahomigi and Wescogame Formations, and the Esplanade Sandstone or its western equivalent, the Pakoon Limestone (McNair, 1951); the fourth conglomerate separates strata of Morrowan and Atokan ages, as indicated by fossils above and below (chapter E) and is informally referred to as the Atokan conglomerate. Unlike the other three conglomerates, it rests on an even surface that seems to be virtually undissected and without local relief.

Traces of a few conglomeratic units other than those already referred to have been noted within the formations of the Supai Group in various stratigraphic sections, but must be considered to be of limited extent and of local origin on the basis of information presently available. On the other hand, a surface of widespread channeling at the top of the Esplanade Sandstone is not associated with any conglomerate although it apparently indicates a break in sedimentation.

Each of the four key conglomerate beds in the Supai Group is composed of gravels having distinctive properties of composition and degrees of roundness. These features probably have resulted from differences in source material and perhaps also from differences in distance and method of transport. They make possible a recognition of specimens from the various conglomerate units with a fair degree of accuracy.

\section{CONGLOMERATES OF THE WATAHOMIGI FORMATION}

A distinctive type of conglomerate occurs in scattered lenses at or near the base of the lower slope unit of the Watahomigi at many places in the walls of Grand Canyon (figs. A2-A8). In 12 of the localities studied, it was at the base of the section and at 5 others, it was less than $15 \mathrm{ft}$ above. In this respect it might be considered a normal basal conglomerate; however, it is not a single continuous bed or unit of conglomerate, but, rather, a large number of separate and independent deposits of gravel ranging from 1 to $12 \mathrm{ft}$ in thickness and forming a zone within the oldest mudstone and limestone accumulations of the formation (table H1). In one measured section at Havasu Canyon, six thin but distinct conglomerate units were recorded in a single traverse of the basal $100 \mathrm{ft}$; at Whitmore Wash, to the northwest, three were noted, and at National Canyon, two.

Gravels forming conglomerates in the basal slope unit of the Watahomigi are composed largely of hard, durable rocks, by far the most common of which is chert in a variety of colors including white, pink, light gray, dark gray, yellow, and reddish brown. Pebbles of smoky quartz and yellow quartz are numerous at some localities, but siltstone pebbles are uncommon and both mudstone and gray limestone pebbles are rare. The matrix for the pebbles is mostly fine-grained sandstone or siltstone, but locally it is reddish-brown mudstone and, in one bed at Whitmore Wash, it is clastic limestone. In general, these conglomerates are dark brown or gray, especially on the weathered surfaces, either because most of the pebbles are dark or because of iron-pigmented cement, or from a combination of matrix and cement.

In most localities the majority of gravels range between 0.25 and $0.75 \mathrm{in}$. in diameter, but some much larger particles occur in many beds. Maximum sizes observed include a cobble of 12 in. diameter at National Canyon, one of 8 in. at Havasu Canyon, and one of 6 in. at both S B and Parashant Canyons. Most of the cobbles and pebbles have high sphericity, probably because of the common spherical shape and uniformity of the rock types from which they were derived. No conspicuous orientation was recognized in any of these deposits.

Most of the gravels, formed of durable, resistant rock such as chert, are angular to subangular (fig. J1). Only in the Blue Mountain Canyon and Whitmore Wash sections are subrounded pebbles of resistant materials present in some abundance. On the other hand, at Andrus Canyon, Twin Springs Canyon, and Whitmore Wash, pebbles of limestone are numerous and these are mostly subrounded or rounded.

The conglomerates of the basal slope unit in the Watahomigi clearly are marine. At seven localities, brachiopods and other fossils considered characteristic of the sea occurred scattered among the gravels. One fossil of very common occurrence is a small, nearly spherical Composita (fig. J1B, E), which at Havasu Canyon, and probably elsewhere, had been rolled around on the sea floor with quartz pebbles of about the same size, and finally was buried with random orientation among fine sand grains that formed a matrix. Elsewhere, brachiopods such as Derbyia and Anthrocospirifer of more delicate shell structure and ornamentation, but showing few signs of abrasion or breakage, are also preserved in conglomeratic beds. These fossils apparently lived and were buried among the gravels without appreciable washing about by waves. 

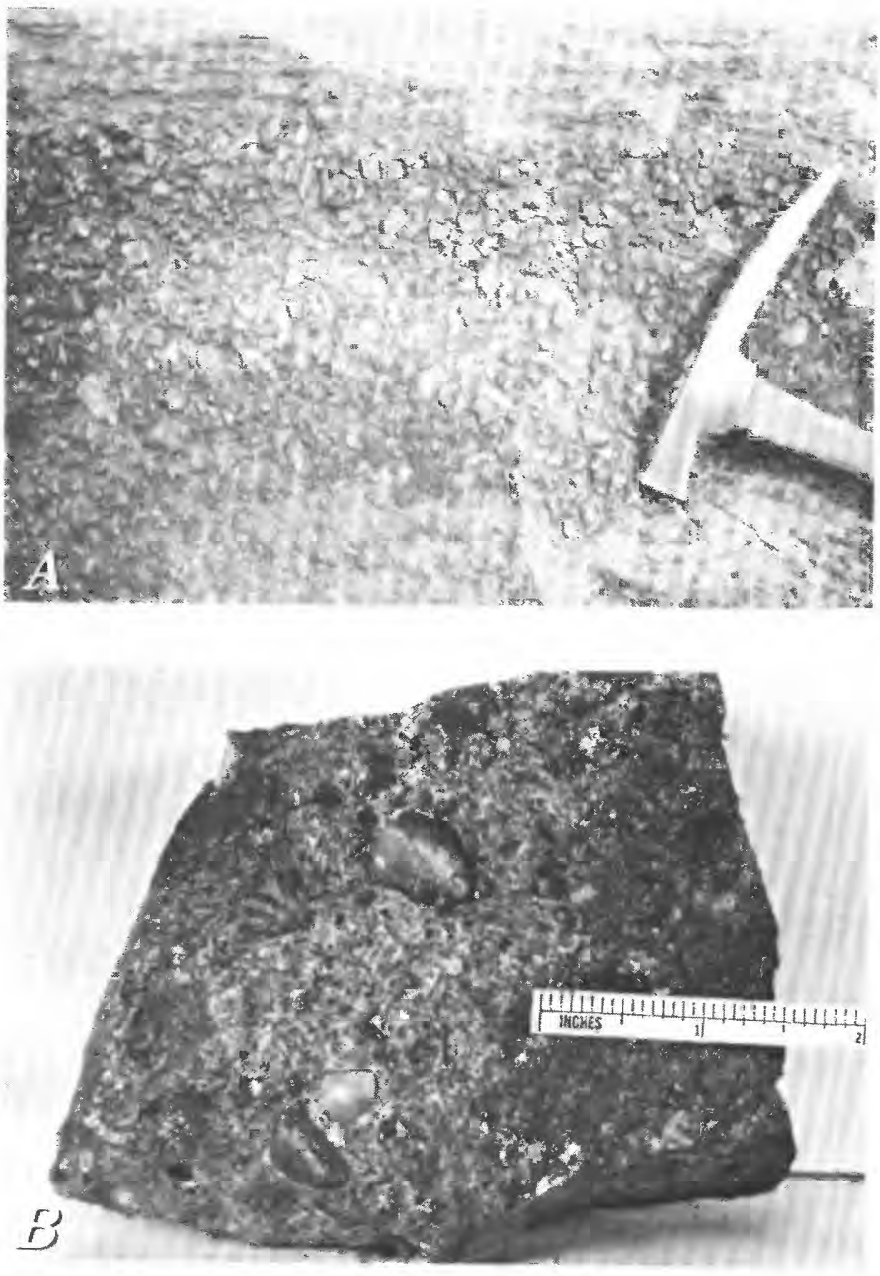

FIGURE 11 (above and facing page).-Basal conglomerate of Watahomigi, which is at or near the base of the lower slope unit, consists mainly of angular to subangular pebbles of flint and chert. A, Base of Watahomigi Formation, east side of Toroweap Valley; $B, 13 \mathrm{ft}$ above

Evidence that the basal Watahomigi conglomerates were derived from a relatively close source is the comparatively small amount of rounding on most pebbles. Surfaces characteristic of strong attrition through rolling by wave action are absent on most specimens; the dominantly chert composition may be attributed to derivation from the underlying Redwall Limestone of Mississippian age. The source of other less-common rock types is not readily apparent, but the friable sandstone and siltstone gravels could not have been transported far. Metamorphic and igneous rock types are lacking.

The age of these conglomerates, determined on the basis of fossils associated with the gravels and of interbedded fossils, is Early Pennsylvanian or Morrowan. Perhaps the most diagnostic forms are brachiopods of the genera Anthrocospirifer, Punctospirifer, and Linoproductus, found at 15, 3, and 7 localities, respectively (fig. E1), and considered most likely to be of Early Pennsylvanian age. Anthrocospirifer occidentalis, also believed of Mor-

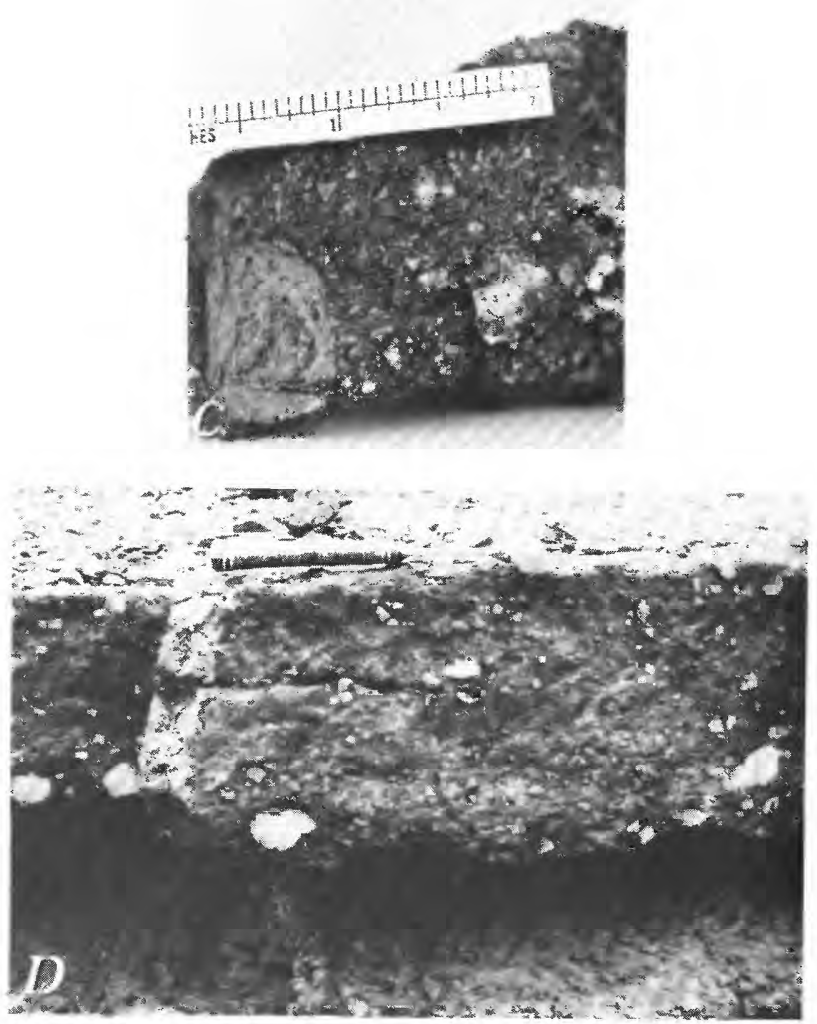

base of formation, includes Spirifer and Composita among highly polished pebbles at Whitmore Wash; $C, 11 \mathrm{ft}$ above base of formation, siltstone and limestone clasts, Eminence Fault; D, $5 \mathrm{ft}$ above base of formation, fossil-bearing conglomerate, dominantly white chert, some large and subangular clasts at National Canyon; $E$, base of Watahomigi, contains scattered chert pebbles and worn specimens of Composita, Havasu Canyon; F, base of formation, north of Hindu Canyon; $G$, basal conglomerate near Navajo Falls, Havasu Canyon. Scale in inches.

rowan age, has been found associated with the conglomerates at Snap Canyon and Guano Cave sections. The upper limit of conglomerates of Morrowan age is not certain, but fossil evidence suggests that at least the lowest 40 $\mathrm{ft}$ of section and possibly more is Early Pennsylvanian. In some places conglomerate units resembling those at or near the base occur $100 \mathrm{ft}$ or more above the base.

\section{ATOKAN CONGLOMERATE}

A conglomerate bed in the upper part of the Watahomigi Formation that probably marks a regional unconformity has been recognized in about one-third of the stratigraphic sections studied in Grand Canyon. It occurs near the top of or slightly above the wedge of cliff-forming limestone that constitutes the middle unit of the formation and is known as the Atokan conglomerate. From the eastern end to the western end of Grand Canyon, the Atokan conglomerate 

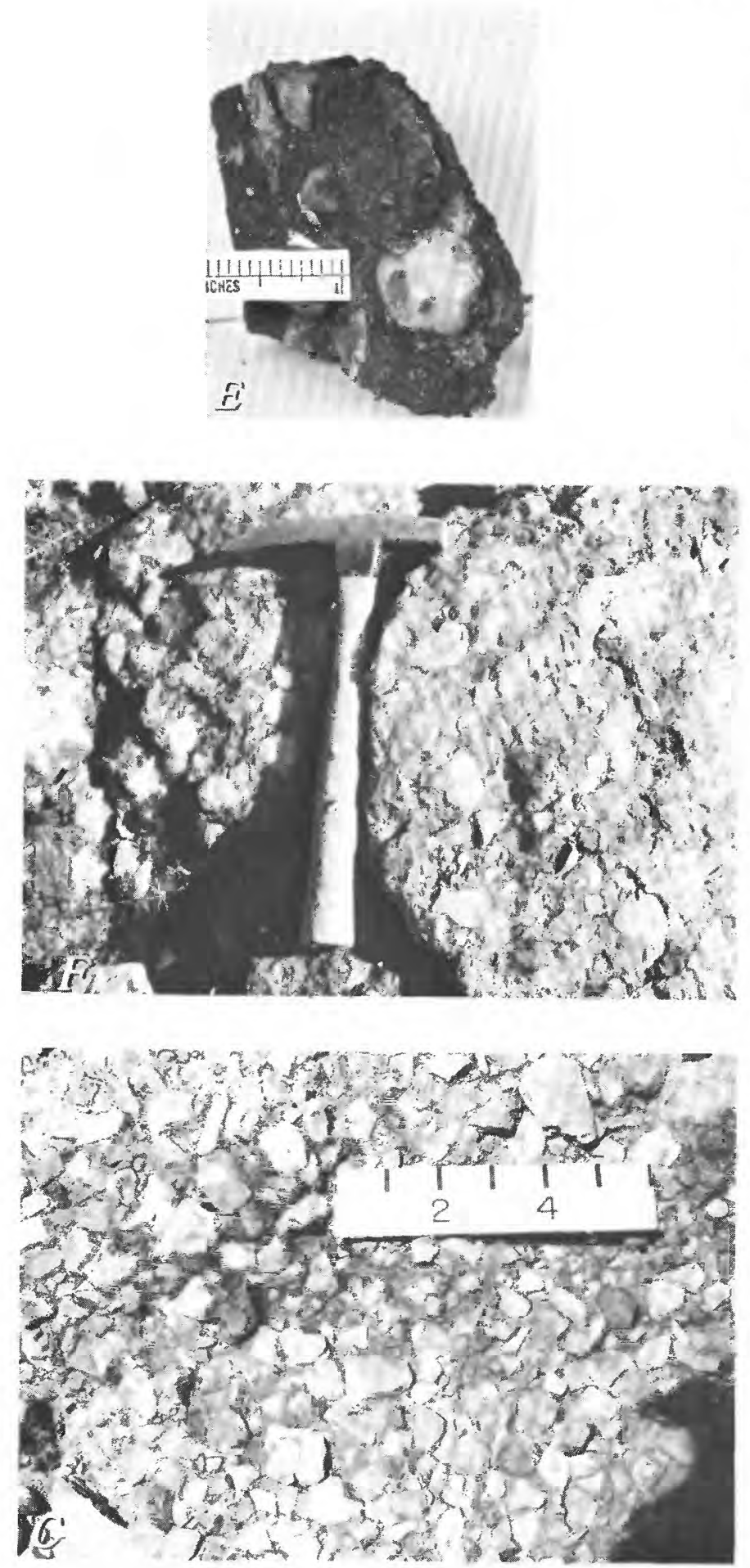

is progressively higher, ranging from about 65 to $150 \mathrm{ft}$ above the base. This increase is roughly in proportion to an increase in thickness of the formation, and reaches a maximum in extreme western Grand Canyon where the limestone wedge is thickest. Abnormally thin sections below the Atokan conglomerate at Snap Canyon and Pigeon Wash in the west are believed to result from a topographic high in that area on the underlying Redwall surface.
The basal Atokan conglomerate occurs 1.iostly as a relatively even bed having a thickness that ranges from place to place between about 1 and $10 \mathrm{ft}$ (table J1). Channel fills are not a common feature as they are with most other conglomerates of the Supai. The surface on which deposition occurred apparently was rather flat and even, and marine fossils, mostly brachiopods, have been found in closely associated beds at Toroweap Valley and at Pigeon Wash.

In most localities, the pebbles and granules that are contained in this conglomerate are composed largely of white to gray or buff chert and dark reddish-brown jasper, but at some localities reddish-brown siltstone, gray limestone, or both are associated, and in one place, Thunder River Trail, milky quartz is included. Particles of durable rock types such as chert and jasper are largely angular to subangular but many of the softer rock types, especially the limestones, are subrounded or rounded. At three measured sections-Havasu Canyon, Blue Spring, and Guano Caveonly limestone pebbles occur, suggesting that these gravel lenses possibly do not actually represent part of a regional erosion surface, but were developed locally following deposition of the limestone strata.

The generally angular to subangular pebbles and granules are mostly $0.25-0.5 \mathrm{in}$. in long dimension, and commonly are scattered with random orientation through a fine matrix. In places, however, as at S B Canyon (fig. $\mathrm{J} 2 A$ ), they are tightly packed together and in contact, one with another; elsewhere, as at Whitmore Wash (fig. J2F), they form horizontal, flat beds of contrasting textures and most of the tabular grains are oriented with long axes parallel to the bedding. Maximum pebble sizes noted were at Toroweap Valley, National Canyon, and S B Canyon where diameters of 3 and 4 in. occur.

Despite the wide variety of colors represented in individual clasts and in matrix materials that range from the gray of clastic limestones to a rusty brown in most siltstones, the overall appearance of the conglomerate in a majority of places is that of a very dark brown ledge, locally yellowish or grayish, but mostly reddish brown.

Interpretation of the Atokan conglomerate of the Watahomigi is based largely on two features-the thin predominantly sheetlike form of the gravel body and a stratigraphic position in some localities directly below fossil-bearing strata of the same rock sequence. The detrital fragments probably were accumulated on a sea floor with a flat, even surface, but the pebble shapes indicate that they were not rolled about greatly, nor transported far. All of the rocks represented by the clasts seem to be of types that occur in underlying parts of the Watahomigi Formation, apparently resulting from local erosion and consequent deposition on the floor of an advancing sea.

The age of the conglomerate is considered Atokan on the basis of the erosion surface between it and the underlying 

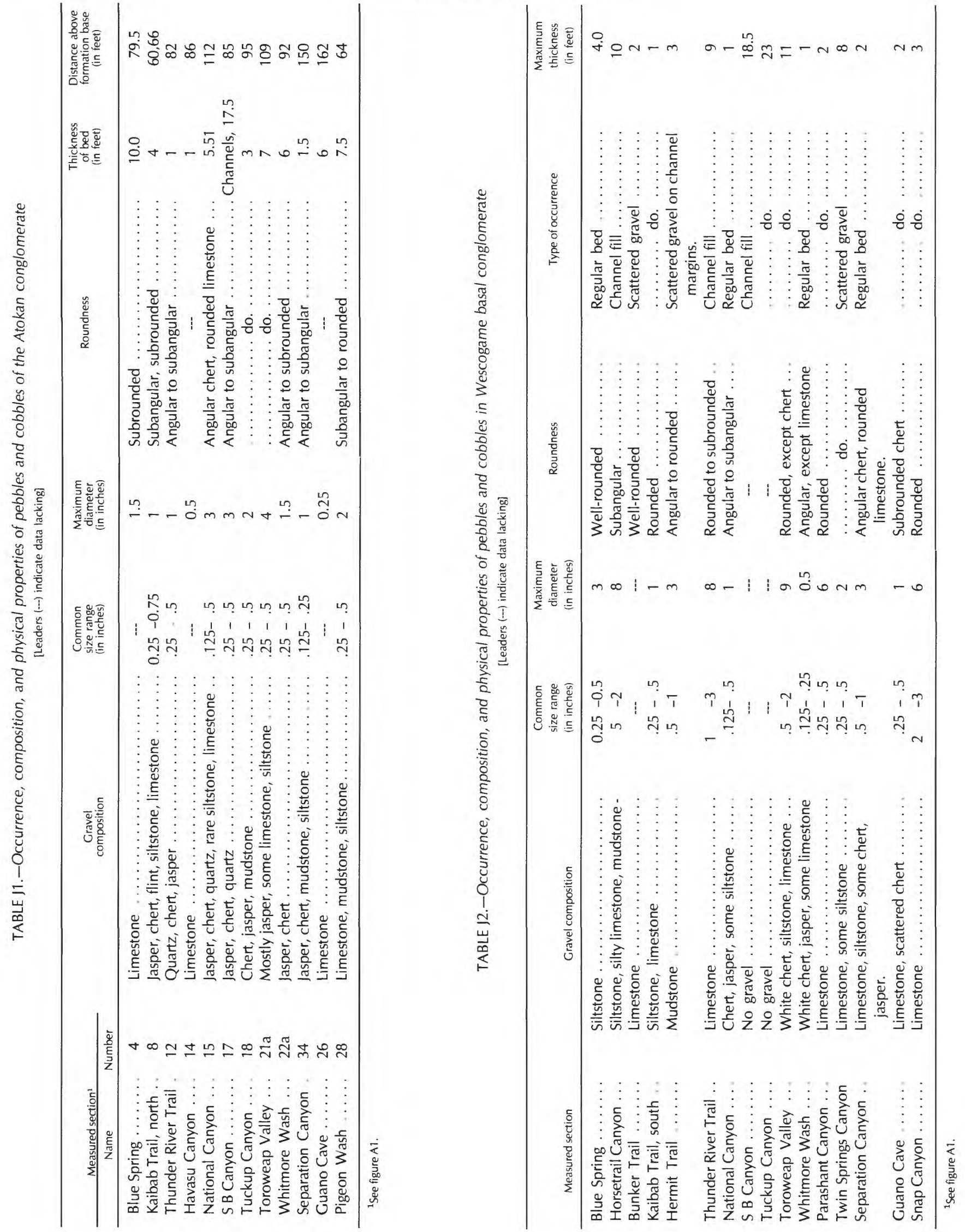
Morrowan strata and the fossils that occur above it in the same stratigraphic sequence. The conglomerate is believed to be the basal deposit of this sequence, formed after a hiatus of unknown, but probably not great, duration.

\section{WESCOGAME BASAL CONGLOMERATE}

Near the base of the cliff unit of the Wescogame Formation a distinctive conglomerate has been recognized at more than half of the basal Wescogame exposures examined in the Grand Canyon. This conglomerate overlies a widespread erosion surface and, in places, fills channel scours of appreciable width and depth. In a majority of localities, especially in western Grand Canyon, however, it constitutes a relatively even, persistent bed of 2- to $3-\mathrm{ft}$ thickness that initiates a sequence of largely cross-bedded detrital deposits believed to be of Virgilian age.

The rock upon which the conglomerate was deposited differs considerably from place to place, but, in general, gravels rest upon structureless to flat-bedded siltstone and mudstone in eastern Grand Canyon and on cross-bedded sandstone or limestone in western Grand Canyon. Thicknesses of channels at this horizon were determined to have been $15 \mathrm{ft}$ deep (fig. H7) at Thunder River Trail, $80 \mathrm{ft}$ deep (figs. H8, H10) at Havasu Canyon, $18.5 \mathrm{ft}$ deep (table J2) at $\mathrm{S}$ B Canyon, and $35 \mathrm{ft}$ deep (fig. H7) at Tuckup Canyon-measured sections all in the central part of the region (fig. A1). Farther east small channels were noted at Horsetrail Canyon, Hermit Trail and elsewhere, but in sections of western Grand Canyon few channels were observed (table H1).

The Wescogame basal conglomerate has a general overall color ranging from pale grayish brown, where limestone pebbles are dominant, to grayish red brown where dark chert and jasper form the major constituents. The matrix in the conglomerate is composed of a gray sandy limestone in many places, but it consists of a gray to rustybrown calcareous siltstone or very fine grained sandstone at Thunder River Trail, Separation Canyon, and some other localities.

The gravel fractions of the conglomerate consist of two very different elements (table J2) that doubtless reflect distinct sources and are represented in greatly differing proportions at various localities. These elements are (1) relatively weak limestones and siltstones, and (2) very durable, resistant cherts and jaspers. The limestones range from dark gray to light gray and from pink to purple; the siltstones are mostly red brown or grayish pink. Chert ranges from light gray to cream to dark gray or brown and the jasper is typically dark reddish brown.
The limestone and siltstone pebbles are mostly well rounded, or at least subrounded, and commonly have diameters of 0.5-1.0 in. In the Thunder River Trail, Horsetrail Canyon, and Toroweap Valley sections rock sizes of 8-9 in. were measured among limestone cobbles, but at Blue Spring, Hermit Trail, and Separation Canyon 3 in. was the largest size noted. In contrast, chert and jasper particles probably average between $0.125-0.5$ in. in diameter and the maximum recorded was 1 in. Many chert pebbles are very angular and most are subangular; they tend to have irregular shapes and many are tabular.

Lithology of pebbles and cobbles in the Wescogame conglomerate (table J2) differs from east to west across the region in a crude distribution pattern. At Blue Spring and Horsetrail Canyon on the Little Colorado River and at Bunker, Kaibab, south, Thunder River, and Hermit Trails in eastern Grand Canyon only well-rounded limestones and calcareous siltstones are represented in the gravel deposits, occurring for the most part as scattered pebbles or as small concentrations of pebbles in pockets. In central Grand Canyon many of the gravel deposits consist mostly or entirely of chert or jasper, or both. In western Grand Canyon thin beds containing rounded limestone and siltstone pebbles, but commonly including some jasper or chert pebbles, seem to be typical.

No obvious relation between channel deposition and rock type is apparent. Deep, buried channel deposits at National Canyon and Toroweap Valley are almost entirely composed of angular chert and jasper, a channel fill at Thunder River Trail contains rounded limestone pebbles only, and channel scours at S B and Tuckup Canyons are filled with silt and fine sand and lack gravel (table J2).

The source of all gravel composing the Wescogame basal conglomerate probably was relatively local, and few, if any, of the cobbles and pebbles were introduced from beyond the northern Arizona region. Most of the lithologic types represented apparently are those of underlying Supai strata and the lack of any appreciable mixture at most localities suggests local derivation. In many places, all pebbles have the same composition and apparently were derived from a single rock unit nearby. The marked angularity of chert or jasper fragments in many outcrops is evidence of little wear from transport; the well-rounded limestone and siltstone pebbles common in some localities did not necessarily move long distances as such roundness may readily be attributed to the very soft and (or) friable nature of the rocks involved, rather than to transport distance.

The composition and general character of the gravel (fig. J3) suggest that at the time of deposition, strata that underlie the Wescogame conglomerate were already lithified. Not only had strata forming channel walls been consolidated into limestones, sandstones, and siltstones, but 

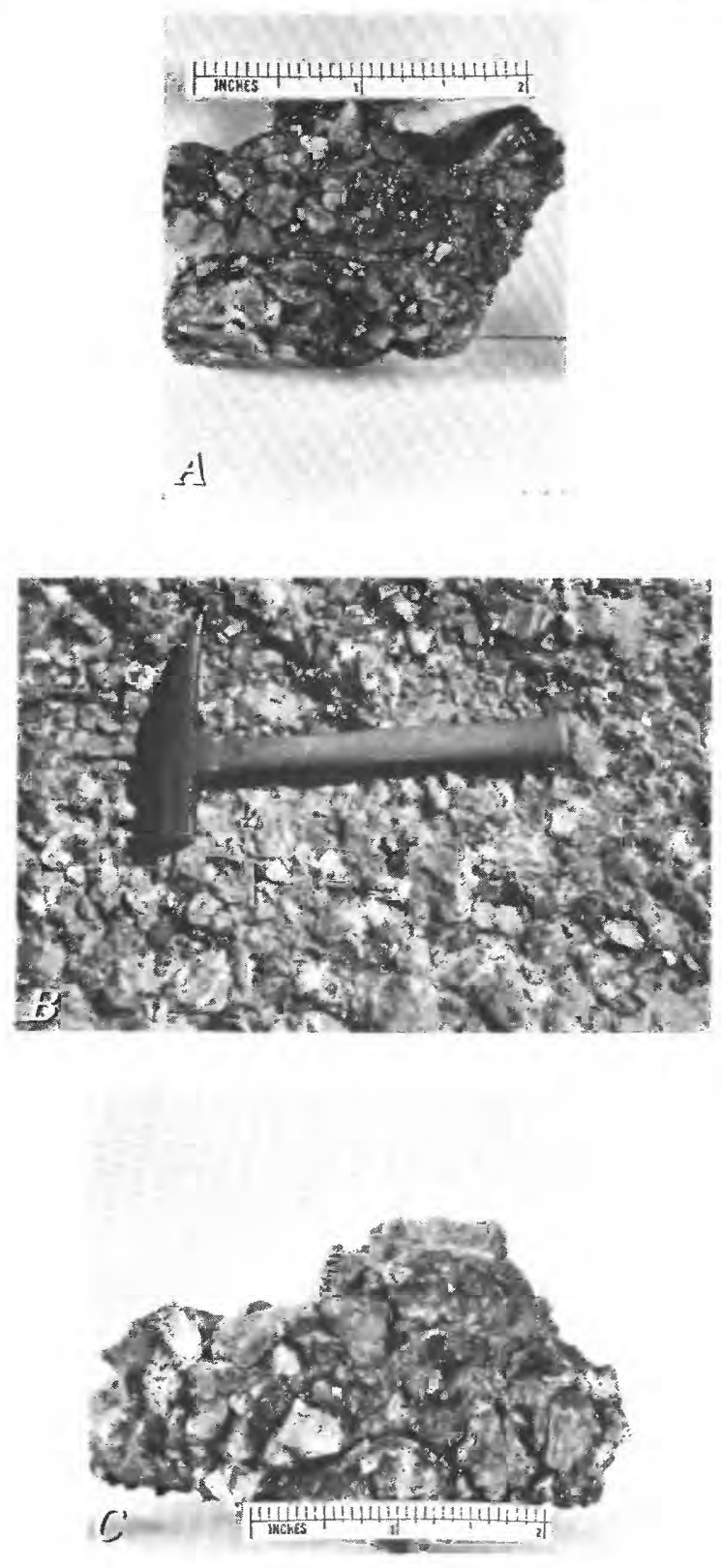

FIGURE 12 (above and facing page).- Atokan conglomerate, at base of upper slope unit of the Watahomigi Formation. Base of Atokan rocks. Mostly of chert and reddish-brown jasper, with angular, closely packed clasts. A, B, S B Canyon, $85 \mathrm{ft}$ above base of Watahomigi; C,

also jasper had been deposited along bedding planes and across strata. Jasper is common locally in the form of pebbles and cobbles. Thus, the erosion surface below the conglomerate probably represents a hiatus of considerable magnitude that, as suggested by paleontological evidence from the western Grand Canyon region, separated deposition of the Atokan Provincial Series from that of the Virgilian Provincial Series.
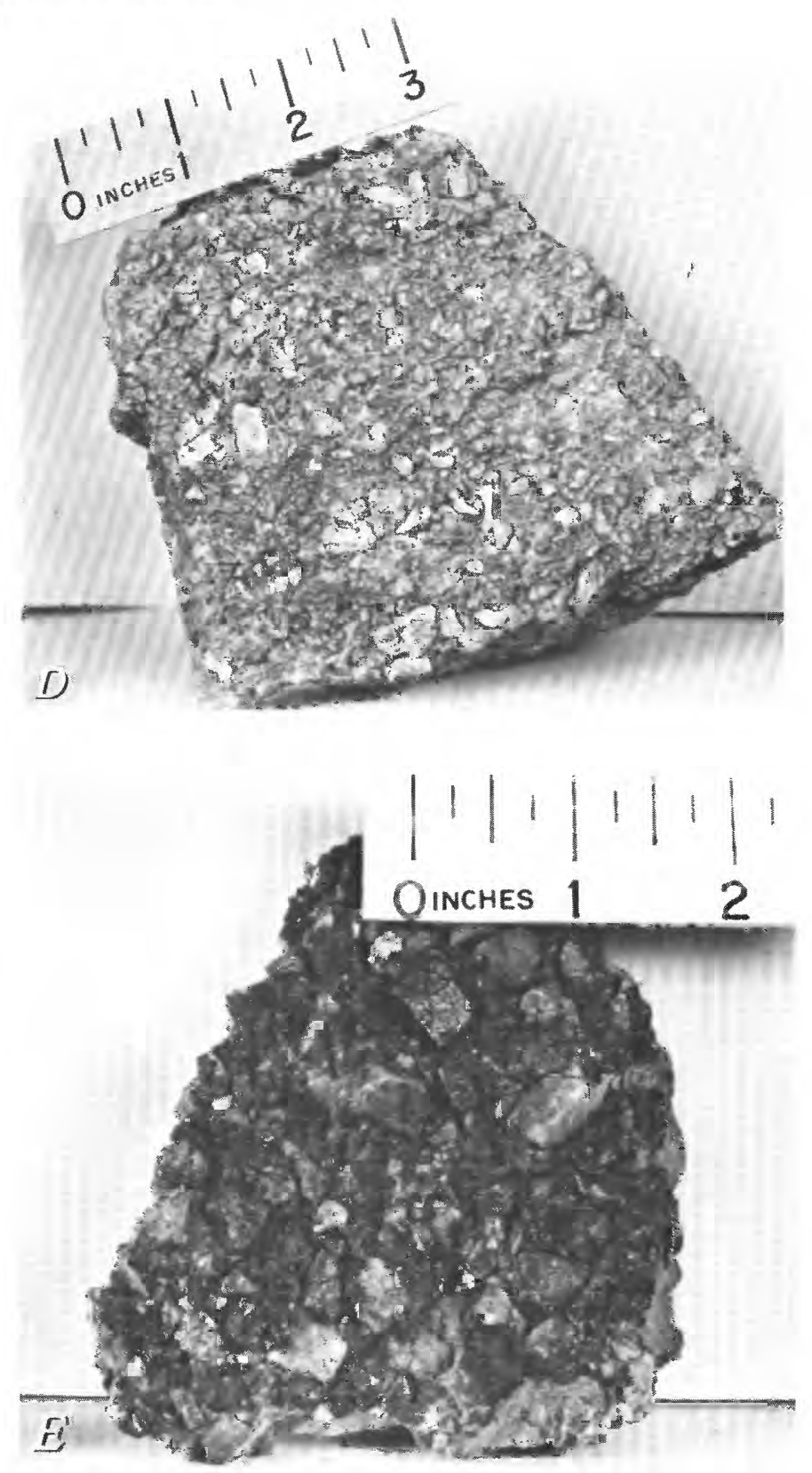

Thunder River Trail; D, Whitmore Wash; E, Toroweap Valley, west side; $F$, Whitmore Wash, flat-bedded and cross-bedded, angular chert fragments; $G$, Tuckup Canyon, chent conglomerate on purple calcareous mudstone.

\section{BASAL CONGLOMERATE OF THE ESPLANADE SANDSTONE AND PAKOON LIMESTONE}

The most widespread and continuous conglomerate in the Supai Group of Grand Canyon occurs in the slopeforming unit underlying the massive sandstone cliff of the 

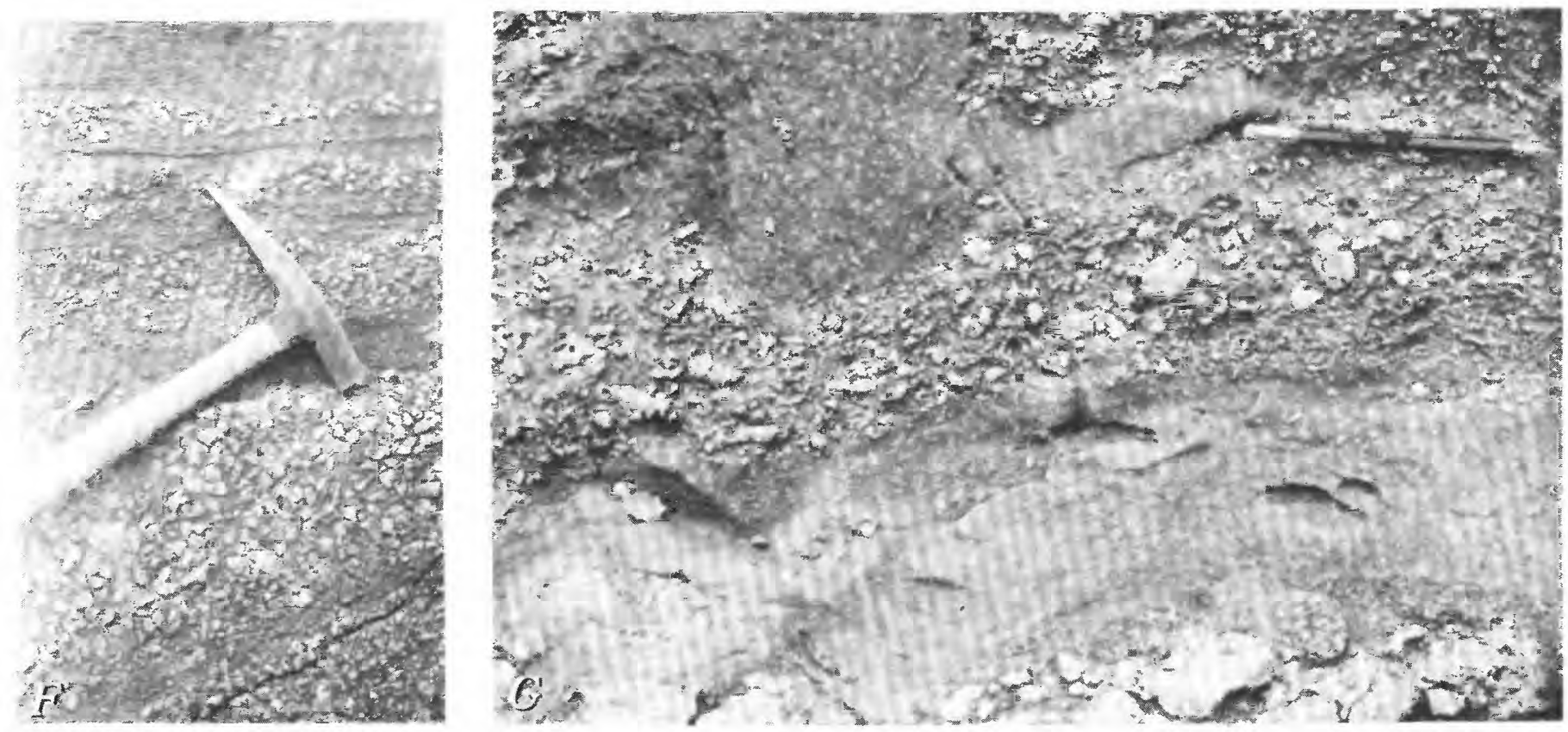

Esplanade (fig. H1). In western Grand Canyon this conglomerate occurs in the same stratigraphic position in the lower slope unit of the Pakoon Limestone (McNair, 1951). The Pakoon intertongues with and replaces the lower part of the Esplanade in extreme western Grand Canyon. This basal conglomeratic unit constitutes an excellent key bed or marker bed, as it has been recognized in nearly every stratigraphic section measured and studied during this investigation. Throughout the region it is remarkably uniform in general character and marks the position of a hiatus in the sedimentary record.

The basal conglomerate in many places partly or entirely fills channels from a few inches to many feet in depth. Elsewhere it extends evenly for great distances across a nearly flat surface of older rock. In a few places, probably where topographic highs existed on the depositional surface, it is absent.

The deepest observed channels occupied by the conglomerate (table J3) are at mile 16.5 on the Colorado River (maximum depth $50 \mathrm{ft}$ ); along the Topocoba Trail (depth $30 \mathrm{ft}$ ), in National Canyon (depth $41 \mathrm{ft}$ ), and in Twin Springs Canyon (depth $34 \mathrm{ft}$ ). The widths of most such channels are difficult to determine both because in many areas the scours merge into one another and because part or all of many channel walls are concealed by talus. Six of the largest channels examined range in width from about 200 to $800 \mathrm{ft}$. Some relatively shallow depressions on broadly exposed surfaces, however, have much greater extent. Thus, a wide variety of forms is represented (fig. J4). These channel scours were cut mostly in cross-stratified sandstone but, in some places, they incised flat-bedded siltstone and, in at least two localities, were cut in silty limestone.
The extent to which gravels of the Esplanade-Pakoon basal conglomerate cover the erosion surface and the nature of their vertical distribution differ greatly from place to place. Large buried channels near the north Kaibab and Topocoba Trails, 17 and $30 \mathrm{ft}$ deep, respectively, and roughly semicircular in profile, are nearly filled with conglomerate. In contrast, the gravels within large channels exposed in the walls of Tuckup Canyon, Havasu Canyon, Kanab Canyon, and some others are restricted to layers at channel bottoms. In still other places, as at mile 17.5 on the Colorado River and parts of S B Canyon, channels of appreciable size contain no pebbles, but are entirely filled with siltstone of a type that elsewhere merely forms a matrix for, or is interstratified with, the gravels. At National Canyon, the topmost thin bed within a large channel is conglomerate, the gravels of which resemble those near the bottom of the same channel; the intervening beds are red sandstones. In the walls of Twin Springs and Hidden Canyon, conglomerates occur as lenses bordering the channel rims.

The Esplanade-Pakoon basal conglomerate in all of the more than 30 localities in the Grand Canyon region where it has been examined has a general uniformity in appearance and in composition. Nearly everywhere it forms a moderately resistant ledge that is dominantly red brown, but locally gray, depending upon the type of pebble that is most prominent in a particular place.

Pebbles and cobbles in the conglomerate consist almost exclusively of siltstones and limestones, but uncommon sandstones and mudstones are included in samples representative of a few localities (fig. J5). These lithologic types seem to be limited to the kinds of rock represented in various older units of the Supai, but they include many 

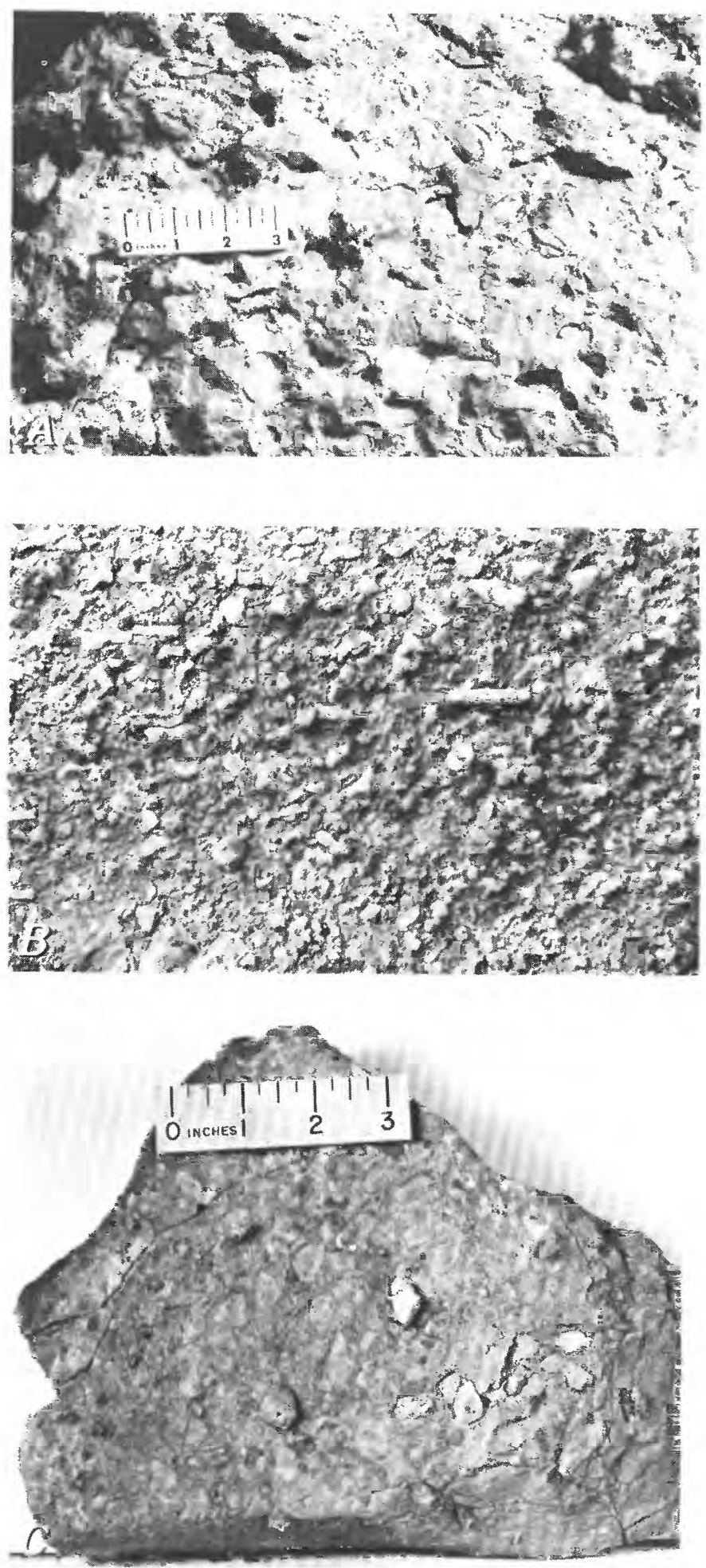

FIGURE 13.-Wescogame Formation, conglomerate at base of cliff unit, bottom of Virgilian strata. Pebbles mostly siltstones and limestones, some cherts. A, Channel-fill conglomerate at Thunder River Trail; $B$, rounded pebbles in Wescogame basal conglomerate at Horsetrail Canyon; C, conglomerate at Guano Cave section with resistant chert pebbles etched in relief, siltstone and limestone pebbles bevelled; $D$, angular chert clasts forming conglomerate at Whit-
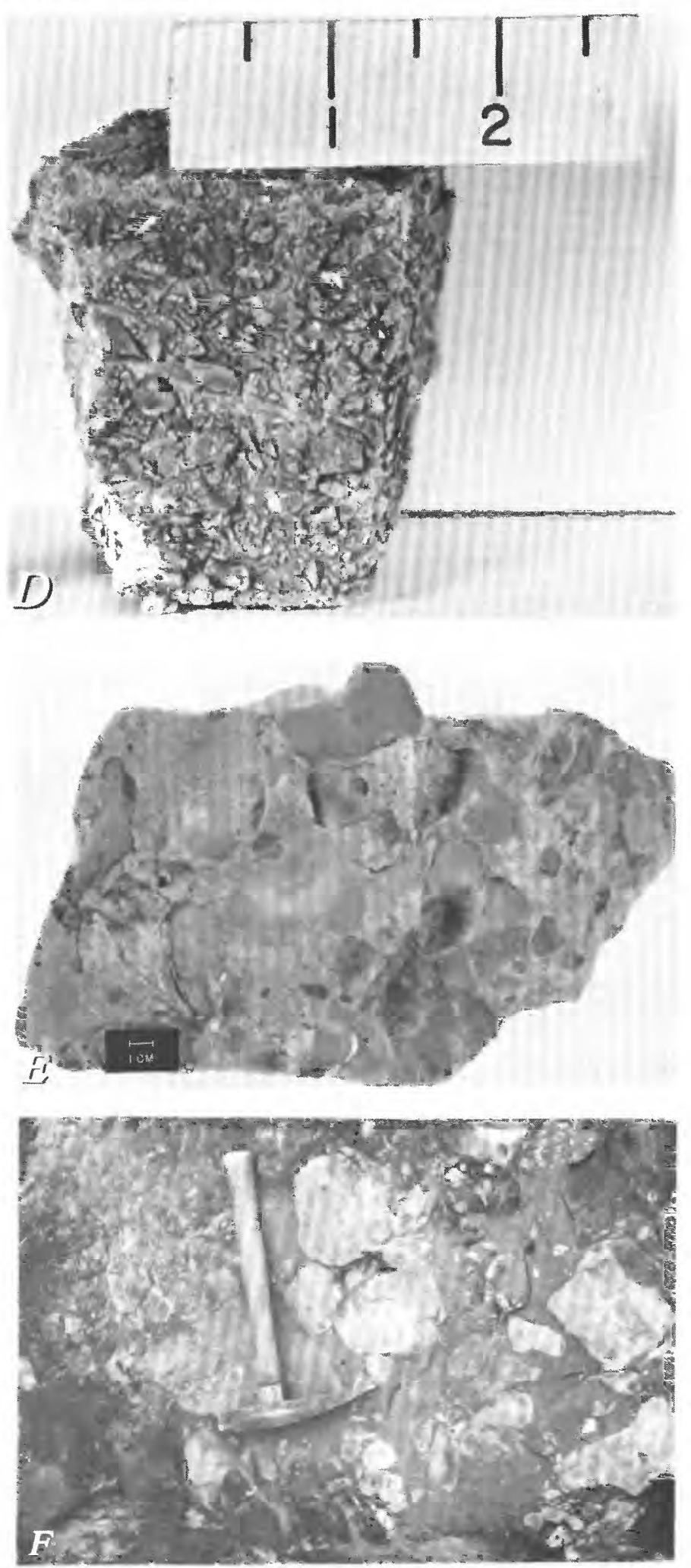

more Wash; $E$, rounded clasts or red siltstone and gray limestone in Wescogame basal conglomerate at Separation Canyon; $F$, gravel conglomerate at bottom of deep channel scour, at base of Wescogame Formation, Havasu Canyon. Scale in inches unless otherwise noted. 


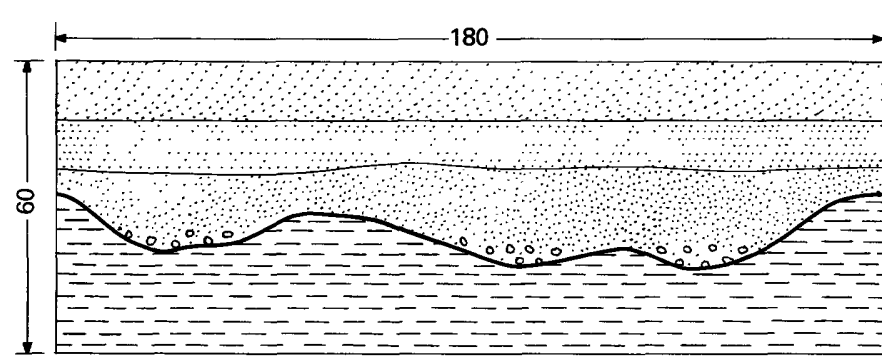

A

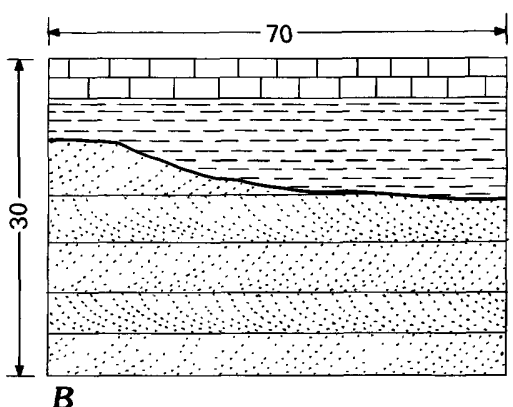

B
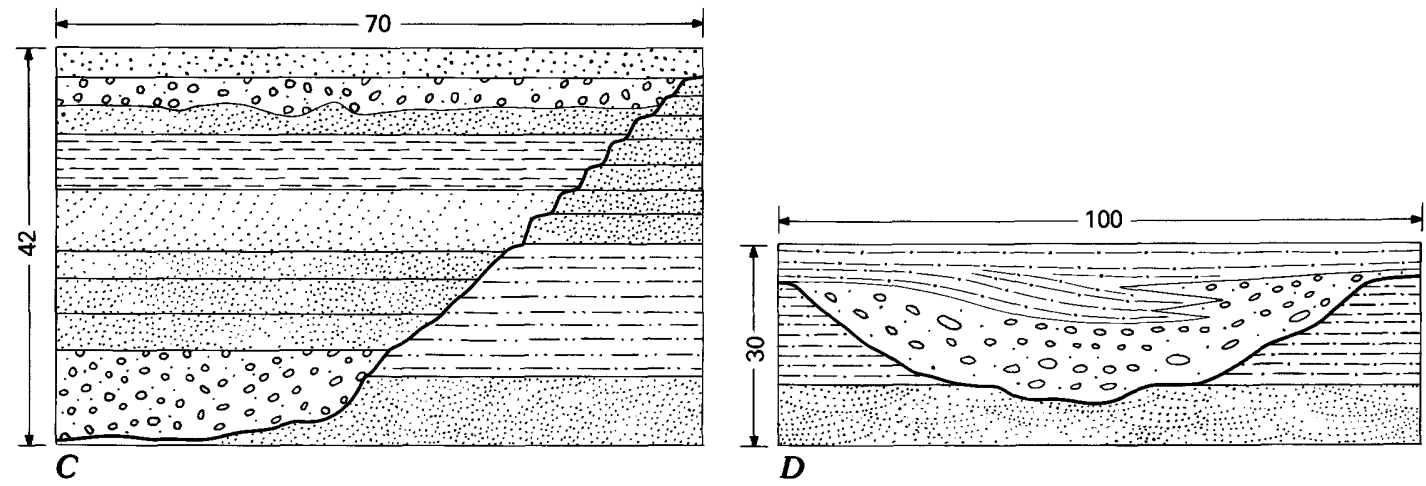
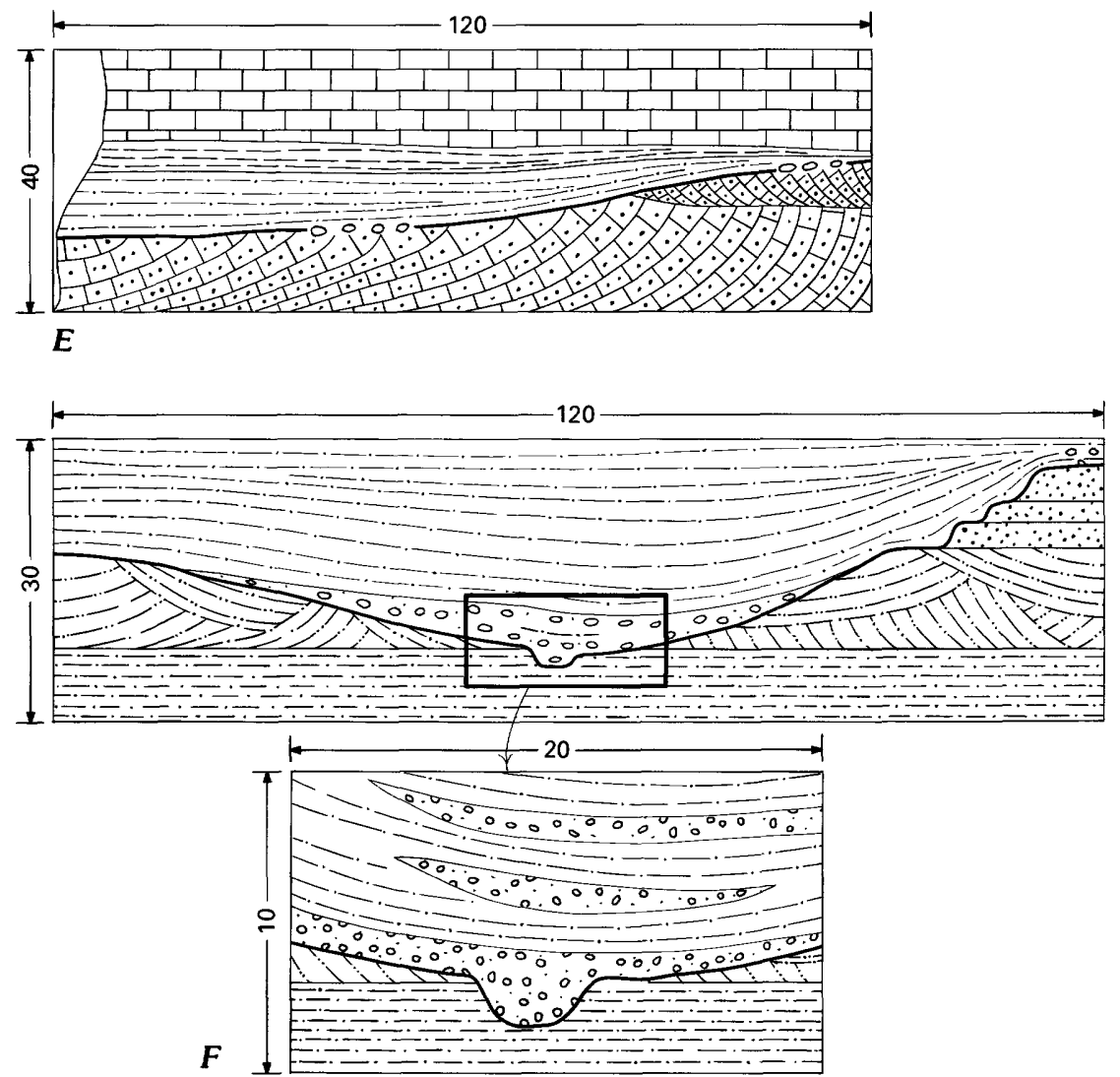

\section{EXPLANATION}

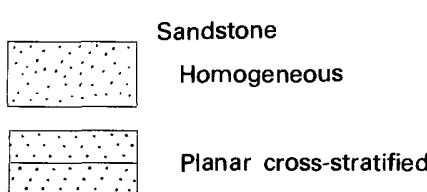

$\because \because \because \because \cdots$

Trough cross-stratified

Flat bedded

Limestone

Homogeneous

Sandy

Sandy cross-stratified
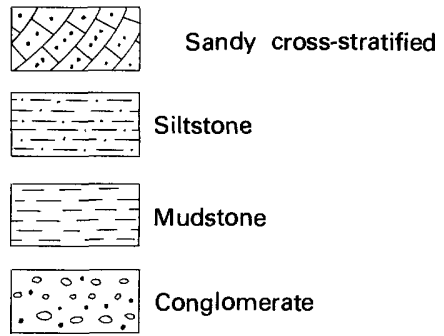

FIGURE 14.-Erosion surface and conglomerate at base of Esplanade Sandstone or Pakoon Limestone (McNair, 1951). A, Series of channels at Esplanade-Wescogame unconformity, Marble Canyon, mile 16.5; $B$, margin of channel at base of Pakoon, Snap Canyon; C, wall of channel carved in sandstone of Wescogame Formation, Esplanade fill includes two conglomerate beds, National Canyon; $D$, basal
Esplanade conglomerate filling channel at top of Wescogame, Kaibab Trail, north; $E$, surface of erosion truncating two sets of crossstratified sandy limestone, Hidden Canyon, north side; $F$, Esplanade basal conglomerate lenses in a channel cut into upper surface of Wescogame, Twin Springs Canyon. Horizontal and vertical distances in feet. 


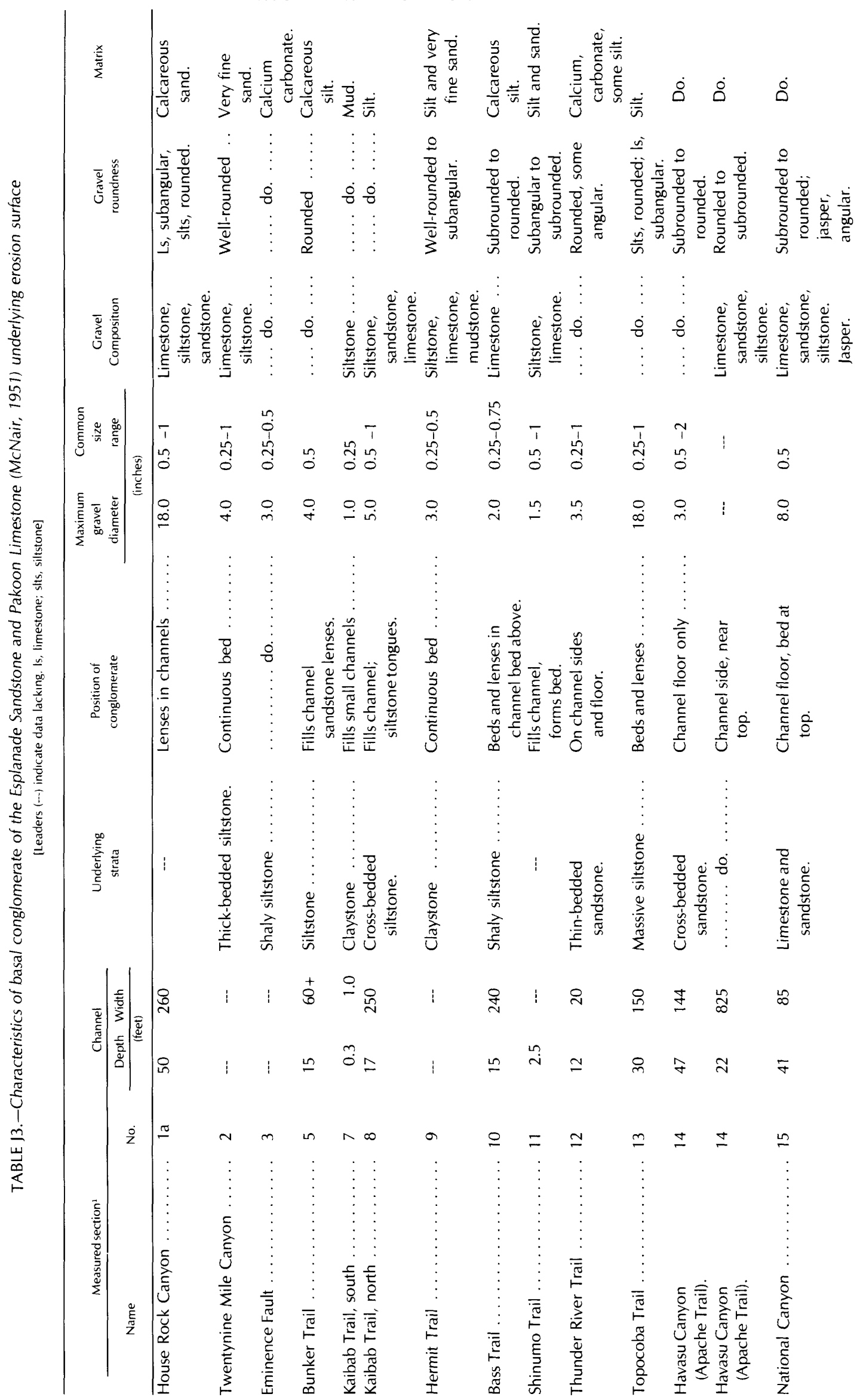




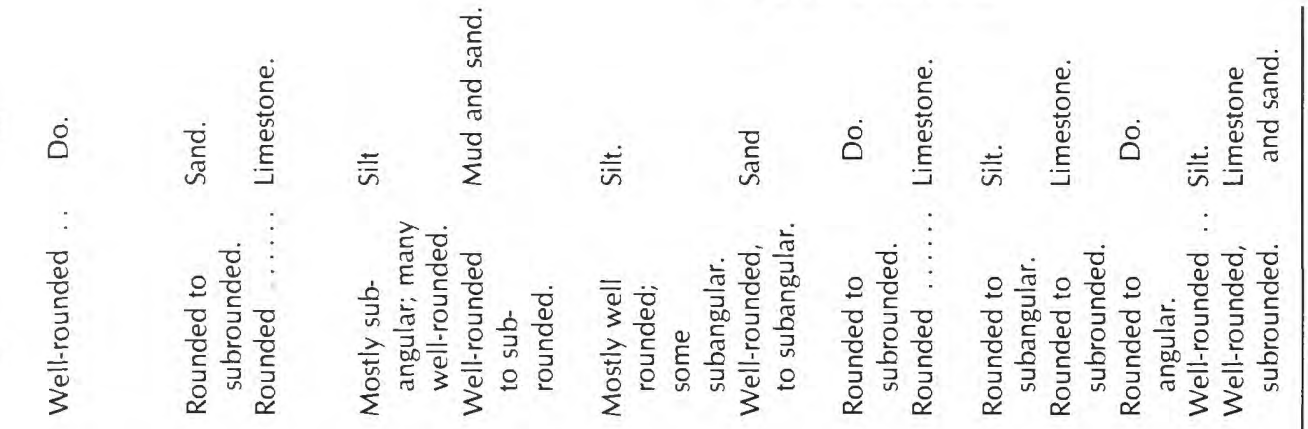

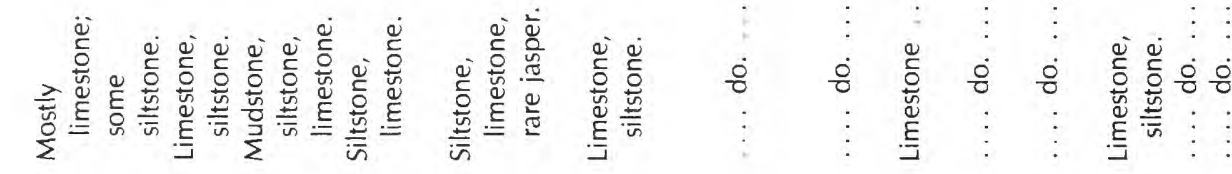

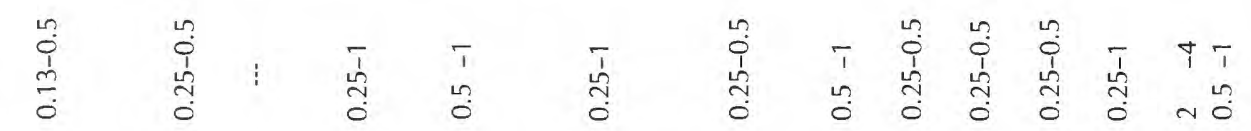

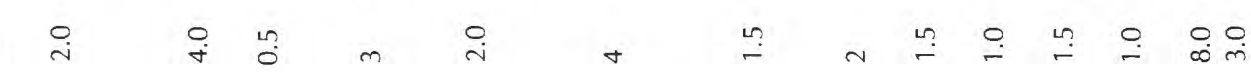

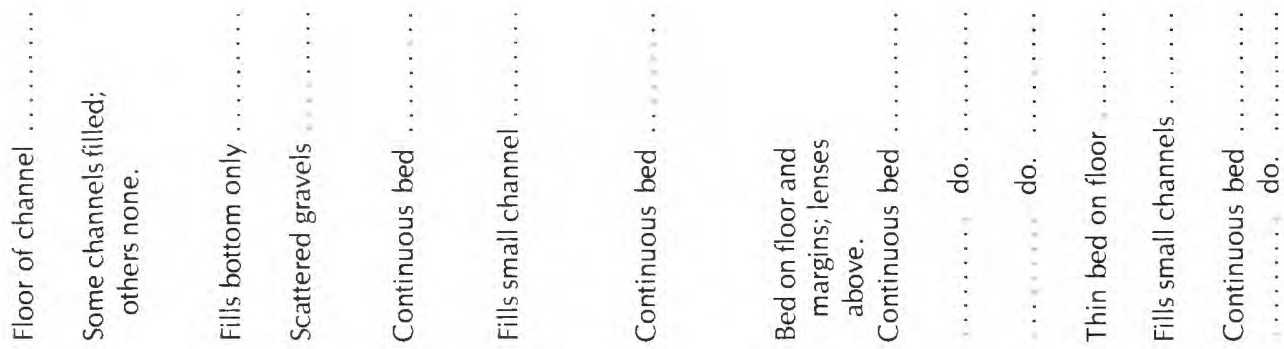

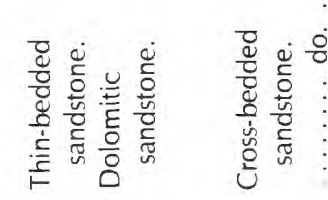

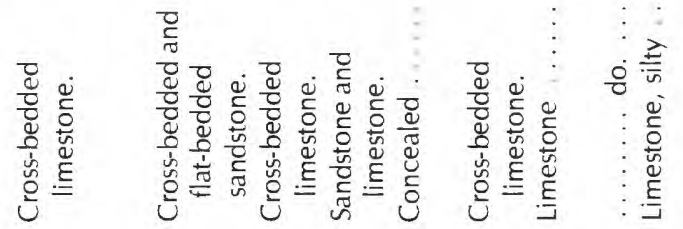

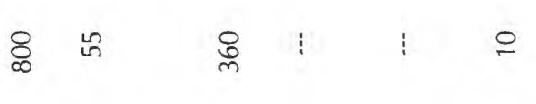

$8: 1: 8 \frac{8}{3}: 1$

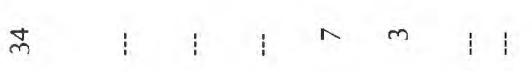

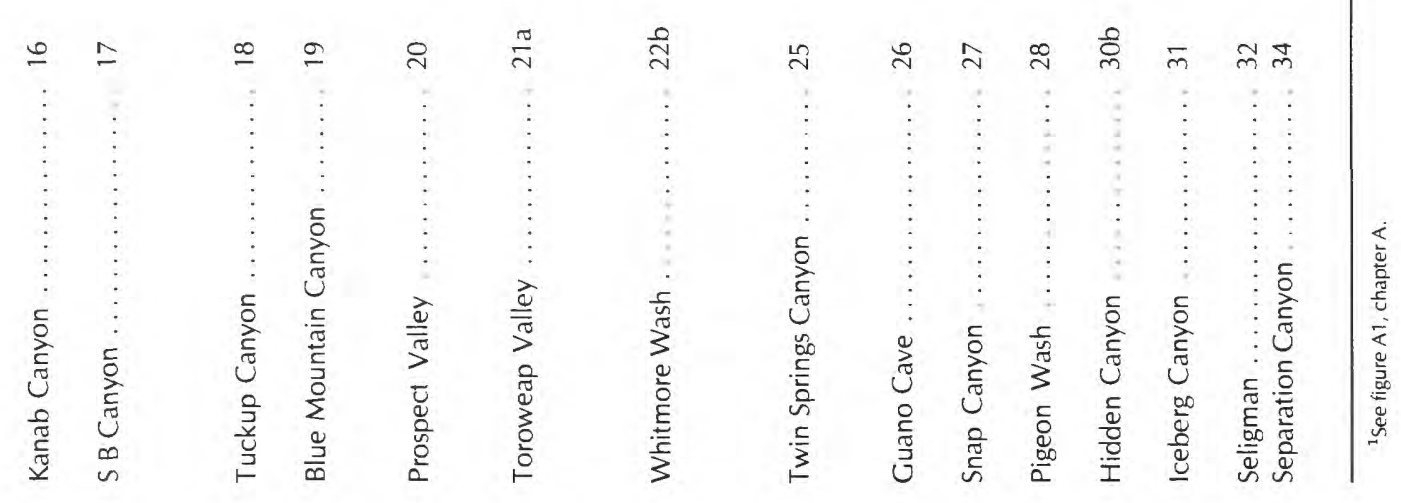



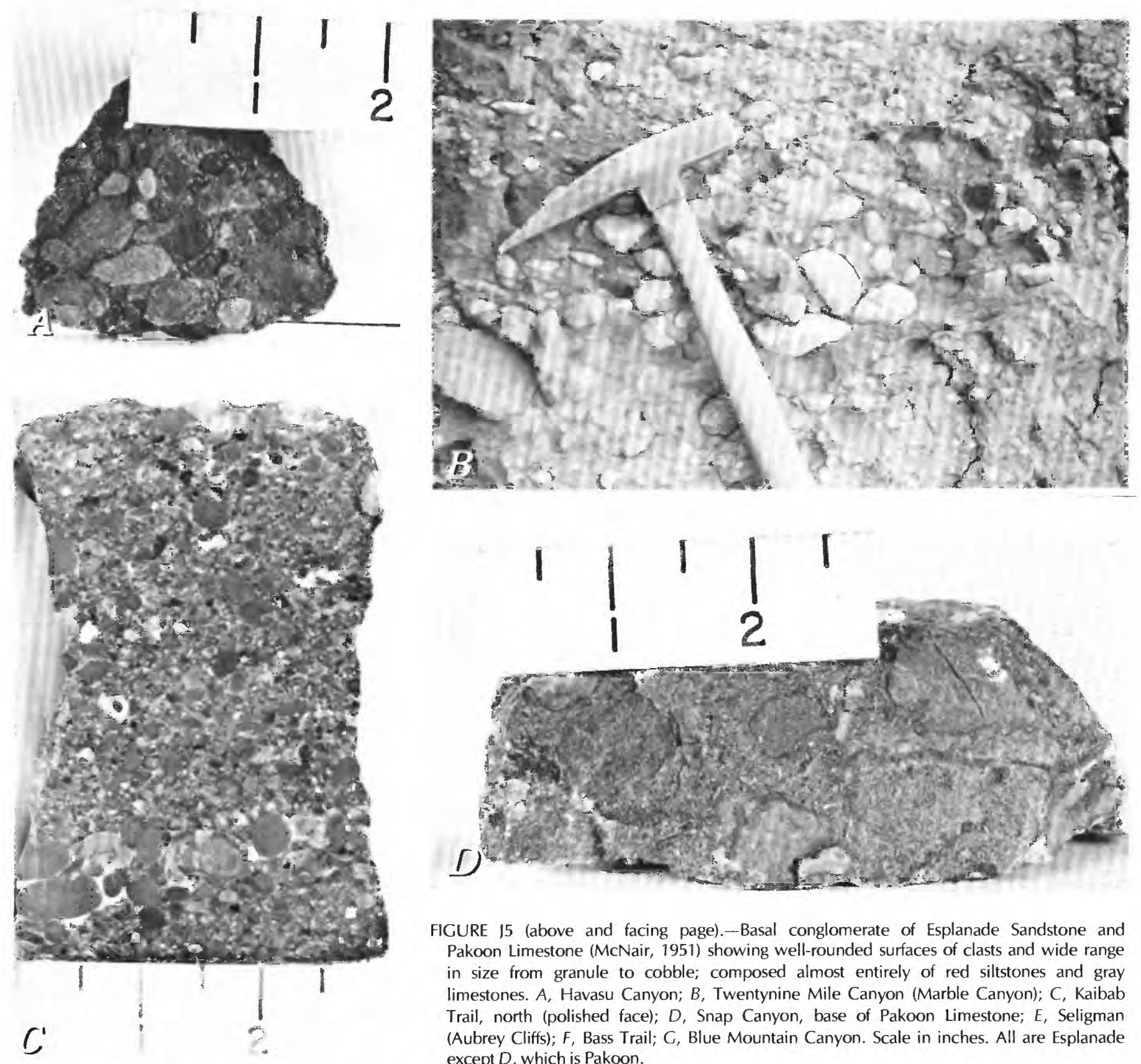

FIGURE 15 (above and facing page).-Basal conglomerate of Esplanade Sandstone and Pakoon Limestone (MCNair, 1951) showing well-rounded surfaces of clasts and wide range in size from granule to cobble; composed almost entirely of red siltstones and gray limestones. A, Havasu Canyon; B, Twentynine Mile Canyon (Marble Canyon); $C$, Kaibab Trail, north (polished face); $D$, Snap Canyon, base of Pakoon Limestone; $E$, Seligman (Aubrey Cliffs); F, Bass Trail; G, Blue Mountain Canyon. Scale in inches. All are Esplanade except $D$, which is Pakoon.

varieties of each as judged by color, texture, and other attributes. Apparently they were derived from numerous different local sources throughout the region. Limestones, for example, include pale-gray, medium-gray, olive-gray, brownish-gray, pale-red, purple, and dark-gray varieties and several distinct textures. Two to four different limestone types are represented in most outcrops. Likewise, siltstones can readily be classified into numerous distinct types; at least six color varieties, mainly reddish browns, are recognized.

Unlike older conglomerate units in the Supai Group, the Esplanade-Pakoon basal conglomerate includes extremely few gravels derived from hard, durable rocks such as quartzite or chert. A few jasper pebbles from National Canyon and from Separation Canyon and some palebrown cherts from Blue Mountain Canyon are the only exceptions recorded from the entire region. Of the other conglomerate units in the Supai, only the Wescogame basal conglomerate contains gravels with a composition that even slightly resembles that of the Esplanade-Pakoon with respect to scarcity of durable rock types.

The range in size represented by gravels of the Esplanade-Pakoon basal conglomerate is considerable (table J3). A boulder with an 18-in. diameter at the Topocoba Trail measured section and one with a 10-in. diameter at Iceberg Canyon are the largest observed during this study, but 

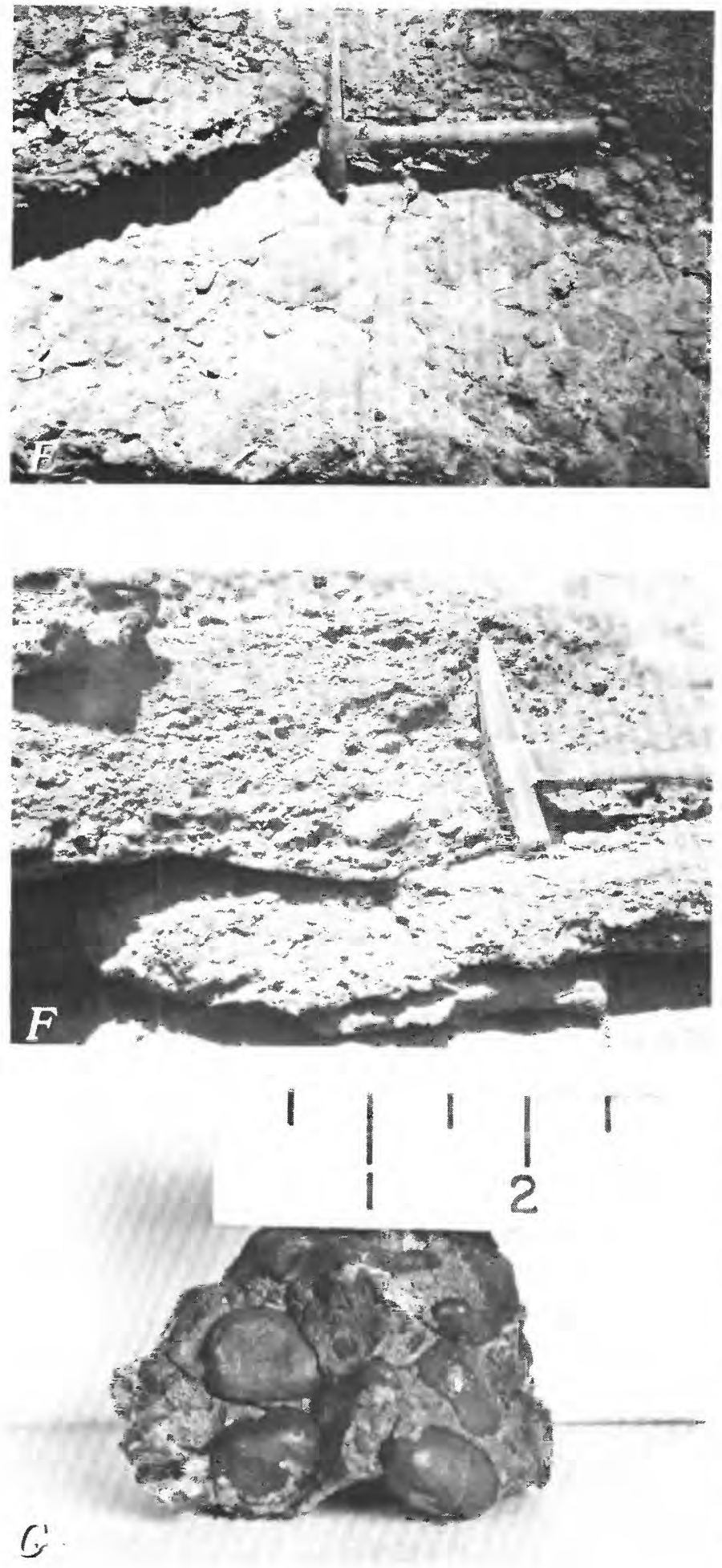

cobbles ranging from 3 to 8 in. in diameter were noted at 18 measured sections. Gravels with diameters between 0.25 and $1 \mathrm{in}$. occur at all measured sections and constitute a major part of the conglomerate throughout the region. Most of the gravels of all sizes are rounded or subrounded; only a few exceptions, determined to be subangular, have been noted.
A majority of all gravels in the Esplanade conglomerate are either spherical or elliptical, because they have been derived largely from uniform-grained siltstone and limestone. Locally, where shaly or platy source rocks contributed some of the pebbles, tabular forms are included. Many of the very large gravels are irregular in shape, apparently not having been transported far enough to develop good sphericity.

The attribute of orientation is weakly developed among these gravels, partly because most deposits contain a high percentage of nearly spherical forms and such forms cannot show alinement in a preferred direction. Among tabular and ellipsoidal pebbles, however, an orientation roughly parallel to the bedding plane is locally developed. No imbricate structures have been observed in the conglomerate.

The matrix of the Esplanade basal conglomerate is predominantly very fine sand or silt. However, in the far western part of the region bordering the Cordilleran geosyncline at Iceberg Canyon and along the Grand Wash fault (at Snap Canyon, Pigeon Wash, and Hidden Canyon), a matrix of granular limestone is characteristic of the conglomerate that occurs at the base of the Pakoon Limestone at these localities.

A second or upper bed of conglomerate, similar in most respects to the Esplanade-Pakoon basal conglomerate, occurs within the slope unit below the main cliff of the Esplanade Sandstone in the central Grand Canyon area. This conglomerate is at Bass Trail, Havasu, National, and S B Canyons, Toroweap Valley, and Whitmore Wash and may be represented at Blue Mountain Canyon. At these localities the bed is somewhat thinner and the maximum pebble size less than in the Esplanade basal conglomerate below. The beds of fine detrital sediments between these conglomerates at the localities examined differ considerably in thickness, but mostly they range between 20 and $50 \mathrm{ft}$.

The history and depositional environment of the Esplanade-Pakoon basal conglomerate probably can be interpreted with reasonable accuracy from a consideration of the types of gravel included and from the character of the erosion surface that these gravels cover. Because the gravels probably were derived entirely from various lithified sediments representing earlier stages in the history of the Supai and contain no presently known foreign or exotic rock types, a source within the northern Arizona region seems likely. Furthermore, the generally good rounding of most pebbles and the large variation in rock types suggest that a moderate amount of transport was involved and that a considerable number of different lithologic units contributed to the deposits.

The surface on which gravels of the Esplanade-Pakoon basal conglomerate accumulated seems to have been fairly uniform across a wide area and to have resulted from erosion of a slightly elevated plain. It was everywhere 
dissected by streams to form a network of narrow channels, some having depths of 30 or $40 \mathrm{ft}$. These channels were subsequently filled or partly filled with pebbles or cobbles, and a thin sheet-like deposit of gravel was spread over most of the interfluve surfaces. Probably a regional change in base level initiated this change from erosion to deposition, but the exact cause is not apparent.

The time represented by the Esplanade-Pakoon basal conglomerate and the underlying surface of erosion involves the time required to lithify the strata of silt, sand, and calcium carbonate that underlie the erosion surface, the time involved in slight regional uplift (or possibly lowering of sea level), and the time required to accumulate the gravel. None of these processes necessarily represents very much time in a geologic sense, but rocks above the hiatus are dated as Permian (Wolfcampian) age on the basis of fossils at a number of localities, whereas those below are considered of Late Pennsylvanian or Virgilian age, but with weaker faunal support as discussed in chapter E.

\section{EROSIONAL SURFACE AT BASE OF THE HERMIT SHALE}

An erosional unconformity at the top of the Esplanade Sandstone was discovered in 1916 by Noble (1922, p. 63), and briefly described two years later by Schuchert (1918, p. 356). After further examination in which this erosion surface was found to be "continuously traceable for at least 15 miles in the Kaibab division," Noble (1922, p. 64) proposed that it be recognized as the lower boundary of his newly recognized Hermit Shale. Its general character as developed near the Hermit Trail is illustrated in his plates XXIII $B$ and XXIVA and his figure $4 a$. Also its profile as observed below Havasupai Point is shown by diagrammatic sketch in his figure $4 b$.

TABLE 14.-Characteristics of the surface of relief at the base of the Hermit Shale

[Leaders (--) indicate data lacking]

\begin{tabular}{|c|c|c|c|c|c|c|}
\hline \multirow[b]{2}{*}{ Locality } & \multirow{2}{*}{$\begin{array}{l}\text { Residual } \\
\text { relief } \\
\text { (in feet) }\end{array}$} & \multirow{2}{*}{$\begin{array}{l}\text { Hill } \\
\text { width } \\
\text { (in feet) }\end{array}$} & \multicolumn{2}{|c|}{ Channel } & \multirow{2}{*}{$\begin{array}{l}\text { Associated } \\
\text { structures }\end{array}$} & \multirow{2}{*}{$\begin{array}{l}\text { Associated } \\
\text { fossils }\end{array}$} \\
\hline & & & Depth & Width & & \\
\hline Badger Canyon & $\ldots$ & -- & 70 & 300 & & \\
\hline Bunker Trail .. & 3 & -- & -- & -- & \multicolumn{2}{|l|}{ Conglomerate lens } \\
\hline Kaibab Trail, south . . & -- & -- & 46 & 100 & $\begin{array}{c}\text { Rain pits, mud cracks, salt molds } \\
\text { do. }\end{array}$ & $\begin{array}{l}\text { Plant impressions, amphibian tracks. } \\
\text { Plant impressions, tracks, burrows. }\end{array}$ \\
\hline Havasu Canyon ..... & --- & -- & 30 & -- & & \\
\hline Thunder River Trail .. & --- & -- & 38 & -- & Conglomerate bed & \\
\hline Kanab Canyon ..... & 8 & 400 & -- & $\ldots$ & & \\
\hline National Canyon .... & 114 & 1,000 & -- & $-\ldots$ & Conglomerate lens & \multirow[b]{3}{*}{ Plant impressions, worm borings. } \\
\hline Tuckup Canyon .... & 3 & -- & --- & -- & & \\
\hline Whitmore Wash .... & -- & -- & 15 & $100+$ & & \\
\hline
\end{tabular}

Subsequent to Noble's investigation in the eastern part have been made in many other parts of the region. In a number of areas no evidence of a physical break has been detected, and at these places a boundary between formations can be established only by placing it arbitrarily where a lithologic change occurs. Thus, the significance of the surface as a record of regional erosion seemed questionable. However, because evidence of an erosion surface at this horizon has now been found at 10 or more places (table $\mathrm{H} 2$ ) beyond the area of Noble's investigation, the concept of a widespread erosion surface at this horizon seems valid.

The surface of relief represented at the contact of the Supai Group and Hermit Shale is of two principal forms. In one the surface is flat and regular for considerable distances with relatively few widely spaced channels incised into it. These channels (table J4) commonly are 30-45 $\mathrm{ft}$ deep and 100 to several hundred feet wide; they are filled with beds of shaly siltstone of the Hermit that commonly dip from the channel margins toward the centers. The second type of surface is the result of more complete dissection where major parts of the original surface have been removed so that only isolated residual hills or remnant mesas of Esplanade Sandstone stand above an erosion plain. In places, these residuals are only 3-8 ft high and a few hundred feet wide, but at National Canyon a mesa more than $100 \mathrm{ft}$ high and $1,000 \mathrm{ft}$ wide is preserved (fig. H15I).

At only three places-Bunker Trail, Thunder River Trail, and National Canyon-were conglomerates noted at the base of the Hermit. These form small lenses or pockets of what appear to be locally derived pebbles and granules of siltstone or limestone. Elsewhere, thin units of reddishbrown, shaly siltstone that fill the channels or form the base of the Hermit locally contain abundant fossil plant impressions (Walchia, Sphenophyllum, seed ferns, and of the Grand Canyon, studies of the Hermit-Supai contact 
others), shrinkage cracks, rain pits, worm borings, amphibian tracks, and patterns assigned to the algal form known as Rivularites. These fossils and structures are well represented near the south Kaibab and Hermit Trails and at Whitmore Wash.

\section{INTRAFORMATIONAL CONGLOMERATES IN THE HERMIT SHALE}

Evidence of local erosion within the sequence of shaly siltstones and mudstones forming the Hermit Shale consists of buried channels and of intraformational conglomerates. Such features are recorded from 14 localities, and in 2 of these at more than one horizon. No clear evidence is available that these features are continuous from one locality to another although, in general, they occur at two principal levels above the formation base. Thin conglomerate beds and lenses occur from 49 to $100 \mathrm{ft}$ above the base at 7 localities (table J5). Erosion channels and (or) conglomerates are in the upper part of the formation, from 215 to $698 \mathrm{ft}$ above the base, at 5 localities.

Intraformational conglomerates of the Hermit Shale are largely reddish brown and consist mostly of rounded pebbles of limestone and siltstone in a silty matrix. Individual pebbles and granules in most exposures are well rounded and, in general, range from 0.125 to 0.5 in. with maximums of 2-4 in. All the pebbles seem to have been locally derived, although they apparently were rolled about sufficiently to be moderately well rounded.

Buried channels within the formation are relatively small with depths ranging from 6 to $15 \mathrm{ft}$. They are filled with shaly siltstone, the bedding planes of which roughly conform with the curving surface of the channel. ln these channel deposits various fossils and minor sedimentary structures are characteristically preserved in abundance.
TABLE 15.-Stratigraphic position of buried channels and local conglomerates above base of Hermit Shale [Leaders (--) indicate not present]

\begin{tabular}{|c|c|c|}
\hline \multirow[b]{2}{*}{ Locality } & \multicolumn{2}{|c|}{$\begin{array}{l}\text { Stratigraphic position (in feet) } \\
\text { above base of Hermit Shale }\end{array}$} \\
\hline & Channel & Conglomerate \\
\hline Whitmore Wash & 100 & --- \\
\hline Tower of Babylon & 215 & --- \\
\hline Blue Mountain Canyon ..... . & 216 & ... \\
\hline National Canyon ......... & ... & 49 \\
\hline Havasu Canyon . & --- & 76 \\
\hline Topocoba Trail & 138 & --- \\
\hline Bass Trail $\ldots \ldots \ldots \ldots \ldots$ & ... & 94 \\
\hline Kaibab Trail, north . . . . . . . & 241 & ... \\
\hline Grandview Trail . . . . . . . . & --. & 98 \\
\hline \multirow[t]{2}{*}{ Bunker Trail } & 64 & 73 \\
\hline & 52 & \\
\hline Blue Spring & 72 & --- \\
\hline Horsetrail Canyon & --- & 65 \\
\hline Eminence Fault .. & 301 & 311 \\
\hline Twentynine Mile Canyon ... & 698 & 89 \\
\hline
\end{tabular}

Worm burrows and amphibian tracks were recorded at Whitmore Wash, impressions of the coniferous plant Walchia at Blue Mountain Canyon, rain pits, plant impressions, and worm tubes at both Topocoba and Bass Trails, and the algal form Rivularites at Twentynine Mile Canyon.

\section{REFERENCES CITED}

McNair, A. H., 1951, Paleozoic stratigraphy of part of northwestern Arizona: American Association of Petroleum Geologists Bulletin, v. 35 , no. 3, p. 503-541.

Noble, L. F., 1922, A section of the Paleozoic formations of the Grand Canyon at the Bass Trail: U.S. Geological Survey Professional Paper 131, p. 23-73.

Schuchert. Charles, 1918, On the carboniferous of the Grand Canyon of Arizona: American Journal of Science, 4th ser., v. 45, no. 267 p. 347-361. 


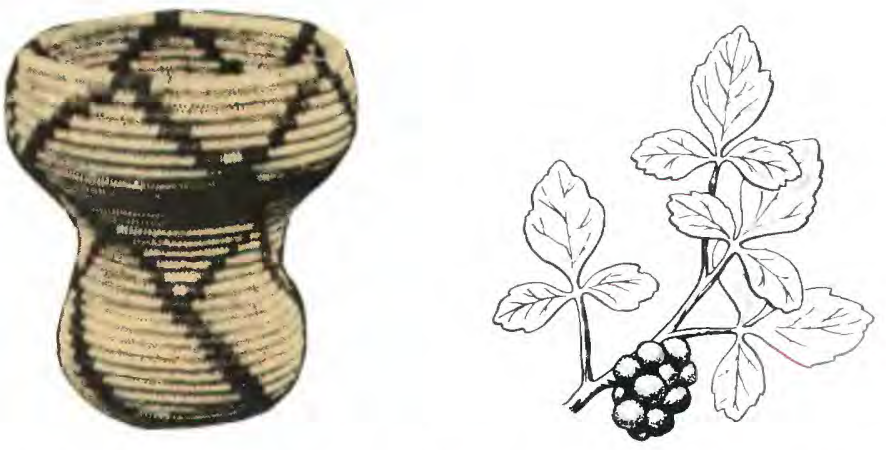

THE SUPAI GROUP OF GRAND CANYON

\title{
SANDSTONES
}

\author{
Chapter $\mathrm{K}$
}

By EDWIN D. McKEE

\section{Contents}

Sandstones of the Supai Group . . . . . . . . . . . . . . . . . . . . . . . . . . . . . . . . . . . . . 207

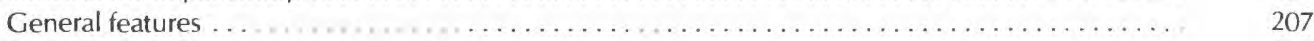

Methods of study . . . . . . . . . . . 207

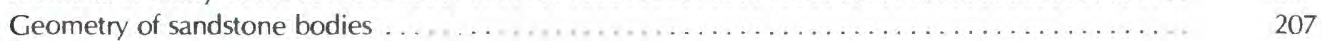

Grain-size distribution in Supai Group . . . . . . . . . . . . . . . . . . . . . . . . . . . . . . 208

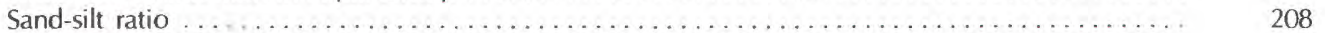

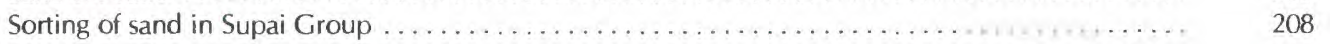

Grain roundness in Supai Group . . . . . . . . . . . . . . . . . . . . . . . . . . . . . 209

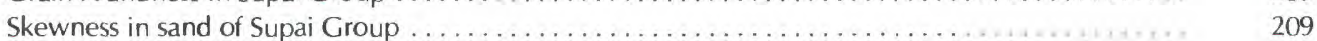

Cross-stratification in the Supai Group . . . . . . . . . . . . . . . . . . . . . . . . . 209

Characteristic features . . . . . . . . . . . . . . . . . . . . . . . . . . . . 209

Statistical studies of current directions . . . . . . . . . . . . . . . . . . . . . . . . . 210

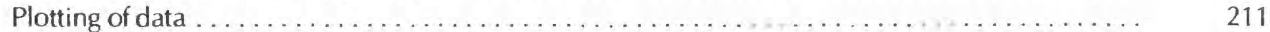

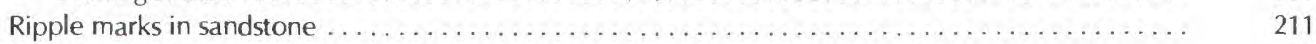

Sandstone of the Watahomigi Formation . . . . . . . . 211

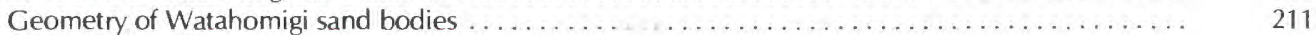

Grain-size distribution in Watahomigi Formation . . . . . . . . . . . . . . . . . . . . . . 211

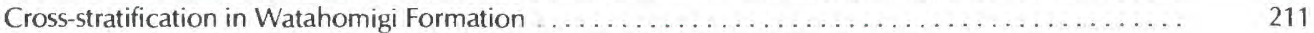

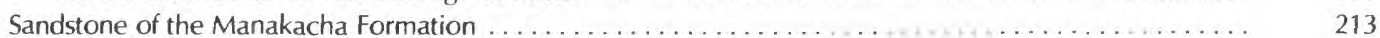

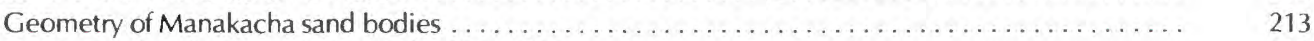

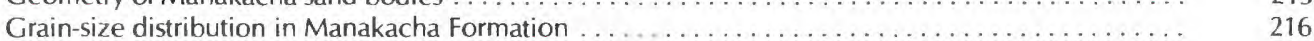

Cross-stratification in Manakacha Formation . . . . . . . . . . . . . . . . . . . . . . . . . . 216

Characteristic features

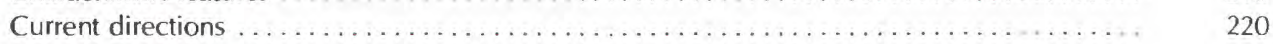

Ripple marks in sandstone . . . . .

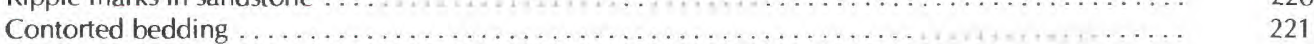

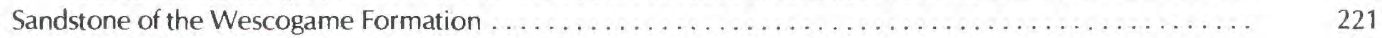

Geometry of Wescogame sand body . . . . . . . . . . . . . . . . . . . . . . . . . . . . . . 221

Grain-size distribution in Wescogame Formation . . . . . . . . . . . . . . . . . . . . 222

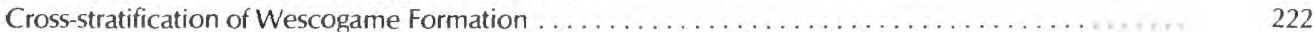

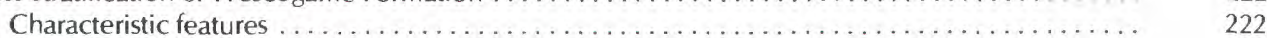

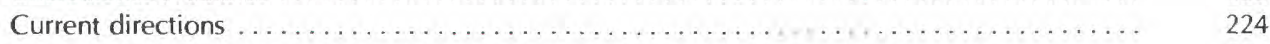

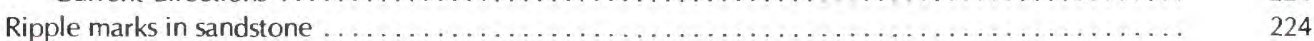




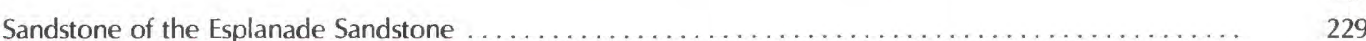

Geometry of Esplanade sand body . . . . . . . . . . . . . . . . . . . . . . . . . . . . . . . 229

Grain-size distribution in the Esplanade Sandstone . . . . . . . . . . . . . . . . . . . . 229

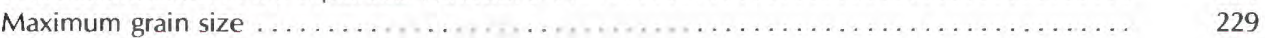

Medium and finer size grades . . . . . . . . . . . . . . . . . . . . . . . . . . 229

Cross-stratification of Esplanade Sandstone . . . . . . . . . . . . . . . . . . . . . . . 229

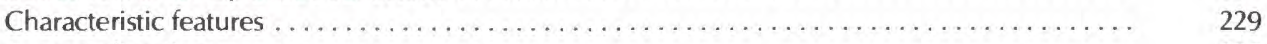

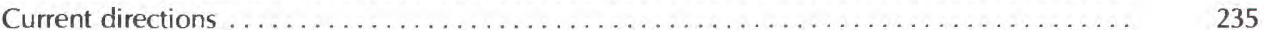

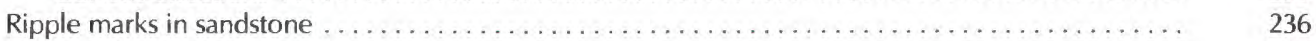

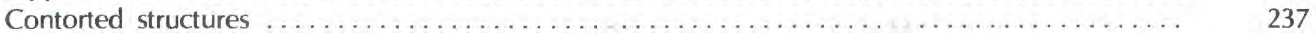

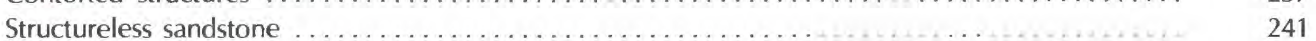

Small-scale structures in associated siltstone lenses . . . . . . . . . . . . . . . . . . 241

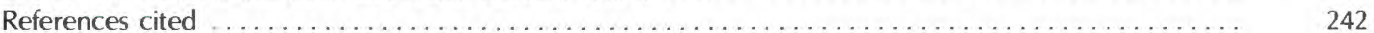

\section{Illustrations}

K1. Dominant size grade, Watahomigi Formation . . . . . . . . . . . . . . . . 212 K3-K8. Manakacha Formation:

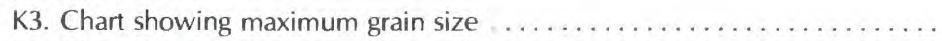

K4. Chart showing dominant size grade . . . . . . . . . . . . . . . .

K5. Sketches of styles of cross-stratification in cliff unit . . . . . . . . . . . . . . . .

K6. Photographs showing cross-strata $\ldots \ldots \ldots \ldots \ldots \ldots \ldots \ldots \ldots \ldots \ldots \ldots \ldots$

K7. Polar coordinate diagrams showing cross-strata dip directions, average

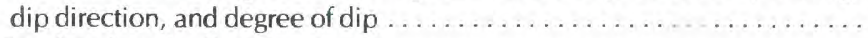

K8. Map showing dip-direction vectors $\ldots \ldots \ldots \ldots \ldots \ldots \ldots \ldots \ldots$

K9-K17. Wescogame Formation:

K9. Chart showing maximum grain size . . . . . . . . . . . . . . . . . 222

K10. Chart showing dominant size grade . . . . . . . . . . . . . . 223

K11. Sketches showing planar cross-strata and trough-like cross-strata . . . . . . . 224

K12. Sketches showing tabular-, wedge-planar and trough sets . . . . . . . . . $\quad 225$

K13. Sketches showing tabular- and wedge-planar cross-strata . . . . . . . . . . 226

K14. Photographs showing cross-strata .................... 228

K15-K16. Polar coordinate diagrams showing cross-strata dip directions, average dip direction, and degree of dip . . . . . . . . . . . . . . . . . .

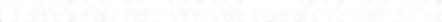

K18-K21. Esplanade Sandstone:

K18. Chart showing maximum grain size $\ldots \ldots \ldots \ldots \ldots \ldots \ldots \ldots \ldots \ldots \ldots$

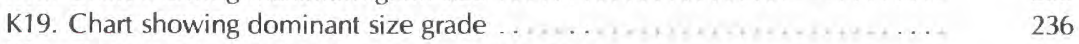

K20. Photographs showing size-scale of cross-strata . . . . . . . . . . . . 237

K21. Polar coordinate diagrams showing cross-strata dip directions, average dip direction, and degree of dip . . . . . . . . . . . . . . . . .

K22. Polar coordinate diagrams showing cross. strata dip directions, average dip direction, and degree of dip of the Esplanade Sandstone and the Pakoon Limestone . . . . .

K23. Map showing dip-direction vectors, Esplanade Sandstone . . . . . . . . . . . . . . . . . .

K24. Map showing dip-direction vectors, Pakoon Limestone . . . . . . . . . . . . .

K25. Sketches showing small-scale cross-strata and contorted bedding in the Esplanade Sandstone

\section{Tables}

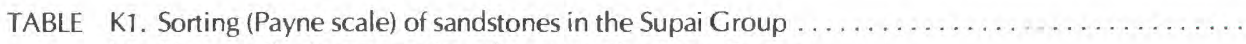

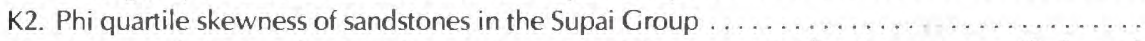

K3. Percent of size grades in adjacent foreset and bottomset beds of a cross-stratified sandstone unit of the Wescogame Formation

K4. Relative abundance of principal types and size classes of cross-strata in the upper three

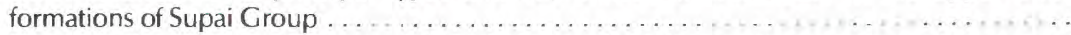

K5. Number and types of cross-strata sets included and thickness of cosets in sandstones and arenaceous limestones in the upper three formations of the Supai Group .

K6. Degree of dip in cross-stratification in upper three formations of Supai Group . . . . . . . . . . .

K7. Proportions of sandstone and siltstone in Supai Group . . . . . . . . . . . . . . . . . . 


\section{SANDSTONES OF THE SUPAI GROUP}

\section{General features}

Sandstone constitutes the major rock type of the upper three formations (Manakacha, Wescogame, Esplanade) of the Supai Group (figs. C10-C13) and it forms small local deposits scattered among the siltstone and limestone beds of the lowermost formation (Watahomigi). Most of these sandstone units are composed of thick, massive beds, extensively cross-stratified, but in some places they appear to be structureless. Locally the sandstone is flat bedded and forms relatively thin sets.

In order to understand the nature of various bodies of sandstone within the Supai Group, to compare one with another, and to interpret the genesis of each, their various properties were studied and analyzed from as many approaches as possible. Results of these studies, presented in this chapter as they apply to each of the four formations of the Supai Group, include the following attributes: geometry of sandstone bodies, grain-size distribution, sorting of sand, grain roundness, skewness, cross-stratification, ripple marks and other minor structures, and contorted bedding.

Interpretation of the sandstone bodies in each formation of the Supai Group is largely deferred until Chapter L, which is entitled "Environment of deposition of sandstone bodies." Although a majority of the basic data used for interpretation is described and discussed in this chapter (K), much supporting evidence is from other chapters, especially those concerning associated rocks of other types and their faunas or floras. Additional information on interpreting depositional environments is treated in chapter I under "Transgression and regression."

\section{Methods of study}

Sandstones of the Supai Group are composed almost entirely of quartz sand grains with a calcareous cement. The proportions of each differ greatly from place to place, especially from a regional standpoint. Weakly cemented sandstones grade into very calcareous sandstones and these may grade into arenaceous limestones. To determine the status of a particular sandstone sample or bed, standard methods of treating with acid to eliminate calcium carbonate, of screening to determine the amount of each size grade, and of weighing to ascertain the percent of each grain size, were used. The Wentworth scale, summarized below, is used throughout the chapter to express grain-size measurements. These measurements are indicated either by stating the largest size represented in a sample which is termed "maximum grain size," or by indicating the size of grain forming the Wentworth size grade that is largest by weight in a sample. This category is referred to as the "dominant size grade."

Wentworth scale (Wentworth, 1922)

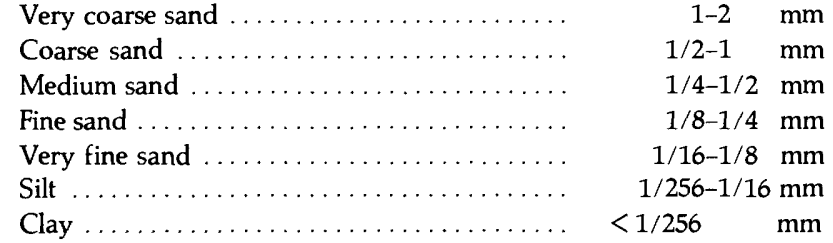

A large proportion of the fine-grained calcareous sandstones and arenaceous limestones in the upper three formations of the Supai Group is cross-stratified; only in the Watahomigi are such cross-strata largely lacking. The structures (cross-strata) show an infinite variety of detail in sections exposed by erosion, some differences being caused by slight variations in the laminae, but most of them resulting from differences in the angle of dissection. When analyzed in three dimensions, however, most of these Supai cross-strata resolve themselves into two fundamental types: tabular planar and wedge planar; the trough type is uncommon.

In the analysis of cross-strata, which necessarily was conducted in the field, five principal attributes were measured and recorded. The resulting averages and trends are presented in the form of tables on following pages. The attributes are: (1) the proportions of basic cross-bed typestabular planar, wedge planar, trough type, and small-scale migrating ripple forms; (2) the thickness and number of sets (and cosets) included in a sand body (McKee and Weir, 1953); (3) the length of foresets in a single set of cross-beds-referred to as large-scale $(>20 \mathrm{ft})$, mediumscale $(1-20 \mathrm{ft})$, or small-scale $(<1 \mathrm{ft}) ;(4)$ angle of dip of foresets-referred to as high-angle $\left(>20^{\circ}\right)$, or low-angle $\left(<20^{\circ}\right)$; (5) directional vectors of foresets-includes the mean or average dip direction and the amount of spread represented by all dip readings.

\section{Geometry of sandstone bodies}

Thirty-two measured sections constitute the principal source of information from which trends have been projected and extrapolated to reconstruct the geometry of sandstone bodies within the Supai Group. These $32 \mathrm{sec}-$ tions in the Grand Canyon region are in two east-west series and several relatively short north-south sequences, shown in figures $\mathrm{P} 6, \mathrm{P} 8, \mathrm{P} 10$, and $\mathrm{P} 12$.

Except in the Watahomigi, where the relatively few sandstone bodies are thin and lensing, most sandstones of the Supai Group are tabular bodies that are continuous 
throughout much of the Grand Canyon embayment. The larger ones extend more than $100 \mathrm{mi}$ east-west and at least $40 \mathrm{mi}$ north-south. None of them exceed a few hundred feet in thickness and therefore they have extremely high ratios of lateral extent to thickness. Although most of the major bodies are relatively uniform in thickness for distances of some tens of miles, they change character within short distances where tongues of other lithologic facies project into them or, as in the case of carbonate rocks, grade laterally into them.

The geometry of the principal sandstone bodies is described in this chapter for each of the formations in the Supai Group.

\section{Grain-size distribution in Supai Group}

The size distribution of quartz sand in sandstones of the Supai Group is effectively illustrated both by (1) the maximum grain sizes represented at various localities, and by (2) the dominant size grades in samples from these localities. Maximum sizes were ascertained on the basis of approximately 300 mechanical analyses, made with Tyler Standard ${ }^{1}$ screens, of samples judged to be representative of the sand units in each locality. Trends in grain-size distribution were determined for the principal sandstone bodies in each formation and are described under appropriate headings in this chapter.

In addition to the several hundred sand samples for which size distribution was determined by screening and weighing, about 500 additional samples were checked for grain size by a visual-comparison method. This technique involved using a binocular microscope for comparing sand samples with measured grains mounted on slides. Although not as accurate as the sieving technique in indicating the proportions of grain size within an individual sample, this relatively rapid method served to give a reasonably good measure of the distribution of grain size within the various sandstone bodies.

Results of the measurements of grain size for the four formations of the Supai Group show that by far the most common size represented in each is very fine. Maximum size ranges up to very coarse grain in a relatively few localities, and to coarse grain in many places. The dominant (largest amount of sand) size grade in strata of the upper three formations ranges up to medium sand, although this is very uncommon.

A comparison of coarse-sediment distribution in the Esplanade Sandstone with that in older units of the Supai Group shows a lateral shift in geographic position. Whereas in the Manakacha and Wescogame units the

\footnotetext{
${ }^{1}$ Use of trade name in this paper is for descriptive purposes only and does not constitute an endorsement of the product by the U.S. Geological Survey.
}

coarsest material is in the eastern and western parts of the area and finer sediment is characteristic of the center, in the Esplanade Sandstone most of the coarsest sediment is in the central, especially the west-central, part of the area.

\section{Sand-silt ratio}

A rough calculation of the proportion of sandstone (ss) to siltstone (sts.), based on samples of about 1,000 bedding sets and representative of the four formations of the Supai Group, has been made (table K7). This calculation was compiled by determining the dominant grain size, either by screening or by the visual-comparison method previously described, for all sandstone units as sampled during the measuring of stratigraphic sections. It shows a marked upward increase in the proportion of sand to silt as follows:

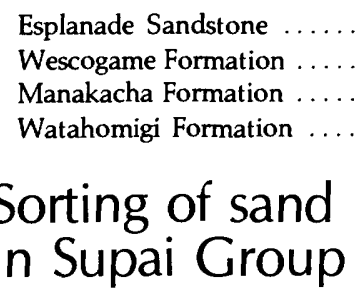

Despite a considerable range in the size of sand at a few localities, a general impression of good sorting is furnished by samples from many horizons throughout the region and detailed measurements tend to confirm this conclusion (table K1). The Payne scale for sorting (Payne, 1942, p. 1707) was applied to more than 130 randomly selected samples representative of all units of the four formations in the Supai Group. In the Payne system, each sample is classed in one of three categories-good, medium (fair), and poor-according to the number of Wentworth-scale grade sizes that comprise 90 percent of the whole. The scale is summarized as follows:

Good sorting-90 percent consists of 1 or 2 grade sizes.

Medium (fair) sorting-90 percent consists of 3 or 4 grade sizes.

Poor sorting-90 percent consists of 5 or more grade sizes.

Sorting in various sandstone-siltstone bodies of the Supai Group, using the Payne scale, shows a general similarity throughout, with a majority (165) of the samples tested showing good sorting and less than half of that number (67) showing fair sorting. None showed poor sorting. As illustrated in table $\mathrm{K} 1$, each of the individual formations shows a rather similar pattern of sorting, but somewhat different results are found when various units within formations are compared. Those units that are largely slope-forming and include much silt but little crossstratified sand (low-energy deposits, continental in part, 
TABLE K1.--Sorting (Payne scale) of sandstones in formations of the Supai Group in Grand Canyon region, Arizona

\begin{tabular}{|c|c|c|c|}
\hline \multirow{2}{*}{$\begin{array}{l}\text { Stratigraphic } \\
\text { unit }\end{array}$} & \multicolumn{3}{|c|}{ Sorting of sets sampled } \\
\hline & Good & Medium & Poor \\
\hline \multicolumn{4}{|l|}{ Esplanade: } \\
\hline Upper cliff-slope . & 12 & 2 & 0 \\
\hline Main cliff & 28 & 17 & 0 \\
\hline Basal slope & 15 & 1 & 0 \\
\hline Total Esplanade. & 55 & 20 & 0 \\
\hline \multicolumn{4}{|l|}{ Wescogame: } \\
\hline Slope $\ldots \ldots \ldots \ldots \ldots \ldots \ldots$ & 7 & 3 & 0 \\
\hline Cliff $\ldots \ldots \ldots \ldots \ldots \ldots \ldots \ldots \ldots$ & 15 & 10 & 0 \\
\hline Total Wescogame & 22 & 13 & 0 \\
\hline \multicolumn{4}{|l|}{ Manakacha: } \\
\hline Slope & 12 & 9 & 0 \\
\hline Cliff . & 38 & 11 & 0 \\
\hline Total Manakacha & 50 & 20 & 0 \\
\hline \multicolumn{4}{|l|}{ Watahomigi: } \\
\hline Upper slope & 17 & 8 & 0 \\
\hline Middle cliff & 9 & 3 & 0 \\
\hline Lower slope & 12 & 3 & 0 \\
\hline Total Watahomigi & 38 & 14 & 0 \\
\hline
\end{tabular}

such as those in the Watahomigi) differ from the mainly cross-stratified, cliff-forming units that probably were formed under higher energy conditions.

\section{Grain roundness in Supai Group}

The degree of roundness in quartz grains of the Supai is believed to be a function of grain size as indicated by the distribution pattern described below. The maturity of the sand and amount of transportation of the particles seem not to be direct causes of the roundness; most of the relatively clean quartz sand probably represents second or later generations of erosion and deposition.

Examination of more than 900 samples of sandstone and siltstone, distributed according to grain size and age as indicated on table $\mathrm{K} 7$, gives what is considered a reliable measure of roundness for quartz particles in rocks of the Supai Group. Observations indicate that nearly all sand grains from the very fine grade size $(1 / 8-1 / 16 \mathrm{~mm})$ and coarser, range from rounded to well rounded. Most of the quartz grains of silt size $(<1 / 16 \mathrm{~mm})$ are angular to subangular.

\section{Skewness in sand of Supai Group}

An attempt was made to determine whether any marked trends in skewness (degree of symmetry of the size distribution with respect to the median) are recorded in sands of the four formations that comprise the Supai Group. For somewhat more than 300 samples, the phi quartile skewness (Folk, 1968) was calculated and is summarized in table $\mathrm{K} 2$.

TABLE K2.-Phi quartile skewness determined for assorted sandstones in Supai Group

\begin{tabular}{|c|c|c|c|c|}
\hline Formation & $\begin{array}{l}\text { Percent samples } \\
\text { skewed }\end{array}$ & $(-)$ & 0 & $(+)$ \\
\hline Esplanade & 33.6 & 34 & 79 & 6 \\
\hline Wescogame & 42.0 & 15 & 30 & 6 \\
\hline Manakacha .... & 42.3 & 33 & 53 & 6 \\
\hline Watahomigi .... & 24.5 & 12 & 46 & 3 \\
\hline
\end{tabular}

The results of this study show few differences in skewness among the various formations. In each formation, more than half of the specimens are not skewed, and of those that show skewness, a much higher percentage is negative than positive. The smallest percentage of skewed samples is in those sandstones from the Watahomigi. A possible reason is that, unlike the other sandstones, they were accumulated in an environment of low energy as indicated by a lack of cross-stratification and by other features.

\section{Cross-stratification in the Supai Group}

\section{Characteristic features}

Cross-strata in the Supai Group are largely of the tabular-planar and wedge-planar types, but include some of the trough type in the Wescogame Formation and Esplanade Sandstone. Small-scale cross-strata including ripple laminae and climbing ripples are uncommon. Most of the cross-strata are compound, consisting of sequences with superimposed sets of dipping beds that form cosets as defined in McKee and Weir (1953, p. 383) that may be as thick as $40 \mathrm{ft}$. These cosets commonly consist of from 2 to 5 sets, but in places are composed of as many as 10 or 11 sets in vertical sequence.

A feature of Supai cross-stratification, both in sandstones and in carbonate rocks, that has been recorded and studied systematically throughout the group, is its scale. On the basis of more than a thousand readings from the three upper formations and from 26 localities throughout the region, a statistical analysis of this feature has been 
made. In classifying the scale of cross-strata, three categories are recognized: small, defined as $1 \mathrm{ft}$ long or less; medium, defined as 1 to $20 \mathrm{ft}$ in length; large, defined as more than $20 \mathrm{ft}$ long. Large-scale foresets in a number of localities are more than $50 \mathrm{ft}$ long and in a few places exceed $100 \mathrm{ft}$. Small-scale structures, as here defined, are formed largely by ripple migration. They are scarce in all formations and limited to relatively few localities; most commonly they occur in the Watahomigi Formation.

The mean degree of dip on cross-strata foresets has been determined for all areas studied and for each formation of the Supai containing cross-strata. Classification has been into two groups: high-angle strata which dip at $20^{\circ}$ or more, and low-angle strata in which the dip is less than $20^{\circ}$ (McKee and Weir, 1953, p. 386). In all three formations, the distribution into low-angle and high-angle types is nearly equal.

Studies of topset and bottomset laminae in Supai crossstrata indicate that only rarely are these structures represented and that foresets form essentially all cross-strata. One of the few good illustrations of topsets to have been recorded is in the Wescogame, near the Kaibab Trail, south, where horizontal topsets are seen connecting with high-angle foresets (fig. K14F). Probably the preservation of these topsets resulted from a local rise in water level, which prevented the usual beveling of uppermost deposits that occurs when water level is stationary or lowering.

Bottomset beds commonly develop because sorting is poor and fine-grained sediment moves outward from the base of foresets. In the Supai Group, where most of the sands have fair to good sorting, bottomset deposits are uncommon, as should be expected. One of the few good examples of bottomsets continuous with foresets is in the Wescogame Formation in Bass Canyon. Samples of sand from above and below the junction of these units (table $\mathrm{K} 3$ ) show in analyses that the percentage of fine grains increases outward from foreset to bottomset deposits.

\section{Statistical studies of current directions}

The Supai Group has afforded an excellent opportunity for making statistical studies of dips and strikes in crossstratification. The extensive clear exposures in the walls of Grand Canyon have permitted accurate measurement of bedding surfaces in many places. Systematic work of this type was begun in the Supai, with good results, in the late 1930's (McKee, 1940), patterned after the pioneer studies elsewhere of Knight (1929), Shotten (1937), and Reiche (1938). In all those early investigations, methods of graphically representing random observations on crossstratification in order to show the presence or absence of dominant dip direction were developed, and techniques from each have been used in the present study.

Cross-strata in the Supai used for measurement of dip and strike were selected entirely at random. Only one recording was made from any single stratum or from any one set of strata, except in a few places where trough deposits were observed. In trough structures, a reading was made of the unit on each side of the axis so that one reading would balance the other and show an average direction of movement. Where exposures permitted measurement down the plunge of a trough, a single measurement was made.

In the Supai, because low angles $\left(<5^{\circ}\right)$ in cross-strata are either the result of irregularities on the surface of deposition or of a normal decrease of angle near the base of a foreset slope, dip readings of those planes were eliminated in determining transport direction of the sediment. On the other hand, all slopes greater than $5^{\circ}$ were considered to have equal importance as indicators of a general direction of movement.

Acquiring sufficient readings to insure statistical significance was a prime consideration in determination of an average direction of movement. Assurance that 30 readings from each locality would suffice to give a reliable average direction was obtained at the start of the Supai investigation by using consistency curves, such as those used by Reiche (1938). Control points were located after 10 observations and were determined every 5 thereafter. Furthermore, 30 readings proved to be a convenient number from a practical standpoint because (1) they could generally all be obtained from a single limited exposure or outcrop, and (2) they normally showed very little overlap of points in plotting on a projection sheet.

In addition to obtaining reliable direction vectors for specific localities, the importance of obtaining a wide geographic spread of locality vectors required consideration. In each of the three formations investigated (figs. K8, K13, $\mathrm{K} 23$ ), the general regional direction or trend of cross-strata dips for the entire sandstone body was determined on the basis of data from 15 to 23 localities distributed over an area of approximately $150 \mathrm{mi}$ by $50 \mathrm{mi}$.

TABLE K3.- Percent of various size grades in the adjacent foreset and bottomset beds of a cross-stratified sandstone unit of the Wescogame Formation, near Bass Trail

\begin{tabular}{lcccc}
\hline & $>0.500 \mathrm{~mm}$ & $0.500-0.246 \mathrm{~mm}$ & $0.246-0.124 \mathrm{~mm}$ & $0.124-0.061 \mathrm{~mm}$ \\
\hline Top of foreset (percent) $\ldots \ldots \ldots \ldots \ldots \ldots \ldots \ldots$ & 0.10 & 0.36 & 42.40 & 47.60 \\
Bottomset (percent) $\ldots \ldots \ldots \ldots \ldots \ldots \ldots \ldots$ & - & .10 & 17.35 & 9.77 \\
\hline
\end{tabular}




\section{Plotting of data}

The general direction of dip for the sloping surfaces of cross-strata in any area represents the dominant direction of movement among the sediments deposited there. On this assumption, readings for each locality in the Supai have been plotted on polar coordinate sheets (figs. K7, $\mathrm{K} 15, \mathrm{~K} 16, \mathrm{~K} 21, \mathrm{~K} 22$ ). Individual directions of dip, and also the amount of consistency in direction for any given area, thus may be seen at a glance. Furthermore the amount of dip, which to some degree illustrates the character of the cross-strata, is shown by dots on the polar coordinate sheets. These dots are plotted at distances from the center proportionate to the degree of dip.

With 30 precise readings of random samples, mean paleotransport (net vector) direction of dip for each locality is illustrated (figs. K7, K15, K16, K21, K22). By showing these mean directions with arrows on a map of areal distribution, a reasonably accurate picture of the regional trend in transport direction is apparent. The degree of accuracy, of course, increases with the number of localities represented by measurements, and because of the broad distribution of these localities it is believed that for the Supai Group enough samples have been examined to justify some generalizations.

Results of these statistical studies of cross-strata and their plots are discussed and illustrated under the texts that follow on sandstones of the various formations of the Supai Group, with the exception of the Watahomigi Formation that has too few cross-strata for significant statistical analysis.

\section{Ripple marks in sandstone}

Ripple marks are notably scarce in the various sandstone bodies of the Supai Group, despite the fact that current action must have been considerable as indicated by the abundance of cross-stratification in the three upper formations. Sequences of ripples were observed in cross-stratified sandstone at only 3 places in the Manakacha, 5 in the Wescogame, and 3 in the Esplanade during investigation of the 32 measured sections included in this study.

A majority of ripple marks on the surfaces of crossstrata are of the parallel-straight or the parallel-wavy types (figs. N3A, N4B). A few have cuspate forms (fig. N3B, $C)$-some linguoid, others lunate in the classification of Allen (1963). Ripple crests are oriented at various angles with respect to dip of the cross-strata foresets on which they repose, but the surfaces containing them mostly have low angles $-15^{\circ}$ or less.

Ripple structures in the Watahomigi are largely in the form of ripple laminae and climbing ripples, and most of them occur in siltstones and silty sandstones. These structures are discussed in chapter $\mathrm{N}$, together with other minor depositional structures.
SANDSTONE OF THE WATAHOMIGI FORMATION

\section{Geometry of Watahomigi sand bodies}

The oldest sandstone beds of the Supai Group are of Morrowan age and form a small percentage of the lower slope unit of the Watahomigi Formation. They occur mostly as thin flat-lying beds or lenses, interspersed among layers of red siltstone and mudstone or between beds of carbonate rock. Nowhere do they constitute a large continuous body and only locally are they cross-stratified. Cross-bedded sands are too sparse in the Watahomigi to give reliable information on current directions. Nearly all sandstones in this formation are very fine grained.

The upper slope unit of the Watahomigi is of Atokan age, and contains somewhat more sandstone than does the lower slope unit of Morrowan age. This sandstone likewise forms as interbeds and lenses among fine detrital rock units and (or) carbonate beds. The Watahomigi, therefore, is the only formation in the Supai Group that does not include an extensive body of sandstone or widespread units of mediumto large-scale cross-stratification. Quartz grains are dominantly of silt size throughout the formation and those that are larger than silt are nearly all very fine grained sand, indicating an environment of low energy.

\section{Grain-size distribution in Watahomigi Formation}

Unlike overlying units of the Supai Group in the Grand Canyon region, the basal Watahomigi Formation contains very little quartz sand. The proportions of sand to mud (including silt) and of sand to carbonate sediment are so small (fig. C10) that no real attempt to systematically show trends in grain-size distribution has been attempted for the Watahomigi. Quartz grains of sand size are nearly all of very fine grade $(1 / 16-1 / 8 \mathrm{~mm})$ in this formation (fig. K1); coarser sand grains are very uncommon except as matrix in the marine conglomerates.

\section{Cross-stratification in Watahomigi Formation}

Compared with the abundant medium- to large-scale cross-stratification in the three upper formations of the Supai Group, cross-strata of all types are very sparse in the Watahomigi. However, the examples that have been recorded in this formation are so distinctive as to merit special consideration. Almost certainly they are the product of low-energy environments very different from those 


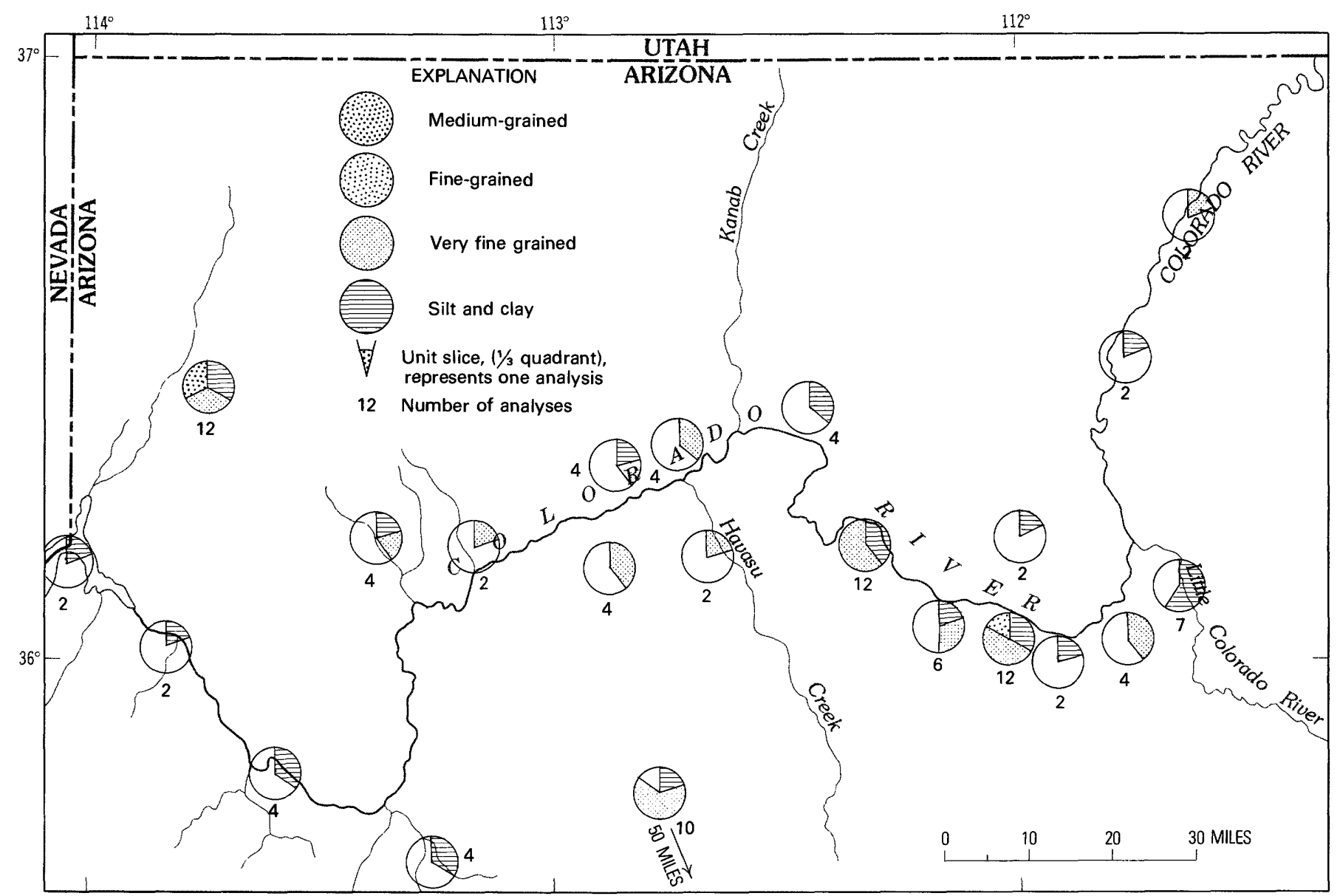

FIGURE K1.-Dominant size grade of particles in detrital rocks of the Watahomigi Formation in Grand Canyon region, Arizona. Each unit slice (1/3 quadrant) in a pie diagram represents the dominant grain size for one analysis from the locally indicated. ("Dominant" refers to the principal size grade represented by largest amount of sand.) Arrow and miles next to a pie indicate direction and distance to actual sample locality.

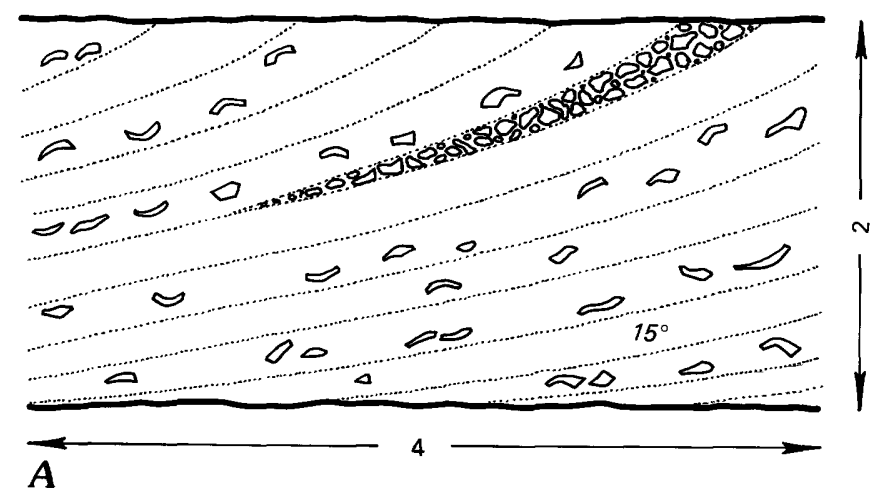

EXPLANATION

Sandstone

$\ldots$ Cross-stratified

Thin flat-bedded

$\because \because \quad$ Very fine grained

-

$\bar{\infty}$ Shells and shell fragments of invertebrate fossils

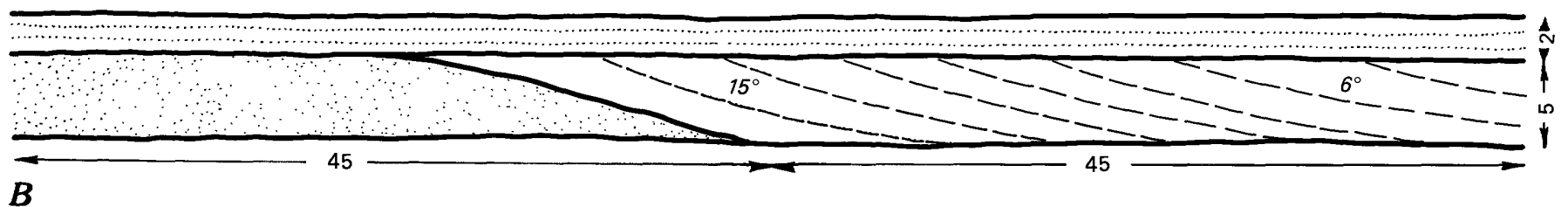

FIGURE K2.-Small-scale structures of the Watahomigi Formation, Grand Canyon region, Arizona. A, low-angle foresets with concentrations and scattered shells of invertebrate fossils, near formation base at Bridge Canyon. $B$, Channel in sandstone filled with gently dipping beds of mudstone, lower slope unit in S B Canyon. Vertical and horizontal distances in feet. 


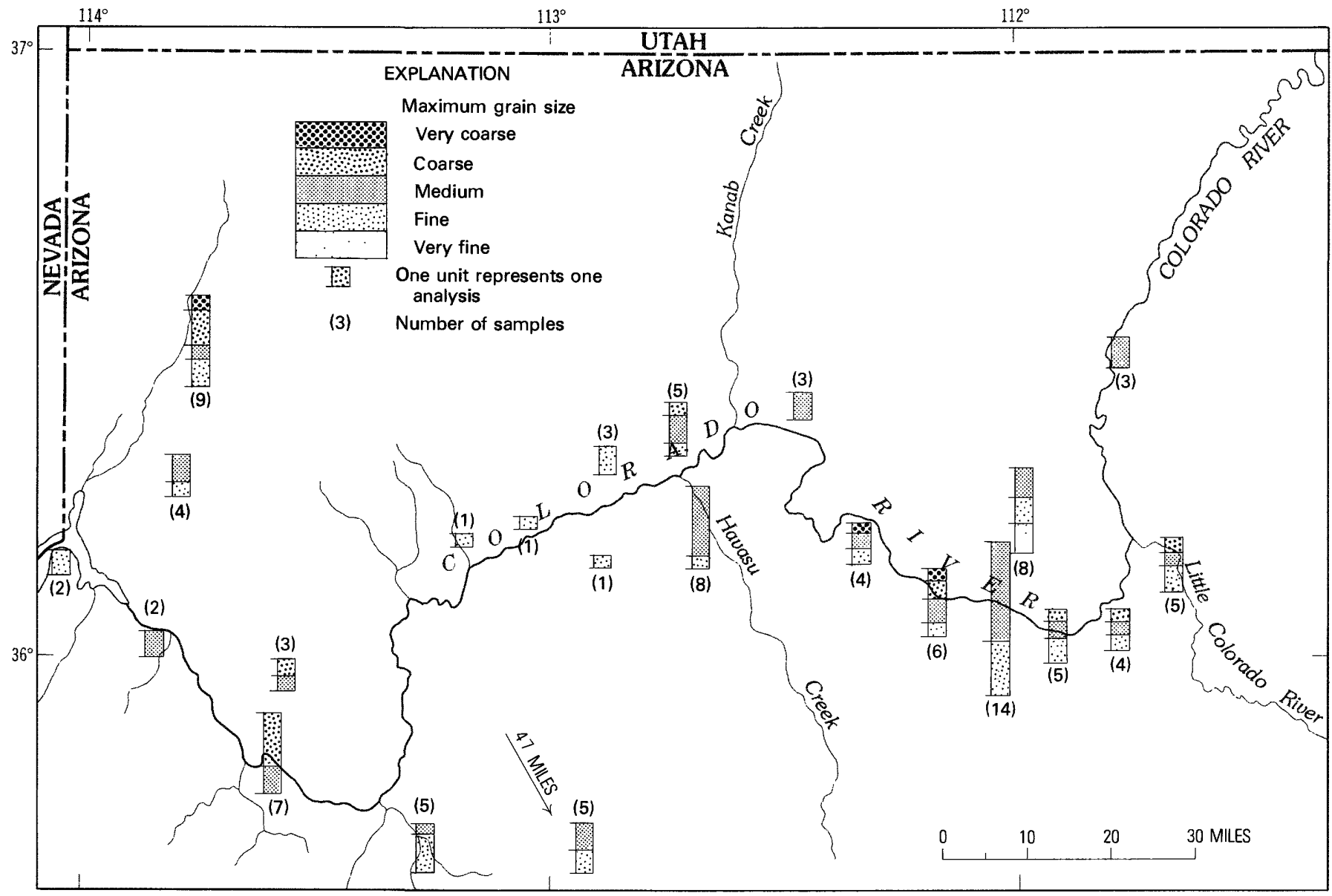

FIGURE K3.- Maximum grain size of particles in detrital rocks of the Manakacha Formation, Grand Canyon region, Arizona. Each unit in a vertical bar graph represents the maximum grain size of one sandstone sample (arranged with coarse to fine, from top to bottom). Arrow and miles next to bar indicate direction and distance to actual sample locality.

represented in the higher formations, and, therefore, are important indicators of the depositional conditions.

Cross-strata of the Watahomigi characteristically are small scale. Mostly they are the result of ripple-migrating sand (climbing ripple structures and ripple laminae), but other types occur. At the east end of Hindu Canyon (measured sec. 35), a 2 -ft thick bed containing tabularplanar cross-strata occurs at $5 \mathrm{ft}$ above the basal conglomerate. The foresets, which dip at $10^{\circ}-20^{\circ}$, contain concentrations of brachiopods, pelecypods, and gastropods, including many fossil fragments (fig. K2A). In addition, the sand contains scattered subangular fragments of chert and jasper. Both the fossils and the pebbles are oriented parallel to the dip of the foreset planes.

Ripple laminae (fig. N1A) are recorded from the lower slope unit (Morrowan age) at Havasu Canyon and climbing ripple structures (fig. $\mathrm{N} 1 B, C$ ) are from the same unit at National Canyon. In both localities, they are stratigraphically close to beds bearing marine fossils.

In the upper slope unit (Atokan age) of the Watahomigi, additional examples of small-scale cross-strata occur among the thin-bedded siltstones and limestones below the major cliff of the Manakacha. In S B Canyon, a 5-ft channel in massive sandstone is filled with red siltstone foresets that dip at $6^{\circ}-15^{\circ}$. A similar example, in which friable vermilion sandstone fills a channel in jasper-bearing limestone, occurs near the Hualapai Trail in Havasu Canyon.

\section{SANDSTONE OF THE MANAKACHA FORMATION}

\section{Geometry of Manakacha sand bodies}

The oldest extensive sandstone body developed in the Grand Canyon region during Pennsylvanian time is in the Manakacha Formation (fig. P8). Sandstone is largely restricted to the upper half of the formation and is thickest $(120-160 \mathrm{ft})$ in the east-central and south-central parts of the region. The main body of this sandstone is tabular and 


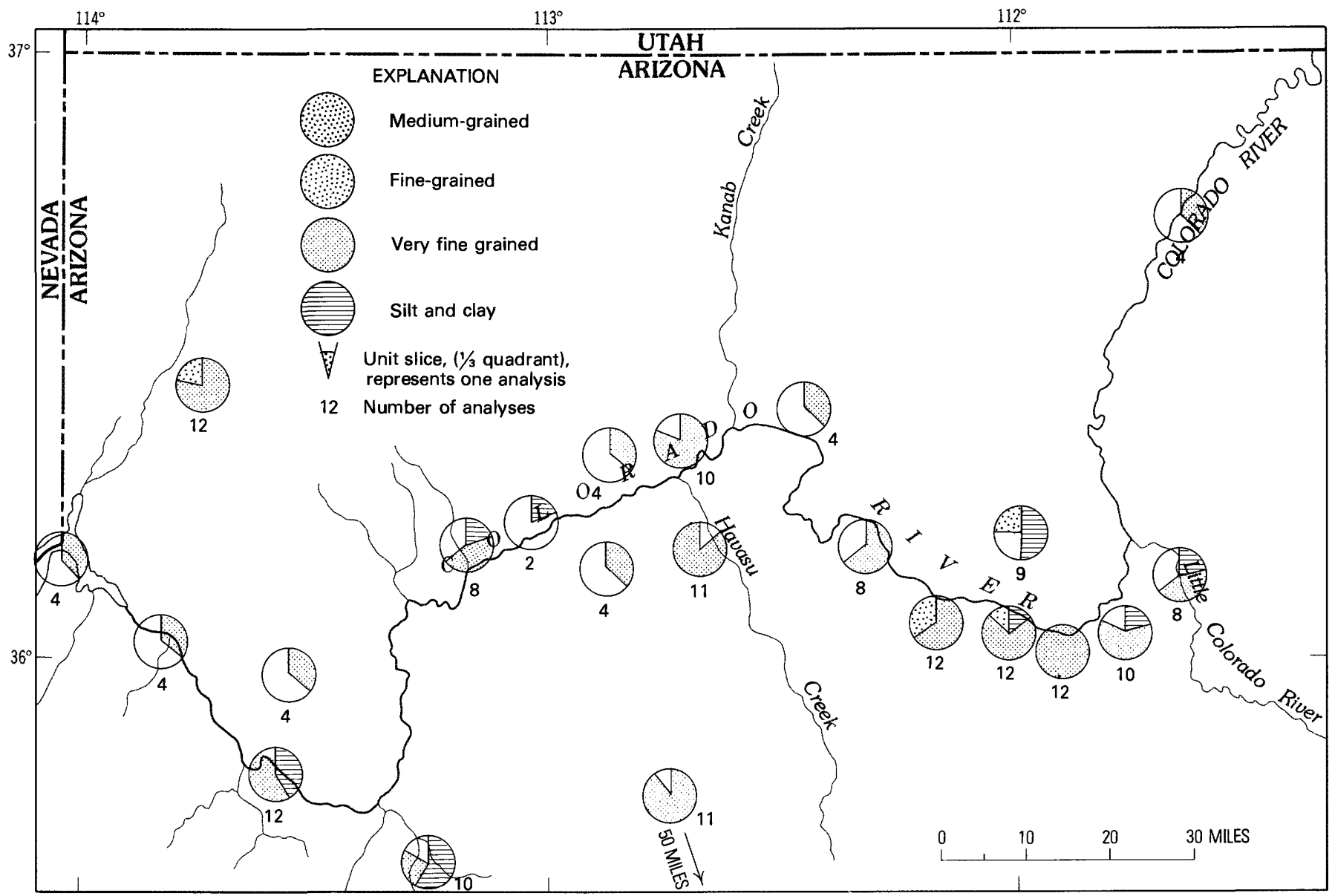

FIGURE K4.--Dominant size grade of particles in detrital rocks of the Manakacha Formation, Grand Canyon region, Arizona. Each unit slice (1/3 quadrant) in a pie diagram represents the dominant grain size for one analysis from the locality indicated. ("Dominant" refers to the principal size grade represented by largest amount of sand.) Arrow and miles next to a pie indicate direction and distance to actual sample locality.

TABLE K4.-Relative abundance of principal types and size classes of cross-strata of upper three formations of the Supai Group, Grand Canyon region, Arizona (based on 30 cross-strata sets at each locality, selected at random)

$[\mathrm{T}$, tabular; $\mathrm{W}$, wedge; $\mathrm{Tr}$, trough; $\mathrm{S}$, small $(<1 \mathrm{ft}) ; \mathrm{M}$, medium $(1-20 \mathrm{ft}) ; \mathrm{L}$, large $(>20 \mathrm{ft})$. Leaders $(---)$ indicate not measured. Numbers in parentheses spanning columns represent a combination of types or scales]

\begin{tabular}{|c|c|c|c|c|c|c|c|c|c|c|c|c|c|c|c|c|c|c|}
\hline \multirow[b]{3}{*}{ Locality } & \multicolumn{6}{|c|}{ Esplanade Sandstone } & \multicolumn{6}{|c|}{ Wescogame Formation } & \multicolumn{6}{|c|}{ Manakacha Formation } \\
\hline & \multicolumn{3}{|c|}{ Type } & \multicolumn{3}{|c|}{ Scale } & \multicolumn{3}{|c|}{ Type } & \multicolumn{3}{|c|}{ Scale } & \multicolumn{3}{|c|}{ Type } & \multicolumn{3}{|c|}{ Scale } \\
\hline & Ta & w & $\operatorname{Tr}$ & $\mathrm{s}$ & M & $\mathrm{L}$ & $\mathrm{Ta}$ & w & $\mathrm{Tr}$ & $\mathrm{s}$ & $M$ & $L$ & $\mathrm{Ta}$ & w & $\operatorname{Tr}$ & $\mathrm{s}$ & $M$ & $\mathrm{~L}$ \\
\hline House Rock Canyon .. . & -.. & -- & -- & --- & $-\ldots$ & --- & 17 & 12 & 1 & 2 & 22 & 6 & -.- & $\ldots$ & -- & -.. & -- & --- \\
\hline Horsetrail Canyon ... & -- & --- & -- & $\ldots$ & -.- & --- & \multicolumn{2}{|c|}{ (30) } & 0 & 0 & \multicolumn{2}{|c|}{ (30) } & -- & --- & --- & --- & --- & -- \\
\hline Bunker Trail ........ & 22 & 5 & 3 & 1 & 20 & 9 & -- & --. & -- & --- & --- & --- & 26 & 4 & 0 & 0 & 19 & 11 \\
\hline Kaibab Trail, south ... & $\ldots$ & $\cdots$ & -- & 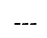 & -- & -- & -- & --- & -- & -- & --- & -- & 10 & 20 & 0 & 0 & 20 & 10 \\
\hline Kaibab Trail, north ... & -.- & -- & -- & -- & $\cdots$ & $\cdots$ & 7 & 23 & 0 & 0 & 21 & 9 & --- & --- & -- & --- & --- & -- \\
\hline Hermit Trail . . . . . . . & 2 & 28 & 0 & 0 & 29 & 1 & 21 & 9 & 0 & 0 & 16 & 14 & 18 & 12 & 0 & 0 & 30 & 0 \\
\hline Thunder River Trail . . . & 12 & 18 & 0 & 0 & 21 & 9 & 27 & 3 & 0 & 0 & 11 & 19 & 24 & 6 & 0 & 0 & 9 & 21 \\
\hline Havasu Canyon ..... & --- & -- & --- & -- & $\cdots$ & --- & 15 & 0 & 15 & -- & $\ldots$ & 16 & --- & --. & --- & -- & --- & -- \\
\hline Tuckup Canyon ...... & 24 & 6 & 0 & 0 & 23 & 7 & 12 & 16 & 2 & 0 & 25 & 5 & --- & -- & --- & -- & --- & -.- \\
\hline Prospect Valley ..... . . & \multicolumn{2}{|c|}{ (30) } & 0 & 0 & 17 & 13 & -- & --. & -- & -- & $\ldots$ & --- & -- & -- & $-\cdots$ & --- & -- & -- \\
\hline Toroweap Valley .... & --. & -- & -- & -- & $\ldots$ & -.. & \multicolumn{2}{|c|}{ (30) } & 0 & 7 & 16 & 7 & -.. & -- & -- & 2 & 9 & 0 \\
\hline Parashant Canyon .... & --- & $\cdots$ & --- & -- & -- & $\ldots$ & 9 & 21 & 0 & 0 & 23 & 7 & --. & -- & --- & -- & --- & -- \\
\hline Guano Cave ........ & -- & --- & -- & -- & -- & -- & \multicolumn{2}{|c|}{$(30)$} & 0 & 0 & \multicolumn{2}{|c|}{ (30) } & -.- & $-\ldots$ & -.- & --- & --- & $\cdots$ \\
\hline Snap Canyon ....... & --. & --- & --- & -- & $\ldots$ & --- & \multicolumn{2}{|c|}{$(26)$} & 4 & 0 & \multicolumn{2}{|c|}{$(30)$} & --- & -- &.-- & --- & --- & -- \\
\hline Pigeon Wash . . . . . . . & 15 & 15 & 0 & 0 & \multicolumn{2}{|c|}{$(30)$} & -- & -- & --- & -- & -- & --- & --- & $\ldots$ & $\ldots$ & --- & -- & $\ldots$ \\
\hline Hidden Canyon ...... & \multicolumn{2}{|c|}{$(26)$} & 4 & 2 & 12 & 16 & \multicolumn{2}{|c|}{ (29) } & 1 & 3 & 21 & 6 & $\cdots$ & -- & -- & --- & -- & $\cdots$ \\
\hline Separation Canyon ... & -- & -- & -- & -- & -- & -- & 22 & 8 & 0 & -- & -- & --- & --- & --- & $\cdots$ & -- & -- & -- \\
\hline
\end{tabular}




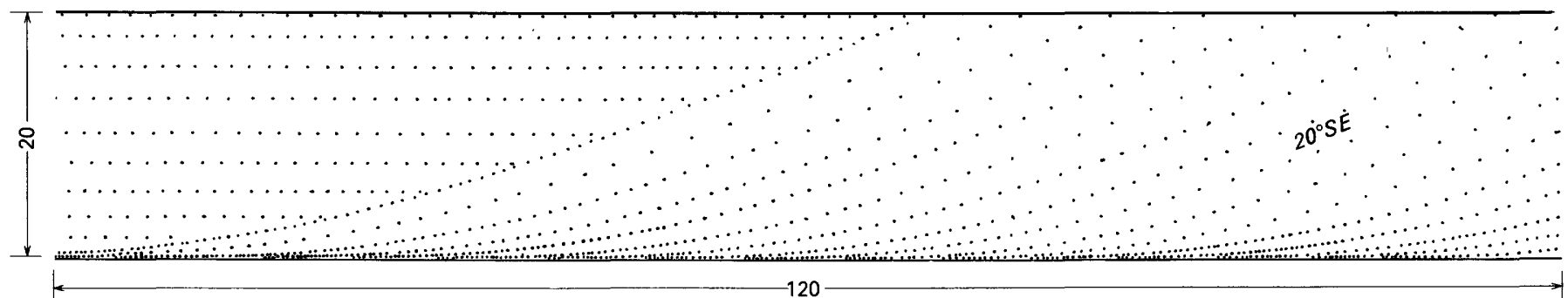

A
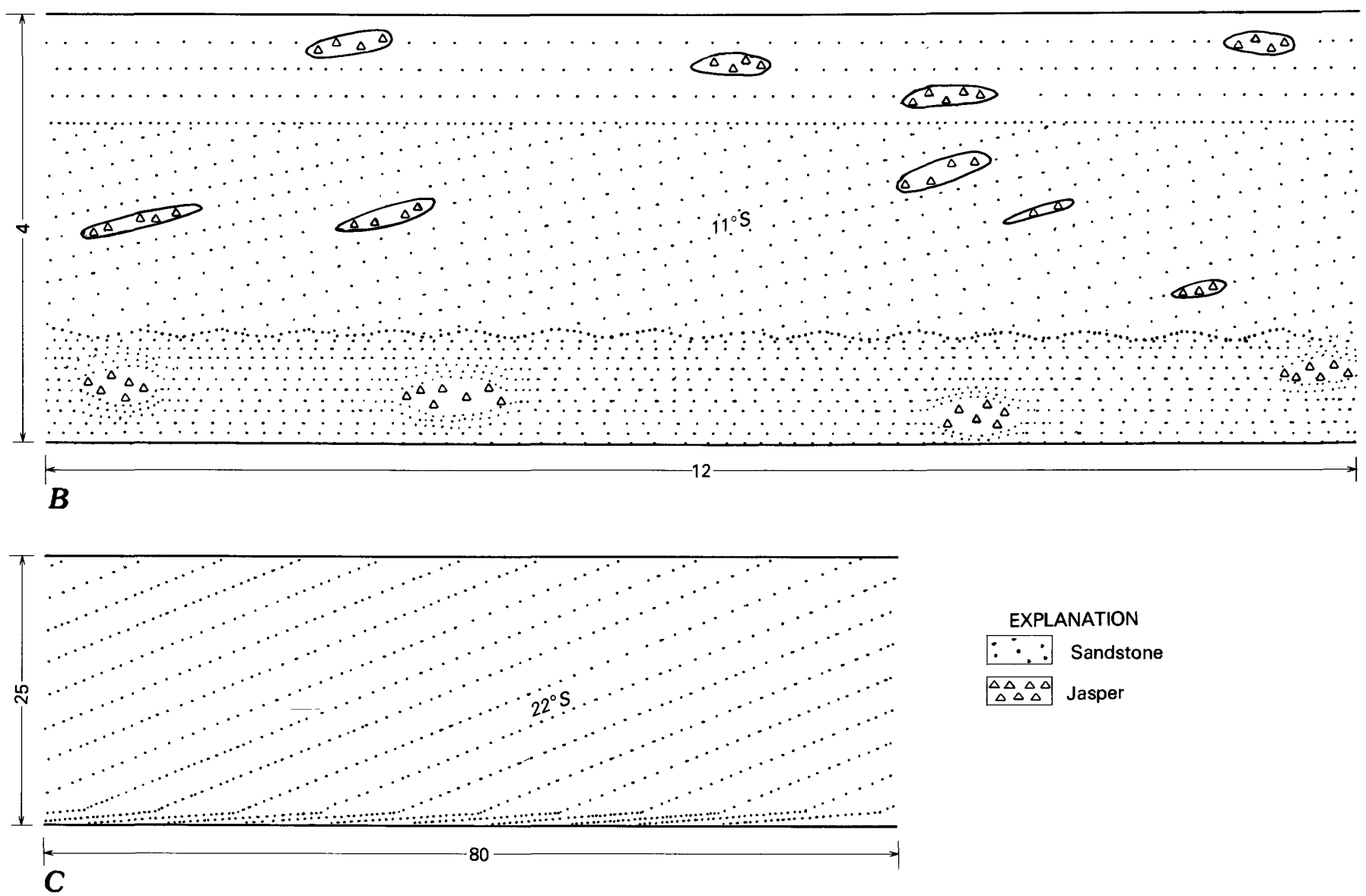

FIGURE K5.-Styles of cross-stratification in cliff unit of Manakacha Formation in Grand Canyon, Ariz. A, Large-scale planar cross-strata and horizontal strata sets in S B Canyon. Foresets $50 \mathrm{ft}$ long. B, Coset of jasper-bearing tabular-planar cross-strata and horizontal strata at S B Canyon. C, Tabular-planar set of cross-strata with geniculated basal sections, Bass Trail. Cross-beds $63 \mathrm{ft}$ long. Vertical and horizontal distance in feet. Degree and direction of dip shown for cross-strata sets.

intertongues eastward into red mudstone and siltstone, although one relatively thin sandstone tongue continues northeastward toward the San Juan Basin. Westward, the main sandstone body grades into various carbonate rock facies, and southwestward, partly into carbonate rock and partly into red mudstone. Most of the sandstone is crossstratified on a medium to large scale; similar cross-stratification occurs to the west in carbonate rock that contains much quartz sand. In brief, the boundary between sandstone and carbonate rock results from a gradual westward increase in the percentage of calcium carbonate or magnesium carbonate, so is extremely tenuous.

Introduction of quartz sand into the area of Manakacha deposition must have been either from the north or the south into the east-central Grand Canyon area where the greatest thickness of sandstone accumulated. These directions of transport are indicated by relations of the sand body to other facies (mudstone, carbonate rock) on the east and west. Evidence from grain-size distribution patterns and cross-strata dip-direction vectors strongly supports transport from the north, as indicated by geometry of the sand body. 
TABLE K5.-Number and types of cross-strata sets included and thickness of cosets in sandstones and arenaceous limestones of the upper three formations of the Supai Group in Grand Canyon (random samples)

\begin{tabular}{|c|c|c|c|}
\hline \multirow[t]{2}{*}{ Locality } & \multirow{2}{*}{$\begin{array}{c}\text { Cosets } \\
\text { Thickness } \\
\text { (in feet) }\end{array}$} & \multicolumn{2}{|l|}{ Sets } \\
\hline & & Types & $\begin{array}{l}\text { Number } \\
\text { ivertical } \\
\text { sequence }\end{array}$ \\
\hline \multicolumn{4}{|c|}{ Esplanade Sandstone } \\
\hline Kaibab Trail, south & 14 & Mostly tabular, one wedge & 5 \\
\hline Do. & 15 & Wedge, tabular, horizontal & 6 \\
\hline Hermit Trail & 6 & Wedges, tabular, two horizontal & 8 \\
\hline Do. . . & 5 & Trough, wedge, tabular & 3 \\
\hline Do.... & . 19 & Mostly tabular, one wedge & 10 \\
\hline Topocoba Trail & 10 & Tabular between horizontal & 3 \\
\hline S B Canyon & 11 & Mostly tabular, one wedge & 4 \\
\hline Prospect Valley & . 3 & All wedges, one mudstone lense & 7 \\
\hline Toroweap Valley . . & . 5 & Two wedges, between horizontal & 4 \\
\hline Do. & 2 & All wedges & 6 \\
\hline Do. . & 2 & Mostly tabular, one horizontal & 4 \\
\hline Do. .. & 9 & $\begin{array}{l}\text { Mostly tabular, one wedge, } \\
\text { one horizontal. }\end{array}$ & 7 \\
\hline Do.... & 33 & Mostly tabular, troughs top and base. & .. 11 \\
\hline Do. $\ldots \ldots \ldots \ldots$ & . 4 & All tabular & . . 7 \\
\hline Do. ......... & 27 & Mostly tabular, horizontal, wedge .. & 6 \\
\hline & 10 & All tabular. & 4 \\
\hline Do. & 25 & Horizontal, tabular, wedge & 6 \\
\hline Whitmore Wash & 10 & Three tabular, three wedge & 6 \\
\hline Andrus Canyon & 2 & All tabular. & 5 \\
\hline \multicolumn{4}{|c|}{ Wescogame Formation } \\
\hline Bunker Trail & 10 & Mostly wedge, one tabular & 6 \\
\hline Do. & 8 & Mostly wedge, one tabular & 6 \\
\hline Kaibab Trail, south & 28 & Tabular, wedge, horizontal & 3 \\
\hline Do. & 4 & All wedge & 5 \\
\hline Do. . . & 6 & Tabular and wedge & 5 \\
\hline Bright Angel Trail . & 10 & Symmetrical trough & 1 \\
\hline Topocoba Trail . & 10 & Asymmetrical trough & 2 \\
\hline Do. ..... & 12 & Symmetrical trough & 3 \\
\hline Do. ........ & 12 & Symmetrical trough & 3 \\
\hline Havasu Canyon & 30 & Tabular & 1 \\
\hline Kanab Canyon . & 40 & Tabular. & 2 \\
\hline Tuckup Canyon & 8 & Asymmetrical trough & 4 \\
\hline Toroweap Valley & 10 & All tabular..... & 4 \\
\hline Do. ........ & 15 & All tabular. & 6 \\
\hline Andrus Canyon ..... & --- & Symmetrical trough & 3 \\
\hline Snap Canyon ....... & 6 & Trough & 5 \\
\hline & 4 & All wedge & 7 \\
\hline Pigeon Wash & 8 & Tabular & 3 \\
\hline Hidden Canyon & 10 & Mostly wedge, two tabular & 11 \\
\hline \multicolumn{4}{|c|}{ Manakacha Formation } \\
\hline Bunker Trail & 13 & Tabular, wedge, horizontal & 4 \\
\hline Bass Trail ... & 24 & Tabular & 1 \\
\hline Havasu Canyon ...... & ---1 & All tabular & 3 \\
\hline S B Canyon & 20 & Tabular, wedge & 2 \\
\hline Do. & 3 & Horizontal tabular & 2 \\
\hline Toroweap Valley. & 2 & All tabular & 3 \\
\hline Do. & 2 & Tabular and wedge & 10 \\
\hline Whitmore Wash & 8 & All tabular. & 7 \\
\hline Do. $\ldots \ldots$. & 6 & All tabular & 5 \\
\hline Do. & 5 & Both tabular and wedge $\ldots \ldots \ldots \ldots$ & .. 2 \\
\hline Snap Canyon & 8 & All wedge & 3 \\
\hline Do. ... & 25 & Wedge, trough & 5 \\
\hline
\end{tabular}

\section{Grain-size distribution in Manakacha Formation}

Both maximum grain size and dominant size grade measurements for the Manakacha Formation indicate two areas of coarse-sediment concentration. The maximum grain size is very coarse sand (1-2 mm) (fig. K3) at Hidden Canyon in western Grand Canyon and at both Bass and Hermit Trails in eastern Grand Canyon. At several other localities in these two widely separated areas the maximum grain size is coarse sand $(1 / 2-1 \mathrm{~mm})$. This grain size occurs at three sections in western Grand Canyon and at five sections in the east.

The dominant or largest size grade in most sandstones of the Manakacha Formation (fig. K4) is very fine grained (1/16-1/8 mm); however, at Hidden Canyon in the west, fine sand locally forms the dominant grade, and at three localities in eastern Grand Canyon it locally constitutes the largest or dominant size grade. Thus, although sand of the Manakacha Formation is largely very fine grained throughout the region, local concentrations of coarser sand appear both in the extreme western and in the eastern Grand Canyon areas.

\section{Cross-stratification in Manakacha Formation}

\section{Characteristic features}

Cross-stratification of medium to large scale (table K4) is a characteristic feature of many rock bodies in the Manakacha Formation-both the sandstone and the carbonate facies. In some places (fig. K5), sets composed of exceptionally long foresets are prominent. For example, at Fishtail Canyon near Thunder River Trail and in S B Canyon dipping cross-beds ranging between 50 and $60 \mathrm{ft}$ long occur, at Havasu Canyon one set about $90 \mathrm{ft}$ long was recorded, and at S B and Kanab Canyons sets more than 100 $\mathrm{ft}$ long were measured.

Nearly all of the cross-strata in the Manakacha are either wedge planar, forming cosets of compound cross-strata, or tabular planar with layers of dipping foresets repeated numerous times in vertical sequence (table $\mathrm{K} 5$ ). The trough type has not been recorded. Horizontal strata are locally common.

Individual sand bodies, most of which constitute cosets (fig. K6) may consist entirely of wedge-planar structures, entirely of tabular-planar types, or of both (table K5; fig. L1). Some also include sets of horizontal laminae and, rarely, of trough types. The number of sets within a coset ranges from 1 to 10, and the entire coset (sand body) may be $20-25 \mathrm{ft}$ thick, but more commonly is between 4 and $8 \mathrm{ft}$ thick. 

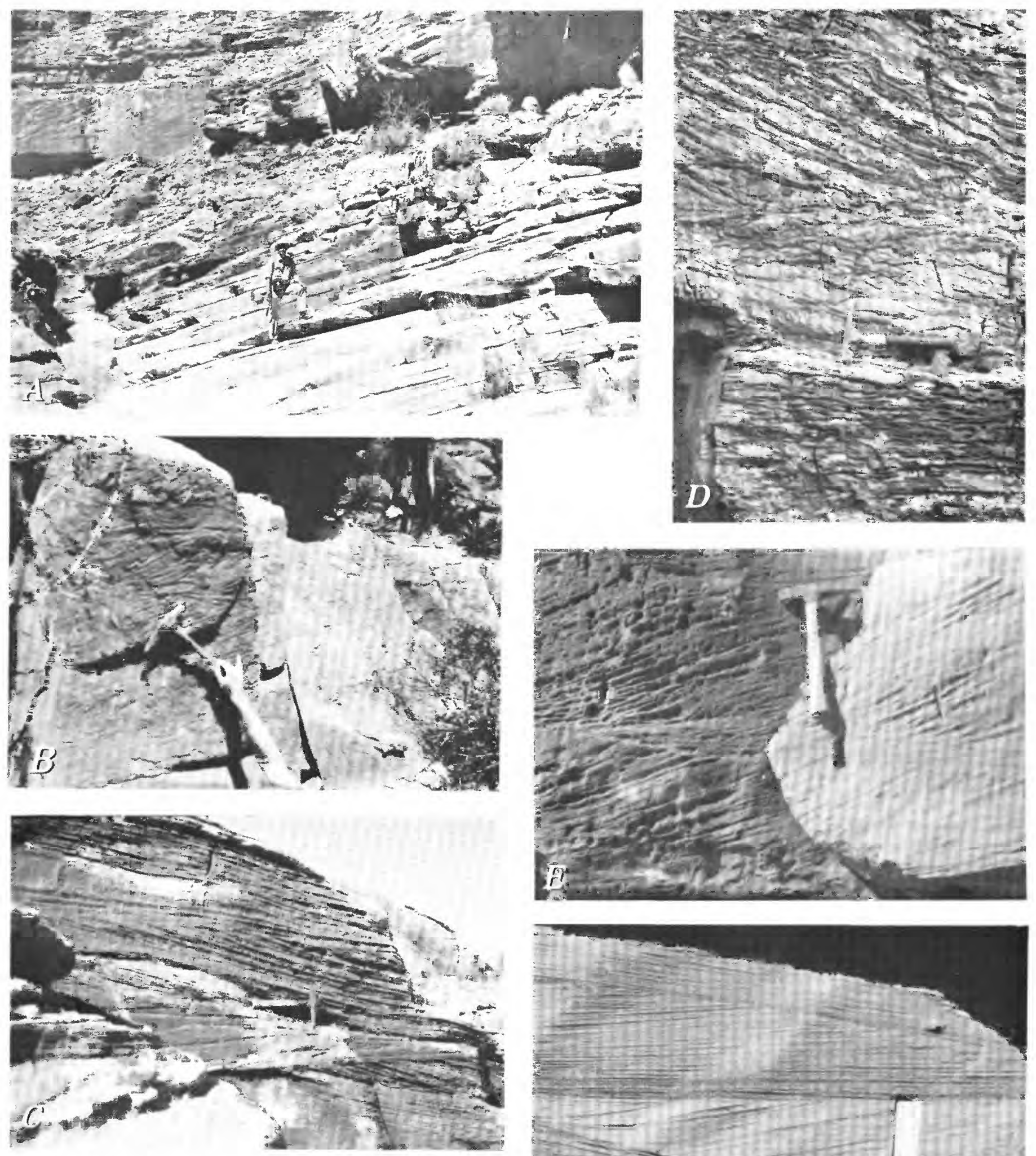

FIGURE K6.-Cross-stratification in cliff unit of the Manakacha Formation, Grand Canyon region, Arizona. A, Large-scale tabular-planar cross-strata in S B Canyon; $B$, small-scale cross-strata on Kaibab Trail, south; $C$, wedge-planar cross-strata in calcareous sandstone, Whitmore Wash; $D$, jasper bands in tabular-planar cross-beds, Toroweap Point; E, tabular-planar cross-strata, Whitmore Wash; F, cross-

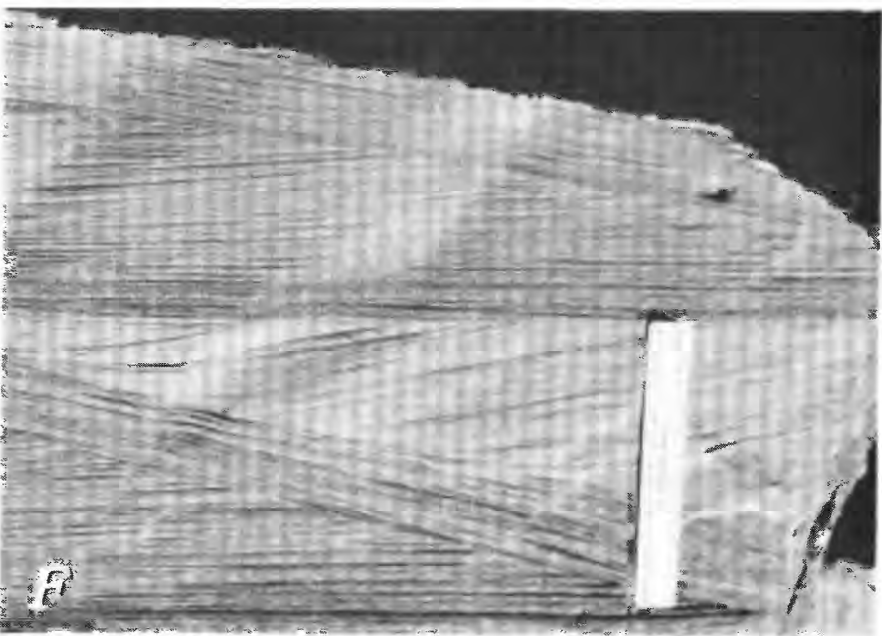
laminated arenaceous limestone, wedge-planar type, $5 \mathrm{mi}$ south of Hidden Canyon. 


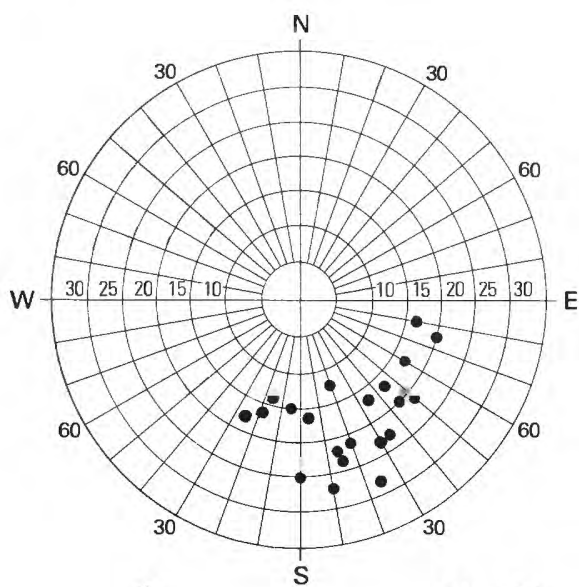

A

Av. 151

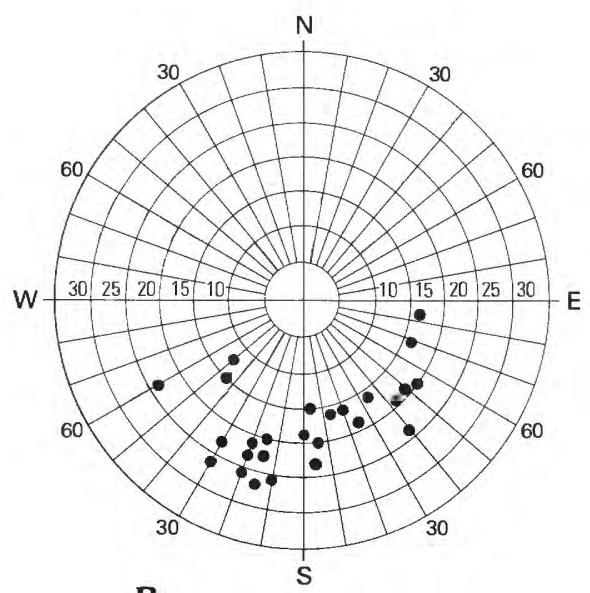

B

Av. 171

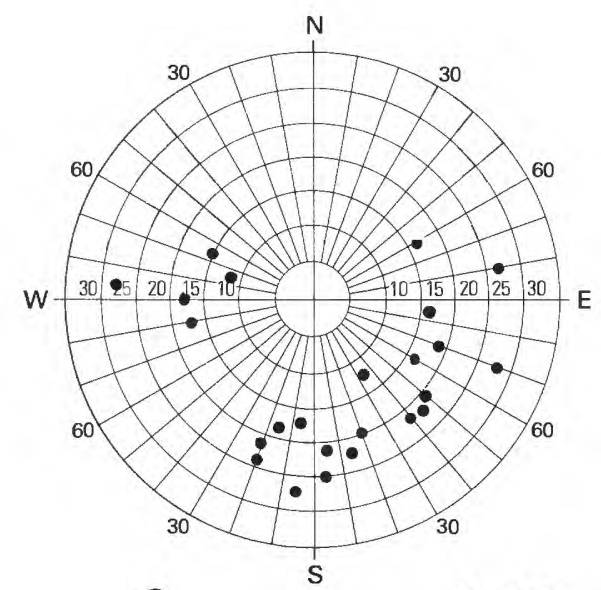

C

Av. 176

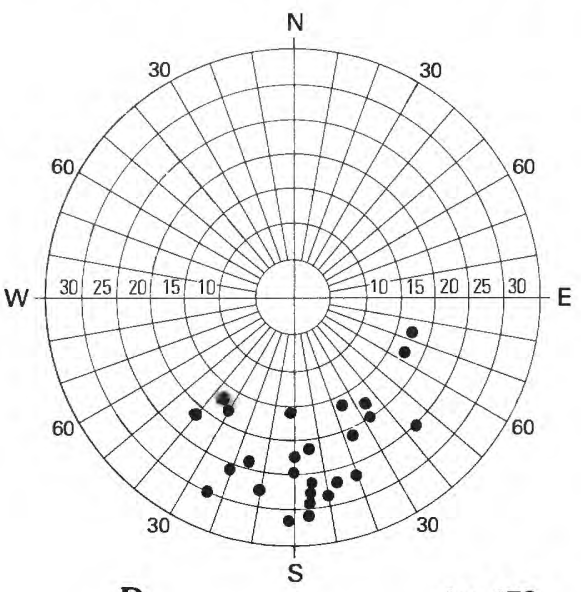

Av. 173

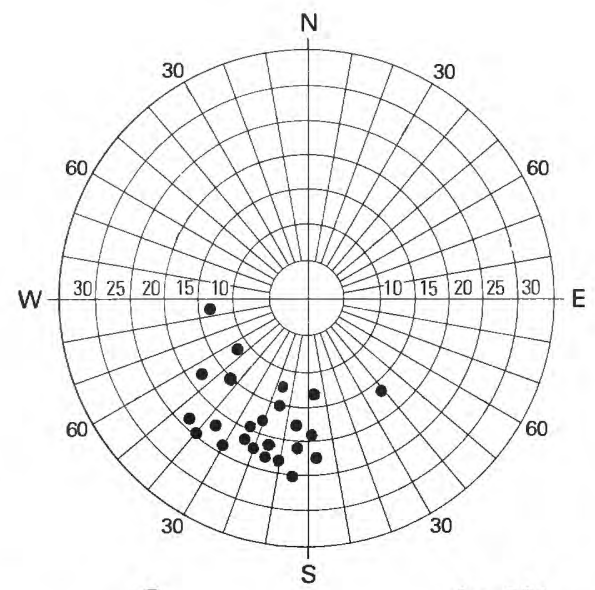

G

Av. 201

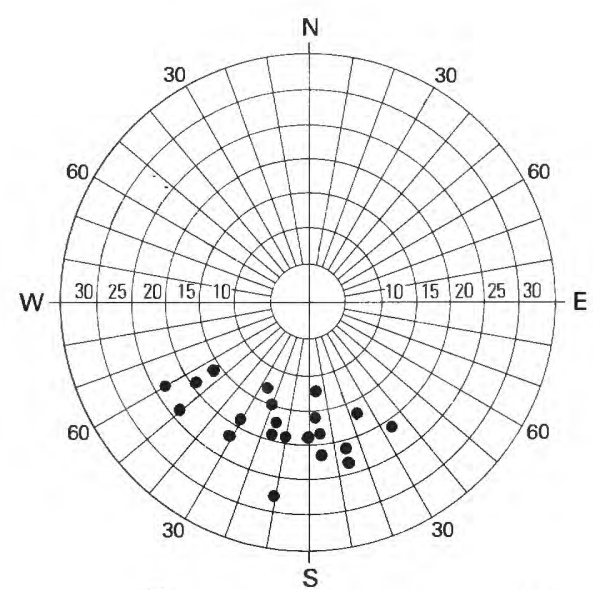

Av. 189

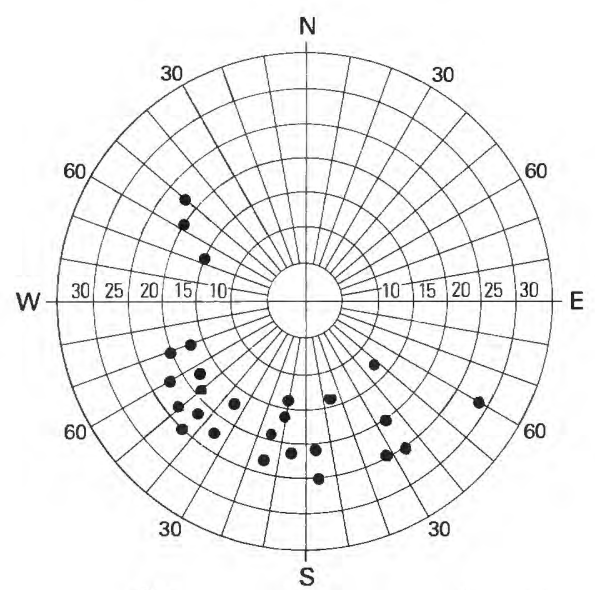

H

Av. 204

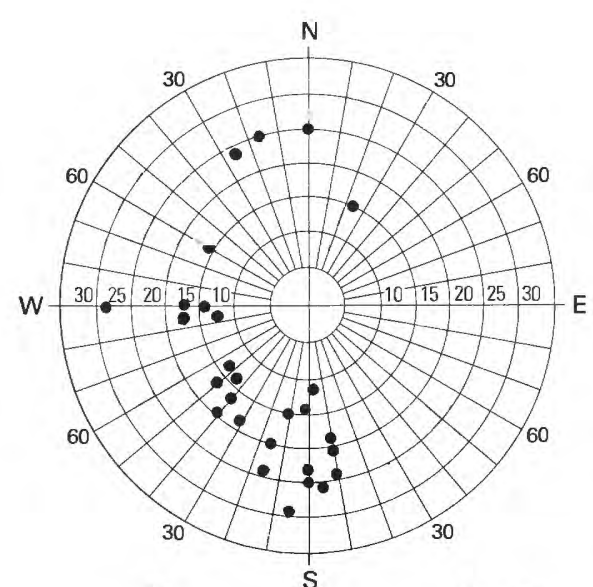

$\boldsymbol{F}$

Av. 209

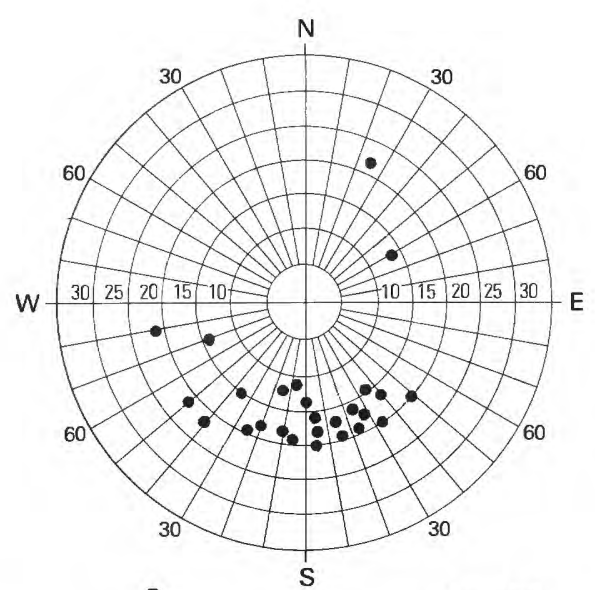

Av. 173 

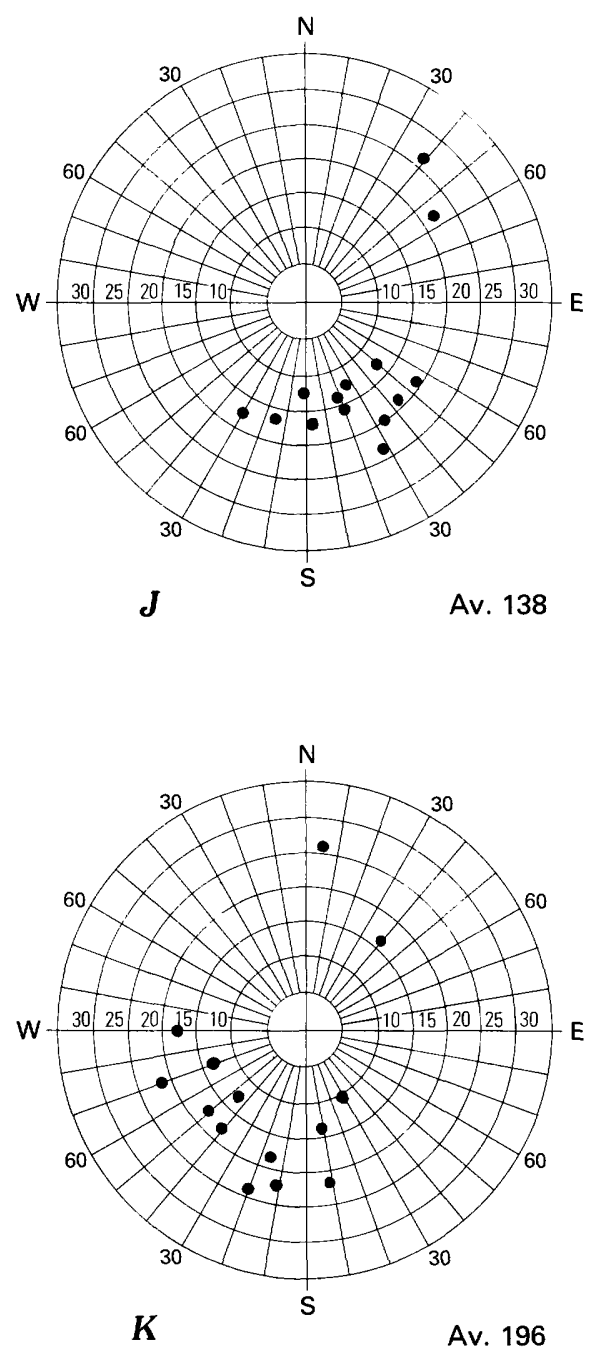

FIGURE K7.-Cross-strata dip direction, average dip direction (Av.), and degree of dip, plotted on polar coordinate sheets for the Manakacha Formation, Grand Canyon region, Arizona. A, Bunker Trail; B, Kaibab Trail, south; $C$, Hermit Trail; $D$, Kaibab Trail, north; $E$, Fishtail Canyon near Thunder River Trail; $F$, Hermit Trail, $G$, Havasu Canyon; $H$, Toroweap Valley; I, Whitmore Wash; I, Grand Wash Cliffs, 6 mi south of Hidden Canyon; and $K$, Hidden Canyon. 
TABLE K6.-Angle of dip in cross-stratification in upper three formations of the Supai Group, Grand Canyon region, Arizona (based on 30 random samples of cross-bed sets at each locality)

[Blank spaces indicate not measured]

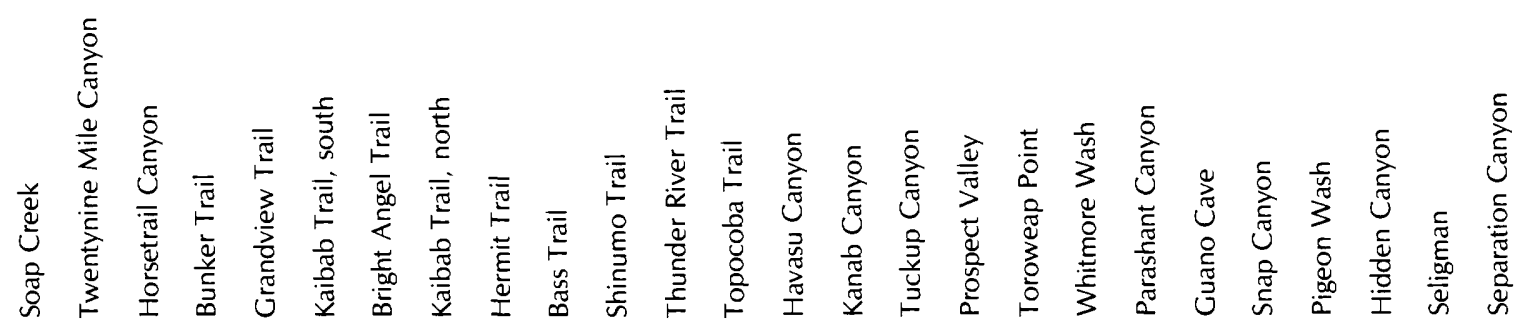

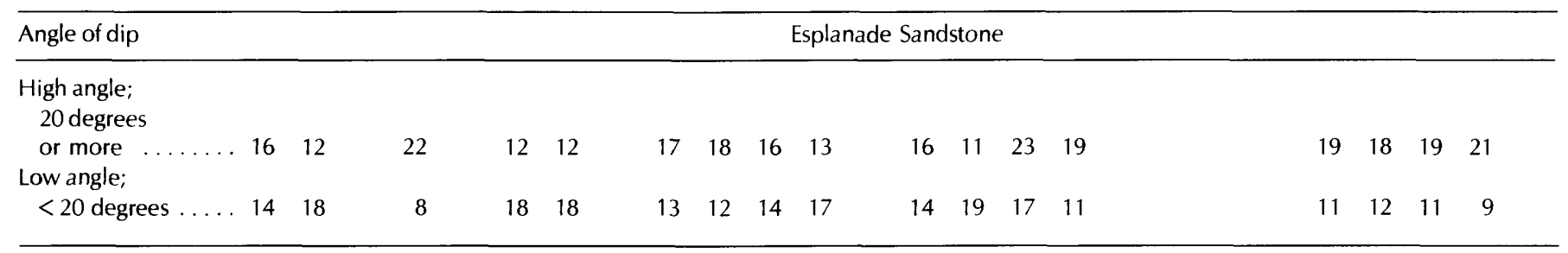

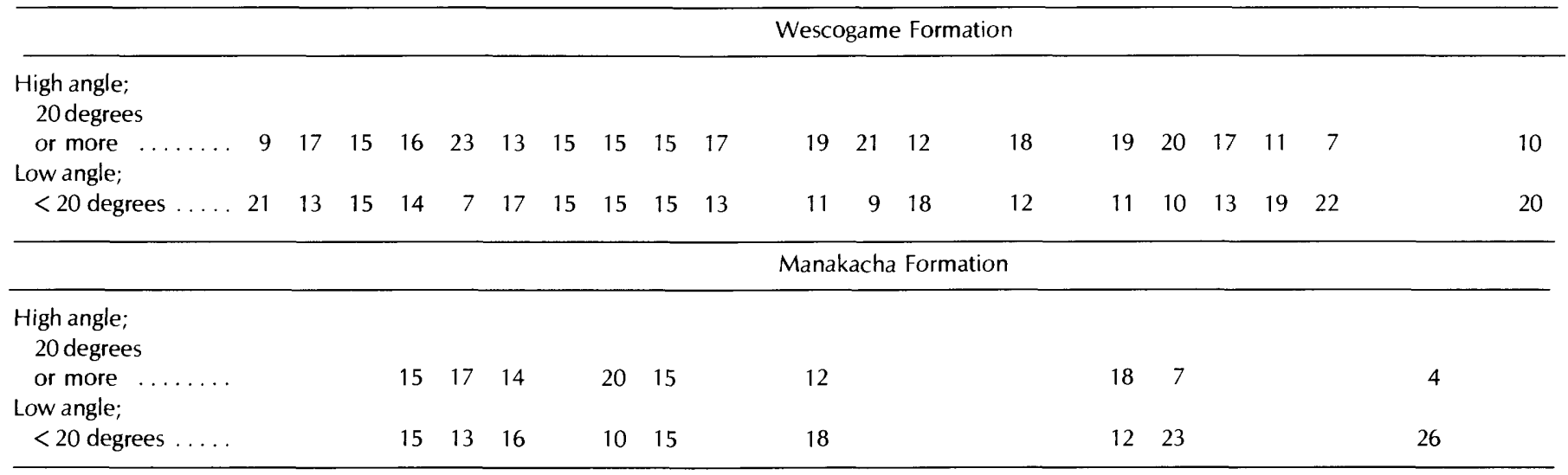

The angle of dip on the foresets of cross-stratified rocks in the Manakacha is moderately steep (table K6). At nine localities where 30 measurements each were made, five showed high-angle dips $\left(20^{\circ}\right.$ or more $)$ to be dominant and four showed low-angle dips $\left(<20^{\circ}\right)$ to be dominant. Most cross-strata in the carbonate rocks of western Grand Canyon showed lower angles than sandstone cross-beds farther east.

\section{Current directions}

Statistical studies of current-direction trends were made of the sandstones and arenaceous limestones in the Manakacha Formation throughout the region. At each locality studied, the maximum dip reading was recorded for crossstrata in each of 30 laminae sets selected at random. The directions of dip were averaged (fig. K7), and the results were plotted on a base map of the region (fig. K8).

Arrows representing average dip directions for the Manakacha show a general southerly direction throughout the Grand Canyon region. The averages range from $42^{\circ}$ east of south to $29^{\circ}$ west of south, giving a spread of $71^{\circ}$, or less than 1 quadrant. Differences in direction show no consistent trend from east to west across the region, and no significant interpretation can be attached to the local minor differences in direction.

Most of the cross-strata in western Grand Canyon are in arenaceous carbonate rocks; those in the east are in sandstones.

\section{Ripple marks in sandstone}

Both parallel-type ripple marks and cusp-shaped (linguloid, lunate) ripple marks occur sparingly in sandstones of the Manakacha Formation. These structures are developed on the dipping surfaces of large-scale and medium-scale cross-beds and probably were formed after the larger structures had been deposited by advancing megaripples. Considering the abundance of cross-stratification in the sandstone facies, the relative scarcity of ripple marks is notable. 


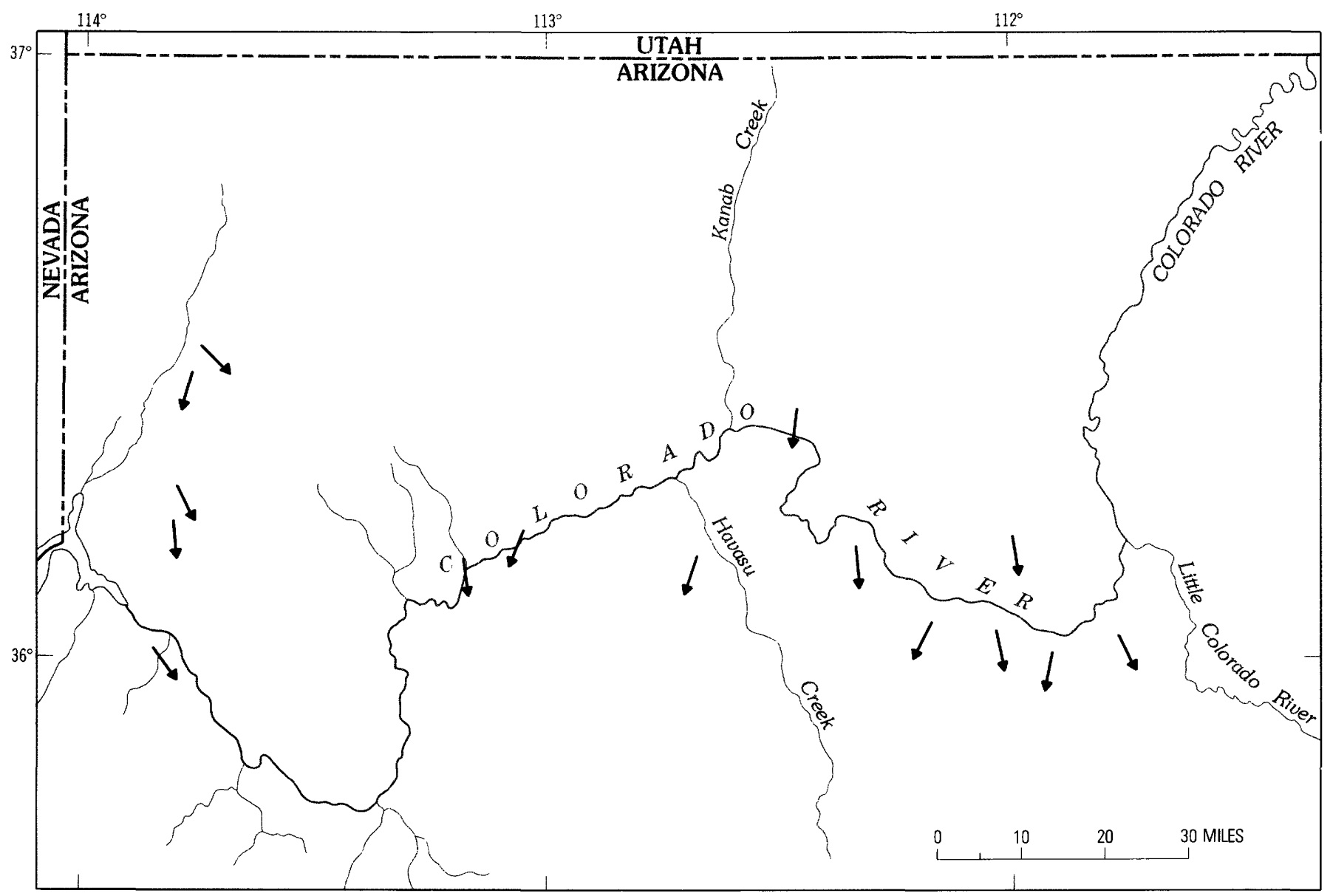

FIGURE K8.-Dip-direction vectors for cross-strata of the Manakacha Formation, Grand Canyon region, Arizona. Each arrow shows average direction determined from 30 measurements of cross-strata selected at random for the locality shown on map.

Detailed descriptions of these ripple marks are covered in chapter $\mathrm{N}$ under minor depositional structures.

\section{Contorted bedding}

Contorted bedding is not a common feature of the Manakacha Formation, but is well developed on a large scale near the base of the unit at several localities. Siltstone beds, several feet thick, are downwarped to form narrow synclinal structures with nearly vertical axes in an 8-ft zone that extends more than $300 \mathrm{ft}$ along the walls of Havasu Canyon. Horizontal, undeformed beds are directly above and below. Similar structures occur along the south wall of a canyon near the Kaibab Trail, north. Contorted structures in both places resemble the warping from differential loading where sediment is in a quicksand condition. At Whitmore Wash, a zone $3 \mathrm{ft}$ thick of crinkled and brecciated sand enclosed by several sets of tabular-planar cross-strata was noted.

\section{SANDSTONE OF THE WESCOGAME FORMATION \\ Geometry of Wescogame sand body}

The Wescogame Formation of Virgilian age contains a single large sandstone body of tabular form that extends across the entire region (fig. P10). Thickness of the main body of sandstone is generally between 75 and $150 \mathrm{ft}$ with the thinnest part in central and west-central Grand Canyon.

Like the Manakacha below, the Wescogame intertongues with red mudstones and siltstones to the east and with limestones and dolostones to the west, but little evidence is available to indicate the north-south extent of this sandstone body. Paleogeographic trends suggest that the seaway at this time probably connected with both the San Juan Basin to the northeast and the Sonoran geosyncline to the southeast (fig. D7). Tongues from the main sand body 


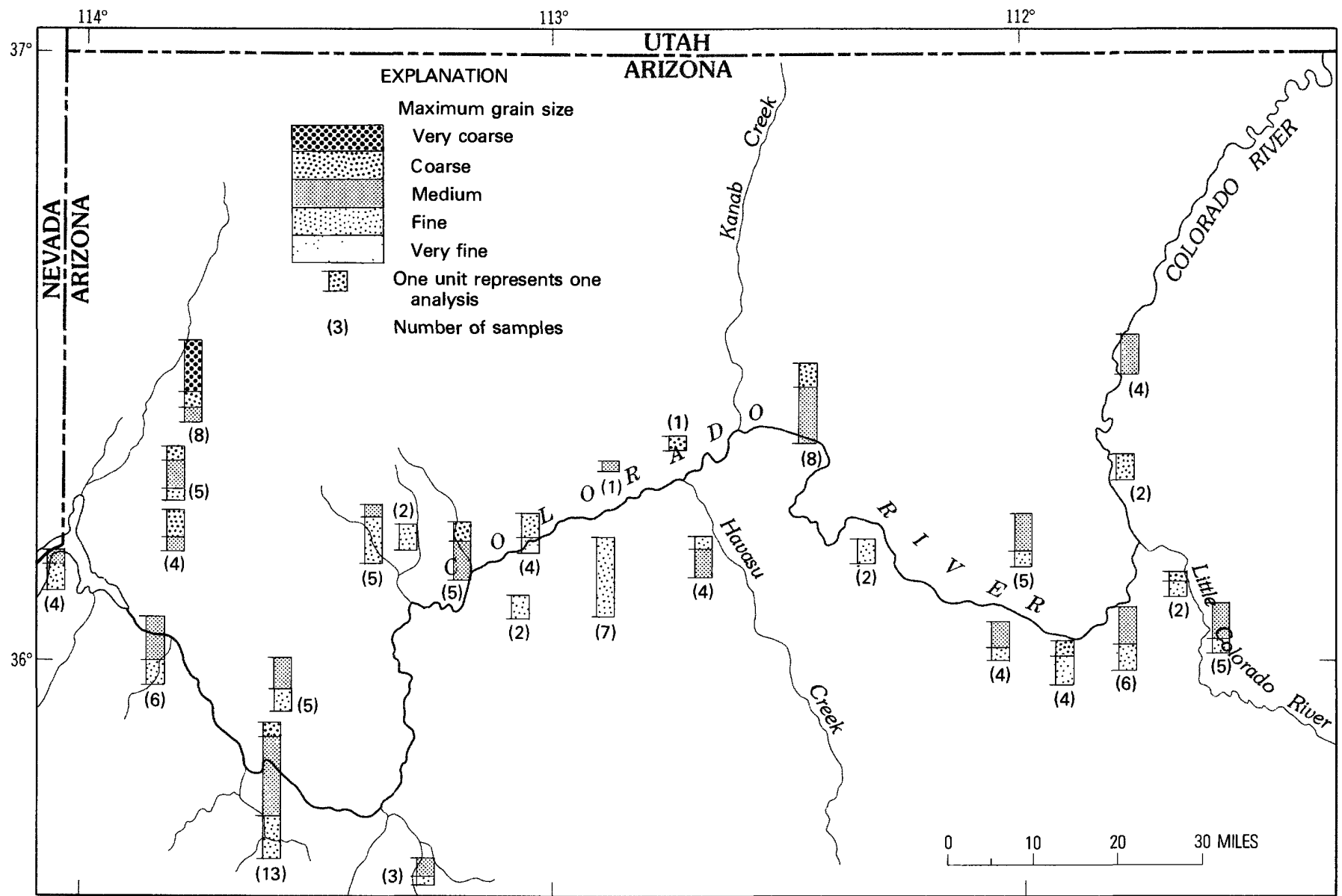

FIGURE K9.-Maximum grain size of particles in detrital rocks of the Wescogame Formation, Grand Canyon region, Arizona. Each unit in a vertical bar graph represents the maximum grain size of one sandstone sample (arranged with coarse to fine, from top to bottom).

extend in these directions as evidence of probable extensions of depositional passageways.

\section{Grain-size distribution in Wescogame Formation}

A comparison of the size-distribution pattern for sand grains of the Wescogame Formation with the pattern for grains of the underlying Manakacha shows similar positions for areas with concentrations of relatively coarse sand. In both formations, two areas of maximum grainsize distribution (fig. K9) and of dominant size grade (fig. K10) are apparent-one in western and the other in eastern Grand Canyon.

Maximum grain sizes in sandstones of the Wescogame were determined through mechanical analyses by sieving. In most samples examined, the sandstones ranged from fine to medium grained, but at 10 localities, 5 in the east and 5 in the west, coarse-grained sand $(1 / 2-1 \mathrm{~mm})$ also was represented. At Hidden Canyon, in the northwestern part of the region, numerous sandstone beds included some very coarse grained sand (1-2 mm).
Throughout the region of study, the dominant size grade, Wentworth scale, for rocks of the Wescogame Formation is very fine grained $(1 / 16-1 / 8 \mathrm{~mm})$. At essentially all localities in eastern Grand Canyon, and at two localities-Hidden Canyon and Pigeon Wash-in the far west, however, at least some of the sandstone beds are dominantly fine grained $(1 / 8-1 / 4 \mathrm{~mm})$, and at Hermit Trail one sandstone sample showed medium-grained sand to be dominant.

\section{Cross-stratification of Wescogame Formation}

\section{Characteristic features}

Cross-stratification is a conspicuous feature of the Wescogame throughout the Grand Canyon region. It occurs both in the sandstones, ranging from fine to very fine grained, that form most of the unit throughout much of the area, and in the carbonate rocks that dominate the unit in far western sequences. Only the mudstones and some limestones that are interbedded in relatively small proportions 


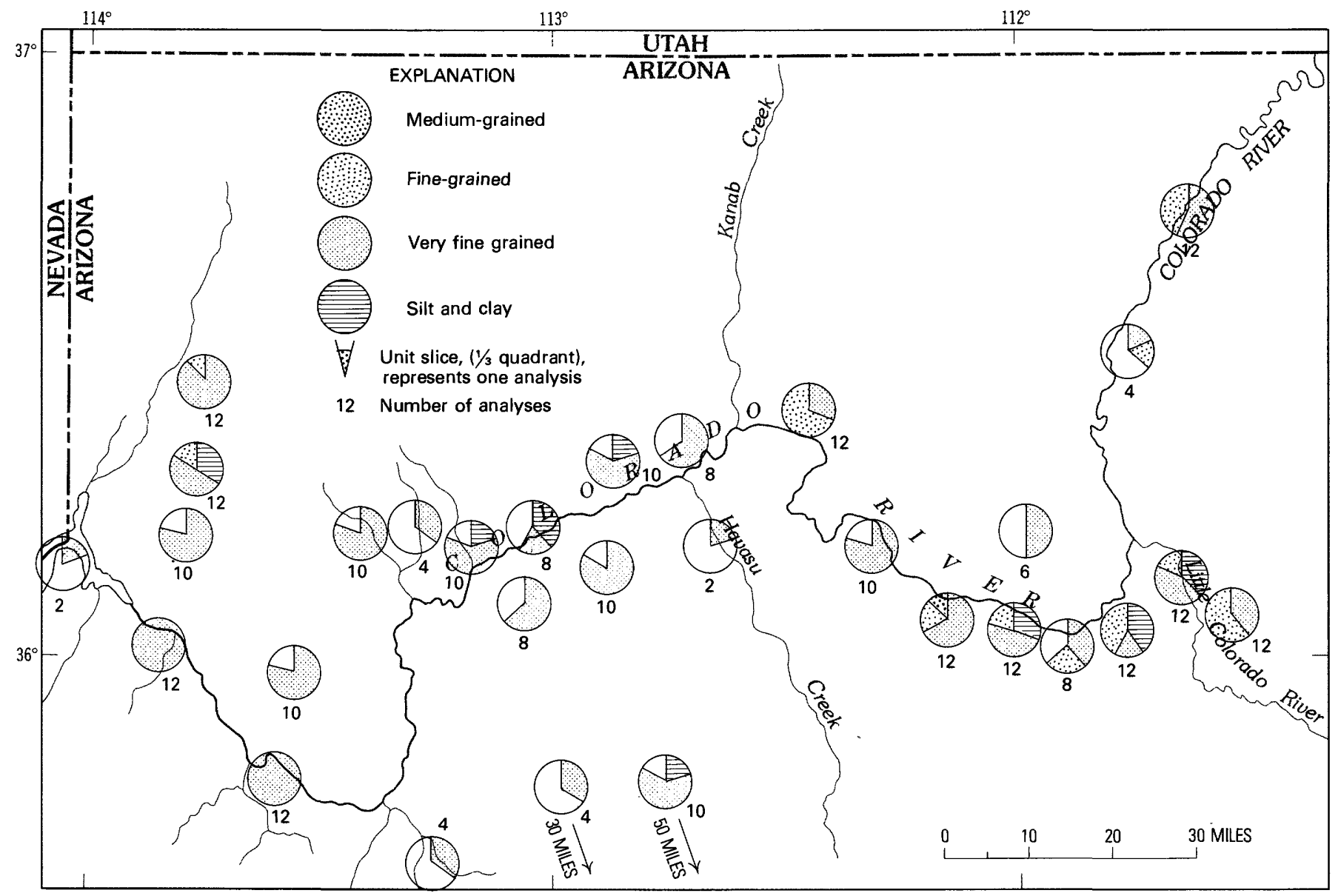

FIGURE K10.-Dominant size grade of particles in detrital rocks of the Wescogame Formation, Grand Canyon region, Arizona. Each unit slice (1/3 quadrant) in a pie diagram represents the dominant grain size for one analysis from the locality indicated. ("Dominant" refers to the principal size grade represented by one analysis.) Arrow and miles next to a pie indicate direction and distance to actual sample locality.

among the major cross-stratified units, are flat bedded or appear structureless.

Much of the cross-stratification is large scale (fig. L4), some at Grandview Trail, Kaibab Trail, north, S B Canyon, and Twin Springs Canyon containing foresets 40-50 $\mathrm{ft}$ in length. At both Grandview Trail and S B Canyon, sets of dipping strata measure 50-60 ft in length, and at Havasu and Parashant Canyons, foresets more than $60 \mathrm{ft}$ long were recorded. Although cross-strata more than $20 \mathrm{ft}$ in length are common in the Wescogame, medium-scale cross-strata (1-20 ft long) are dominant in most places, as indicated in table K4. Small-scale cross-strata (less than $1 \mathrm{ft}$ ) are very uncommon in these rocks and only locally occur in some abundance.

The principal types of cross-stratification are planar (figs. K11-K14; L3) with tabular and wedge varieties in about equal proportions, distributed without any recognizable relationship to either geographic or stratigraphic positions (table K5). Trough cross-strata are less common than either of the other types, but are more numerous than in the Manakacha below or the Esplanade Sandstone above. Most strata of this type form festoon patterns and the troughs are shallow but wide $(8-45 \mathrm{ft})$. Conspicuous examples of cosets containing this structure were noted near Topocoba Trail and in Havasu, Tuckup, and Andrus Canyons.

High-angle dips $\left(20^{\circ}\right.$ or more) on foreset beds were dominant at 13 localities at each of which 30 random measurements were recorded. Lower angles were dominant at seven localities and equal numbers of high- and low-angle dip surfaces at four others (table K6).

Most of the cross-stratified sandstone and arenaceous limestone bodies (cosets) of the Wescogame are relatively thin compared with those in the overlying Esplanade unit. A majority are between 4 and $12 \mathrm{ft}$ thick, although at Havasu Canyon a unit measuring $30 \mathrm{ft}$ thick, and at Kanab Canyon one measuring $40 \mathrm{ft}$ thick, were noted (table $\mathrm{K} 5$ ).

Cosets show a wide range in the number of superimposed sets included in each. They range from 1 to 11 , but most commonly are 3 or 4 (table K5). Such compound structures are characteristic features in both the sandstones of eastern 


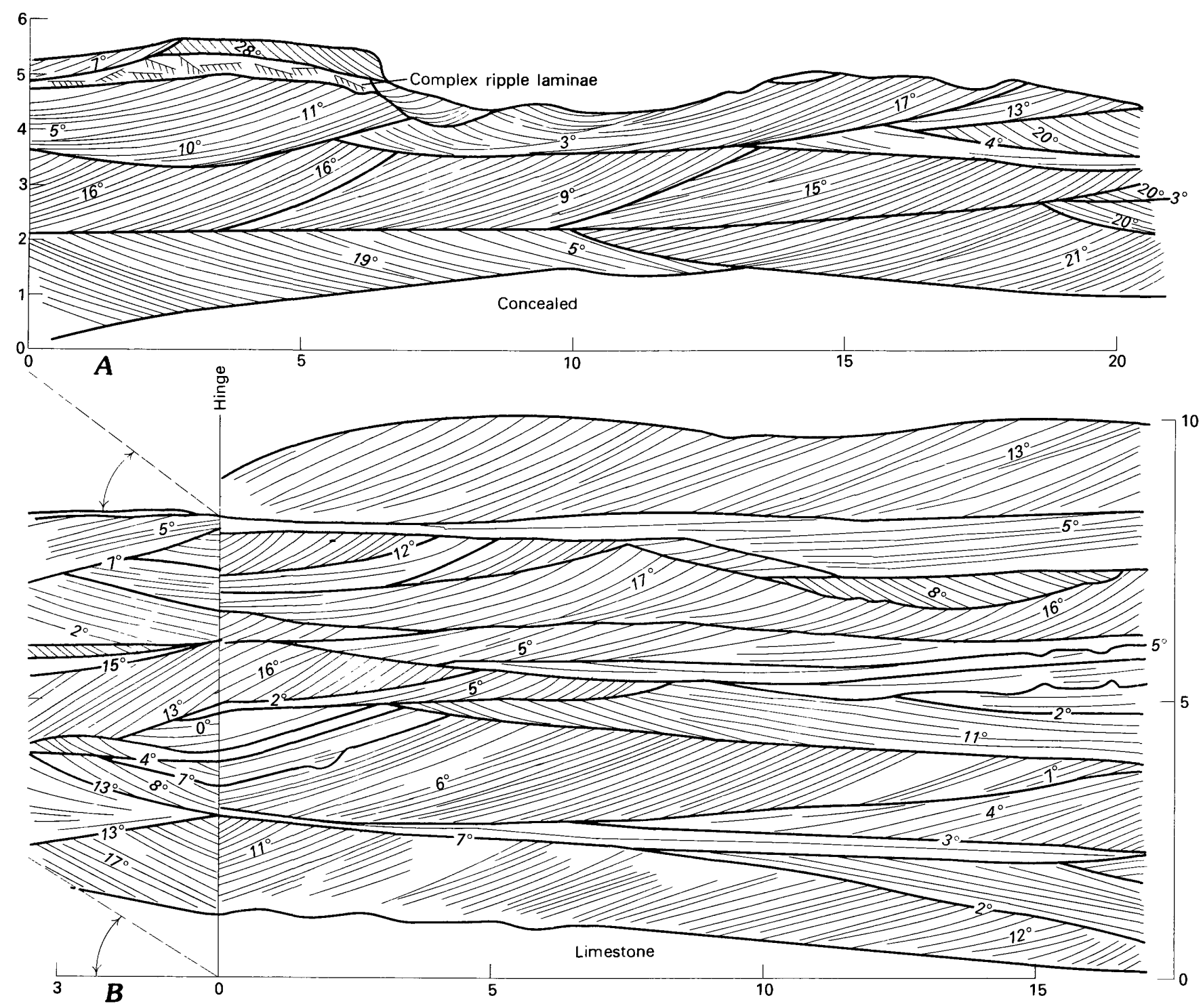

FIGURE K11.-Sets of planar cross-strata and trough-like cross-strata in arenaceous limestone, Wescogame Formation, Grand Canyon region, Arizona. A, Slope unit, Snap Canyon; B, cliff unit, Hidden Canyon. Vertical and horizontal distances in feet.

Grand Canyon and the arenaceous limestones in the west. Only in a few places, as at Eminence Fault and Twentynine Mile Canyon, are the units so massive as to appear structureless.

The cross-stratified units of the Wescogame range from sandstones with considerably less than 50 percent carbonate content in eastern Grand Canyon, to highly calcareous sandstones mostly in the central Grand Canyon area, to sandy limestone with an insoluble residue less than 50 percent in the far west.

\section{Current directions}

Cross-strata in sandstones and arenaceous limestones of the Wescogame were analyzed statistically in order to determine average directions of the depositing currents.
Methods used were the same as those described for the Manakacha, with 30 sets being measured at each locality (figs. K15, K16). The results as plotted are shown in figure K17.

Directions of sediment transport as indicated by mean dip directions of cross-beds are dominantly toward the south, but with more of an easterly trend than in the Manakacha. The eastward trend is especially pronounced in averages from western Grand Canyon which attain a maximum of $42^{\circ}$ east of south. The total spread across the region is $103^{\circ}$, which is greater than in the Manakacha but still relatively small.

\section{Ripple marks in sandstone}

Only a few cross-stratified sandstone beds of the Wescogame Formation exhibit foreset surfaces that are covered 

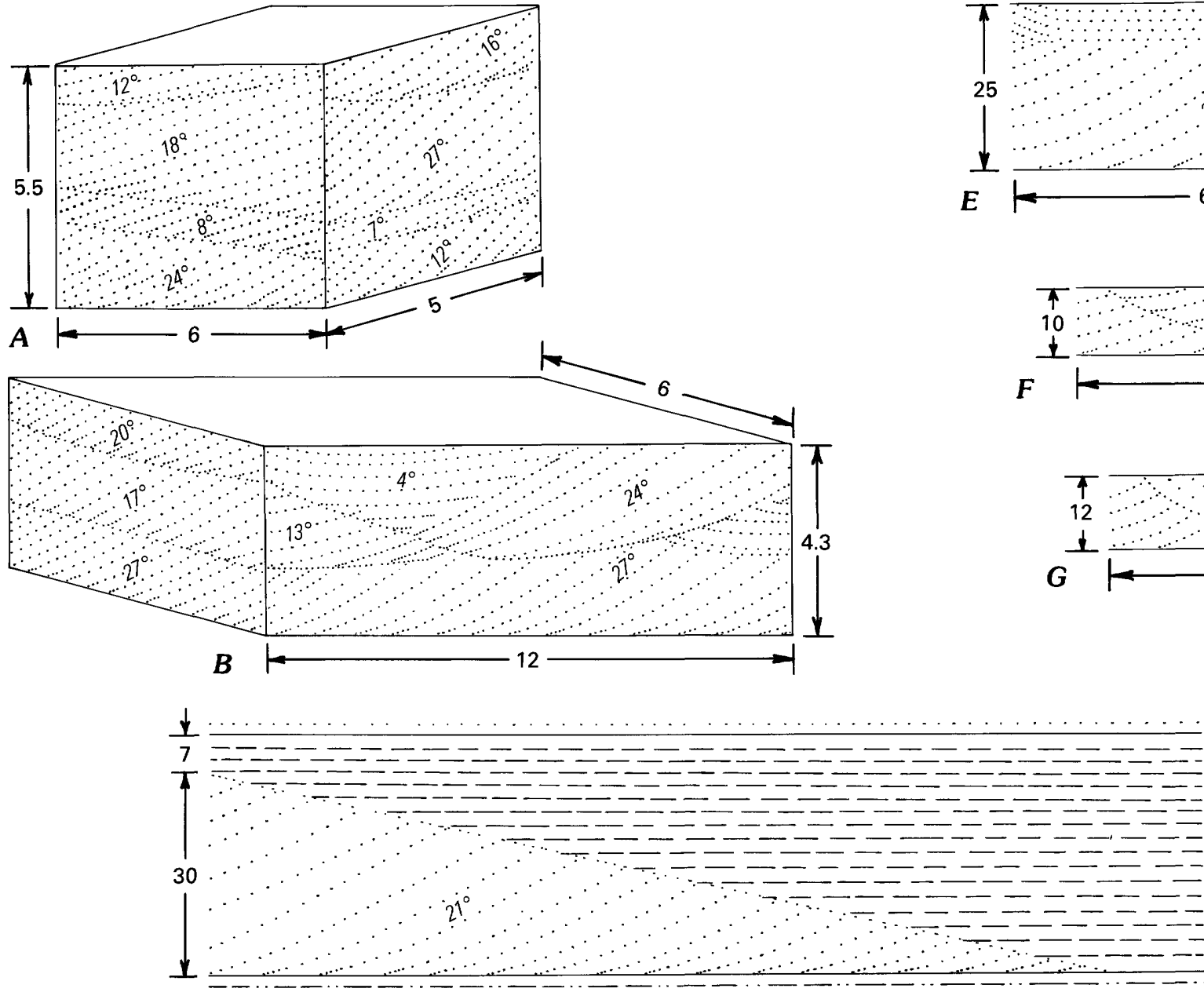

C

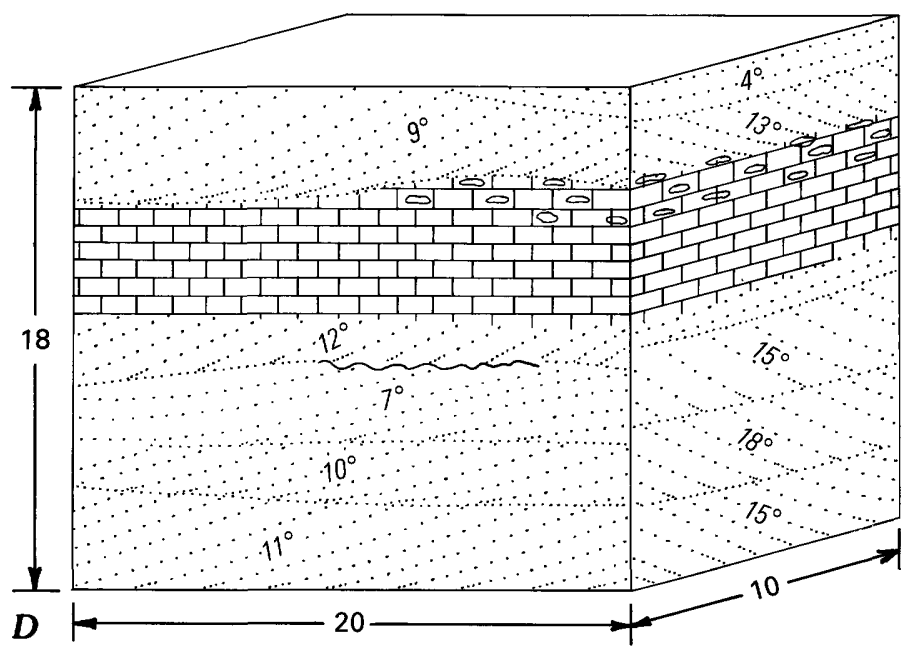

FIGURE K12.-Sets of tabular-planar, wedge-planar and trough crossstrata in calcareous sandstone of Wescogame Formation, Grand Canyon region, Arizona. A, Red-brown sandstone with tabular-planar crossstrata; slope unit near Kaibab Trail, south. $B$, Trough structures above tabular-planar cross-strata; slope unit near Kaibab Trail, south. C, Channel cut in planar cross-stratified sand, filled with horizontal shaly mudstone; base of cliff unit, Apache Trail above Supai village. D,
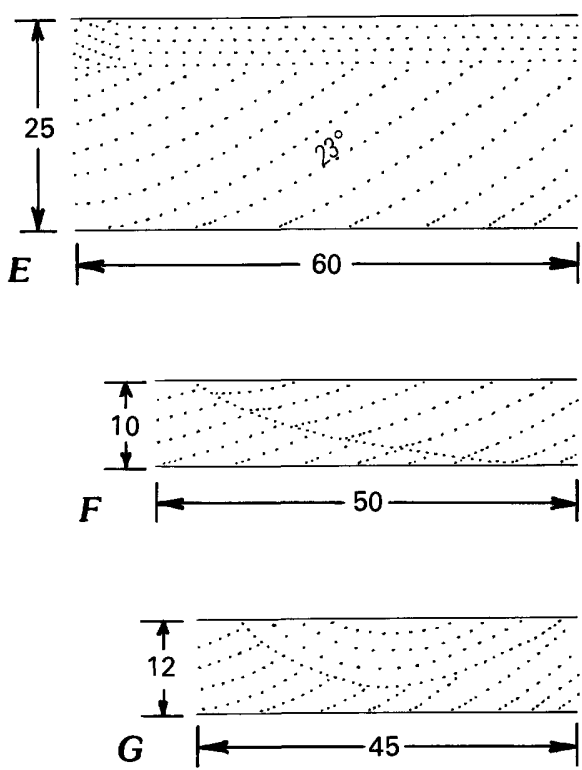

EXPLANATION

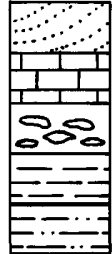

Sandstone

Limestone

Jasper concretions

Shaly mudstone

Siltstone
Tabular-planar structures forming cosets above and below limestone with jasper concretions; base of cliff unit, Toroweap Valley. E, Horizontal sand laminae overlying truncated top of tabular-planar set; near top of cliff unit in Havasu Canyon. F, Asymmetrically filled, and $G$, symmetrically filled trough structure in sandstone of cliff unit; Bright Angel Trail. Vertical and horizontal measurements in feet. 

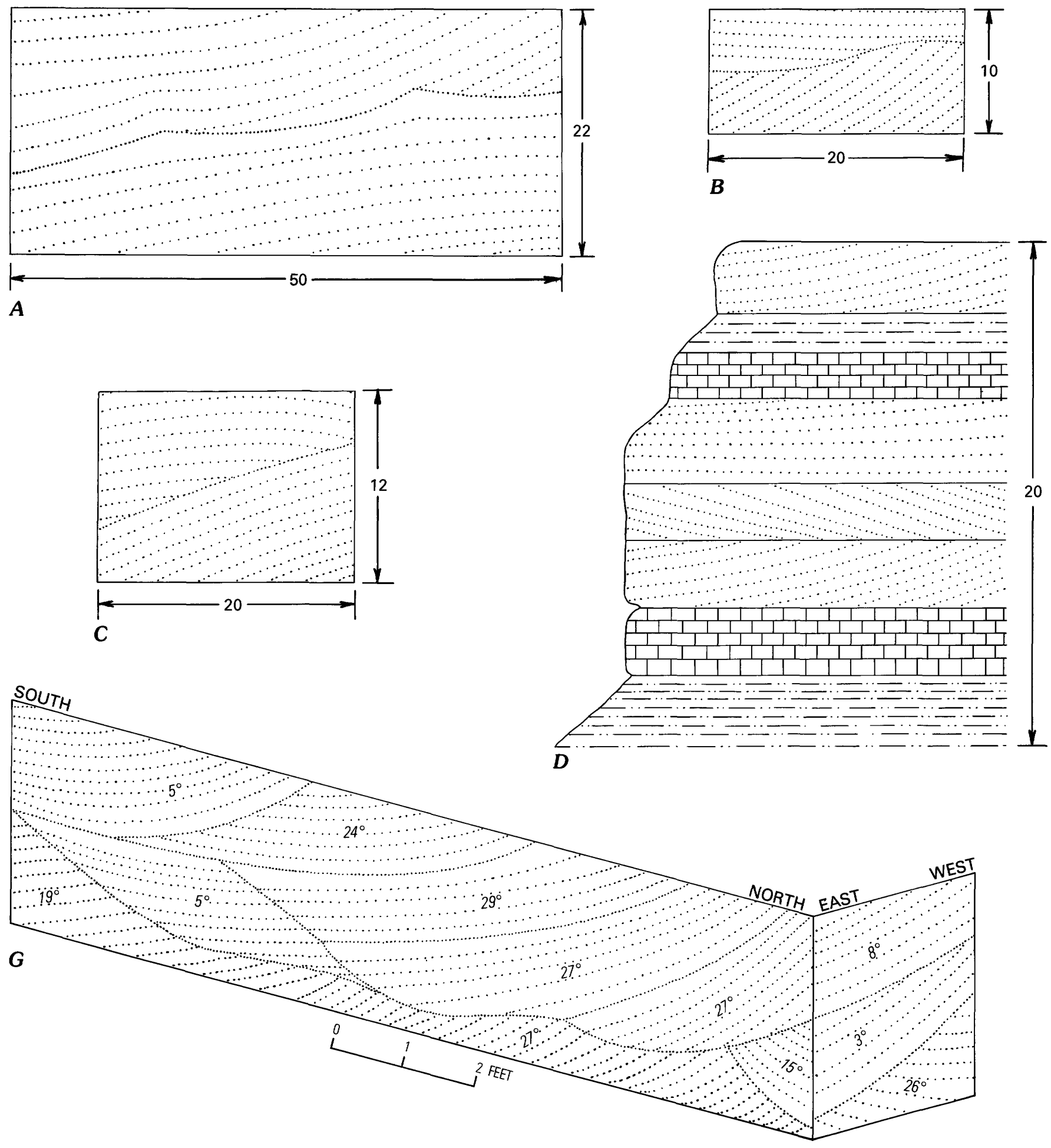


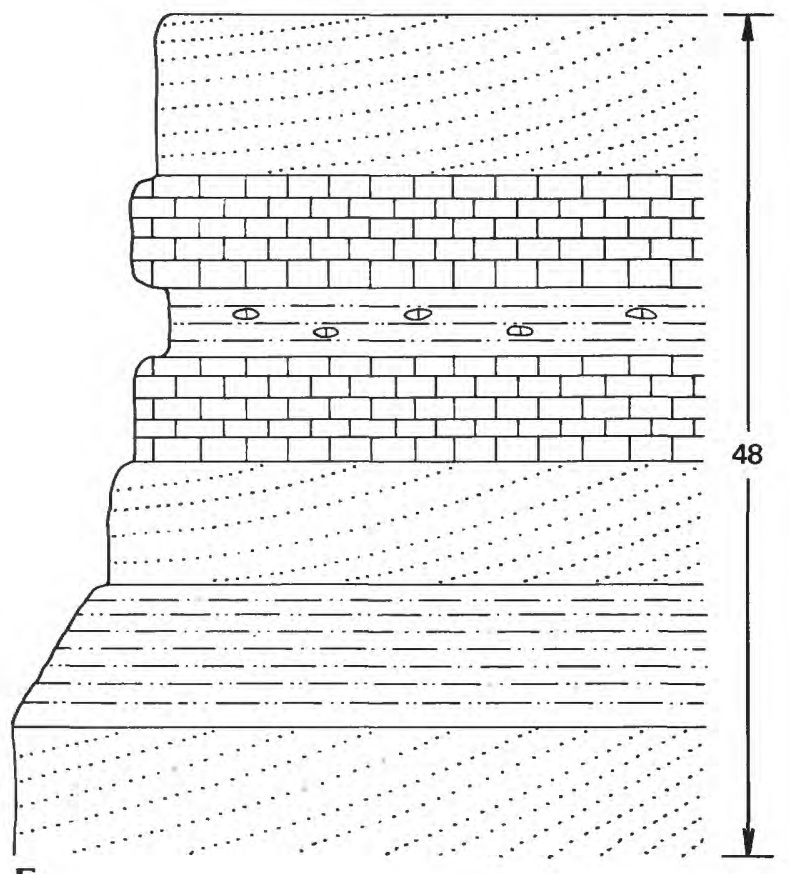

E

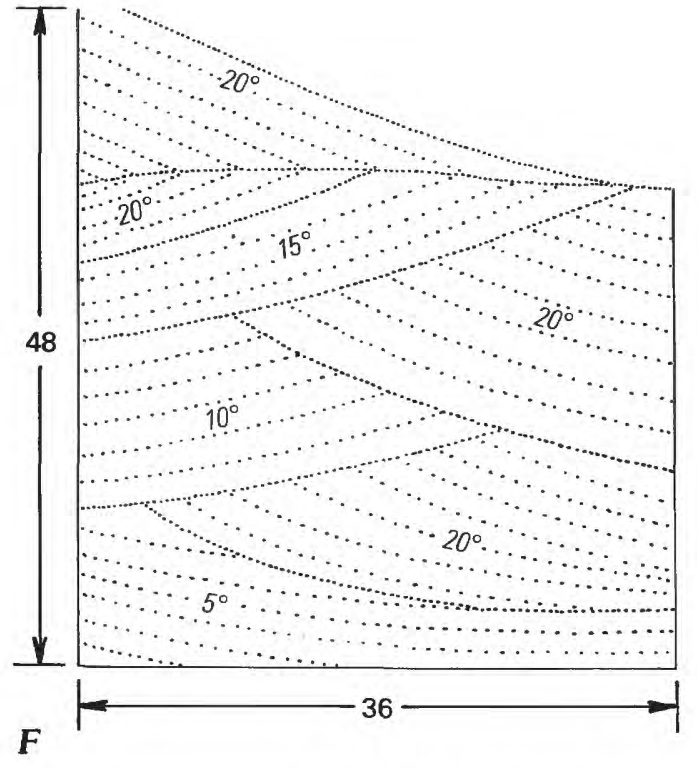

EXPLANATION

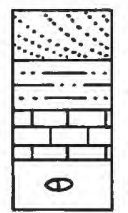

Sandy limestone

Siltstone or mudstone

Limestone

Limestone concretion
FIGURE K13.-Tabular-planar, wedge-planar, and festoon cross-strata, Wescogame Formation, Grand Canyon region, Arizona. A, B, Sets of sandstone cross-strata with erosion surface between; Kaibab Trail, south. $C$, Sets of sandstone cross-strata with depositional contact; Kaibab trail, south. $D, E$, Cyclothem with units of siltstone, limestone, and crossstratified sandstone; Grand Gulch Wash (D) and Pigeon Wash (E). F, Festoon cross-strata; Grand Wash Cliffs. G, Asymmetrically filled trough cross-strata near base of slope unit; Kaibab Trail, south. Vertical and horizontal measurements in feet. 

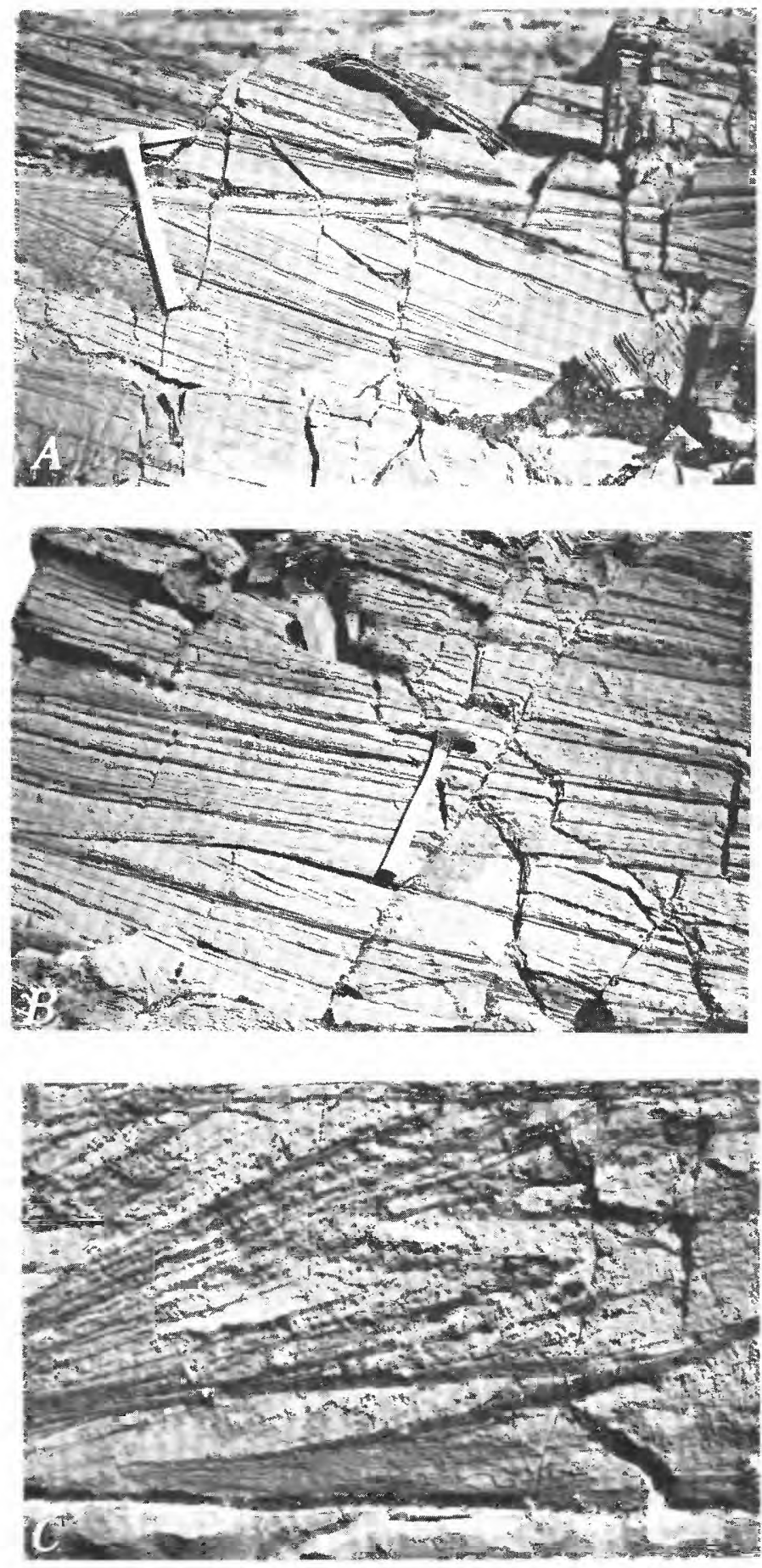

FIGURE K14.-Cross-strata in sandstone and in carbonate rock of the Wescogame Formation, Grand Canyon region, Arizona. A, Wedgeplanar cross-beds with quartz grains etched out on limestone surface; Iceberg Canyon. B, Wedge- and tabular-planar cross-beds in limestone; Iceberg Canyon. $C$, Cross-strata of wedge-planar type in arenaceous limestone; Twin Springs Canyon. Scale-pencil in bottom center. D,

with ripple marks. Rippled surfaces recorded during the measuring of stratigraphic sections in Grand Canyon are of several types, including linguoid (fig. $\mathrm{N} 3 \mathrm{C}$ ), lunate (fig. $\mathrm{N} 3 B$ ), and parallel-straight or parallel-sinuous (fig. N3A).
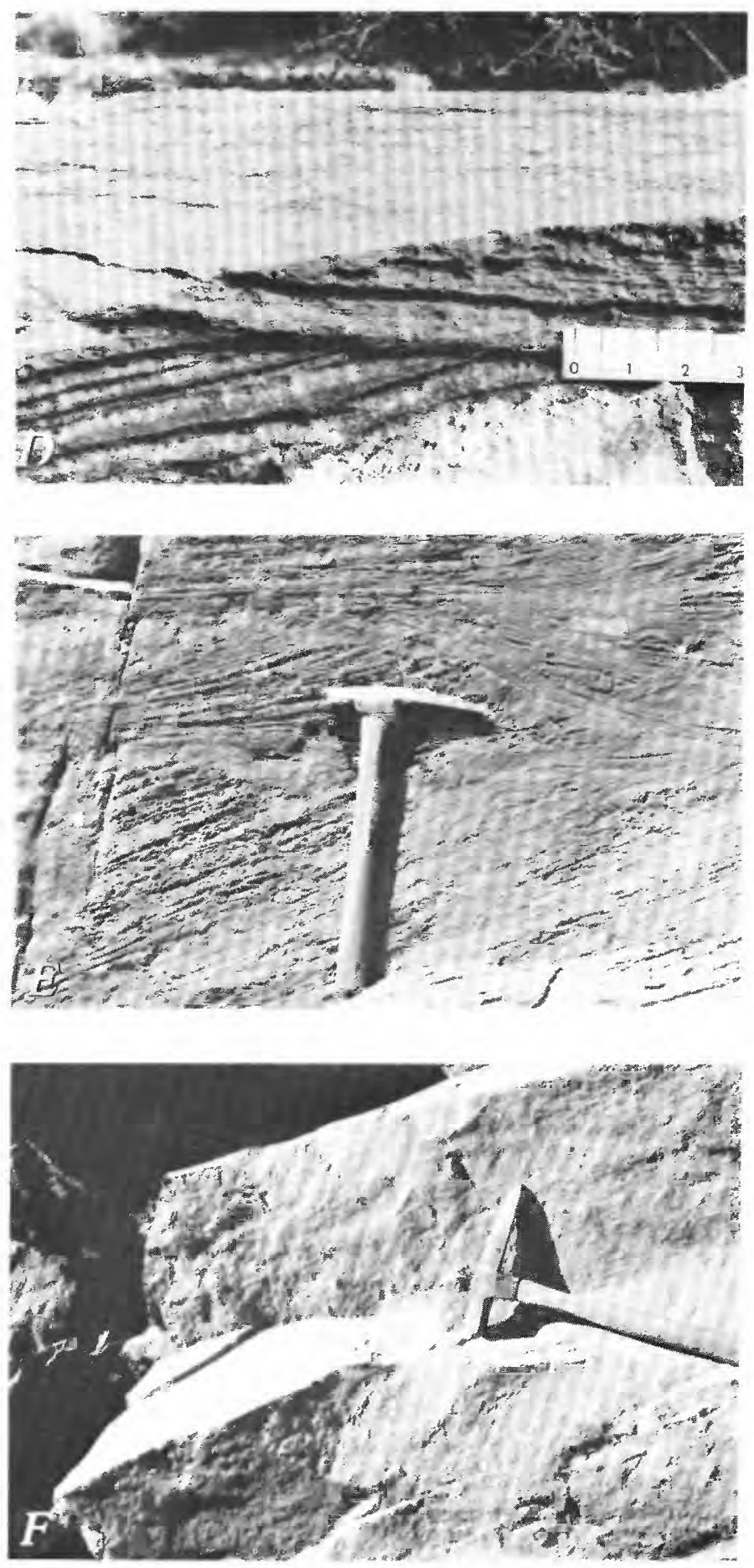

Contact between sets in tabular-planar cross-strata, calcareous sandstone; Fishtail Canyon near Thunder River Trail. Scale in inches. $E$, Trough structure in tabular-planar cross-strata; Kaibab Trail, south. F, Topset bed (below hammer) continuous with foreset bed, to left, in sandstone; Kaibab Trail, south.

Mostly they occur in very fine grained sandstone of the cliff unit, but at least one set was observed in arenaceous limestone and one in clean siltstone. These are discussed in detail in chapter $\mathrm{N}$ under minor depositional structures. 
SANDSTONE OF THE ESPLANADE SANDSTONE

\section{Geometry of Esplanade sand body}

The youngest and the thickest major sand body in the Supai Group forms the main cliff unit of the Esplanade Sandstone (fig. P12). In general, its form is that of a wedge, gradually thickening westward, where the lower part interfingers with limestone and dolostone of the Pakoon Limestone of McNair (1951) and the upper part merges (probably grades laterally) into siltstone and mudstone. Thickest parts of the sandstone body (300-400 $\mathrm{ft}$ ) are in the central part of the region, but whether this is the result of a greater amount of deposition or a lesser subsequent erosion in that area is not known. Nearly everywhere in the region deposition began with mud and silt of the basal slope unit, but because these red beds alternate upward in the section with beds of pure sand, it seems probable that base level rose periodically. No information is available on the extent of the sand body in a north-south direction.

\section{Grain-size distribution in the Esplanade Sandstone}

Analysis of grain size in sandstones of the Esplanade has been made for the Grand Canyon region. In addition to mechanical analyses from sieving more than a hundred selected samples (fig. K18), grain sizes for a large number of other samples, representing most of the sandstone units in each measured section, were roughly determined by a visual-comparison method using a binocular microscope. Sorting was sufficiently good in nearly all samples to determine the dominant size grade from a single analysis; a sample was obtained for each set or coset of strata and cross-strata as recognized in a measured section.

\section{Maximum grain size}

The bulk of the Esplanade is very fine sand but a few grains in some samples are coarse or very coarse. Very coarse grains were observed in sieved samples from a majority of the sand units at Andrus Canyon in west-central Grand Canyon (fig. K18) and also from nearby sections at Whitmore Wash, Toroweap Valley, and Separation Canyon and, farther south, at Picacho Butte (fig. K18). Coarse grains were observed in samples from 14 localities including 4 in eastern Grand Canyon and 3 to the south. However, a large majority of all sandstones containing either coarse or very coarse grains were found in west- central Grand Canyon; none were noted in the far western sections.

\section{Medium and finer size grades}

Sandstone of the Esplanade contains a great preponderance of sets and cosets (290 samples, considered representative) in the very fine grained sand category $(1 / 16-1 / 8 \mathrm{~mm})$ (table K7). Dominantly fine grained sand $(1 / 8-1 / 4 \mathrm{~mm})$ was found in 35 samples at 15 localities, and mediumgrained sand (1/4-1/2 mm) was dominant (size grade containing largest amount of sand) in 9 samples from 7 localities (fig. K19).

TABLE K7.-Proportion of sets and cosets of sandstone units to siltstone units in each formation of the Supai Group. Dominant grain size (size grade with largest amount of sand) was determined by method of visual comparison using standard mounts under microscope. Figures refer to number of samples in each grade class

\begin{tabular}{|c|c|c|c|c|}
\hline & Esplanade $^{1}$ & Wescogame & Manakacha & Watahomigi \\
\hline Siltstone ........ & 70 & 40 & 93 & 75 \\
\hline \multicolumn{5}{|l|}{ Very fine grained } \\
\hline sandstone . . . . . . & 290 & 114 & 113 & 17 \\
\hline \multicolumn{5}{|l|}{ Fine-grained } \\
\hline sandstone . . . . . . & 35 & 34 & 22 & 4 \\
\hline \multicolumn{5}{|l|}{ Medium-grained } \\
\hline sandstone . . . . . . & 9 & 1 . & 2 & 2 \\
\hline Total samples.. & 404 & 189 & 230 & 98 \\
\hline
\end{tabular}

${ }^{1}$ Esplanade Sandstone includes Pakoon Limestone (McNair, 1951) in far western Grand Canyon, and a few tongues of Pakoon farther east.

Fine-grained sandstone seems to be widely scattered geographically, though it is most common in western and northern localities. It is largely from the main cliff unit, but three exceptions in central Grand Canyon represent the upper cliff-slope unit. Medium-grained sandstone is from the middle-western and western parts of the area and is nearly entirely from the main cliff unit. The conclusion based on grain-size distribution, therefore, is that most of the sand in the Esplanade was derived from a source to the north and northwest of the area under study, but that grain size, in general, is very uniform across the region.

\section{Cross-stratification of Esplanade Sandstone}

\section{Characteristic features}

The dominantly well sorted, very fine grained sandstone of the main cliff unit of the Esplanade is characteristically cross-stratified throughout most of the Grand Canyon region. Planes of cross-strata are conspicuously etched in relief by weathering at nearly all localities in central and 


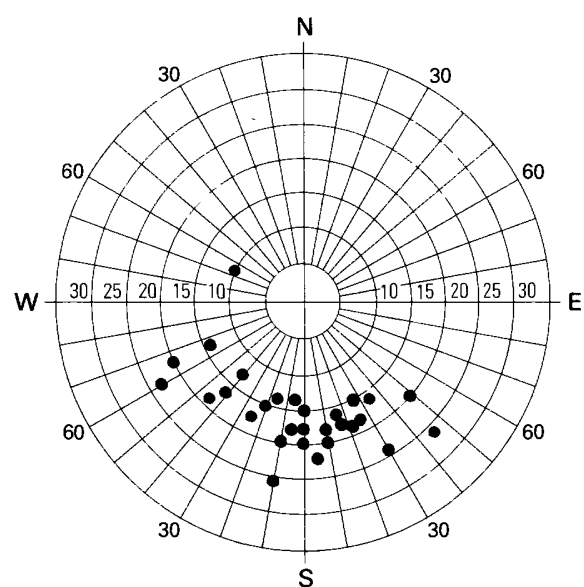

A

Av. 188

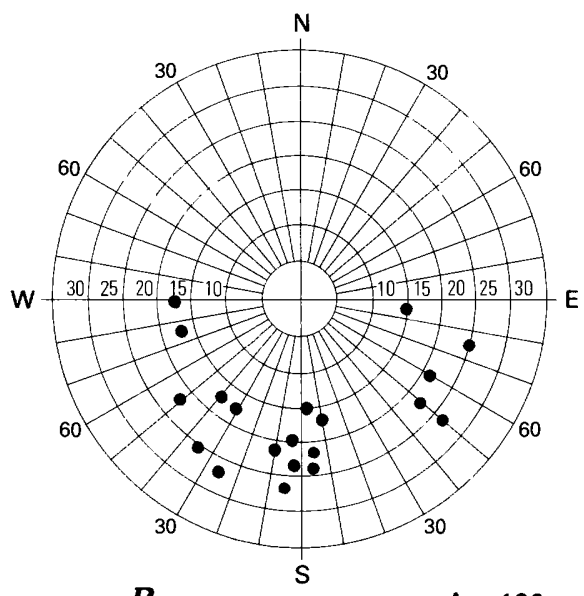

B

Av. 190

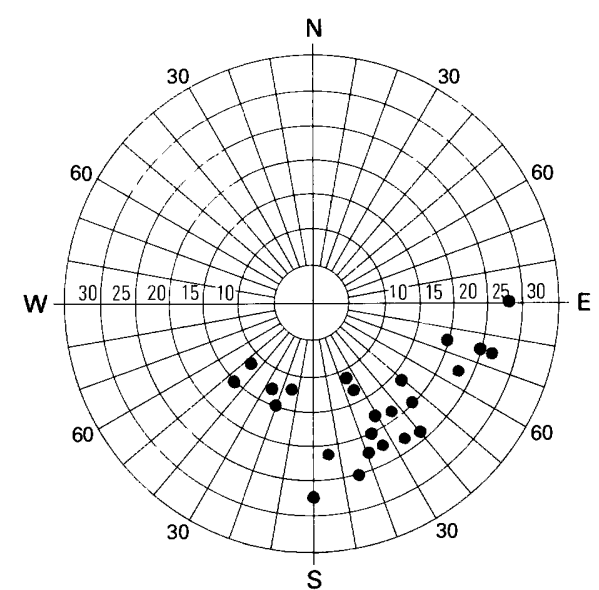

D

Av. 143

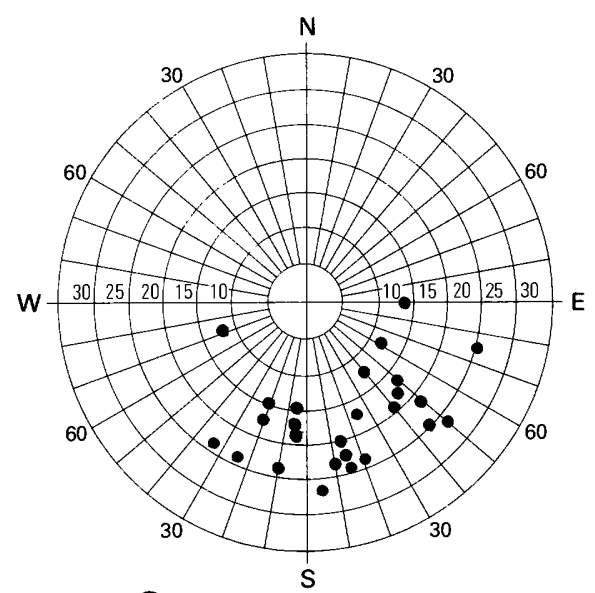

G

Av. 151

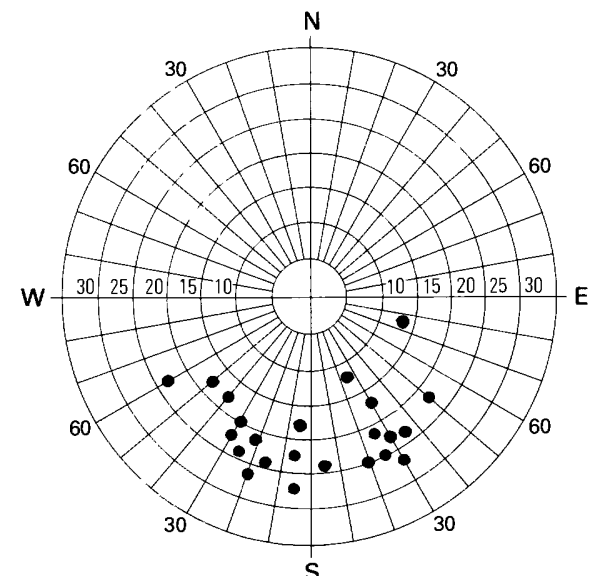

E

Av. 180

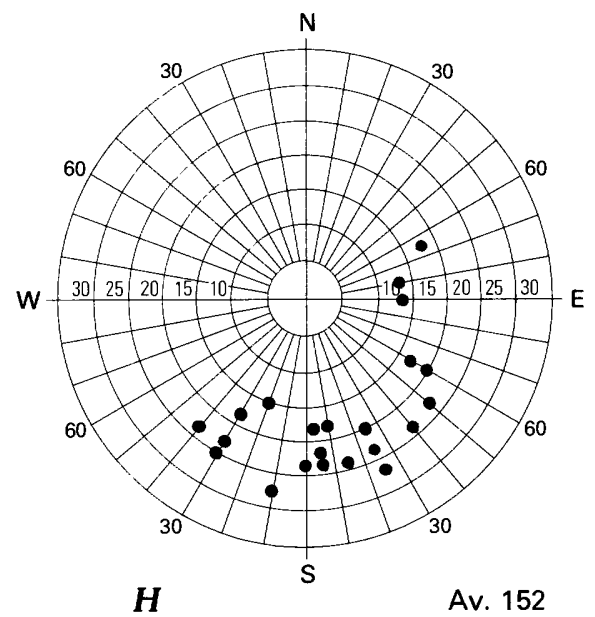

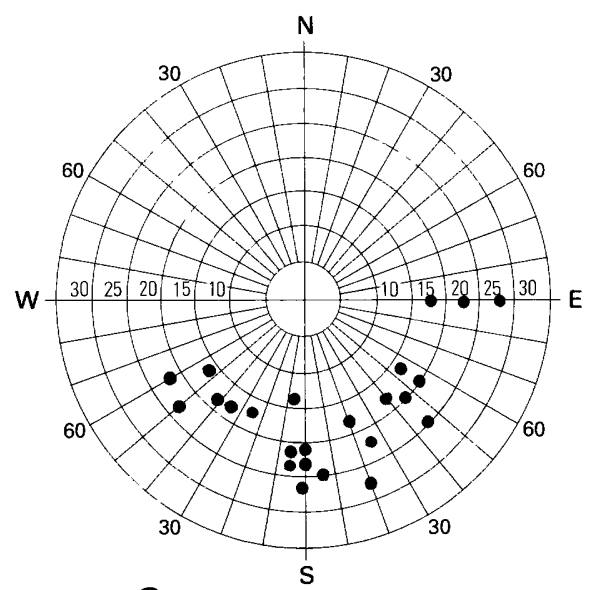

C

Av. 175

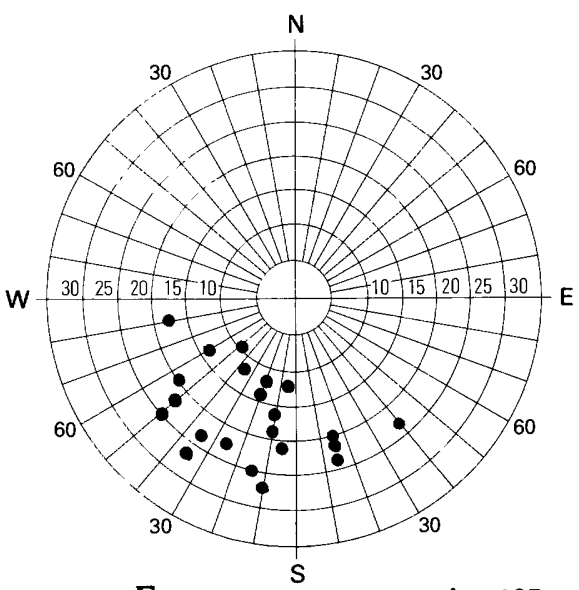

F

Av. 195

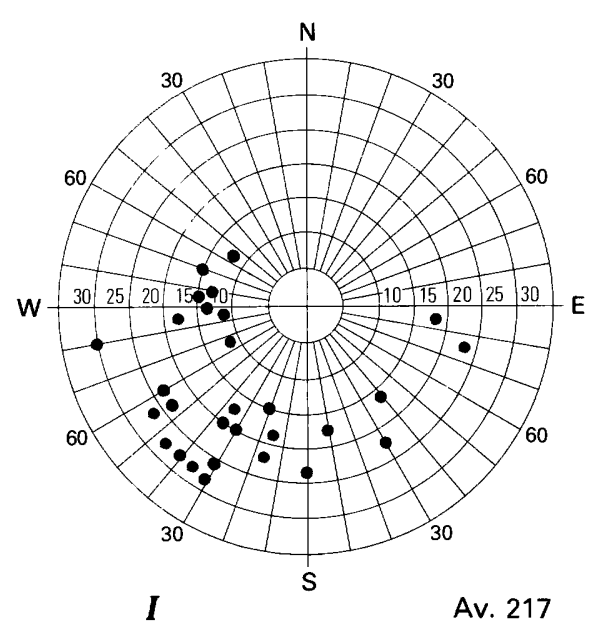

Av. 217 

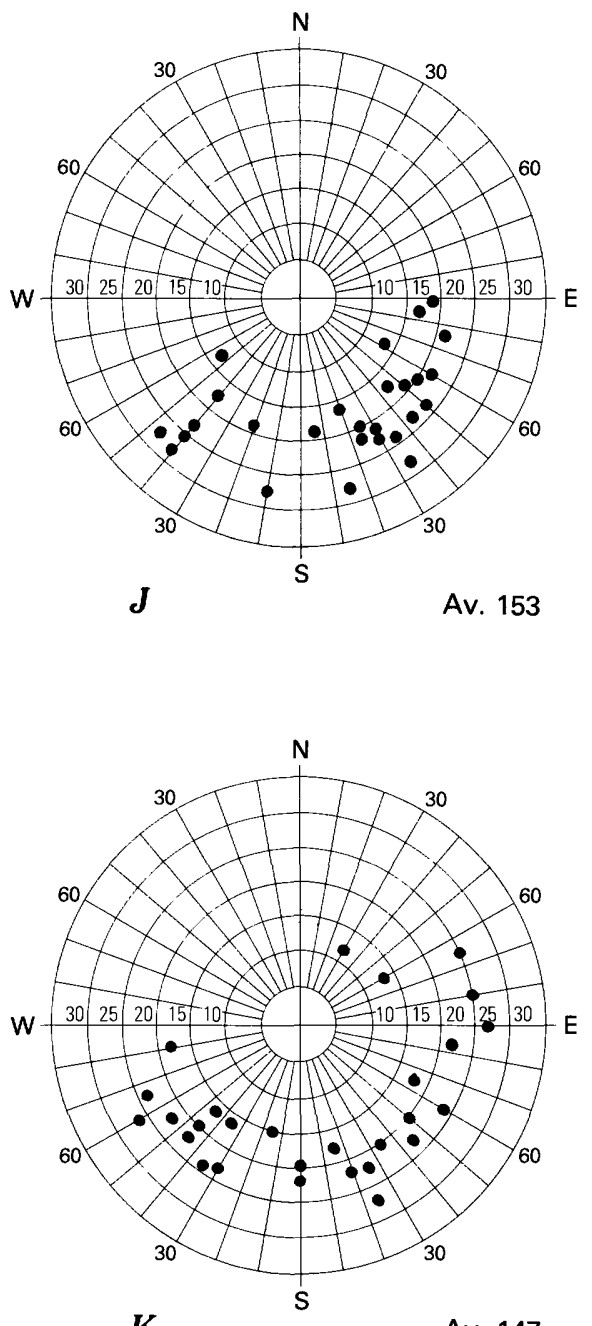

$\boldsymbol{K}$

Av. 147

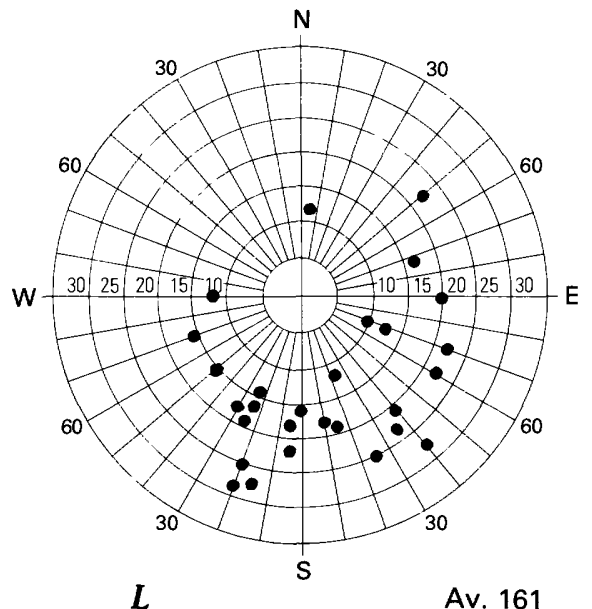

FIGURE K15.-Cross-strata dip directions, average dip direction (Av.), and degree of dip, plotted on polar coordinate sheets for the Wescogame Formation. Grand Canyon region, Arizona. A, House Rock Canyon; $B$, Marble Canyon; $C$, Horsetrail Canyon; $D$, Bunker Trail; $E, F$, Grandview Trail; $C$, Kaibab Trail, south; $H$, Bright Angel Trail; I, Hermit Trail; I, Bass Trail; K, Topocoba Trail; and $L$, Havasu Canyon. 


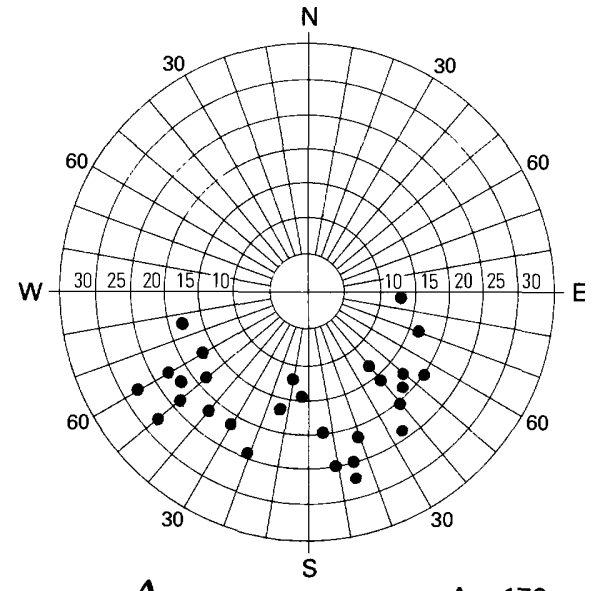

A

Av. 179

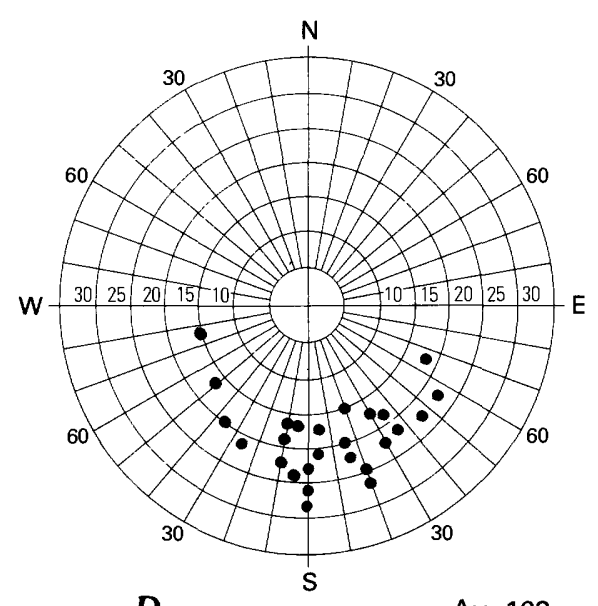

D

Av. 168

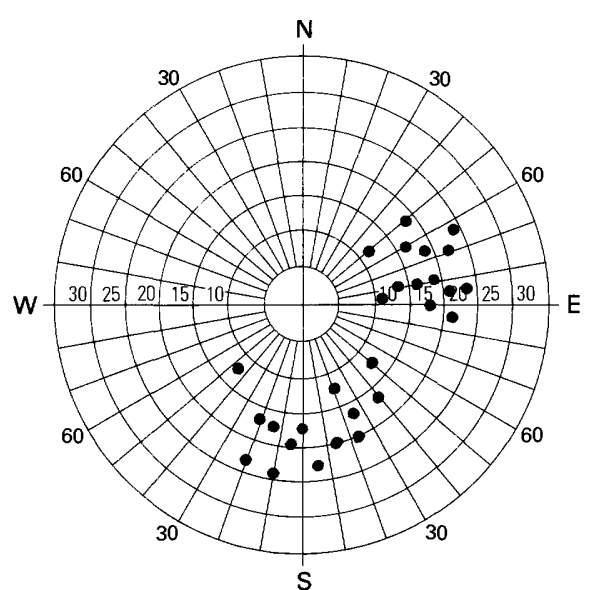

G

Av. 126

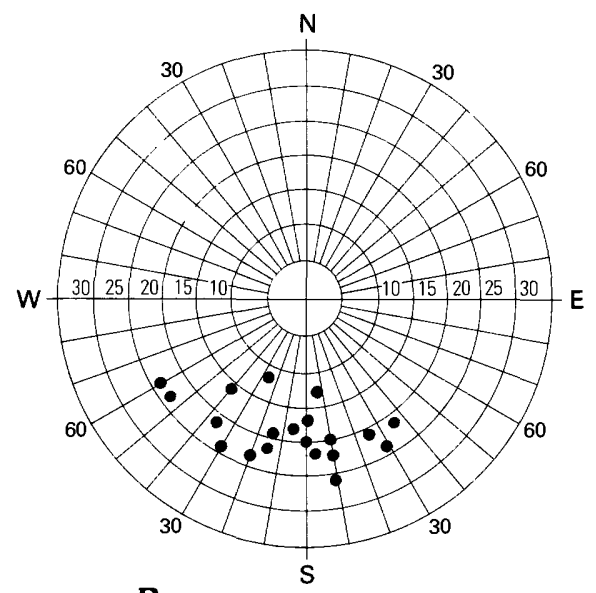

B

Av. 194

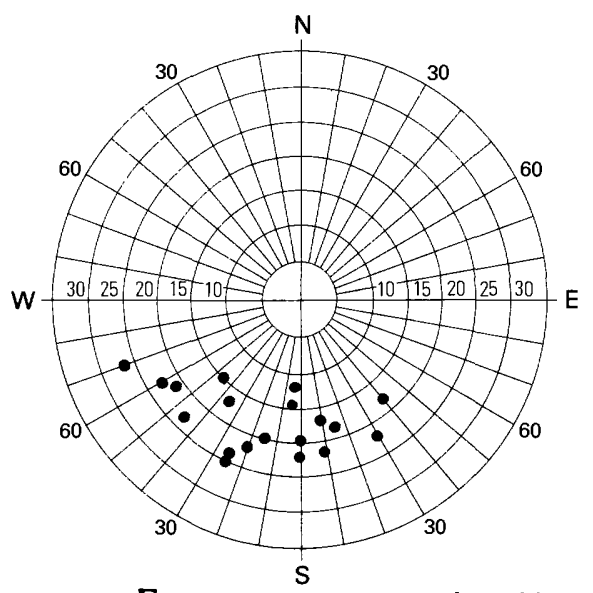

E

Av. 192

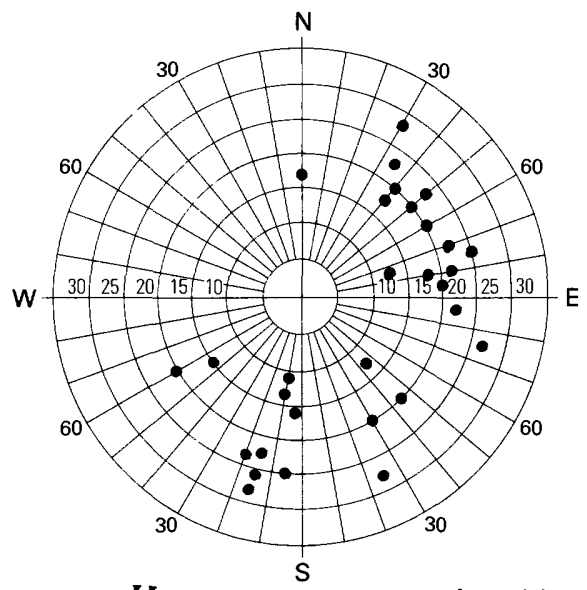

$\boldsymbol{H}$

Av. 124

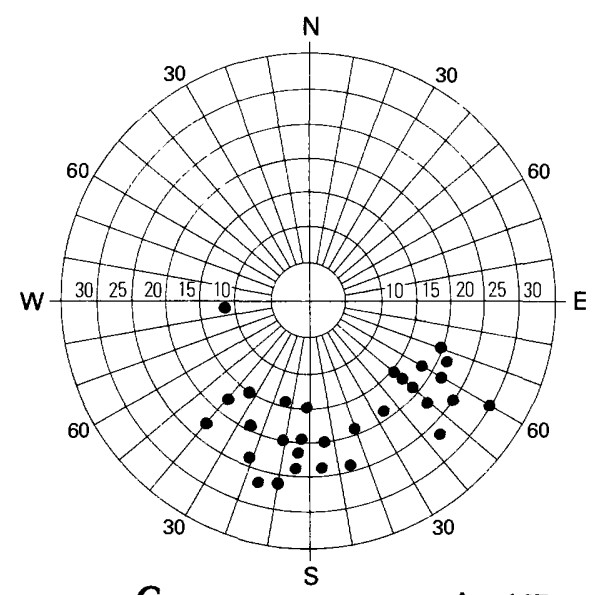

C

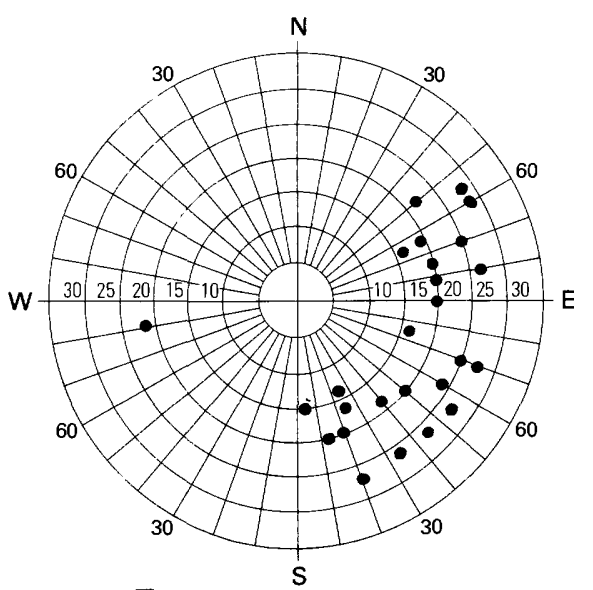

F

Av. 114

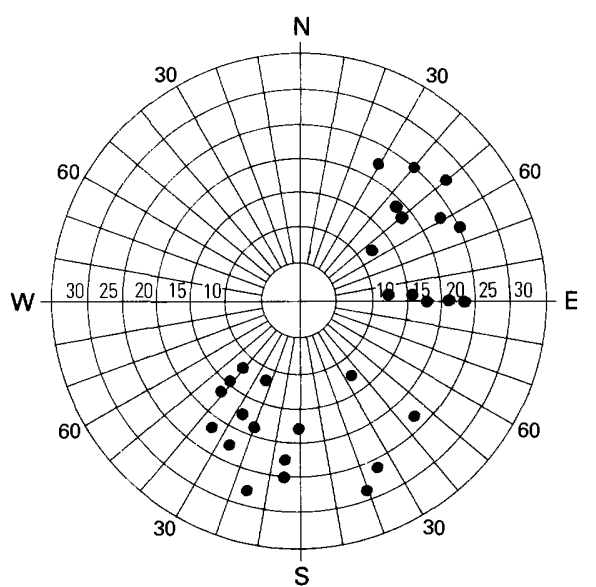

Av. 137 

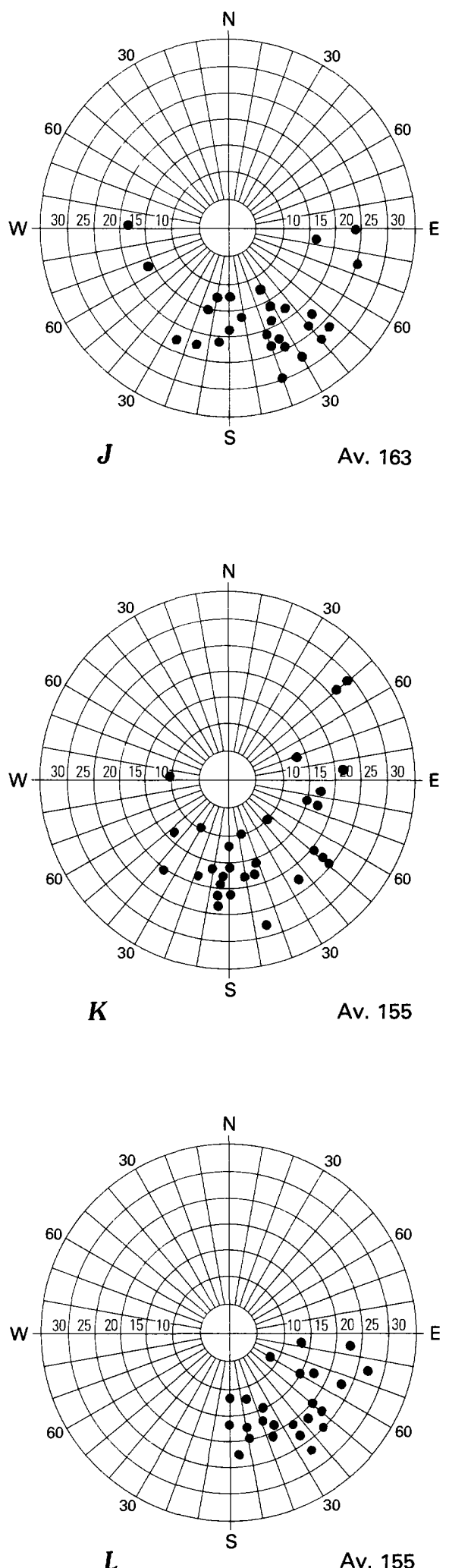

Av. 155

FIGURE K16.-Cross-strata dip directions, average dip direction (Av.), and degree of dip, plotted on polar coordinate sheets for the Wescogame Formation, Grand Canyon region, Arizona. A, Kaibab Trail, north; $B$, Fishtail Canyon near Thunder River; $C$, Tuckup Canyon; $D, E$, Toroweap Valley; $F$, Whitmore Wash; $G$, Separation Canyon; $H$, Guano Cave (lower part of section); I, Guano Cave (upper part of section); I, Parashant Canyon; $K$, Snap Canyon; and L, Pigeon Viash. 


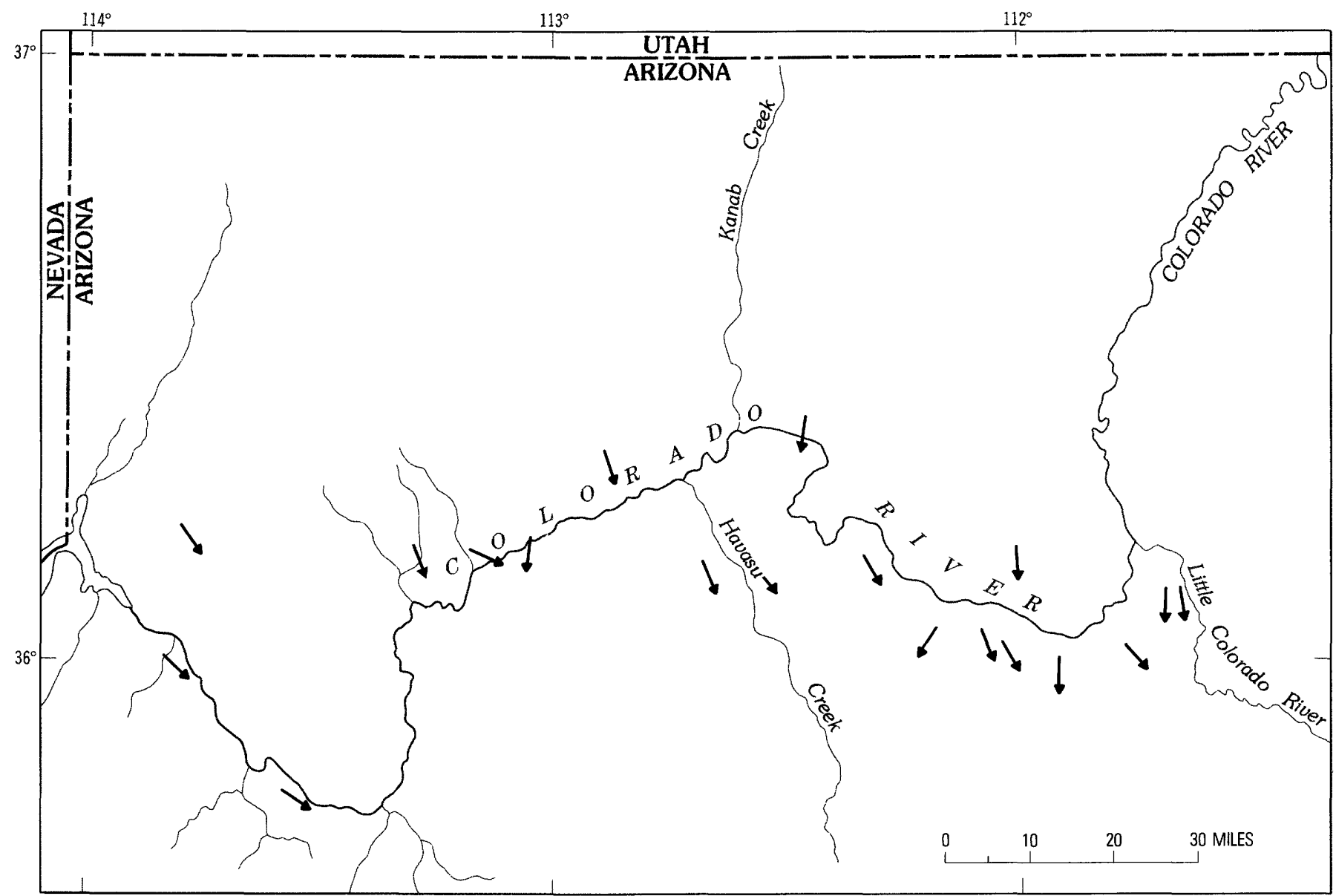

FIGURE K17.-Dip-direction vectors for cross-strata of the Wescogame Formation, Grand Canyon region, Arizona. Each arrow shows average direction determined from 30 measurements of cross-strata selected at random for the locality shown on map.

western Grand Canyon. In eastern Grand Canyon, for some reason not readily apparent, they are only weakly developed in various parts of the unit and many beds, especially in the vicinity of the Grandview, Kaibab, south, and Bright Angel Trails, appear massive and structureless or exhibit only traces of cross-stratification.

Nearly all of the cross-stratification in the Esplanade Sandstone is of the planar type (fig. L5), represented both by tabular and by wedge varieties in roughly equal amounts throughout the region (table K4). Horizontal or flat-lying laminae are not uncommon, interstratified among sets of planar type in most places, but in general they form relatively thin sets that represent a very small percentage of any sand body. Trough-type cross-strata are even less numerous than horizontal and were recorded from only 6 of the 32 localities studied. Mostly they form the characteristic pattern referred to as festoon (Knight, 1929), and are filled with curving laminae of sand in asymmetrical pattern (fig. L5E,F).

The tabular-planar cross-strata of the Esplanade Sandstone typically form layers or sets of dipping beds that maintain fairly constant thickness over distances of 20,30 , or more feet. They commonly form a vertical sequence (coset) in which the characteristic layers of steeply dipping foresets are repeated numerous times (fig. K20). In contrast, the wedge-planar sets form layers that are best described as compound because each set thickens or thins in a short distance, commonly forming a wedge that ranges from one to several feet thick within a lateral distance of 10 $\mathrm{ft}$ or less. Actually no sharp line of distinction is recognized between the tabular and wedge types, as all sets or layers must thin to a vanishing point eventually; however, where seen in the limited exposure of an outcrop, the repeated layers of tabular sets and the compound patterns of wedge sets look very different.

Most cross-stratification in the Esplanade Sandstone is medium scale, with steeply dipping foresets between 1 and $20 \mathrm{ft}$ long (table K4). A moderate number of sets, however, at localities scattered throughout the region, contain largescale foresets (dipping strata more than $20 \mathrm{ft}$ long) (fig. K20). Large-scale cross-stratification both at Fishtail Canyon near Thunder River Trail and at S B Canyon includes tabular-planar sets with dipping laminae 60 to $70 \mathrm{ft}$ long; dipping strata $40 \mathrm{ft}$ in length were recorded at Twentynine 


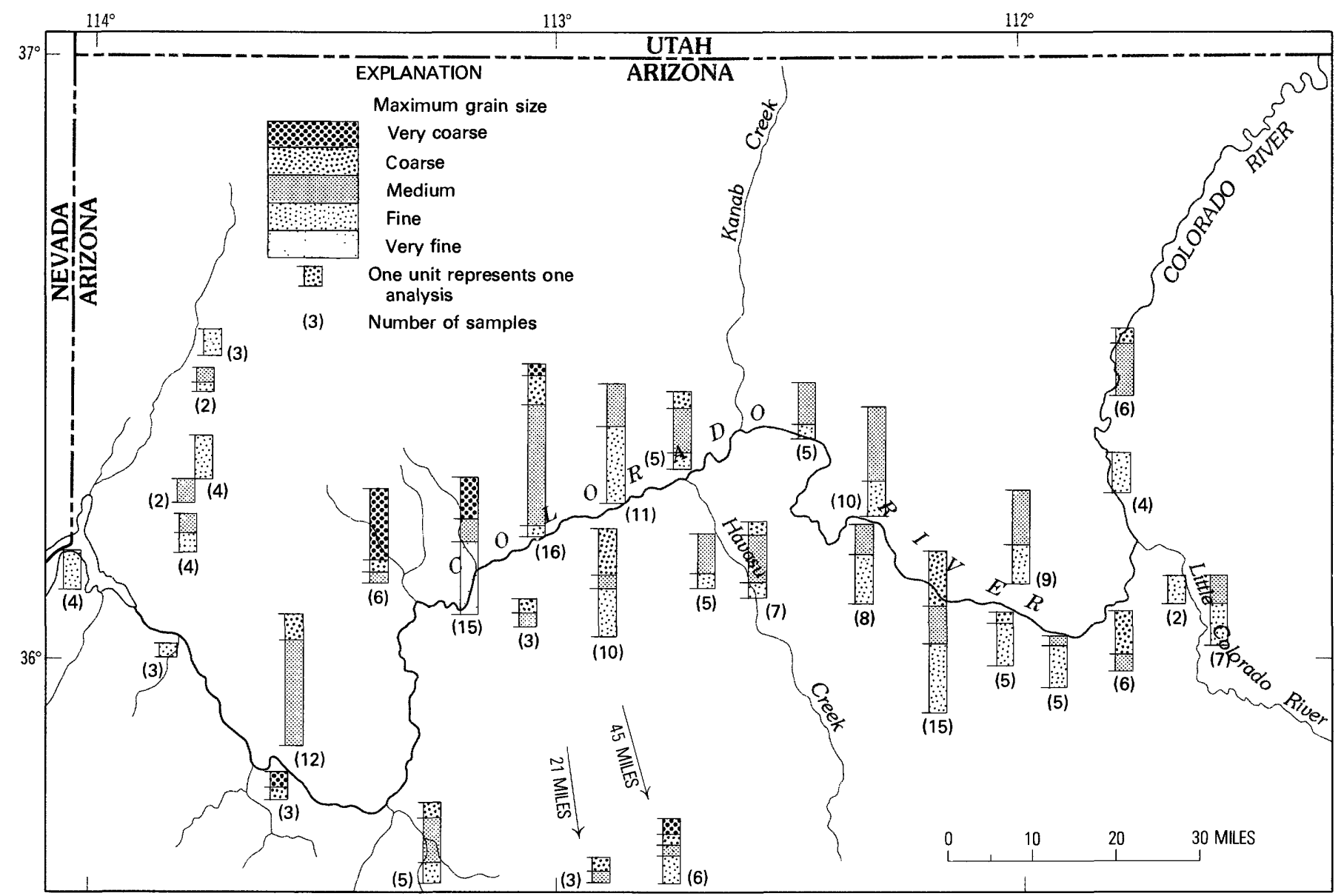

FIGURE K18. - Maximum grain size of particles in detrital rocks of the Esplanade Sandstone, Grand Canyon region, Arizona. Each unit in a vertical bar graph represents the maximum grain size of one sandstone sample (arranged with coarse to fine, from top to bottom). Arrow and miles next to a bar indicate direction and distance to actual sample locality.

Mile Canyon, Topocoba Trail, and Tuckup Canyon. Relatively uncommon in the Esplanade are small-scale crossstrata (table K4).

Stratification cosets (as defined in McKee and Weir, 1953, p. 383) have thicknesses that are determined in part by the amount of deposition in each set and in part by erosion that bevelled the upper surface of each set; their thickness constitutes a rough measure of the scale on which sedimentary processes operated in the area. This measure applies to both wedge- and tabular-planar types and to trough types. In the Esplanade Sandstone, thickness of cosets as determined from 3-dimensional studies of structure ranges from less than $2 \mathrm{ft}$ to $33 \mathrm{ft}$ (table $\mathrm{K} 5$ ). A large but representative coset measured at Toroweap was $33 \mathrm{ft}$ thick and consisted of 11 sets of tabular-planar crossstrata. A second coset from the same area was only $8.5 \mathrm{ft}$ thick, but included 5 sets of tabular-planar and 2 sets of wedge-planar cross-strata.

Maximum angle of dip was determined for the foresets of 30 cross-strata sets in the Esplanade Sandstone at each of 18 localities in the Grand Canyon region (table K6). In this count, the sets containing cross-strata dipping $20^{\circ}$ or more were classed as high angle; those less than $20^{\circ}$ as low angle, following the terminology of McKee and Weir (1953, p. 386). Table K6 shows that the total number of high-angle foresets is about equal to the total number of low-angle foresets and that no regional distribution trend is apparent.

\section{Current directions}

Cross-stratification in the Esplanade Sandstone and Pakoon Limestone, western equivalent of lower part of Esplanade, has been measured for mean current direction at 22 localities (figs. K21, K22) in the Grand Canyon region and is shown to have a very pronounced southeasterly trend in average direction of dip (fig. K23). This trend contrasts with that of the underlying Manakacha and Wescogame Formations, which are dominantly toward the south.

Because of the similarity in type and scale of cross-strata and in the grain size and sorting within the several Supai 


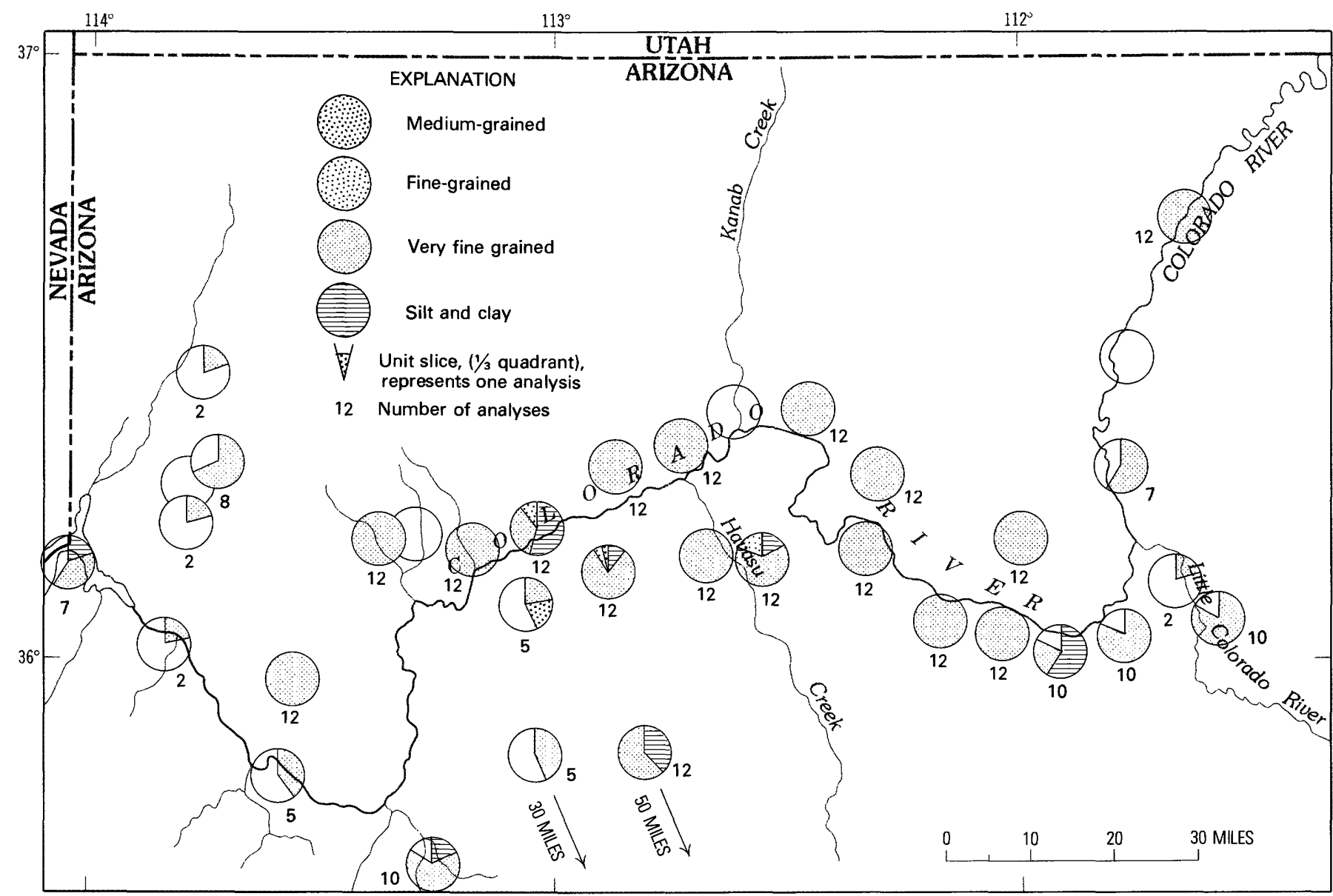

FIGURE K19.-Dominant size grade of particles in detrital rocks of the Esplanade Sandstone, Grand Canyon region, Arizona. Each unit slice (1/3 quadrant) in a pie diagram represents the dominant sand size for one analysis from the locality indicated. ("Dominant" refers to the principal size grade represented by on analysis.) Arrow and miles next to a pie indicate direction and distance to actual sample locality.

sandstones, an explanation for the marked change in directional trends between units is not readily apparent. Possibly, the gradual east-west merging from sandstone into arenaceous limestone, in the lower two units but not in the Esplanade, is indicative of a major difference in the depositional environments, or perhaps the more easterly trend of the Esplanade current direction is the result of a new source area developed to the northwest.

The Pakoon Limestone in the westernmost part of the Grand Canyon is believed to be a lateral equivalent of the lower part of the Esplanade Sandstone, and contains similar cross-stratification in many of its arenaceous dolostone and limestone beds. Statistical studies were made of these strata at three localities and average dip directions were determined for them (fig. K24). The vectors indicate directions east of south-very similar to those of the Supai sandstones to the east and essentially the same as directions determined for Esplanade sandstones that overlie the Pakoon in western Grand Canyon (fig. C8).

\section{Ripple marks in sandstone}

Ripple marks are relatively scarce in the well-sorted, cross-bedded sandstone of the Esplanade. Extensive sets of ripples were found during the study of this formation only in Fishtail Canyon near the Thunder River Trail, in S B Canyon, and at Mile 16 (House Rock Canyon) in Marble Canyon. These ripple marks included both the lunate and the parallel-straight types.

A high-energy environment of deposition is inferred for the sandstone of this formation because of the ubiquitous presence of medium- to large-scale cross-stratification in it. The general scarcity of ripple marks, therefore, seems to be anomalous, as it is in sandstone of the underlying Wescogame. In both formations, a high stage of the lower flow regime seems to have been responsible for development of foresets in the sandstone, but ripple marks-characteristic of an early stage of the lower flow regime-apparently were not commonly formed in this environment. 

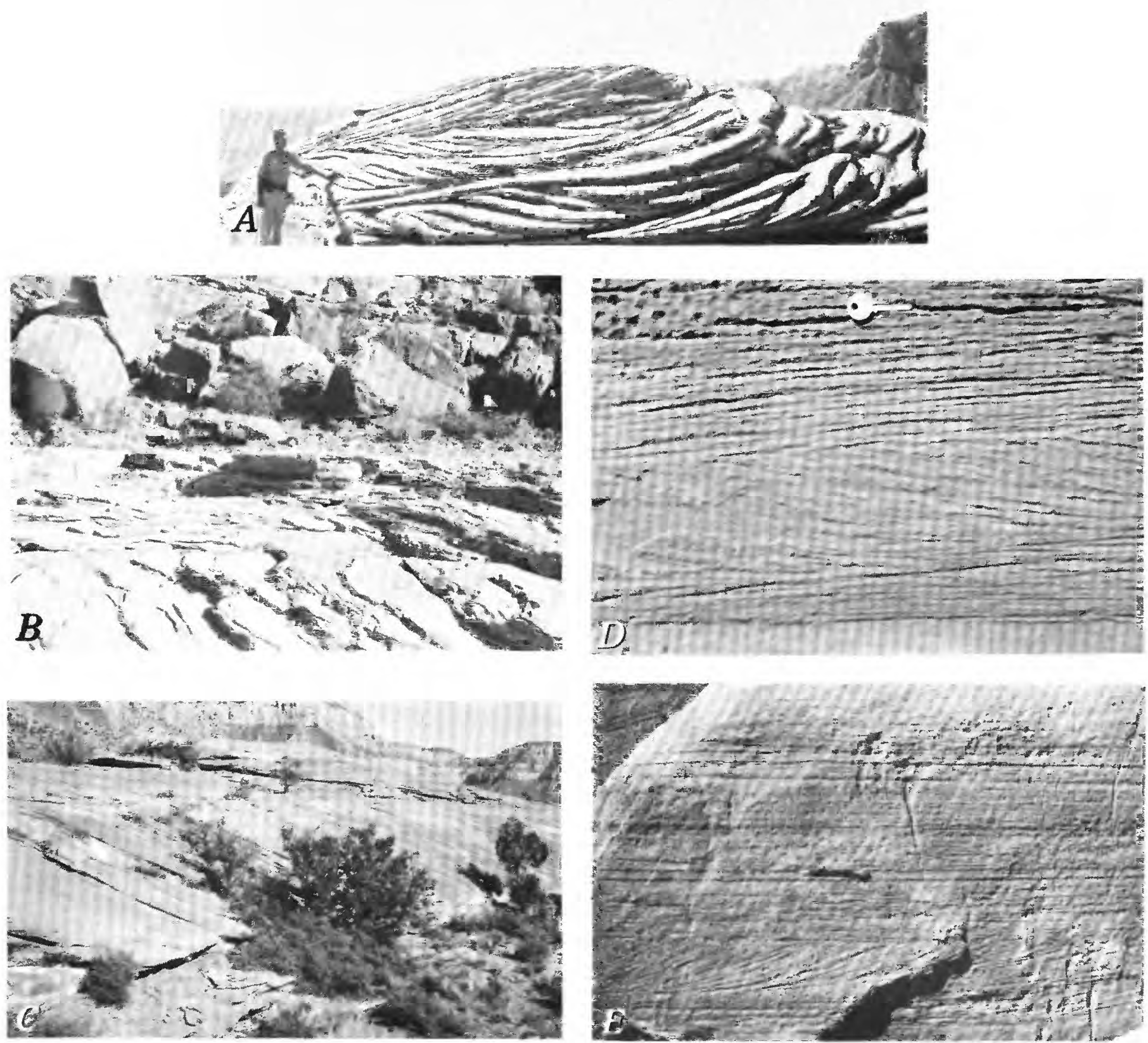

FIGURE K20.-Size-scale of cross-strata in Esplanade Sandstone of Grand Canyon, Ariz. A, Compound cross-strata consisting of dipping planar sets filling shallow trough; Fishtail Canyon near Thunder River Trail. B, Large-scale, tabular-planar cross-strata underlying thin-bedded horizontal strata; Topocoba Trail. C, Large-scale, tabular-planar cross-

\section{Contorted structures}

Contorted structures are uncommon in the Esplanade Sandstone and, except at one locality near Toroweap Valley where numerous sets of strata are contorted within a limited area, they must be considered atypical of the formation. The structures at Toroweap are in cross-stratified,

strata near top of formation; Fishtail Canyon near Thunder River Trail. D, Small-scale, tabular-planar set between sets of thin, horizontal strata; Kaibab Trail, south. Key in top center is about 2 in. long. E, Small-scale, tabular-planar set between sets of thin horizontal strata; Toroweap Point.

very fine grained sandstone (fig. K25) and seem to consist mainly of faults with accompanying brecciation and of very irregular anticlinal folds, probably the result of loading when the sand was incompetent. All of the contortion is within a single coset of planar cross-beds where the sand grains probably were in a near quicksand condition when contortion developed. 


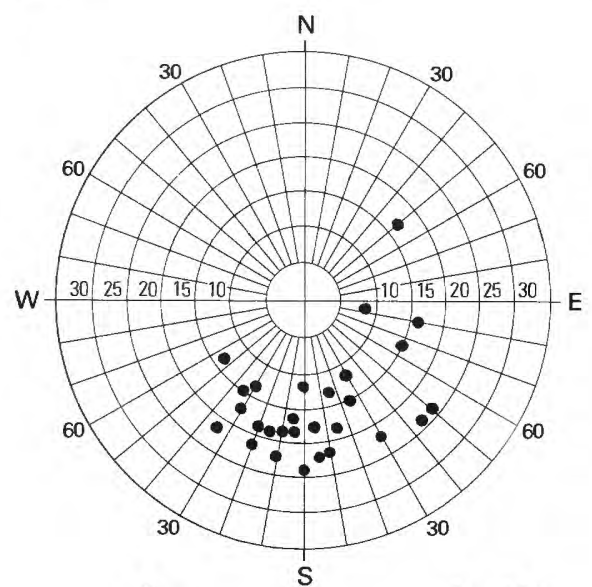

A

Av. 166

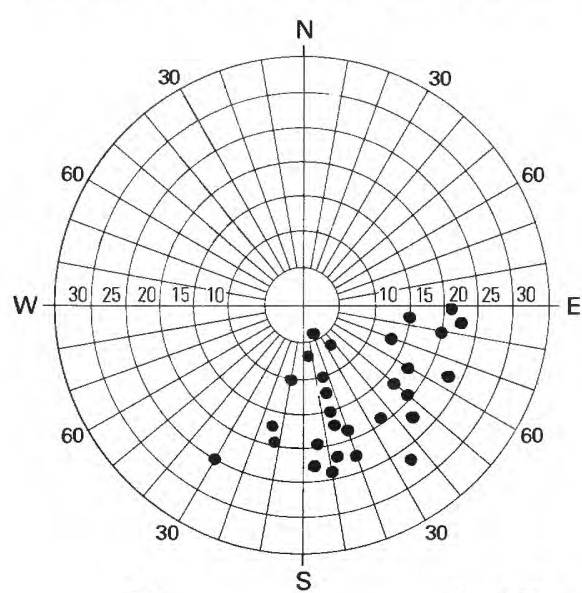

D

Av. 148

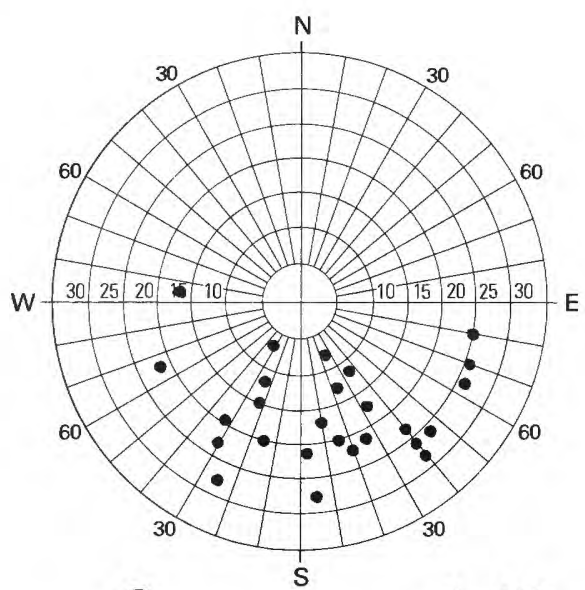

Av. 166

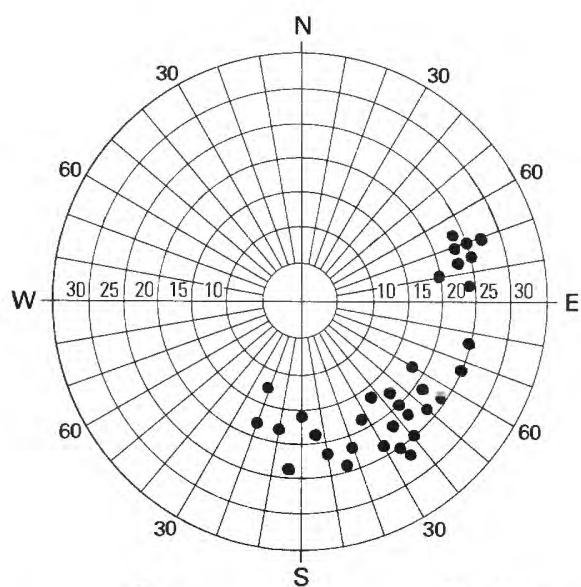

B

Av. 132

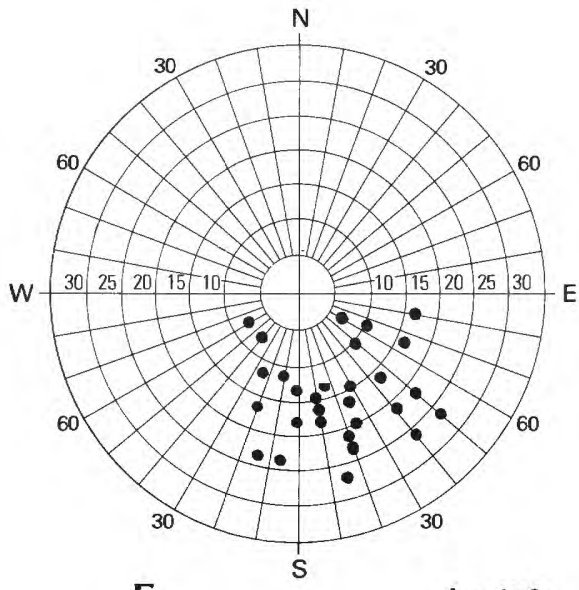

E

Av. 156

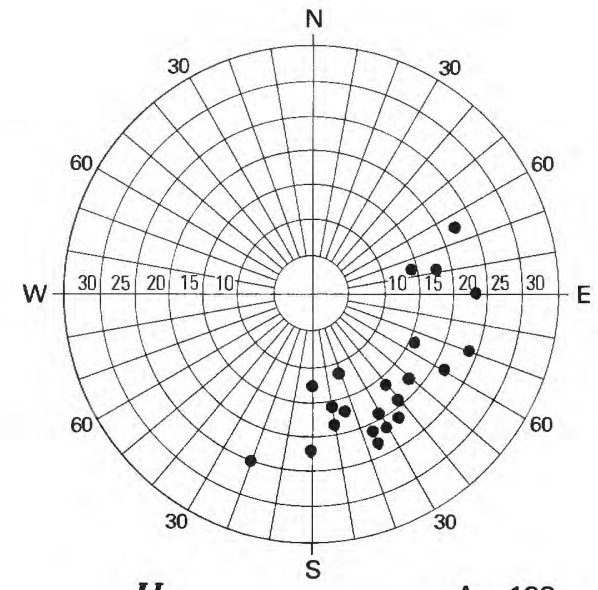

H

Av. 138

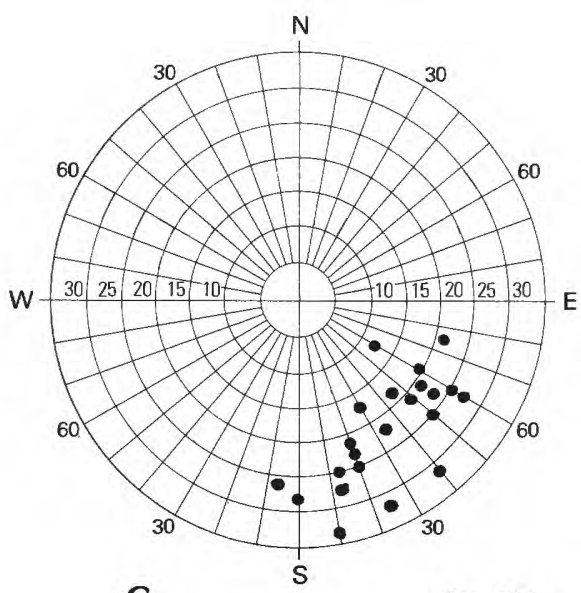

C

Av. 144

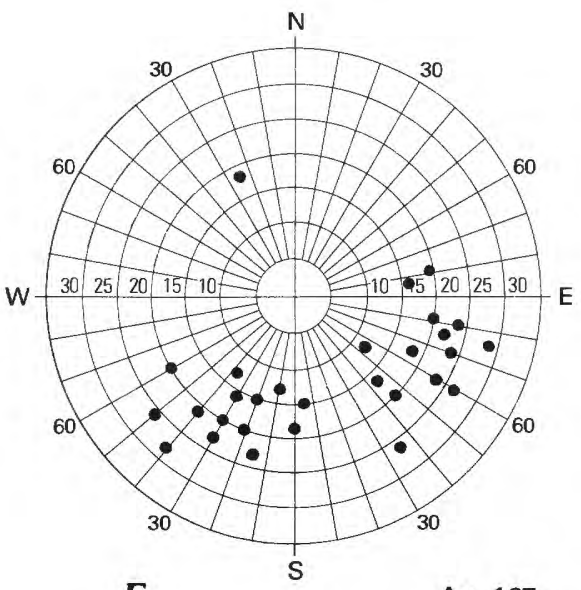

F

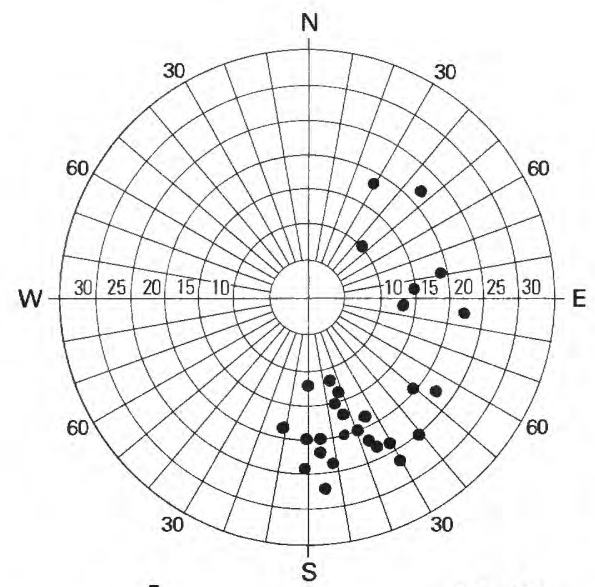

Av. 130 

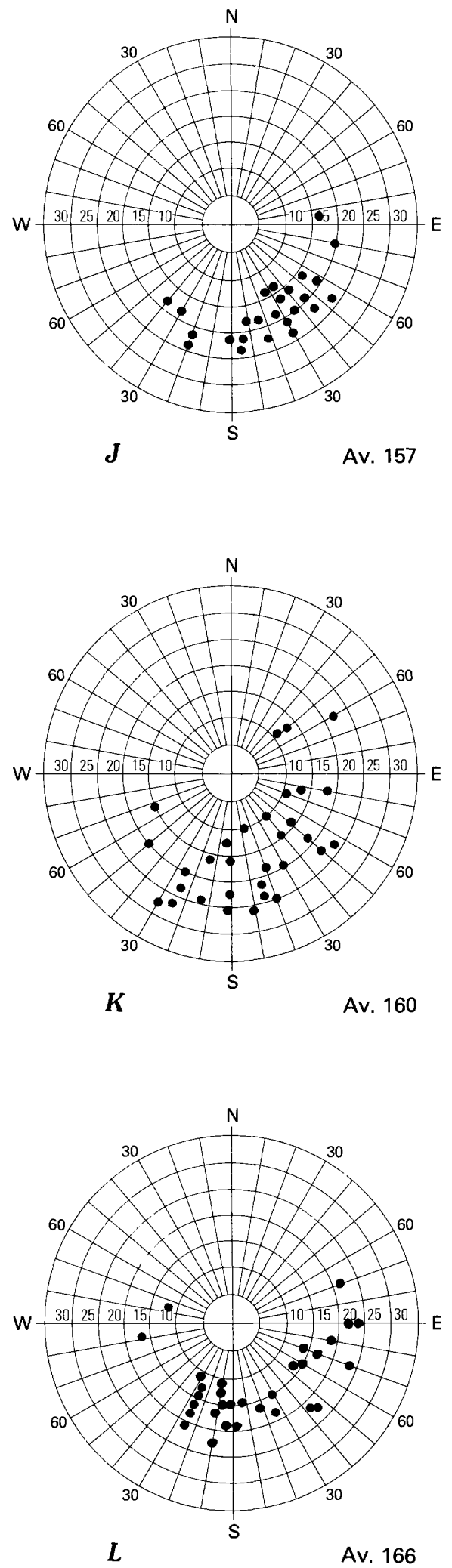

FIGURE K21.-Cross-strata dip direction, average dip direction (Av.), and degree of dip, plotted on polar coordinate sheets for Esplanade Sandstone, Grand Canyon region, Arizona. A, Twentynine Mile Canyon; $B, C$, Bunker Trail; $D$, Kaibab Trail, south; $E$, Bright Angel Trail; $F$, Hermit Trail; G, Kaibab Trail, north; $H$, Shinumo Trail; I, Bass Trail; I, Fishtail Canyon near Thunder River Trail; $K$, Havasu Canyon; and L, Tuckup Canyon. 


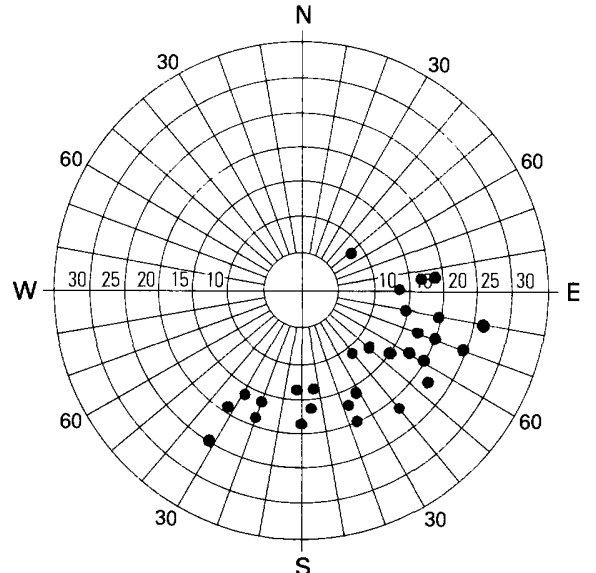

A

Av. 139

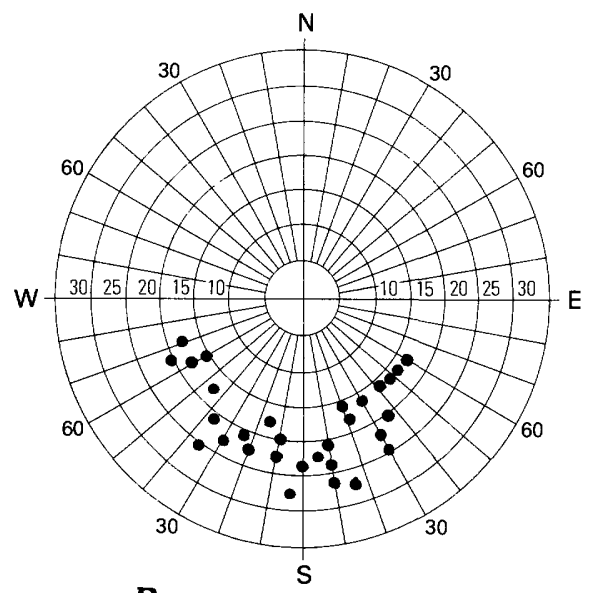

B

Av. 178

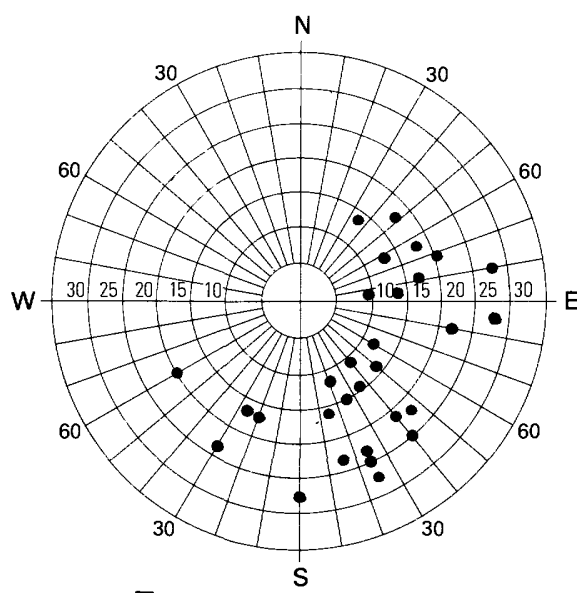

Av. 130

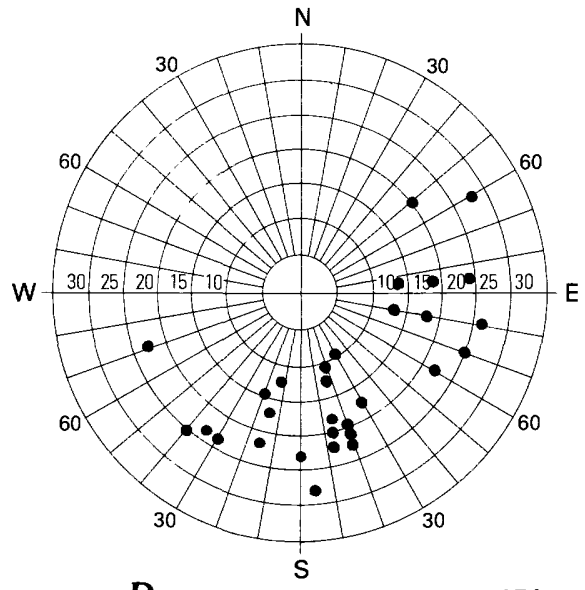

Av. 151

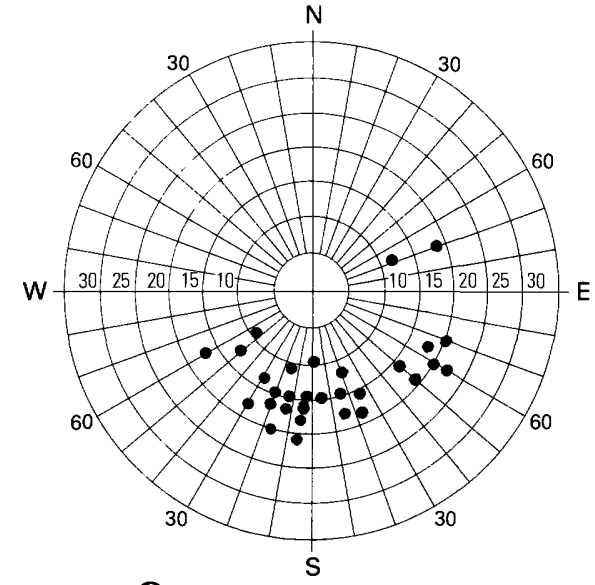

$\boldsymbol{G}$

Av. 169

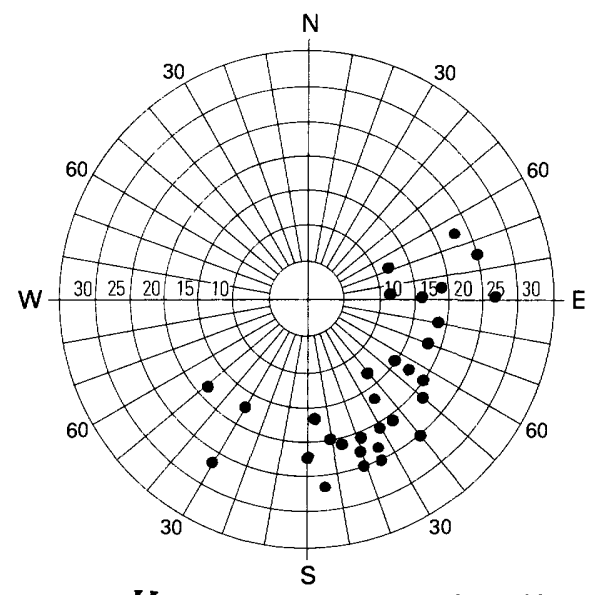

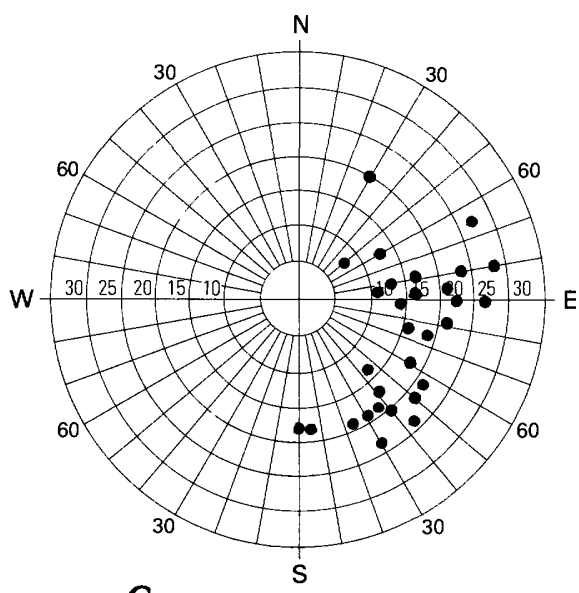

C

Av. 114

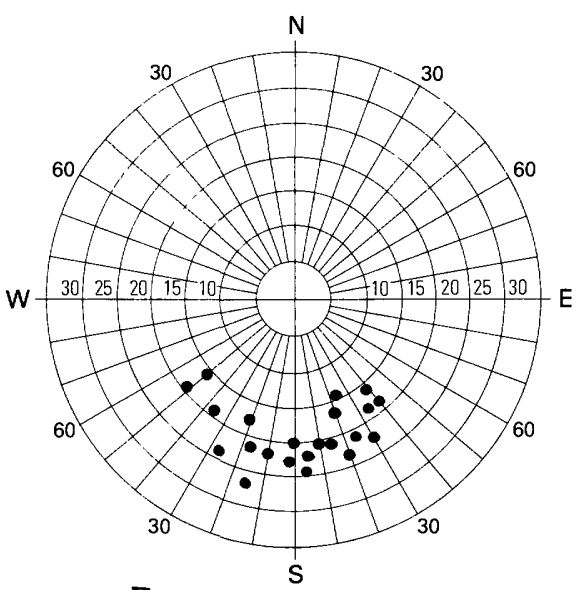

Av. 171

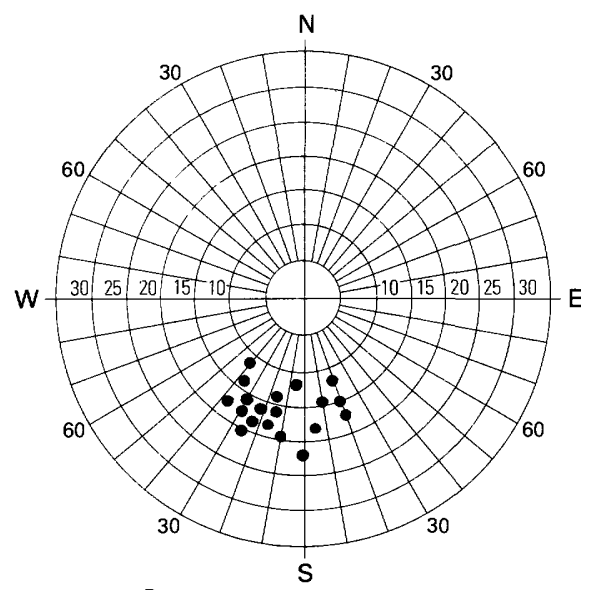

Av. 141

FIGURE K22.-Cross-strata dip direction, average dip direction (Av.), and degree of dip, plotted on polar coordinate sheets for the Esplanade Sandstone $(A-F)$, and Pakoon Limestone of MCNair, 1951 (G-I), Grand Canyon region, Arizona. A, Toroweap Valley; B, Prospect Valley; C, Whitmore Wash; $D$, Snap Canyon; $E$, Pigeon Wash; $F$, Hidden Canyon; $G$, Snap Canyon; $H$, Grand Gulch; and $I$, south Hidden Canyon. 


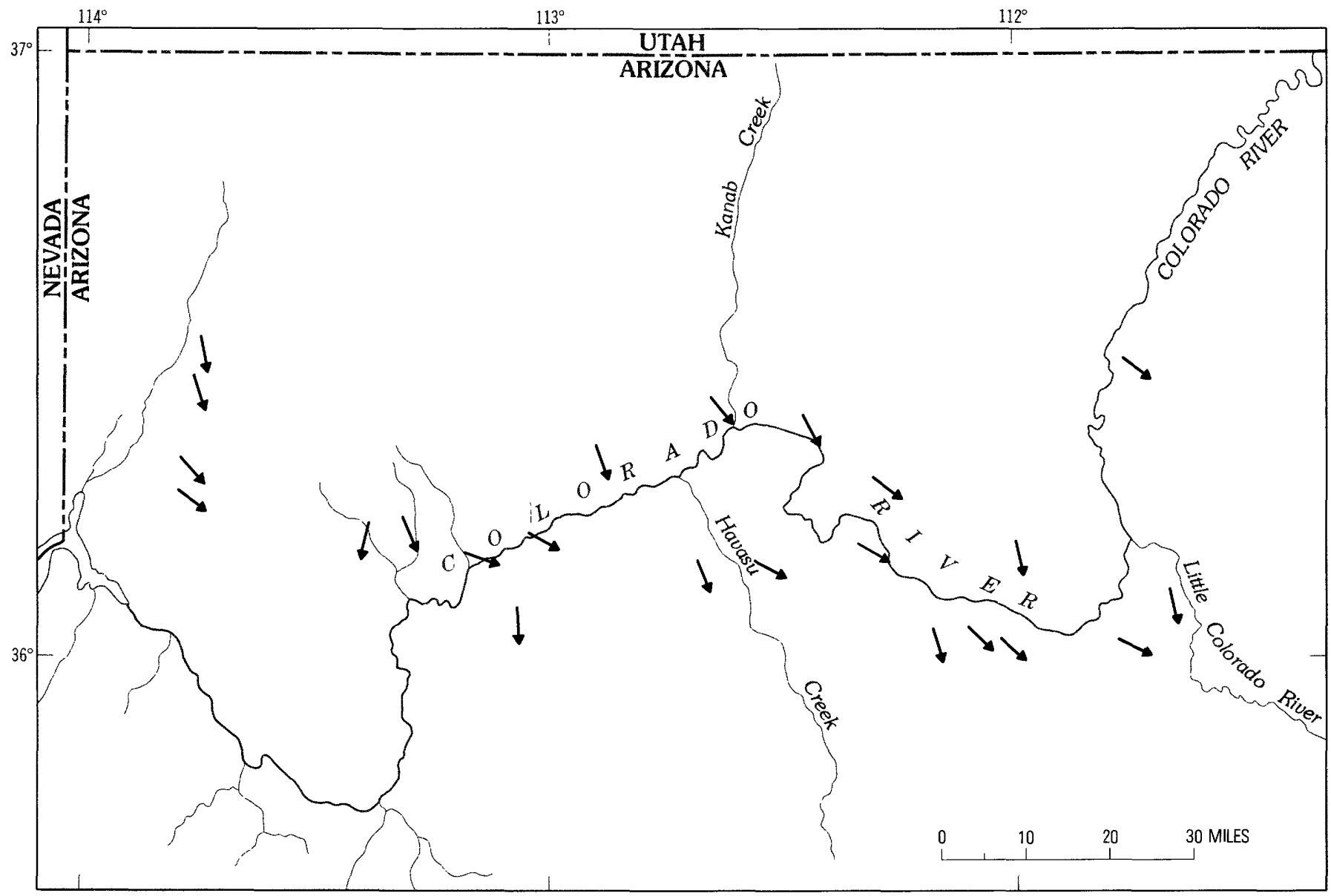

FIGURE K23.-Dip-direction vectors for cross-strata of the Esplanade Sandstone, Grand Canyon region, Arizona. Each arrow shows average direction determined from 30 measurements of cross-strata selected at random for the locality shown on map.

\section{Structureless sandstone}

Structureless sandstone that forms massive units ranging from a few to 20 or more feet in thickness are not uncommon in sections of eastern Grand Canyon. Near Grandview Trail, structureless units $23 \mathrm{ft}$ and $26 \mathrm{ft}$ thick are recorded and near Kaibab Trail, north, a unit $21 \mathrm{ft}$ thick is prominent. Despite the fact that at many places no trace of stratification can be detected in cliff faces and no evidence of laminae shows in thin-sections of the rock, the suspicion is strong that originally these units were sets or cosets of well-stratified sand. Evidence consists of (1) the texture and thickness of individual sand bodies, similar to those elsewhere that are well stratified, (2) some units that can be traced laterally into sets or cosets with well-defined crosslaminae, and (3) selected samples that show in X-ray the weak traces of dipping foreset planes and the cross-cutting tunnels or borings of wormlike animals (fig. N9).

\section{Small-scale structures in associated siltstone lenses}

Various small-scale structures occur commonly in the shaly or thin-bedded silty units that form parting beds or lenses in sandstone of the Esplanade. Such siltstone units locally contain the impressions of plants, especially Walchia sp., thin, irregular shrinkage cracks, the tracks of reptiles, rain pits, and the borings or burrows of wormlike animals. At a few places they are associated with large cuspate-type ripple marks. These structures are especially numerous at several localities near the Kaibab Trail, north, and have been recorded locally from other places throughout the region. 


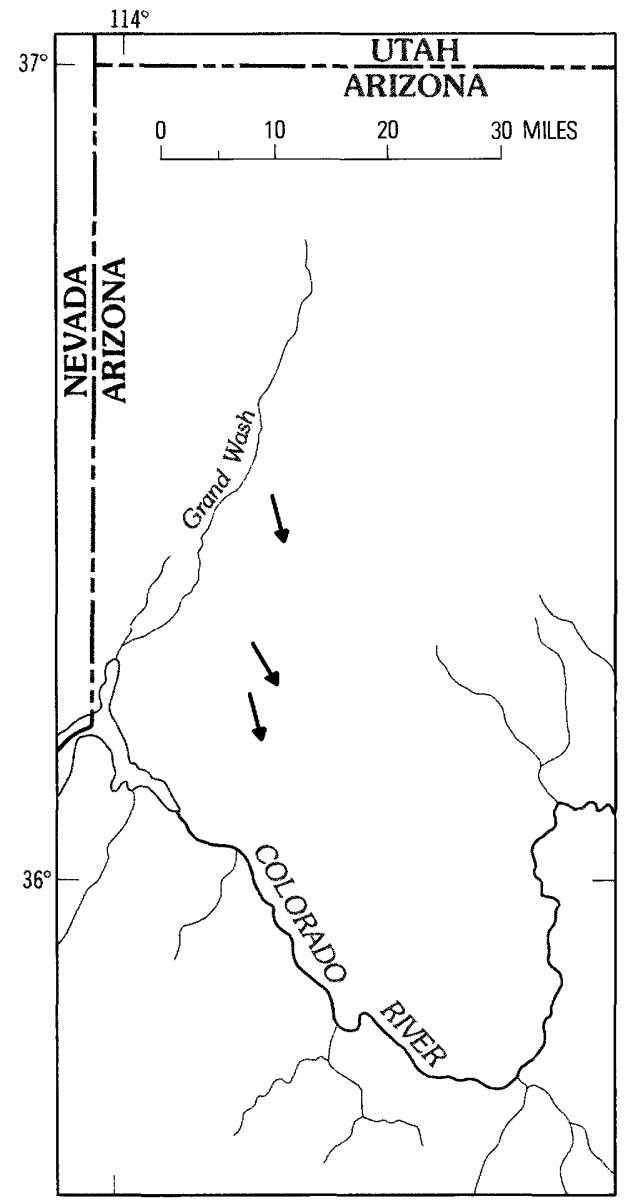

FIGURE K24.-Dip-direction vectors for cross-strata of the Pakoon Limestone (McNair, 1951), western Grand Canyon region, Arizona. Each arrow shows average direction determined from 30 readings of cross-strata selected at random for each locality shown on map.

\section{REFERENCES CITED}

Allen, J.R.L., 1963, Asymmetrical ripple marks and the origin of waterlaid cosets of cross-strata: Liverpool and Manchester Geological Journal, v. 3, p. 187-236.

Folk, R. L., 1968, Petrology of sedimentary rocks-University of Texas Geology 370K, 383L, 383M: Austin, Texas, Hemphills, 170 p.

Knight, S. H., 1929, The Fountain and the Casper Formations of the Laramie Basin: Wyoming University Publications in Science, Geology, v. 1, p. 1-82.

McKee, E. D., 1940, Three types of cross-lamination in Paleozoic rocks of northern Arizona: American Journal of Science, v. 238, p. 811-824.

McKee, E. D., and Weir, G. W., 1953, Terminology for stratification and cross-stratification in sedimentary rocks: Geological Society of American Bulletin, v. 64, p. 381-390.

McNair, A. H., 1951, Paleozoic stratigraphy of part of northwestern Arizona: American Association of Petroleum Geologists Bulletin, v. 35, no. 3, p. 503-541.

Payne, T. G., 1942, Stratigraphical analysis and environmental reconstruction: American Association of Petroleum Geologists Bulletin, v. 26 , no. 11 , p. $1697-1770$.

Reiche, Parry, 1938, An analysis of cross-lamination-The Coconino Sandstone: Journal of Geology, v. 46, no. 7, p. 906-932.

Shotton, F. W., 1937, The lower Bunter sandstones of North Worcestershire and East Shropshire: Geological Magazine, v. 74, no. 882, p. 547-550.

Wentworth, C. K., 1922, A scale of grade and class terms for clastic sediments: Journal of Geology, v. 30, no. 5, p. 377-392. 

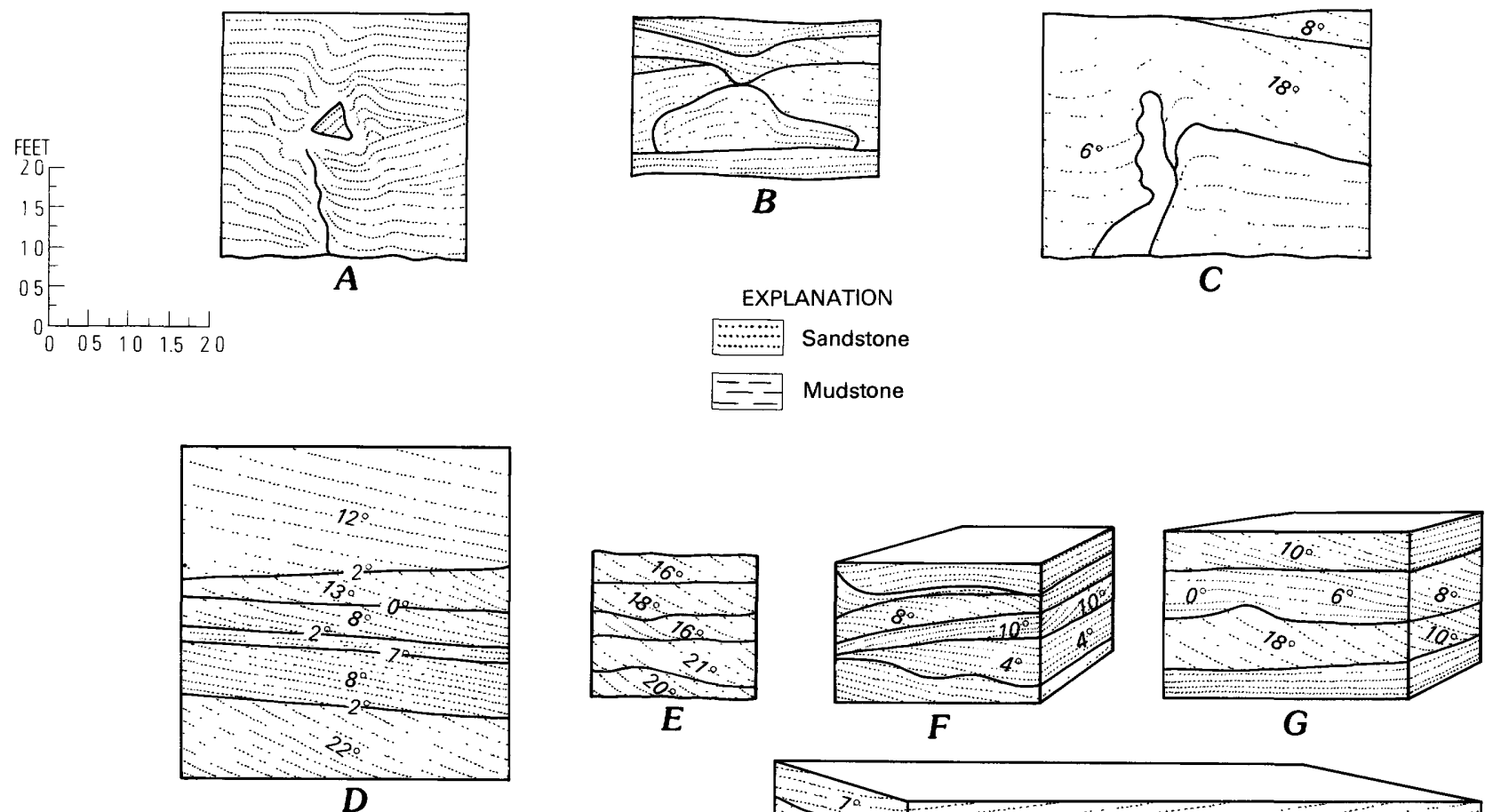

EXPL:

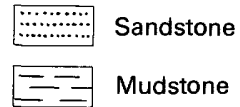

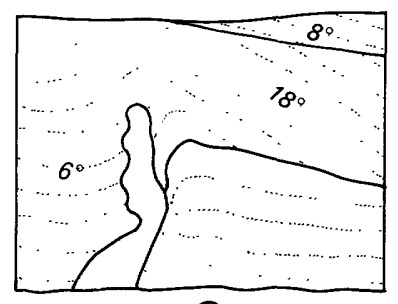

C

\section{D}

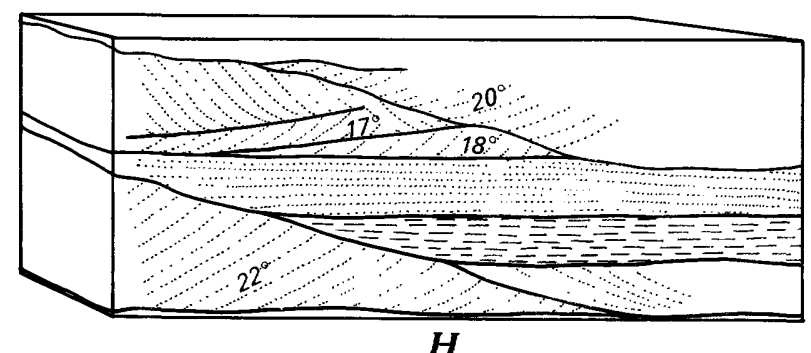

H
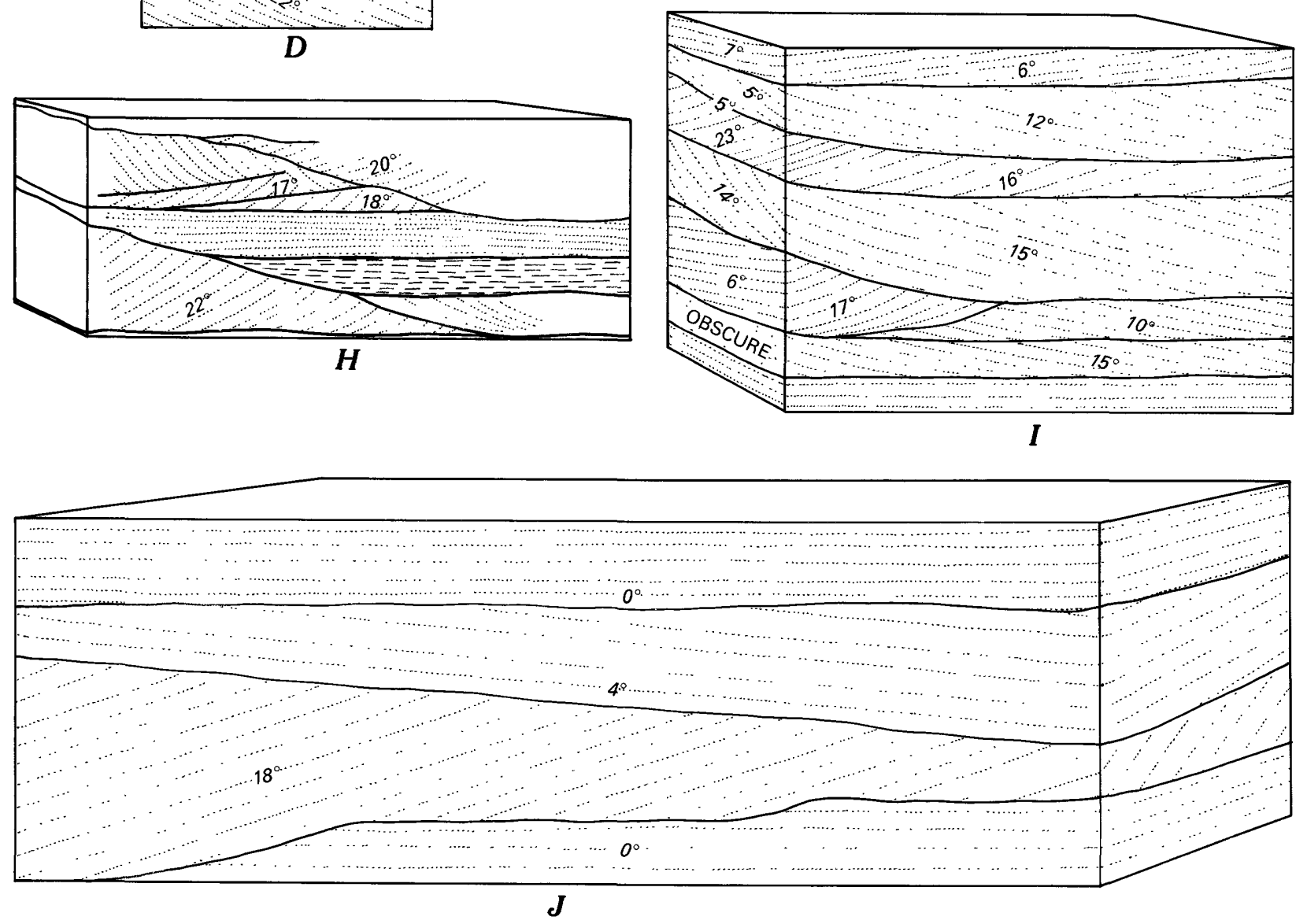

FIGURE K25.-Small- and medium-scale cross-strata and contorted bedding in the Esplanade Sandstone, Grand Canyon, Ariz. A, Contorted beds showing faulting, brecciation, and folding on small scale; Toroweap Point. B, Contorted beds illustrating complex structures resulting from penecontemporaneous deposition, erosion, and warping; Toroweap Point. $C$, Contorted beds probably resulting from local loading to produce fold and displacement of strata; Toroweap Point. $D$, Low-angle, wedge-planar and tabular-planar cross-strata, middle of Esplanade; Toroweap Point. E, Coset of small-scale tabular-planar cross-strata; Andrus Canyon. F, G, Low-angle wedge-planar crossstrata showing local penecontemporaneous warping and erosion; Toroweap Point. $H$, Compound cross-strata with trough-filling consisting of horizontal mud and sand beds; Prospect Valley. I, Small-scale tabular-planar, wedge-planar, and horizontal bed of sand; Hermit Trail. /, Compound-planar and horizontally bedded sandstone; middle of Esplanade Sandstone; Toroweap Point. 


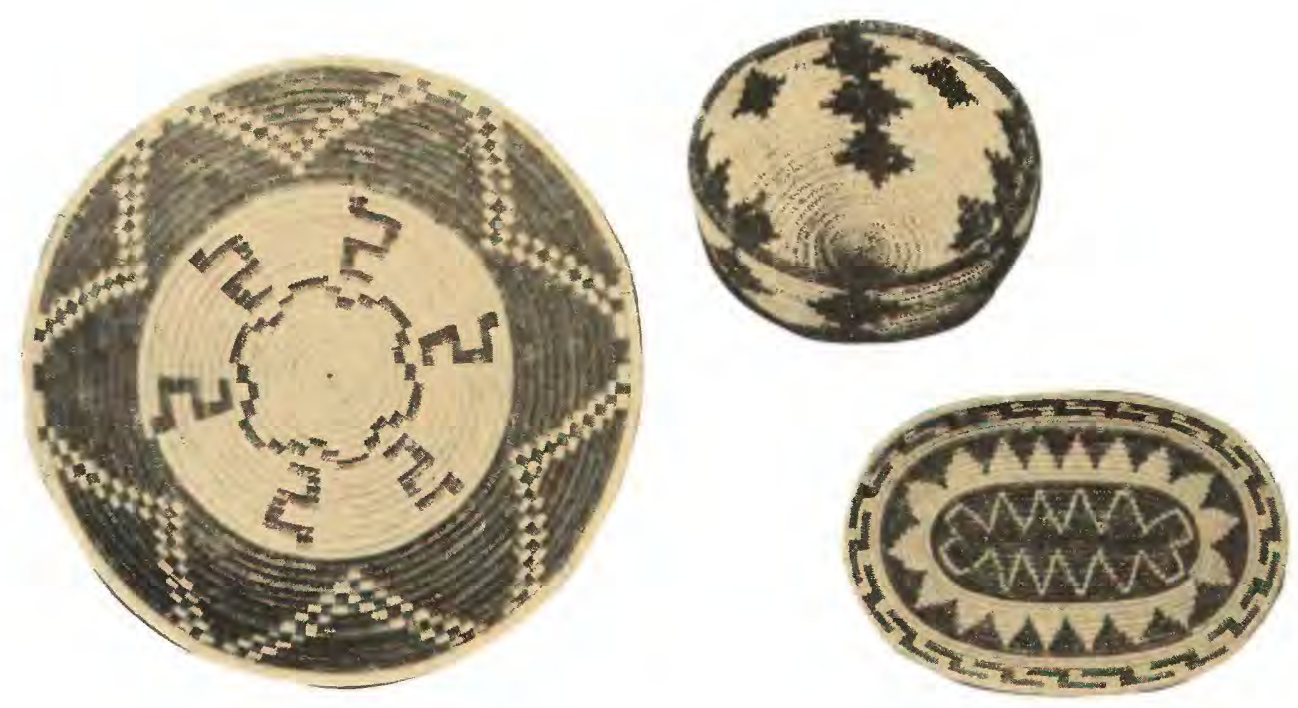

THE SUPAI GROUP OF GRAND CANYON

\section{ENVIRONMENT OF DEPOSITION OF SANDSTONE BODIES}

Chapter L

By EDWIN D. McKEE

\section{Contents}

Historical review ..................................... 247

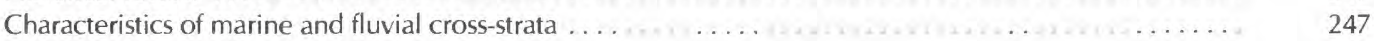

Nearshore marine stratification $\ldots 147$

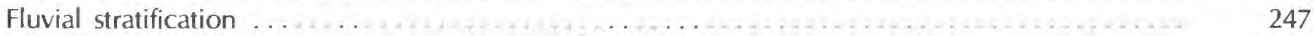

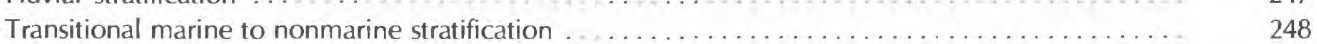

Some diagnostic attributes of cross-stratified sands . . . . . . . . . . . . . . . . . . . . . . . . 248

Abundance and diagnostic features of planar cross-strata $\ldots \ldots \ldots \ldots \ldots \ldots \ldots \ldots \ldots \ldots \ldots \ldots . \ldots \ldots$

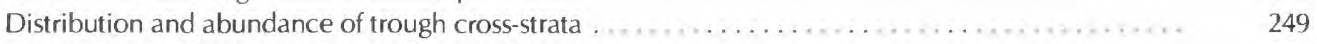

Associated horizontal and low-angle cross-strata . . . . . . . . . . . . . . . . . . . . . . . . . . . . . . . 253

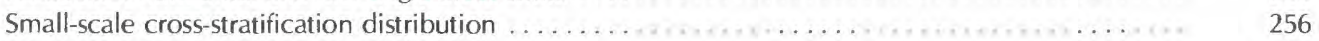

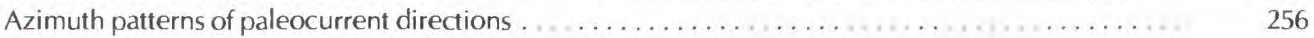

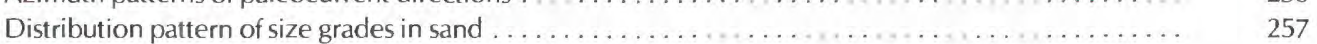

General scarcity of normal ripple marks . . . . . . . . . . . . . . . . . . . . . . . . . . 257

Gradation from calcareous sandstone to arenaceous limestone . . . . . . . . . . . . . . . . . 257

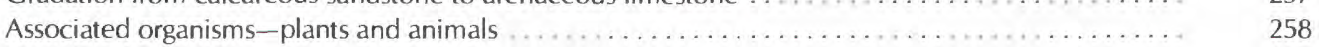

Associated evaporites . . . . . . 260

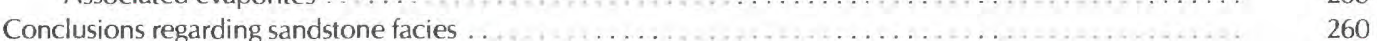

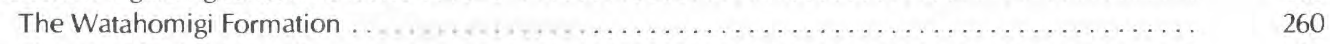

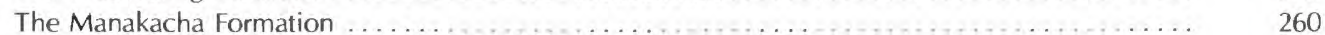

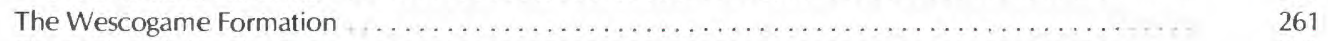

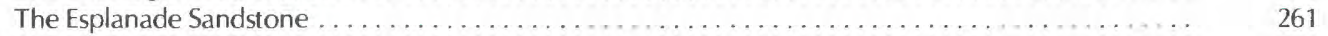

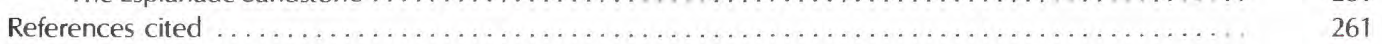




\section{Illustrations}

FIGURE L1. Sketches of cross-strata in cliff unit of the Manakacha Formation $\ldots \ldots \ldots \ldots \ldots \ldots \ldots$

L2. Maps showing percentage of cross-strata that are trough type in sand bodies of each formation of the Supai Group . . . . . . . . . . . . . . . . . . . . . .

L3. Sketches of cross-strata, wedge-planar and trough types, in sandstone of the Wescogame

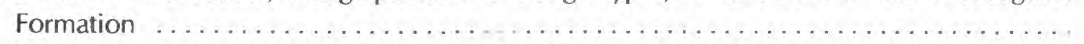

L4. Photographs showing large-, medium-, and small-scale cross-strata in sandstone of the

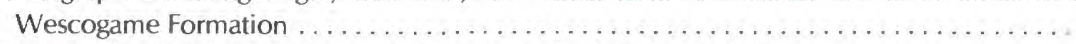

L5. Photographs showing types of cross-strata in the Esplanade Sandstone

\section{Table}

TABLE L1. Size determinations for some megaripples and sand waves responsible for foreset cross-

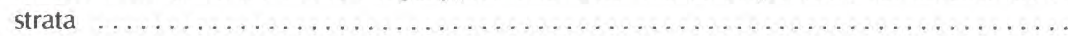




\section{HISTORICAL REVIEW}

Interpretation of the environment of deposition of the Supai Group was first considered in detail and discussed by Schuchert (1918, p. 357) when studying the "Carboniferous of Grand Canyon" along the Hermit Trail. Largely because of the association of mud cracks, rain pits, amphibian tracks, and impressions of land plants, he concluded that the Supai, as developed in that area, was "of fresh-water origin on a delta flood-plain of a river or rivers fronting the sea." He further stated that basal beds containing oolites "may have been formed under brackish water, but elsewhere the Supai is a typical series of continental floodplain deposits accumulated on a subsiding area under a semi-arid climate."

Recognition of a terrestrial genesis for the Supai was given considerable support through the studies of fossil plants made by David White in the late 1920's (White, 1927, 1928, 1929). Although the work by White was mainly on the overlying Hermit Shale, which seems unquestionably of fluviatile origin, many observations in the Supai led him to conclude (White, 1929, p. 10) that "the upper and middle parts ${ }^{* * *}$ are terrestrial-laid down on an old floodplain." Thus, the Supai Group came to be recognized during the first half of the present century as a classic example of deposition in a continental environment, based on evidence from a limited area in eastern Grand Canyon and from a few horizons only, in that area.

Starting with the discovery of numerous marine invertebrate fossils in the Watahomigi Formation at Toroweap Point in the early 1940's and followed by other unequivocal evidence of a nonterrestrial environment, from various parts of the region and at numerous horizons, a strong case for the marine origin of the Supai gradually developed with the detailed studies of recent decades.

Attempting to assess the evidence for and against a marine or terrestrial environment, it now is clear that no single simple explanation is possible. The Supai Group not only consists of sequences of distinctive facies of equivalent age, but also represents a number of transgressions so that both land and sea deposits form a complex horizontal and vertical pattern. The end members in this patternstrictly marine and strictly continental facies-are relatively easy to recognize by various diagnostic features as discussed in chapter I on transgressions and regressions. The facies are represented primarily by carbonate rocks and associated marine faunas at one extreme, and by mudstones and siltstones with plants and subaerial structures at the other. But the bulk of the strata between these extremes in the Supai-the dominantly cross-stratified sandstones with few fossils-can not easily be interpreted. Their genesis constitutes the principal subject matter of this chapter.

\section{CHARACTERISTICS OF MARINE AND FLUVIAL CROSS-STRATA}

The principle that down-current migration of megaripples (aqueous dunes) is responsible for the development of most medium- and large-scale cross-stratification is well established. This has been shown to apply to meandering river systems (Frazier and Osanik, 1961; Allen, 1965; Bernard and others, 1970), to braided river systems (Williams, 1968, 1971; Smith, 1970; Collison, 1970), to nearshore sand bodies (Clifton and others, 1971; Davidson-Arnott and Greenwood, 1974), and to several other environments. Cross-strata formed from megaripples occur nearly everywhere that bedforms commonly referred to as sand waves transport sediment loads down-current. Straightcrested (transverse) megaripples form the planar type cross-strata, whereas lunate and linguoid megaripples develop into medium- or large-scale, trough cross-stratification (Allen, 1965; Clifton, 1976, p. 143).

\section{Nearshore marine stratification}

Characteristic sedimentary structures of sand bodies in nearshore coastal areas have been examined and documented by several detailed studies of recent years. Diagnostic stratification of a high-energy, nonbarred coast as represented by nearshore areas in Oregon and Washington were studied and described by Clifton (1976). Structures of a low-energy barrier-bar shoreline in New Brunswick, Canada, have been recorded and illustrated in the works of Davidson-Arnott and Greenwood (1974; 1976). These studies provide considerable information concerning criteria by which the nearshore marine environments should be recognizable in ancient sediments.

\section{Fluvial stratification}

The principal types of fluvial systems commonly recognized in modern sand environments are the meandering stream and the braided stream. Sedimentary structures formed in both of these types, like those of nearshore marine sands, contain an abundance of planar cross-strata resulting from migrating sand bodies. Fluvial sands, however, also include in many places large-scale trough cross-strata. Additional characteristic features of a fluvial sand environment that help to distinguish these deposits are horizontal strata of the upper flow regime and migrating ripple or climbing ripple structures of lower energy conditions.

Structures characteristic of meandering river systems have been described by numerous geologists, for example 
Sundborg (1956), Harms, MacKenzie, and McCubbin (1963), McGowen and Garner (1975), and Bernard and others (1970). Models of point bars, which are the principal units of deposition through lateral and downstream accretion, have been developed by Bernard and Major (1963), Allen (1965), and others. Thus, the process of sedimentation through erosion along concave banks and deposition on convex points to form a migrating sand body, apparently is well recognized. Most mud and silt deposits are restricted to bordering flood basins and levees.

In the point-bar models, referred to above, two features useful for recognition are suggested: (1) upward fining of sediment, and (2) a characteristic succession of stratification consisting of, in ascending order, trough crossstratification, horizontal lamination, and ripple structures. However, point bars of other types have been recorded as, for example, deposits of the Colorado River in Texas, and the Amite in Louisiana described by McGowen and Garner (1975) in which "no systematic upward change in grain size is apparent" and the vertical sequence of sedimentary structures differs from that of the standard models.

Summarizing the characteristic features of meandering stream deposits that might be useful criteria in the recognition of ancient fluvial systems of the meander type, the following are suggested by Walker (1976, p. 101):

1. Commonly, but not necessarily, a floor of lag gravel with associated plant debris and trash.

2. Large trough cross-strata (as much as $3 \mathrm{ft}$ thick) formed mostly from sinuous crested dune sands or megaripples.

3. Small trough structures formed from normal ripple migration in sand.

4. Horizontal laminations at various places in the sequence, resulting from extra-high current velocities or shallowing depths.

5. Fine sediments, such as silts and clays, deposited during overbank flooding to form vertical accretion deposits on the flood plains or filling abandoned channels, lake basins, and other depressions. These strata consist largely of small-scale ripple structures and flat beds formed from settling. They may contain root traces or caliche.

The braided stream environment differs from the meander-type largely because of its basic controls, which are high gradient, noncontinuous discharge rate, unconfined flow, high ratio of bed load to suspended load, and weak development of levees (Brown, 1973, p. 12). These controls characteristically bring about a high sand-mud ratio, a wide rather than narrow sand body, and a straight rather than meandering course. Although typically developed in upstream areas (Brown, 1973, figs. 8 and 9), braided streams may also form in coastal areas as fan deltas where mountains are nearby or in regions of aridity where vegetation is sparse.

Sedimentary structures of braided stream systems as described by Off (1963), Smith (1970), and Williams (1968) are primarily those of migrating transverse bars or sand waves, of longitudinal bars, and of channel-fill deposits. The distinguishing features of the structures according to Brown (1973, p. 13) are (1) few varieties of stratification, (2) mostly horizontal strata, tabular-planar cross-strata and (or) trough cross-strata, (3) rare ripple cross-strata, (4) high proportions of sand, (5) multilateral sand bodies with high ratios of width-thickness, and (6) no definite trends in vertical variation of grain size or sedimentary structure.

Proportions of the various types of cross-strata in braided streams apparently vary widely with different environments and geographic settings. An increase in the ratio of cross-stratification to horizontal stratification occurs downstream along the Platte River in Nebraska, U.S.A. (Smith, 1970). An abundance of large-scale trough crossstrata in channel-sand deposits in the piedmont plain of South Australia is recorded by Williams (1968).

\section{Transitional marine to nonmarine stratification}

Environments intermediate between nearshore marine and fluvial are estuarine, tidal delta, and channel-mouth bar, in which sand deposits show some features of the sea and some of the land. Such mixtures of marine and continental deposits commonly occur as extensive areas of large sedimentation and probably account for many accumulations in the geologic record.

\section{SOME DIAGNOSTIC ATTRIBUTES OF CROSS-STRATIFIED SANDS}

Sandstone facies in each of the four formations of the Supai Group are examined in this study by analyzing for each unit the information available concerning 10 selected attributes of the rock. It was hoped that evidence would be procured in this way to distinguish between, first, the continental and the marine sands, and second, between meander-belt and braided-stream environments in the continental deposits and between those formed as barrier bars, estuaries, nearshore marine deposits and tidal deltas in the marine deposits. The attributes of the various sandstones to be discussed and interpreted on the following pages are: 
1. Abundance and diagnostic features of planar crossstrata.

2. Distribution and abundance of trough cross-strata.

3. Associated horizontal and low-angle cross-strata.

4. Distribution of small-scale cross-strata.

5. Azimuth patterns of paleocurrent dip directions.

6. Distribution pattern of size grades in sand.

7. General scarcity of normal ripple marks.

8. Gradation from calcareous sandstone to arenaceous limestone.

9. Associated organisms-plants, animals.

10. Associated evaporites.

\section{Abundance and diagnostic features of planar cross-strata}

By far the most abundant structure in sand bodies of the Supai Group is planar cross-stratification of both tabular and wedge type in roughly equal proportions (table K4). The reason for the difference in form between the tabular and wedge varieties is not clearly understood, but because the horizonal and sloping surfaces that distinguish them might have some important significance not yet recognized, the two were separated in field counts and investigations. Here they will be treated together under the name of planar cross-strata.

The abundance of planar cross-strata in the Manakacha and Wescogame Formations, and Esplanade Sandstone can be considered normal for sand-wave deposition in any of numerous environments. In an attempt to discover which environment is represented by the sand bodies in each of these formations, various attributes of the cross-strata were studied statistically throughout the region. These include: (1) length of foresets (table K4) - small scale, $<1 \mathrm{ft}$, medium scale, 1-20 ft, large scale, $>20 \mathrm{ft}$; (2) number of sets in a vertical sequence (table K5); (3) thickness of coset (table K5); (4) foreset dip degree (table K6) - high angle, $20^{\circ}$ or more, low angle $<20^{\circ}$.

Perhaps the most potentially significant of the various attributes of the cross-strata examined in the upper three formations of the Supai (Manakacha, Wescogame, and Esplanade) is the length of the foresets, referred to as the scale of the cross-strata. As shown in table K4, extremely few small-scale structures (ripple laminae, climbing ripples) were noted in any of these formations, although a moderate number was found in the underlying Watahomigi. Medium-scale cross-strata were approximately twice as numerous as large-scale in all three formations. Most important, however, is the number of sets in the Manakacha containing outstandingly long foresets (30-100 ft), especially in the central Grand Canyon area. It seems doubtful that planes of this magnitude could represent the fronts of migrating megaripples; the alternative, that they were formed as foresets of small (Gilbert-type) deltas seems more likely.

In order to obtain an appreciation of the dimensions of foresets developed by the movement of sand waves in various modern environments, a search was made in the literature for foreset measurements. Very few data were found for dip surfaces of cross-strata, but measurements of sand waves and (or) megaripples were numerous and are believed to approximate dimensions of foresets in crossstrata formed by them (table L1).

\section{Distribution and abundance of trough cross-strata}

The abundance and presence or absence of trough crossstrata within sand bodies of the Supai Group is considered important evidence bearing on the depositional environment of these strata. Trough-type structures are distinctive and relatively easy to recognize. Furthermore, in recent years many observations have been made on modern analogs so that today a considerable fund of information has accumulated relative to the distribution, variation, and genesis of trough structures in sand bodies.

Trough cross-stratification is the product of deposition from migrating megaripples or subaqueous dunes of lunate and linguoid form or of sinuous-crested ridges that are compound varieties of these (Allen, 1965; Williams, 1971; Walker, 1976, p. 105). The relative abundance or the absence of this structure, therefore, should be an indication of the type of environment in which a particular sand body was developed. Although megaripples are known to form in many different environments, they are much more common in some facies than in others and differ greatly in size and shape.

Fluvial environments, in general, are favorable to the forming of trough cross-stratification (Allen, 1963a, p. 219), but the meandering stream, because of its point-bar development, is especially characterized by this structure. The abundance of trough cross-strata in this facies was emphasized by Frazier and Osanik (1961, p. 121) in their description of an exposure in the Mississippi River delta where they state: "The entire exposed section is characterized by festoon (trough) crossbedding-the only type of bedding present." Further, Bernard and Major (1963, p. 350), in a description of the recent meander belt deposits of the Brazos River, Texas, stated that the normal occurrence of festoon or trough structure constitutes one of four zones in each point bar.

Aside from its abundance, trough cross-strata formed by meandering streams should be recognizable because of the common association with it of leaves, sticks, and other trash and the accumulation of lag gravel on the scour floors (Frazier and Osanik, 1961, p. 136; Bernard and 
TABLE L1.-Size determinations for some megaripples and sand waves responsible for foreset cross-strata [Leaders (--) indicate no data; max., maximum]

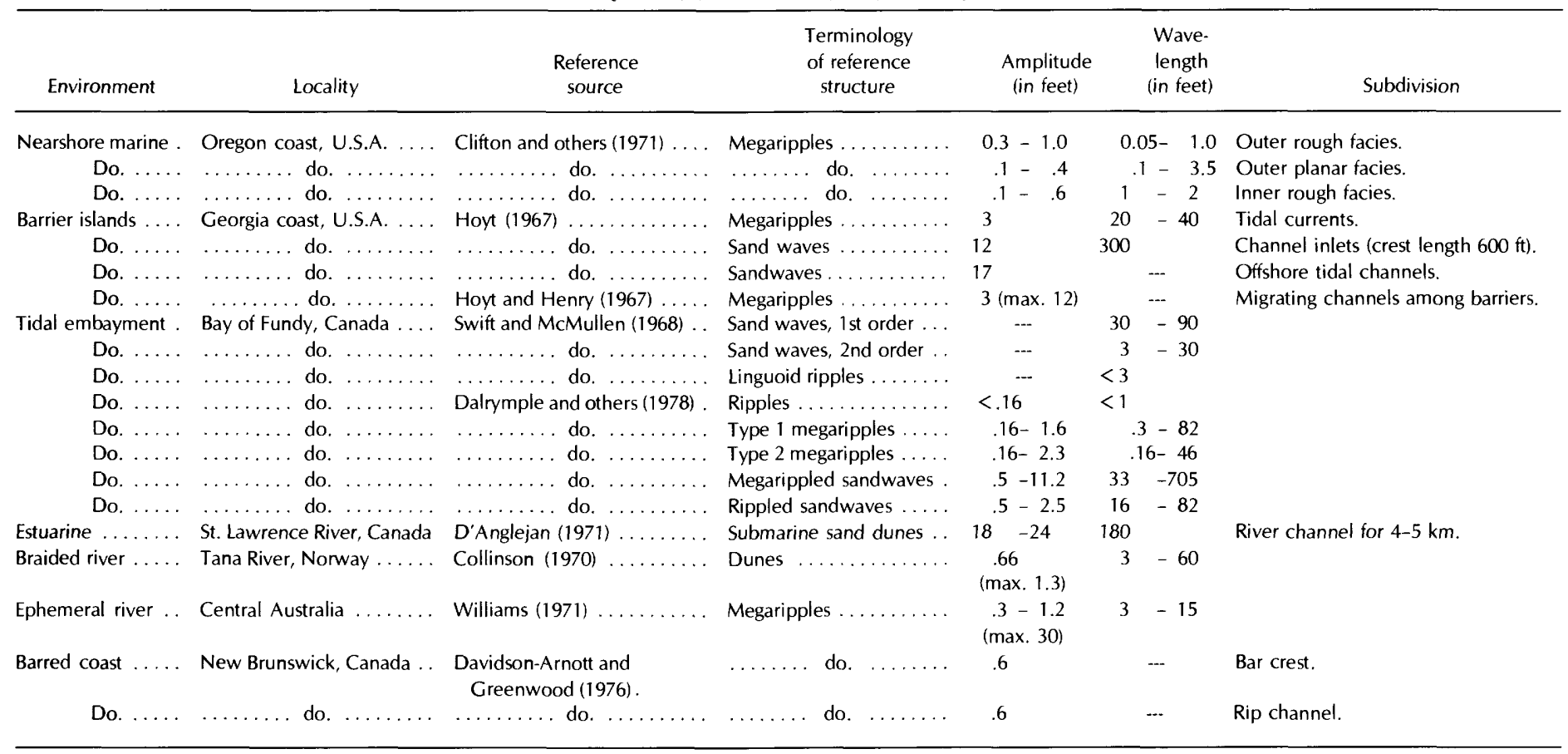

others, 1970, fig. 21). Additional evidence may be furnished by the upward gradation from troughs to small-scale or climbing-ripple structures, to laminated clays and silts of channel abandonment at the top. In some places, natural levee sediments may overlie the point-bar sequence.

But trough structure is by no means restricted to point bars of meandering streams. Braided stream deposits of the Platte River, Colorado and Nebraska, are described by Smith (1970, p. 3002) as containing "varying amounts of trough and planar cross-stratification" in longitudinal bars and "trough cross-strata" in upstream parts of horizontal bars. Ephemeral streams of central Australia, according to Williams (1971, p. 21), contain "large-scale trough crossstratification ${ }^{* *}$ in channel sands beneath trains of largescale ripples, cosets erosively overlying older flood deposits. The [trough] structure formed about 60 percent of the 1967 deposits." Many other records of large trough structures, involving various types of streams, but always related to megaripple migration, have been described in the literature.

Trough cross-strata in sand of the marine nearshore zone, as described by Clifton, Hunter, and Phillips (1971, p. 656) for the Oregon Coast, is developed in several of the "facies" or belts that parallel the shore at different depths. Relatively small troughs form in the "inner rough facies" or surf zone and are parallel to the strand. In the "outer rough facies," or buildup zone, lunate megaripples produce crossstrata with a trough geometry. These trough-structures, with landward-facing slipfaces, seem to be very irregular (weakly developed festoon patterns) and are restricted to a very narrow belt " $30-120 \mathrm{~m}$ wide" (10-40 ft), bounded by facies with different hydrodynamic controls and containing structures of contrasting types.

In the Supai Group as a whole, trough cross-strata may be classed as uncommon, and relatively little of it shows good festoon development. From the standpoint of interpreting depositional environments, however, the distribution of this structure for each formation and also for each principal geographic area, must be considered separately. Accordingly, the proportions of trough to other types of cross-strata have been calculated with respect to both time and space.

The Watahomigi is not discussed here in connection with types of cross-strata because, as already pointed out, it contains only very small sand bodies. These have some small-scale cross-stratification, but medium- to large-scale types have not been recorded.

The Manakacha, in contrast, contains extensive, thick units of sandstone that are highly cross-stratified as described and illustrated (fig. L1) and in chapter K (figs. K5, K6). Medium- and large-scale trough cross-stratification is absent in the Manakacha Formation (table K4). Sandstone structure in this formation consists of medium- to largescale planar cross-beds of both tabular and wedge type, and of a moderate amount of horizontal stratification.

The lack of trough-type cross-strata in Manakacha sandstone bodies is believed to constitute strong evidence of a nonfluviatile origin for most of this formation in the Grand 

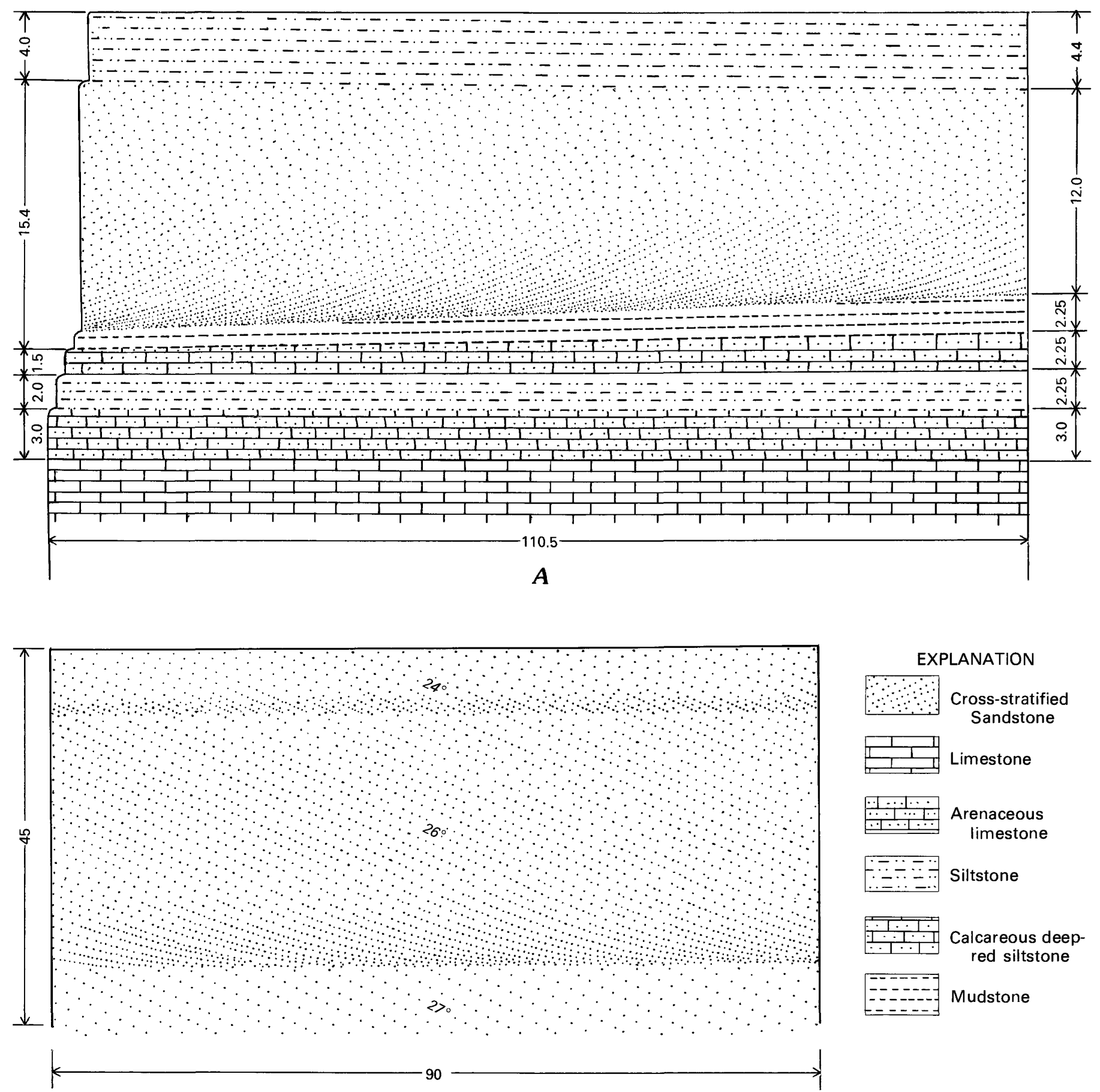

B

FIGURE L1.-Cross-strata in cliff unit of the Manakacha Formation in Grand Canyon, Ariz. A, Tabular-planar set in sequence of strata including siltstones, mudstones, arenaceous limestones, and limestones; Bright Angel Trail. B, Coset composed of three tabular-planar sets of sandstone cross-strata; Havasu Canyon. Vertical and horizontal distances in feet.

Canyon area. The large sandstone body involved contains mostly planar structures and grades into arenaceous limestone with similar structures to the west. This is believed to indicate deposits of a shallow-water, coastal area.

The Wescogame Formation, unlike the Manakacha, in- cludes a large proportion of trough cross-strata within sandstone units. In fact, considerably more trough structures occur in this formation than in any other of the Supai Group. In eastern Grand Canyon they represent 22.4 percent of all cross-strata in the Wescogame, in central Grand 
Canyon 50.0 percent, and in western Grand Canyon 27.0 percent (fig. L2).
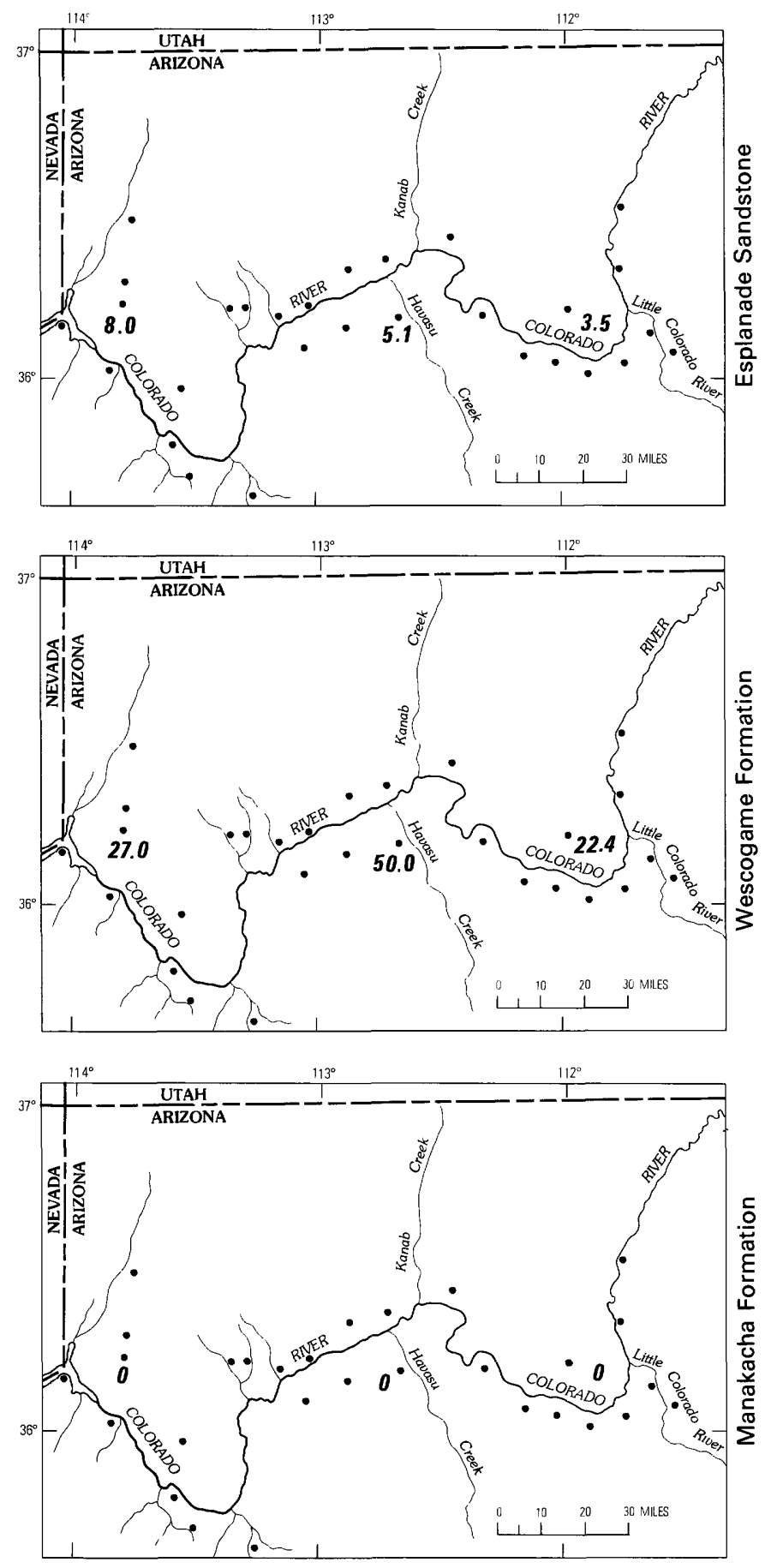

FIGURE L2.-Percentage of cross-strata that are trough-type in sand bodies of upper three formations of Supai Group, Grand Canyon region, Arizona.
Much of the trough cross-stratification in the Wescogame, especially in the central part of Grand Canyon, is large-scale, forming wide, shallow troughs that make a typical festoon pattern (figs. K11-K14; L3, L4). Mostly, the troughs are filled symmetrically, but some of them display very asymmetrical patterns of gently curving laminae that are tangential at their bases. Groups of festoon or trough structures in some places compose entire units or cosets, 6-12 ft thick (table K5), with few other structures associated, but elsewhere they occur in various combinations with wedge or tabular-planar sets.

The interpretation assigned to the widespread development of trough-type structures in the Wescogame throughout the Grand Canyon embayment is that deposition of the sand bodies was in large part by sand waves of a fluvial system. Furthermore, evidence seems to favor a braidedstream environment rather than one of meander type, because no ripple laminae or climbing ripple structures are known to overlie the troughs, and because neither pebble lag nor plant debris seem to be associated with them (Frazier and Osanik, 1961).

Additional structures support a general fluvial environment hypothesis for the Wescogame. These structures consist of: (1) reactivation surfaces (Harms and others, 1975, p. 51), present in various localities, (2) bottomsets and topsets, as well as foresets (fig. K14F), preserved locally and indicating deposition of small Gilbert-type deltas, and (3) clearly preserved footprints (figs. E21, E22) of quadrupeds climbing up foreset surfaces.

In the Esplanade Sandstone, the main or cliff unit is characterized throughout by cosets of strata and crossstrata as much as 30 or more feet thick (table K5). Included within the cosets are numerous thin units of flat-lying or horizontal beds that are interpreted as deposits of the upper flow regime; however, a great preponderance of all structures are planar-type cross-strata with wedge and tabular forms (table K4) in about equal proportions (figs. K20; L5). Trough cross-strata occur in numerous places, but cannot be considered common anywhere.

Origin of the Esplanade Sandstone seems less easy to interpret on the basis of cross-strata than either the Manakacha, in which trough structures are absent, or the Wescogame, in which they are numerous. Tabulations made at various sections throughout Grand Canyon indicate that about 8.0 percent of structures in the western part of the region are trough type; about 5.1 percent in the central part and only 3.5 percent in the eastern part are of this type. Thus, the amount of lunate or linguoid megaripples represented in all parts of the region is not sufficiently great to form compelling evidence of a fluvial environment. Conclusions concerning the genesis of this sand body obviously must depend on evidence other than that of cross-stratification, and this evidence is presented later. 


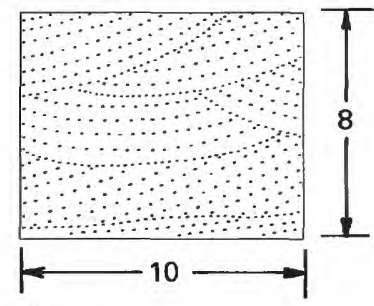

A

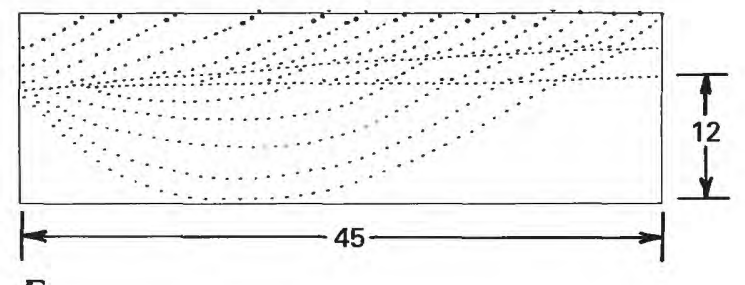

E

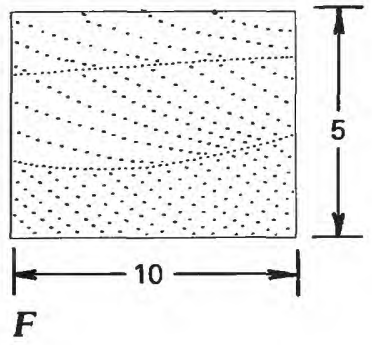

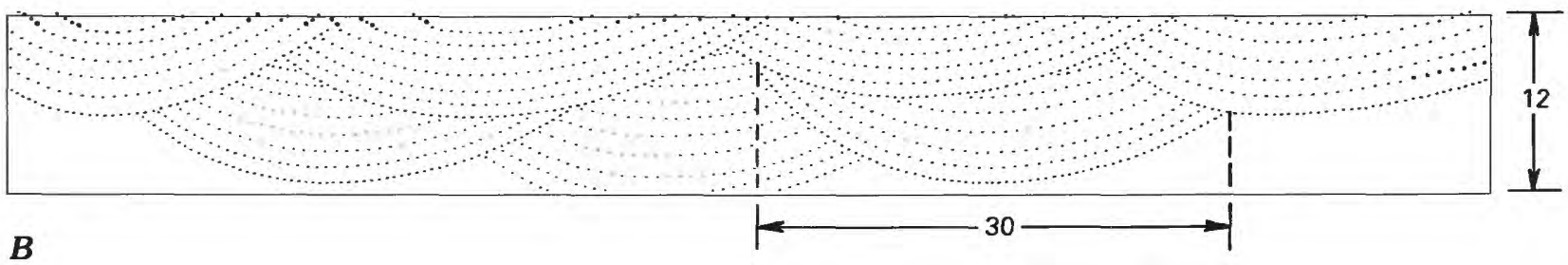

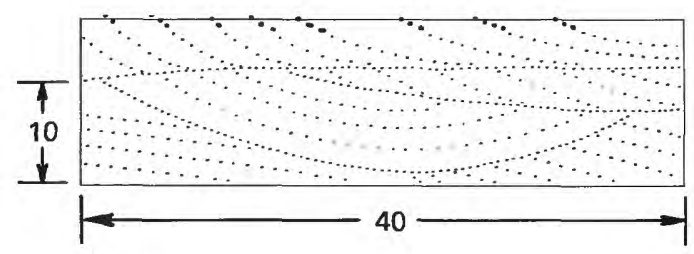

C

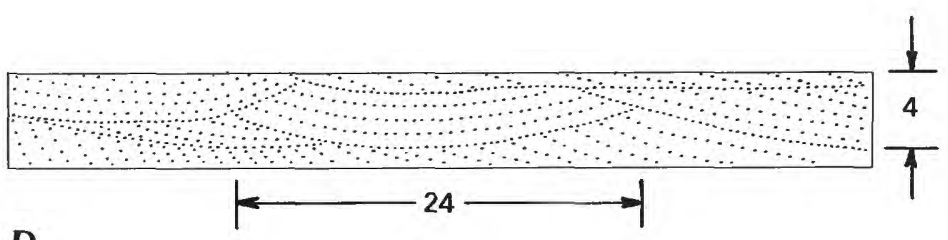

D

EXPLANATION

Sandstone

Cross-stratified

Flat-bedded
FIGURE L3.-Cross-strata, wedge-planar and trough types in sandstone of Wescogame Formation: A, Cliff unit in Tuckup Canyon; trough cross-strata. $B$, Base of cliff unit, Topocoba Trail; trough structure forming festoon cross-strata. C, Middle of cliff unit, Topocoba Trail; mixed tabular-planar, wedge-planar, and trough cross-strata types. $D$, Top of

\section{Associated horizontal and low-angle cross-strata}

Although cross-strata of several types form the dominant structure of sandstone bodies in the Manakacha, Wescogame, and Esplanade Formations, horizontal or flatlying strata are not uncommon, especially in the Esplanade. These strata mostly form sets that range in thickness from a few inches to a few feet and occur above (fig. L4), below (figs. $\mathrm{L} 4 B ; \mathrm{K} 20 B$ ), or adjacent to (figs. $\mathrm{K} 5 A, \mathrm{~K} 12 C$ ) sets of cross-strata. They are formed in arenaceous limestones as well as in sandstones (fig. K20D, E).

The usual interpretation of horizontal strata such as those that occur in the widespread sandstone bodies of the Supai is that they were formed in the upper flow regime, in contrast to associated megaripple structures that represent cliff unit, Andrus Canyon; festoons formed by shallow overlapping troughs. E, Cliff unit near Topocoba Trail; asymmetrically filled trough structure overlain by wedge-planar cross-strata. F, Cliff unit near Bright Angel Trail; wedge-planar structure. Vertical and horizontal measurements in feet.

the lower flow regime (Simons, Richardson, and Nordin, 1965). This combination of strata suggests a high-energy environment in which water movement fluctuated back and forth from one flow regime to the other.

The horizontal structures not only occur in various marine environments (Clifton and others, 1971, p. 658), but also in fluviatile settings (Williams, 1971, p. 32; Singh, 1972 , p. 312). Thus, considered alone, they probably are not diagnostic of any one environment, but in a vertical sequence and in relation to other bedforms they may mean a great deal.

Because the type of structure (horizontal or planar crossstrata) is largely a function of stream flow or of current and tide strength at a particular stage, the proportions of each type vary widely in most environments. Horizontal 

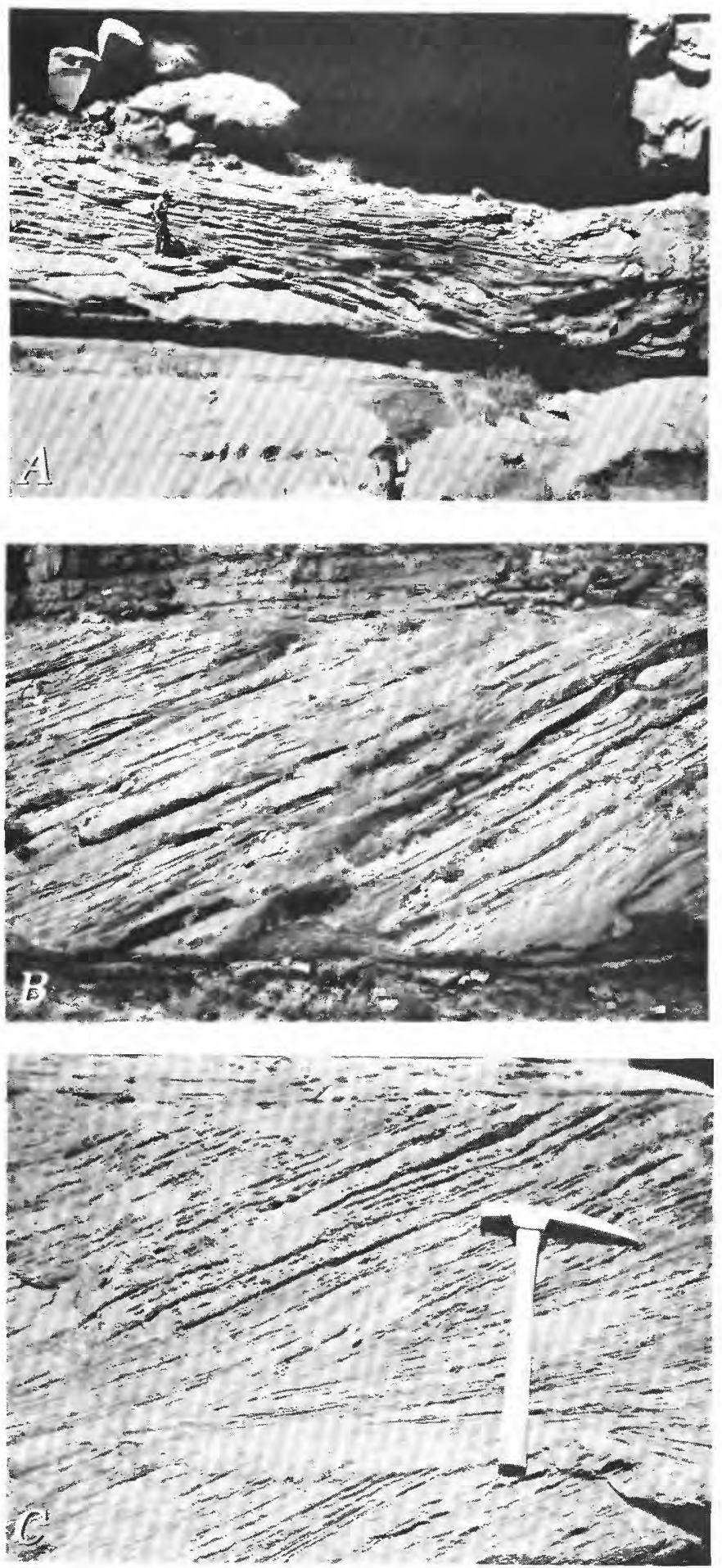

stratification is the main structure in longitudinal bars along the Platte River in Nebraska, U.S.A., but transverse bars contain very few horizontal strata and are composed mainly of planar and trough cross-strata (Smith, 1970, p. 3002). Flat bedding with parting lineation is estimated by Williams (1971, p. 32) to account "for no more than 5 percent of the flood deposits" studied in central Australia,
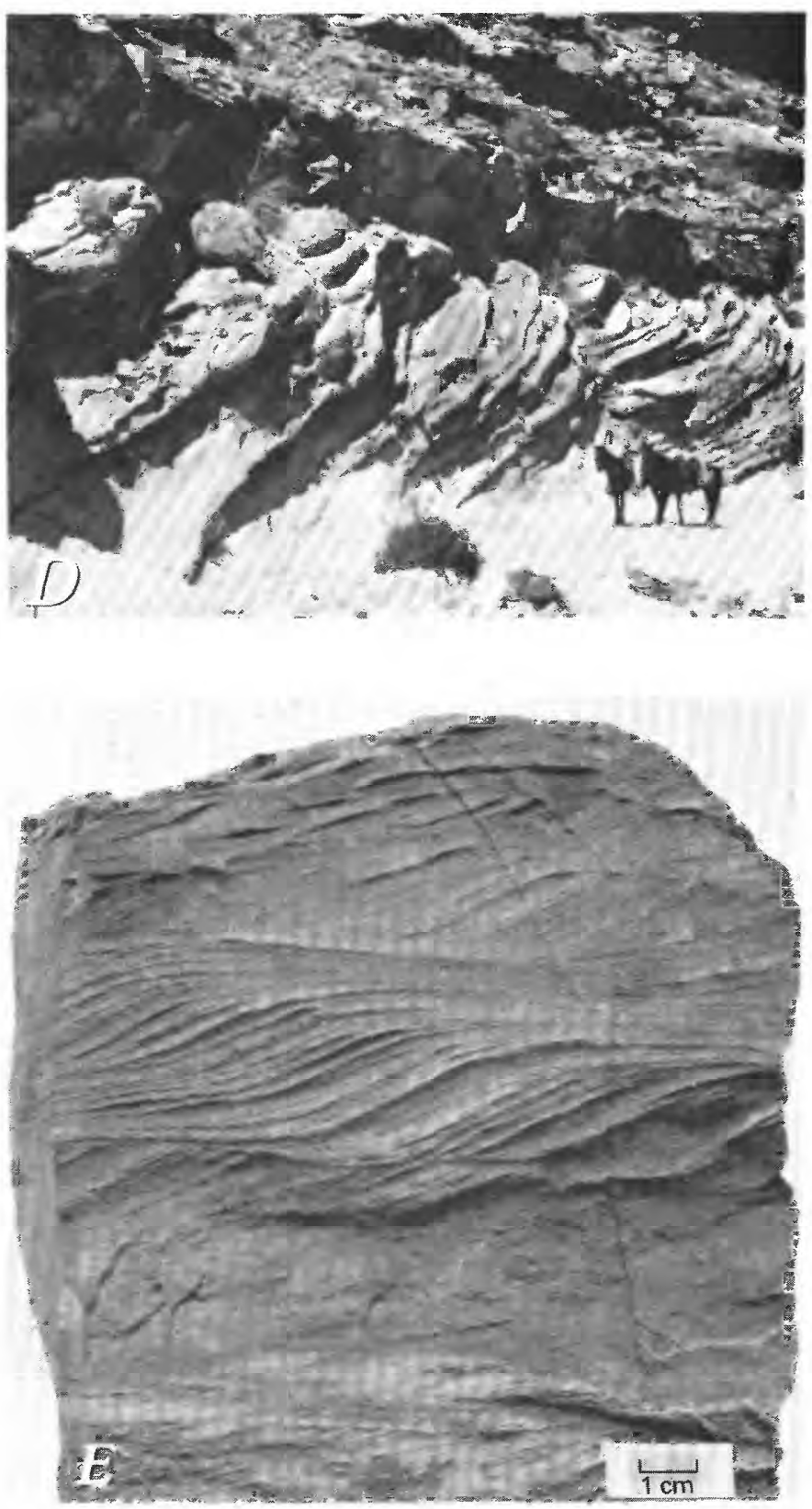

FIGURE L4.-Large-, medium-, and small-scale cross-strata in sandstone of the Wescogame Formation, Grand Canyon region, Arizona. A, Trough structure in large-scale cross-strata of Wescogame cliff unit; Marble Canyon. B, Large-scale, tabular-planar cross-strata (foresets about 35 ft long); Tobocoba Trail. C, Medium-scale, tabular-planar cross-strata; Kaibab Trail, south. D, Large-scale tabular-planar cross-strata; Hualapai Trail to Supai Village. E, Small-scale cross-strata formed by climbing ripple structures that indicate relatively low-energy environment with abundance of available sand; Iceberg Canyon.

but elsewhere he stated that along the Finke River it was "the dominant structure in flood deposits" among fine to medium sands. Even more extreme are results of the Bijou Creek flood in Colorado (McKee, Crosby, and Berryhill, 1967 , p. 829) where an estimated 90-95 percent of all deposits were horizontal strata. 

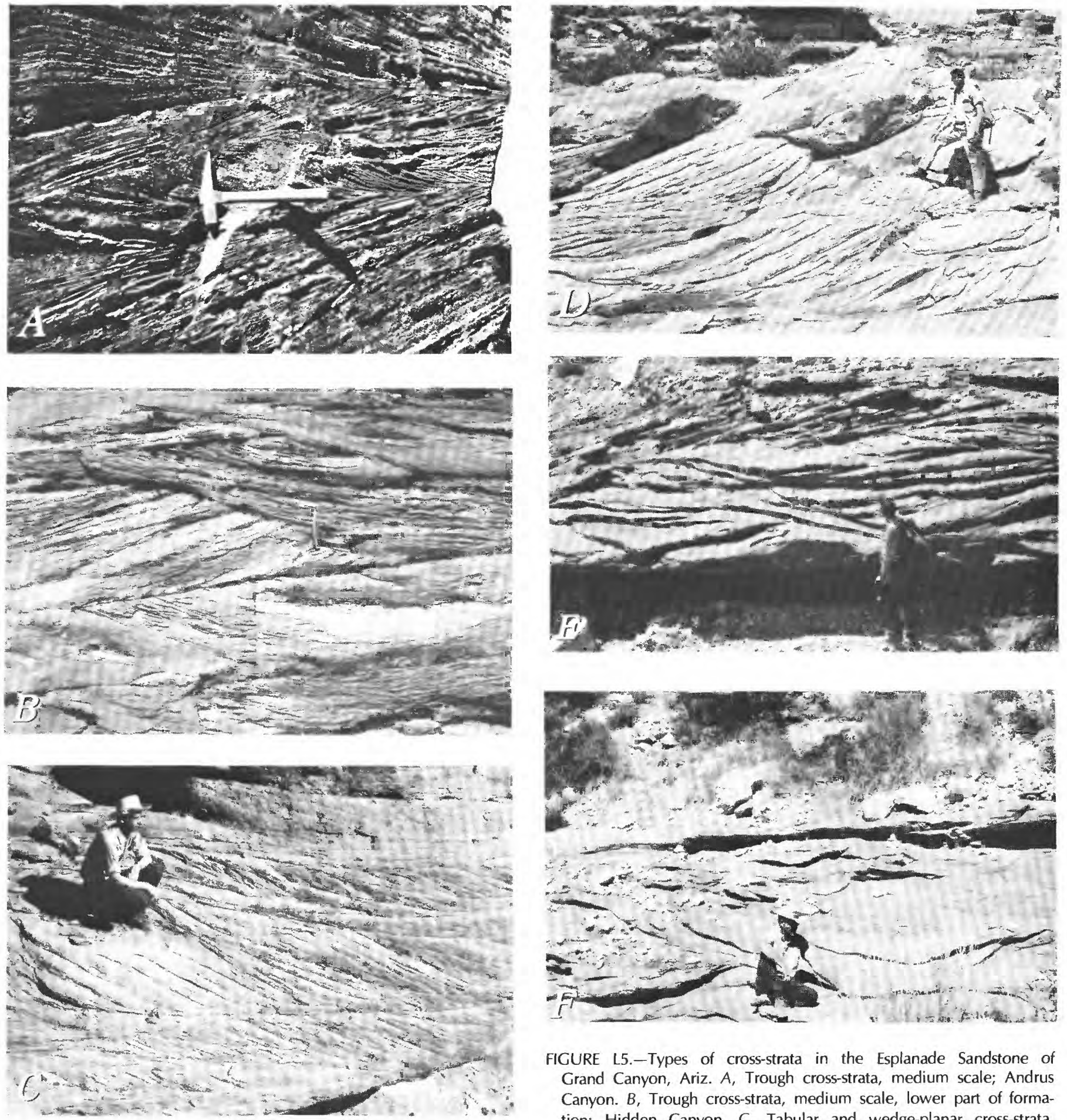

FIGURE L5.-Types of cross-strata in the Esplanade Sandstone of Grand Canyon, Ariz. A, Trough cross-strata, medium scale; Andrus Canyon. $B$, Trough cross-strata, medium scale, lower part of formation; Hidden Canyon. C, Tabular and wedge-planar cross-strata, medium scale; Fishtail Canyon near Thunder River Trail. D, Tabularplanar cross-strata, medium scale; Apache Trail, Havasu Canyon. E, Trough cross-strata above basal conglomerate; Topocoba Trail. F, Trough cross-strata, lower part of formation; Topocoba Trail.

Clearly, a great disparity exists in the amount of horizontal stratification formed under different stages of any depositional agent. This fact is shown for stream deposits cited above and is illustrated by several studies of nearshore marine deposits. For this reason, low percentages of horizontal strata found in the Manakacha and Wescogame Formations and the relatively small amount in the Espla-

nade Sandstone seem to show only that these sandstones were formed very largely under conditions of lower flow regime, whether in streams or in marine environments.

The flat, uniform, low-angle $\left(2-10^{\circ}\right)$ stratification characteristic of foreshore beaches is very distinctive and has 
been described in detail by numerous geologists (Thompson, 1937; McKee, 1957, p. 1706). These structures should be readily recognized in the Supai Group, especially if in juxtaposition with backshore deposits that likewise have distinctive structure patterns, but none have been recognized during this study of the sandstone bodies.

\section{Small-scale cross-stratification distribution}

The term "small scale" as applied to cross-strata in this investigation refers to structures measured in inches, rather than in feet. Thus, it applies to ripple lamination, climbing ripples (ripple drift), flaser bedding, lenticular bedding, small-scale festoon patterns, and probably a few others. Because small-scale structures are the product of relatively low energy and represent an early stage of the lower flow regime (Simons and Richardson, 1961), they cannot normally be expected in association with those sand bodies of the Supai Group formed from megaripples and sand waves, except where waning stages are represented.

The modern environments from which small-scale ripple cross-strata have been reported as abundant are mostly associated with river flood plains such as the Colorado (McKee, 1938, 1939), the Rhone and Mississippi (Van Straaten, 1959, p. 213), the Indus (McKee, 1966), and many others. Such structures also occur in the upper parts of pơint bars as on the Mississippi (Frazier and Osanik, 1961), the Gomti River, India (Singh, 1972, p. 310), and the Brazos River (Bernard and others, 1970). Small-scale ripple festoons are illustrated from the Red River, Louisiana, by Harms, MacKenzie, and McCubbin (1963), and on bar crests of offshore bars in New Brunswick (DavidsonArnott and Greenwood, 1974). Perhaps the most extensive and impressive examples of ripple lamination to be recorded, however, are from topset, foreset, and bottomset areas of an "esker delta" bordering the Yoldia Sea in Finland (Aario, 1971, 1972). Here, deposition was mainly from suspension and occurred in deep sea water. Variations and vertical successions of sedimentary structures in this environment show many pulsations in the regime of meltwater.

Other types of small-scale cross-strata for which the environment of deposition has been identified are the "flaser and lenticular" bedding types. These are related to the "alternation of current or wave action and slack water" according to Reineck and Wunderlich (1968, p. 103). "The preferred environments are areas where a change takes place between slack water and water turbulence. The genesis is related to tidal rhythms ${ }^{* * * \prime}$

In interpreting sandstones of the Supai Group, the question arises as to why small-scale cross-strata are, in general, so uncommon. The major sandstone units of the Supai are composed mostly of medium- to large-scale cross-strata representing deposits of megaripples and of high energy. Two examples (figs. L4E; N2A) of ripple laminae associated with the high-energy sandstones are from the Wescogame at Toroweap Point and at Iceberg Canyon where it is considered to be of fluvial origin. Most examples of climbing ripples are in the lower part of the Watahomigi (figs. N1 $A, B, C$ ) where they are among siltstones and other fine-grained rocks resulting from deposition in a low-energy environment.

\section{Azimuth patterns of paleocurrent directions}

Mean dip-direction vectors and the amount of spread were determined for cross-strata dips in each of the three upper formations of the Supai Group (chapter K). Results of this statistical study, as illustrated in figures $\mathrm{K} 7, \mathrm{~K} 15$, $\mathrm{K} 16, \mathrm{~K} 21$, and $\mathrm{K} 22$, show that the general current dipdirection in the Manakacha was southerly across the entire Grand Canyon area. In the Wescogame it was southeasterly in the west, but ranged between south and southsoutheast in the rest of the area. In the Esplanade it was consistently southeasterly in nearly all of the area.

The significance of these directional patterns is not easy to determine. The implication for all three formations is a source of sediment to the north with a positive area in that direction (figs. D4, D7, D8). In the Manakacha, however, where most of the cross-stratified sands are believed to be marine, for reasons including (1) the types of structure, (2) the associated fauna, and (3) the lateral gradation into limestone, a tidal-controlled reversal as in an estuary might be represented. Dip-direction measurements of cross-strata at Hermit Trail, Whitmore Wash, and Hidden Canyon show some reversals (fig. K7). The Grand Canyon embayment at that time (Atokan age) appears on an isopach map to have been a passageway that connected the Cordilleran seaway on the southwest with the San Juan Basin to the northeast, and with restricting land on each side (fig. D4).

In the Wescogame Formation and Esplanade Sandstone, the patterns of paleocurrents apparently are easier to interpret than those of the Manakacha. Cross-stratified sand of the Wescogame seems to be stream-deposited, as indicated by the common trough structures and by other features to be discussed. A landmass (fig. D7) lay to the north, in northwestern Arizona, during Virgilian time and seems to have furnished the southward-moving sand bodies of this formation. Probably the Esplanade also was fluvial, although this is more difficult to document. A source, similar to that of the Wescogame but more distant and more obscure, probably was operative for the Esplanade Sandstone. 
Determinations of the amount of spread in the current vectors for the principal localities of Supai study have been made (figs. K7, K15, K16, K21, K22). For the Manakacha, the maximum spread determined for a single locality was $209^{\circ}$, the minimum $151^{\circ}$. For most localities, the spread was about $160^{\circ}$. Similar measurements for the Wescogame show a maximum of $240^{\circ}$, a minimum of $90^{\circ}$, and an average of about $170^{\circ}$. The Esplanade measurements showed a maximum of $210^{\circ}$, and a minimum of $60^{\circ}$. The average was approximately $150^{\circ}$. No significant trends can be recognized in a comparison of the spread of dip directions within these three sandstone bodies.

In a study of dip-azimuth variability (comparing tabular and trough cross-strata), Meckel (1967, p. 85, table 1) determined foresets of tabular cross-strata to have a scatter of $150^{\circ}$, and a comparable group of trough foresets, a scatter of $330^{\circ}$. Trough axes, however, showed only a $93^{\circ}$-spread. In the Supai study, one might expect the Manakacha, with no trough structures, and the Wescogame, with many, to show differences in spread comparable to those determined by Meckel, but such were not found.

\section{Distribution pattern of size grades in sand}

More than 800 grain-size determinations (figs. K4, K10, K19) for sandstones of the Supai Group indicate a remarkable uniformity across the entire Grand Canyon area and for all ages from Early Pennsylvanian through Early Permian. In all four formations, a large majority of samples show most mean values to be in the very fine grained class (Wentworth scale). In the Watahomigi, comparatively litthe sand is coarser than very fine grained, and quartz grains are mostly of silt size. In the three upper formations, finegrained sand is relatively abundant, but very little sand is coarser. Sparse accumulations of grains in the coarse and very coarse classes are scattered through localities of both eastern and western, but not central, Grand Canyon in the Manakacha and Wescogame Formations (figs. K3, K9), and are interpreted as evidence of two source areas-northwest and northeast. Similar uncommon concentrations of coarse and very coarse sand occur in the Esplanade Sandstone (fig. K18), but are distributed mostly through west-central Grand Canyon, suggesting a single main source of sand to the north in Permian time.

\section{General scarcity of normal ripple marks}

The general scarcity, rather than the overall distribution, of ripple marks in the extensive, cross-stratified sandstones of the Supai Group, is characteristic. Considering the evidence of high-energy conditions furnished by the presence of medium- to large-scale cross-strata almost everywhere throughout the sandstone bodies, this paucity of ripple marks seems sufficiently distinctive to be a diagnostic feature of the facies.

Although ripple marks occur in shaly siltstones and mudstones of all formations, as described in chapter $\mathrm{N}$, these strata represent relatively low-energy environments. In the highly cross-stratified sands formed by trains of megaripples or sand waves, the only small-scale ripple marks to be recorded were in the Manakacha (three sites), Wescogame (five sites), and Esplanade (three sites).

This small distribution of ripple marks suggests that in the sandstone environment, ripples were developed on the surfaces of subaqueous dunes or megaripples only rarely, as during waning stages, when the current energy had been reduced greatly from that responsible for the crossstratification itself. This, of course, is in direct contrast to the environment of a river floodplain or overbank deposit (Collinson, 1970, p. 42), or a tidal-flat surface such as that at Cholla Bay, Mexico (McKee, 1957, p. 1735), in all of which facies ripple marks are abundant.

\section{Gradation from calcareous sandstone to arenaceous limestone}

The distribution of lithologic facies in the Supai Group, perhaps better than any other single feature, serves to indicate the general pattern of environments. Medium- to large-scale cross-stratified sandstones and limestones give evidence of high-energy conditions, and the limestones, dolostones, and mudstones indicate various degrees of low-energy environments (Lumsden, 1974, p. 453). Also pertinent are the lateral relations between cross-stratified limestones and cross-stratified sandstones for they serve to locate areas of mingling between definite marine deposits and deposits of questionable origin-nearshore, barrierbar, estuarine, or fluvial environments.

The carbonate rock facies in the Supai are described in chapter $\mathrm{P}$, and diagnostic features of the mudstones are treated in chapter I. It now remains to discuss for each formation the distribution of facies within the high-energy, cross-stratified deposits where sand and carbonate sediments mingle.

In the Watahomigi Formation, all or nearly all deposits of the Grand Canyon area indicate a low-energy environment (fig. P6). This is expectable in view of the paleogeography-nearly enclosed embayment with entrance only from the west (fig. D3). The upper and lower units of this formation are composed of alternations of mudstone or siltstone and limestone, and the middle unit is mostly limestone. 
A few thin sets of cross-stratified sandstone (at Twentynine Mile Canyon, Kaibab Trail, north), and cross-stratified limestone (at Twin Springs and at north Hidden Canyon) occur in the upper unit of the Watahomigi as shown in stratigraphic profiles (figs. A2-A8). These sets constitute the only evidence of high-energ: deposition. Limestones in the eastern half of the region are aphanitic types (micrite), probably indicative of very low-energy conditions. Only in the west do dominantly bioclastic, peloidal, and accretal limestones, indicating moderate energy, occur.

In the Manakacha Formation, in contrast to the Watahomigi, extensive, thick sandstone and limestone units characterized by medium- to large-scale cross-strata constitute much of the formation. Analysis of the measured sections shows that in western and west-central Grand Canyon, limestone constitutes a major part of the formation, the lower part and the topmost part being very arenaceous and cross-stratified, whereas much of the middle part is massive and jasper-bearing. In addition to the limestone, some thick beds of calcareous sandstone, which are largely cross-stratified, make up the section.

This sequence of strata extends eastward to about Toroweap Valley, beyond which the preponderance of arenaceous limestone over calcareous sandstone is reversed and an appreciable increase in siltstone is evident. In easternmost Grand Canyon, cross-stratified sandstone is the dominant element, but limestones of the massive, jasperbearing type are also present. Thus, an interpretation for the Manakacha of a largely marine environment, with a large proportion of high-energy deposits, is supported by data on facies change from carbonate rock (seaward), through arenaceous limestone, to siltstone (landward). Furthermore, paleogeography of Atokan time gives evidence that a channel connection extended northeastward to the San Juan Basin (fig. D4). The extensive sandstone body of the Manakacha, including some exceptionally large-scale foresets $(60-100 \mathrm{ft}$ long), may possibly represent an estuary (d'Anglejan, 1971), or a tidal sand body as in the Bay of Fundy (Swift and McMullen, 1968), or Lower Cook Inlet (Bouma and others, 1977). Table L1 lends support to this interpretation.

The Wescogame Formation consists almost entirely of medium- to large-scale, cross-stratified sandstone throughout most of the Grand Canyon area. Only in the extreme western part (Iceberg Canyon) and northwestern area (Snap Canyon, Hidden Canyon, and others) is this sandstone supplanted or partly supplanted by crossstratified limestone. Therefore, aside from relatively minor units of mudstone and siltstone largely in the basal and topmost parts, this formation represents the high-energy deposits of megaripples and sand waves throughout. Probably the entire central and eastern parts, excluding a few tongues of cross-stratified limestone at Whitmore Wash,
Toroweap Valley, and elsewhere, were formed in a continental environment. Based on other evidence already discussed, a braided-stream environment is postulated.

The main cliff unit of the Esplanade Sandstone is highly cross-stratified on a medium to large scale nearly everywhere in the Grand Canyon area. An exception is in the extreme west where its stratigraphic position is taken by the Pakoon Limestone (McNair, 1951) - a carbonate rock, mostly dolostone. A few thin tongues of carbonate rock extend eastward into central Grand Canyon from the Pakoon (fig. P12), and partings or thin lenses of mudstone and siltstone occur between major sandstone units throughout the area. Otherwise the high-energy, partly upper-flow regime, strata and cross-strata make up the entire cliff unit.

The relatively abrupt change from fine-grained dolostone in the west, which presumably represents nearshore, shallow water, and low-energy deposits, and the highenergy environment sandstones to the east is difficult to explain. As discussed earlier, several types of evidence seem to indicate a fluvial origin for the sandstone, so it may have formed as a southward-advancing sand sheet from braided streams, with sand sources to the north or northwest. A barrier-bar environment must also be considered as a possibility, especially in the northwest where evaporite deposits are associated.

\section{Associated organisms- plants and animals}

In determining the genesis of various sand bodies in the Supai Group on the basis of associated fossils, a considerable amount of discretion must be used. In the first place, extremely few fossils occur actually within the sand, but rather they occur in limestones and mudstones above or below, so they may represent very different environments of deposition that resulted from transgressions and regressions. In the second place, even those fossils that occur within the cross-bedded sands may have been transported great distances from places of origin for they are nearly all comminuted and abraded and are in sediments that represent high-energy conditions.

Despite all the inherent difficulties in using faunal and floral features for interpreting the sandstone facies, a survey of evidence is desirable. For the Watahomigi Formation, because it contains very little sandstone, conclusions are relatively simple. Marine invertebrate fossils extend eastward in limestone and mudstone beds of the formation at least to the central part of the Grand Canyon region, as described in chapter E (figs. E1-E6). Five species of brachiopods have been recorded from Toroweap Valley, also one from Tuckup, five from National, and 
two from Havasu Canyons, farther east. Gastropods, pelecypods, trilobites, corals, and bryozoans are also represented in the central and western parts of the embayment indicating that much of the deposition there was under low-energy, marine, or brackish-water conditions, and explaining why medium- and large-scale, cross-stratified sands that form under high-energy conditions are absent in this formation.

Microfossils provide additional environmental evidence for the Watahomigi. In the upper unit of the formation (Atokan age), fusulinids have been found at Grandview Trail, Eminence Fault, and Kaibab Trail, north, in eastern Grand Canyon. Furthermore, bioclasts consisting of pelmatozoans, foraminifers, and bivalves, even though not as abundant as in the west, are represented at a number of localities in the far eastern sections (figs. E25-E28) and help to confirm the general concept of a marine environment.

The Manakacha Formation apparently represents a continuation in time of marine conditions found in the Watahomigi, although its abundant highly cross-stratified sandstones and limestones testify to a much higher energy situation. Apparently the very mobile and constantly shifting sand of the extensive sand bodies in this formation constituted an environment unfavorable to most forms of life. Fusulinids are found near the formation base in sections at Hermit and Grandview Trails and at Eminence Fault and in the middle part of the formation at Parashant and Twin Springs Canyons (fig. E11), but nowhere are they as abundant as in localities farther west. Endothyra occur in the upper part of the Manakacha in sections at Bass Trail, Whitmore Wash, and Twin Springs Canyon (fig. E12). Larger animals (macrofossils) are represented in these sandstone strata only as bioclasts, and these fragments are progressively less numerous toward the east. A few clasts of pelmatozoans, bryozoans, and bivalves are found at scattered localities in eastern and central Grand Canyon (figs. E29, E30). Thus, the faunal distribution within the Manakacha seems to show a progressive change from more marine deposits in the west to more nonmarine in the east.

In the Wescogame Formation, a marine fauna in its life habitat, with unbroken shells and skeletons preserved, seems to be restricted to the extreme western margins of the region of deposition. It occurs at Hidden Canyon, Pigeon Wash, Snap Canyon, and Guano Cave sections. The principal forms at these localities are pelecypods, corals, and fusulinids (fig. E13). Eastward from this area, only the clasts of marine fossils, uncommon and scattered, have been found and they are far more numerous in the west than in the east (fig. E31). Pelmatozoan clasts were noted at Bunker Trail and Kaibab Trail, north, in the east and at many places in central Grand Canyon. Bryozoan clasts were found only at Thunder River Trail in the east, and clasts of bivalves at Grandview Trail, and Kaibab
Trail, south, and Havasu and S B Canyons.

In no part of the Wescogame in the Grand Canyon region can fossils be considered abundant, but they are especially uncommon in the highly cross-stratified sandstone facies that composes a major part of the formation. The principal animal forms recorded in the sandstones are fusulinids, small foraminifers, and sharks teeth, all of which may have been transported far from their life habitats. Mollusks, which apparently favored a quietwater environment and are found in some parts of the formation, are not known from either the sandy crossstratified limestones or the calcareous sandstones. Thus, the conclusion seems inescapable that a very impoverished fauna is represented by fossils of the Wescogame-likely the result of vigorous estuarine conditions across much of the region.

In contrast to the marine fauna of the Wescogame in the far western parts of the region and the scattered clasts and tests of marine animals farther east, possibly transported long distances, are the tracks or footprints of terrestrial quadrupeds that are present on the foresets of crossstratified sandstones, mostly in eastern Grand Canyon. These vertebrate tracks, probably formed by amphibians (figs. E22, E21), have been found near the Bright Angel, Hermit, and Kaibab (north and south) Trails in the east and at S B, Parashant, and Andrus Canyons in the center and west. They probably indicate a stream-bank environment, which is compatible with the estuarine conditions at the mouths of braided streams, suggested by the marine bioclasts.

In the Esplanade Sandstone, fossil evidence of the depositional environment is much like that for the underlying Wescogame. Complete specimens of marine animals such as brachiopods, corals, bryozoans, and gastropods have been found only in carbonate rocks (referred to the Pakoon) of far western sections, along the Grand Wash Cliffs (fig. E17). Such fossils are locally abundant in those facies, as also are fusulinids; however, some fusulinids are recorded from as far east as Whitmore Wash and S B, Blue Mountain, and Twin Springs Canyons (figs. E18, E19).

Bioclasts, formed mostly of pelmatozoan and bivalve fragments and of small foraminifers (fig. E32), are relatively widespread in the formation throughout the region, occurring as far east as 16.5 Mile Canyon, Hermit Trail, and Thunder River Trail, and being represented in many sections of central Grand Canyon. Some of the bioclastic debris may have been locally derived as suggested by its broad distribution, discussed in chapter $\mathrm{E}$. The alternative explanation, that it was entirely the result of eastward transportation, is supported by the evidence of a highenergy environment indicated by cross-stratified sandstone and by independent evidence of a transitional marine environment. 


\section{Associated evaporites}

The Esplanade Sandstone is the only formation in the Supai Group, so far as is known, that includes evaporite deposits. As described in chapter $S$, such deposits are known to occur as facies within strata of Early Permian age in four areas of northern Arizona and adjacent states. The largest of these deposits is composed of the saltgypsum beds of the Holbrook basin, southeast of the Grand Canyon area. The other three consist of small deposits or series of deposits of bedded gypsum (1) in northeastern Arizona and adjoining Utah, (2) in the northwestern part of the Grand Canyon area, and (3) west of Grand Canyon in southern Nevada.

The importance of the evaporite deposits in western Grand Canyon to the interpretation of the Esplanade sand bodies probably is considerable; however, many details of their relationship are not known because of a lack of exposures in critical areas. The implication of an arid or semiarid climate in which gypsum was precipitated from concentrated waters seems inescapable. Less clear, however, is the exact relationship of the adjacent cross-stratified sands to the evaporites on the north. Whether these sands were part of a shallow, marine barrier-bar system that was responsible for lagoon development or, as seems likely from evidence already cited, were the product of braided river or estuarine development, cannot be determined without more data.

Dolostone and limestone of the Pakoon to the southwest of the gypsum beds probably are at a slightly lower stratigraphic horizon (fig. C8). The high-energy cross-stratified sandstone below, and therefore older than the gypsum, is a time-equivalent of the Pakoon carbonate rocks. Thus, the lateral relations of the evaporites to the nearest definite marine deposits are not yet known for this area.

\section{CONCLUSIONS REGARDING SANDSTONE FACIES}

\section{The Watahomigi Formation}

In the Watahomigi Formation, a low-energy, marine environment of deposition is postulated for the small sandstone bodies. Evidence bearing on this environmental interpretation is summarized below.

A nearly complete absence of medium- or large-scale cross-strata of either planar or trough type indicates that high-energy conditions did not prevail. No horizontally laminated beds of the type characteristic of upper flow regime have been recorded. Low-angle strata that are distinctive of foreshore beaches have not been observed.

Small-scale cross-strata, especially ripple laminae and climbing ripples, relatively numerous in detrital sediments of the upper and lower units, are interpreted as the result of low-energy conditions. Further evidence is furnished by the grain-size distribution of quartz particles. A large majority are of silt size and nearly all the others are very fine sand-considerably finer than in the three overlying "high energy" formations of the Supai.

Principal evidence that the depositional environment of the Watahomigi was marine is found in the close association of the sandstone beds with limestone that extends across the entire region. Furthermore, some of this limestone contains brachiopods, corals, bryozoans, trilobites, and other normal sea types, eastward as far as Havasu Canyon in central Grand Canyon. Small foraminifers and bioclasts of several animal groups are fairly numerous in most localities, even in the easternmost parts of the embayment, and are considered further evidence of a marine environment throughout the area.

\section{The Manakacha Formation}

In the Manakacha Formation, the principal sand bodies are moderately thick and very widespread, with sheetlike proportions, and are interpreted as having formed in a high-energy marine or estuarine environment. Principal evidence of this high-energy environment is furnished by the large proportion of sandstone beds that show either the tabular-planar structure of sand waves or the horizontal laminae of an upper flow regime. Evidence of low-energy levels is generally lacking because small-scale cross-strata and ordinary ripple marks-both characteristic of lowenergy conditions in the sandstones-are rare.

Principal evidence of marine genesis of the Manakacha is the large amount of cross-stratified limestone that extends eastward across the entire area of Grand Canyon, apparently grading into sandstone with similar cross-strata in many places. Foreset planes of these structures are exceptionally long, ranging from 50 to $100 \mathrm{ft}$ or more in numerous localities, especially in central Grand Canyon. Such long foresets can best be explained as the fronts of very large sand sheets, formed perhaps in strong tidally affected areas (table L1) or as the foresets of small deltas built into standing bodies of water. The absence of trough-type structures throughout the sandstone bodies seems to indicate that megaripples (subaqueous dunes) were not important in sedimentation and that neither braided-stream nor meander-belt rivers were involved.

Organisms preserved in the sand bodies indicate a very unfavorable environment for life. A few fusulinids have been found scattered throughout the region and bioclasts derived chiefly from bivalves, bryozoans, and pelmatozoans are accumulated locally, but may have been transported from a distance. 


\section{The Wescogame Formation}

Sandstones of the Wescogame Formation are interpreted as having formed primarily in a high-energy, fluvial environment. Within the Grand Canyon region, most of this formation consists of a cross-stratified facies that includes both tabular and trough structures that clearly indicate high-energy conditions. The high proportion of large trough cross-strata in association with tabular crosssets and horizontal bedding suggests development from megaripples, probably as migrating point bars in a fluvial system. The common association of horizontal strata indicates frequent change from lower to upper flow regime.

Current vectors determined from cross-strata dip directions indicate a unidirectional, south or southeasterly movement with a spread of less than two quadrants at all localities. Sand-size studies show a distribution pattern of grain size in which coarse and very coarse grains are concentrated in western and eastern, but not in central, localities. This is interpreted as indicating sources for the sand to the northwest and northeast.

Faunal evidence seems to indicate a cyclical mixture of environments. The preservation of five-toed quadruped tracks on the dip slopes of large-scale cross-strata at numerous localities in the east and north (chapter E) is believed to indicate stream-bank environments at those places. Fusulinids, small foraminifers, and sharks teeth in central and western Grand Canyon suggest a possible estuarine environment at the river mouths where tidal exchange could have caused vigorous upstream movement, transporting these fossils. In any event, the fauna was an impoverished one, for well-preserved marine fossils occur only in the extreme western or seaward margin of the area at Grand Wash Cliffs.

\section{The Esplanade Sandstone}

Although most of the Esplanade Sandstone clearly is a high-energy deposit, the problem of whether the large- to medium-scale cross-strata within it are marine or continental is difficult to determine. Available data seem to indicate that deposition of this sandstone took place along a strandline, so evidence of both marine and nonmarine sediments is represented. The sandstone is referred to a fluvial(?) genesis in this publication, but several features included in the sandstone seem to point toward a marine or estuarine environment.

The cross-stratification, which is dominantly of the planar type, might be attributed equally well to each of several marine and continental environments. Very large scale foresets such as occur in the Manakacha are not known, and trough-type structures, which are abundant in the Wescogame, are relatively uncommon in the Esplanade. Thus, these structural features, which are considered useful indicators of marine and fluvial conditions, respectively, cannot be used for interpretation.

Horizontal stratification, locally in juxtaposition with large-scale cross-strata, is considered evidence of occasional high-flow regime in the Esplanade. In contrast, a general scarcity of small-scale structures such as climbing ripples and flaser bedding and of normal ripple marks in the sandstone negates the likelihood of a low-energy environment.

The association of bedded gypsum with the sandstone (chapter S) in the north-central and northwestern parts of the Grand Canyon region suggests that there a series of lagoons was cut off from the sea by sands. A few fusulinids in the central part of the region and bioclasts widespread in areas of cross-bedded sand seem to indicate marine encroachment, perhaps estuarine, into this central part. Carbonate rock (Pakoon) and complete skeletons of marine animals are restricted to the extreme western part of the region and probably mark the himits of normal sea encroachment from the west.

A distribution pattern of quartz-size grades and the vector direction of cross-strata dips both indicate a south to southeasterly transport direction of sand. This evidence indicates that sands were deposited as a product of streams from the north with possibly some sand being reworked into a barrier-bar system on the south, beyond the gypsumforming lagoons.

The presence of scattered fusulinids and bioclasts in the central area indicates possible upstream transport of marine invertebrates-perhaps by tides active in an estuarine system.

\section{REFERENCES CITED}

Aario, Risto, 1971, Syndepositional deformation in the Kurkiselfa Esker, Kiiminki, Finland: Geological Society of Finland Bulletin, v. 43, p. 163-172.

1972, Associations of bed forms and paleocurrent patterns in an esker delta, Haapajaervi, Finland: Academia Scientiarum Fennicae, Annales, ser. A, III, Geologica-Geographica, Helsinki, 55 p.

Allen, J.R.L., 1963a, Asymmetrical ripple marks and the origin of waterlaid cosets of cross-strata: Liverpool and Manchester Geological Journal, v. 3, p. 187-236.

$1963 \mathrm{~b}$, The classification of cross-stratified units, with notes on their origin: Sedimentology, v. 2, no. 2, p. 93-114.

1965, Fining upwards cycles in alluvial successions: Liverpool and Manchester Geological Journal, v. 4, pt. 2, p. 229-246.

d'Anglejan, B. F., 1971, Submarine sand dunes in the St. Lawrence Estuary: Canadian Journal of Earth Sciences, v. 8, p. 1480-1486.

Bernard, H. A., and Major, C. F., Jr., 1963, Recent meander belt deposits of the Brazos River-An alluvial "sand" model [abs.]: American Association of Petroleum Geologists Bulletin, v. 47, no. 2, p. 350.

Bernard, H. A., Major, C. J., Jr., Parrott, B. S., and LeBlanc, R. J., Sr., 1970, Recent sediments of southeast Texas-A field guide to the Brazos alluvial and deltaic plains and the Galveston barrier island complex: Austin, Texas University Bureau of Economic Geology Guidebook 11, 83 p. 
Bouma, A. H., Hampton, M. A., Wennekens, M. P., and Dygas, J. A., 1977, Large dunes and other bedforms in Lower Cook Inlet, Alaska: Offshore technology conference, 9th Annual, Houston, Texas, Proceedings, v. 1, OTC 2737, p. 79-90.

Brown, L. F., Jr., 1973, Cratonic basins; Terrigenous clastic models, in L. F. Brown, Jr., A. W. Cleaves, II, and A. W. Erkleben, eds., Pennsylvanian depositional systems in north-central Texas; a guide for interpreting terrigenous clastic facies in a cratonic basin: Geological Society of America Guidebook 14, p. 10-30.

Clifton, H. E., 1976, Wave formed sedimentary structures; a conceptual model, in Beach and nearshore sedimentation: Society of Economic Paleontologists and Mineralogists Special Publication 24, p. 126-148.

Clifton, H. E., Hunter, R. E., and Phillips, R. L., 1971, Depositional structures and processes in the non-barred high-energy nearshore: Journal of Sedimentary Petrology, v. 41, no. 3, p. 651-670.

Collinson, J. D., 1970, Bedforms of the Tana River, Norway: Geografiska Annaler, Series A, v. 52, no. 1. p. 31-56.

Dalrymple, R. W., Knight, R. J., and Lambiase, J. J., 1978, Bedforms and their hydraulic stability relationships: Nature, v. 275, no. 5676, p. 100-104.

Davidson-Arnott, R.G.D., and Greenwood, Brian, 1974, Bedforms and structures associated with bar topography in the shallow-water wave environment, Kouchibouguac Bay, New Brunswick, Canada: Journal of Sedimentary Petrology, v. 44, no. 3, p. 698-704.

1976, Facies relationships on a barred coast, Kouchibouguac Bay, New Brunswick, Canada, in Beach and nearshore sedimentation: Society of Economic Paleontologists and Mineralogists Special Publication 24, p. 149-168.

Frazier, D. E., and Osanik, A., 1961, Point-bar deposits, Old River Locksite, Louisiana: Gulf Coast Association of Geological Societies Transactions, v. 11, p. 121-137.

Harms, J. C., MacKenzie, D. B., and McCubbin, D. G., 1963, Stratification in modern sands of the Red River, Louisiana: Journal of Geology, v. 71, no. 5, p. 566-580.

Harms, J. C., Southard, J. B., Spearing, D. R., and Walker, R. G., 1975, Depositional environments as interpreted from primary sedimentary structures and stratification sequences: Society of Economic Paleontologists and Mineralogists, lecture notes for short course no. 2, Dallas, April 5, 1975, p. 103-132.

Hoyt, J. H., 1967, Occurrence of high-angle stratification in littoral and shallow neritic environments, central Georgia coast, U.S.A.: Sedimentology, v. 8, no. 3, p. 229-238.

Hoyt, J. H., and Henry, V. J., Jr., 1967, Influence of island migration on barrier-island sedimentation: Geological Society of America Bulletin, v. 78, no. 1, p. 77-86.

Lumsden, D. N., 1974, Relationships among insoluble residue, dolostone and limestone facies: Journal of Sedimentary Petrology, v. 44, no. 2, p. $450-455$.

McGowen, J. H., and Garner, L. E., 1975, Physiographic features and stratification types of coarse-grained point bars; modern and ancient examples: Austin, Texas University Bureau of Economic Geology, Geological Circular 75-9, 25 p.

McKee, E. D., 1938, Original structures in Colorado River flood deposits of Grand Canyon: Journal of Sedimentary Petrology, v. 8, no. 3, p. 77-83.

1939, Some types of bedding in the Colorado River delta: Journal of Geology, v. 47, no. 1, p. 64-81.

1957, Primary structures in some Recent sediments: American Association of Petroleum Geologists Bulletin, v. 41, no. 8 , p. 1704-1747.
1966, Significance of climbing-ripple structure, in Geological Survey Research 1966: U.S. Geological Survey Professional Paper 550-D, p. D94-D103.

McKee, E. D., Crosby, E. J., and Berryhill, H. L., Jr., 1967, Flood deposits, Bijou Creek, Colorado, June 1965: Journal of Sedimentary Petrology, v. 37, no. 3, p. 829-851.

McNair, A. H., 1951, Paleozoic stratigraphy of part of northwestern Arizona: American Association of Petroleum Geologists Bulletin, v. 35, no. 3, p. 503-541.

Meckel, L. D., 1967, Tabular and trough cross-bedding-Comparison of dip azimuth variability: Journal of Sedimentary Petrology, v. 37, no. 1, p. 80-86.

Off, Theodore, 1963, Rhythmic linear sand bodies caused by tidal currents: American Association of Petroleum Geologists Bulletin, v. 47, no. 2, p. 324-341.

Reineck, H. E., and Wunderlich, Friedrich, 1968, Classification and origin of flaser and lenticular bedding: Sedimentology, v. 11, p. 99-104.

Schuchert, Charles, 1918, On the Carboniferous of the Grand Canyon of Arizona: American Journal of Science, 4th ser., v. 45, p. 347-361.

Simons, D. B., and Richardson, E. V., 1961, Forms of bed roughness in alluvial channels: American Society of Civil Engineers Proceedings, v. 87, paper 2816, Hydraulics Division Journal, no. HY3, pt. 1, p. 87-105.

Simons, D. B., Richardson, E. V., and Nordin, C. F., Jr., 1965, Sedimentary structures generated by flow in alluvial channels, in G. U. Middleton, ed., Primary sedimentary structures and their hydrodynamic interpretation-A symposium: Society of Economic Paleontologists and Mineralogists Special Publication 12, p. 34-52.

Singh, I. B., 1972, On the bedding in the natural-levee and the pointbar deposits of the Gomti River, Uttar Pradesh, India: Sedimentary Geology, v. 7, no. 4, p. 309-317.

Smith, N. D., 1970, The braided stream depositional environmentComparison of the Platte River with some Silurian clastic rocks, north-central Appalachians: Geological Society of America Bulletin, v. 81, no. 10, p. 2993-3013.

Sundborg, Ake, 1956, The river Klaralven; a study of fluvial processes: Geografiska Annaler, v. 38, p. 127-316.

Swift, D.J.P., and McMullen, R. M., 1968, Preliminary studies of intertidal sand bodies in the Minas Basin, Bay of Fundy, Nova Scotia: Canadian Journal of Earth Sciences, v. 5, no. 2, p. 175-183.

Thompson, W. O., 1937, Original structures of beaches, bars, and dunes: Geological Society of America Bulletin, v. 48, no. 6, p. 723-751.

Van Straaten, L.M.J.U., 1959, Minor Structures of some recent littoral and neritic sediments: Geologie en Mijnbouw, v. 21, p. 197-216.

Walker, R. G., 1976, Facies models 3; sandy fluvial systems: Geoscience Canada, v. 3, no. 2, p. 101-109.

White, David, 1927, Study of the fossil floras in the Grand Canyon, Arizona: Carnegie Institution of Washington Year Book 26, p. 366-369.

1928, Study of the fossil floras in the Grand Canyon, Arizona: Carnegie Institution of Washington Year Book 27, p. 389-390.

1929, Flora of the Hermit Shale, Grand Canyon, Arizona: Carnegie Institution of Washington Publication 405, $221 \mathrm{p}$.

Williams, G. E., 1968, Formation of large-scale trough cross-stratification in a fluvial environment: Journal of Sedimentary Petrology, v. 38, no. 1 , p. $136-140$.

1971, Flood deposits of the sand-bed ephemeral streams of central Australia: Sedimentology, v. 17, no. 1-2, p. 1-40. 


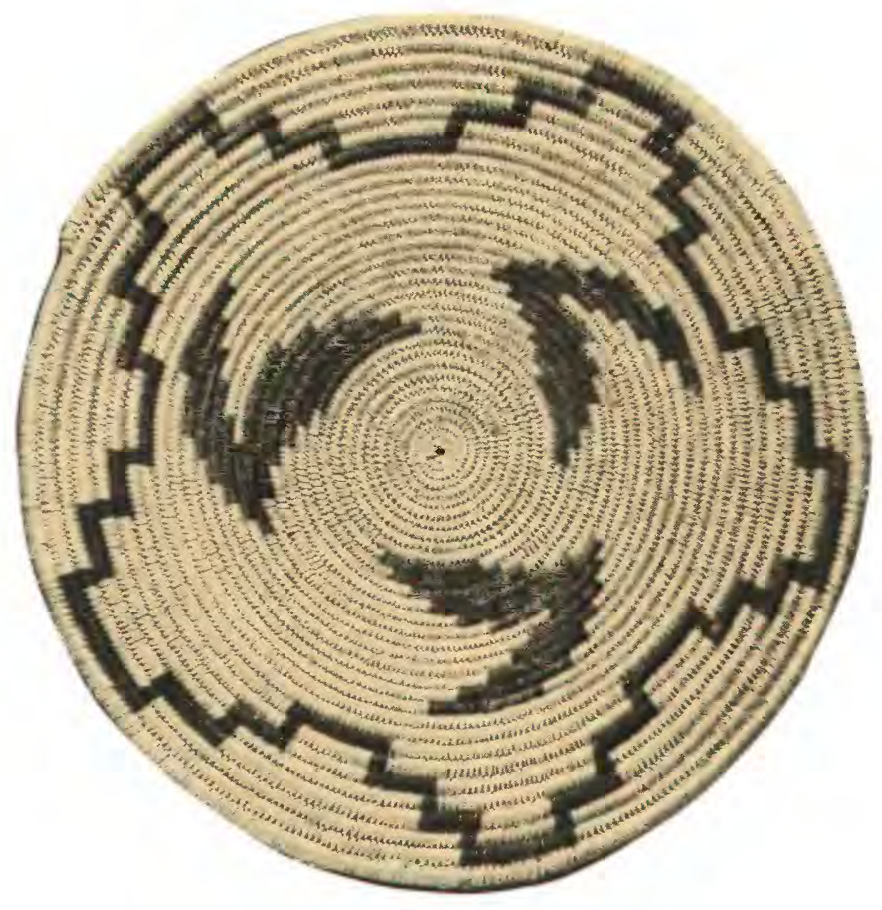

THE SUPAI GROUP OF GRAND CANYON

\title{
INSOLUBLE RESIDUE PATTERNS
}

\author{
Chapter $\mathrm{M}$
}

By WALTER PIERCE, A. J. GUDE, III, and EDWIN D. McKEE

\section{Contents}

\begin{tabular}{|c|}
\hline General features \\
\hline 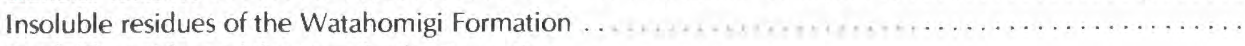 \\
\hline Insoluble residues of the Manakacha Formation... \\
\hline Insoluble residues of the Wescogame Formation. \\
\hline Insoluble residues of Esplanade Sandstone and Pakoon Limestone \\
\hline 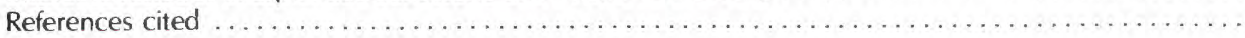 \\
\hline
\end{tabular}




\section{Illustrations}

FIGURES M1-M6. Histograms showing distribution by 10-percent classes of insoluble residues in rocks of Supai Group (Pakoon Limestone included in western Grand Canyon):

M1. Generalized total . . . . . . . . . . . . . . . . . . . . . . . . . 266

M2. From northwest to southeast in western Grand Canyon . . . . . . . . . . . . . . 267

M3. From north to south in western Grand Canyon . . . . . . . . . . . . 268

M4. From west to east in western Grand Canyon . . . . . . . . . . . . . . . . . . . . . . . 269

M5. From west to east in eastern Grand Canyon . . . . . . . . . . . . . . . . . . . 270

M6. From west to east in central and eastern Grand Canyon . . . . . . . . . . . . 271 


\section{GENERAL FEATURES}

The four formations that comprise the Supai Group (ascending order), the Watahomigi, Manakacha, and Wescogame Formations, and the Esplanade Sandstone, show considerable differences in the amount and distribution of insoluble residues across the region. Determinations obtained mostly as byproducts from sieve analyses of sandstones and from $\mathrm{Ca}-\mathrm{Mg}$ analyses of carbonate rocks from 1,018 samples were used in a study of distribution patterns. Cross-checks were available for some samples that were determined for both mechanical and $\mathrm{Ca}-\mathrm{Mg}$ analyses.

In this investigation, all available analyses were compiled and organized into two types of histogram. In one of these (fig. M1) the insoluble residue distribution was generalized for each formation of the Supai to show the total number of analyses in each 10-percent class of residues. In the other type of histogram (figs. M2-M6) the percent of samples in each 10-percent insoluble residue class was plotted for 12 to 22 localities representing each of the formations.

Histograms of the second type were arranged with localities roughly along east-west and north-south lines so that their relative geographic positions are indicated and comparisons of localities across the region are facilitated. Because the detrital and carbonate rocks are transitional and grade from one area to another, the insoluble residue distribution serves well to indicate places of good and poor mixing. In western Grand Canyon, the Pakoon Limestone (McNair, 1951) was combined with the Esplanade Sandstone because of the intertonguing relationship between these two formations.

Histograms of the first type (fig. M1) show a distinct bimodality in insoluble residue distribution for Watahomigi (fig. M1D), Wescogame (fig. M1B), and EsplanadePakoon (fig. M1A) rocks, whereas several nearly equal peaks of distribution are found in the Manakacha (fig. $\mathrm{M} 1 \mathrm{C})$. In the Wescogame and Esplanade-Pakoon histograms, the detrital peak is definitely in the $60-80$ percent insoluble residue range, but in the Watahomigi it is both higher and less pronounced (fig. M1D), which may be a reflection of the low-energy depositional environment involved.

Rocks intermediate in their insoluble content are generally considered to be uncommon in the geologic record. This situation is represented by the three bimodal histograms (figs. M1A, B, D) referred to above, but the Manakacha Formation (fig. M1C) seems to represent a notable exception. Possibly the good mixing of detrital and carbonate elements in this formation can be attributed to the high-energy environment of deposition, as illustrated by the abundance of cross-stratified limestones throughout.
Very few detrital rocks in the Supai Group are without carbonate cement, which accounts for some rock types in the 90-100 percent class of insolubles in all formations. In contrast, appreciable amounts of pure limestone and pure dolostone in all but the Manakacha Formation are represented in the $0-10$ percent class of these formations.

\section{INSOLUBLE RESIDUES OF THE WATAHOMIGI FORMATION}

A composite histogram of insoluble residues for the Watahomigi Formation (fig. M1D) shows that most sandy carbonate rocks of this formation are relatively pure carbonates with less than 10 percent insoluble material. A small insoluble residue peak at $80-90$ percent exists, but a major part of the population is in the range from 10 to 50 percent insoluble residue.

In a series of histograms extending generally across the Grand Canyon region (figs. M2-M6), a trend is apparent from relatively pure carbonate rocks in the west to rocks of highly divergent insoluble content, distributed more or less evenly throughout the section, in the east. Between these extremes the insoluble residue content seems to be transitional. This record apparently is representative of a lowenergy marine environment, with detritus being introduced mostly in the eastern area.

\section{INSOLUBLE RESIDUES OF THE MANAKACHA FORMATION}

A composite histogram for the Manakacha Formation in Grand Canyon (fig. M1C) seems to be atypical for populations of carbonate-sandstone transition, in general. In the Manakacha, several distinct peaks occur in the percent classes of insoluble residues indicative of a gradual transition between detrital and carbonate sediments. Furthermore, in these strata more mixtures or combinations of rock types are represented than in any other formation in the Supai Group as shown by the large number of samples ranging between 30 and 70 percent insoluble residues.

A trend toward more carbonate-rich rocks in the west, as in the Watahomigi, Wescogame, and EsplanadePakoon, is recognized, however, in the Manakacha. Carbonate rocks of the western sections contain much more detrital sediment as illustrated by percent insoluble residues (figs. M2-M6) and by interbeds of noncarbonate types. Sandstones in the Manakacha generally contain 


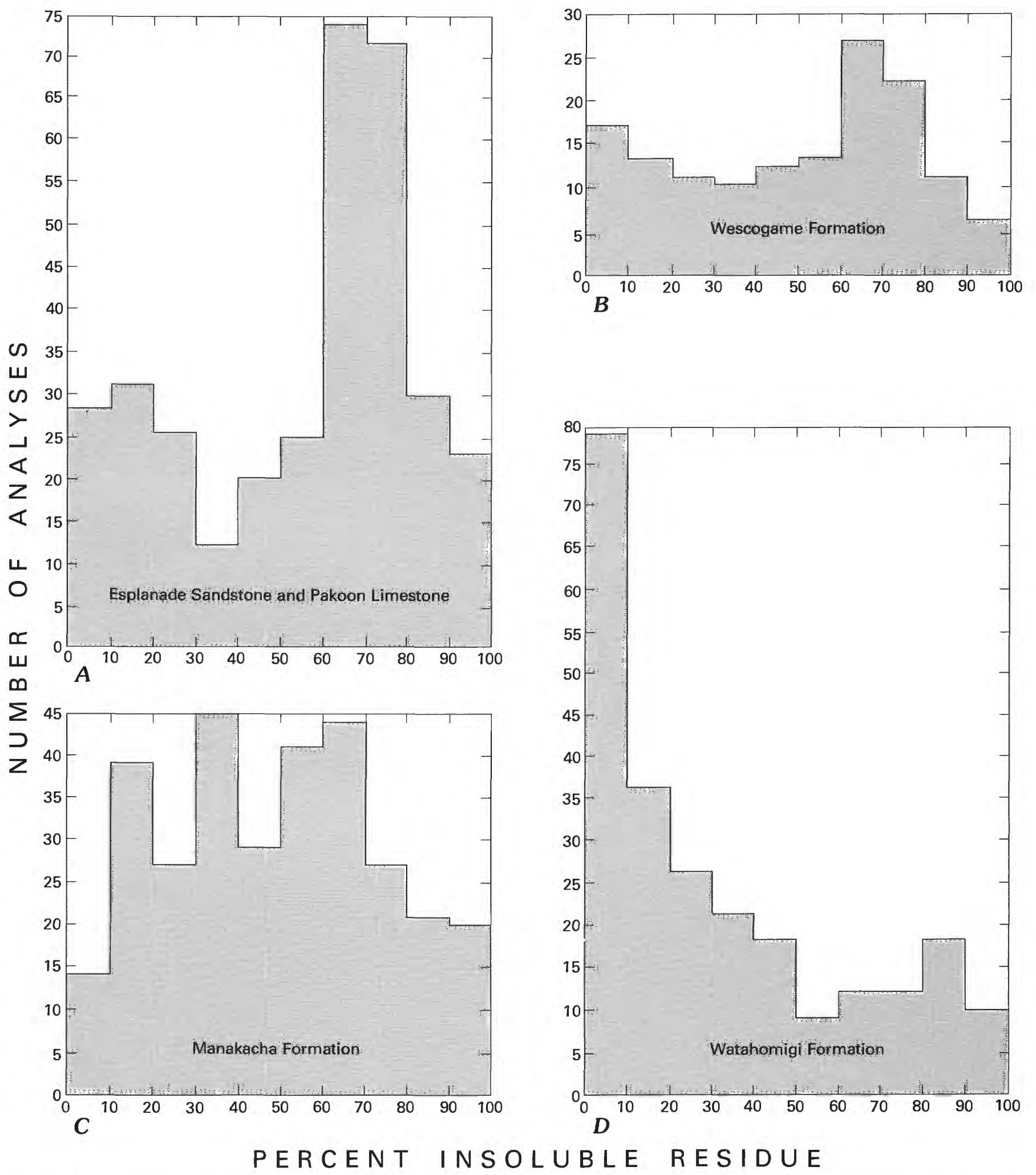

FIGURE M1.- Histograms showing distribution, by percent, of insoluble residues in rocks of the Supai Group and the Pakoon Limestone (McNair, 1951). A, Esplanade-Pakoon; B, Wescogame; C, Manakacha; D, Watahomigi. 

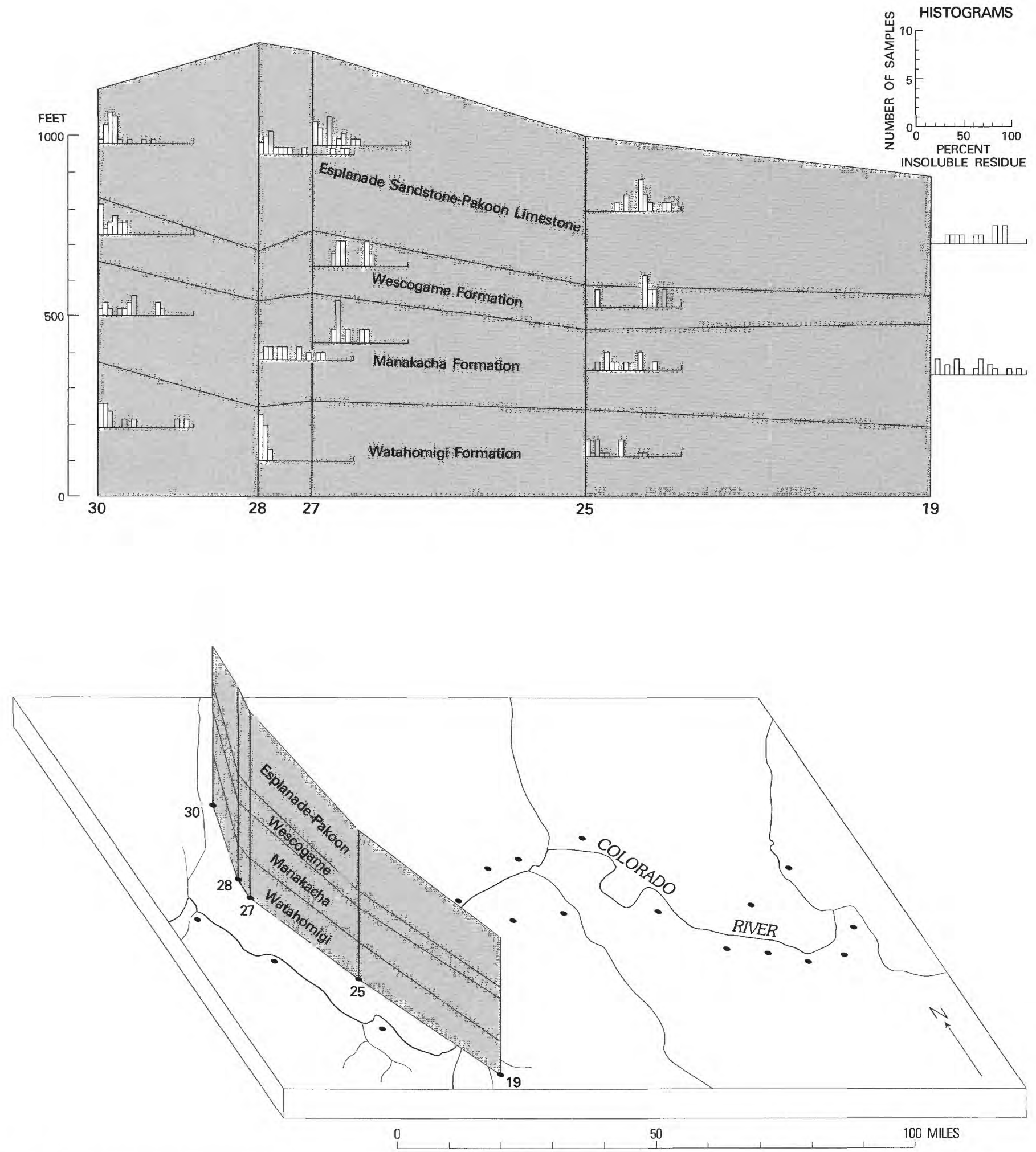

FIGURE M2.-Histograms showing distribution of insoluble residues by 10-percent classes in Supai Group and Pakoon Limestone (MCNair, 1951) from northwest to southeast in western Grand Canyon. Solid circles and numbers represent measured sections (fig. A1). 

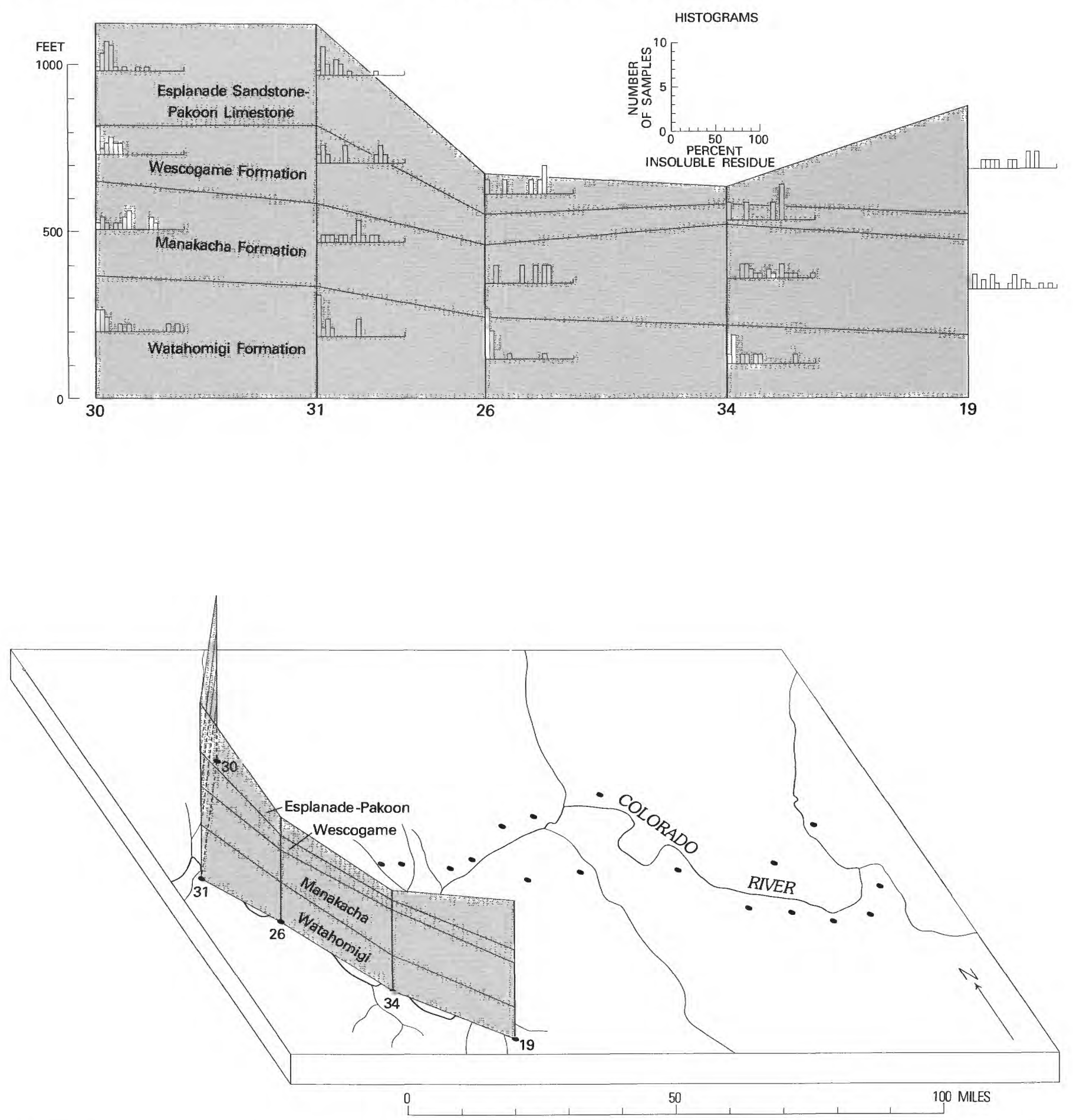

FIGURE M3.-Histograms showing distribution of insoluble residues by 10-percent classes in Supai Group and Pakoon Limestone (McNair, 1951) from north to south in western Grand Canyon. Solid circles and numbers represent measured sections (fig. A1). 

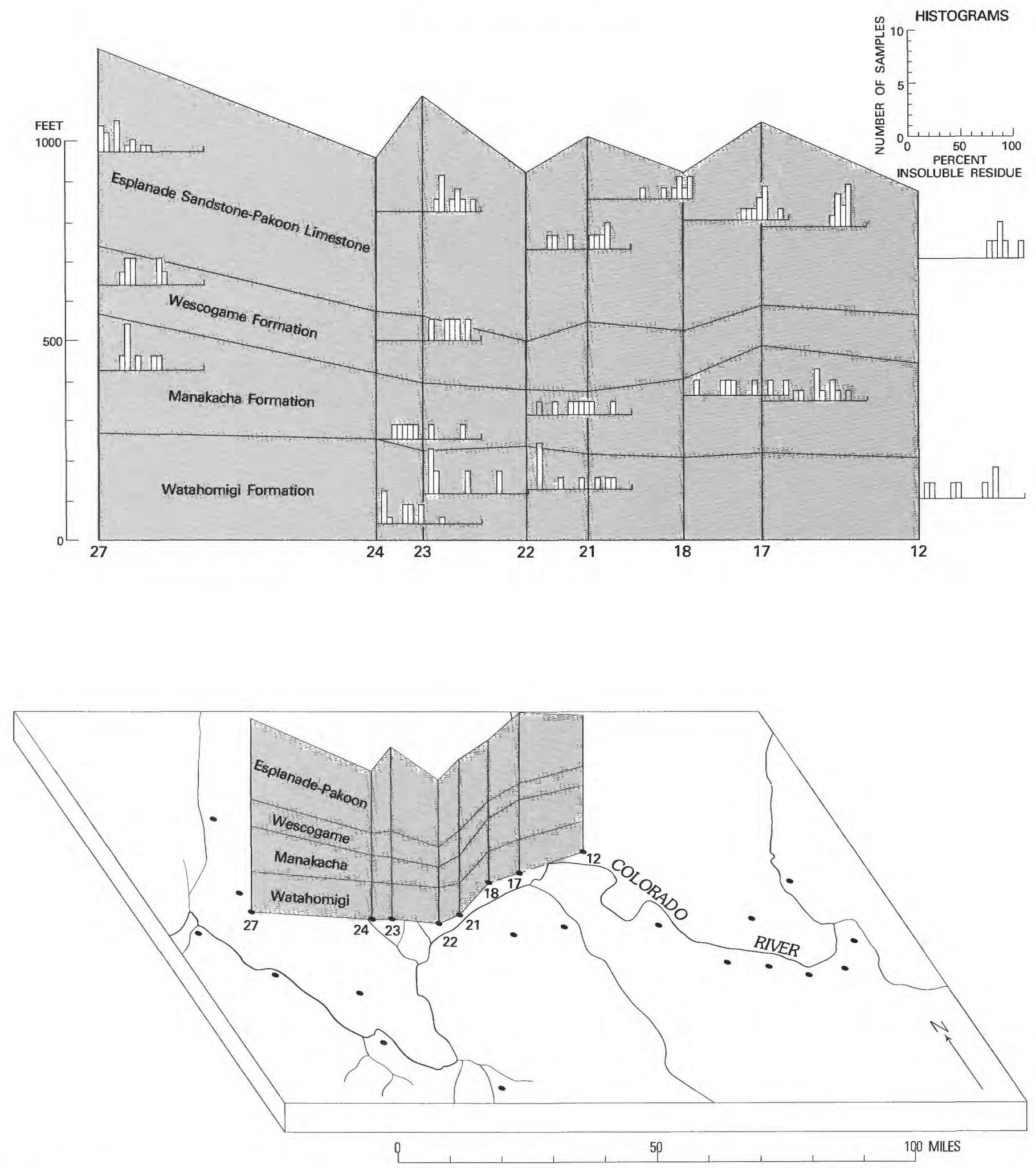

FIGURE M4.- Histograms showing distribution of insoluble residues by 10-percent classes in Supai Group and Pakoon Limestone (McNair, 1951) from west to east in western Grand Canyon. Solid circles and numbers represent measured sections (fig. A1). 

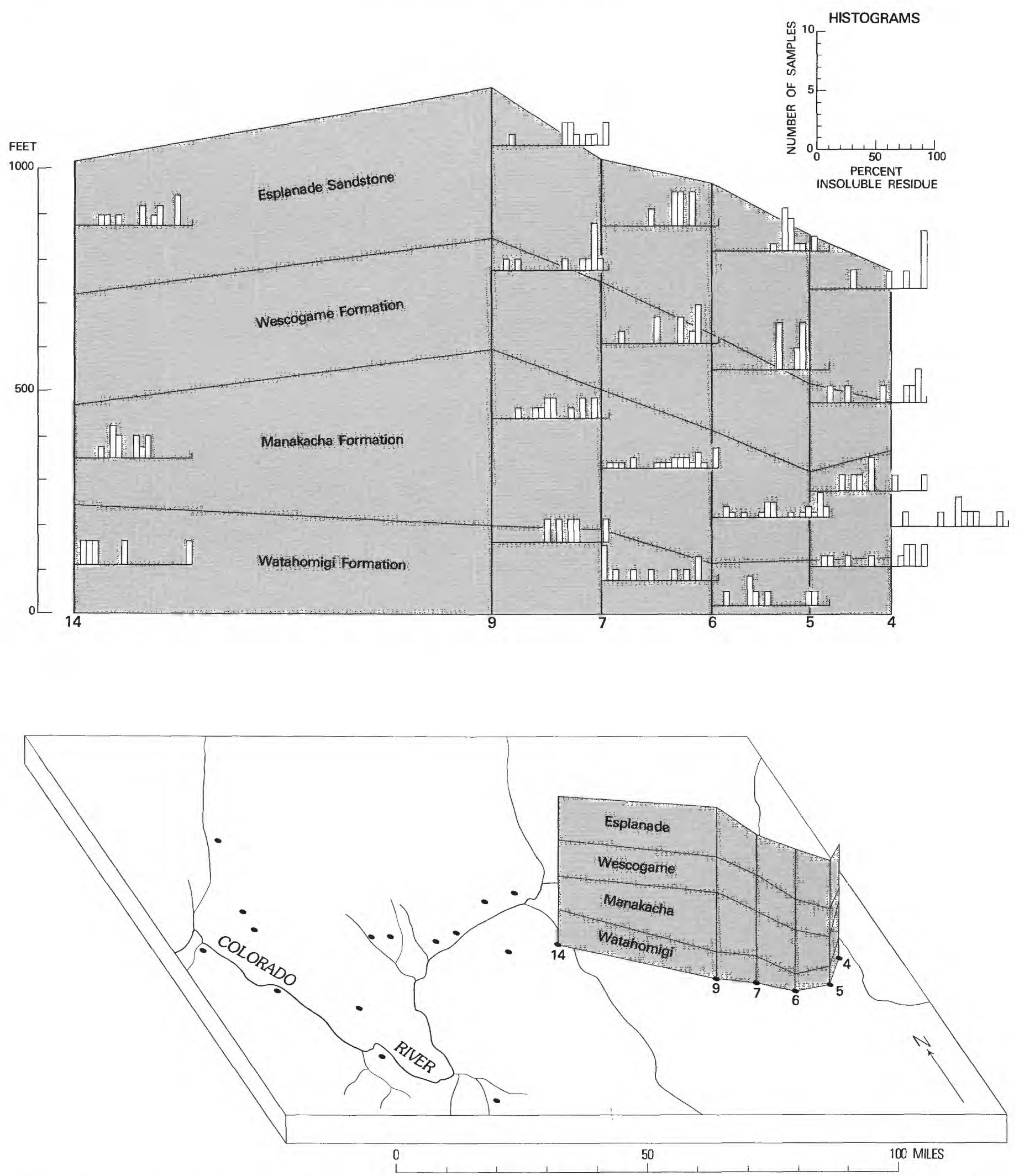

FIGURE M5. - Histograms showing distribution of insoluble residues by 10-percent classes in Supai Group and Pakoon Limestone (McNair, 1951) from west to east in eastern Grand Canyon. Solid circles and numbers represent measured sections (fig. A1). 

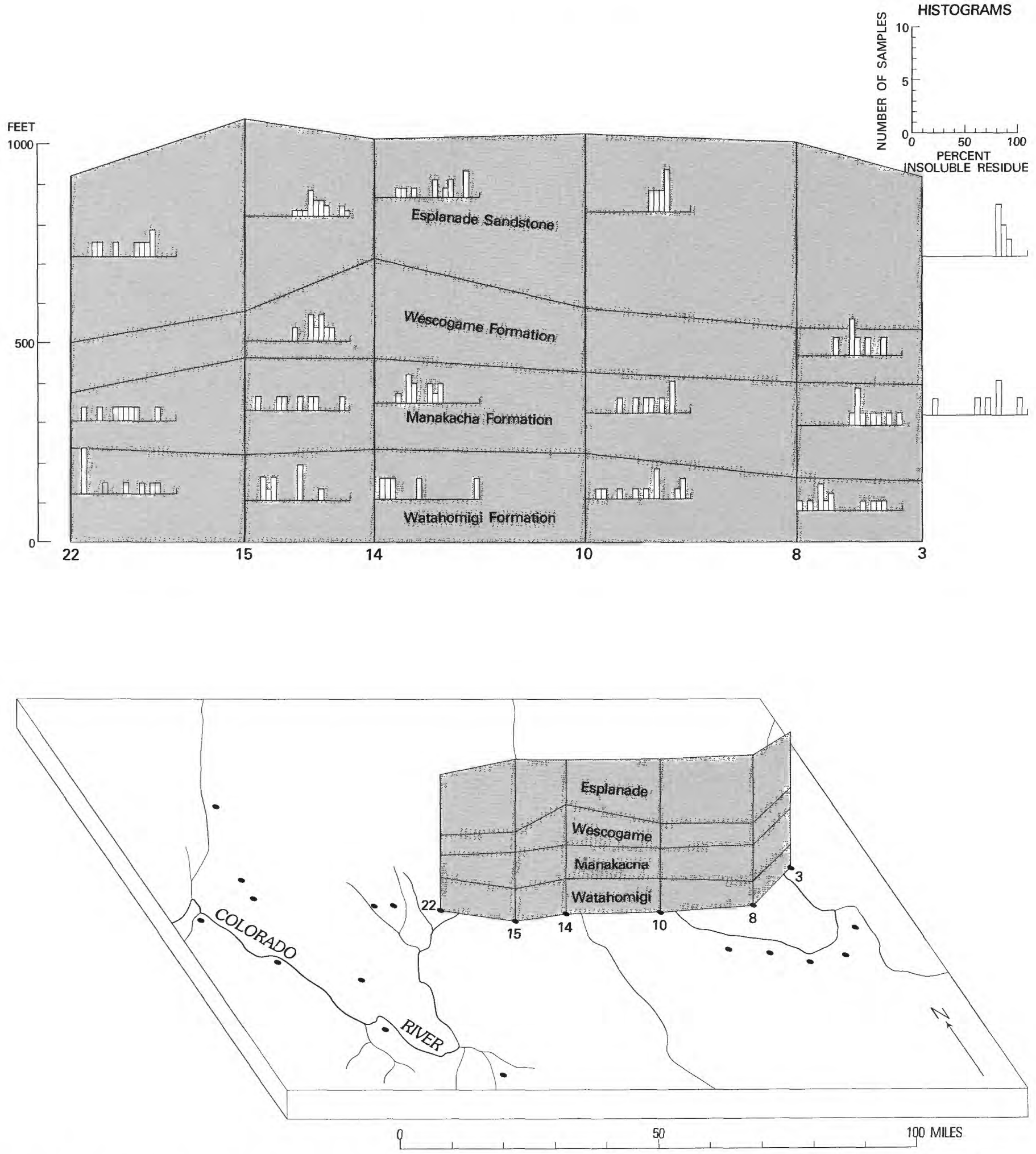

FIGURE M6.-Histograms showing distribution of insoluble residues by 10-percent classes in Supai Group and Pakoon Limestone (McNair, 1951) from west to east in central and eastern Grand Canyon. Solid circles and numbers represent measured sections (fig. A1). 
more carbonate material than do those of the overlying formations, as indicated by the relatively small number of analyses in the higher insoluble percentage classes (fig. M1C).

\section{INSOLUBLE RESIDUES OF THE WESCOGAME FORMATION}

The histogram for total insoluble residue analyses of the Wescogame Formation (fig. M1B) is similar to those of the Watahomigi and Esplanade-Pakoon in that it shows two detrital peaks, but it is smaller because it is based on fewer samples. Apparent on the histogram is the maximum concentration of insoluble residue samples at the 60 to 80 percent range.

The general trend in insoluble residue (sand) modes from west to east (figs. M2-M6) shows an eastward increase in size. The rate of change is by no means constant, however, and in two places, reversals are recorded. Most obvious is the change from Hidden Canyon (sec. 30) to Iceberg Canyon (sec. 31), although this is in a southwesterly, rather than a westerly, direction. The actual variation in modes across the region is summarized as follows:

\begin{tabular}{|c|c|c|}
\hline $\begin{array}{l}\text { Class, in percent } \\
\text { insoluble residue }\end{array}$ & $\begin{array}{l}\text { Measured section localities (name and no.), } \\
\text { from west to east (top to bottom) }\end{array}$ & \\
\hline $70-8$ & Iceberg Canyon & 31 \\
\hline $0-10$ & Hidden Canyon .. & 30 \\
\hline $20-30$ & Snap Canyon ........ & 27 \\
\hline $60-70$ & Andrus Canyon $\ldots \ldots \ldots \ldots \ldots \ldots$ & 24 \\
\hline $40-50$ & Prospect Valley $\ldots \ldots \ldots \ldots \ldots \ldots \ldots \ldots$ & 20 \\
\hline $80-90$ & National Canyon ............. & 15 \\
\hline $70-80$ & Hermit Trail ........ & 9 \\
\hline $70-80$ & Kaibab Trail, south $\ldots \ldots \ldots \ldots$ & 7 \\
\hline $90-100$ & Bunker Trail $\ldots \ldots \ldots \ldots \ldots \ldots \ldots$ & 5 \\
\hline
\end{tabular}

Two localities-Snap Canyon and Prospect Valleystand out as having especially large numbers of samples in the intermediate range between sandstone and carbonate rock.

\section{INSOLUBLE RESIDUES OF ESPLANADE SANDSTONE AND PAKOON LIMESTONE}

The generalized histogram for insoluble residues of the Esplanade Sandstone and Pakoon Limestone, undivided (fig. M1A), gives expectable results. Two peaks are apparent: the larger one in the insoluble residue classes between 60 and 80 percent, caused by the relatively pure sandstone that dominates the Esplanade in most of central and eastern Grand Canyon; the lesser one in the class of 0-20 percent insolubles reflecting the relatively pure carbonate rocks of the Pakoon in the extreme western edge of the Grand Canyon region.

Histograms from west to east (figs. M2-M6) illustrating Esplanade-Pakoon insoluble residue analyses show clearly the effects of an abrupt facies change. As stated by Winchell (1924), this feature probably can be explained as the result of retarding the activities of calcium carbonatesecreting organisms by a flooding of the area with noncarbonate detritus.

\section{REFERENCES CITED}

McNair, A. H., 1951, Paleozoic stratigraphy of part of northwestern Arizona: American Association of Petroleum Geologists Bulletin, v. 35 , no. 3, p. 503-541.

Winchell, A. N., 1924, Petrographic studies of limestone alterations at Bingham [Utah] (with discussion): American Institute of Mining and Metallurgical Engineers Transactions, v. 70, p. 884-903. 

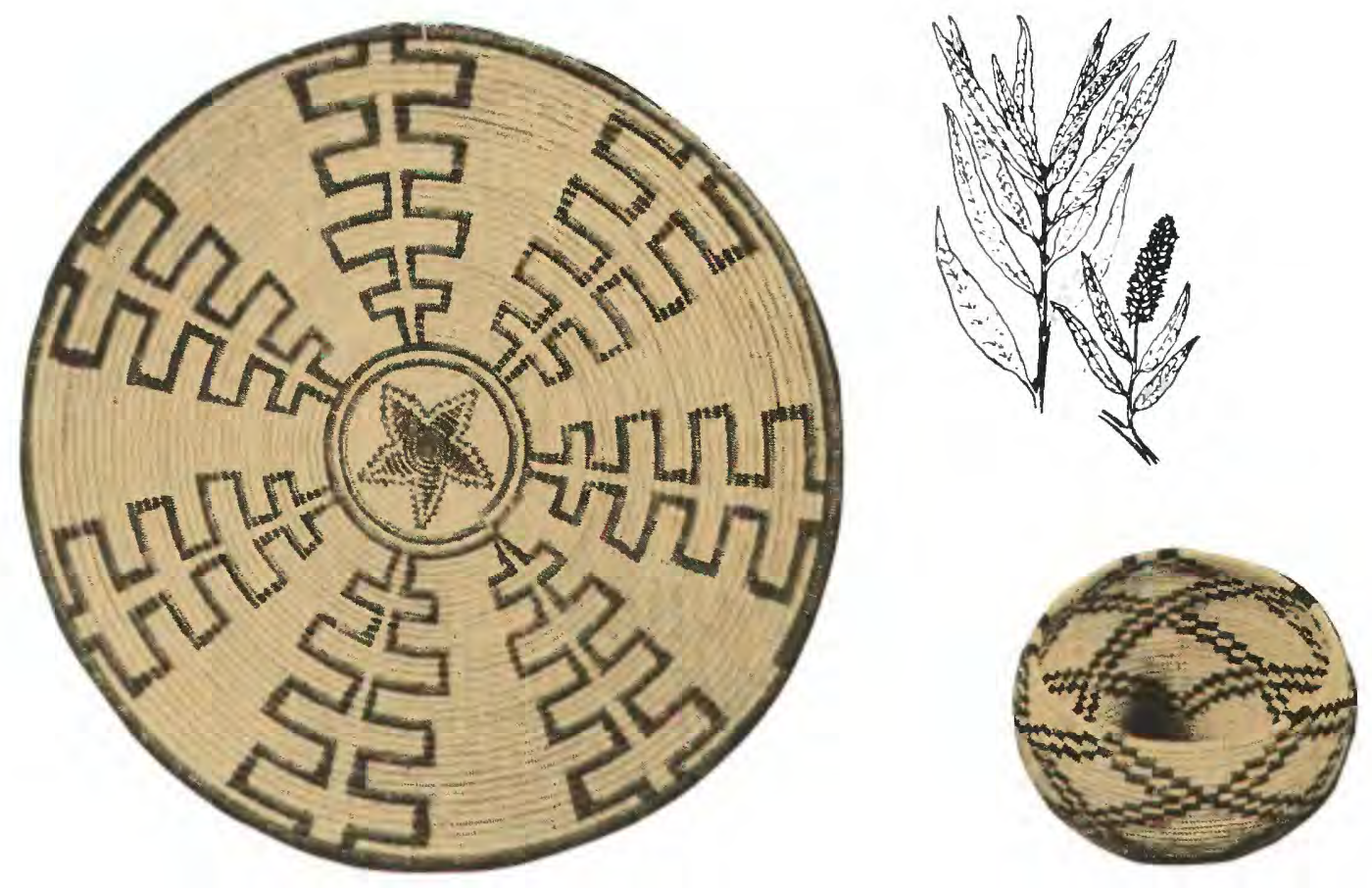

THE SUPAI GROUP OF GRAND CANYON

\section{MINOR SEDIMENTARY FEATURES, CONTORTED STRUCTURES, AND HOMOGENEOUS SEDIMENTARY ROCKS}

Chapter $\mathrm{N}$

By EDWIN D. McKEE

Contents

\begin{tabular}{|c|c|}
\hline & Page \\
\hline Ripple marks & 275 \\
\hline Shrinkage cracks ............ & 276 \\
\hline Rain pits or craters $\ldots \ldots \ldots \ldots \ldots \ldots \ldots \ldots \ldots \ldots \ldots \ldots \ldots \ldots \ldots \ldots$ & 277 \\
\hline 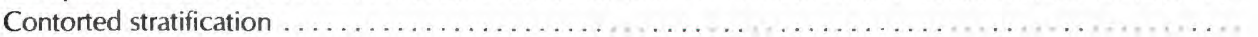 & 277 \\
\hline Homogeneous sandstones & 280 \\
\hline 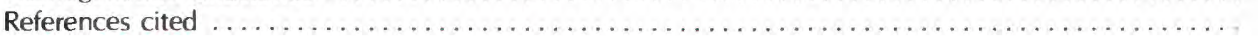 & 285 \\
\hline
\end{tabular}




\section{Illustrations}

FIGURES N1-N4. Photographs showing minor sedimentary structures in:

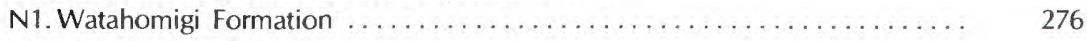

N2. Wescogame Formation .............................. 277

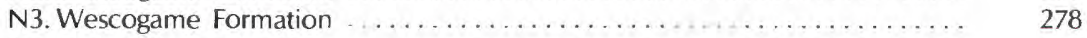

N4. Esplanade Sandstone ................................... 279

N5. Sketches of crinkled beds near base of Manakacha Formation ............. 281

N6. Photographs of contorted stratification in sandstones of Supai Group . . . . . . . . 282

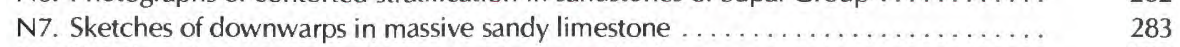

N8. Sketches of compressional structures in foreset beds . . . . . . . . . . . . . . 284

N9. X-ray radiographs of homogeneous sandstone, Esplanade Sandstone .......... 285 


\section{RIPPLE MARKS}

Ripple marks have been found in all of the four formations of the Supai Group. They occur in numerous stratigraphic sections from Marble Canyon on the east to Iceberg Canyon on the west. Ripple marks are on the foreset surfaces of cross-stratified sandstones, on shaly siltstones and mudstones, and on silty or sandy limestones and dolostones.

Despite the broad range in distribution, both vertically and horizontally, only in a few places can ripple marks be considered common; in overall distribution they are very uncommon. Ripple marks are considerably less common in the Supai Group than in the overlying Permian Hermit Shale and very much less common than in the Triassic Moenkopi Formation of the same region. Their relative scarcity, rather than their presence or their diversity of form, probably is the most significant feature of this structure with regard to the Supai Group.

A considerable variation in depositional environments is represented by ripple marks of the Supai Group. Some are formed in flatbedded siltstones and mudstones that accumulated under continental conditions as indicated by associated mud cracks, rain pits, leaves of land plants, and other diagnostic features. Other ripple marks were formed under shallow marine waters as deduced from their occurrence in sandy or silty carbonate rocks interlayered with fossil-bearing marine limestones. Still other ripple marks are on the dipping foreset planes of sandstone cross-strata, the genesis of which may be difficult to determine.

Ripple marks of the Supai Group are of three principal types: (1) the parallel straight (figs. N $3 A, N 4 B$ ) and the parallel sinuous or caternary (fig. N3D); (2) the tonguelike form that extends down-current (fig. N3B), named linguoid by Bucher (1919, p. 164); (3) the crescent form that faces down-current (fig. $\mathrm{N} 3 \mathrm{C}$ ), which is the lunate form of Allen (1968, p. 60). Of 21 sets of ripple marks examined and measured during the present study (see measured stratigraphic sections), 10 sets consisted of parallelstraight or parallel-sinuous and the other 11 sets were of crescentic (lunate or linguoid) forms.

In measuring various sets of ripple marks, the dimension descriptions of Allen (1963) were followed. In parallelstraight or parallel-sinuous ripples of the Supai Group, the height $(\mathrm{H})$ ranged from 0.3 to $0.8 \mathrm{~cm}$, and the wave length (L) from 4.2 to $9.1 \mathrm{~cm}$. In crescentic forms, the range was from 0.6 to $1.3 \mathrm{~cm}$ in height and from 6.4 to $8.5 \mathrm{~cm}$ in wave length. The width range (B) was between 11.5 and $33.2 \mathrm{~cm}$.

Ripple structures in the Watahomigi Formation consist mainly of ripple laminae (figs. N1A, B, C; K2), in the form of small-scale cross-strata. These structures locally are numerous as in the lower slope unit of the Watahomigi in the central part of Grand Canyon, at Havasu and National Canyons. Linguoid ripples occur in siltstones of the upper slope unit at Guano Cave (sec. 26).

In the Manakacha Formation, parallel-straight ripple marks occur in very fine grained sandstone units at three localities (National Canyon, Thunder River Trail, and Bass Trail) in central Grand Canyon and in shaly siltstone at Separation Canyon in the west. The first two of these ripple localities are in the upper or slope unit, in deposits that probably are continental. The Separation Canyon site is near the base of the main cliff, associated with shrinkage cracks, and likely also represents a continental environment.

Considerably more ripple marks were observed in the Wescogame Formation than in any other formation of the Supai Group. More than half of the ripple-bearing surfaces examined were in the main cliff unit in localities between Bass Trail and Andrus Canyon. All were in sandstones or very sandy limestones and included parallel-type ripples (fig. $\mathrm{N} 3 A$ ), linguoid ripples (fig. $\mathrm{N} 3 B$ ), parallel-sinous ripples (fig. $\mathrm{N} 3 D$ ), and climbing ripple laminae (fig. $\mathrm{N} 2 A$ ). The climbing ripple laminae indicate deposition with an abundance of clastic particles available, possibly the result of very rapid accumulation on a flood plain, point bar, or similar fluvial environment (McKee, 1965, 1966).

The overlying slope unit of the Wescogame Formation, which includes much shaly siltstone, mudstone, and some very fine grained sandstone, locally contains ripple marks, mostly of the parallel-straight type, but some of crescentic forms. The localities represented are mostly in central Grand Canyon, but some ripple structures were at Iceberg Canyon in the extreme western part of the area. At that locality, ripple lamination is recorded near the top of the unit among sediments considered, on the basis of other structures, to be continental in origin.

The Esplanade Sandstone, which includes the largest sandstone body in the Supai Group, contains ripple marks at a number of widespread localities. Most of the ripple marks, however, are not in the massive sandstone of the main cliff unit, but are in shaly siltstone and mudstone near the formation base. Both on Kaibab Trail, north, in the east and in Iceberg Canyon to the west, tongue-shaped (linguoid) ripples are recorded in association with beds containing shrinkage cracks, leaves and stems of land plants, and other indicators of a continental environment. In a few places, ripple marks occur on surfaces of the massive sandstone of the main cliff unit as, for example, near Topocoba Trail where long parallel-straight type ripples cover large bedding surfaces (fig. N4B) and near Thunder River Trail where they cover foresets that have a $12^{\circ}$ dip. At S B Canyon crescent-shaped ripple marks occur in very fine grained sandstone. 

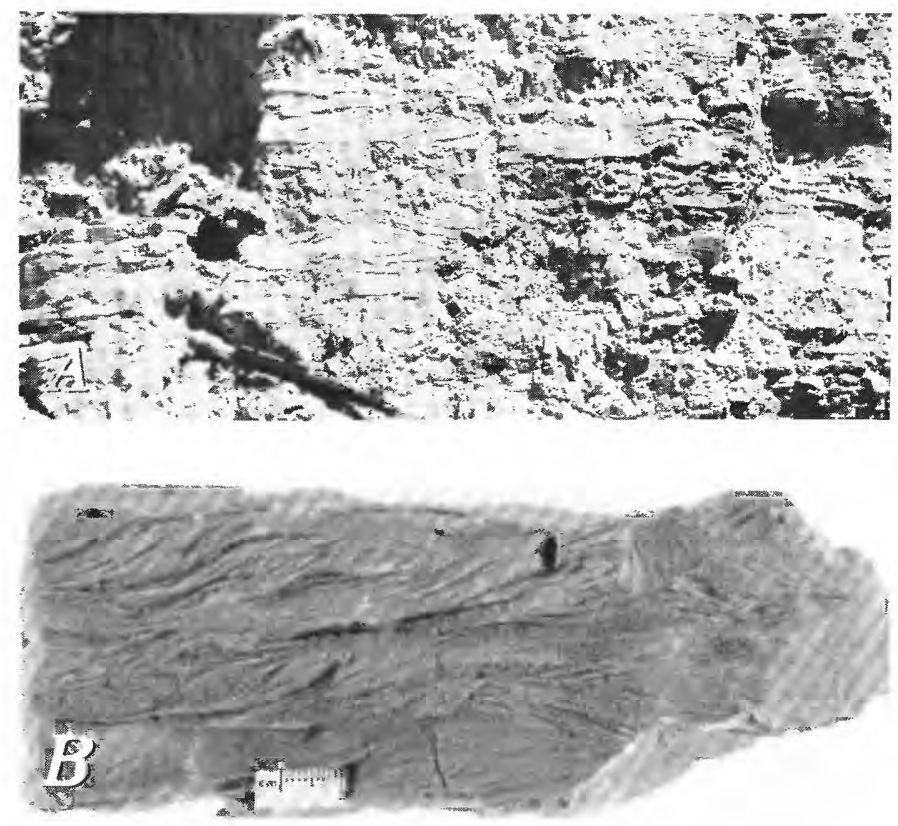

FIGURE N1.-Minor sedimentary structures in Watahomigi Formation, Grand Canyon, Ariz. A, Ripple laminae in siltstone near base of formation at Navajo Falls, Havasu Canyon; $B, C$, ripple lamination in silty limestone at $50 \mathrm{ft}$ above formation base, National Canyon; $D$, molds of shrinkage cracks in red-brown mudstone, basal slope of Watahomigi Formation, Picacho Butte, south side.

\section{SHRINKAGE CRACKS}

Shrinkage cracks, normally of polygonal form, occur in the Supai Group, mostly in thin mudstone and siltstone beds (fig. N1D). They constitute one of the best criteria for the recognition of continental strata for they are characteristically developed in muddy subaerial environments such as estuaries, lagoons, river flood plains, or playas. Mostly they are formed through desiccation by the sun. Shrinkage cracks in the Supai commonly are associated with raindrop pits and various types of land plants.

The distribution of shrinkage cracks in the Supai Group is extensive, both from a geographic and a stratigraphic standpoint, yet they are not abundant in any one locality. Descriptions of measured sections show the presence of shrinkage cracks from Blue Spring and Kaibab Trail, north, in the east to Pigeon Wash and Snap Canyon in the west. They are reported from near the base of the Watahomigi (Schuchert, 1918, p. 357) and from the three overlying formations as described in the present publication.

The most laterally extensive single exposure of shrinkage cracks noted in the Supai of Grand Canyon during this study was in a small canyon north of Snap Point. In the Wescogame Formation at this locality, a mudstone layer 2-4 in. thick, with cross-bedded calcareous sandstone above and below, contained shrinkage cracks for a distance of $70 \mathrm{ft}$, traceable along the canyon wall. The
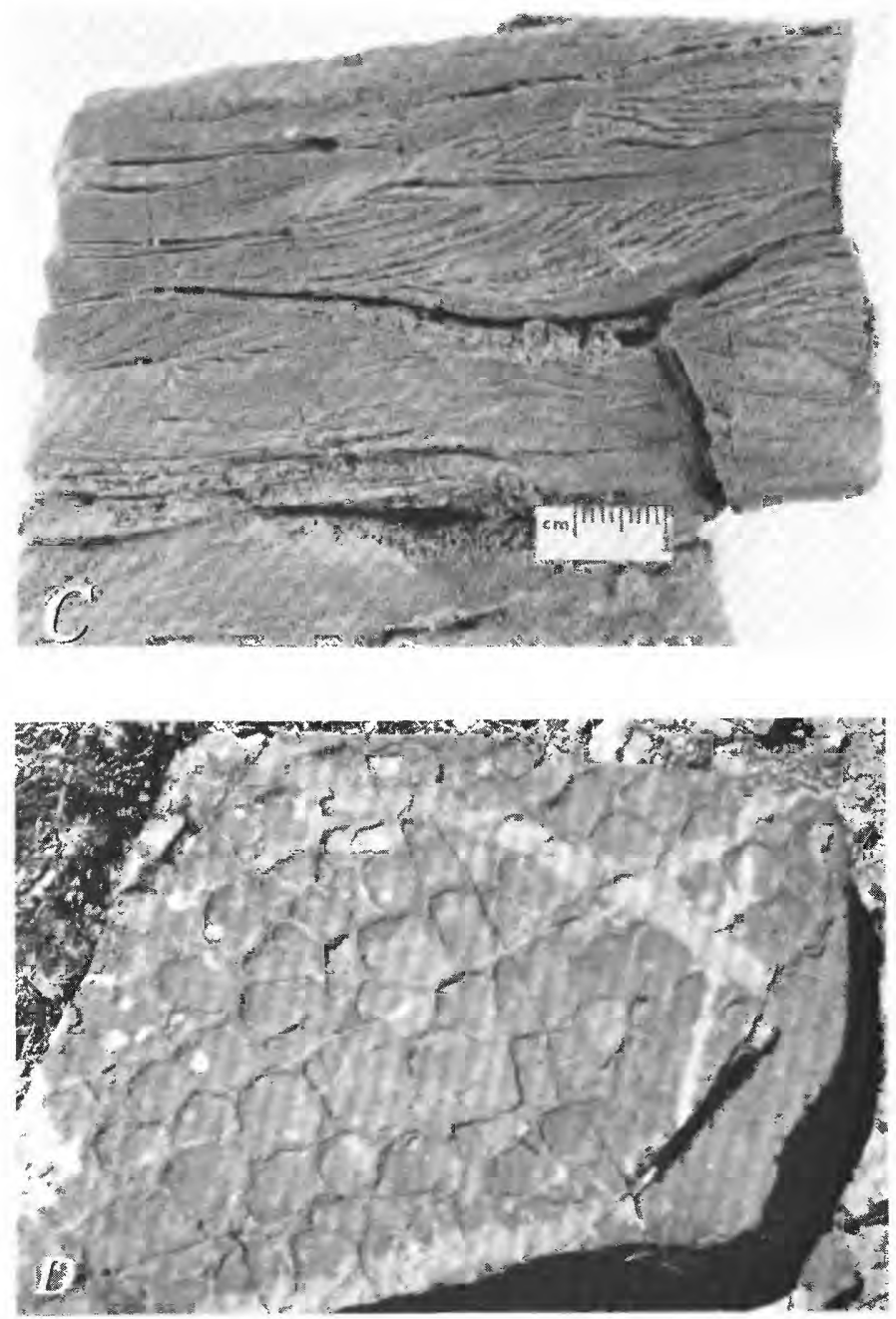

cracks consisted of polygons 6-10 in. in diameter and cracks $0.5-1.0$ in. wide. Similar features also occur at several lower horizons in the slope member of the Wescogame.

An analysis of the stratigraphic positions from which Supai shrinkage cracks have been recorded and which, therefore, indicate times of subaerial environment, has been made. It shows about one-half to be in the slope (mudstone) units of each formation and one-half in mudstone interbeds or lenses within the cliff (sandstone, limestone) units. An obvious conclusion from this vertical distribution pattern is that relative sea level was repeatedly rising and lowering in this area throughout PennsylvanianPermian time, causing surfaces of deposition to be above water level for short intervals, even during general periods of sedimentation.

Rounded pillow-shaped molds on the bottom of a massive sandstone bed (fig. N4A) occur in the lower slopeforming unit of the Esplanade Sandstone near the Topocoba Trail to Supai Village. They closely resemble the sand polygons described by Conybeare and Crook (1968, p. 42, pl. 52C) that are interpreted as "mudcrack moulds." The rounding of the polygons is attributed by 

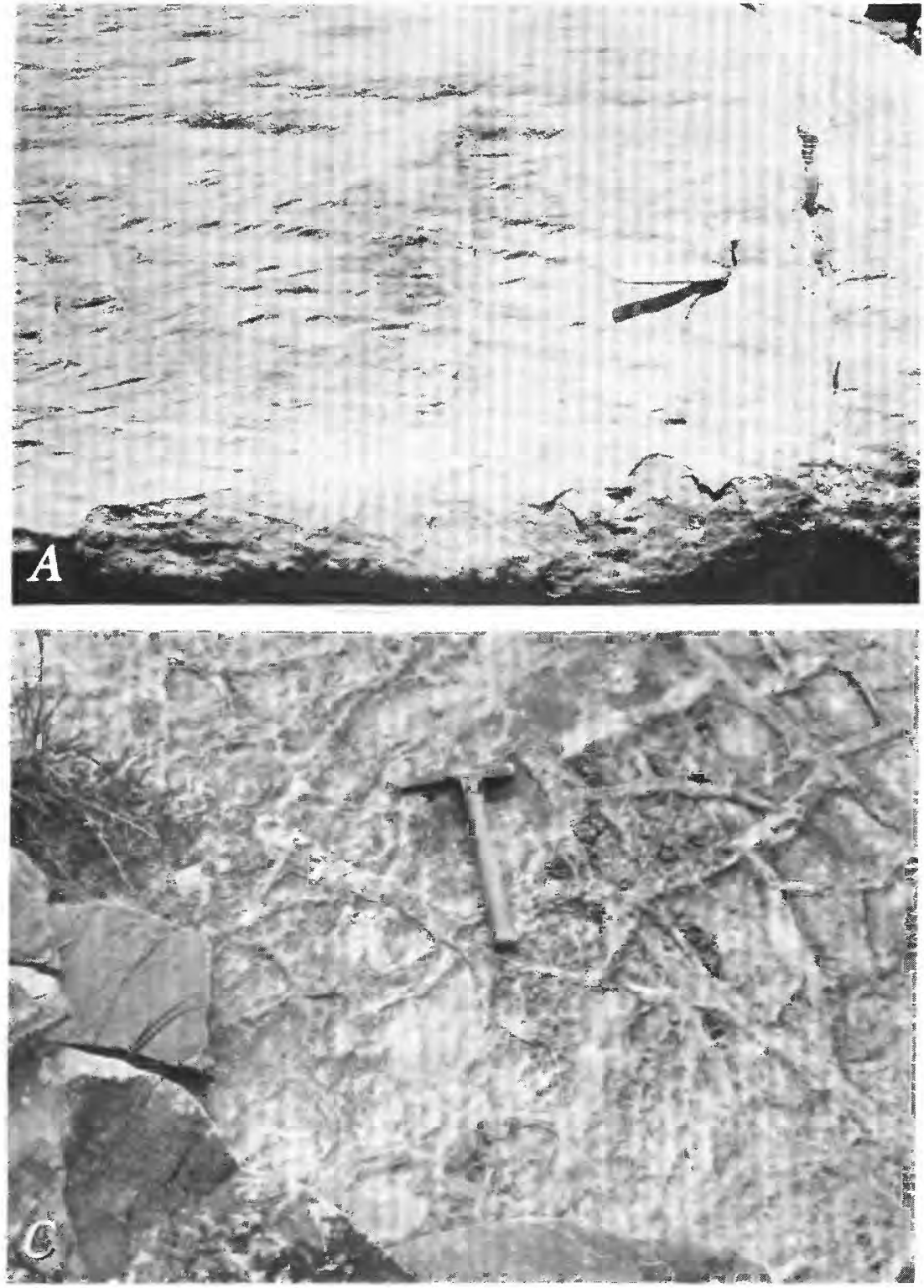

FIGURE N2.-Minor sedimentary structures in Wescogame Formation, Grand Canyon, Ariz. A, Climbing ripple laminae, overlain by horizontal laminae, in sandy limestone at top of cliff unit, Toroweap Point. Ripple migration from right to left. $B$, Contorted structure in thick-bedded sandstone showing folds probably caused by differential loading of sand in quicksand condition, cliff unit, Thunder River Trail. C, Shrinkage cracks in talus block from cliff unit, Apache Trail, Havasu Canyon.

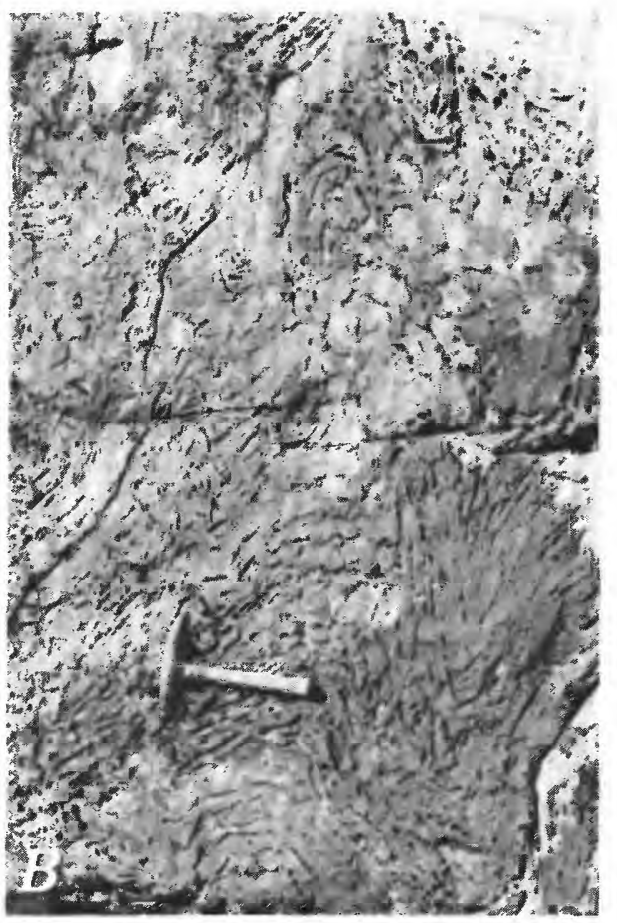

them to weathering, but the original curved surfaces probably were concave upward as in normal polygons formed by cracks.

\section{RAIN PITS OR CRATERS}

An "abundance of rain prints and a few rill markings" were reported by Schuchert $(1918$, p. 357) from "thin bedded flaggy sandstones" at the base of the slope (probably Wescogame slope unit) below the Esplanade Sandstone along Hermit Trail. Since this initial report, the craters of raindrops have been recorded from the slope unit of the Manakacha Formation at Thunder River Trail and from the basal slope unit of the Esplanade at Kaibab Trail, north, and in Twin Springs Canyon.
The principal significance of these observations of rain pits in mudstone is that they further substantiate the occurrence of periodic times of subaerial conditions within an environment of dominantly subaqueous deposition. They are commonly associated with shrinkage cracks, plant impressions, worm burrows, and the probable algal surfaces known as Rivularites.

\section{CONTORTED STRATIFICATION}

Penecontemporaneous deformation is responsible for a number of distinct types of contorted stratification, each with an infinite variety of forms. Contortion may result 

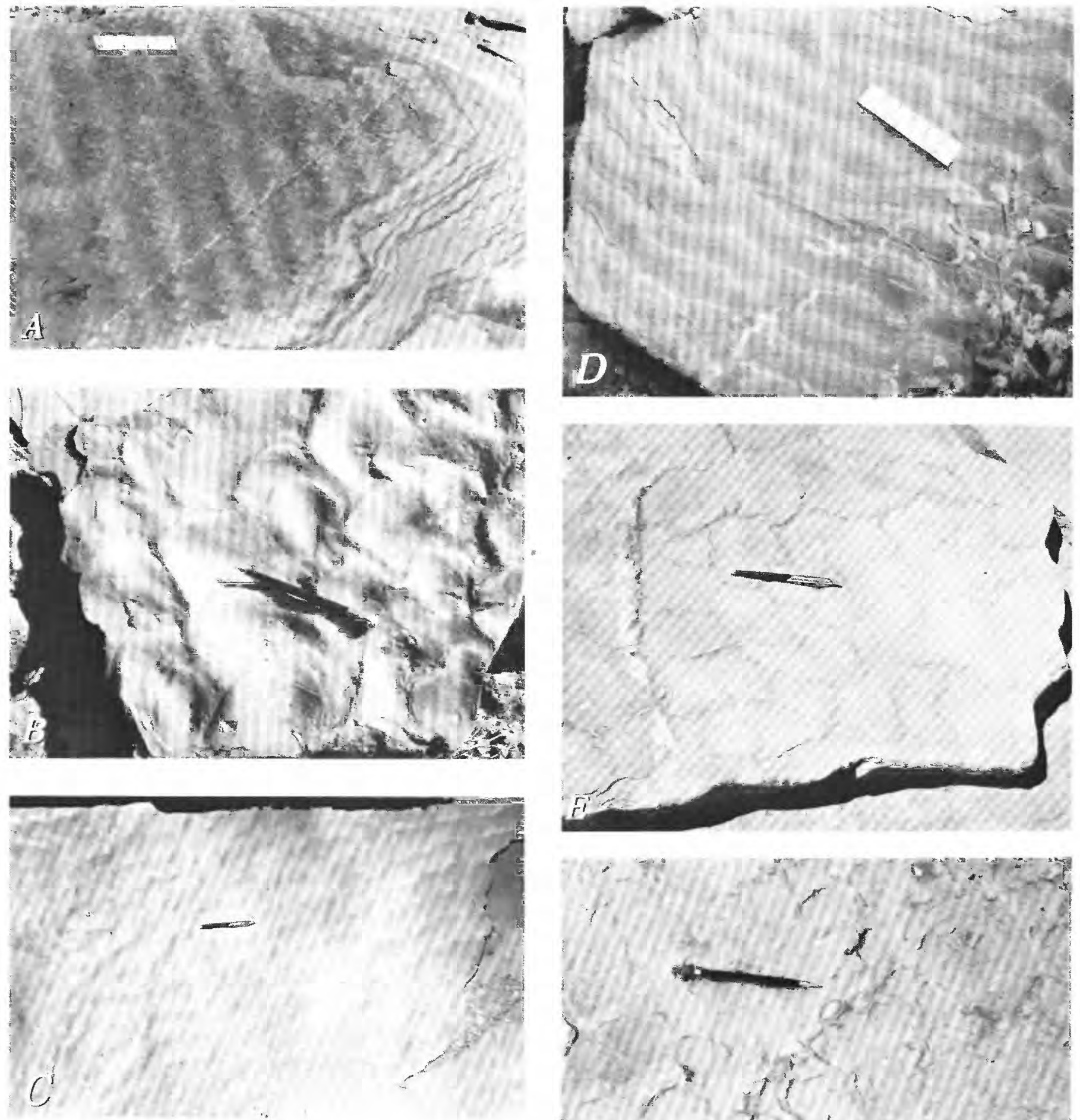

FIGURE N3.-Varieties of ripple marks and shrinkage cracks in Wescogame Formation, Grand Canyon, Ariz. A, Parallel-straight ripple marks on inclined $\left(20^{\circ}\right)$ bedding plane of foresets, Thunder River Trail. Scale in inches. B, Linguoid or crescent-shaped ripple marks, Apache Trail in Havasu Canyon. C, Lunate or cresent-shaped ripple marks and drag marks, Andrus Canyon. D, Parallel-sinuous ripple marks, Apache Trail in Havasu Canyon. Scale in inches. E, Shrinkage cracks and probable mold

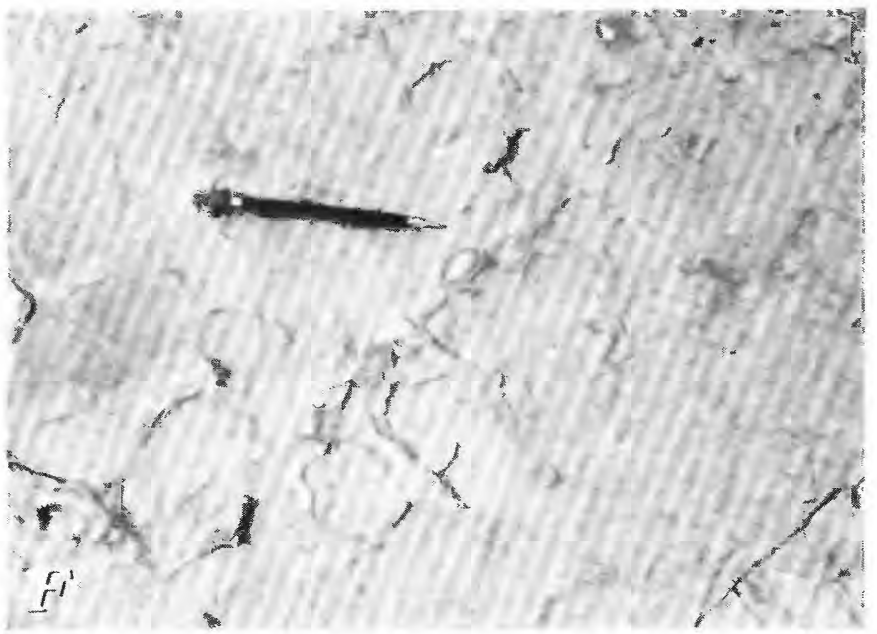

of plant stem, near top of cliff unit, Andrus Canyon. F, Molds of shrinkage cracks in green siltstone; locally replaced with jasper, Hidden Canyon. 

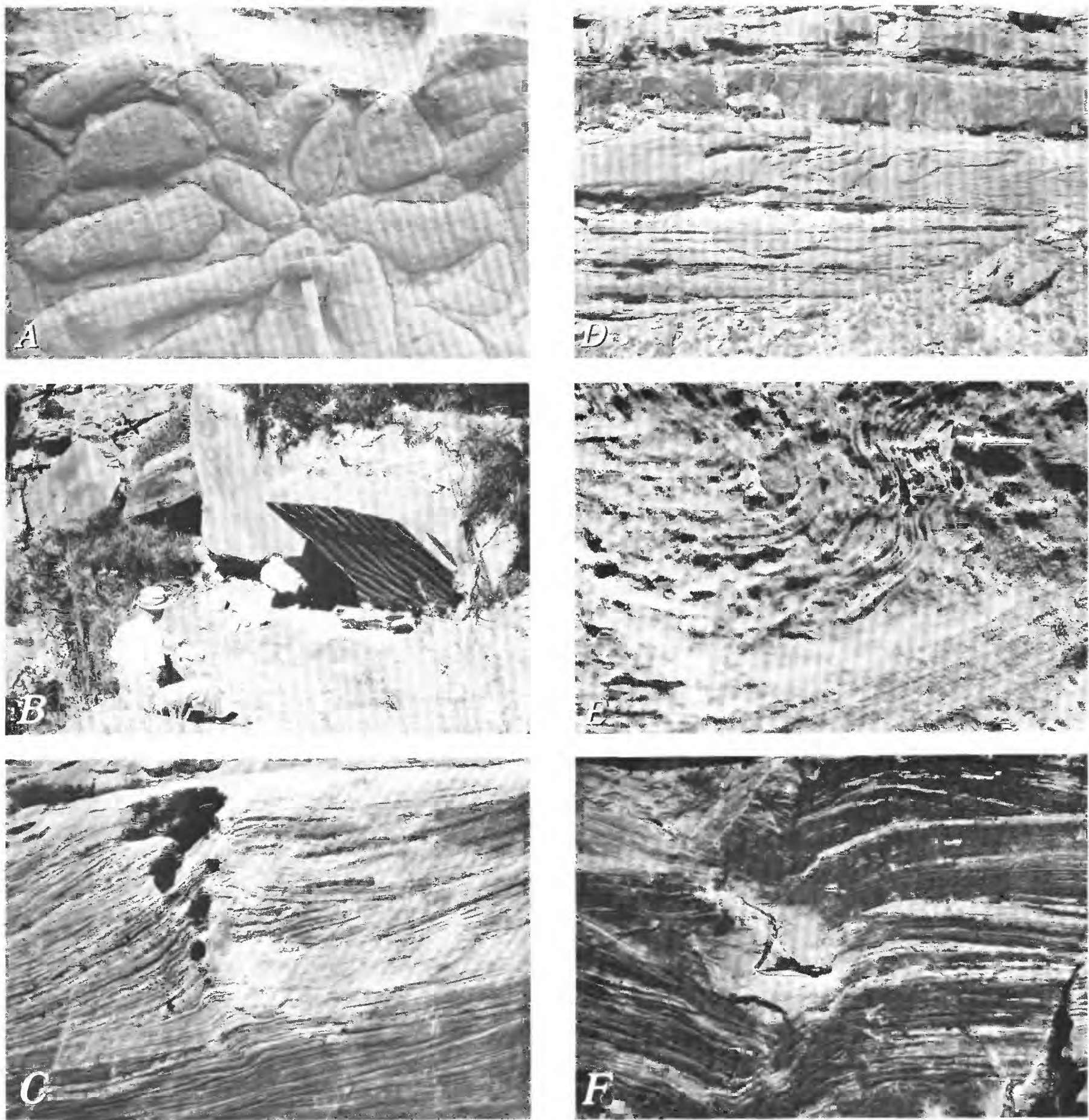

FIGURE N4.- Minor sedimentary structures and contorted bedding in Esplanade Sandstone, Grand Canyon, Ariz. A, Pillow-shaped molds developed on bottom of bed near base of main cliff unit, Topocoba Trail. B, Parallel-straight ripple marks and casts, on sandstone blocks near base of main cliff unit, Topocoba Trail. C, Contorted structure in cross-strata of calcareous sandstone, probably resulting from differential loading. Anticline in center from escaping gas or water.

Toroweap Point. D, Small-scale contortions in thin- to mediumbedded sandstone, Kaibab Trail, north. Middle ledge with contorted bedding is $4 \mathrm{ft}$ thick. $E$, Contorted structure (fold), possibly result of slumping at base of foresets, Bright Angel Trail. Pencil in upper right gives scale. $F$, Contorted structure, probably from loading of crossstrata sets, in limy sandstone. Toroweap Point. Pencil in center gives scale. 
from differential loading, from avalanching in the form of mass slumping, from surface drag caused by sedimentladen currents, and probably from other processes (McKee, Reynolds, and Baker, 1962; Conybeare and Crook, 1968, p. 37). In the Supai Group, nearly all contorted structures seem to be attributable to either loading or avalanching. The numerous varieties of contorted strata occur widely scattered through the four formations of the Supai.

Differential loading with detritus at the time of, or soon after, deposition of a sedimentary bed normally is recognized by high-angle folds, as demonstrated by experiments (McKee and Goldberg, 1969). The form and size of the folds varies widely according to (1) the manner of deposition of the overlying unit, (2) the form of the underlying surface, (3) the direction of loading, and (4) the current velocity or lack of movement during loading. Anticlinal structures, resulting from differential loading, tend to be narrow and pointed; synclinal structures commonly are somewhat rounded or flat-bottomed (McKee, 1966, fig. 3; Aario, 1971, fig. 5). Most contorted strata of this type are restricted to a single set of strata or cross-strata; however, the thickness of layers that are affected depends both on the consistency of the sediment that is folded and on the weight of the overburden.

Near the base of the cliff unit of the Manakacha Formation, a zone of gnarly-bedded, crinkled silty limestone is conspicuous in numerous localities because of its distinctive structure. This zone is a prominent feature along both the Hualapai and the Apache Trails into Havasu Canyon and near Kaibab Trail, north. In these places, the zone containing the crinkled or crenulated beds is $1-2 \mathrm{ft}$ thick; the beds are light-colored and form irregular, rounded anticlines and synclines spaced randomly along an extensive plane (fig. N5A). The crinkled folds seem to have formed within layers of light-red mud, which apparently was squeezed while in a very fluid condition. Layers of limestone or sandstone above and below this zone are horizontal and seemingly undisturbed.

Crenulations somewhat similar to those in the Manakacha are described and illustrated by Conybeare and Crook $(1968$, pls. 29, 30, 31) in mudstones, siltstones, and carbonate rocks of various ages and from widely scattered geographical areas. They occur between undeformed beds and mostly are referred to as convolute bedding. Various interpretations are suggested for these structures, most of which are considered to be marine turbidites; one variety from the Miocene of Italy is attributed (Conybeare and Crook, 1968, p. 142) to "sheet slumping of unconsolidated sediments," possibly triggered by "weight of sediment, earthquake shock, or thrust turbidity currents."

Large isolated downwarps, in contrast to the folds-inseries referred to above, occur in medium to thick beds in sequences of otherwise horizontal strata and represent a second variety of contortion from sediment loading. Downwarps of this type are found in massive beds of sandy limestone in the cliff unit of the Manakacha at Parashant Canyon (fig. N6D) and in thick-bedded sandy limestone of the Pakoon Limestone of McNair (1951), at Iceberg Canyon (fig. N7A). The consistency of the sediment involved in these folds must have been that of quicksand.

Contorted bedding, where slumping of a slipface is the mechanism for deforming the strata, normally involves two main types-that resulting from tensional stress at the top of a slope, and that from compression at the base. Eight principal types of deformational structures have been recognized (McKee, Douglass, and Rittenhouse, 1971). Most of the structures in the Supai Group that are considered typical of compression, occur in the medium- to large-scale cross-stratified sandstones. Compressional folds are numerous near the bases of avalanche planes on high-angle cross-strata where sand tends to pile up. Tightly folded strata are developed on foreset surfaces of the Wescogame at Thunder River Trail (fig. N6A) and along the Apache Trail to Supai Village (fig. N8B). An overturned fold in the Esplanade Sandstone on the Bright Angel Trail (fig. N8E) and rotated blocks in slump strata of the Manakacha at Whitmore Wash (fig. N8B) are typical.

\section{HOMOGENEOUS SANDSTONES}

At many places in eastern Grand Canyon, thick, massive sandstone units at various levels in the Supai Group seem to be structureless. These sandstones range from a few feet to 15 or $20 \mathrm{ft}$ in thickness and show no visible textural or compositional changes either in outcrop or in hand specimen. Such sandstone units are seemingly homogeneous, but when traced laterally along canyon walls may be found to grade into sandstone in which structural features are clearly delineated.

Using the technique of radiography in a study of seemingly homogeneous or structureless sandstones that represent a wide variety of environments, ages, and geographic situations, W. K. Hamblin $(1962,1965)$ reached the conclusion that most such sandstones actually contain a definite internal structure. In more than 300 samples examined, Hamblin determined $(1965$, p. 3$)$ that 97 percent contained grains "not packed together in random fashion, but arranged into distinctive structural units." Furthermore, he was able to recognize structural frameworks consisting of (1) various cross-strata types and (2) rhythmic laminations; also, modifications caused by "(1) burrowing organisms, (2) secondary mineral growth, and (3) penecontemporaneous deformation."

In the Esplanade Sandstone of eastern Grand Canyon, where seemingly homogenous units of sandstone are 


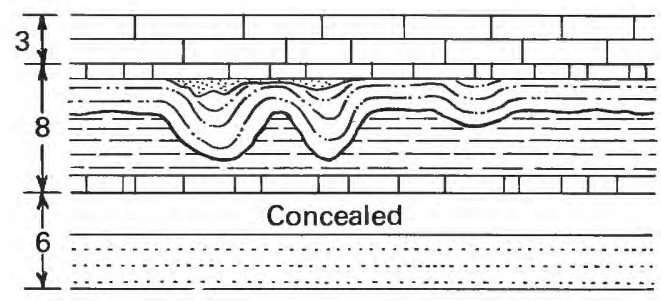

A

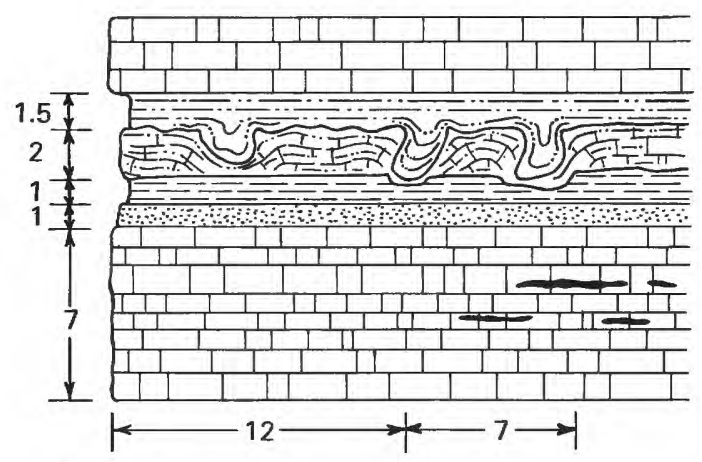

B

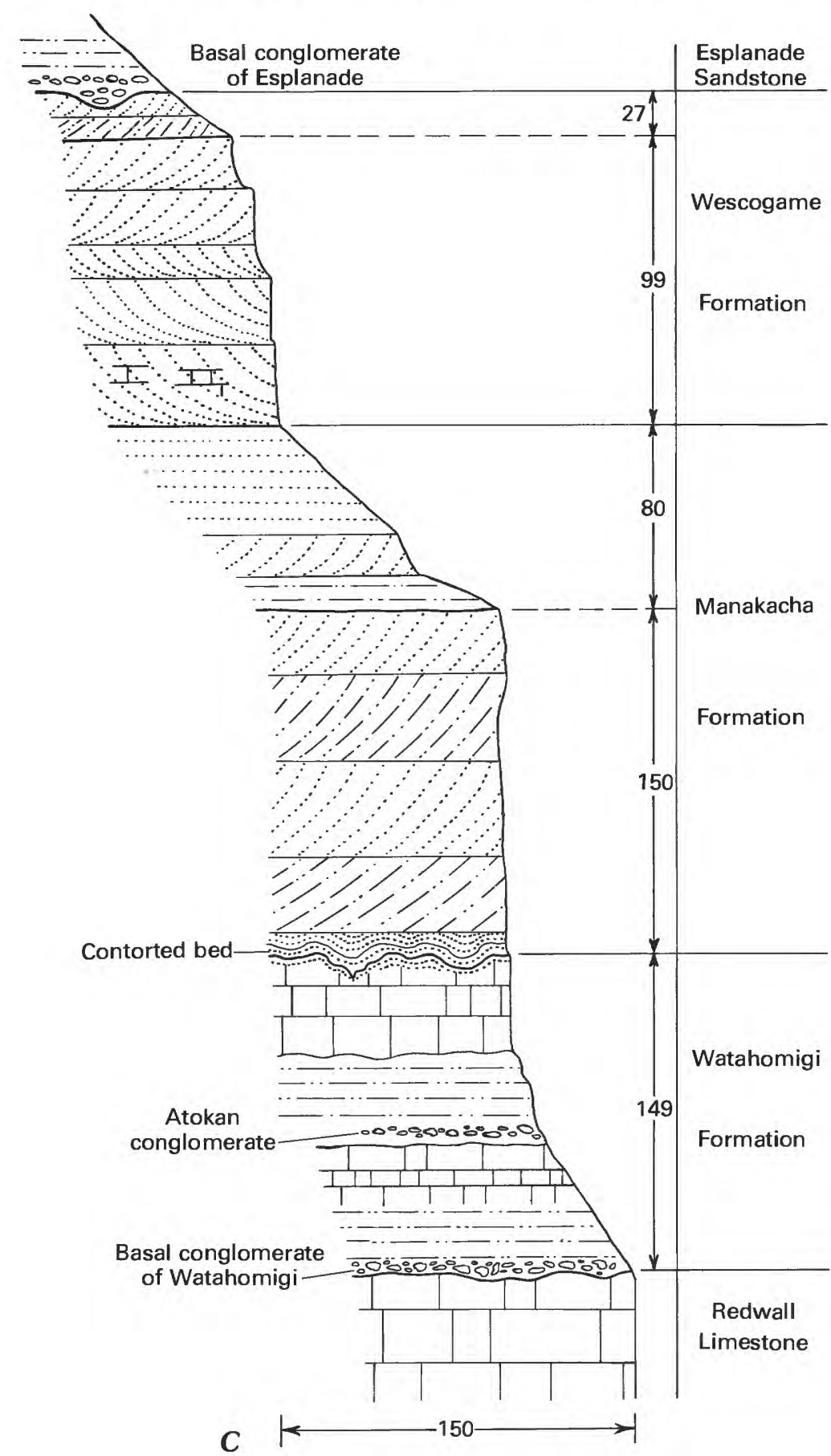

FIGURE N5.-Crinkled beds near base of Manakacha Formation, Grand Canyon, Ariz. A, East of Supai Village near old fort; B, along Hualapai Trail to Supai Village; $C$, south wall of canyon near Kaibab Trail, north. Vertical and horizontal distances in feet.

numerous, samples a few inches in diameter were obtained from several localities for study. X-ray radiographs were kindly prepared by W. K. Hamblin from thin slices of these rocks. Structures present in the rock, but not discernable in the hand specimen were visible in the radiographs. Most of the samples included parts of what was believed to be medium- or large-scale cross-stratification (this is the dominant structure in sandstone bodies throughout the Wescogame Formation and Esplanade Sandstone).

One sample of massive sandstone from the Esplanade on the Kaibab Trail, north, showed disrupted high-angle laminae and some traces of burrows or tubes (fig. N9) crosscutting its laminae. Probably the distortion of strata represents a penecontemporaneous depositional feature. 

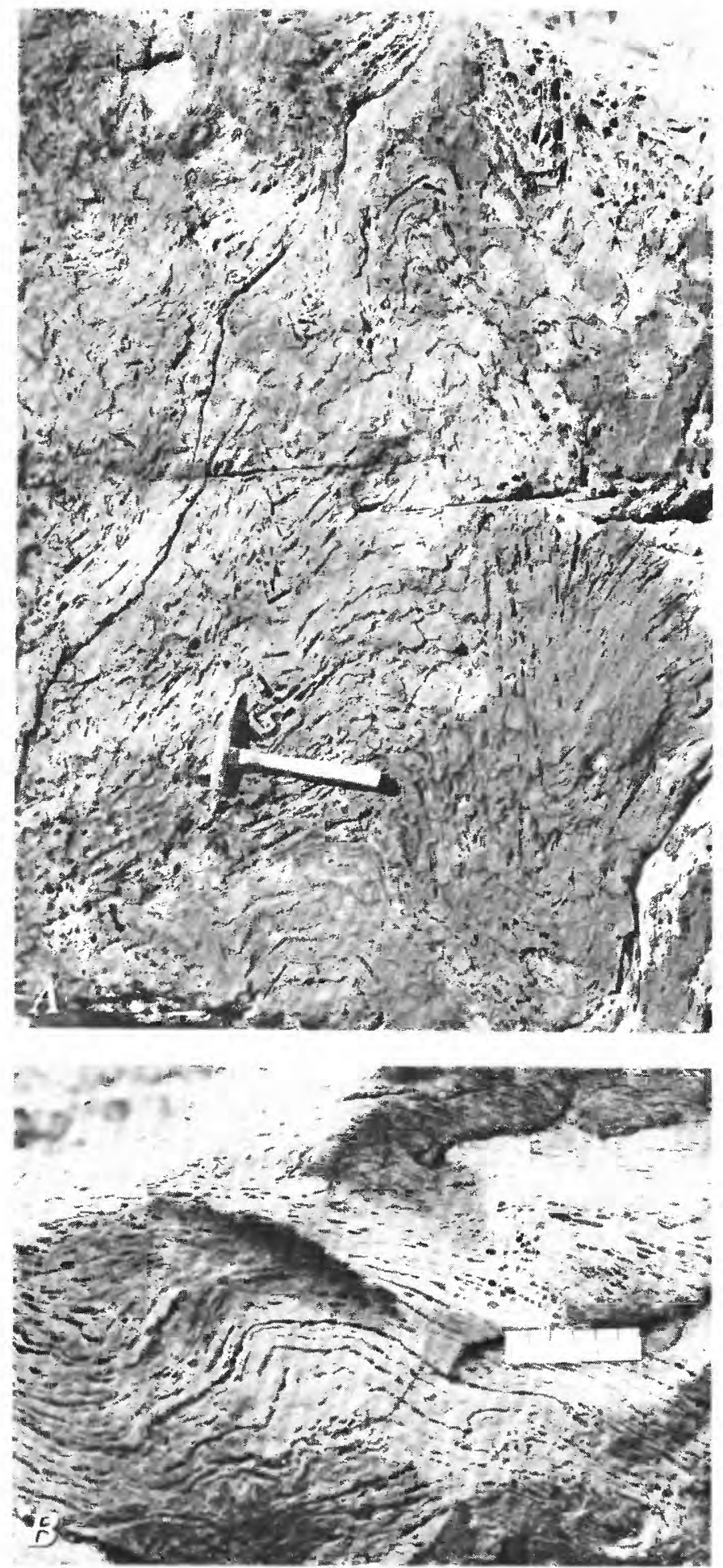

FIGURE N6.-Contorted stratification in sandstones of Supai Group Grand Canyon, Ariz. A, Anticlines and synclines in Wescogame Formation from penecontemporaneous tight folding of sand body. Traces of structure etched on surface by weathering, Thunder River Trail. B, Asymmetrical anticlines in massive bed of sandstone, Wescogame Formation, near Apache Trail to Supai Village. Scale in inches. C, Con-
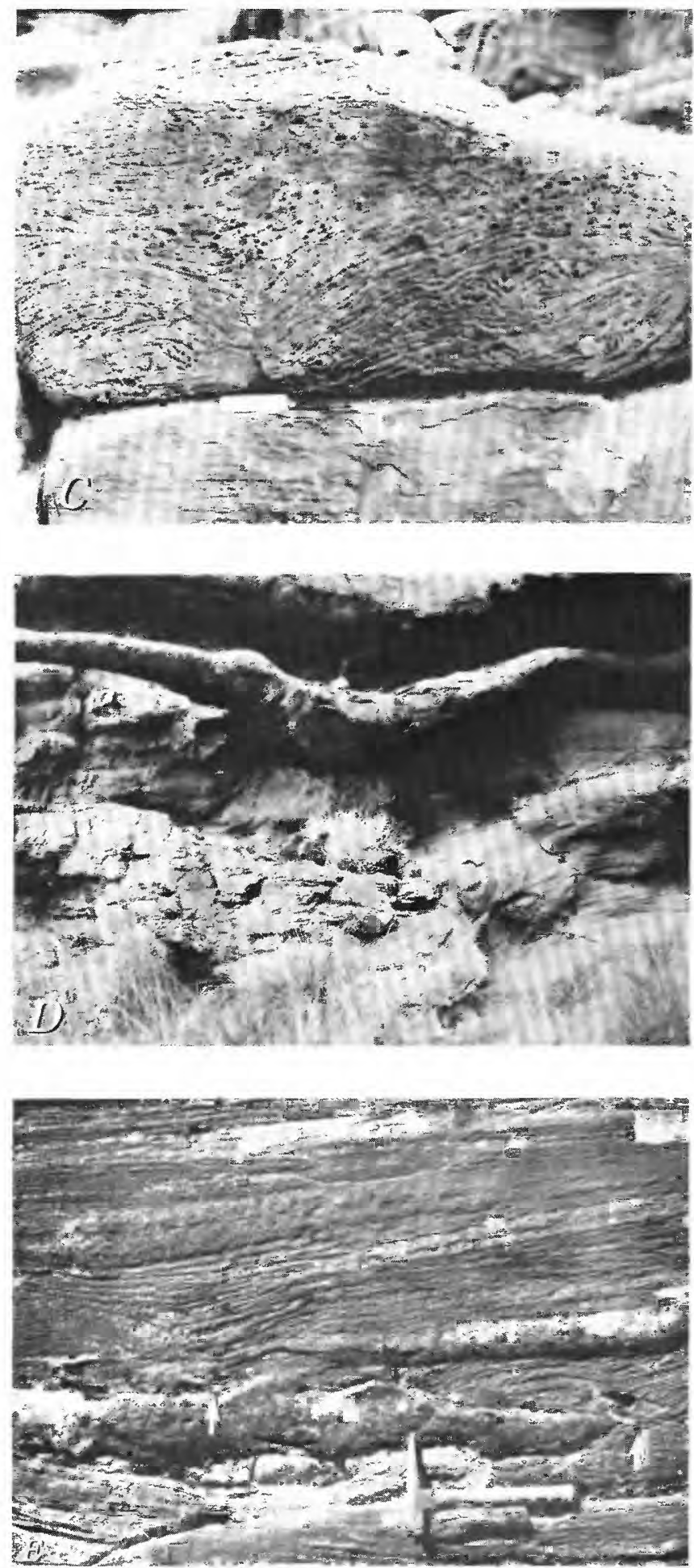

volute structure in massive sandstone of Wescogame on Apache Trail to Supai Village. Scale in inches. D, Penecontemporaneously downwarped bed of sandstone in Manakacha Formation, Parashant Canyon. E, Downwarped small-scale cross-strata among sandy limestone lenses of Manakacha Formation, Twin Springs Canyon. Arrows indicate areas of downwarp. 


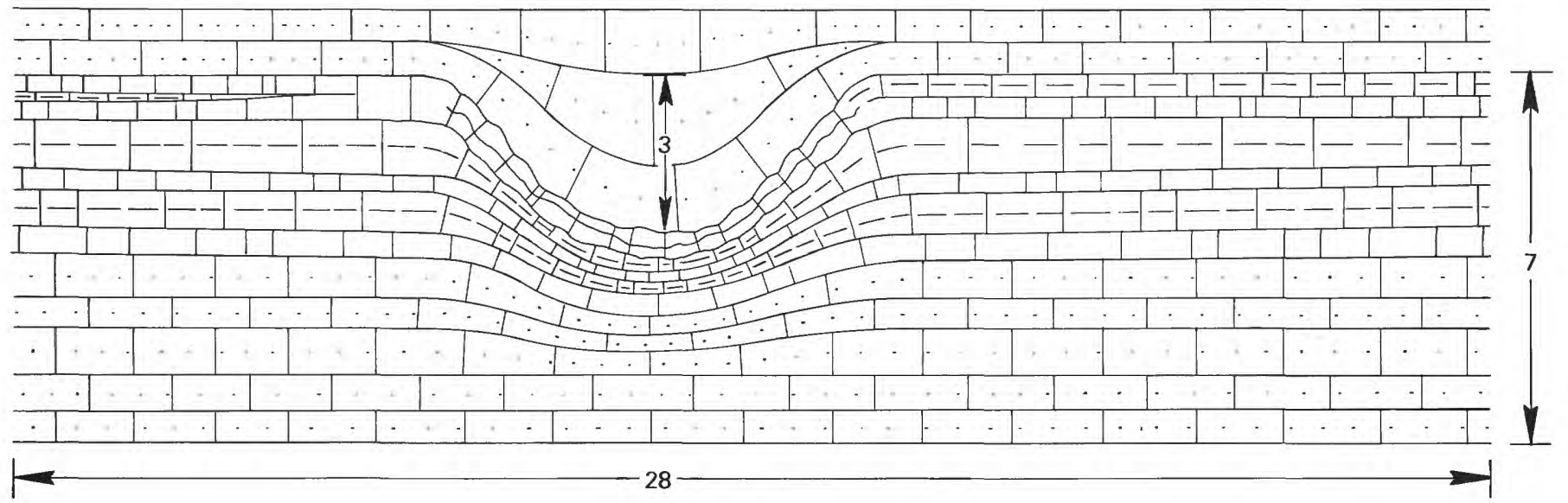

A

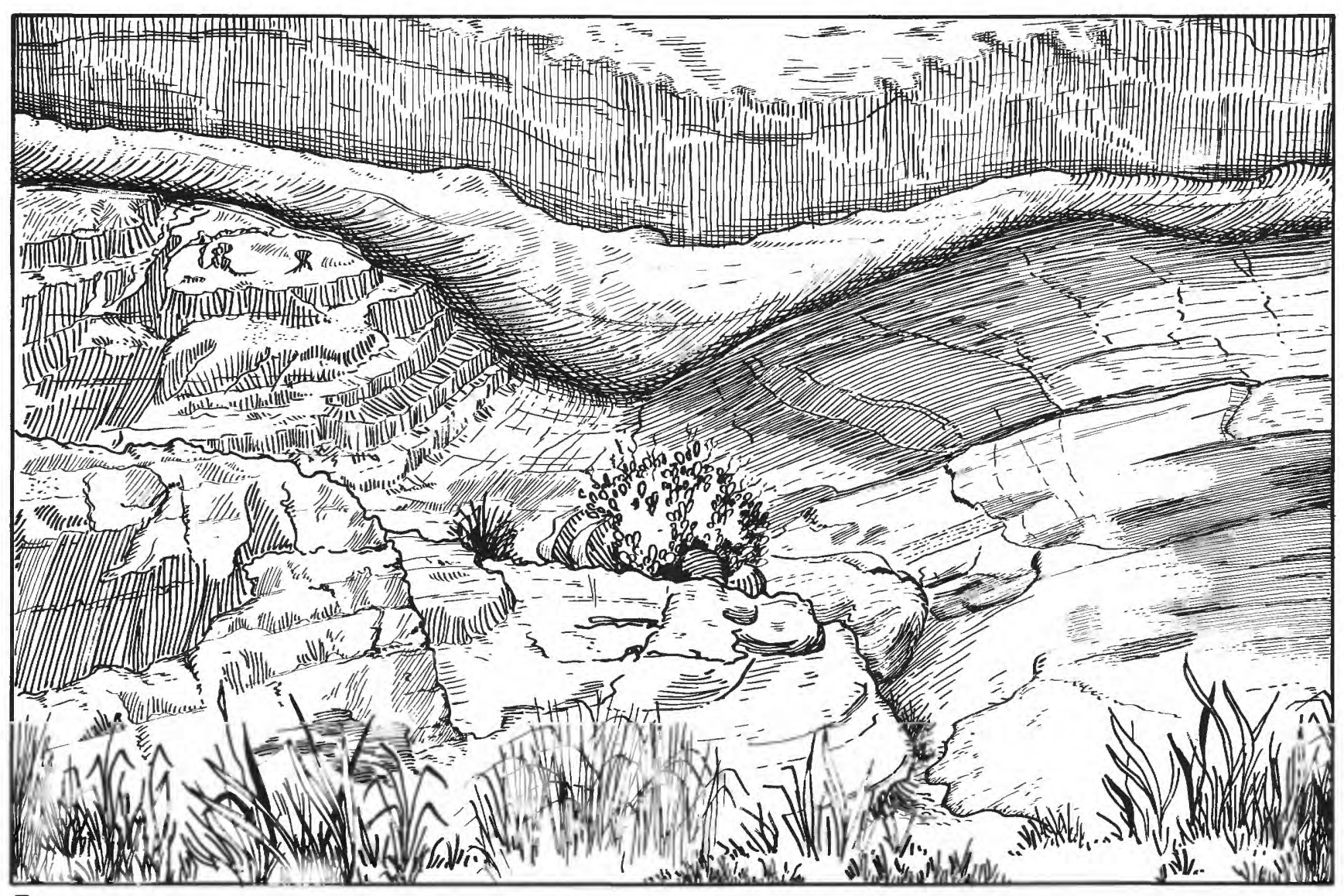

$B$

FIGURE N7.-Downwarps in massive sandy limestone, Grand Canyon, Ariz. A, Contorted structure in cliff unit of Manakacha Formation, Parashant Canyon. Vertical and horizontal distances in inches. B, Contorted structure at $152 \mathrm{ft}$ above base of Pakoon Limestone (McNair, 1951), Iceberg Canyon. Vertical and horizontal distances in feet. Drawing by W. L. Chesser from photographs.

The relatively few clear records of borings by organisms that were noted in the samples examined make it seem unlikely that a complete reworking of the sand by burrowing animals was responsible for any of the extensive "homogenous" sandstone deposits in the Supai Group. No evidence of destruction of cross-strata by plant growth was observed. 


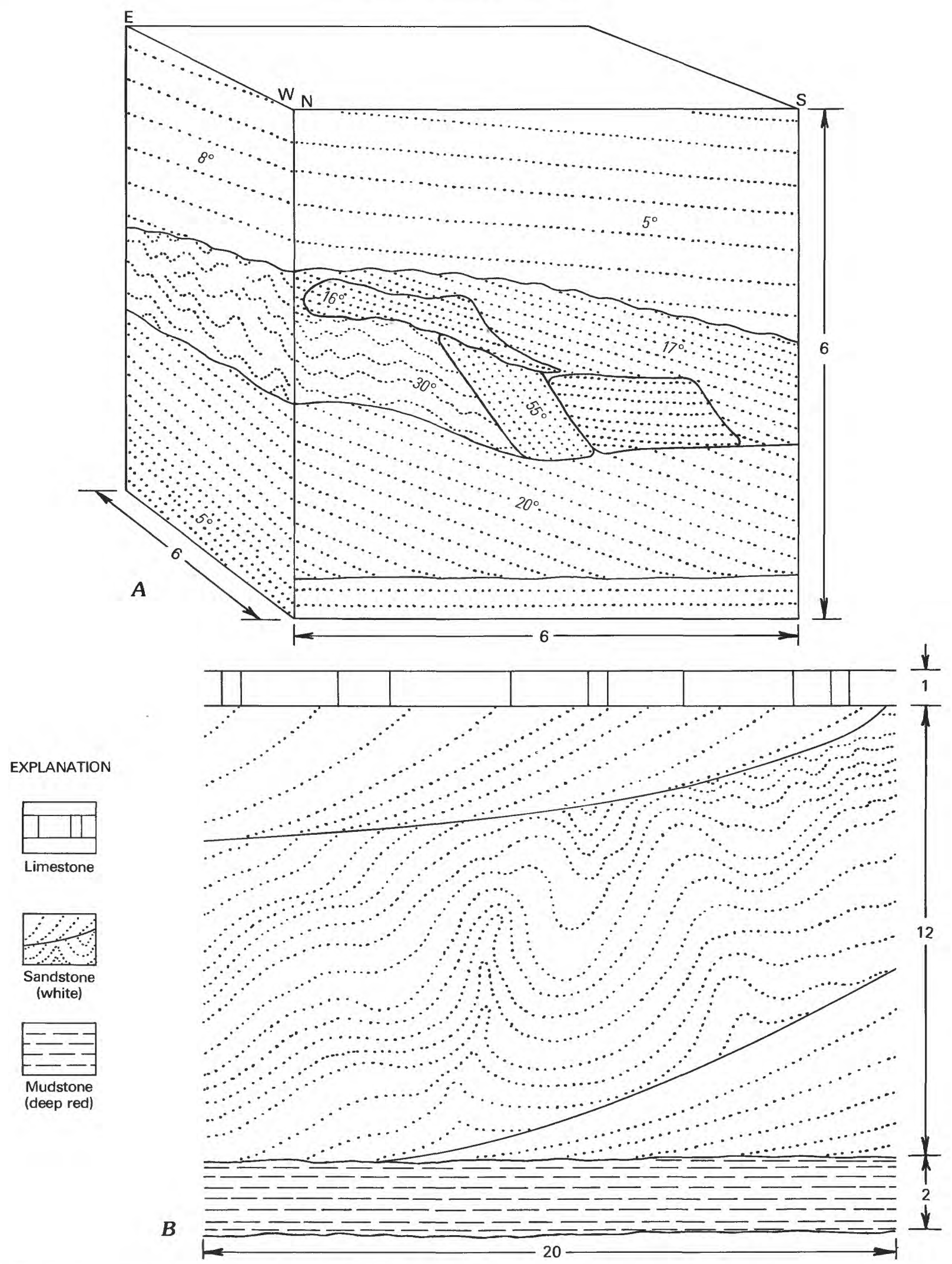

FIGURE N8.-Compressional structures in foreset beds, Grand Canyon, Ariz. A, Rotated blocks, Manakacha Formation, east side of Whitmore Wash; $B$, high-angle folds, Wescogame Formation, Apache Trail to Supai Village. Vertical and horizontal distances in feet. 

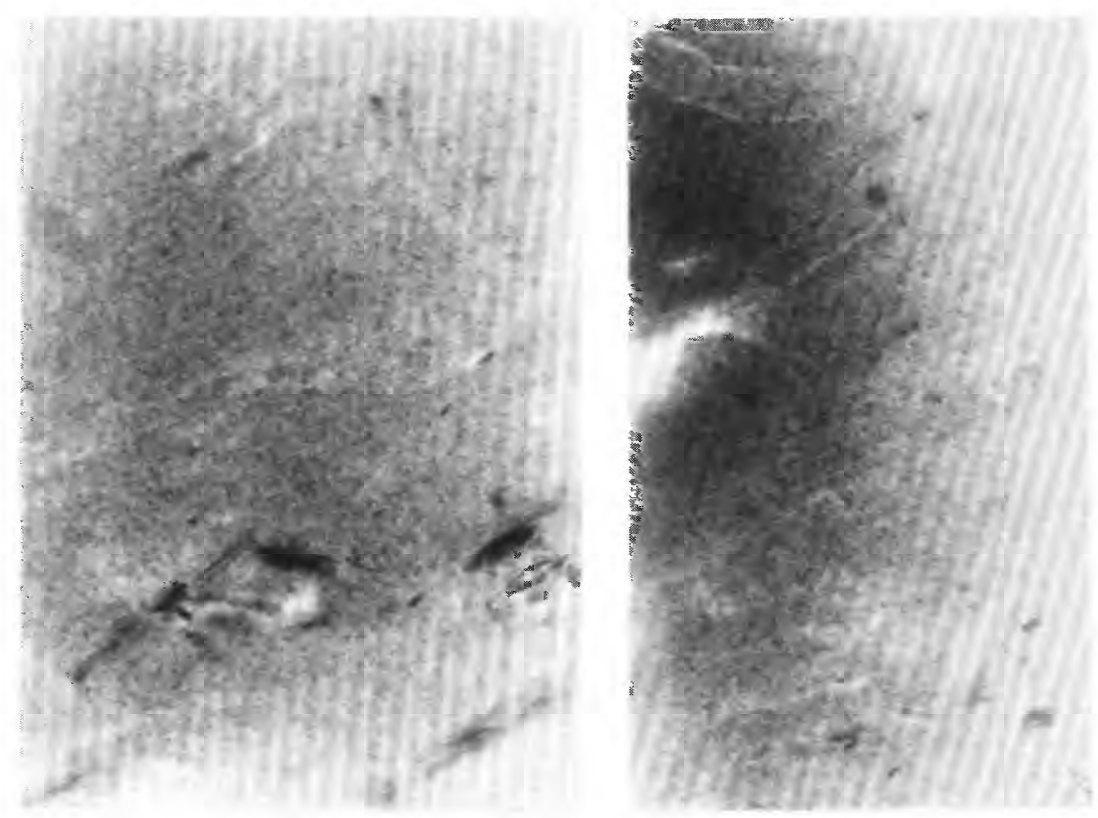

FIGURE N9.-X-ray radiographs of homogeneous sandstone, massive unit in middle of Esplanade Sandstone, Kaibab Trail, north, Grand Canyon, Ariz. Scale is natural size. Radiographs by W. K. Hamblin.

\section{REFERENCES CITED}

Aario, Risto, 1971, Syndepositional deformation in the Kurkiselkaesker, Kiiminki, Finland: Geological Society of Finland Bulletin 43, pt. 2, p. 163-172.

Allen, J.R.L., 1963, Asymmetrical ripple marks and the origin of waterlaid cosets of cross-strata: Liverpool and Manchester Geological Journal, v. 3, pt. 2, p. 187-236.

1968, Current ripples-Their relations to patterns of water and sediment motion: Amsterdam, Netherlands, North-Holland Publishing Co., $433 \mathrm{p}$.

Conybeare, C.E.B., and Crook, K.A.W., 1968, Manual of sedimentary structures: Canberra, A.C.J., Bureau of Mineral Resources, Geology and Geophysics Bulletin 102, 327 p.

Hamblin, W. K., 1962, X-ray radiography in the study of structures in homogeneous sediments: Journal of Sedimentary Petrology, v. 32, no. 2, p. 201-210.

1965, Internal structures of "homogeneous" sandstones: Kansas Geological Survey Bulletin 175, pt. 1, p. 3-37.

McKee, E. D., 1965, Experiments on ripple lamination, in Primary sedimentary structures and their hydrodynamic interpretation-A sym- posium: Society of Economic Paleontologists and Mineralogists Special Publication 12, p. 66-83.

1966, Significance of climbing-ripple structure, in Geological Survey Research 1966: U.S. Geological Survey Professional Paper 550-D, p. D94-D103.

McKee, E. D., and Goldberg, Moshe, 1969, Experiments on formation of contorted structures in mud: Geological Society of America Bulletin, v. 80, no. 2, p. 231-244.

McKee, E. D., Douglass, J. R., and Rittenhouse, Suzanne, 1971, Deformation of lee-side laminae in eolian dunes: Geological Society of America Bulletin, v. 82, no. 2, p. 359-378.

McKee, E. D., Reynolds, M. A., and Baker, C. H., Jr., 1962, Laboratory studies on deformation in unconsolidated sediment, in Geological Survey Research 1962: U.S. Geological Survey Professional Paper 450-D, p. 155-159.

McNair, A. H., 1951, Paleozoic stratigraphy of part of northwestern Arizona: American Association of Petroleum Geologists Bulletin, v. 35 , no. 3, p. 503-541.

Schuchert, Charles, 1918, On the Carboniferous of the Grand Canyon of Arizona: American Journal of Science, 4th ser., v. 45, no. 267, p. $347-361$. 


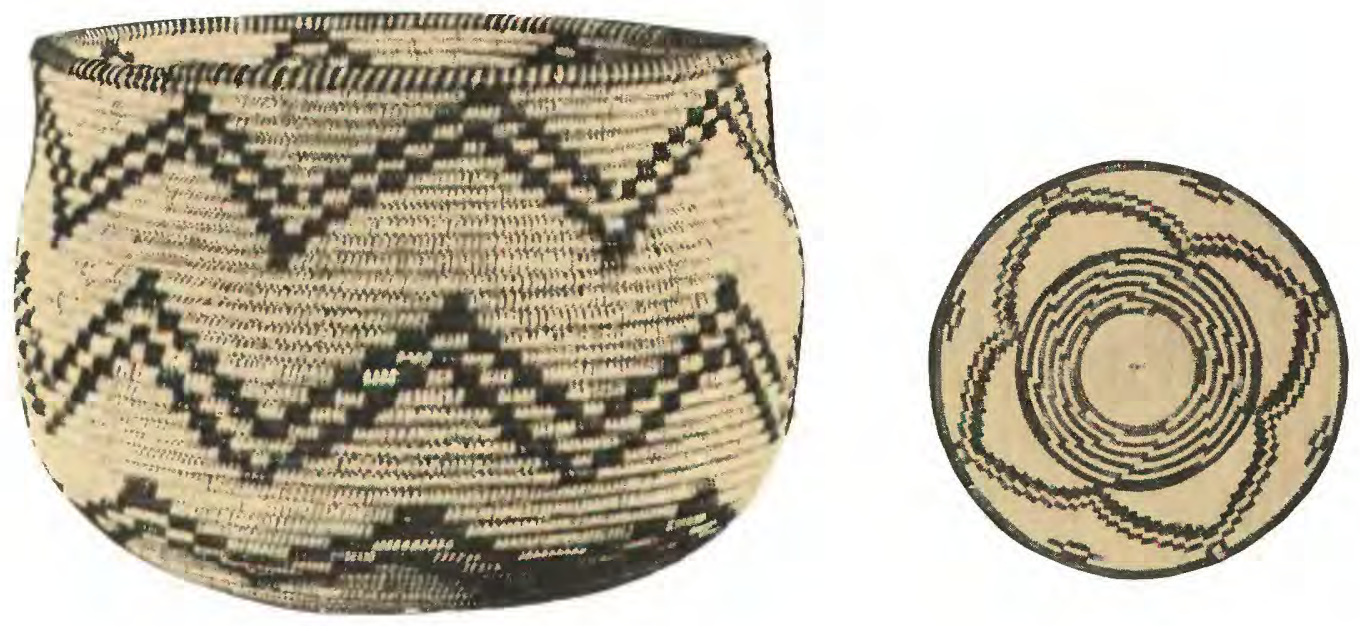

THE SUPAI GROUP OF GRAND CANYON

CLAY MINERALOGY

Chapter $\mathrm{O}$

By PHOEBE L. HAUFF and EDWIN D. McKEE

\section{Contents}

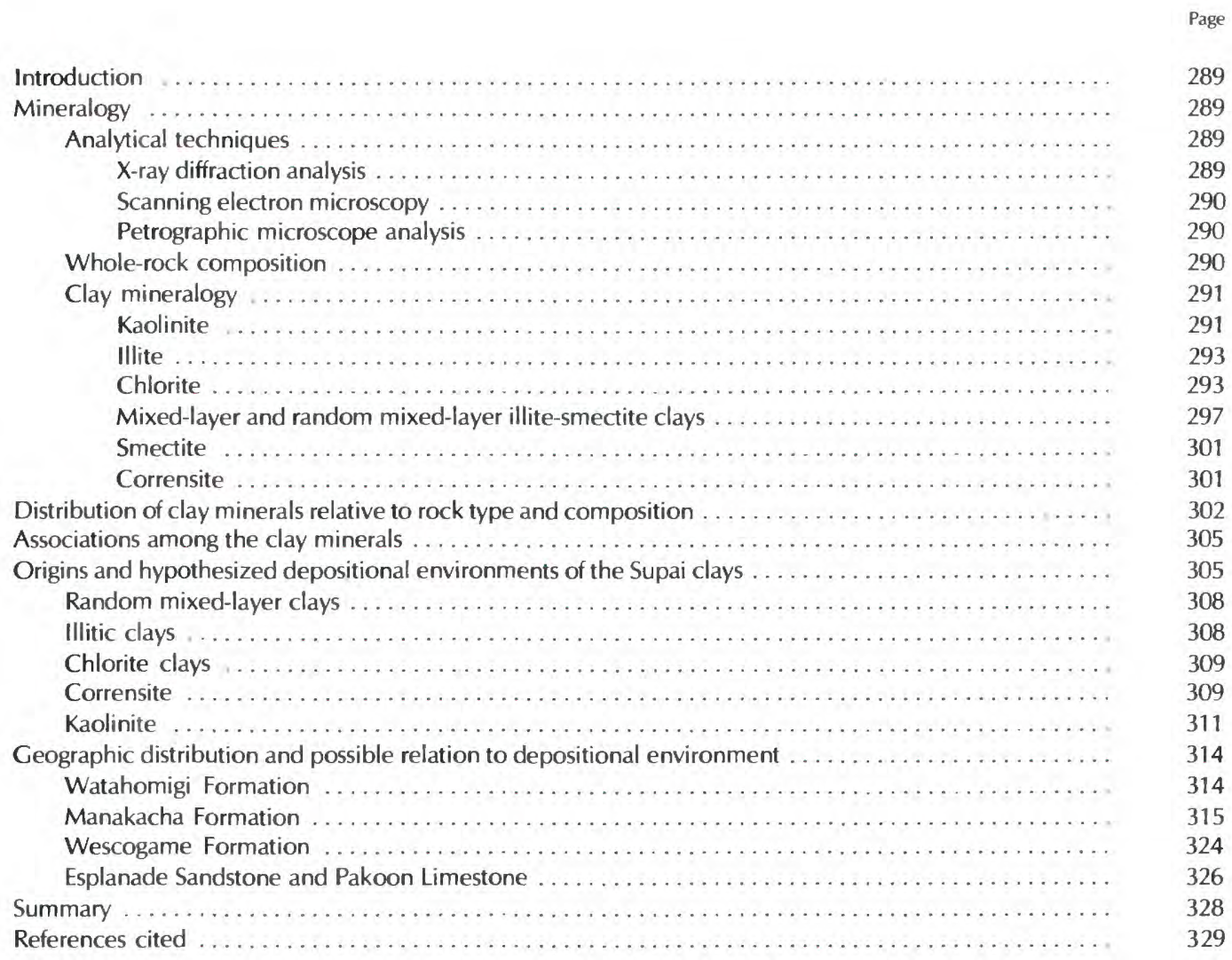




\section{Illustrations}

FIGURE O1. Graph showing percentage distribution of total clay minerals in rocks of Supai

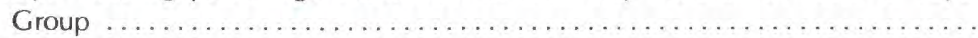

O2. Diagram of mineral assemblages and principal nonclay minerals occurring in the Supai rocks

O3. Examples of $\mathrm{X}$-ray diffraction patterns of several mineral assemblages identified

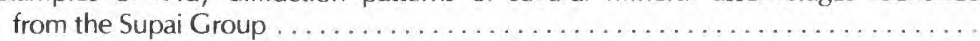

O4. Typical X-ray diffraction patterns for Supai Group clays illustrating the various treatments used in the identification processes $\ldots \ldots \ldots \ldots \ldots \ldots \ldots \ldots$

O5. Scanning electron microscope photographs of Supai Group clay minerals .........

O6. Graphs showing percentage distribution of clay minerals within the Supai Group

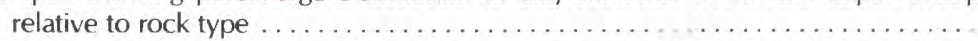

O7. Graphs showing distribution of clay type against generalized mineral compositions

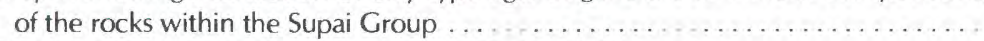

O8. Diagram showing hypothesized origins of the Supai Group clays . . . . . . . . . .

O9. Diagrams showing corrensite stability relationships $\ldots \ldots \ldots \ldots \ldots \ldots \ldots$

010. Scanning electron microscope photograph of kaolinite illustrating various criteria

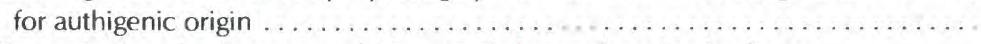

011. Photomicrograph of potassium feldspar grain being altered to kaolinite ............

012-015. Color fence diagrams showing vertical distribution of clay minerals relative to lithologic facies within the:

012. Watahomigi Formation of the Supai Group . . . . . . . . . . . . . . . . .

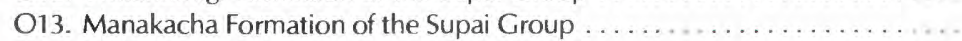

014. Wescogame Formation of the Supai Group . . . . . . . . . . . . . . . . . . . . . . . .

O15. Esplanade Sandstone of the Supai Group $\ldots \ldots \ldots \ldots \ldots \ldots \ldots \ldots$

O16. Maps showing horizontal distribution of clay minerals within the Watahomigi and Manakacha Formations . . . . . . . . . . . . . . . . . . . .

O17. Graphs showing distribution of clay minerals by numerical count within each for-

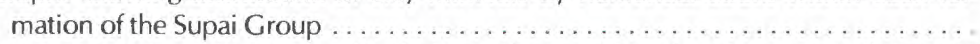

018. Graphs showing percentage distribution of clay minerals within each formation of the Supai Group and relative to rock type $\ldots \ldots \ldots \ldots \ldots \ldots \ldots \ldots \ldots \ldots \ldots \ldots$

O19. Maps showing horizontal distribution of clay minerals within the Wescogame For-

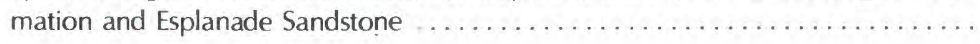

\section{Tables}

TABLE

O1. Compilation of literature references to corrensite-type minerals $\ldots \ldots \ldots \ldots \ldots \ldots$

O2. X-ray diffraction identification criteria for corrensite species . . . . . . . . . . 


\section{INTRODUCTION}

The Supai study presented an excellent opportunity to show how clay minerals can be useful as indicators of depositional environments. Within this Professional Paper exists petrographic, lithologic, paleontologic, mineralogic, and other information that assists in reconstruction of the geologic history of the Supai Group and its formations (ascending): the Watahomigi, Manakacha, Wescogame, and Esplanade. This study would not seem complete without an attempt to identify the clay minerals within this immensely fascinating and diverse suite of rocks and to integrate clay mineralogy data into a picture well defined by other geologic analytical techniques.

As a generalization, clay minerals seem to become less diverse and more stable with age (Weaver, 1957). Illite and chlorite, irrespective of host rock type, emerge as the dominant species for the Paleozoic, with only minor amounts of kaolinite and even less montmorillonite surviving the rigors of all that time. The Supai with its seven types of clay minerals, the major one being a highly unstable type of random mixed-layer (illite-smectite), presents an obvious and intriguing challenge. Initial plots of the clay data also indicated a high correlation between clay type and rock type; that is, those clays considered to be marine are found in marine type rocks, and clays considered to be continental are found in continental rocks.

This clay study was not meant to be exhaustive as it includes only about 700 samples from more than $15,000 \mathrm{mi}^{2}$ of the study area. The objective was to delineate general trends of the clay species and to associate these trends with the overall picture as developed from other available data. Good fortune came in the guise of the Supai itself, which seemingly has been little disturbed through vast lengths of time -300 m.y. - and has preserved, not in total entirety, but in significant quantity, a meaningful legacy from the past. In so doing, it has contributed to the reconstruction and interpretation of its own geologic history and depositional environments.

\section{MINERALOGY}

The clays studied in the Supai Group can be divided into seven distinct types. These include random mixed-layers (illite with various amounts of swelling clay), kaolinite, illite, chlorite, corrensite, mixed-layer (illite-smectite), and montmorillonite or smectite. Figure $\mathrm{O} 1$ shows their relative abundance in these rocks. The clay minerals comprise less than 5 percent by volume of the total rock composition and in most localities they form closer to 1 or 2 percent. For this reason, and also because of the relatively poor crystallinity of the majority of the samples, only a qualitative investigation was undertaken.

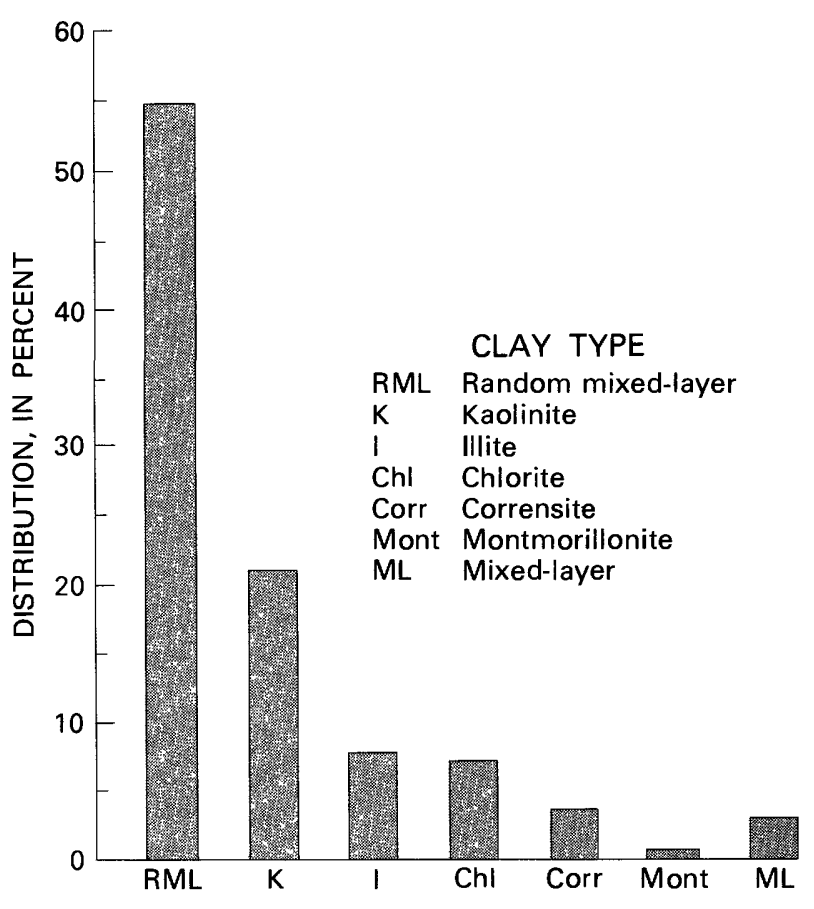

FIGURE O1.-Graph showing percentage distribution of total clay minerals in rocks of the Supai Group including tongues of Pakoon Limestone (McNair, 1951) in the upper part of the Supai in the western part of the area, Grand Canyon, Ariz.

Samples were chosen on the basis of the whole-rock composition as previously determined by petrographic microscope examination. Pure quartz and pure carbonate rocks were avoided whenever possible as they probably were less hospitable to clay mineral development than were rocks of mixed composition. Although many rocks in carbonate sequences contained some clay minerals, those clays that were present in the very thick sequences of pure limestone or dolostone were in such miniscule amounts and so poorly developed that identification was marginal.

\section{Analytical techniques}

Identification of the various clay minerals was made primarily on the basis of $\mathrm{X}$-ray diffraction analysis. This was supplemented by scanning electron microscopy (SEM). Elemental composition was verified with the energy dispersive system (EDAX) of the SEM. The petrographic microscope was also utilized in an attempt to determine textural relationships of the clays with associated minerals.

\section{X-ray diffraction analysis}

A method of qualitative X-ray diffraction analysis, routinely done at the U.S. Geological Survey was used in this study for the identification of the clay minerals. An 
X-ray trace was first made on a randomly oriented, packed powder sample of the whole rock that was ground to about 200 mesh. This trace gave an approximate idea of the principal clays present and also defined the mineral suite so that the necessary concentration and separation procedures could be determined. Mineral constituents of the Supai rocks that presented masking problems in the interpretation of the X-ray diffraction patterns were: the finegrained carbonates-calcite and dolomite-minor iron oxides in the form of hematite, and gypsum.

A 3-5 gram sample was crushed to free the less-than-2micron fraction. A sonic probe was used to mechanically disaggregate the clay particles, and larger quartz and feldspar grains were removed by wet sieving. Using a variation on M. L. Jackson's (1974) method, the carbonates were removed from the samples. The powder was placed in a 250-ml centrifuge bottle with a sodium acetate-acetic acid solution, buffered to a $\mathrm{pH}$ of 5 . This was subjected to the sonic probe for 10 minutes and then put into a steam table and held just below boiling (about $90^{\circ} \mathrm{C}$ ) for an average of 8 hours. The time depended on the amount of carbonate present. The $\mathrm{pH}$ was restored toward neutral by washing with distilled water and centrifuging several times at a high $(2,000) \mathrm{rpm}$ (revolutions per minute) for 10 minutes. If the solution was allowed to remain too acidic, the clays would flocculate. A few drops of 10-percent ammonium hydroxide $\left(\mathrm{NH}_{4} \mathrm{OH}\right)$ assisted the suspension process. The iron oxides were not considered a sufficient interference to need removal. Gypsum was dissolved during the various water treatments.

Still in the centrifuge bottles, the clay samples were centrifuged for 3-5 minutes at $600 \mathrm{rpm}$ to achieve suspension. This suspension was later pipetted onto unglazed, porous, ceramic tiles and air dried. Two tiles were made simultaneously for each sample to assure consistency in the following treatments.

Four X-ray diffraction runs were made per sample. The chart recorder was calibrated in such a fashion that these charts were physically stacked one above the other so that the reactions to the various treatments could be observed efficiently. The untreated sample was X-rayed first, then the tile was treated with ethelene glycol, and finally the tiles were heated to $400^{\circ}$ and $500^{\circ} \mathrm{C}$. A different color ink was used for each of the separate runs. A set of this type of diffractograms was made for each sample included in the study. Scans were made at 2 degrees two-theta per minute; chart speed of 1 inch per minute, which gives 2 degrees two-theta per inch. The target material of the tube is copper and at this scan speed with a 0.005 receiving aperature and $1^{\circ}$ scatter and divergence slits, the diffracted radiation would be $\mathrm{Cu} \mathrm{K} \mathrm{K}_{\alpha}$. The pulse height analyzer was set at 1,000 counts per one second.

\section{Scanning electron microscopy}

Samples for scanning electron microscopy were chosen as a function of relative abundance of the clay mineral in the sample and also for highest degree of crystallinity. Some clay species are not commonly known for good resolution even under the high powers of the scanning electron microscope. From the X-ray traces of the Supai clays, it became apparent that good crystallinity was more of an exception than a rule in these samples. Even with careful concentration efforts many of the samples yielded small amounts of clay material. Only a cursory examination and a verification with the energy dispersive system could be made for many of the samples. Considering the length of burial time of these materials and the probable amounts of subsequent alteration, it is fortuitous that the few specimens of recognizable crystallinity survived to the present.

Because these materials were so fine grained, in the 1-2 and less micron range, sample preparation for the SEM was difficult. The clay specimens would not take a uniform coating and had to be repeatedly coated with the goldpalladium alloy used to promote the conductivity of the samples. An antistatic preparation was also used to ultimately enhance resolution. Constant electronic manipulation was necessary to achieve and maintain resolution, especially at higher magnification. The very poor crystallinity of the majority of the samples, which was initially indicated by the X-ray analysis, was further emphasized by the SEM work.

The energy dispersive system was used as a qualitative indicator of the elements present and to verify the specific clay mineral being examined. Identifications from the powder patterns correlated with SEM analyses were made with confidence.

Because nearly all the samples contained iron oxides as grain coatings, the presence of iron within any of the clay minerals remained undetermined.

\section{Petrographic microscope analysis}

A selected number of thin-section slides was examined specifically to determine relationships of the clays to the associated minerals. The clays are so very fine grained that this method was not satisfactory. Some of the alteration relationships (feldspar to clays) were discernible. However, without the X-ray diffraction identifications, in the majority of the thin sections, it would not have been possible to determine which clays were present.

\section{Whole-rock composition}

The whole-rock composition of the Supai rocks has been presented in detail in other chapters of this publication. The mineral constituents of the clay samples were compiled as 
a byproduct of the clay study from the $X$-ray diffraction traces. This information is useful as supporting data for differentiation of the two carbonate rocks present and also in determining, to some extent, which feldspars occur. The major application here of the clay mineralogy is as an indicator of diagenetic patterns of the clays.

From a compilation of the diffraction data, 10 mineral assemblages composed of five dominant minerals become evident and appear to represent the major mineral constituents in the study area. The minerals are quartz, calcite, dolomite, potassium feldspar, and another feldspar of indeterminate though probably albitic, composition. The assemblages and their interrelationships are shown in figure $\mathrm{O} 2$.

Examples of $\mathrm{X}$-ray traces of these various combinations are given in figure O3. The patterns in this figure also illustrate the good crystallinity found within the Supai mineral suite, the typical relationships between the minerals, and the proportions of clay to nonclay. Identification of some feldspars is marginal, for it must be made on one or two peaks. In such marginal identifications the phase is merely labeled "feldspar." Only potassium feldspar can be identified as a discrete phase. Another feldspar was probably present in some samples. In the vast majority of the samples, however, this feldspar existed in such minute quantities that the precise identity was not discernible. The SEM energy dispersive system was used to determine the presence of the potassium and to substantiate the X-ray diffraction identification.
Hematite is present in nearly all the samples. The only other accessory mineral, gypsum, was restricted to the evaporite sequence in the Esplanade Sandstone. Heavymineral separations were not done on the samples. Any minerals present in amounts of less than 1 percent were therefore not detected nor considered pertinent to this study.

\section{Clay mineralogy}

Each of the seven clay minerals found in the Supai Group will be discussed separately relative to its response to the various analytical techniques used to identify it. The references from the literature defining each clay type are listed and the delimiting criteria are summarized.

\section{Kaolinite}

Kaolinite, in this study, is defined by using the presence of its $7 \AA(001)$ and $3.57 \AA(002)$ peaks on an oriented pattern. These peaks remained constant after glycolation and heating to $400^{\circ} \mathrm{C}$, but vanished with $550^{\circ} \mathrm{C}$ heat treatment. Figure $\mathrm{O} 4 A$ illustrates the $\mathrm{X}$-ray diffraction pattern from a typical kaolinite of the Supai suite. Most of these peaks were well defined, indicating good crystallinity. In some of the samples, where kaolinite was present in trace amounts, the crystallinity appeared to break down slightly as shown in figure $O 4 B$.

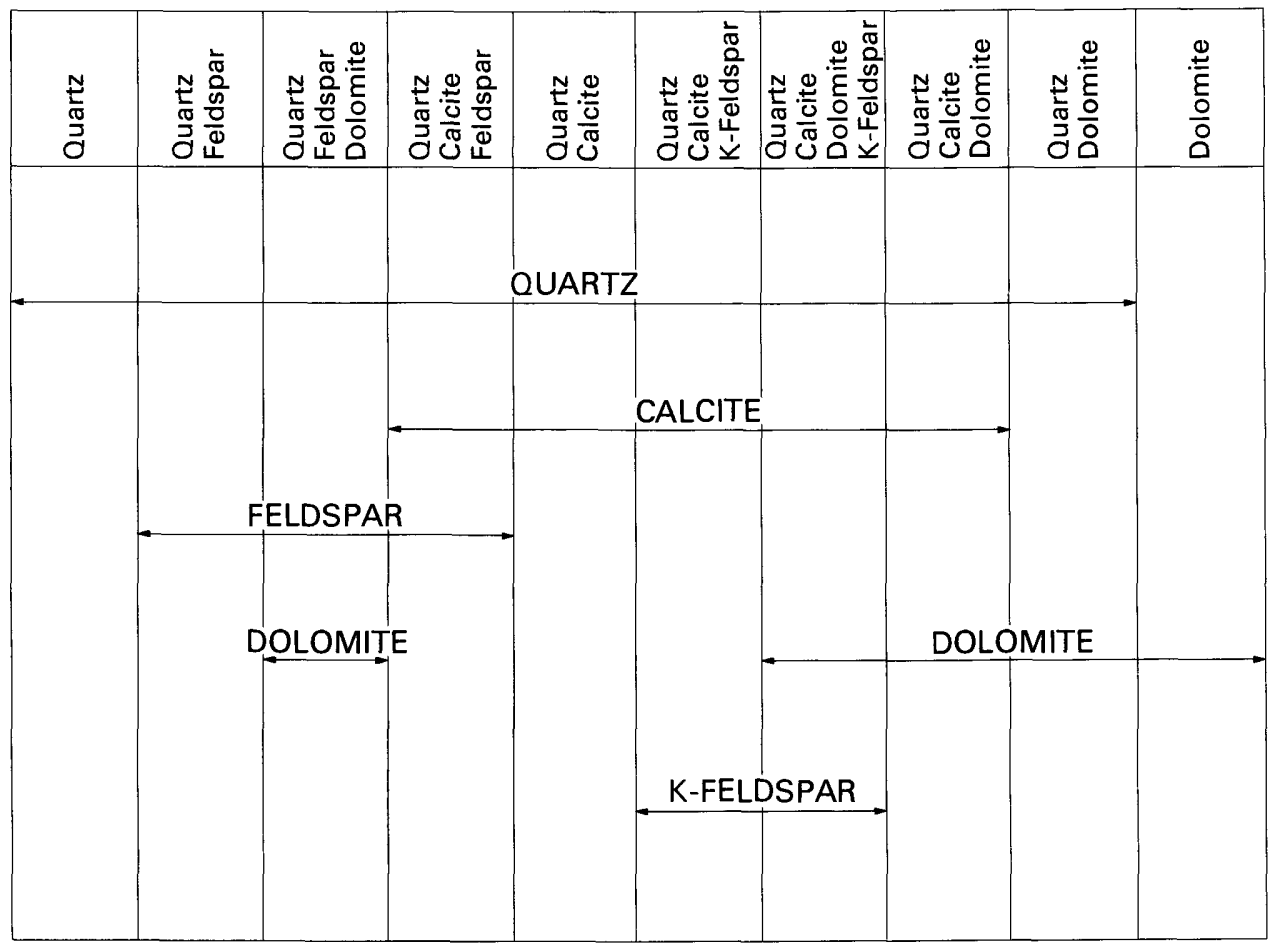

FIGURE O2.-Mineral assemblages and principal nonclay minerals occurring in the Supai rocks, Grand Canyon region, Arizona. 
A

$B$
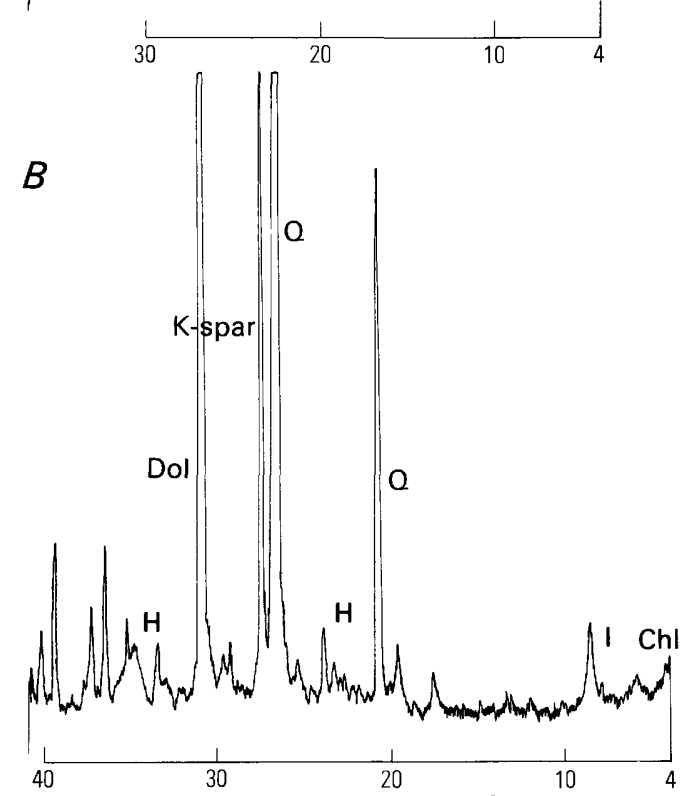

C

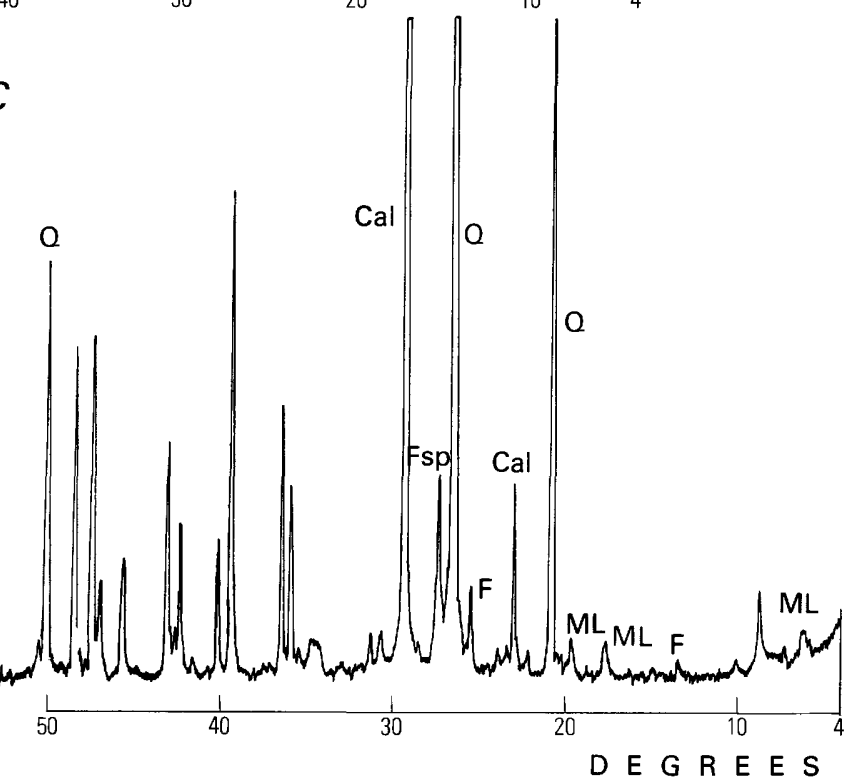

THE SUPAI GROUP OF GRAND CANYON

$$
D
$$

E

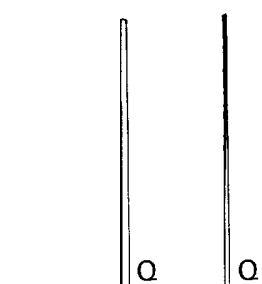

1)
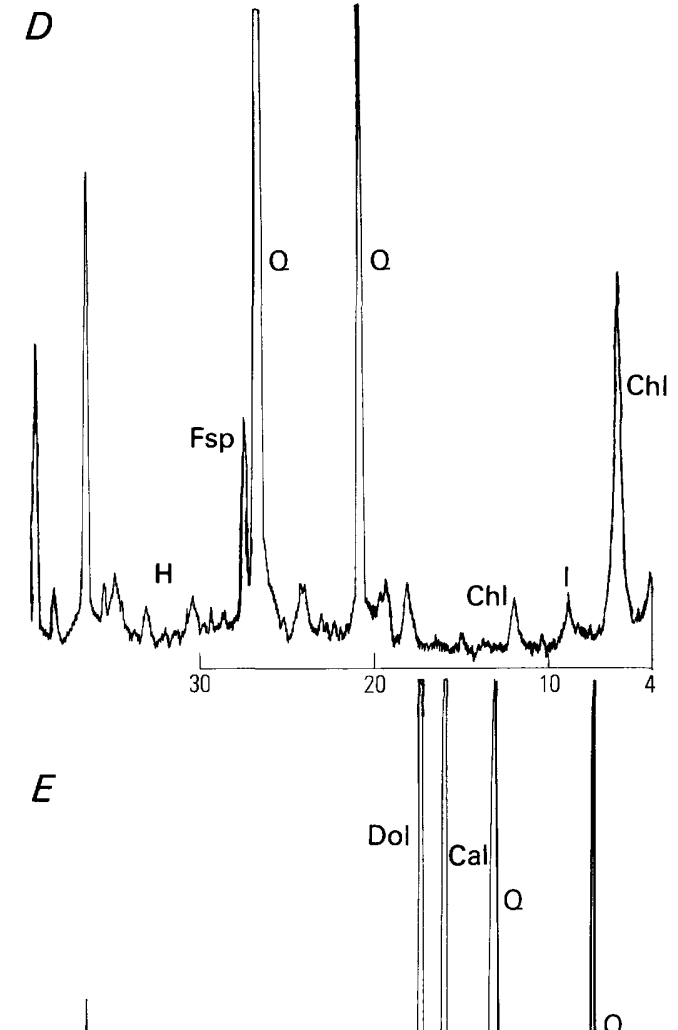

F
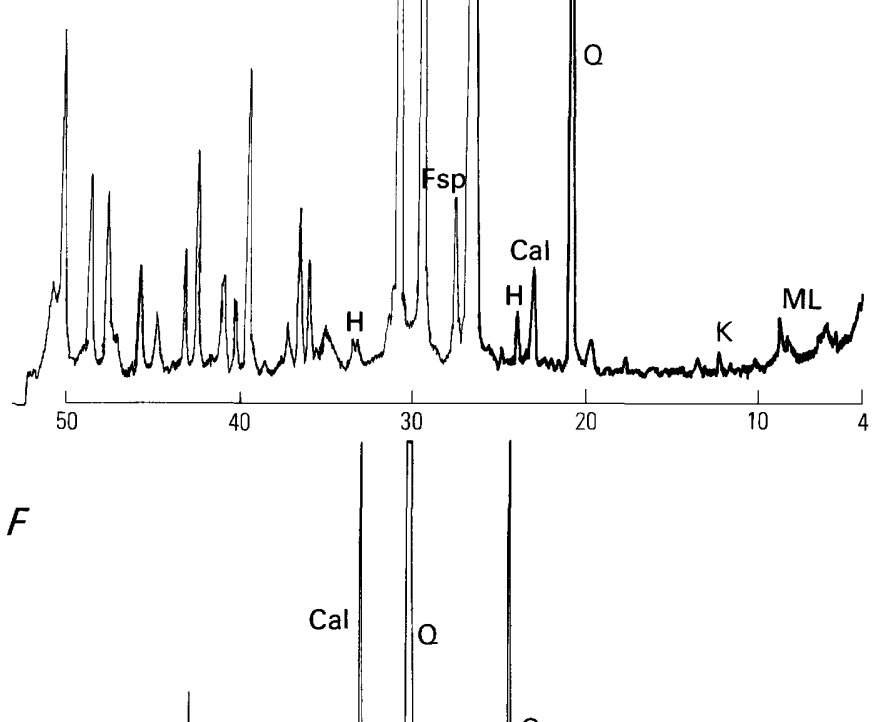
The kaolinite samples were the best specimens in the suite for definitive SEM analysis as a function of grain size, of better crystallinity than other clays present, and of stilldiscernible crystal habit.

Figure O5B is representative of the average appearance of kaolinite samples as viewed by the SEM. The EDAX spectra for this sample showed high alumina and silica. Without the substantiating $X$-ray diffraction analyses and some hint of crystal morphology, kaolinite cannot always be identified positively. Considering the potential time factors involved, it is understandable that even stable kaolinite shows clearly the ravages of time and alteration processes. Possible authigenic criteria, on the basis of SEM pictures and photomicrographs, will be discussed in a later section of this chapter.

\section{Illite}

Following the definition of Gaudette, Eades, and Grim (1966), illites identified in this study are those $10 \AA$ clay minerals that do not expand upon glycolation. Figures $O 4 B$ and $\mathrm{O} 4 \mathrm{C}$ show, by $\mathrm{X}$-ray diffractograms, that typical illites of the Supai Group just barely conform to this criterion. They better fit the theories of Velde (1966) and Rex (1966) that all illitic clay types contain some degree of mixed layering. Applying the nonexpansion criterion can become a function of choice of scale factor on the pulse height analyzer of the $X$-ray machine.

In the suite of Supai Group clay samples, a total gradational spectrum exists from a $10 \AA$ nonexpanding "illite" through varying percentages of mixed-layer (illitesmectite), and random mixed-layer (illite-smectite) configurations. The $\mathrm{X}$-ray diffraction pattern is relatively consistent. The $10 \AA$ peak, unless of a highly random mixed-layer composition, is steep toward the low angstrom values, but asymmetrical toward high angstrom values. The asymmetry is a direct function of increasing mixed-layer content. The more illitic a sample is, the better

FIGURE O3 (facing page).-Examples of X-ray diffraction patterns of several of the mineral assemblages identified from the Supai Group, Grand Canyon, Ariz., including tongues of Pakoon Limestone (McNair, 1951) in the upper part of the Supai in western Grand Canyon. $\mathbf{Q}$, quartz; Cal, calcite; Dol, dolomite; $\mathbf{H}$, hematite; Fsp, feldspar; I, illite; K, kaolinite; Chl, chlorite; ML, mixed-layer clay; K-spar, potassium feldspar. Scale is in degrees two theta. A, Quartz with kaolinite, chlorite, and hematite. $B$, Quartz, dolomite, and potassium feldspar with illite, chlorite, and hematite. C, Quartz, calcite, and feldspar with mixedlayer clays. $D$, Quartz and feldspar with chlorite, illite, and hematite. $E$, Quartz, calcite, dolomite, and feldspar with kaolinite, mixed-layer clays, and hematite. F, Quartz, calcite, dolomite, and hematite with mixed-layer clays. crystallinity it possesses. Except in samples of total random mixed-layer composition, the $10 \AA$ peak is mostly sharp, indicating that the illite phase is dominant.

Illite in the Supai Group is extremely fine grained, and even very high SEM magnification fails to resolve individual grains. Figure $\mathrm{O} 5 \mathrm{C}$ shows a typical specimen configuration for illite. This curved-festoon type of habit was found throughout the samples. Several types of surface textures were observed at magnifications from $\times 8,500$ (figure O5D) to $\times 12,000$. The EDAX spectrum showed aluminum, silicon, potassium, and, in some samples, very minor calcium. This was consistent for all samples examined.

\section{Chlorite}

Chlorite in the Supai rocks occurs almost exclusively in trace amounts. For this reason, only its presence, and not its species, can be indicated. Figure $O 4 D$ shows an X-ray diffractogram of an illite-chlorite-bearing sample. Even more typically, the existence of chlorite in a sample commonly is substantiated by the appearance of a $14 \AA$ peak on the $400^{\circ} \mathrm{C}$ or $550^{\circ} \mathrm{C}$ pattern. The apparent crystallinity of the $14 \AA$ and $7 \AA$ peaks in almost all specimens is poor. The peaks are broad or just barely discernible. In some samples, peak resolution is improved with heating. On the basis of the criteria established by Hayes (1970), the speculation can be made that this is a type I chlorite polytype; formed at low temperature, fairly unstable, and possibly authigenic in origin. Sample restrictions and low concentration of the chlorite phase made it impossible to determine the diagnostic h01 reflections required to identify polytypes.

Figure O5F illustrates a habit common to the samples scanned. The very high magnifications emphasize the fine

FIGURE O4 (following pages).--Typical X-ray diffraction patterns of clays from the Supai Group and Pakoon Limestone (McNair, 1951) tongues in western Grand Canyon illustrating various types of clay minerals and the treatments used in their identification. Scale is in degrees two theta. $A$, Kaolinite as the major clay present and showing good crystallinity. $B$, Kaolinite as a trace amount showing poor crystallinity. Illite is the major clay present. $C$, Illite as the major clay showing slight mixed-layer (illite-smectite) configuration. D, Chlorite and illite. E, Chlorite containing some expansive layers. $F$, Mixed-layer clay composed of illite and smectite. $G$, Mixed-layer clay composed of illite and smectite with a hydration layer. $H$, Transitional mixed-layer clay. I, Random mixedlayer clay (illite-smectite) showing shift of $5 \AA$ peak with glycolation and estimate of percent expansible layers. 1, Graphical representation of Reynolds and Hower (1970) method for determining percent expansible layers present. $K$, Smectite. $L$, Corrensite. $M$, Corrensite-related mineral; shows expansive layers. $N$, Totally random mixed-layer phase; probably illite-smectite. 


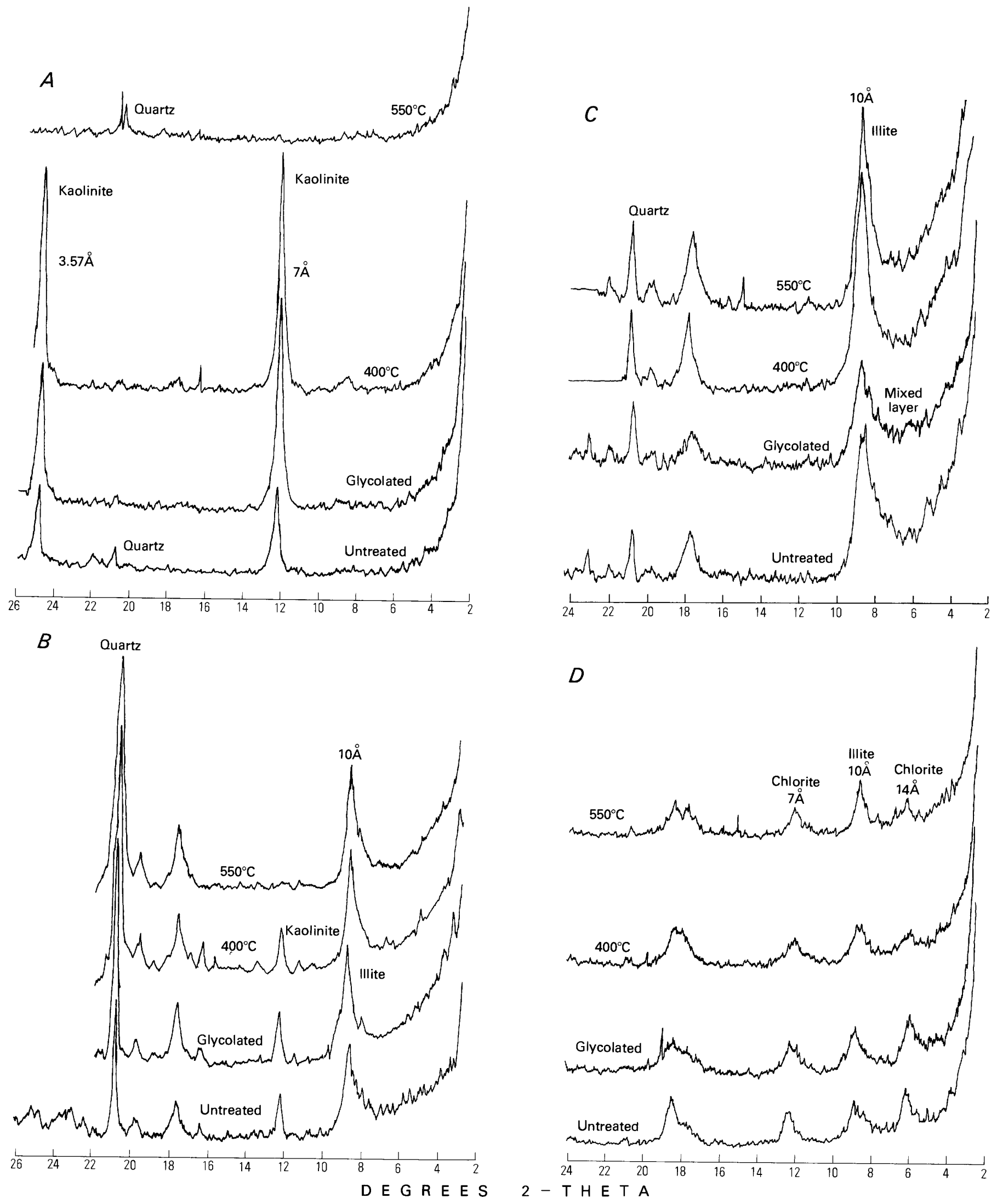

FIGURE O4. 

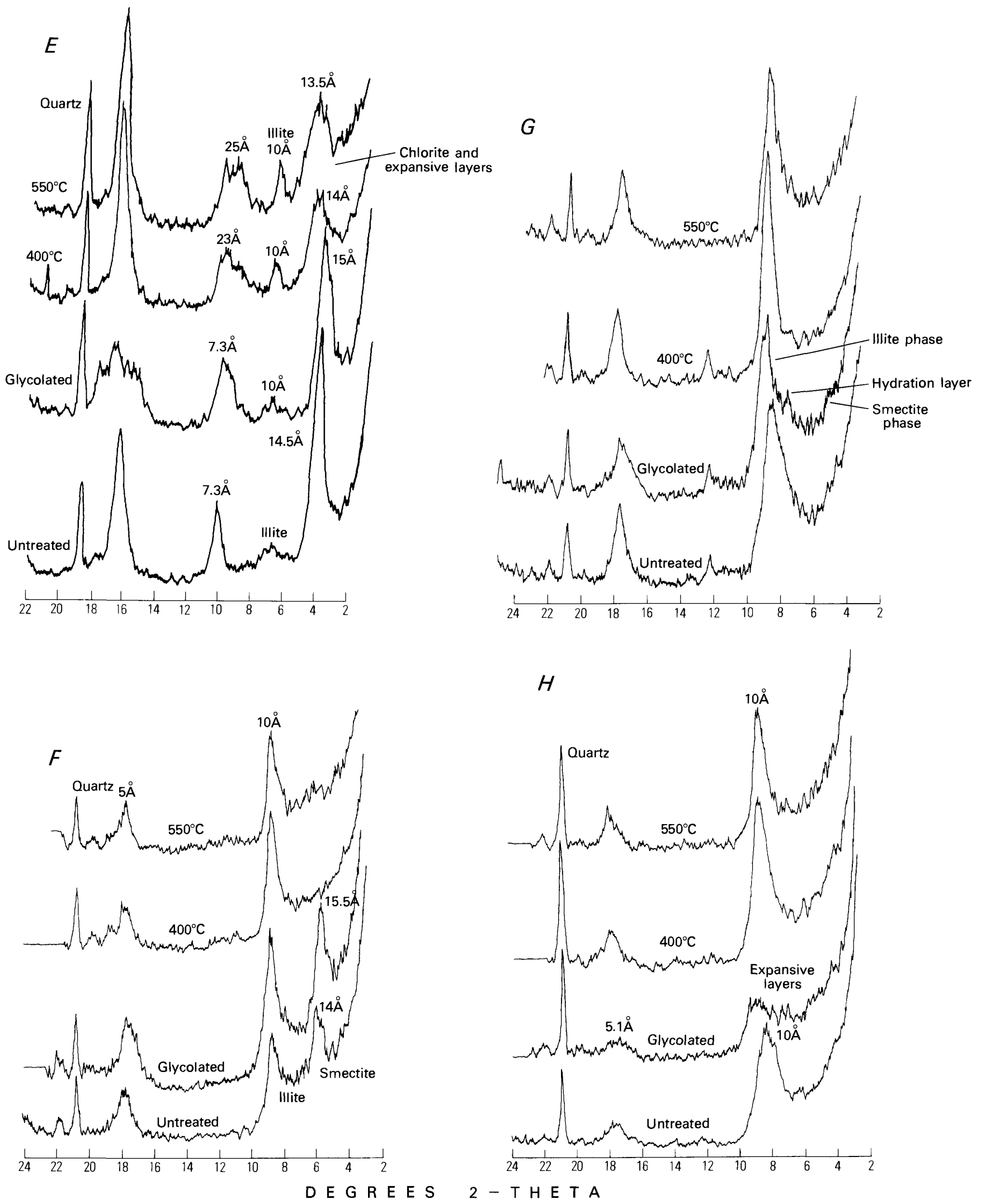

FICURE O4-Continued. 

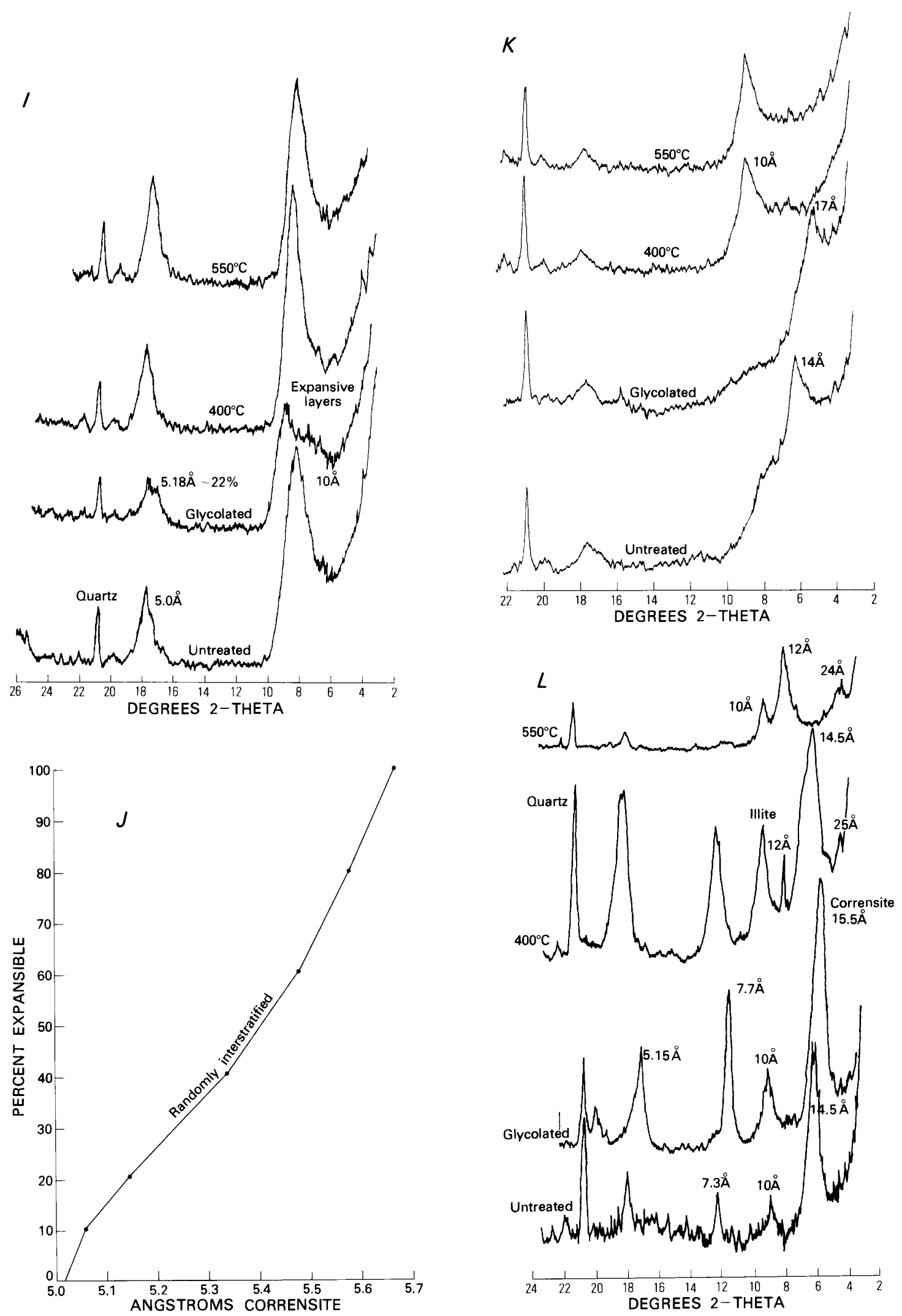

FIGURE O4-Continued. 

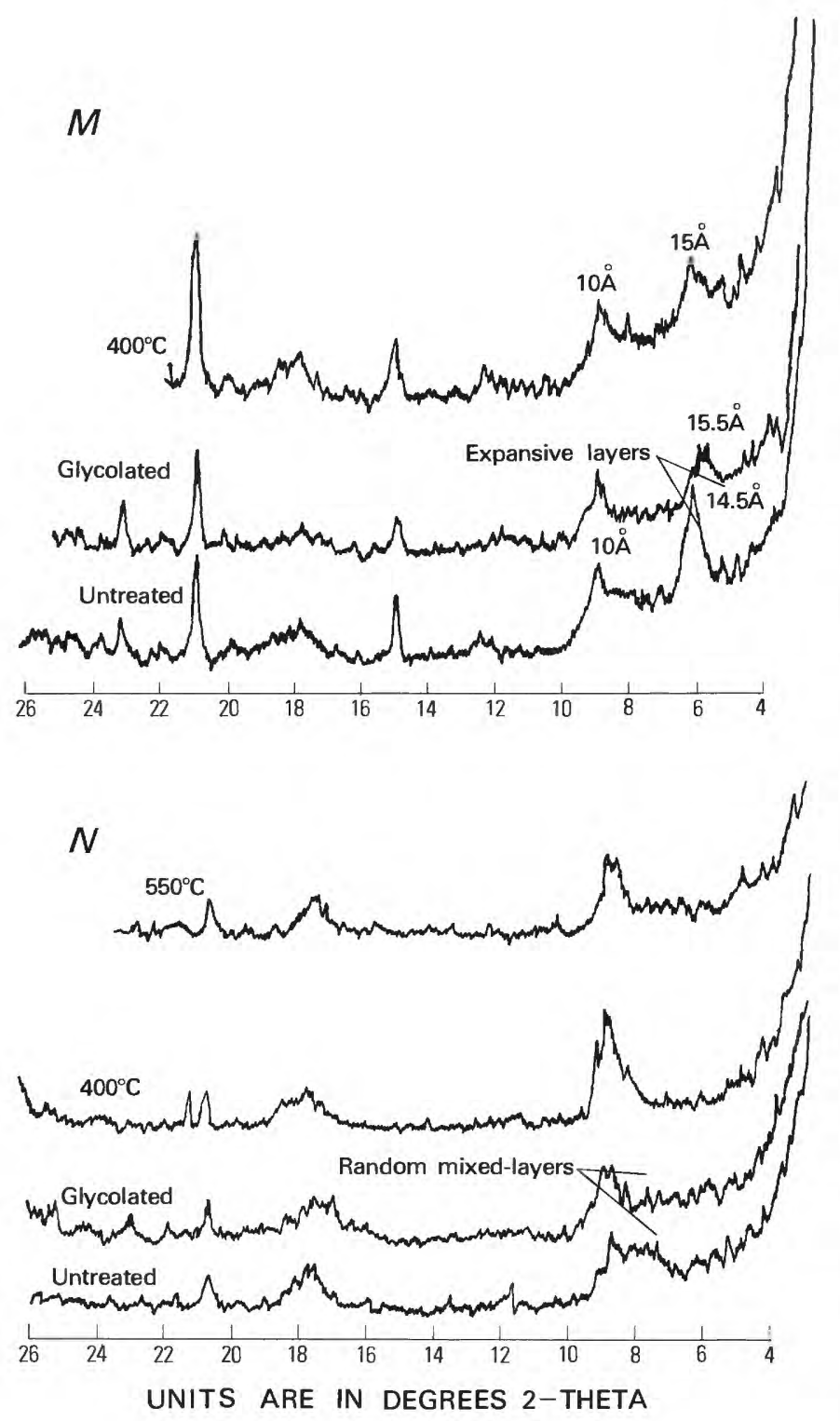

FIGURE O4-Continued.

grain size of the mineral. The EDAX spectra showed silicon, aluminum, magnesium, titanium, and iron(?).

Petrographic microscope examination indicated isolated detrital chlorite grains mostly in sandstone or arkosic matrices. This observation probably explains some of the anomalous associations of the chlorite samples in the continental rocks.

The X-ray diffractogram (fig. O4E) for figure O5F shows a possible transition from pure chlorite to a more mixedlayer mineral, a possible corrensite-type. There is a swelling chlorite layer developed here, as shown by the expansion from $14 \AA$ (untreated) to $15 \AA$ with glycol and the collapse to the $14 \AA$ chlorite position with heat. Because iron is ubiquitous in these samples and there are not sufficient basal peaks present, whether this is a dominantly magnesium chlorite or an iron chlorite could not be determined conclusively.

\section{Mixed-layer and random mixed-layer illite-smectite clays}

Clay minerals of the Supai illustrate a transitional sequence from smectite through mixed-layer (illite-smectite), or random mixed-layer (illite-smectite), possibly to illite. This is a gradational sequence and some steps in the progression can be seen starting with figure $\mathrm{O} 4 \mathrm{~J}$, a fully expanded smectite; to figure $\mathrm{O} 4 \mathrm{~F}$, a mixed-layer (illitesmectite) with incomplete expansion to only $15.5 \AA$, with glycol; to figure $\mathrm{O} 4 \mathrm{G}$, which shows a mixed-layer (illitesmectite) with a hydration layer developing; to figures $\mathrm{O} 4 \mathrm{H}$ and $\mathrm{O} 4 \mathrm{I}$, both of which illustrate the transitional random mixed-layer (illite-smectites) phases that are so prevalent throughout the Supai.

Mixed-layers of illite and smectite-type layers in this study are defined as those clays that show discernible $10 \AA$ and $14 \AA$ peaks in the untreated sample; show expansion of the $14 \AA$ peak anywhere up to $17 \AA$, but no $10 \AA$ expansion under glycolation; and collapse to $10 \AA$ and intensification or sharpening of peaks with heat. The criterion of Reynolds and Hower (1970) to estimate an approximate percentage of smectite layers present was applied whenever it was possible to measure the shift in the glycolated $5 \AA$ peak position. Determining an exact value was complicated by the fact that, with glycol, the more randomness involved, the broader the $5 \AA+$ peak, and percentages subsequently became approximate. Because the Supai samples were not as well defined as the samples used by Reynolds and Hower (1970), some additional interpolation was necessary.

A random mixed-layer clay, in the present study, is probably composed of degraded illite-mica with expansible layers; shows a $10 \AA$ peak with moderate to extensive asymmetry toward the high angstrom values in the untreated sample; expands upon glycolation into a broad, poorly defined "peak," from 10 to $17 \AA$, which may show separation, be concentrated near the $10 \AA$ area, or merely show a higher background hump from $10 \AA$ upward; and collapses again asymmetrically about the $10 \AA$ position with heat.

Using a loose interpretation of Reynolds and Hower (1970), these random mixed-layer type patterns are interpreted to indicate the presence of a dominant $10 \AA$ phase, which can be termed a degraded mica or illite accompanied by randomly stratified expansible layers of smectite derivation. The majority of the samples labeled "random mixed-layers" in the present study conform to the above criteria and appear to contain less than 25 percent expansible layers. Subsequently, it is hypothesized that a detrital mica in the source rock is being degraded to the mixedlayer phases. Figure $\mathrm{O} 4 I$ is an illustration of the shift in the 

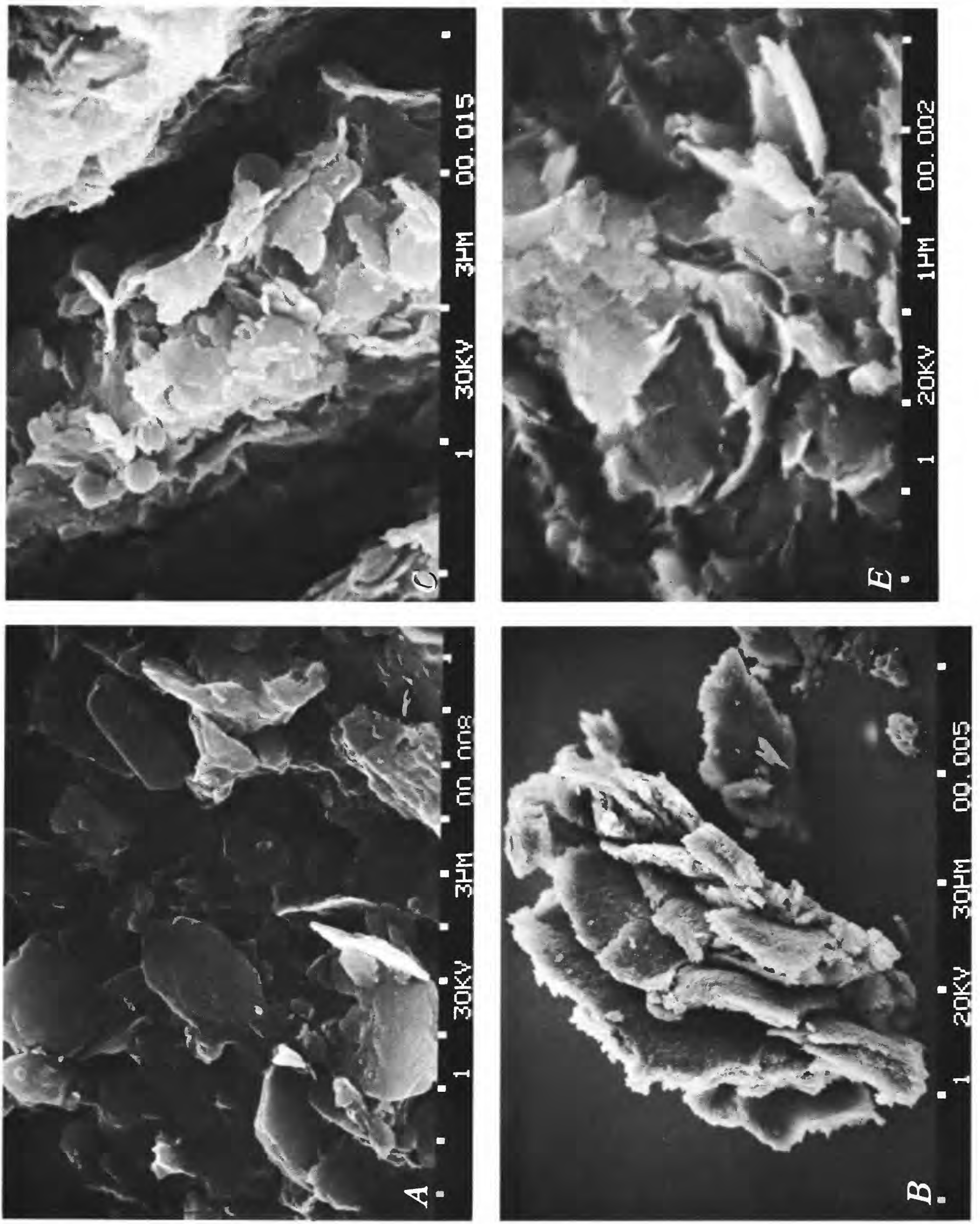

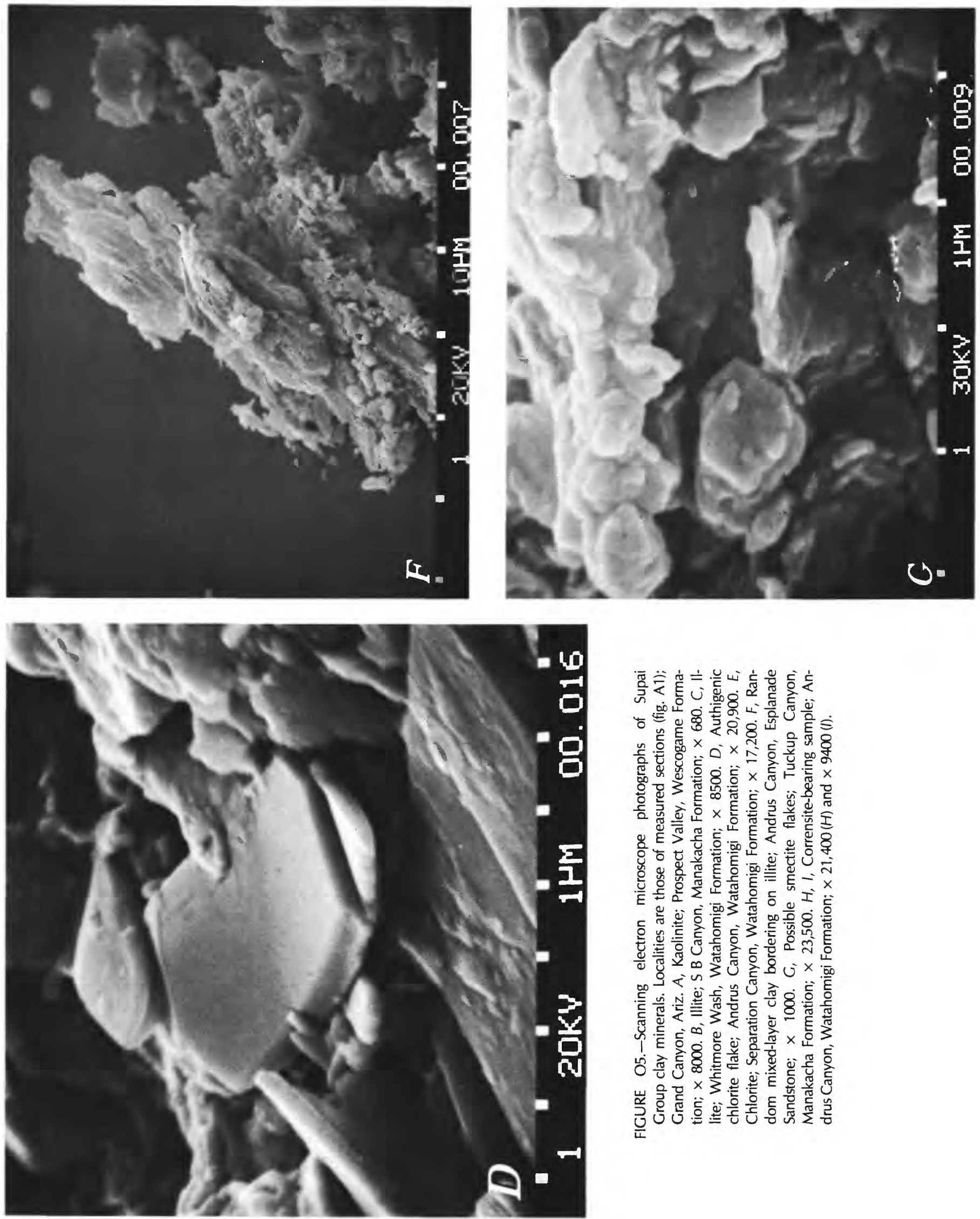

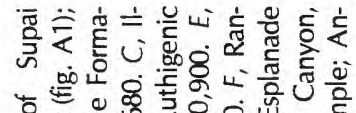

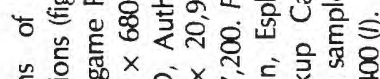

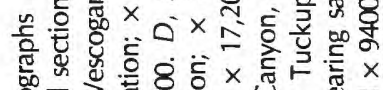

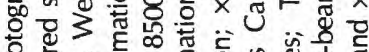

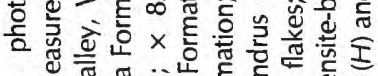

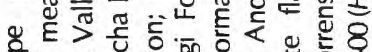

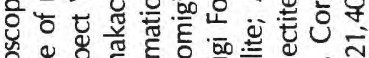

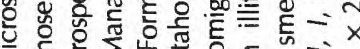

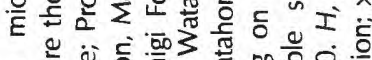

흔

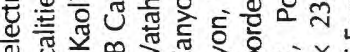

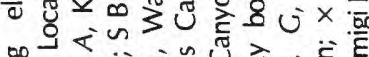

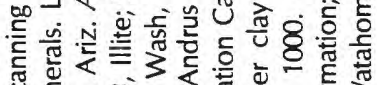

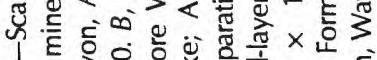

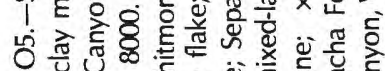

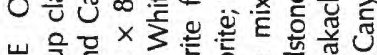

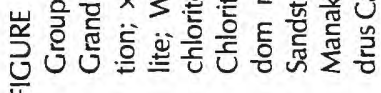



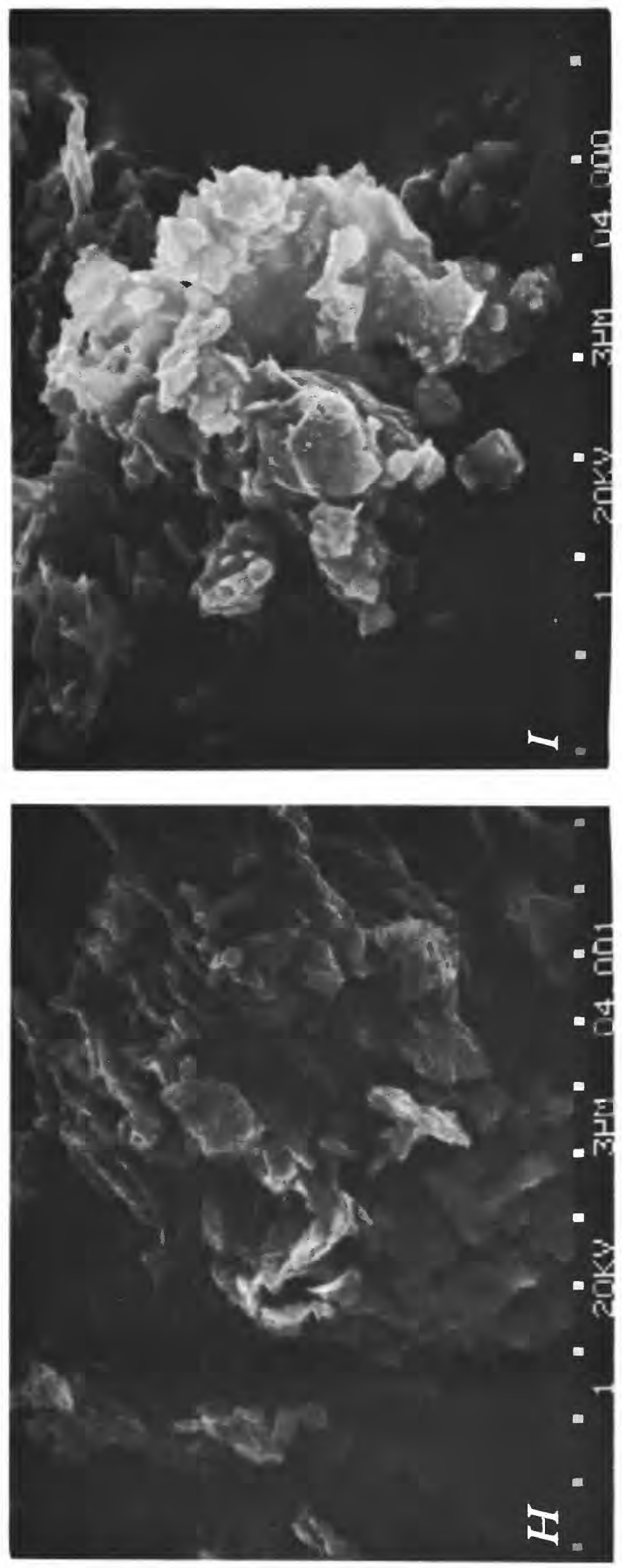

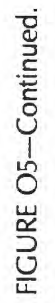


$5 \AA$ peak showing the $5.0 \AA$ position of the $10 \AA$ illitic component with the $5.18 \AA$ shifted peak of the expansible layer component. Figure $\mathrm{O} 4 \mathrm{~J}$ is a fitted curve of the values given in Reynolds and Hower (1970); the $5.18 \AA$ position indicates about 23 percent expansible layers present.

Figure O5G is an SEM photograph of a random mixedlayer (illite dominant) sample. The illite habit of previous illustrations (O5C and O5D) is clearly evident, but another phase, probably smectite, is also present. The poor crystallinity and the fine grain size suggested by the $\mathrm{X}$-ray diffraction patterns is confirmed by this photograph (fig. O5G), which reiterates the proposed degraded mica origin by showing the dominant illite phase.

\section{Smectite}

Smectite is sparsely dispersed as a discrete phase in the Supai Group. It is characterized by a strong, well-crystallized $14 \AA$ peak in the untreated state. This expands to $17 \AA$ upon glycolation and, with heat, loses water and collapses to $10 \AA$ (Carroll, 1970). Figure O4K is a diffractogram of Supai smectite. EDAX analysis and the untreated $14 \AA$ peak position indicates the Supai smectite to be primarily the common dioctahedral variety. This smectite is very fine grained and subsequently undetectable as discrete grains with the optical microscope. Even with the SEM, very high magnifications $(\times 23,100)$ were necessary to resolve crystal habit, and the success of that procedure is questionable. Figure $\mathrm{O} 5 \mathrm{H}$ is an SEM photograph of a montmorillonitebearing sample. The EDAX indicates the presence of silicon, aluminum, calcium, and potassium. The flakes in this photograph are less than 1 micron in size.

Throughout the entire Supai suite there are less than 10 samples containing smectite. For reasons of time and depth of burial, smectite generally does not survive in rocks older than Mesozoic age, nor in deeply buried sediments (Hower and others, 1976; Van Moort, 1971; Perry and Hower, 1970; Burst, 1959; Weaver, 1957, among others). The Supai study seems to add further credence to this theory. There is such an insignificant amount of smectite in Supai rocks that its existence is reported, but its presence should be integrated with great care into the whole Supai history. The smectite found in the Supai probably is a product of surface weathering and is not related to the ancient environments.

\section{Corrensite}

The exact nature of corrensite is the subject of considerable discussion and disagreement in the literature. There are three different descriptions of this mineral cited in the literature. Table $\mathrm{O} 1$ lists some of the references for each type.

Table O2 shows how each of the three types generally responds to the standard clay analyses methods.

The swelling-chlorite variety expands with glycol but does not collapse with heat; the montmorillonite type both expands and collapses; the vermiculite layer does not expand but collapses. Each of these appears to be a distinct species.

The literature is in agreement that, in general, "corren-

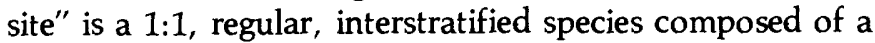
chlorite layer and a swelling-clay layer. Disputation arises when the swelling layer is characterized. Brucite sheets of the swelling layers may be incomplete and weakly bonded, resulting in preferential removal of parts of the sheets. Hydroxyl ions surround magnesium in the brucite sheet. Introduction of hydronium ion into the system converts the $\mathrm{OH}^{-}$to $\mathrm{H}_{2} \mathrm{O}$, weakening the structure and freeing the $\mathrm{Mg}^{+2}$ which can then be exchanged from the structure. The resulting "island" or "pillar" configuration is not strong enough to oppose introduction of polar molecules,

TABLE O1.-Compilation of literature references to corrensite-type minerals

\begin{tabular}{|c|c|c|}
\hline Chlorite-swelling chlorite & Chlorite-montmorillonite & Chlorite-vermiculite \\
\hline $\begin{array}{l}\text { Honeyborne (1951). } \\
\text { Stephen and MacEwan (1951). } \\
\text { Lippman (1954). } \\
\text { Martin-Vivaldi and MacEwan (1957, 1960). } \\
\text { Heckroodt and Roering (1965). } \\
\text { Wilson and Bain (1970). } \\
\text { Sawatzki (1975). }\end{array}$ & $\begin{array}{l}\text { Honeyborne (1951). } \\
\text { Sudo and Matsui (1954). } \\
\text { Earley and others (1956). } \\
\text { Sudo (1959) } \\
\text { Wilson and Bain (1970). } \\
\text { lijima and Utada (1971). } \\
\text { Tardy, Krempp, and Trauth (1972). } \\
\text { Tomasson and Kristmannsdottir (1972). } \\
\text { Blatter, Roberson, and Thompson (1973). } \\
\text { Kimbara (1973). } \\
\text { Kimbara and Sudo (1973). } \\
\text { Sawatzki (1975). } \\
\text { Lippman (1976). }\end{array}$ & $\begin{array}{l}\text { Bradley and Weaver (1956). } \\
\text { Lippman (1956). } \\
\text { Alietti (1958). } \\
\text { Melnik (1959). } \\
\text { Harvey and Beck (1960). } \\
\text { Peterson (1961, 1962). } \\
\text { Bodine (1971). } \\
\text { Rao and Bhattacharya (1973). } \\
\text { Kopp and Fallis (1974). } \\
\text { Furbish (1975). }\end{array}$ \\
\hline
\end{tabular}


TABLE O2.-X-ray diffraction identification criteria for corrensite species

\begin{tabular}{ccccc}
\hline Type & Untreated & $\begin{array}{c}\text { Ethylene } \\
\text { glycol }\end{array}$ & $550^{\circ} \mathrm{C}$ & Spacings \\
\hline Chlorite-swelling-chlorite ... & $28 \AA$ & $31 \AA$ & $28 \AA$ & $14 \AA+14 \AA=28 \AA$ \\
Chlorite-montmorillonite ... & $28 \AA$ & $31 \AA$ & $24 \AA$ & $14 \AA+14 \AA=28 \AA$ \\
Chlorite-vermiculite ...... & $28 \AA$ & $28 \AA$ & $24 \AA$ & $14 \AA+14 \AA=28 \AA$
\end{tabular}

such as glycol, into the structure causing the subsequent swelling that occurs from their presence. However, sufficient integrity still remains to prevent collapse to less than $12 \AA$ with heat, subsequently giving a characteristic physical response that defines corrensite in a clay analyses technique. The preceding theory from Martin-Vivaldi and MacEwan (1960) is a simplified version of the degradation hypothesis.

From the work of Lucas and Ataman (1968) and from that done by Lucas (1962), Millot, Lucas, and Wey (1963), Millot (1964), and Millot, Lucas, and Paquet (1966) came the hypothesis of corrensite formation by aggradation of random mixed-layer phases in a magnesium-enriched environment. The "equivalence" theory that Powers (1959) developed explains the preferential adsorption of magnesium over potassium when the ratio of the $\left[\mathrm{Mg}^{2} / \mathrm{K}^{+}\right]$is about 5 to 1 in seawater. Not only will the magnesium be absorbed into the degraded material, but it will unite with free silica tetrahedra. With this incorporation of magnesium into the lattice, water is lost and a rearrangement to a higher level of ordering results in a decrease of expansible layers. This theory involves ion migration from the surrounding solutions to interlayer cation positions and then to the octahedral layer sites and finally to the tetrahedral layer sites (Millot, Lucas, and Paquet, 1966). This is a diagenetic process that can be followed from detrital random mixed-layers through a corrensite phase to a wellcrystallized chlorite (fig. O8).

An untreated Supai corrensite sample gave major basal spacings at $29.0 \AA, 14.5 \AA$, and $7.2 \AA$. With glycol these spacings expand to $31.0 \AA\left({ }_{5}\right), 15.5 \AA$, and $7.75 \AA$, respectively; at $550, \mathrm{C}$ they collapse to $24 \AA, 12 \AA$, and $6 \AA$, respectively. Such values are in agreement with data in the literature (Lippmann, 1956, 1976; Honeyborne, 1951; Bradley and Weaver, 1956; Peterson, 1961; and Almon and others, 1976).

Figure O4L shows an X-ray diffraction pattern typical of a Supai specimen of corrensite. The corrensite phase is not always present in large enough amounts in the Supai Group to show all the major basal spacings, but the definitive $7 \AA$ and $14 \AA$ peak shifts could be characterized and followed through the various treatments. The peaks were always sharp and well defined, indicating good crystallinity. All the corrensite samples reacted consistently to the treatments, expanding and collapsing to the required values.

Figures $\mathrm{O} 4 \mathrm{E}$ and $\mathrm{O} 4 \mathrm{M}$ are diffraction patterns for a corrensite-related mineral. This clay, which is generally in close stratigraphic association with the corrensite, reacts differently to the various treatments. The expansion with glycol is about the same as $15 \AA$ versus $15.5 \AA$ for corrensite; but this clay does not collapse with heat as far as does corrensite. The implication is that this phase has fewer gaps in the brucite layer, has less water replacing the hydroxyls and, therefore, is a transitional species between corrensite and chlorite. The existence of this phase strongly suggests that the mixed-layer configuration of the corrensite is upgrading toward a nonexpanding chlorite, supporting the aggradation theory and corresponding with the theory presented by Dunoyer de Segonzac (1970). See also figure O8.

Figures $\mathrm{O} 5 \mathrm{I}$ and $\mathrm{O} 5 \mathrm{~J}$ are SEM photographs of corrensitebearing samples. They are unsatisfactory in terms of resolution, but they do illustrate the mixed-layering nature of this species.

\section{DISTRIBUTION OF CLAY MINERALS RELATIVE TO ROCK TYPE AND COMPOSITION}

The geographic, stratigraphic, and lithologic distributions of the clay minerals in the Supai Group furnish evidence of the origin of the Supai clays. This part of the chapter will discuss briefly these distribution patterns and generally relate them to the origins of the various clay species. The distribution of the seven clay mineral specieskaolinite, random mixed-layer, mixed-layer (illitesmectite), chlorite, illite, corrensite, and smectite-relative to general rock types is shown in figure $\mathrm{O} 6$. The dominant clay of the suite is the random mixed-layer type. This species, or its immediate antecedent, is probably detrital in origin. It is the major clay throughout all the rocks thought to be continental. It is uncommon in the dolostone and limestone. It may not have been transported far enough into the marine environment to accumulate as the dominant species or it may have undergone subsequent 

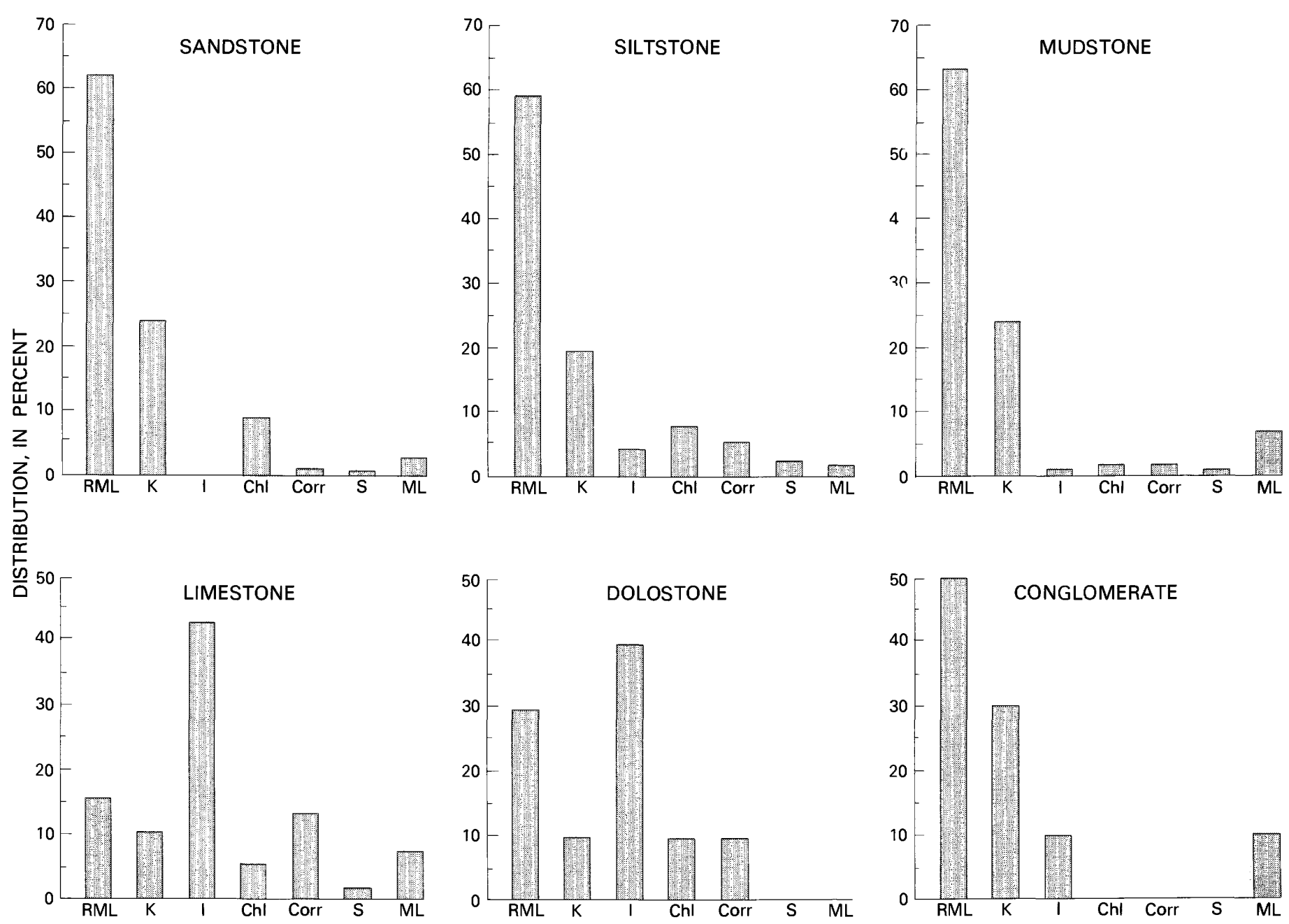

FIGURE O6.-Percentage distribution of clay minerals within the Supai Group and the intertonguing Pakoon Limestone (McNair, 1951) in western Grand Canyon relative to rock type. RML, random mixed-layer; K, kaolinite; I, illite; Chl, chlorite; Corr, corrensite; S, smectite; ML, mixedlayer.

diagenesis toward an illite phase. The latter premise can be supported to some degree by the large amount of illite present in the marine rocks and also by the evidence seen in the X-ray diffraction patterns as discussed in the prior section; the illitic phase of the random mixed-layer clays seems better developed in the marine environment.

Kaolinite is the most abundant of the clays believed to be potentially authigenic. It predominates in the sandstones, mudstones, siltstones, and conglomerates, indicating a probable continental environment of formation. Where kaolinite occurs in limestones and dolostones, local facies change to a nonmarine rock type is commonly described (see measured sections). Such data indicate that the clay mineral types are consistent with depositional environment.

The illite, chlorite, and corrensite clays are more common in marine rocks than in rocks considered to be of continental origin. Most of the chlorite observed in sandstones is thought to be detrital. Although the close numerical relationship of chlorite to corrensite in several of the rock types may be coincidental, it may also indicate a common origin. What seems to be an anomalous occurrence of marine clays in the nonmarine siltstone probably is the function of a local facies.

Because of its lack of a distinctive distribution pattern, the mixed-layer clay mineral might be detrital or possibly a diagenetically upgraded form of another clay species.

Montmorillonite is too insignificant in the sample suite to discuss any possible relationships it may have to the origins of the Supai.

Figure $07 A$ shows the distribution of clay type versus a generalized mineral composition from the whole-rock $X$-ray analyses. All the clay minerals appear to be present in greatest amounts in a rock with quartz, feldspar, and carbonates (type B). Fortunately, rocks with all these constituents compose 74 percent of the total samples analyzed, whereas type A (quartz and feldspar) is only 6 percent, and type $C$ (quartz and carbonates) is 19 percent of the total suite. Illite, chlorite, and corrensite do occur in greater 


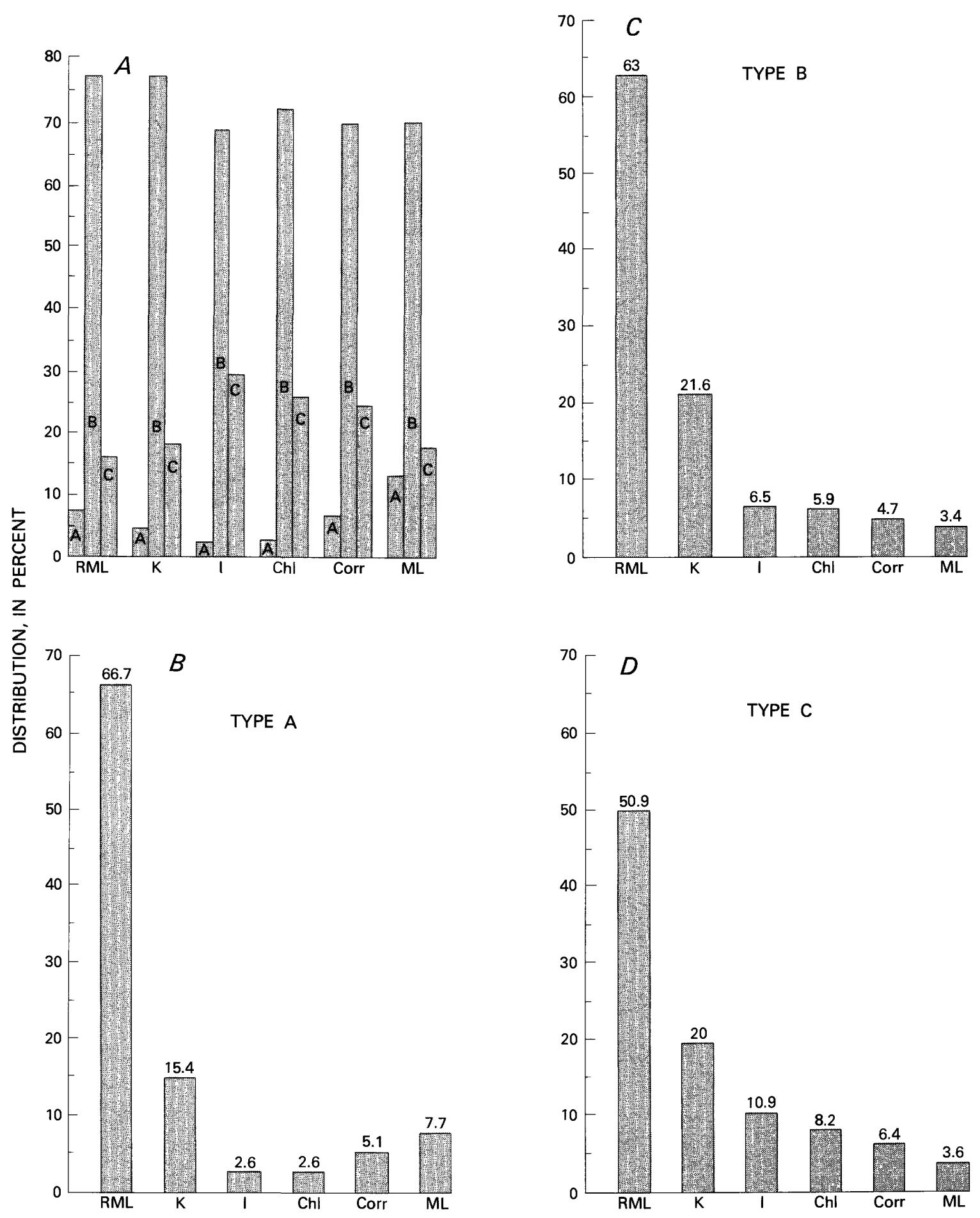

FIGURE O7.-Graphs showing distribution of clay type against generalized mineral compositions of the rocks within the Supai Group, Grand Canyon, Ariz. Tongues of Pakoon Limestone (McNair, 1951) are included in the upper part of the Supai in western Grand Canyon. Rock compositions are: type A, quartz and feldspar; type B, quartz, feldspar and carbonates; type $C$, quartz and carbonates. Clay types are: RML, random mixed-layer; $\mathbf{K}$, kaolinite; I, illite; Chl, chlorite; Corr, corrensite; ML, mixed layer. A, Clay type against composition of rocks; $B$, clay types within type $A$ rocks ( 39 samples); $C$, clay types within type $B$ rocks ( 430 samples); $D$, clay types within type $C$ rocks (110 samples). 
quantity in the more marine type $\mathrm{C}$ than does the hypothesized continental kaolinite.

An even more detailed breakdown is given in figures $\mathrm{O} 7 B, C$, and $D$. The distribution of kaolinite is a little ambiguous from these data. The marine clays, however, are relatively consistent in favoring the carbonate facies over the probable continental quartz and feldspar rocks. The random mixed-layer clay is also significantly less in the marine rocks.

\section{ASSOCIATIONS AMONG THE CLAY MINERALS}

Distinct patterns of clay-mineral association occur in the Supai Group sedimentary rocks. Random mixed-layer clays frequently occur discretely without other clay minerals. Kaolinite, in minor amounts, is commonly associated with random mixed-layer clays. Chlorite, in trace amounts, is also found with the random mixed-layer clays. Corrensite has not been observed in direct association with the random mixed-layer clay type. Illite may occur with random mixed-layer clays, but it is usually the dominant clay phase where the two are associated.

When kaolinite is relatively abundant in a rock, there is rarely another clay mineral associated with it. In some places it occurs with mixed-layer clays and, infrequently, with chlorite. If kaolinite and illite are found together, the illite is usually degraded. A corrensite and kaolinite association has not been observed, agreeing with Velde's observations (1977b). Corrensite and illite occur together exclusive of other clay minerals. Chlorite is usually present with illite, but illite is not necessarily accompanied by chlorite.

Kaolinite, illite, and montmorillonite locally occur by themselves, but this is not the usual pattern. Chlorite usually occurs as an accessory clay phase. Mixed-layer clays and montmorillonites are present in such minor amounts that a recognizable pattern of distribution has not been established for them.

\section{ORIGINS AND HYPOTHESIZED DEPOSITIONAL ENVIRONMENTS OF THE SUPAI CLAYS}

Reconstructing the possible depositional environments of clay minerals, some of which are possibly 300 million years old, is to some degree highly speculative. However, this study is based on considerable data in the form of $X$-ray diffraction analyses, scanning electron microscope photographs, and energy dispersive elemental determinations, with the paleogeographic, lithologic, and mineralogic distributions and associations already presented in previous chapters, and with prior research documented in the literature. All this can at least allow for an educated speculation. Several explanations are possible for the origins of the clay minerals in the Supai Group. The authors have chosen that explanation which appears to be the simplest, yet which incorporates most of the data with the fewest apparent contradictions.

Definition of the terms detrital, authigenic, and diagenetic, as used in the following discussion, is required to ensure a general understanding. "Detrital" indicates an origin other than the rock in which the mineral is found; it infers transport from another area before deposition. "Authigenic" is defined as formed or generated in place; a mineral that has not been transported but rather formed where it occurs, and at the time of or very shortly after deposition of the rock. "Diagenetic" as it will be used in this context refers to processes of formation subsequent to deposition and implies a passage of time during which these processes may operate. These definitions have been taken from the Glossary of Geology (American Geological Institute, 1972). Millot, Lucas, and Wey (1963) further refined the term "diagenetic" by defining it as transformations that take place within the sediments after sedimentation but before low-grade metamorphism. Unfortunately, the transition between "authigenic" and "diagenetic" is not always apparent.

Judging by evidence derived from the clay minerals, the Supai has led a rather structurally quiet existence through time. The temptation is great to follow the theory of burial diagenesis presented by Burst (1959, 1969), detailed by Powers (1967), and refined by Perry and Hower (1970) and by Hower and others (1976). Although the montmorillonite-mixed layer-illite configurations are present and the time factor certainly is viable, sufficient depth of burial to generate the necessary temperature-pressure gradient for burial diagenetic transformation apparently is lacking. There is also not sufficient ordering to the mixed-layer clays for any great depth of burial (Hower, 1967). There is no direct evidence that montmorillonite could have been the precursor of the random mixed-layer species. The interrelationships of the clays are more of a horizontal nature than of the vertical type, which would be more suggestive of burial diagenesis. However, many of the reactions illustrated in that process are most helpful in reconstructing the history of the Supai. Figure O8 diagrammatically shows the hypothesized origins of the Supai Group clays. The general theory of the depositional conditions of these clays will be presented and each species and its interactions with the whole will be discussed. 


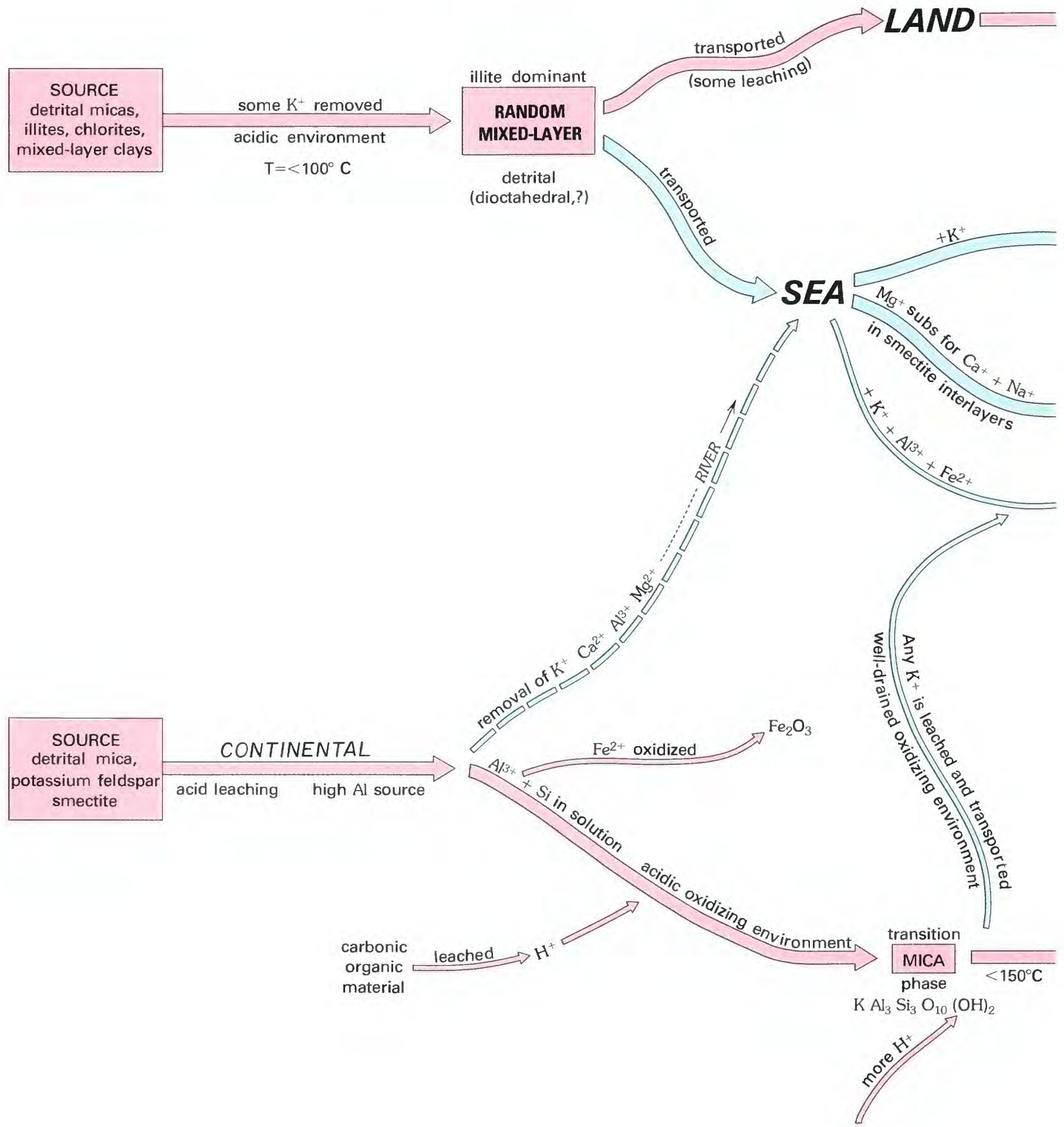

FIGURE O8.-Diagram showing hypothesized 
remain in RML

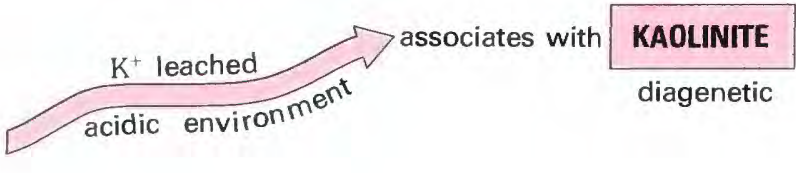

$-75^{\circ} \mathrm{C}$

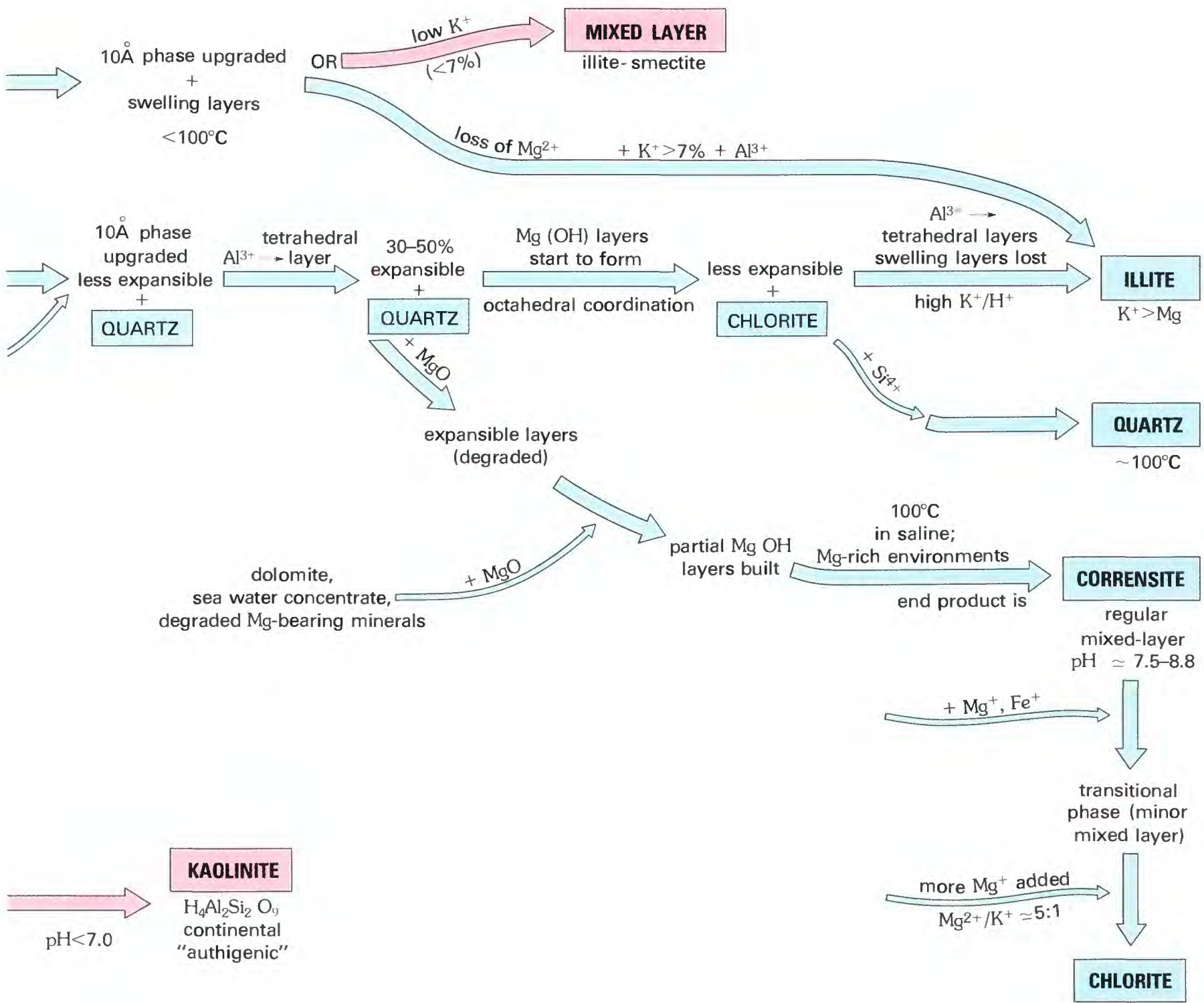

origins of the Supai Group clays. 


\section{Random mixed-layer clays}

The abundance and completely general distribution of the random mixed-layer clays, irrespective of lithology or paleogeography, led to the conclusion that they are detrital in origin. Rather than smectite, as in the burial diagenesis theory, the random mixed-layer clays have probably been derived from detrital micas and clay phases; they have been transported and stripped of sufficient potassium to degrade them to their present state. A definite trend toward the lost potassium reestablishing itself, with the $10 \AA$ phase taking some precedence, occurs in the marine facies. The interlayer sites of an illitic-type structure tends to concentrate potassium $\left(\mathrm{K}^{+}\right)$because it is both abundant and a cation most easily dehydrated (Hower and others, 1976). A lower layer charge to dehydrate potassiumbearing layers is required. These layers therefore lose water faster and collapse toward an illite (Eberl, 1978; Eberl and Hower, 1977). The greater abundance of illite over the random mixed-layer clays in the marine facies is considered a further indication that potassium fixation has occurred within the random mixed-layer species of the Supai, upgrading them to illites or to dominantly illitetype phases. This non-aggradation was discussed by Weaver (1956).

The random mixed-layers of those rocks considered to be continental, however, show a lack of consistent crystallinity. This factor could indicate that there was a minimum amount of diagenetic activity in the continental environment after deposition. A most useful diagram relating subsurface temperature to percent of expansible layers is shown by Perry and Hower (1970, p. 175). This diagram indicates that random mixed-layer phases are stable up to $75^{\circ} \mathrm{C}$; regular interlayered species can exist from $75^{\circ}$ to at least $100^{\circ} \mathrm{C}$ and possibly, but in smaller percentages, at slightly higher temperatures. Perry and Hower (1970) emphasized temperature rather than depth of burial as the dominant agent of diagenesis. The investigations of Van Moort (1971) pointed out that at temperatures of about $105^{\circ} \mathrm{C}$, the next to the last water interlayer of a mixed-layer species is removed. Velde (1977a), in his compilations, mostly agreed with these temperature parameters. He also hypothesized a solid-solution series from smectite through various mixed-layer phases (lower temperatures giving more random structures) to illite. His experiments with Bystrom-Bruzewitz (Velde and Bystrom-Bruzewitz, 1972) presented additional evidence. In general, these investigators concluded that random mixed-layers occur at low temperatures-usually less than $100^{\circ} \mathrm{C}$; that if there is potassium in the environment, it will migrate into the structure, upgrading it toward a mica; and that not much energy is required for this process to operate. This progression is in agreement with the comprehensive summary of Dunoyer de Segonzac (1969, 1970). He presented two paths of formation for intermediate-mixed layer clays: (1) If potassium and sodium ions are introduced into the lattice of random mixed-layer clays, regular mixed-layer clay evolves; with additional $\mathrm{K}^{+}$and $\mathrm{Na}^{+}$illite forms and with metamorphism becomes a mica. (2) A magnesiumenriched environment may produce a corrensite mixedlayer upgrading through transition phases into a chlorite. All these various phases and transitions between them are observed within the Supai Group.

\section{Illitic clays}

The preceding discussion leads logically to the illites in the Supai. The X-ray diffraction patterns indicate that even the most crystalline of the illites have some minor expansive material in them. Temperatures and pressures comparable to low-grade metamorphism may be required to change mixed-layer phases completely toward a "pure" illite (Weaver, 1957; Hower and Mowatt, 1966). The distribution diagrams (fig. O6) for the clay minerals show illite nearly confined to limestone and dolostone (marine environment) in the Supai. The few probable continental facies that carry illite, upon close examination, mostly are found to have local marine connections. Illite associates primarily with other probable marine clays such as chlorite and corrensite. When it does occur with kaolinite, the illite shows signs of degradation as though it had been partially leached of its potassium content. In its association with random mixed-layers, illite is the dominant phase and the occurrence is within definitely marine rocks.

Illite is frequently a clay of marine environments, favoring carbonate facies, and also enjoying dominance over other clay types in ancient sediments (Millot, 1949; Weaver, 1957; Tooker, 1960; and Grim, 1968). Brooks and Ferrell (1970) and Velde (1977b) noted that with increasing salinity illite becomes more stable and that in a fluviatile environment it is unstable. The chemical transformation that creates illite is discussed in various details by Powers (1959), Weaver and Beck (1971), Weaver and Pollard (1973), Hower and others (1976), Reesman and Keller (1967), and Harder (1974).

Illite forms in waters having a high $\left[\mathrm{K}^{+} / \mathrm{H}^{+}\right]$ratio (Garrels and Christ, 1965). For it to become stable, the potassium ion must be fixed within the structure. This requires an increase in the net interlayer charge of the expanded layers. These layers do not convert to a nonexpansive state merely with an influx of potassium. The $\mathrm{Al}^{3+}$ is replaced by $\mathrm{Mg}^{2+}$ or $\mathrm{Fe}^{3+}$ in the octahedral layers. Aluminum migrates into the tetrahedral layers, substituting for $\mathrm{Si}^{4+}$, which leaves the structure to later form quartz. The $\mathrm{Mg}^{2+}$ sites are filled with $\mathrm{K}^{+}$, which then consolidates the structure from a mixed-layer to an illitic phase, the nature of which is a function of the amount of potassium present. Weaver and Beck (1971) stated that if 
this potassium fixation is less than 7 percent, the expanding layers will remain in the structure, the main indication of which is a broader $10 \AA$ peak on the X-ray diffraction trace.

In the framework of the Supai illites, the preceding data seem to indicate that the illites have formed in a marine environment, most likely from the upgrading of the random mixed-layer clays and (or) weathered, detrital mica. The fact that not all clay phases within the marine environment have been completely converted to illites, but do exhibit various stages of conversion, may suggest that both authigenesis and diagenesis could be operating here. This may also be a function of the composition of the original phases, for some contained less potassium initially than others, and were not able to make the complete conversion before marine waters gave way to consolidated sediments. The $\mathrm{Mg}^{+}$and $\mathrm{K}^{+}$are mobile ions and the structures are variable. With the amount of time ( $300 \mathrm{m.y}$.$) and an envi-$ ronment potentially close to equilibrium, cation exchange is very much to be expected and should be considered as an important process in the formation of these clays.

\section{Chlorite clays}

Chlorite occurs in the marine rocks of the Supai Group intimately with illite. It shares with illite, through geologic time, the same associations, abundance in ancient sediments, and tenacity with depth. Various researchers in the field, among them Weaver and Pollard (1973), Weaver and Beck (1971), Powers (1959, 1957), and Millot (1964), have observed empirically the reaction series that Velde and Bystrom-Bruzewitz (1972) were able to produce in the laboratory: the transformations of a mixed-layer phase through less expansive species plus quartz, to minor expansible plus chlorite, to illite plus chlorite plus quartz. (See fig. O8.) From Millot's observations this is a typical assemblage in older sedimentary rocks. The chlorite is formed either by destabilization of a mixed-layer (illite-smectite) phase or of kaolinite (Dunoyer de Segonzac, 1969; Van Moort, 1971; Perry and Hower, 1970; and Muffler and White, 1969).

The existence of chlorite in a marine environment becomes a function of the salinity; with increasing salinity the production of chlorite phases from mixed-layer species also increases (Powers, 1957). This transformation starts as lateral growths of brucite $\left(\mathrm{Mc}(\mathrm{OH})_{2}\right)$ sheets between the basal surfaces of the swelling layers of the smectite phases present (Griffin, 1962). Chlorite forms in seawater because the necessary magnesium is most abundant there. The equivalence level concept proposed by Powers (1957) is a detailed discussion of the process. As long as the $\left[\mathrm{Mg}^{2+} / \mathrm{K}^{+}\right]$ratio is about $5: 1$, which usually occurs at shallower depths, the magnesium will be absorbed preferentially into the mixed-layer structure before the potassium, where it substitutes for the existing calcium and sodium. Potassium is also absorbed into the illite phase, but at a slower rate. When these ions, $\mathrm{Mg}^{2+}$ and $\mathrm{K}^{+}$, exist in equivalent concentrations, then potassium is absorbed more rapidly than magnesium. This explains the association of illite (dominant in ancient sediments) and chlorite (associated but not primary).

The chlorites of the Supai clay suite are proposed to be authigenic when they occur in marine facies. They have developed nearly simultaneously with the considered authigenic illites by the above processes, which are also illustrated in figure 08 , from the detrital, random mixedlayer phases. The dominant occurrence in marine rocks or in calcareous marine facies, except for the definitely detrital samples that show the effects of transport; the close association with the illites; the existence as an accessory phase; and the very fine grain size coupled with some well-defined, unaltered crystal habit (fig. O5E) - all these factors can be considered supporting evidence for the hypothesized authigenic origin of the chlorites in marine sediments.

\section{Corrensite}

An extensive discussion relative to the origin and occurrence of corrensite or "corrensite-type" clay minerals is in the literature. Some of the diverse environmental associations are described by Blatter, Roberson, and Thompson (1973). In sedimentary rocks, corrensite is most commonly associated with carbonate and evaporite deposits and therefore its occurrence is important in the reconstruction of the Supai history.

The age, occurrence, mineral associations, and environments of formation of some of the sedimentary corrensites documented in the literature are summarized in table O3. Several conclusions can be drawn from this information: (1) corrensite appears to be stable through long periods of geologic time, and is shown by Weaver and Beck (1977, p. 216) to have been most abundant during the Paleozoic and Mesozoic Eras; (2) carbonates, and especially dolostones, are always associated; (3) evaporite minerals are commonly present, but not required; and (4) illite is normally present. Although some previous researchers (Lippmann, 1956; Grim and others, 1959; Millot, 1964; Lucas and Ataman, 1968) have hypothesized that corrensite is restricted to a narrow, hypersaline environment, subsequent investigations (Johnson, 1964; Peterson, 1961; Almon and others, 1976; Velde, 1977b) suggested broader geochemical parameters for its authigenic development.

From the mineral associations shown in table O3, the shallow marine conditions of an epicontinental sea seem to favor corrensite formation. Localized salinity changes, where slightly hypersaline conditions occur as large concentrations of magnesium build up (possibly due to calcium precipitation into calcite) in lagoonal settings 
TABLE O3.--Sedimentary corrensite occurrences

\begin{tabular}{|c|c|c|c|c|}
\hline Reference & Age & Formation-locality & Mineral association & Environment-description \\
\hline Bradley and Weaver (1956) & Late Mississippian .. & $\begin{array}{l}\text { Brazer Limestone, } \\
\text { Colorado. }\end{array}$ & $\begin{array}{l}\text { Calcite, quartz } \\
\text { (incomplete data). }\end{array}$ & Carbonate. \\
\hline Lippmann (1956) . . . . . . . . . . . & Triassic ......... & $\begin{array}{l}\text { Rot member, } \\
\text { Buntsandstein, } \\
\text { Germany. }\end{array}$ & $\begin{array}{l}\text { Dolomite, calcite, } \\
\text { illite, quartz, hematite, } \\
\text { halite, gypsum. }\end{array}$ & $\begin{array}{l}\text { Continental salt lake and } \\
\text { salt flat. }\end{array}$ \\
\hline Honeyborne (1951). & Triassic $\ldots \ldots \ldots \ldots$ & $\begin{array}{l}\text { Keuper marl, } \\
\text { England. }\end{array}$ & $\begin{array}{l}\text { Calcite (dolomite), } \\
\text { illite (gypsum). }\end{array}$ & $\begin{array}{l}\text { Hot, semidesert conditions; } \\
\text { warm sea-shales, } \\
\text { dolomites, sandstones } \\
\text { with coal stringers. }\end{array}$ \\
\hline Earley and others (1956) ... & Permian & Yates Formation, Texas & $\begin{array}{l}\text { Dolomite, quartz, feldspar, } \\
\text { mica, organics. }\end{array}$ & Argillaceous siltstone. \\
\hline Grim, Droste, and Bradley (1959) ... & Permian & $\begin{array}{l}\text { Salado Formation, } \\
\text { New Mexico. }\end{array}$ & $\begin{array}{l}\text { Dolomite, } \\
\text { evaporite minerals. }\end{array}$ & $\begin{array}{l}\text { Mildly acidic } \mathrm{Mg}^{+2} \\
\mathrm{Na}^{+} \mathrm{K}^{+} \text {-rich } \\
\text { environment. }\end{array}$ \\
\hline Kopp and Fallis (1974) . . . . . . . . . . & 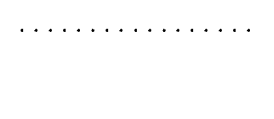 & $\begin{array}{l}\text { Wellington Formation, } \\
\text { Kansas, Hutchinson } \\
\text { Salt Member }\end{array}$ & $\begin{array}{l}\text { Dolomite, gypsum, } \\
\text { anhydrite, quartz } \\
\text { illite or mica. }\end{array}$ & Hypersaline. \\
\hline Almon, Fullerton, and Davies (1976) & Late Cretaceous ... & $\begin{array}{l}\text { Horsethief Formation, } \\
\text { Montana }\end{array}$ & Calcite, dolomite . . . & $\begin{array}{l}\text { Delta distributary channels } \\
\text { and distributary mouth- } \\
\text { bar environment. }\end{array}$ \\
\hline Peterson $(1961,1962)$ & Late Mississippian . . & $\begin{array}{l}\text { Cumberland Plateau, } \\
\text { Tennessee. }\end{array}$ & $\begin{array}{l}\text { Dolomite, calcite, quartz, } \\
\text { K-spar, albite, illite- } \\
\text { mica. }\end{array}$ & Carbonate. \\
\hline Martin-Vivaldi and MacEwan (1957). . & Triassic . & $\begin{array}{l}\text { Catalan and Jura } \\
\text { Formation, } \\
\text { Spain, France. }\end{array}$ & $\begin{array}{l}\text { Calcite, dolomite, } \\
\text { quartz, illite. }\end{array}$ & $\begin{array}{l}\text { Rocks corresponding to } \\
\text { Keuper muschelkalk, } \\
\text { Bunter of Germany; } \\
\text { carbonates, shales, } \\
\text { muds. }\end{array}$ \\
\hline Lucas and Ataman (1968). & Triassic & Jura Basin, France .... . & $\begin{array}{l}\text { Gypsum, anhydrite, } \\
\text { halite, dolomite. }\end{array}$ & $\begin{array}{l}\text { Carbonates, evaporites, } \\
\text { argillaceous sandstones. }\end{array}$ \\
\hline Millot, Lucas, and Wey (1963) . . . . . & Triassic . .... & $\begin{array}{l}\text { Muschelkalk Formation, } \\
\text { Keuper Formation. }\end{array}$ & Calcite + (?) & \\
\hline Lippman (1976) . . . . . . . . . . . . & Triassic . . . . . . . . & $\begin{array}{l}\text { Keuper Formation, } \\
\text { "Gipskeuper." }\end{array}$ & $\begin{array}{l}\text { Quartz, mica, illite, } \\
\text { gypsum, dolomite, } \\
\text { anhydrite. }\end{array}$ & $\begin{array}{l}\text { Argillaceous sediments, } \\
\text { mudstones. }\end{array}$ \\
\hline Rao and Bhattacharya (1973) ...... & Tertiary & $\begin{array}{l}\text { Sirban Limestone, } \\
\text { Himalayas, India. }\end{array}$ & Dolomite, clays .... & $\begin{array}{l}\text { Microdolosparite, limestone } \\
\text { and shales, some } \\
\text { hypersalinity. }\end{array}$ \\
\hline
\end{tabular}

behind barrier bars. The equivalence level concept of Powers (1957) can again be cited in support of shallowwater deposition of corrensite. Magnesium substitution is favored at shallow depths.

Corrensite can also exist in restricted, large evaporite basins, and it is found in deltaic channels and distributary mouth bars (Almon and others, 1976). These locales imply low-energy environments and impounded waters. Corrensite seems to equate with a magnesium-enriched environment.

The conclusions of Lucas and Ataman (1968) imply that corrensite can find stability in a carbonate facies where much of the magnesium is related to the dolostones. Too little is then left to form a true chlorite but the silica tetrahedra acquire some of the $\mathrm{Mg}^{2}+$ ions to form corrensite.
The fact that corrensite is also found with evaporites is probably only a function of whatever amount of silica (diatoms, smectite) has managed to infiltrate the sulfatechloride environment and this silica actively competes for the magnesium, capturing enough to form corrensite but not consistently a sufficient amount to complete all the chlorite layers of the structure. A deficiency in aluminum, which is relatively insoluble and immobile, may be a further consideration relative to corrensite formation over chlorite.

Stability temperature, according to Velde (1977b), appears to be from $100^{\circ} \mathrm{C}$ to possibly $280^{\circ} \mathrm{C}$. Corrensite has been synthesized from montmorillonite in a magnesiumenriched solution at temperatures between $300^{\circ}$ and $600^{\circ} \mathrm{C}$ by Wyart and Sabatier (1966). The stability field of 
authigenic corrensite has been calculated by Almon, Fullerton, and Davies (1976). The parameters that they derived have a $\mathrm{pH}$ between 7.5 and 8.8 and a high magnesium-calcium ratio. As would be anticipated, the stability field of corrensite is somewhat limited, which makes it a potentially useful environmental indicator. Figure O9, modified from Almon, Fullerton, and Davies (1976, fig. 7) illustrates stability fields for corrensite and associated minerals. This is also in agreement with the work done by Peterson $(1961,1962)$. It is supported by synthesis experiments conducted by DeKimpe, Gastuche, and Brindley (1961); by Caillère, Hénin, and Esquevin (1953); and by Kotov, Lebedev, and Tarlakov (1969).

Some parallels can be drawn from Peterson's (1961, 1962) work on the carbonate rocks of the Cumberland Plateau in Tennessee and the two lower formations of the Supai Group. Most of the same mineral assemblages are present, although the Supai seems to be more siliceous and to contain more detritus in its nearshore carbonate sequence. The dolomite-corrensite, calcite-dolomitecorrensite, and calcite-corrensite mineral assemblages of the Cumberland Plateau are recognized and their chemical origins can perhaps be equated with similar parts of the Watahomigi and the Manakacha. The Supai does not appear to have had as much magnesium because it does not contain all the more complex magnesium-bearing minerals of the Cumberland rocks. However, the basic authigenic mechanisms seem applicable. These mineralogical and lithologic assemblages, which seem to satisfy Gibb's phase rule, are a definite function of the chemical equilibrium established at the time of deposition and so subsequent diagenesis is unlikely, according to Peterson $(1961,1962)$.

The probable authigenic origin of the corrensite in the Supai Group is supported by its lithologic associations. It occurs throughout the marine facies of the Watahomigi and Manakacha Formations, the two showing the least energy of the group. Corrensite occurs in the Esplanade, but only very selectively associated with the gypsum deposits. Figures $\mathrm{O} 12$ and $\mathrm{O} 13$, the fence diagrams for the Watahomigi and Manakacha, show corrensite occurring exclusively in the limestones or in siltstones closely associated with limestones, particularly in the nearshore areas and in narrow limestone lenses that may have been restricted lagoons surrounded by calcareous silt and mud.

The cluster configuration of many corrensite samples suggests localized conditions especially favorable to its formation. Calcite, dolomite, quartz, feldspars, and illite are associated with corrensite in the Supai rocks. Kaolinite, with its implications of an acidic, high-alumina environment has not been found associated with corrensite. No indications of hypersaline conditions occur in the Watahomigi and the Manakacha, but rather a relatively normal marine salinity with localized areas of high magnesium concentration. Possible magnesium sources would be the

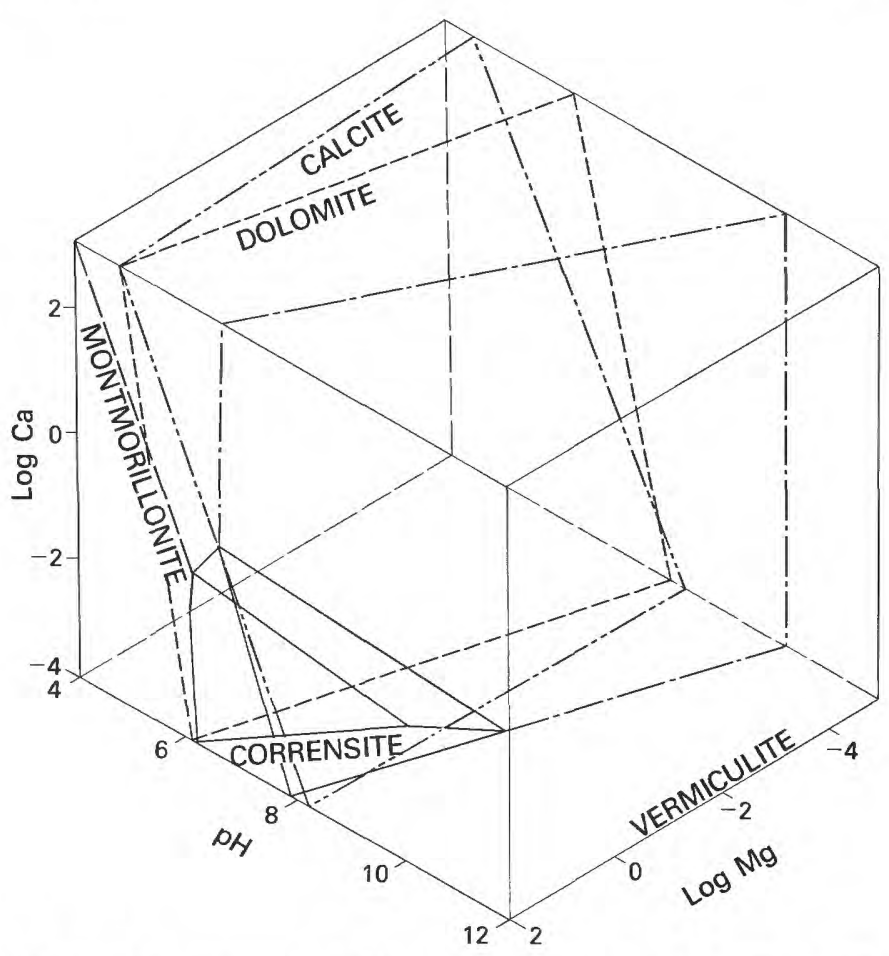

FIGURE O9.-Corrensite stability relationships; modified from Almon, Fullerton, and Davies (1976, fig. 7). This diagram implies environmental compatability but not necessarily contemporaneous deposition.

evaporation of seawater along a shallow broad shelf near shore, degradation of detrital magnesium-bearing minerals, and high magnesium-bearing dolostones. The corrensite-carrying gypsum rocks of the Esplanade are closely associated with dolostones, which would support the theory of a magnesium-enriched environment. The transitional swelling chlorite-type minerals that occur in stratigraphic proximity are additional indicators of the authigenic origin of this assemblage.

\section{Kaolinite}

Kaolinite is not considered to be a common clay constituent of older rocks. It is destroyed with long periods of time. In many places, the nearshore environment, where a high volume of probably detrital kaolinite is deposited, has been eroded. Another factor against its formation in ancient sediments was unfavorable climatic conditions (Weaver, 1957, 1958; Rateev, 1963; Parham, 1966). However, the Permian is known to have had periods of lateritic weathering that promotes kaolinite formation (Weaver, 1957; Weaver and Beck, 1971).

Kaolinite is a primary clay mineral of continental environments. Kaolinite does not form in a marine environment although it is known to exist in transitional marine waters as a function of transport from its continental origins (Grim and others, 1949; Millot, 1970; Keller, 1970; 


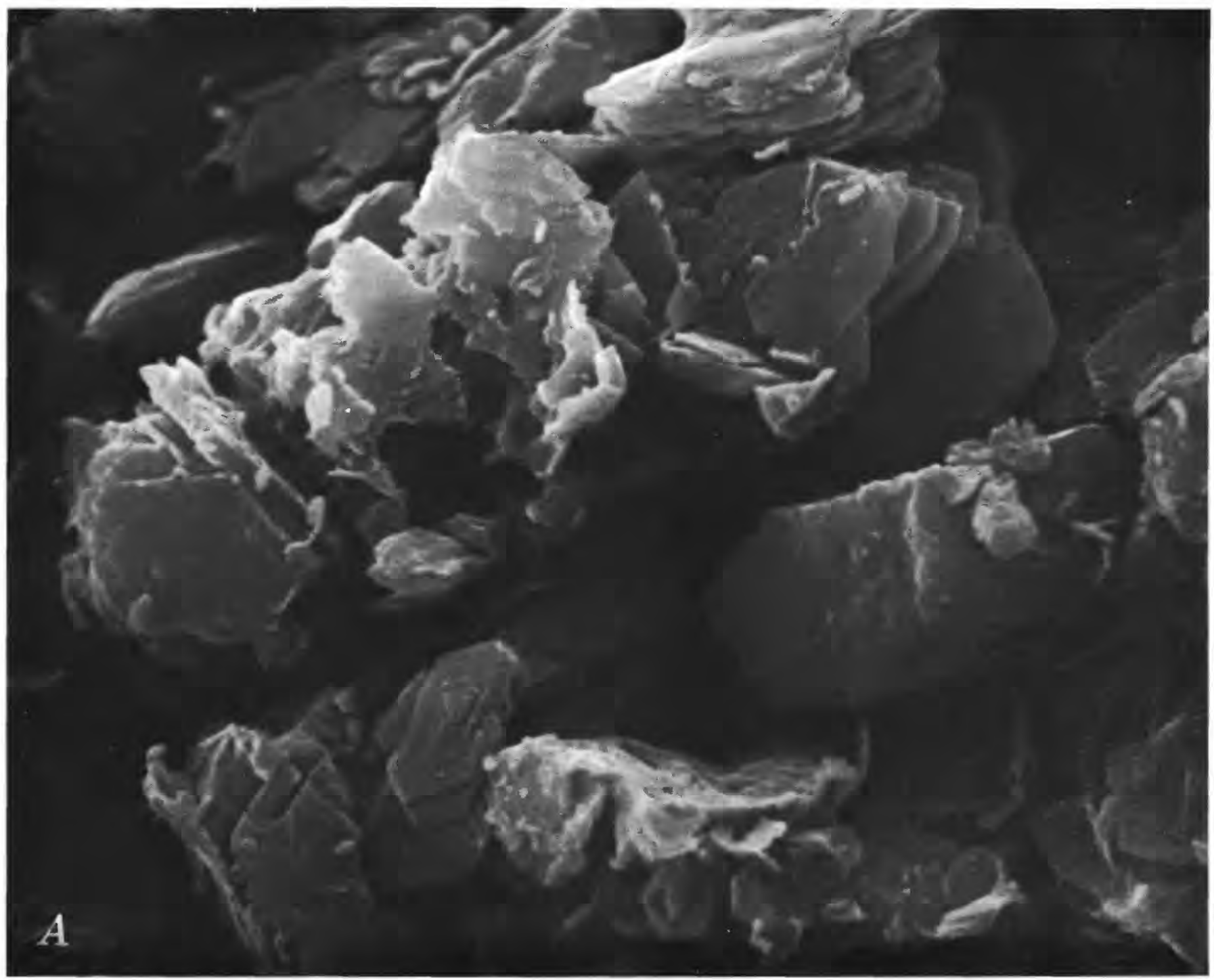

FIGURE O10 (above and facing page).-A, Scanning electron microscope photograph of a kaolinite sample which illustrates various criteria for authigenic origin. B, Sketch of photograph indicating examples of criteria; 1 , Pseudo-hexagonal plates stacked face to face along the $c$ axis in randomly oriented "books"; 2, twinning notches; 3 , helical growth patterns; 4 , serrated edges.

Weaver and Pollard, 1973); however, it is considered to be unstable in seawater (Rex and Martin, 1966).

Where kaolinite is present as a dominant phase, there is usually no other clay mineral in the rock. This relationship could support the authigenic premise as the formation of kaolinite requires leaching of cations needed for other claymineral formation, unless those other clays are detrital. If the Supai kaolinite has a detrital origin, it would probably be found in more abundance with clay minerals that have not been leached, but it is not. Most associated illite is degraded, indicating again a possible leaching environment. The nonassociation of corrensite and kaolinite substantiates the authigenesis of both as they form in mutually incompatible environments.

The general consensus of the authors just cited and of numerous others is that kaolinite forms in an acidic, ox- idizing environment-one where intensive leaching of an aluminum-silicate parent rock is occurring. Potassium, sodium, calcium, magnesium, and iron must be removed with the addition of the hydrogen ion to create this nearly pure aluminum-silicate $\left(\mathrm{Al}_{2} \mathrm{Si}_{2} \mathrm{O}_{5}(\mathrm{OH})_{4}\right)$. This process implies permeable rock or soil with a sloping drainage, greater precipitation than evaporation with a $\mathrm{pH}$ of equal to or less than 7.0 (according to the stability diagram of Garrels and Christ, 1965), and a high aluminum to silica ratio. Removing especially the magnesium will keep the silica in solution and mobile as this ion will enhance silica precipitation. Potassium and sodium feldspars from granitic rocks would probably lose silica faster with subsequent aluminum enrichment than would the more mafic calcium-magnesium rocks (Keller, 1964). The hydrogen ion is added from decomposed organics in the percolating 


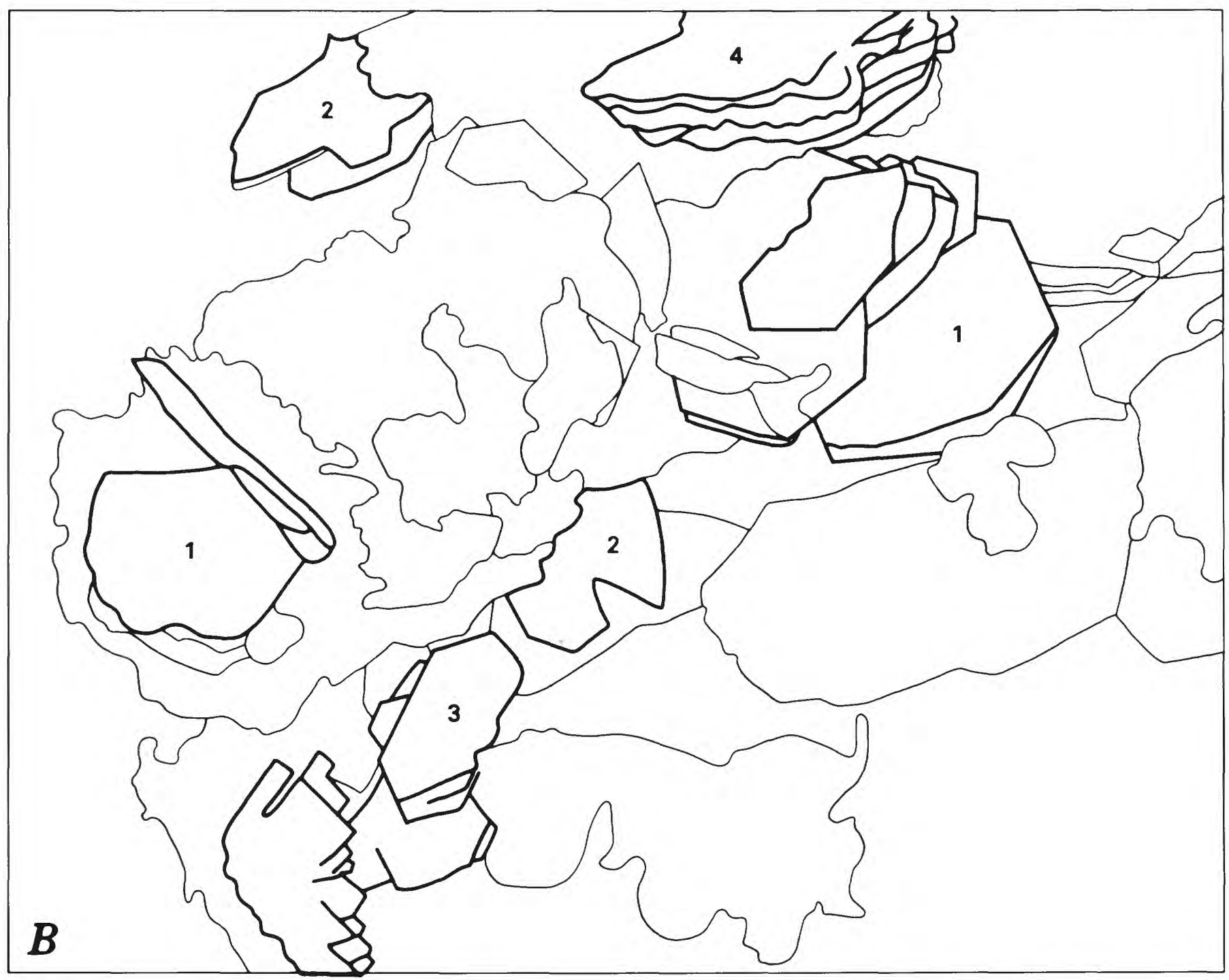

ground water. If the potassium is not efficiently removed, then a lower $\mathrm{pH}(4.5)$ is required for kaolinite formation (Keller, 1970). Seawater usually contains sufficient potassium so that illitic phases are preferentially formed over kaolinite in a marine environment (Keller, 1970). Conversely, detrital kaolinite introduced into marine waters may combine with $\mathrm{K}^{+}$and evolve toward an illite (Grim and others, 1949; Kulbicki and Millot, 1963). Theoretically, kaolinite could be created in a potassiumdeficient marine environment. However, that would be a very rare situation. This $\mathrm{K}^{+}$preference is one reason for the use of the presence of kaolinite in a rock as a demarcation line between marine and continental facies, as even detrital kaolinite is usually not transported very far into the marine environment, but flocculates and settles out upon contact with saline waters (Keller, 1970; Grim and others, 1949; Dunoyer de Segonzac, 1969; Parham, 1966).

The stability range of kaolinite relative to temperature is highly variable. Data compiled by Dunoyer de Segonzac
(1969) indicate stability to $190^{\circ} \mathrm{C}$. However, the properly constituted circulating geochemical solutions can destroy kaolinite at $80^{\circ} \mathrm{C}$. The phase diagrams of Garrels and Christ (1965) were drawn for $25^{\circ} \mathrm{C}$. Velde (1977a) synthesized kaolinite at $300^{\circ} \mathrm{C}$. It is stable in seawater to $100^{\circ} \mathrm{C}$, according to work done by Hemley (1959). The majority of the data would indicate a low stability temperature, one compatible with sedimentary processes, and one that suggests shallow burial.

In the interpretation of the origins of the Supai Group, kaolinite will be treated as an authigenic clay mineral formed in a continental environment. This conclusion is based on mineralogic, petrographic, lithologic, and paleogeographic criteria.

The SEM photograph shown in figure O10 is an exceptionally good illustration of various mineralogic, authigenic parameters. The kaolinite appears to consist of welldeveloped, pseudo-hexagonal plates stacked face to face along the $c$ axis. These "books" are randomly oriented 
relative to each other (Wilson and Pittman, 1977). Some of the flakes and books show grooves or notches, which according to Mansfield and Bailey (1972) may be indicators of twinning. Additional criteria include helical growth patterns and serrated edges listed by Bohor and Hughes (1971). EDAX spectra for the sample shown in figure O10 indicate high silica and aluminum with minor potassium and calcium.

Petrographic evidence for a possible authigenic origin is shown in figure O11, which is a photomicrograph of a potassium feldspar grain being altered to kaolinite.

From figure $\mathrm{O6}$, it becomes apparent that kaolinite in the Supai favors rocks of continental origins. Among the proposed authigenic clay species present, kaolinite is the dominant clay in the sandstones, siltstones, mudstones, and conglomerates-the most permeable and therefore most leached rock types. Its minor associations with carbonate rocks can be accounted for by local sand, silt, and mud facies within limestones and dolostones, and by transport as detritus into the fringes of the sea. Paleogeographically, kaolinite is almost exclusively confined to continental facies and is therefore useful in delineating marine from continental environments. Kaolinite is best developed in the Esplanade Sandstone (fig. O15) and in the Manakacha Formation (fig. O13), and is consistently present in the Wescogame Formation (O14). The distribution of kaolinite in the Watahomigi Formation (fig. O12) best demonstrates its nonassociation with corrensite.

The above criteria can, admittedly, also be convincingly applied to a diagenetic origin for this clay species. Whether kaolinite was formed at the time of the deposition of the Supai or during subsequent eons cannot unquestionably be determined; however, the mineral was formed in place, it was not transported from an outside source, and as such is a valid indicator of continental facies.

\section{GEOGRAPHIC DISTRIBUTION AND POSSIBLE RELATION TO DEPOSITIONAL ENVIRONMENT}

The generalized paleoenvironment of a facies can be briefly sketched from the distribution of the authigenic clays and possibly also from some of the diagenetic clay species contained in the rocks. With only limited exceptions, the hypothesized authigenic clay minerals of the Supai occur in compatible lithologies. Kaolinite seems to be most abundant in the muds, sands, and silts of continental environments. Illite and most of the chlorite occur in the marine carbonate rocks. Corrensite occurs in the more restricted nearshore carbonate and calcareous mud

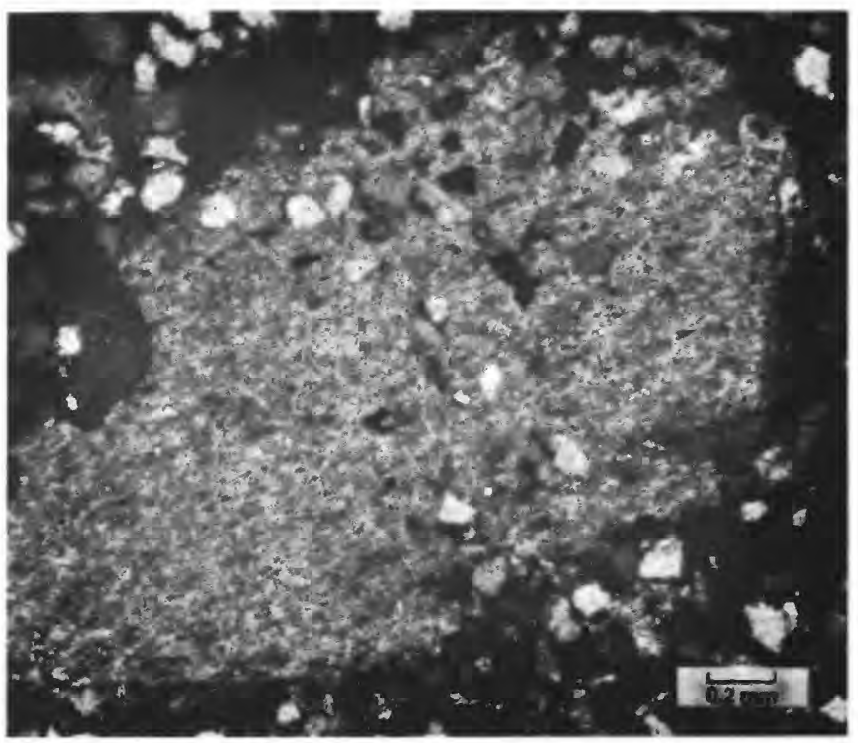

FIGURE O11.- Photomicrograph of a potassium feldspar grain being altered to kaolinite.

facies and is also associated with the gypsum facies. However, the random mixed-layer (illite-smectite) phases and the mixed-layer (illite-smectite) clays appear in all the rock types, which suggests either a more complex history of development or a detrital origin, and possibly both.

A general trend occurs with the random mixed-layers for the illite phase to dominate or to show better development in the more extensive marine lithologies to the west, whereas the structure of the eastern clays is less ordered and the peak definition is poorer. This determination commonly is very subtle and the differentiation with depth does not seem everywhere to prevail.

In figures $\mathrm{O} 16$ and $\mathrm{O} 19$, each formation of the Supai Group has been divided into the topographically defined slope and cliff units. Clay minerals in each unit have been summarized and plotted on a map of the Grand Canyon area.

Figures $\mathrm{O} 12-\mathrm{O} 15$ show rock types and associated clay minerals in three-dimensional color fence diagrams.

Each formation in the Supai Group will be individually discussed in the following sections relative to the clay types present, their geographic and lithologic distribution, and their possible relationships to the depositional environment.

\section{Watahomigi Formation}

Figure $\mathrm{O} 16 \mathrm{~A}$ shows the lateral distribution of clay minerals in the lower slope unit of the Watahomigi. The illites, chlorites, and corrensites are evidence that a marine environment prevailed in the western half of the area during Morrowan time. There may have been a shallow, 
warm, quiet sea with impounded-but not hypersalineevaporite basins, lagoons, ponds, or restricted embayments. Water bodies were cut off from freshening influxes sufficiently to concentrate the seawater with some salts.

The occurrence of corrensite as far east as Grandview Trail section (no. 6), and of illite directly to the north along Kaibab Trail, north, section (no. 8), but with kaolinites between, suggests that part of the sea extended far eastward. The sea possibly ended or was restricted at the Grandview area, allowing the corrensite to form. The intermittent distribution of continental type clay (kaolinite) and marine clays (illite, chlorite, corrensite) indicate that the facies intertongue and that a transitional land-sea interface existed in this area. The kaolinite may delineate a delta.

The random mixed-layer clays of central and western Grand Canyon (fig. O16) show a dominantly illitic character. These clays were subjected to seawater for a sufficiently long time to fix the requisite potassium that upgrades their structure toward a marine illite. The somewhat incongruous combination of kaolinite, chlorite, montmorillonite, and random mixed-layer clay at Marble Canyon section (no. 3) and at Twentynine Mile Canyon section (no. 2) are probably the result of detrital clays in the conglomerate. The chlorite may result from an isolated, marginal, marine pool.

$\mathrm{O} 16 \mathrm{~B}$ shows that the upper slope unit has a distribution of clay minerals similar to that of the lower slope. The sample distribution, however, is not as well placed for purposes of interpretation as is that of the lower slope. The main sea boundary was about the same. Silt and mud may have advanced farther west; at least, there is less evidence of a continuous sea embayment extending eastward. The isolated illite at Fishtail Canyon section (no. 12) is probably comparable to the chlorite at Twentynine Mile Canyon, for both seem to record a small marine embayment.

The general impression of the Watahomigi environment is that it consisted of quiet water, transitional marine embayments with fluctuating water levels, some of which became restricted and were cut off from freshening waters, possibly a river forming a delta with many tributaries that migrated across tidal flats to the open sea. The types of clay present and their distribution suggest such an interpretation.

\section{Manakacha Formation}

The clay mineralogy shows that in some respects the Manakacha environment was similar to that of the Watahomigi, but in others quite different. The land-sea interface is more clearly defined in the Manakacha because of less intertonguing of marine and continental facies (fig. O13). The greater amount of marine clays such as illite, chlorite, and corrensite (figs. O16A, B and O17) also indicates the continuing and dominant role of the saltwater facies in the
Manakacha. The clays show a less scattered pattern in their geographic distribution (figs. O16 and O13). In the northeast part of the Grand Canyon region, a marine environment persisted. Illite is abundant, and at Andrus Canyon section (no. 24) it is the only clay detected in the section. As 80 percent of the illite samples that occur in this formation are associated with limestone (fig. O18), an authigenic origin of the illite seems probable.

The common occurrence of corrensite, especially as represented in Toroweap Valley section (no. 21) and in Separation Canyon section (no. 34) seems to indicate, as in the Watahomigi, that at least those parts of the sea were quiet areas of low energy. Corrensite development continued in the Separation Canyon area throughout the time of carbonate and argillaceous mud deposition, suggesting that this area was possibly impounded for an appreciable length of time. Blue Mountain Canyon section (no. 19), directly east of Separation Canyon, also contains corrensite in a fairly thick limestone unit, substantiating the idea of a large, quiet, marine lagoon in that area. Although most of the corrensite occurs associated with limestone as figures $\mathrm{O} 18$ and $\mathrm{O} 13$ show, corrensite also occurs with calcareous silts in proximity to the carbonate rocks (figs. $\mathrm{O} 18$ and O13). Corrensite does not occur in the Manakacha east of National Canyon section (no. 15) and Tuckup Canyon section (no. 18), nor does it occur anywhere in proximity to the sand facies of this formation. As in the Watahomigi, the presence of corrensite appears to be useful as an indicator of depositional environment.

The random mixed-layer clays, when found in the carbonate, marine facies of the west, tend to favor the $10 \AA$ or illite phase of their development. This situation suggests a marine environment where potassium fixation was possibly upgrading less-ordered clays toward illite. Otherwise, the random mixed-layer clays do not show any useful distribution patterns relative to paleoenvironmental interpretations.

The Manakacha has more definite boundaries than does the Watahomigi between sea and land as indicated by the distribution of the authigenic clay types in the formation. Figure $\mathrm{O} 13$ seems to be a more realistic representation of the general configuration of the clay minerals in the Manakacha than does figure O16, in which time planes are lacking. A close examination of the illite associated with continental sediments at measured sections 2, 8, 9, and 6 shows that these illites are probably degraded, detrital micas and therefore not very useful as depositional environmental indicators.

The chlorite is also probably detrital; its occurrence is ubiquitous. There are too few chlorite samples to speculate on their origin.

Toward the east, Manakacha marine deposits grade into continental facies, which are probably delimited by the distribution of the kaolinite. Kaolinite is found mostly east 


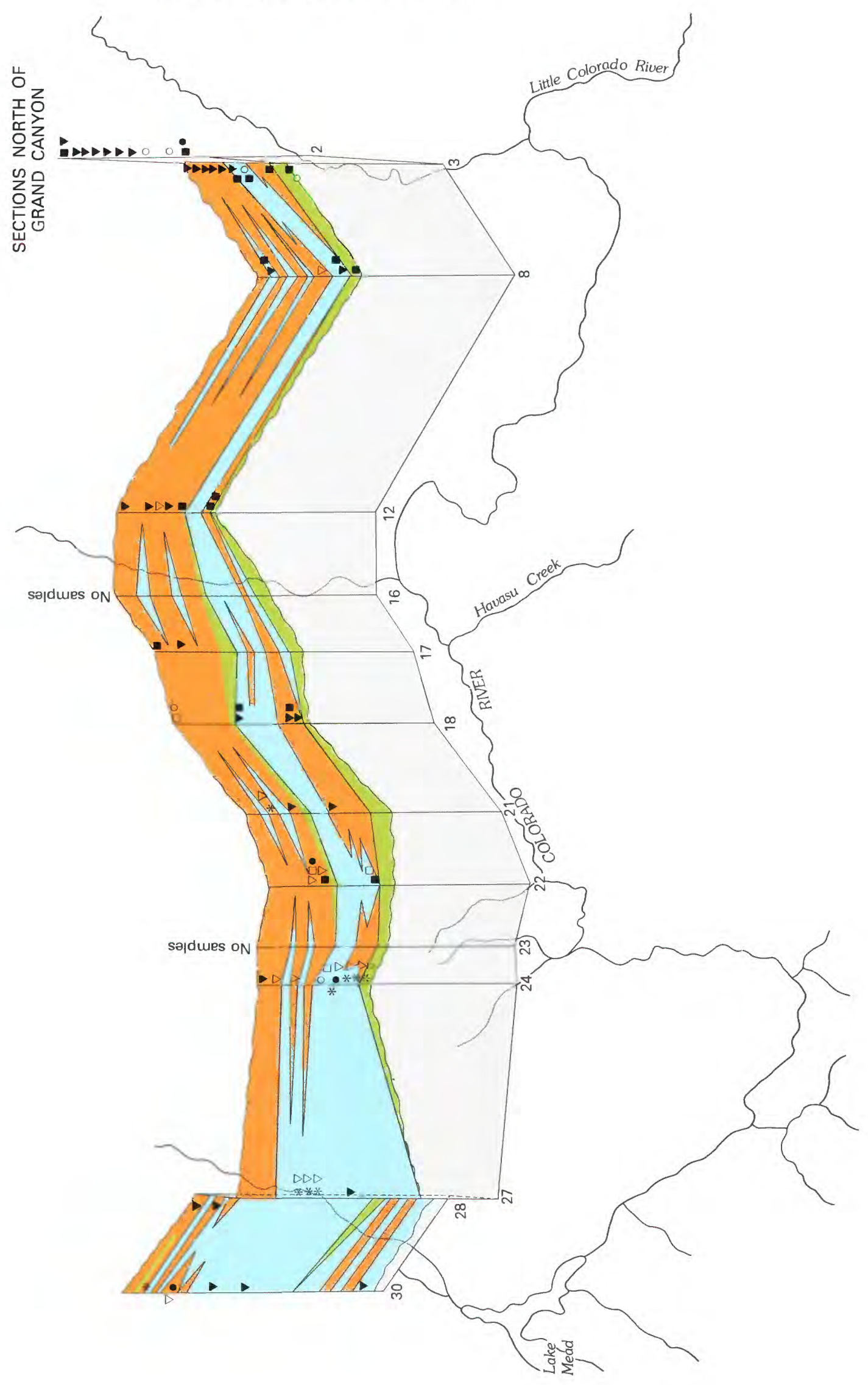




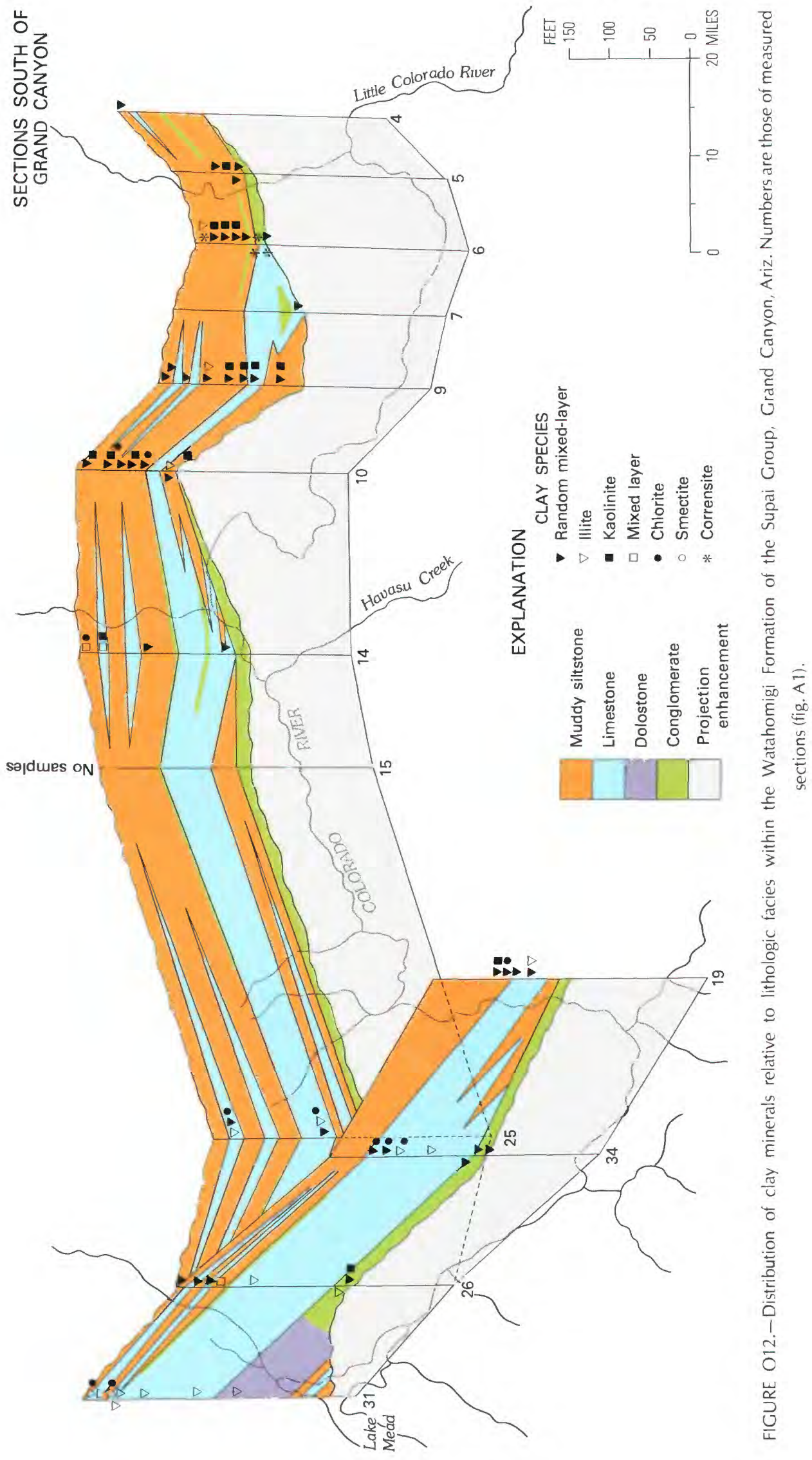




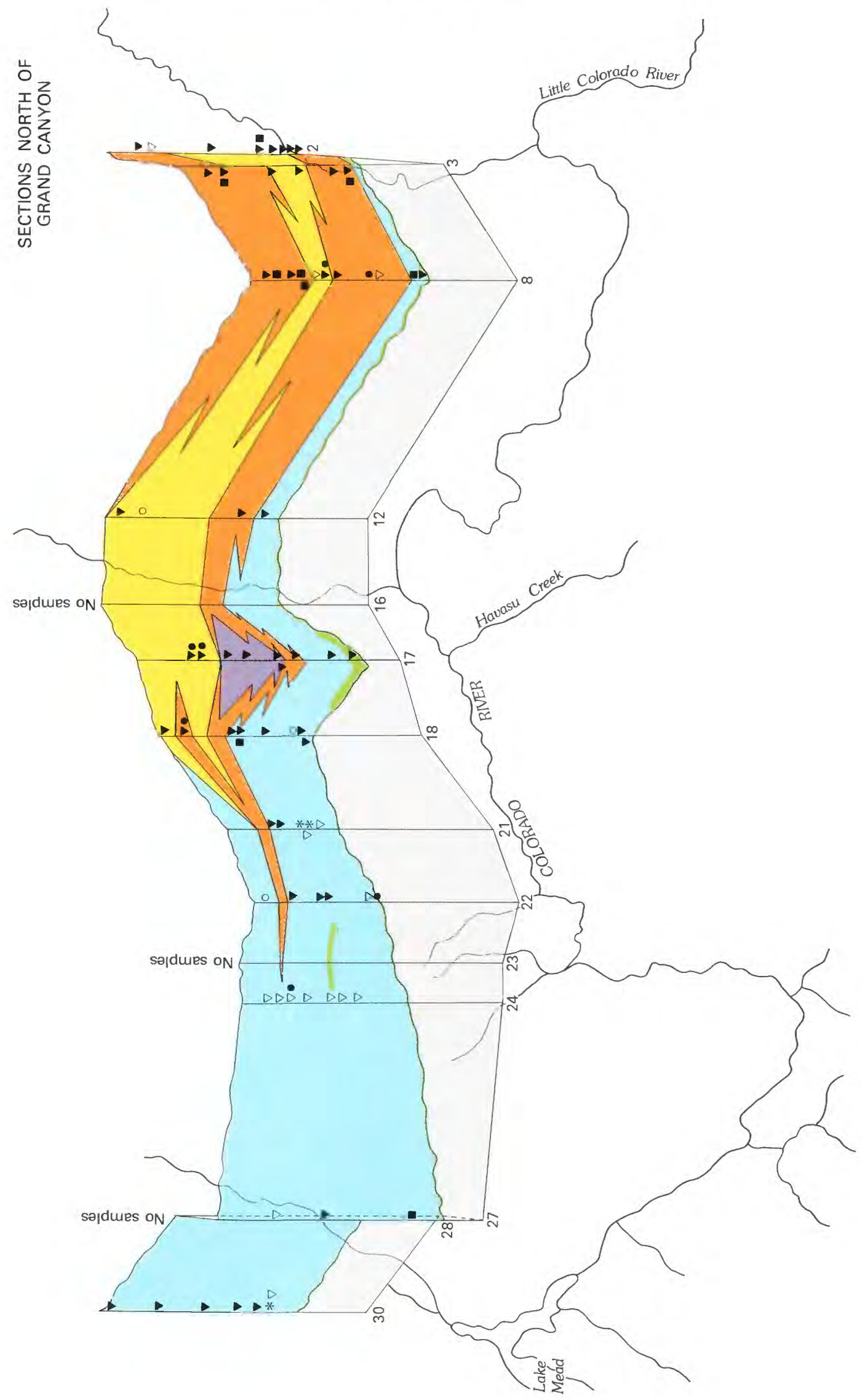


CLAY MINERALOGY

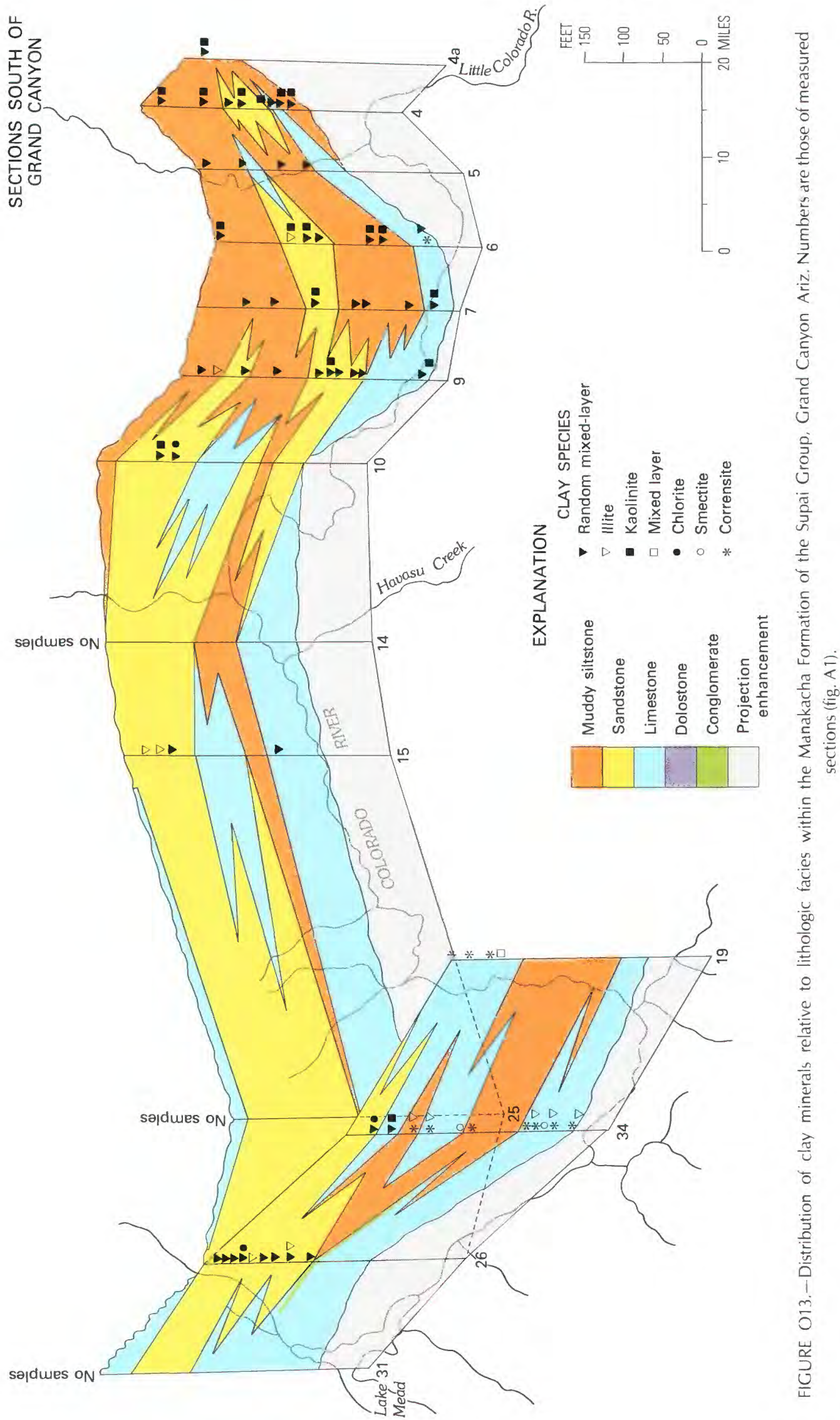




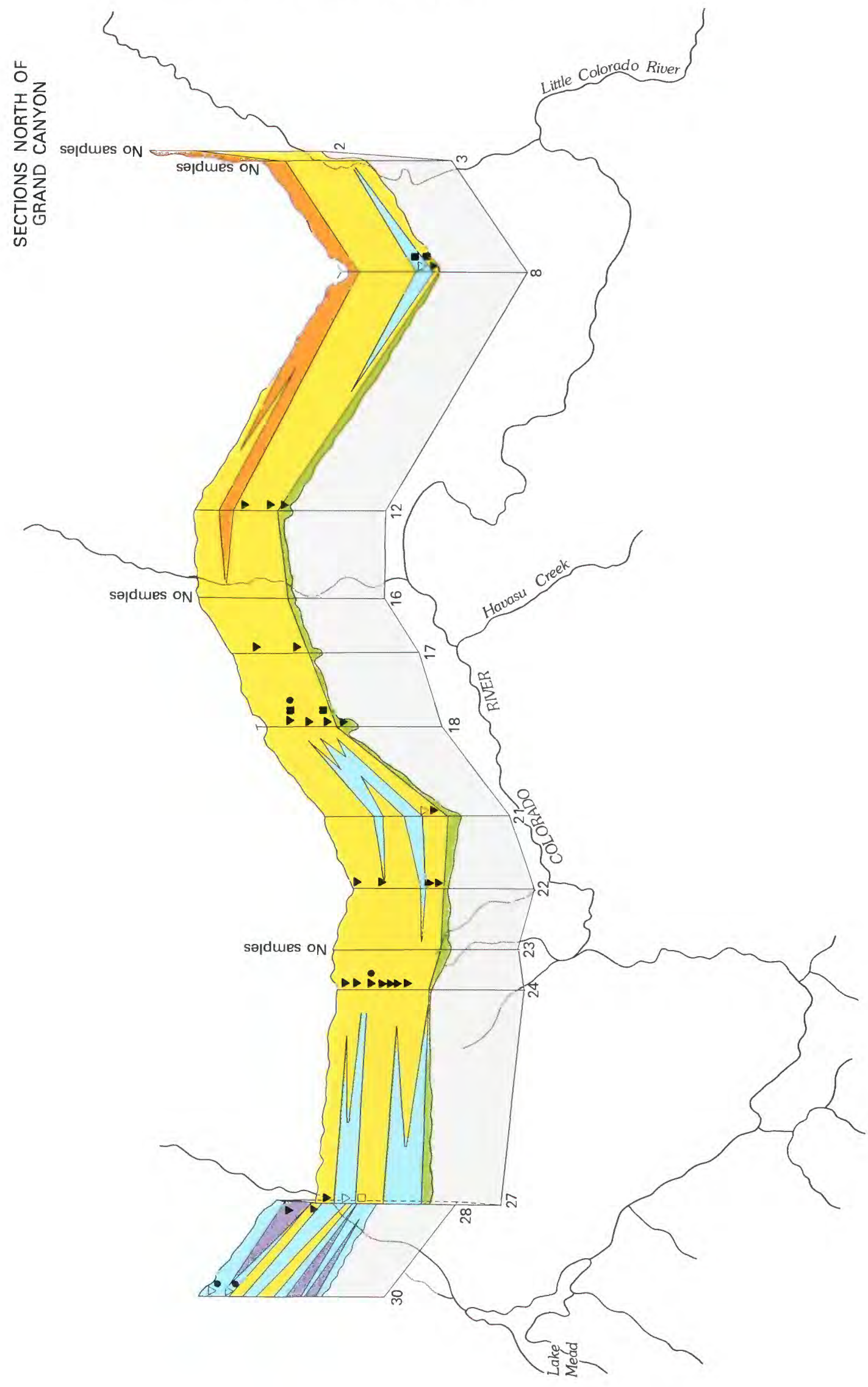


CLAY MINERALOGY

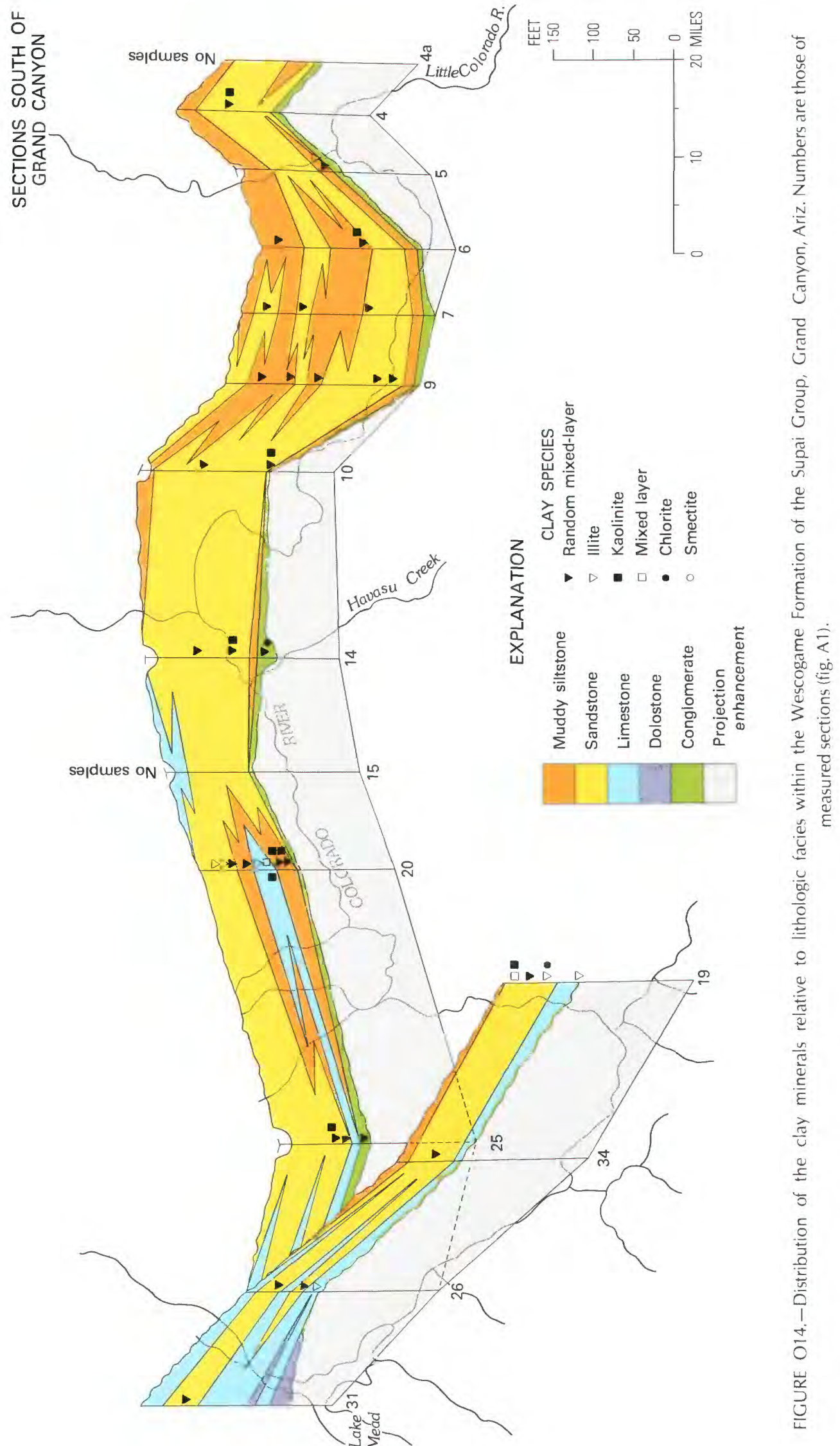



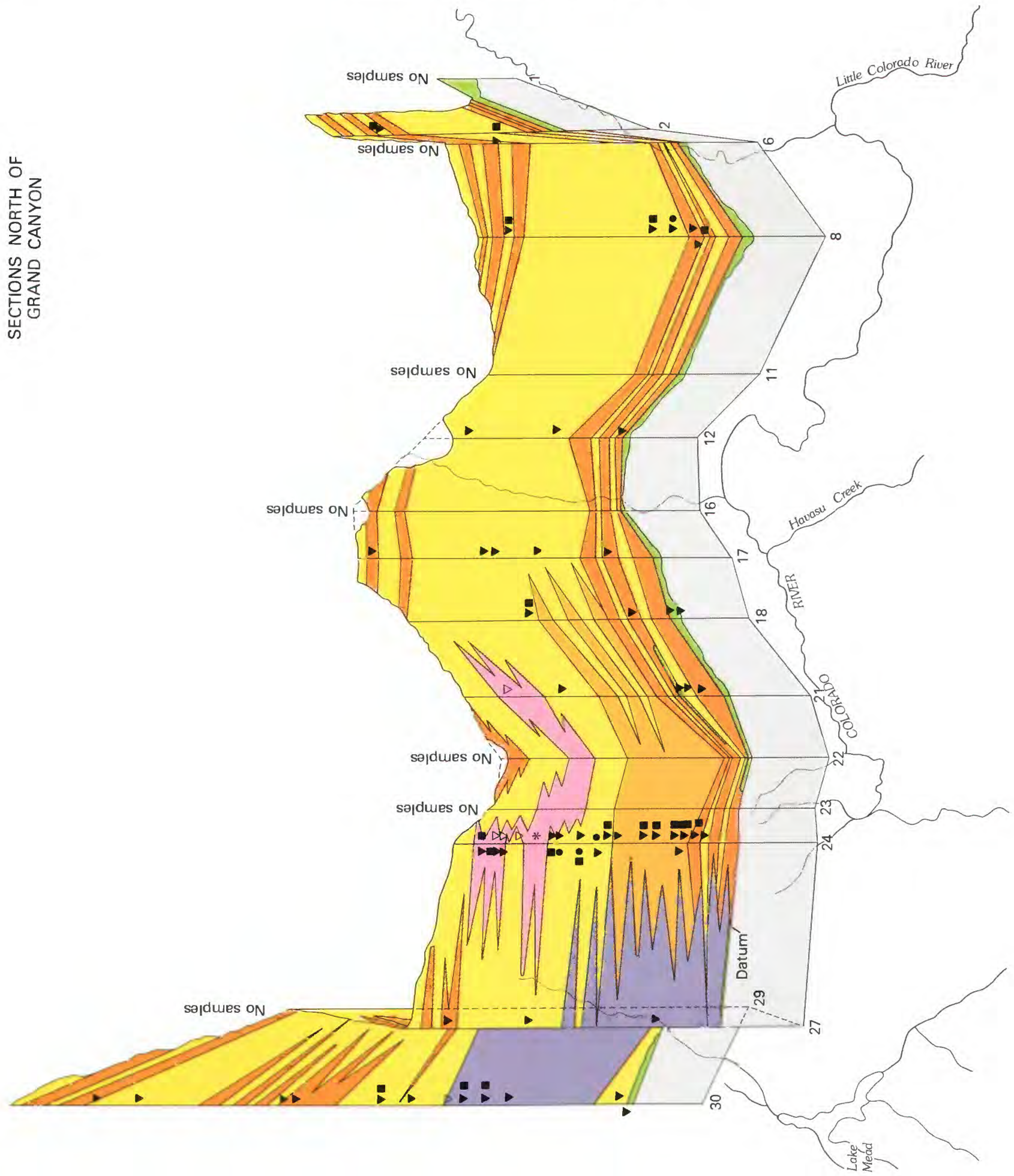


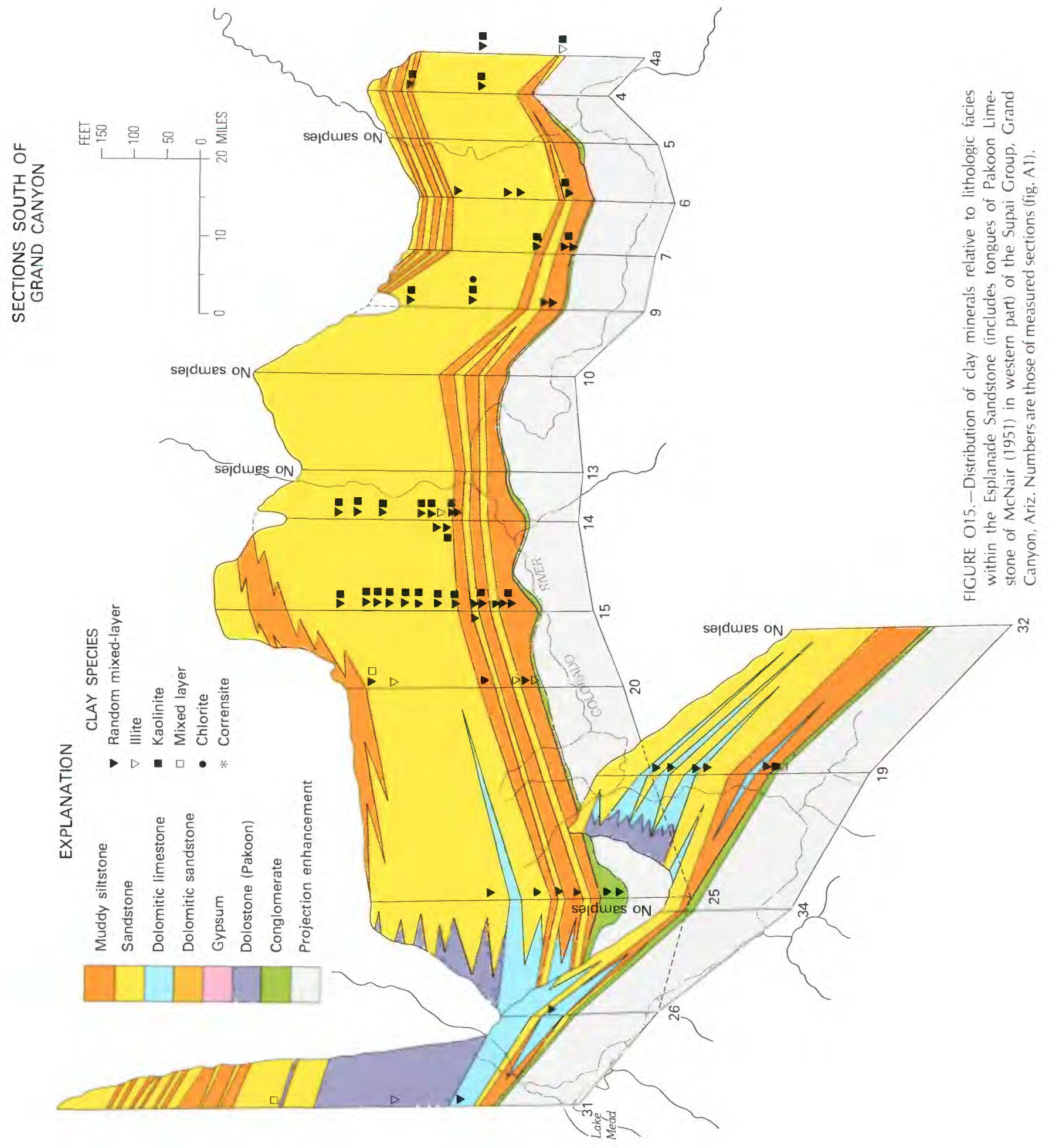



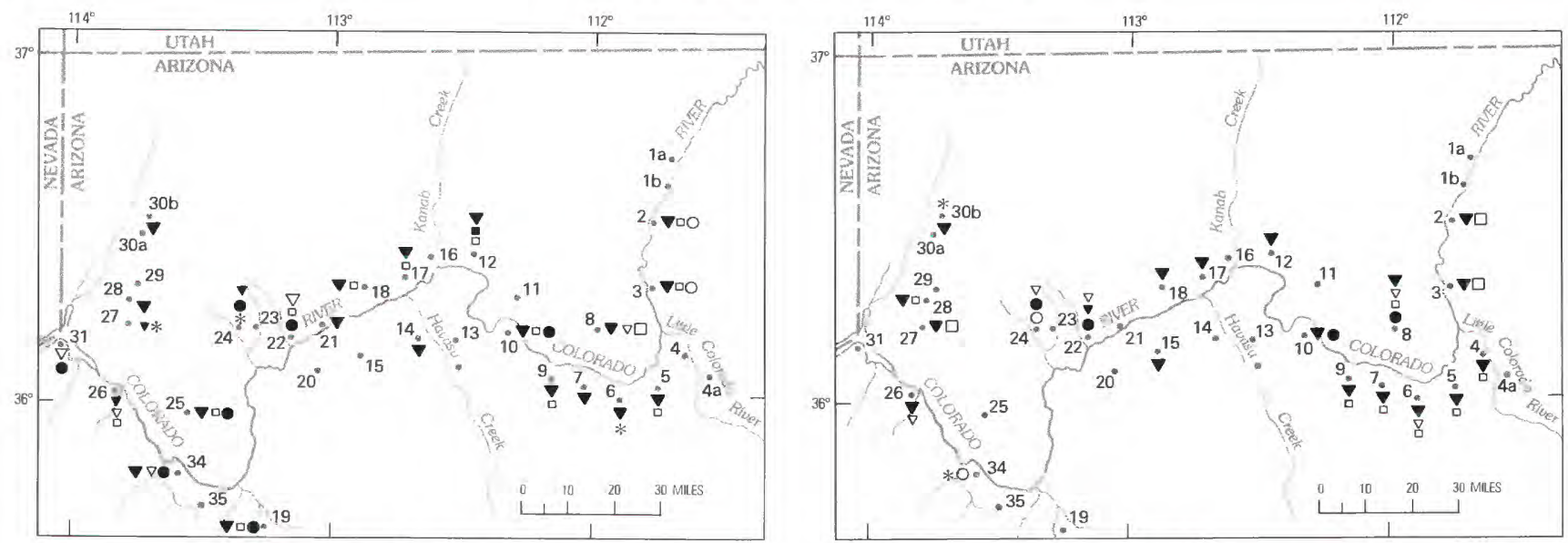

A
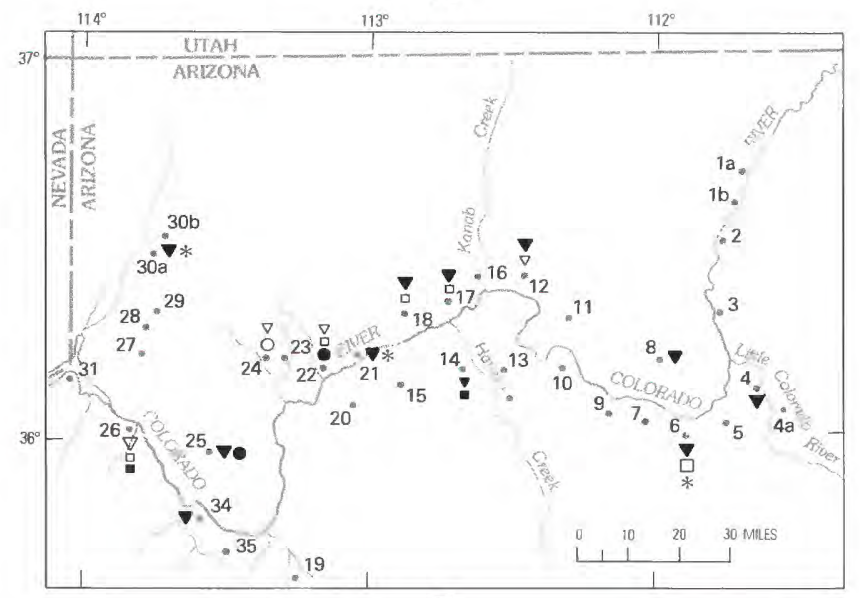

B

\section{CLAY SPECIES}

AMOUNT
Major Minor

$\checkmark \quad$ Random mixed-layer

$\begin{array}{lll}\nabla & \text { Illite }\end{array}$

$\square \quad$ Kaolinite

- Mixed layer

- Chlorite

- $\quad$ Smectite

* * Corrensite

FIGURE O16.- Horizontal distribution of clay minerals within the Watahomigi and Manakacha Formations of the Supai Group, Grand Canyon, Ariz. A, Lower slope unit, Watahomigi; B, upper slope unit. Watahomigi; C, cliff unit, Manakacha; D, slope unit, Manakacha. Numbered dots are localities of measured sections (fig. A1).

of Fishtail Canyon section (no. 12) on the north and Havasu Canyon section (no. 14) on the south. Its occurrence is sharply defined and should be an indicator of the transition zone between marine and freshwater environments. The kaolinite distribution pattern is clearly shown on both the vertical (fig. O13) and horizontal (fig. O16) illustrations. Kaolinite appears to slightly favor the silts and muds over the sands (fig. O18). The broad vertical distribution (fig. O16) of the kaolinite strongly suggests the terminus of a river delta outlining zones where a delta meets the sea and freshwater mixes with seawater. The authigenic origin of this clay is suggested by its restriction primarily to the continental facies of the Manakacha.

\section{Wescogame Formation}

The Wescogame Formation has not been as thoroughly analyzed for clays as have the other three formations of the Supai Group. Speculations about the paleoenvironment of the Wescogame are not, therefore, as completely supported as are those of the other units.

Relatively few carbonate rocks occur in the Wescogame and, probably for this reason, little authigenic illite is present. The illite, with only a couple of exceptions that are probably of detrital origin, occurs in the limestone (fig. O18). Some of the illite is accompanied by chlorite.

In the Wescogame, marine clays are largely restricted to 

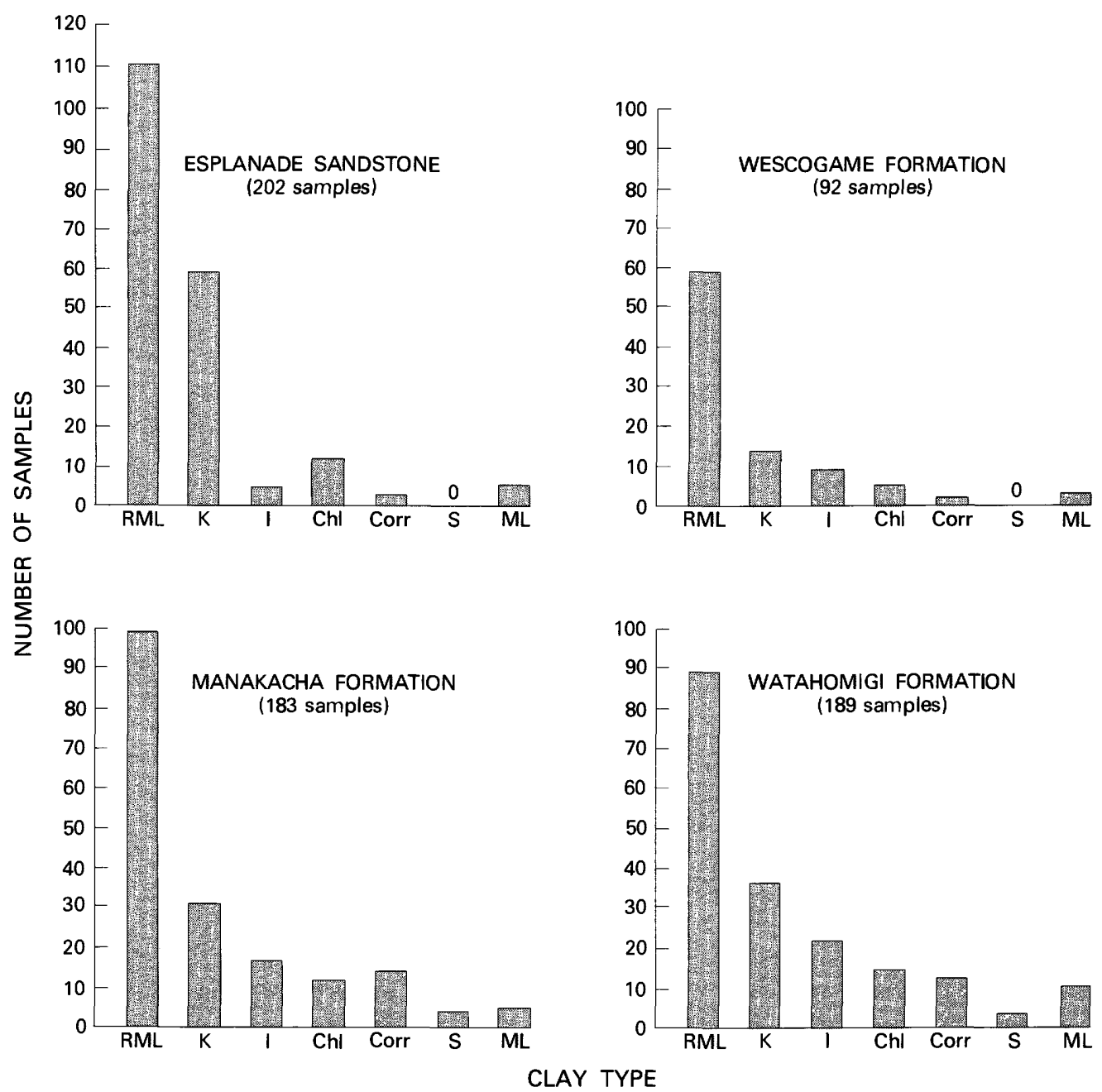

FIGURE O17.-Distribution of clay minerals by numerical count within each formation of the Supai Group, Grand Canyon, Ariz. Esplanade Sandstone includes tongues of Pakoon Limestone (McNair, 1951) in western Grand Canyon. Clay types are: RML, random mixed-layer; K, kaolinite; I, illite; Chl; chlorite; Corr, corrensite; S, smectite; $\mathbf{M L}$, mixed-layer.

the far western part of the area (fig. O14). Illite occurrences to the east of Andrus Canyon section (no. 24) on the north side of the embayment, are confined to small areas that seem to have developed in lagoons, cut off from the sea by great sand bodies. One probable small lagoon, centered near Kaibab Trail, north, section (no. 8), may have had minor amounts of corrensite associated with the illite. The sample is poorly defined, but such a restricted marine environment might have been favorable for corrensite production. On the south side of the embayment, deposits in one slender arm of the sea that extended landward contain some illite, considered to be of marine origin.

Chlorite in the Wescogame may be mostly detrital. Figure $\mathrm{O} 17$ shows only five chlorite-bearing samples. Two of these were in marine associations with illite; the others were in sands and silts. Therefore, chlorite in this formation does not seem to be very useful in reconstructing the paleoenvironment.
Kaolinite in the Wescogame (fig. O17), as in the other formations, is the second most abundant clay mineral. It occurs exclusively among sandstones and siltstones (fig. O18) and, therefore, is restricted to the eastern two-thirds of the Grand Canyon area. It is mostly in sandstones and those conglomerates with less than 15 percent of the analyzed samples of silt size. However, this may be somewhat misleading as less silts than sands were analyzed, and less samples in general were analyzed in this formation. The existence of kaolinite within the sandstone suggests that it contains or contained sufficient feldspar to produce the kaolinite and that it was permeable enough to allow leaching waters to percolate freely throughout.

The random mixed-layer clays, like the kaolinites, are commonly associated with the sandstones and very few occur in the carbonate rocks. The depositional environment in which these potentially detrital clays accumulated possibly was shallow water and nearshore, and their agent 


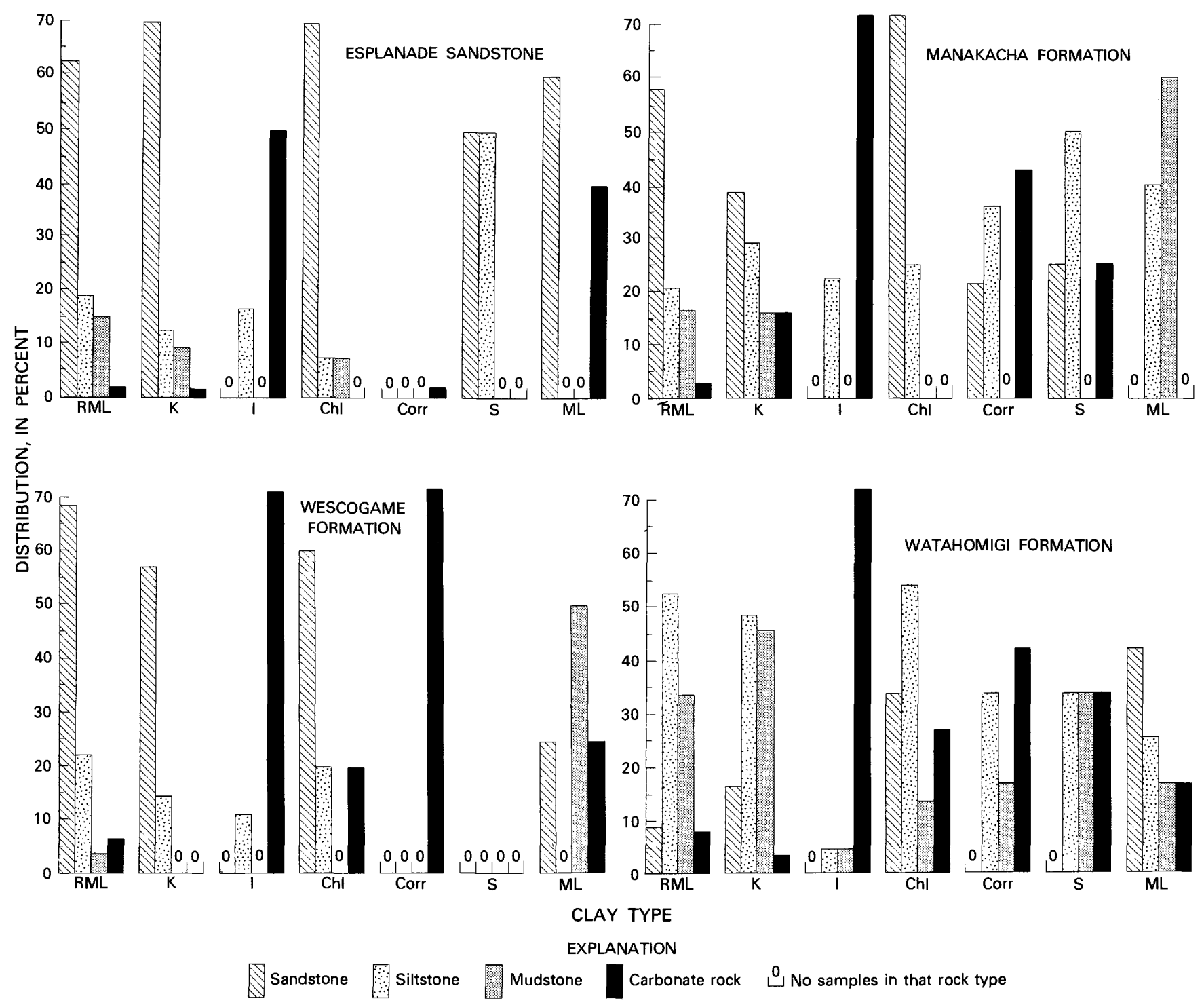

FIGURE O18.-Percentage of distribution of clay minerals within each formation of the Supai Group and relative to rock type. Esplanade Sandstone includes of Pakoon Limestone (McNair, 1951) in western Grand Canyon. RML, random mixed-layer clays; K, kaolinite; I, illite; Chl, chlorite; Corr, corrensite; $\mathbf{S}$, smectite; $\mathbf{M L}$, mixed-layer clays.

of transport did not seem able to carry them far from the shoreline.

With the limited number of samples available from the Wescogame, the paleoenvironment cannot be reconstructed in any detail. Illite deposits shown in figure O14 probably represent the locations of isolated lagoons and the illite-kaolinite interface in figure O14. Although the sea again covered extensive areas during Wescogame deposition, the small number of marine clays (fig. O17) indicates that it was considerably smaller than during deposition of the Manakacha and Watahomigi. A continental environment was increasingly more widespread in the region than before.

\section{Esplanade Sandstone and Pakoon Limestone}

The Esplanade Sandstone is very different from the other three formations in the Supai Group. Figures O15 and $\mathrm{O} 18$ indicate mostly continental facies. Figure $\mathrm{O} 17$ further illustrates this relationship by pointing out the dominance of continental clay types. In western Grand Canyon, tongues of the Pakoon Limestone (McNair, 1951) replace the lower part of the Esplanade. These tongues are predominantly dolostone, indicating a restricted marine environment. 


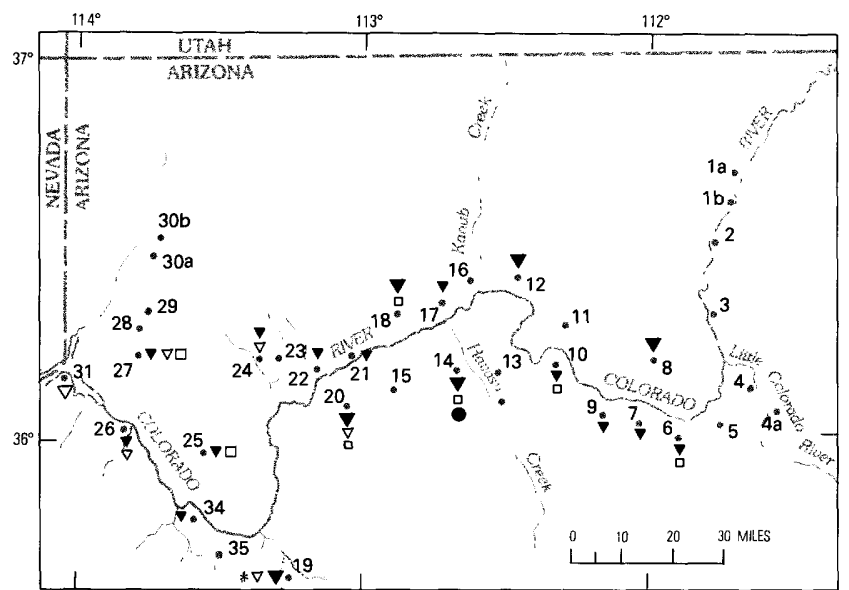

$A$

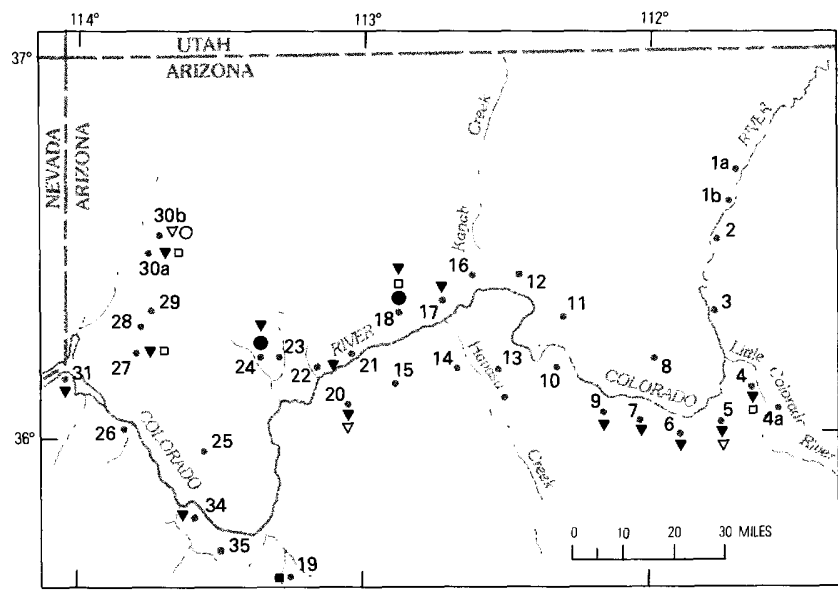

B

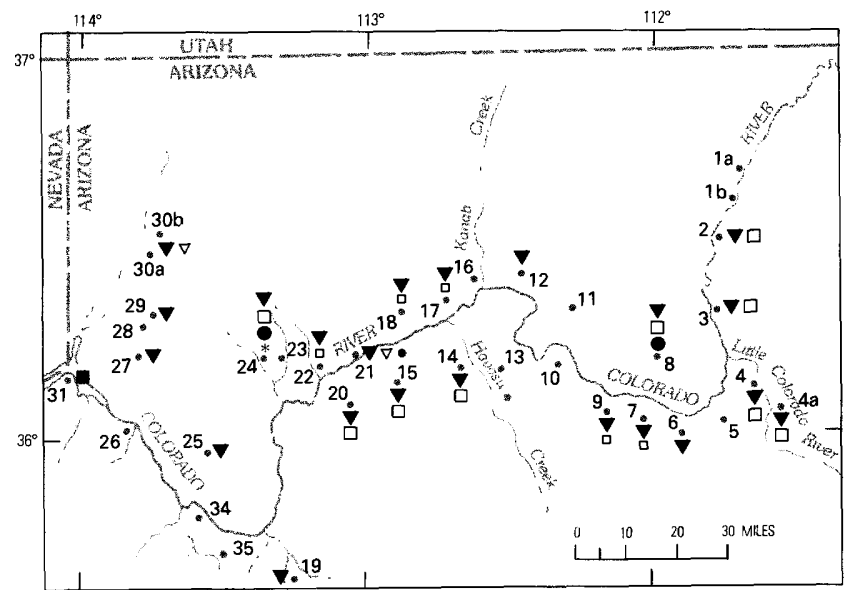

C

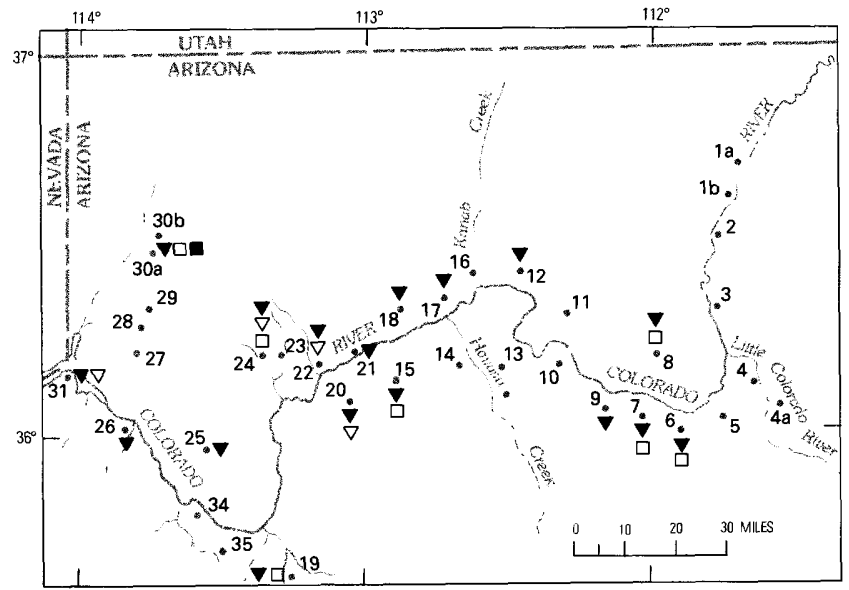

D

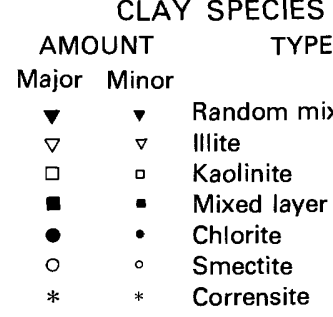

FIGURE O19.- Horizontal distribution of clay minerals within the Wescogame Formation and Esplanade Sandstone of the Supai Group, Grand Canyon, Ariz. A, Cliff unit, Wescogame; $B$, slope unit, Wescogame; $C$, main cliff unit, Esplanade; $D$, slope unit, Esplanade (includes tongues of Pakoon Limestone of McNair, 1951, in western Grand Canyon). Numbered dots are localities of measured sections (fig. A1).

The small amount of illite occurring in this interval (fig. O17) is associated predominantly with carbonate Pakoon tongues (fig. O18). Authigenic illites are in dolostones of the Pakoon of Hidden Canyon (no. 30) and Iceberg Canyon (no. 31) measured sections in the far west. Also the illites are associated with the Esplanade gypsum beds of Andrus Canyon section (no. 24). In brief, all illites occur west of Toroweap Valley section (no. 21) (figs. O15 and O19). Although figure O15 seems to indicate that the illite is associated with sandstones, it actually occurs in calcareous and dolomitic lenses within the sandstones. Samples identified as illite from the siltstones in figure O18 likewise are probably not authigenic illite but detrital, degraded micas. This distribution pattern seems to put a strictly marine environment (Pakoon) largely beyond the area of study, and the only marinelike facies are those of restricted, quiet waters of evaporitic chemical-precipitate basins and embayments that extend from these basins into continental facies of the Esplanade Sandstone.

Andrus Canyon section (no. 24) contains sparse deposits of corrensite in a gypsum facies of the cliff-slope unit of the Esplanade. This is compatible with the magnesiumenriched environment of the evaporite basin of gypsum deposition. 
Chlorite is more common than illite in the Esplanade Sandstone (fig. O17). Its distribution (fig. O18) is chiefly in sandstone, siltstone, and mud rocks believed to be continental. It is associated with both random mixed-layer and kaolinite clay types, but not with illite (fig. O15). Chlorite is confined to the cliff-slope unit of the Esplanade (fig. O19) and no definitive pattern is recognized in its lateral distribution. These data seem to indicate that chlorite of the Esplanade may be detrital in origin.

Aside from random mixed-layer clays, kaolinite is the most abundant clay mineral of the Esplanade (fig. O17). It occurs primarily in the sandstones, less than 25 percent is in mudstone and siltstone, and about 1 percent is in carbonate rocks (fig. O18). On the north side of the Grand Canyon, kaolinite occurs throughout the region, but it is most abundant east of Andrus Canyon section (no. 24). Kaolinite occurs primarily in the sandstone facies; it is associated with random mixed-layer clays and, notably at Andrus Canyon, has probable detrital chlorite also associated with it. To the south, except for a single sample in a conglomerate at Blue Mountain Canyon section (no. 19), kaolinite is found only east of Prospect Valley section (no. 20). Nearly all samples are associated with sandstones, two exceptions being in siltstone. Chlorite associated with kaolinite has been found only at Hermit Trail section (no. 9), on the south side of Grand Canyon.

The abundance of kaolinite in the Esplanade Sandstone assists in reconstruction of the history of this formation. Very little kaolinite is found to the west of measured sections 20 and 24 (Prospect Valley and Andrus Canyon), so these sections mark the easternmost extent of the marine facies and the presence of kaolinite is considered as an indicator of the continental-marine interface. Kaolinite implies an oxidizing environment with associated $\mathrm{Fe}_{2} \mathrm{O}_{3}$ (as hematite) as evidence. Most of the samples examined contain accessory hematite. The feldspar-bearing, more continental rocks, especially those with potassium feldspar, apparently favored kaolinite formation. The sands must have been well drained and had moderate to high permeability for the kaolinite to form. The environment must have been acidic or well leached because the cations were efficiently removed and bordering areas of moderate relief may have helped accelerate the leaching processes. Because this clay mineral does not form in areas of enrichment and poor drainage, the kaolinite probably did not concentrate in basins.

The Esplanade Sandstone of the Grand Canyon consists mostly of continental sediments. The lower part of the Esplanade in western Grand Canyon is replaced by marine dolostone of the Pakoon. Later, the aridity was such that gypsum formed in the upper part of the Esplanade Sandstone. A small source area to the south may have provided the limited amount of detrital chlorite present in some sections of eastern Grand Canyon (Kaibab Trail, north, meas- ured section 8, and Hermit Trail, measured section 9). Most of the Esplanade seems to have been laid down in an oxidizing environment, probably warm and fairly dry, but with sufficient drainage to decompose the feldspars and to carry away the leached material.

\section{SUMMARY}

Considering the interrelationships illustrated in figure 08 and integrating these with the paleogeographical ones of figures O12-O15, some of the transformations suggested by Lucas and Ataman (1968), Millot, Lucas, and Wey (1963), and ably summarized by Dunoyer de Segonzac (1969) seem to find reaffirmation in the Supai Group. These theories of authigenic formation, of aggradation from preexisting detrital materials and unstable clay phases seem to offer the simplest explanation for the origins of the Supai clays.

The abundance of random mixed-layer clays in various stages throughout the Supai would seem to illustrate that the aggradation processes of Lucas and Ataman (1968), among others, were in operation on the detrital, degraded, and micaceous materials, which were obviously abundant throughout the Supai. In the marine environment these are upgraded through random mixed-layers to illites or corrensites to chlorites, depending on the available plentiful cation. In the continental environment with minor circulating waters, the aggradation processes have been considerably less rapid, resulting in only a random mixedlayer configuration; at least some of the kaolinite has been created through feldspar weathering.

The marine environment seems to have been more active than the continental relative to clay authigenesis. The presence of the somewhat rare mineral corrensite has been of great assistance in the reconstruction of possible depositional conditions, because its stability field and preferred environment are fairly limited and can be defined to some degree.

In general, the hypothesized authigenic clays-illite, chlorite, corrensite, and kaolinite-favor compatible relationships among themselves relative to the rocks within which they occur, and with other environmental data presented within other chapters of the present Professional Paper. Therefore, they are considered as valid indicators of original depositional environments within the various formations. The Watahomigi Formation, with its preponderance of marine clays, especially corrensite, is interpreted to be a result of a quiet marine and transitional marine environment with emphasis on restricted, lowenergy conditions. The Manakacha was probably also largely marine with its illite, chlorite, and corrensite clays prominent to the west. However, a definite continental environment also is present in the Manakacha and is 
delineated by the kaolinite distribution pattern. With the Wescogame, continental facies start to dominate in the embayment. Finally, a progression from marine to continental is completed, as shown by the continental kaolinite of the Esplanade Sandstone. In this formation, the continental clays far outnumber the marine species. Even though the dominant clay type-random mixed-layer (illite-smectite) - of the Supai Group is probably a detrital interloper, even this phase has been significantly altered with time. There are still sufficient authigenic phases to reconstruct, admittedly in a generalized way, a concept of the depositional environments 300 million years in the past.

\section{REFERENCES CITED}

Alietti, Andrea, 1958, Some interstratified clay minerals of the Taro Valley: Clay Minerals Bulletin, v. 3, no. 19, p. 207-211.

Almon, W. R., Fullerton, L. B., and Davies, D. K., 1976, Pore space reduction in Cretaceous sandstones through chemical precipitation of clay minerals: Journal of Sedimentary Petrology, v. 46, no. 1 , p. 89-96.

American Geological Institute, 1972, Glossary of Geology: American Geological Institute, Washington, D.C. (4th printing, 1977), 805 p.

Blatter, C. L., Roberson, H. E., and Thompson, G. R., 1973, Regularly interstratified chlorite-dioctahedral smectite in dike intruded shales, Montana: Clays and Clay Minerals, v. 21, p. 207-212.

Bodine, M. W., Jr., 1971, Alteration of basic volcanic rocks by marine hypersaline brines, Hallstatt, Upper Austria: Geological Society of America Abstracts with Programs, v. 3, no. 7, p. 509.

Bohor, B. F., and Hughes, R. E., 1971, Scanning electron microscopy of clays and clay minerals: Clays and Clay Minerals, v. 19, p. 49-54.

Bradley, W. F., and Weaver, C. E., 1956, A regularly interstratified chlorite-vermiculite clay mineral: American Mineralogist, v. 41, p. 497-504.

Brooks, R. A., and Ferrell, R. E., Jr., 1970, The lateral distribution of clay minerals in Lakes Pontchartrain and Maurepas, Louisiana: Journal of Sedimentary Petrology, v. 40, no. 3, p. 855-863.

Burst, J. F., Jr., 1959, Postdiagenetic clay mineral environmental relationships in the Gulf Coast Eocene, in A. Swineford, ed., Clays and clay minerals, National conference on clays and clay minerals, 6th, Berkeley, Calif., 1957, Proceedings: London, New York, Pergamon Press, International Series of Monographs on Earth Sciences, v. 2 , p. 327-341.

1969, Diagenesis of Gulf Coast clayey sediments and its possible relation to petroleum migration: American Association of Petroleum Geologists Bulletin, v. 53, no. 1, p. 73-93.

Caillére, S., Hènin, S., and Esquevin, J., 1953, Recherches sur la synthèse des minéraux argileux: Bulletin de la Société Française de Minéralogie et de Cristallographie, v. 76, p. 300-314.

Carroll, Dorothy, 1970, Clay minerals; A guide to their X-ray identification: Geological Society of America Special Paper 126, 80 p.

DeKimpe, C., Gastuche, M. C., and Brindley, G. W., 1961, Ionic coordination in alumino-silicic gels in relation to clay mineral formation: American Mineralogist, v. 46, p. 1370-1381.

Dunoyer de Segonzac, G., 1969, Les minéraux argileux dans la diagenese Passage au metamorphisme: Mémoires du Service de la Carte Géologique D' Alsace et de Lorraine, v. 29, 320 p.

1970, The transformation of clay minerals during diagenesis and low-grade metamorphism-A review: Sedimentology, v. 15, p. 281-346.
Earley, J. W., Brindley, G. W., McVeagh, W. J., and Heuvel, R. C. Vanden, 1956, A regularly interstratified montmorillonite-chlorite: American Mineralogist, v. 41, p. 258-267.

Eberl, Dennis, 1978, The reaction of montmorillonite to mixed-layer clay; the effect of interlayer alkali and alkaline earth cations: Geochemica et Cosmochimica Acta, v. 42, p. 1-7.

Eberl, Dennis, and Hower, John, 1977, The hydrothermal transformation of sodium and potassium smectite into mixed layer clay: Clays and Clay Minerals, v. 25, p. 215-227.

Furbish, W. J., 1975, Corrensite of deuteric origin: American Mineralogist, v. 60, p. 928-930.

Garrels, R. M., and Christ, C. L., 1965, Solutions, minerals, and equilibria: San Francisco, Calif., Freeman, Cooper, and Company, 449 p.

Gaudette, H. E., Eades, J. L., and Grim, R. E., 1966, The nature of illite, in W. F. Bradley and S. W. Bailey, eds., Clays and clay minerals, National conference on clays and clay minerals, 13th, Madison, Wis., 1964, Proceedings: London, New York, Pergamon Press, International Series of Monographs on Earth Sciences, v. 25, p. 33-47.

Griffin, G. M., 1962, Regional clay-mineral facies-Products of weathering intensity and current distribution in the northeastern Gulf of Mexico: Geological Society of America Bulletin, v. 73, p. 737-768.

Grim, R. E., 1968, Clay mineralogy (2nd ed.): New York, McGraw-Hill, $596 \mathrm{p}$.

Grim, R. E., Dietz, R. S., and Bradley, W. F., 1949, Clay mineral composition of some sediments from the Pacific Ocean off the California coast and the Gulf of California: Geological Society of America Bulletin, v. 60 , p. 1785-1808.

Grim, R. E., Droste, J. B., and Bradley, W. F., 1959, A mixed-layer clay mineral associated with an evaporite, in A. Swineford, ed., Clays and clay minerals, v. 8, National conference on clays and clay minerals, 8th, Norman, Okla., 1959, Proceedings: London, New York, Pergamon Press, International Series of Monographs on Earth Sciences, v. 9, p. 228-236.

Harder, H., 1974, Illite mineral synthesis at surface temperatures: Chemical Geology, v. 14, 241-253.

Harvey, R. D., and Beck, C. W., 1960, Hydrothermal regularly interstratified chlorite-vermiculite and tobermorite in alteration zones at Goldfield, Nevada, in A. Swineford and P. C. Franks, eds., Clays and clay minerals, National conference on clays and clay minerals, 9th, Lafayette, Indiana, October 5-8, 1960, Proceedings: National Research Council and Purdue University, p. 343-353.

Hayes, J. B., 1970, Polytypism of chlorite in sedimentary rocks: Clays and Clay Minerals, v. 18, p. 285-306.

Heckroodt, R. O., and Roering, C., 1965, A high-aluminous chloriteswelling chlorite regular mixed-layer clay mineral: Clay Minerals, v. 6 , no. 2 , p. $83-89$.

Hemley, J. J., 1959, Some mineralogical equilibria in the system $\mathrm{K}_{2} \mathrm{O}$ $\mathrm{Al}_{2} \mathrm{O}_{3}-\mathrm{SiO}_{2}-\mathrm{H}_{2} \mathrm{O}$ : American Journal of Science, v. 257, p. 241-270.

Honeyborne, D. B., 1951, The clay minerals in the Keuper Marl: Clay Minerals Bulletin, v. 1, p. 150-155.

Hower, John, 1967, Order of mixed-layering in illite/montmorillonites, in S. W. Bailey, ed., Clays and clay minerals, Conference on clays and clay minerals, 15th, Pittsburgh, Pa., 1966, Proceedings: London, New York, Pergamon Press, International Series of Monographs on Earth Sciences, v. 27, p. 63-74.

Hower, John, Eslinger, E. V., Hower, M. E., and Perry, E. A., 1976 , Mechanism of burial metamorphism of argillaceous sediment; mineralogical and chemical evidence: Geological Society of America Bulletin, v. 87, p. 725-737.

Hower, John, and Mowatt, T. C., 1966, The mineralogy of illites and mixed-layer illite/montmorillonites: American Mineralogist, v. 51, p. 825-854.

Iijima, A., and Utada, M., 1972, A critical review on the occurrence of zeolites in sedimentary rocks in Japan: Japanese Journal of Geology and Geography, v. 42, p. 61-84. 
Jackson, M. L., 1974, Soil chemical analysis-Advanced course: 2nd edition, 9th printing, published by the author, Wisconsin University, Madison, Department of Soil Science, $895 \mathrm{p}$.

Johnson, L. J., 1964, Occurrence of regularly interstratified chloritevermiculite as a weathering product of chlorite in a soil: American Mineralogist, v. 49, p. 556-572.

Keller, W. D., 1964, Processes of origin and alteration of clay minerals, in Soil clay mineralogy-A symposium: Chapel Hill, N.C., North Carolina University Press, p. 3-76.

1970, Environmental aspects of clay minerals: Journal of Sedimentary Petrology, v. 40, no. 3, p. 788-813.

Kimbara, K., 1973, Clay minerals in the Miocene low-grade metamorphic rocks, Tanzawa Mountains, Kanagawa Prefecture, Central Japan: Japanese Association of Mineralogists, Petrologists, and Economic Geologists Journal, v. 68, p. 311-328.

Kimbara, K., and Sudo, T., 1973, Chloritic clay minerals in tuffaceous sandstone of the Miocene green tuff formation, Yamanaka district, Ishikawa Prefecture, Japan: Japanese Association of Mineralogists, Petrologists, and Economic Geologists Journal, v. 68, p. 246-258.

Kopp, O. C., and Fallis, S. M., 1974, Corrensite in the Wellington Formation, Lyons, Kansas: American Mineralogist, v. 59, p. 623-624.

Kotov, N. V., Lebedev, V. I., and Tarlakov, Yu.P., 1969, Mixed-layer phases; the products of dissociation of kaolinite and mettahalloysite during hydrothermal heating under pressure: Doklady Akad. Nauk SSSR, v. 191, p. 122-125.

Kulbicki, Georges, and Millot, Georges, 1963, Diagenesis of clays in sedimentary and petroliferous series: Clays and Clay Minerals, Monograph no. 12, Earth Science Series, p. 329-330.

Lippmann, Friedrich, 1954, Uber einen Keuperton von Zaisersweiher bei Maulbronn: Heidelberger Beitrage zur Mineralogie und Petrographie, v. 4 , p. $130-134$.

1956. Clay minerals from the Röt member of the Triassic near Göttingen, Germany: Journal of Sedimentary Petrology, v. 26, no. 2, p. 125-139.

1976, Corrensite, a swelling clay material and its influence on floor heave in tunnels in the Keuper Formation: International Association of Engineering Geology Bulletin, no. 13, p. 65-70.

Lucas, Jacques, 1962, The transformation of clay minerals during sedimentation-Study on Triassic clays [La transformation des minéraux argileux dans la sédimentation. Études sur les argiles du Trias]: Université de Strasbourg; Translation of Mémoires du service de la carte Géologique D' Alsace et de Lorraine; no. 23 [Translated from French], published by Israel Program for Scientific Translations, 203 p.

Lucas, Jacques, and Ataman, Gurol, 1968, Mineralogical and geochemical study of clay mineral transformations in the sedimentary Triassic Jura Basin (France): Clays and Clay Minerals, v. 16, p. 365-372.

McNair, A. H., 1951, Paleozoic stratigraphy of part of northwestern Arizona: American Association of Petroleum Geologists Bulletin, v. 35, no. 3, p. 503-541.

Mansfield, C. F., and Bailey, S. W., 1972, Twin and pseudotwin intergrowths in kaolinite: American Mineralogist, v. 57, p. 411-425.

Martin-Vivaldi, J. L., and MacEwan, D.M.C., 1957, Triassic chlorites from the Jura and the Catalan coastal range: Clay Minerals Bulletin, v. 3, p. 177-184.

1960, Corrensite and swelling chlorite: Clay Minerals Bulletin, v. 4 , no. 24 , p. $173-181$.

Melnik, U. M., 1959, Corrensite (vermiculite-chlorite) from the gabbrodiabases of Volhynia: Mineralog. Sbornik L'vov Geol. Obshch., v. 13, p. $387-395$

Millot, Georges, 1949, Relations entre la constitution et la gènese des roches sédimentaires argileuses: Géologie Appliquée et Prospection Minière, v. 2, nos. 2, 3, 4, p. 1-352.

1964, Géologie des Argiles: Paris, Masson et Cie., 499 p.

1970, Geology of clays: New York, Springer-Verlag, 429 p.
Millot, Georges, Lucas, Jacques, and Paquet, H., 1966, Evolution chimique par degradation et agradation des minéraux argileux dans 1' hydrosphere: Geologisches Rundschau, v. 55, p. 1-20.

Millot, Georges, Lucas, Jacques, and Wey, Raymond, 1963, Research on evolution of clay minerals and argillaceous and siliceous neoformation, in A. Swineford, ed., Clays and clay minerals, National conference on clays and clay minerals, 10th, Austin, Texas, Proceedings: London, New York, Permagon Press, International Series of Monographs on Earth Sciences, v. 12, p. 399-412.

Muffler, L.J.P., and White, D. E., 1969, Active metamorphism of Upper Cenozoic sediments in the Salton Sea geothermal field and the Salton trough, southeastern California: Geological Society of America Bulletin, v. 80 , p. 157-182.

Parham, W. E., 1966, Lateral variations of clay mineral assemblages in modern and ancient sediments [with French abs.], in International Clay Conference, Jerusalem, Israel, 1966, Proceedings: Jerusalem, Israel Program of Science Translations, v. 1, p. 135-145.

Perry, Ed, and Hower, John, 1970, Burial diagenesis in Gulf Coast pelitic sediments: Clays and Clay Minerals, v. 18, p. 165-177.

Peterson, N.M.A., 1961, Expandable chloritic clay minerals from Upper Mississippian carbonate rocks of the Cumberland Plateau in Tennessee: American Mineralogist, v. 46, p. 1245-1269.

1962, The mineralogy and petrology of Upper Mississippian carbonate rocks of the Cumberland Plateau in Tennessee: Journal of Geology, v. 70, no. 1, p. 1-31.

Powers, M. C., 1957, Adjustment of land-derived clays to the marine environment: Journal of Sedimentary Petrology, v. 27, no. 4, p. 355-372.

1959, Adjustment of clays to chemical change and the concept of the equivalence level, in A. Swineford, ed., Clays and clay minerals, National conference on clays and clay minerals, 6th, Berkeley, Calif., 1957, Proceedings: London, New York, Pergamon Press, International Series of Monographs on Earth Sciences, v. 2, p. 309-326.

1967, Fluid release mechanisms in compacting marine mudrocks and their importance in oil exploration: American Association of Petroleum Geologists Bulletin, v. 51, no. 7, p. 1240-1254.

Rao, C. Gundu, and Bhattacharya, C., 1973, Corrensite from the Sirban Limestone of Riasi, Jammu and Kashmir State, India: Geological Society of India Journal, v. 14, p. 193-196.

Rateev, M. A., 1963, Regularities in the spatial distribution of kaolinite in marine sediments: Doklady Akad. Nauk SSSR, v. 141, p. 1271-1274.

Reesman, A. L., and Keller, W. D., 1967, Chemical composition of illite: Journal of Sedimentary Petrology, v. 37, no, 2, p. 592-596.

Rex, R. W., 1966, Authigenic kaolinite and mica as evidence for phase equilibria at low temperatures, in W. F. Bradley and S. W. Bailey, eds., Clays and clay minerals, National conference on clays and clay minerals, 13th, Madison, Wis., 1964, Proceedings: London, New York, Pergamon Press, International Series of Monographs on Earth Sciences, v. 25, p. 95-104.

Rex, R. W., and Martin, B. D., 1966, Clay mineral formation in seawater by submarine weathering of K-feldspar: Clays and Clay Minerals, v. 14, p. 235-240.

Reynolds, R. C., Jr., and Hower, John, 1970, The nature of interlayering in mixed-layer illite-montmorillonites: Clays and Clay Minerals, v. 18, p. 25-36.

Sawatzki, G. G., 1975, Étude Géologique et mineralogique des flyschs a grauwackes volcaniques due synclinal de Thônes (Haute-Savoie, France): Archives des Sciences, v. 28, no. 3, p. 267-368.

Shelton, J. W., 1964, Authigenic kaolinite in sandstone: Journal of Sedimentary Petrology, v. 34, no. 1, p. 102-111.

Stephen I., and MacEwan, D.M.C., 1951, Some chloritic clay minerals of unusual type: Clay Minerals Bulletin, v. 1, p. 157-162. 
Sudo, T., 1959, Mineralogical study on clays of Japan: Maruzen, 328 p.

Sudo, T., Takahashi, H., and Matsui, H., 1954, On X-ray properties of the Fireclay from the Kurata Mine, Yamaguchi Prefecture: Japanese Journal of Geology and Geography, v. 24, p. 71-87.

Tardy, Y., Krempp, G., and Trauth, N., 1972, Le lithium dans les minéraux argileux des sédiments et des sols: Geochimica et Cosmochimica Acta, v. 36, p. 397-412.

Tettenhorst, Rodney, 1962, Cation migration in montmorillonites: American Mineralogist, v. 47, p. 769-773.

Tómasson, Jens, and Kristmannsdottir, Hrefna, 1972, High temperature alteration minerals and thermal brines, Reykjanes, Iceland: Contributions to Mineralogy and Petrology, v. 36, p. 123-134.

Tooker, E. W., 1960, Clay minerals in rocks of the lower part of the Oquirrh Formation, Utah: Clays and Clay Minerals, v. 9, p. 355-364.

Van Moort, J. C., 1971, A comparative study of the diagenetic alteration of clay minerals in Mesozoic shales from Papua, New Guinea, and in Tertiary shales from Louisiana, U.S.A.: Clays and Clay Minerals, v. 19, p. 1-20.

Velde, Bruce, 1966, Mixed layer mineral associations in muscoviteceladonite and muscovite-chlorite joins, [abs.], in W. F. Bradley and S. W. Bailey, eds., Clays and clay minerals, National conference on clays and clay minerals, 13th, Madison, Wis., 1964, Proceedings: London, New York, Pergamon Press, International Series of Monographs on Earth Sciences, v. 25, p. 29-32.

1977a, A proposed phase diagram for illite, expanding chlorite, corrensite and illite-montmorillonite mixed layer minerals: Clays and Clay Minerals, v. 25, p. 264-270.

$1977 \mathrm{~b}$, Clays and clay minerals in natural and synthetic systems: Amsterdam, Elsevier, $218 \mathrm{p}$.

Velde, Bruce, and Bystrom-Bruzewitz, A. M., 1972, The transformation of natural clay minerals at elevated temperatures and pressures: Geologiska Foreningens i Stockholm Forhandlingar, v. 94, p. 449-458.
Weaver, C. E., 1956, The distribution and identification of mixed-layer clays in sedimentary rocks: American Mineralogist, v. 41, p. 202-221.

1957, The clay petrology of sediments, in A. Swineford, ed., Clays and clay minerals, National conference on clays and clay minerals, 6th, Berkeley, Calif., 1957, Proceedings: London, New York, Pergamon Press, International Series of Monographs on Earth Sciences, v. 2, p. 154-187.

1958, Geologic interpretation of argillaceous sediments, Part I. Origin and significance of clay minerals in sedimentary rocks: American Association of Petroleum Geologists Bulletin, v. 42, no. 2, p. 254-271.

Weaver, C. E., and Beck, K. C., 1971, Clay water diagenesis during burial; How mud becomes gneiss: Geological Society of America Special Paper 134, $96 \mathrm{p}$.

1977. Miocene of the southeastern United States-A model for chemical sedimentation in a peri-marine environment: Sedimentary Geology, v. 17, nos. 1/2, p. 215-218.

Weaver, C. E., and Pollard, L. D., 1973, The chemistry of clay minerals: Amsterdam, New York, Elsevier, 213 p.

Wilson, M. J., and Bain, D. C., 1970, The clay mineralogy of the Scottish Dalradian meta-limestones: Contributions to Mineralogy and Petrology, v. 26, p. 285-295.

Wilson, M. D., and Pittman, E. D., 1977, Authigenic clays in sandstones; Recognition and influence on reservoir properties and paleoenvironmental analysis: Journal of Sedimentary Petrology, v. 47, no. 1 , p. 3-31.

Wyart, J., and Sabatier, G., 1966, Synthèse hydrothermale de la corrensite: Bulletin du Groupe Française des Argiles, v. 18, no. 13, p. 33-40. 


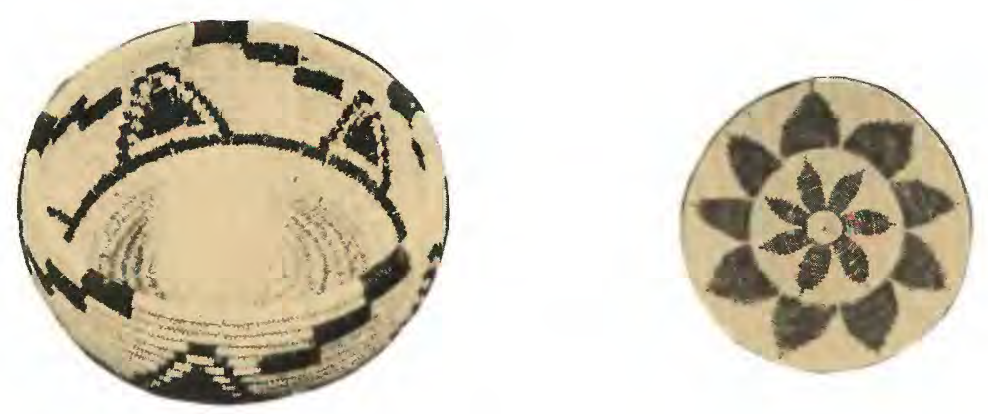

THE SUPAI GROUP OF GRAND CANYON

\section{PETROGRAPHY OF THE SUPAI GROUP AND PAKOON LIMESTONE}

Chapter $\mathrm{P}$

By EDWIN D. McKEE and WALTER PIERCE

\section{Contents}

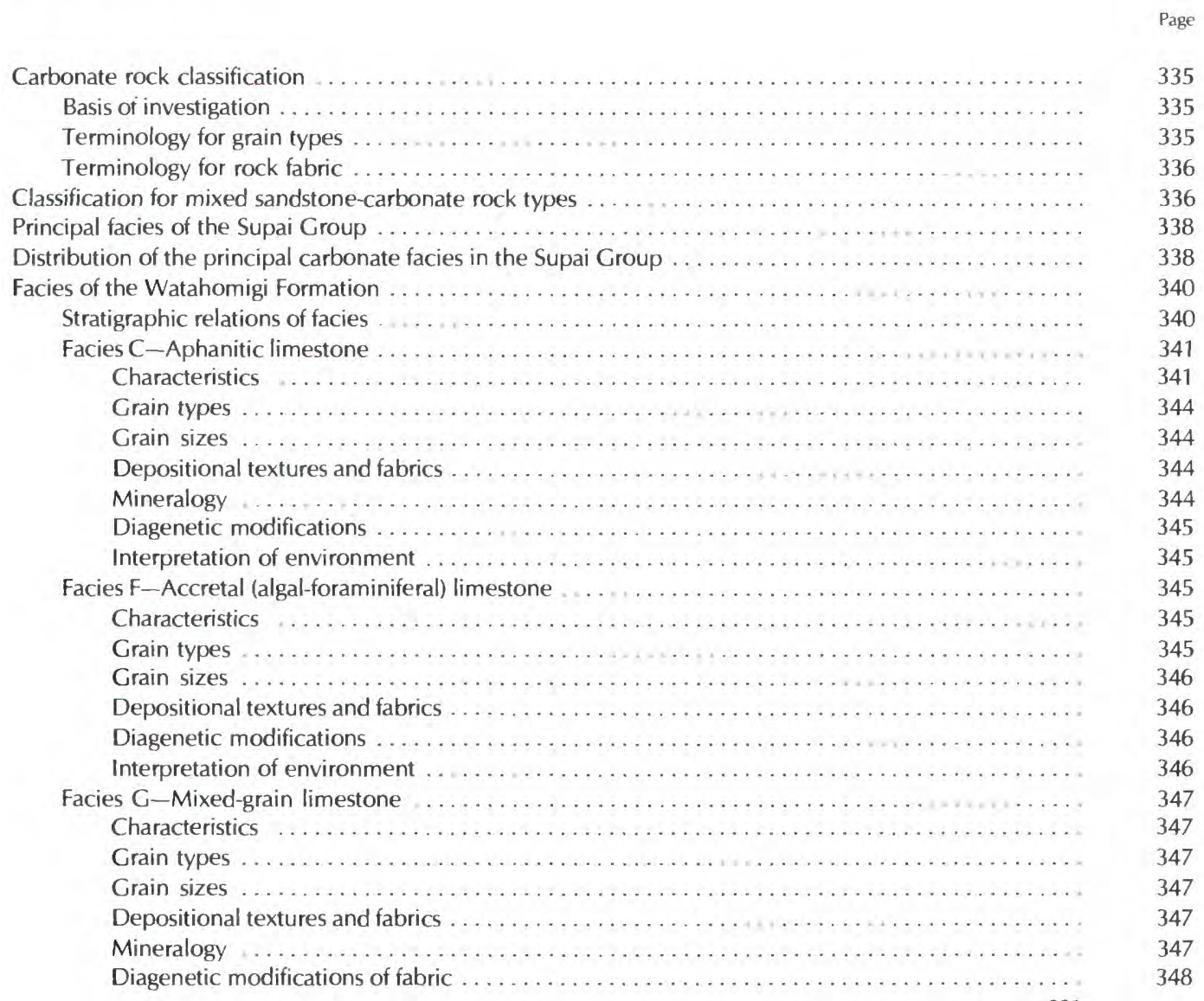


Facies of the Watahomigi Formation-Continued

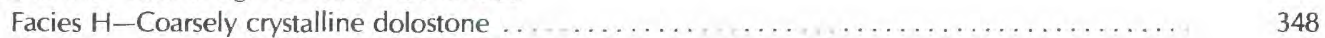

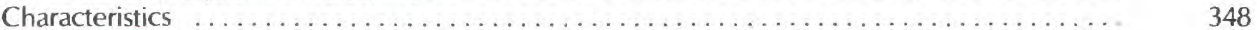

Texture and fabrics . . . . . . . . . . . . . . . . 348

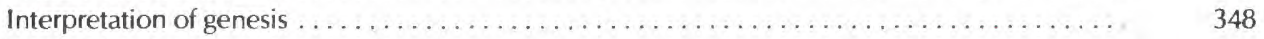

Facies of the Manakacha Formation . . . . . . . . . 348

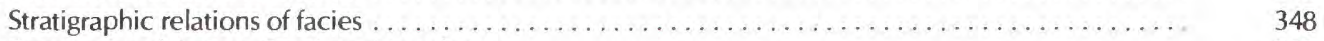

Conventional facies-Stratigraphic relations . . . . . . . . . . . . . . . . . . . . . . . . . 350

Facies A-Red argillaceous mudstone . . . . . . . . . . . . . . 350

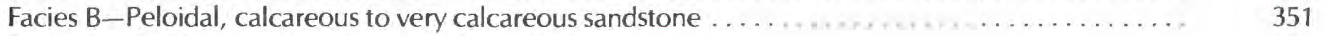

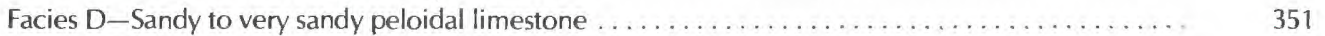

Facies E-Bioclastic limestone . . . . . . . . . . . . . . . . . . . . . . . . . . . . . . . . . . . . 351

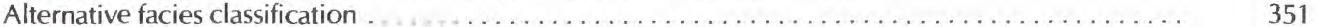

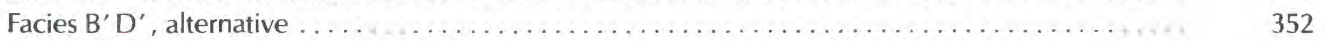

Interpretation of facies . . . . . . . . . . 352

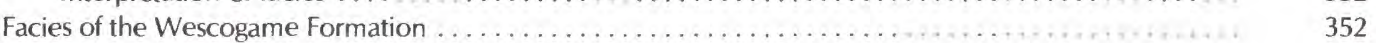

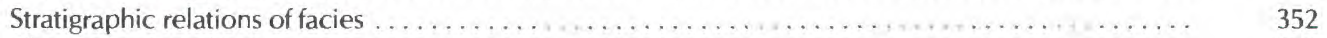

Characteristics of facies .......................................... 354

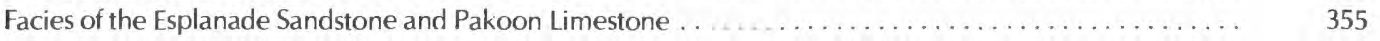

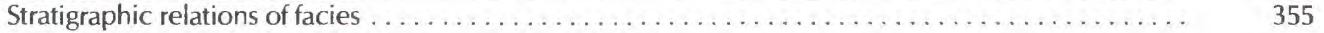

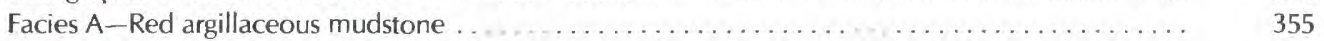

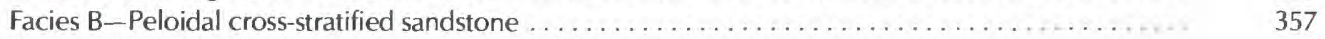

Facies E-H-Bioclastic limestone and calcitic dolostone . . . . . . . . . . . . . . . . . . . . . . . . . 357

Facies I-Dolomitic sandstone . . . . . . . . . . . . . . . . . . . . . . . . . . . . . . 357

Facies J-Bedded gypsum . . . . . . . . . . . . . . . . . . . . . . . . . . . 358

References cited . . . . . . . . . . . . . . . . . . . . . . . . . . . . . . . . . . . . . 359

\section{Illustrations}

FIGURE P1. Maps of distribution of thin sections showing facies of Supai Group and Pakoon

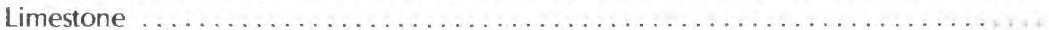

P2. Maps of distribution of thin sections showing rock fabrics of Supai Group and Pakoon

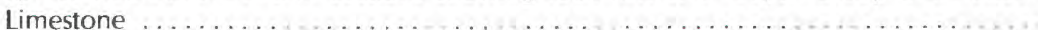

P3. Photomicrographs of rocks of principal facies of Supai Group and Pakoon Limestone .....

P4. Maps showing areal distribution of principal types of clasts of Supai Group and Pakoon Limestone

P5. Maps showing areal distribution of carbonate mudstone (micrite) and clastic limestone of Supai Group and Pakoon Limestone ...............................

P6. Color fence diagrams of facies of the Watahomigi Formation . ......................

P8. Color fence diagrams of facies of the Manakacha Formation . . . . . . . . . . . . . . 349

P9. Photomicrographs of rocks from principal facies of the Manakacha Formation . . . . . . . . 350

P10. Color fence diagrams of facies of the Wescogame Formation . .................................

P11. Photomicrographs of rocks from principal facies in the Wescogame Formation . . . . . . . 354

P12. Color fence diagrams of rocks from facies of the Esplanade Sandstone and Pakoon

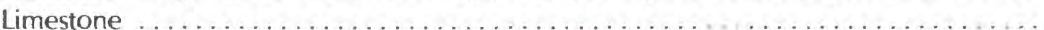

P13. Photomicrographs of rocks from facies of the Esplanade Sandstone and Pakoon Limestone

\section{Tables}

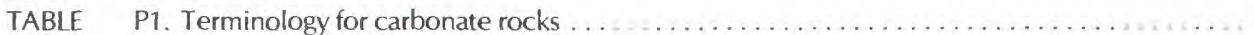




\section{CARBONATE ROCK CLASSIFICATION}

\section{Basis of investigation}

The collection of samples used in this investigation includes specimens, considered representative, from nearly all rock units of the Supai Group ${ }^{1}$ as recognized in 32 measured section descriptions, and illustrated in figures A2-A8. These specimens were selected and documented during field studies by McKee and various assistants, spanning a period of more than a dozen years. Petrographic analysis of thin sections was by Walter Pierce who contributed much important information based on his systematic examinations.

Based on the examination of nearly 1,000 specimens in thin section, a twofold classification of microfacies considered both practical and meaningful, has been adopted for use in describing carbonate rocks of the Supai Group. This classification (table P1) recognizes (1) three categories of limestone based on grain type, and (2) three categories based on amounts of carbonate mud matrix, following Dunham (1962, table 1). An additional class of limestone consists of carbonate mudstone (micrite), with both laminated and nonlaminated varieties. Recrystallized carbonate rock occurs as dolostone and as crystalline limestone.

\section{Terminology for grain types}

The principal grain types recognized in carbonate rocks of the Supai Group are (1) bioclastic, (2) accretal, and (3) peloidal (fig. P1).

Bioclastic grains, referred to as skeletal by some geologists, commonly are easy to identify for they consist of the

${ }^{1}$ The Pakoon Limestone (McNair, 1951) is included with the Supai Group for the purposes of this discussion as it intertongues with the lower part of the Esplanade Sandstone in western Grand Canyon. shells or tests of various marine invertebrate animals. Mostly they are fragments that are comminuted or worn, but some, especially small varieties, may be unbroken and fresh. Animals most commonly represented are brachiopods, mollusks, pelmatozoans (crinoids, echinoids), bryozoans, foraminifers, and ostracodes; they may or may not be preserved in recognizable form.

Accretal grains consist primarily of those particles formed through the buildup of concentric layers of calcium carbonate as in ooids, oncolites, and pisolites, and they are mostly spheroidal. Within the Supai Group the most common accretal grains are those formed by algal and foraminiferal encrustations in various proportions. Unfortunately, the biogenic origin of these accretal grains is difficult to determine from hand specimens in the field, and many strata referred to as oolitic (for example, McNair, 1951) may have been of this type. Algal-foraminiferal accretal grains are prominent in the Watahomigi and lower part of the Manakacha. True ooids are uncommon in the Supai Group, but locally occur as scattered grains seen in thin sections or, rarely, as small concentrations. Pisolites are also rare in the Supai Group. Isolated examples come from various horizons and localities.

Peloidal grains as originally defined (McKee and Gutschick, 1969, p. 101) are largely rounded and ovoid, but highly variable in size and shape. Most of them are believed to have been derived through erosion of carbonate mud deposits accumulated nearby. Some peloidal grains may have formed as fecal pellets and others through diagenesis of bioclasts, ooids, or other varieties of grains.

Peloids of the Supai Group probably are polygenetic. In the Watahomigi Formation, the presence of two definite size groups may indicate that the smaller clasts represent fecal pellets. In the Manakacha, however, a consistently even size of peloids, similar to that of associated detrital quartz grains, probably is the result of derivation from deposits of carbonate mud, followed by transportation with consequent rounding and sorting of grains.

TABLE P1.-Terminology for carbonate rocks

[Moditied trom Dunham, 1962]

\begin{tabular}{|c|c|c|c|c|c|c|}
\hline \multicolumn{5}{|c|}{ Depositional fabric } & \multicolumn{2}{|c|}{ Recrystallized fabric } \\
\hline Name ... & Grainstone & Packstone & Wackestone & $\begin{array}{l}\text { Carbonate } \\
\text { mudstone (micrite) }\end{array}$ & $\begin{array}{l}\text { Crystalline } \\
\text { dolostone }\end{array}$ & $\begin{array}{l}\text { Crystalline } \\
\text { limestone }\end{array}$ \\
\hline $\begin{array}{l}\text { Amount } \ldots \ldots \ldots \\
\text { of mud } \\
\text { matrix }\end{array}$ & $\begin{array}{l}\text { Grain-supported, } \\
\text { lacks carbonate } \\
\text { mud. }\end{array}$ & $\begin{array}{l}\text { Grain-supported, } \\
\text { contains } \\
\text { carbonate mud. }\end{array}$ & $\begin{array}{l}\text { Matrix-supported, } \\
\text { "floating" grains. }\end{array}$ & None. & & \\
\hline $\begin{array}{l}\text { Grain } \ldots \ldots \ldots \\
\text { types }\end{array}$ & Bioclastic $^{1}$, accr & tal, peloidal. & & & & \\
\hline
\end{tabular}

${ }^{1}$ Common varieties of bıoclastic graıns toramınıters, bıvalves (brachıopods, pelecypods), pelmatozoan icrinoids, echinoıds), ostracodes, bryozoans, algae. 

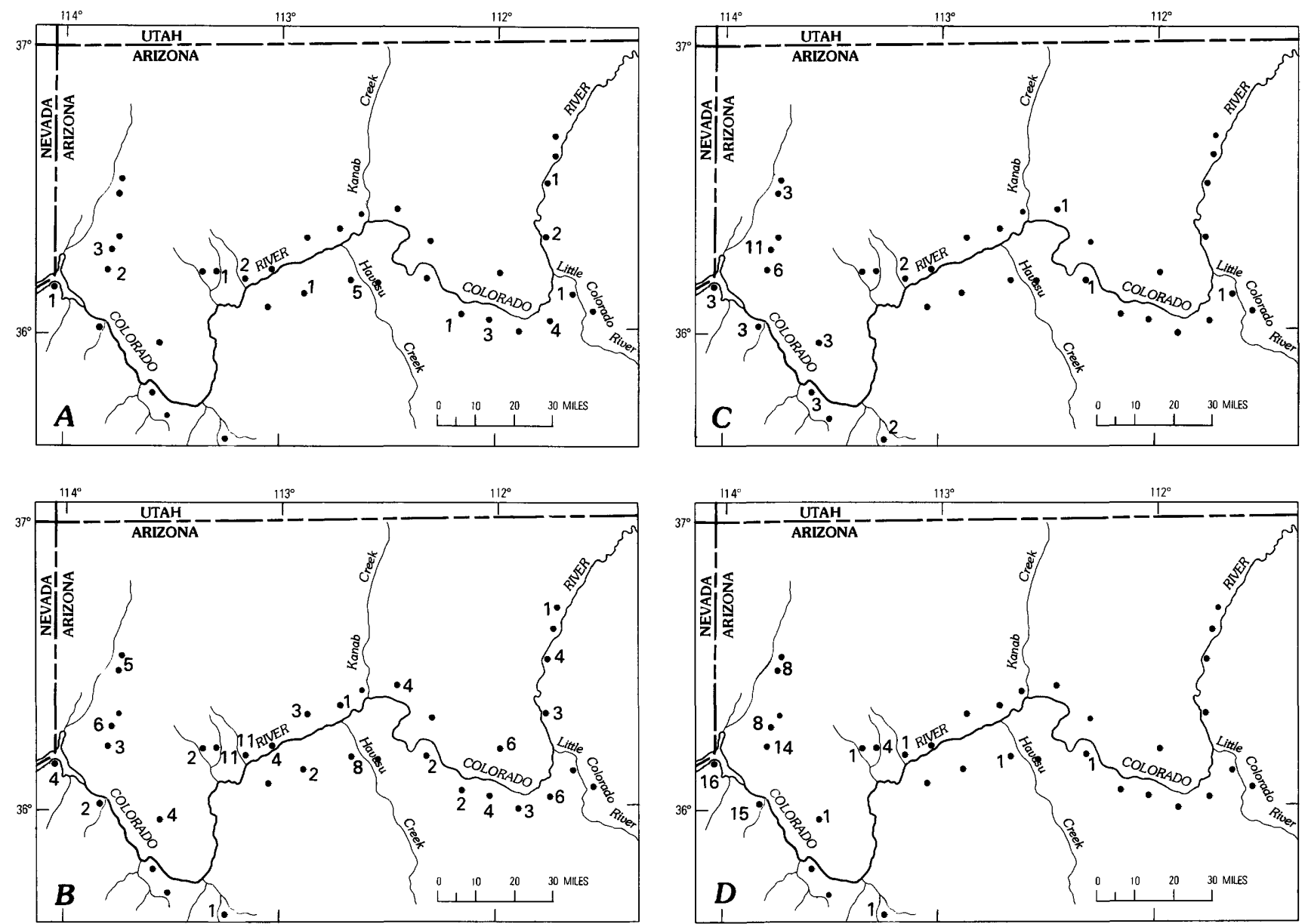

FIGURE P1.-Distribution of thin sections representing various facies (based on type of grain) in carbonate rocks of Supai Group and Pakoon Limestone (MCNair, 1951). Grand Canyon region, Arizona. Numbers on maps refer to number of specimens taken from each locality. A, Carbonate mudstone; $B$, peloidal grains; $C$, accretal grains; and $D$, bioclasts.

Many small foraminifers that apparently have been micritized are among the Manakacha peloids.

\section{Terminology for rock fabric}

Varieties of fabric as recognized in carbonate rocks of the Supai Group (table P1) can be assigned to various classes based on relations of grains to carbonate mud or micritic matrix as described by Dunham (1962). These classes consist of (1) grainstone in which carbonate mud is lacking so that grains rest upon other grains and are "grain-supported," (2) packstone, also with particles that are "grain-supported," but containing some carbonate mud as a matrix, and (3) wackestone in which grains are "floating" in carbonate mud, so they are described as "matrix-supported."

An additional common type of depositional fabric in limestones of the Supai Group is that of rocks normally referred to as aphanitic, in which grains are of microcrystalline (between 0.004 and $0.006 \mathrm{~mm}$ ) or cryptocrystalline $(<0.004 \mathrm{~mm})$ size. Macrocrystalline grains are absent and the rock is commonly called a carbonate mudstone or micrite. In the following discussions the term carbonate mudstone will be used in order to emphasize the very fine, mudlike texture of the rock.

Fabrics resulting from recrystallization are not uncommon locally in the Supai and consist both of dolostone with medium to coarse rhombs or crystals, and of coarsely crystalline limestone. The term dolostone is used for the rock name; dolomite for the mineral.

The general distribution of the principal rock fabrics recognized in the Supai Group is shown in figure P2.

\section{CLASSIFICATION FOR MIXED SANDSTONE-CARBONATE ROCK TYPES}

Rocks of the Supai Group, especially the Manakacha and Wescogame Formations, consist in many places of mixtures of terrigenous quartz sand and clastic carbonate 

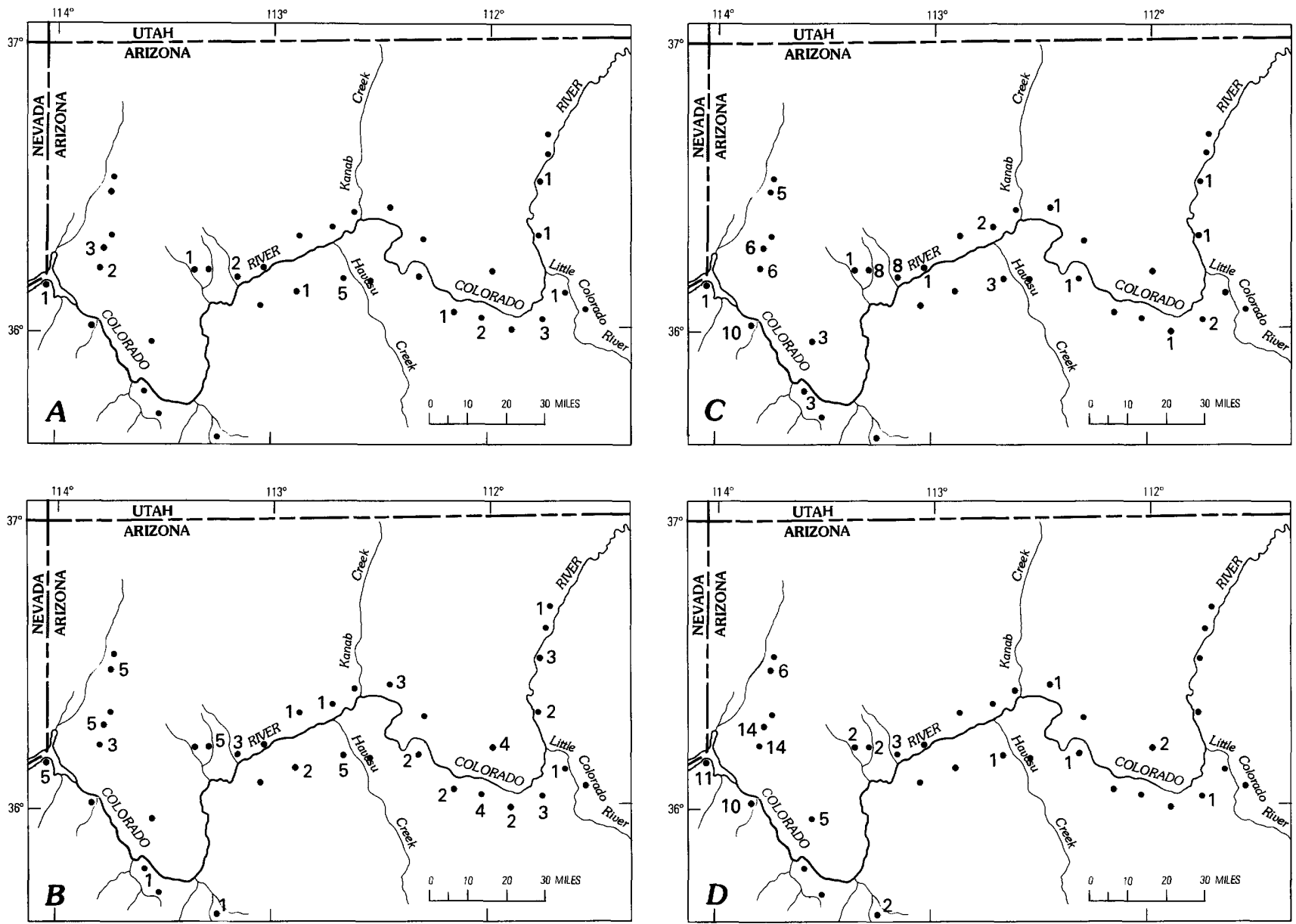

FIGURE P2.-Distribution of thin sections representing various facies (based on rock fabric), in carbonate rocks of Supai Group and Pakoon Limestone (McNair, 1951). Numbers on maps refer to number of specimens taken from each locality. A, Carbonate mudstone; $B$, wackestone; $C$, packstone; and $D$, grainstone.

grains; all proportions of one to the other are represented. Thus, in many sequences of beds, a complete range from pure limestone to pure sandstone may occur with relatively small differences in rock appearance. Distinguishing between such sandstones and limestones in the field generally is very difficult. The proportion of quartz grains to carbonate grains, especially as it approaches the 50-percent boundary, can only be accurately determined by percentages obtained through insoluble-residue measurements. Furthermore, characteristic features such as crossstratification and red color are common to both.

In this study, the designation of mixed sandstonelimestone units is determined most accurately on the basis of percent insoluble residue, as illustrated in table $\mathrm{P} 2$; more than 300 of these determinations were made. For a majority of specimens, however, reasonable approximations of grain percentages have been determined from thin-section analysis or from point counting.

Subdivision of the mixed sandstone-carbonate rock was greatly facilitated by the large number of insoluble-residue analyses that were available (fig. M1). Each thin section was assigned to one of the six categories of mixed-rock type following comparison with a series of photomicrographs of facies in which the percentage of insoluble residue had been determined. The 30-percent and 70-percent boundaries seem to be especially meaningful

TABLE P2.-Terminology for mixed sandstone-carbonate rock

\begin{tabular}{cccccc}
\hline $\begin{array}{c}\text { Percent insoluble } \\
\text { residue ..... }\end{array}$ & $0-10$ & $10-30$ & $30-50$ & $50-70$ & $70-90$ \\
\hline Designation ...... & Limestone & $\begin{array}{c}\text { Sandy } \\
\text { limestone }\end{array}$ & $\begin{array}{c}\text { Very sandy } \\
\text { limestone }\end{array}$ & $\begin{array}{c}\text { Very calcareous } \\
\text { sandstone }\end{array}$ & $\begin{array}{c}\text { Calcareous } \\
\text { sandstone }\end{array}$ \\
\hline
\end{tabular}


because they approximately correspond to normal interstitial pore space in a packing arrangement of equidimensional grains.

Using only the percent insoluble residue as determined by weight, a comparison of histograms for each of the formations of the Supai Group is made. The Watahomigi Formation histogram (fig. M1A) shows a typical bimodal distribution of percent in soluble material, indicating that this formation has a high frequency of pure limestones (0-10 percent insoluble) and a relatively smaller mode of carbonate mudstone (80-90 percent insoluble).

A bimodal distribution of limestone and sandstone is typical of the Wescogame, Esplanade, and Pakoon formations (fig. M1A, $B, C, D$ ). In contrast, the Manakacha Formation is distinctive in not having a minimum of samples in the middle of the histogram (fig. M1B) but, instead, a maximum, showing the very transitional or mixed nature of the rock in this formation.

\section{PRINCIPAL FACIES OF THE SUPAI GROUP}

Ten principal facies (fig. P3), designated by the letters A through $\mathrm{J}$ for convenience in discussion, have been recognized in a thin-section study of the Supai Group. Six of these facies are types of carbonate rock, three are detrital rock, and one gypsum. Other minor types and variations are locally present.

The 10 common facies are located and discussed in detail in the descriptions that follow on the petrography of each formation. The letter designations and diagnostic features of these facies are:

A-Mudstone and siltstone, red, argillaceous.

B-Sandstone, commonly calcareous and peloidal, mostly cross-stratified.

C-Limestone, aphanitic (carbonate mudstone or micrite), including peloidal types (wackestone).

D-Limestone, peloidal, sandy (grainstone and packstone), commonly cross-stratified, chert-bearing.

E- Limestone, bioclastic (grainstone and packstone), locally sandy, cross-stratified, shell fragments (brachiopods, pelecypods).

F- Limestone, accretal, algal-foraminiferal (grainstone and packstone).

G-Limestone, mixed grains; peloidal, bioclastic (skeletal), accretal (grainstone and packstone).

$\mathrm{H}$-Dolostone and calcitic dolostone, crystalline.

I- Dolomitic sandstone.

J- Gypsum, bedded.

\section{DISTRIBUTION OF THE PRINCIPAL CARBONATE FACIES IN THE SUPAI GROUP}

The distribution of carbonate facies as recognized by grain types is shown in figure $\mathrm{P} 4$ and summarized as follows:

Facies $E$ and $G$; bioclastic limestones. - Limestones of the Supai Group in which the grains are formed in part or entirely by fragments of marine invertebrate skeletons (bioclasts) seem to be very largely concentrated in the western Grand Canyon area (fig. P4). They have been recognized in small amounts at a few localities in central Grand Canyon, but not in the east. Possibly this distribution is related to the continuous proximity of western Grand Canyon to open marine waters of the Cordilleran trough (fig. D1) during deposition of the Supai.

Facies $F$ and $G$; accretal limestones. - Accretal limestones, including oolitic, oncolitic, and pisolitic, of the Supai, have a limited geographic distribution similar to that of the bioclastic limestones (fig. P4), but they are even less numerous. The greatest number of specimens represented in thin sections are from Pigeon Wash in westernmost Grand Canyon.

Facies $D$ and $G$; peloidal limestones. - Limestones of this type have by far the widest distribution of the varieties classified according to grain character (fig. P4). Their distribution is not concentrated in the area of western Grand Canyon as with the bioclastic and accretal limestones, but is rather evenly distributed throughout the region with probably a maximum abundance in the west-central area. This implies that an environment favorable to the development and accumulation of peloidal limestone prevailed throughout the Grand Canyon embayment during several stages of Supai deposition.

Facies $C$; carbonate mudstones. - Carbonate mudstones (micrites) of the Supai are widely distributed from east to west in the Grand Canyon region (fig. P5), but are somewhat more abundant in the eastern and central parts than in the west (fig. P2A). Reference to paleogeographic maps of Pennsylvanian and Early Permian time (figs. D3-D8) indicates that an abundance of carbonate mud accumulated along the south side of the Grand Canyon embayment, as represented both by this facies and by the wackestones in which it forms the matrix. The adjacent southerly landmass apparently provided a protected low-energy setting during much of Supai time. The general absence of carbonate mud in the southwestern localities probably reflects high energy of the adjacent open seaway. 

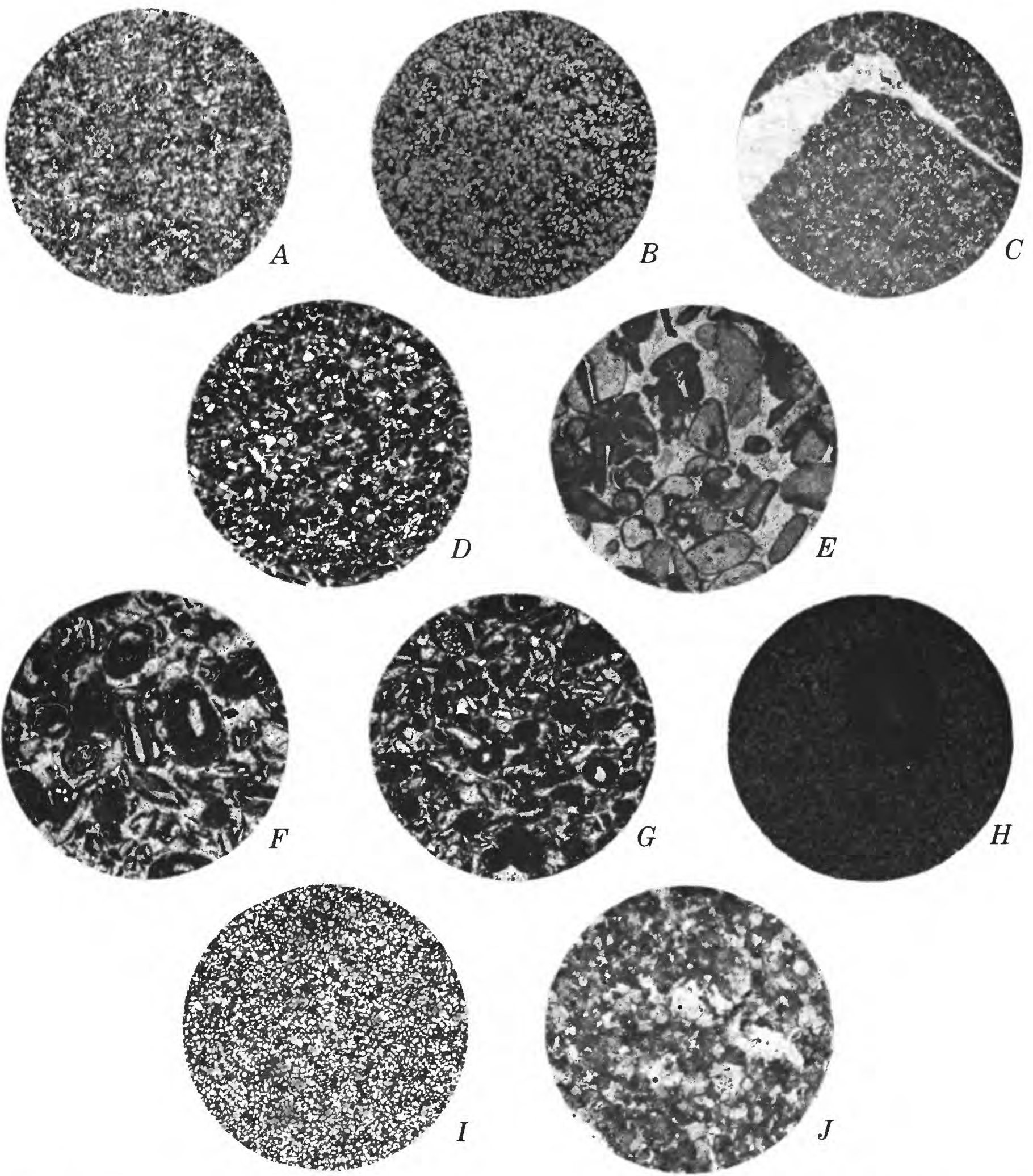

FIGURE P3.-Photomicrographs $(\times 10$ ) of examples of principal facies of Supai Group and Pakoon Limestone (McNair, 1951) recognized in Grand Canyon region, Arizona. A, Red argillaceous mudstone; $B$, calcareous cross-stratified sandstone; $C$, aphanitic limestone; $D$, peloidal sandy limestone; $E$, bioclastic limestone; $F$, accretal limestone; $G$, mixed-grain limestone; $H$, calcitic dolomite; 1 , dolomitic sandstone; and I, bedded gypsum. 

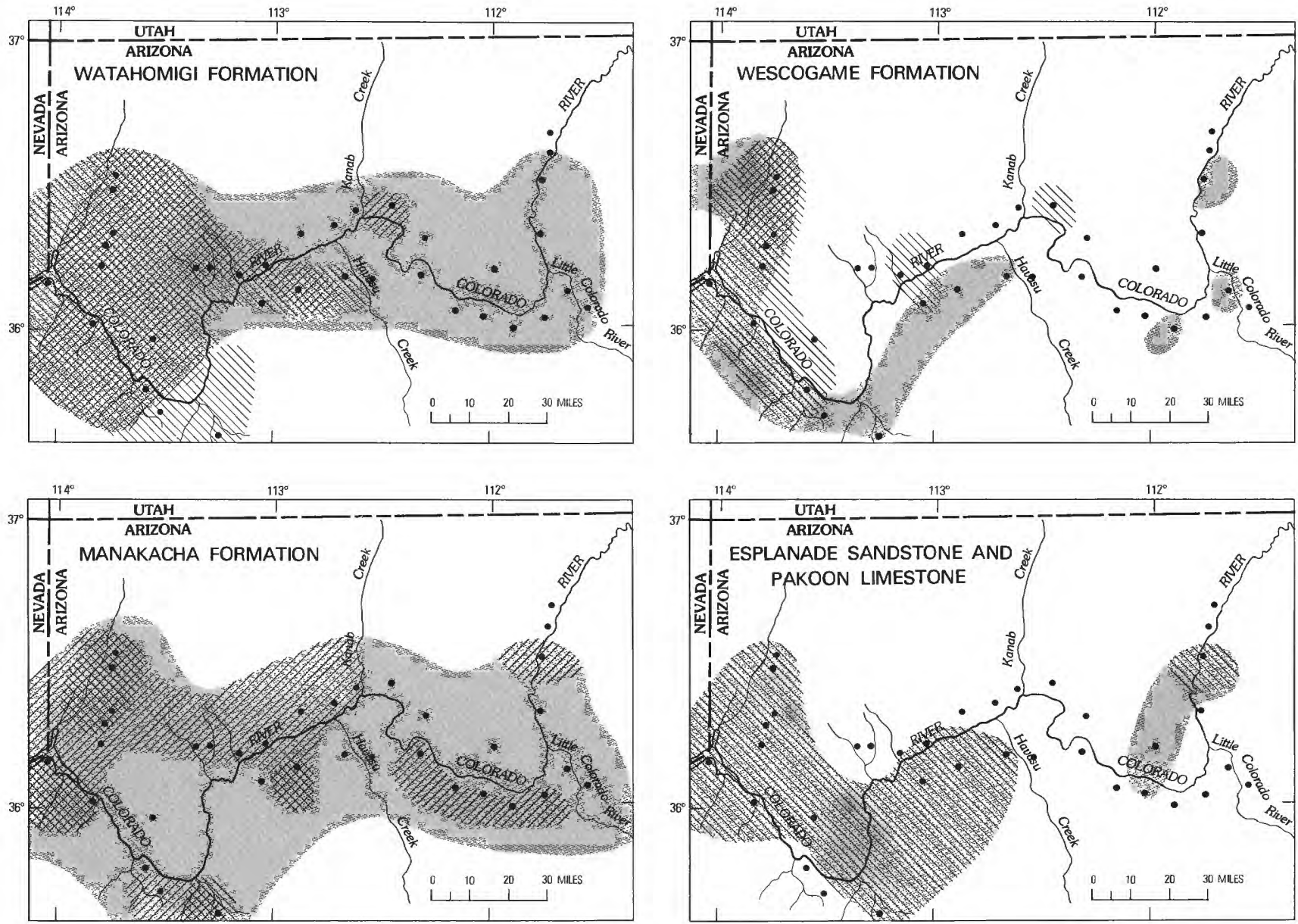

EXPLANATION
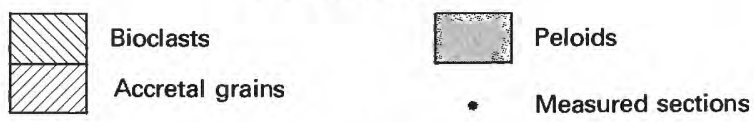

FIGURE P4.-Areal distribution of principal types of clasts that form limestones in each formation of Supai Group and in the Pakoon Limestone (McNair, 1951).

FACIES OF THE

\section{WATAHOMIGI FORMATION}

\section{Stratigraphic relations of facies}

The Watahomigi is composed of three units or vertical subdivisions as described in the chapter on stratigraphy. These units find topographic expression as a lower slope, a middle cliff, and an upper slope. The middle cliff unit is thickest and best developed in the west and seems to be a tongue that extends eastward through most of Grand Canyon but is absent at Blue Spring (sec. 4, fig. A1) on the Little Colorado River.

Both the lower and the upper units are composed largely of red argillaceous mudstone and siltstone, and represent a single facies, A, as shown in figure P6. In contrast, the middle unit, which is composed largely of carbonate rock, includes four facies. These are: the mixed-grain limestone, $\mathrm{G}$, containing combinations of peloidal, bioclastic, and accretal grains; a relatively pure, accretal limestone facies, F, in the thick western sections; a coarsely crystalline dolostone facies, $\mathrm{H}$, in the southwest; and a carbonate mudstone, $\mathrm{C}$, in the central and eastern parts.

The main body of the mixed-grain limestone, $G$, that constitutes most of the middle unit of the Watahomigi in western Grand Canyon not only thins eastward through the canyon, but also intertongues with carbonate mudstone (micrite) of facies $\mathrm{C}$ in central and eastern Grand Canyon (fig. P6). 

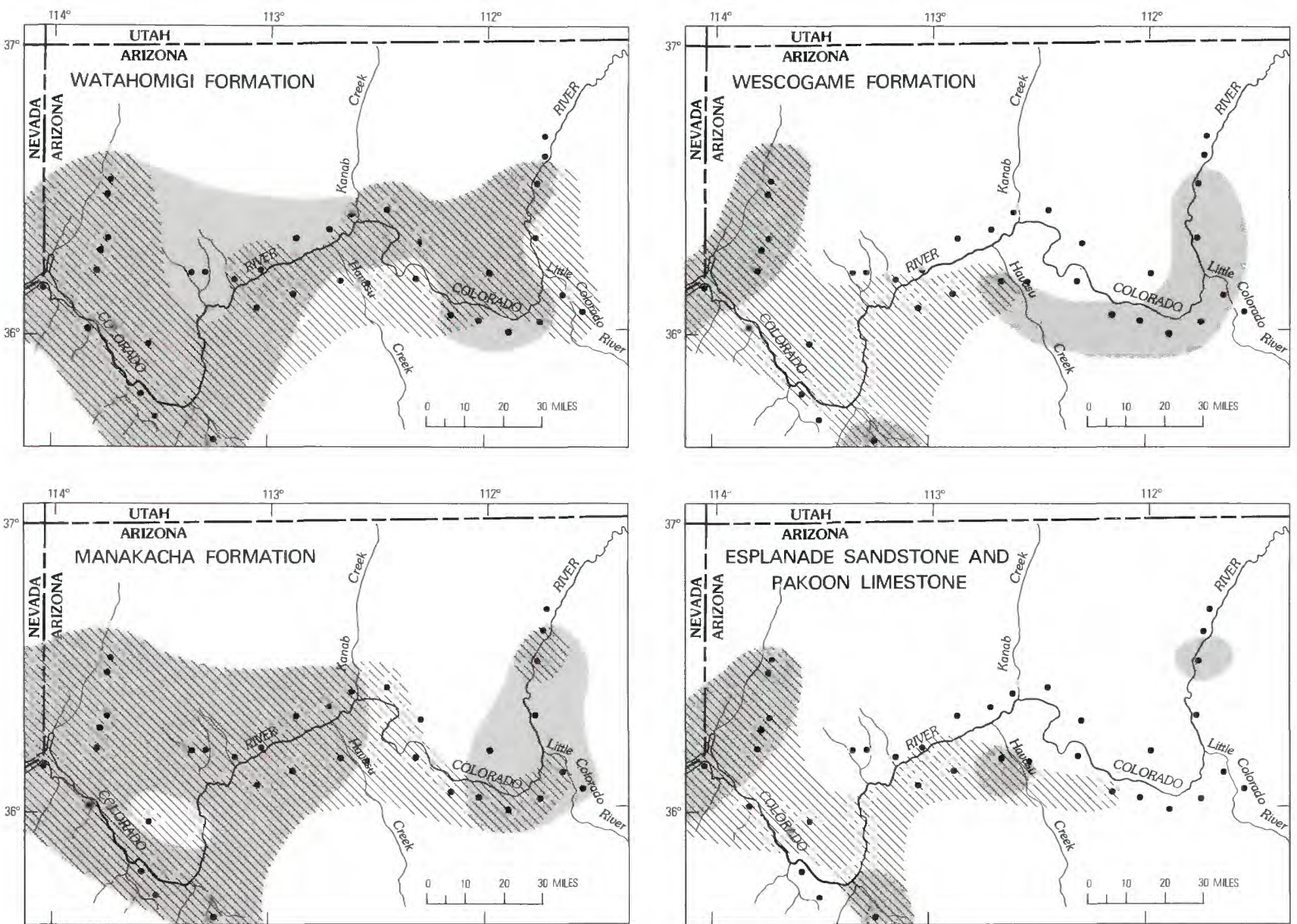

\section{EXPLANATION}

Carbonate mudstone with few or no clastsMicrite and (or) wackestone
Mostly clastic limestone with little or no carbonate mud-Packstone and (or) grainstone
- Measured sections

FIGURE P5.-Maps showing areal distribution of carbonate mudstone (micrite) and clastic limestone as determined by thin-section examination in formations of Supai Group and in Pakoon Limestone (McNair, 1951).

\section{Facies C-Aphanitic limestone}

\section{Characteristics}

Aphanitic limestone that consists of both peloidal wackestone and carbonate mudstone represents most of the limestone in the Watahomigi of eastern Grand Canyon. From facies $C, 56$ thin sections, 30 insoluble-residue analyses, and 26 determinations of calcium-magnesium ratios have been prepared and examined. The following generalizations are made from the data.

Facies $C$ is basically a sandy, matrix-supported limestone (wackestone) in which the quartz component ranges from very fine grained sand to coarse silt (fig. P7C). Sparfilled openings (fenestrae) or bird's-eye structures are common. The detailed description that follows considers first, grain types; second, depositional textures and fabrics; third, size relationship in quartz-carbonate grains; fourth, depositional and postdepositional mineralogy; fifth, diagenetic fabric modifications; and sixth, environmental interpretation.

Facies $\mathrm{C}$ is the most extensive and lithologically constant of all the carbonate rock facies in the Watahomigi. It extends far eastward from Whitmore Wash and National Canyon where it is interbedded with mixed-grain limestone, both grainstone and packstone, and is exposed throughout nearly two-thirds of the Grand Canyon (fig. P6). The basal contact is gradational into an underlying red argillaceous mudstone. Possibly this facies onlaps the Redwall Limestone between the Kaibab Trail, south, and Grandview Trail measured sections. Such relationship suggests that the limestone in the eastern area may thin from 


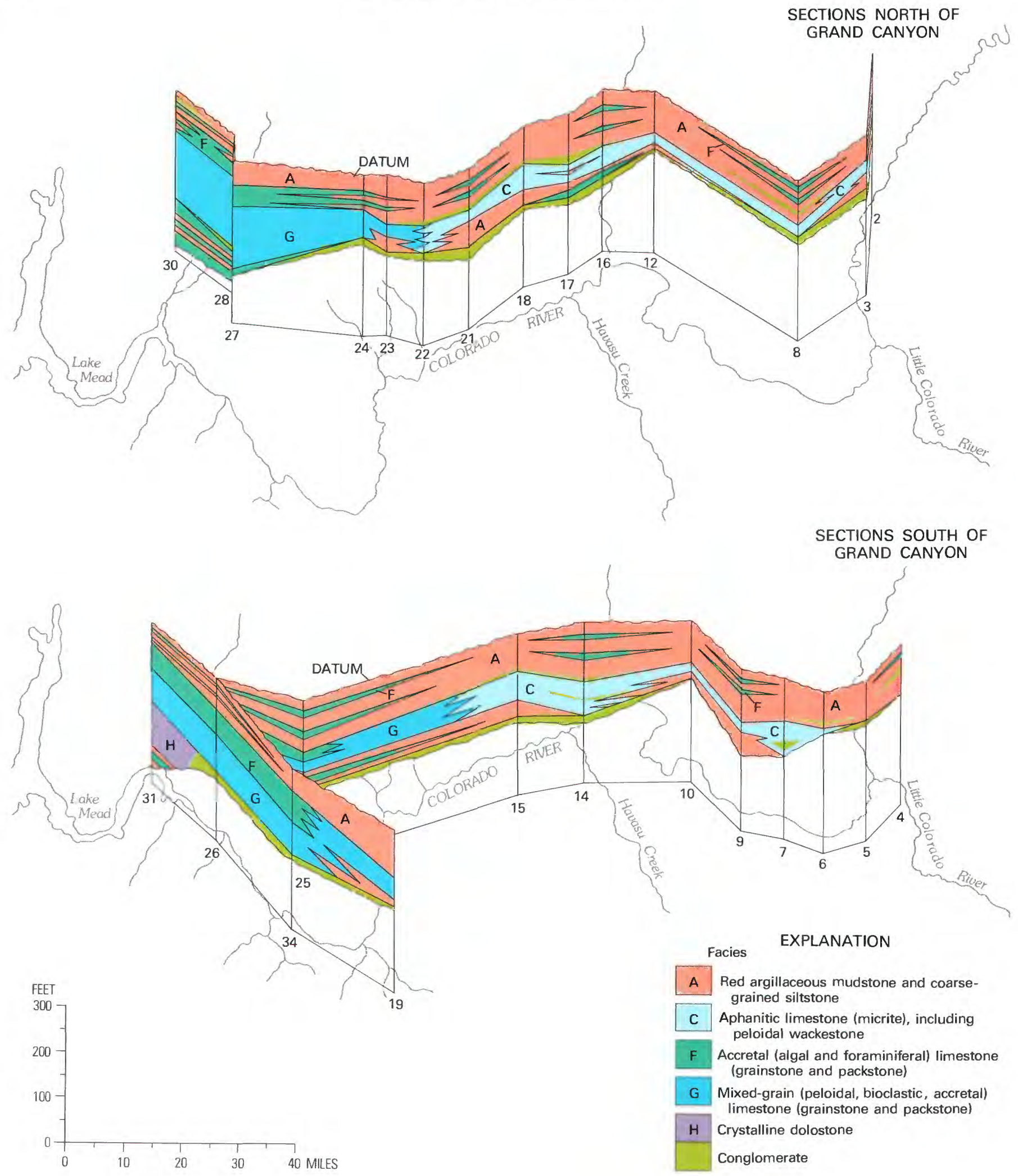

FIGURE P6.-Fence diagram of east-to-west sections showing distribution of facies of the Watahomigi Formation in Grand Canyon region, Arizona. Number at base of each vertical line refers to measured section locality as shown on figure A1. 


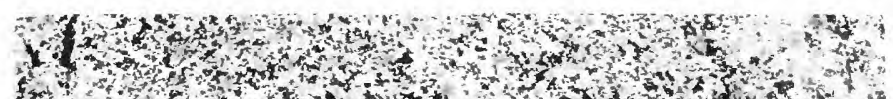

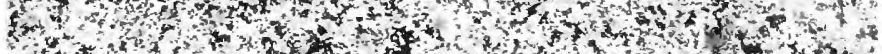

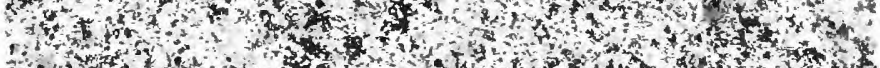

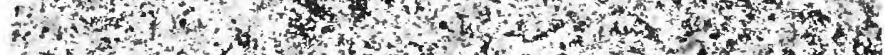

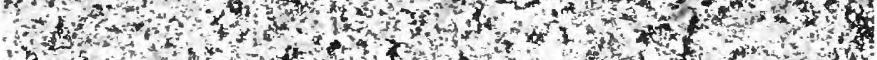

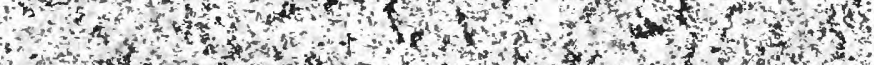

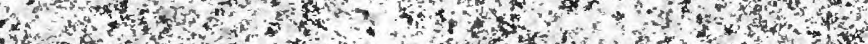

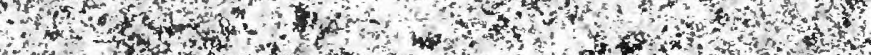

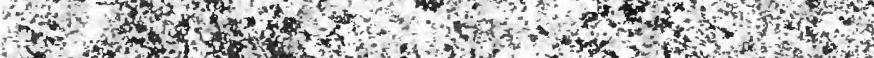

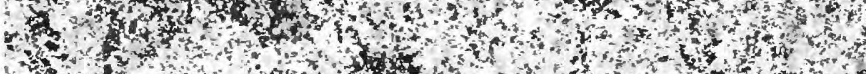

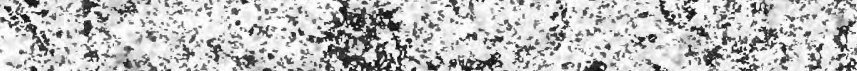

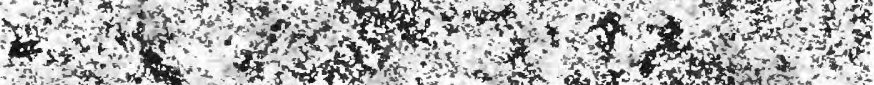

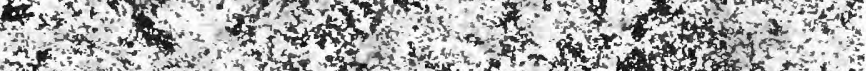

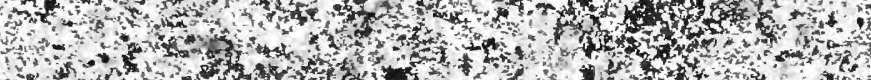

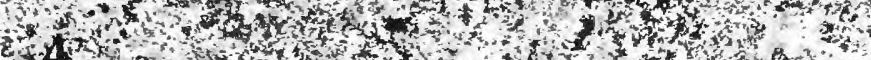

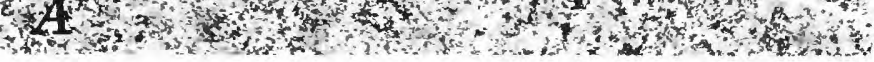
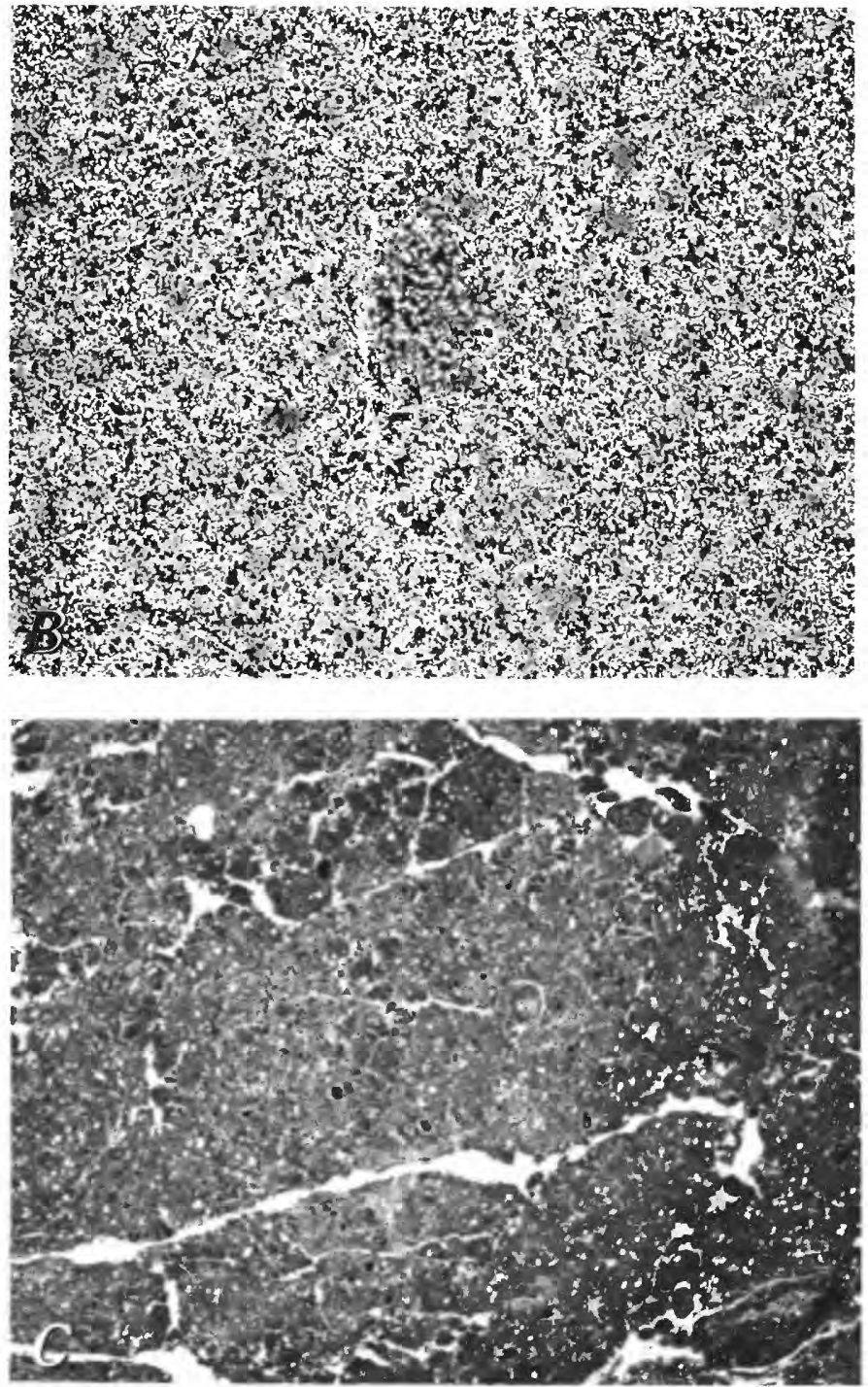

FIGURE P7.-Photomicrographs $(\times 10)$ of rocks of facies in the Watahomigi Formation, Grand Canyon region, Arizona. A, Argillaceous mudstone of facies A, Twentynine Mile Canyon. B, Very fine grained sandstone of facies B, Whitmore Wash. C. Aphanitic limestone of
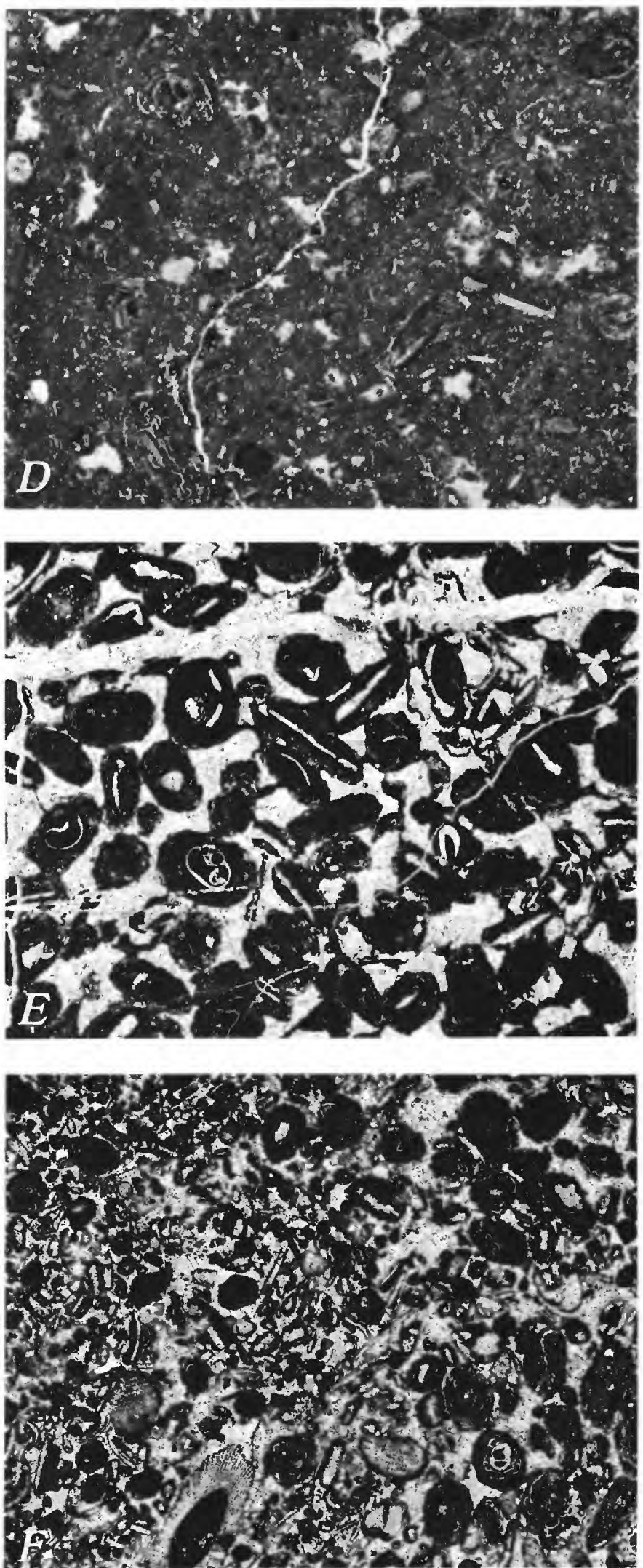

facies C, Blue Spring. D. Accretal limestone (packstone) of facies C encrusting foraminifera, Pigeon Wash. $E$, Accretal limestone (grainstone) of facies $F$, Thunder River Trail. F, Mixed-grain limestone of facies $\mathrm{G}$, Iceberg Canyon. 
onlap, rather than from intertonguing with red mudstone. The upper contact of this facies is sharp and, in many places, is overlain by a conglomerate which probably represents the boundary between strata of Morrowan and Atokan age (table J1).

\section{Grain types}

Bioclastic grains.-Scarcity of skeletal material is a feature that helps distinguish the aphanitic limestone facies from others. Grains of pelmatozoans and small foraminiferal debris occur in some central and western sections such as Havasu and National Canyons and Whitmore Wash, probably because the sediment was derived from marine areas farther west. The only skeletal materials observed in sections of eastern Grand Canyon are small indeterminate plates, tubes, and calcisphaerids. One exception is at Bunker Trail where there occurs a rather coarse pelmatozoan grainstone.

Accretal grains. - Grains of this type are rare in facies C. One exception is recorded from Havasu Canyon (sec. 14) where, locally, pisoliths display rude concentric lamination into which displacive rhombic calcite has grown. Another occurrence is at Kaibab Trail, north, where concentric bands in a clastic dolomitic limestone (wackestone) include coated grains.

Peloidal grains. - Two principal size grades of peloidal material occur in facies $\mathrm{C}$. One grade ranges from 0.5 to $0.12 \mathrm{~mm}$ in diameter (dominantly coarse-silt size) and is typically well sorted. The other size grade ranges from 0.1 to $2 \mathrm{~mm}$ and typically has fair sorting. Grains of these size grades commonly occur together. The genetic terms "pellet" and "intraclast" probably apply to these size classes only in part.

Interbedding of laminated and nonlaminated peloidal limestone is not uncommon in this facies. The laminated units contain more carbonate mud matrix than do the others, and contain little intergranular spar; the nonlaminated limestone constitutes a peloidal packstone or grainstone with abundant intergranular spar.

\section{Grain sizes}

For each thin section of carbonate rock with grains large enough to measure, the relative size of quartz and carbonate grains has been recorded. With peloidal grains, 38 percent were the same size as associated quartz grains, whereas 62 percent were coarser. With skeletal grains, 35 percent were the same size as the associated quartz, whereas 65 percent were coarser. All accretal carbonate grains were coarser than associated quartz.

\section{Depositional textures and fabrics}

Optical similarity between carbonate matrix and the micrite of peloids makes recognition of depositional textures difficult, but carbonate mudstones, wackestones, packstones, and grainstones are all represented in this facies. Some algal accretal limestone occurs in the Kaibab Trail, south, section. Carbonate mudstone is most common in southern Grand Canyon sections, especially at National and Havasu Canyons, and Bass and Hermit Trails (secs. 15, 14, 10, and 9). Grain-supported textures are distributed mostly along the western margins of the facies, near its transition into other carbonate facies (F, G), although a few such textures, together with quartz sandstones, exist near the eastern part of the middle or carbonate rock unit of the Watahomigi Formation. Laminated fabrics are most common in the eastern Grand Canyon although they are also abundant in the National Canyon section.

\section{Mineralogy}

Most of the quartz that occurs in facies $C$ is detrital. The quartz grains are predominantly coarse silt or very fine grained sand. They are largely angular to subangular and are well sorted. Based upon insoluble-residue determinations, much of this facies has an average quartz content of about 18 percent. Seventy percent of all samples contain between 10 and 30 percent insoluble residue. Typical rocks of this facies are sandy or silty peloidal wackestones.

Authigenic quartz in the form of chert or jasper occurs, commonly replacing coarse, blocky, void-filling spar. In facies $C$, cryptocrystalline varieties of quartz occur rarely as fillings in former pore spaces or in fractures and rarely as reworked chert or jasper lithoclasts. In a single specimen, from the Kaibab Trail, north, measured section (8), coarse rhombohedral calcite with wavy extinction was seen to have replaced cryptocrystalline quartz. Replacement of this type probably was late diagenetic, following development of a coarse cement. However, the entire process was prior to erosion of the rock and incorporation of clasts in the Atokan-age conglomerate above the middle or cliff unit of the Watahomigi.

A complete discussion of the various types of calcite in the Watahomigi is beyond the scope of this study; however, one type called vadose silt and crystal silt by Dunham (1969) and rhombic silt by Folk (1973) and microspar rhombs (Folk and Land, 1975) merits some discussion because of its possible genetic implication. This calcite consists of silt-size grains filling voids as internal sediment. It is characteristically geopetal, allowing tops to be determined. In many places this silt-size calcite underlies blocky calcite spar. As suggested both by Dunham and by Folk, it probably results from diagenesis in vadose water or water 
of considerably less than normal marine salinity. This type of calcite occurs in nine measured sections of the Watahomigi, both north and south of Grand Canyon.

Muscovite is an accessory mineral in the fine-grained parts of facies $C$, but it is considerably less abundant than in the overlying formations of the Supai.

Based on 26 calcium-magnesium determinations, dolomite is not a common mineral of this facies. At Tuckup Canyon (sec. 18) one sample of peloidal packstone with silt-size carbonate grains is classed as a calcitic dolomite. Dolomitic limestone forms part of the carbonate rock at Havasu Canyon and Kaibab Trail, north, localities (secs. 14, 8) and magnesian limestone forms part of the lithology at National and Havasu Canyons and Hermit Trail (secs. 15, 14, and 9). The peloidal wackestone fabric of these rocks, as well as the grains interpreted as vadose silt, suggest that dolomitization was in a supratidal environment; however, the small amount of dolomite is difficult to explain in this setting.

\section{Diagenetic modifications}

One of the most conspicuous attributes of facies $C$ is bird's-eye structure consisting of calcite-filled openings or fenestrae. These openings are polygenetic voids, which are larger than normal pore spaces in the rock. Several examples of enlarged intergranular cavities, similar to those in belteroporic fabric described by Sander (1951), have been observed. This fabric may form by vadose water flushing through primary intergranular pore spaces or along desiccation cracks in such a way as to enlarge the pore spaces. Gas bubbles may also form voids. One characteristic of the fabric, as seen in thin section, is that adjacent to large voids or probable water courses the pore walls are more rounded and smooth than are those adjacent to narrow water courses.

Voids of an unusual type, which may or may not share a common origin, seem to have been formed as burrows or bore holes of organisms. Many are vertical, some follow bedding. Many have inner linings of carbonate silt and these linings are subparallel to the walls of the openings. Mostly, inner linings have spar on the sides and many are segmented. The impression is given that spar partially filled the cavities, after which deposition of micrite or siltsize carbonate material occurred. Later came erosion or breakage of the fine coating, and finally a filling with spar.

Definite fractures do not have the same characteristic inner lining as do the cavities. The lining parallel to bedding in some specimens forms a compartmentalization within the large openings. Peloids of the typical 0.05-0.1-mm-size range do not seem to be associated with or to fill any of these burrowlike openings. In at least one example, the silt lining seems to have broken away from the surrounding peloidal rock as if a burrow surface was partially ce- mented and was of a greater strength than the surrounding matrix.

\section{Interpretation of environment}

The aphanitic limestone of facies $\mathrm{C}$ with its characteristic carbonate mud (micrite) and its considerable peloidal content is interpreted as having formed in a lowenergy, shallow-water environment, probably shallow subtidal. Possibly the environment was intertidal or supratidal, although such sites commonly show characteristic tidal flat deposits including well-developed algal stromatolites and channels with distinctive sedimentary structures. In the easternmost part of the Grand Canyon area, strata of facies $C$ seem to onlap a topographic high of the underlying Redwall Limestone (fig. P6). The common occurrence of vadose silt filling cavities and voids in the sediment suggests, although it does not prove, intermittent subaerial exposure. The abundance of carbonate mud matrix among peloids favors the concept of quiet waters.

\section{Facies F-Accretal (algal-foraminiferal) limestone}

\section{Characteristics}

Twenty thin sections representing six measured sections, supplemented by 13 insoluble-residue analyses and 11 calcium-magnesium ratio determinations have been used in preparing this description of facies $F$, an accretal (algalforaminiferal) limestone (grainstone). Uniformity of depositional texture and distinctive character of grains make this facies the easiest to recognize of those comprising the Watahomigi Formation.

The base of facies $\mathrm{F}$ grades into the underlying mixedgrain limestone $(G)$. It occurs exclusively in western Grand Canyon (fig. P6) and intertongues eastward from Separation Canyon (sec. 34) and Whitmore Wash (sec. 22) into red mudstone. Because the mixed-grain limestone $(G)$ apparently is a time equivalent of the carbonate mudstone and peloidal-wackestone $(\mathrm{C})$ to the east, the overlying accretal limestone $(\mathrm{F})$ probably is younger than the carbonate mudstone and peloidal-wackestone facies $(\mathrm{C})$. Thus, the accretal limestone facies may be represented in eastern Grand Canyon by the hiatus below the conglomerate of Atokan age and the underlying aphanitic limestone facies (C) of carbonate mudstone and peloidal wackestone that forms the middle cliff unit.

\section{Grain types}

Peloidal grains are scattered throughout facies $\mathrm{F}$ (recorded in 12 of 20 thin sections), but they are not abundant and are relatively inconspicuous because of the greater size 
of associated accretal grains. Several types of peloids have been recognized, and they range in size from 0.04 to $0.4 \mathrm{~mm}$. Many large peloids contain internal structures that may indicate origin as lithoclasts. Some peloids consist of microspar. Others have a stumpy rodlike shape, and still others appear abraded. Most of the peloids are round to elliptical in cross section.

Bioclastic grains in facies $\mathrm{F}$ are of many varieties. Nearly every thin section contains some skeletal material representative of three or more animal phyla. Pelmatozoan plates, encrusting foraminifers, gastropods, brachiopods, and bryozoans are the most common types. Less common are trilobites (Twin Springs Canyon, sec. 25), ostracodes (Guano Cave, sec. 26), and vertebrate fragments (Hidden Canyon, sec. 30a).

Accretal grains are both the most common and most distinctive grain type of facies F. These grains are composed of Girvanella-like "algae," many of which are intergrown with the encrusting foraminifers Apeterrinella sp. or Hedraittes sp. as determined by L. G. Henbest (written commun., 1963). These intergrowths may or may not encrust skeletal fragments. Similar associations among grains have been called Osagia (Twenhofel, 1919; L. G. Henbest, written commun., 1963; and Toomey, 1969).

An important difference between the Supai accretal grains and those originally described as Osagia by Twenhofel (1919) is that the Supai variety is a spherical to rounded-plate shape, rather than a spherical to fusiform shape. The Supai encrusting foraminifers, furthermore, are associated with grains in 75 percent of the samples studied, whereas such foraminifers are not mentioned in Twenhofel's description. Cores of the grains, where visible, are either rounded or angular. Spar shell fragments constitute the most typical core material, but pelmatozoan plates are also common. Peloidal material and, rarely, microspar, form cores.

The radius of most cores appears to be less than the thickness of the accretionary crust; however, the angle of the thin-section slice with respect to the accretal grain axis may prejudice an observation of this feature. In 75 percent of thin sections examined, the grains are better sorted than are the cores within them. Most deposits of accretal grains exhibit good sorting, implying that the accretionary process accounts for this texture.

\section{Grain sizes}

Most accretal grains range in size from 0.4 to $1.0 \mathrm{~mm}$ (coarse sand size), but a few are very coarse or even granule size. Only a small percentage (20 percent) of the accretal grains have a smooth external surface. In many places where a smooth surface occurs, encrusting foraminifers have attached themselves, causing a rough surface to result. In only two samples (10 percent) were the en- crusting skeletons of the foraminifers truncated by abrasion. Broken material containing encrusting forams was not observed.

\section{Depositional textures and fabrics}

Texture and fabric of the bioclasts of facies $\mathrm{E}$ and $\mathrm{G}$ contribute to an understanding of the nature of transport of the grains. About 80 percent of the samples studied were grainstone (no matrix) and 95 percent were grain-supported. However, only 40 percent of the samples show any stratification. Preferential orientation is a result of the platelike form of many of the cores, and foliation is not apparent when plate-shaped cores (on which accretion material can form) are rare or absent. Field observations indicate that this facies is not cross-stratified in most localities-a single exception being at Twin Springs Canyon.

The accretal limestone (facies F) is the purest carbonate unit in the Watahomigi Formation. Its insoluble-residue content averages 6.6 percent. Mostly the quartz grains are finer grained than those associated with skeletal or peloidal grains of other facies. Although this facies is one of the purest limestones, it is adjacent to facies of red argillaceous mudstone at various places such as the Guano Cave and Separation Canyon measured sections.

\section{Diagenetic modifications}

Jasper "bands" or veins occur in 7 of 20 of the sampled outcrops of facies F. Secondary silica is present in 8 of 20 thin sections, but is volumetrically less important than in other facies. Two types of silica exist: (1) cryptocrystalline silica that in many places replaces pelmatozoan material and, in one locality, replaces spar; and (2) euhedral quartz that occurs as overgrowths on silt or sand grains.

Eleven calcium-magnesium analyses of rocks from facies F showed very pure limestone; only one analysis indicated a magnesian limestone.

Calcite cement typically is a blocky spar (void-filling cement). Only three samples contained silt-size rhombohedral cement (Folk, 1962) or vadose silt (Dunham, 1969). These samples were from Guano Cave, Snap Canyon, and Hidden Canyon (fig. P6, secs. 26, 27, 30). No prismatic calcite cement was noted in this facies.

Examples of animal burrows or of spar-filled openings, typical of the carbonate mudstone and peloidal limestone of facies $C$ and $G$, were few.

\section{Interpretation of environment}

The association in facies $\mathrm{F}$ of algae and of certain invertebrate fossils seems to imply deposition in shallow marine waters. However, this association might have resulted from similar temperatures, salinities, or other ecological 
factors, rather than from water depth. Accretal grains of the type represented, like ooids, commonly are considered to be the product of high-energy conditions. On the other hand, lack of cross-stratification and the general absence of abrasion on delicate encrusting foraminifers, oppose this interpretation.

\section{Facies G-Mixed-grain limestone}

\section{Characteristics}

The mixed-grain limestone (facies $\mathrm{G}$ ) of the Watahomigi Formation consists of rock types that are not easily characterized by a simple lithologic description. Diversity of grain form is one of the most unifying attributes of this facies. The rock contains abundant peloids (about 75 percent of all samples), numerous skeletal fragments (in approximately 88 percent of the samples), and accretal grains, mostly biogenic (in about 35 percent of the samples).

Limestones of facies $G$ have a considerable range in the amount of lime-mud matrix included and contain both grainstones and packstones (table P1).

Mixed-grain (peloidal, skeletal, accretal) limestone of facies $G$ merges into other facies in all directions. At Iceberg Canyon (fig. P6, sec. 31) it overlies crystalline dolomite (facies $\mathrm{H}$ ); at Guano Cave, Twin Springs Canyon, Hindu Canyon, and Blue Mountain Canyon, measured sections $26,25,35$, and 19, it grades downward into conglomerate and red mudstone of facies A; at Bridge Canyon (sec. 35) it overlies relatively pure bioclastic grainstone and packstone (facies E). Farther north it overlies red mudstone (facies A) and crystalline dolomite (facies $\mathrm{H}$ ). To the east at Whitmore Wash and near National Canyon sections 22 and 15 interbedded relations suggest that it is laterally equivalent to the carbonate mudstone and peloidal wackestone of facies $C$ of eastern Grand Canyon.

\section{Grain types}

Shapes of peloids in facies $G$ constitute a wide range including spherical, ovoid, and irregular. Many peloids in the $0.1-0.2-\mathrm{mm}$-size class contain vague internal structures, indicating an origin other than as fecal pellets. Many peloids of large size within the same thin section have different fabrics. Some contain quartz silt, whereas others are composed of translucent microspar. Still others are composed of very opaque micrite. In general, peloids of this facies are not well sorted like those in the carbonate mudstone of facies $\mathrm{C}$. Almost all associated quartz grains are finer than the peloidal grains.

Presence and diversity of fossil fragments help to distinguish facies $G$ (mixed-grain limestone) from its eastern lateral equivalent-the carbonate mudstone of facies $C$.
Nineteen of 34 samples had three or more animal phyla represented within a sample, and 83 percent had at least one phylum included. Compared to other facies in the Watahomigi Formation, varieties of skeletal components are numerous.

Pelmatozoan plates are the most common bioclastic forms in the mixed-grain facies. Other major skeletal constituents are small fragments of foraminifers, undifferentiated mollusks, brachiopods, bryozoans, and algae, mostly Girvanella types. Echinoid spines, ostracodes, calcisphaerids, trilobites, unidentified pelmatozoan plates, gastropods, and vertebrate fragments are less numerous and are only minor constituents.

Accretal grains are the least common grain type in facies G; they occur in minor amounts in about one-third of the thin sections. Accretal grains of algae and foraminifers are the most common types; micrite-coated skeletal grains constitute the remainder of the accretal grains in this facies.

\section{Grain sizes}

Two major size-groups of peloids exist in the mixedgrain facies $(G)$. One is small, typically ranging from 0.05 to $0.1 \mathrm{~mm}$; the other is larger, ranging from 0.1 to $0.2 \mathrm{~mm}$. Other peloids are rare. One very small, well-sorted variety ranges in size from 0.04 to $0.05 \mathrm{~mm}$ and has a rounded cylindrical shape. This rare type has been found only at Hindu Canyon (sec. 35).

Only a few samples of facies $G$ contain quartz grains equal in size to the carbonate grains (peloids). In more than 90 percent of the samples, carbonate grains are coarser than quartz. The average insoluble-residue (quartz-grain) content of this facies is $\mathbf{1 1 . 4}$ percent; however, more than two-thirds of the samples contain less than 10 percent insoluble residue.

\section{Depositional textures and fabrics}

About two-thirds of the thin sections of this facies (G) are from grain-supported limestone; however, more than two-thirds contain appreciable amounts of carbonate mud. Packstone (containing carbonate mud) is more common than grainstone (lacking carbonate mud). A plotting of the grain-support relationships of the facies (fig. P5) shows that in the west, south, and north parts of the Grand Canyon region, more grains are grain-supported than otherwise. Only in the east are more than 50 percent of the samples mud-supported.

Most beds of this facies are horizontally stratified.

\section{Mineralogy}

Detrital quartz of coarse silt size makes up most of the insoluble-residue content of this facies. Some of the quartz is very fine grained sand, much of it is well sorted and 
angular to subangular. Secondary silica is considerably less common in this facies than in the carbonate mudstone and peloidal wackestone of facies $C$. Some reworked clasts of chert occur at Whitmore Wash and total replacement by chert of a peloidal wackestone was noted at Guano Cave. Replacement by small fine-grained euhedral crystals of quartz at both Guano Cave and Iceberg Canyon is recorded. At Iceberg this replacement is most concentrated near fractures, suggesting that the euhedral quartz is late diagenetic to epigenetic in origin. A small amount of interstitial cryptocrystalline silica occurs at Twin Springs Canyon.

The most common interstitial cement is blocky calcite spar. Although some microspar is present (interpreted as the vadose silt of Dunham, 1962), it is less common in this facies than in the microcrystalline, lateral equivalent (facies C) to the east. Dolostone is rare. Peloidal carbonate rocks (wackestones) at Iceberg and Hidden Canyons were determined to be calcitic dolostone and dolomitic limestone, respectively. The only pure dolostone is a coarsely crystalline rock from the Guano Cave locality. This sample is anomalous, for $\mathrm{Ca}-\mathrm{Mg}$ analyses of $\mathbf{1 7}$ other samples indicate a predominant calcite composition for the carbonate part of the mixed-grain facies.

\section{Diagenetic modifications of fabric}

Chief among processes of modification represented in lateral equivalents of the mixed-grain facies $(G)$ were those that formed openings. Micrite-filled linear burrows and borings are also numerous. In the mixed-grain facies, however, such structures are rare or absent. Belteroporic fabrics are also missing.

Porosity is difficult to appraise in the mixed-grain facies. Carbonate mud fills a substantial amount of the intergranular areas. Because peloids are the major grain constituent, an interconnected porosity could not readily be formed from molds of dissolved skeletal debris. The absence of openings suggests that subaerial exposure was not characteristic of this facies.

\section{Facies $\mathrm{H}$-Coarsely crystalline dolostone}

\section{Characteristics}

Both chemical analyses and stained thin sections have been used to identify dolostones of the Watahomigi. Many dolostone beds are a light cream color as seen in the field, in contrast to other carbonate rocks that have grayer tones. Most dolostones of the Watahomigi are coarsely crystalline.

\section{Texture and fabrics}

Floating quartz grains and phosphatic skeletal parts attest to a replacement origin. In many places where silicification is present, the primary limestone fabric of the accretal facies $(F)$ is readily seen in the silicified rock, indicating that dolomitization came after silicification. Chemical analyses show that most of the dolomitized rocks are true dolostone, but some samples are dolomitic limestone and some are calcitic dolostones.

\section{Interpretation of genesis}

The crystalline dolostone facies $(\mathrm{H})$ occurs only at the Iceberg, Snap, and Andrus Canyon measured sections (31, 27, and 24). At Iceberg Canyon it overlies a red mudstone that forms the lower slope unit of the formation, but northeastward toward Snap Canyon, the basal red mudstone unit is progressively thinner as it onlaps a high area of the underlying Redwall Limestone. Finally, at Snap Canyon (sec. 27) crystalline dolostone rests on the Redwall Limestone. Farther east, at Andrus Canyon, thin beds of crystalline dolostone are interbedded with red argillaceous mudstone. This interbedded relationship suggests intertonguing, and the dolostone apparently is a lateral equivalent of the argillaceous mudstone. Stratal correlation between Iceberg Canyon and Guano Cave sections (31 and 26) implies that the crystalline dolostone may also be a lateral equivalent of the lower mixed-grain limestone facies $(G)$ in that area.

\section{FACIES OF THE MANAKACHA FORMATION}

\section{Stratigraphic relations of facies}

Throughout much of the Grand Canyon region, the Manakacha forms two distinct topographic units (fig. C5): the lower unit is a massive, persistent cliff commonly referred to as the "lower cliff unit of the Supai"; it is overlain by a relatively small slope called the "middle slope unit of the Supai."

The massive cliff unit is largely formed of resistant calcareous sandstone and sandy limestone, cross-stratified on a medium-to-large scale. In contrast, the weak upper slope unit consists mostly of red mudstone in eastern Grand Canyon, and of bioclastic limestone in the west. Between the eastern and western areas, near Tuckup Canyon, Toroweap Valley, and Whitmore Wash (secs. 18, 21, and 22) in central Grand Canyon, the slope unit seems to be largely or entirely missing as shown by a relative thinness of the formation at those localities (fig. P8). This local 

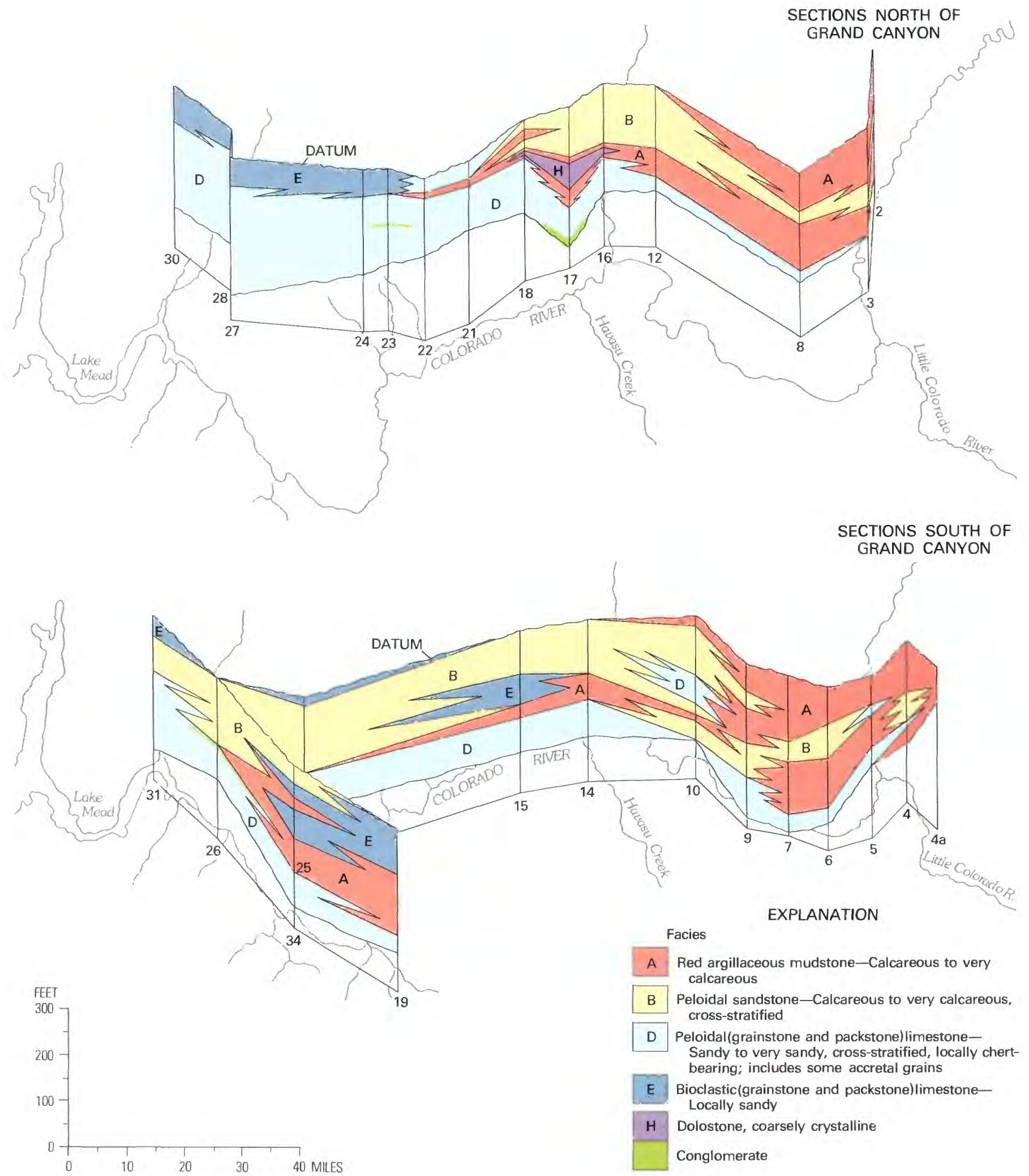

FIGURE P8,-Fence diagrams of east-to-west sections showing distribution of facies of the Manakacha Formation, Grand Canyon region. Arizona. Sandstone and limestone designations determined by percent insoluble residue. Limestone is rock with less than 50 per- cent insoluble residue; sandstone, greater than 50 percent insoluble residue. Number at base of each vertical line refers to measured section locality as shown on figure A1. 

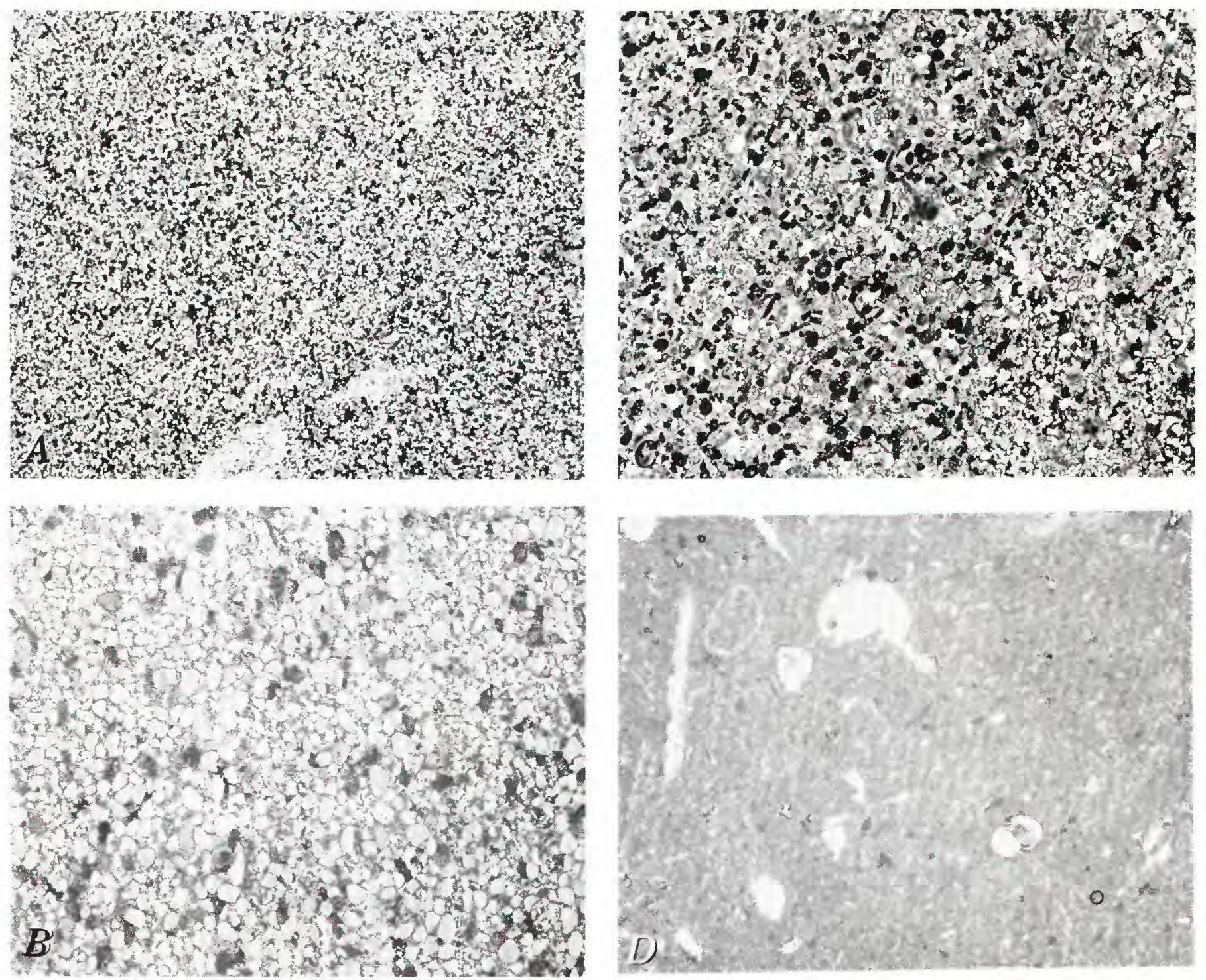

FIGURE P9.-Photomicrographs $(\times 10)$ of typical specimens from principal facies of Manakacha Formation. A, Facies A, red argillaceous mudstone, Blue Mountain Canyon, sec. 19. B, Facies B, calcareous pelcidal sandstone, fine- to medium-grained, Thunder

absence of the slope unit probably is the result of postAtokan erosion in that area.

\section{Conventional facies- Stratigraphic relations}

Four of the principal facies recognized in the Supai Group compose the Manakacha Formation of the Grand Canyon. These are: A, red argillaceous mudstone; B, peloidal, calcareous to very calcareous sandstone; $\mathrm{D}$, sandy to very sandy, peloidal limestone; and $\mathrm{E}$, bioclastic limestone, locally sandy.

The distribution of facies in the Manakacha (fig. P8) illustrates well the trends, both horizontally and vertically,

River Trail, sec. 12. C, Facies D, peloidal sandy limestone with some bioclastic grains, Toroweap Valley, sec. 21A. D, Facies E, bioclastic limestone with micritic matrix, Hidden Canyon, sec. 30.

in proportions of detrital sediment to carbonate sediment and in high-energy deposits to low-energy deposits.

\section{Facies A-Red argillaceous mudstone}

The red argillaceous mudstone constituting facies $\mathrm{A}$ in the Manakacha Formation commonly is calcareous to very calcareous. As seen in thin section, much of this mudstone contains a large percentage of silt-size quartz grains that are angular and well sorted, and that occur in a matrix of dark clay or ferruginous material (fig. P9).

This facies occurs extensively in the eastern part of the area (Blue Spring, Bunker Trail), but also is well repre- 
sented in the southwestern part, as in the vicinity of Blue Mountain Canyon. The distribution pattern means that the sources of mud probably were to the southeast and south, as confirmed by tongues of red mudstone that extended from these areas outward across an embayment of Atokan age that connected the Cordilleran geosyncline in the west with the Paradox basin to the northeast (fig. D4).

\section{Facies B-Peloidal, calcareous to very calcareous sandstone}

Peloidal, calcareous to very calcareous standstone of facies B (fig. P9) is a highly cross-stratified rock consisting largely of quartz sand, but containing peloidal limestone grains in various proportions and, in many places, grading into sandy or very sandy limestone of facies D (fig. P8). The boundary between these facies is considered to be where 50 percent of the rock is $\mathrm{HCl}$-soluble and 50 percent $\mathrm{HCl}$-insoluble. Many strata are close to this boundary and, therefore, may be similar in appearance even though some are sandstone and others limestone; they can be differentiated with assurance only through insoluble-residue measurements.

Facies B, and also facies D into which B grades laterally, contain some skeletal and accretal grains as well as the more abundant and characteristic peloidal grains.

Accretal grains, although uncommon, are represented by sparse oolitic grainstones in facies $B$ and $D$ at a few localities in the Manakacha as at Blue Mountain Canyon, National Canyon, Pigeon Wash, and Hidden Canyon (secs. 19, 15, 28, 30).

The peloids seem to be polygenetic. They are not restricted to a specific size range in a given area as are those of the middle unit in the Watahomigi, but most of them are similar in size to the quartz grains with which they are associated, suggesting similar conditions of sorting.

Peloids in this facies commonly exhibit an internal structure suggesting an origin either as rounded intraclasts or as micritized small foraminifers. In a few places micritized small foraminifers compose most of the rock.

Bioclastic grains in this facies (B) mostly record transportation with abrasion of particles. Pelmatozoan plates-many well rounded-and small foraminifers in particular, seem to have undergone extensive transport and to have accumulated as concentrations more than did most other skeletons.

\section{Facies D-Sandy to very sandy peloidal limestone}

Limestone of facies D (fig. P9C) is highly cross-stratified like sandstone of facies B. It differs from that facies in containing a greater amount of carbonate peloids and fewer quartz grains. It is grain supported and is designated as either grainstone or packstone (table P1). In brief, it may be without a carbonate mud matrix or may contain carbonate mud in moderate amounts. Some limestones of this facies are jasper-bearing.

Facies B and facies D, which together represent essentially all of the conspicuously cross-stratified rocks of the Manakacha, extend from east to west across the entire region as shown in a cross section (fig. P8). From this illustration, it is apparent that the sandstone of facies B is more concentrated in the east and the limestone (facies D) in the west. However, also evident from the diagram, there is a progressively greater sandiness upward in the formation, resulting in facies $B$ overlying facies $D$ in most places.

Carbonate grains in facies $D$ are like those of facies B described in the preceding section but are more numerous (>50 percent). In both facies, the grains consist dominantly of peloids and, to a small extent, of skeletal debris and accretal types.

\section{Facies E-Bioclastic limestone}

Limestone of facies $E$ is skeletal and commonly referred to as bioclastic (fig. P9D). It may or may not contain a carbonate mud matrix, but generally is grain-supported and includes both grainstone and packstone. Locally it contains some quartz sand. This facies occurs only in the upper part of the formation and is distributed throughout the western and southwestern parts of the Grand Canyon area (fig. P8).

\section{Alternative facies classification}

The transitional nature of the highly cross-stratified units of sandstone and limestone that form a major part of the Manakacha is apparent both in the field and in thin section. Because of this gradation from one rock type into another, an alternative facies classification was devised by Walter Pierce while making petrographic studies. In this classification the relatively pure sandstone $(>70$ percent quartz sand) and the relatively pure peloidal limestone ( $>70$ percent peloidal carbonate) are considered as distinctive facies $\left(B^{\prime}\right.$ and $D^{\prime}$, respectively). A gradational mixture of calcareous peloidal sandstone $(>30$ percent peloidal carbonate) and sandy peloidal limestone $(>30$ percent quartz sand) is considered facies $B^{\prime} D^{\prime}$.

The most notable feature of this classification that is not apparent from the more orthodox classification is the widespread distribution and abundance of facies $B^{\prime} D^{\prime}$, which consists dominantly of cross-stratified sandstone and peloidal limestone with little or no matrix of carbonate mud. Secondly, relatively pure sandstone of facies $B^{\prime}$ is largely restricted to the area of middle Grand Canyon, whereas the rocks of facies $D^{\prime}$, relatively pure limestone 
with little quartz sand, are mostly in western Grand Canyon and, to a small extent, in eastern Grand Canyon. Argillaceous mudstone (facies A) occurs principally along the southern and eastern margins.

The several types of grain-peloidal, bioclastic, and accretal-that occur in facies $\mathrm{B}^{\prime} \mathrm{D}^{\prime}$ and in $\mathrm{D}^{\prime}$ are the same as those described earlier under the title "facies B" (Manakacha Formation). In texture, grain form, and mineralogy the carbonate rocks are alike, in general, throughout the region so the difference in classifications is one involving the arbitrary boundaries selected to show the proportions of quartz sandstone to peloidal limestone. In the alternative classification suggested by Pierce, the 30-percent and 70-percent boundaries are believed to approximate the limits of carbonate-grain support and quartz-grain support, respectively. Further, distribution of the remaining intermediate 40 percent, represented by facies $B^{\prime} D^{\prime}$, emphasizes the extent of transition between soluble and insoluble fractions.

\section{Facies $B^{\prime} D^{\prime}$, alternative}

The mixed quartz sand and carbonate peloids of facies $B^{\prime} D^{\prime}$ are characterized by cross-stratification throughout, and by a lack of algal-foraminiferal grains. Both of these features imply a high-energy environment. The quartz is largely angular to subangular and is well sorted, especially within individual laminae. Rounded jasper and chert grains are numerous, one or two occurring in nearly every thin section. Silt-size peloids and quartz grains are numerous and muscovite flakes are common accessories.

Cross-stratified rocks of facies $\mathrm{B}^{\prime} \mathrm{D}^{\prime}$ in the Manakacha apparently differ from those of the overlying Wescogame Formation. In the Manakacha, bimodal quartz is relatively rare, but it is common in the Wescogame. In the Manakacha, secondary silica in the form of jasper, both replacing carbonate rock and locally filling vugs, is especially common; it is far less abundant in overlying formations.

\section{Interpretation of facies}

Interpretation of the facies distribution described above strongly suggests several features of the depositional environment and paleogeography during Atokan time. First, the Grand Canyon embayment was the recipient of an abundance of relatively high-energy deposits (facies B', quartz-sand; and $\mathrm{D}^{\prime}$, peloidal carbonates) as illustrated by the abundance of cross-stratification and by the relatively small amount of carbonate mudstone (facies $\mathrm{C}$ ), either as matrix or in beds. Second, areas of pure carbonates (facies $\left.D^{\prime}\right)$ in the extreme west and, to a small extent in the east, suggest marine connections with the Cordilleran seaway and the Paradox basin, respectively, whereas the central area of pure sand (facies $B^{\prime}$ ) reflects greater distance from the permanent marine bodies. Finally, areas of argillaceous red mud (facies A) to the south and southeast probably indicate proximity to sources along the southern margins of the embayment (fig. D4).

\section{FACIES OF THE WESCOGAME FORMATION}

\section{Stratigraphic relations of facies}

The Wescogame Formation of the Grand Canyon consists of two dominantly detrital facies and two of carbonate sediments. The detrital strata are referred to facies A of the Supai Group, composed of red argillaceous mudstone with some carbonate mudstone, and to facies B, which is a cross-stratified calcareous sandstone. Facies of the carbonate sediments consist of facies $\mathrm{E}$, a sandy to very sandy, cross-stratified limestone with bioclasts, but no carbonate-mud matrix (grainstone), and facies $\mathrm{H}$, which is thin-bedded dolostone. Facies $\mathrm{H}$ includes some skeletal limestone (packstone of facies E).

The distribution of these facies is indicated in the fence diagrams, figure P10. Cross-stratified calcareous sandstone of facies B comprises a major part of the formation throughout the area. In the west, this merges into the very sandy bioclastic limestone of facies $E$, which likewise is conspicuously cross-stratified. In the extreme northwest at Hidden Canyon (sec. 30), the lower part of the formation is dolostone (facies $\mathrm{H}$ ), but no readily apparent explanation is available for its presence in that area. Red argillaceous mudstone of facies A occurs almost exclusively in eastern Grand Canyon where it probably developed in areas of low energy bordering channelways that connected the Cordilleran marine waters with those of the Paradox and Sonora basins during Virgilian time (fig. D7). In the southeast, the argillaceous mudstone sections are thicker than average for the Wescogame so may represent an area of deltaic or alluvial accumulation.

Deposits of jasper, both interbedded and cross-cutting, which are abundant in the two underlying formations of the Supai Group, are nearly absent in all facies of the Wescogame. The significance of this feature is not known, but probably it stems from the general scarcity of carbonate rocks in the Wescogame in all but the westernmost areas. 

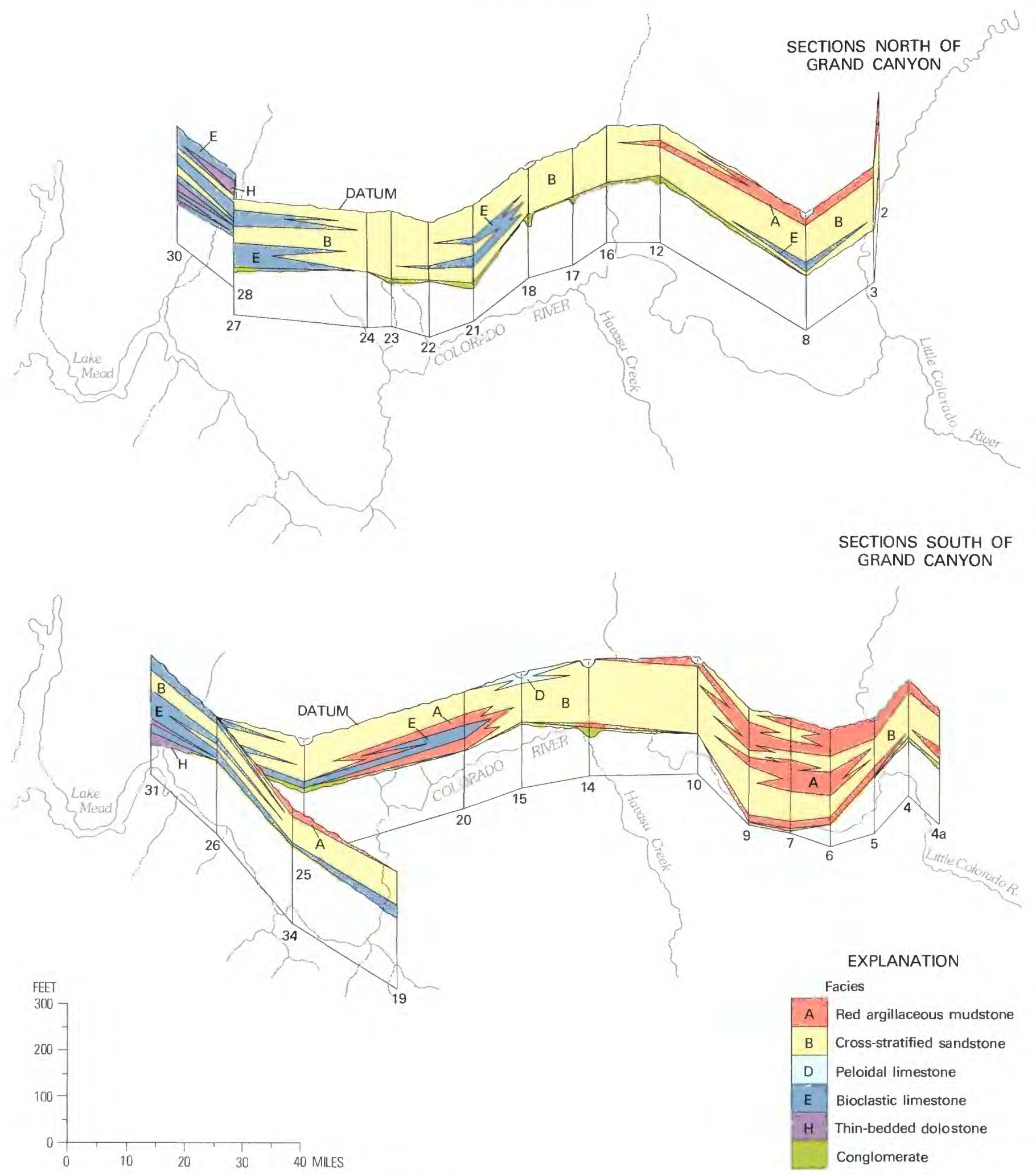

FIGURE P10.-Fence diagrams of east-to-west sections showing distribution of facies of the Wescogame Formation in Grand Canyon region Arizona. Number at base of each vertical line refers to measured section locality as shown on figure A1. 


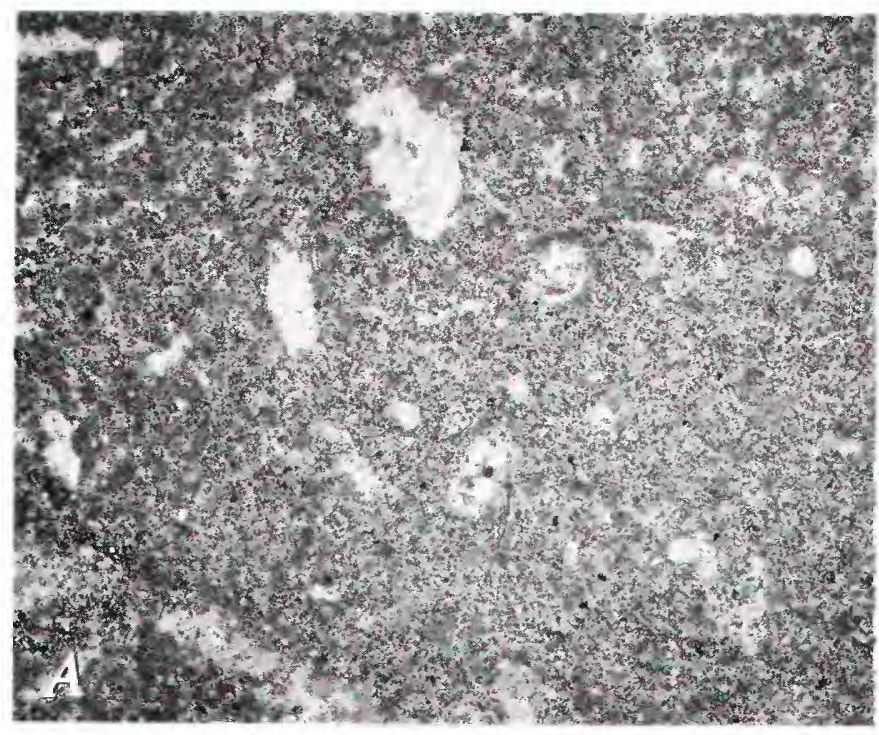

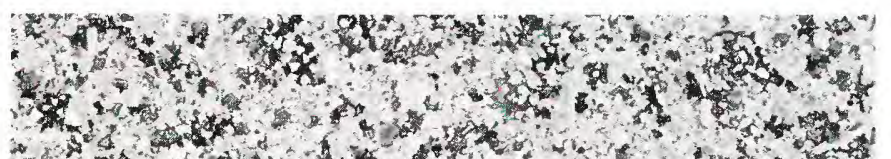

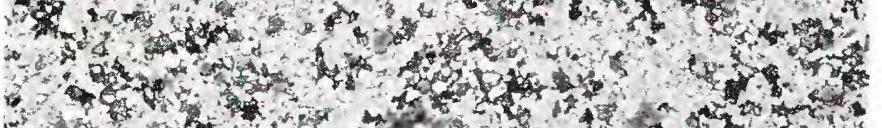

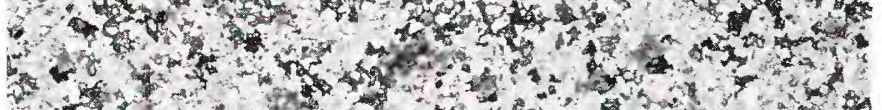
C.

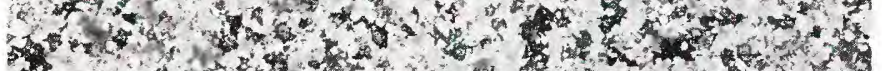

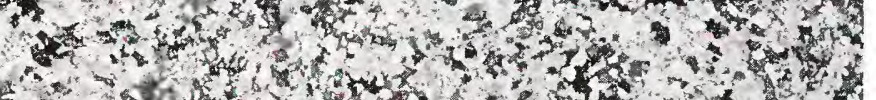

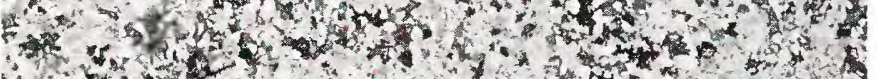

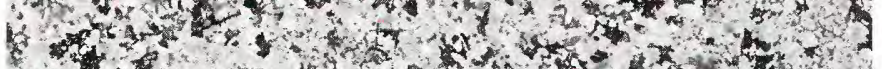

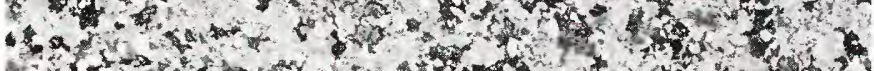

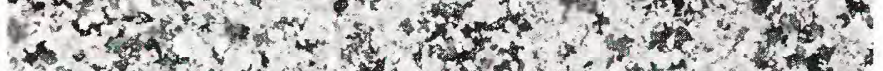

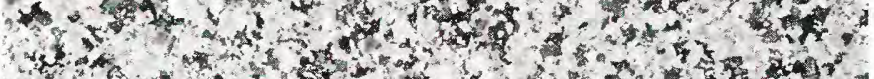

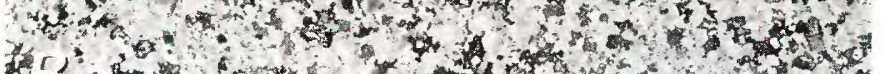

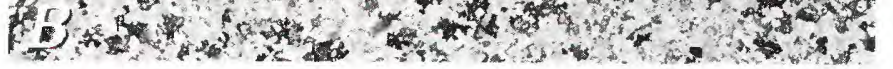

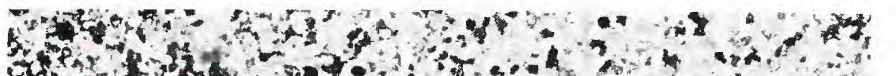
(3)

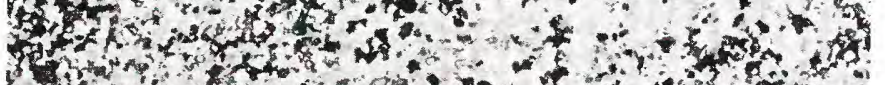
If

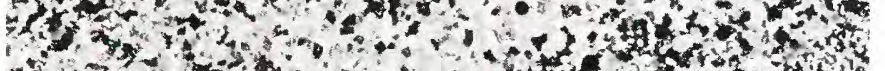

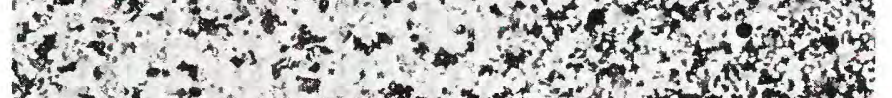

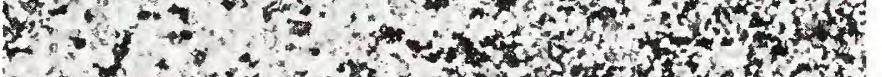

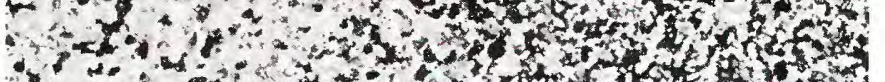

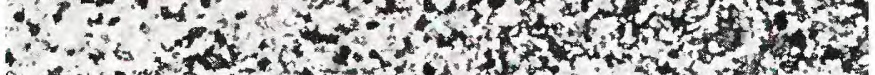

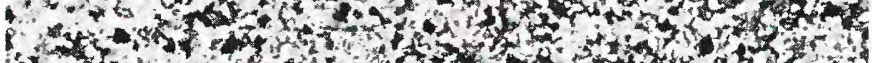

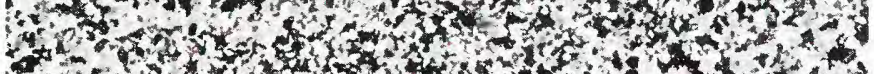

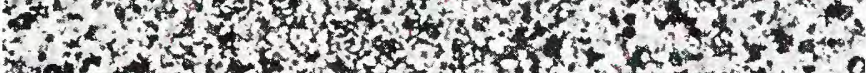
20

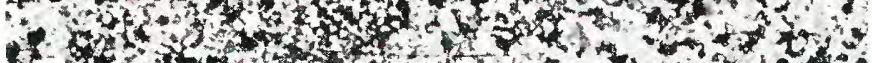
4.
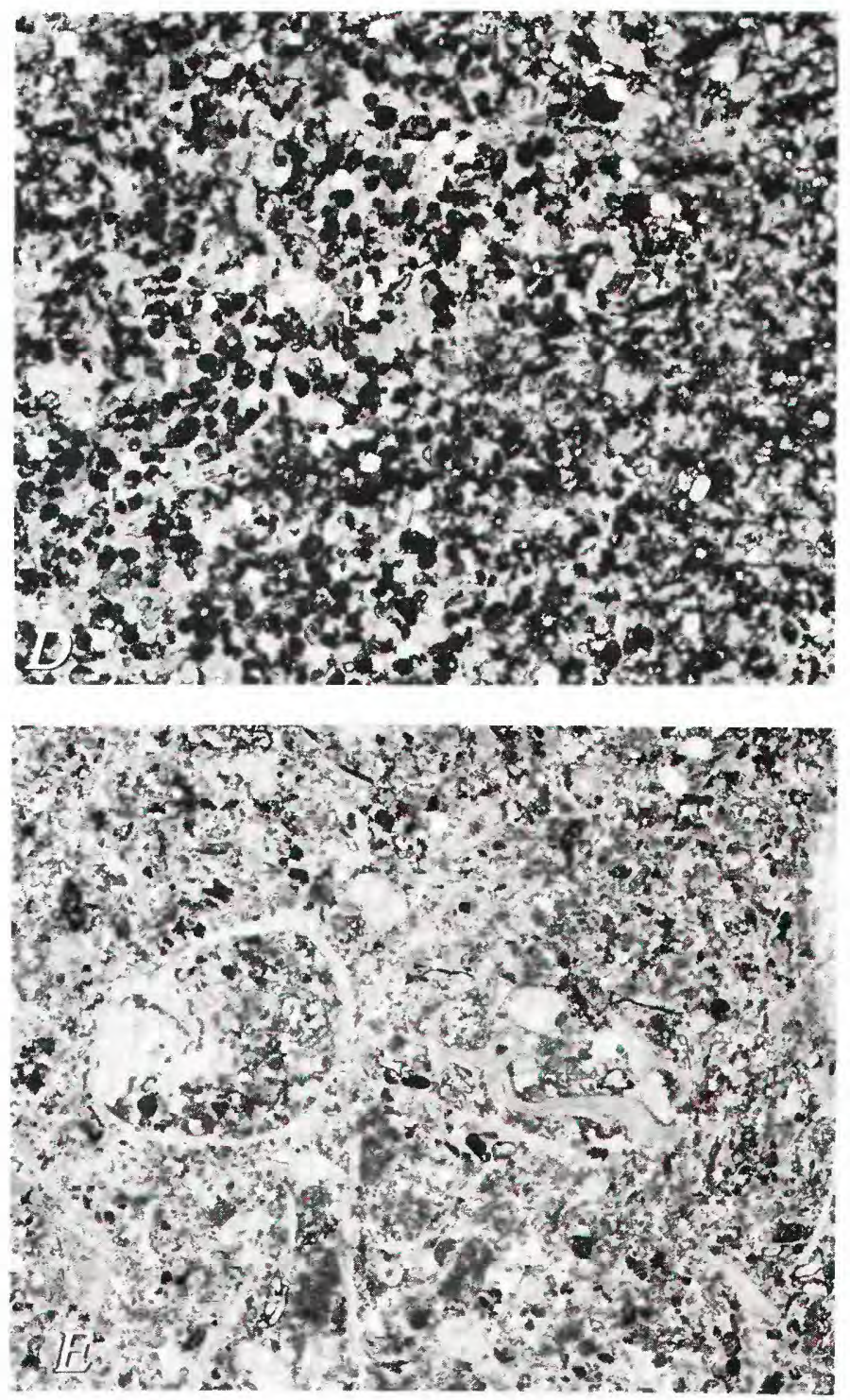

FIGURE P11.- Photomicrographs $(\times 10)$ of principal facies of Wescogame Formation recognized in Grand Canyon. A, Facies A, red argillaceous mudstone and carbonate mudstone, Kaibab Trail, south, sec. 7. B, Facies $B$, fine-grained calcareous to very calcareous sandstone; cross-stratified. Hermit Trail, sec. 9. C. Facies B, very fine grained calcareous sandstone, Hermit Trail, sec. 9. D. Facies E, sandy to very sandy, bioclastic limestone (grainstone); cross-stratified, Snap Canyon, sec. 27. E, Facies E-H, bioclastic limestone (packstone) interbedded with thin-bedded dolostone, Guano Cave, sec. 26.

\section{Characteristics of facies}

Facies $A_{;}$red argillaceous mudstone.-Argillaceous mudstone of facies $\mathrm{A}$ is restricted to the eastern part of Grand Canyon. The red color of this rock appears in thin section to result from ferruginous matrix in a quartz siltstone. The quartz grains are angular and medium- to 
well-sorted (fig. P11). Muscovite is a common accessory mineral. Some aphanitic limestone (carbonate mudstone), mostly nonlaminated, is associated with the mudstone. In the lower part of the Bunker Trail section (5), laminated carbonate mudstone (micrite) contains spar-filled fenestral areas; at Twentynine Mile Canyon (sec. 2) in the upper part of the section, belteroporic fabric as described by Sander (1951) is present.

Facies $B$; calcareous to very calcareous, cross-stratified sandstone. - This is the most widespread facies of the Wescogame Formation. It consists of quartz sand, which is mostly very fine grained to fine grained and subangular, and it has fair to good sorting on the Payne scale. It grades into bioclastic limestone of facies $\mathrm{E}$ to the northwest and west.

In the western third of Grand Canyon much of the quartz in this facies is bimodal, with the inclusion of a sparse medium- to coarse-grained sand component most of which is well rounded. These large quartz grains are conspicuous but not volumetrically important. Rounded chert grains are a common accessory.

The carbonate content of facies B results both from calcite cement and from allochthonous grains. Bioclastic grains are the most common type, but peloidal grains also occur. Pelmatozoan plates are numerous and widespread. Calcite cement is especially common in the southeastern measured sections.

Many quartz grains contain postdepositional quartz overgrowths. Secondary silica preceded calcium carbonate in the cementation process. Where quartz overgrowths are common, marine detritus such as peloids and bioclasts seem to be scarce or absent.

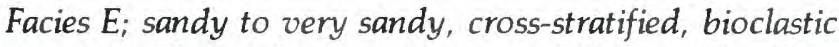
limestone.-This is the most common lithology (fig. P11) in the northwestern area of Wescogame distribution. The quartz sand resembles sand of facies B. Bimodal sand is locally common and a grain-supported texture is characteristic. Most grains are skeletal fragments, but in approximately one-third of the thin sections examined, high proportions of peloids occur. Two measured sections included accretal grains: oolitic grainstones at Hidden Canyon (sec. 30) and oolitic packstones at Pigeon Wash (sec. 28). Numerous fragments of encrusting foraminiferal tests occur in thin sections. The surfaces from which these tests were dislodged probably were flat.

Facies $E-H$; bioclastic limestone and thin-bedded dolostone.-In parts of the westernmost Grand Canyon area, facies $E$, which consists of sandy bioclastic limestone; commonly cross-stratified, is closely associated with thinbedded dolostones of facies $\mathrm{H}$. Where this combination occurs the term facies $\mathrm{E}-\mathrm{H}$ is applied, indicating that it is not practical to separate these types at the scale used.

Because the largely bioclastic grains of facies $\mathrm{E}$ are rounded and form cross-strata, they imply an environment of high energy. The genesis of the associated thin-bedded dolostone has not been determined.

\section{FACIES OF THE ESPLANADE SANDSTONE AND PAKOON LIMESTONE Stratigraphic relations of facies}

Seven of the facies characteristic of the Supai Group are recognized in the Esplanade Sandstone and Pakoon Limestone (McNair, 1951). The cross-stratified calcareous sandstone, referred to as facies $\mathrm{B}$, constitutes the dominant rock in the Esplanade throughout nearly all of the Grand Canyon region (fig. P12). This sandstone forms the massive cliff that underlies the platform known as the Esplanade.

The lower half of the main sandstone body represented by facies B of the Esplanade Sandstone projects westward as tongues into carbonate rocks, facies $E$ and $H$, of the Pakoon (fig. P12). These Pakoon facies are well developed along the Grand Wash Cliffs in extreme western Grand Canyon (measured secs. 27, 28, and 30), at Iceberg Canyon (sec. 31) and at Guano Cave (sec. 26). Farther east, at Andrus Canyon (sec. 24), Separation Canyon (sec. 34) and elsewhere, they occur only as tongues within thick sandstone units of the Esplanade.

Other distinctive facies of the Esplanade Sandstone and Pakoon Limestone are the bedded gypsum deposits that form a large lens (facies J) within massive sandstones in the northwestern part of the area, from Toroweap Valley (sec. 21) to Andrus Canyon (sec. 24), and the dolomitic sandstone of facies I in the lower part of the formation in the same general area. Facies A, composed largely of reddishbrown to pale-reddish-brown mudstone and siltstone is distributed largely in the eastern Grand Canyon area, partly as the basal slope-forming unit of the Esplanade and partly interbedded with massive sandstones of facies B, especially in the upper part of the formation.

\section{Facies A-Red argillaceous mudstone}

This facies consists of fine-grained detrital sediment, including both siltstone (composed largely of silt-size particles) and mudstone (defined here as a mixture of clay-size material and silt grains). Mostly this facies is argillaceous but, in some places, it is also calcareous. The color of the mudstone is reddish brown, ranging from pale to moderate to dark; where relatively pure, the siltstone tends to be reddish orange. 


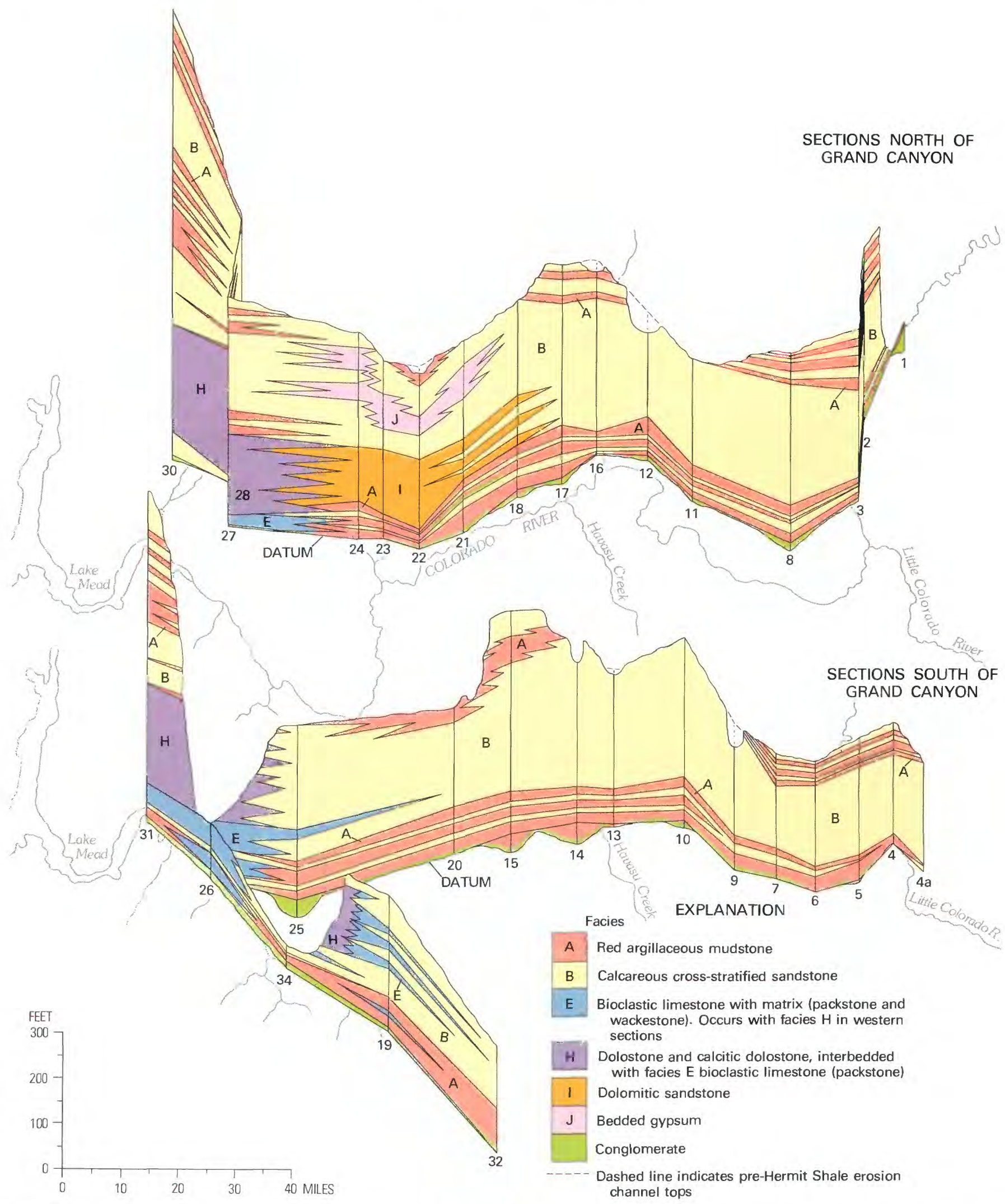

FIGURE P12.-Fence diagrams of east-to-west sections showing distribution of facies of the Esplanade Sandstone and Pakoon Limestone (McNair, 1951) of Grand Canyon region, Arizona. Number at base of each vertical line refers to measures section locality as shown on figure A1. 
Mudstone and siltstone of facies A of the Esplanade commonly are structureless, but in some places consist of thin flat beds and elsewhere have irregular wavy bedding. Throughout the Grand Canyon region this facies forms the basal slope unit, 40-100 ft thick, except in the far western area where the rock consists largely of limestone and forms the basal slope unit of the Pakoon. Thin units of facies A occur also in the upper cliff-slope unit of the Esplanade, alternating with thick cross-stratified sandstones of facies $\mathrm{B}$ at Twentynine Mile Canyon, Bunker Trail, and elsewhere in the northeastern and eastern parts of the region.

Minor structures, including mud pellets, rain pits, shrinkage cracks, and asymmetrical ripple marks, also fragments of land plants, especially the coniferous genus Walchia and the algae Rivularities sp., give some suggestions concerning the depositional environment. Apparently facies $A$, at least locally, represents continental sedimentation.

From the standpoint of geographic distribution, most of the finest detritus-the mudstones-occur in eastern Grand Canyon and to the northeast in Marble Canyon. They form most of the basal slope unit, $40-100 \mathrm{ft}$ thick, above the basal conglomerate of the Esplanade and below the main sandstone cliff. They also occur in the upper part of the main cliff unit, especially in Marble Canyon, where thin units alternate with thick sandstone beds. Some mudstone beds extend westward into central Grand Canyon at Toroweap and Prospect Valley sections (21, 20), but farther west the stratigraphic position in the basal Esplanade slope unit is occupied by friable, very fine grained sandstones.

\section{Facies B-Peloidal \\ cross-stratified sandstone}

This facies constitutes a major part of the Esplanade Sandstone and is by far the most widespread and characteristic rock in the formation. It consists of calcareous cross-stratified sandstone (fig. P13A) that is largely a moderate reddish orange, but ranges into weak orange and very pale orange according to the rock color chart (Goddard, 1948). The sandstone weathers to a resistant cliff supporting the prominent bench or platform known as the Esplanade in the upper walls of Grand Canyon.

The sandstone of facies $B$ of the Esplanade is predominantly very fine grained as determined by many mechanical analyses and by a large number of thin-section measurements. In a very few places the mean grain size is fine and in some other localities a high percentage of silt is present. In most places the sorting is good. Quartz grains are rounded to subrounded except where they are of silt size; those are mostly angular to subangular.

Although facies B is composed dominantly of quartz sand, it includes scattered grains of bioclastic calcium car- bonate in most measured sections. Especially numerous among the bioclasts are foraminifers and crinoidal debris. With a calcareous cement, the rock typically contains 10-50 percent calcite so is classed as a calcareous to very calcareous sandstone; similar rock with a dolomitic cement, occurring in the lower half of the formation from Tuckup Canyon (sec. 18) to Andrus Canyon (sec. 24), is designated as facies $\mathrm{I}$.

\section{Facies E-H-Bioclastic limestone and calcitic dolostone}

Bioclastic limestone typical of facies $\mathrm{E}$ and dolostone or calcitic dolostone of facies $\mathrm{H}$ are interbedded and are so closely associated in some places that they are shown as combined in parts of figure P12. They occur together, especially in southwestern parts of the Grand Canyon region where they form the lower part of the Pakoon Limestone and tongues of the Pakoon within the Esplanade. Generally, limestones of facies E-H are easily distinguished from those of underlying formations in the Supai Group by (1) a lack of accretal grains, (2) a relatively small number of peloidal grains, and (3) a predominance of skeletal grains.

Skeletal grains of facies E mostly are contained in a matrix of carbonate mud. In some places they are grainsupported (packstone), but elsewhere are mud-supported (wackestone). The grains commonly are well sorted and rounded and presumably were formed in an environment of high energy, directly above gravels of the basal conglomerate of the Esplanade that mark the beginning of a major transgression. Especially abundant among the grains are fragments of pelmatozoans.

The dolostone and calcitic dolostone of facies $\mathrm{H}$, which are intimately associated with bioclastic limestone, are thin bedded and abundant in the southwestern Grand Canyon area adjacent to the Cordilleran geosyncline.

\section{Facies 1-Dolomitic sandstone}

The lower part of the Esplanade Sandstone in northwestern Grand Canyon resembles the sandstone of facies B except that the cement is dolomite, rather than calcite. This dolomitic sandstone is referred to as facies I (fig. P12). It is typically developed at Tuckup Canyon, Whitmore Wash, Andrus Canyon (secs. 18, 22, 24), and other nearby sections.

The quartz sand grains of facies I seem in some places to be supported by recrystallized dolomite, suggesting that the sand may have contained a significant amount of bioclastic material prior to emplacement of the dolomite. As in the correlatable calcite-cemented sandstones to the east and south, the quartz grains mostly are very fine grained, well sorted and subangular; likewise the sandstone is 

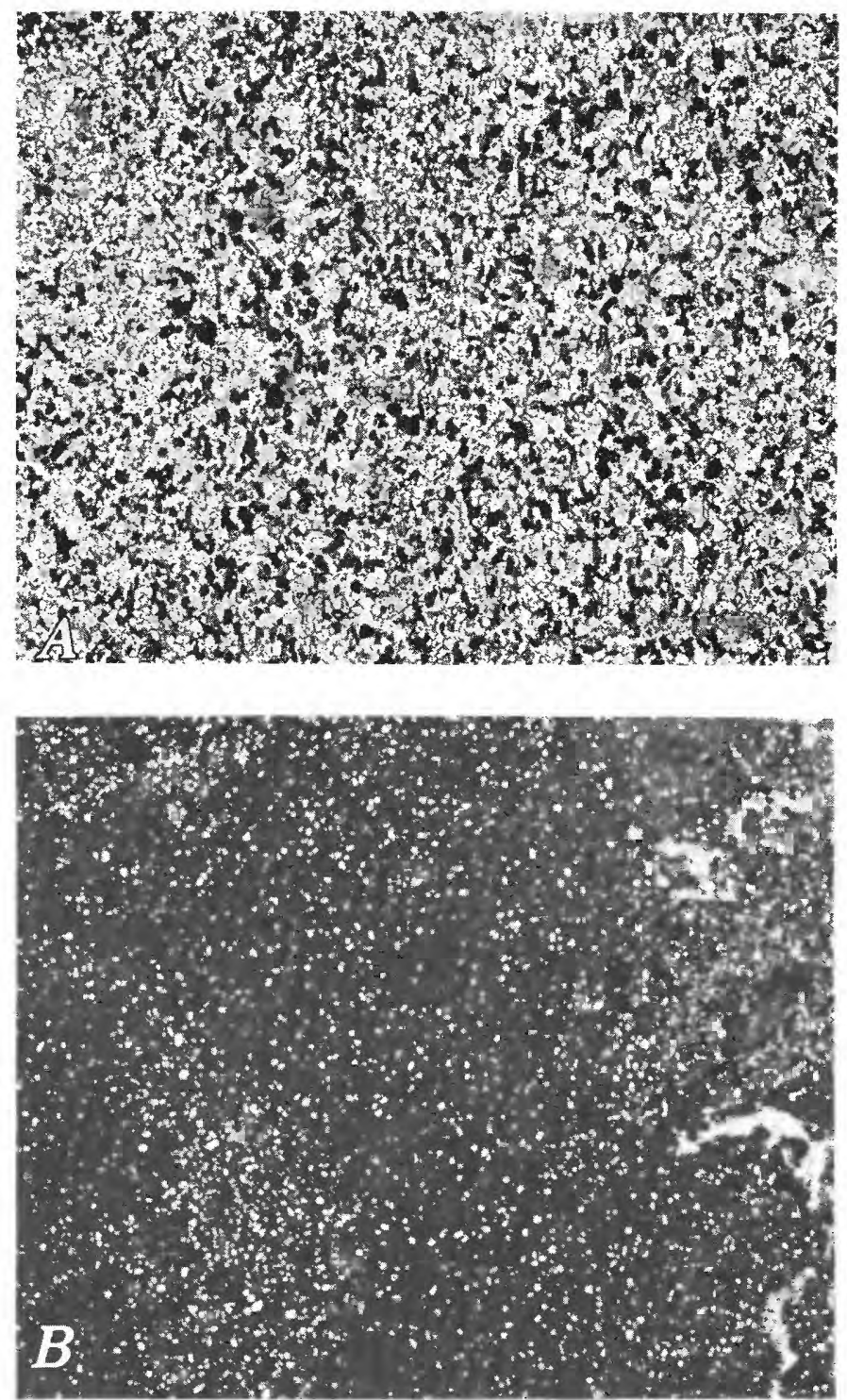

FIGURE P13.-Photomicrographs $(\times 10)$ of facies in the Esplanade Sandstone and Pakoon Limestone (MCNair, 1951). A, Very fine grained, cross-stratified sandstone of facies B, containing angular to subangular quartz grains, peloids of limestone, foraminiferal debris and micritic matrix; from main cliff of Esplanade Sandstone, Thunder River Trail, sec. 12. B, Silty carbonate mudstone of facies $C$ (insoluble residue 12.5 percent); from basal slope unit, Esplanade Sandstone, Twentynine Mile Canyon, sec. 2. C, Bioclastic limestone in-

highly cross-stratified. Small foraminifers, numerous in some related, adjacent facies, are uncommon in this sand.

At Parashant Canyon (sec. 23) and Andrus Canyon (sec. 24) measured sections, the dolomitic sandstone of facies I includes a relatively sparse component of bimodal, wellrounded, medium- to coarse-grained sand (fig. P13D). Abundant particles of chert occur in this sand.
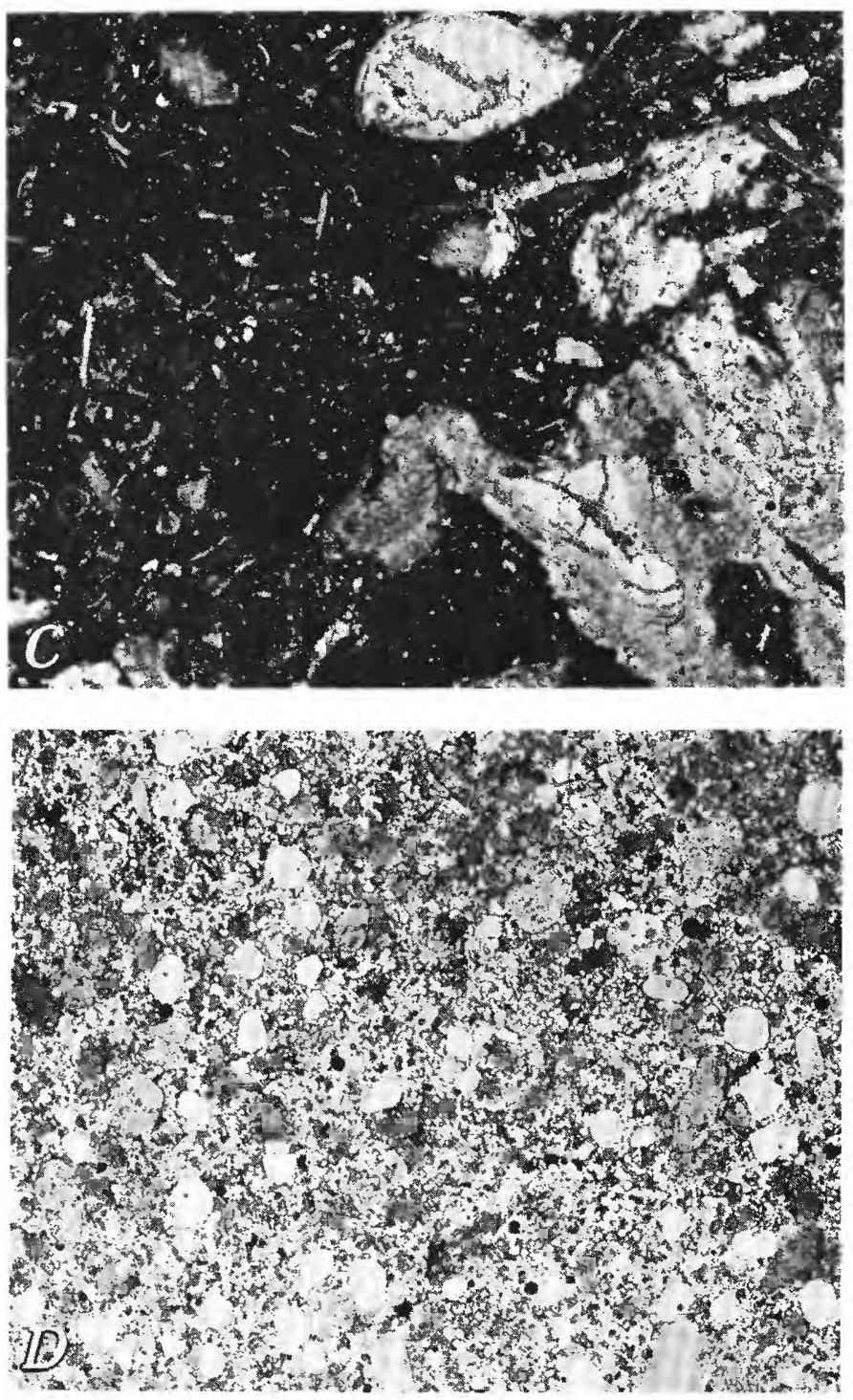

cluding fragments of bryozoans, pelmatozoans, and pelecypods of facies $\mathrm{E}$ mixed with cryptocrystalline dolomitic limestone of facies $\mathrm{H}$; insoluble residue, 12.6 percent; from Iceberg Canyon, lower part of cliff unit, Pakoon Limestone. D, Dolomitic sandstone of facies I composed of medium- to coarse-grained sand of well-rounded quartz, chert, and pelmatozoan particles, and very fine grained subangular sand grains with dolomite cement; from upper part of main cliff, Esplanade Sandstone, Parashant Canyon, sec. 23.

\section{Facies J-Bedded gypsum}

Bedded gypsum of facies J (fig. P12) extends across a considerable area in west-central Grand Canyon-from Toroweap Valley (sec. 21) to Andrus Canyon (sec. 24). It occurs between massive units of cross-stratified sandstone of facies B. Based on stratigraphic relations, these gypsum 
deposits seem to have been accumulated in an area landward of the Cordilleran seaway and separated from it by extensive cross-stratified sands of the upper cliff-slope unit of the Esplanade. Paleogeographic considerations indicate that they represent accumulations in lagoons bordering the main seaway to the west and the marine embayment to the south (fig. D8).

\section{REFERENCES CITED}

Dunham, R. J., 1962, Classification of carbonate rocks according to depositional texture, in W. E. Ham, ed., Classification of carbonate rocks-A symposium: American Association of Petroleum Geologists Memoir 1, p. 108-121.

1969, Early vadose silt in Townsend mound (reef), New Mexico, in G. M. Friedman, ed., Depositional environments in carbonate rocks-A symposium: Society of Economic Paleontologists and Mineralogists Special Publication 14, p. 139-181.

Folk, R. L., 1962, Spectral subdivision of limestone types, in W. E. Ham, ed., Classification of carbonate rocks-A symposium: American Association of Petroleum Geologists Memoir 1, p. 62-84.
1973, Carbonate petrography in the post-Sorbian age, in R. N. Ginsburg, ed., Evolving concepts in sedimentology: The Johns Hopkins University Studies in Geology, no. 21, p. 118-158.

Folk, R. L., and Land, L. S., 1975, Mg/Ca ratio and salinity; Two controls over crystallization of dolomite: American Association of Petroleum Geologists Bulletin, v. 59, no. 1, p. 60-68.

Goddard, E. N., chm., and others, 1948, Rock-color chart: National Research Council (reprinted by the Geological Society of America, 1951, 1970), 6 p.

McKee, E. D., and Gutschick, R. C., 1969, History of the Redwall Limestone of northern Arizona: Geological Society of America Memoir $114,726 \mathrm{p}$.

McNair, A. H., 1951, Paleozoic stratigraphy of part of northwestern Arizona: American Association of Petroleum Geologists Bulletin, v. 35 , no. 3 , p. 503-541.

Sander, Bruno, 1951, Contributions to the study of depositional fabrics: rhythmically deposited Triassic limestones and dolomites: Tulsa, Okla., American Association of Petroleum Geologists, 207 p.

Toomey, D. F., 1969, The biota of the Pennsylvanian (Virgilian) Leavenworth Limestone, midcontinent region-Part 2, Distribution of algae: Journal of Paleontology, v. 43, no. 6, p. 1313-1330.

Twenhofel, W. H., 1919, Pre-Cambrian and Carboniferous algal deposits: American Journal of Science, 4th Ser., v. 48, p. 339-352. 


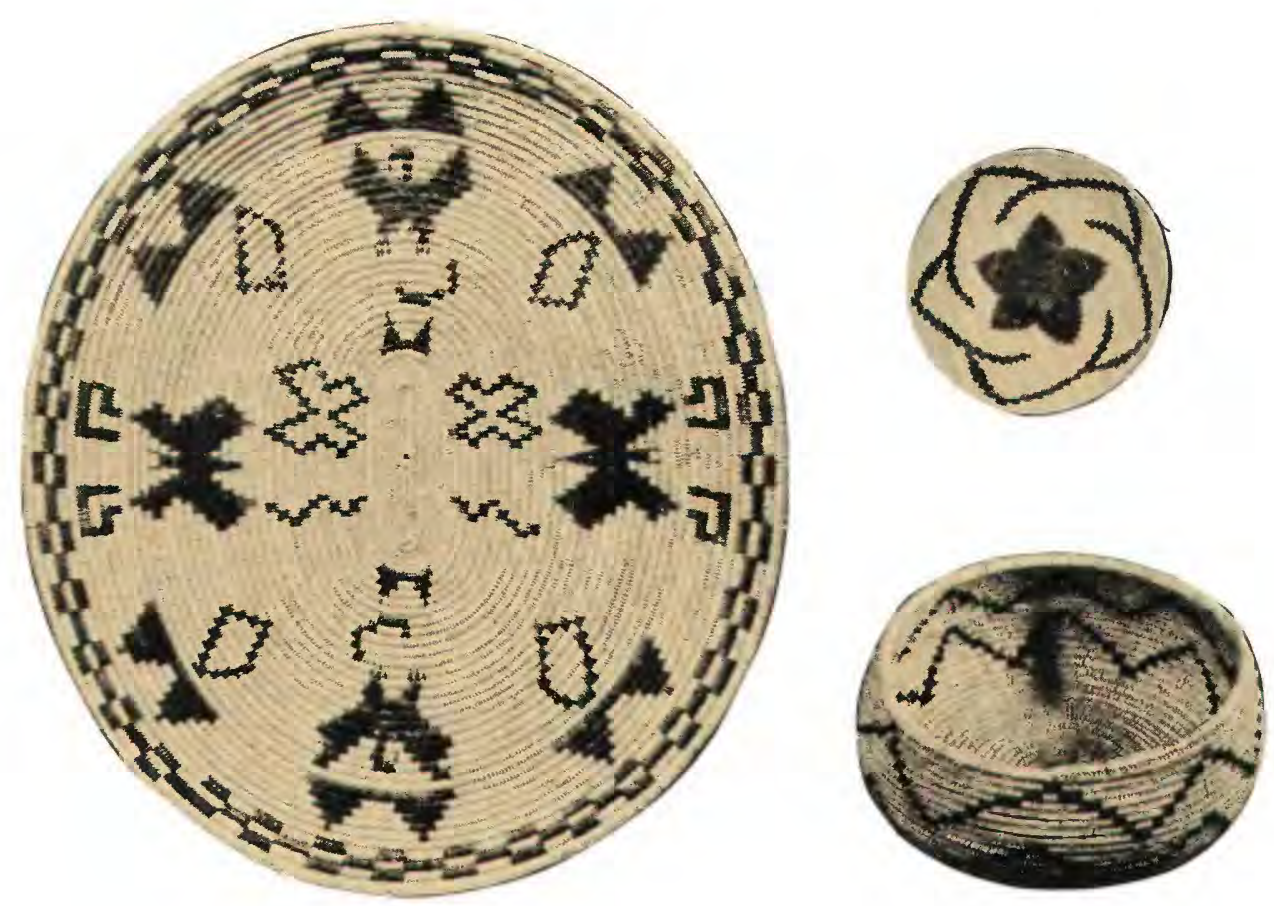

THE SUPAI GROUP OF GRAND CANYON

\section{STABLE ISOTOPE ANALYSES}

Chapter Q

By EDWIN D. McKEE

\section{Contents}

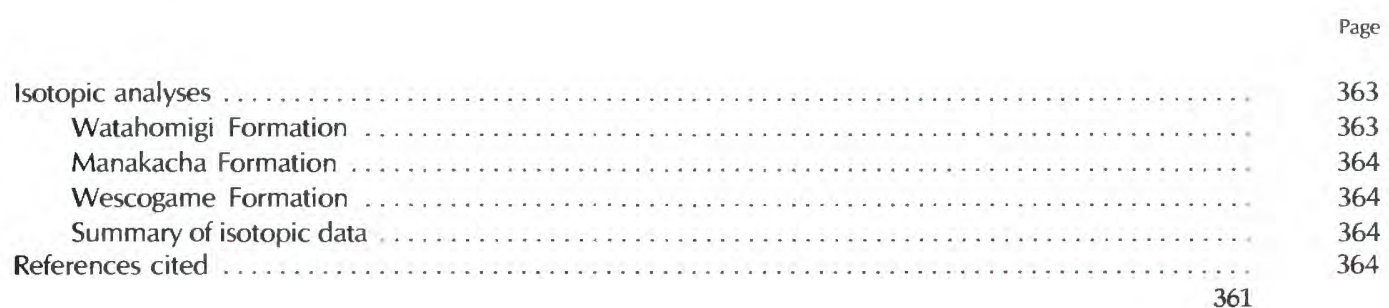




\section{Table}




\section{ISOTOPIC ANALYSES}

Stable isotope abundance measurements were made for limestones from a selected suite of samples representing the lower three formations of the Supai Group along the Kaibab Trail, south, in eastern Grand Canyon (table Q1). For this project both oxygen and carbon isotope analyses were kindly made by J. R. O'Neil in the Menlo Park laboratories of the U.S. Geological Survey. The objective in making these measurements was to obtain, if possible, evidence pertaining to the environments of deposition as recorded by various carbonate rocks within the Supai Group. Such evidence should supplement data based on faunal analysis, cross-strata studies, clay-mineral investigations and other environmental indicators.

The premise upon which isotopic data are considered useful in determining environmental conditions is that marine carbonate rocks are normally richer in ${ }^{13} \mathrm{C}$ than are freshwater types. The first study to promote this concept was by Clayton and Degens (1959) who reported in their table 1 a mean $\delta^{13} \mathrm{C}$ of -1.54 for marine rocks and of -6.66 for freshwater types. A later study by Keith and Weber (1964) based on analyses of 500 marine and nonmarine limestones showed mean $\delta^{13} \mathrm{C}$ values of +0.56 for marine rocks and -4.93 for those of freshwater origin. These results support the view that nonmarine types have lower $\delta^{13} \mathrm{C}$ values than marine limestones.

Studies by Keith, Anderson, and Eichler (1964) and by Weber (1964) lend support to this concept that marine limestones are enriched in ${ }^{13} \mathrm{C}$ relative to nonmarine limestones. A comparison of recent marine and nonmarine mollusk shells has been made by Keith, Anderson, and Eichler (1964); analyses of freshwater carbonate rocks of the Flagstaff Limestone (Paleocene and Eocene) of Utah are described by Weber (1964). Not all continental deposits are freshwater, however, and the recognition of brackish- water and hypersaline environments must also be considered in the interpretation of isotopic analyses. In a study of hypersaline lake deposits of the Lake Bonneville area by Degens and Epstein (1964), for instance, relatively high $\delta^{13} \mathrm{C}$ values ranging from +0.12 to +4.50 are recorded.

Although both $\delta^{18} \mathrm{O}$ and $\delta^{13} \mathrm{C}$ were measured in attempting to interpret formation conditions of the Supai carbonate rocks, the $\delta^{18} \mathrm{O}$ values that range from -4.5 to -6.2 in the samples analyzed were not used because, as indicated by Keith and Weber (1964, p. 1787), compositions "exhibit a progressive increase in average oxygen-18 content from oldest to youngest age group," (for example, Cambrian -9.7 to Quaternary -1.2 permil). In contrast, "no great change has occurred in the carbon isotopic composition of marine bicarbonate over geologic time," according to the same investigators.

\section{Watahomigi Formation}

Isotopic analyses of two limestone samples from the lower or Morrowan part of the Watahomigi (table Q1) are interpreted as indicating a marine environment. The $\delta^{13} \mathrm{C}$ value of -0.8 for sample KS-1, an aphanitic limestone from near the base, is well within the normal range $(0.0 \pm 3)$ for marine limestones. Sample KS-2 from near the top of the Morrowan limestones has a $\delta^{13} \mathrm{C}$ value of -3.4 , which is near the upper limit for Carboniferous marine limestones as recorded by Keith and Weber (1964, p. 1805, 1806).

Supporting evidence of marine origin is a brachiopod fauna in the same unit at National and Tuckup Canyons to the west. Clay minerals from this formation include some kaolinite in eastern Grand Canyon that is considered nonmarine, but they also include illite and corrensite, which are interpreted as representing deposits laid down during periodic marine incursions. Probably the limestones under consideration reflect the same environmental control.

TABLE Q1.-Stable isotope analyses of limestone from Supai Group, Kaibab Trail, south [Analyses by I. R. O'Nell. $\delta$-values are given in per mil relative to the PDB standard]

\begin{tabular}{|c|c|c|c|c|c|}
\hline Formation & Age & $\begin{array}{c}\text { Sample } \\
\text { No. }\end{array}$ & $\delta^{13} \mathrm{C}$ & $\delta^{18} \mathrm{O}$ & Type of carbonate rock \\
\hline Watahomigi & Morrowan & $\mathrm{KS}-1$ & -0.8 & -5.0 & Aphanitic limestone; chert concretions \\
\hline Do. ..... & do. .... & $\mathrm{KS}-2$ & -3.4 & -5.9 & Thin limestone bed, top of unit. \\
\hline Do. & Atokan & $\mathrm{KS}-3$ & -4.7 & -6.2 & Jasper-bearing limestone. \\
\hline Manakacha & Atokan & $\mathrm{KS}-7$ & -4.6 & -6.2 & Limestone bed between sandstones. \\
\hline Do. ...... & do. $\ldots \ldots \ldots$ & KS-8 & -3.8 & -5.6 & Limestone bed, top of sandstones. \\
\hline Wescogame & Virgilian ......... & KS-11 & -5.4 & -4.6 & Thin limestone, base of sandstones. \\
\hline Do. ..... & do. . & $\mathrm{K}-13$ & -4.3 & -4.8 & Limestone lens in upper red beds. \\
\hline Do. ....... & do. & $K-14$ & -5.0 & -4.5 & Do. \\
\hline Do. .......... & do. & K-14a & -5.4 & -5.3 & Do. \\
\hline
\end{tabular}




\section{Manakacha Formation}

Isotopic data for the Manakacha (table Q1) are compatible with the idea that these rocks were deposited in an environment in which the water was less saline than normal marine water and that some carbon of organic origin was incorporated in the limestone. Samples KS-7 and KS-8 (table Q1) are from limestone lenses within thick beds of highly cross-stratified, calcareous sandstone interpreted as marine.

Because the limestone lenses and associated clays of the Manakacha clearly did not form under the high-energy conditions represented by the sandstones, they may well have been deposited in brackish-water environments developed between times of marine sand accumulation. Thus, the $\delta^{13} \mathrm{C}$ values of -4.6 and -3.8 for the Manakacha limestones possibly explain an isotopic composition that is generally intermediate in heaviness between the freshwater Pennsylvanian analyses and the marine Pennsylvanian analyses recorded by Keith and Weber (1964, p. 1805, 1806).

Associated clay minerals in eastern Grand Canyon include much kaolinite, considered nonmarine, but are largely marine types, especially illite, to the west. Probably marine conditions merged into nonmarine in the eastern area where the limestones under discussion were deposited.

\section{Wescogame Formation}

Limestones of the Wescogame (table Q1) have $\delta^{13} \mathrm{C}$ values ranging between -4.3 and -5.4 . These $\delta^{13} \mathrm{C}$ values are close to the value of -4.93 recorded by Keith and Weber $(1964$, p. 1787) for freshwater limestones and the -6.66 recorded by Clayton and Degens (1959, p. 891) for "non-marine carbonate rocks." The interpretation of a freshwater environment for these thin limestone beds and lenses that occur among red beds of the Wescogame in eastern Grand Canyon is in keeping with evidence from other sources. In the abundant sandstones of the Wescogame, reptilian tracks occur, and distinctive cross-strata of types common to braided streams are present. Furthermore, the common association of kaolinite considered diagnostic of a freshwater environment also supports the interpretation of fluvial conditions.

\section{Summary of isotopic data}

Summarizing conclusions concerning the isotopic composition of Supai Group limestones from the Kaibab Trail, south, the values obtained seem to form three general groups, representing each of the three formations considered. The oldest formation, the Watahomigi, shows values favorable to a marine interpretation. The second formation or Manakacha, has intermediate values considered possibly to represent brackish-water environments. The youngest or Wescogame Formation is interpreted as including freshwater limestones.

As suggested by the recent work of Hoefs (1973, p. 98), "isotopic criteria should be regarded as additional parameters, supplemental to paleontologic and petrographic criteria, for determining the depositional environments." Limitations in the application of isotope data in interpreting depositional environments are stated by Hoefs (1973, p. 98) as follows: "isotopic composition * * * depends not only on the environment at the time of deposition, but also on isotopic exchange processes since deposition." It therefore must be demonstrated "that carbonate in sediments is of sedimentary origin and not contaminated by either detrital or post sedimentary processes."

\section{REFERENCES CITED}

Clayton, R. N., and Degens, E. T., 1959, Use of carbon isotope analyses of carbonates for differentiating freshwater and marine sediments: American Association of Petroleum Geologists Bulletin, v. 43, no. 4, p. 890-897.

Degens, E. T., and Epstein, Samuel, 1964, Oxygen and carbon isotope ratios in coexisting calcites and dolomites from recent and ancient sediments: Geochimica et Cosmochimica Acta, v. 28, p. 23-44.

Hoefs, Jochen, 1973, Stable isotope geochemistry: New York, Heidelberg, Berlin, Springer-Verlag, $140 \mathrm{p}$.

Keith, M. L., and Weber, J. N., 1964, Carbon and oxygen isotopic composition of selected limestones and fossils: Geochimica et Cosmochimica Acta, v. 28, p. 1787-1816.

Keith, M. L., Anderson, G. M., and Eichler, R., 1964, Carbon and oxygen isotopic composition of mollusk shells from marine and freshwater environments: Geochimica et Cosmochimica Acta, v. 28, p. 1757-1786.

Weber, J. N., 1964, Carbon-oxygen isotopic composition of Flagstaff carbonate rocks and its bearing on the history of Paleocene-Eocene Lake Flagstaff of central Utah: Geochimica et Cosmochimica Acta, v. 28 , p. 1219-1242. 

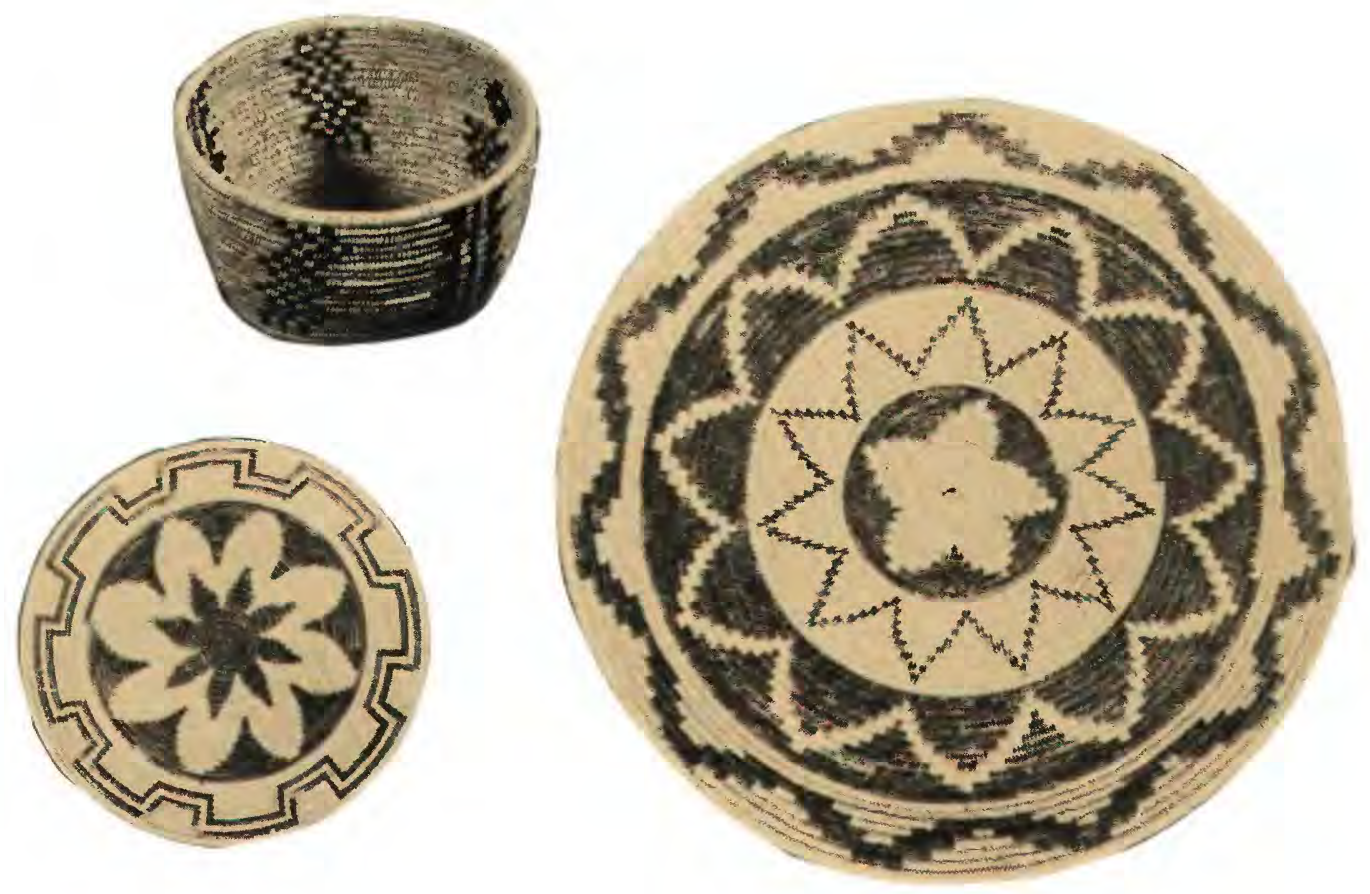

THE SUPAI GROUP OF GRAND CANYON

APHANITIC SILICA ROCK

Chapter R

By EDWIN D. McKEE

\section{Contents}

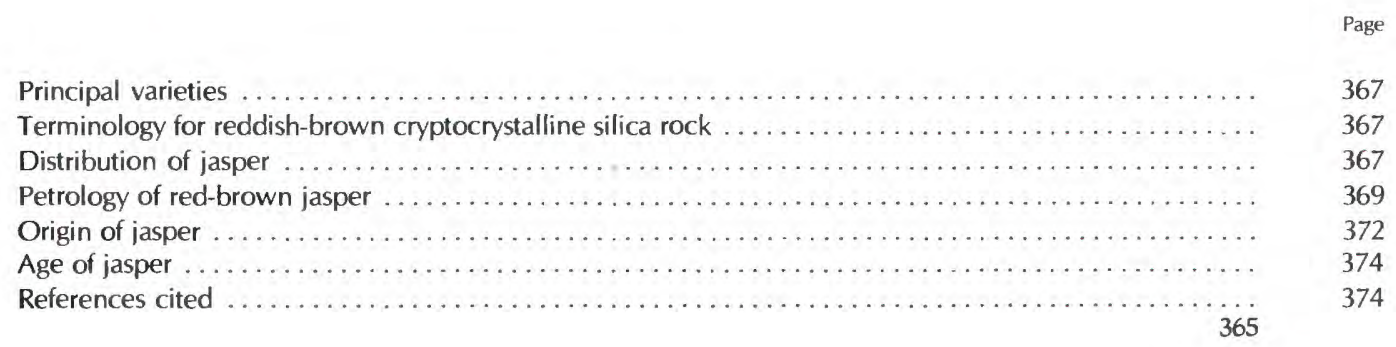




\section{Illustrations}

FIGURE R1. Photographs of deposits of cryptocrystalline silica $\ldots \ldots \ldots \ldots \ldots \ldots \ldots \ldots \ldots \ldots \ldots \ldots$

R2. Color photograph of typical banded jasper in limestone, Manakacha Formation, Para-

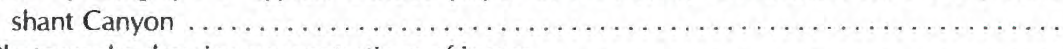

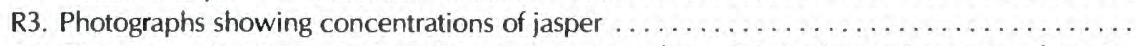

R4. Diagrams showing stratigraphic and geographic distribution of jasper deposits,

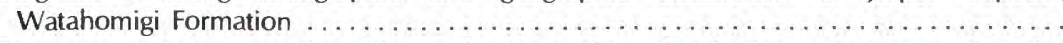

R5. Diagrams showing stratigraphic and geographic distribution of jasper deposits,

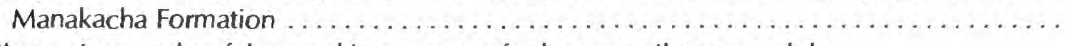

R6. Photomicrographs of deep-red jasper core of calcareous siltstone nodule . . . . . . . . . .

R7. Electron micrograph of red-brown jasper from limestone bed, Manakacha Formation ......

\section{Tables}

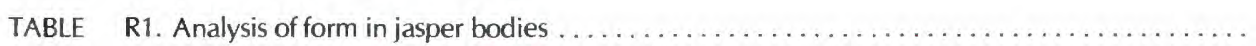

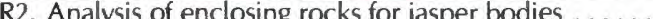

R3. Analysis of bedding-types containing jasper bodies . . . . . . . . . . . . . . . . 369

R4. Semiquantitative spectrographic analysis of jasperoid sample . . . . . . . . . . . . . 371

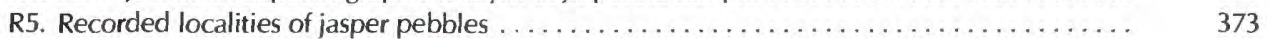




\section{PRINCIPAL VARIETIES}

Cryptocrystalline silica rock of several varieties occurs in various parts of the Supai Group, but is especially common in the Watahomigi and Manakacha Formations. Some of it is in the form of siliceous crusts that form highly irregular, concentric, or other striking patterns (fig. R1D, $E$ ) that suggest, at least superficially, some reeflike, stromatolitic structures. This type commonly is porous, dull buff or pale gray, but weathers to hard, dark-brown or black surfaces that etch out in relief. Such stromatolitic structures are common near the base of the Watahomigi near the Kaibab Trail of eastern Grand Canyon and about midway in the lower unit of the Manakacha Formation along the walls of Snap Canyon in the west.

A second variety of cryptocrystalline silica rock is translucent and is white, yellow, pink, or other light color; it has commonly been referred to as chert (Walcott, 1880; Noble, 1922, p. 60, 61). This variety forms thin anastomosing layers in massive carbonate beds near the base of the Watahomigi Formation (fig. R1A), or irregular bands of concretions (fig. R1C) in the Pakoon Limestone (McNair, 1951). Much of this chert seems to be chalcedonic.

By far the most common variety of cryptocrystalline silica in the Supai Group is a dense, reddish-brown type that occurs throughout the two lower formations in sheetlike and concretionary forms similar to those of the chert, and also in other forms described later. This form is referred to as jasper and is very consistent in color and aphanitic texture (fig. R2). The color range as determined on the rock-color chart (Goddard, 1948) is between moderate reddish brown and dark reddish brown.

\section{TERMINOLOGY FOR REDDISH-BROWN CRYPTOCRYSTALLINE SILICA ROCK}

The reddish-brown, opaque variety of cryptocrystalline silica that is widespread in the Supai Group throughout the Grand Canyon region is difficult to classify. It occurs largely as an extremely fine grained and relatively homogenous rock and has an aphanitic, almost glassy texture-characteristics that fit the definitions of numerous cryptocrystalline silica rocks. The term "jasperoid," introduced by Spurr (1898), recently has been discussed by Lovering $(1972$, p. 3), who stated that "jasperoids are composed predominantly of silica which in most places is in the form of aphanitic to fine-grained quartz and forms by replacement of the enclosing rock." These features seem to apply to many of the Supai silica rocks.
In his detailed treatment of this rock type, Lovering restricts the term jasperoid to "an epigenetic siliceous replacement of a previously lithified host rock" and excludes what he considers syngenetic or diagenetic forms of silica, such as primary chert and novaculite. The following criteria, according to Lovering (1972, p. 6), serve to distinguish jasperoid from bedded chert, which it closely resembles: "(1) jasperoid beds are localized in a relatively small area in contrast to the broad regional distribution of bedded cherts, and (2) jasperoid layers commonly grade laterally into larger masses with evident structural control." Although a genesis by replacement may apply to most, if not all, of the reddish-brown silica deposits of the Supai, the matters of localized distribution and of regional structure control do not.

In this publication, the term "jasper" is used in referring to the reddish-brown silica rock that is the dominant cryptocrystalline form in irregular layers or sheets, lenses, and other forms throughout much of the Supai Group. In texture, color, and genesis this rock seems to fit the term, as used by most geologists, better than any other.

\section{DISTRIBUTION OF JASPER}

Dark reddish-brown, cryptocrystalline silica, referred to as jasper, is a common and characteristic lithologic constituent of the Watahomigi and Manakacha Formations. It occurs mostly as thin, extremely uneven layers or "bands" within massive beds of carbonate rock, but it also forms lenses, irregular masses, concretions, and crosscutting "veins" (fig. R3; table R1). Aphanitic limestone is the most

TABLE R1.-Analysis of form in jasper depositional bodies. Figures refer to number of rock units containing each form in measured sections under study

\begin{tabular}{cccccc}
\hline Formation & $\begin{array}{c}\text { Uneven layers } \\
\text { ("bands") }\end{array}$ & Lenses & $\begin{array}{c}\text { Nodular } \\
\text { concretions }\end{array}$ & $\begin{array}{c}\text { Crosscut } \\
\text { veins }\end{array}$ & $\begin{array}{c}\text { Irregular } \\
\text { masses }\end{array}$ \\
\hline Manakacha ... & 69 & 39 & 9 & 2 & 1 \\
Watahomigi ... & 58 & 25 & 7 & 5 & 1
\end{tabular}

common host rock, although granular limestone, silty or sandy limestone, and dolomite, as well as some detrital rocks such as calcareous mudstone, calcareous siltstone, and calcareous sandstone, are also jasper-bearing (table $\mathrm{R} 2$ ). Jasper deposits occur in both flat-bedded and crossstratified rock units, but more commonly are in thick massive beds than in thin ones (table R3). Jasper deposits are relatively uncommon in cross-stratified units, and, in sandstone, seem to be restricted to those beds that are very calcareous.

Charts of jasper distribution-both stratigraphic and 

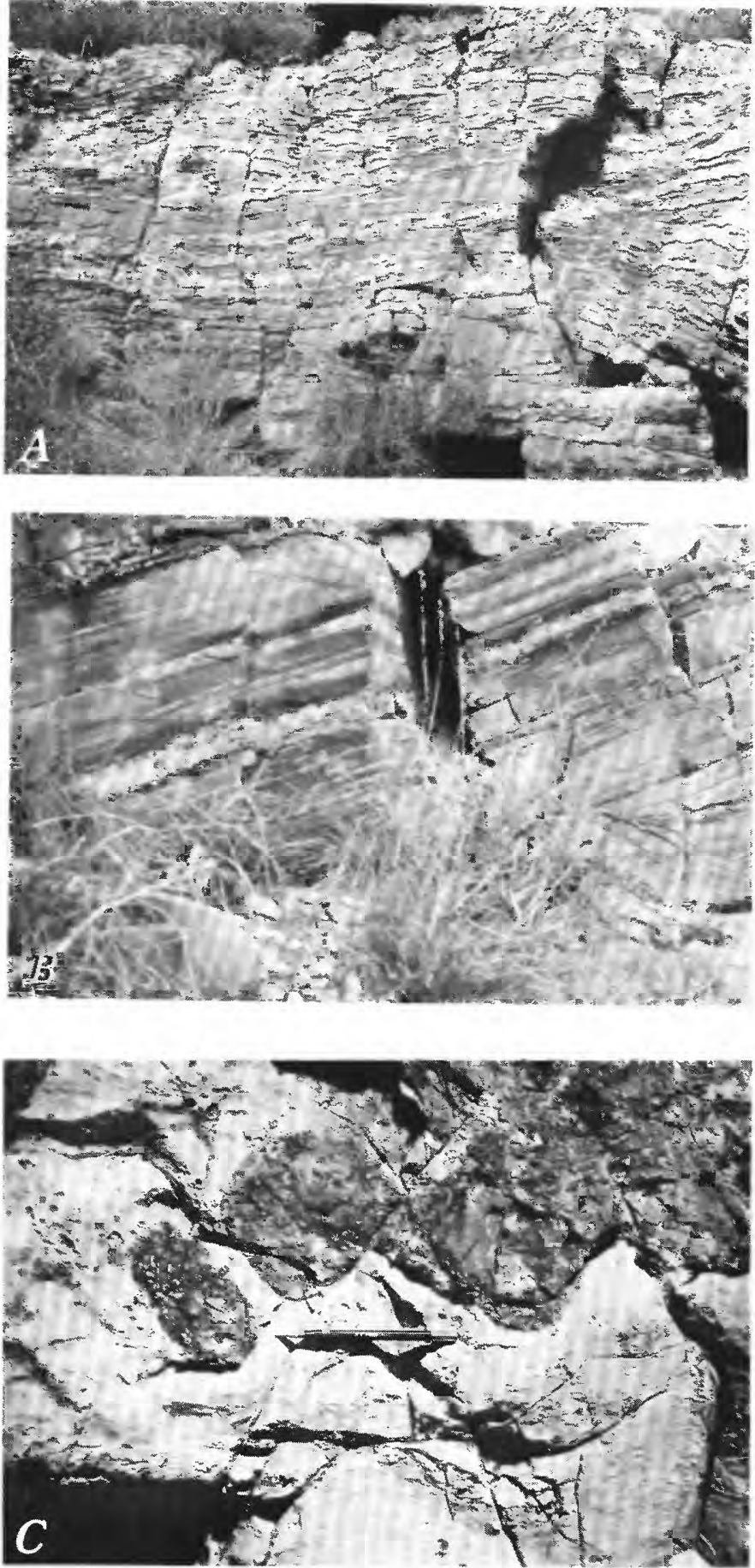
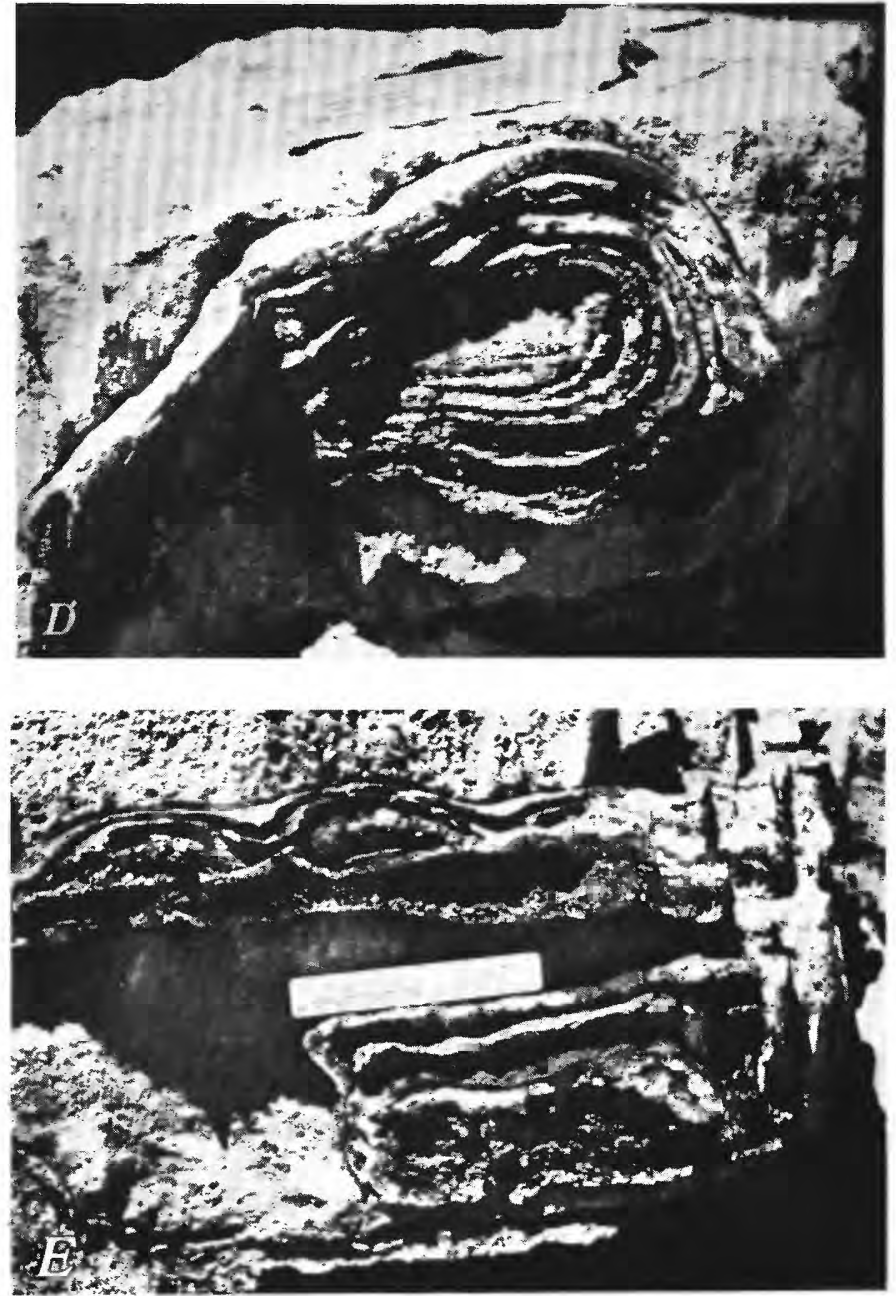

FIGURE R1.-Deposits of cryptocrystalline silica in carbonate rocks of Supai Group and Pakoon Limestone (McNair, 1951), Grand Canyon region, Arizona. A, Irregular layers or "bands" of white chert in thick-bedded limestone. Chert follows planes of dipping cross-strata in right center. Near base of Watahomigi Formation near Bass Trail. $B$, Layers of red jasper between foreset beds of sandy limestone with large-scale tabular-planar structure, Wescogame Formation, Pigeon Wash. C, Concretions of reddish-brown chert containing concentrations of crinoids in thick-bedded aphanitic limestone of Pakoon Limestone, Iceberg Canyon. $D, E$, Crust or shells of chertlike, cryptocrystalline silica forming irregular and inconsistent structure pattern in limestone near base of Watahomigi Formation, Kaibab Trail; scale is in centimeters. Photographs by L. M. Hinchliffe.

TABLE R2.-Analysis of enclosing rocks for depositional bodies of jasper. Figures refer to number of rock units in measured sections under study that represent each rock type

\begin{tabular}{|c|c|c|c|c|c|c|c|}
\hline \multirow[b]{2}{*}{ Formation } & \multicolumn{3}{|c|}{ Limestone } & \multirow{2}{*}{$\begin{array}{l}\text { Dolostone, } \\
\text { calcareous }\end{array}$} & \multirow{2}{*}{$\begin{array}{l}\text { Mudstone, } \\
\text { calcareous }\end{array}$} & \multirow{2}{*}{$\begin{array}{l}\text { Sandstone, } \\
\text { fine-very } \\
\text { fine }\end{array}$} & \multirow{2}{*}{$\begin{array}{l}\text { Siltstone, } \\
\text { calcareous }\end{array}$} \\
\hline & Aphanitic & Granular & $\begin{array}{l}\text { Siny, } \\
\text { sandy }\end{array}$ & & & & \\
\hline Manakacha ... & 49 & 26 & 31 & 4 & 0 & 11 & 10 \\
\hline Watahomigi & 45 & 30 & 20 & 7 & 3 & 2 & 3 \\
\hline
\end{tabular}




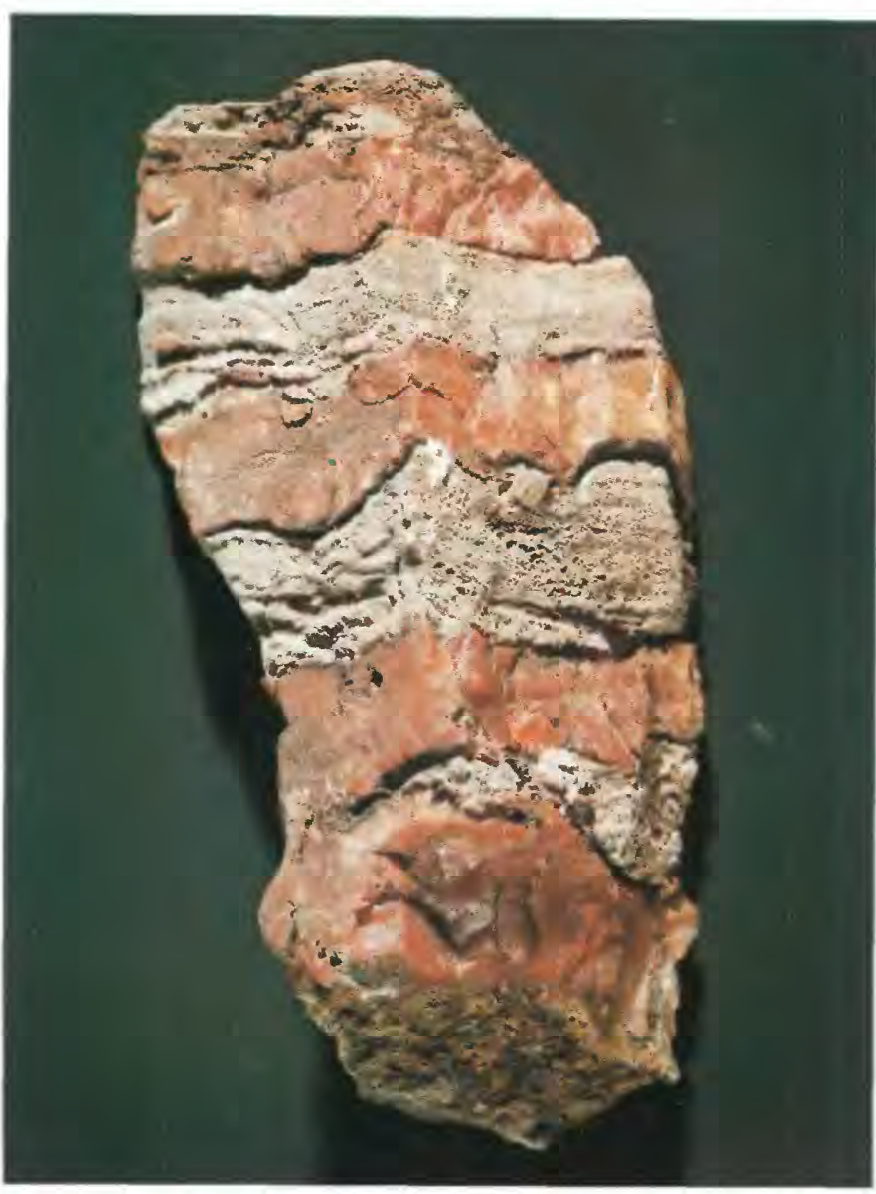

FIGURE R2.-Typical "banded" jasper in limestone, Manakacha Formation, Parashant Canyon, Ariz. Natural size. Illustrates dark reddishbrown color that distinguishes it from all other silica rock in the Supai Group.

geographic - in the Grand Canyon region (figs. R4, R5) show that nearly all of the jasper deposits of the Supai Group are in the lower two formations, the Watahomigi and the Manakacha. A probable reason for this stratigraphic control is the relative scarcity of limestone strata in the Wescogame Formation and Esplanade Sandstone. Some cross-stratified sets in limestone and calcareous sandstone in the Wescogame of far western Grand Canyon (fig. R1B) are jasper-bearing units, but outcrops of the Wescogame in most other areas are barren of jasper.

Distribution of jasper in the two lower formations of the

TABLE R3.-Analysis of bedding-types containing jasper depositional bodies. Figures refer to number of rock units in measured sections under study that contain jasper deposits

\begin{tabular}{|c|c|c|c|c|}
\hline \multirow[b]{2}{*}{ Formation } & \multicolumn{2}{|c|}{ Flat-bedded } & \multicolumn{2}{|c|}{ Cross-stratified } \\
\hline & Thin & Thick & Sandstone & Limestone \\
\hline Manakacha .... & 7 & 113 & 6 & 8 \\
\hline Watahomigi .... & 7 & 115 & 0 & 4 \\
\hline
\end{tabular}

Supai Group seems to be dependent on the presence of carbonate rocks within a stratigraphic section. In the Watahomigi Formation, for instance, concentrations of jasper everywhere are greatest in the middle cliff or limestone unit, and generally are least common in the lower slope or red mudstone unit where limestone is relatively scarce (fig. R4). In the Manakacha Formation, jasper concentrations are absent in the upper (slope) unit of nearly all sections of eastern Grand Canyon where sandstone, rather than limestone, is dominant. In general, jasper is characteristic of the lower (cliff) unit of the Manakacha and seems to rise stratigraphically in a southwesterly direction (fig. R5) where the lower unit is thicker and carbonate rock is an increasingly greater component of the formation.

\section{PETROLOGY OF RED-BROWN JASPER}

During the present investigation of the Supai Group, samples considered typical of the red-brown jasper were referred for examination to T. G. Lovering of the U.S. Geological Survey, who was at that time making a detailed study of jasperoids in the United States (Lovering, 1972). Two selected samples were examined in thin section-one was the common "banded" variety in limestone; the other was a jasper core within concentrically laminated nodular limestone. A semiquantitative spectrographic analysis was made of the banded type.

The banded jasper examined by Lovering was described by him from hand specimen as a dense, aphanitic paleorange to reddish-orange rock, forming irregular lenses elongated parallel to the bedding in a gray, fine-grained, irregularly banded limestone. In thin section, the $\mathrm{SiO}_{2}$ in this specimen is described ( $T$. G. Lovering, written commun., 1971) as consisting "of interlocking, but more or less equant quartz grains averaging about $0.05 \mathrm{~mm}$ and ranging from 0.02 to $0.1 \mathrm{~mm}$ and containing abundant inclusions of fine-grained calcite" (figs. R6A, B). He further stated that "both texture and grain size of this quartz are more suggestive of jasperoid than of chert."

In the spectrographic analysis (table R4) made of the banded jasper, most of the elements seem to be represented in amounts expectable for jasperoid. Comparing these with data in figure 33 of Lovering (1972, p. 32) that shows comparisons between cherts and jasperoids, in distribution of elements, it is evident that the Supai specimen is normal jasperoid in most respects. The large amount of $\mathrm{SiO}_{2}$ is expectable, and the high calcite content probably reflects the inclusion of some carbonate matrix. Only the copper seems slightly anomalous for it is well above the median figure obtained by Lovering (written commun., 1977), for both primary and supergene chert $(0.0015$ percent $)$, and is 

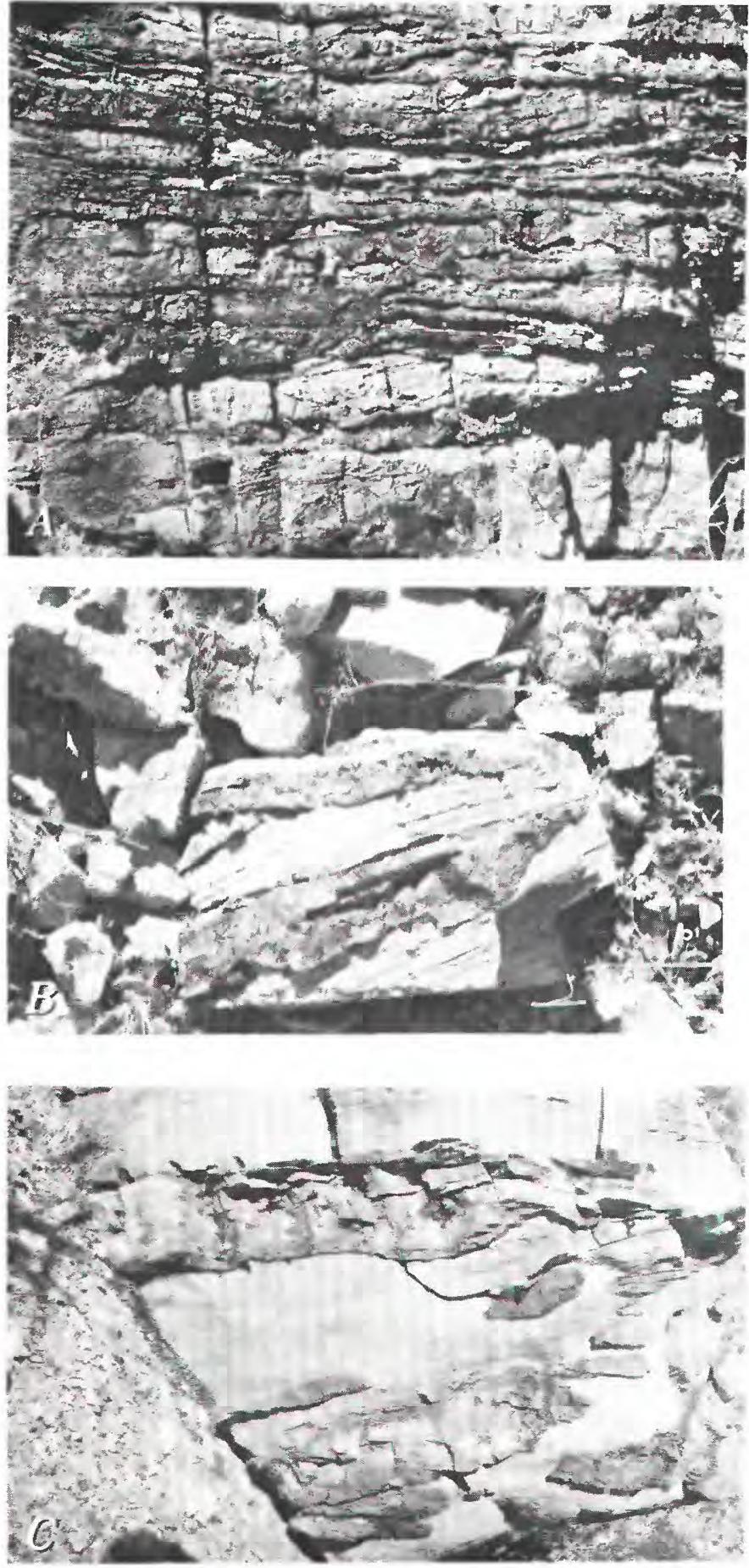

even above that for primary jasper ( 0.0030 percent). It is not above his figure for supergene jasper $(0.017)$.

Examination of the red jasper core in a silty limestone nodule enabled Lovering to furnish the following petrographic description:

The red jasper consists of heterogeneous quartz grains with 'jigsaw puzzle' texture and abrupt variations in grain size from $0.1 \mathrm{~mm}$ to $0.01 \mathrm{~mm}$ with small masses of penecontemporaneous flamboyant chalcedony. Numerous inclusions of irregular red hematite grains, showing about the same size range as the quartz, also inclusions of calcite aggregates $(0.1-0.2$
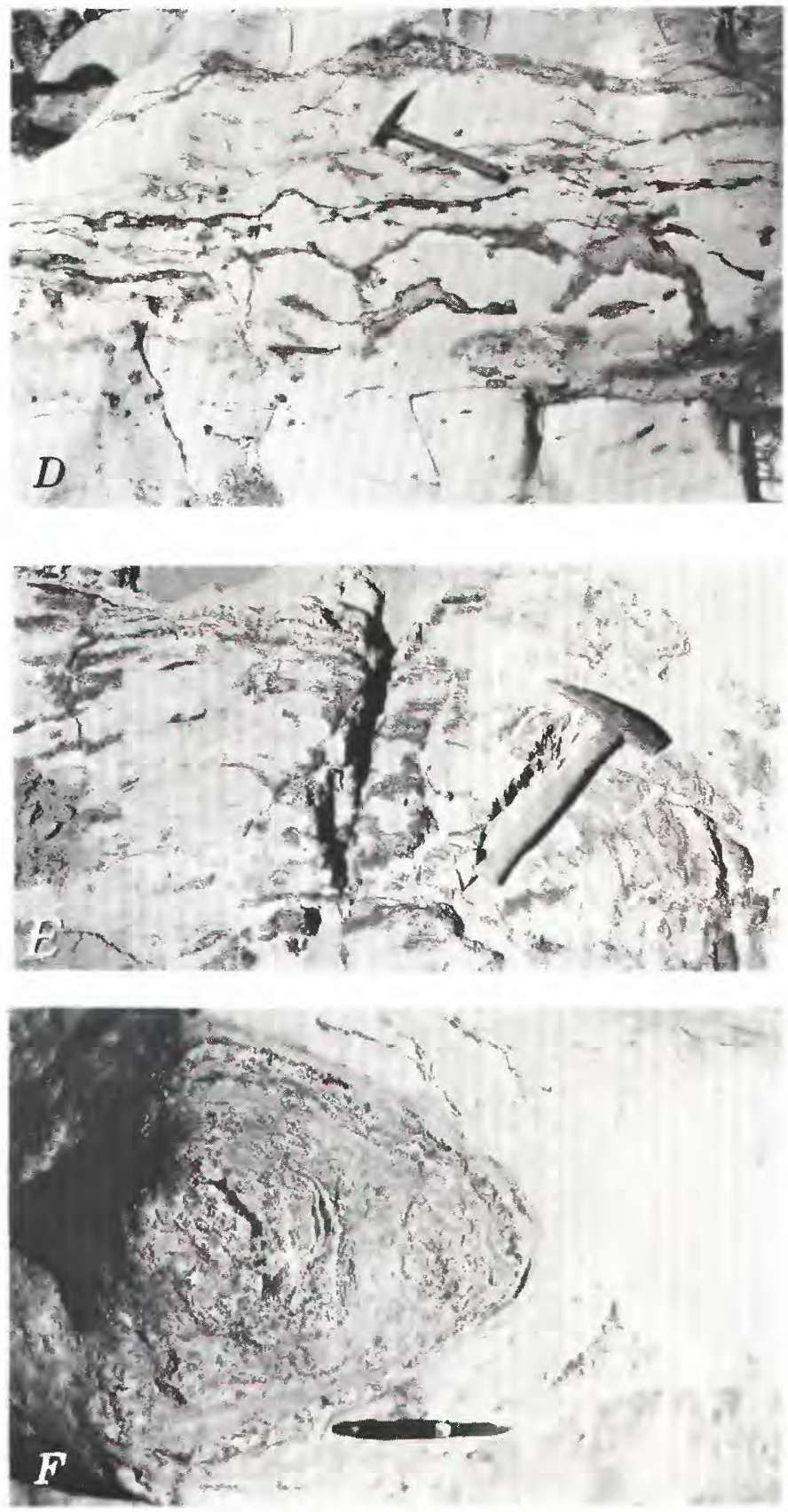

FIGURE R3.-Concentrations of jasper in carbonate rocks of the Supai Group, Grand Canyon region, Arizona. A, Irregular layers or "bands" of deep-red jasper alternating with layers of light-gray limestone in massive bed. Individual jasper layers are mostly 2-4 in. thick. Massive cliff unit of Manakacha Formation. Toroweap Valley measured section $B$, Jasper layers following foreset parting plane and upper bounding plane of cross-stratified sandy limestone in cliff unit of Wescogame Formation, south of Grand Gulch Mine near Pigeon Wash. C, Irregular layers and lenses of jasper in laminated pink sandy limestone of Wescogame cliff unit, Picacho Butte. D, Jasper lenses and irregular masses in massive aphanitic limestone of Manakacha Formation, Parashant Canyon. E, Horizontal surface of concentric layers of jasper in massive bed of aphanitic limestone, base of Manakacha Formation, S B Canyon. F, Mound of roughly elliptical thin layers of jasper embedded in sandy limestone of Watahomigi Formation, Parashant Canyon. 

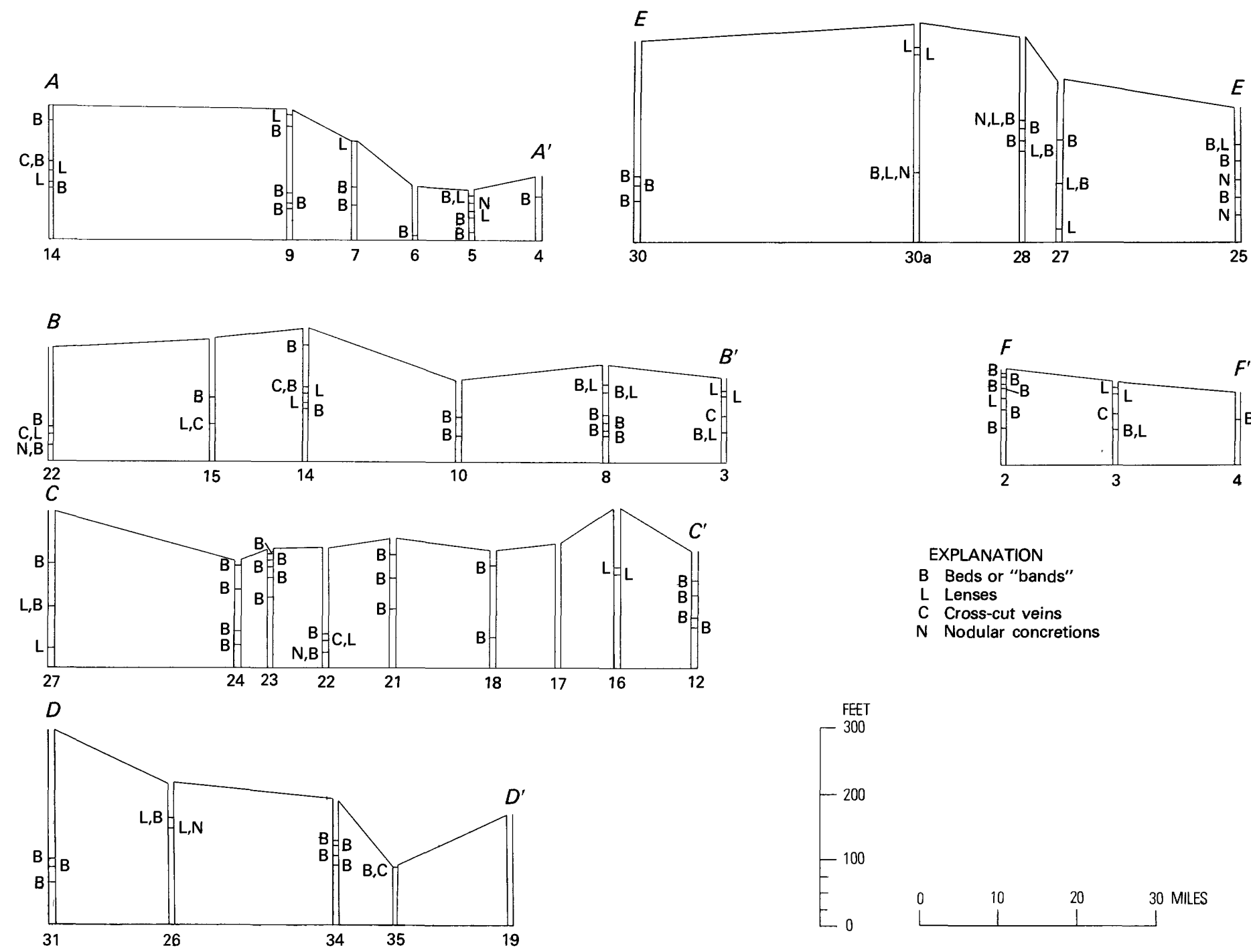

FIGURE R4.-Stratigraphic and geographic distribution of jasper deposits in Watahomigi Formation along principal lines of sections $A-A^{\prime}$ to $F-F^{\prime}$ as shown in figure $A 1$; numbers are those of measured sections shown on same figure.

$\mathrm{mm}$ ) that look like calcite in the host rock, are present. The jasper ground mass is cut by small branching veinlets of fibrous chalcedony. Pigmentation of ferric oxide is extremely fine grained (less than $0.005 \mathrm{~mm}$ in diameter).

Electron microscope examination of jasper fracture surfaces, using the replica technique, was made by Kenneth Gardner in connection with this study. Unpolished surfaces of freshly fractured rock showed polyhedral blocks with smooth faces and sharp definition (fig. R7). The blocks appeared nearly equal in size and had slightly curved surfaces. Probably the form was governed by the spacing of initial centers of crystallization as described by Folk and Weaver (1952, p. 507) who postulated that replacement was favored by "close spacing, resulting in the formation of microcrystalline quartz."
TABLE R4.-Semiquantitative spectrographic analysis of aphanitic, red jasperoid sample from limestone of the Manakacha Formation at Pigeon Wash, Arizona

[Data from T. G. Lovering]

\begin{tabular}{|c|c|c|c|}
\hline Element & Percent & Element & Percent \\
\hline$\ldots$ & $>10$ & $M n \ldots \ldots \ldots$ & 0.01 \\
\hline $\mathrm{Al}$ & .3 & Ba $\ldots \ldots \ldots \ldots$ & .0015 \\
\hline $\mathrm{Fe} \ldots \ldots \ldots \ldots$ & .15 & $\mathrm{Cr} \ldots \ldots \ldots \ldots$ & .0007 \\
\hline$M g \ldots \ldots \ldots$ & .07 & $\mathrm{Cu} \ldots \ldots$ & ${ }^{2} .01$ \\
\hline Ca .. & $\left({ }^{1}\right)$ & $\mathrm{Sr} \ldots \ldots$ & .003 \\
\hline $\mathrm{Na} \ldots$ & .05 & $\mathrm{Zr} \ldots \ldots \ldots$ & .001 \\
\hline $\mathrm{Ti} \ldots \ldots \ldots$ & .007 & & \\
\hline
\end{tabular}

1Probably includes some carbonate matrix. 'Slightly anomalous. 

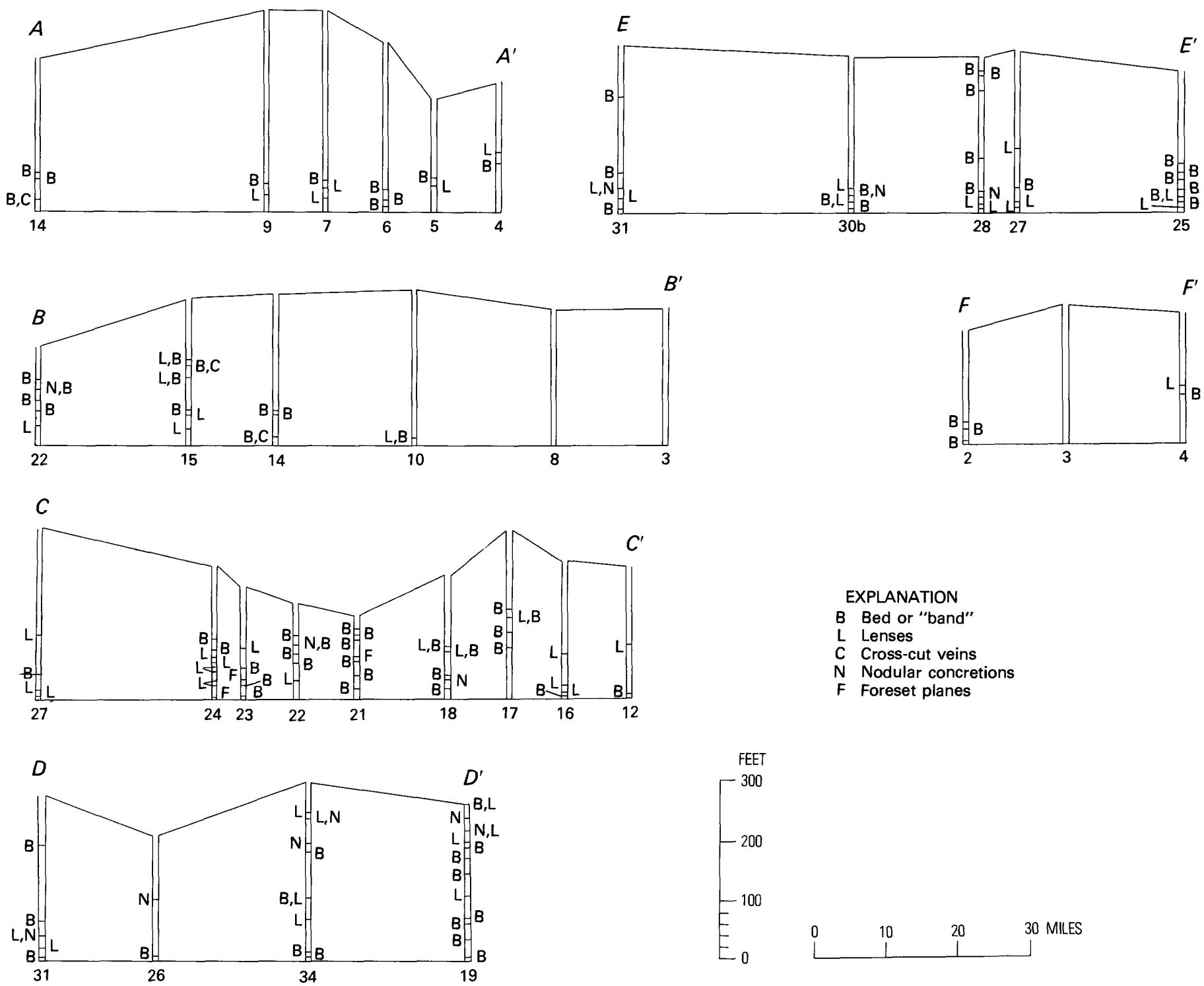

FIGURE R5.-Stratigraphic and geographic distribution of jasper deposits in Manakacha Formation along principal lines of sections $A-A^{\prime}$ to $F-F^{\prime}$ as shown in figure $A 1$; numbers are those of measured sections shown on same figure.

\section{ORIGIN OF JASPER}

The dark-red-brown jasper of the Supai Group clearly is a product of replacement for, although in most places it occurs as nearly horizontal layers that are parallel to bedding planes or it follows foreset surfaces of cross-strata, many examples of crosscutting veins, also are recorded. Furthermore, at a number of localities, such as in the Watahomigi Formation at Pica, Arizona (Hughes, 1952), examples of brachiopods and other marine fossils that are preserved in the form of jasper indicate replacement. Abundant petrographic evidence showing replacement also is available.

A specimen from a jasper lens in limestone of the
Manakacha Formation at Pigeon Wash showed in thin section that the jasper was younger than the recrystallized calcite at its boundary, according to T. G. Lovering (written commun., 1971). "Thus, the sequence of events seems to be (1) recrystallization of limestone, (2) chalcedony locally replacing limestone, goethite and hematite, (3) quartz, (4) late calcite."

The time of quartz replacement can be determined within certain limits for jasper in the formations of the Supai Group. Probably all quartz replacement took place during Pennsylvanian time. Some replacement was between Morrowan time and the beginning of Atokan deposition, for the conglomerate at the base of the Atokan in the Watahomigi Formation is, in places, replete with jasper 

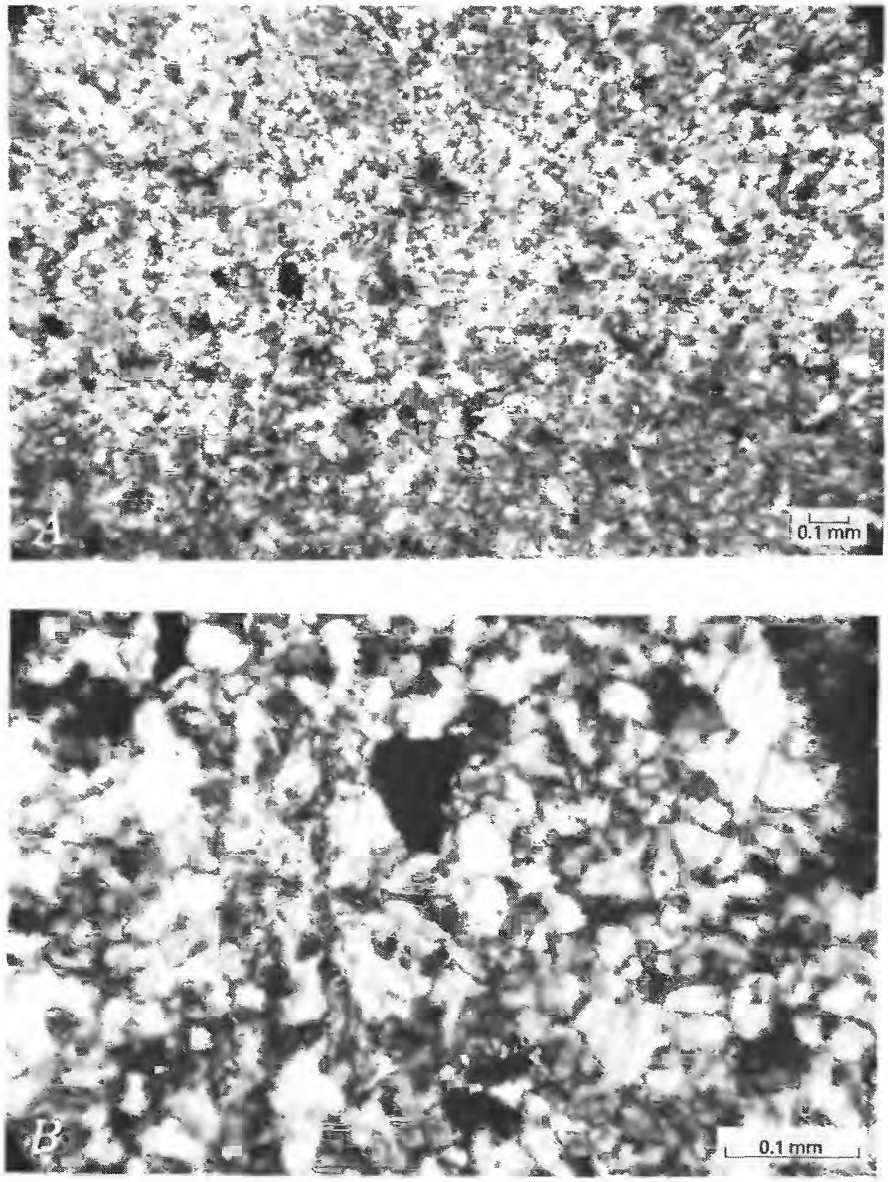

FIGURE R6.-Photomicrographs of deep-red jasper core of calcareous siltstone nodule. Manakacha Formation, Grand Gulch Wash, Ariz. Prepared by T. G. Lovering. A, Core of jasper illustrating roughly equant quartz grains containing abundant inclusions of fine-grained calcite. Texture and grain size suggestive of jasperoid. B, Center of jasper core shown in $A$, at higher magnification. Largely xenomorphic texture. Opaque grain is red hematite.

clasts. Nearly all exposures of the Atokan conglomerate throughout the region contain some pebbles of jasper (table R5). These pebbles suggest that jasperization had taken place and that jasper-bearing strata were subsequently eroded, with the siliceous sheets and nodules broken and slightly rounded into pebbles, prior to deposition of the upper slope unit of the Watahomigi Formation.

TABLE R5.-Recorded occurrences (number of localities) of jasper pebbles or clasts in conglomerates of the Supai Group

\begin{tabular}{|c|c|c|c|c|c|}
\hline & \multicolumn{5}{|c|}{ Conglomerates } \\
\hline & Esplanade & Wescogame & Manakacha & Atokan & Watahomigi \\
\hline $\begin{array}{l}\text { Number of } \\
\text { measured } \\
\text { sections }\end{array}$ & 2 & 2 & 5 & 10 & 4 \\
\hline
\end{tabular}

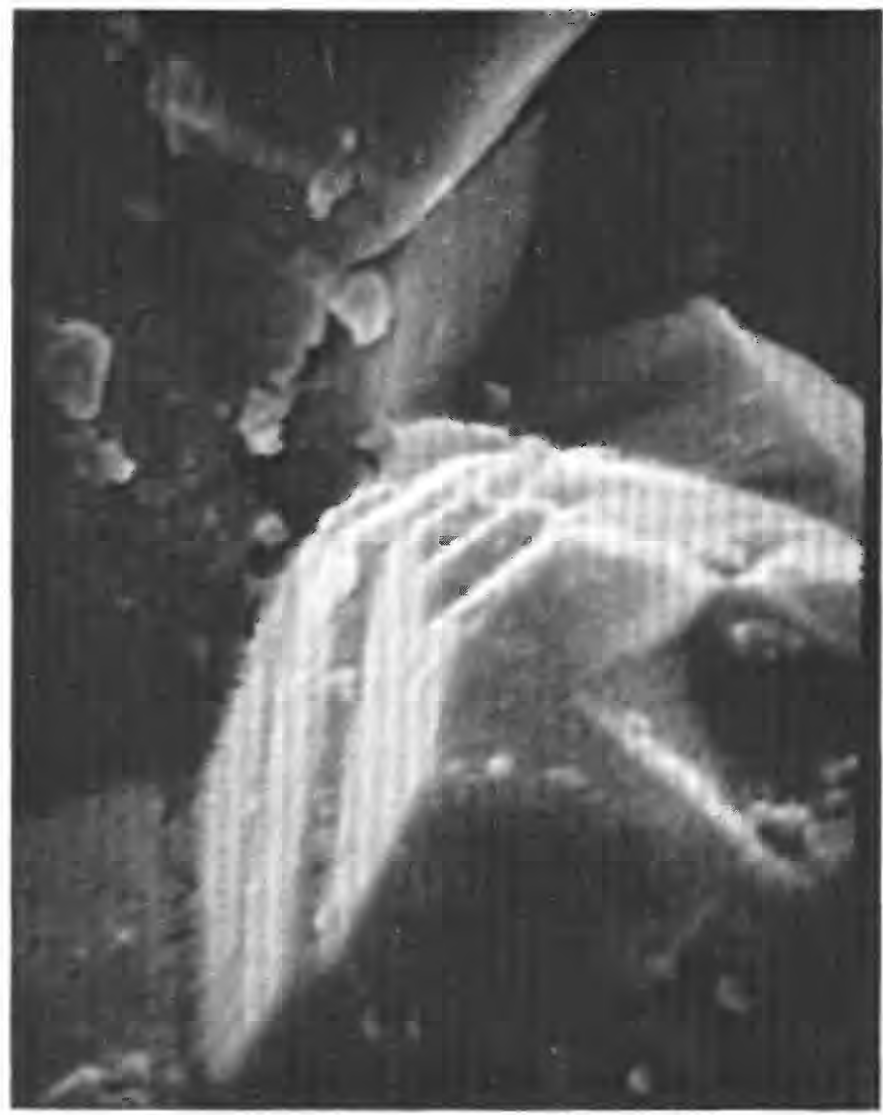

FIGURE R7. - Electron micrograph $(\times 15,000)$ of red-brown jasper from banded limestone bed at $73 \mathrm{ft}$ above base of Manakacha Formation, Havasu Canyon, Ariz. Illustrates smooth, sharply defined faces of polyhedral blocks of quartz. Prepared by Kenneth Gardner.

The process of replacement of carbonate rocks by jasper may well have continued periodically through Atokan and later parts of Pennsylvanian time. Conglomerates in the Manakacha Formation and at the base of the Wescogame (fig. R5) indicate that local sources of jasper were being exposed at various times during the Pennsylvanian and were contributing material to these gravel beds. It seems unlikely that jasper in the Watahomigi was the only source for jasper in all later conglomerate beds. Rocks in the Watahomigi must have been buried too deeply to be exhumed by normal processes active in that region during later parts of the Pennsylvanian.

An environment suitable for the dissolving of carbonate rock and the precipitation of silica in its place quite certainly required the activity of slightly acid solutions. Such an environment is postulated for strata of the Supai Group during Early Pennsylvanian time when the region was at or near sea level and a cover of vegetation extended across much of the adjacent land. Major regressions mark the late stages of each formation in the Supai Group and terrestrial deposits were periodically accumulated above marine as indicated by the occurrence of land plants, land animals, and associated sedimentary structures at various intervals 
in the stratigraphic column (see chapter I on regressions).

An alternative explanation accounting for the weakly acid environment considered necessary for the exchange of carbonates and silicates within limestones of the Supai was proposed by E. K. Maughan (written commun., 1978). He postulated that decomposition of algal and other organic matter within the carbonate beds would provide a likely process, involving an internal rather than external source of the acids. Maughan inferred that "the very shallow water deposition of the limestone beds and consequent, or even subsequent, exposure to an oxidizing environment may have been important factors in creating aerobic, rather than anaerobic, decomposition of the organic matter." Those limestones of the Supai that are lacking in jasper may therefore be explained, in part, as having remained in a reducing environment following deposition.

The high copper content in the jasper is consistent with the hypothesis stated above, according to Maughan, for "the 0.01 percent is only slightly less than 0.014 percent content of copper reported for phytoplankton." In a reducing environment "the copper would have been mobilized and probably expelled, but it has been retained as an oxide in the chert."

An hypothesis for the development of cryptocrystalline silica deposits of the type under discussion, based on textures observed under the electron microscope, has been suggested by Folk and Weaver (1952, p. 506). Because this hypothesis seems to explain satisfactorily the distinct but minute polyhedral blocks of quartz that form jasper of the Supai, it is here quoted in full:

[Prime control of the quartz development is] spacing of the centers of crystallization. It is suggested that microcrystalline quartz results when crystal growth begins at very numerous, closely spaced centers arranged in a three-dimensional array. The individual microcrystals, in random orientation, grow in all directions until they meet the advancing edges of adjacent microcrystals. If all crystallization centers are evenly spaced, the resulting microcrystals will form equant, polyhedral blocks of subuniform size such as those observed with the electron microscope. The surfaces of the blocks are slightly curved because they do not represent crystal faces, but merely the interface between two conformable masses . ${ }^{* *}$ "The rate of formation presumably governs the closeness of the spacing, and this in turn determines the grain size of the chert.

\section{AGE OF JASPER}

Pebbles and angular clasts of reddish-brown jasper, mostly $0.25-0.5 \mathrm{in}$. in diameter, are included in various conglomerates of the Supai Group at many localities. A majority (10) of the recorded jasper pebble deposits are from the Atokan conglomerate of the Watahomigi Formation (table R5), but 5 are from conglomerates in the Manakacha and 2 from the basal conglomerate of the Wesco- game. This distribution pattern is to be expected because strata of Morrowan age underlay the Atokan conglomerate and strata of Atokan age underlay channels in which the latter two conglomerates were deposited. These jasperbearing strata doubtless formed an abundant source of jasper pebbles in outcrops of the surrounding region.

Less easy to explain are the two occurrences of jasper pebbles in the basal conglomerate of the Esplanade (table R5). They are from channels exposed in National Canyon and Toroweap Valley and occur as rare angular to subrounded pebbles among an abundance of well-rounded sandstone, siltstone, and limestone pebbles of the normal assemblage in this conglomerate. Perhaps even more difficult to explain is the presence of jasper clasts in the basal conglomerate of the Watahomigi. At least two (Parashant and Bridge Canyons) of four occurrences are, at the base, resting upon a surface of Redwall Limestone, yet this type of jasper is not known to occur in the Redwall.

The presence of jasper in the form of pebbles or granules implies that jasperization must have occurred at a relatively early stage, certainly before the gravel was transported to its ultimate resting place within the conglomerate. Most of the jasper pebbles are angular to subangular, as might be expected considering both the durable nature of the material and the probability that the pebbles were locally derived from the abundant jasper beds or veins represented in older strata nearby. A few exceptions to the common angularity are clasts that probably were rolled about in a marine environment, for many of the conglomerates (Atokan, basal Watahomigi) of which these rounded jaspers are a part, also contain brachiopods.

\section{REFERENCES CITED}

Folk, R. L., and Weaver, C. E., 1952, A study of the texture and composition of chert: American Journal of Science, v. 250, no. 7, p. 498-510.

Goddard, E. N., chm., and others, 1948, Rock-color chart: National Research Council (reprinted by Geological Society of America, 1951, 1963, 1970), $6 \mathrm{p}$.

Hughes, Paul, 1952, Stratigraphy of Supai formation, Chino Valley area, Yavapai County, Arizona: American Association of Petroleum Geologists Bulletin, v. 36, no. 4, p. 635-657.

Lovering, T. G., 1972, Jasperoid in the United States-Its characteristics, origin, and economic significance: U.S. Geological Survey Professional Paper 710, $164 \mathrm{p}$.

McNair, A. H., 1951, Paleozoic stratigraphy of part of northwestern Arizona: American Association of Petroleum Geologists Bulletin, v. 35 , no. 3, p. 503-541.

Noble, L. F., 1922, A section of the Paleozoic formations of the Grand Canyon at the Bass Trail: U.S. Geological Survey Professional Paper 131, p. 23-73.

Spurr, J. E., 1898, Geology of the Aspen mining district, Colorado: U.S. Geological Survey Monograph 31, 260 p.

Walcott, C. D., 1880. The Permian and other Paleozoic groups of the Kanab Valley, Arizona: American Journal of Science, 3d ser., v. 20, p. 221-225. 

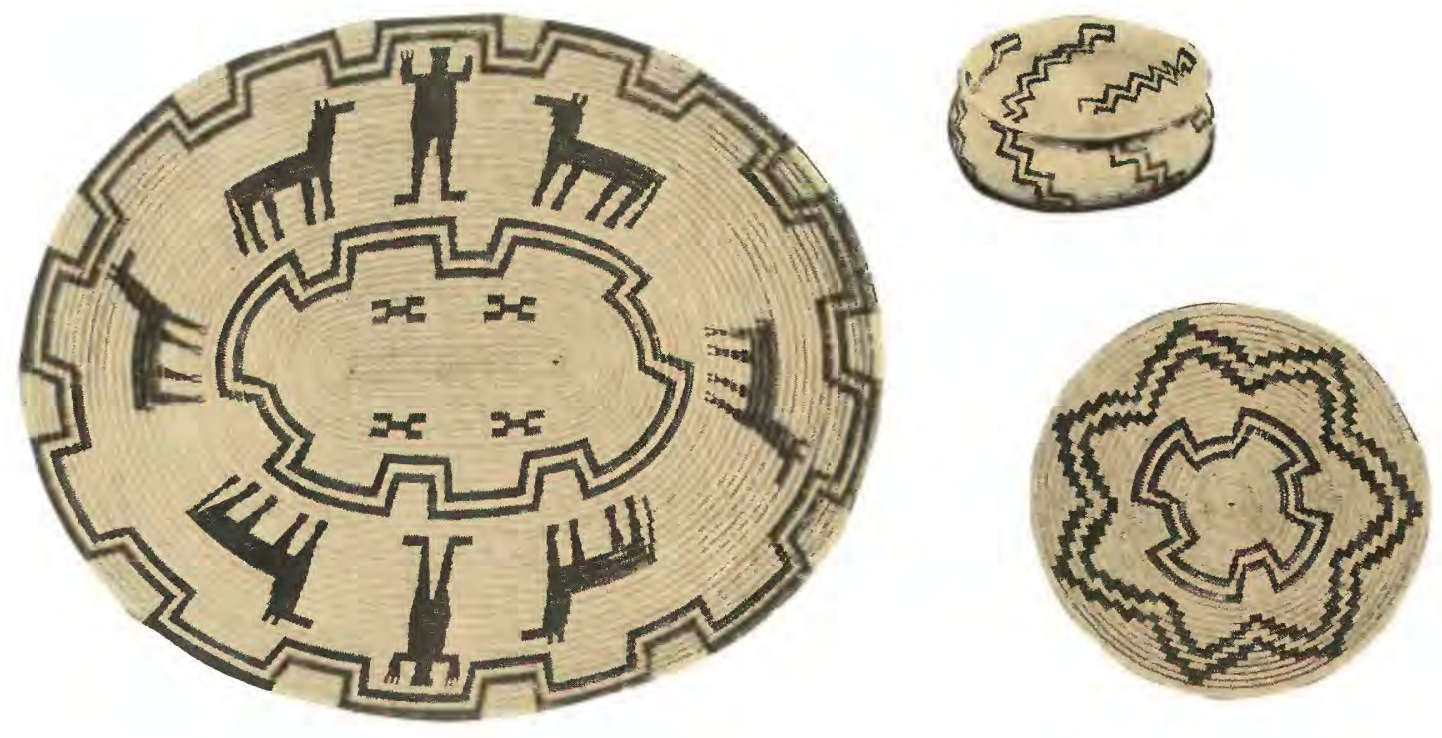

THE SUPAI GROUP OF GRAND CANYON

\section{EVAPORITE DEPOSITS AND MAGNESIAN CARBONATE ROCKS}

Chapter S

By EDWIN D. McKEE

\section{Contents}

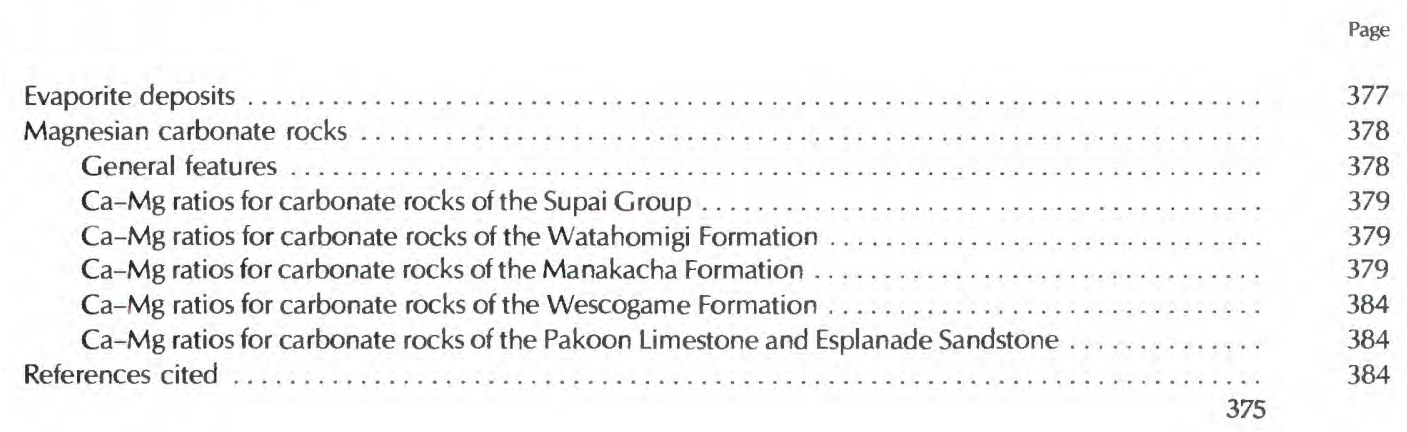




\section{Illustrations}

FIGURE S1. Map of northern Arizona and parts of adjacent states showing locations of principal gypsum-anhydrite deposits of Early Permian age $\ldots \ldots \ldots \ldots \ldots \ldots \ldots \ldots \ldots$

S2-S5. Maps showing distribution of carbonate rocks, classified according to $\mathrm{Ca}-\mathrm{Mg}$ ratio, in the:

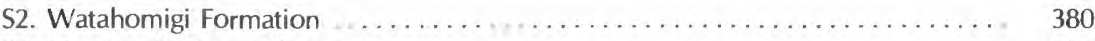

\$3. Manakacha Formation .................................. 381

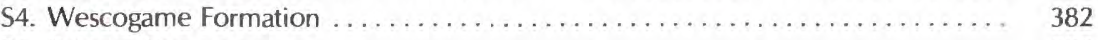

S5. Pakoon Limestone . . . . . . . . . . . . . . . . . . . . . . . . . . . . . . . . . . . 383 


\section{EVAPORITE DEPOSITS}

Of the four formations in the Supai Group, only the uppermost - the Esplanade Sandstone-contains evaporite deposits in the Grand Canyon region. These deposits consist of beds of gypsum and gypsiferous sandstone in the upper part of the formation. They are represented in sections northeast and east of the Grand Wash Cliffs (fig. S1, locality 1) where the Pakoon Limestone (McNair, 1951) intertongues with the Esplanade Sandstone. They were referred to by Fisher and Sorauf (1962, p. 651, fig. 1) as "a local gypsiferous facies present in the Hermit Formation below the Supai tongue and above the Esplanade."

The gypsiferous deposits in the Esplanade Sandstone range in thickness from $115 \mathrm{ft}$ at Andrus Canyon to $74 \mathrm{ft}$ at Toroweap Point, $20 \mathrm{mi}$ to the east (fig. C8). They occur at Andrus and Parashant Canyons and in Toroweap Valley, but are absent in sections at Blue Mountain, Prospect Valley, and elsewhere to the south and southeast. Their extent in the subsurface to the north is unknown. These gypsiferous beds probably represent a belt or band of lagoons that formed among nearshore sands to the north and west of the Wolfcampian cross-stratified sands of the Grand Canyon area.

Evaporite deposits also occur in rocks of Early Permian (Wolfcampian) age west of the Grand Canyon region. They are recorded (Welsh, 1959, p. 80) from immediately above the Pakoon Limestone in southern Nevada at Frenchman Mountain, the Muddy Mountains, and at Pakoon Ridge. These evaporite deposits formed in an elongate northeast-trending basin (fig. S1, locality 2) suggesting (Welsh, 1959, fig. 9), "that the last environment of the Pakoon Formation was a widespread evaporating lagoon." Along the northwest margin of the lagoon were (barrier) bars built of sand detritus carried by longshore currents from the northeast and on the opposite margin was the "platform dolomite facies" of the Pakoon (Welsh, 1959, p. 78).

The geographic relations in the Grand Canyon area between the sandstone facies and the gypsum facies of the Esplanade seem to be very different from those described for Nevada. In the Grand Canyon area, the gypsum accumulations are along the north margin of cross-statified sands and have an east-west linear trend. The evaporite deposits may represent a single long, narrow lagoon that extended from Andrus Canyon to Toroweap (about $20 \mathrm{mi}$ ) or they may represent several small lagoons as suggested by the absence of gypsum and the presence of flat-bedded sandstone in its place in the Whitmore Wash section. Although the gypsum deposits both in the Nevada and Grand Canyon areas are probably the same age and have about the same stratigraphic position with respect to dolostone of the Pakoon, no evidence is available to suggest that they were once connected.
Lower Permian (Wolfcampian) evaporite deposits near the San Juan River in southeastern Utah and northeastern Arizona (fig. S1, locality 3) are similar to the Esplanade gypsum deposits in most respects. These evaporites, like those of the Esplanade, consist mostly of gypsum or anhydrite in the subsurface, and generally occur as thin beds or disseminated through sandstone, within a sequence of shales, siltstones, and other red beds (Sears, 1956, p. 183). Furthermore, this gypsiferous sequence, called the Cedar Mesa Sandstone Member of the Cutler Formation, grades laterally into a massive, highly cross-stratified sandstone facies (O'Sullivan, 1965, p. 1), similar to that of the Esplanade.

The Cedar Mesa evaporite deposits differ from those of the Esplanade in the thickness of individual beds-some as much as $5 \mathrm{ft}$ (O'Sullivan, 1965, p. 42)-and in their close association with limestone beds (Sears, 1956, p. 183; O'Sullivan, 1965, p. 41). These differences may be explained by differing degrees of marine restriction and the duration of evaporite conditions. Marine waters that were responsible for limestone and evaporites of the Cedar Mesa probably were derived directly from the sea to the east; those of the Esplanade were from the Cordilleran seaway to the west.

The Lower Permian evaporite deposits of the Cedar Mesa probably are far more extensive and numerous than indicated by the outcrops that have been described from southeastern Utah. Thin beds of anhydrite, which are reported from the subsurface of the eastern Wayne County in central Utah by the American Stratigraphic Co., Denver, Colo. (Hallgarth, 1967, p. 185) and other sources, suggest that scattered lagoons along margins of marine passages in the Grand Canyon region were periodically cut off and their waters subjected to concentration. As postulated by O'Sullivan (1965, p. 45) "the gypsiferous facies was deposited in a slight downwarp or basin" flooded "from time to time by an arm of the sea" where the gypsum "was deposited under conditions of high evaporation."

An extensive evaporite basin (fig. S1, locality 4) likewise developed southeast of the Grand Canyon region during Early Permian time (Huddle and Dobrovolny, 1945; McKee, and Oriel, and others, 1967, p. 212, fig. 80). This basin has been referred to as the Yeso evaporite basin (Elston, 1960, p. 33) and as the Permian Holbrook basin (Peirce, 1958; Peirce and Gerrard, 1966). The evaporitic sequence in this basin is called the "upper Supai" (Gerrard, 1964). It ranges in thickness from $450 \mathrm{ft}$ along its southern margin to $1,300 \mathrm{ft}$ near the basin center and includes three principal lithofacies: (1) clastic facies, (2) halite-rich evaporite facies, and (3) sulfate-carbonate facies (Peirce and Gerrard, 1966, p. 9). The bedded halite is confined to a belt less than $50 \mathrm{mi}$ wide and is nearly parallel to the basin axis that trends southeast-northwest.

Evaporites of the Holbrook basin consist of anhydrite, 


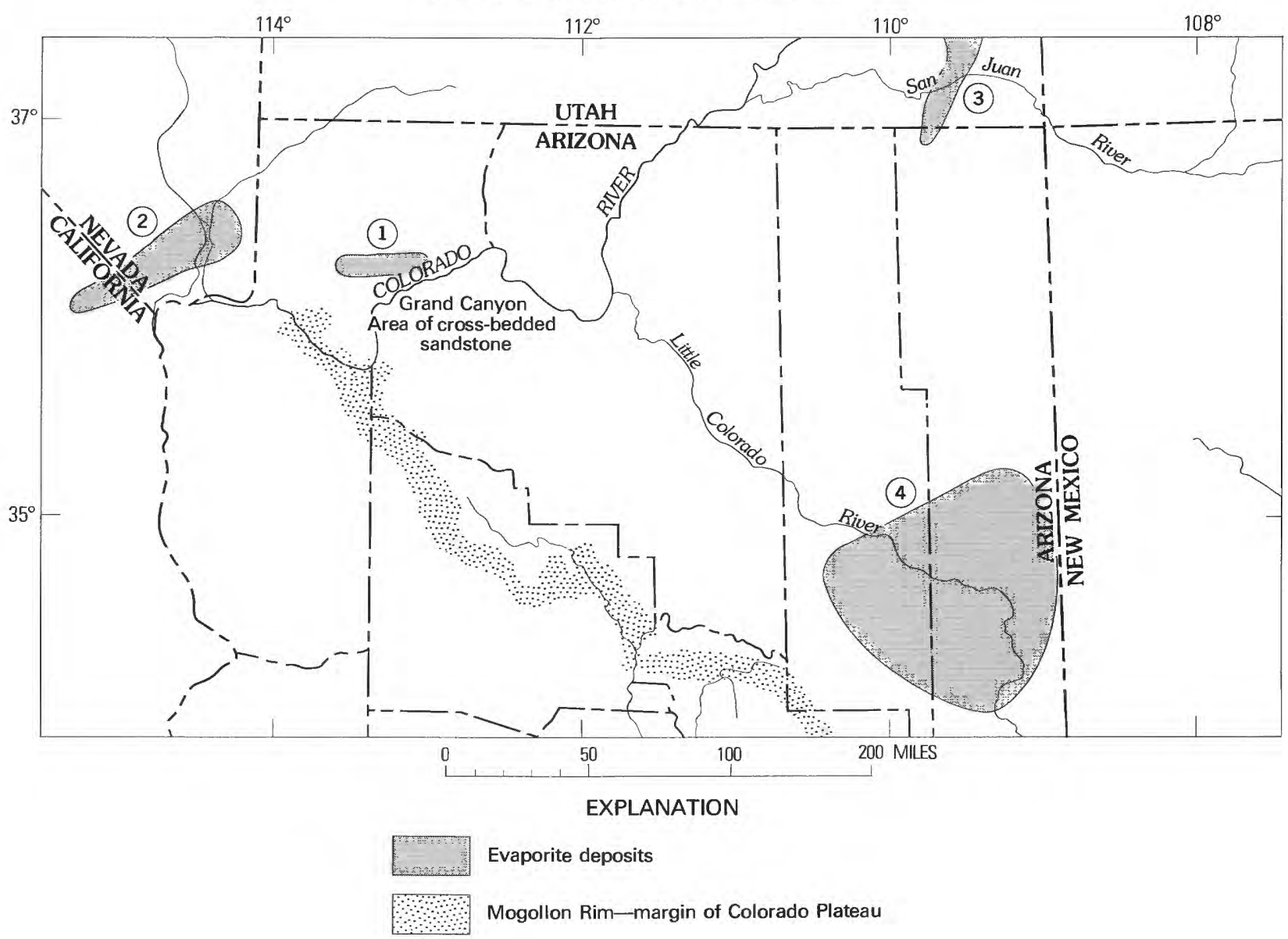

FIGURE S1.-Northern Arizona and parts of adjacent states showing locations of principal gypsum-anhydrite deposits of Early Permian age: 1. Esplanade Sandstone, western Grand Canyon area (this paper). 2. Pakoon Limestone (McNair, 1951), southeastern Nevada region (modified from Welsh, 1959). 3. Evaporites of Cedar Mesa Sandstone Member (Cutler Formation), San Juan County, Utah (modified from O'Sullivan, 1965). 4. "Upper Supai" halite and gypsum, Holbrook basin (modified from Peirce, 1966).

gypsum, halite, and sylvite, interbedded with limestone, dolostone, and siliceous clastic deposits. The halite exhibits a considerable amount of lensing among the clastic deposits. The "sylvite occurs near the top of the halite sequence" and probably "originated as a precipitate from a final bittern phase of an evaporite environment" (Peirce and Gerrard, 1966, p. 9). The distribution pattern of evaporites suggests frequent shifting in time and space of the loci of accumulation. Probably marine waters to the south and southeast periodically entered a subsiding Holbrook basin and evaporite deposition resulted from intermittent restriction of the access ways, while an increasing influx of clastic sediment from the north gradually filled the basin (Peirce and Gerrard, 1966, p. 9). Trace and minor elements in anhydrite and halite of this basin are described and discussed by Dean and Tung (1974).

The southern Nevada, Holbrook, and southeastern Utah basins, which border the Grand Canyon embayment, probably were contemporaneous or nearly contemporaneous with the Esplanade gypsum deposits and reflect a similar depositional environment. Therefore, a semiarid to arid climate with high evaporation is postulated for the entire region during Early Permian time when these evaporites accumulated. Areas in which the gypsum or anhydrite formed probably had a shallow-water, nearshore, lagoonal, or perhaps a sabkha-type environment.

\section{MAGNESIAN CARBONATE ROCKS}

\section{General features}

Whether magnesian carbonate rocks of the Supai Group are of primary (including penecontemporaneous) origin or are late diagenetic is difficult to determine. Where the 
dolostones are very fine grained with cryptocrystalline or microcrystalline texture as in the Pakoon Limestone and Wescogame Formation, they are believed to have developed on the sea floor either from direct precipitation or from early diagenesis and, therefore, probably reflect a semievaporitic environment of deposition. In contrast, the coarser-grained dolostones of the Watahomigi seem to indicate a secondary or late diagenetic origin resulting in recrystallization of the originally fine textured carbonate rock. Similar conclusions regarding genesis were reached by Lumsden, Ledbetter, and Smith (1973, p. 662) who believed that they could recognize the secondary dolostone by such features as fossil ghosts, micrite patches, and gradational boundaries between finely and coarsely crystalline textures.

Studies of insoluble residues by Lumsden (1974, p. 452) showed no significant correlation between the amount of residue and the dolomite content in rocks of mixed calcitedolomite mineralogy. A similar lack of relationship is found in analyses made of dolomitic rocks from the Grand Canyon region. Similarities both in residues and in dolomite content may result, however, from variations in nearshore processes, as suggested by Lumsden (1974, p. 445).

A common feature of carbonate rocks is their occurrence either as pure limestone or as pure dolostone, with relatively small amounts having intermediate composition. This characteristic has been recognized by numerous geologists (Steidtmann, 1917, p. 437; Scobey, 1940, p. 34; Chave, 1954, p. 599; Schmidt, 1965), and is clearly demonstrated in the Redwall Limestone that underlies the Supai Group in Grand Canyon (McKee and Gutschick, 1969, p. 105). It has been described from southern Nevada in strata equivalent to the Supai (Lumsden, 1974, p. 451). The fact that most carbonate rocks are either entirely calcitic or entirely dolomitic seems to indicate that once begun, dolomitization tends to go to completion (Lumsden, 1974, p. 454). The rocks of intermediate composition commonly are referred to as rocks of mixed calcite-dolomite mineralogy. Such rocks seem to be moderately common in the Supai Group (figs. S2-S5), especially in the thick carbonate sequences of western Grand Canyon.

Where dolostones of the Supai are associated with claystones that occur either as lenses or as thin parting beds, the clay mineral represented almost invariably is illite, as described in chapter $O$. This association apparently reflects a specialized marine environment common to both.

\section{$\mathrm{Ca}-\mathrm{Mg}$ ratios for carbonate rocks of the Supai Group}

The distribution and amount of carbonate rock and the proportions of dolomite to calcite in the carbonate rock are summarized for the Supai Group in figures S2-S5. The car- bonates are classified according to the system of Guerrero and Kenner (1955, p. 46) into five groups, based on Ca-Mg molal ratio. These groups are as follows: limestone, more than 36.19; magnesian limestone, 17.67-36.19; dolomitic limestone, 2.85-17.67; calcitic dolostone, 1.2-2.85; and dolostone, less than 1.2. Proportions of each type for a particular locality are based on five or more samples per section. Where less than five samples were available for the calculation, blank slices in the pie diagram indicate the number of carbonate rocks without analysis.

For this study 524 samples of carbonate rock, representing the four formations of the Supai Group and the Pakoon Limestone throughout the Grand Canyon region, were selected for analysis. The molal ratio of calcium oxide to magnesium oxide-a measure of excess calcium over that needed for pure dolostone-has been calculated from the $\mathrm{CaO}-\mathrm{MgO}$ determinations. All magnesium in the calculations is assumed to be in the form of dolomite, and calcium in excess of that required for a 1:1 molal ratio with magnesium is considered to be in the form of calcite.

\section{$\mathrm{Ca}-\mathrm{Mg}$ ratios for carbonate rocks of the Watahomigi Formation}

In the western part of the Grand Canyon region most of the Watahomigi Formation is composed of carbonate rocks and where these carbonate rocks are more than 100 $\mathrm{ft}$ thick, limestone is the dominant type. In most places, limestone constitutes 75 percent or more of the total. Only at Iceberg Canyon (fig. S2) is the percentage of limestone less than 50 percent. The especially high amount of dolostone and calcitic dolostone at that locality possibly is accounted for by secondary dolomitization related to faulting.

\section{$\mathrm{Ca}-\mathrm{Mg}$ ratios for carbonate rocks of the Manakacha Formation}

Carbonate rocks of the Manakacha Formation show two definite trends from east to west across the Grand Canyon region (fig. S3). First, they increase from less than $50 \mathrm{ft}$ in thickness in the east to more than $100 \mathrm{ft}$ in the extreme west. Second, carbonate rocks high in magnesium, as shown by molal ratios, are entirely in western Grand Canyon. The significance of this distribution pattern (fig. S3) is not clearcut, but because some of the Manakacha Formation in the western area is essentially free of dolostone and no definite trend in high magnesium carbonate distribution is apparent, a control by depositional environment seems unlikely. The magnesian rocks may be secondary and structurally controlled. 


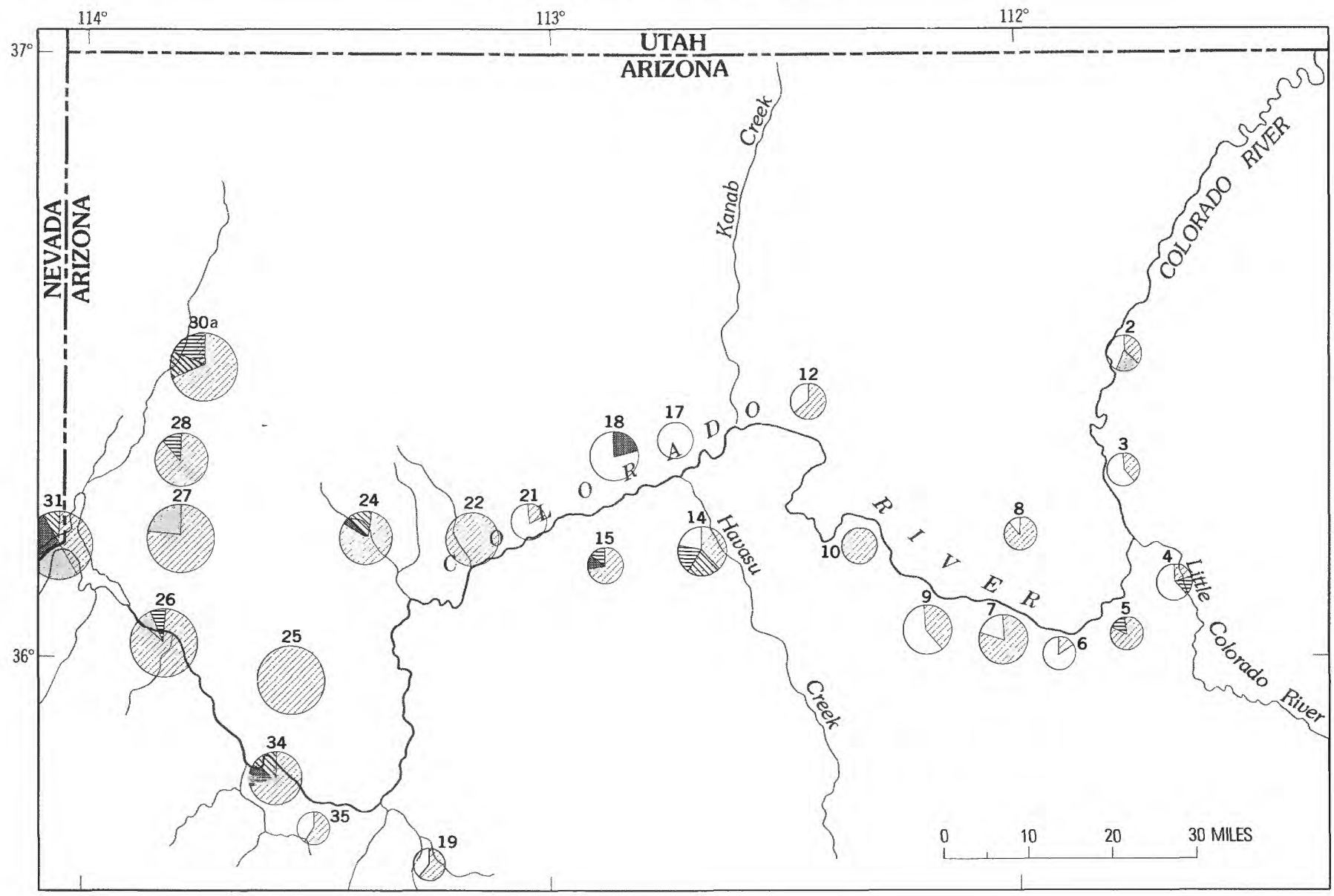

\section{EXPLANATION}

Circle size represents carbonate rock thickness, in feet Each pie based on 5 or more samples
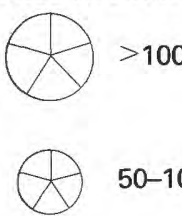

$50-100$

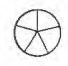

$<50$

Ca-Mg molal ratios

More than 36.19 Limestone

17.67-36.19 Magnesian limestone

2.85-17.67 Dolomitic limestone

1.2-2.85 Calcitic dolostone

Less than 1.2 Dolostone

\section{Rock type}

Limestone

Magnesian limestone

Dolomitic limestone

Calcitic dolostone

Dolostone

Carbonate rocks without analysis

FIGURE S2.-Distribution of carbonate rocks, classified according to Ca-Mg ratio, in the Watahomigi Formation of Grand Canyon, Ariz. Numbers above pies are those of measured sections (fig. A1). 


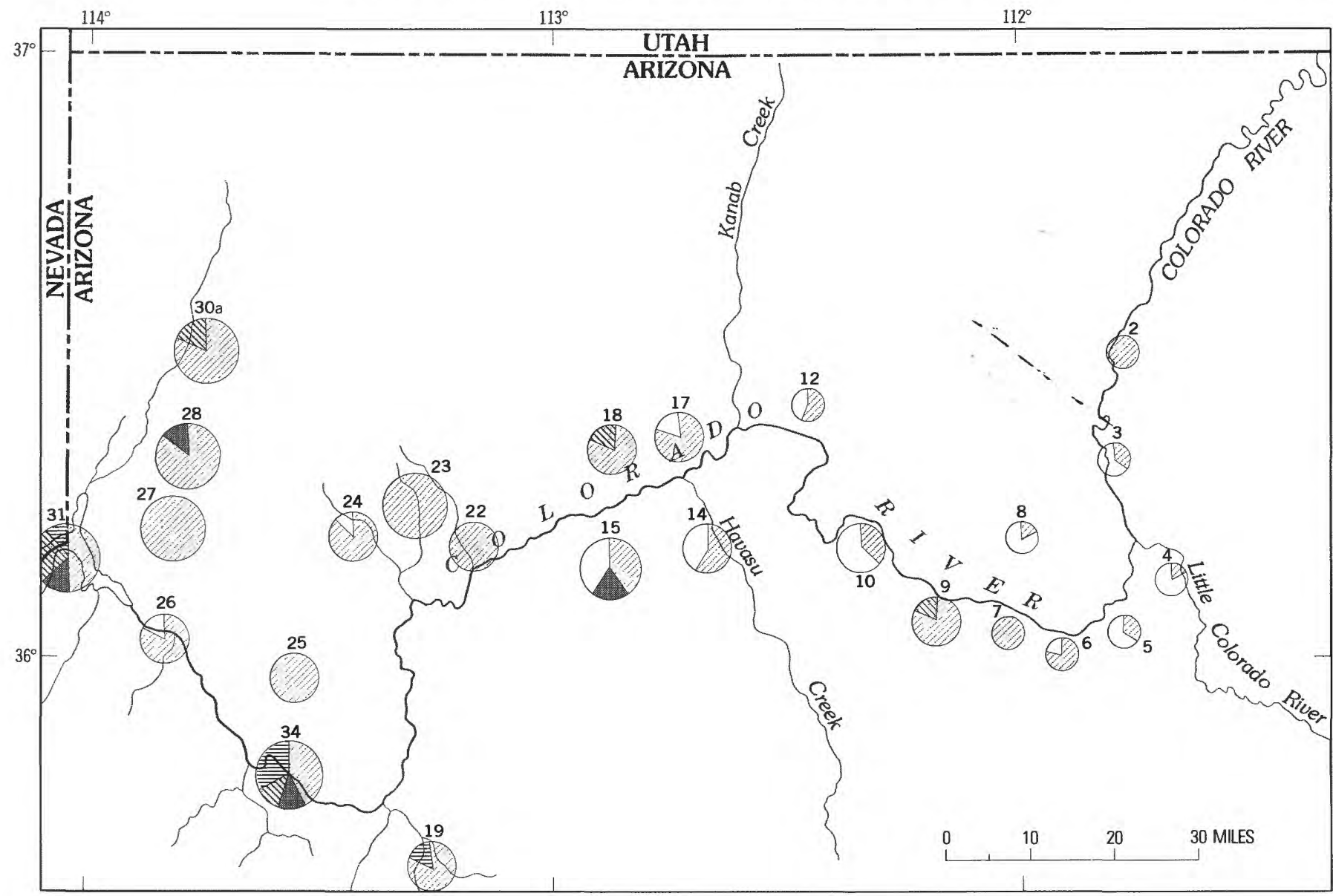

\section{EXPLANATION}

Circle size represents carbonate rock thickness, in feet Each pie based on 5 or more samples
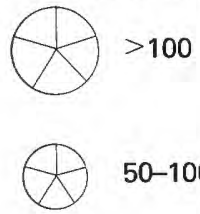

$50-100$

$\theta<50$

Ca-Mg molal ratios

More than 36.19 Limestone

17.67-36.19 Magnesian limestone

2.85-17.67 Dolomitic limestone

1.2-2.85 Calcitic dolostone

Less than 1.2 Dolostone
Rock type

Limestone

Magnesian limestone

Dolomitic limestone

Calcitic dolostone

Dolostone

Carbonate rocks without analysis

FIGURE S3,-Distribution of carbonate rocks, classified according to Ca-Mg ratio, in the Manakacha Formation of Grand Canyon, Ariz. Numbers above pies are those of measured sections (fig. A1). 


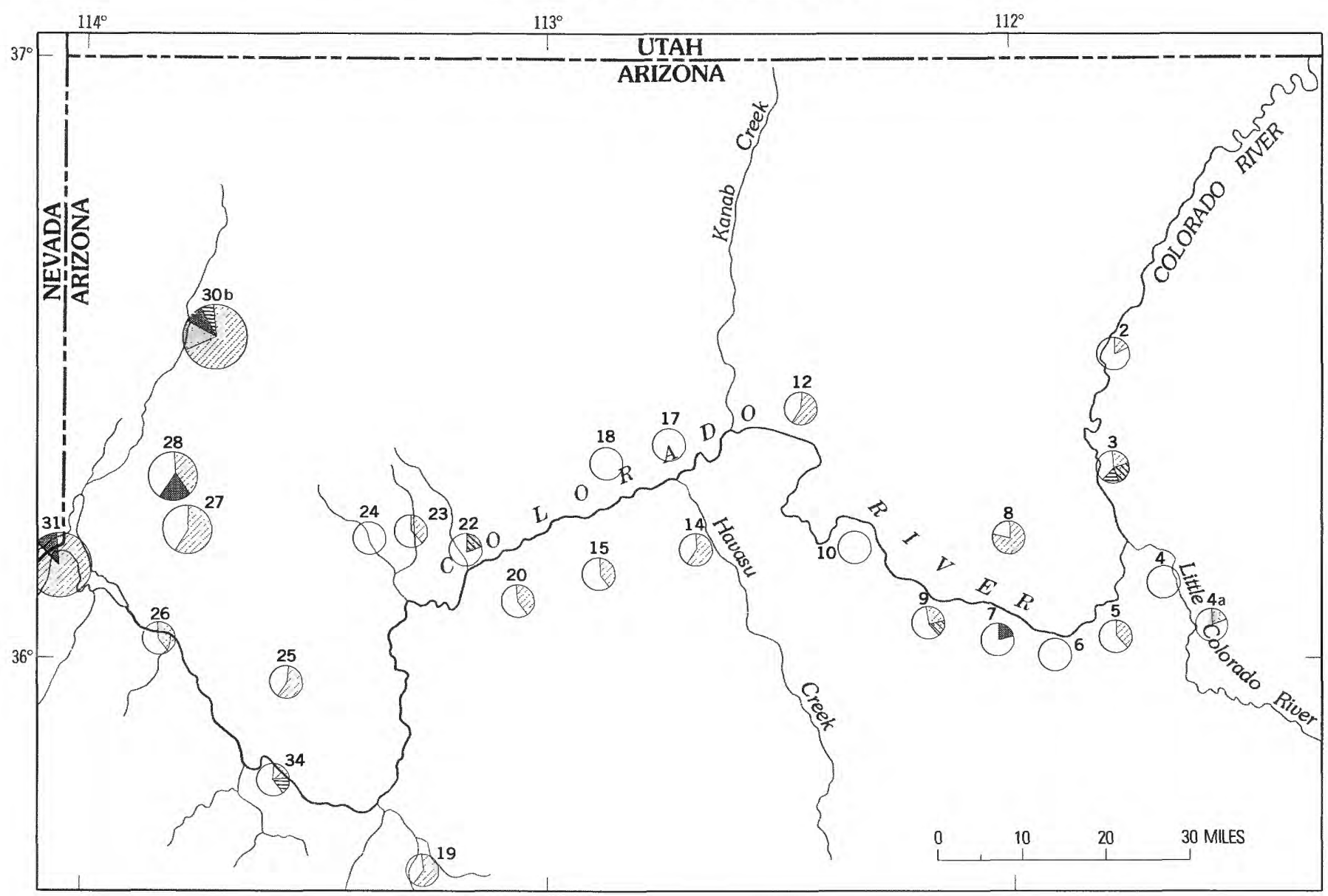

\section{EXPLANATION}

Circle size represents carbonate rock thickness, in feet Each pie based on 5 or more samples

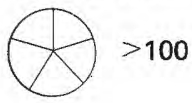

$50-100$

B $<50$

Ca-Mg molal ratios

More than 36.19 Limestone

17.67-36.19 Magnesian limestone

2.85-17.67 Dolomitic limestone

1.2-2.85 Calcitic dolostone

Less than 1.2 Dolostone
Rock type

Limestone

Magnesian limestone

Dolomitic limestone

Calcitic dolostone

Dolostone

Carbonate rocks without analysis

FIGURE S4.-Distribution of carbonate rocks, classified according to Ca-Mg ratio, in the Wescogame Formation of Grand Canyon, Ariz. Numbers above pies are those of measured sections (fig. A1). 


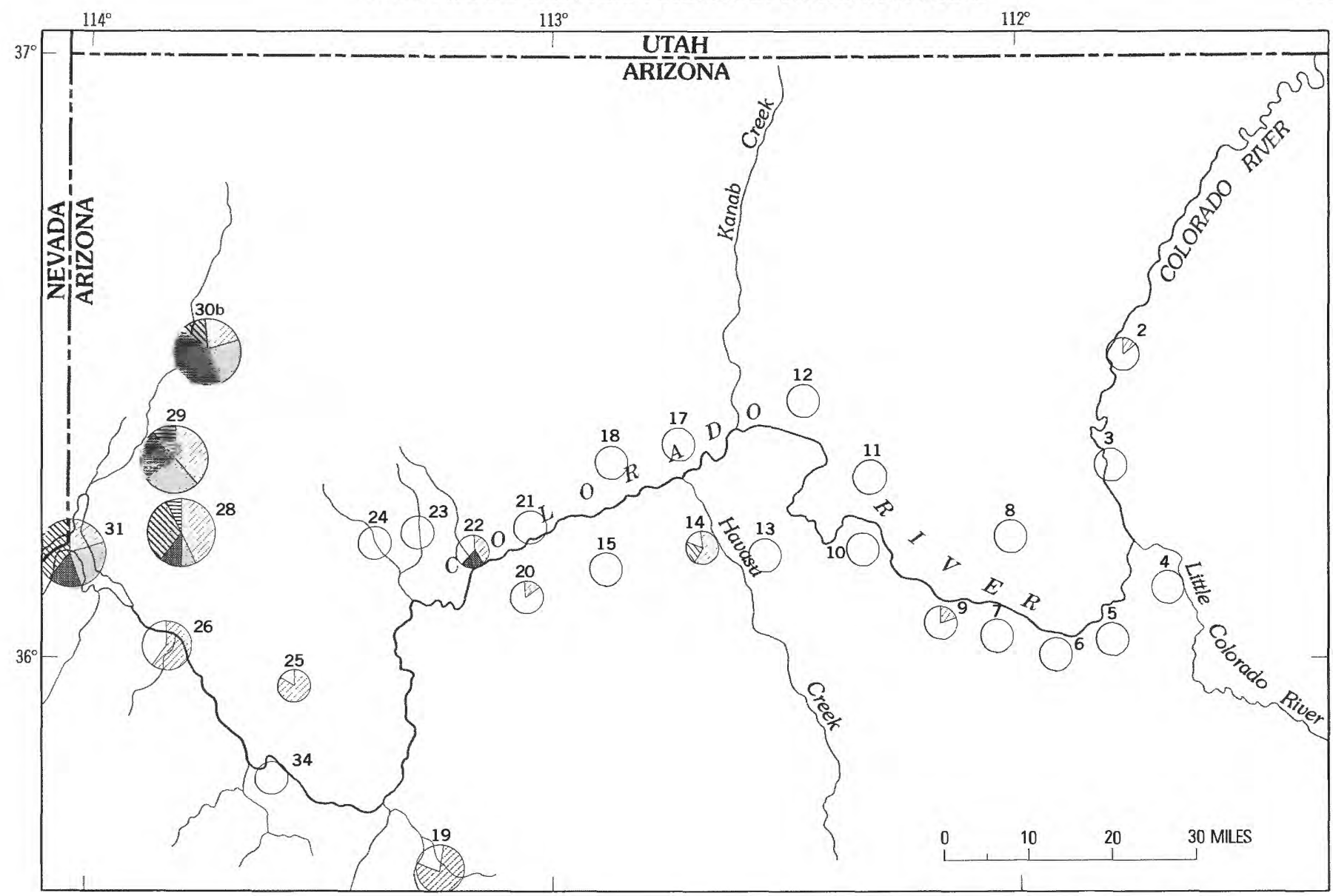

\section{EXPLANATION}

Circle size represents carbonate rock thickness, in feet Each pie based on 5 or more samples

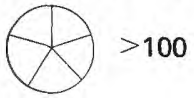

50-100

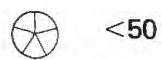

Ca-Mg molal ratios

More than 36.19 Limestone

17.67-36.19 Magnesian limestone

2.85-17.67 Dolomitic limestone

1.2-2.85 Calcitic dolostone

Less than 1.2 Dolostone
Rock type

Limestone

Magnesian limestone

Dolomitic limestone

Calcitic dolostone

Dolostone

Carbonate rocks without analysis

FIGURE S5-Distribution of carbonate rocks, classified according to Ca-Mg ratio, in the Pakoon Limestone (McNair, 1951) and Esplanade Sandstone of Grand Canyon, Ariz. Numbers above pies are those of measured sections (fig. A1). 


\section{$\mathrm{Ca}-\mathrm{Mg}$ ratios for carbonate rocks of the Wescogame Formation}

The proportion of carbonate rock to detrital rock in the Wescogame Formation is lower than in either of the underlying Pennsylvanian formations. Throughout eastern and central Grand Canyon, the total thickness of Wescogame carbonates is less than $100 \mathrm{ft}$ and in several sections of central Grand Canyon, carbonate rocks are lacking. Coincidentally, the Wescogame Formation in the central area where no dolostone occurs, has exceptionally high sand accumulation (70-100 percent).

$\mathrm{Ca}-\mathrm{Mg}$ molal ratios (fig. S4) indicate that only a small percentage of the Wescogame carbonate rocks contain appreciable amounts of magnesium. Rocks ranging from magnesian limestone to "pure" dolostone occur both in the far eastern and far western parts of the region, but are not recorded from the middle part.

\section{$\mathrm{Ca}-\mathrm{Mg}$ ratios for carbonate rocks of the Pakoon Limestone and Esplanade Sandstone}

The great mass of detrital sediment, mostly very fine grained sand, that comprises the Esplanade Sandstone doubtless precluded deposition of any appreciable amount of carbonate sediment in the Grand Canyon area. A few thin beds of limestone in some sections in the middle and western parts of the area are interpreted as tongues that extend eastward from the Pakoon Limestone in extreme northwestern Arizona.

The Pakoon, now established as a lateral equivalent of the lower part of the Esplanade Sandstone, represents a nearly complete change of lithofacies within a relatively few miles. It occurs between sections along the Grand Wash Cliffs (fig. A1, secs. 28, 29, 30) and the nearest outcrops to the east (secs. 24 and 25). The lateral termination of about $250 \mathrm{ft}$ of carbonate rock, and the beginning of a sandstone sequence, with little recognizable intertonguing between, is a striking feature that requires explanation.

Carbonate rock of the Pakoon has low $\mathrm{Ca}-\mathrm{Mg}$ ratios. Sections at Hidden Canyon and Pigeon Wash on the Grand Wash Cliffs and at Iceberg Canyon (fig. S5) show dolostone and calcitic dolostone to be about 50 percent or more of the carbonate rock, and, in numerous sections farther west, a similar high magnesium content has been recognized (Welsh, 1959; Lumsden, 1974). This distribution pattern, with much dolostone along the eastern margin of the Pakoon Limestone adjacent to the sand mass of the Esplanade, probably suggests a depositional environmental control, rather than a secondary structurally controlled diagenesis.

\section{REFERENCES CITED}

Chave, K. E., 1954, Aspects of the biogeochemistry of magnesium-[pt.] 1, Calcareous marine organisms; [pt.] 2, Calcareous sediments and rocks: Journal of Geology, v. 62, no. 3, p. 266-282; no. 6, p. 587-599.

Dean, W. E., and Tung, A. L., 1974, Trace and minor elements in anhydrite and halite, Supai Formation (Permian), east-central Arizona, in A. H. Coogan, ed., Fourth symposium on salt, v. 1, Geochemistry and mineralogy: Cleveland, Ohio, Northern Ohio Geological Society, p. 287-301.

Elston, W. E., 1960, Structural development and Paleozoic stratigraphy of Black Mesa basin, northeastern Arizona, and surrounding areas: American Association of Petroleum Geologists Bulletin, v. 44, p. 21-36.

Fisher, W. L., and Sorauf, J. E., 1962, Correlation chart of the Permian formations of North America-Discussion of the Grand Canyon section: Geological Society of America Bulletin, v. 73, p. 649-752.

Gerrard, T. A., 1964, Stratigraphy of the Fort Apache Member, Supai Formation (Permian), east-central Arizona, in Contributions to the geology of northern Arizona-Major Brady Memorial: Museum of Northern Arizona Bulletin 40, p. 33-48.

Guerrero, R. G., and Kenner, C. T., 1955, Classification of Permian rocks of western Texas by a versenate method of chemical analysis: Journal of Sedimentary Petrology, v. 25, no. 1, p. 45-50.

Hallgarth, W. E., 1967, Western Colorado, southern Utah, and northwestern New Mexico, in McKee, E. D., and Oriel, S. S., and others, Paleotectonic investigations of the Permian System in the United States, chapter I: U.S. Geological Survey Professional Paper 515, p. 171-197.

Huddle, J. W., and Dobrovolny, E., 1945, Late Paleozoic stratigraphy and oil and gas possibilities of central and northeastern Arizona: U.S. Geological Survey Oil and Gas Investigations Preliminary Chart 10.

Lumsden, D. N., 1974, Relationships among insoluble residue, dolostone and limestone facies: Journal of Sedimentary Petrology, v. 44, no. 2 , p. $450-455$.

Lumsden, D. N., Ledbetter, M. T., and Smith, G. T., 1973, Lithostratigraphic analysis of the Bird Spring-Callville Group and Pakoon Formation (Pennsylvanian-lower Permian), southern Clark County, Nevada: Journal of Sedimentary Petrology, v. 43, no. 3, p. 655-671.

McKee, E. D., and Gutschick, R. C., 1969, History of the Redwall Limestone of northern Arizona: Geological Society of America Memoir $114,726 \mathrm{p}$.

McKee, E. D., and Oriel, S. S., and others, 1967, Paleotectonic investigations of the Permian System in the United States: U.S. Geological Survey Professional Paper 515, 271 p.

McNair, A. H., 1951, Paleozoic stratigraphy of part of northwestern Arizona: American Association of Petroleum Geologists Bulletin, v. 35, no. 3, p. 503-541.

O'Sullivan, R. B., 1965, Geology of the Cedar Mesa-Boundary Butte area, San Juan County, Utah: U.S. Geological Survey Bulletin 1186, $128 \mathrm{p}$.

Peirce, H. W., 1958, Permian sedimentary rocks of the Black Mesa basin area, in New Mexico Geological Society Guidebook, 9th Field Conference, October 1958: p. 82-87.

Peirce, H. W., and Gerrard, T. A., 1966, Evaporite deposits of the Permian Holbrook basin, Arizona, in Second symposium on salt, v. 1, Geology, geochemistry, mining: Cleveland, Ohio, Northern Ohio Geological Society, p. 1-10.

Sears, J. D., 1956, Geology of Comb Ridge and vicinity north of San Juan River, San Juan County, Utah: U.S. Geological Survey Bulletin 1021-E, p. 167-207. 
Schmidt, V., 1965, Facies, diagenesis, and related reservoir properties in the Gigas beds (Upper Jurassic), northeastern Germany: Society of Economic Paleontologists and Mineralogists Special Publication 13, p. 124-168.

Scobey, E. H., 1940, Sedimentary studies of the Wapsipinicon formation in Iowa: Journal of Sedimentary Petrology, v. 10, no. 1, p. 34-44.
Steidtmann, Edward, 1917, Origin of dolomite as disclosed by stains and other methods: Geological Society of America Bulletin, v. 28, p. 431-450.

Welsh, H. E., 1959, Biostratigraphy of the Pennsylvanian and Permian Systems of southern Nevada: Utah University, Ph. D. thesis, 106 p. 

Measured stratigraphic sections of the Supai Group, Grand Canyon, Arizona $^{1}$

${ }^{1}$ In Western Grand Canyon includes Pakoon Limestone of McNair, A. H., 1951, Paleozoic stratigraphy of part of northwestern Arizona: American Association of Petroleum Geologists Bulletin, v. 35, no. 3, p. 503-541. 


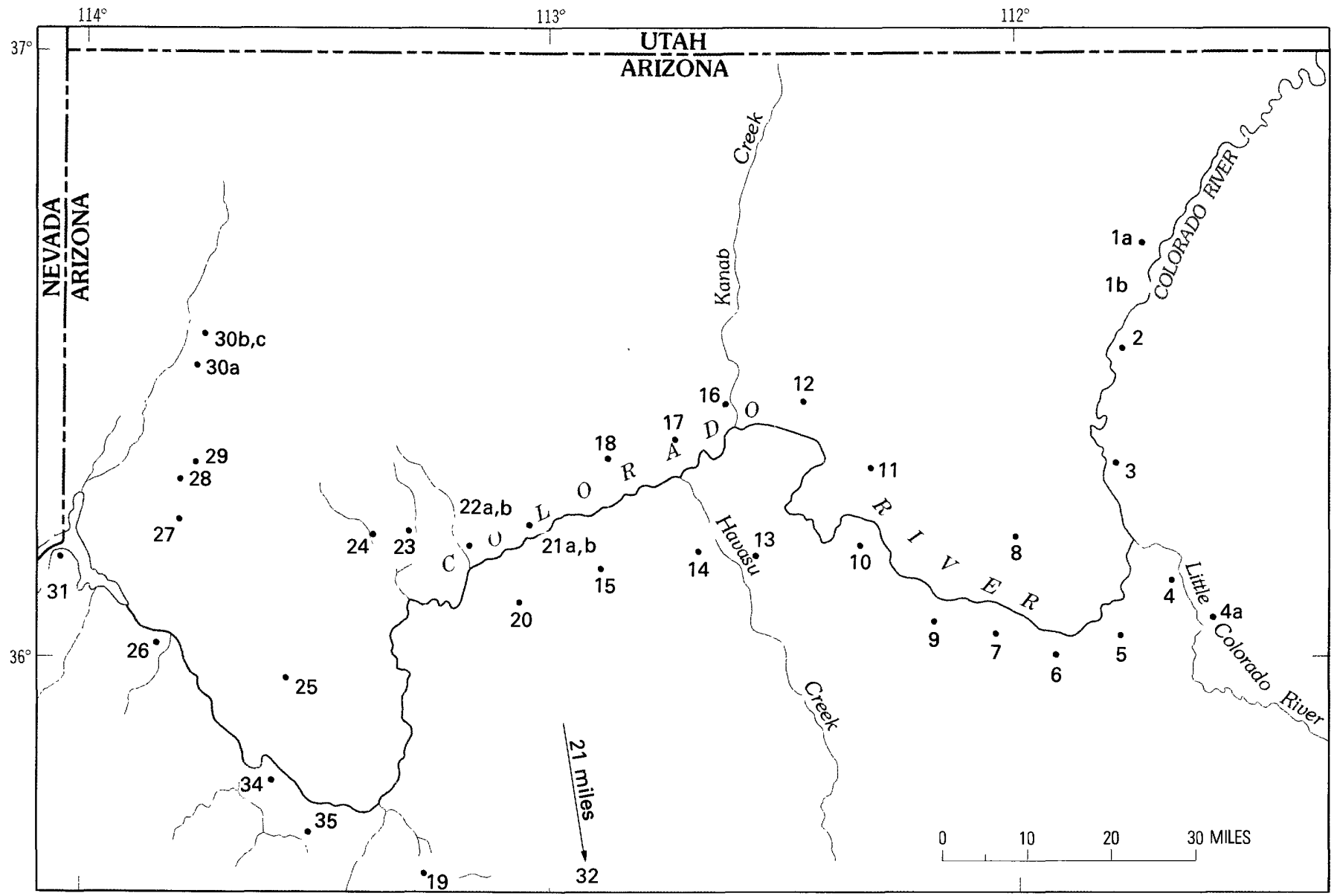

FIGURE MS1.-Locality map of Grand Canyon region, Arizona, showing positions (solid circles) of numbered measured stratigraphic sections (1-35). Arrow and miles indicate direction and distance to actual locality of section.

\section{NOTES ON TERMINOLOGY}

Names of carbonate rocks, where based on analyses of quantitative data (molal ratio), follow the five-fold system of Cayeux ${ }^{1}$ and of Pettijohn ${ }^{2}$. The modifying adjective as calcitic, dolomitic, or magnesian, follows the principal name in its description and is separated by a comma.

Most of the color names are based on the Rock Color Chart ${ }^{3}$; determination was by visual comparison, and terminology conforms with that of the chart. Hyphenation follows U.S. Government Printing Office style for unit modifiers.

Names of grain sizes follow those of the Wentworth Scale (see also chapter A, p. 10) and use the terminology throughout of very coarse, coarse, medium, fine, and very fine as determined by analysis or by grain comparison on slides.

1Cayeux, Lucien, 1935, Les roches sedimentaires de France; Roches carbonattes (calcaires et dolomies): Paris, Masson $463 \mathrm{p}$.

${ }^{2}$ Pettijohn, F. J., 1949, Sedimentary rocks: New York; Harper and Bros., p. 312.

${ }^{3}$ Goddard, E. N., and others, 1948, Rock color chart: National Research Council (reprinted by Geological Society of America, 1951, 1970), $6 \mathrm{p}$ 


\title{
MEASURED STRATIGRAPHIC SECTIONS
}

\author{
By EDWIN D. McKEE
}

\section{Contents}

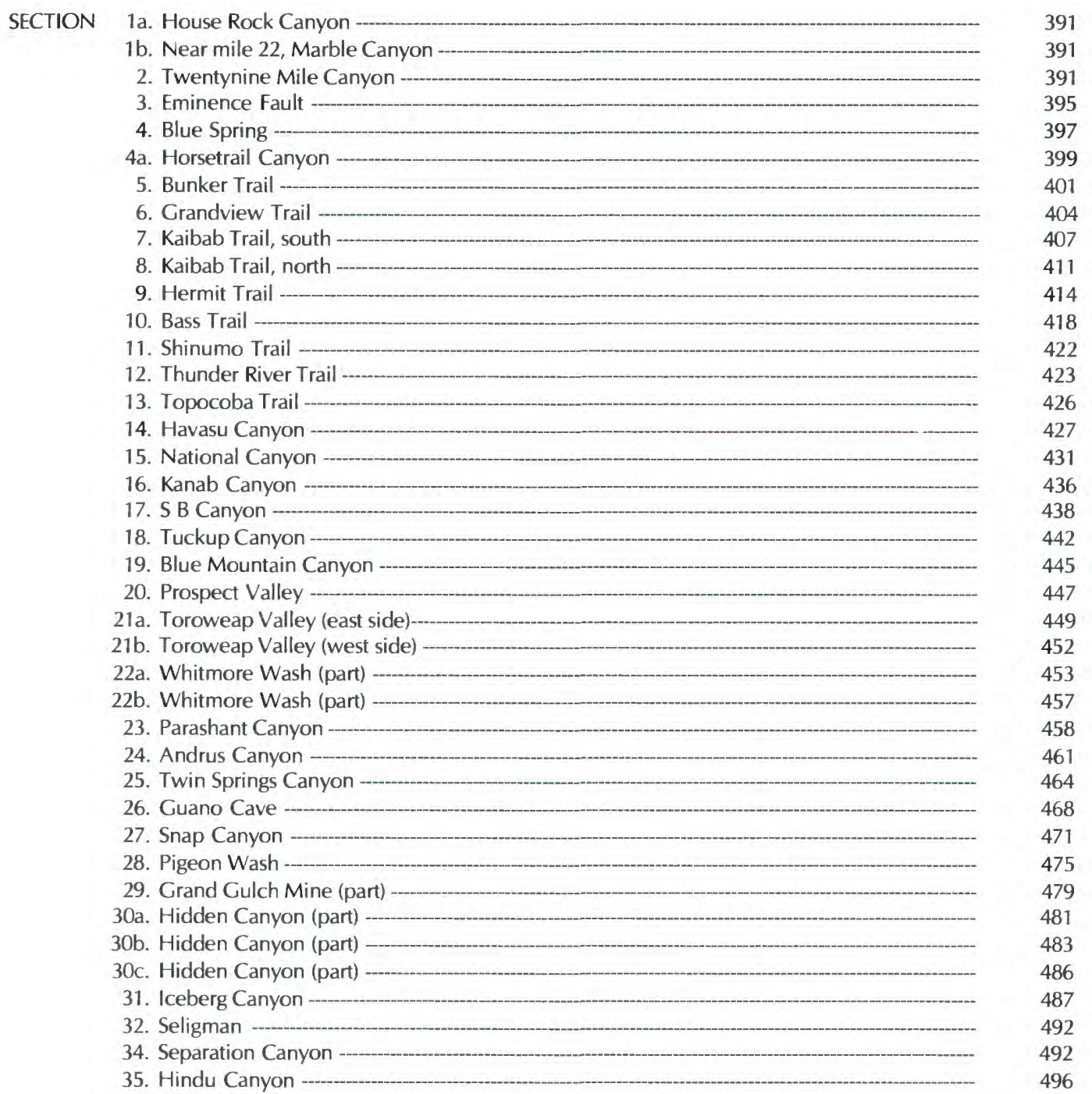

\section{Illustrations}

FIGURE MS1. Map showing localities of measured sections MS2. Color photographs of strata of Supai Group - 390 

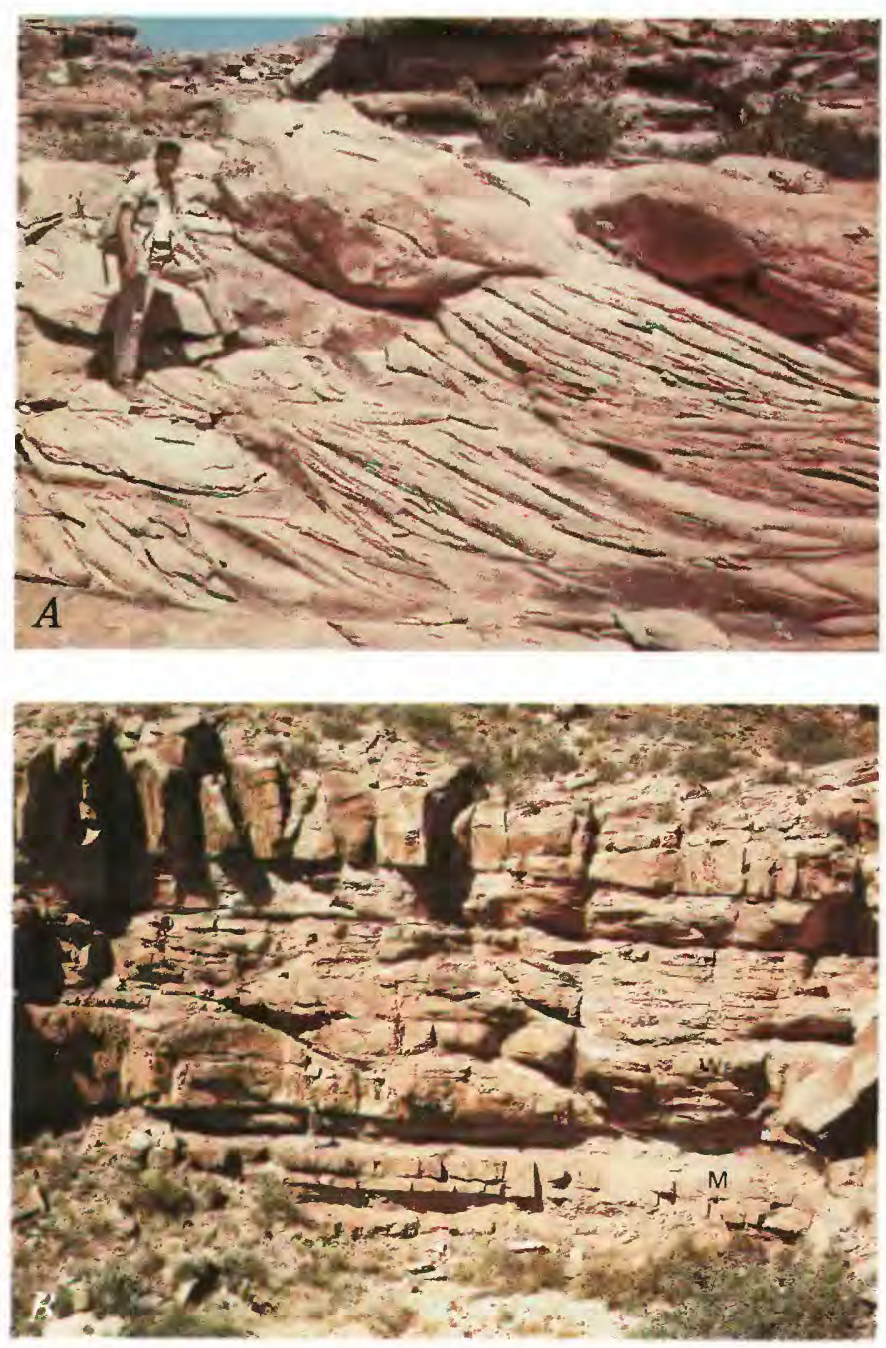

FIGURE MS2.-Strata of Supai Group, Grand Canyon, Ariz. A, Tabularplanar sets of cross-strata in middle of Esplanade Sandstone, main cliffunit. Sandstone foresets show variation of orange-pink to reddish-orange color characteristic of most surfaces in this unit. Apache Trail into Havasu Canyon. B, Massive sandstone beds of cliff unit of Wescogame Formation (We) are mostly various shades of grayish orange-pink. Channels near base are filled with conglomerate. Manakacha Formation (M) below. Thunder River Trail. C, Cliff of Manakacha Formation (M) in right foreground. Massive beds of limestone and sandstone of Manakacha cliff unit show normal reddish brown in lower part and black varnished sur-
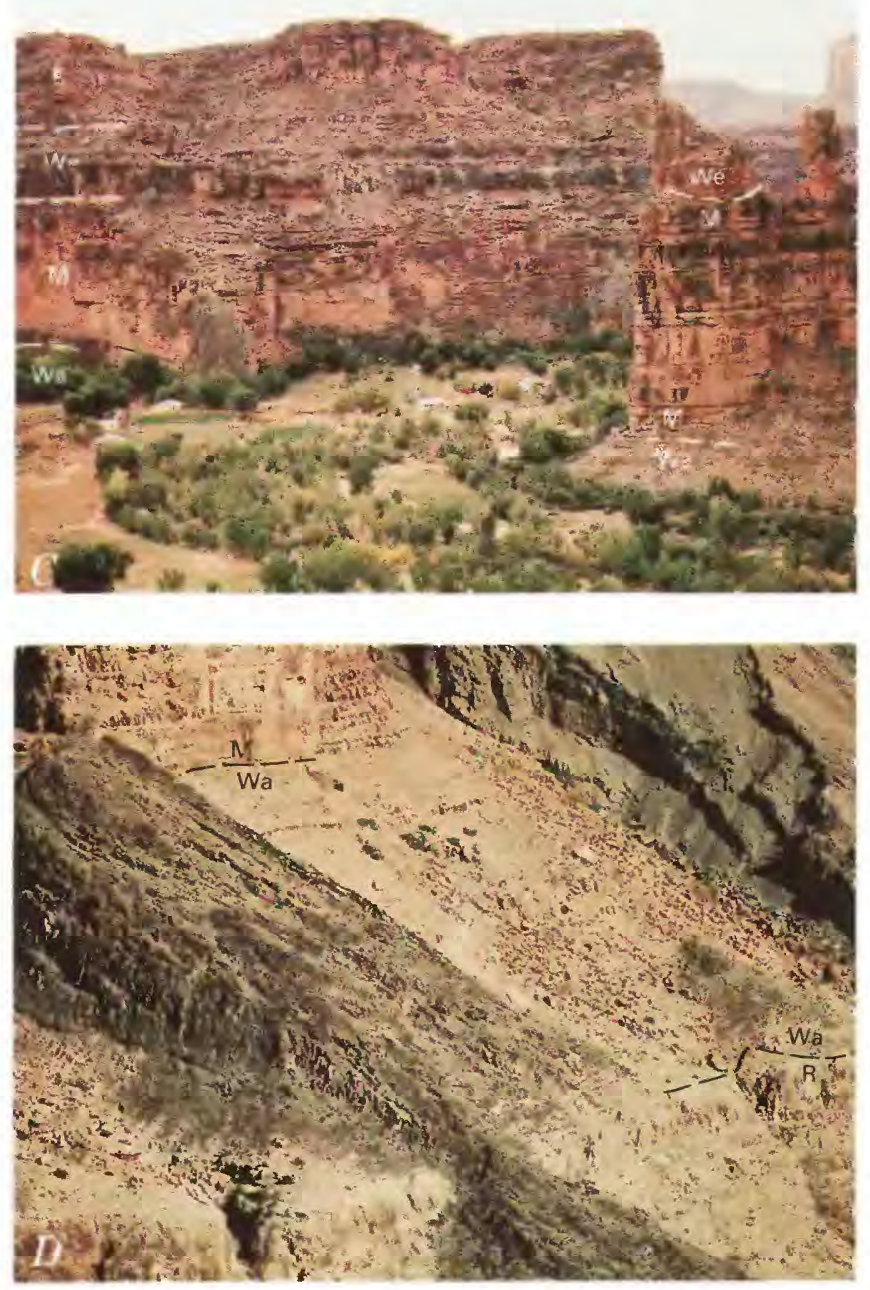

faces in upper part; thin slope unit at top is moderate reddish orange. Wa, Watahomigi Formation; We, Wescogame Formation; E, Esplanade Sandstone. Strata form walls of Havasu Canyon above Supai Village. $D$, Window of Watahomigi Formation (Wa) with basalt flows on each side; base of Manakacha Formation (M) cliff above and Redwall Limestone (R) cliff below. Total thickness of Watahomigi is $215 \mathrm{ft}$. Deep reddish brown of mudstone slopes largely concealed by talus; limestone and sandstone ledges appear as dark brown on weathered surfaces. Marine fossils numerous on lower siltstone slopes and conglomerate ledges. West side of Toroweap Valley, south of Colorado River. 
Section 1a (part)

\section{HOUSE ROCK CANYON}

[Basal conglomerate of Esplanade Sandstone at mile 16.5 in Marble Canyon, west wall]

Esplanade Sandstone:

Main cliff and basal slope units not measured here.

Conglomerate, forms lenses within channels at base of basal slope unit; channels $40-50 \mathrm{ft}$ deep and extend laterally about $260 \mathrm{ft}$.

Matrix: calcareous sandstone.

Gravel: gray, aphanitic, laminated limestone; redbrown siltstone; purple, aphanitic limestone; dark-gray limestone; pale-red sandstone.

Sphericity-spherical to flat; limestones mostly platy, siltstones and sandstones spherical.

Roundness-well-rounded to angular; limestones largely angular or subangular; siltstones rounded.

Size-average 0.5-1 in. Maximum-sandstone block 18 by 6 in.; sandstones 11 and 7 in. diameters; limestone 6 in. diameter.

Section $1 b$ (part)

\section{NEAR MILE 22, MARBLE CANYON}

[Upper part of Watahomigi formation measured in west side of Colorado River near Mile 23]

Supai Group:

(Overlying cliff-forming beds not examined)

Manakacha Formation or upper slope unit of

Watahomigi:

Limestone, gray-brown, and conglomerate, gray-brown to black, beds medium (1-2 ft), some beds contorted on large scale; Pennsylvanian age solution channel filled with purple mudstone; forms basal unit of cliff; weathers to rough surface

Matrix: limestone, light- to dark-gray.

Gravel: abundant jasper and black chert, some dark-gray, silty limestone; chert pebbles angular, carbonate pebbles rounded to subrounded; diameters mostly $0.25-0.5$ in., maximum 2 in.

Contact:

Irregular wavy surface.

Watahomigi Formation:

Sandstone, red-brown, very fine grained, friable; cross-stratified on medium scale; weathers to weak cliff with receding ledges at top

Concealed: talus-covered slope
Section $1 \mathrm{~b}-$ Continued

NEAR MILE 22, MARBLE CANYON-Continued

Supai Group-Continued

Watahomigi Formation-Continued

(Basal conglomerate measured on east side of river)

Conglomerate, red-brown to light-gray, limy; forms rounded massive cliff; rests on karst surface of Redwall Limestone --.--..--..-

Matrix: dark-red-brown silty limestone.

Gravel: light-gray limestone, dark-gray limestone, purple silty limestone; mostly rounded to subrounded; diameters largely $0.5-1$ in., maximum 4 in.

Total Watahomigi Formation --- $\overline{87.0}$

\section{Section 2}

\section{TWENTYNINE MILE CANYON}

[Along northeast wall at Marble Canyon (section progresses up Twentynine Mile Canyon)]

Feet

Hermit Shale:

Siltstone, pale-reddish-brown, shaly; forms slope

Contact:

No erosion surface apparent near line of section.

Supai Group:

Esplanade Sandstone, upper cliff-slope unit:

Sandstone, moderate-orange-pink, very fine grained; contains tabular-planar crossstratification on large scale $(20-30 \mathrm{ft})$; forms resistant ledge

Mudstone, moderate-reddish-brown, crumbly; forms slope and recess

Siltstone, red-brown, medium-bedded; forms ledges

Sandstone, moderate-reddish-orange, very fine grained, very calcareous, friable, flatbedded, thin-bedded (2-12 in.); contains much silt, skeletal fragments; forms series of receding ledges

Sandstone, very pale orange, very fine grained, hard; contains tabular-planar cross-stratification on large scale $(20-30 \mathrm{ft})$; weathers red-brown; forms resistant ledge

Mudstone, dark-reddish-brown, structureless; forms slope

Limestone, grayish-red-purple, very fine grained, thin-bedded (1-2 in.); very irregular surface; forms slope

\section{et} 40

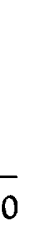


Section 2-Continued

TWENTYNINE MILE CANYON-Continued

Supai Group-Continued

Esplanade Sandstone, upper cliff-slope unit-

Continued

Mudstone, pale-reddish-brown, flat-bedded, thin-bedded (1-5 in.); forms slope -.-.-_-

Siltstone, very pale orange, structureless, very hard, calcareous; forms resistant ledge --.-----

Mudstone, moderate-reddish-orange, crumbly; forms slope and recess

Sandstone, moderate-orange-pink, very fine grained, thick-bedded (3-6 ft); contains wedge-planar cross-stratification on large scale (10-20 ft); forms resistant ledges -..--..--

Mudstone, moderate-reddish-brown, crumbly, structureless; forms slope or recess --.-.-.-.-

Sandstone, pale-orange, very fine grained (68 percent), fine-grained ( 26 percent), limy ( 30 percent), thick-bedded $(6-10 \mathrm{ft})$, weakly cross-stratified; weathers to rounded surface; forms series of receding ledges ---------

Total upper cliff-slope unit, Esplanade Sandstone

Esplanade Sandstone, main cliff unit:

Sandstone, grayish-white, fine-grained to very fine grained, hard; contains tabular- and wedge-planar cross-stratification; locally weathers white; forms cap of main cliff --..-

Limestone, olive-gray, very fine grained, structureless, hard, silty; brown silt grains weather out on surface; forms resistant ledge

Sandstone, pale-orange, very fine grained (59 percent), fine-grained (31 percent), resistant, calcareous (21 percent); contains tabularplanar cross-stratification on large scale (30-40 ft); weathers brown, locally white; forms resistant cliff

Mudstone, deep-red-brown, crumbly; forms recess

Sandstone, moderate-orange-pink, very fine grained; contains planar cross-stratification on large scale $(30-40 \mathrm{ft})$ throughout; thick unit; weathers to pale-brown surface; forms prominent straight cliff

Sandstone, moderate-orange-pink, very fine grained, hard, thick-bedded $(2-4 \mathrm{ft})$; weathers to rounded spheroidal surface; forms cliff

Mudstone, moderate-reddish-brown, structureless; forms recess
Feet

Section 2-Continued

TWENTYNINE MILE CANYON-Continued

Supai Group-Continued

Esplanade Sandstone, main cliff-slope unit-

Continued

Sandstone, very pale orange to moderatereddish-orange, very fine grained, calcareous, structureless, thick-bedded (2-8 ft); beds separated locally by thin partings of deep-red-brown mudstone; weathers redbrown; forms cliff

Sandstone, moderate-reddish-orange, very fine grained, calcareous, hard, structureless to weakly cross-stratified (tabular-planar type); includes two layers, each $10-20 \mathrm{ft}$ thick, with thin parting of deep-red-brown mudstone between; weathers to black surface; grades laterally into gray silty limestone; forms part of main cliff -..._-_-

Sandstone, pale-gray to reddish-brown, very fine grained (64 percent), fine-grained (30 percent), very limy (50 percent), hard; clean quartz grains; contains tabular-planar crossstratification on large scale $(20-25 \mathrm{ft})$; weathers to black surface; forms cliff

Total main cliff unit, Esplanade

Sandstone

Esplanade Sandstone, basal slope unit:

Mudstone, moderate-reddish-brown, limy, crumbly; contains layers of intraformational mud pellets and local white spots (deoxidized patches); forms recess ----.---

Siltstone, pale-reddish-brown, calcareous, hard, thick-bedded (4-6 ft); contains thin partings of deep-red mudstone; weathers to black surface; forms cliff

Sandstone, moderate-reddish-orange, very fine grained, thin-bedded (6-24 in.); alternates with moderate-reddish-brown, shaly siltstone; total includes one thin (6 in.) bed of olive-gray rubbly limestone $16 \mathrm{ft}$ above base; forms slope with receding ledges -------

Sandstone, moderate-reddish-brown, very fine grained (15 percent), silty (31 percent), friable, thin-bedded (2-12 in.); forms weak cliff

Conglomerate, irregular channel-scoured base where observed; forms ledge --_-_-_-_Matrix: gray- to moderate-reddish-brown, very fine grained sandstone.
Feet

28.5

31.5

16.5

31.5 
Section 2-Continued

TWENTYNINE MILE CANYON-Continued

Supai Group-Continued

Esplanade Sandstone, basal slope unit

Conglomerate-Continued

Gravel: pale-red, medium-gray, and olivegray limestone and moderate-reddishbrown siltstone; well-rounded; many pebbles elongate and oriented parallel to bedding; diameter maximum 4 in., 2 in. common, mostly $0.25-1$ in.

Total basal slope unit, Esplanade Sandstone --- 70.0

Total Esplanade Sandstone ------ 377.5

Wescogame Formation, slope and cliff units:

Siltstone, moderate-reddish-brown, thickbedded (1-3 ft); contains thin parting zones of moderate-reddish-brown, structureless mudstone; locally forms weak cliff

Limestone, dark-olive-gray to purple, concretionary; includes some moderate-reddishbrown mudstone; limy masses locally weather to greenish surface with gray rodlike structures; total forms slope with very weak rounded ledges

Sandstone, moderate-orange-pink, very fine grained, structureless, very hard; forms resistant ledge

Siltstone, pale-reddish-brown, concretionary; forms weak ledge and slope

Sandstone, moderate-reddish-orange, very fine grained, structureless; contains scattered limy concretions

Mudstone, deep-red, brittle; forms slope --.-.--Sandstone, pale-orange-pink, very fine grained, calcareous; contains planar cross-stratification on large scale; weathers to black surface; forms cliff

Siltstone, dark-reddish-brown; contains concretionary structures (balls of limy mudstone, $2-3$ in. in diameter) throughout; moderately resistant; forms recess and base of cliff

Total Wescogame Formation $-\frac{14.0}{98.5}$

Manakacha Formation, slope unit:

Sandstone, pale-reddish-brown, muddy, crumbly, irregularly bedded; locally forms weak ledge, commonly forms slope

Feet

Section 2-Continued

TWENTYNINE MILE CANYON-Continued

Supai Group-Continued

Manakacha Formation, slope unit-Continued

Sandstone, moderate-reddish-orange, very fine grained; cross-stratified on medium scale; forms cliff

Siltstone, pale-reddish-brown, mediumbedded; forms cliff -

Siltstone, dark-reddish-brown, shaly, crumbly; contains gray nodular balls of limestone, 0.25-0.5 in. in diameter; forms slope ------

Limestone, dark-reddish-brown, very fine grained, structureless, silty; weathers brown; forms resistant ledge --

Mudstone, deep-reddish-brown, crumbly; forms slope

Sandstone, moderate-orange-pink, very fine grained; cross-stratified on medium scale $(5-10 \mathrm{ft})$; friable; forms cliff

Siltstone, pale-red, calcareous, mediumbedded (1-2 ft); weathers red; forms cliff -----

Mudstone, moderate-reddish-brown, crumbly, forms slope

Siltstone, moderate-reddish-orange, friable; contains limy balls, $0.5-1$ in. in diameter, in upper part; grades into pure gray limestone at top; forms slope

Mudstone, deep-reddish-brown, crumbly; forms slope

Sandstone, moderate-reddish-orange, very fine grained, structureless; forms ledge --.--..--

Siltstone, moderate-reddish-brown, shaly, locally nodular; forms slope --.-.-.--

Siltstone, moderate-reddish-brown, shaly, nodular; contains scattered hard balls of gray limy siltstone covered with thin layers of shaly red-brown siltstone; forms weak cliff

Total slope unit, Manakacha Formation

Manakacha Formation, cliff unit:

Sandstone, pale-orange-pink, poorly sorted; lower part flat-bedded, upper part wedgeplanar, cross-stratified; weathers to light-red surface; forms cliff with vertical even face ----

Limestone, pale-red, nodular; contains patches of red-brown siltstone; weathers to rounded nodular surface; forms recess

Siltstone, moderate-reddish-brown, structureless, moderately resistant; forms ledge
Feet

18.0 
Section 2-Continued

TWENTYNINE MILE CANYON-Continued

Supai Group-Continued

Mankacha Formation, cliff unit-Continued

Mudstone, deep-reddish-brown, crumbly; forms recess

Sandstone, moderate-orange-pink, fine- (52 percent) to very fine grained ( 39 percent), calcareous (30 percent); contains wedgeplanar cross-stratification on small to medium scale $(1-10 \mathrm{ft})$; forms prominent cliff

Limestone, medium-light-gray, very fine grained, medium-bedded $(2-3 \mathrm{ft})$; weathers to irregular knobby surface; forms cliff --------

Siltstone, pale-red, crumbly, structureless; forms slope, largely concealed --_-_-_-_-

Limestone, light-brownish-gray, very fine grained, hard, structureless; silty laminae locally etched out; forms cliff

Siltstone, bright-red, structureless; resistant -----

Limestone, light-brownish-gray, very fine grained to aphanitic, concretionary; contains patches of purple siltstone; forms rounded ledge

Siltstone, pale-reddish-brown, flat-bedded, thin-bedded (1-12 in.); resistant -..........

Siltstone, shaly, nodular

Siltstone, bright-red, structureless --.--_--_-_-

Limestone, gray; contains jasper ---_--_--------

Siltstone, shaly, nodular

Siltstone, bright-red, structureless

Limestone, gray, aphanitic; contains bands of jasper

Sandstone, pale-red, very fine grained, limy, shaly, thin-bedded (0.5-1 in.); contains limy concretions -

Limestone, gray, aphanitic; contains bands of jasper; contains rounded limestone pebbles near top

Sandstone, moderate-reddish-brown, very fine grained, flat-bedded; forms massive ledge ----

Total cliff unit, Manakacha

Formation --_- 95.0

Total Manakacha Formation ---- 193.0

Watahomigi Formation:

Limestone, gray, aphanitic; contains bands of jasper
Feet

10.0
Section 2-Continued

TWENTYNINE MILE CANYON-Continued

Supai Group-Continued

Watahomigi Formation-Continued

Sandstone, moderate-reddish-orange, very fine grained, flat-bedded -------

Limestone, grayish-red, very fine grained, hard; contains bands of jasper ---..--..--

Mudstone, deep-red, crumbly; forms recess --.--

Siltstone, pale-reddish-brown, shaly, thinbedded; concretionary near top with gray rounded spheres, $0.5-1$ in. in diameter; forms weak cliff

Limestone, gray; contains bands of jasper; forms resistant cliff

Mudstone, dark-grayish-red, brittle; includes dolomite (15 percent); forms recess ---.-----

Limestone, light-olive-gray, aphanitic; contains bands of jasper; forms ledge --.---.----

Mudstone, deep-red-brown; forms recess ---.---

Siltstone, moderate-reddish-brown, sandy, crumbly; mostly flat-bedded and shaly, but locally cross-stratified at low angles; contains small $(0.5 \mathrm{in}$.) white siltstone concretions scattered throughout; forms weak cliff -

Mudstone, deep-reddish-brown; forms recess --

Limestone, light-brownish-gray, very fine grained to aphanitic; nodular with purple siltstone patches; contains local bands of jasper; forms base of cliff

Mudstone and siltstone, interlayered. Mudstone is moderate-reddish-brown, crumbly; forms series of slopes, $1-3 \mathrm{ft}$ thick. Siltstone is pale red, forms ledges, $0.5-2 \mathrm{ft}$ thick ---.---

Dolomite, calcitic, light-olive-gray, coarsely crystalline, hard; contains lenses and bands of jasper; grades upward into moderatereddish-brown siltstone; forms ledge --------

Siltstone, moderate-reddish-brown, crumbly, structureless; includes 1-ft-thick bed of gray limestone near middle; forms slope --.--..----

Limestone, medium-light-gray, aphanitic, thick-bedded (3-8 ft); contains bands of jasper; weathers to olive-gray; forms ledge --Mudstone, dark-reddish-brown, fissile, very crumbly; contains white limy concretions, 1-3 in. in diameter, scattered throughout; forms slope

Mudstone, dark-reddish-brown, hard, brittle; forms weak rounded ledges ---_-
1.0 
Section 2-Continued

TWENTYNINE MILE CANYON-Continued

Supai Group-Continued

Watahomigi Formation-Continued

Conglomerate; forms prominent ledges

Matrix: crumbly to hard, moderate-reddishorange, very fine grained sandstone.

Pebbles: white, yellowish-gray, and paleorange chert; angular to subrounded; mostly $0.5-1$ in. in diameter; maximum diameter 3 in.

Total Watahomigi Formation -- 150.5

Total Supai Group -

Unconformity:

Unconformity assumed; surface seems even and flat in area observed.

Redwall Limestone:

Horseshoe Mesa Member:

Limestone, yellowish-gray, very fine grained, thin-bedded $(0.5-2 \mathrm{ft})$; forms receding ledges at rim of canyon Not measured

Section 3

\section{EMINENCE FAULT}

[Along east side of Eminence Fault in Marble Canyon, east wall]

Hermit Shale:

Siltstone and mudstone, light-red-brown to red-brown; forms series of weak ledges separated by thin slopes

Contact:

Horizontal surface, where exposed, between relatively weak beds of Hermit Shale and underlying massive beds of Supai.

Supai Group:

Esplanade Sandstone, upper cliff-slope unit:

Siltstone, pale-red; silt (70 percent), includes some very fine grained sand, calcareous ( 33 percent); contains thin (1-3 ft), flat beds near base, weakly laminated and cross-laminated; upper part very massive and resistant; forms rounded cliff

Sandstone, pale-red, very fine grained; consists of thin, flat beds below and rounded massive above like overlying unit
Section 3-Continued

EMINENCE FAULT-Continued

Feet

Supai Group-Continued

Esplanade Sandstone, upper cliff-slope unit-

Continued

Mudstone, deep-red-brown; weathers to spheroidal surface; forms recess

Sandstone, grayish-orange-pink; very fine grained; flat-bedded to cross-stratified on small to medium scale; some wavy beds; forms cliff

Mudstone, deep-red-brown; weathers to spheroidal surface; forms recess

Siltstone, very pale red, very limy, hard; contains wedge- and tabular-planar crossstratification; forms cliff

Sandstone, moderate-red-orange, very fine grained, calcareous (25 percent), mediumbedded (2-3 ft), flat-bedded; forms receding ledges

Total upper cliff-slope unit, Esplanade Sandstone

Esplanade Sandstone, main cliff unit:

Sandstone, pale-red, very fine grained, resistant, massive; forms cliff ---

Mudstone, deep-red-brown, structureless, brittle; forms thin bench

Sandstone, light-olive-gray, very fine grained, massive; contains wedge-planar crossstratification throughout; forms cliff ----------

Siltstone, pale-red, structureless; some finegrained sand; weathers to rounded surface, forms recess in cliff

Sandstone, very pale red, silty, massive; contains weakly developed cross-stratification; weathers to black face; forms major cliff -.---

Sandstone, moderate-red-orange, very fine grained, thin-bedded (1-3 in.), flat-bedded; forms cliff continuous with units above and below

33.5

Sandstone, pale-red-brown, very fine grained; some silt, massive; contains weakly developed cross-stratification; weathers to black face; forms cliff

Siltstone, very pale orange to reddish-brown, sandy, massive, calcareous, thick-bedded $(4 \mathrm{ft})$, cliff-forming

Mudstone, dark-reddish-brown, silty, crumbly; forms ledge or recess in cliff 
Section 3-Continued

EMINENCE FAULT-Continued

Supai Group-Continued

Esplanade Sandstone, main cliff unit-Continued

Sandstone and sandy siltstone, grayish-orangepink to moderate-orange-pink, very fine grained, massive, limy ( 30 percent), thickbedded (4-10 ft); contains tabular-planar cross-stratification, medium to large scale; weathers red-brown; forms sheer cliff -

Total main cliff unit, Esplanade Sandstone

Esplanade Sandstone, basal slope unit:

Mudstone, pinkish-gray, brittle, crumbly, slope-forming

Conglomerate and conglomeratic limestone, pale-reddish-brown to medium-light-gray, ledge-forming

Matrix: limestone.

Gravel: olive-gray and medium-gray limestone; reddish-brown siltstone; mostly $0.25-0.5$ in. diameter, 3 in. maximum; well-rounded.

Total basal slope unit, Esplanade Sandstone --_-_ $\quad 41.5$

Total Esplanade Sandstone ----- $\overline{362.0}$

Wescogame Formation, slope unit:

Largely concealed, slope: locally moderatereddish-brown, shaly siltstone; includes several thin (1-ft) ledges of medium-lightgray limestone

Total slope unit, Wescogame Formation

Wescogame Formation, cliff unit:

Sandstone, pale-reddish-brown, very calcareous, very fine grained, silty, massive; forms two thick beds $(8-12 \mathrm{ft})$ forming cliff with prominent recess in middle

Siltstone, red-brown; thin flat beds with one thick bed (3-4 ft); similar to underlying unit; forms slope with one ledge

Sandstone, pale-red, very fine grained, weakly cross-stratified; forms rounded ledge, base of cliff unit

Sandstone, pale-reddish-brown to moderatereddish-orange, very silty, platy to nodular and brittle; contains two ledges of mediumbedded ( 2 - $\mathrm{ft}$ ) flat-bedded siltstone ( 81 percent silt), very limy (50 percent); forms long slope
Section 3-Continued

EMINENCE FAULT_Continued

Feet

Supai Group-Continued

Wescogame Formation, cliff unit-Continued

Sandstone, moderate-reddish-orange, finegrained, hard; weathers to red-brown or black surface; forms resistant ledge

Total cliff unit, Wescogame

Formation --- -114.0
Total Wescogame Formation --- 132.5

Manakacha Formation, slope unit:

Siltstone, pale-red, friable; contains weak ledge of nodular siltstone in middle; forms slope

Sandstone, pale-red, very fine grained, thickbedded (2-4 ft), cross-stratified, calcareous; like cliff below

Limestone, pale-red, silty ( 20 percent), thinbedded (1-3 in.); forms bench or slope ------

Sandstone, grayish-red, very fine grained, very limy, thick-bedded (2-4 ft); includes beds of pale-red, cross-stratified siltstone, and one of light-gray limestone; forms cliff --.---.---.-

Siltstone, moderate-reddish-brown to palereddish-brown, very limy (49 percent), sandy, platy; contains three weak ledges of thin-bedded sandstone; forms long slope --.--

Sandstone, moderate-orange-pink to pale-red, very fine grained, some fine-grained, very sandy, hard; forms rounded white ledge near top of slope

Siltstone, red-brown, shaly ---otal slope unit, Manakacha
Total Formation

Manakacha Formation, cliff unit:

Sandstone, moderate-reddish-brown, fine- to medium-grained, friable; cross-stratified on medium scale to structureless; forms conspicuous ledge

Sandstone, red-brown, very fine grained to fine-grained, shaly, slope-forming; includes one bed (1.5 ft thick) of dark-red-brown siltstone

Sandstone, moderate-orange-pink, finegrained thick-bedded (2-10 ft); includes flatlying laminae and large-scale tabular-planar cross-laminae (dip $20^{\circ} \mathrm{SW}$ ); contains abundant sand concretions ( 0.25 in. diameter); weathers to cliff, dark-brown or black -------

Limestone, grayish-red, locally light-olivegray, aphanitic, medium-bedded (1-2 ft); forms receding ledges or weak cliff 
Section 3-Continued

EMINENCE FAULT -Continued

Supai Group-Continued

Manakacha Formation, cliff unit-Continued

Concealed bench

Siltstone, grayish-orange-pink, very limy; contains foraminifers; includes sand, palereddish-brown, very fine grained, calcareous; hard, thick-bedded (2-4 ft), flatbedded; forms major cliff

Mudstone, pale-red to dark-reddish-brown, structureless, silty; weathers to conchoidal surface; forms recess in cliff -

Siltstone, pale-red, very thin bedded, flatbedded; uniform texture; forms weak cliff --.-

Total cliff unit, Manakacha

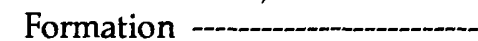
Total Manakacha Formation --- 231.0

Watahomigi Formation:

Mudstone, moderate-reddish-brown, silty, brittle, crumbly; forms slope; much concealed

Limestone, light-olive-gray and grayish-red, aphanitic, medium-bedded ( $2-3 \mathrm{ft})$; contains a massive pale-reddish-brown siltstone bed in middle; contains jasper lenses; forms ledges

Siltstone, red-brown, shaly, crumbly; forms slope

Limestone, light-olive-gray with dark-reddishbrown blotches, aphanitic; contains jasper lenses and abundant dark-gray structures, possibly algal; forms ledge

Siltstone, pale-reddish-brown, thin-bedded (1-3 in.) to shaly, flat-bedded, friable; forms weak ledge

Largely concealed slope: probably mostly grayish-red, shaly siltstone; contains one thin ledge $(1 \mathrm{ft})$ of red-brown, aphanitic limestone (17 percent insoluble)

Limestone, pale-red, locally light-olive-gray, aphanitic, resistant; lower part is silty with wavy laminae and lime nodules; upper part even-grained with crosscutting jasper bands; forms ledge

Limestone, pale-red and light-olive-gray banded, aphanitic, silty, medium-bedded $(1-2 \mathrm{ft})$; includes shaly mudstone partings; contains irregular lenses and bands of jasper and light-gray worm-shaped structures, possibly algal; forms receding ledges and slope
Section 3-Continued

EMINENCE FAULT_Continued
Feet

4.0
3.0

8.5

22.0

Supai Group-Continued

Watahomigi Formation-Continued

Concealed slope

Limestone, grayish-red, with light-olive-gray bands; aphanitic; contains streaks of redbrown mudstone

Siltstone, purple, shaly to thin-bedded; forms slope with weak ledges

Conglomerate, dusky-red-purple, with moderate-orange-pink spots; ledge-forming -.-.--.Matrix: brown silt.

Pebbles: siltstone and limestone; rounded to sub-angular; maximum 2 in., average $0.25-0.5$ in. diameter.

Unconformity: Assumed.

Redwall Limestone:

Horseshoe Mesa Member:

Limestone, yellowish-gray, aphanitic, mediumbedded.

\section{Section 4}

\section{BLUE SPRING}

[Along the trail to Blue Spring]

Coconino Sandstone.

Contact.

Hermit Shale:

Sandstone, moderate-reddish-orange, very fine grained, silty, hard, thick-bedded (4-20 ft); weathers to black varnished surface; forms cliff

Siltstone, moderate- to dark-reddish-brown; yellowish-gray spots, shaly to structureless; forms recess under cliff

Conglomerate, intraformational; forms ledge --Matrix: siltstone, moderate-reddish-brown. Pebbles: limestone, grayish-orange-pink, and moderate- to pale-reddish-orange and moderate-reddish-brown siltstone.

Mudstone, dark-reddish-brown, structureless; weathers to rounded surface; forms slope or recess

Conglomerate, intraformational; contains many cavities forming geodes; forms ledge ---

Feet

Siltstone, grayish-red, shaly, slope-forming --- 11.0 Total Watahomigi Formation ---

$$
\text { Total Supai Group - }
$$


Section 4-Continued

BLUE SPRING-Continued

Hermit Shale-Continued

Conglomerate-Continued

Matrix: gray limestone.

Pebbles: gray limestone and moderatereddish-brown to dark-reddish-brown siltstone; mostly $0.25-0.5$ in. in diameter, maximum 1 in.

Mudstone, moderate-reddish-orange, shaly or very weakly bedded; forms slope ------------

Siltstone, moderate-reddish-orange, limy; forms bench

Mudstone, moderate-reddish-brown, structureless, medium-bedded ( $1-2 \mathrm{ft}$ ); weathers to rounded surfaces; forms slope

Total Hermit Shale

$\begin{array}{r}22.0 \\ \hline 124.5 \\ \hline\end{array}$

Contact, Hermit Shale-Supai Group.

Supai Group:

Esplanade Sandstone, main cliff unit:

Sandstone, moderate-reddish-orange, very fine grained, hard; forms upper part of cliff --.----

Mudstone, moderate-reddish-brown, very limy, silty, structureless; forms slope --.---.-

Sandstone, moderate-reddish-orange, very fine grained; structureless to weakly cross-stratified; thick-bedded (2-10 ft); forms cliff ------

Siltstone, moderate-reddish-brown, irregularly bedded, limy; weathers to rounded concretionary surface; forms weak ledge -----------

Sandstone, moderate-reddish-orange, very fine grained, structureless to weakly crossstratified, thick-bedded ( $2-10 \mathrm{ft})$; forms cliff -

Siltstone, red, flat-bedded, thin-bedded (24 in); forms cliff

Sandstone, moderate-reddish-orange, very fine grained (subangular), calcareous, structureless to weakly cross-stratified, thick-bedded $(2-10 \mathrm{ft})$; forms cliff

Total main cliff unit, Esplanade

Sandstone

Esplanade Sandstone, basal slope unit:

Siltstone, moderate-reddish-brown, shaly siltstone; forms prominent bench --._-_-_-_-_-

Total basal slope unit, Esplanade

Sandstone - $-\frac{16.0}{261.5}$

Total Esplanade Sandstone ------ $\frac{16.0}{261.5}$

Wescogame Formation, slope unit:

Limestone, pale-red, silty, platy, and moderate reddish-brown, shaly siltstone; slope-forming
Section 4-Continued

BLUE SPRING-Continued

Supai Group-Continued

Wescogame Formation, slope unit-Continued

Shale, red-brown; forms recess --.--.------

Total slope unit, Wescogame

Formation

3.0

19.5

Wescogame Formation, cliff unit:

Sandstone, very pale orange, very fine grained, prominently cross-stratified; forms sheer cliff

Sandstone, moderate-reddish-orange, very fine grained, calcareous, thick-bedded $(2-6 \mathrm{ft})$; very resistant; weakly cross-stratified locally; contains large shrinkage cracks; parting beds of dark-reddish-brown, structureless mudstones form recesses as much as $4 \mathrm{ft}$ thick; weathers to black varnished surface; forms sheer cliff

66.0

Siltstone, red, structureless; forms slope --.--.--

Conglomerate, forms weak ledge --.--

Matrix: moderate-reddish-brown siltstone.

Pebbles: gray limestone and some moderatereddish-brown siltstone; well-rounded, mostly 0.25-0.5 in. in diameter, maximum diameter 3 in.

Total cliff unit, Wescogame Formation ---.-- 106.0

Manakacha Formation, slope unit:

Siltstone, moderate-reddish-brown, structureless; includes weak ledges of nodular limestone, each 2-3ft thick; total forms slope -----

Siltstone, structureless; single bed; forms ledge -----

Mudstone, deep-red, structureless, brittle; forms slope

Sandstone, very pale orange, fine-grained, thick-bedded (3-6 ft); contains planar crossstratification on medium scale; weathers yellow, locally with black varnish; forms resistant ledge

Siltstone, light-brown; contains concretionary limestone masses; forms slope with weak ledges

Siltstone, moderate-reddish-orange, very limy, medium-bedded $(1-3 \mathrm{ft})$; forms ledge ---.----

Concealed slope

Sandstone, pale-reddish-orange, very poorly sorted, friable; forms ledge -----

Concealed slope

Total slope unit, Manakacha Formation --_-_-_-_-_-_-_-_-_ 


\section{Section 4-Continued \\ BLUE SPRING-Continued}

Supai Group-Continued

Manakacha Formation, cliff unit:

Siltstone, moderate-reddish-orange, limy, medium-bedded (1-3 ft); structureless in lower part, cross-stratified in upper part; forms weak cliff

Siltstone, reddish-brown; contains nodules of light-gray limestone throughout; forms

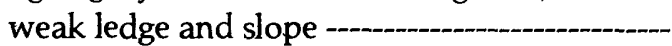

Sandstone, very pale reddish-brown, very fine grained (many scattered fine grains), thin-bedded (3-5 ft), calcareous; includes partings of deep-red structureless mudstone; contains abundant small (0.25-0.5 in.) fragments of jasper and chert scattered throughout; forms cliff

Limestone, olive-gray and pale-orange, dolomitic, very fine to fine-grained; contains abundant thin jasper layers and probable stromatolite structures; forms cliff

Sandstone, very pale red, very fine grained, thick-bedded (3-5 ft); contains partings and thin $(0.5-1 \mathrm{ft})$ layers of pale-reddish-brown, laminated mudstone; forms cliff

Limestone, dark-reddish-brown, nodular, silty; alternates with pale-reddish-brown mudstone; total forms slope with one weak ledge near middle

Siltstone, moderate-reddish-orange, calcareous, sandy (43 percent); medium-bedded (2-3 ft) at base, thick-bedded $(6 \mathrm{ft})$ in middle; forms massive cliff

Total cliff unit, Manakacha Formation --_-_-_-_-_-_-_-_--_-Total Manakacha Formation ---- $\overline{223.0}$

Watahomigi Formation, upper slope unit:

Mudstone, moderate-reddish-brown, structureless; forms recess

Concealed slope

Conglomerate and dolomitic limestone, palereddish-brown, very fine grained; pebbly in part; locally massive; contains much red siltstone throughout as matrix between pebbles and as lenses; forms ledges

Total upper slope unit, Watahomigi Formation

Watahomigi Formation, middle cliff and lower slope units:

Siltstone, reddish-brown; forms slope; largely concealed

7.5

Section 4-Continued

BLUE SPRING-Continued

Feet

Supai Group-Continued

Watahomigi Formation, middle cliff and lower slope units-Continued

Limestone, grayish-red, very finely crystalline, silty; contains thin jasper layers and lenses of

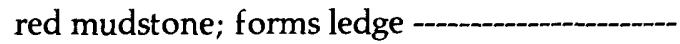

Mudstone, reddish-brown; forms slope; largely concealed

Siltstone, pale-reddish-brown, very limy, shaly; contains abundant spheroidal limy concretions, $0.25-0.75$ in. in diameter, with shaly siltstone wrapped around concretions;

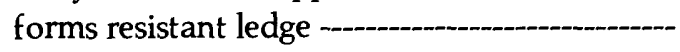

Siltstone, conglomeratic, moderate-reddishbrown, structureless, crumbly; contains many gray limestone pellets, $0.25-0.5$ in. in diameter, and tubular structures; forms weak ledge

Mudstone, reddish-brown, shaly; forms slope; mostly concealed ---------

Total middle cliff and lower slope units, Watahomigi Formation - - 79.5 Total Watahomigi Formation -- -105.0 Total Supai Group -

Unconformity:

Surface not exposed, but limestone pebbles, which are light gray, dark gray and black, occur near contact.

Redwall Limestone:

Horseshoe Mesa Member:

Limestone, dark-reddish-brown, very finely crystalline, thin-bedded (1-2 ft); forms top of cliff

Section $4 a$

\section{HORSETRAIL CANYON}

[At Little Colorado River, 0.5 mile downstream from Waterhole Canyon]

Coconino Sandstone:

Feet

Sandstone, very pale orange, fine-grained, cross-stratified on large scale; forms vertical cliff Not measured

Sandstone, very pale orange, fine-grained, laminated, horizontally bedded; forms base of cliff - $\quad 9.0$

Contact:

7.5 Flat, even surface. 
Section $4 a-$ Continued

\section{HORSETRAIL CANYON-Continued}

Hermit Shale:

Siltstone, pale-reddish-brown, weakly bedded; locally shaly; contains small conglomerate lens near middle; weathers to rounded knobs; forms recess below Coconino cliff -.... Conglomerate, red-brown, thin-bedded (1$2 \mathrm{ft}$ ), flat-bedded; forms weak ledge -........ Gravel: mostly pale-gray, silty limestone, some red-brown siltstone, rounded; average $0.12-0.25$ in.; maximum 0.75 in. Matrix: red-brown siltstone.

Mudstone, dark-reddish-brown to moderatereddish-orange, coarse, silty, rubbly; contains cream-colored nodules throughout; forms slope with one resistant ledge of structureless siltstone

Sandstone, pale-reddish-brown, very fine grained, calcareous (20 percent), shaly to medium-bedded; forms slope and thin weak ledge, and pale-reddish-brown mudstone, brittle, slope-forming -..-_-

$$
\text { Total Hermit Shale - }
$$

Contact:

Horizontal surface where exposed, between weak beds of Hermit Shale and more massive beds of Supai below.

Supai Group:

Esplanade Sandstone, main cliff unit:

Sandstone, light-brown, very fine grained; contains prominent crossbedding etched on surface; forms small cliff

Sandstone, moderate-orange-pink, very fine grained, friable, very thin bedded (1-3 in.) to shaly; includes several thin beds of gray, structureless siltstone; forms bench or slope with thin ledges

Sandstone, pale-red-brown, very fine grained (81 percent), calcareous (35 percent); contains wedge-planar cross-stratification, small-scale (6-30 in.) in lower part, mediumscale (3-10 ft) above; weathers with black, varnished surface; forms cliff consisting of two massive ledges

Siltstone, pale-reddish-brown to light-brown, limy (45 percent), thin-bedded to shaly; detritus (88 percent silt); forms slope and weak ledges; includes two thin units of friable, light-red-brown sandy siltstone that forms resistant ledges near middle and at top
76.0

Feet

16.0

21.0

Section $4 a-C o n t i n u e d$

\section{HORSETRAIL CANYON-Continued}

Supai Group-Continued

Esplanade Formation, main cliff unit-

Continued

Sandstone, grayish-orange, fine-grained, prominently cross-stratified (tabular-planar and wedge-planar), very thick bedded (15$30 \mathrm{ft}$ ); weathers dark gray to black; forms cliff

Sandstone, moderate-orange-pink, finegrained; composed of series of very thick (5-15 ft), structureless beds; very resistant; weathers to varnished surface; forms vertical cliff

Sandstone, pale-reddish-brown, very fine grained; flat bedding weakly developed; forms cliff -

Siltstone, moderate-red, limy; laminated throughout; weathers dark brown; forms base of main cliff

Total main cliff unit, Esplanade

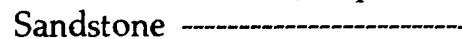

Esplanade Sandstone, basal slope unit:

Siltstone, dark-red-brown, shaly, wavybedded, slope-forming -.-..-_-_-

Sandstone, pale-red, very fine grained; silty (29 percent), calcitic dolomite ( 28 percent); medium-bedded $(1-3 \mathrm{ft})$; forms receding ledges or slope

Total basal slope unit, Esplanade Sandstone --- 14.0

Total Esplanade Sandstone --.-- $-\frac{14.0}{235.0}$

Wescogame Formation, slope unit:

Siltstone, pale-reddish-brown, shaly, wavybedded, slope-forming -._-__-_-_-_-_-_-_-_

Concealed: slope-forming ---
Total slope unit, Wescogame Formation ---

Wescogame Formation, cliff unit:

Sandstone, grayish-orange, very fine grained; contains wedge-planar cross-stratification, medium to large scale $(5-15 \mathrm{ft})$; sets very thick (5-15 ft); forms massive cliff -..-.......

Siltstone, light-brown, locally red-brown, thin-bedded (2-12 in.); forms slope with weak ledges at base of main cliff -...-..--

Siltstone, grayish-red, argillaceous; basal $2 \mathrm{ft}$ structureless, upper part shaly; forms weak cliff or slope 
Section $4 a-$ Continued

\section{HORSETRAIL CANYON-Continued}

Supai Group-Continued

Wescogame Formation, cliff unit-Continued

Sandstone, pale-reddish-brown, very fine grained, muddy (20 percent), very thin to thin-bedded (0.5-12 in.); forms slope with weak ledges

Conglomerate, pale-red-brown; red-brown pebbles etched in prominent relief; weathers to dark-gray; forms weak receding ledge and fills channel in underlying resistant siltstone

Gravel: largely light-gray to light-red-brown siltstone and silty limestone, some deepred-brown mudstone; subangular to subrounded; closely packed; average 0.5-2 in.; maximum 8 in.; elliptical to rectilinear.

Matrix: red-brown siltstone or sandstone.

Total cliff unit, Wescogame Formation --- 108.0

Total Wescogame Formation ---- 126.0

Manakacha Formation, slope unit:

Siltstone, grayish-red; includes much coarse silt; beds thin $(1-2 \mathrm{ft})$ to very thick $(4-5 \mathrm{ft})$, irregular; spheroidal weathering locally; forms gentle slope or receding thick ledges ---

Sandstone, grayish-orange-pink, very fine grained, limy, thick-bedded $(2-3 \mathrm{ft})$; weathers red-brown to yellow-brown; forms resistant ledge

Siltstone, pale-reddish-brown to moderatereddish-brown; includes much coarse silt; shaly to blocky; forms slope or recess -..-...-.

Siltstone, pale-reddish-brown to moderatereddish-brown; contains gray calcareous concretions; weathers dark-gray; forms resistant ledge with pebble surface --..-..-..-..-

Sandstone, moderate-orange-pink, finegrained, limy, cross-stratified; weathers with black varnish; forms resistant ledge

Siltstone, very pale orange; coarse silt; contains wavy (ripple) laminae; forms recess ---.

Sandstone, grayish-orange-pink, fine-grained; contains medium-scale $(5-10 \mathrm{ft}$ ) cross-strata, wedge-planar type; forms resistant ledge -.-.-.

Siltstone, very pale orange, shaly, calcareous; forms slope or recess
Feet

Section 4a-Continued

HORSETRAIL CANYON-Continued

Supai Group-Continued

Manakacha Formation, slope unit-Continued

Sandstone, grayish-orange, fine-grained, calcareous; cross-stratified on medium to large scale $(10-20 \mathrm{ft})$, tabular-planar; forms series of resistant ledges

Total of Manakacha Formation exposed

Feet

Total Supai Group - $-\frac{74.0}{-}+$

Base of unit concealed by talus near floor of Little

Colorado River Gorge.

Section 5

\section{BUNKER TRAIL}

[Along west side of Bunker Trail (locally called Tanner Trail) below Lipan Point]

Hermit Shale:

Mudstone, pale-reddish-brown, silty; forms slope between weak ledges.

Supai Group:

Esplanade Sandstone, upper cliff-slope unit:

Sandstone, light-red, very fine grained, noncalcareous, sugary; forms cliff

Mudstone, dark-red, thin-bedded, flat-bedded, slope-forming

Sandstone, light-brown, very fine grained; noncalcareous, sugary; forms ledge -.---.--

Mudstone, dark-red, sandy, thin-bedded, flatbedded, slope-forming

Sandstone, light-brown, very fine grained, calcareous, sugary; forms ledge --..--

Mudstone, dark-red, sandy, thin-bedded, flatbedded, slope-forming

Conglomerate, pale-reddish-brown; contains rounded limestone pebbles, average 0.25 in.; locally distributed in channels --
Total upper cliff-slope unit, Esplanade Sandstone ---.--..-

Erosion surface: local channeling in massive sandstone of the Esplanade.

Esplanade Sandstone, main cliff unit:

Sandstone, pale-orange, very fine grained, calcareous, hard; cross-laminated on large scale; weathers pale reddish-brown; forms massive cliff 
Section 5-Continued

BUNKER TRAIL-Continued

Supai Group-Continued

Esplanade Sandstone, main cliff unit-

Continued

Siltstone, pale-reddish-brown, friable; forms slope - -._-

Sandstone, pale-orange, fine- to very fine grained, noncalcareous; cross-laminated on large scale; forms massive cliff

Siltstone, pale-reddish-brown, irregularly bedded; forms weak cliff; less massive than underlying sandstone

Sandstone, pale-orange, very fine grained, calcareous, cross-laminated; forms massive cliff

Sandstone, pale-red, very fine grained, very calcareous; with thin, wavy, argillaceous laminae of same color; weathers pale-red with pale-reddish-brown laminae etched out; forms cliff base

Total main cliff unit, Esplanade Sandstone

Esplanade Sandstone, basal slope unit:

Mudrock, pale-reddish-brown, friable; forms conspicuous recess

Siltstone, dark-brown, thick-bedded (2-4 ft); forms ledge

Sandstone, pale-orange, very fine grained, calcareous; forms massive cliff

Siltstone, pale-reddish-brown, argillaceous; lower beds hard, upper two beds softer; weathers same color; forms massive cliff --.---

Sandstone, white, fine-grained; forms ledge; weathers black and dark-brown

Conglomerate, ledge-forming; basal contact with sandstone sharp but undulating -._-_--Matrix: pale-reddish-brown silt, calcareous. Gravel: size-average 0.5 in., maximum 4 in. in diameter; shape, rounded; composition, medium-gray limestone and palereddish-brown siltstone.

Total basal slope unit, Esplanade Sandstone $-69.5$

Total Esplanade Sandstone ------ $\quad-\quad 325.5$

Erosion surface: channel $4 \mathrm{ft}$ deep and $50 \mathrm{ft}$ wide cut in underlying siltstone.
Section 5-Continued

BUNKER TRAIL-Continued

Feet

Supai Group-Continued

Wescogame Formation, slope unit:

Siltstone, pale-reddish-brown, calcareous (soluble 20 percent); includes limestone lenses with irregular siliceous (organic?) particles; much concealed; forms slope --_-_-_-_--

Total slope unit, Wescogame Formation

Wescogame Formation, cliff unit:

Limestone, dark-reddish-brown, silty (30 percent), partly laminated and partly structureless, alternating with grayish-orange-pink, fine-grained (73 percent), hard sandstone; noncarbonate cement; average thickness of sets 5-15 ft; forms series of receding ledges ----

Siltstone, pale-red-brown, muddy, slightly calcareous, crumbly; includes limestone concretions, light-gray, sublithographic, with problematic structures (organic?); forms slope

Sandstone, pale-reddish-brown, calcareous, fine- to very fine grained (rounded), crossbedded at one-third above base; interbedded with few thin shaly beds; forms major cliff ---

Limestone, pale-red-brown, very fine grained, insoluble ( 20 percent), nodular; lower part argillaceous, upper part contains traces of organisms(?); forms recess in major cliff -------

Siltstone, grayish-red, sandy, noncalcareous, structureless; sets $2-5 \mathrm{ft}$ thick; basal beds contain limestone balls and pellets in redbrown mudstone; forms cliff

Conglomerate, pale-grayish-brown; pockets filled with well-rounded pebbles of limestone

Total cliff unit, Wescogame
Formation -om
Total Wescogame Formation --- $\frac{147.5}{190.5}$

Manakacha Formation, slope unit:

Mudstone, pale-red-brown, silty, slightly calcareous, irregularly bedded, crumbly; forms slope

Limestone, light-olive-gray, sublithographic; weathers to rough surface; forms ledge -

Siltstone, very light gray, calcareous, sandy; forms weak ledge; partly concealed 
Section 5-Continued

BUNKER TRAIL-Continued

Supai Group-Continued

Manakacha Formation, slope unit-Continued

Siltstone, pale-red-brown, muddy; forms ledges 1-2 ft thick; alternates with mudstone beds, shaly, slope-forming; includes thin limestone interbeds

Sandstone, grayish-red, slightly calcareous, very fine grained to silty; weathers to black or brown; nodular in top $2 \mathrm{ft}$; forms massive cliff

Concealed

Siltstone, and sandstone, pale-reddish-brown, very calcareous, muddy, flat-bedded; forms weak ledge

Sandstone, grayish-orange-pink, calcareous, fine-grained; crossbedded on large scale; weathers locally to black surface; forms cliff

Mudstone, grayish-red, very calcareous, structureless, crumbly; contains small limestone nodules; forms recess

Limestone, grayish-red, sublithographic (insoluble 27 percent); contains red, silty stringers and brown flint lenses

Limestone, grayish-red, sublithographic; contains gray nodules; forms weak ledge -

Total slope unit, Manakacha Formation ---

Manakacha Formation, cliff unit:

Siltstone, grayish-red, very fine grained, limy (47 percent), muddy, very thick bedded (4$15 \mathrm{ft}$ ); forms major cliff with two underlying units consisting of pale-reddish-brown, slightly calcareous, very fine grained sandstone; cross-stratified on large scale (above $25 \mathrm{ft}$ ), and pale-reddish-brown, slightly calcareous, very fine to fine-grained, very thick bedded sandstone

Sandstone, moderate-reddish-brown, very fine grained, noncalcareous, silty, forms weak ledge

Sandstone, pale-reddish-brown, calcareous, very fine grained (rounded); weathers reddish-brown; forms massive ledge --.--_---

Limestone, pale-red, sublithographic (insoluble residue, 25 percent); contains jasper; weathers dark gray

Sandstone, moderate-reddish-brown, very fine grained (subrounded), muddy, slightly calcareous; forms rounded ledge
Section 5-Continued

BUNKER TRAIL-Continued

Feet

Supai Group-Continued

Manakacha Formation, cliff unit-Continued

Concealed

Limestone, grayish-orange-pink, very fine grained (subrounded), silty, insoluble (40

5.5 percent); crossbedded, small scale, weathers to black, locally jasper in the middle; forms ledge

10.0

Sandstone, pale-reddish-brown, very fine grained (subrounded), slightly calcareous, silty, structureless; forms rounded ledges --.--

Siltstone, dark-reddish-brown, muddy, slightly calcareous, thin-bedded $(0.25-2$ in.); weathers to black surface; forms irregular, weak cliff

Limestone, pale-red-brown, insoluble (40 percent), very fine grained (rounded); cross13.5 stratified on medium scale; locally contains limestone nodules; weathers to black surface; forms cliff

Concealed

Limestone, grayish-orange-pink, sublithographic; weathers to black or dark-gray surface; thick-bedded (2-5 ft); and sandstone, pale-red to pale-reddish-brown, very fine grained, very limy (47 percent); weathers to black or dark gray surface; thick-bedded; forms cliff

Total cliff unit, Manakacha

Formation -- 114.0

Total Manakacha Formation ---- 194.5

Watahomigi Formation:

Limestone, grayish-red, mottled, silty, sublithographic, concretionary; contains jasper lenses and thin irregular beds (6-12 in.); forms ledge

49.5 Siltstone, moderate-reddish-brown, slightly calcareous --- 1.0-1.5

Limestone, grayish-red, motled, sublithographic, concretionary; contains jasper lenses; forms ledge

Sandstone, moderate-reddish-brown, very fine grained, structureless; forms rounded ledge --

Limestone, grayish-red, sublithographic (70 percent insoluble); weathers to dark-gray or black; forms ledge

Sandstone, moderate-reddish-brown, very fine grained, silty, iron-oxide coated, structureless; forms rounded ledge 
Section 5-Continued

BUNKER TRAIL_Continued

Supai Group-Continued

Watahomigi Formation-Continued

Siltstone, pale-red and pinkish-gray, very sandy, limy, thick-bedded (3-15 ft); weathers to black or red; locally contains small limestone nodules and jasper lenses; bedding planes weakly developed near top and bottom; mostly forms massive cliff

Siltstone, grayish-red, crumbly; forms slope --.-

Siltstone, pale-reddish brown, calcareous; basal part argillaceous; contains irregular limestone nodules $(0.5-1$ in. to $2-10 \mathrm{in}$.); forms weak ledges $(1-2 \mathrm{ft})$-........

Concealed

Limestone, grayish-red, sublithographic; weathers to dark-gray or black; contains variegated bands of jasper; forms massive bed

Concealed

Sandstone, pale-reddish-brown (top) and moderate-reddish-orange, calcareous, very fine grained, muddy, medium-bedded (1-2 ft); forms rounded ledge

Concealed

Siltstone, pale-reddish-brown, sandy, calcareous, thick-bedded; forms ledge

Mudstone, grayish-red, crumbly, brittle, limy (47 percent); structureless; forms slope (much concealed)

Sandstone, pale-reddish-brown, calcareous, very fine grained, silty, friable, mediumbedded $(0.5-2 \mathrm{ft})$; weathers to red- or darkgray surface; forms weak ledge

Limestone, grayish-orange-pink, sublithographic, silty (40 percent), medium-bedded $(2-3 \mathrm{ft})$; weathers to dark-gray or black surface; contains irregular thin layers of jasper; bottom half contains abundant red mud balls and pellets (0.5-1 in.), also lenses (as long as 5 in.)

Claystone, pale-red, limy (39 percent), fissile; forms slope (partly concealed)

Conglomerate, pale-reddish-brown; contains flint, quartzite and limestone pebbles; matrix of platy very fine grained sand - -

Total Watahomigi Formation --r $-\frac{92.5}{803.0}$

Total Supai Group -
Section 5-Continued

BUNKER TRAIL-Continued
Feet

16.5

1.0

4.0

12.0
Contact:

Unconformity not observed at this locality.

Supai Group:

Esplanade Sandstone, upper cliff-slope and main cliff units:

Sandstone, very pale orange, very fine grained, silty, structureless; weathers to black surface; forms vertical face

Siltstone, pale-reddish-brown, muddy; contains some very fine grained sand; flatbedded, very thin bedded ( 6 in. $-1 \mathrm{ft}$ ); forms recess

Sandstone, very pale orange, very fine grained, structureless; weathers to black surface; forms vertical face at top of Esplanade cliff ---

Siltstone, pale-reddish-brown, muddy, shaly; forms slope

Sandstone, very pale orange, very fine grained, silty, slightly calcareous, thin-bedded (1-3 $\mathrm{ft}$ ); forms receding ledges

Mudstone, pale-reddish-brown, very calcareous, silty, shaly; forms slope

Sandstone, moderate-orange-pink, very fine grained, slightly calcareous, thin-bedded (1-2 ft); forms weak cliff

Sandstone, moderate-orange-pink, very fine grained, slightly calcareous, thin-bedded $(1-2 \mathrm{ft})$; forms series of receding ledges, partly concealed 
Section 6-Continued

GRANDVIEW TRAIL-Continued

Supai Group-Continued

Esplanade Sandstone, upper cliff-slope and main cliff units-Continued

Sandstone, moderate-orange-pink, very fine grained, calcareous (35 percent); very thick bedded (6-8 ft); commonly weathers to black surface; forms massive, sheer cliff --.--

Mudstone, pale-reddish-brown, calcareous, very thin to thin-bedded (1-6 in.); forms slope --

Siltstone, moderate-reddish-orange, hard; contains some very fine grained sand; very thick bedded (5-7 ft); weathers to surface of rounded knobs (diameters 1-2 in.); forms cliff

Mudstone, pale-reddish-brown, calcareous, concretionary; weathers to surface of rounded knobs (diameters 1-2 in.); forms cliff

Sandstone, pinkish-gray, very fine grained, slightly calcareous; consists of thick, structureless beds; forms sheer cliff

Siltstone, pale-reddish-brown, shaly to thinbedded (0.25-3 in.); forms slope ---

Sandstone, very pale orange to moderateorange-pink, very fine grained, calcareous (35 percent), very thick bedded $(5-20 \mathrm{ft})$; contains several thin, pale-reddish-brown mudstone parting zones; weathers to black surface; forms major, sheer cliff

Sandstone, pale-red, very fine grained, silty, calcareous, massive; weathers to black, rounded surface; forms resistant ledge at base of major cliff

Total upper cliff-slope and main cliff units, Esplanade Sandstone

Esplanade Sandstone, basal slope unit:

Siltstone, pale-reddish-brown, very thin bedded ( 2 in.), calcareous; contains Rivularites; forms steep slope or recess ---.--

Concealed slope

Limestone, grayish-red, silty; forms resistant ridge

\footnotetext{
Total basal slope unit, Esplanade

Sandstone -- $-\frac{53.5}{285.0}$
Total Esplanade Sandstone -----
}

Section 6-Continued

\section{GRANDVIEW TRAIL-Continued}

Supai Group-Continued

Wescogame Formation, slope unit:

Concealed slope

Sandstone, moderate-orange-pink, very fine grained, calcareous ( 26 percent), thin- to thick-bedded (1-4 ft), structureless; contains some grayish-red mudstone partings between ledges; weathers to gray face; forms resistant ledges

Concealed slope

Total slope unit, Wescogame

Formation

Feet

Wescogame Formation, cliff unit:

Sandstone, moderate-orange-pink, very fine grained (well-rounded); contains many fine grains; slightly calcareous; forms series of ledges $(2-4 \mathrm{ft})$, separated by concealed slopes of muddy, grayish-red siltstone $(2-4 \mathrm{ft})$-------

Siltstone, pale-reddish-brown, muddy, slightly calcareous; bedding irregular; forms weak receding ledge

Concealed slope

Sandstone, moderate-reddish-orange (very pale orange at top), very fine grained, limy (42 percent); small- to medium-scale $(8-20$ in.); cross-stratification; forms resistant ledge with straight face --_-_-_-

Siltstone, grayish-red, muddy, calcareous, mostly concealed; contains local irregular bedding structures; forms weak ledges --------

Sandstone, pinkish-gray, very fine grained (subrounded to rounded); contains scattered fine grains; calcareous; prominently crossstratified, planar type; locally crossbeds are large-scale $(50+\mathrm{ft})$, elsewhere two or three small sets of similar cross-stratified structures, form cosets; weathers to surface of black varnish; forms sheer cliff

Mudstone, grayish-red, structureless; forms recess --_-

Siltstone, pale-reddish-brown, very calcareous, thin- to thick-bedded (1-4 ft); contains medium-scale, wedge-planar cross-stratification (1-3 ft); includes lime balls and pellets in mud matrix at base; forms base of main cliff -Total cliff unit, Wescogame Formation -- 142.0 Total Wescogame Formation ---- 201.5 
Section 6-Continued

\section{GRANDVIEW TRAIL-Continued}

Supai Group-Continued

Manakacha Formation, slope unit:

Siltstone, grayish-red, muddy, calcareous, structureless; forms weak rounded ledges at base of major cliff

Concealed slope, grayish-red, crumbly mudstone locally exposed

Siltstone, pale-reddish-brown, calcareous, thin-bedded $(0.5-1.5 \mathrm{ft})$; contains nodular zones; weathers to rounded, irregular weak ledges and slope

Sandstone, moderate-orange-pink, very fine grained (subrounded); contains scattered fine grains; slightly calcareous; forms resistant ledges in middle of slope; unit is twice

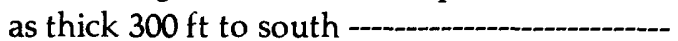

Concealed slope

Siltstone, pale-reddish-brown, muddy, calcareous, thin-bedded $(0.5-1 \mathrm{ft})$; forms slope and weak ledges -

Total slope unit, Manakacha Formation

Manakacha Formation, cliff unit:

Sandstone, pale-red, very calcareous, very thick bedded $(4-8 \mathrm{ft})$; thin mudstone partings; tabular-planar cross-stratified in part; locally weathers to black varnish; forms cliff

Mudstone, grayish-red, crumbly; forms recess ---

Sandstone, pale-reddish-brown, very fine grained; grades upward into a pale-red silty limestone near middle of unit and into lightbrownish-gray limestone at top of unit; forms rounded ledges or slope --.

Sandstone, grayish-orange-pink, very fine grained, thick- to very thick bedded $(3-5 \mathrm{ft})$, structureless; forms rounded cliff -...-...-

Sandstone, pale-red, very fine grained, calcareous; structureless; forms bench composed of two rounded ledges, separated by partings of grayish-red, shaly mudstone -------

Sandstone, very pale orange, very fine grained; thick- to very thick bedded $(2-8 \mathrm{ft})$; contains prominent, medium-scale $(5-15 \mathrm{ft})$, wedgeplanar cross-stratification; forms cliff -.--_-_Mudstone, grayish-red, brittle; forms recess --.Siltstone, very pale orange, limy, very muddy, thick- to very thick bedded ( $2-8 \mathrm{ft})$; weakly cross-stratified; forms cliff

Section 6-Continued

GRANDVIEW TRAIL-Continued

Feet

24.0

16.5

11.0

16.5
Supai Group-Continued

Manakacha Formation, cliff unit-Continued

Limestone, grayish-red; contains spheroidal structure; forms recess

Siltstone, pale-reddish-brown, calcareous, very hard, thick-bedded $(2-3 \mathrm{ft})$; forms base of major sheer cliff

Mudstone, grayish-red, crumbly; contains abundant gray limestone concretions (0.5-1 in. diameter); forms weak ledge or slope ------

Sandstone, moderate-orange-pink, very fine grained; forms resistant rounded ledge ---.---

Concealed slope

Sandstone, pinkish-gray, fine-grained to very fine grained, slightly calcareous, structureless; forms rounded ledge

Sandstone, moderate-reddish-orange, very fine grained, friable; forms weak ledge --.---.

Siltstone, grayish-red, muddy, shaly; includes some very thin bedded (0.5-1 in.) siltstone containing light-gray, limy nodules; forms slope

Sandstone, moderate-reddish-orange, very fine grained, calcareous, weakly cross-stratified; weathers to straight face; forms ledge

Mudstone, grayish-red, crumbly; includes one thin bed $(1 \mathrm{ft})$ of gray limestone --

Limestone, pale-red, very silty; contains nodular structure; weathers to pale-reddishbrown surface; forms weak ledge --..-.-.-.-

Sandstone, moderate-orange-pink, very fine grained, silty ( 20 percent), very limy ( 47 percent); contains wedge-planar cross-stratification; weathers to straight face with much varnish; laminae etched out; forms cliff --..--

Concealed slope, probably much pale-reddishbrown, fissile mudstone --..-_...-..-

Sandstone, pale-reddish-brown, very fine grained, calcareous, structureless; forms rounded ledge

Limestone, pale-red, silty; contains lumps of pale-reddish-brown mudstone; forms rounded ledge

Siltstone, pale-red, muddy, very calcareous, structureless; contains small (0.13-0.25 in.) limestone nodules throughout; forms weak rounded ledge

Concealed slope

Limestone, brownish-gray, aphanitic, thinbedded $(0.5-2 \mathrm{ft})$; contains thin jasper layers; forms weak ledge
Feet

4.0

10.0

7.0 
Section 6-Continued

GRANDVIEW TRAIL_Continued

Supai Group-Continued

Manakacha Formation, cliff unit-Continued

Sandstone, very pale orange, very fine grained; slightly calcareous; mostly structureless but locally cross-stratified; contains scattered elongate gray limestone nodules $(0.5-2 \mathrm{ft})$; weathers to pale-reddish-brown or black varnished surface; forms thick cliff with straight face

Siltstone, grayish-red, sandy, muddy, slightly calcareous, friable; forms recess

Limestone, pale-red, very fine grained, silty (32 percent); weathers to rough surface; contains Fusulinella sp., Pseudostaffella sp.; forms resistant ledge -

Sandstone, pale-reddish-brown, very fine grained, silty; grades upward into pale-reddish-brown siltstone; locally weathers to a black varnished surface; forms resistant, rounded ledge

Limestone, light-brownish-gray, muddy (22 percent), aphanitic to very fine grained, irregularly bedded; contains thick jasper layer; weathers to rough surface; forms resistant ledge

Sandstone, pale-reddish-brown, very fine grained, silty, slightly calcareous, structureless; weathers to conspicuous, rounded ledge with black varnished surface

Limestone, grayish-red, silty ( 20 percent); contains thin jasper layers; includes limestone pebbles; weathers to rough surface; forms base of cliff unit

Total cliff unit, Manakacha Formation - 218.0 Total Manakacha Formation ---- 293.5

Watahomigi Formation, upper slope unit:

Mudstone, grayish-red, crumbly; forms slope --

Siltstone, grayish-red, slightly calcareous, friable, thin-bedded $(0.5-1 \mathrm{ft})$; contains Fusulinella sp.; forms weak ledge ----------

Siltstone, pale-reddish-brown, thin-bedded $(1 \mathrm{ft})$; contains much grayish-red, crumbly mudstone; forms slope, mostly concealed ----

Siltstone, pale-reddish-brown, muddy, thinbedded $(0.5-2 \mathrm{ft})$, friable; forms weak ledge -Mudstone, grayish-red, crumbly; forms slope -Siltstone, grayish-red, very muddy, calcareous, thin-bedded (1-2 ft); forms resistant ledge

Feet
Section 6-Continued

GRANDVIEW TRAIL - Continued

Supai Group-Continued

Watahomigi Formation, upper slope unit-

Continued

Mudstone, grayish-red, brittle; forms slope -----

Siltstone, grayish-red, muddy, shaly, and irregularly bedded; forms series of very

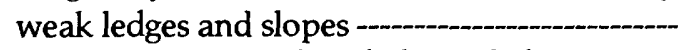

Conglomerate, grayish-red; forms ledge ---.---.Matrix: grayish-red siltstone.

Gravel: mostly $0.16-0.25$ in. diameter; maximum diameter $0.5 \mathrm{in}$.; subrounded to rounded pebbles; composed of greenishgray and grayish-red limestone and siltstone.

Total upper slope unit, Watahomigi Formation ---.--.--

Watahomigi Formation, middle cliff and lower slope units:

Mudstone, grayish-red, slightly calcareous, crumbly; forms slope

Limestone, pale-reddish brown, silty, insoluble (34 percent), concretionary; grades upward into silty (44 percent), light-gray, irregularly bedded limestone that contains thin jasper

5.5 layers. Weathers into spheres (1-2 in. diameter); forms weak ledge --.--.-.-.-.-

Mudstone, grayish-red, brittle, and mediumlight-gray, shaly limestone; forms slope ------

Total middle cliff and lower slope units, Watahomigi Formation --- 24.5 Total Watahomigi Formation ----

Total Supai Group

Unconformity: not observed at place of section.

Redwall Limestone:

Horseshoe Mesa Member:

Limestone, light-olive-gray, aphanitic; thinbedded $(0.5-2 \mathrm{ft})$; cavernous.

Section 7

KAIBAB TRAIL, SOUTH

[Along ridge extending north from Yaki Point]

6.0 Hermit Shale:

1.5 Claystone, pale-reddish-brown, shaly, thinbedded.

Unconformity: erosion channels shallow, filled with
8.5

1.0

Feet 
Section 7-Continued

KAIBAB TRAIL, SOUTH-Continued

Supai Group:

Esplanade Sandstone, upper cliff-slope and main cliff units:

Siltstone, light-reddish-brown, structureless; beds 2-3 ft thick; forms ledge. Alternates with pale-reddish-brown, brittle claystone; forms slope; beds 2-3 ft thick. Total forms series of ledges and slopes

27.5

Sandstone, moderate-orange-pink, very fine grained, calcareous, cross-laminated, hard; beds 2-6 ft thick; weathers pale-brown to dusky-brown; forms cliff

Mudstone, pale-reddish-brown, structureless, brittle; contains 2 -ft bed of resistant, very fine grained sandstone; forms slope ---------

Sandstone, light-brown, very fine grained, argillaceous, calcareous, cross-laminated, resistant; beds $2-6 \mathrm{ft}$ thick; locally contains lenses of mudrock; weathers pale-reddishbrown or light-brown

Mudstone, pale-reddish-brown, structureless, brittle; forms slope

Sandstone, very pale reddish-brown to palered, very fine grained, argillaceous; crosslaminated on large scale, very resistant; bedding sets $12-30 \mathrm{ft}$ thick; locally contains scattered fine- to medium-sand grains; weathers pale-reddish-brown or black; forms sheer cliff

Sandstone, very pale orange, very fine grained, argillaceous, silty, structureless, resistant; beds 2-4 ft thick; contains pale-reddishbrown, argillaceous siltstone at top; weathers light-brown; forms cliff ---_-_.-.

Claystone, pale-reddish-brown, structureless, brittle; forms slope

Sandstone, pale-reddish-brown to reddishgray, very fine grained, calcareous, very resistant; beds $3-8 \mathrm{ft}$ thick with parting planes of pale-red, calcareous claystone forming recesses; weathers same; forms cliff -----

Total upper cliff-slope and main cliff units, Esplanade Sandstone

Esplanade Sandstone, basal slope unit:

Claystone, pale-reddish-brown, structureless, brittle; forms slope with thin ledge of very fine grained sandstone in middle

Feet

Section 7-Continued

KAIBAB TRAIL, SOUTH-Continued

Supai Group-Continued

Esplanade Sandstone, basal slope unit-Continued

Sandstone, light-reddish-brown, very fine grained, argillaceous, very calcareous, structureless; beds $2-4 \mathrm{ft}$ thick with thin mudstone partings; weathers pale-reddishbrown, forms ledge

Claystone, light-reddish-brown, silty; thinbedded except near top; forms slope --..--..Conglomerate

Matrix: pale-reddish-brown claystone.

Gravel: Size-average 0.25 in., but commonly $0.5-1$ in.; mostly rounded; composition-pale-reddish-brown siltstone.

Total basal slope unit, Esplanade Sandstone -- 70.0

Total Esplanade Sandstone --.--

Unconformity: surface of small relief.

Wescogame Formation, slope unit:

Claystone, pale-reddish-brown, structureless, silty; forms slope; contains pale-red, rubbly limestone at top

Sandstone, light-brown, very fine grained, argillaceous, very calcareous, structureless, hard; weathers light-brown to dark-brown; forms ledge

Dolostone, calcitic, pale-reddish-brown, structureless, brittle; forms slope

Sandstone, very pale orange, very fine grained, cross-laminated; weathers pale-reddishbrown; forms cliff

Mudstone, pale-reddish-brown, slope-forming; structureless, brittle, and alternating lightbrown, argillaceous, calcareous, thinbedded siltstone that forms ledges; unit forms series of slopes and ledges --_-_-_-_-

Siltstone, light-brown, argillaceous, calcareous, thin-bedded; forms ledge -.._-_._-_-_-_-_.--

Claystone, pale-reddish-brown, structureless; forms slope

Limestone, pale-red, very silty; weathers palereddish-brown, silty; forms cliff -

Total slope unit, Wescogame Formation --_-

Wescogame Formation, cliff unit:

Mudstone, pale-reddish-brown, structureless, brittle; forms slope. Alternates with a few beds of sandstone that are pale-reddishbrown, very fine grained, shaly, friable, argillaceous sandstone; weathers same. Unit forms slope
Feet 
Section 7-Continued

KAIBAB TRAIL, SOUTH-Continued

Supai Group-Continued

Wescogame Formation, cliff unit-Continued

Sandstone, very pale orange, very fine grained, calcareous, cross-laminated except at base; weathers pale-reddish-brown to black; forms cliff

Claystone, pale-red spotted with yellowishgray, silty, calcareous, brittle; forms slope --.-

Sandstone, pale-red, very fine grained, calcareous, argillaceous, structureless; forms ledge; weathers very pale reddish-brown. Alternates with pale-reddish-brown, shaly, friable claystone. Unit forms series of ledges and slopes

Claystone, dusky-red, brittle, structureless; forms slope

Claystone, pale-red, silty, resistant; resembles mud-ball structure; forms rounded ledge --..-

Sandstone, very light brown, fine-grained, calcareous; cross-laminated on large scale, hard; contains large reptilian footprints; weathers pale-reddish-brown; forms sheer cliff

Claystone, pale-red, brittle, structureless; forms slope

Siltstone, very pale brown, calcareous, argillaceous, structureless; forms ledge -..-..-...-

Claystone, pale-reddish-brown, silty, flatbedded; contains calcareous nodules and siliceous rods; forms weak, rounded ledge ----

Mudstone, conglomeratic; local accumulations of rounded pebbles (light- and darkgray limestone, red-brown siltstone), mostly $0.25-0.5 \mathrm{in}$. in diameter with matrix of darkred-brown mud that probably infiltrated pebble deposits -
Total cliff unit, Wescogame For-

mation -- 163.0

Erosion surface: Small-scale irregularities.

Manakacha Formation, slope unit:

Mudstone, pale-reddish-brown, brittle, structureless; forms slope; contains weak, shaly siltstone and limestone beds near top -.---.---

Siltstone, pale-reddish-brown, calcareous, argillaceous, structureless; forms ledge -------

Claystone, pale-reddish-brown, structureless, slope-forming; interbedded with pale-red siltstone; beds $0.5-1 \mathrm{ft}$ thick

Feet

2.0

Section 7-Continued

KAIBAB TRAIL, SOUTH-Continued

Supai Group-Continued

Manakacha Formation, slope unit-Continued

Sandstone, very light brown, very fine grained, silty, calcareous; cross-laminated on large scale, hard; weathers light-brown; forms cliff -

Siltstone, light-brown, argillaceous, calcareous, structureless; forms ledge; contains claystone at top

Claystone, pale-reddish-brown, structureless, brittle; forms slope --

Siltstone, light-brown, argillaceous, calcareous, structureless; forms ledge --..--..-.

6.0 Claystone, pale-reddish-brown, structureless, brittle; alternates with pale-red, calcareous, thin-bedded siltstone; weathers same; total forms slope

Sandstone, very pale reddish brown, very fine grained, very calcareous, structureless; weathers moderate-brown; forms ledge -----.

Claystone, pale-reddish-brown, structureless, brittle; forms slope

Sandstone, very light brown, very fine grained, calcareous, locally cross-laminated; weathers light-brown; forms cliff --_-_-_-_.

Claystone, pale-red, mottled with yellowishgray; structureless, brittle; forms slope --.--.-

Sandstone, very light brown, very fine grained, calcareous, cross-laminated; weathers palereddish-brown; forms ledge

Claystone, pale-red, structureless, brittle; forms slope

Sandstone, reddish-gray, very fine grained, argillaceous, calcareous, structureless; weathers pale-reddish-brown; forms ledge ---

Claystone, pale-red, structureless, brittle; forms slope

Siltstone, pale-red, argillaceous, calcareous; forms ledge

Limestone, brownish-gray to pale-red, aphanitic, silty, irregularly bedded; weathers rough, rounded

Siltstone, pale-reddish-brown, argillaceous; beds weakly developed, thin (0.25-0.5 in.), irregular; forms slope

Siltstone, pale-red, argillaceous, calcareous, structureless; forms ledge

Siltstone, pale-reddish-brown, argillaceous,

Feet

9.5 beds thin, irregular; forms slope --_-_----- 
Section 7-Continued

KAIBAB TRAIL, SOUTH-Continued

\section{Supai Group-Continued}

Manakacha Formation, slope unit-Continued

Siltstone, pale-red, calcareous, weathers palereddish-brown; forms ledge

Total slope unit, Manakacha

Formation ---_-_-_-_-_-_

Manakacha Formation, cliff unit:

Sandstone, very pale brown, very fine grained, resistant; weathers very pale reddish brown, mottled with pale-reddish-brown; forms ledge

Sandstone, very pale orange, fine-grained, calcareous (30 percent); cross-laminated; contains light-brownish-gray limestone bed at center; weathers very pale reddish brown; forms prominent cliff

Limestone, light-brownish-gray, argillaceous (40 percent), irregularly bedded; upper surface wavy; weathers very pale reddish brown, clay-coated

Claystone, dusky-red with pale-yellow deoxidized patches, brittle; beds 1-3 ft thick; alternating with pale-reddish-brown, resistant claystone; three beds 1-2 ft thick; total forms series of slopes and ledges

Sandstone, very pale reddish brown, very fine grained, calcareous; beds flat; forms ledge -..-

Claystone, dusky-red, structureless, brittle; forms slope

Limestone, brownish-gray, very sandy; grades down into reddish-gray, calcareous siltstone; cross-laminated on large scale; total unit forms prominent cliff

Claystone, dusky-red, structureless, brittle; forms slope

Siltstone, reddish-gray speckled with yellowishwhite, calcareous; weathers very pale red-

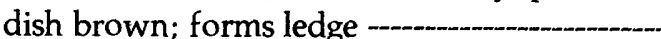

Claystone, pale-red, structureless, brittle; forms slope

Siltstone, pale-red, calcareous (30 percent), argillaceous, hard; contains lenses and thin beds of brownish-gray limestone; weathers pale-reddish-brown; forms weak cliff

Limestone, very pale reddish-brown, sandy, cross-laminated, resistant; weathers lightbrown or brownish-black with laminations etched out

Sandstone, pale-reddish-brown, very fine grained, structureless, friable; weathers same; forms slope

Section 7-Continued

KAIBAB TRAIL, SOUTH-Continued

Feet

10.0
Supai Group-Continued

Manakacha Formation, cliff unit-Continued

Limestone, reddish-gray to brownish-gray, aphanitic, pebbly; intermixed with deep-redclaystone; weathers pale-reddish-brown, clay-coated; forms slope --.--

Siltstone, pale-red, calcareous, structureless, hard; contains limestone inclusions --.---.---

Claystone, dusky-red, structureless, brittle; forms slope -

Claystone, pale-reddish-brown; beds thin and flat; forms massive ledge grading down into weak cliff or slope

Claystone, pale-reddish-brown, structureless, brittle; forms slope

Limestone, brownish-gray; contains thin layers of jasper; weathers with wavy silt laminae etched out; forms ledge

Siltstone, light-reddish-brown, argillaceous, friable; contains limestone concretions; forms slope

Claystone, pale-red, structureless, shaly; forms slope

Limestone, brownish-gray, aphanitic; contains lenses of dark-reddish-gray siltstone near base; weathers light-olive-gray; forms ledge --

Sandstone, light-reddish-brown, very fine grained, argillaceous, friable; forms slope -----

Limestone, brownish-gray, aphanitic; grades upward into dark-reddish-gray siltstone; contains jasper lenses; forms ledge ---.---.---

Sandstone, light-reddish-brown, very fine grained, friable; forms slope --.--..--

Limestone, brownish-gray, aphanitic; weathers light-olive-gray; forms ledge -.............

Sandstone, reddish-gray speckled with very light brown, very fine grained, calcareous, structureless; weathers pale-reddish-brown, rounded ledge

Limestone, brownish-gray, aphanitic; weathers light-olive-gray; contains jasper lenses --.---.--

Siltstone, pale-red, argillaceous, friable; forms slope -

Claystone, pale-red, structureless; forms rounded ledge

Limestone, pale-reddish-brown, silty (15 percent); weathers massive; grades into underlying unit

Total cliff unit, Manakacha Formation -

Total Manakacha Formation -- $-\frac{190.5}{338.0}$ 
Section 7-Continued

KAIBAB TRAIL, SOUTH-Continued

\section{Supai Group-Continued}

Watahomigi Formation:

Claystone, pale-red, structureless; forms rounded ledge

Limestone, brownish-gray, aphanitic; contains jasper lenses; weathers dusky-red --..--.

Sandstone, pale-red, very fine grained, very calcareous; weathers pale-reddish-brown; forms massive ledge

Sandstone, pale-reddish-brown, very fine grained, resistant; weathers pale-reddishbrown; grades down into pale-reddishbrown, shaly, brittle mudstone; forms slope; partly concealed

Concealed, probably pale-reddish-brown claystone

Siltstone, light-reddish-brown, calcareous, structureless, resistant; forms rounded ledge -

Siltstone, moderate-reddish-brown; beds thick and irregular near top, shaly toward bottom; contains worm borings; locally shows scour-and-fill structure; forms slope; much concealed

Claystone, pale-reddish-brown, calcareous; contains thin jasper layers; contains thin tongues, beds and balls of light-brownishgray limestone; forms resistant ledge --.---.-

Siltstone, moderate-reddish-brown, shaly; forms slope

Limestone, brownish-gray, aphanitic, hard; contains thin layers of very pale brown and pale-red jasper; shows weak parting plane at base; weathers light-brownish-gray, rough; forms ledge

Limestone, very light brownish gray, aphanitic; beds 1-3 ft thick; contains oval, siliceous concretions with concentric structure; weathers light-brownish-gray, pitted; local, thin, concretionary beds show trough crossbedding in channels $17 \mathrm{ft}$ deep, $100 \mathrm{ft}$ wide, with limestone pebbles in bottom; forms weak cliff

Conglomerate, calcareous mudstone, and argillaceous limestone; unit is pale red, thinbedded (1-6 in.); forms persistent slope ---.--

Limestone, brownish-gray, aphanitic; beds 2-4 in. thick; contains brown, oval concretions; shows weak parting plane at base; forms cliff

Total Watahomigi Formation --- 158.5

Total Supai Group - -
Section 7-Continued

KAIBAB TRAIL, SOUTH-Continued
Feet

8.0

7.0

2.5

51.0
Unconformity.

Redwall Limestone:

Limestone, gray, massive; forms sheer cliff.

Section 8

KAIBAB TRAIL, NORTH

[Slope and cliff units of Esplanade Sandstone measured on north side of Roaring Springs Canyon; lower part of Supai Group measured on south sidel

Feet

Hermit Shale: Concealed slope

Contact:

Contact not visible at this locality.

Supai Group:

Esplanade Sandstone, upper cliff-slope and main cliff units:

Sandstone, grayish-orange, very fine grained, hard, massive, thick-bedded (4-8 ft); weathers to rough, gray surface; forms resistant cliff

Mudstone, grayish-red-brown, calcareous, structureless, conchoidal fracture; forms recess

Sandstone, pale-reddish-brown, very fine grained, flat-bedded, thin- to mediumbedded (6-30 in.); forms receding ledges --.--

Sandstone, moderate-orange-pink, very fine grained, calcareous, weakly cross-stratified on medium scale; weathers red-brown to black; forms cliff with sheer face ---.-----.-

Mudstone, light-brown, calcareous, shaly; forms slope or bench -..--.----

Sandstone, moderate-reddish-orange, grayishorange-pink, pale-red, very fine grained (scattered fine grains), slightly limy; locally grades into gray, very thick bedded $(4-30 \mathrm{ft})$ sandstone; structureless in lower half, crossstratified (planar type) on medium scale in upper part; includes mudstone partings; forms main cliff with sheer face and prominent bench about 30 feet below top -.---.--.-

Mudstone, grayish-red, brittle; forms slope --.--

Siltstone, pale-reddish-brown, with greenish streaks, calcareous; weathers to black varnished face; includes a mudstone parting; forms sheer cliff 
Section 8-Continued

KAIBAB TRAIL, NORTH-Continued

Supai Group-Continued

Esplanade Sandstone, upper cliff-slope and main cliff units-Continued

Mudstone, pale-reddish-brown, calcareous, weak, medium-bedded (1-2 ft); forms rounded base of cliff

Total upper cliff-slope and main cliff units, Esplanade Sandstone

Esplanade Sandstone, basal slope unit:

Mudstone, pale-reddish-brown, calcareous, structureless, weak; contains plant-stem fragments; forms recess

Sandstone, grayish-orange-pink, calcareous, weathers red-brown; forms small resistant ledge

Mudstone, pale-reddish-brown, brittle, crumbly; forms slope

Sandstone, very pale orange, altered to greenish-gray in upper part, very fine grained, calcareous; forms conspicuous resistant ledge; locally has white cast --_-_-_-_-_-_--

Sandstone, pale-reddish-brown, very fine grained, very silty, calcareous, locally shaly, elsewhere structureless; forms series of resistant ledges (2-6 ft thick) separated by thin slopes; total forms receding ledges ---_------

Siltstone, pale-red, calcareous, shaly; contains Rivularites sp., Walchia sp., rain pits, shrinkage cracks and ripple marks (cusp type); tongues laterally into conglomerate at channels; forms major slope --.--_-_--.---

Conglomerate, brown to gray, weathers reddish-brown; fills channels in underlying unit; beds dip up to $10^{\circ}$ into channel along borders; topmost beds tongue into overlying shaly siltstone; forms weak rounded cliff ----- 0-17.0 Gravel: about 60 percent red-brown siltstone and sandstone, 40 percent pale-gray, dark-gray and greenish-gray limestone; mostly well-rounded and largely spheroidal, especially in larger grade sizes; limestone pebbles well-polished; elongate pebbles locally oriented parallel to rude bedding; maximum diameter at bottom near channel center about 5 in., common size near base $0.5-1$ in., in upper part, $0.25-0.5 \mathrm{in}$.
Section 8-Continued

KAIBAB TRAIL, NORTH-Continued

Feet

Supai Group-Continued

Esplanade Sandstone, basal slope unit-

Continued

Matrix: reddish-brown siltstone; coarsely crystalline calcite cement locally abundant.

$$
\begin{aligned}
& \text { Total basal slope unit, Esplanade } \\
& \text { Sandstone - } \\
& \text { Total Esplanade Sandstone }-\overline{427.0-444.0}
\end{aligned}
$$

Unconformity:

Surface of upper slope unit contains irregular channels filled with conglomerate and shaly siltstone; channel at section measured approximately $250 \mathrm{ft}$ wide, $17 \mathrm{ft}$ deep.

5.5 (Units below Esplanade Sandstone measured on south side of Roaring Springs Canyon)

Wescogame Formation, slope unit:

Siltstone, pale-reddish-brown, very limy; cross-stratified on medium scale, planar type; forms ledge

Siltstone, gray, thin-bedded; forms thin weak ledges on otherwise concealed slope; total slope

Total slope unit, Wescogame Formation

Wescogame Formation, cliff unit:

Sandstone, moderate-orange-pink, fine- to very fine grained, thick-bedded $(2-4 \mathrm{ft})$; cross-stratified on medium scale, planar type; weathers to black varnished surface; forms series of receding ledges ---_-_-_-_-_---

Sandstone, pale-reddish-brown, fine-grained, very limy, massive; cross-stratified on medium to large scale ( $45 \mathrm{ft}$ long), (sets $4-20$ $\mathrm{ft}$ thick); locally grades into limestone; forms major cliff

Mudstone, bright-reddish-brown; forms recess

Limestone, pale-red, aphanitic, muddy; contains thin flat beds (1-2 in. thick), weakly developed within massive unit; forms ledge -Limestone, pale-reddish-brown, aphanitic, concretionary; locally contains mudstone; weathers to rounded surface; forms recess ----

Sandstone, very pale orange, fine-grained, calcareous, sugary, massive; weathers to dark-gray; forms resistant ledge --_- 6.0

Total cliff unit, Wescogame
Formation -
Total Wescogame Formation ---
Tog.0


Section 8-Continued

KAIBAB TRAIL, NORTH-Continued

Supai Group-Continued

Manakacha Formation, slope unit:

Sandstone, pale-reddish-brown, calcareous, very fine grained; includes much fine sand; shaly; forms slope or bench, locally contains weakly developed ledge near middle -...-...-.

Sandstone, moderate-orange-pink, finegrained, calcareous, sugary; cross-stratified on large scale; forms massive cliff with sheer face

Mudstone, pale-red, slightly calcareous, brittle; forms recess

Limestone, moderate-orange-pink, very fine grained, massive, medium-bedded $(2 \mathrm{ft})$; forms weak rounded ledge ---_-_-_-

Siltstone, pale-red, slightly calcareous; shaly at base, thin-bedded (6-24 in.) above; forms prominent bench

Total slope unit, Manakacha

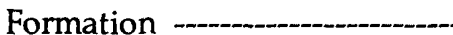

Manakacha Formation, cliff unit:

Sandstone, moderate-orange-pink, finegrained, friable, medium- to thick-bedded (1-5 ft); cross-stratified on medium scale, low-angle planar type; forms cliff with straight face

Mudstone, pale-reddish-brown, calcareous; contains much concretionary limestone; forms recess

Siltstone, pale-reddish-brown, calcareous, medium- to thick-bedded (2.5-10 ft); weakly cross-stratified on medium scale in upper part; zone of warping (differential loading) near base; forms series of cliffs with thin recesses of bright-red mudstone between -----

Surface of contorted beds.

Sandstone, moderate-orange-pink, calcareous, very fine grained, massive, very resistant, thick-bedded (2-6 ft); weakly cross-stratified; forms ledge

Total cliff unit, Manakacha

Formation - _-_ 150.5

Total Manakacha Formation ---- 231.0

Watahomigi Formation, upper slope unit:

Limestone, dark-gray, granular; contains patches and lenses of red-brown mudstone; forms recess

Limestone, pale-reddish-brown, aphanitic, medium-bedded $(2-3 \mathrm{ft})$; contains very thin siliceous layers; weathers to brown rounded surface; forms ledge
Section 8-Continued

KAIBAB TRAIL, NORTH-Continued
Feet

21.5

102.0
Supai Group-Continued

Watahomigi Formation, upper slope unit-

Continued

Limestone, medium-gray, aphanitic, granular; contains patches and lenses of moderatereddish-brown mudstone; locally fills erosion channels extending several feet into underlying unit; forms recess --...-...--

Limestone, pale-reddish-brown, includes much very fine grained sand; mediumbedded $(2-3 \mathrm{ft})$; weakly cross-laminated on medium scale, wedge-planar type; contains fusulinids (Pseudostaffella sp.); weathers to straight, varnished face with silt etched on surface; forms ledge

Limestone, pale-reddish-brown, and mediumgray, very fine grained, very muddy; forms resistant, rounded ledges -..-_-_-_..--

Siltstone, pale-reddish-brown, limy; bedding flat, weakly developed; weathers to straight face; forms ledge

Mudstone, bright-reddish-brown, shaly; contains some concretionary red-brown siltstone; forms recess -

Limestone, light-brownish-gray, aphanitic; contains thin jasper layers and lenses; forms ledge

Siltstone, reddish-brown, shaly; forms recess --Limestone, pale-reddish-brown, aphanitic; contains thin jasper layers and lenses; forms two irregular but resistant ledges with lenses of red mudstone in middle --_-

Siltstone, pale-reddish-brown, calcareous, flat-bedded; weathers to straight, black varnished face; forms base of cliff

Siltstone, pale-reddish-brown, friable, structureless; contains thin beds of crumbly, bright-red mudstone at top and bottom; forms recess

Sandstone, pale-gray, very fine grained; crossstratified, planar type; weathers to black varnished face; forms ledge --_-_-_-

Concealed slope, probably contains friable, pale-reddish-brown, calcareous siltstone ------

Siltstone, pale-red, calcareous, shaly; contains layers of limestone concretions; grades upward into dark-gray, jasper-bearing limestone; forms weak ledge --_-

Conglomerate, grayish-red; weathers to grayish-red-purple ledge; forms bed of irregular thickness, filling small channels
4.0

0.5 
Section 8-Continued

KAIBAB TRAIL, NORTH_Continued

Supai Group-Continued

Watahomigi Formation, upper slope unit-

Continued

Conglomerate-Continued

Gravel, composed largely of red jasper pebbles, but also contains black to gray flint, white and yellow chert, red siltstone, light-gray limestone; mostly subangular to subrounded, small clasts well-rounded; maximum diameter 6 in., common range $0.25-0.75$ in

Matrix: dark-red-brown, calcareous mudstone.

Total upper slope unit, Watahomigi Formation

84.5

Watahomigi Formation, middle cliff and lower slope units:

Concealed slope

Limestone, light-brownish-gray, aphanitic; contains siliceous bands; forms massive ledge

Siltstone, pale-reddish-brown, shaly, and palereddish-brown, very fine to fine-grained, shaly sandstone; forms slope, largely concealed -

Limestone, dolomitic, medium-light-gray, aphanitic, massive; contains thin layers of jasper; forms ledge

Limestone, dark-gray, fine-grained; contains jasper; forms series of thin (2-3 in.) ledges; alternates with pale-reddish-brown, calcareous, shaly, silty mudstone; forms slope ------

Limestone, grayish-red-purple, aphanitic, massive thick-bedded $(3 \mathrm{ft})$; contains thin irregular siliceous bands; weathers to purplish surface; forms ledge

Concealed slope

Siltstone, grayish-red, muddy, thin-bedded $(0.5-2 \mathrm{ft})$; forms weak ledges -.-.

Conglomerate, moderate- to dark-reddishbrown; locally distributed as pockets in basal mudstone

Gravel: composed locally of white quartz, elsewhere of chert and flint; angular to subrounded; maximum diameter 1 in.; common range $0.25-0.5 \mathrm{in}$.

Matrix: dark-reddish-brown mudstone; clasts loosely packed.

Feet

8.0

Section 8-Continued

KAIBAB TRAIL, NORTH-Continued

Supai Group-Continued

Watahomigi Formation, middle cliff and lower

slope units-Continued

Mudstone, grayish-reddish-purple, noncalcareous, hard, brittle, crumbly; forms slope --

Total middle cliff and lower slope units, Watahomigi Formation --_-_-_-_-_-_- 64.5

Total Watahomigi Formation -- $-\frac{64.0}{149.0}$

Total Supai Group ---

Unconformity:

Unconformity inferred-surface even and flat where observed in area.

Redwall Limestone:

Horseshoe Mesa Member:

Limestone, olive-gray, aphanitic; contains much red-brown mudstone filling solution cavities; forms top of main cliff --.----- Not measured

Supai Group:

Hermit Shale.

Unconformity:

Channels with sloping sides cut as much as $55 \mathrm{ft}$ deep into massive beds of Supai and filled with shaly siltstone of Hermit Shale.

Esplanade Sandstone, upper cliff-slope and main cliff units:

Siltstone, grayish-orange-pink, sandy (very fine grained, some fine-grained), massive, cross-stratified on large scale; forms cliff ------

Siltstone, moderate-orange-pink, sandy, shaly; forms bench

19.0

Sandstone, very pale gray to moderate-orangepink, very fine grained (subrounded, sphericity good), silty (32 percent), thick-bedded $(6-8 \mathrm{ft})$; contains thin shaly parting; forms cliff

Sandstone, moderate-reddish-brown, very fine grained (scattered fine grains), structureless; includes thin ledge of grayishorange-pink siltstone, muddy, near middle; total forms prominent bench 
Section 9-Continued

HERMIT TRAIL-Continued

\section{Supai Group-Continued}

Esplanade Sandstone, upper cliff-slope and main cliff units-Continued

Sandstone, moderate-orange-pink, very fine grained, silty, thick-bedded (3-4 ft), crossstratified on small scale; forms resistant ledge

Siltstone, pale-reddish-brown, sandy, gnarlybedded, friable; forms bench

Sandstone, moderate-orange-pink, very fine grained (subrounded, sphericity fair), limy (30 percent), cross-stratified on large scale; grades downward into pale-reddish-brown, very fine grained sandstone; grains subrounded, sphericity good; iron-oxide coatings; comprised of several beds, thicker toward top; total forms prominent red to black cliff

Mudstone, moderate-reddish-brown, sandy (subrounded grains), structureless; weathers shaly; forms slope with rounded ledges -...---

Sandstone, moderate-reddish-brown to grayish-orange-pink, poorly sorted, very fine grained (51 percent), much medium- and fine-grained (subangular to subrounded), sphericity fair, calcareous (35 percent), very hard; contains low-angle cross-stratification on medium scale near bottom, large-scale near top; four massive units (8-20 ft thick) with thin (6-24 in.) parting zones of shaly siltstone; forms major cliff

Sandstone, dark-reddish-brown, very fine grained, silty, cross-stratified; contains limy concretionary balls $0.5-3$ in. in diameter --..-

Sandstone, grayish-red, very limy, very fine grained, fossiliferous, cross-stratified on medium scale; forms resistant, black cliff --.--

Concealed slope

Sandstone, moderate-reddish-brown, very fine grained, (subrounded, sphericity fair), calcareous, friable, cross-stratified on large scale; forms double ledge

Total upper cliff-slope and main cliff units, Esplanade Sandstone --.--

10.0

Esplanade Sandstone, basal slope unit:

Siltstone, bright-red, shaly; forms slope, partly concealed
Section 9-Continued

HERMIT TRAIL_Continued

Feet

Supai Group-Continued

Esplanade Sandstone, basal slope unit-

Continued

Sandstone, moderate-reddish-brown to moderate-orange-pink, very fine grained (subrounded), calcareous ( 30 percent), sphericity fair, silty, massive, structureless; forms prominent rounded cliff

Siltstone, moderate-reddish-brown, muddy, iron-oxide-coated grains, calcareous, flatbedded, thin-bedded, $(0.5-1 \mathrm{ft})$; forms base of cliff - -

Mudstone, moderate-reddish-brown; silty; iron-oxide-coated grains, very calcareous, contains pale-yellowish-gray limy concretions, 0.5-4 in. in diameter; forms recess --.--

Siltstone, red-brown, thick-bedded $(2-3 \mathrm{ft})$; forms rounded ledges --..--

Concealed slope

Sandstone, moderate-reddish-orange, very fine grained, resistant; contains elongate nodules of limestone, $0.5-1$ in. thick, 5-15 in. long; forms resistant ledge -...-...-

Siltstone, moderate-reddish-brown, muddy, calcareous, iron-oxide-coated grains, shaly; contains one bed of resistant bright-red siltstone; forms slope - -..-...-

Limestone, pale-red, very fine grained, concretionary; with red-brown structureless mudstone; forms slope

Concealed slope

Mudstone, moderate-reddish-brown, shaly; contains shrinkage cracks; forms slope -------

Conglomerate, red-brown and gray, resistant, medium-bedded $(0.5-2 \mathrm{ft})$; well-stratified, locally with sand laminae, elsewhere gravel layers; locally cross-stratified on small scale; weathers gray; forms ledge

Matrix: pale- to moderate-reddish-brown, siltstone and sandstone.

Pebbles: moderate-reddish-brown, siltstone, olive-gray and medium-gray limestone, moderate-reddish-brown mudstone; mostly well-rounded, some subangular; diameter $0.25-0.5 \mathrm{in}$. in most layers, locally as much as 3 in.

Total basal slope unit, Esplanade Sandstone -- $\quad 79.5$ 
Section 9-Continued

HERMIT TRAIL-Continued

Supai Group-Continued

Wescogame Formation, slope unit:

Claystone, light-green and red, structureless; forms recess

Sandstone, very pale orange to pale-orangepink, very fine grained (grains subrounded, sphericity fair), silty, calcareous, thickbedded $(3-6 \mathrm{ft})$ in middle, medium-bedded $(1-3 \mathrm{ft})$ at top and bottom; weakly crossstratified on large scale; forms cliff -.........

Siltstone, moderate-reddish-brown, muddy, brittle, structureless; forms slope --.---.-.

Limestone, pale-red, very fine grained, muddy (insoluble, 30 percent); contains limestone concretions 1-2 in. in diameter; forms rounded ledge

Siltstone, dark-reddish-brown, very limy (42 percent), very hard; weathers to resistant ledge

Mudstone, moderate-reddish-brown, shaly to thin-bedded (0.5-1 in.); forms slope -...-...

Sandstone, moderate-orange-pink, fine- to very fine grained, silty, calcareous; includes two thick (3-5 ft) beds; weathers to rounded black surface; forms resistant ledge ----------

Siltstone, moderate-reddish-brown to palered, muddy, very calcareous, thin-bedded $(0.5-2$ in.); contains one medium-bedded $(1-2 \mathrm{ft})$ ledge near center; forms slope ---.----Total slope unit, Wescogame Formation

Wescogame Formation, cliff unit:

Sandstone, moderate-orange-pink, very fine grained, subrounded, sphericity good, silty, thin-bedded (0.5-2 in.); grades upward to pale-reddish-brown, medium-bedded siltstone; weathers white; forms conspicuous weak ledge

Sandstone, very pale orange, fine-grained (scattered very fine grains), (grains subrounded, sphericity good), weakly crossstratified on large scale; forms resistant gray ledge

Claystone, dark-reddish-brown, silty and very light grayish-green limestone, silty, structureless; brittle, crumbly; forms recess --------

Mudstone, pale-red, very silty, shaly to thinbedded (2-12 in.), calcareous; contains a few limestone concretions; forms weak ledges ---. 32.5

Feet

10.0

Section 9-Continued

HERMIT TRAIL-Continued

Supai Group-Continued

Wescogame Formation, cliff unit-Continued

Siltstone, moderate-reddish-brown with palegray spots, muddy, sandy (grains subrounded to rounded); forms slope, partly concealed

Sandstone, pale-orange-pink, fine- to very fine grained (grains subrounded, sphericity fair), medium-bedded (0.5-3 ft), weakly cross-stratified on medium scale; weathers gray; forms resistant ledge

Sandstone, pale-reddish-brown, very fine grained, (grains subrounded, sphericity fair), friable; forms slope or weak, rounded ledge

Sandstone, pale-grayish-orange with very pale greenish gray, fine-grained (47 percent) to very fine grained ( 32 percent); grains subrounded, sphericity good, very thick bedded $(2-15 \mathrm{ft})$, cross-stratified on medium to large scale; weathers red to brown; forms major cliff

Mudstone, dark-reddish-brown, calcareous, very silty, hard, thick-bedded $(6-20 \mathrm{ft})$; contains elongate, unoriented nodules of gray limestone ( 1 in. thick by $6-20$ in. long); forms lower part of main cliff

Mudstone, reddish-brown, structureless, crumbly; forms recess ---.-Unconformity:

Erosion surface; irregular surface with channels 2-3 ft deep in limestone filled with reddish-brown mudstone; locally contains pebbles at surface.

Total cliff unit, Wescogame
Formation - $-\frac{148.5}{240.5}$
Total Wescogame Formation ----

\section{Manakacha Formation, slope unit:}

Limestone, pale-reddish-gray, very fine grained, silty ( 25 percent); contains pockets of mudstone; forms rounded ledge ---.-----

Siltstone, moderate-reddish-brown, muddy, contains gray limestone concretions $0.5-1$ in. in diameter; forms weak, rounded ledge --

Siltstone, moderate-reddish-brown, thickbedded $(2-5 \mathrm{ft})$, massive, friable; forms weak, rounded ledges; alternating with moderate-reddish-brown, limy (42 percent), shaly mudstone; forms slopes; total bed ------ 
Section 9-Continued

HERMIT TRAIL-Continued

Supai Group-Continued

Manakacha Formation, slope unit-Continued

Sandstone, grayish-orange-pink, medium- to fine-grained (grains subangular to subrounded, sphericity fair), friable, crossstratified on large scale; forms prominent white cliff

Dolostone, moderate-reddish-brown, silty (muscovite-rich), thin-bedded (2-24 in.); locally weathers shaly; forms series of weak ledges

Total slope unit, Manakacha Formation

Manakacha Formation, cliff unit:

Siltstone, light-brownish-gray to light-olivegray, very limy, dolomitic (44 percent), thick-bedded (6-20 ft); cross-stratified on medium scale, massive, silty (sandy); weathers black to red; forms cliff -

Siltstone, pale-red, very fine grained, very limy (46 percent calcitic dolomite), thinbedded (2-12 in.); forms slope, partly concealed

Sandstone, very pale orange, very fine grained, (grains subrounded, sphericity fair), (scattered fine and medium grains), thickbedded, friable, massive; forms cliff ---_----

Sandstone, moderate-reddish-orange, very fine grained, limy (33 percent), very silty, crossstratified on medium scale; forms weak ledge

Sandstone, moderate-reddish-brown, very fine grained (grains subrounded), sphericity good, structureless, friable; forms slope, much concealed -.-...-.

Sandstone, moderate-orange-pink, very fine grained, subrounded, sphericity good, medium-bedded (2-4 ft), limy, structureless; forms rounded ledges

Concealed slope

Sandstone, grayish-orange-pink, very fine grained (grains subrounded, sphericity fair), friable, cross-stratified on large scale; weathers pink; forms cliff

Limestone, pale-red, fine-grained, silty (44 percent); contains fusulinids (Fusulinella sp.); cross-stratified on medium scale; forms cliff --

Mudstone, moderate-reddish-brown, structureless, crumbly; forms slope, partly concealed

Feet
Section 9-Continued

HERMIT TRAIL-Continued

Supai Group-Continued

Manakacha Formation, cliff unit-Continued

Limestone, pale-red, dolomitic, silty, very fine grained, medium-bedded ( $2-3 \mathrm{ft})$; forms receding ledges

Limestone, dolomitic, pale-red, very fine grained, silty (40 percent), concretionary, forms rounded ledge

Siltstone, very pale orange gray to palereddish-brown, calcareous, thin-bedded (2-6 in.); includes 1-ft-thick ledge of pale-reddishbrown siltstone with limy lenses; forms slope, partly concealed --.-.---.--

Sandstone, moderate-reddish-orange, very fine grained, muddy, calcareous, thick-bedded (3-6 ft); cross-stratified on small scale; forms resistant cliff

Mudstone, deep-reddish-brown, structureless; forms slope

Limestone, light-grayish-red, fine-grained, silty (40 percent); contains jasper near top; forms ledge

Sandstone, moderate-reddish-brown to paleorange-pink, very fine grained (scattered fine grains), calcareous, structureless; forms slope

13.5 fine grained, silty (40 percent), thick-bedded $(2-4 \mathrm{ft})$; forms cliff

Limestone, olive-gray and dark-greenish-gray, 18.5 very fine grained, thick-bedded, insoluble (40 percent); contains jasper lenses; forms cliff

Mudstone, dark-reddish-brown, very silty, very thick bedded (4-10 ft), massive; forms cliff

Total cliff unit, Manakacha Formation -- 255.5

Total Manakacha Formation --- $\quad 345.0$

5.0 Watahomigi Formation:

Siltstone, moderate-reddish-brown, muddy, structureless; forms rounded ledge -...-...-..-

Limestone, reddish-gray, very fine grained, silty (insoluble, 42 percent); contains jasper lenses near top; forms ledge

Limestone, gray to purple, nodular; matrix shaly, red-brown mudstone; forms recess ----

Mudstone, moderate-reddish-orange, very silty, calcareous, thick-bedded $(2-4 \mathrm{ft})$; weathers shaly; forms ledge

Feet 
Section 9-Continued

HERMIT TRAIL_Continued

Supai Group-Continued

Watahomigi Formation-Continued

Siltstone, reddish-brown, structureless; forms slope

Limestone, pale-red with light-olive-gray, finegrained, very silty, medium-bedded; weathers black; forms ledge

Limestone, gray to purple, aphanitic; contains jasper bands; forms ledge -

Limestone, gray, concretionary; forms weak ledge

Concealed slope

Mudstone, dark-reddish-brown, silty; contains gray limestone concretions; forms ledge

Limestone, dark-reddish-brown to moderatereddish-brown, muddy (25 percent), medium-bedded, crumbly; forms slope, largely concealed -

Siltstone, pale-red-purple, calcareous (30 percent), locally very shaly; forms cliff -...-.--

Siltstone, moderate-reddish-brown and grayish-red, muddy, shaly; forms slope -..-...--

Limestone, grayish-red, very fine grained, silty, wavy bedded; locally concretionary; forms rounded ledge -

Siltstone, reddish-brown, shaly; forms slope --.-

Limestone, moderate-reddish-brown, silty ( 30 percent), thick-bedded $(2-4 \mathrm{ft})$; weathers black; forms ledge

Mudstone, reddish-orange, and grayish-redpurple, shaly, muddy, limy siltstone; forms long slope

Limestone, brownish-gray, fine-grained, silty, thick-bedded; contains irregular jasper bed at top; forms ledge

Limestone, grayish-red, very fine grained, very muddy, concretionary; contains red mudstone matrix; forms weak ledge --_-_-_-

Mudstone, grayish-red, brittle; forms slope --.--

Limestone, light-brownish-gray with pale-red, very fine grained (insoluble, 30 percent), concretionary to massive; contains jasper; forms ledge

Limestone, gray, concretionary; contains red mudstone matrix; forms slope --_............

Limestone, light-brownish-gray with lightolive-gray spots, very fine grained; contains many jasper bands, 1-3 in. thick; forms ledge
Section 9-Continued

HERMIT TRAIL-Continued
Feet

2.0

20.0

11.0

8.5

2.0

13.0

39.5
Supai Group-Continued

Watahomigi Formation-Continued

Limestone, dark-gray to purple; muddy (40 percent); concretionary, with matrix of red, crumbly mudstone; forms weak ledge ---.----

Mudstone, deep-red, silty, weakly bedded, brittle; contains many rounded to subangular pebbles (1-6 in. diameter) of underlying Redwall Limestone near base; forms slope ---.-- 44.0

Unconformity:

Total Watahomigi Formation --- 206.5

Total Supai Group --

Erosion surface; shows channels with relief of 12-17 ft in horizontal distance of $50 \mathrm{ft}$; sink topography.

Redwall Limestone:

Horseshoe Mesa Member:

Limestone, gray, aphanitic, thin-bedded forms receding ledges Not measured

Section 10

BASS TRAIL

[On west side of Bass Canyon east of Mount Huethawali]

Feet

Hermit Shale:

Mudstone, moderate-reddish-brown, shaly; forms slope

Contact:

Not described.

Supai Group:

Esplanade Sandstone, upper cliff-slope and main cliff units:

Sandstone, very pale orange, very fine grained, moderately resistant; forms ledge --.-...-...---

Sandstone, moderate-reddish-orange, very fine grained, shaly; includes two small $(1-2 \mathrm{ft}$ thick) ledges of weak, structureless siltstone; total forms slope

Sandstone, moderate-reddish-orange, very fine grained, moderately friable, weakly cross-stratified; forms resistant, rounded ledge

Siltstone, moderate-reddish-orange, friable; forms bench 
Section 10-Continued

BASS TRAIL_Continued

Supai Group-Continued

Esplanade Sandstone, upper cliff-slope and main cliff units-Continued

Sandstone, light-red-brown, very fine grained; forms ledge

Mudstone, dark-red-brown, shaly; forms

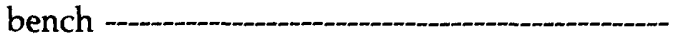

Sandstone, moderate-reddish-brown, very fine grained, medium-bedded (1-2 ft); forms resistant ledge

Siltstone, moderate-reddish-orange, shaly; forms bench

Sandstone, moderate-reddish-brown, very fine grained, medium-bedded (1-2 ft); forms cliff -

Siltstone, moderate-reddish-orange, sandy, friable, medium-bedded ( $1-3 \mathrm{ft})$; forms wide bench

Sandstone, moderate-reddish-orange, fine- to very fine grained, thick-bedded $(3-4 \mathrm{ft})$; weathers to black varnished surface; forms cliff

Mudstone, dark-red-brown, silty, mediumbedded ( $1-3 \mathrm{ft})$; forms slope

Sandstone, moderate-reddish-brown, very fine grained, thick-bedded (3-4 ft); weathers to black varnished surface; forms cliff or series of resistant ledges

Siltstone, moderate-reddish-orange, silty, medium-bedded (1-3 ft); forms irregular ledges or slope

Sandstone, moderate-reddish-brown to white, very fine grained, very thick bedded (2-30 $\mathrm{ft}$ ); large-scale compound cross-strata etched out on surface; weathers with black varnish; forms cliff with straight face

Sandstone, moderate-reddish-orange, very fine grained, silty, medium-bedded (1-3 ft); forms irregular ledges or slope --.--

Sandstone, pale-red to grayish-orange-pink, very fine grained to silty, hard, very thick bedded (2-30 ft); weakly tabular-planar to wedge-planar cross-stratification on medium to large scale $(10-40 \mathrm{ft})$; weathers to rounded, black varnished surface; forms straight cliff

111.0

Mudstone, deep-red-brown; forms "parting" ---
Feet

12.0

Section 10-Continued

BASS TRAIL-Continued

Supai Group-Continued

Esplanade Sandstone, upper cliff-slope and main cliff units-Continued

Sandstone, very pale red, very fine grained, medium- to thick-bedded $(2-4 \mathrm{ft})$; planar cross-stratified on medium to large scale (10-30 ft); weathers to black varnished surface; forms weak, rounded cliff -

Total upper cliff slope and main cliff units, Esplanade Sandstone

Esplanade Sandstone, basal slope unit:

Sandstone, pale-reddish-brown, very fine grained, silty, flat-bedded, thin- to mediumbedded (1-24 in.); moderately resistant; surface weathers shaly, locally micaceous; forms base of main cliff, locally forms slope --

Siltstone, moderate-reddish-orange, calcareous, shaly; forms slope at base of cliff -------

Sandstone, bright-red-brown, very fine grained, friable, cross-stratified on medium scale; forms cliff

Siltstone, pale-red, noncalcareous, friable, structureless; forms ledges 2-3 ft thick with slopes of deep-red-brown, brittle mudstone between

Sandstone, moderate-reddish-orange, very fine grained, calcareous, friable, cross-stratified on medium scale; forms ledge -

Concealed slope

Siltstone, pale-red, limy, flat-bedded, thinbedded (4-12 in.); weathers to blocks; forms receding ledges or slope

Conglomerate, brownish-gray; fills erosion channels in underlying siltstone; forms weak ledge or slope

15.0

Pebbles: brownish-gray, pale-gray, and dark-gray limestone; subrounded to rounded; largely spheroidal, but some elongate and tabular; elongate pebbles oriented parallel to weakly developed bedding; average diameter $0.25-0.75$ in., maximum 2 in.

Matrix: red-brown, limy siltstone.

Total basal slope unit, Esplanade Sandstone --_-_-_-_-_ 114.0

Total Esplanade Sandstone ---.-- $\overline{416.5}$ 


\section{Section 10-Continued}

BASS TRAIL-Continued

Supai Group-Continued

Unconformity:

Channel $240 \mathrm{ft}$ wide and $15 \mathrm{ft}$ deep where observed, cut into shaly siltstone and filled with limestone pebble conglomerate.

Wescogame Formation, slope unit:

Siltstone, pale-reddish-brown, shaly; some very fine sand; forms slope --...-

Sandstone, moderate-orange-pink, very fine grained (scattered rounded, fine grains), calcareous, friable, cross-stratified on medium scale, planar type; forms bench and $2-\mathrm{ft}$ thick ledge

Total slope unit, Wescogame Formation

Wescogame Formation, cliff unit:

Sandstone, white, fine- to very fine grained, cross-stratified on large scale; forms cliff ---.--

Sandstone, moderate-orange-pink, very fine grained, calcareous, friable, platy to thinbedded; forms slopes or recesses --.--

Sandstone, moderate-orange-pink, very fine grained, includes many fine grains, crossstratified on large scale; forms cliff with sheer face -..-_.

Sandstone, pale-reddish-brown, very fine grained, noncalcareous, muddy, friable, structureless; forms recess under cliff --..--.--

Sandstone, moderate-reddish-orange, very fine grained, calcareous, structureless, hard; forms ledge

Sandstone, moderate-orange-pink, very fine grained, includes many fine grains, friable, calcareous, medium-bedded $(2-4 \mathrm{ft})$; crossstratified on small to medium scale; forms cliff or series of receding ledges -.._-_._-_.-.-

Sandstone, moderate-orange-pink, very fine grained, slightly calcareous, cross-stratified

on large scale; forms cliff -
Total cliff unit, Wescogame

Formation --oscogame Formation --- -140.5
Total Wes.5

Manakacha Formation, slope unit:

Siltstone, pale-reddish-brown; includes very fine sand grains; shaly to thin-bedded; forms slope or weak ledge --

Concealed slope

Sandstone, moderate-reddish-orange, very fine grained, calcareous, flat-bedded; forms resistant cap to underlying cliff
Section 10-Continued

BASS TRAIL-Continued

Feet

Supai Group-Continued

Manakacha Formation, slope unit-Continued

Sandstone, moderate-orange-pink, fine- to very fine grained; includes much silt-size quartz; slightly calcareous, friable, crossstratified on large scale (planes $50+\mathrm{ft}$ long); forms cliff with sheer face

Mudstone, grayish-red, noncalcareous, brittle, crumbly; forms slope

Sandstone, pale-red, silty, calcareous, platy to thin-bedded (0.5-6 in.); contains plant impressions; forms slope and weak ledges --.--..-

Total slope unit, Manakacha Formation

Manakacha Formation, cliff unit:

Sandstone, moderate-orange-pink, very fine grained (includes many fine grains), calcareous, friable, flat-bedded, medium-bedded $(2-4 \mathrm{ft})$; forms rounded ledges

Sandstone, moderate-orange-pink, very fine grained, calcareous, friable, cross-stratified on large scale (wedge-planar type); forms rounded, resistant cliff -_-_-_-_-_-_-

Concealed slope

Sandstone, grayish-orange-pink, very fine grained, some fine grains, calcareous, flatbedded, medium-bedded (1-2 ft); forms bench or weak cliff

Limestone, pinkish-gray, very sandy, grades upward into very fine grained, moderatereddish-orange sandstone, with some fine sand; hard, cross-stratified on medium to large scale, planar type; units medium to thick (2-10 ft); weathers to black varnished face; forms resistant cliff

Limestone, medium-gray, very silty, structureless or contains wavy laminae (probably algal); weathers black; forms resistant ledge at base of cliff

Sandstone, pale-red, very calcareous, silty; contains scattered limestone nodules; also contains chert in upper part; forms slope or rounded ledges

Limestone, pale-red; contains very fine grained quartz, and rounded carbonate grains scattered throughout; sandy, prominently crossstratified on medium scale; forms resistant ledge

\section{5}


Section 10-Continued

BASS TRAIL - Continued

Supai Group-Continued

Manakacha Formation, cliff unit-Continued

Siltstone, pale-red, limy, shaly to thin-bedded (1-4 in.); contains limestone concretions 1-2 in. in diameter parallel to beds; forms slope or weak ledge

Siltstone, pale-reddish-brown, calcareous; forms weak, rounded ledge

Sandstone, grayish-pink, very fine grained, very silty; grades upward into medium-lightgray, hard, weakly-laminated and crosslaminated limestone; contains dark limestone nodules (probably algal) in upper part; forms resistant receding ledges

Sandstone, moderate-orange-pink, finegrained, calcareous, weakly cross-stratified on medium scale; contains abundant jasper lenses and bands; weathers gray; grades upward into silty gray aphanitic limestone; forms massive cliff

Mudstone, deep-red-brown; forms recess ------

Sandstone, moderate-orange-pink, very fine grained, friable, cross-stratified on medium scale, units 3-5 ft thick; contains scattered white grains; forms resistant cliff

Total cliff unit, Manakacha Formation --.-_ 179.0

Total Manakacha Formation ----- 263.5

Watahomigi Formation:

Sandstone, pale-red, very fine grained, calcareous, thin- to medium-bedded; contains plant stems (Walchia?) and worm trails; weathers blocky; forms recess under cliff

Concealed slope, with deep-red-brown mudstone at top

Siltstone, pale-red, slightly calcareous, shaly; forms slope with weak, 2-ft-thick ledge in middle

Sandstone, pale-reddish-brown with white specks throughout, fine- to very fine grained, calcareous, cross-stratified on medium scale, planar type; weathers to rounded surface; forms ledge

Sandstone, moderate-reddish-orange, very fine grained, slightly calcareous, friable, structureless, hard; forms resistant ledge

Feet
Section $10-$ Continued

BASS TRAIL-Continued

Supai Group-Continued

Watahomigi Formation-Continued

Siltstone, pale-red, limy, thin-bedded (1-4 in.); contains limestone concretions $1-2$ in. in diameter parallel to beds; forms slope or weak ledge

Concealed slope amount of jasper; forms resistant ledge --.-.---

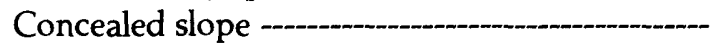

Sandstone, grayish-orange-pink, very fine grained, limy, medium- to thick-bedded (1.5-4 ft); weathers to black varnished surface; underlain by variable thicknesses of fissile, pale-red, noncalcareous siltstone that forms recesses; bottom contact irregular; forms resistant ledge

Siltstone, pale-red, calcareous, fissile; contains abundant gray limy concretions, $0.5-2$ in. in longest dimension (mostly flattened ovoids); forms slope or recess

Siltstone, pale-reddish-brown, calcareous, structureless, crumbly; forms slope ---.-----

Concealed slope

Limestone, gray, aphanitic; contains bands of white chert and jasper; forms ledge -

Siltstone, pale-red, very limy, crumbly; forms slope

Limestone, grayish-red, aphanitic; contains very irregular masses of chert; weathers to silty, needlelike surface; forms weak ledge ----

Limestone, pale-red with very light gray blotches, aphanitic; contains abundant thin (0.25-2 in.) bands of chert, both parallel to bedding and crosscutting at low angles; chert weathers to white conspicuous surface; forms ledge

Concealed slope, with crumbly, pale-red, calcareous claystone near top --Total Watahomigi Formation --- 125.0 Total Supai Group

Unconformity:

Unconformity assumed-surface essentially horizontal for 0.25 mile where observed.

Redwall Limestone:

Horseshoe Mesa Member:

Limestone, light-olive-gray, aphanitic, mediumbedded; forms rough, receding ledges at top of cliff Not measured 
Section 11

\section{SHINUMO TRAIL}

[Measured northeast of trail in Muav Canyon, western part of Shinumo Amphitheater]

Hermit Shale:

Siltstone, red-brown, shaly to thin-bedded; forms slope

Contact:

Contact even and flat where exposed.

Supai Group:

Esplanade Sandstone, main cliff unit:

Sandstone, moderate-orange-pink with reddish-brown speckles (lower and middle part), pinkish-gray, locally white (upper part); very fine to fine-grained, calcareous except in lower part; weathers to moderatereddish-orange; forms series of massive, rounded ledges

Sandstone, moderate-orange-pink, very fine grained (scattered fine grains), thick-bedded $(2-4 \mathrm{ft})$; calcareous; weathers to rounded ledges

Concealed slope; probably shaly, red-brown siltstone

Sandstone, moderate-orange-pink with moderate-reddish-brown speckles, very fine grained, calcareous, resistant; crossstratified on medium to large scale, tabularand wedge-planar types; forms ledge --.---.--

Sandstone, pale-reddish-brown, flat-bedded; very fine grained, calcareous; forms bench --

Sandstone, moderate-orange-pink with moderate-reddish specks, very fine grained, limy, calcareous; cross-stratified; forms resistant cliff

Sandstone, moderate-orange-pink, calcareous, very fine grained, silty, friable; crossstratified on small to medium scale; beds 1-2 ft thick; forms weak cliff

Siltstone, pale-red, calcareous, shaly to thinbedded; forms slope

Siltstone, red-brown, resistant; cross-stratified on medium scale; forms cliff

Siltstone, deep-red-brown, flat-bedded, thinbedded (2-6 in.); forms recess -..-_-_-_-_._-

Sandstone, moderate- to orange-pink, calcareous, very fine grained, cross-stratified on large scale, planar type; forms cliff with sheer face
Section 11-Continued

\section{SHINUMO TRAIL-Continued}

Supai Group-Continued

Esplanade Sandstone, main cliff unit-

Continued

Siltstone, pale-red; includes scattered very fine grains; calcareous, flat-bedded, thinbedded (2-6 in.); contains worm borings with muddy films; forms recess

Sandstone, red-brown, very fine grained, limy, resistant; cross-stratified on medium to large scale, tabular- and wedge-planar types; locally weathers with black varnish; forms cliff

Sandstone, moderate-reddish-orange, very fine grained (includes scattered fine grains), calcareous, flat-bedded, shaly to thinbedded (6-12 in.); forms bench or slope --.-.-

Sandstone, pale-red, calcareous, very fine grained, cross-stratified on medium scale, wedge-planar type; bedding units thick (2-8 $\mathrm{ft}$ ); weathers dark-gray; forms base of main cliff

Total main cliff unit, Esplanade Sandstone

Esplanade Sandstone, basal slope unit:

Mudstone, pale-red, structureless, silty; contains scattered very fine grains; calcareous, moderately resistant; forms rounded ledge ---

Concealed slope

Siltstone, moderate-reddish-orange; contains scattered very fine grains; calcareous; weakly cross-stratified on medium scale, planar type, in lower part; appears structureless above; weathers to red surface, locally with black varnish; forms massive rounded cliff ---

Concealed slope

Siltstone, pale-red with irregular concretionary masses of very pale orange, calcareous; contains scattered very fine sand and a few widely scattered pebbles of gray limestone, $0.5-1$ in. in diameter; massive; forms ledge --12.5 Conglomerate, pale-reddish-brown; calcareous; forms massive ledge

Gravel: gray limestone, pink and gray sandstone, and red-brown siltstone; subangular to subrounded; spheroidal to ellipsoidal; average diameter $0.5-1$ in., maximum 1.5 in.

Matrix: red-brown siltstone to sandstone.

Total basal slope unit, Esplanade Sandstone ---_ $\quad 75.5$

Total Esplanade Sandstone ------ 307.5 
Section 11-Continued

SHINUMO TRAIL-Continued

Unconformity:

Erosion surface at base of conglomerate assumed; base not exposed in this area.

Section 12

\section{THUNDER RIVER TRAIL}

[Measured in Fishtail Canyon about 3 miles from Thunder River Trail]

Hermit Shale:

Lower ledge-slope unit:

Siltstone, pale-reddish-brown, horizontal bedding, shaly; forms slope.

Unconformity:

Channels $37.5 \mathrm{ft}$ deep in upper surface of Supai filled with Hermit Shale.

Supai Group:

Esplanade Sandstone, main cliff unit:

Sandstone, very pale orange to pale-reddishbrown, very fine grained; contains mediumscale, wedge-planar, cross-stratification at base; large-scale, tabular-planar crossstratification near top; cross-strata not prominent, but locally etched by weathering; forms resistant cap rock

Sandstone, moderate-reddish-brown, very fine grained, thick-bedded (2-6 ft); structureless within beds; bottom of unit fine-grained (subrounded) sand; total weathers to rough, irregular surface

Sandstone, grayish-orange, very fine grained (subrounded); unit contains medium-scale, wedge-planar, cross-strata near base; largescale, tabular-planar cross-strata near top; stratification locally etched out on exposure; surface weathers to rounded hills forming Esplanade bench

Sandstone, grayish-orange-pink, very fine grained (angular); locally contains medium grains (rounded); unit prominently crossstratified (locally tabular-planar type crossstrata, large-scale, 60-70 ft long; elsewhere wedge-planar, cross-strata; structures etched out in fine detail); total weathers to mounds and odd erosional forms
Section 12-Continued

THUNDER RIVER TRAIL-Continued

Supai Group-Continued

Esplanade Sandstone, basal slope unit-

Continued

Sandstone, pale-red to grayish-orange-pink, very fine grained (subangular); unit thinbedded at base (1-3 ft); very thick bedded in middle and at top (5-20 ft); in part, crossstratified; unit weathers to rounded surfaces of grayish-orange-pink; forms massive cliff with wide bench at base

Sandstone, grayish-orange-pink, very fine grained, calcareous; thick-bedded $(2-4 \mathrm{ft})$ with sets of medium-scale, tabular-planar cross-stratification; weathers to light-gray, rounded surface; retreats from underlying ledge to form shelf

Sandstone, grayish-pink, very fine grained, very calcareous; contains prominent, smallto medium-scale, wedge-planar crossstratificaiton; weathers yellowish-gray; forms cap above extensive shelf --...-...-Total main cliff unit, Esplanade Sandstone

Esplanade Sandstone, basal slope unit:

Siltstone, pale-red, calcareous, shaly; mostly concealed; forms slope

Sandstone, pale-reddish-brown at base, grading upward into moderate-reddish-orange, very fine grained; grains angular to subrounded; unit thick- to very thick bedded at base (2-8 $\mathrm{ft})$; grades upward to thin beds $(0.5-2 \mathrm{ft})$; upper part moderate-reddish-orange, weakly cross-stratified; contains worm borings; forms resistant major cliff; lowest continuous sandstone bed above erosion channel --.--

Sandstone, pale-reddish-brown, very fine grained, structureless; contains clay balls (0.25-0.5 in. diameter); weathers to rounded boulders; forms filling along margins and in upper part of buried channel

Sandstone, pale-reddish-brown, very fine grained; grains subrounded; thin-bedded $(0.5-1 \mathrm{ft})$; forms filling in lower part of buried channel; weathers to weak ledges ------

Conglomerate, moderate-reddish-orange, locally greenish-gray; forms distinctive marker at base of upper cliff

Matrix: moderate-reddish-orange siltstone.

Gravel: as large as 1 in. in diameter; mostly well-rounded; composed of grayish-red siltstone and greenish-gray limestone.
55.0 
Section 12-Continued

\section{THUNDER RIVER TRAIL-Continued}

Supai Group-Continued

Esplanade Sandstone, main cliff unit-

Continued

(Detailed description of conglomerate, obtained one-half mile west of measured section.)

Conglomerate, moderate-reddish-orange; forms distinctive marker at base of upper cliff --..--_Matrix: greenish-gray, silty limestone.

Gravel: locally derived pebbles; mostly $0.25-1$ in. diameter; maximum 3.5 in.; mostly well-rounded but some angular; oriented in crude layers; ellipsoidal pebbles with long axis horizontal; composed mostly of moderate-reddish-orange siltstone; some greenish-gray limestone.

Total basal slope unit, Esplanade Sandstone

Total Esplanade Sandstone ------ $\quad 312.0$

Unconformity:

Surface of erosion: contains channel as deep as $12 \mathrm{ft}$; filled with structureless red limy mudstone on north side of erosion pocket; unoriented shaly slabs on channel side; inner part of channel contains limestone pebbles, 1-2 in. diameter, in red mudstone matrix.

Wescogame Formation, slope unit:

Sandstone, pale-reddish-brown, very fine grained (grains subrounded), laminated ( $0.25-0.5$ in.); in part, thin-bedded $(1-2 \mathrm{ft})$; contains abundant cusp ripple marks; forms prominent slope with small ledges

Siltstone, pale-red, very limy; weathers to dark-gray; forms prominent ledge --_------

Siltstone, pale-red; shaly at base; grades upward into platy limestone; forms slope or bench

Total slope unit, Wescogame Formation

Wescogame Formation, cliff unit:

Sandstone, grayish-red, fine-grained, mediumbedded (1-4 ft); locally contains tabularplanar cross-stratification; weathers to rounded top; forms cliff ---

Sandstone, grayish-orange-pink, very fine grained (angular grains), horizontallybedded; bedding weakly developed; forms bench

Feet
Supai Group-Continued

Wescogame Formation, cliff unit-Continued Sandstone, grayish-orange-pink, fine-grained; contains some very fine grains (subrounded); unit very resistant, locally friable; thickbedded (1-4 ft); contains some tabularplanar cross-bedding; weathers to rounded knobs on top with black varnish; forms resistant cliff

Conglomerate, fills erosion channels --

Total cliff unit, Wescogame

Formation --- 76.0

Total Wescogame Formation ---- 125.0

Manakacha Formation, slope unit:

Sandstone, pale-reddish-brown, very fine grained (subangular to angular); includes 2-ft thick, structureless, weak ledge; grades upward into pale-reddish-brown, silty, medium-bedded mudstone; beds irregular, very weak; unit contains limy concretions at top; forms weak slope

Sandstone, moderate-orange-pink, finegrained; contains large-scale, planar crossstratification and, locally, medium- to largescale, wedge-planar cross-stratification $(10-40 \mathrm{ft})$; very thin bedded $(0.25-2 \mathrm{in}$.$) ;$ weathers to pinkish-gray; forms slope or weak receding cliff

Sandstone, pale-reddish-brown, very fine grained (grains subrounded), friable; horizontally-bedded; thin-bedded or shaly; beds weakly developed; unit includes siltstone beds with Rivularites, worm trails, shrinkage cracks, parallel ripple marks, rain pits, and poorly preserved ferns; forms recess under minor cliff --

Total slope unit, Manakacha Formation

Manakacha Formation, cliff unit:

Sandstone, moderate-reddish-orange, very fine grained (subrounded to angular), friable; contains prominent, large-scale, tabularplanar cross-stratification (40-60 ft long); weathers to rounded surface; forms upper part of cliff -

Sandstone, grayish-orange-pink, very fine grained (subrounded), silty, calcareous; contains jasper lenses; forms resistant cliff

Feet

0
.0
0

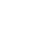


Section 12-Continued

\section{THUNDER RIVER TRAIL-Continued}

Supai Group-Continued

Manakacha Formation, cliff unit-Continued

Mudstone, pale-reddish-brown, limy, thickbedded $(2-6 \mathrm{ft})$; beds weather with closely spaced parting planes (1-2 in.); rock grades upward into alternating units of palereddish-brown, very fine grained (subangular grains), limy, thick-bedded sandstone; contains large-scale, tabular-planar cross-stratification, and pale-reddish-brown, very thin bedded (2-12 in.) mudstone; total forms major cliff

Limestone, pale-red to light-brownish-gray, silty (35 percent); contains tabular-planar cross-stratification; forms recess under major cliff

Limestone, yellowish-gray; contains jasper; forms three resistant, very thick bedded ledges $(5-10 \mathrm{ft})$; separated by grayish-red mudstone recesses $(1-2 \mathrm{ft})$; total forms resistant cliff

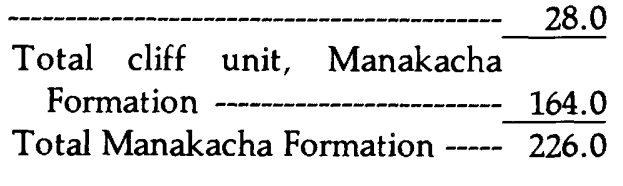

Watahomigi Formation, upper slope unit:

Limestone, grayish-red; insoluble residue (40 percent); moderately resistant; contains mudstone lenses; alternates with grayishred, structureless mudstone; develops spheroidal weathering; total forms slope --.-.-.--

Limestone, grayish-red-purple, silty, massive; forms slope or rounded ledge --..--

Dolomite, pale-red, silty, hard; black cliff continuous with underlying unit -.-_-_._-_.--

Siltstone, pale-reddish-brown, scattered very fine grained sand (angular grains), massive; contains elongate, very pale orange siltstone lenses that suggest bedding throughout; forms lower part of massive ledge --_-_----

Limestone, dark-gray, aphanitic; contains jasper bands; forms cliff -

Mudstone, grayish-red, structureless; forms slope

Limestone, light-brownish-gray; forms ledge ---

Siltstone, pale-reddish-brown (angular grains); contains several silty limestone ledges (2-4 in.); upper portion contains limestone concretions; forms slope

Feet
Section 12-Continued

THUNDER RIVER TRAIL-Continued

Supai Group-Continued

Watahomigi Formation, upper slope unit-

Continued

Limestone, pale-red, aphanitic; contains abundant jasper bands; with underlying $9 \mathrm{ft}$ of mudstone forms cliff

Mudstone, pale-red, shaly; includes scattered sand grains (angular); contains abundant ellipsoidal mud concretions (1-3 in. wide); shaly beds wrap around concretions; forms conspicuous ledge

60.5 Mudstone, pale-red, shaly, limy; forms slope or recess

Limestone, medium-light-gray; weathers to rounded surface; forms resistant ledge --.-.---

Mudstone, pale-red, shaly; forms slope

Limestone, greenish-gray, silty (angular grains); contains angular fragments of grayish-red mudstone; forms ledge

Mudstone, grayish-red, shaly, silty (angular grains); contains several thin (2-6 in.) limestone ledges; forms slope

Conglomerate, pale-red; forms key bed; forms ledge

Matrix: pale-red siltstone.

Gravel: composed of white and lightgreenish-gray quartz and chert, and palered jasper pebbles; $0.25-0.5$ in. diameter; subangular to angular; densely packed.

Total upper slope unit, Watahomigi Formation -

Watahomigi Formation, middle cliff unit:

14.5 Sandstone, medium-light-gray, very fine grained; insoluble 93 percent; gnarly; forms slope --.--_-

Limestone, medium-light-gray, aphanitic; includes much fine-grained sand; contains jasper; forms ledge

Limestone, medium-light-gray, aphanitic; contains small siliceous(?) rods or spines; forms ledge

Mudstone, light-brownish-gray, silty, structureless, calcareous; forms slope

1.0

Limestone, light-olive-gray, aphanitic; locally contains stromatolitic structure; weathers to slope or rounded ledges

Limestone, light-brownish-gray, very resistant; contains bands of jasper and patches of palered siltstone near top; forms ledge

Total middle cliff unit, Watahomigi Formation ---_------

Feet

5

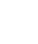


Section 12-Continued

THUNDER RIVER TRAIL_Continued

Supai Group-Continued

Watahomigi Formation, lower slope unit:

Mudstone, pale-reddish-brown, silty, brittle, structureless; slope at base (lower $16.5 \mathrm{ft}$ ) largely concealed; upper portion (11 ft) forms weak slope -

Mudstone, grayish-red, silty, locally sandy (angular grains); weakly bedded; forms slopes; alternates with grayish-red, finegrained, angular-grained sandstone; forms crumbly ledges

Siltstone, dark-reddish-brown, sandy (subrounded grains), structureless to weakly bedded; contains grayish-red mud peloids; forms slope

Total lower slope unit, Watahomigi Formation ----- 57.0

Total Watahomigi Formation --- $-\frac{180.5}{84.5}$

Total Supai Group -

Unconformity:

Irregular erosion surface at top of Redwall Limestone filled with mudstone of Supai Group. Erosion surface shows as much as 5 $\mathrm{ft}$ of relief in $25-\mathrm{ft}$ lateral distance.

Redwall Limestone:

Horseshoe Mesa Member:

Limestone, yellowish-gray, aphanitic; irregularly bedded; bedding planes and solution holes filled with red mudstone to depth of 10 $\mathrm{ft}$; forms cliff.

Section 13 (part)

TOPOCOBA TRAIL

[Along south side of trail, 1 mile west of Topocoba Hilltop; lower part of Supai Group not measured]

Hermit Shale:

Siltstone, weak-reddish-brown, argillaceous, friable; forms slope; grades upward into light-brown, thick-bedded (1-3 ft) siltstone; forms ledge; total

Feet
Contact:

Uppermost bed of massive sandstone of Supai; overlain by shaly siltstone of Hermit Shale. Large erosion channel at this horizon onefourth mile farther west, filled with Hermittype siltstone.

Supai Group:

Esplanade Sandstone, upper cliff-slope and main cliff units:

Sandstone, white, calcareous, very friable, cross-stratified (tabular-planar type); forms cap of platform

Sandstone, red-brown to white, very fine grained, medium- to thick-bedded (1-10 ft), cross-stratified, ledge-forming; very limy with thin siliceous rods near top; alternating with deep-red-brown, structureless, brittle mudstone, in lower part; shaly in upper part; contains worm trails at $35 \mathrm{ft}$ above base, plant fragments and worm borings near top

Siltstone, bright-red-brown, flat-bedded, medium-bedded (1-3 ft); forms bench at top of main cliff

Siltstone, red-brown, very calcareous, thickbedded (4-15 ft); cross-stratified; weathers to sheer cliff with black varnish on surface; forms upper part of main cliff

Mudstone, deep-red-brown; displays concretionary structure; forms bench or undercut --

Sandstone, bright-red, very fine grained, thickbedded (2-15 ft); cross-stratified on medium to large scale; forms massive cliff; resistant ---

Siltstone, red-brown, thin-bedded (1-3 ft), flat-bedded; relatively weak; locally forms bench

Sandstone, white, very fine grained, thickbedded, cross-stratified on large scale (30-40 $\mathrm{ft}$ ), tabular-planar type; forms weak ledge or bench; makes conspicuous color band midway in Esplanade

Sandstone, red-brown, very fine grained, cross-stratified on medium to large scale (5-30 ft, tabular-planar and wedge-planar); weathers red-brown to dark-brown; forms sheer cliff
Feet

5.5 
Section 13 (part)-Continued

TOPOCOBA TRAIL-Continued

Supai Group-Continued

Esplanade Sandstone, upper cliff-slope and main cliff units-Continued

Siltstone, red-brown, structureless; weathers to spheroidal surface; locally forms ledges with limestone nodules; forms base of main cliff

Total upper cliff-slope and main cliff units, Esplanade Sandstone

Esplanade Sandstone, basal slope unit:

Siltstone, deep-red-brown, argillaceous, brittle; forms slope; undermines main cliff above -----

Sandstone, pale-red-brown, very fine grained, friable, cross-stratified (low-angle, mediumscale); much concealed

Siltstone, red-brown to gray, massive, friable; weathers to rounded ledge

Siltstone, bright-red-brown, shaly to thinbedded; forms slope

Feet
[Watahomigi Formation measured on west side of canyon at Navajo Falls; upper part of group measured along Apache Trail, northeast of Supai village]

\section{Section 14}

\section{HAVASU CANYON}

Sandstone, red-brown to gray, very fine grained, massive, resistant, structureless; weathers to rounded, red ledge --._-

Siltstone, bright-red-brown, shaly to thinbedded; fills channels in conglomerate; forms weak ledge or slope

Conglomerate, red-brown to gray; gravels in beds and lenses (0.5-12 in. thick) with redbrown siltstone partings; total is lenticular, wedging out laterally in about $100 \mathrm{ft}$--.---- 1.0-4.0 Matrix: siltstone, red-brown, like $27.5-\mathrm{ft}$ siltstone above.

Gravel: Composition-light-gray, aphanitic limestone, olive-gray limestone with thin siliceous rods, dark-gray limestone, darkred-brown, calcareous siltstone, redbrown siltstone, chocolate-brown siltstone, pink siltstone; Size-mostly $0.25-1$ in. diameter, maximum 18 by 9 in.; Shape-limestone mostly subangular, some angular; siltstones rounded.

Total basal slope unit, Espla-
nade Sandstone -
Total Esplanade Sandstone ----- $-\frac{81.5}{343.0}$

Wescogame Formation, slope unit:

Siltstone, white to gray, calcareous, structureless, forms massive rounded ledge
Esplanade Sandstone, main cliff unit:

Sandstone, moderate-orange-pink, fine- (24 percent) to very fine grained (57 percent), calcareous, very thick bedded $(10-20 \mathrm{ft})$, massive; locally weathers to pinkish-gray; forms massive cliff

Sandstone, moderate-reddish-orange, very fine grained, friable; contains medium-scale, wedge-planar cross-stratification (planes 1-10 ft long)

Sandstone, moderate-reddish-orange, very fine grained, thin- to thick-bedded (1-4 ft); flat-bedded; less resistant than underlying sandstone unit; upper portion contains several 2-3 ft beds of pale-red, calcareous sandstone; forms cliff or receding ledges ------

Sandstone, pale-reddish-brown, fine- to very fine grained, calcareous, friable; and moderate-reddish-orange, very fine grained, calcareous, silty sandstone; and pale-red, silty, clastic limestone; grains etched out on surface; the three overlying sandstone units form cliffs separated by prominent partingplanes; all four contain medium- to largescale cross-stratification; contain local festoon structures; weather with black varnish est. 40.0

\section{0}

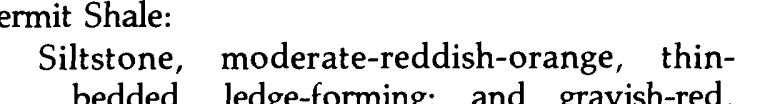
Feet 
Section 14-Continued

\section{HAVASU CANYON-Continued}

Supai Group-Continued

Esplanade Sandstone, main cliff unit-Continued

Sandstone, pale-reddish-brown, very fine grained, calcareous (26 percent), silty (19 percent), flat-bedded; forms recess between major cliffs

Sandstone, moderate-reddish-orange, very fine grained ( 76 percent), calcareous ( 25 percent); contains subangular to subrounded grains; massive, structureless; contains parting zone of flat-bedded siltstone that separates unit into two parts; forms base of Esplanade cliff -

Total main cliff unit, Esplanade Sandstone

Esplanade Sandstone, basal slope unit:

Sandstone, moderate-reddish-orange, very fine grained (rounded to subrounded); calcareous, thin-bedded $(2-3 \mathrm{ft})$, structureless; contains several pale-red, calcareous siltstone partings; forms recess below massive cliff

Sandstone, moderate-reddish-orange, very fine grained, silty; very thin to thin-bedded (1-4 in.); contains irregular to festoon-type structures; forms weak ledge --_-_-

Conglomerate, pale-red, irregularly bedded; fills channels in underlying unit; forms resistant ledge

Matrix: pale-red, fine-grained sand.

Gravel: diameter of most pebbles $0.25-1$ in.; maximum diameter 3 in.; pebbles subrounded to rounded; poorly sorted; composed of olive-gray, light-gray, and palered limestone and siltstone.

Sandstone, moderate-reddish-orange, very fine grained; some fine-grained; silty, very thin to thin-bedded (1-4 in.); contains irregular to festoon-type structure; forms slope with weak ledges

Limestone, light-brownish-gray, aphanitic to very fine grained; surface markings suggest stromatolitic structures; contains thin, locally developed bands of chert; forms two thin beds ( 6 in. and 20 in.) separated by gray siltstone ( 20 in. thick) and capped by 8 -in. bed of concretionary limestone

Sandstone, grayish-orange-pink, very calcareous, very fine grained; very thin bedded (0.5-2 in.); flat-bedded; forms receding ledges

.

Feet

16.0
Section 14-Continued

\section{HAVASU CANYON-Continued}

Supai Group-Continued

Esplanade Sandstone, basal slope unit-

Continued

Limestone, pale-red, concretionary, very hard, includes grayish-red silt; forms rounded ledge or slope

Sandstone, pale-reddish-brown, very fine grained, silty; grains iron-coated; brittle, structureless; forms slope --...-..-..-..-

Sandstone, pale-red, very fine grained, silty, structureless; crumbly; forms slope ---.-----

Sandstone, grayish-pink, very fine grained (angular), silty, thin-bedded (1-2 ft); weathers to rounded ledge

Feet

Sandstone, grayish-orange-pink, very fine grained, calcareous, friable; forms slope ------

Sandstone, like overlying $4.5-\mathrm{ft}$ sandstone but filling channel

Conglomerate, pale-red to light-gray, forms thin bed at bottom of erosion channel -...-... Matrix: pale-red to light-gray silt.

Gravel: diameter range $0.5-2$ in.; maximum diameter 3 in.; mostly subrounded, few rounded, some well-rounded; composed of light-gray limestone, reddish-brown and purplish-gray siltstone.

Total basal slope unit, Esplanade Sandstone

Total basal slope unit with basal channel sand, Esplanade SandTotal Esplanade Sandstone --.-. 121.0

Unconformity:

Channel $47.5 \mathrm{ft}$ deep and $144 \mathrm{ft}$ wide at top; cut into massive and cross-bedded, gray sandstones; filled largely with thin-bedded, pink sandstone, conglomerate at bottom.

Wescogame Formation, slope unit: absent.

Wescogame Formation, cliff unit:

Sandstone, pinkish-gray (with small rustybrown spots) at base, grading upward to pale-red, fine- to very fine grained; calcareous; thin-bedded $(2-4 \mathrm{ft})$ at base and at $50 \mathrm{ft}$ above base; elsewhere very thick bedded (10-15 ft); thinner beds contain flat laminae, thicker beds contain large-scale, planar cross-stratification (as much as $50 \mathrm{ft}$ long); contains two dark-reddish-brown lenses of flat-bedded siltstone at $55 \mathrm{ft}$ and $82.5 \mathrm{ft}$ above base; weathers with dark-brown varnish; forms massive cliff 
Section 14-Continued

HAVASU CANYON-Continued

Supai Group-Continued

Wescogame Formation, cliff unit-Continued

Mudstone, light-brown, noncalcareous, thinbedded (0.5-2 ft); flat-bedded; contains abundant Rivularites; forms recess at base of cliff

Sandstone, moderate-reddish-orange, very fine grained, calcareous, shaly to structureless; forms slope with weak ledges; fills upper part of large channel in older Pennsylvanianage rocks

Sandstone, moderate-reddish-orange; fine- to very fine grained, calcareous, flat-bedded; includes mud pellets and scattered pebbles near base; forms slope; fills channel bottoms -

Total cliff unit, Wescogame Formation

Total cliff unit with basal channel sand, Wescogame Formation - 199.5

Unconformity:

Wide channels with rounded bottoms, cut to depths as much as $80 \mathrm{ft}$ in cross-stratified sandstones of older Pennsylvanian age (locally $52.5 \mathrm{ft}$ deep); exposed at this horizon at many places in vicinity.

Manakacha Formation, slope unit:

Sandstone, moderate-reddish-orange, fine- to very fine grained; cross-stratified on large scale (as much as $40 \mathrm{ft}$ long); includes grayish-red, muddy, noncalcareous, very fine grained sandstone near base; total forms slope

Total slope unit, Manakacha Formation, pre-erosion ---------

Manakacha Formation, cliff unit:

Limestone, grayish-orange-pink, very fine grained, (subrounded), silty, (insoluble 33 percent); cross-stratified on small to medium scale; weathers with black varnished surface; forms massive, resistant cliff with rounded edges

Sandstone, pale-red-purple, very fine grained, limy, strongly cross-stratified (tabularplanar, sets $2-3 \mathrm{ft}$ thick); contains some limestone lenses; forms cliff or receding ledge
Section 14-Continued

HAVASU CANYON-Continued

Feet

Supai Group-Continued

Manakacha Formation, cliff unit-Continued

Siltstone, pale-reddish-brown, calcareous, shaly to thin-bedded; grades upward into pale-red-purple, very fine grained, locally massive and thick-bedded sandstone, with limestone lenses; total forms receding ledges -

Limestone, grayish-red; includes much very fine grained sand (insoluble 40 percent); cross-bedded (tabular-planar); sets mediumthick (1-3 ft); contains jasper near top; forms receding ledges

Limestone, medium-light-gray; includes scattered fine- to very fine grained sand; crossstratified (medium scale); contains abundant chert and jasper; weathers to rough black surface; forms prominent massive cliff

Limestone, light-brownish-gray with pale-red blotches, thick-bedded (4-15 ft); contains jasper layers and veins near base; crossstratified (medium-scale); forms cliff

Siltstone, dark-reddish-brown, calcareous (22 percent); crumbly; rests on irregularly channeled surface of bright-reddish-brown mudstone

Total cliff unit, Manakacha Formation - 181.0

Total Manakacha Formation ---- 254.5

Erosion surface:

Structureless reddish-brown siltstone surface is channeled to depths of $1-2 \mathrm{ft}$ at irregular intervals and locally entirely removed by erosion.

Watahomigi Formation, upper slope unit:

Concealed slope

Sandstone, pale-reddish-brown, very fine grained, noncalcareous, structureless; forms conspicuous marker bed; weathers into rounded ledge overlying weak cliff --_-.---.--

Siltstone, grayish-red, muddy, very limy; wavy- to flat-bedded; laminated (0.13-0.5 in.); contains thin jasper lenses at top; forms weak cliff

Mudstone, pale-red, silty, calcareous; wavyto flat-bedded; laminated (0.13-0.5 in.); forms steep slope

Concealed slope; probably grayish-red mudstone 
Section 14-Continued

\section{HAVASU CANYON-Continued}

Supai Group-Continued

Watahomigi Formation, upper slope unit-

Continued

Conglomerate, consisting of intraformational limestone pebble lenses; in medium-darkgray, concretionary limestone; contains some jasper; forms rounded ledge or steep slope; marks base of Atokan-age strata Total upper slope unit, Watahomigi Formation

Watahomigi Formation, middle cliff unit:

Limestone, very light gray, magnesian, very silty; contains abundant elongate concretions and lenses of gray chert; forms ledge at top of series

Siltstone, dark-gray, friable; forms bench --..-.

Limestone, very light gray, silty, fine-grained; thick-bedded $(2-6 \mathrm{ft})$; contains thin jasper layers and crosscutting veins throughout; forms series of ledges separated by thin $(0.5-1 \mathrm{ft})$ mudstone beds

Limestone, light-brownish-gray, dolomitic; interbedded with black mudstone containing network of calcite veins; weathers to concretionary spheres; forms slope

Limestone, medium-gray, fine-grained; contains abundant jasper layers and secondary calcite fillings along fractures; weathers to rough surface; forms ledge -.-.--

Limestone, light-brownish-gray, silty; weathers brown; forms weak ledge with straight face

Limestone, grayish-red, irregularly bedded; interbedded with brown mudstone; forms slope

Total middle cliff unit, Watahomigi Formation -_-

Watahomigi Formation, lower slope unit:

Conglomerate, consisting of lenses of dark intraformational limestone pebbles (maximum, 0.5 in.) at top of unit and beds of medium-light-gray, silty limestone that contain local jasper lenses and form series of resistant ledges

Mudstone, pale-red-purple, slightly calcareous, crumbly; forms slope -.-.

Limestone, medium-light-gray, fine-grained; contains thin, irregular jasper layers; consists of a single very thick bed; forms resistant cliff

Concealed, talus slope
Section 14-Continued

\section{HAVASU CANYON-Continued}

Feet

6.0

6.5 33.0
Supai Group-Continued

Watahomigi Formation, lower slope unitContinued

Siltstone, pale-red, shaly; largely concealed; forms slope -.-.--

Conglomerate, pale-red, very thick bedded; forms resistant ledge

Matrix: pale-red, fine- to very fine grained sandstone.

Gravel: mostly $0.25-0.75$ in. diameter; angular to subangular; composed of darkreddish-brown, moderate-orange-pink, and very dark red chert and flint.

Concealed slope

Siltstone, pale-red, shaly, fissile; includes laminated limestone beds (0.25-0.5 in.) scattered throughout; forms slope ---_-

Conglomerate, dark-reddish-brown; thinbedded to shaly; forms ledge --_.-.--

Matrix: pale-red, very fine grained sandstone and siltstone.

Gravel: abundant $0.13-0.25$ in. diameter pebbles, with a maximum diameter of 0.5 in.; composed of very light gray, pale-red, and dark-gray chert; contains abundant brachiopods (Composita sp.) at top of unit.

Conglomerate, pale-red, massive; forms ledge -Matrix: pale-red mudstone.

Gravel: mostly 3-6 in. diameter, with maximum diameter of 8 in.; irregularly shaped with random orientation; composed of light-olive-gray and dark-reddish-brown chert.

Limestone, yellowish-gray, aphanitic; thickbedded ( $2-4 \mathrm{ft})$; weathers to very pitted surface; forms ledge

Conglomerate, dark-reddish-brown; contains much iron oxide; fills channel

Matrix: dark-reddish-brown mudstone.

Gravel: mostly $0.5-1$ in. diameter, maximum diameter 4 in.; mostly angular; composed of chert.

Total lower slope unit, Watahomigi Formation --. $\quad 92.0$

Total Watahomigi Formation -- $-\frac{215.0}{1.010 .0}$

Total Supai Group - -

Unconformity:

Channeled surface with 5 - $\mathrm{ft}$ relief in $100 \mathrm{ft}$ horizontal distance. 
Section 14-Continued

HAVASU CANYON_-Continued

Redwall Limestone:

Horseshoe Mesa Member:

Limestone, yellowish-gray, aphanitic, thinbedded (1-2 ft); forms receding ledges.

Section 15

\section{NATIONAL CANYON}

[In National Canyon, Hualapai Indian Reservation. Watahomigi measured on west side above the gorge formed by the Redwall Limestone; from Manakacha to Esplanade, measured on east side; Esplanade measured on west side of canyon]

Coconino Sandstone:

Sandstone, medium-light-gray, fine-grained; cross-stratified on large scale; forms vertical cliff.

Sandstone, medium-light-gray, fine-grained, thin-bedded; horizontal-bedding

Hermit Shale:

Siltstone, moderate-reddish-orange, weakly cemented; contains some very fine grained sand; forms ledges; alternating with palereddish-brown, brittle mudstone; forms crumbly slopes; ratio of ledge to slope is 3:1 - 275.0

Mudstone, pale-reddish-brown; forms crumbly slopes; alternating with moderate-reddishorange, blocky, poorly bedded siltstone; forms weak ledges; and bright-red, relatively resistant siltstone; forms rounded ledges (2-3 $\mathrm{ft}$ thick); ratio of ledge to slope is 1:2 ---

Mudstone, pale-reddish-brown, slope-forming; interbedded with moderate-reddishorange, thin- to medium-bedded $(0.5-2 \mathrm{ft})$ siltstone; forms resistant ledges; ratio of ledge to slope is $1: 5$

Total Hermit Shale 546.5

Unconformity:

Large hill or mesa of Esplanade-type sandstone and siltstone rises $114 \mathrm{ft}$ above general flat surface of Esplanade near place of measured section. Mesa top exposed for about $1,000 \mathrm{ft}$ north-south along present canyon.
Section 15-Continued

NATIONAL CANYON-Continued

Feet

Supai Group:

Esplanade Sandstone, upper cliff-slope unit:

Sandstone, moderate-reddish-orange, very fine grained, friable, hard, medium-bedded $(2-4 \mathrm{ft})$; forms massive, rounded ledges; resembles sandstone of Esplanade main cliff unit; includes a few parting units of flat, shaly siltstones; stands above general base of Hermit

Conglomerate, yellow-brown, thick-bedded; contains geodes of calcite; very resistant; forms prominent ledge

Matrix: fine-grained, moderate-reddishorange sand.

Gravels: Composition-light-gray, aphanitic limestone, chalky limestone, darkbrown siltstone, deep-reddish-brown claystone; Size-mostly 0.25-0.5 in. diameter, maximum 2 in.; Shape-rounded to subrounded.

Siltstone, pale-red, shaly, slope-forming; includes some ledges of thin-bedded $(1-2 \mathrm{ft})$, friable, pale-reddish-brown, very fine grained sandstone forming weak ledges ------

Total upper cliff-slope unit, Esplanade Sandstone

Esplanade Sandstone, main cliff unit:

(The upper surface of this sandstone forms contact with Hermit Shale across most of the exposed area).

Sandstone, grayish-orange-pink to moderatereddish-orange, very fine grained, calcareous (33 percent), friable, thick-bedded (3-15 $\mathrm{ft}$ ), weakly cross-stratified near top; forms massive rounded cliff (rim of Esplanade) -...-

Siltstone, moderate-reddish-orange, includes very fine grained sandstone, flat-bedded, crumbly, slope-forming; includes thin ledges of hard, cross-stratified sandstone $(2-3 \mathrm{ft}$ thick)

43.0

Sandstone, grayish-orange-pink to palereddish-brown, medium- to very fine grained (bimodal); forms cliff of three massive units; lower and upper units, hard, flat-bedded; middle unit, friable, strongly cross-stratified; weathers with black varnish --_-_-_----

Siltstone, moderate-reddish-orange, very friable, platy; forms recess 
Section 15-Continued

\section{NATIONAL CANYON-Continued}

Supai Group-Continued

Esplanade Sandstone, main cliff unit-Continued

Sandstone, grayish-orange-pink, very fine grained, cross-stratified, tabular-planar, on large scale $(5-15 \mathrm{ft}$ thick); forms part of high cliff

Limestone, grayish-orange-pink; contains very fine grained sand; cross-stratified on medium scale (planar-type), medium thick $(1-3 \mathrm{ft})$; forms basal part of high cliff --.--

Sandstone, pale-reddish-brown, very fine grained; includes silt; strongly cross-stratified, large-scale, planar-type; forms weak ledge below main cliff

Sandstone, pale-red, very fine grained, friable; irregularly bedded to weakly crossstratified; forms receding ledges (1-2 ft thick)

Sandstone, moderate-reddish-orange, very fine grained, friable; cross-stratified on large scale, tabular-planar type; weathers red; forms rounded cliff continuous with underlying cliff

Sandstone, pale-red, very fine grained with some silt, resistant; medium-thick units $(2.5-5 \mathrm{ft})$; contains limestone concretions; weathers to black surface; forms rounded cliff

Sandstone, pale-reddish-brown and light-olivegray to white, fine- to very fine grained, friable; contains fragments and blocks of moderate-reddish-orange, aphanitic limestone; forms receding ledges

Sandstone, pale-red, fine- to very fine grained, limy; cross-stratified, medium-scale, tabular-planar; locally with primary recumbent structures; sets 3-4 ft thick; weathers to gray or black, pitted surface; forms rounded cliff -

Sandstone, pale-red, fine- to very fine grained, friable; weathers to weak ledge or slope -..---

Sandstone, moderate-reddish-orange, very fine grained, friable; prominent cross-stratification (festoon-type), medium-scale; forms cliff

Total main cliff unit, Esplanade Sandstone

(Esplanade Sandstone basal slope unit measured on east wall of Canyon)

Feet
Section 15-Continued

\section{NATIONAL CANYON-Continued}

Supai Group-Continued

Esplanade Sandstone, basal slope unit:

Siltstone, pale-red, thin-bedded, flat-bedded; forms slope or recess; includes two resistant ledges $(2-3 \mathrm{ft}$ thick) of hard, moderatereddish-orange, very fine grained sandstone -

Sandstone, moderate-reddish-orange, finegrained; weathers with rounded surface; erodes into large blocks; forms basal, resistant cliff

Sandstone, moderate-reddish-orange, very fine grained, rubbly, concretionary, very calcareous; forms weak ledge or recess --.----

19.0 Mudstone, dark-reddish-brown, brittle, crumbly; contains silt and some very fine grained sand; forms slope; includes two thin ledges of resistant siltstone and one ledge of conglomerate

Sandstone, pale-red, very fine grained with some silt, calcareous; contains weakly developed cross-strata (large-scale, planar) and local thin (1-3 in.) flat beds; forms rounded, massive ledges with black varnish; consists of lowest continuous strata in Esplanade section

Channel rim:

Conglomerate, topmost bed filling channel at base of unit; similar to basal conglomerate but pebbles all small (maximum diameter 2 in.)

Sandstone, dark-reddish-brown, very fine grained, cross-stratified; forms resistant ledge; channel-fill deposit

Sandstone, moderate-reddish-orange, very fine grained, platy, flat-bedded; forms slope; channel-fill deposit

Sandstone, moderate-reddish-orange, very fine grained; cross-stratified on large scale, tabular-planar type; forms resistant ledge; channel-fill deposit

Sandstone, pale-reddish-brown, very fine grained, friable, thin-bedded $(0.5-3$ in.); forms slope, channel-fill deposit --------

Conglomerate, reddish-gray; forms massive ledge; basal deposit in channel $40 \mathrm{ft}$ deep --Matrix: red-brown, fine-grained siltstone. 
Section 15-Continued

\section{NATIONAL CANYON-Continued}

Supai Group-Continued

Esplanade Sandstone, basal slope unit-

Continued

Conglomerate-Continued

Gravel: Composition-purple limestone, light-gray limestone, red-brown siltstone, red jasper, pink laminated sandstone; Shape-rounded to subrounded, angular (jasper); Size-0.5 in. to 8 in. maximum dimension; Sorting - very poor.

Total basal slope unit, Esplanade Sandstone

Total Esplanade Sandstone ----- ${ }^{1496.5}$

Unconformity, erosion surface marked by channel $40.5 \mathrm{ft}$ deep and $85 \mathrm{ft}$ wide, with steplike sides; cut into underlying limestone and sandstone units.

(From base of Manakacha Formation to Esplanade basal conglomerate measured on east side of canyon about $2 \mathrm{mi}$ above head of Redwall gorge.)

Wescogame Formation, slope unit:

Limestone, dark-reddish-brown, muddy (46 percent); contains small spherical and rodlike siliceous inclusions; weathers to rounded, nodular surface; forms weak, receding ledges or slope --- 11.0-27.5

Total slope unit, Wescogame Formation

Wescogame Formation, cliff unit:

Sandstone, grayish-orange-pink, very fine grained (contains some fine grains); very calcareous, contains cross-strata, mediumto large-scale (wedge-planar); weathers pink-to medium-gray; forms weak receding ledges

Sandstone, very pale orange, medium- to finegrained, calcareous, weakly cross-stratified (medium-scale); weathers generally palegray, locally black; forms rounded, moderately resistant ledges

Sandstone, pale-red, very fine grained, very silty, prominently cross-stratified on large scale (30-40 ft long, tabular-planar); includes pale-red, calcareous siltstone with spheroidal weathering, forming 2 - $\mathrm{ft}$ recess at $22 \mathrm{ft}$ up; weathers grayish-orange-pink; forms weak cliffs or bench

${ }^{1}$ Thickness includes channel-fill deposits at base

Feet

Section 15-Continued

NATIONAL CANYON-Continued

Supai Group-Continued

Wescogame Formation, cliff unit-Continued

Sandstone, pale-reddish-purple, very fine grained, calcareous, weakly cross-stratified; weathers dark-brown; forms rounded, receding ledge

Conglomerate, gray, speckled with white, ledge-forming ---

Matrix: sandy limestone, purple, finegrained.

Gravel: mostly white chert, some gray and brown chert, some brown siltstone; angular to subangular; average diameter $0.13-0.5$ in., maximum 1 in.

Total cliff unit, Wescogame Formation ---.---.--

Total Wescogame Formation ----- $\overline{113.0}$

Manakacha Formation, slope unit:

Sandstone, pale-reddish-purple, contains much sand, medium- to thick-bedded $(2-10 \mathrm{ft})$; ripple-marked and cross-stratified, mediumto large-scale (wedge-planar); weathers to black face with laminae etched out; forms massive cap on cliff

Sandstone, pale-reddish-purple, very fine grained (angular grains), argillaceous, structureless; forms prominent recess with spheroidal weathering

Limestone, grayish-orange-pink, sandy (45 percent), thick-bedded $(2-6 \mathrm{ft})$, crossstratified (wedge-planar type), medium-scale grading upward to large-scale; basal part pale-red, very sandy and thin-bedded (1-12 in.); weathers to black face

Limestone, pale-red-purple with light-gray, irregular blotches, silty; weathers purplishgray, mottled with light-gray; forms weak ledge or recess below cliff

Siltstone, pale-reddish-brown; much very fine grained sand; platy to medium-bedded; contains many thin lenses of gray, shaly mudstone; forms series of rounded ledges, receding
Total slope unit, Manakacha Formation
Feet 
Section 15-Continued

NATIONAL CANYON-Continued

\section{Supai Group-Continued}

Manakacha Formation, cliff unit:

Limestone, olive-gray with dark-greenishgray, medium-grained, very sandy; contains wedge-planar cross-strata; includes redbrown mudstone parting at base; weathers to flat, black face with laminae etched on surface; forms cliff

Limestone, medium-light-gray, aphanitic, cross-stratified (tabular-planar type); weathers to flat surface, black face

Limestone, medium-light-gray, aphanitic, contains many thick, irregular lenses and layers of jasper; weathers to rounded purplish ledge

Erosion surface; underlying limestone bed is cut out for $100 \mathrm{ft}$ laterally; channel filled with red-brown mudstone; channel bottom penetrates sandstone below to depth of $2 \mathrm{ft}$.

Limestone, medium-light-gray, aphanitic (insoluble 15 percent); includes many molds of pelloids, probably organic; contains thin jasper layers and crosscutting veins; forms rounded ledge

Sandstone, pale-buff, very fine grained, limy, silty, thick-bedded (3-6 ft), cross-stratified (wedge-planar), medium-scale; forms massive ledge with flat face

Limestone, olive-gray with dark-greenish-gray, aphanitic (insoluble 13 percent); contains lenses and thin layers of jasper; includes deep-reddish-brown mudstone forming recess at base; forms resistant ledge near base of cliff

Siltstone, moderate-reddish-orange, limy, thick-bedded; forms double ledge with parting planes of pale-red, shaly mudstone at base and in middle; contains thin, flatlaminae; resistant

Limestone, grayish-pink, sandy, fine- to very fine grained, thick-bedded; contains thin chert layers, lenses and nodules; weathers to resistant ledge with black surface; forms top unit in receding series

Sandstone, moderate-reddish-orange, very fine grained (upper half); and moderate-reddishbrown, thin-bedded (0.5-1 ft) siltstone; forms slope with crumbly ledges; largely concealed

Feet
Section 15-Continued

NATIONAL CANYON-Continued

Supai Group-Continued Manakacha Formation, cliff unit-Continued

Siltstone, grayish-red, calcareous, thinbedded; contains thin layers $(0.5-1$ in.) of jasper in lower part, thick layers above; grades upward into pale-yellowish-brown, resistant, aphanitic limestone; forms cliff -... Limestone, moderate-reddish-brown, very fine grained, silty, platy; forms slope or receding ledges; grades upward into grayish-orangepink, calcareous limestone; contains jasper lenses; includes grayish-pink, platy limestone at top

Limestone, grayish-orange-pink, sandy (very fine grained), thick-bedded ( $3 \mathrm{ft}$ ), weakly cross-stratified (tabular-planar); weathers to mottled black and gray surface; forms cliff ---

Siltstone, brownish-gray, calcitic dolomite matrix, sandy, aphanitic; weathers to rounded black face

Concealed slope

Limestone, brownish-gray, fine-grained, thinbedded; contains thin jasper lenses; weathers to weak rounded ledge -

Concealed slope

Sandstone, moderate-reddish-orange, very fine grained, sugary; forms conspicuous marker bed; forms rounded ledge at cliff top; bedding surface at base irregular

Sandstone, grayish-orange-pink, very fine grained, irregularly bedded; weathers to banded white and red-brown cliff; recess of crumbly green siltstone at base -----------

Siltstone, pale-red, very sandy, dolomitic, 6.5 medium- to thick-bedded $(2-4 \mathrm{ft})$; contains horizontal laminae and cross-laminae, includes scattered gray chert lenses; forms resistant cliff

Total cliff unit, Manakacha For-

mation - $-\frac{160.0}{253.0}$

Watahomigi Formation, upper slope unit:

Siltstone, dark-reddish-brown, structureless, friable; much concealed; forms slope ---------

Mudstone, moderate-reddish-brown, structureless; contains scattered, fine quartz grains; forms prominent marker bed at base of receding ledges; weathers to rounded ledge
Feet

6.0

6.5 
Section 15-Continued

NATIONAL CANYON-Continued

Supai Group-Continued

Watahomigi Formation, upper slope unit-

Continued

Siltstone, moderate-reddish-orange to white, shaly; grades upward into limy siltstone and platy limestone; contains many Rivularites impressions; much concealed; forms slope -.-.

Conglomerate, dark-brown, cross-stratified (low-angle) resistant, ledge-forming ----_----Matrix: fine- to coarse-grained sand.

Gravel: jasper, chert, red-brown siltstone (rare), quartz, gray limestone; chert subrounded, siltstone and limestone rounded; oriented parallel to current bedding; diameter average $0.13-0.5 \mathrm{in}$. chert; jasper 0.5 in.; siltstone, limestone 1 in.

Conglomerate, pebble, pale-reddish-brown, friable

Matrix: coarse-grained sand and fine gravel. Gravel: gray fine-grained limestone (like underlying bed); diameter average 1-3 in.; rounded to subrounded.

Total upper slope unit, Watahomigi Formation ---_-_----

Watahomigi Formation, middle cliff unit:

Limestone, pale-yellowish-brown, fine-grained, thick-bedded (2-4 ft); contains many thin jasper layers (about 80 percent of rock near base); weathers to dark-gray, rough surface; forms receding ledges or slope

Limestone, medium-light-gray, aphanitic, thinto medium-bedded (2-12 in.), irregularly bedded; contains little chert; forms rounded, receding ledges or slope

Mudstone, very dusky red, shaly, crumbly; forms slope -

Limestone, medium-light-gray, dolomitic, aphanitic; contains much white to brown chert in wavy layers (50 percent of rock); weathers to gray surface with brown chert bands; forms resistant ledge

Total middle cliff unit, Watahomigi Formation ---_-

Watahomigi Formation, lower slope unit:

Mudstone, light-brownish-gray, shaly, crumbly; contains two ledges of limestone, medium-light-gray, medium-grained (lower unit bioclastic with silicified Spirifers, crinoid joints; upper unit with chert lenses and contorted laminae; each limestone unit $2 \mathrm{ft}$ thick)
Section 15-Continued

\section{NATIONAL CANYON-Continued}

Feet

Supai Group-Continued

Watahomigi Formation, lower slope unit-

Continued

Limestone, grayish-red, aphanitic; contains much chert and jasper, forming lenses and crosscutting veins; consists of fine, wavy laminae etched on surface; forms upper part of cliff

10.5

Limestone, grayish-orange-pink, aphanitic, silty; climbing-ripple structure etched on face; contains ripple marks on bedding surfaces; thin- to medium-bedded (0.5-12 in.); weathers to brown surface with conspicuous laminae; forms base of steplike cliff

Mudstone, dark-reddish-brown, shaly, calcareous; forms slope; upper part much concealed

Conglomerate, reddish-brown, sandy; forms thin, resistant ledge --Matrix: sand, calcitic, granular, friable; weathers to sandy surface.

Gravels: chert, red, yellow and a few white; hematitic rock, red-brown; subangular to subrounded; average diameter 0.25-0.5 in., maximum 2 in.; contains abundant fossils (high-spired gastropods, flat-coiled gastropods, Bellerophontids, pelecypods, Spirifers, trilobite phygidia).

Conglomerate, reddish-brown with white gravels, pebbly; forms weak ledges -..--..-Matrix: brown sand and purplish mud; contains brachiopod molds.

Gravels: mostly white chert, some red or gray; largely angular, some subrounded; diameter averages $0.5-2$ in., maximum 12 in.

Mudstone, dark-reddish-brown, silty; forms weak slope; mostly concealed -------- Watahomigi Formation --_-_-_- $\quad 70.0$ Total Watahomigi Formation -- $-\frac{188.5}{1.051 .0}$

Total Supai Group -

Unconformity:

Irregular surface with many pits and cracks in Redwall to depth of several feet filled with grayish-orange-pink conglomeratic sandstone. 
Section 15-Continued

NATIONAL CANYON-Continued

Redwall Limestone:

Horseshoe Mesa Member:

Limestone, yellowish-gray, aphanitic, thinto medium-bedded (1-3 ft); includes one thick bed $(4.5 \mathrm{ft})$ near top; weathers to gray or brown, pitted, rough surface; forms receding ledges.

Section 16

\section{KANAB CANYON}

[On west side of Kanab Canyon, 2 miles north of Colorado River]

Hermit Shale, slope unit:

Siltstone, bright-red-brown, shaly, slopeforming; contains worm borings, ripple marks, impressions of Walchia; surrounds and covers rounded hill or mesa of resistant siltstone of Esplanade on pre-Hermit erosion surface

$81-110.0$

Unconformity:

Erosion surface with relief of $28 \mathrm{ft}$.

Supai Group:

Esplanade Sandstone, main cliff unit:

Sandstone, reddish-brown, massive, cliffforming, lamination absent or weakly developed; upper surface eroded, forms platform $28 \mathrm{ft}$ high and $400 \mathrm{ft}$ wide

Mudstone(?), deep-reddish-brown, thin, flatbedded; forms prominent bench (Esplanade); contains a few thick beds

Sandstone, grayish-pink, very fine grained (subrounded), hard, calcareous, massive; forms cliff

Sandstone, reddish-brown, very fine grained, friable, thick-bedded; cross-laminated on large-scale; thin, shaly beds at top; weathers to slope or recess

Sandstone, moderate-reddish-orange, mediumto fine-grained (grains frosted, wellrounded), calcareous, hard; alternates with pale-reddish-brown to grayish-orange-pink, very fine grained (subrounded grains), silty, hard, calcareous, massive sandstone; beds thick $(2-30 \mathrm{ft})$; contains lenses and thin beds of deep-reddish-brown, silty mudrock, mostly near base

Total main cliff unit, Esplanade
Section 16-Continued

KANAB CANYON-Continued

Supai Group-Continued

Esplanade Sandstone, basal slope unit:

Sandstone, moderate-reddish-brown, very fine grained, to white (angular, iron-stained), argillaceous, massive; beds thick $(2-6 \mathrm{ft})$,

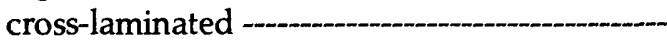

Total basal slope unit, Esplanade Sandstone ---

Total Esplanade Sandstone --_-_- $\overline{423.0}$

Wescogame Formation, slope unit:

Sandstone, red-brown, very fine grained, sugary, thin-bedded (1-3 ft) -.- 22.0

Total slope unit, Wescogame Formation - 22.0

Wescogame Formation, cliff unit:

Sandstone, pale-reddish-brown, calcareous, fine-grained and very fine grained (wellrounded, ovoid, bimodal) thick-bedded, prominently cross-laminated; weathers to black, straight face ---

Sandstone, pale-reddish-brown, very fine grained (subangular to subrounded, ironcoated), calcareous, cross-laminated; weathers to bright-reddish-brown; forms rounded cliff; beds 1-4 ft thick

Sandstone, grayish-orange-pink, fine- to very fine grained (subangular), calcareous, crosslaminated; like overlying sandstone but beds thick (10-20 ft); massive; weathers brightreddish-brown; deposited on surface of relief from pre-Wescogame erosion ---.-- 30.0-51.0

Conglomerate, brownish-gray, forms massive bed at base of erosion channels --_-_-_-_Matrix: reddish-brown siltstone, purple limestone.

Gravel: gray limestone; rounded; maximum diameter 3 in., average $0.5-1$ in.

Total cliff unit, Wescogame For-

mation - 80.0-101.0

Total Wescogame Formation ---- 123.0

Unconformity:

Erosion surface.

Manakacha Formation, slope unit:

Sandstone, pink, very fine grained, crosslaminated, sugary; beds 2-6 ft thick; weathers gray; forms cliff; upper surface cut through by erosion $0-51.5$ 
Section 16-Continued

KANAB CANYON-Continued

Supai Group-Continued

Manakacha Formation, slope unit-Continued

Limestone, brownish-gray, silty, flat-bedded, hard; beds 1-3 ft thick; forms slope with receding ledges

Total slope unit, Manakacha Formation

70.0

Manakacha Formation, cliff unit:

Sandstone, pale-reddish-brown, very fine grained (scattered fine grains), subangular, calcareous, hard, very massive; crosslaminated on large scale (tabular-planar type); weathers gray, silty surface; forms cap of cliff in most places -

Sandstone, grayish-pink, very fine grained, calcareous, cross-laminated, thick-bedded $(2-6 \mathrm{ft})$; weathers to straight face --..--.---.--

Siltstone, grayish-orange-pink, sandy, friable, calcareous, cross-laminated (festoon-type); flat laminae at top; like overlying sandstone, but thinner sets $(0.5-2 \mathrm{ft})$; locally shaly; forms weak cliff

Limestone, brownish-gray, aphanitic; contains jasper lenses -

Siltstone or sandstone(?), reddish-brown; forms thick sets $(2-6 \mathrm{ft})$; lower part flatbedded, upper part cross-laminated (shallow festoon-type); locally shaly

Limestone, reddish-brown, aphanitic; contains jasper lenses

Siltstone, reddish-brown, forms lenses -

Limestone, blue-gray, very fine grained, massive; weathers to lavender ledge with silty surface; contains reeflike structures of jasper -

Limestone, pale-reddish-purple, silty, crosslaminated, hard; contains jasper bands; weathers to lavender, silty surface; forms ledge

Total cliff unit, Manakacha Formation

Total Manakacha Formation ----- $\frac{160.0}{230.0}$

Watahomigi Formation, upper slope unit:

Siltstone, deep-reddish-brown, structureless, slope-forming

Limestone, pale-reddish-purple, silty, crosslaminated, hard; forms ledge --..-

Siltstone, deep-reddish-brown, structureless, slope-forming

Limestone, pale-reddish-purple, silty, hard; forms ledge
Section 16-Continued

KANAB CANYON-Continued

Feet

Supai Group-Continued

Watahomigi Formation, upper slope unit-

Continued

Siltstone, deep-reddish-brown, structureless, slope-forming

Limestone, pale-reddish-purple, silty, hard, ledge-forming; basal portion, reddish-brown siltstone, with white clayballs

Siltstone, deep-reddish-brown; structureless, slope-forming

Limestone, pale-reddish-purple; silty, hard; forms ledge

Concealed

Limestone, pale-reddish-purple; silty, crosslaminated; forms ledge

Siltstone, deep-reddish-brown; structureless, slope-forming

Limestone, pale-reddish-purple; silty, crosslaminated; forms ledge

Siltstone, deep-reddish-brown; structureless, slope-forming

Limestone, purple, fine-grained, argillaceous, thin-bedded (2-3 in.); contains jasper lenses; forms weak ledge

Siltstone, moderate-reddish-brown; structureless, slope-forming

Limestone, grayish-red, fine-grained, argillaceous; contains jasper lenses; forms weak ledge

Limestone, light-gray, with purple, silty blotches; aphanitic; weathers to rounded surface; includes purple shale lenses; forms slope

Limestone, pale-reddish-purple; silty, crosslaminated; forms ledge - -

Limestone, light-gray, with purple, silty blotches; aphanitic; weathers to rounded surface; forms slope -.--

Limestone, bluish-gray, silty, hard; forms ledge

Concealed

Limestone, pale-reddish-purple; silty, crosslaminated; forms ledge - -

Conglomeratic limestone, medium-light-gray, fine-grained; filled with granules or pelloids of dark-gray, rounded limestone; contains some jasper; includes red-brown, shaly mudstone at base; forms ledge ---

Total upper slope unit, Watahomigi Formation 
Section 16-Continued

KANAB CANYON-Continued

\section{Supai Group-Continued}

Watahomigi Formation, middle cliff unit:

Claystone, pale-reddish-purple, argillaceous, calcareous; contains creamy-white blotches and deoxidation spots; much concealed; forms slope

(13)

Limestone, pale-reddish-purple, silty; forms ledge

Limestone, medium-light-gray, with purple, silty blotches; aphanitic; weathers to rounded surface; forms slope -.._-_-_-_-_-_-_._-

Limestone, grayish-orange-pink, silty, crosslaminated; forms ledge - -

Total middle cliff unit, Watahomigi Formation

Watahomigi Formation, lower slope unit:

Siltstone, reddish-brown, irregularly-bedded, slope-forming; largely concealed; exposed at 11,33 , and $55 \mathrm{ft}$ above base

Limestone, dull-gray, aphanitic, mediumbedded; weathers with pitted surface; forms ledge

Siltstone, reddish-brown, irregularly-bedded; contains limestone fragments; forms slope ----

Limestone, light-olive-gray, aphanitic, mediumbedded; forms ledge

Sandstone, grayish-orange-pink, very fine grained, shaly

Limestone, light-olive-gray, aphanitic; forms ledge; bedding gnarly and irregular -----------

Sandstone, pale-reddish-brown to white; finegrained (subrounded) and coarse (wellrounded), silty; includes white quartz, red quartz, and flint granules scattered through matrix of red, limy silt; bedding gnarly --- 3.0-5.0

Total lower slope unit, Watahomigi Formation --ar- 92.5

Total Watahomigi Formation --- $-\underline{248.0}$

Total Supai Group -

Unconformity:

Irregular surface with relief as much as $2 \mathrm{ft}$, covered with reddish-brown sandstone.

Redwall Limestone.
Section 17

\section{S B CANYON}

[In S B Canyon (Hundred and Fifty Mile Canyon)]

Feet

Hermit Shale:

Succession of alternating bright-reddish-brown, ledge-forming siltstones and dark-reddishbrown, slope-forming mudstones, each 2-12 $\mathrm{ft}$ thick.

Unconformity:

Not recognized at this locality. Contact placed where thin-bedded siltstone of Hermit Shale rests on highest massive sandstone of Supai.

Supai Group:

Esplanade sandstone, upper cliff-slope and main cliff units:

Sandstone, pale-reddish-brown, very fine grained (subangular grains); rounded beds; medium-bedded (1-4 ft); locally planar cross-stratified; upper part white; forms prominent cliff --.

Siltstone, pale-reddish-brown, very sandy, shaly, beds $0.25-0.5$ in. thick; forms slope ----

Sandstone, moderate-reddish-orange, very fine grained, angular, friable, structureless; forms receding ledges

Siltstone, pale-reddish-brown, shaly, thinbedded (0.25-0.5 in. thick); forms bench --.--

Sandstone, moderate-reddish-orange, fine- to very fine grained, friable; planar crossstratified on medium to large scale; thick sets (4-8 ft); forms receding ledges at top of gorge

Sandstone, moderate-reddish-orange, very fine grained; cross-stratified on medium to large scale (10-60 ft), wedge-planar type; extremely massive; weathers to rounded surface; forms cliff

Sandstone, grayish-red, very fine grained, angular, structureless; contains lightgrayish-green deoxidation spots; weathers with conchoidal fracture; forms recess -------

Sandstone, pale-red-brown, very fine grained, limy (30 percent), thick-bedded $(2-5 \mathrm{ft})$; weathers brown; forms cliff with resistant, straight face and sharp corners

Sandstone, grayish-red, very fine grained (angular grains), very muddy, structureless; contains light-grayish-green deoxidation spots; weathers with conchoidal fractures; forms recess

\section{5}

18.5 
Section 17-Continued

\section{S B CANYON-Continued}

Supai Group-Continued

Esplanade Sandstone, upper cliff-slope and

main cliff units-Continued

Sandstone, moderate-orange-pink, very fine grained, calcareous (28 percent), thickbedded (3-8 ft), massive; wedge-planar cross-stratification locally etched on surface; weathers to dark-brown; forms resistant major cliff

Sandstone, moderate-reddish-orange, very calcareous, fine- to very fine grained (includes skeletal fragments), friable; contains thin, pinkish-gray streaks; weathers to redbrown; forms irregular ledges (1-3 ft thick) ---

Sandstone, grayish-pink, very fine grained; contains tabular-planar cross-stratification; weathers dark-gray; forms resistant ledge --.--

Sandstone, moderate-reddish-orange, very fine grained (angular), calcareous ( 30 percent), friable; composed of irregular flat beds; weathers red-brown with white streaks; forms weak cliff

Sandstone, pale-reddish-brown, very fine grained; structureless, forms recess --...-...-.

Sandstone, moderate-orange-pink, very fine grained; weathers to pale-reddish-brown with thin, pinkish-gray streaks; forms irregular ledges (1-3 ft thick) within weak cliff -

Sandstone, grayish-orange-pink, very fine grained, calcareous, friable; contains series of flat-bedded to structureless sets $(1-3 \mathrm{ft}$ thick) and tabular-planar cross-stratified sets, medium-scale (2-8 ft); forms weak cliff -

Sandstone, grayish-orange-pink, very fine grained, thick sets $(2-6 \mathrm{ft})$; large-scale (20-30 $\mathrm{ft})$ tabular-planar cross-stratification $\left(17^{\circ}\right.$ dip)

Sandstone, moderate-orange-pink, very fine grained (grains angular), calcareous (21 percent); weak cross-stratification, wedgeplanar type, medium- to large-scale (5-40 $\mathrm{ft}$ ), includes asymmetric trough-filling and wedge-shaped beds; includes some shaly siltstone; contains current crescents and cusp ripples (0.25-0.5 in. wide); contains Rivularites imprints; weathers white to reddishbrown; honeycombed with solution holes; forms massive cliff

Total upper cliff-slope and main cliff units, Esplanade Sandstone

\section{5}

Section 17-Continued

S B CANYON-Continued

Feet

Supai Group-Continued

Esplanade Sandstone, basal slope unit:

Siltstone, pale-reddish-brown; contains rounded sand grains; thin- , flat-bedded (1-6 in.); shows brownish-gray streaks (1-2 in. thick); films of muddy slime common; worm borings, plant stems, mud pellets locally common; forms slope - -

Sandstone, reddish-brown, very fine grained, medium- , flat-bedded (1-3 ft thick); contains irregular white streaks (1-2 in. thick) ----

Sandstone, pale-reddish-brown, very fine grained, friable; contains irregular, massive beds ( $2-8 \mathrm{ft}$ thick)

Intraformational conglomerate, light-greenishgray to pale-reddish-brown, thickness variable $2.0-5.0$

Matrix: gray, calcareous siltstone.

Pebbles: $0.13-0.5$ in. diameter; rounded to subrounded; widely spaced; maximum pebbles 4 in. in diameter; composed of gray to black limestone and red siltstone.

Sandstone, pale-reddish-brown, very fine grained (rounded grains), calcareous (25 percent), beds flat, shaly (1.5-2 in. thick); forms slope

Conglomerate, pale-reddish-brown, fills de-

pressions, thickness variable $-5.5-7.5$ Matrix: gray, calcareous siltstone.

Gravels filling depressions: $0.5-2$ in. in diameter; maximum 5 in.; well-rounded; composed of gray to purple limestone.

14.5 Gravels of upper part: $0.13-0.5$ in. in diameter; maximum 1 in.; composed of brown, sandy limestone and gray to red limestone; also some red siltstone pebbles.

Total basal slope unit, Esplanade Sandstone - - 121.0 Total Esplanade Sandstone --.--

Erosion surface: Channels as much as $11 \mathrm{ft}$ deep filled with conglomerate.

Wescogame Formation, slope unit:

Sandstone, grayish-red, very fine grained, dolomitic; grades upward into pale-red, dolomitic sandstone, fine-grained; consists of lenses and irregular beds (0.5-3 ft thick); weathers to a series of red to gray receding ledges

Total slope unit, Wescogame Formation 
Section 17-Continued

\section{S B CANYON-Continued}

Supai Group-Continued

Wescogame Formation, cliff unit:

Sandstone, pale-red and pinkish-gray, very fine grained, flaggy; contains large-scale cross-stratification $\left(40-60 \mathrm{ft}\right.$; dips $\left.20^{\circ}-25^{\circ}\right)$; contains invertebrate tracks; forms weak cliff

Sandstone, pale-reddish-brown, very fine grained, crumbly, flat-bedded; forms bench -

Sandstone, grayish-orange-pink, fine-grained, friable, flat-bedded (0.5-2 ft thick); laps against dipping beds in channel walls, replacing upper part of underlying sandstone cross-strata

Total cliff unit, Wescogame Formation

Total Wescogame Formation --.--

\section{Unconformity:}

Channels, 2-6 ft deep, in cross-stratified sandstone filled with flat-bedded sandstone.

Manakacha Formation, slope unit:

Sandstone, pale-reddish-brown, very fine grained, very dolomitic, cross-stratified on large-scale; contains invertebrate tracks resembling horseshoe crab trails, on dip-slope, extending for $2 \mathrm{ft}$; forms prominent slope --.--

Sandstone, grayish-orange-pink, very fine grained, dolomitic; contains medium-scale $(10-30 \mathrm{ft})$, wedge-planar cross-stratification; weathers black; forms cap of major cliff ---_---

Sandstone, pale-reddish-brown, very fine grained, dolomitic, silty; contains large-scale $(40-60 \mathrm{ft})$, planar cross-stratification (beds dip $\left.18^{\circ}-23^{\circ}\right)$; forms major cliff near top of member

Sandstone, grayish-orange-pink, very fine grained, dolomitic; contains medium-scale $(10-30 \mathrm{ft})$; planar cross-stratification, thickbedded (3-8 ft thick); weathers black; forms resistant ledge

Sandstone, pale-reddish-brown, very fine grained, dolomitic, nonstratified; contains pinkish-gray, spherical sand concretions scattered throughout; forms weak ledge ------

Total slope unit, Manakacha Formation
Section 17-Continued

\section{S B CANYON-Continued}

Feet

Supai Group-Continued

Manakacha Formation, cliff unit:

Sandstone, grayish-orange-pink, very fine grained, very dolomitic; contains mediumscale $(10-30 \mathrm{ft})$, planar cross-stratification; thick-bedded (3-8 ft); weathers black; forms resistant ledge

Dolostone, pale-reddish-brown, silty, aphanitic to very finely crystalline, structureless; contains light-greenish-gray spots $(0.25-0.5$ in. in diameter) scattered throughout; forms ledge

Sandstone, pale-reddish-brown, very fine grained, calcitic-dolomite matrix (42 percent), flat-bedded; contains low-angle, medium-scale cross-stratification (10-20 ft); bedding sets, $1-3 \mathrm{ft}$ thick; local partings of deep-red-brown mudstone at several horizons; white streaks scattered throughout; forms series of ledges

Dolostone, calcitic, pale-red-brown, finely crystalline, sandy (very fine grains), contains medium-scale cross-stratification (2-5 $\mathrm{ft}$ ) of low-angle, compound, channel-fill type; weathers grayish-orange-pink; forms resistant ledge

Dolostone, calcitic, brownish-gray, aphanitic; contains abundant thin jasper layers scattered throughout; weathers to rough surface; forms weak cliff

Sandstone, grayish-orange-pink, very fine grained, very dolomitic; contains large-scale $(40 \mathrm{ft})$, wedge-planar cross-stratification (tangential base)

Limestone, brownish-gray, aphanitic, irregularly bedded; contains many jasper lenses and thin beds; forms recess

Sandstone, grayish-orange-pink, very fine grained, dolomitic, platy; thick-bedded (2-8 $\mathrm{ft})$; tabular-planar cross-stratification, largescale $(30-40 \mathrm{ft})$; grades laterally into sandy dolomite; contains thin jasper layers; weathers brown to black; forms weak cliff or slope 
Section 17-Continued

\section{S B CANYON-Continued}

\section{Supai Group-Continued}

Siltstone, conglomeratic, pale-reddish-brown, thin- , flat-bedded (0.25-2 in.); alternating with dolomitic ( 28 percent), white siltstone beds; occur as channel-fills in underlying siltstone; locally beds dip a few degrees; contain many angular fragments of jasper, dolomite, and mudstone near bases and along margins of channels; unsorted, unoriented; commonly 1-2 in. in diameter with a maximum of 6 in.

Erosion surface.

Siltstone, pale-reddish-brown, fine-grained (54 percent), limy, massive, thick-bedded (10-12 ft); cut by series of channels, some of which extend to base; contains irregular layers of jasper at various horizons, but mostly at top of unit; weathers black; forms cliff

Mudstone, grayish-red-brown, dolomitic; forms prominent recess

Limestone, pale-reddish-brown, finely crystalline, silty, sparkly, resistant, thick-bedded $(10-12 \mathrm{ft})$; locally weathers to thinner units $(0.5-1 \mathrm{ft})$; grayish-red-brown mudstone partings locally developed; forms massive cliff

Limestone, grayish-reddish-brown; locally fills channels 1-2 ft deep in underlying siltstone --

Siltstone, grayish-pink, sandy, calcareous, resistant; contains medium-scale, planar cross-stratification; forms prominent cliff ---.-

Limestone, grayish-red-brown, silty, aphanitic, thin-bedded $(2-3 \mathrm{ft})$; weathers lightbrownish-gray; forms resistant ledge --.--.--.

Siltstone, grayish-orange-pink, sandy, dolomitic, irregularly bedded; thin-bedded (2-3 $\mathrm{ft}$ ); weathers shaly; forms two weak ledges ---

Sandstone, pale-reddish-brown, very fine grained, dolomitic; locally reddish-gray; crumbly; forms slope

Sandstone, yellowish-gray, very fine grained, dolomitic, thick-bedded (3-4 ft); weathers to rounded, pale-reddish-brown surface; forms ledge

Total cliff unit, Manakacha

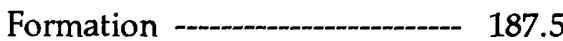
Total Manakacha Formation ----- 285.5
Section 17-Continued

S B CANYON-Continued

Supai Group-Continued

Watahomigi Formation, upper slope unit:

Mudstone, grayish-red, structureless, brittle; locally contains pinkish-gray-brown dolomitic limestone concretions; forms slope ---.-

Siltstone, very pale orange, calcareous ( 26 percent), shaly; weathers to pale-reddishbrown; forms resistant ledge --.---.----

Mudstone, pale-reddish-brown, silty, calcareous, massive on fresh surface; shaly on weathered surface; contains large deoxidation spots; forms weak slope --_-

Concealed, talus covered

Conglomerate, thick-bedded $(2-6 \mathrm{ft})$; weathers dark-brown to black

Matrix: calcitic dolomite.

Gravel: $0.25-0.5$ in. diameter, some 1 in., maximum 2-3 in.; angular to subangular, some rounded grains; composed of white, yellow, and red chert and jasper, some yellow quartz; no orientation of pebbles.

Total upper slope unit, Watahomigi Formation

Watahomigi Formation, middle cliff and lower slope units:

Concealed, talus-covered

Mudstone, pale-reddish-brown, crumbly, structureless

Concealed, talus covered -____ 9.0

Mudstone-conglomeratic, dark-reddish-brown, dolomitic, structureless; forms conchoidal masses; locally contains subrounded pebbles of dark-gray chert (maximum 6 in. diameter); forms slope --.--

Total middle cliff and lower slope units, Watahomigi Formation

Total Watahomigi Formation -- $-\frac{893.5}{1954.0}$

Total Supai Group - -

Unconformity:

Surface of relief includes 4-ft channel; solution cracks and bedding planes to $8 \mathrm{ft}$ below surface filled with red mud from above.

Redwall Limestone:

Horseshoe Mesa Member:

Limestone, yellowish-gray, aphanitic; thinbedded $(0.5-2 \mathrm{ft})$; pitted surface; forms receding ledges. 
Section 18

\section{TUCKUP CANYON}

[Upper part measured in Cottonwood Canyon; lower part in Tuckup Canyon]

Hermit Shale:

Basal ledge-slope member:

Siltstone, pale-red, shaly, flat-bedded, laminated (0.13-0.25 in.); fills channels in underlying unit; forms slope

3.0

Unconformity:

Small channels $(3.0 \mathrm{ft}$ deep) in sandstone of Supai filled with shaly siltstone of Hermit.

Supai Group:

Esplanade Sandstone, upper cliff-slope and main cliff units:

Sandstone, grayish-red, very thin bedded (1-4 in.); locally platy; locally contains cross-stratified wedges; includes many worm trails and borings; contains channel fills; forms weak ledges

Siltstone, pale-red, shaly, flat-bedded (0.130.25 in.); forms slope

Sandstone, grayish-red, very fine grained (angular grains), laminated ( 0.25 in.); locally platy; elsewhere contains cross-stratified wedges; contains worm trails; forms weak ledges

Sandstone, very pale orange, very fine grained (angular grains), friable; forms prominent, resistant cap rock

Sandstone, moderate-reddish-orange, very fine grained (subrounded grains); contains large-scale, cross-stratification $(20-30 \mathrm{ft})$ of wedge-planar type; forms rounded ledge -----

Sandstone, moderate-reddish-orange, very fine grained (subrounded to angular grains), flat-bedded, friable; forms wide bench and recess

Sandstone, moderate-reddish-brown, very fine grained, (subrounded to angular grains), calcareous, resistant; upper half very pale orange; forms prominent ledge -..--..--

Sandstone, pale-reddish-brown, very fine grained (rounded grains), thin-bedded (6-24 in.), flat-bedded; forms receding ledges -------

Sandstone, moderate-reddish-orange, very fine grained (rounded grains); contains large-scale cross-stratification $(20-40 \mathrm{ft})$; weathers to massive rounded ledge

Feet

11.0

26.5

\section{Supai Group-Continued}

Esplanade Sandstone, upper cliff-slope and

main cliff units-Continued

Mudstone, moderate-orange-pink, sandy, shaly, laminated (0.13-0.25 in); forms bench -...-...-.

Sandstone, moderate-reddish-orange, very fine grained, limy (40 percent); contains medium-scale cross-stratification $(2-20 \mathrm{ft})$ of wedge-planar type; forms massive rim

Siltstone, pale-reddish-brown, flat-bedded; forms weak cliff

Mudstone, pale-reddish-brown, sandy, shaly, laminated (0.13-0.25 in.); forms bench --.-.--

Sandstone, moderate-orange-pink, very fine grained, calcareous; contains medium-scale cross-stratification $(2-20 \mathrm{ft})$ of wedge-planar type; weathers to dark-gray surface; forms massive cliff

Sandstone, pale-reddish-brown, very fine grained, flat-bedded (2-12 in.); forms bench -

Sandstone, moderate-reddish-orange, very fine grained to medium-grained (subangular grains), calcareous; very thick sets of strata (15-25 ft); each set contains medium-scale cross-stratification $(2-20 \mathrm{ft})$ of wedge-planar type; weathers to dark-gray surface; forms sheer cliff

Total upper cliff-slope and main cliff units, Esplanade Sandstone

22.0 Esplanade Sandstone, basal slope unit:

Mudstone, grayish-red; alternating with moderate-orange-pink, very fine grained (subangular grains), hard, thick-bedded (1-3 $\mathrm{ft}$ ) sandstone; forms bench

Sandstone, pale-reddish-brown, very fine grained, calcareous (38 percent), resistant; contains weakly developed cross-stratification of wedge- and tabular-planar types; also contains very pale orange streaks; forms resistant ledge

11.0 Mudstone, grayish-red; includes scattered very fine grained sand; alternating with very pale orange, very fine grained, thin-bedded $(1-2 \mathrm{ft})$ sandstone; forms series of weak rounded ledges

Feet

24.0 
Section 18-Continued

\section{TUCKUP CANYON-Continued}

Supai Group-Continued

Esplanade Sandstone, basal slope unit-

Continued

Sandstone, pale-reddish-brown, very fine grained, (angular grains), resistant; contains three sets of weakly developed cross-stratification of wedge- and tabular-planar types; also contains white streaks; forms resistant ledge

Sandstone, very pale orange to pale-reddishbrown, very fine grained; locally contains small-scale cross-stratification (1-3 ft) with low-angle dips; alternating with grayish-red mudstone; unit forms series of alternating resistant ledges $(3-4 \mathrm{ft})$ and partings $(0.5-1 \mathrm{ft})-$

Mudstone, grayish-red, brittle; structureless; forms recess

Sandstone, pale-reddish-brown, very fine grained, flat-bedded $(0.25-1 \mathrm{ft})$; forms weak, rounded ledges

Conglomerate, bedding weakly developed; irregular basal contact; scattered along bottom of channel $19 \mathrm{ft}$ deep

Matrix: red-brown, very fine grained sandstone, calcareous cement.

Gravel: $0.25-0.5$ in. in diameter, maximum 4 in.; rounded to subrounded; composed of gray to blue-gray silty limestone, and red and white siltstone.

Total basal slope unit, Esplanade Sandstone -...........-

Total Esplanade Sandstone --- $-\frac{103.0}{241.0}$

Wescogame Formation, slope unit:

Sandstone, moderate-reddish-orange, very fine grained (angular grains), irregular, flatbedded $(2-8 \mathrm{ft})$; contains lenses of grayishred, sandy mudstone at several horizons; (forms recess); upper one-third pinkish-gray, forms series of receding ledges

Total slope unit, Wescogame Formation

Wescogame Formation, cliff unit:

Sandstone, pale-red, calcareous (28 percent), very fine grained, silty ( 23 percent), largely massive, thick-bedded (4-6 ft), forms series of ledges; alternating with pale-red, silty, thick-bedded (1-3 ft), mudstone
Supai Group-Continued

Wescogame Formation, cliff unit-Continued

Unconformity: buried erosion surface; channel

$23 \mathrm{ft}$ deep, several hundred feet wide, cut into underlying sandstone; filled with fine-grained sandstone and red-brown siltstone.

Total cliff unit, Wescogame Formation (basal channel sand and silt included) -

Total Wescogame Formation ----- $\overline{112.0}$

Manakacha Formation, slope unit:

Sandstone, moderate-orange-pink, very fine grained (angular grains), calcareous; contains wedge-planar cross-stratification (2-20 $\mathrm{ft})$; weathers with abundant solution holes; forms prominent cliff --.---.--

Sandstone, pale-red, very fine grained (angular grains), calcareous; contains medium- to large-scale cross-stratification $(5-30 \mathrm{ft})$; mostly tabular-planar type with some wedge-planar; cosets of cross-stratification very thick $(3-20 \mathrm{ft})$; contains layer with spherical stromatolites (8-12 in. diameter) covering surface for $30 \mathrm{ft}$; forms very resistant cliff

Mudstone, grayish-red, brittle; structureless; forms recess

Siltstone, pale-reddish-brown; forms weak ledge

Sandstone, pale-reddish-brown, very fine grained, muddy, brittle; structureless; forms recess

Conglomerate, brown sandy ledge

Matrix: sandstone, brown; cement calcareous.

Gravel: mostly white chert; $0.13-0.5$ in. in diameter, maximum 8 in.; angular fragments.

Total slope unit, Manakacha Formation

Manakacha Formation, cliff unit:

Limestone, dolomitic, pale-red, silty, thickbedded $(2-4 \mathrm{ft})$, flat-bedded; forms part of major cliff

Limestone, olive-gray, aphanitic; contains irregular thin layers and lenses of jasper; forms cliff 
Section 18-Continued

\section{TUCKUP CANYON-Continued}

\section{Supai Group-Continued}

Manakacha Formation, cliff unit-Continued

Limestone, light-brownish-gray, finely crystalline, sandy; contains planar cross-stratification conspicuously etched on surface ---------

Limestone, light-olive-gray, aphanitic; contains irregular, thin layers and lenses of jasper; forms basal cliff

Siltstone, pale-reddish-brown; many scattered fine- to very fine grained quartz particles; brittle, very thin bedded (0.5-1 ft); contains partings of brittle, structureless grayish-red mudstone; forms slope

Limestone, light-brownish-gray, finely crystalline, resistant, silty; contains grayish-red mudstone partings and thin jasper layers; forms series of ledges

Limestone, pale-red, muddy, silty; very thin bedded (1-3 in.); contains some jasper nodules; forms rounded ledge

Sandstone, pale-reddish-purple, very fine grained (angular grains), calcareous; contains thin jasper layers; weathers black; forms ledge

Sandstone, pale-reddish-brown, very fine grained, muddy, weakly bedded; forms slope

Sandstone, light-brownish-gray, dolomitic; contains planar cross-stratification; laminae etched on black weathered surface; forms resistant ledge

Total cliff unit, Manakacha Formation

Total Manakacha Formation -- $-\frac{120.5}{204.0}$

Watahomigi Formation, upper slope unit:

Limestone, light-brownish-gray, silty, very thin bedded (1-3 in.); contains concretions; weathers black; forms rounded ledge

Siltstone, pale-reddish-brown, shaly, irregularly bedded; contains limestone nodules; forms slope

Dolostone, calcitic, light-brownish-gray, silty, contains thin jasper layers; weathers to black face; forms resistant ledge

Siltstone, pale-reddish-brown, muddy, crumbly; largely concealed; locally exposed; forms slope -

Conglomerate, gray; contains Orbiculoidea and other fossils; weathers to rounded ledge -

Feet
Section 18-Continued

TUCKUP CANYON-Continued

Supai Group-Continued

Watahomigi Formation, upper slope unit-

Continued

Conglomerate-Continued

6.0 Matrix: brown siltstone.

Cement: siliceous.

Gravel: greenish-gray and orange chert, jasper, mudstone; $0.25-0.5$ in. in diameter; maximum diameter 2 in.; angular to subangular.

Total upper slope unit, Watahomigi Formation

Watahomigi Formation, middle cliff unit:

Claystone, pale-reddish-purple, brittle; contains white limestone concretions; forms slope --.--

Dolostone, calcitic, to limestone (25 percent insoluble) yellowish-gray, with thin beds of pale-red limestone; aphanitic; thick-bedded $(2-4 \mathrm{ft})$; contains grayish-red mudstone parting beds (1-2 in.) and irregular layers of jasper and white chert at various horizons; forms series of ledges or a weak cliff

Total middle cliff unit, Watahomigi Formation --_-_-_-

Watahomigi Formation, lower slope unit:

Siltstone, pale-reddish-brown, muddy, calcareous, shaly (0.13-0.15 in.); forms slope ----

Mudstone, pale-reddish-brown, brittle, crumbly; conglomeratic; contains Spirifer, Spiriferina, and productid brachiopods; forms slope

Conglomerate, grayish-red; forms weak ledge -Matrix: grayish-red mudstone.

Gravel: white chert fragments; average $0.15-1$ in. in diameter, maximum 3 in.; angular.
Feet
Unconformity:

Channel-cut erosion surface.

Redwall Limestone:

Horseshoe Mesa Member:

Total lower slope unit, Watahomigi Formation --- 36.5

Total Watahomigi Formation -- $-\frac{36.5}{912.5}$

Total Supai Group -.-_

Limestone, light-olive-gray, aphanitic; thinbedded (6-24 in.); weathers to rough surface; forms receding ledges. 
Section 19

\section{BLUE MOUNTAIN CANYON}

[In Blue Mountain Canyon, southwest side, T. 26 N., R. 9 W.; upper part measured on west side of Tower of Babylon]

Feet

Hermit Shale:

Mudstone, pale-reddish-brown, shaly; forms bench and slope 9.0

Contact:

Surface even; no evidence of erosion detected at this locality.

Supai Group:

Esplanade Sandstone, main cliff unit:

Sandstone, moderate-orange-pink, very fine grained, some fine-grained ( 15 percent), very limy (48 percent), friable; contains mediumscale, tabular-planar cross-stratification (1-4 ft), and some flat beds with Rivularites impressions and worm trails, at $50 \mathrm{ft}$ up; forms rounded blocks and receding ledges --.-

Limestone, pale-red and light-gray, fine- to medium-grained, very sandy ( 30 percent), rounded quartz, rounded pelloids in sparry calcite; medium- to thick-bedded $(2-4 \mathrm{ft})$; forms prominent ledge

Concealed slope, locally medium-bedded,

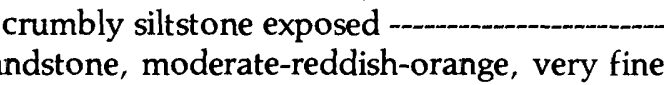
grained, resistant; limy (35 percent); weakly cross-stratified on medium to large scale; contains thin mudstone partings throughout; forms series of receding, massive, rounded ledges

Limestone, pale-red; fine-grained; very sandy; cross-stratified on medium scale, tabularplanar units 1-3 ft thick; middle part grades into pale-red, silty sandstone (60 percent insoluble) and forms bench; weathers with conspicuous brown laminae etched on gray surface

Siltstone, pale-red-brown, very limy (49 percent); weathers to rounded massive beds $(1-2 \mathrm{ft})$; forms part of cliff series

Concealed slope

Sandstone, pale-reddish-brown, very fine grained; limy ( 25 percent), very resistant, medium-bedded ( $2-3 \mathrm{ft})$, flat-bedded; forms rounded ledge
Section 19-Continued

BLUE MOUNTAIN CANYON-Continued

Feet

Supai Group-Continued

Esplanade Sandstone, main cliff unit-Continued

Sandstone, moderate-reddish-orange, very fine grained, limy (33 percent); massive (units 5-10 ft thick), calcareous; contains planar cross-stratification on large scale; forms bottom of prominent cliff

Total main cliff unit, Esplanade Sandstone

Esplanade Sandstone, basal slope unit:

Siltstone, pale-reddish-brown, shaly, limy, muddy, grains iron-oxide coated; contains abundant lenses and irregular layers of palebrown siltstone; abundant worm tubes and Rivularites sp. impressions; forms slope -------

Concealed slope

Siltstone, medium-light-gray and moderateorange-pink, very sandy, limy, thin-bedded (1-6 in.); irregular, nodular structure; and light- to dark-gray, rubbly, nodular limestone; forms bench

Sandstone, moderate-orange-pink, very fine grained (88 percent), friable; limy ( 25 percent); contains cross-stratification, mediumscale; forms upper part of ledge

Sandstone, pale-reddish-brown, very fine grained, muddy, medium-bedded $(1-2 \mathrm{ft})$; contains white deoxidation spots; forms bottom half of ledge

Concealed slope; probably thin-bedded siltstone

Sandstone, pale-reddish-brown, very fine grained, limy, structureless; forms ledge --..-

Limestone, moderate-orange-pink, very silty (45 percent), thin-, flat-bedded (0.5-1 in.), friable; forms slope

Conglomerate, pebbly, with scattered fragments of reddish-brown mudstone, brown siltstone and gray limestone, as much as 0.5 in. in diameter; and pale-reddish-brown, aphanitic, silty (33 percent), flat-bedded, medium-bedded (1-2 ft) limestone; forms ledge

Total basal slope unit, Esplanade Sandstone -.-_-_-_- 67.0 


\section{Section 19-Continued}

\section{BLUE MOUNTAIN CANYON-Continued}

Supai Group-Continued

Wescogame Formation, slope unit:

Sandstone, grayish-pink, very fine grained, slightly calcareous; contains planar crossstratification, medium- to large-scale; weathers reddish-brown and gray; forms massive, rounded, receding ledges --.--_..--

Conglomerate-limestone, medium-light-gray with pebbles of pale-reddish-brown chert; forms cap to cliff

Total slope unit, Wescogame Formation

2.0

Wescogame Formation, cliff unit:

Limestone, sandy (35 percent); grades upward into grayish-pink and moderate-orangepink, very fine grained, friable, very limy (49 percent) sandstone; cross-stratified, medium- to large-scale wedge-planar type; forms major cliff

Total cliff unit, Wescogame For-

mation - -77.0
Total Wescogame Formation --- 102.0

Manakacha Formation, slope unit:

Siltstone, pale-reddish-brown, resistant; contains planar cross-stratification with wavy, irregular laminae; contains jasper lenses and layers (0.5-2 in. thick); forms series of resistant ledges $(2-4 \mathrm{ft})$

Concealed slope

Limestone, pale-reddish-brown, very fine grained, silty ( 30 percent), resistant; contains scattered concretions of jasper; weathers to resistant, black face with irregular laminae etched on surface

Limestone, medium-gray, aphanitic, thinbedded (4-8 in.); contains white chert bands; forms steep slope or ledge; partly concealed --

Limestone, light-brownish-gray, aphanitic, silty (25 percent), resistant; contains crosslamination, medium-scale, locally wavy and irregular; contains chert and jasper in lenses and rounded nodules; weathers black; forms vertical cliff

Concealed slope, locally pale-reddish-brown, blocky, silty mudstone

$$
\text { Total slope unit, Manakacha }
$$

Feet

(1)

Supai Group-Continued

Manakacha Formation, cliff unit:

Limestone, pale-reddish-brown, aphanitic; abundant jasper lenses; forms cliff -..........-

Siltstone, bright-reddish-brown, crumbly, irregularly bedded; forms weak ledge or slope - -

Limestone, dull-gray; contains abundant, irregular layers of jasper and white chert forming conspicuous reticulate pattern on face; forms resistant cliff

Sandstone, moderate-reddish-orange, very fine grained, limy, crumbly, irregularly bedded; forms slope

Limestone, light-brownish-gray; aphanitic; contains abundant irregular layers of jasper and white chert forming conspicuous reticulate pattern on face; forms resistant cliff at bottom of series

Concealed slope

Siltstone, pale-reddish-brown, very limy (48 percent), aphanitic to very fine grained; irregularly laminated; contains some jasper; forms resistant ledge ---_-_-

Concealed slope

Siltstone, pale-reddish-brown, limy (35 percent magnesian ls.); forms resistant ledge --.--

Siltstone, pale-reddish-brown, limy (35 percent), structureless; forms partly concealed slope -

Siltstone, light-brownish-gray, aphanitic, very limy (47 percent); forms irregular rounded ledge -

Concealed slope

Siltstone, pale-reddish-brown, thick-bedded $(4 \mathrm{ft})$; forms resistant cap to cliff -.-.-.-.

Siltstone, light-brownish-gray, very limy (47 percent); contains irregular, purple laminae; includes lenses of jasper and dark-gray chert; forms lower half of prominent ledge -..-.-.-.

Siltstone, light-brownish-gray with pale-red streaks; contains 35 percent very fine grained sand; resistant, thick-bedded $(2-3 \mathrm{ft})$; forms rounded ledges --_-_-_-_-_-_-

Limestone, pale-reddish-brown, silty (20 percent), aphanitic; forms resistant ledge --.---- 
Section 19-Continued

BLUE MOUNTAIN CANYON-Continued

Supai Group-Continued

Manakacha Formation, cliff unit-Continued

Concealed slope; few beds of purple-gray and pale-reddish-brown, flat-bedded (1-2 ft) muddy siltstone, locally exposed

Siltstone, reddish-brown, calcareous, mediumbedded; contains several jasper beds (2-3 in. thick); forms ledge

Concealed slope

Siltstone, pale-reddish-brown, muddy, calcareous, medium-bedded; contains several jasper layers (2-3 in. thick); forms ledge -------

Limestone, pale-reddish-brown; shaly, very silty (46 percent); forms slope --..-..-..--

Concealed slope --

Limestone, light-brownish-gray, aphanitic to very fine grained, very silty (insoluble 33 percent), thick-bedded ( $4 \mathrm{ft})$; contains thin, irregular jasper layers; forms resistant ledge --

Concealed slope

Limestone, light-brownish-gray at base, very fine grained; medium-light-gray above; aphanitic with fine grains locally concentrated; medium-bedded ( $2-3 \mathrm{ft})$; contains irregular and crosscutting layers of jasper; forms resistant cliff -.......-

Total cliff unit, Manakacha Formation --- 201.0

Total Manakacha Formation ---- 267.0

Watahomigi Formation:

Concealed slope

Mudstone, pale-reddish-brown, brittle; forms slope --..--

Siltstone, pale-reddish-brown, flat-bedded, thin- to medium-bedded (2-12 in.); forms weak ledge

Mudstone, grayish-red and moderate-orangepink layers; brittle, crumbly; and grayishred, shaly, thin-bedded siltstone; total forms slope

Limestone, light-brownish-gray, medium- to very coarse grained, crinoidal; forms resistant ledge -

Concealed slope

Limestone, very light gray, aphanitic; weathers to rough surface; forms rounded ledge -.--

Feet
Section 19-Continued

BLUE MOUNTAIN CANYON-Continued

Supai Group-Continued

Watahomigi Formation-Continued

Concealed slope; probably red-brown mudstone

Conglomerate, grayish-orange; contains thick, irregular bedding; massive; forms ledge --..-Matrix: coarse sandstone.

Gravel: scattered pebbles of gray to white chert, subangular to angular (maximum diameter 2 in.); weathers yellow-brown.

Contact:

Total Watahomigi Formation -- $\overline{174.0}$

Total Supai Group -

Unconformity not apparent locally.

Redwall Limestone:

Horseshoe Mesa Member:

Limestone, light-brownish-gray, fine- to very fine grained, thin-bedded (4-12 in.).

Section 20

\section{PROSPECT VALLEY}

[On east side of Prospect Valley, 6 miles south of Colorado River]

Hermit Shale:

Mudstone, red-brown, shaly; includes weak ledge of thin- , flat-bedded siltstone in middle; forms slope -

Contact:

Flat, shaly beds of Hermit rest on resistant sandstone of Supai with no noticeable surface of relief.

Supai Group:

Esplanade Sandstone, upper cliff-slope and main cliff units:

Siltstone, moderate-reddish-orange, calcareous, hard; weakly cross-stratified on medium scale; forms rounded ledges (3-5 ft thick)

Concealed slope --

Sandstone, moderate-reddish-orange, fine- to
very fine grained; calcareous, cross-stratified on medium-scale (sets 1-3 ft thick), tabularplanar; includes some thin (1-12 in.), horizontal beds; contains a thick (10 ft) tabular-planar bed; total forms receding, rounded ledges 
Section 20-Continued

PROSPECT VALLEY - Continued

Supai Group-Continued

Esplanade Sandstone, upper cliff slope and main cliff units-Continued

Sandstone, moderate-reddish-brown, silty; calcareous, friable; beds medium $(0.5-1 \mathrm{ft}$ thick); structureless; forms recess or slope --.-

Siltstone, reddish-brown, shaly, flat-bedded; forms wide bench

Sandstone, moderate-orange-pink, fine- to very fine grained, calcareous; contains series of massive, cross-stratified units (each 15-20 $\mathrm{ft}$ thick); cross-strata mostly wedge-planar type, 1-3 ft thick; total forms single, resistant cliff

Total upper cliff-slope and main cliff units, Esplanade Sandstone

Esplanade Sandstone, basal slope unit:

Mudstone, pale-reddish-brown, calcareous, medium-bedded (1-2 ft thick), moderately resistant; alternating with pale-reddishbrown, calcareous, shaly, medium-bedded (1-3 ft thick) siltstone; unit forms base of cliff or recess under Esplanade cliff

Concealed slope; mudstone locally exposed -----

Siltstone, moderate-orange-pink and moderatereddish-brown; slightly calcareous, mediumto thick-bedded, structureless; contains liesegang bands in many places; weathers palereddish-brown; forms well-rounded, receding ledges

Sandstone, pale-reddish-brown, very limy, thick-bedded (3-8 ft), weakly crosslaminated locally, resistant; commonly develops black varnish on face; forms small cliff

Limestone, pale-reddish-brown, very silty, flat-bedded; contains gray concretionary structures; forms slope or rounded ledges --.--

Sandstone, pale-reddish-brown, calcareous, silty, very friable, very fine grained, thinbedded, flat-bedded; contains low-angle cross-beds (cosets 6-24 in. thick); contains small conglomerate lenses $5 \mathrm{ft}$ above base; forms slope with weak ledges
Feet

10.0

16.0

Section 20-Continued

PROSPECT VALLEY - Continued

Supai Group-Continued

Esplanade Sandstone, basal slope unitContinued

Conglomerate, gray to reddish-brown; forms resistant ledge with great lateral variation in thickness

Matrix: siltstone, gray to reddish-brown.

Pebbles: Composition-reddish-brown siltstone, light-gray limestone, dark-gray limestone; Size-mostly $0.25-1$ in. in diameter, maximum 3 in.; Roundnessmostly subangular but many wellrounded.

Total basal slope unit, Esplanade
Sandstone -
Total Esplanade Sandstone -- -111.5

Wescogame Formation, slope unit:

Sandstone, grayish-orange-pink, very fine grained, silty, calcareous, friable; weakly cross-stratified in thick cosets $(2-4 \mathrm{ft})$; upper part more resistant and structures more prominent than below; forms resistant ledges or rounded cliff

Limestone, moderate-reddish-orange, very silty with some very fine grained sand, calcareous, structureless; forms rounded ledge or part of cliff

Sandstone, moderate-orange-pink, fine- to very fine grained, calcareous; prominently cross-stratified (tabular- and wedge-planar); cosets 2-4 ft thick; weathers to resistant ledge with brown varnish on face --_-_-_--

Total slope unit, Wescogame Formation

Wescogame Formation, cliff unit:

Siltstone, pale-reddish-brown, calcareous, friable; contains some very fine grains; cross-stratified on medium scale $(10-20 \mathrm{ft})$; contains many white deoxidation spots; forms bench or recess

Siltstone, pale-reddish-brown, calcareous; contains some very fine grains; flat-bedded, shaly to medium-bedded (0.5-12 in. thick); forms receding ledges and weak benches ------

Limestone, pale-reddish-brown, silty, fine- to very fine grained; conspicuously crossstratified (trough-type structure) locally; weathers to reddish-brown, silty surface; forms receding ledges (2-4 ft thick) ---_-_-_-$-7.0$ 25.0 
Section 20-Continued

\section{PROSPECT VALLEY - Continued}

Supai Group-Continued

Wescogame Formation, cliff unit-Continued

Sandstone, pale-reddish-brown, very fine grained, calcareous, cross-stratified (lowangle, large-scale); weathers reddish-brown; forms resistant ledge -

Limestone, pale-reddish-brown near base, light-brownish gray above, very silty at bottom, less silt above; very fine grained, upper part prominently cross-stratified (troughtype); medium- to thick-bedded $(2-4 \mathrm{ft})$; forms receding rounded ledges

Concealed slope; probably shaly siltstone -..--..-

Siltstone, pale-reddish-brown, calcareous, structureless; contains some very fine grained sand; forms resistant ledge -----.----

Concealed slope, locally exposed, palereddish-brown, slightly calcareous, shaly siltstone, like that below

Feet

Sandstone, pale-reddish-brown, very fine grained, slightly calcareous; forms resistant ledge

Siltstone, pale-reddish-brown, slightly calcareous, shaly to thin-bedded (0.25-0.5 in.); contains shrinkage cracks and algal forms, cf. Rivularites; forms weak ledge --_-_-_-_-

Concealed slope

Total cliff unit, Wescogame For-
mation - $-\frac{75.0}{-3}$
Total Wescogame Formation -----

Manakacha Formation, slope unit: Absent.

Manakacha Formation, cliff unit:

Sandstone, moderate-orange-pink, very fine grained, silty; slightly calcareous, crossstratified (tabular- and wedge-planar); cosets of medium scale (1-3 ft thick); near top it is thicker bedded, calcareous, very fine grained, more massive, grayish-pink, weathers to rounded surface with many solution pits; forms resistant cliff

Siltstone, creamy-white; contains some very fine grained sand; calcareous, friable; medium-bedded (1-3 ft thick); weathers pale-gray, locally with brown reticulate pattern of siliceous material; forms rounded ledges

Total exposed cliff unit, Manakacha Formation --- 40.0+

Concealed by talus.
Section 21a

\section{TOROWEAP VALLEY}

[Measured south of Toroweap Point, east of lava flows]

Feet

Hermit Shale:

Ledge-slope unit:

Siltstone, pale-reddish-brown, shaly, forms slope

Unconformity:

Top of Supai (sandstone, moderate-orangepink, cross-stratified) bevelled to nearly flat, slightly undulating surface with relief as much as $4 \mathrm{ft}$ in $0.25 \mathrm{mi}$; shaly to mediumbedded siltstone rests on erosion surface and overlaps small hills.

Supai Group:

Esplanade Sandstone, upper cliff-slope unit:

Sandstone, moderate-reddish-orange, very fine grained (angular grains); includes finegrained sand ( 20 percent) near top; calcareous, resistant, thick-bedded (3-8 ft); locally cross-stratified (medium-scale, tabularplanar); includes shaly, muddy partings, sand ( 37 percent), pale-reddish-brown (2-12 in.) and lens of bright red-brown, shaly mudstone, $4 \mathrm{ft}$ thick, pinching out in $600 \mathrm{ft}$, weathers gray to light-red-brown; forms massive cliff

Mudstone, pale-reddish-brown, calcareous, silty, shaly; forms slope ---.--

Siltstone, moderate-reddish-orange, very fine grained sand (41 percent), calcareous (20 percent), friable; weathers to weak, rounded ledge or slope

Mudstone, pale-reddish-brown, calcareous (43 percent), shaly; contains sand ( 9 percent); forms slope

Sandstone, moderate-orange-pink, very fine grained, friable; weathers to weak, rounded ledge or slope

Siltstone, pale-reddish-brown, muddy, shaly, gypsiferous (35 percent); forms slope -------

5.5 Sandstone, moderate-orange-pink, very fine grained (angular grains), very gypsiferous (48 percent); forms weak ledges -_- 13.0 Total upper cliff-slope unit, Esplanade Sandstone 126.0 


\author{
Section 21a (east side)-Continued \\ TOROWEAP VALLEY - Continued
}

\section{Supai Group-Continued}

Esplanade Sandstone, main cliff unit:

Sandstone, moderate-reddish-brown, finegrained (38 percent); contains very fine grained quartz; clay matrix (22 percent); limy (45 percent); thick-bedded $(2-12 \mathrm{ft})$; locally massive to cross-stratified (mediumto large-scale); contains scattered grains of well-rounded, frosted, medium-size quartz; forms receding cliff

Sandstone, yellowish-white to pale-red, calcareous; cross-laminated on large scale; weathers same with black varnish; forms massive cliff

Sandstone, dark-reddish-brown, very fine grained; weathers same; forms massive cliff with rounded surfaces

Total main cliff unit, Esplanade Sandstone

Esplanade Sandstone, basal slope unit:

Mudstone, pale-reddish-brown, silty, calcareous, beds thin (2-6 in.) and flat; forms slope -

Sandstone, pale-reddish-brown to moderatereddish-orange; very fine grained, friable, silty ( 30 percent), mostly flat-bedded, locally cross-stratified on small scale; forms series of weak ledges

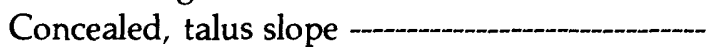

Sandstone, moderate-reddish-orange, very fine grained, silty (30 percent), friable, thinbedded $(1 \mathrm{ft})$; forms rounded ledge -...-...-...

Siltstone, pale-reddish-brown, contains scattered very fine grained sand, thin-bedded (2-12 in.); irregular beds; forms ledge -..-...-

Conglomerate, moderate-reddish-brown with scattered light-gray pebbles throughout; fills channels 1-2 ft deep and 6-10 ft wide --..-- 1.0Gravel: light-gray siltstone, deep-reddishbrown mudstone; maximum diameter 2 in., average diameter $0.25-0.5$ in.; wellrounded.

Matrix: very fine grained quartz sand and reddish-brown mud.

Sandstone, pale-reddish-brown, platy, very fine grained, and sandstone, grayish-orangepink, very fine grained, friable, thin-bedded; form weak ledges and slope

Section 21a (east side)-Continued

TOROWEAP VALLEY-Continued

Feet

105.5

176.0
Supai Group-Continued

Esplanade Sandstone, basal slope unit-

Continued

Sandstone, moderate-reddish-brown, very fine grained, flat-bedded; and pale-reddishpurple, very fine grained, laminated sandstone; form rounded ledges and weak cliffs ---

Sandstone, yellowish-white, calcareous; crossstratified on large scale; includes local sandstone conglomerate; forms massive ledge -.---

Conglomerate, light-brownish-gray, thinbedded (2-12 in.); weathers to rough surface; forms weak ledge

Gravel: reddish-brown siltstone, greenishgray limestone, rare red jasper; maximum diameter 2 in., average diameter $0.5-1$ in.; rounded to subrounded.

Matrix: poorly sorted sand.

Total basal slope unit, Esplanade Sandstone - -

Total Esplanade Sandstone

130.0

432.0

Wescogame Formation, slope unit:

Sandstone, moderate-reddish-orange, very fine grained, calcareous (33 percent); crossstratified on large scale; weathers palereddish-brown; pitted in many places -...-..-

Sandstone, pale-reddish-purple, very fine grained, silty ( 24 percent); beds thin and flat (0.5-12 in.); forms slope -._. Total slope unit, Wescogame Formation - 71.5

Wescogame Formation, cliff unit:

Limestone, light-brown, very sandy, massive --Limestone, pale-reddish-brown, sandy, crossstratified; weathers moderate-brown; forms ledge

Sandstone, moderate-reddish-orange, very fine grained, cross-stratified on large scale; forms weak cliff

Limestone, grayish-orange-pink, sandy, crossstratified; weathers moderate-brown; forms ledge

Limestone, light-brownish-gray and moderateorange-pink, aphanitic, hard; forms ledge ---.

Limestone, grayish-orange-pink, sandy, crossstratified; contains fusulinids (chapter E, p. 85); weathers moderate-brown; forms ledge -

Sandstone, moderate-reddish-orange, very fine grained, friable, structureless; grains iron-stained; forms slope 
Section 21a (east side)-Continued

TOROWEAP VALLEY - Continued

Supai Group-Continued

Wescome Formation, cliff unit-Continued

Sandstone, pale-reddish-brown; channel deposits; contains much very fine grained sand, silty ( 30 percent); calcareous, resistant; beds . 1-4 ft thick; weakly crossstratified; forms weak cliff

Conglomerate, gray- to brown-ledge; fills narrow channels and covers irregular surface of crossbedded, sandy limestone -.......-1.0-11.0

Matrix: gray, limy sandstone and sandy limestone.

Gravel: white chert, reddish-brown siltstone, light-gray limestone, pink limestone, dark, silty limestone (no jasper noted); Size-maximum diameter 9 in.; commonly $6-8$ in.; mostly $0.5-2$ in.; wellrounded; shape elongated, mostly platy; Orientation-long axis mostly horizontal.

Total cliff unit, Wescogame Formation

Total Wescogame Formation -----

Feet

Manakacha Formation, slope unit: Absent.

Manakacha Formation, cliff unit:

Limestone, pale-reddish-purple, sandy, crosslaminated; weathers moderate-brown; forms ledge

Limestone, medium-light-gray, aphanitic, ledge-forming

Limestone, grayish-pink, sandy, cross-laminated; contains detrital fusulinids; weathers with moderate-brown laminae on gray surface; forms ledge

Limestone, gray, aphanitic, ledge-forming; contains bands of red jasper -

Siltstone, grayish-red-brown, silty, calcareous, friable; contains limestone concretions -..-..-

Limestone, pale-reddish-brown, fine-grained; contains jasper; weathers pale-reddishbrown; forms sharp-cornered ledge --_--.----

Siltstone, pale-reddish-brown, friable, structureless; forms slope

Limestone, light-brownish-gray, aphanitic, resistant, ledge-forming --_-_-_-_-_-_-_-_.-_

Sandstone, light-olive-gray, fine- to very fine grained; calcareous (18 percent); contains jasper; weathers pale-reddish-brown; forms ledges with sharp corners

Section 21a (east side)-Continued

TOROWEAP VALLEY-Continued

Supai Group-Continued

Manakacha Formation, cliff unit-Continued

Mudstone, dark-reddish-brown, friable; forms slope

Limestone, light-brownish-gray, aphanitic, resistant, ledge-forming --_-_-_-_-_-_-_-

Limestone, brownish-gray, aphanitic, and moderate-reddish-brown mudstone; thin, irregularly bedded $(0.5-2$ in.), shaly; forms slope or recess

Limestone, very light gray, silty, platy, aphanitic, ledge-forming; cross-laminated; contains jasper along bedding planes -.-.-.--..-

Siltstone, light-brown, friable; contains limestone concretions; forms slope -.-..--..-...

Limestone, pale-reddish-purple, aphanitic, cross-laminated; contains jasper bands; ledge-forming

Siltstone, grayish-pink, friable, limy, structureless; slope-forming -

Limestone, pale-reddish-purple, aphanitic, hard; contains chert; weathers brownishblack; forms ledge with sharp corners --.-----

Siltstone, grayish-red, friable, muddy, structureless; slope-forming

Limestone, brownish-gray, aphanitic, crosslaminated; contains jasper bands; ledgeforming

Sandstone, grayish-pink, very fine grained, cross-laminated; forms ledge --_-_-_----

Limestone, medium-light-gray, aphanitic; contains jasper bands; ledge-forming --..-..-.

Siltstone, light-brown, friable, structureless, slope-forming

Siltstone, light-brown mottled with white; contains many hard, reddish-gray, spherical concretions; forms massive ledge

Total cliff unit, Manakacha Formation - - 144.5

Total Manakacha Formation --.-- 144.5

4.0

Feet

Watahomigi Formation, upper slope unit:

Siltstone, light-brown, friable, thin-bedded, slope-forming

Limestone, light-gray, aphanitic; contains peloids or lumps of moderate-reddish-brown mudstone; weathers to knobby surface --.--.

Siltstone, light-brown, friable, structureless, slope-forming 
Section 21a (east side)-Continued

TOROWEAP VALLEY - Continued

Supai Group-Continued

Watahomigi Formation, upper slope unit-

Continued

Limestone, light-brownish-gray, aphanitic, cross-laminated; contains jasper bands; ledge-forming

Mudstone, reddish-gray mottled with white, thin-bedded, shaly; forms slope or recess -----

Siltstone, moderate-reddish-brown, friable, structureless, slope-forming

Limestone, brownish-gray, aphanitic, crosslaminated; contains jasper bands; ledgeforming

Limestone, yellowish-white and light-brown, fine-grained, hard; weathers with darkbrownish varnish; forms massive cliff with sharp edges

Limestone, reddish-gray, aphanitic, sandy, thin-bedded (average 6 in.); contains some rounded pebbles; contains abundant fossils (Orbiculoidea sp., Lingula sp.?, bryozoa, gastropods, fish tooth); weathers to moderate-brown, irregular surface

Largely concealed; local exposures of calcareous, silty mudstone and siltstone

Conglomerate, gray-brown; contains brachiopods; forms ledge

Matrix: light-brownish-gray siltstone, hard.

Gravel: Size $0.25-1$ in., a few 4 in. in diameter; Shape - angular to subangular; Composition-mostly jasper, some siltstone and limestone.

Total upper slope unit, Watahomigi Formation

Watahomigi Formation, middle cliff unit:

Mudstone, reddish-gray mottled with white, thin-bedded, shaly; forms slope --_-_-_._-

Limestone, brownish-gray, aphanitic; contains jasper bands; forms massive cliff --..--_-

Limestone, brownish-gray; aphanitic, massive; contains no jasper; forms weak ledge ----

Total middle cliff unit, Watahomigi Formation

Watahomigi Formation, basal slope unit:

Mudstone, reddish-gray, shaly; forms slope -----

Siltstone, light-brown, friable, structureless, slope-forming; much concealed

19.5

5.0

10.5

7.0

Conglomerate, gray-brown; forms ledge; contains limestone, sandstone and few jasper pebbles; no fossils

53.5
Section 21a (east side)-Continued

TOROWEAP VALLEY - Continued

Feet

Supai Group-Continued

Watahomigi Formation, basal slope unit-

Continued

Conglomerate-Continued

Concealed, probably light-brown siltstone --.--

21.0

Total basal slope unit, Wata-

homigi Formation -

Total Watahomigi Formation --- $-\frac{78.5}{96.0}$

Total Supai Group -

Unconformity.

Redwall Limestone:

Limestone, light-brownish-gray, sandy, thickbedded; contains lenses of red beds with angular chert pebbles; weathers to pitted, cavernous surface; overlies crystalline limestone containing corals and spirifers.

Section $21 b$ (west side)

\section{TOROWEAP VALLEY}

[On west side of Toroweap Valley (measured at foot of valley, to record fossil horizons)]

Feet

Supai Group:

Manakacha Formation, cliff unit. Not measured.

Watahomigi Formation:

Concealed slope. Not measured.

Sandstone, dark-reddish-brown, very fine grained; cross-stratified on medium scale; weathers to black, flat face; forms ledge --.--

Siltstone, purplish-brown, shaly; forms slope; much concealed

Sandstone, bright-reddish-brown, very fine grained, friable, thin-bedded; forms weak ledge or slope

Siltstone, purplish-brown, shaly; forms slope ---

Limestone, light-gray; contains jasper bands; forms weak ledge

Concealed slope

Limestone, light-gray, silty, massive; contains shell sections; forms ledge --.---.---

Concealed slope -

Conglomerate, speckled light-brownish-gray on yellowish-gray; contains scattered chert pebbles and very coarse grained sand in matrix of silt; thin-bedded (2-6 in.); forms weak ledge 
Section $21 \mathrm{~b}$ (west side)-Continued

TOROWEAP VALLEY - Continued

Supai Group-Continued

Watahomigi Formation-Continued

Conglomerate-Continued

Gravel: chert; light-brown, dark-reddishbrown, grayish-orange-pink; about 33 percent pebble size, 66 percent granule and coarse-grained sand; angular to subrounded.

Matrix: silt; light-olive-gray; calcareous cement.

Concealed slope; purplish-brown, shaly siltstone locally exposed --.--

Dolostone, dark-gray, fine-, even-grained; contains brown wavy laminae; forms ledge --

Conglomerate, pale-reddish-brown, thinbedded (1-6 in.); forms receding ledges; resembles conglomerate above

Gravel: chert and flint, some jasper; lightbrown, moderate-reddish-brown, grayishorange-pink; common size range 0.060.25 in.; maximum 0.75 in.; angular to subrounded.

Matrix: very coarse grained sand; grayishorange-pink, silty, calcareous.

Limestone, light-gray, thick-bedded $(2-4 \mathrm{ft})$; contains many jasper bands; weathers black to brown; forms cliff

Limestone, pale-gray, aphanitic to fine-grained, thick-bedded (2-4 ft), resistant, includes brown, silty laminae; forms receding ledges --

Mudstone, deep-reddish-brown, brittle, crumbly; forms slope -

Limestone, dark-gray, aphanitic; includes jasper bands; contains wavy (stromatoloid?) laminae; forms resistant ledge

Concealed slope; probably siltstone like underlying beds

Siltstone, purplish-brown, shaly; includes few thin limestone beds; contains many fossils at $4 \mathrm{ft}$ above base (M-35, brachiopods, bryozoans) and at $16 \mathrm{ft}$ above base (M-36, brachiopods, coral, bryozoans; small Spirifers very common); forms slope -..--.--.

Conglomerate, light-brownish-gray; contains abundant fossils (M-34, brachiopods, gastropods, bryozoans); weathers brown ----Gravel: chert; pale-reddish-purple, grayishred; mudstone, dark-reddish-brown; limestone, light-gray, subangular to rounded; common size range $0.13-0.25$ in.; maximum 0.5 in.

Section $21 b$ (west side) - Continued

TOROWEAP VALLEY - Continued

Feet

Supai Group-Continued

Watahomigi Formation-Continued

Conglomerate-Continued

Matrix: light-gray limestone.

Mudstone, purplish-brown, shaly; forms slope -

Siltstone, light-purplish-brown, thin-bedded;

forms weak ledge

Mudstone, deep-reddish-brown, crumbly, brittle; contains scattered chert pebbles; forms slope

Conglomerate, moderate-brown; forms weak 11.0

ledge

Gravel: chert, light-brown to dark-reddishbrown; mostly $0.25-0.5$ in., maximum 4-in. diameter; mostly angular, some rounded.

Matrix: moderate-brown, fine-grained quartz sandstone, weakly cemented.

Total Watahomigi Formation ---- $\overline{266.0}$

Unconformity:

Surface of low relief but includes sink hole with depth of $14 \mathrm{ft}$, largely filled with conglomerate.

\subsection{Supai Group:}

Top of escarpment: See section $22 \mathrm{~b}$ for uppermost unit.

2.5 Esplanade Sandstone, main cliff unit:

Sandstone, very pale orange, fine- to very fine grained, calcareous, friable; crossstratified, mostly tabular-planar, on medium to large scale (some $70 \mathrm{ft}$ long); cosets thick (3-10 ft); forms massive, rounded cliff 
Section 22a (part)-Continued

WHITMORE WASH_Continued

Supai Group-Continued

Esplanade Sandstone, main cliff unit-

Continued

Sandstone, pale-reddish-brown or laminated, red and buff, very fine grained; includes few medium grains; prominently cross-stratified, low-angle, large-scale (mostly wedgeplanar); cosets 1-3 ft thick; contains two light-olive-gray, coarse- to fine-grained calcitic dolomite (52 percent) in lenses $(1 \mathrm{ft}$ thick) near top; forms cliff

Sandstone, moderate-orange-pink, very fine grained, many fine grains; calcareous, hard, structureless; forms weak cliff at base of resistant cliff

Sandstone, pale-reddish-brown, very fine grained, calcareous, medium-bedded (1-3 $\mathrm{ft}$ ); forms series of receding weak, rounded ledges or slope; includes some beds of deepred-brown, crumbly mudstone

Sandstone, moderate-reddish-orange, fine- to very fine grained, slightly calcareous, friable; contains small-scale, wedge-planar cross-strata in cosets of medium thickness $(2-5 \mathrm{ft})$; forms small, reddish-brown cliff -----

Limestone, light-olive-gray, aphanitic; weathers to pitted surface; locally conspicuous -----

Sandstone, bright-red-brown; like second bed below

Sandstone, very pale orange, very fine grained, very hard; forms resistant, rounded ledge; makes prominent marker

Sandstone, pale-reddish-brown, very fine grained, silty ( 30 percent), calcareous ( 30 percent), friable, medium-bedded $(1-2 \mathrm{ft})$; forms receding ledges

Sandstone, pale-reddish-brown, very fine grained, calcareous, crumbly, slopeforming; includes 1- $\mathrm{ft}$ ledge of hard, limy sandstone

Sandstone, pale-buff, like massive cliff unit below

Sandstone, moderate-orange-pink, very fine grained, calcareous, medium-bedded (2-3 $\mathrm{ft}$ ); weathers reddish-brown; forms weak ledges, receding locally

Feet

Section 22a (part)-Continued

WHITMORE WASH-Continued

Supai Group-Continued

Esplanade Sandstone, main cliff unit-

Continued

Sandstone, very pale orange, very fine grained; includes fine grains; slightly calcareous, cross-stratified on large scale (tabularplanar); weathers to rough, yellow-brown surface and rounded edges; forms massive cliff

Total main cliff unit, Esplanade Sandstone

17.5 Esplanade Sandstone, basal slope unit:

Sandstone, moderate-orange-pink, very fine grained, calcareous, friable, thin-bedded (2-12 in.); locally contains lenses of algal(?) limestone with dark-gray structures prominent; forms slope or receding ledges

Sandstone, moderate-reddish-orange, calcareous, very fine grained, silty, platy, slopeforming

Sandstone, grayish-pink, very fine grained, calcareous, structureless; forms resistant ledge

Sandstone, pale-reddish-brown, very fine grained, calcareous, friable; contains small limestone nodules in upper part; forms slope or receding ledges

Conglomerate, gray to brown

Matrix: purple, sandy limestone.

Gravel: Composition-dark-gray limestone, olive-gray limestone, pale-gray limestone, red-brown siltstone; mostly well-rounded, some subangular; mostly range from 0.25 to 1 in., maximum 2 in.; many limestone pebbles are coated with concentric layers of olive-green limestone forming band about 0.25 in. wide, probably algal deposits.

6.0 Limestone, pale-reddish-brown and pinkishgray, aphanitic to coarse-grained, resistant, cross-stratified throughout (wedge-planar and tabular-planar types); some laminae contain medium- to coarse-size quartz and jasper grains that etch out on surface; weathers to ledge with sharp corners, sandy 5.5 surface and conspicuous black laminae --.----
Feet

5.0 


\author{
Section 22a (part)-Continued \\ WHITMORE WASH-Continued
}

Supai Group-Continued

Esplanade Sandstone, basal slope unit-

Continued

Sandstone, pale-reddish-brown very fine grained, calcareous, friable, medium-bedded (1-2 ft ); forms receding ledges

Conglomerate, reddish-brown to gray, silty; forms resistant ledge -.-_-_Matrix: siltstone, reddish-brown.

Gravel: dark-gray limestone, buff siltstone, red-brown siltstone; mostly $0.25-1$ in. in diameter, maximum 4 in.; most wellrounded, some subangular.

Total basal slope unit, Esplanade
Sandstone - $-\frac{39.5}{247.0}$

Wescogame Formation, slope unit:

Sandstone, pale-reddish-brown, very fine grained, silty, calcareous, friable, flat-, irregularly bedded; forms rounded ledge -.--

Sandstone, pinkish-gray, very fine grained, slightly calcareous, friable, massive, weakly cross-stratified on large-scale; weathers to conspicuous white ledge

Sandstone, moderate-orange-pink to yellowbrown, very fine grained, calcareous ( 28 percent), friable, medium-bedded (1-3 ft); weathers bright-reddish-brown, forms series of receding rounded ledges

Total slope unit, Wescogame Formation

Wescogame Formation, cliff unit:

Sandstone, pale-reddish-brown, very fine grained, very limy (40 percent), cross-stratified (tabular-planar); cosets medium-thick $(1-3 \mathrm{ft})$; weathers reddish-brown, locally with black varnish; forms massive cliff -------

Sandstone, moderate-reddish-orange, very fine grained, calcareous, friable, thin- , flatbedded $(0.5-2$ in.); forms recess --._-_._-_._.

Limestone, pale-reddish-brown, aphanitic; 49 percent sand (very fine grained); resistant, cross-stratified (tabular-planar type); forms resistant ledge at base of cliff

Feet
Section 22a (part)-Continued

WHITMORE WASH-Continued

Supai Group-Continued

Wescogame Formation, cliff unit-Continued

Sandstone, pale-reddish-brown, very fine grained, calcareous; weakly cross-stratified on large-scale, mostly structureless; weathers to brown, rounded ledge ---.---.-

Sandstone, grayish-pink, very fine grained; some fine grains; calcareous, friable, thinbedded ( $2-12$ in.); beds mostly flat, some with tabular-planar cross-strata; weathers reddish-brown; forms rounded, receding ledges

Conglomerate, pale-gray to white; weathers reddish-brown and dark-brown; forms ledge Matrix: calcareous, fine-grained sandstone.

Gravel: mostly jasper and white chert, some pale-gray limestone, dark-gray limestone; generally $0.13-0.25$ in. in diameter, maximum 0.25 in.; angular and subangular, except limestones that are rounded.

Total cliff unit, Wescogame Formation --._- 77.0 Total Wescogame Formation -- $-\overline{127.0}$

Manakacha Formation, slope unit:

Limestone, light-brownish-gray, aphanitic, insoluble (28 percent), sandy (fine- to very fine grained); resistant; breaks with clinkery ring; contains many grains of conspicuous white kaolinite throughout; prominently cross-stratified (tabular-planar and wedgeplanar types) with both high- and low-angle laminae; cosets medium-thick $(0.5-3 \mathrm{ft})$; weathers with dark-brown laminae in relief; forms cliff

Limestone, dolomitic, pale-reddish-brown to purple; some parts very silty (49 percent), crumbly; consists of two thin beds with resistant, aphanitic, medium-gray limestone between; forms prominent recess

Siltstone, moderate-orange-pink, limy, locally friable; contains flat beds and cosets of tabular-planar cross-strata (6-36 in.); weathers to black varnished surface; forms weak ledges within main cliff -

Total slope unit, Manakacha
Formation 


\section{Section 22a (part)-Continued \\ WHITMORE WASH-Continued}

\section{Supai Group-Continued}

Manakacha Formation, cliff unit:

Limestone, pale-reddish-brown, aphanitic, very silty, prominently cross-stratified (wedge-planar type); surfaces between cosets locally consist of very irregular erosion planes; weathers with dark-brown laminae etched on bluish-gray base; forms cliff with angular margins

Limestone, pinkish-gray, very fine grained; medium- to thick-bedded (1-4 ft); contains many irregular jasper bands $(0.25-3$ in. thick); locally cross-stratified on medium scale; forms cliff or receding ledges --..--.-.-

Limestone, pale-reddish-brown, silty, very fine grained; prominently cross-stratified (wedge-planar type) on medium scale; contains scattered, ellipsoidal concretions oriented parallel to crossbeds; weathers dark-brown with cross-strata in prominent relief; forms massive cliff

Limestone, grayish-orange-pink, very fine grained; stratification weakly developed (horizontal strata and small-scale crossstrata; contains many thin layers and concretions of jasper)

Limestone, light-brownish-gray, aphanitic, sandy and silty (44 percent), cross-stratified (tabular-planar type) on medium scale; weathers with dark-brown varnish; forms base of resistant cliff

Mudstone, moderate-reddish-orange, calcareous; contains flat, concretionary bedding (beds 1-2 in. thick); forms bench and recess under main cliff

Sandstone, light-gray, aphanitic, limy; weakly cross-stratified on small-scale; contains irregular layers of chert and jasper; weathers dark-gray; forms resistant ledge

Concealed slope, brittle, silty, pale-red limestone locally exposed near top - -

Manakacha Formation, cliff unit:

Limestone, light-gray, thin- to medium-bedded (1-24 in.), aphanitic; contains irregular layers of jasper (0.5-3 in. thick); forms series of weak ledges

Concealed slope
Feet

16.0

Section 22a (part)-Continued

WHITMORE WASH-Continued

Supai Group-Continued

Manakacha Formation, cliff unit-Continued

Limestone, pale-reddish-brown, aphanitic, silty; includes cosets with thin, flat laminae and low-angle cross-laminae (2-3 ft thick); weathers with black varnish irregularly distributed

Concealed slope, pale-reddish-brown, shaly siltstone with limy concretions and jasper lenses locally exposed

Sandstone, grayish-red, very fine grained, calcareous, speckled brown; includes many fine grains; friable; cross-stratified on medium scale; weathers pink with brownish spots; forms weak, rounded ledges --..---.-Total cliff unit, Manakacha Formation --_- 124.5 Total Manakacha Formation - $-\frac{124.5}{167.5}$

Watahomigi Formation, upper slope unit:

Siltstone, grayish-orange-pink, shaly, thinbedded $(0.25-2$ in.); locally contains mudballs and wavy structure; forms slope --.---.-

Concealed slope, basal third with local exposures of reddish-brown, crumbly sandstone and pale reddish-brown shaly siltstone

Conglomerate, weathers brown to gray; forms resistant, rounded ledge Matrix: finely-crystalline limestone.

Gravel: exclusively durable rocks including jasper, white and brown chert; mostly $0.25-0.5$ in. in diameter, maximum 0.5 in.; angular to subrounded.

Total upper slope unit, Watahomigi Formation ---.--

Watahomigi Formation, middle cliff and lower slope units:

Concealed slope

Limestone, pale-yellowish-brown, fine-grained; thin-bedded (6-12 in.); forms receding ledges

Concealed slope

Limestone, medium-light-gray, even-grained, medium-bedded $(2-3 \mathrm{ft})$; contains thin jasper layers; cut with many calcite veins; forms weak ledges 
Section 22a (part)-Continued

WHITMORE WASH-Continued

\section{Supai Group-Continued}

Watahomigi Formation, middle cliff and lower slope unit-Continued

Limestone, medium-light-gray, rubbly, irregularly bedded, brittle; forms weak ledges on slope

Limestone, light-gray with purple blotches; aphanitic; contains few jasper lenses and crosscutting veins; forms ledge

Concealed slope -

Limestone, medium-light-gray, fine-grained, thin-bedded (2-12 in.); contains much jasper (50 percent) in wavy layers and one bed of concretions ( 0.25 in. diameters); forms weak ledge

Limestone, olive-gray and dark-greenish-gray, aphanitic, medium-bedded (1-2 ft); forms rounded ledge

Conglomerate, gray to brown, thin-bedded (412 in.); grades into conglomeratic limestone; contains many fossils (brachiopods, crinoid joints, trilobites, gastropods), concentrated locally, also scattered among pebbles --.--.---Matrix: aphanitic to fine-grained limestone. Gravel: mostly durable rocks including flint, chert, and quartzite; some dark-gray and light-gray limestone and red-brown siltstone; largely $0.25-0.5$ in. in diameter, maximum 1 in.; subangular to rounded.

Claystone, dark-reddish-brown with white deoxidation spots; structureless; brittle; forms slope

\begin{tabular}{l} 
Total middle cliff and lower \\
slope units, Watahomigi For- \\
mation - 86.5 \\
Total Watahomigi Formation -178.0 \\
Total Supai Group - \\
\hline
\end{tabular}

Unconformity:

Irregular surface with small relief (a few feet in one-half mile exposure).

Redwall Limestone:

Horseshoe Mesa Member:

Limestone, light-olive-gray, aphanitic, thinto medium-bedded (6-24 in.); weathers to rough, pitted surface; forms receding ledges.
Section $22 b$ (part)

\section{WHITMORE WASH}

[Complete Esplanade section on east side of Whitmore Wash; measured north of section 22a, between major basalt cascades]

Feet

Hermit Shale:

1.0 Sandstone, moderate-reddish-brown, very fine grained (angular), micaceous, platy; forms series of weak ledges (2-8 in. thick); fills channels in top of Supai

Unconformity:

Channels $10-15 \mathrm{ft}$ deep in massive sandstone of Supai, filled with platy sandstone and siltstone of Hermit.

Supai Group:

Esplanade Sandstone, upper cliff-slope unit:

Sandstone, pale-reddish-brown to moderate-

5.0 reddish-brown, very fine grained (angular), platy; silty near top; forms receding ledges ---

Sandstone, moderate-reddish-orange, very fine grained (93 percent), subrounded, thickbedded (1-4 ft), flat-bedded; forms resistant, rounded cliff

Sandstone, moderate-reddish-orange, very fine grained (angular) with concentration of medium-grained sand, well-rounded, frosted, limy (45 percent); poor sorting; thin- to thick-bedded $(0.5-3 \mathrm{ft})$, friable; forms bench and rounded ledges with quartz grains etched out on surface; thin, platy siltstone at top -..-_..-

Total upper cliff-slope unit, Esplanade Sandstone --------

Esplanade Sandstone, main cliff unit:

Sandstone, moderate-reddish-orange, mediumto very fine grained, and pale-reddishbrown, very fine grained ( 74 percent) sandstone; total cross-stratified on large scale $(20-30 \mathrm{ft})$; forms resistant cap rock for major cliff; pit holes from solution common ---------

Sandstone, moderate-reddish-orange (lower and middle part), very fine grained, subrounded (75 percent); to moderate-orangepink (upper), very fine grained (subangular); silty in upper part; cross-stratified on medium to large scale; sets of strata very thick $(10-20 \mathrm{ft})$; forms cliff, weaker and more rounded than underlying 


$$
\begin{gathered}
\text { Section 22b (part)-Continued } \\
\text { WHITMORE WASH-Continued }
\end{gathered}
$$

Supai Group-Continued

Esplanade Sandstone, main cliff unitContinued

Sandstone, moderate-reddish-orange, fine(82 percent) to very fine grained (round to subrounded), calcareous (36 percent), lower part, and moderate-reddish-brown, very fine grained (angular), silty (upper part) sandstone; very thick bedded $(10-30 \mathrm{ft})$; cross-stratified on medium to large scale; forms lower half of major cliff; weathers to sheer face with brown to black varnish --.----

Sandstone, moderate-orange-pink; very fine grained (subrounded), very thick bedded (4-10 ft); flat-bedded (near base), mediumscale cross-bedding above; contains some fine-grained sand in upper part; laminae of sand etched out; forms basal part of main cliff; weathers to straight face; pink in these beds contrasts with orange above

Total main cliff unit, Esplanade

Sandstone ----- 215.0
Total Esplanade Sandstone ----- 363.5

Section 23

\section{PARASHANT CANYON}

[East of Shivwits Plateau]

Hermit Shale:

Contact:

Unconformity not observed at this locality.

Supai Group:

Esplanade Sandstone, upper cliff-slope unit (part);

Sandstone, grayish-orange to moderatereddish-orange, very fine grained, locally quartzitic, friable, highly cross-stratified; weathers with weak-brown varnish on surface; forms resistant cliff with sharp edges ----

Mudstone, moderate-reddish-brown, shaly; forms slope

Sandstone, pale-yellowish-orange, very fine grained, friable; forms cliff

$$
\begin{aligned}
& \text { Total upper cliff-slope unit } \\
& \text { (part), Esplanade Sandstone --- }
\end{aligned}
$$

Feet

\section{Supai Group-Continued}

Esplanade Sandstone, upper cliff-slope unit, gypsiferous facies:

Siltstone, moderate-orange-pink, thin-bedded to shaly; includes some friable, very fine grained (scattered fine grains) sandstone beds and beds of gypsum; forms slope with few small ledges

Total upper cliff-slope unit, gypsiferous facies, Esplanade Sandstone

Total upper cliff-slope unit, Esplanade Sandstone

Esplanade Sandstone, main cliff unit:

Sandstone, moderate-orange-pink, very fine grained, well-sorted, cross-stratified; forms receding ledge

Sandstone, moderate-orange-pink, silty, shaly, slope-forming

Sandstone, moderate-orange-pink to moderate-reddish-orange, very fine grained (scattered fine grains), silty (18 percent); cross-stratified on medium to large scale, friable, calcareous (34 percent); forms resistant cliff and rim of Esplanade

Sandstone, grayish-orange-pink, very fine grained; contains white chert specks; crossstratified (medium-scale); forms small cliff with bench at base

Sandstone, moderate-orange-pink, very fine grained (scattered fine grains), silty ( 20 percent), calcareous (33 percent); crossstratified on medium to large scale, thickbedded; forms massive cliff

Sandstone, moderate-reddish-orange, finegrained, bimodal, calcareous, silty, flatbedded; forms bench

Sandstone, moderate-reddish-orange (upper) to moderate-orange-pink (lower), and medium-grained (rounded, 11 percent), upper part bimodal, calcareous (33 percent); thin- to medium-bedded; weathers to white or pale-gray surface; forms weak cliff with bench or slope at base
Sandstone, grayish-orange-pink, very fine grained, limy (25 percent), medium- to thick-bedded; forms resistant cliff

Total main cliff unit, Esplanade Sandstone

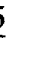

.


Section 23-Continued

PARASHANT CANYON-Continued

Supai Group-Continued

Esplanade Sandstone, basal slope unit:

Sandstone, pale-reddish-brown to grayishpink, very fine grained, locally limy (42 percent), thin- to medium-bedded; forms weak receding ledges or slope

Sandstone, reddish-orange, very fine grained, calcareous; forms weak ledge --.-.-.-.-.

Total basal slope unit, Esplanade Sandstone

Total Esplanade Sandstone ------- $\frac{52.0}{381.0}$

Wescogame Formation, slope unit:

Sandstone, very pale brown, mottled with light-brown; very fine grained, silty, calcareous, prominently cross-laminated; forms cliff

Sandstone, pale-reddish-brown (upper $3 \mathrm{ft}$ very pale brown), very fine grained (subangular), calcareous, argillaceous; weathers moderate-brown; forms ledge

Sandstone, moderate-reddish-brown, very fine grained, friable; forms slope ---.--.-.---.-

Sandstone, light-brown, very fine grained, calcareous; massive; forms ledge --..--..-.-.-

Sandstone, moderate-reddish-brown, very fine grained, friable; forms slope --.-.-.-.

Sandstone, strong-reddish-brown, very fine grained (angular to subangular), friable, highly cross-laminated; weathers same; forms weak, rounded ledges --_-_-_._-

Sandstone, light-brown, very fine grained, very friable, brittle; weathers same; forms slope

Total slope unit, Wescogame Formation

Wescogame Formation, cliff unit:

Sandstone, reddish-gray, very fine grained, silty, cross-laminated on large scale; two lower beds about $10 \mathrm{ft}$ thick, upper bed $50 \mathrm{ft}$, separated by reddish-brown siltstone partings locally; grades above into friable, red siltstone

Conglomerate, forms massive ledge

Gravel: elliptical, unoriented, limestone pebbles (diameter 0.25-6 in.).

Total cliff unit, Wescogame Formation -
Total Wescogame Formation ---
151.5
Section 23-Continued

PARASHANT CANYON-Continued

Supai Group-Continued

Manakacha Formation, slope unit:

Siltstone, moderate-reddish-brown, friable, weak, structureless; contains abundant impressions of Walchia

Limestone, reddish-gray, aphanitic, silty, friable, thin-bedded (1-2 ft); weathers with silty surface; forms weak ledges -...-...-.-.

Limestone, reddish-gray, fine-grained, prominently cross-laminated; forms ledge -.-.-.-.-

Limestone, reddish-gray, flat-bedded; forms ledge

Claystone, weak-reddish-brown, very thin bedded, crumbly; forms slope --_-_-_..-_..-

Limestone, reddish-gray, fine-grained, thinbedded (1-2 ft); forms weak, receding ledges

Limestone, reddish-gray, fine-grained, hard; much cross-laminated in scour-and-fill type; forms ledges with rounded or sharp edges ----

Claystone, weak-reddish-brown, very thin bedded; crumbly; forms slope --.--.--.--

Sandstone, reddish-gray, very fine grained (angular), silty, calcareous, friable; weathers brown; forms rounded ledge

Claystone, pale-reddish-brown, thin-bedded, crumbly; forms slope - -

Total slope unit, Manakacha Formation

Manakacha Formation, cliff unit:

Limestone, dark-reddish-gray, fine-grained, cross-laminated; beds thick (5-10 ft); contains a few jasper lenses; weathers reddishbrown; locally forms crumbly cliff

Conglomerate, rusty-brown to gray, base of cliff

Matrix: clastic limestone, gray.

Gravel: abundant small (0.06-0.13 in.), angular, jasper and chert fragments and few scattered, subangular to subrounded, gray, fine-grained limestone pebbles (0.5-2 in.).

Claystone, pale-reddish-brown, thin-bedded, crumbly; forms slope

Limestone, light-brownish-gray, aphanitic, hard; cross-laminated on large-scale; contains a few jasper bands; weathers brownishgray or weak-brown; forms ledges $10-15 \mathrm{ft}$ thick with thin shale partings 
Section 23-Continued

PARASHANT CANYON-Continued

Supai Group-Continued

Manakacha Formation, cliff unit-Continued

Limestone, reddish-gray, aphanitic; contains jasper bands; forms cliff

Claystone, pale-reddish-brown, thin-bedded, crumbly; forms slope ------.---.--

Limestone, reddish-gray with bands of palebrown, aphanitic, sandy (very fine grained); contains jasper bands; weathers palereddish-brown; forms cliff -

Claystone, pale-reddish-brown, thin-bedded, crumbly; forms slope --_-_-

Limestone, reddish-gray, aphanitic, silty, thinbedded; weathers with silty surface; forms ledge

Claystone, pale-reddish-brown, thin-bedded, crumbly; forms slope -...-................

Limestone, reddish-gray, aphanitic, silty; contains many jasper bands; very resistant near top; forms small cliff

Total cliff unit, Manakacha Formation

Total Manakacha Formation -.--- 198.0

Watahomigi Formation:

Claystone, pale-reddish-brown, very thin bedded, crumbly; forms slope -.-_-_-_-_-

Limestone, reddish-gray, aphanitic, silty; forms ledge -

Claystone, pale-reddish-brown, very thin bedded, crumbly; forms slope --_--.--

Limestone, reddish-gray, aphanitic; forms thin beds; contains some jasper; forms series of thin ledges

Claystone, pale-reddish-brown, very thin bedded, crumbly; forms slope --.---.--

Limestone, reddish-gray, with bands of lightbrownish-gray; aphanitic, silty; contains many jasper bands; weathers with lightbrown stain; forms cliff

Claystone, pale-reddish-brown, very thin bedded, crumbly; forms slope --..-_-_.-.-.

Limestone, brownish-gray, aphanitic, silty, hard; weathers light-brownish-gray, silty; forms rounded ledge --_-_-_-_-_-_-_-_-_

Claystone, pale-reddish-brown, very thin bedded, crumbly; forms slope --..-...--

Limestone, light-brownish-gray, aphanitic, sandy (very fine grained, some fine-grained); contains much jasper; weathers pale-brown, silty; forms ledge with sharp corners

Feet
Section 23-Continued

PARASHANT CANYON-Continued

Supai Group-Continued

Watahomigi Formation-Continued

Claystone, pale-reddish-brown and yellowish-

4.5 white, soft; forms rounded knobs --..--

Limestone, dark-reddish-gray, very silty; beds thin and wavy; grades upward into massive, aphanitic, reddish-gray limestone containing jasper bands; weathers pale-brown

Limestone, reddish-gray, very silty, very thin bedded $(0.25-0.5$ in.); weathers palereddish-brown, silty, forms cliff

Siltstone, very pale orange, mottled with paleyellow, calcareous (24 percent), dolomitic, 7.5 aphanitic, very silty; contains molds of fossils; weathers light-brown, silty surface; forms prominent ledge with sharp edges and straight faces

Limestone, light-olive-gray, aphanitic, hard; beds average 6 in.; contains oöids; contains fossils (crinoids); weathers dusky-yellow, oölitic

Concealed, probably pale-reddish-brown mudstone

Limestone, pale-brown or very pale brown, coarse-grained, soft; beds average $1 \mathrm{ft}$, with thin, mud parting planes and fucoidal structures in many places; contains abundant fossils, especially at base (trilobite, gastropods, brachiopods); weathers same or pale-yellow; forms weak ledges ---.-----.--

Claystone, very pale brown, shaly, calcareous; cross-laminated on small scale; weathers pale-brown and reddish-gray, ripple- and irregularly bedded limestone, contains some mud films; weathers same -.----

Claystone, pale-reddish-brown, slightly silty, crumbly; lacks bedding; forms slope --.--..-

Conglomerate, fills erosion channels

Matrix: dark-brown silt.

Gravel: jasper, chert, and other durable materials; average diameter 2 in., maximum 6 in.; well-rounded.

$$
\begin{aligned}
& \text { Total Watahomigi Formation }-\overline{177.5} \\
& \text { Total Supai Group - } \\
& \hline
\end{aligned}
$$

Unconformity.

9.0 Redwall Limestone. 
Section 24

\section{ANDRUS CANYON}

[Upper part measured on canyon wall about 2 miles southeast of Grassy Mountain; lower part on southwest side of canyon, west of fault zone about 9 miles southeast of Grassy Mountain]

Hermit Shale:

Concealed, long slope; probably mostly shaly, red-brown siltstone

Contact:

Not well-exposed, but apparently flat, even surface.

Supai Group:

Esplanade Sandstone, upper cliff-slope unit (part):

Sandstone, grayish-orange-pink to moderateorange-pink, very fine grained, with scattered fine grains ( 26 percent); limy (49 percent), cross-stratified on large scale (laminae 20-30 ft long); very resistant; forms straight face with black varnish; makes massive cap rock of cliff; thickness of $55 \mathrm{ft}$ at about $2 \mathrm{mi}$. farther east

Sandstone, moderate-reddish-orange, very fine grained, friable, thin- , flat-bedded; forms slope

Sandstone, grayish-orange-pink, very fine grained, dolomitic (38 percent); weakly cross-stratified, medium-scale; weathers yellowish; forms base of cliff unit

Total upper cliff-slope unit (part), Esplanade Sandstone --.

Erosion Surface.

Esplanade Sandstone, upper cliff-slope unit, gypsiferous facies:

Sandstone, moderate-reddish-brown, very fine grained, friable, flat-bedded, largely concealed; forms slope

Gypsum, white, bedded; and moderate-reddish-orange, very fine grained, calcareous (37 percent), friable, sandstone stratified on small scale near top; forms weak cliff --.-.-.-

Siltstone, moderate-reddish-brown, argillaceous, shaly; forms slope

Sandstone, moderate-reddish-orange, very fine grained, silty (27 percent), calcareous (31 percent), cross-stratified on medium scale; forms cliff

Concealed, talus slope; flat-bedded sandstone, moderate-reddish-orange, locally exposed ---
Section 24-Continued

ANDRUS CANYON-Continued

Supai Group-Continued

Esplanade Sandstone, upper cliff-slope unit, gypsiferous facies-Continued

Sandstone, moderate-reddish-orange, very fine grained, dolomitic (34 percent); thin to medium bedding sets $(0.5-2 \mathrm{ft})$; massive units cross-stratified; friable; includes some thin mudstone and siltstone beds; forms weak ledges and slopes -------or cliff-slope unit,
Total upper gypsiferous facies, Esplanade Sandstone ---.-.-.-.-.-.-.

Total upper cliff-slope unit, Esplanade Sandstone --------- 149.0

Esplanade Sandstone, main cliff unit:

Sandstone, moderate-orange-pink, very fine grained, limy; weathers to gray, rough surface; forms resistant cap rock

Siltstone, moderate-reddish-orange, fissile, shaly; forms bench

Sandstone to dolostone, pale-red to palereddish-brown, very fine grained (angular to subangular), dolomitic (50 percent), friable; forms massive, cross-stratified units (laminae $40 \mathrm{ft}$ long); weathers to brown or light-gray, rounded ledges

Sandstone, pale-reddish-brown, very fine grained, thin-bedded (6-12 in.), flat-bedded; forms slope

Sandstone, moderate-reddish-orange to palereddish-brown, very fine grained, calcareous (25 percent); locally contains white kaolin specks; cross-stratified on large scale (tabular-planar) upper part, and medium scale (wedge-planar) lower part; locally contains recesses of thin, shaly, moderatereddish-orange siltstone; forms massive cliff -

Dolostone, grayish-orange-pink, granular, insoluble ( 20 percent), flat-bedded; forms bench

Sandstone, pale-reddish-brown and grayishpink, laminated, medium- to very fine grained (subrounded), poorly sorted, calcareous (35 percent); wedge-planar crossstratification (medium-scale); forms massive sets (10-15 ft thick); uppermost part granular, pale-reddish-brown dolomite; total weathers to gray-brown surface; forms cliff -- 


\author{
Section 24-Continued \\ ANDRUS CANYON-Continued
}

Supai Group-Continued

Esplanade Sandstone, main cliff unit-Continued Sandstone, moderate-reddish-orange, very fine grained (angular grains), calcareous (22 percent), silty ( 25 percent), massive; contains layers with abundant brown sand concretions (0.5-0.75 in. diameter); forms rounded ledge with conspicuous pale-gray surface ----

Total main cliff unit, Esplanade Sandstone

Esplanade Sandstone, basal slope unit:

Concealed, talus slope with local outcrops of shaly, dark-reddish-brown mudstone --.-----

Sandstone, moderate-reddish-orange, very fine grained, silty ( 37 percent), calcareous (35 percent); forms small cliff

Concealed, talus slope with local outcrops of shaly dark-reddish-brown mudstone --.--_--

Sandstone, moderate-reddish-orange, very fine grained (angular grains), calcareous (39 percent), cross-stratified, tabular-planar on large scale (laminae $50 \mathrm{ft}$ long) in upper part; wedge- and tabular-planar, small- to medium-scale near base; forms prominent cliff

Total basal slope unit, Esplanade Sandstone

Total Esplanade Sandstone

Wescogame Formation, slope unit:

Sandstone, moderate-reddish-orange, very fine grained, silty (13 percent), dolomitic (32 percent), thin-bedded (1-2 ft), flat-bedded; forms ledges at base of cliff

Sandstone, moderate-reddish-brown, very fine grained; includes sandy (40 percent) limestone; forms series of ledges, 1-2 ft thick; mostly concealed

Concealed, slope, probably shaly siltstone --..--

Sandstone, moderate-reddish-orange, very fine grained, massive; surface locally black; forms weak ledge

Sandstone, pale-reddish-brown, very fine grained, calcareous, friable; prominent scour-and-fill bedding; forms weak cliff --.---

Total slope unit, Wescogame Formation

Feet
Supai Group-Continued

Wescogame Formation, cliff unit:

Sandstone, moderate-reddish-orange, very fine grained, calcareous (37 percent), silty, crumbly, medium-bedded (1-2 ft); weathers red-brown; forms rounded, receding ledges; partly concealed

Sandstone, moderate-reddish-orange, very fine grained, calcareous, weakly cross-stratified on large-scale (units 10-15 ft); forms massive cliff

Concealed slope

Sandstone, pale-reddish-brown, very fine grained, calcareous; massive bed; weathers to rounded black surface; forms part of cliff -

Siltstone, brown to white, laminated, friable; forms recess

Total cliff unit, Wescogame
Formation - $-\frac{73.5}{129.0}$

Manakacha Formation, slope unit:

Limestone, pale- to dark-gray, very sandy; planar cross-strata etched out on surface; forms cliff

Limestone, purple, sandy, thin- to mediumbedded $(0.5-2 \mathrm{ft})$; forms two receding ledges -

Concealed slope

Sandstone, grayish-orange-pink, very fine grained, limy (20 percent), weakly crossstratified; surface black; forms rounded ledge

Sandstone, light-brownish-pink, silty, limy, thin- to medium-bedded $(0.5-2 \mathrm{ft})$; forms series of receding ledges

Concealed slope

Total slope unit, Manakacha Formation

Manakacha Formation, cliff unit:

Limestone, grayish-pink, very limy; and siltstone with cross-strata etched out on surface; forms cliff

Limestone, grayish-pink with yellowish-gray, sandy (very fine grained, scattered mediumgrains), sandstone; weakly cross-stratified in upper part; forms rounded ledge -.-.--.---.--..

Sandstone, grayish-orange-pink, very fine grained, limy (31 percent), friable, thinbedded (6-12 in.); forms rounded ledges on bench
Feet 
Section 24-Continued

\section{ANDRUS CANYON-Continued}

Supai Group-Continued

Manakacha Formation, cliff unit-Continued

Limestone, medium-light-gray, mediumgrained, sandy; planar cross-stratified; forms cliff

Limestone, dark-olive-gray, very fine grained; contains abundant jasper (50-60 percent); weathers to pitted surface; forms part of cliff

Limestone, medium-light-gray with light-olivegray, very fine grained, very sandy; planar cross-strata etched out on surface; weathers dark-brown to black; forms cliff -

Limestone, dolomitic, medium-light-gray, very fine grained; weathers to rough gray surface; contains jasper bands; forms base of large cliff

Concealed slope

Limestone, grayish-red-purple, streaked, silty, very fine grained, irregularly bedded; contains jasper lenses; forms ledge

Siltstone, brown to white, laminated, friable; forms bench

Limestone, medium-light-gray, very fine grained; weathers to pitted surface; contains abundant, irregular, jasper lenses; forms weak ledge

Concealed slope

Limestone, purple to gray, fine-grained, irregularly bedded; contains jasper lenses; forms ledge

Siltstone, brown, laminated, friable; forms bench and slope -.-_-

Limestone, medium-light-gray, streaked, finegrained, silty; contains jasper lenses; forms ledge

Siltstone, brown to white; laminated; friable; forms slope

Siltstone, light-brownish-gray, streaked, very limy, irregularly bedded; contains jasper lenses; forms ledge

Siltstone, brown; laminated, friable; forms slope --_--_-

Limestone, light-brownish-gray with yellowish-gray streaks, fine-grained, irregularly bedded; contains jasper lenses; forms ledge ---

Sandstone, grayish-orange-pink, very fine grained, very calcareous; compound planar cross-stratified on medium scale $(3-15 \mathrm{ft})$; weathers to black face; forms base of cliff with underlying bed

Section 24-Continued

\section{ANDRUS CANYON-Continued}

Feet

Supai Group-Continued

Manakacha Formation, cliff unit-Continued

Limestone, very pale gray with dark-reddishbrown, very fine grained, sandy; planar cross-stratified; contains prominent jasper bands; forms base of cliff with overlying bed

Total cliff unit, Manakacha For-

$$
\text { mation ---_- }
$$$$
\text { Total Manakacha Formation ---- } 226.5
$$

Watahomigi Formation:

2.0

6.0

5.5
Limestone, moderate-reddish-orange with pale-greenish-gray, very fine grained, silty, laminated, friable; contains rows of hard, brown, concretionary limestone masses; forms bench and recess --_- 5.0

Limestone, pale-greenish-gray with streaks of light-brownish-gray, fine-grained, silty; contains abundant irregular bands of jasper forming as much as 70 percent of rock; forms resistant ledge -

Siltstone, grayish-reddish-brown, shaly, calcareous, weakly developed laminae; weathers brown to black; forms weak cliff and slope --

Limestone, dolomitic, dark-grayish-red to purple, very fine grained, very silty, irregularly bedded; contains jasper bands and concretions; forms weak ledge and slope ---.----

Concealed slope ---amestone, dolomitic, moderate-reddishbrown, silty, brittle, structureless; weathers vermilion; forms slope - -

Concealed slope ---olctic, pale-reddish-purple, silty,
Dolostone, calcitis coarse- to medium-grained; weathers to black ledge

Claystone, purple, structureless, brittle; forms slope

Limestone, medium-light-gray, coarse- to medium-grained, silty; forms ledge -...-...--

Limestone, olive-gray, aphanitic, irregularly bedded, crumbly; contains much jasper; forms slope, largely concealed --..--...--..-

Limestone, yellowish-gray, fine-grained with scattered large crystals as much as $2 \mathrm{~mm}$, silty, medium-bedded (1-4 ft); contains jasper bands near top; weathers to darkgray; forms ledge -Concealed slope
Feet

\author{
(1)
}

24.0

16.5 
Section 24-Continued

\section{ANDRUS CANYON-Continued}

Supai Group-Continued

Watahomigi Formation-Continued

Limestone, light-brownish-gray, coarsegrained, with scattered crystals as large as $3 \mathrm{~mm}$, medium-bedded ( $1-3 \mathrm{ft}$ ); weathers to dark-gray, silty surface; forms ledge

Concealed slope; probably red-brown mudstone

Limestone, medium-light-gray, coarse- to medium-grained, with a few crystals as much as $3 \mathrm{~mm}$; medium-bedded ( $1-3 \mathrm{ft}$ ); forms ledge

Claystone, purple, structureless, brittle; forms slope, largely concealed

Conglomerate, purple to gray, thin-bedded; contains fish tooth, abundant Composita; forms weak ledge

Matrix: pale-reddish-purple limestone.

Pebbles: commonly $0.25-0.5$ in. in diameter, many 0.13 in. in diameter; wellrounded; pale-reddish-brown siltstone, olive-gray limestone and pale-red limestone.

Limestone, grayish-pink, aphanitic, very silty, structureless, brittle; forms slope - -

Limestone, grayish-pink with pale-reddishbrown spots, coarse- to very coarse grained, thin-bedded (0.5-1 ft); contains abundant fossil fragments, especially crinoids; weathers to dark-gray; forms receding ledges $2-4.0$

Total Watahomigi Formation -- 164.0

Total Supai Group -

Unconformity:

Even, regular surface where observed. Local depressions as deep as $4 \mathrm{ft}$ filled with clastic limestone of Supai.

\section{Redwall Limestone:}

Horseshoe Mesa Member:

Limestone, yellowish-gray, aphanitic to very fine grained, thin- to medium-bedded; forms receding ledges.
Section 25

\section{TWIN SPRINGS CANYON}

[Lower part measured on west side of canyon; Esplanade Sandstone measured on east side]

Hermit Shale:

Basal unit: slope with thin ledges.

Siltstone, reddish-brown, thin-bedded (2-24 in.); forms weak ledges, each 2-6 ft thick; and pale-reddish-brown, slightly calcareous, shaly mudstone; forms slopes between ledges; total forms long slope, much concealed

Contact:

Conformable where observed; even, flat surface for 0.25 mile.

Supai Group:

Esplanade Sandstone, main cliff unit:

Sandstone, very pale orange, very fine grained, (includes much fine-grained sand), calcareous, thick-bedded (3-4 ft); massive; weathers to prominent cliff with rounded edges -----

Sandstone, moderate-reddish-orange, very fine grained (subrounded), calcareous, shaly to weakly thin-bedded; forms slope

Siltstone, buff; contains many trace fossils (tubes $0.13 \mathrm{in}$. in diameter extending vertically); forms resistant ledge

Sandstone, moderate-reddish-orange, very fine grained, friable, cross-stratified on medium scale; forms weak ledge or slope with redbrown siltstone at base

Sandstone, moderate-orange-pink, very fine grained (subrounded), calcareous, very friable, cross-stratified on medium scale; forms slope

Sandstone, moderate-orange-pink, very fine grained (subrounded), calcareous, thinbedded (6-12 in.); bedding weak and irregular, locally shaly; forms slope

Concealed slope

Sandstone, grayish-orange-pink, very fine grained, limy, contains many trace fossils (vertical tubes $0.13 \mathrm{in}$. in diameter); forms resistant ledge 
Section 25-Continued

TWIN SPRINGS CANYON-Continued

Supai Group-Continued

Esplanade Sandstone, main cliff unit-

Continued

Sandstone, moderate-reddish-orange, very fine grained (subrounded), calcareous, structureless; commonly forms slope, locally weak ledges; contains a thin, weak ledge of very friable yellow-brown sandstone; very fine grained, limy; total forms slope, much concealed

Sandstone, moderate-orange-pink, very fine grained, platy, calcareous, friable, crossstratified on medium scale; forms weak ledge

Siltstone, reddish-brown, shaly; forms slope ----

Sandstone, moderate-reddish-orange, very fine grained, calcareous, friable; medium-bedded $(1-3 \mathrm{ft})$; forms weak ledge

(Line of section crosses fault at this point)

Sandstone, grayish-orange-pink, very fine grained, (includes much fine-grained sand), very limy; grades into sandy limestone; cross-stratified on medium scale; weathers gray with laminae etched out; forms ledge ----

Concealed slope

Limestone, grayish-orange-pink, very sandy, cross-stratified on medium to large scale, planar-type; weathers to gray surface with red laminae and sand grains etched out; forms ledge

Sandstone, moderate-orange-pink, very fine grained (subrounded), calcareous, structureless; forms rounded ledge

Sandstone, moderate-orange-pink, very fine grained (subangular), locally very limy; cross-stratified on medium to large scale, tabular- and wedge-planar, some crossstrata 20-30 ft long; locally weathers to sugary surface; forms cliff with rounded edges

9.0

11.0

6.5

Sandstone, moderate-orange-pink, very fine grained, limy, poorly sorted, cross-stratified on medium scale, planar-type; weathers to brown surface; forms straight ledge --..--..-

Limestone, light-brownish-gray, very sandy, poorly sorted, medium-bedded (1-2 ft); weathers blue-gray with sand grains etched out on surface; forms rounded ledges

Feet

Section 25-Continued

TWIN SPRINGS CANYON-Continued

Supai Group-Continued

Esplanade Sandstone, main cliff unit-

Continued

Limestone, pale-reddish-brown with brown laminae, sandy (fine- to very fine grained); cross-stratified on medium scale, tabularplanar type; weathers to straight, darkbrown face; forms base of main cliff

Total main cliff unit, Esplande

$$
\text { Sandstone }
$$

(Underlying units measured on west side of canyon)

Esplanade Sandstone, basal slope unit:

Concealed slope; locally shows some palereddish-brown, calcareous, crumbly mudstone

Sandstone, pale-reddish-brown, very fine grained, limy, structureless; weathers to sheer face; forms resistant ledge -

Concealed slope

Sandstone, pale-reddish-brown, very fine grained, very calcareous, friable; forms rounded boulderlike surface on slope --_-_---

Sandstone, moderate-reddish-orange with pale-reddish-brown specks, very fine grained (subrounded), limy, thick-bedded $(2-4 \mathrm{ft})$; contains abundant lime nodules $(0.5-1$ in. diameter) in upper layers; forms weak cliff -..

Siltstone, pale-reddish-brown, sandy, calcareous, shaly; contains rain pits; includes a few thin (6-24 in.) ledges of thin-bedded siltstone; total forms slope

Sandstone, pale-reddish-brown, very fine grained (subangular), calcareous, friable, flat-bedded; contains thin conglomerate lenses and scattered limestone pebbles; forms weak ledges 1-2 ft thick on slope ------

Sandstone, pale-reddish-brown, very fine grained, limy, silty, thin- to medium-bedded (1-36 in.); fills channels in underlying rock to depth of $35 \mathrm{ft}$, together with tongues and wedges of brownish-gray conglomerate that forms rude beds along margins and in bottom of channel; beds fit topography of underlying surface, dipping steeply on channel margins; total forms cliff with straight face; thickness of channel fill 


\section{Section 25-Continued} TWIN SPRINGS CANYON-Continued

Supai Group-Continued

Esplanade Sandstone, basal slope unit-

Continued

Pebbles: dark-gray, pale-gray, and olivegray limestone, pale- and dark-reddishbrown siltstone; subangular to wellrounded; spheroidal to ellipsoidal; average diameter $0.25-0.5 \mathrm{in.,}$ maximum $1.5 \mathrm{in.}$

Matrix: sandstone, fine- to very fine grained; moderate-reddish-brown; much calcite cement locally.

$$
\begin{aligned}
& \text { Total basal slope unit, Esplanade } \\
& \text { Sandstone - - 85.0-120.0 } \\
& \text { Total Esplanade Sandstone ----- } 419.0
\end{aligned}
$$

Unconformity:

Channel approximately $500-700 \mathrm{ft}$ wide, $35 \mathrm{ft}$ deep cut through upper two beds of Wescogame slope unit, largely filled with conglomerate.

Wescogame Formation, slope unit:

Sandstone, pinkish-gray, speckled with palereddish-brown, very fine grained (subangular), calcareous, medium- to thickbedded (2-3 ft); locally cross-stratified on small scale, elsewhere massive; weathers to rounded surface with brown varnish in places; forms resistant ledge

Sandstone, moderate-orange-pink, very fine grained, calcareous, cross-stratified on large scale (foreset 30-50 ft long); weathers brightreddish-brown; forms weak cliff

$$
\text { Total slope unit, Wescogame }
$$$$
\text { Formation }
$$

Wescogame Formation, cliff unit:

Sandstone, pale-reddish-brown with palereddish-brown specks, very fine grained (subrounded), calcareous, flat-bedded, thinto medium-bedded (2-24 in.); locally shaly; forms weak cliff

Sandstone, pale-reddish-brown, calcareous, friable, thick-bedded; forms upper part of bench, concealed below

Sandstone, gray, very fine grained (subrounded), scattered medium grains, limy, thin- to medium-bedded $(0.5-2 \mathrm{ft})$; flatbedded; forms weak cliff

Feet
Supai Group-Continued

Wescogame Formation, cliff unit-Continued

Sandstone, grayish-red, very fine grained, muddy, noncalcareous, silty; locally contains worm borings and small limestone nodules; alternating with pale-red, very fine grained, limy sandstone; each unit in beds $0.5-1 \mathrm{ft}$ thick; total forms receding ledges or bench

Limestone, pale-reddish-brown, very fine grained, sandy, prominently cross-stratified on medium scale, planar- and compoundtypes (sets 1-3 ft thick); cross-strata etched on surface; upper surface contains scattered mudstone pebbles, $0.25-1 \mathrm{in}$. in diameter, subangular to subrounded; forms ledge with sheer face

Sandstone, conglomeratic, pale-reddishbrown, mostly very fine grained, limy, weakly cross-stratified; contains abundant pebbles of dark-gray limestone, a few brown siltstone pebbles, and some elongate limestone nodules all in upper part; average diameter of pebbles $0.25-0.5$ in., maximum 2 in.; weathers to black varnished surface; forms rounded ledge

Total cliff unit, Wescogame Formation -- 77.5 Total Wescogame Formation ---- $\overline{112.0}$

Manakacha Formation, slope unit:

Limestone, grayish-red, muddy (10 percent), irregularly bedded; layers $2-3 \mathrm{ft}$ thick; alternating with pale-reddish-brown, sandy, limy, structureless siltstone; forms weak, rounded ledges, 2-3 ft thick; total forms bench

Sandstone, grayish-orange-pink with palereddish-brown laminae, very fine grained, very limy (44 percent), thin- to mediumbedded $(0.5-3 \mathrm{ft})$; locally cross-stratified on small to medium scale; contains a parting of reddish-brown shaly mudstone $12 \mathrm{ft}$ above base; forms prominent cliff

6.5 Sandstone, pale-reddish-brown, very fine grained, limy (31 percent), thin-bedded

(2-12 in.) to shaly; forms bench --anakacha
Total slope unit, Manak Formation 
Section 25-Continued

TWIN SPRINGS CANYON-Continued

Supai Group-Continued

Manakacha Formation, cliff unit:

Sandstone, pale-reddish-brown, very fine grained, limy (25 percent); weakly developed, medium-scale cross-stratification; laminae locally horizontal; units $0.5-3$ $\mathrm{ft}$ thick; locally weathers with black varnish; forms prominent cliff

Limestone, pale-reddish-brown, very sandy (fine-grained); cross-stratified on medium to large scale, planar- and compound-types; contains fusulinds (Eoschubertella); forms ledge

Sandstone, pale-reddish-brown, very fine grained, limy, flat-bedded, thin- to mediumbedded $(0.5-3 \mathrm{ft})$; weathers dark-brown; forms bench or recess

Sandstone, pale-reddish-brown, very fine grained, very limy (49 percent), crossstratified on medium to large scale; planarand compound-types; weathers brown to pink with cross-strata prominently etched on surface; forms cliff

Limestone, light-brownish-gray, silty (25 percent), aphanitic; contains bands of jasper along bedding planes and also crosscutting beds; forms part of cliff

Limestone, dark-gray; concretionary with dark-reddish-brown siltstone matrix; forms recess

Siltstone, light-brownish-gray, limy (42 percent), hard; cross-stratified on medium scale; weathers to black vertical face; forms base of main cliff

Sandstone, light-brownish-gray, very fine grained, calcareous, friable, gnarly bedded; forms slope

Limestone, olive-gray, aphanitic, mediumbedded (6-24 in.); contains bands of jasper; forms weak ledges

Concealed slope; contains nodular limestone with shaly siltstone at top ---

Limestone, blue-gray, silty, flat-bedded; contains bands of jasper; forms receding ledges, $1-2 \mathrm{ft}$ thick
Section 25-Continued

TWIN SPRINGS CANYON-Continued

Feet

Supai Group-Continued

Manakacha Formation, cliff unit-Continued

Limestone, medium-light-gray, very fine grained, sandy ( 30 percent), cross-laminated on small to medium scale; contains bands of jasper; weathers to black surface with laminae prominently etched out; forms uppermost of two prominent ledges ---------

Limestone, dark-brownish-gray, nodular, silty; forms recess between prominent ledges -

Siltstone, medium-light-gray and light-brownish-gray, aphanitic, very limy (45 percent); contains very irregular masses of chert and jasper, which weather dark-brown; forms lower of two prominent ledges ---.---.-------

Limestone, light-brownish-gray, nodular, silty ( 35 percent); forms bench and recess --.-.

Limestone, medium-gray, silty (23 percent), aphanitic; contains bands of jasper; forms

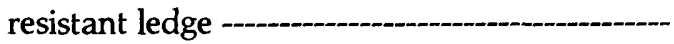

Limestone, pale-reddish-brown, very fine grained, silty (37 percent), nodular; contains lenses of jasper and crumbly, brown siltstone; forms slope, partly concealed, and recess - - -

Siltstone, light-brownish-gray, limy (38 percent), fine-grained, hard; weathers to black face; forms resistant ledge --- 4.5

Total cliff unit, Manakacha Formation -- 178.5

Total Manakacha Formation ----- 243.0

Watahomigi Formation:

Concealed slope -

Limestone, medium-gray, aphanitic; contains very irregular masses of jasper; weathers to rough surface; forms resistant ledge --..--..-

Concealed slope

Limestone, purple, speckled with red, finegrained, cross-stratified on medium scale; contains jasper; forms receding ledges -----.--Concealed slope

Limestone, light-gray, aphanitic with scattered coarse grains in lower part, thickbedded (3-8 ft); contains brachiopod outlines and scattered concretions of jasper; weathers to rough, pitted surface; forms upper part of cliff
49.5

3.5

4.5

8.0

4.0

36.0 
Section 25-Continued

\section{TWIN SPRINGS CANYON-Continued}

Supai Group-Continued

Watahomigi Formation-Continued

Limestone, very light gray, very fine grained, silty (40 percent), laminated and crosslaminated on small scale; contains abundant beds of chert, which weather black, giving unit dark conspicuous face; forms part of cliff

Limestone, pinkish-gray, fine- to mediumgrained, medium- to thick-bedded $(2-6 \mathrm{ft})$; contains scattered bands of jasper; weathers to rough, dark-gray surface; forms base of prominent cliff, which separates lower Watahomigi in about middle

Concealed slope

Limestone, medium-gray, crystalline to aphanitic, thin-bedded (6-24 in.); contains numerous brachiopods (Composita sp.); contains scattered bands of nodular jasper; forms ledge

Mudstone, pale-reddish-brown, calcareous, very brittle; forms slope

Limestone, medium-gray, fine-grained, thinbedded (2-4 in.); contains numerous brachiopods (Derbyia, Spirifer, Composita); forms weak ledge --_-_-

Limestone, medium-gray, muddy, shaly; weathers reddish-brown; forms slope --..-.

Limestone, medium-gray, very fine grained, thin-bedded (0.5-12 in.); contains dark siliceous stringers

Claystone, light-brownish-gray, shaly, very calcareous, very brittle; forms slope, partly concealed

Conglomerate, very pale orange and palereddish-brown, forms ledge --.-_-_-_-_-

Pebbles: gray limestone and reddish-brown siltstone; average diameter $0.5-1$ in.; rounded.

Matrix: buff siltstone.

Siltstone, pale-reddish-brown, silty, calcareous, fissility weakly developed; forms slope --

Mudstone, grayish-red-brown, noncalcareous, brittle, structureless; forms slope --- $\quad 3.5$

Total Watahomigi Formation -- $-\frac{199.0}{97.0}$

Total Supai Group -

Contact:

Unconformity assumed; surface poorly exposed.

Feet

6.5

16.0

11.0

10.5

1.0
Section 25-Continued

TWIN SPRINGS CANYON-Continued

Redwall Limestone:

Horseshoe Mesa Member:

Limestone, yellowish-gray, aphanitic, thinbedded (1-2 ft); weathers to rough surface; forms receding ledges Not measured

Section 26

\section{0}

13.0

face of recent erosion.

Pakoon Limestone, cliff unit:

Sandstone, moderate-reddish-brown and gray in irregular bands, very fine grained, medium-bedded (1-3 ft); contains smallscale cross-stratification; hard; forms resistant cap

Sandstone, pale-red, very fine grained, limy ( 30 percent), medium-bedded (1-2 ft); contains parting zones of crumbly, red-brown, very fine grained sandstone; similar to underlying sandstone bed but forms slope with steplike ledges --.--..--

Sandstone, grayish-pink, aphanitic, limy (35 percent), thick-bedded (2-4 ft), massive, weakly cross-stratified locally; weathers reddish-brown or with black varnish; forms rounded, receding ledges -

Cliff unit, part, Pakoon Limestone -..--

Pakoon Limestone, slope unit:

Sandstone, moderate-reddish-brown, very fine grained, structureless; weathers to rounded surface; forms weak ledge or slope -

Sandstone, moderate-reddish-orange, very fine grained, calcareous (30 percent), thickbedded (2-3 ft); contains wedge-planar cross-stratification, medium-scale $(5-10 \mathrm{ft}$ long); contains abundant worm borings (diameter $0.25 \mathrm{in}$.); forms series of receding ledges

Sandstone, pale-reddish-brown, aphanitic, very limy (44 percent), very resistant, medium-to thick-bedded (1-8 ft); forms resistant cliff 
Section 26-Continued

\section{GUANO CAVE-Continued}

Pakoon Limestone, slope unit-Continued

Claystone, pale-reddish-brown, shaly, crumbly; forms bench --.-.-.-.-.-.

Limestone, pale-reddish-brown, aphanitic, silty, (10 percent), platy, thin- to mediumbedded (1-3 ft); contains tabular-planar cross-stratification; brown, silty laminae etched on surface; forms ledge -

Sandstone, grayish-orange-pink, very fine grained, friable, structureless; weathers to gray, rounded surface; forms ledge --..........-

Limestone, pale-reddish-brown, aphanitic, very sandy (33 percent), platy, hard, medium-bedded (1-3 ft); contains planar cross-stratification; forms ledge

Conglomerate, pale-reddish-brown, forms part of ledge

Gravel: limestone, gray, brown and white, and siltstone, pink and gray; rounded to subrounded; diameter maximum 2 in., average $0.5-1$ in.; contains local concentrations of a large pelecypod.

Total slope unit, Pakoon LimeTotal Pakoon Limestone ----- $\frac{65.0}{117.5}+$

\section{Supai Group:}

Wescogame Formation, cliff and slope units undifferentiated:

Limestone, light-brownish-gray, aphanitic, sandy (18 percent), resistant, mediumbedded (1-3 ft); contains flat to irregular laminae in part, planar cross-strata in part; brown, silty laminae etched on surface; contains abundant pelecypods in thin zone $5 \mathrm{ft}$ above base; forms ledge

Sandstone, pinkish-gray, very fine grained (subrounded to subangular), mediumbedded (1-3 ft), structureless; weathers to brown, rounded surface; forms base of cliff --

Sandstone, pale-reddish-brown, very fine grained, limy (39 percent), friable, thinbedded (6-12 in.); partly flat-bedded, partly cross-bedded, planar-type; weathers to rounded surface; forms prominent bench ----Limestone, grayish-pink, aphanitic, sandy (14 percent); contains wedge-planar crossstratification on medium scale; brown, silty laminae etched on surface; forms weak ledge
Feet

Section 26-Continued

GUANO CAVE-Continued

Supai Group-Continued

Wescogame Formation, cliff slope units undifferentiated-Continued

Sandstone, pale-reddish-brown, very fine grained, very limy (35 percent), flat-bedded, medium-bedded (1-2 ft); weathers to weak, rounded ledge or bench

Limestone, pale-reddish-purple, silty (17 percent), aphanitic with siltstone partings, hard, platy; contains wedge-planar crossstratitication on medium to large scale; brown, silty laminae etched on surface; forms slope and weak ledges (3-4 ft thick) ---Conglomerate, pale-gray, ledge-forming -------Gravel: limestone, reddish-brown, white, gray; and chert, white, buff; and siltstone, gray; diameter maximum 2 in., average 0.25-0.5 in.; mostly subrounded to rounded.

Matrix: coarse-grained limestone.

$$
\text { Total Wescogame Formation ----- }
$$

Manakacha Formation, slope unit:

Sandstone, grayish-orange-pink to palereddish-brown, very fine grained, thin, platy, limy, cross-stratified, medium-scale (5-10 ft long, wedge-planar); forms series of weak ledges

Sandstone, grayish-orange-pink, very fine grained, calcareous (30 percent), crumbly, weathers pink to white, platy (beds 0.25-1 in.); forms slope

Sandstone, grayish-orange-pink, very fine grained, very silty $( \pm 50$ percent $)$, friable, calcareous, like overlying bed but thin- to medium-bedded (0.5-2 ft); forms series of receding ledges or slopes ------.----

Total slope unit, Manakacha Formation ------_--_--

Manakacha Formation, cliff unit:

Sandstone, pale-orange-pink, very fine grained, hard, calcareous ( 30 percent), thick-bedded (2-6 ft); planar cross-stratified throughout; forms cliff

Limestone, olive-gray, very fine grained, thickbedded (3-4 ft); contains jasper concretions; weathers gray; forms part of cliff 
Section 26-Continued

GUANO CAVE-Continued

Supai Group-Continued

Manakacha Formation, cliff unit-Continued

Sandstone, very pale orange, very fine grained, hard, limy (40 percent), thick-bedded (2-6 $\mathrm{ft}$ ); planar cross-stratified on medium to large scale throughout; forms major cliff --.--Limestone, olive-gray, very fine grained, sandy (45 percent), cross-stratified on medium scale; locally contains chert concretions; weathers dark-gray; forms ledge

Conglomerate, possible marker bed; deposited on erosion surface and in channels cut into underlying limestone

Matrix: very fine grained, olive-gray limestone.

Pebbles: medium-light-gray and olive-gray chert and red jasper, angular, mostly 0.13-0.25 in. in diameter, maximum diameter 1 in.

Limestone, medium-light-gray, very fine grained with scattered large crystals, resistant, medium-bedded ( $1-3 \mathrm{ft}$ ), silty ( 30 percent); locally cross-stratified; includes thin partings or recesses of red, shaly siltstone; contains abundant lenses and irregular beds of jasper; forms series of ledges -------

Total cliff unit, Manakacha Formation

Total Manakacha Formation ----- $\frac{161.0}{210.0}$

Watahomigi Formation, upper slope unit:

Siltstone, pale-reddish-brown to grayish-redbrown to grayish-green, shaly; contains flattened, silty, limestone balls scattered throughout; forms slope -

Siltstone, moderate-reddish-brown, very sandy, irregularly bedded; makes conspicuous marker; forms slope

Limestone, grayish-reddish-purple, very fine grained, silty ( 32 percent); concretionary; forms rounded ledge

Siltstone, pale-reddish-brown, limy (35 percent), shaly; includes several ledges of resistant siltstone containing limestone concretions; contains cusp-type ripple marks; forms slope

28.0

Feet
Supai Group-Continued

Watahomigi Formation, upper slope unit-

Continued

Limestone, medium-light-gray, fine-grained, thin-bedded; base contains abundant fusulinids(?), crinoids, brachiopods (Composita); forms weak ledges 6-12 in. thick; alternates with purple, shaly mudstone, locally contains limy pellets, $0.25-0.5 \mathrm{in}$. in diameter; forms slopes 2-4 ft thick; total forms slope --.-----Limestone, light-gray, conspicuously oolitic (1-2 mm diameters); forms weak ledge ------Limestone, magnesian, medium-light-gray, with light-olive-gray spots and streaks, very fine grained; contains abundant thin layers and lenses of jasper; forms series of small ledges (1-2 ft thick) separated by concealed slopes

Conglomerate, locally developed; contains intraformational limestone granules and pebbles (maximum $4 \mathrm{~mm}$ ); and mediumlight-gray limestone with light-olive-gray spots, very fine grained, thin-bedded (2-8 in.); locally contains abundant crinoids; forms rounded ledges -

Total upper slope unit, Watahomigi Formation --_-

Watahomigi Formation, middle cliff and lower slope units:

Limestone, light-gray, very fine grained; thickbedded (1-5 ft); contains lenses and concretions of jasper; forms small cliff

Limestone, pale-red-purple with gray blotches, fine-grained with scattered larger crystals, granular; forms rounded ledge

2.5 Limestone, olive-gray, very fine grained, thinbedded (6-30 in.); forms series of ledges or slope

2.0 Limestone, light-olive-gray, aphanitic to very fine grained; contains abundant conspicuous white chert bands composing as much as $\mathbf{8 0}$ percent of the rock; individual layers commonly $0.25-0.5 \mathrm{in}$. thick; forms ledge at top of cliff

Feet 


\section{Section 26-Continued GUANO CAVE-Continued}

\section{Supai Group-Continued}

Watahomigi Formation, middle cliff and lower slope units-Continued

Dolostone, very pale gray, with pale-reddishbrown bands, medium-grained, hard, crystalline, medium-bedded (1-2 ft); shows lamination with alternate layers leached on surface; rests with sharp but irregular contact on underlying unit; weathers dark-gray; forms cliff

Limestone, olive-gray, fine-grained, forms one massive bed; weathers gray; forms resistant cliff

Limestone, light-olive-gray, aphanitic, thinbedded (2-6 in.); forms recess

Limestone, light-olive-gray with pale-brown, fine-grained, hard, very thick bedded (5-15 $\mathrm{ft}$ ); grades upward into pale-olive-gray and pinkish-gray, medium-grained, sandy limestone; contains brachiopods and ostracodes (?); weathers to rough gray surface; forms sheer cliff

Limestone, grayish-pink to light-gray, aphanitic, thick-bedded (2-3 ft); contains many small (0.25-0.5 in.) orange to black chert nodules; forms ledges

Limestone, light-brownish-gray, mediumgrained, locally crystalline; weathers darkgray; forms ledge

Concealed slope

Limestone, medium-light-gray, aphanitic, with scattered crystals as much as $0.6 \mathrm{~mm}$ in diameter, thin-bedded (0.5-1 ft); contains scattered fragments of chert $0.25-0.5$ in. in diameter; forms receding ledges

Limestone, pale-grayish-pink, coarse-grained, thick-bedded ( $2-4 \mathrm{ft})$; forms resistant ledge -.-

Limestone, pinkish-gray, fine-grained, thinbedded $(1 \mathrm{ft})$; weathers to rough surface; forms receding ledges

Limestone, grayish-pink, very fine grained; contains light-brownish-gray and olive-gray pellets and fragments of intraformational origin, mostly $2-4 \mathrm{~mm}$ in diameter, maximum diameter 1 in.; forms ledge --..-..--

Sandstone, pale-reddish-brown, very fine grained, soft; forms slope, largely concealed
Section 26-Continued

GUANO CAVE-Continued
Feet

28.5

4.0

5.5

9.0

11.0
Supai Group-Continued

Feet

Watahomigi Formation, middle cliff and lower slope units-Continued

Siltstone, pale-pinkish-gray, structureless, hard, quartzitic; weathers to dark-brown varnished surface; forms ledge

Limestone, light-olive-gray, very fine grained, very sandy, hard, medium-bedded (1-2 ft); contains abundant worm borings; forms resistant ledge

Mudstone, moderate-reddish-brown, crumbly, forms slope; largely concealed

Total middle cliff and lower slope units, Watahomigi Formation --- 162.0

Total Watahomigi Formation ---- 226.5

Total Supai Group and Pakoon Limestone

Unconformity:

Not recognized at this locality.

Redwall Limestone:

Horseshoe Mesa Member:

Limestone, yellowish-gray, aphanitic, mediumbedded (1-2 ft); weathers to rough, pitted surface; forms receding ledge Not measured

\section{Section 27}

\section{SNAP CANYON}

[Grand Wash Cliffs; measured in Snap Canyon about 5 miles south of Grand Gulch Mine]

Hermit Shale:

Sandstone, moderate-reddish-orange, very fine grained; thick-bedded $(1-3 \mathrm{ft})$; alternating with pale-reddish-brown, shaly, slope-forming mudstone; total forms slope with ledges ( 40 percent: 60 percent)

Contact: Surface of unconformity not noted here.

Supai Group:

Esplanade Sandstone, upper cliff-slope unit:

Sandstone, very pale orange to moderatereddish-orange, very fine grained (subangular), calcareous; cross-stratified on medium scale; forms resistant cap rock --..-_- 
Section 27-Continued

\section{SNAP CANYON-Continued}

Supai Group-Continued

Esplanade Sandstone, upper cliff-slope unit-

Continued

Siltstone, pale-reddish-brown, muddy; shaly near base, massive above; forms slope and weak ledge

Sandstone, moderate-reddish-orange, very fine grained (subangular), massive; locally cross-stratified; forms very resistant ledge --.-

Sandstone, pale-reddish-brown, very fine grained, very silty, resistant, ledge-forming, thin-bedded $(1-2 \mathrm{ft})$; alternating with palereddish-brown, silty, very thin bedded (1-2 in.) mudstone; slope-forming; contains shrinkage cracks and many worm borings; total forms slopes and ledges -

Sandstone, moderate-reddish-orange (local white layers in middle); fine- to very fine grained (subangular); cross-stratified on medium to large scale; cliff-forming ---------

Mudstone, pale-reddish-brown, silty, thickbedded $(2-4 \mathrm{ft})$; forms rounded ledge ---_---

Siltstone, pale-reddish-brown; includes some very fine grained, angular sand; shaly to thin-bedded (2-12 in.), slope-forming --.----

Sandstone, moderate-reddish-orange, calcareous, fine- to very fine grained; resembles basal bed; forms weak cliff

Mudstone, pale-reddish-brown, silty, thinbedded (2-6 in.), slope-forming --_-

Sandstone, moderate-reddish-orange, very fine grained (subangular), calcareous, friable; cross-stratified, medium-scale; forms weak, rounded cliff

Sandstone, moderate-reddish-orange, very fine grained (subangular), calcareous, thinbedded (1-2 ft), friable; forms slope and weak cliff with prominent bench at top -------

Sandstone, moderate-reddish-orange, very fine grained (angular); massive; forms cap rock ---

Sandstone, moderate-orange-pink, very fine grained, locally cross-stratified, weathers to shaly beds

Sandstone, moderate-reddish-orange, very fine grained (subrounded), silty, platy, slopeforming

Sandstone, moderate-orange-pink, very fine grained (subangular), calcareous, thinbedded (1-2 ft), friable; forms rounded ledges
Section 27-Continued

SNAP CANYON-Continued
Feet

Supai Group-Continued

Esplanade Sandstone, upper cliff-slope unit-

Continued

Siltstone, grayish-red, thin-bedded (2-6 in.) to shaly; alternating with grayish-orange-pink, very fine grained (subangular), calcareous, thin-bedded (2-12 in.) sandstone; moderately resistant; forms weak ledges ---.------
Total upper cliff-slope unit, Esplanade Sandstone ---.-_ 299.0

Total Esplanade Sandstone --.--- 299.0
Pakoon Limestone, cliff unit:

Limestone, light-brownish-gray, fine-grained, very thin bedded (0.5-2 in.), platy, sandy (10 percent); contains oöids $(2-4 \mathrm{~mm})$; weathers to smooth, even surface with 71.5 grayish-red laminae etched out; contains jasper concretions

9.5 Limestone, light-olive-gray, aphanitic, very thin bedded (0.5-1 in.); contains many brown chert concretions near top; (colonial $14.0 \quad$ corals at $21 \mathrm{ft}$ up; hexacorals and Favosites at top); forms receding ledges

Limestone, dolomitic, and limestone, light7.5 olive-gray, very coarse grained, thin- to thick-bedded (1-4 ft); fossiliferous (hexacorals at $8 \mathrm{ft}$ and above; many crinoids at $16 \mathrm{ft}$ ); weathers to series of rough, gray to brown ledges

Sandstone, grayish-orange, very fine grained with scattered fine grains (angular to subangular), calcareous; thick-bedded $(2-4 \mathrm{ft})$; weathers to dark-brown surface; cliffforming --.--

41.5 Limestone-magnesian, pale-reddish-brown, aphanitic, very sandy, cross-stratified on large scale, platy; sandy laminae etched on surface; forms weak cliff

Limestone, light-brownish-gray, mediumgrained, sandy; forms resistant cliff with rough surface

Dolostone, very pinkish gray, aphanitic, thinbedded $(0.5-2 \mathrm{ft})$; laminated upper part; weathers cream-colored; forms recess --.-----

Dolostone, calcitic, pale-yellowish-brown, aphanitic, very thick bedded $(5 \mathrm{ft})$; weathers rough, gray surface
Feet 
Section 27-Continued

SNAP CANYON-Continued

Pakoon Limestone, cliff unit-Continued

Limestone-dolomitic, olive-gray to pinkishgray, fine-grained, very fossiliferous (fusulinids, crinoids, brachiopod fragments; large hexacoral colonies at top), thin-bedded $(1-2 \mathrm{ft})$; forms weak cliff

Limestone, light-gray, medium-grained, thinbedded (1-2 ft), cliff-forming; weathers to rough, black surface

Limestone, olive-gray, aphanitic, thick-bedded $(2-4 \mathrm{ft})$; very fossiliferous near base (hexacorals, horn corals, crinoids, echinoid spines); weathers to yellow-brown cliff -...-.

Total cliff unit, Pakoon Limestone

Pakoon Limestone, slope unit:

Limestone, light-brownish-gray, mediumgrained; thin-bedded (2-6 in.) at base, irregularly bedded above; contains chert beds in middle; very fossiliferous (bryozoans, crinoids, echinoid spines, brachiopods); forms weak cliff and slope

Limestone, light-gray to grayish-red, mediumgrained, very sandy ( 25 percent angular, very fine grained), thin- to very thin bedded (0.5-6 in.), weakly-laminated; includes some grayish-orange-pink sandstone; weathers to slope or ledge

Conglomerate, light-olive-gray; forms rounded ledge

Matrix: light-olive-gray limestone, coarsegrained.

Gravel: limestone, dark-gray to olive-gray, rounded; mostly $0.25-1$ in. diameters.

Total slope unit, Pakoon Lime$\begin{array}{rr}\text { stone - } & 22.5 \\ \text { Total Pakoon Limestone -.- } & 199.5\end{array}$

Supai Group:

Wescogame Formation, slope unit:

Sandstone, pale-reddish-brown, very fine grained (subrounded) and pale-red, fine- to very fine grained, shaly, slope-forming sandstone; contains three beds of resistant, ledgeforming, light-brownish-gray, sandy limestone, each $2-3 \mathrm{ft}$ thick

Limestone, pale-red, aphanitic, sandy, crossstratified (medium- to large-scale), thickbedded (1-4 ft); sandy laminae etched prominently; forms cliff with pink to dark-brown surface
Section 27-Continued

SNAP CANYON-Continued

Feet

Supai Group-Continued

Wescogame Formation, slope unit-Continued Siltstone, grayish-red, flat-bedded, friable, slope-forming

Total slope unit, Wescogame

Formation

Wescogame Formation, cliff unit:

Sandstone, pale-reddish-brown, very fine grained (rounded), limy (30 percent); forms cliff

Sandstone, pale-red, calcareous (28 percent); like siltstone bed in slope unit above; contains some very fine grained sand ---.--..--..-

Limestone-magnesian, moderate-orange-red, insoluble (43 percent); like limestone bed in slope unit above; contains large shrinkage polygons near base -...-......................

Sandstone, moderate-reddish-orange, silty, platy; forms bench -...-....................

Limestone, light-brownish-gray, coarsegrained, thick-bedded $(2-5 \mathrm{ft})$; weathers to rough surface; forms weak ledge --_-.---

Conglomerate, pale-reddish-brown; forms rounded ledge

Matrix: pale-reddish-brown limestone.

Gravel: rounded limestone pebbles (2-6 in. diameter).

Total cliff unit, Wescogame For-
mation - -101.0
Total Wescogame Formation --- 156.0

Unconformity:

Erosion surface. Channels cut to depth of 34 $\mathrm{ft}$ in limestone.

Manakacha Formation, slope unit:

Limestone, pale-reddish-brown, aphantic, sandy (22 percent); cross-stratified throughout (medium-scale, lower two-thirds; large-scale above); forms major cliff, rounded lower part, angular above; contains two beds of flat, rubbly lime-stone with calcareous concretions at $27 \mathrm{ft}$ up; fossiliferous (straight cephalopods, many bellerophons); contains unoriented slumped block ( $2 \mathrm{ft} \times 3$ in.) of cross-stratified limestone incorporated at $33 \mathrm{ft}$ up 
Section 27-Continued

SNAP CANYON-Continued

Supai Group-Continued

Manakacha Formation, slope unit-Continued

Sandstone, pale-red, very calcareous (44 percent), very fine grained, weakly crossstratified; forms rounded ledges at base of main cliff

Total slope unit, Manakacha Formation -._-_-_-_-_-_-_-_-_

Manakacha Formation, cliff unit:

Limestone, light-brownish-gray (near base), pale-reddish-brown (above), aphanitic; very sandy; cross-stratified on medium scale; contains near base bed of irregularly concentric layers (10-20 in. diameters), probably stromatolitic; contains at $33 \mathrm{ft}$ up many elliptical, jasper lenses (diameters to $3 \mathrm{ft}$ ) -...-

Limestone, light-gray to light-olive-gray, aphanitic, thick-bedded $(2-3 \mathrm{ft})$; contains beds of spherical, gray concretions with concentric layers, possibly stromatolitic; weathers to rough, gray ledge; forms marker bed

Limestone, light-gray, sandy (32 percent), grades upward into grayish-orange-pink, very fine grained (subangular), calcareous sandstone; cross-stratified on medium scale; flat-bedded at top; contains fusulinids (Eoschubertella)

Sandstone, pale-reddish-brown, very fine grained, very calcareous ( 45 percent), flatbedded; contains thin jasper layers at top; fossiliferous in jasper layers; forms cliff --..----

Limestone, light-brownish-gray to palereddish-brown, aphanitic, very sandy (20 percent); cross-stratified on medium scale; laminae etched on surface; like $44-\mathrm{ft}$ limestone above

Sandstone, medium-gray to brownish-gray, very fine grained, very limy (42 percent), very thick bedded $(3-8 \mathrm{ft})$; contains flat, laminated beds with prominent concretionary layers (0.5-2 in. thick) in lower part; cross-stratification, medium- to large-scale in upper part; contains some jasper lenses $30-40 \mathrm{ft}$ long

Limestone, pale-reddish-brown to very light gray, very fine grained, silty ( 25 percent), thick-bedded $(2-3 \mathrm{ft})$, laminated; contains spherical, white chert concretions (1-6 in.) in upper part; cliff-forming
Section 27-Continued

SNAP CANYON-Continued

Feet

Supai Group-Continued

Manakacha Formation, cliff unit-Continued

Limestone, light-brownish-gray to lightolive-gray, fine-grained; contains many jasper lenses; forms base of main cliff -.......

Total cliff unit, Manakacha Formation --- 229.0
Feet
Watahomigi Formation:

Concealed largely, slope probably mostly silty mudstone; contains ledge ( 6 in.) of very fossiliferous, coarse-grained, medium-gray limestone at $10 \mathrm{ft}$ up; contains beds $(1 \mathrm{ft})$ of grayish-red siltstone and moderate-reddishbrown mudstone about $28 \mathrm{ft}$ up --..--..--

Limestone, light-brownish-gray, fine-grained; weathers to ledge with rough surface containing siliceous, reticulate ridges --_-_-_-_--

Concealed, forms slope

Limestone, light-brownish-gray, coarsegrained, thick-bedded (2-3 ft), very fossiliferous (brachiopods); forms ledge ---_--.--

Limestone, light-brownish-gray to mediumlight-gray, coarse-grained, thin-bedded (1 $\mathrm{ft}$ ); includes near base thick (10 in.) jasper bed; very fossiliferous (brachiopods, pelecypods, others); forms series of weak, rounded ledges

Limestone, light-olive-gray to light-brownishgray, mostly aphanitic, thin- to thickbedded (1-4 ft); contains many thin, jasper layers in lower part, lenses above; includes coarse-grained, accretal-grained limestone with fossils (brachiopod molds) at $44 \mathrm{ft}$ up; forms top of cliff

Limestone, light-olive-gray, very thick bedded (4-8 ft); forms upper part of cliff; locally is unconformable with underlying unit, which thickens and thins laterally; weathers lightgray, in contrast to black surface below -------

Dolostone, pinkish-gray, coarse- to very coarse grained, thick-bedded $(2-4 \mathrm{ft})$; contains stylolites, jasper lenses and possible stromatolite structures at $33 \mathrm{ft}$; has cavernous texture, possibly reefoid, at $40 \mathrm{ft}$; fossiliferous (many colonial corals) at $55 \mathrm{ft}$ above base; forms cliff -...-..Limestone, light-brownish-gray, aphanitic, thin-bedded (1-3 ft); forms massive cliff ------ 
Section 27-Continued

SNAP CANYON-Continued

Supai Group-Continued

Watahomigi Formation-Continued

Limestone, grayish-red and light-olive-gray, fine-grained; contains fossil fragments; fills pockets, but upper beds are continuous across surface of relief; contains thin parting-beds (2-4 in.) of red mudstone; weathers to yellowish-brown -- 2.0-5.0

Zone of weathered limestone beds and reddishbrown, silty clay with very irregular, gnarly structure, overlain by $2-3 \mathrm{ft}$ of reddishbrown mudstone containing rounded, weathered limestone pebbles (2-4 in.) - - $\quad 3.0$

Total Watahomigi Formation --

Total Supai Group and Pakoon

Limestone - 1198.0

Unconformity:

Surface of erosion is undulating; depressions, 2-3 ft deep, and small mounds occur within 20-ft exposure. Basal unit in Watahomigi of adjacent sections is missing here; probably caused by topographic high on Redwall.

\section{Redwall Limestone:}

Horseshoe Mesa Member:

Limestone, yellowish-gray to dark-olive-gray, aphanitic; forms receding ledges; contains many cavities and channels filled with laminated, reddish-brown siltstone.

\section{Section 28}

\section{PIGEON WASH}

[On north side of Pigeon Wash, Grand Wash Cliffs]

Recent erosion surface.

Pakoon Limestone, cliff unit:

Limestone, magnesian, light-brownish-gray, very fine grained, scattered medium grains; medium-bedded (1-3 ft); upper 16-17 ft contain abundant crinoid and echinoid fragments; also contains colonial corals, productids; forms rounded receding ledges -.----

Limestone, grayish-orange-pink; contains 40 percent very fine grained quartz and scattered pebbles of quartz, sugary; abundant very small bioclasts; weathers to weak, rounded ledges

Limestone, light-brownish-gray, very fine grained; scattered fine grains; weathers to sandy surface; forms ledge

Section 28-Continued

PIGEON WASH-Continued

Feet

Pakoon Limestone, cliff unit-Continued

Concealed slope

Dolostone, calcitic, grayish-orange-pink, finegrained, thin-bedded (6-12 in.); weathers buff; forms receding ledges on slope ---------

Dolostone, calcitic, pale-yellowish-brown, very fine grained; medium-to thick-bedded (1-3 ft); contains many vugs and fossil molds filled with calcite; contains abundant corals (conspicuous zone near base); and crinoid joints, which weather brown; forms receding ledge with rough, pitted surface; weathers very pale orange

Limestone, magnesian, light-brownish-gray; aphanitic; similar to underlying limestone bed (except for color); contains bryozoans, fusulinids, brachiopods, abundant crinoid joints; weathers light-gray; forms receding ledge

Limestone, grayish-orange-pink, aphanitic, thin- to medium-bedded (6-30 in.); weathers to creamy-white surface; forms series of receding ledges with pitted surfaces -------------

Dolostone, grayish-orange-pink, very fine grained; includes scattered coarse grains; contains abundant geodes and fossil casts, partly filled with calcite; weathers to rough surface; forms prominent, resistant ledge --.--

Dolostone, pale-reddish-brown, very fine grained, silty ( 23 percent), medium-bedded (2-3 ft); contains abundant sea urchin spines; weathers to cream color; forms receding ledges

Dolostone, calcitic, pale-reddish-brown, very silty (46 percent), thin-bedded (1-6 in.); contains large brachiopods; forms slope

Limestone, dolomitic, grayish-orange-pink, aphanitic with scattered medium grains; medium-bedded (1-2 ft); contains very irregularly layered brown chert; contains brachiopods and abundant crinoids, silicified at surface; forms cliff continuous with underlying unit

Limestone, light-brownish-gray, aphanitic, with scattered fine grains; very thick bedded $2.5 \quad(2-3 \mathrm{ft})$; contains abundant silicified fossils (brachiopods, sea urchin spines, crinoids, fusulinids, bryozoans); forms prominent resistant cliff near base of member
Feet 
Section 28-Continued

PIGEON WASH-Continued

Pakoon Limestone, cliff unit-Continued

Limestone, light-brownish-gray, aphanitic, irregularly bedded; largely concealed by talus; upper beds contain much irregular brown chert; locally forms thin, rounded ledges; mostly slope-forming

(Underlying units measured on south side of Pigeon Wash)

Limestone, pale-reddish-brown, very fine grained, sandy; cross-stratified on medium scale; contains small, rounded, dark-gray limestone pebbles scattered throughout upper part; weathers to brown or dark-gray cliff, with cross-stratification prominent ------

Siltstone-conglomeratic, reddish-brown; contains scattered pebbles of gray, aphanitic limestone (average diameter 0.25-0.5 in.; maximum 1 in.); forms weak ledge

Limestone, pale-reddish-brown, very sandy (48 percent very fine grained), crumbly, weakly bedded; largely concealed ---.--_--

Limestone, pale-reddish-brown, with grayishred laminae; contains very fine grained sand (46 percent); contains wedge-planar crossstratification on medium scale; weathers to

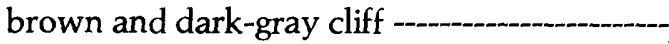

Total cliff unit, Pakoon Limestone

Pakoon Limestone, slope unit:

Concealed slope, largely talus-covered; palereddish-brown, shaly, limy siltstone, locally exposed

Sandstone, very pale orange with pale-reddishbrown specks, very fine grained (subangular), limy, friable; weathers to rounded ledge

Concealed slope --_-_-_-

Limestone, pale-reddish-brown, very fine grained, includes very fine ( 37 percent) sand; cross-stratified, medium-scale; weathers to resistant ledge with prominent brown and

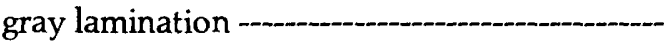

Concealed slope

17.0

Conglomerate, red-brown to gray; contains gray limestone clasts; forms ledge Matrix: red-brown silt.
Section 28-Continued

PIGEON WASH-Continued

Feet

Pakoon Limestone, cliff unit-Continued

Gravel: pebbles and granules of gray, aphanitic limestone; maximum diameter 1 in., average $0.25-0.5$ in.; subangular to rounded; oval to quadrate.

Total slope unit, Pakoon Limestone - - $\quad 70.5$

Total Pakoon Limestone -...- 285.0

Supai Group:

Wescogame Formation, slope unit:

Concealed slope

Limestone, pale-reddish-brown, sandy (30 percent, very fine, subrounded), structureless; forms weak ledge

Concealed slope

Dolostone, calcitic, moderate-orange-pink, sandy (17 percent, very fine grained); crossstratified on medium scale, wedge-planar type; weathers with brown and gray laminae prominently etched; forms resistant ledge ----

Concealed slope

Limestone, dolomitic, pale-reddish-brown, aphanitic, silty ( 35 percent); contains scattered, very fine grained sand; structureless; series of rounded, receding ledges $2-3 \mathrm{ft}$ thick

Total slope unit, Wescogame Formation --_-_-

Wescogame Formation, cliff unit:

Sandstone, moderate-reddish-orange, very fine grained (rounded), silty, calcareous, friable; contains cross-stratification on medium scale, low-angle; alternating with laminated gray and red, very sandy limestone; cross-stratified on medium scale (sets 1-3 ft thick); weathers to platy slabs; forms slopes in most places, locally makes weak, receding ledges -

Limestone, grayish-orange-pink, aphanitic with scattered fine grains; cross-stratification, medium- to large-scale; laminae weather brown and gray; forms resistant ledge

Limestone, medium-light-gray; aphanitic with scattered fine grains; massive; weathers moderate-reddish-orange; forms resistant ledge 
Section 28-Continued

PIGEON WASH-Continued

Supai Group-Continued

Wescogame Formation, cliff unit-Continued

Concealed slope, locally exposed pale-reddishbrown, shaly, sandy, siltstone

Limestone, light-brownish-gray, fine-grained; horizontal bedding; thick-bedded $(2-4 \mathrm{ft})$; forms rough, resistant cliff

Sandstone, pale-reddish-brown, very fine grained, very limy (30 percent), crossstratified, wedge-planar type; weathers black to pink; forms resistant, rounded ledge

Concealed slope, locally exposed moderateorange-pink, fine-grained sandstone -.------

Limestone, grayish-pink; aphanitic, sandy; contains cross-stratification on large scale; forms small cliff

10.0

Concealed slope

Total cliff unit, Wescogame Formation

Total Wescogame Formation -- $-\frac{86.5}{134.0}$

Erosion surface: Broad depressions (10 ft deep) filled with clayey limestone.

Manakacha Formation, slope unit:

Concealed bench

Sandstone, pale-gray, limy, cross-stratified; contains Fusulinella sp., Staffella sp.; forms weak ledge

Concealed slope

Limestone, dark-gray, aphanitic; contains abundant crinoids and echinoids; forms ledge

Concealed slope

Limestone, gray; contains jasper bands; forms ledge

Limestone, well-laminated; medium-bedded $(1-2 \mathrm{ft})$; forms ledge

Limestone, gray, aphanitic; contains jasper bands; forms ledge - -

Mudstone, purple, crumbly, slope-forming ----Total slope unit, Manakacha Formation

Manakacha Formation, cliff unit:

Limestone, gray, contains irregular jasper bands; abundant casts of pelecypods; includes thin layer of ooids and kaolin grains at top; forms resistant ledge
Section 28-Continued

PIGEON WASH-Continued

Feet

Supai Group-Continued

Manakacha Formation, cliff unit-Continued

Limestone, purple, sandy, thin-bedded, laminated; contains Fusulinella sp.; forms slope --

Limestone, light-gray, aphanitic; contains jasper bands in lower part, buff chert concretions above; contains crinoids and Bellerophontids, Fusulinella sp.; makes prominent marker bed of massive dark-gray ledges

Concealed slope, probably purple mudstone ----

Mudstone, deep-red-brown, brittle; forms ledge

Concealed slope, locally exposed

14.5

Limestone, light-brownish-gray, aphanitic, medium-bedded (1-2 ft); contains accretal grains; forms rough, resistant ledge

Limestone, grayish-pink, sugary, sandy (40 percent), very fine grained (subrounded), flat-bedded; locally cross-stratified on medium scale; forms bench or weak ledge ----

Limestone, light-brownish-gray, aphanitic; includes scattered very fine grained sand ( 30 percent); contains prominent tabular-planar cross-stratification in sets 6-12 ft thick; weathers with brown and gray cross-laminae etched on surface; forms cliff

16.5

Sandstone, grayish-pink, very fine grained, very limy (40 percent), aphanitic, scattered fine-grained quartz; cross-stratification on large scale (beds 30-40 ft long); weathers dark-gray; forms massive bed at base of cliff -

Dolostone, calcitic, light-gray, earthy, medium-bedded (1-2 ft); weathers creamcolored; forms slope or receding, rounded ledges

Limestone, magnesian, pale-reddish-brown and grayish-pink, very fine grained, very silty; locally distinct conglomerate with angular fragments of jasper and chert; thinbedded (6-12 in.); laminae prominently etched on surface; forms brown, receding ledges 
Section 28-Continued

PIGEON WASH-Continued

Supai Group-Continued

Manakacha Formation, cliff unit-Continued

Limestone, light-brownish-gray, aphanitic to very fine grained, oolitic, silty clay (22 percent); contains irregular, white chert masses in lower part; contains thin jasper layers along stratification and large-scale crossstratification planes in upper part; forms series of thick ledges (3-10 ft); contains fossils below crossbedding (Neospirifer, Syringopora, Composita, Phricodothyris); contains large gastropods (bellerophontids) in red chert

Limestone, pinkish-gray, aphanitic to very fine grained, silty; contains irregular thin beds, abundant nodules of gray to brown chert, and cores of red jasper; weathers lavender to cream; forms slope ---_-_-_-_.-.

Limestone, medium-light-gray, aphanitic, silty (24 percent), thin- to medium-bedded (6-30 in.); contains thin jasper layers, fossiliferous (brachiopods); forms receding

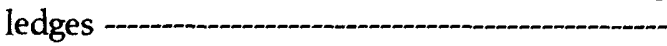

Limestone, light-brownish-gray, aphanitic with scattered very fine grains, very silty ( 43 percent); contains layers of large elliptical and spherical concretions of purplish quartzite that weather brown; forms thick ledge with flat vertical face

Limestone, medium-gray, aphanitic with scattered very fine grains, sandy; contains abundant jasper layers (locally 50 percent of rock); contains fossils (crinoid stems, Punctospirifer, Bellerophon); forms resistant ledge

Total cliff unit, Manakacha Formation

Total Manakacha Formation ---- 254.5

Watahomigi Formation:

Concealed slope, locally exposed, grayishpurple, crumbly mudstone and rubbly, crumbly, pale-reddish-brown dolostone near base, and a bright reddish-brown, brittle claystone at $33 \mathrm{ft}$ above base; total forms slope

Feet
Section 28-Continued

PIGEON WASH-Continued

Supai Group-Continued

Watahomigi Formation-Continued

Limestone, light-brownish-gray and palereddish-purple; aphanitic with scattered coarse grains; very silty, thin-bedded (2-12 in.); contains fossils including algae(?), crinoids, and brachiopods (Neospirifer); forms receding ledges or slope - -

Limestone, light-brownish-gray with palereddish-brown, aphanitic with scattered medium grains; contains abundant red accretal grains etched out on surface; weathers to resistant ledge

Siltstone, moderate-reddish-orange, limy; and medium-gray, aphanitic, concretionary limestone; total forms slope, largely concealed

Concealed slope

Limestone, light-brownish-gray, aphanitic with scattered fine to coarse grains; mediumbedded $(2-3 \mathrm{ft})$; contains much jasper in irregular layers, lenses, and spherical concretions; total forms series of three massive ledges, each $10-15 \mathrm{ft}$ thick

Limestone, medium-light-gray, aphanitic; contains irregular jasper layers with pink, platy, very fine grained sandstone partings above and below, forming prominent recesses

Limestone, medium-light-gray, aphanitic with scattered very coarse to very fine grains; thick-bedded $(2-5 \mathrm{ft})$; abundant thin jasper layers (2-4 in.); contains many brachiopods (Spirifers); forms massive cliff

Limestone, light-brownish-gray, mediumgrained with scattered coarse grains; contains thin layers and lenses of jasper; massive; forms three resistant ledges $(5-8 \mathrm{ft}$ ); alternates with limestone; light-brownishgray and pale-red, aphanitic with scattered fine grains, hard, thin-bedded (6-12 in.) contains jasper layers (2-6 in.); includes weak units forming slopes and recesses; total contains fossils (Spirifer, echinoderms, small gastropods and crinoid joints) 
Section 28-Continued

PIGEON WASH-Continued

Supai Group-Continued

Watahomigi Formation-Continued

Limestone, light-brownish-gray, aphanitic with scattered medium grains; mediumbedded (1-2 ft) with weak, shaly parting beds; weathers to purplish surface; contains fossils (fragments of stromatolites, crinoids, and brachiopods) that etch out on surface; forms receding ledges

Limestone, magnesian, grayish-orange-pink, aphanitic with scattered fine to coarse grains; thick-bedded (3-5 ft); contains red silt parting-plane at base; weathers gray; contains brachiopods (Neospirifer) and crinoids; includes much bioclastic material; forms cliff

Limestone, medium-light-gray to grayish-pink, aphanitic, thin- to medium-bedded (6-24 in.); contains gastropods (like Naticopsis); forms bench or receding ledge

Limestone, light-brownish-gray; oolitic, lower part aphanitic with scattered fine to coarse grains; upper part largely fine-grained; thick-bedded (3-5 ft); weathers gray; contains abundant fossils: pelecypods (like Myalina), gastropods (Bellerophon), and brachiopods (Spirifer, Strophomina-type); includes a local shell concentration with nearly all shells concave downward; total forms lowest thick, resistant ledge

Siltstone, brownish-gray, largely concealed; similar to 12 -ft siltstone below; forms slope

Conglomerate, pink to gray; composed of clastic limestone, which is pebbly near base but conglomeratic above; contains scattered brachiopods (large spirifers, Orbiculoidia?); forms resistant ledge

Matrix: limestone, reddish-brown, very granular.

Gravel: includes pebbles and granules of light-gray, aphanitic limestone, deepreddish-brown mudstone, dark-gray limestone, and pale-reddish-brown siltstone; maximum size 2 in.; average size $0.25-0.5$ in.; mostly rounded, some subangular.

Siltstone, light-brownish-gray and palereddish-brown, limy, brittle, crumbly; largely concealed; forms slope
Section 28-Continued

PIGEON WASH_Continued

Feet

Supai Group-Continued

Watahomigi Formation-Continued

Limestone, medium-gray, aphanitic with scattered very fine grains; thin- to mediumbedded (2-3 in.); rubbly surface; forms ledge

Mudstone, light-brownish-gray, silty; includes some sand; brittle, crumbly; forms slope ---.--

Limestone, medium-gray and pale-reddishbrown, aphanitic to very fine grained; sandy, thin-bedded (6 in.); forms ledge --.---

Concealed slope

Limestone, light-brownish-gray, aphanitic to very fine grained, silty; weathers olive-gray; forms rounded ledge with silty surface --------

Slope, partly concealed, contains reddishbrown, platy, silty sandstone --- $\quad 6.0$

Total Watahomigi Formation --- 319.0

Total Supai Group (without Esplanade Sandstone) and Pakoon Limestone

Unconformity:

Surface of relief; two limestone ledges (total $11 \mathrm{ft}$ ) of Redwall rise above base of measured section at $50 \mathrm{ft}$ to west.

Redwall Limestone:

Horseshoe Mesa Member:

Limestone, light-olive-gray, aphanitic; scattered fine grains; thin- to medium-bedded (6-24 in.); forms receding ledges.

Section 29 (part)

\section{GRAND GULCH MINE}

[Measured northeast of mine]

7.5

Hermit Shale:

Mudstone and siltstone, pale-reddish-brown and moderate-reddish-orange; forms series of slopes and small ledges --- 111.0

Unconformity:

Assumed; not observed here.

Supai Group:

Esplanade Sandstone, upper cliff-slope unit:

Sandstone, very pale orange, very fine grained, planar cross-stratified; weathers to rounded, white ledge 
Section 29-Continued

\section{GRAND GULCH MINE-Continued}

Supai Group-Continued

Esplanade Sandstone, upper cliff-slope unitContinued

Siltstone, pale-reddish-brown; contains much sand; grains coated with iron oxide; brittle, structureless; forms slope -

Sandstone, moderate-reddish-orange, very fine grained (includes some fine-grained sand); grains coated with iron oxide, subrounded, very friable; contains wedge-planar crossstratification; forms weak ledge or slope -----

Sandstone, very pale orange, very fine grained; consists of two thick (4-ft) beds; forms prominent ledge

Siltstone, reddish-brown; like $11-\mathrm{ft}$ siltstone below; contains worm borings; forms slope --

Sandstone, moderate-reddish-orange, very fine grained, friable, wedge-planar cross-stratification throughout on medium scale; forms rounded, weak cliff

Sandstone, grayish-orange, very fine grained, silty (27 percent), friable, medium-bedded (0.5-1 ft thick); contains many shrinkage cracks, worm borings and Rivularites; forms ledge below small cliff

Sandstone, reddish-brown, very fine grained, silty, friable, platy; weathers creamy-white; contains ledge (1-ft thick) of resistant, crossbedded siltstone; forms ledge --

Siltstone, reddish-brown, shaly, friable; contains prominent planar-type cross-stratification; weathers creamy-white; forms ledge ----

Siltstone, reddish-brown; includes very fine grained sand (46 percent), shaly; forms slope

Sandstone, moderate-orange-pink, very fine grained, silty, friable; weathers creamywhite; forms prominent ledge

Siltstone, moderate-reddish-orange, shaly; contains cross-stratification locally, structureless elsewhere

Sandstone, moderate-reddish-orange, very fine grained, silty, friable; forms receding ledges (mostly 2-4 ft thick); partly concealed --.-----

Siltstone, pale-reddish-brown, mediumbedded (1-2 ft), structureless; forms weak ledge

Siltstone, moderate-reddish-orange, sandy; forms thin $(0.5 \mathrm{ft})$ ledges; contains imprint of conifer stem; largely concealed
Section 29-Continued

GRAND GULCH MINE-Continued
Feet

16.0

10.0

11.0

11.0
Supai Group-Continued

Esplanade Sandstone, upper cliff-slope unitContinued

Sandstone, moderate-reddish-orange and grayish-orange, very fine grained, friable; weathers to weak, rounded ledge ---

Siltstone, moderate-reddish-orange, poorly sorted (angular grains), medium-bedded (1-1.5 ft thick), structureless; forms weak, rounded ledge and slope; partly concealed ---

Sandstone, very pale orange and moderateorange-pink; very fine grained (scattered fine grains, 23 percent); contains planar cross-stratification with cosets $2-3 \mathrm{ft}$ thick; massive; weathers gray and light-red-brown; forms resistant, gray cliff with rounded edges

Siltstone, grayish-red; grains coated with iron oxide; brittle; forms slope; largely concealed

Sandstone, very pale orange, very fine grained, crumbly; forms rounded ledge ( $2 \mathrm{ft}$ exposed)

(Section projected north across extensive concealed area)

Limestone, gray to moderate-reddish-orange, very sandy, thin-bedded (2-12 in.); horizontal laminae weathered in relief: platy; forms weak ledge or cap of mesa ---_-_-

Sandstone, moderate-orange-pink, very fine grained, very crumbly; contains wedgeplanar cross-stratification; forms rounded slope -------

Concealed slope

Sandstone, moderate-reddish-orange, very fine grained, friable; locally contains planar cross-stratification, elsewhere structureless; forms resistant, rounded ledge ---

Sandstone, moderate-orange-pink, very fine grained, friable, medium-bedded ( $1-3 \mathrm{ft}$ ); forms crumbly slope and receding, rounded ledges

Siltstone, reddish-brown, shaly; forms slope ---Sandstone, grayish-orange-pink, very fine grained, calcareous (34 percent), silty, thinbedded (2-12 in.); weathers with laminae and cross-laminae in relief; weathers reddish-brown; forms weak ledge, grading upward into slope --

Sandstone, moderate-orange-pink, very fine grained, calcareous ( 36 percent), thin- to medium-bedded (2-24 in.); forms slope and weak ledge; upper part largely concealed ----- 


\section{Section 30a (part)-Continued \\ HIDDEN CANYON_Continued}

Supai Group-Continued

Manakacha Formation, cliff unit-Continued

Limestone, dark-brownish-gray, aphanitic, sandy, medium-bedded (2-4 ft); laminae horizontal, etched on surface as brown lines on lavender background; locally includes jasper beds or lenses; contains fusulinids (fig. E11) and brachiopods (fig. E3); forms cliff or receding ledges

Limestone conglomerate, and dark-reddishbrown to grayish-orange-pink, aphanitic, thick-bedded (3-10 ft) limestone; contains abundant jasper beds, some horizontal, some crosscutting; contains many brachiopods, including jasperized spirifers; contains some pebbles of jasper at base; total forms massive cliff

Total cliff unit, Manakacha Formation

Total Manakacha Formation ---- 261.5

Watahomigi Formation, upper slope unit:

Mudstone, moderate-reddish-brown, silty, brittle, apparently structureless; much concealed; forms slope --

Limestone, olive-gray with dark-greenishgray, aphanitic, sandy; contains thin jasper lenses; weathers to olive-gray sandy surface with red-brown reticulate pattern of ridges; contains lenses of purple mudstone; forms ledge

Limestone, grayish-orange-pink to light-purple, silty, crumbly; forms slope --..-...-...-

Conglomerate, medium-light-gray, mediumbedded (1-2 ft); very fossiliferous with brachiopods (fig. E1), many archeocidaris spines, trilobites and bryozoans; contains jasper lenses; forms receding ledges -.--...-_-.-Matrix: aphanitic limestone.

Gravels: gray limestone; mostly rounded; diameters range mostly from 0.25 to 1 in.

Concealed slope

Limestone, light-gray, very coarse grained, bioclastic, fossiliferous with brachiopods (fig. E1) and pelecypods (fig. E3); forms two resistant ledges

Concealed slope

Feet
Section 30a (part)-Continued

HIDDEN CANYON-Continued

Supai Group-Continued

Watahomigi Formation, upper slope unitContinued

Limestone, magnesian, light-brownish-gray and greenish-gray, silty (39 percent), mottled, aphanitic, hard; weathers with darkreddish-brown wavy bands separating sets of low-angle cross-strata from sets of horizontal strata, each 1-8 in. thick; forms resistant ledge

Siltstone, grayish-orange-pink, crumbly, slope-forming

Limestone, purple-gray and pale-buff, mottled, thin-bedded (6-12 in.); contains abundant brachiopods; weathers to olive-gray surface; forms rounded ledges --.--

Concealed slope

Total upper slope unit, Watahomigi Formation

Watahomigi Formation, middle cliff unit:

Limestone, light-olive-gray to grayish-pink, coarse-grained, thick-bedded (2-3 ft); contains prominent chert bed (marker bed) $2.5 \mathrm{ft}$ thick; forms cap rock or small cliff --..--..-

Limestone, light-gray, aphanitic, mediumbedded (1-3 ft); forms receding ledges with concealed slopes between

Limestone, dolomitic, and limestone, lightbrownish-gray with pale-reddish-brown aphanitic with scattered coarse grains, medium-bedded (2-4 ft); contains jasper and chert nodules in irregular bands throughout; abundant jasper beds and lenses near top; weathers to rough, light-gray surface; forms resistant ledges

Total middle cliff unit, Watahomigi Formation

Watahomigi Formation, lower slope unit:

Concealed slope, reddish surface, with thin ledges of reddish-brown siltstone, sandstone, and limestone, and patches of mudstone cropping out locally; limestone is light gray, aphanitic to fine-grained, weathers cream-colored; siltstone is very friable, laminated --.-- 106.5

Total lower slope unit, Watahomigi Formation --ar. 106.5

Total Watahomigi Formation --- $-\frac{341.0}{625.0}$

Total Supai Group - 


\section{Section 30a (part)-Continued \\ HIDDEN CANYON-Continued}

Unconformity:

Surface of small relief, shallow channels and ridges.

Redwall Limestone:

Horseshoe Mesa Member:

Limestone, light-gray, aphanitic; locally replaced by coarsely crystalline pink dolomite; contains a few spherical gray flint concretions in layers; forms series of receding ledges above massive cliff

Section 30b (part)

\section{HIDDEN CANYON}

[Main part of Hidden Canyon section]

Hermit Shale:

Contact:

Contact not described.

Supai Group:

Esplanade Sandstone, upper cliff-slope unit:

Sandstone, grayish-orange-pink, very fine grained, slightly calcareous, weakly crossstratified on medium scale; forms rounded ledge at top of formation

Siltstone, bright-reddish-brown, shaly; forms slope --

Sandstone, grayish-orange-pink, very fine grained, structureless at base, weakly crossstratified in upper part; forms weak cliff -.-.-

Mudstone, bright-reddish-brown, flat-bedded; forms slope, partly concealed --_-_-_-

Sandstone, grayish-orange-pink, very fine grained, cross-stratified on large scale; forms small cliff

Siltstone, bright-reddish-brown; forms bench --

Sandstone, pink, flat-bedded to structureless; forms cliff continuous with underlying sandstone bed

Sandstone, grayish-orange-pink, fine- to very fine grained, calcareous, cross-stratified on large scale; forms massive cliff with overlying sandstone

Siltstone, moderate-orange-pink shaly, slightly calcareous, flat-bedded, friable; contains Walchia sp.; includes one thin, weak ledge of pink siltstone in middle; total forms bench

11.5

10.0

\section{Section 30b (part)-Continued \\ HIDDEN CANYON-Continued}

Feet

Supai Group-Continued

Esplanade Sandstone, upper cliff-slope unit-

Continued

Sandstone, pale-reddish-brown, very fine grained (subrounded), thick-bedded (5-15 $\mathrm{ft}$ ), structureless to weakly cross-stratified; forms massive cliff - -

Siltstone, bright-reddish-brown, flat-bedded, thick-bedded, friable; forms series of receding ledges

Sandstone, moderate-orange-pink, fine- to very fine grained (subrounded), slightly calcareous, cross-stratified on large scale; forms small cliff

Siltstone, bright-reddish-brown, shaly to thinbedded; forms weak, thin ledges on long slope ---_-_-_-_-

Sandstone, pink, very fine grained (subrounded), well-sorted, calcareous, crossstratified on large scale (planes $30-40 \mathrm{ft}$ long); forms cliff

Sandstone, moderate-reddish-orange, very fine grained (subangular to subrounded), calcareous, flat-bedded, massive; forms receding ledges on bench

Sandstone, moderate-orange-pink, poorly sorted and limy near base, very fine grained at top; includes scattered fine grains; crossstratified; includes two 1-ft thick beds of limestone, $5 \mathrm{ft}$ and $15 \mathrm{ft}$ above base; forms cliff

Concealed slope; includes a few thin ledges of moderate-orange-pink, calcareous, very fine grained sandstone and gray, muddy limestone

Total upper cliff-slope unit, Esplanade Sandstone - -

Total Esplanade Sandstone -..-- 569.0

Pakoon Limestone, cliff unit:

Limestone, medium-light-gray, silty, mediumbedded (1-2 ft); contains scattered, nodular concretions that weather with black varnished surfaces; dolostone forms receding ledges; weathers to rough, buff surface -----.--

38.5 Sandstone, pale-reddish-brown, very fine grained, very dolomitic (41 percent); weathers buff to brown; forms rounded ledge - -

Siltstone, pale-reddish-brown, slightly calcareous, crumbly; forms slope --.--..--

22.0

16.5 
Section 30b (part)-Continued

HIDDEN CANYON-Continued

Pakoon Limestone, cliff-unit-Continued

Dolostone, pale-reddish-brown, fine-grained; contains abundant silicified fossils (crinoids, brachiopods, sea urchin spines); weathers to rough, buff surface; forms series of ledges ----

Siltstone, pale-reddish-brown, shaly; contains calcitic-dolostone (30 percent); forms slope, partly concealed

Limestone, gray, fine-grained, medium-bedded ( $3 \mathrm{ft}$ ); contains chert lenses that weather black; contains fossils (brachiopods, sea urchin spines); forms prominent dark-gray ledge, conspicuous in light-gray sequence ----

Dolostone, calcitic, pale-reddish-brown, finegrained, medium-bedded (1-3 ft); contains abundant fossil fragments and unbroken brachiopods; weathers light-gray; forms ledge

Concealed slope

Dolostone, grayish-pink, very fine grained, thin-bedded (6-12 in.); weathers buff; forms weak ledge

Dolostone, calcitic, pale-reddish-brown, very fine grained with scattered fine to coarse grains; medium-bedded $(2.5 \mathrm{ft})$; weathers to light-gray, sandy surface; forms ledge --.--.-

Dolostone, calcitic, pale-reddish-brown with white blotches, very fine grained, massive; weathers to very rough, rounded surface; forms ledge

Dolostone and calcitic-dolostone, grayish-pink to pale-reddish-brown, aphanitic, mediumto thick-bedded (1-4 ft); contains scattered, ellipsoidal concretions of chert, which weather black; brachiopods common near base; weathers light-gray; forms receding ledges or cliff

Limestone, medium-gray with pale-reddishbrown blotches, aphanitic with scattered fine grains, medium-to thick-bedded $(1-3 \mathrm{ft})$; contains fossils (crinoids, sea urchin spines, brachiopods, colonial corals; abundant fragments); weathers to rough surface; forms cliff

\author{
Section 30b (part)-Continued \\ HIDDEN CANYON-Continued
}

Feet
Pakoon Limestone, cliff-unit-Continued

Limestone, dolomitic, pale-reddish-brown, aphanitic with scattered very fine to coarse grains; medium-bedded (1-3 ft); contains abundant fossils at $20 \mathrm{ft}$ above base (bryozoans, horn corals, crinoids, sea urchin spines, and fusulinids); contains chert beds and lenses, many with abundant fusulinids; weathers light-gray; forms cliff

Dolostone, calcitic, pale-reddish-brown, very fine grained; contains abundant small fossil fragments scattered throughout; weathers buff; forms ledge

Dolostone, calcitic, bluish-gray, earthy, aphanitic, medium-bedded (1-3 ft), locally laminated; weathers buff; forms ledges -------

Dolostone, calcitic, pale-reddish-brown, aphanitic; contains abundant brachiopods; weathers buff; forms thin, receding ledges with straight faces

Limestone, dolomitic, medium-light-gray, aphanitic, brittle; forms rounded ledge ------

Concealed slope

5.0

Limestone, dolomitic, pale-reddish-brown, very fine grained, thin-bedded (2-6 in.); contains two beds of gray crinoidal limestone, one near middle, the other near top; contains a few bryozoans and brachiopods, abundant crinoids and horn corals; contains near top three layers of chert concretions that weather black; forms part of cliff; weathers buff

Limestone, light-brownish-gray, aphanitic with scattered fine grains; medium-bedded $(1-3 \mathrm{ft})$; weathers to rough surface; forms part of main cliff

Dolostone, very pale orange, aphanitic, calcitic, thin- to medium-bedded $(0.5-2 \mathrm{ft})$; casts of fossils common; forms part of cliff --

Dolostone, calcitic, grayish-orange-pink, fineto very fine grained; contains abundant casts of fossils; forms ledge (n) 


\author{
Section 30b (part)-Continued \\ HIDDEN CANYON-Continued
}

Feet

Pakoon Limestone, cliff-unit-Continued

Limestone, grayish-orange-pink, very fine grained with scattered fine and medium grains; crinoidal in part, elsewhere laminated or cross-laminated on medium scale; weathers gray to black with laminae prominently etched out on surface; crinoidal units 1-5 in. thick; forms ledge --_-

Total cliff unit, Pakoon Limestone

Pakoon Limestone, slope unit:

Sandstone, very pale orange and pale-reddishbrown, very fine grained (angular), calcareous, friable, structureless, medium-bedded (0.5-1 ft); includes thin beds of limestone near base; forms slope

Sandstone, grayish-orange-pink to brown, very fine grained, calcareous, massive, thick-bedded (2-4 ft); weathers white, locally with black varnish; forms resistant, conspicuous ledge

Sandstone, grayish-pink, very fine grained (subangular to subrounded), calcareous, friable, thick-bedded (1-4 ft); locally forms rounded ledge, elsewhere concealed slope ---.

Sandstone, pale-reddish-brown with moderate reddish-brown, horizontal laminae, very fine grained (subrounded), very limy (45 percent); weathers to reddish-brown surface with conspicuous laminae; forms weak, rounded ledge

Conglomerate, grayish-brown; forms ledge -..-Pebbles: light-gray and dark-gray limestone; subrounded to rounded; mostly spheroidal, some elongate; average diameter $0.25-0.5$ in., maximum 1.5 in.

Matrix: light-brownish-gray limestone.

Limestone, pale-reddish-brown, fine- to very fine grained with scattered medium grains; shaly, very sandy, friable; forms slope --..-...

Limestone, pale-reddish-brown, medium- to coarse-grained, sandy, friable, flat-bedded; occurs as channel fill

Total slope unit, Pakoon Lime-
stone -
Total Pakoon Limestone - $-\frac{1.0}{287.0}$

11.0

16.5

\author{
Section 30b (part)-Continued
}

HIDDEN CANYON-Continued

Feet

Erosion surface.

Supai Group:

Wescogame Formation, slope unit:

Limestone, pale-reddish-brown, fine- to very fine grained; silty, cross-stratified on medium scale; cross-strata prominently etched on surface; forms part of cliff

15.5

Limestone, light-gray, locally moderatereddish-brown, medium- to very fine grained, crinoidal, thick-bedded (3-7 ft); light-brownish-gray and locally in upper part aphanitic with scattered coarse grains; reticulate siliceous pattern prominent on weathered surface; forms base of cliff --.---.--

(Section continued on south side of Hidden Canyon)

Concealed slope

Total slope unit, Wescogame Formation

Wescogame Formation, cliff unit:

Sandstone, pale-reddish-brown, very fine grained (subangular to subrounded), limy, friable, structureless to weakly laminated; weathers reddish-brown; forms rounded ledges or slope

Concealed slope

Limestone, grayish-pink, very fine grained; scattered fine grains, silty, cross-stratified on medium scale; laminae prominently etched and reddish-brown on gray surface; forms weak cliff

Dolostone, grayish-pink, medium-grained; weathers dark-gray to black; forms massive ledge

Sandstone, grayish-orange-pink, very fine grained; scattered fine- to medium-grains; laminated; forms weak rounded ledges --.---.-

Concealed slope

Limestone, grayish-pink, fine- to very fine grained, medium-bedded (1-2 ft); locally grades into gray, aphanitic limestone containing abundant gastropods (Bellerophontidae); weathers to silty surface; forms weak ledge 


\section{Section 30b (part)-Continued}

\section{HIDDEN CANYON-Continued}

\section{Supai Group-Continued}

Wescogame Formation, cliff-unit-Continued

Limestone, light-brownish-gray, mediumgrained, silty, cross-stratified on medium scale; weathers with silty cross-strata etched on surface; forms ledge

Limestone, magnesian, light-gray, aphanitic with scattered fine to very coarse grains; thick-bedded; weathers to rough, gray surface; forms ledge

Limestone, light-brownish-gray, aphanitic with scattered very coarse to very fine grains; weathers to rough, light-gray surface; forms weak ledge or recess

Concealed slope

Limestone, medium-gray, very fine grained with scattered coarse grains; contains concretions of dark-gray chert that weather blackish-brown; forms weak ledge or slope --

Limestone, very light gray, aphanitic with scattered fine to medium grains; weathers to rough surface; forms ledge

Dolostone, calcitic, pale-reddish-brown, fineto very fine grained, thin-bedded $(0.5-1 \mathrm{ft})$; weathers pale-gray; forms receding ledges ----

Limestone, magnesian, light-brownish-gray, fine- to very fine grained, sandy; crossstratified on medium scale, wedge-planar type; weathers to gray surface with reddishbrown strata prominently etched out; bedding units thick (2-4 ft); forms weak cliff -.---

Limestone, very light gray, aphanitic, thickbedded (2-4 ft); weathers to rough surface; includes thin $(2-\mathrm{ft})$ band of very fine grained, pale-reddish-brown dolostone, calcitic, that weathers to dark-gray band; forms massive cliff

Dolostone, calcitic, light-brownish-gray, aphanitic with scattered very fine grains; locally with reddish tinge, medium-bedded (1-2 ft); weathers to blocky surface; forms recess between massive cliffs

Total cliff unit, Wescogame Formation

Total Wescogame Formation ---.- 1158.5

Manakacha Formation, slope unit:

Limestone, yellowish-gray, aphanitic, mediumbedded (1-4 ft); includes thin ( $1 \mathrm{ft}$ ) parting of light-brownish-gray, aphanitic, sandy dolomite; weathers with reticulate siliceous pattern on surface; forms cliff
Feet

Section 30b (part)-Continued

HIDDEN CANYON-Continued

Supai Group-Continued

Manakacha Formation, slope unit-Continued

Limestone, medium-gray, aphanitic, mediumbedded $(0.5-2 \mathrm{ft})$; contains abundant, large horn corals; forms cliff

Total exposed slope unit, Manakacha Formation ---_-_.-- 27.5+

Total measured Supai Group

and Pakoon Limestone ---.-- 1042.0+

Concealed beneath canyon bottom. See Section 30a.

Section 30c (part)

\section{HIDDEN CANYON}

[Measured on east side of Jump Canyon, 0.5 mile from junction with Hidden Canyon]

$$
\text { Hidden Canyon] }
$$

Hermit Shale:

Basal slope unit:

Siltstone, moderate-reddish-orange; forms slope with rounded surface; locally shaly.

Unconformity:

Erosion surface assumed; not observed here.

Supai Group:

Esplanade Sandstone, upper cliff-slope unit:

Sandstone, grayish-orange-pink, very fine grained, calcareous, resistant; crossstratified on medium scale; forms cap rock ---

Siltstone, moderate-reddish-orange, calcareous, flat-bedded to shaly; weathers to massive, rounded ledge - -

Sandstone, grayish-orange-pink, very fine grained, calcareous, cross-stratified (smallscale, trough-type); forms rounded ledge; thickness doubles within $600 \mathrm{ft}$ to north --.---

Siltstone, moderate-reddish-orange, coarse, calcareous, shaly; forms slope ---

Sandstone, grayish-orange-pink, very fine grained, calcareous, friable, structureless; forms rounded ledge -._-_-_-_-

Siltstone, moderate-reddish-orange, coarsegrained, calcareous; massive near base, shaly above; forms slope ---

Sandstone, very pale orange, very fine grained, calcareous; weakly cross-stratified; mediumbedded (1-2 ft); weathers to knobby surface

Siltstone, moderate-reddish-orange, coarse; massive near base, shaly above; forms slope
7.5 
Section 30c (part)-Continued

HIDDEN CANYON-Continued

Supai Group-Continued

Esplanade Sandstone, upper cliff-slope unit-

Continued

Sandstone, grayish-orange-pink, very fine grained, calcareous; cross-stratified on large scale; forms ledge

Siltstone, moderate-reddish-orange, coarse, calcareous; structureless to shaly; forms slope

Sandstone, grayish-orange-pink, very fine grained, slightly calcareous; forms ledge ------

Siltstone, moderate-reddish-orange, coarse, slope-forming

Siltstone, pale-reddish-brown, coarse-grained, calcareous, medium-bedded (1-2 ft); forms weak ledge

Sandstone, pale-reddish-brown, very fine grained, slope-forming ---.--

Sandstone, grayish-orange-pink, very fine grained, slightly calcareous, structureless, ledge-forming

Sandstone, moderate-reddish-brown, very fine grained, silty, calcareous, structureless, slope-forming

Sandstone, grayish-orange-pink, very fine grained, slightly calcareous, structureless, ledge-forming

Sandstone, moderate-reddish-brown, very fine grained, silty, calcareous, slope-forming --.--

Sandstone, grayish-orange-pink, very fine grained, resistant; forms ledge ---_-_-_-

Sandstone, moderate-orange-pink, finegrained, calcareous, shaly, slope-forming ----Total upper cliff-slope unit, Esplanade Sandstone --.-_-_-_--

Esplanade Sandstone, main cliff unit:

Sandstone, light-buff, massive, crossstratified.

\section{Section 31}

\section{ICEBERG CANYON}

[Measured on east side; regional dip $45^{\circ}$ ]

Hermit Shale:

Siltstone, very pale reddish brown to very Contact:

light brown, shaly; forms long slope.

No erosion channels apparent in this area, but thickness of underlying sandstone ranges from 4 to $12 \mathrm{ft}$ in distance of 0.25 mile.
Section 31-Continued

ICEBERG CANYON-Continued

Feet

Supai Group:

Esplanade Sandstone, upper cliff-slope unit:

Sandstone, grayish-orange-pink, very fine grained, friable; forms massive, rounded

Siltstone, moderate-reddish-brown, shaly; alternating with moderate-reddish-orange to light-brownish-orange with brown speckles, very fine grained, friable, thin-bedded sandstone; contains some very thin bedded, yellowish-gray limestone (insoluble 11 percent); total forms long slope with weak ledges --_-_-

Sandstone, grayish-orange-pink with reddishbrown speckles, very fine grained, very friable; contains medium-scale crossstratification; weathers bright-reddishbrown; forms massive, crumbly ledge -------

Siltstone, moderate-reddish-orange, very fine grained (subrounded), calcareous; locally crops out on largely concealed slope -------

Dolostone, calcitic, grayish-pink, silty (48 percent), and olive-gray, thin-bedded (2-6 in.) limestone; includes interbedded reddishbrown siltstones; forms receding ledge, more resistant upward

Concealed slope

Dolostone, calcitic, grayish-orange-pink, silty (12 percent), thin-bedded (6-12 in.); weathers to rough, pitted surface; forms ledge --.---

Limestone, moderate-reddish-orange, friable, silty, argillaceous, insoluble (21 percent); weathers to rough black surface; forms slope

Dolostone, grayish-orange-pink, silty (15 percent); weathers to smooth gray surface; forms ledge

\section{0}

Sandstone, moderate-reddish-orange, very fine grained, silty, friable, very calcareous; weathers to rough surface; forms weak ledges or slope

Sandstone, moderate-orange-pink, very fine grained, very calcareous; weathers to pitted, rough surface, porous; forms weak ledge ---_-_ 11.5 Total upper cliff-slope unit, Esplanade Sandstone --------

Contact:

No unconformity apparent in this area; lithologic change marks boundary. 
Section 31-Continued

\section{ICEBERG CANYON_-Continued}

Pakoon Limestone, cliff unit:

Dolostone, very pale orange, very fine grained, silty (30 percent), thin-bedded (2-6 in.), laminated; forms weak bench -..-_..-

Dolostone, light-olive-gray, fine-grained, silty, thin-bedded (1-2 in.); contains local chert lenses, 1-2 in. thick; forms series of ledges ----

Dolostone, very pale yellowish-gray, very fine grained, silty (15 percent), thin-bedded (6-12 in.); weathers $\tan$ with cross-laminae etched on surface; forms ledge

Dolostone, very pale orange, aphanitic, weakly bedded; beds 1-3 ft thick; locally contains scattered intraformational fragments of silty limestone, including laminated types, 6-8 in. across; weathers gray-brown, very rough and pitted; red-brown oxidation most intense toward top; forms cliff -...-...

Limestone, dolomitic, olive-gray with lightbrownish-gray, silty ( 30 percent), finegrained; contains abundant small fossils (crincids, corals, brachiopods); contains intraformational conglomerate near top with fragments of shaly limestone as long as 6 in.; weathers yellowish-brown to dark-gray; forms ledge

Mudstone, yellowish-gray with moderatereddish-orange; weathers reddish-brown; forms slope

Limestone, dolomitic, olive-gray, very fine grained, even, flat beds, $0.5-2 \mathrm{ft}$ thick; weathers light-gray; contains abundant crinoids near top; forms ledge

Dolostone, calcitic, pale-orange-pink, silty, irregularly bedded; forms slope ---

Limestone, grayish-orange-pink, fine-grained to aphanitic, beds thin $(0.5-1 \mathrm{ft})$; weathers to rough, gray surface; forms ledge

Limestone, dolomitic, grayish-pink, fine- to medium-grained, silty; beds thin (2-6 in.); contains abundant but scattered fossils; weathers to silty, brownish surface; forms slope

Limestone, dolomitic, olive-gray, fine-grained, silty (35 percent), thick-bedded $(2-4 \mathrm{ft})$; weathers to rusty-brown, rough surface; laminae highly contorted locally; forms ledge

Section 31-Continued

\section{ICEBERG CANYON-Continued}

Feet
Pakoon Limestone, cliff unit-Continued

Limestone, dolomitic, and limestone, olivegray to pale-reddish-brown, fine-grained; aphanitic and pure gray near top; contains fossils (urchin spines, crinoids, and brachiopods) near top; weathers to rough, sandy surface; forms ledge

Limestone, dolomitic, light-olive-gray, medium-grained, silty; contains planar cross-strata etched prominently on surface; weathers brown; convolute structure locally developed; forms ledge

Limestone, dolomitic, brownish-gray, speckled with pale-reddish-brown, medium-grained, thick-bedded (2-4 ft); weathers to rough, brown surface; forms ledge

Dolostone, light-olive-gray, speckled with pale-reddish-brown, very fine grained, mostly thick-bedded (2-4 ft), but thinbedded (6-12 in.) near top; contains abundant corals and many silicified mounds; contains fragments of reddish-brown siltstone 1 in. in diameter near top of limestone; lower part forms cliff; upper part forms receding ledges

Limestone, dolomitic, pinkish-gray, very fine grained, thick-bedded (2-4 ft); contains abundant nodules of chert, which weather black; contains crinoids and urchin spines scattered throughout; forms weak ledge --.--

Limestone, dolomitic, dark-grayish-pink, aphanitic, thick-bedded (2-6 ft); weathers rough, gray; contains scattered chert concretions; contains abundant fossils (lithostrotion and other colonial corals, urchin spines, crinoids, bryozoa, Deltodus, abundant fusulinids; including Schubertellids, Triticites); forms cliff

Dolostone, calcitic, grayish-pink, very fine grained, thin-bedded $(0.5-1 \mathrm{ft})$; contains chert nodules, which weather black; very fossiliferous in upper part (fusulinids, horn corals, crinoids, bryozoans, and urchin spines); weathers buff to cream; forms weak ledge

Limestone, pale-gray, fine-grained, beds $1-2 \mathrm{ft}$ thick; weathers rough; forms ledge 
Section 31-Continued ICEBERG CANYON-Continued

Pakoon Limestone, cliff unit-Continued

Limestone, dolomitic, dark-grayish-pink, very fine grained with scattered large grains up to $3 \mathrm{~mm}$; beds $1-2 \mathrm{ft}$ thick; contains silicified fossil fragments and concretions with abundant crinoids; weathers to smooth face; stained brown; forms recess

Limestone, olive-gray, fine-grained; beds $1-2 \mathrm{ft}$ thick; contains fossils (colonial corals, horn corals, brachiopods, many foraminifers, gastropods and urchin spines); weathers to rough surface; forms ledge

Limestone, light-olive-gray with pale-reddishbrown, fine-grained, silty, cross-stratified on large scale (sets 2-15 ft thick); weathers with thin, reddish-brown bands on light-gray surface; some following cross-strata, others crosscutting; forms cliff

Sandstone, light-olive-gray speckled with palereddish-brown, very hard, quartzitic, calcareous, thick-bedded (2-3 ft); laminae nearly horizontal, locally wavy; weathers to smooth face with black varnish; forms prominent dark layer at base of cliff

Total cliff unit, Pakoon Limestone

Pakoon Limestone, slope unit:

Sandstone, grayish-red, very fine grained, calcareous; weathers to thick $\left(\begin{array}{lll}1-3 & \mathrm{ft}\end{array}\right)$ rounded beds; contains many limestone pelloids; forms weak ledge --..--

Mudstone, reddish-brown, shaly; locally contains cusp-type ripple marks and worm tubes; contains a few weak ledges of calcareous, lavender siltstone; forms slope --..--.--

Conglomerate, brownish-gray; fills broad channel in underlying limy sandstone -.----Gravel: includes (a) blocks of limestone, maximum 10 in. long; many 5 in. long; gray with silty surface; also gray with reddish-brown silty laminae etched on surface; some imbricated, mostly flat; and (b) small pebbles of reddish-brown siltstone, dark-gray limestone, and light-gray limestone; some angular, mostly rounded; mostly $0.25-1$ in. in diameter; rude layering.

Feet
Section 31-Continued

\section{ICEBERG CANYON-Continued}

4.5 Supai Group:

Wescogame Formation, slope unit:

Limestone, dark-grayish-pink, silt and sand (35 percent), resistant; contains low-angle, planar cross-strata in sets $0.5-2 \mathrm{ft}$ thick; con-

4.0 tains plant stems and branches of Walchia; locally less limy with shale partings or lenses as much as $3 \mathrm{ft}$ thick; weathers with black or brown laminae etched out on gray surface; forms ledge

Siltstone, pale-reddish-brown, shaly; forms slopes 2-3 ft thick; alternating with moderate-reddish-gray, very fine grained, ripple-laminated, calcareous (30 percent) sandstone; forms weak ledges $2-6 \mathrm{ft}$ thick; locally structureless; develops spheroidal weathering; ratio of siltstone to sandstone,

$$
\begin{gathered}
\text { Total slope unit, Wescogame } \\
\text { Formation }
\end{gathered}
$$
295.0

Wescogame Formation, cliff unit:

Dolostone, calcitic, light-olive-gray to palereddish-brown, aphanitic; forms resistant ledge

Sandstone, grayish-orange-pink, very fine grained, crumbly, calcareous; forms slope ----

Limestone, grayish-orange-pink, fine-grained; insoluble residue (35 percent) contains (2-6 $\mathrm{ft}$ ) thick wedge-planar cross-stratification; weathers with brown silt layers etched on gray surface; forms cliff

Limestone, light-gray, very fine grained; weathers to rough surface with black siliceous outlines; forms base of cliff

Concealed slope

Dolostone, calcitic, moderate-reddish-orange, very fine grained, silty, thick-bedded (2-4 $\mathrm{ft}$ ); contains chert concretions locally; weathers to rough, gray surface; forms resistant ledge

Limestone, grayish-orange-pink, very silty; weathers to brownish silty surface; forms ledge 
Section 31-Continued

\section{ICEBERG CANYON-Continued}

\section{Supai Group-Continued}

Wescogame Formation, cliff unit-Continued

Limestone, pale-grayish-pink, medium-grained; beds 1-2 ft thick; contains horizontal bands of silt, 1-2 in. apart; forms ledge

Limestone, dark-olive-gray, very fine grained; beds 1-2 ft thick; weathers to rough surface; forms ledge

Dolostone, calcitic, moderate-reddish-orange, fine-grained, silty (35 percent), mediumbedded (6-24 in.); weathers to rough, silty, buff-colored surface; forms series of ledges ---

Total cliff unit, Wescogame Formation

Total Wescogame Formation --- 180.0

Manakacha Formation, slope unit:

Limestone, grayish-orange-pink, fine-grained, silty; forms ledge

Limestone, light-brownish-gray, very fine grained; weathers to rough surface; forms ledge

Limestone, grayish-orange-pink, fine-grained, silty; forms ledge -...-_.

Concealed slope

Limestone, light-olive-gray, aphanitic to medium-grained; weathers to rough surface; forms ledge

Sandstone, dark-grayish-pink, very fine grained, limy (41 percent); forms ledge --.---..

Limestone, grayish-orange-pink, silty; weathers to brownish, silty surface; forms weak ledge

Limestone, grayish-orange-pink, silty, crossstratified; weathers gray; forms ledge ---.----

Siltstone, pink, calcareous, crumbly; forms slope --...-

Limestone, very light brownish-gray, finegrained, silty (18 percent), cross-stratified; weathers to gray surface with brown streaks; forms ledge

Sandstone, dark-grayish-pink, very fine grained, limy (40 percent); contains wedgeplanar cross-stratification; weathers to brown silty surface; forms ledge --

Sandstone, very pale grayish-orange, fine- to very fine grained; many medium grains (well rounded); very limy, cross-stratified; contains irregular jasper beds; forms ledge --.---
Feet

6.0
Section 31-Continued

\section{ICEBERG CANYON-Continued}

Supai Group-Continued

Manakacha Formation, slope unit-Continued

Limestone, grayish-pink, fine-grained, very silty, friable; grades upward into pink siltstone; forms slope

Total slope unit, Manakacha Formation

Manakacha Formation, cliff unit:

Limestone, dolomitic, very light-brownishgray, medium-grained, very sandy (44 percent), platy; contains horizontal lamination and local cross-lamination; laminae etched on surface; weathers to brownish, silty surface; forms cliff

Sandstone, grayish-orange-pink, very fine grained, crumbly, calcareous (30 percent); contains massive sets of cross-strata $(2-3 \mathrm{ft}$ thick); tabular-planar type cross-stratification with very even planes; many flatbedded strata in upper half; forms cliff -...-...

Limestone, dolomitic, medium-light-gray, medium-grained; contains abundant concretions and irregular masses of chert, which weather black; limestone weathers very rough; forms cliff --_-_-_-_-_-_-

Siltstone, pink, crumbly; forms slope --..--..--

Limestone, pale-red-purple, fine-grained, silty (45 percent), very hard; weathers to brown, silty bands; forms ledge

Limestone, dark-gray, aphanitic; contains much chert; forms ledge --_-_-_-

Siltstone, pink, crumbly, calcareous; contains single thick chert layer near middle; forms slope

Limestone, pale-red, very fine grained, sandy (47 percent); contains thin, flat laminae etched on surface; weathers brown; forms ledge

Limestone, light-olive-gray, very fine grained (insoluble 27 percent); contains tabularplanar cross-stratification; weathers to silty surface

Sandstone, grayish-pink, very fine grained, very silty, crumbly, calcareous; contains jasper layer ( $1 \mathrm{ft}$ thick) near base; forms ledge

Limestone, dolomitic, very pale grayish-orange, very fine grained, silty (51 percent); forms resistant, rounded ledge
Feet 
Section 31-Continued

ICEBERG CANYON-Continued

Supai Group-Continued

Manakacha Formation, cliff unit-Continued

Limestone, dolomitic, grayish-orange-pink, very fine grained, silty (45 percent); contains brachiopod sections; weathers tan with gray streaks; forms rounded ledge -

Limestone, grayish-red-brown, fine-grained, very sandy ( 30 percent); contains crossstratification (wedge- and trough-types) on medium scale; weathers purple-brown with laminae etched on surface; forms resistant ledge

Limestone, medium-light-gray, fine-grained, thin-bedded (0.5-2 in.), platy; surfaces show many fossil traces, especially bryozoan; contains jasper lenses and concretions; weathers pale-gray; forms weak ledge

Limestone, light-gray, fine-grained, evengrained; contains thin, brown, silty layers, 1-2 in. apart, which weather to conspicuous brown bands; forms resistant ledge

Limestone, medium-light-gray, fine-grained; contains thick, irregular jasper lenses; forms resistant ledge

Limestone, pale-pinkish-gray, mediumgrained, even-grained; weathers to sandy surface; forms part of cliff

Limestone, olive-gray, aphanitic, thick-bedded (3-6 ft); contains abundant thin (1-2 in.) layers of jasper and white chert, roughly parallel to bedding; forms resistant ledge -----_ $\quad 17.0$

Total cliff unit, Manakacha

Formation -- -163.0
Total Manakacha Formation ---- 277.5

Watahomigi Formation:

Concealed slope

Limestone, grayish-pink with light-olive-gray, very fine grained, silty ( 30 percent), thinbedded (2-12 in.); forms weak ledge --..--

Concealed slope; probably reddish-brown beds

10.0

Limestone, grayish-red, very fine grained, thin-bedded (2-12 in.); weathers light-gray; forms ledge

Chert, white, brittle; forms slope --_-_-_-_---

Concealed slope, probably reddish-brown beds

Mudstone, grayish-red-purple, very fine grained, dolomitic, very hard; weathers with black varnish; forms ledge
Section 31-Continued

\section{ICEBERG CANYON-Continued}

Feet

Supai Group-Continued

Watahomigi Formation-Continued

Concealed slope, probably reddish-brown beds

Limestone, light-brownish-gray, very fine grained; includes scattered grains up to $1 \mathrm{~mm}$; contains brachiopod casts; weathers light-gray; forms ledge

Concealed slope, probably reddish-brown beds

Limestone, grayish-red, fine-grained, thinbedded ( $2-4$ in.); forms weak ledge -.--_-

Limestone, medium-light-gray, very fine grained, thin-bedded (6-12 in.); alternating with grayish-pink, very fine grained, thinbedded calcitic-dolostone; weathers buff; forms cliff

Limestone, medium-light-gray, very fine grained; includes scattered grains up to $1 \mathrm{~mm}$; thick-bedded (3-6 ft); contains scattered chert lenses; forms cliff

60.5

Limestone, dark-gray, very fine grained; contains layers of concretionary chert; contains brachiopods (Spirifer, productids); forms ledge

Dolostone, grayish-white, fine-grained, thickbedded; weathers to buff, pitted surface; forms ledge

Dolostone, pale-pinkish-gray, medium-grained; weathers to $\tan$ surface; contains silty laminae and thin silicified layers; forms ledge

Dolostone, pale-pinkish-white, mediumgrained, thick-bedded (2-15 ft); weathers dark-gray with rough, pitted surface; contains three lensing layers of brownweathering chert, each 1-2 ft thick, at distances of $27 \mathrm{ft}, 49 \mathrm{ft}$, and $62 \mathrm{ft}$ from bottom; contains trilobites at 19 and $41 \mathrm{ft}$ up; forms cliff

Concealed slope; probably reddish-brown, shaly siltstone -

Limestone, pale-reddish-brown, very sandy (47 percent), thin- to medium-bedded (2-24 in.); irregularly bedded; forms ledge -------

Dolostone, calcitic, grayish-orange-pink, finegrained, sandy (30 percent), shaly, friable; forms slope -Total Watahomigi Formation -- $\mathbf{3 0 4 . 0}$ Total Supai Group and Pakoon 
Section 31-Continued

ICEBERG CANYON-Continued

Unconformity

Redwall Limestone:

Horseshoe Mesa Member:

Limestone, pale-gray, aphanitic, thin-bedded (0.5-1 ft); locally dolomitized with medium crystalline texture, white; contains corals, foraminifers (204)

Section 32 (part)

SELIGMAN

[On Aubrey Cliffs, 4 miles west of Seligman]

Hermit Shale:

Unconformity:

Assumed.

Supai Group:

Esplanade Sandstone, main cliff unit:

Sandstone, pale-reddish-brown, calcareous, thick-bedded, cross-laminated, cliffforming; alternates with pale-reddishbrown, friable, structureless sandstone; slope-forming; unit forms series of cliffs and slopes --_-_-

Sandstone, pale-reddish-brown, very fine grained, calcareous; includes sandy, crystalline limestone; beds near base very thick, near top, thinner; middle portion structureless, weakly cemented; weathers to palereddish-brown; forms massive cliff with bench at weak, middle portion -._-_-_._-

Siltstone, dark-reddish-gray, calcareous, weakly cemented; forms slope with rounded knobs

Limestone, reddish-gray, fine-grained, crosslaminated; weathers pal/s-brown, sandy surface with laminae etched out; forms cliff with straight face and sharp edges --------

Concealed, probably pale-reddish-brown, thin-bedded siltstone

Sandstone, pale-reddish-brown, uniformly very fine grained, calcareous, crosslaminated (prominently at base); beds $2-4 \mathrm{ft}$ thick; weathers pale-reddish-brown; forms massive cliff, rounded at top
Section 32 (part)-Continued

SELIGMAN-Continued

Feet

Supai Group-Continued

Esplanade Sandstone, main cliff unit-

Continued

Limestone, reddish-gray, fine-grained, crosslaminated, cliff-forming; like limestone above but less sandy

Total main cliff unit, Esplanade

Sandstone

12.0

Esplanade Sandstone, basal slope unit:

Concealed, probably pale-reddish-brown,

thin-bedded siltstone ----areous, structure-
Siltstone, reddish-gray, calcareons less; weathers same color; forms rounded cliff

Feet

Siltstone, pale-reddish-brown, argillaceous, thin-bedded (less than $0.5 \mathrm{in}$.); weathers same color; forms slope -.-_-

Siltstone, reddish-gray to light-brown, calcareous, cliff-forming; weathers to palebrown

Feet

Siltstone, pale-reddish-brown, thick-bedded, structureless; forms weak cliff with rounded surfaces

Conglomerate, forms rounded massive ledge --Matrix: reddish-gray silt.

53.5

Gravel: commonly $2-4$ in. in diameter, as much as 8 in.; mostly well-rounded, palebrown, reddish-gray, and light-brownishgray limestones and siltstones.

Total basal slope unit, Esplanade Sandstone - $-\frac{90.0}{260.5}$

77.0 Wescogame Formation, slope unit:

Limestone, dark-reddish-gray, crystalline; weathers to pale-brown, sandy surface; forms cliff

Concealed, probably continuation of overlying limestone.

\section{SEPARATION CANYON}

[Measured on south side of Colorado River at Separation Canyon, east of Spencer Canyon]

Tertiary rocks:

Basaltic flows and stream gravels of Tertiary age forming cap of mesa. 
Section 34-Continued

\section{SEPARATION CANYON-Continued}

Contact:

Irregular surface of Tertiary erosion.

(Base of slope unit of Manakacha to top of Supai Group, measured on east side of lava-

Supai Group: capped hill).

Esplanade Sandstone, main cliff unit:

Sandstone, grayish-pink, very fine grained, very limy (45 percent), thick-bedded; weakly cross-stratified on medium to large scale; locally friable; forms massive cliff at top of section

Total main cliff unit, Esplanade Sandstone

$11.0+$

Esplanade Sandstone, basal slope unit:

Sandstone, pale-reddish-brown, structureless, very fine grained, calcareous, silty; grains with iron oxide coatings; forms recess below massive cliff; lower part of slope concealed ---

Siltstone, deep-reddish-brown, thin-bedded (0.5-1 in.); contains horizontal laminae and cross-laminae; resistant; forms receding ledges

Conglomerate, grayish-red; forms massive ledge $2.0-10.0$

Matrix: granule-sized limestone clasts and quartz sand.

Cement: calcareous.

Gravel: pale-reddish-brown siltstone, lightgray, medium-gray and grayish-pink limestone; mostly well-rounded, some subrounded; average diameters $0.5-1$ in. (maximum 3 in.).

Total basal slope unit, Esplanade

Sandstone - $\quad 31.0$

Total Esplanade Sandstone --- $-\frac{31.0}{42.0}+$

Wescogame Formation, slope unit:

Siltstone, reddish-brown, shaly; consists of thin, flat beds; includes one resistant, sandy, limestone bed; forms bench

Total slope unit, Wescogame Formation 15.0

Feet
Section 34-Continued

SEPARATION CANYON-Continued

Supai Group-Continued

Wescogame Formation, cliff unit:

Sandstone, grayish-orange-pink, very fine grained, limy (37 percent), thick-bedded $(2-4 \mathrm{ft})$; cross-stratified on medium to large scale (tabular-planar, wedge-planar, locally trough type); forms series of receding ledges and small cliffs; includes limestone ledge near middle; weathers to rounded edges and surface of dark-gray or black varnish; friable; contains $16 \mathrm{ft}$ of very massive ledges at $30 \mathrm{ft}$ above base

Sandstone, pale-reddish-brown, very fine grained, very limy (49 percent); crossstratified (medium-scale); forms resistant ledge; weathers to black surface with laminae strongly etched in relief -.--_-_---

Concealed slope

Conglomerate, varicolored; dominantly gray, with reddish-brown and purple ---.---.Matrix: gray, granular limestone; dominated by medium-size clasts; includes many granule-size clasts.

Gravel: gray, aphanitic limestone; purple, silty limestone; reddish-brown siltstone (dominant); angular, red jasper (rare); angular, white chert; medium-grained, brown sandstone; average $0.5-1$ in. in diameter (maximum 3 in.); mostly subangular to rounded.

Total cliff unit, Wescogame Formation --.- 59.0

Total Wescogame Formation ---- 74.0

Manakacha Formation, slope unit:

Sandstone, pale-reddish-brown, very fine grained, very limy (47 percent), crossstratified (medium-scale); forms ledges $(0.5-2 \mathrm{ft})$; alternating with pale-reddishbrown, very fine grained, shaly, flat-bedded sandstone; forms slopes, much concealed -----

Sandstone, pale-reddish-brown, very fine grained, very limy (49 percent), shaly; some horizontally laminated, some crosslaminated; includes $5 \mathrm{ft}$, weak, rounded ledge of siltstone; total much concealed; forms long slope
49.5

Feet 
Section 34-Continued

SEPARATION CANYON-Continued

Supai Group-Continued

Manakacha Formation, slope unit-Continued

Limestone, light-brownish-gray, fine-grained, very sandy to very silty (39 percent), medium-bedded $(0.5-2 \mathrm{ft})$; contains irregular jasper lenses; weathers to dark-brown surface with sandy laminae etched in relief; cross-laminated near top; forms receding ledges

Limestone, magnesian, medium-gray, finegrained, medium-bedded $(0.5-2 \mathrm{ft})$; contains abundant lenses and nodules of jasper; forms ledge

Limestone, light-brownish-gray, very sandy (46 percent); cross-laminated on medium scale; forms ledge capping plateau --..-_-_.--

Siltstone, pale-reddish-brown, shaly; contains few thin, reddish-brown sandstone beds; forms long slope overlying major cliff

Total slope unit, Manakacha Formation

(Watahomigi Formation and cliff unit of Manakacha Formation measured in canyon 0.5 mile east of lava-capped mesa)

Manakacha Formation, cliff unit:

Limestone, grayish-red, sandy (30 percent); medium-bedded (1-3 ft); cross-laminated at low angle and horizontally laminated; contains jasper concretions; weathers with etched, brown laminae; forms top of main cliff

Limestone, medium-gray, medium-bedded (1-3 ft); contains irregular jasper bands; weathers to rough surface; forms rounded ledge in cliff

Limestone, grayish-pink, sandy; like cliff unit above but cherty

Limestone, medium-gray, medium-bedded; like jasper unit above --_-_-

Limestone, grayish-pink, sandy; like lowangled, cross-laminated cliff unit at top ------

Limestone, medium-gray, medium-bedded; like jasper-banded cliff unit at top --...-..-

Limestone, grayish-red, sandy (40 percent); like low-angle, cross-laminated cliff unit at top

Limestone, dolomitic, medium-gray, very fine grained; medium-bedded; like jasper-banded unit above; forms base of major cliff -........-

Concealed slope

\section{Section 34-Continued \\ SEPARATION CANYON-Continued}

Feet

Supai Group-Continued

Manakacha Formation, cliff unit-Continued

Sandstone, medium-light-gray, very fine grained, some fine-grained, limy (44 percent), thick-bedded ( $2-4 \mathrm{ft}$ ); locally contains many jasper layers and lenses; forms cliff with prominent parting; top bed crossstratified

Feet

16.5 Siltstone, pale-reddish-brown, shaly; uniform in texture and structure; forms series of rounded ledges or a weak cliff, underlying major sandstone cliff

5.0 Sandstone, pale-reddish-purple, very fine grained; contains dolomitic limestone (20 percent); includes $1 \mathrm{ft}$ reddish-brown mudstone parting; forms two resistant ledges --..--

Limestone, pale-brownish-gray; granular; contains irregular jasper lenses; forms rounded ledge

Limestone, pale-reddish-purple to purple, silty, sandy (insoluble 36 percent), resistant; medium-bedded (2-4 ft); cross-stratified on medium-scale; locally capped by few inches of fine-grained, pale-reddish-brown sandstone; forms ledge with straight face ---.----

Siltstone, grayish-red-brown, shaly; locally contains mudcracks, ripple marks, burrows; beds progressively thicker near top; forms slope or weak ledges

11.0 Mudstone, brownish-gray; intertonguing with dark-gray limestone; forms resistant ledge at cliff summit

Siltstone, dark-reddish-brown, crumbly; forms recess

Limestone, light-gray, granular, thick-bedded; contains abundant jasper layers; forms resistant ledge

Limestone, light-brownish-gray, aphanitic; contains many jasper layers (0.5-2 in. thick), some are parallel to bedding, others crosscut beds; weathers to rough surface, with vertical face; forms prominent marker ---_-----

Limestone, pale-reddish-brown, very silty (48 percent), platy, flat-bedded; forms weak, rounded ledge beneath resistant cap rock --..-

Total cliff unit, Manakacha Formation - 205.0 Total Manakacha Formation --- $-\frac{205.0}{300.0}$ 
Section 34-Continued

SEPARATION CANYON-Continued

Supai Group-Continued

Watahomigi Formation, upper slope unit:

Concealed slope

Total upper slope, Watahomigi

Formation --.--.--.--

Watahomigi Formation, middle cliff and lower slope units:

Conglomerate, pale-gray and brown, locally crumbly; forms weak ledge

Matrix: pale-gray to white silt.

Gravel: closely packed; angular to subangular; jasper, white siltstone, quartz, red-brown mudstone, flint; average 0.13-0.25 in. in diameter (maximum 1 in.).

Siltstone, grayish-red-brown, brittle; grains with iron-oxide coatings, slope-forming -------

Limestone, pale-reddish-brown, silty (26 percent), platy, irregularly bedded; contains wavy beds of white chert; capped by bed of light-gray, fine-grained limestone --..---.--

Mudstone, purplish-brown, very crumbly, slope-forming

Siltstone, light-brownish-gray, limy (30 percent); contains irregular jasper layers; weathers to brown surface; forms rounded, resistant ledge

Concealed slope

Limestone, brownish-gray, fine-grained, silty; contains abundant jasper layers; locally forms resistant ledge; weathers to rough, gray surface

Concealed slope

Siltstone, medium-light-gray, calcareous, thinbedded (6-12 in.); weathers dark-brown to black with thick laminae etched on surface; forms receding ledge

Limestone, light-brownish-gray to pale-brown; includes much chert; contains fusulinids; forms resistant, rough ledge -.-_-_-_-_-

Concealed slope -

Limestone, light-gray, fine-grained; contains many thin jasper layers crosscutting bed in various directions; weathers to rough, gray surface; forms resistant ledge

Concealed slope

Limestone, yellow-brown, granular, mediumbedded $(1-2 \mathrm{ft})$; contains abundant foraminifers(?); forms weak, rounded ledge or slope

Section 34-Continued

\section{SEPARATION CANYON-Continued}

Feet
Supai Group-Continued

Watahomigi Formation, middle cliff and lower slope units-Continued

Limestone, grayish-orange-pink, fine-grained; contains much jasper near top; forms receding ledges

Limestone, light-gray to very light gray, finegrained, thick-bedded (2.5-4 ft); contains thin chert beds near top; fossiliferous (lowspired gastropod, conodonts); weathers brownish-gray; contains prominent parting bed in middle; forms major cliff

Concealed slope

Limestone, light-brownish-gray, aphanitic to fine-grained, massive, thick-bedded $(2.5 \mathrm{ft})$; forms resistant ledge

Limestone, dolomitic, light-brownish-gray to grayish-orange-pink, aphanitic to finegrained; includes beds of white limestone breccia and bed with angular, purple mudstone fragments; thin- to mediumbedded $(0.5-2 \mathrm{ft})$; contains beds with white, elongate spheres, in part hollow; forms slope with series of weak, receding ledges, mostly rounded

Limestone, grayish-red-purple, aphanitic with scattered granules throughout; mediumbedded $(2.5-3 \mathrm{ft})$; includes parting zone of thin-bedded (0.5-2 in.) limestone; contains brachiopods (spiriferid, Composita) and fish tooth; weathers dark-gray; forms double ledge; prominent marker bed

Limestone, grayish-red-purple, mediumgrained; weathers dark-gray, pitted; forms weak ledge

Claystone, pale-reddish-purple, fissile; forms slope; largely concealed -.--_-_-

Conglomerate, dark-reddish-brown, forms thin, resistant ledge

Matrix: gray and reddish-brown sandstone to gray, granular limestone.

Gravel: white and gray chert, white and red quartz; average diameters $0.25-0.5$ in. (maximum $1.5 \mathrm{in.}$ ); angular to rounded, mostly subangular; very concentrated locally, elsewhere scattered; locally contains fossils (Composita, high-spired gastropod, spiriferid, pelecypod, fish tooth).
Feet

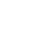


Section 34-Continued

\section{SEPARATION CANYON-Continued}

Supai Group-Continued

Watahomigi Formation, middle cliff and lower slope units-Continued

Claystone, reddish-brown, structureless, weak, largely concealed --..-. cliff and lower
Total middle

Total middle cliff and lower
slope units, Watahomigi For-

$\begin{array}{rr}\text { mation } & 151.0 \\ \text { Total Watahomigi Formation }-197.0\end{array}$

Unconformity:

Surface even and relatively flat with local mounds a few feet high; much concealed.

Total Supai Group exposed --.-- 613.0+

Redwall Limestone:

Horseshoe Mesa Member:

Limestone, light-olive-gray, aphanitic, medium-bedded; weathers to rough surface; forms receding ledges.

\section{Section 35}

\section{HINDU CANYON}

[In eastern end of Hindu Canyon, south of Bridge Canyon, on small mesa at approximately sec. 24, T. 27 N., R. 12 E. and sec. 19, T. 27 N., R. $11 \mathrm{~W}$.

Top of mesa (recent erosion surface):

Overlying red-slope member visible $0.5 \mathrm{mi}$ to north.

Supai Group:

Watahomigi Formation:

Limestone, dark-gray, medium- to thickbedded $(1-3 \mathrm{ft})$; contains many bands and crosscuts of jasper; forms cliff

Limestone, pale-gray, aphanitic, thin-bedded $(0.5-1 \mathrm{ft})$; forms weak, rounded, receding ledges

Limestone, gray, medium-grained, mediumbedded $(3 \mathrm{ft})$; weathers to rough, pitted surface; forms ledge

Concealed slope
Section 35-Continued

HINDU CANYON-Continued

Feet

Supai Group-Continued

Watahomigi Formation-Continued

Limestone, medium-gray, aphanitic, thinbedded $(0.5-1 \mathrm{ft})$; forms ledges - 3.0 .

Concealed slope

Limestone, gray to purple, thin-bedded (0.5$1 \mathrm{ft}$ ); forms ledges -

Mudstone, deep-reddish-brown, structureless; forms slope

Limestone, light-gray, fine-grained, thinbedded $(0.5 \mathrm{ft})$; contains few, scattered pebbles of jasper; forms resistant ledge -.-.---_-

Concealed slope --.---

Siltstone, pale-gray, shaly; alternating with reddish-brown, brittle, crumbly, structureless mudstone; forms slope

Limestone, gray with reddish-brown blotches, silty, cross-stratified (tabular-planar); contains scattered pebbles of chert and jasper (0.13-0.25 in. in diameter); very fossiliferous with large local concentrations (brachiopods including Composita, Spirifer, Hustedia?, gastropods, crinoids; fig. E1); forms ledge ----

Mudstone, dark-reddish-brown, shaly; alternating with bright-reddish-brown, calcareous (42 percent), thin-bedded siltstone; forms slope

Conglomerate, reddish-brown, forms massive ledge --_Matrix: gray to reddish-brown, finegrained calcareous sandstone.

Pebbles: gray limestone, abundant red jasper, yellow and white chert, black ironstone; subangular to well-rounded; average $0.25-0.5$ in., maximum 1.5 in. in diameter.

Total Watahomigi Formation --- $\overline{92.5}+$

10.0 Unconformity:

Assumed; contact not exposed.

Redwall Limestone:

3.0 Limestone, gray, aphanitic, massive; weathers to rough, pitted surface; forms receding ledges. 


\section{INDEX}

\section{[Italic page numbers indicate major references]}

Page

\section{A}

Accretal, defined ........................................ 335 Accretal limestone, Watahomigi Formation ............ 345 Acknowledgments ......................................... 11 Age, determination .................................... 15 Esplanade Sandstone ............................. 111 Manakacha Formation ............................... 10 Pakoon Limestone ................................... 11 valley-fill deposits .................................. 144 Watahomigi Formation …1. 105, 115 Wescogame Formation ........................... 109 Algae

Hermit Shale

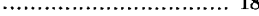

Manakacha Formation ............................ 335
Watahomigi Formation ....... 83, 144, 335, 346, 347 altirostris, Schizophoria ............. 80, 116, 122; pl. F1

Aluminum ...................... 293, 297, 301, 308, 310

Amite River, Louisiana ................................ 248 Ammobatrachus turbatans .................................. 92 Amphibians, tracks ............................... 203, 247

Wescogame Formation amplus, Schizodus ........................ 120, 125; pl. F4 Amsden Formation, Wyoming ......... 117, 120, 122, 125 Anapiculatisporites concinnus .................... 143, 144 Anaplanisporites globulus ........................ 143, 144 Andrus Canyon ....................................... 144 conglomerate ....................................... 189 corrensite ................................... 26, 327 cross-stratification ..................................... 223

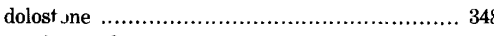
erosion surfaces ............................... 166, 167 evaporite deposits ................................... 377 fish ..................................................... 12 grain size ................................................ 229 gypsum …....................... 46, 48, 327, 377 Hermit Shale $\ldots$ illite ........................ $24,25,26,315,325,327$ kaolinite ...................................... 26, 328

Pakoon Limestone ................................., 49 petrography ................................... 355, 357 ripple marks ......................................... 275 stratigraphic sections ................................ 461

vertebrate animals ............................. 91, 259 Anematina sp. ......................................... pl. G2 Anhydrite ............................................... 377 Anomalopus sturdevanti .................................. 92

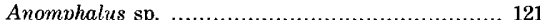
Anteridocus sp. ...................................... pl. F2 Anthracospirifer bifurcatus ............................. 115

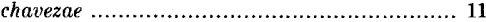
curvilateralis ….......................... 144; pl. G1 newberryi ...................... 80, 117, 122; pl. F3 occidentalis ....................................... 190 occiduus ....... 70, 78, 80, 107, 117, 121, 122; pl. F3 opimus ............................... 80, 117 tanoensis .................. 80, 117, 121, 122; pl. F3 sp. .................. $77,85,116,117,121,189 ;$ pl. G1 Apache Trail ......................... 35, 39, 171, 280, 427 Apeterrinella sp. ............................................ 346 Apterrinellids ........................................... 144 Arbuckle Mountains, Oklahoma ......................... 123

Arenaceous, defined ….................................. 10 Arizona sag ........................................... 56 arizonae, Callipteris ....................................... 111 Arrow Canyon, Nevada …...................... 108, 145 Asphaltina sp. .............................................. 144 Asteroarchaediscus sp. ......................... 83, 107 Athyridacea .................................................... 117
Page

Atoka Formation, Arkansas ... 123 Atokan conglomerate Atokan Provincial Series ................................. 194 Aubrey Cliffs ......................................... 3, 31 Aubrey Group ......................................... 3, 31 Aubrey Valley ............................................. 3 Aubry Group. See Aubrey Group. Auroraspora solisortus ............... 143, 144 Authigenic, defined ..................................... 305 Aviculopecten gravidus ................ 120, 122, 125; pl. F4 sp. ......................................... 81, 82, 120

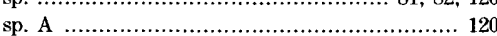
sp. B ….................................... 120; pl. F4

Badger Canyon, erosion surface ........................ 171 Barnett Hill Formation, Oklahoma .................. 123 Barytichisma sp. ....................................... 143 Bashkirian Provincial Stage, Ural Mountains ......... 123 Bass Canyon ............................................. 210 Bass Trail .......................................... 31, 418 carbonate mudstone ................................ 344 conglomerate ......................................... 201 endothyra ........................................... 259 flora

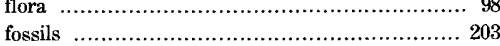
grain size ........................................ 216

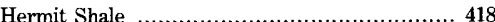

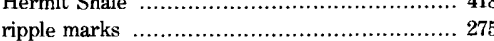
stratigrahic sections ............................... 418

Bat Tower, buried valleys ............................... 139

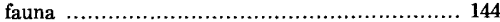
foraminifera ....................................... 144 Battleship Wash Formation, Nevada .................. 145 Bay of Fundy .............................................. 258

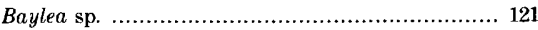
Beaver Dam Mountains, Utah .................... 107, 160 Beedeina sp. ............................................. 108 Bellerophon sp. ..................... 81, 85, 121, 478, 480 bellerophontidae .................................... 85, 121 bifurcatus, Anthracospirifer ............................ 115

Big Spring .................................................. 109

Big Spring Canyon, fauna ................................ 70 fossils ...................................................... 69 Bijou Creek Flood, Colorado ............................ 254 Bioclastic, defined ........................................... 335 Bioclastic debris $\ldots \ldots \ldots \ldots .100,338$ Esplanade Sandstone .......................... 104, 259 Manakacha Formation ....................... 102, 259 Pakoon Limestone ................................ 26, 10 Watahomigi Formation .............. 23, 100, 259, 346 Wescogame Formation ....................... 103, 355 Biostratigraphy, Watahomigi Formation ............... 115 Bird Spring basin ...1........ 55 Bird Spring carbonate shelf .............................. 56 Bird Spring-Ely basin. See Cordillerian miogeosyncline. Bird Spring Range, fusulinids ........................... 72 Biseriamminds . 91 Bivalves .................................................. 24 Esplanade Sandstone ...................... 104, 259 Manakacha Formation ........................ 102, 259 Pakoon Limestone ................................... 26 Watahomigi Formation ...................... 23, 259 Wescogame Formation .................. 25, 103, 259 Black Mesa basin ......................................... 57 Black Mesa sag .......................... 57, 102, 103, 182 Black River ................................ 69, 70, 108
Page

Bloyd Shale ...................................... 117, 126

Blue Mountain Canyon ................................. 445 chert ............................................ 200 conglomerate ....................... 114, 163, 189, 201 corrensite ........ 315 erosion surface ........................................ 171 fauna .............................................. 203 fusulinids ............................................... 259

Hermit Shale …...... 445 kaolinite ............................................... 328 Pakoon Limestone .............................. 49 petrography ................................. 347, 351 stratigraphic sections ............................... 445

Blue Spring ..................................... 340, 397

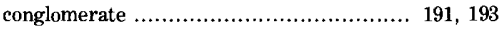
erosion surface ................................... 171 Hermit Shale ........................................... 397 petrography .......................................... 350 shrinkage cracks .................................. 276 stratigraphic sections ............................ 397 Bone Spring Limestone, New Mexico ................. 111 Bostwick Conglomerate Member, Lake Murray Formation ................................. 123 Brachiopods, abundance ........................... 77, 105 Atokan conglomerate ........................... 191 buried-valley deposits ............................. 144 Esplanade Sandstone ......................... 104, 259 Manakacha Formation ....................... 85, 102 Pakoon Limestone ................................... 89 Watahomigi Formation .......... 23, 65, 69, 70, 77, $84,100,105,115,116,122,258,346,347,363$; pls. F1, F2, F3

Wescogame Formation 103 Brachydactylopus ........................................ 92 Brazos River, Texas .............................. 249, 256 Breezy Point ............................................... 91 Brentwood Limestone Member of the Bloyd Shale . 117, 122,123 Bridge Canyon ................................... 115, 496 brachiopods ............................................ 117

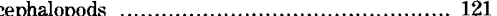

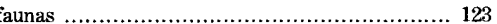
gastropods ............................................ 121 jasper .................................................. 374 pelecypods ............................................ 121 petrography ...................................... 347

Bright Angel Trail .................................. 157 contorted stratification ........................... 280 cross-stratification ...................................... 234 erosion surface .................................... 169 fossils .............................................. 115 vertebrate animals ............................ 91, 259

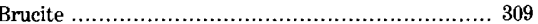

Bryozoans, abundance .................................... 77 buried-valley deposits .............................. 144 Esplanade Sandstone ................................ 259 Manakacha Formation .................. 85, 102, 259 Pakoon Limestone ............. 26, 89, 104, 182, 183 Watahomigi Formation ................. 23, 82, 100, $115,116,122,258,346,347$ Wescogame Formation ...................... 103, 259 Bunker Trail .................................. 40, 145, 401 conglomerate ........................ 41, 164, 193, 202 erosion surfaces ................................ 166, 171 foraminifers ........................................ 102 Hermit Shale …............................... 401 pelmatozoans ........................................... 259 petrography …....................... 350, 355, 357 stratigraphic sections .............................. 401 
Page

Buried valleys ............................................ 139 Butterfield Peaks Formation, Utah .................... 123 Buxtonia sp. ............................... 70, 117; pl. F

Calamites .................................................... 97 Calamospora sp. ......................................... 143 Calcispherids .................................. 24, 85, 102 Calcite ....................................... 290, 291, 311 Calcium …................. 50, 298, 301, 309, 312, 379 Calcivertella sp. ..................................... 89, 111 Callipteris arizonae ...................................... 111 Callville Limestone ....................................... 31, 33 Callville Mountain ............................................ 31 Callville shelf ......... 56 Cameron Creek Member, Tyler Formation ........... 122 campestris, Raticulariina ................................. 105 Canina sp. ........................................ 85, 111 Carbonate facies, distribution ..................... 338 Carbonate rocks .................................. 303, 378 Esplanade Sandstone .............................. 384 Manakacha Formation ............................... 379 Pakoon Limestone .............................. 379, 38 Watahomigi Formation ............................ 379 Wescogame Formation ....................... 379, 384 Carrizo Creek ............ 69, 70, 109 Cataract Canyon .................................... 4, 35

See also Havasu Canyon.

Cataract Creek ............................................ 4 Cavusgnathus gigantus ................................ 84 Cedar Creek ................................................. 3

Cedar Mesa Sandstone Member of the Cutler Formation ................................. 377 Cephalopods, Watahomigi Formation ........... 116, 121 Chainman Shale, Utah ............................... 144 Channeling ................................... 157, 160, 193 chavezae, Anthracospirifer .............................. 117 Chert, Atokan conglomerate ............................. 191 Blue Mountain Canyon ............................... 200 Esplanade-Pakoon conglomerate ............. 200, 358 Pakoon Limestone ................................. 367 Watahomigi Formation ............ 190, 213, 344, 367 Wescogame Formation ........................... 193 Chinle, Arizona ....................................... 57 Chlorite ................... 289, 293, 302, 305, 308, 809 Esplanade Sandstone ...... 26, 328 Manakacha Formation ....................... 315, 328 Watahomigi Formation ............................. 23, 315 Wescogame Formation ......................... 25, 325 Choliohnus gigas Cholla Bay, Mexico ........................................ 267 Circle Cliffs uplift ......................................... 55 clatriformis, Dictyotriletes ......................... 143, 144

Clay minerals ........................................... 289 associations ................................................. 305 depositional environments ......................... 305 distribution ........................................... 302 Esplanade Sandstone ........................ 326, 329 Manakacha Formation .................... 315, 328 Pakoon Limestone .................................. 326

Watahomigi Formation .................... 314, 328 Clay minerals, Wescogame Formation ........... 324, 329 Claystone, defined ..................................... 11 clydensis, Inflatia ....................... 143; pls. G1, G2 Coconino Sandstone ................. 3, 31, 397, 399, 431 Coledium sp. ........................................... 117 Colorado Plateau ......................................... 64 Colorado River ................................ 66, 248, 256 Composita elongata .......... gibbosa .............. 77, 117, 121, 122, 144; pl. F2 ovata .............. 117, 121, 122, 144; pls. F2, G1 subtilita .................................. 117; pl. F3 sp. ......... 91, 116, 121, 189, 478, 496; pls. F3, G2 concinnus, Anapiculatisporites ................. 143, 144 Conglomerate beds $\ldots \ldots \ldots \ldots .107,163,171,189,201,203$ Conifers ................................................. 179 Conodonts ........................................... 77 Lime Ridge ................................... 84
Page

Conodonts-Continued

Pakoon Ridge

Separation Canyon Conulariids, Watahomigi Formation ............ 77, 82, 116 Convolutispora florida ............................ 143, 144

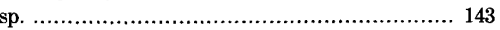

Coral, abundance .................................... 77, 105 buried-valley deposit ............................... 143 Esplanade Sandstone ......................... 69, 259 Granite Park .......................................... 143 Hidden Canyon ......................................... 85 Manakacha Formation ............................... 85 Pakoon Limestone ........ 26, 89, 104, 111, 182, 183 Parashant ... 82 Toroweap ............................................. 82 Watahomigi Formation ... 70, 82, 115, 116, 125, 258 Wescogame Formation ................. 85, 111, 259

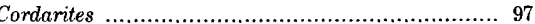
Cordilleran geosyncline ..................... 23, 25, 40, $55,56,67,68,351,357$ deposits . Cordilleran miogeosyncline ................... 55, 57, 66 Cordilleran negative belt ............................. 55 Cordilleran seaway ...................... 102, 103, 104, 125, $181,256,352,359,377$ Cordilleran trough .............................. 55, 338 Correlations, valley-fill deposits ....................... 144 Watahomigi Formation .......................... 122 Corrensite ................. 289, 301, 303, 305, 308, 309 Andrus Canyon ............................. 26, 327 Blue Mountain Canyon ............................. 315 Esplanade Sandstone .................... 26, 311, 327 Grandview Trail ..................................... 315 Kaibab Trail, north .......................... 25, 325 Manakacha Formation .................. 311, 315, 328 Separation Canyon ............................. 24, 315 Toroweap Point ................................... 24 Watahomigi Formation ........ 23, 311, 315, 328, 363 Wescogame Formation .............................. 325 Cottonwood Canyon ...................................... 442 Cranaena sp. .......................................... pl. G1 Crinoids, abundance .................................... 77 Esplanade Sandstone ................................ 104 Watahomigi Formation .................... 82, 100, 122 Wescogame Formation ............................ 103 Cross-bedding, Watahomigi Formation ............... 23 Cross-stratification ........................ 207, 209, 223, 247 Esplanade Sandstone ............... 26, 229, 249, 261 horizontal ........................................... 253 low-angle ............................................. 253 Manakacha Formation ........ 24, 216, 249, 256, 260 planar .................................................. 249 small-scale ........................................... 256 See also ripple marks.

trough ................................................. 249 Watahomigi Formation .................... 211, 249, 260 Wescogame Formation ............. 25, 222, 249, 261 Crurithyris planiconvexa ................ 117, 122; pl. F2 Cumberland Plateau, Tennessee ....................... 311 Cupularostrum sp. ............................ 117, 122 curvilateralis, Anthracospirifer ....................... 144 Cutler Formation ................................... 92, 96 Cyanophyceae ............................................. 99 Cyclothems ................................................. 184 Cystodictya sp. ............................................. 116

\section{D}

Defiance positive element ............. 25, 53, 57, 67, 68 Defiance uplift. See Defiance positive element.

Deoldus sp. ........................................... 83, 85 Deltodus mercurii ......................................... 122 sp. ............................................. 121, 12 Deposition, Esplanade Sandstone …................... 25 Wescogame Formation ........................... 24 Derbyia robusta ......................................... 117 sp. .............................. $70,80,91,107,189$ sp. A ...................................... 116; pl. F1 Detrital, defined ............................................ 305 Diabolocera varicostatum Zone .......................... 123
Page

Diagenetic, defined ............................................ 305 Diamond Creek, buried valleys .......................... 139 Dictyotriletes clatriformis ........................ 143, 144 Dielasmoid ............................................ pl. F2 Diplosphaerina sp. ......................................... 91

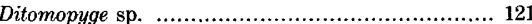
Dolostone ............................................ 26, 379 defined ................................................ 11 Esplanade Sandstone ......................... 42, 384

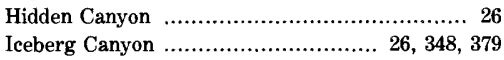
Watahomigi Formation .............................. 348

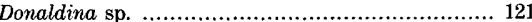
Dunbarinella sp. ....................................... 70 Dye Shale Member Bloyd Shale ...................... 123

\section{$\mathbf{E}$}

East Verde River 69,108 eastoni, Linoproductus ..................................... 122 Echinoderms, abundance ................................. 77 Esplanade Sandstone ................................. 104 Pakoon Limestone ............................. 89 Watahomigi Formation ................. 82, 116, 121 Edmondia sp. ............................. 82, 120; pl. F4 elongata, Composita ............................. pl. G1

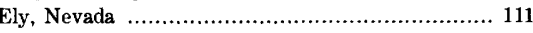
Ely basin ................................................... 55

Ely Limestone ................... 123 Ely-Bird Spring basin ................................. 55 Emery uplift ............................................ 53

Eminence Fault ........................................... 395 cross-stratification .................................... 224 erosion surface ....................................... 171 fusulinids ......................................... 85, 259 Hermit Shale ........................................ 395 stratigraphic sections ............................. 395

Endothyra, Manakacha Formation ........................ 259

Endothyra excellens ....................................... 144 media ................................................. 85

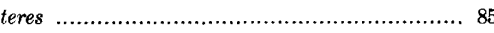
sp. ........................................... 91, 144

Endothyridae, Wescogame Formation ................. 87

English-metric conversion scale ........................ 11 Ensenada land ............................................ 55

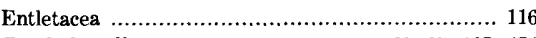

Eoschubertella sp. ........................ 69, 85, 107, 474 Eosigmoilina explicata .................................... 144 rugosa

equus, Hoplichnus lanade Sandstone ..... 163, 165, 18 Hermit Shale ................................... 169, 202 Manakacha Formation ...................... 160, 182 Watahomigi Formation ....................... 157, 182 Wescogame Formation ..................... 160, 182 Esplanade Platform ..................................... 39 Esplanade Sandstone ........................... 5, 25, 35, 41 age ..................................................... 111 bioclastic debris .............................. 104, 259 bivalves .................................... 104, 259 brachiopods .................................... 104, 259

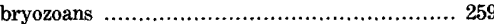
carbonate rocks ...................................... 884 chlorite ...................................... 26, 328 clay mineralogy .............................. 326,329 conglomerate ........................................ 194 corals ......................................... 69, 259 corrensite .............................. 26, 311, 327 crinoids ........................................... 104 cross-stratification ................... 26, 229, 249, 261 deposition ............................................. 25 dolostone ....................................... 42, 384 echinoderms ........................................ 104 erosion surface $\ldots \ldots \ldots \ldots \ldots \ldots \ldots \ldots \ldots \ldots \ldots \ldots, 163,165,182$ evaporite deposits ............................... 260 flora $\ldots \ldots \ldots \ldots \ldots \ldots \ldots \ldots \ldots \ldots \ldots \ldots . . \ldots, 98,183,241$ foraminifers …......................... 104, 259, 358 fossils ........................................ 26, 241 fusulinids .......................................... 259 
Esplanade Sandstone-Continued

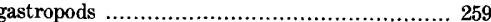
geometry ………………......................... 229 grain-size distribution ......................... 229, 261 gypsum …......... 26, 46, 69, 260, 261, 328, 358, 377

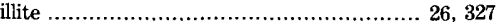
insoluble residues ........................................... 272

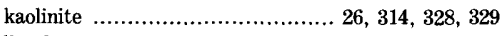
lithology .......................................... 48 marine fauna ........................................... 259 paleogeography .......................................... 67 pelmatozoans ................................ 105, 259, 357 petrography ............................................. 355 rain pits .................................................... 277 ripple marks ..................................... 236, 241 vertebrate animals ..................................... 93 worm trails ................................................. 183

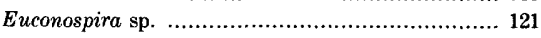

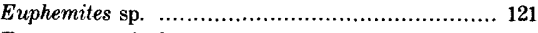

European equivalents ...................................... 123 Evaporite deposits ..................................... 309, 377 Esplanade Sandstone ………………………... 260 excellens, Endothyra …..................................... 144

explicata, Eosigmoilina ……………………….. 144

Fauna

distribution Manakacha Formation ........................ 24, 85, 259 marine ……..................................... 77,181

Esplanade Sandstone ……....................... 259

Pakoon Limestone ………………..... 87, 183

Pakoon Limestone ………………………..... 26 Watahomigi Formation …................. $77,115,258$ Wescogame Formation …............ 25, 85, 182, 259

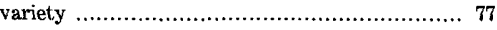
Fayetteville Shale, Arkansas and Oklahoma ……..... 143 Feldspars …......................... 291, 303, 311, 312, 328 Fenestella sp. ................................... 116, 122 Fenestrae, Watahomigi Formation .......................... 345

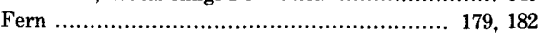
buried-valley deposit ................................... 141

Festoons ......................... 256

Finke River, Australia ……………………….... 254 Fish fossils, Watahomigi Formation ................ 116, 121

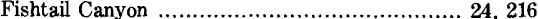
cross-stratification ......................................... 234

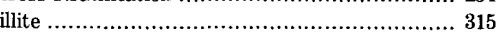
kaolinite ........................................... 24, 324 ripple marks … Flagstaff Limestone, Utah .................................. 363 Flaser bedding ................................................... 256 Flint, Watahomigi Formation ............................. 46

Flora $\ldots$ Esplanade Sandstone ……............... 98, 183, 241 Hermit Shale .................................. 97, 111, 202 Manakacha Formation ……....................... 98 Pakoon Limestone ...................................... 183 Watahomigi Formation …….......................... 97 Wescogame Formation ……………………..... 98 florida, Convolutispora …............................ 143, 144 Folk, R. L., quoted ………………………...... 374 Foraminifers, Esplanade Sandstone ......... 104, 259, 358 Iceberg Canyon ……........................... 89, 111 Manakacha Formation …................ 102, 182, 335 Pakoon Limestone ................................... 26, 89 valley-fill deposits ..................................... pl. G3 Watahomigi Formation .... 23, 70, 83, 84, 100, 144, $182,259,335,344,346,347$

Wescogame Formation ................... 103, 182, 259 See also fusulinids.

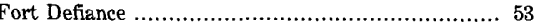
Fossil Bay, vertebrate animals ............................. 93 Fossil Creek, fossils ........................................... 69

Fossils ……............... 3, 69, 105, 182, 247, 258, 275

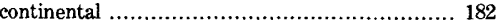
marine ........................................... 23, 258 Esplanade Sandstone .............................. 26, 241
Fossils-Continued

Hermit Shale

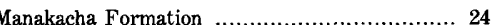

Pakoon Limestone .......................................... 26

Watahomigi Formation ........................ 3, 23, 46, $115,182,258,346$

Wescogame Formation .......................... 25, 259 See also specific types of fossils.

Four Corners …………....................... 24, 67, 72 Frenchman Mountain, Nevada ............. 71, 107, 160, 377

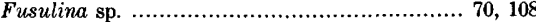
Fusulinella sp. ...... 69, 77, 85, 107, 123, 407, 417, 477 Zone .........

Fusulinellids ....................................................... 77

Fusulinids, distribution . . Esplanade Sandstone _............................. 259 Manakacha Formation ..... 24, 69, 85, 104, 182, 259 Pakoon Limestone …............. 26, 70, 89, 111, 183 Watahomigi Formation .............. 23, 69, 105, 259 Wescogame Formation .... 25, 67, 85, 111, 182, 259

Gastropods, abundance .................................... 77 buried-valley deposits ............................... 144 Esplanade Sandstone .................................. 259 Manakacha Formation ................................ 85 Pakoon Limestone $\ldots$ Watahomigi Formation .................. 80, 84, 115, $120,258,346 ;$ pl. F4

Wescogame Formation ......................... 25, 85 Geinitzina sp. . gibbosa, Composita ........ 77, 117, 121, 122, 144; pl. F2 gigantus, Canusgnathus ................................ 84 gigas, Choliohnus ........................................ 94 Girvanella ................................ 24, 102, 346, 347 Glabrocingulum quadrigatum ........................ pl. G2 sp. ................................................... 144 globulus, Anaplanisporites ...................... 143, 144 Goddard Formation, Oklahoma ........................ 144 Goddard Shale Member, Goddard Formation ........ 144 Golf Course Formation, Oklahoma .................... 123 Gomti River, India ....................................... 256 gonionota, Reticulariina ............................... 117 gracilis, Scoyenia .............................. 100, 180 Grain-size distribution ........................... 208,257 Esplanade Sandstone ........................ 229, 261 Manakacha Formation .............................. 216 Watahomigi Formation ............ 211, 344, 345, 347 Wescogame Formation ........................ 222, 261 Grain types, defined ........................................ 335 Grand Gulch Mine ................................ 471, 479

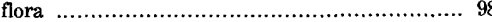
Hermit Shale .......................................... 479 Pakoon Limestone ................................... 48 stratigraphic sections ............................. 479

Grand Wash Cliffs ........................ 31, 46, 48, 384 brachiopods ....................................... 80 carbonate rocks ......................................... 384 cyclothems ........................................ 186 evaporite deposits ..................................... 377 marine faunas .................................. 88, 259 megafossils ........................................... 85 Pakoon Limestone ................................ 49 petrography ............................................ 355 warping ................................................. 145

Grand Wash fault ..................................... 20

Grandview Trail .................... 40, 49, 160, 241, 404 bivalves ............................................. 259

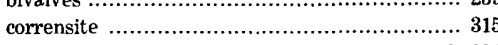
cross-stratification ........................... 223, 234 foraminifers ................................. 102, 18 fusulinids ................................. 85, 107, 259 Hermit Shale ..................................... 404 Redwall Limestone .......................... 341, 407 stratigraphic sections ................................. 404

Granite Park, algae .................................... 144

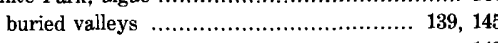
corals ................................................ 143
Granite Park-Continued

foraminifera Granite Park valley ........................................ 139 Granulatisporites granulatus ........................... 143

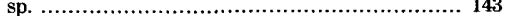
granulatus, Granulatisporites ......................... 143 Grassy Mountain ....................................... 461 gravidus, Aviculopecten ............ 120, 122, 125; pl. F4 Great Basin fauna ............................................... 121 fusulinids ............................................... 107

Guano Cave ...................................... 40, 468 accretal hmestone .................................. 346 brachiopods ........................................... 117 cephalopods ........................................ 121 conglomerate ................................. 190, 191 fauna .................................................... 122

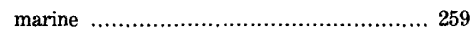
fish .................................................. 121

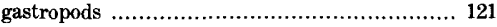
mineralogy .......................................... 348

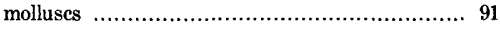

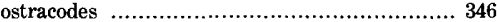
pelecypods ................................... 85, 120 petrography ............................... 347, 355

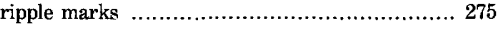
sharks teeth .... stratigraphic sections ........................... 468 Gypsum ................................. 3, 290, 291, 311 Andrus Canyon ...................... 46, 48, 327, 377 Esplanade Sandstone ........................ 26, 46, $69,260,261,328,358,377$

Parashant Canyon ........................ 46, 48, 377 Shivwitz Plateau ........................................ 46

Toroweap Valley ..........................46, 48, 377

H

Hack Canyon, erosion surface .......................... 169 Hadrohercos stereon ............................... 143, 144 Hale Formation ..................................... 122, 123 Halgaito Tongue ............................................. 96 Halite ... Hardinsburg Formation, Illinois ...................... 144 Havasu Canyon ..................................... 4, 427 accretal grains ..................................... 344 algae $\ldots \ldots \ldots \ldots . \ldots 182$ bivalves ........................................... 259 brachiopods ..................................... 77,258 carbonate mudstone ................................ 344 channels ......................................... 193, 195 channel-fill .................................... 164 conglomerate $\ldots \ldots \ldots . .42,46,163,189,191,193,201$ contorted stratification ............................. 280 cross-stratification .......................... 216, 223 erosion surface ..................... 42, 160, 163, 171 foraminifers ......................................... 344 fossils Hermit Shale ..................................... 427 kaolinite ........................................ 24, 324 mineralogy ............................................ 345 Pakoon Limestone .................................... 49 pelmatozoans ......................................... 344 ripple laminae ............................. 213, 275 stratigraphic sections .............................. 427 surfaces of erosion ..................................... 40 type locality ........................................... 35 Havasupai Point, erosion surface ................. 169, 202

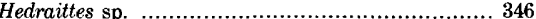
Hematite .................................... 290, 291, 328 Hermit Canyon, erosion surfaces ............ 169, 171, 202 Hermit Shale ....................... 3, 27, 31, 46, 68, 247 algae ................................ 180 Andrus Canyon ...................................... 461 Bass Trail ............................................. 418 Blue Mountain Canyon .............................. 445 Blue Spring ............................................. 397

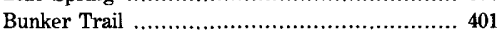
conglomerates ......................................... 203 
Hermit Shale—Continued

Eminence Fault ......................... 395 erosion surface …............................ 169, 202

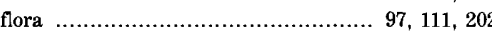
fossils ................................................... 202

Grand Gulch Mine ................................... 479

Grandview Trail ....................................... 404

Havasu Canyon .................................... 427

Hermit Trail ....................................... 414

Hidden Canyon ............................. 483, 486

Horsetrail Canyon .................................. 400

Iceberg Canyon .................................... 487

Kaibab Trail, north ................................. 411

Kaibab Trail, south ................................. 407

Kanab Canyon ........................................ 436

National Canyon .................. 431

Parashant Canyon .................................. 458

Prospect Valley ...................................... 447

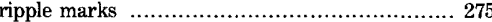

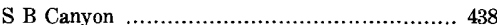

Seligman ........................................... 492

Shinumo Trail ..................................... 422

Snap Canyon ..................................... 471

Thunder River Trail ............................... 423

Topocoba Trail ............................................ 426

Toroweap Valley .................................. 449

Tuckup Canyon .................................... 442

Twentynine Mile Canyon .......................... 391

Twin Springs Canyon ............................... 464

Whitmore Wash ................................... 457

Hermit Trail .............................. 31, 49, 247, 414 bioclasts ........................................... 259 carbonate mudstone ................................... 344 channels .............................................. 193 chlorite .......................................... 328 conglomerate ....................................... 193 cross-stratification .............................. 256

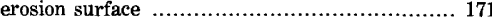

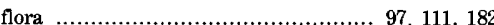

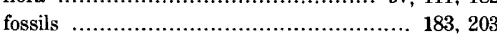
fusulinids .................................... 85, 259 grain size .................................. 216, 222 Hermit Shale ......................................... 414 kaolinite .................................................. 328 mineralogy …........................................ 345 pelmatozoans ...................................... 100 rain pits .............................. 182, 203, 277 shrinkage cracks ............................ 182, 203 strata ....................................... 40, 182 stratigraphic sections $\ldots \ldots \ldots \ldots \ldots \ldots \ldots \ldots \ldots \ldots . . \ldots 14$ vertebrate animals ........................... 91, 259

heterofiliferous, Punctatisporites ...................... 143

Hidden Canyon ............ 40, 46, 48, 163, 481, 483, 486 accretal limestone ................................. 346

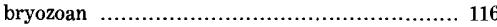

carbonate rocks ..................................... 384 channels ......................................... 164, 195 conglomerates ............................ 195, 201 corals ................................................. 85 cross-stratification .......................... 256, 258 dolostone ............................................. 26

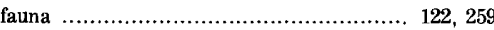

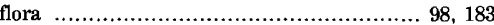

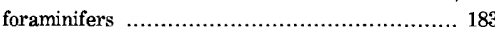
fusulinids ...................................... 85,111 gastropods ............................................ 85 grain size .................................... 216, 222 Hermit Shale ............................. 483, 486 illite ................................................. 327 insoluble residue .................................... 272 marine faunas ................................ 88, 259 marine fossil ........................................... 85 mineralogy ........................................... 348 Pakoon Limestone ............................... 483 pelecypods ........................................ 120 petrography ..................... 347, $351,352,355$ sharks teeth ............................................. 85 stratigraphic sections .................. 481, 483, 486 vertebrate fragments .............................. 346
Page

Hindu Canyon ................................... 213, 496 stratigraphic sections ............................. 496

History

Hogan basin ............................................ 55

Holbrook basin ................................... 260, 377

Hoplichnus equus ......................................... 94

Horseshoe Mesa Member of the Redwall Limestone.. 115 Andrus Canyon ....................................... 464 Bass Trail .............................................. 421

Blue Mountain Canyon ............................. 447

Blue Spring ............................................. 399

Bunker Trail ........................................... 404

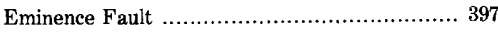

Grandview Trail ................................... 407

Guano Cave ............................................ 471

Havasu Canyon ....................................... 431

Hermit Trail ............................................... 418

Hidden Canyon ....

Iceberg Canyon ..................................... 492

Kaibab Trail, north ................................. 414

National Canyon ....................................... 436

Pigeon Wash .......................................... 479

S B Canyon ........................................ 441

Separation Canyon .................................. 496

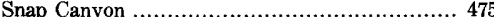

Thunder River Trail .................................. 426

Toroweap Valley ..................................... 453

Tuckup Canyon ......................................... 444

Twentynine Mile Canyon ........................... 395

Twin Springs Canyon ............................... 468 Whitmore Wash ................................... 457

Horsetrail Canyon ...................................... 399 channels ............................................. 193 conglomerate .......................................... 198 erosion surface ..................................... 171

Hermit Shale ....................................... 400 stratigraphic sections ............................. 399

Horton group, Nova Scotia ........................... 144

House Rock Canyon ................................ 183, 391 ripple marks ........................................ 236 stratigraphic sections ............................... 891 House Rock Rapids ................................... 165 Hualapai Trail .......................... 35, 39, 213, 280 Hundred and Fifty Mile Canyon .................. 438 Hustedia miseri ............................................. 70

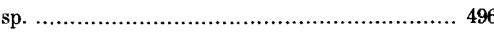

I

Iceberg Canyon .............. 31, 40, 46, 48, 49, 163, 487 carbonate rocks ............................... 379, 384 conglomerate ............................... 200, 201 contorted stratification .............................. 280 cross-stratification .......................... 256, 258 cyclothems ......................................... 186

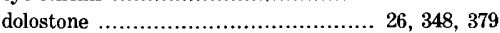

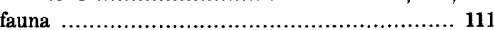

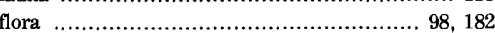
foraminifers ................................... 89, 111 Hermit Shale ....................................... 487 illite ................................................ 327 insoluble residue ...................................... 272 marine faunas ...................................... 88 mineralogy ........................................ 348 Pakoon Limestone ............................... 488 petrography .................................. 347, 355 ripple marks ........................................ 275 sediments ........................................... 184 sharks teeth ........................................ 85 stratigraphic sections ........................... 487 Ichnite fauna, Wescogame Formation ................ 92 Illite .......... 289, 299, 297, 303, 305, 308, 309, 311, 379 Andrus Canyon ............ 24, 25, 26, 315, 325, 327 Esplanade Sandstone ......................... 26, 327 Fishtail Canyon ........................................ 315 Hidden Canyon ................................... 327 Iceberg Canyon ..................................... 327 Kaibab Trail, north $\ldots \ldots \ldots \ldots \ldots \ldots \ldots . .25,315,325$ Manakacha Formation .............. 24, 315, 328, 364
Illite-Continued

Pakoon Limestone

Pation ....................... 23, 363

Wescogame Formation ....................... 25, 324

Illite-smectite clays ............................ 289, 297 incertus, Neoarchaediscus ............................. 83, 107

Indian Springs Formation, Nevada .................. 145

Indus River ................................................... 256 Inflatia clydensis .......................... 143; pls. G1, G2 sp. ..................................................... 144

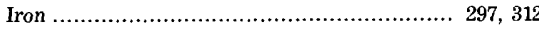

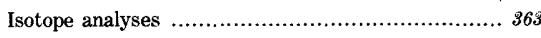

Jasper .............

age ................................................ 374

Atokan conglomerate ............................ 191

Esplanade-Pakoon conglomerate ........... 200, 374

Manakacha Formation ............ 258, 351, 367, 374 origin ................................................... 372 Parashant Canyon .................................. 374 petrology ............................................ 369

Separation Canyon ................................... 200

Toroweap Valley ................................ 374

Watahomigi Formation .................... 40, 46,

$213,344,346,367,374$

Wescogame Formation ..................... 193, 374 Jasperoid, defined .................................... 367

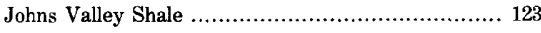

Jump Canyon ........................................... 486

\section{K}

Kaibab Limestone .............................................. 3

Kaibab Plateau ............................................. 55

Kaibab Trail, flora ........................................ 111 silica rock ......................................... 367 strata

Kaibab Trail, north ................................ 241, 411 aceretal grains .................................... 34 channel-fill ................................... 164, 195

chlorite ............................................. 328

conglomerate .............................. 164, 195

contorted bedding ................................ 221

contorted stratification .............................. 280

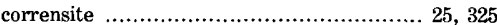
cross-stratification ............................ 223, 258 flora .............................................. 98 fusulinids ................................ 85, 107, 259

Hermit Shale illite ........................................ 25, 315,325

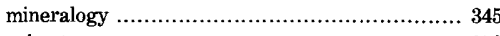
pelmatozoans ....................................... 259

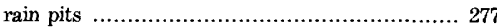

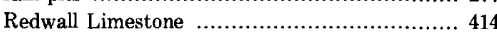
ripple marks ..................................... 275 shrinkage cracks ................................... 276 stratigraphic sections ................................ 411 surfaces of erosion .................................. 40 vertebrate animals ............................. 91, 259

Kaibab Trail, south ............................ 49, 203, 407 algal accretions ................................... $\mathbf{3 4 4}$ bivalves .............................................. 259 conglomerate ........................................... 193 cross-stratification ............................. 210, 234 erosion surface ................................... 171 flora .................................... 97, 182, 208 Hermit Shale ...................................... 407 isotope analyses ..................................... 368 Redwall Limestone ......................... 341, 411 stratigraphic sections .............................. 407 vertebrate animals ............................ 91, 259

Kaibab uplift .............................................. 55

Kanab Canyon ....................................... 3, 436 channels .............................................. 195 cross-stratification .......................... 216, 223 erosion surface ......................... 160, 164, 169 Hermit Shale ...................................... 436 


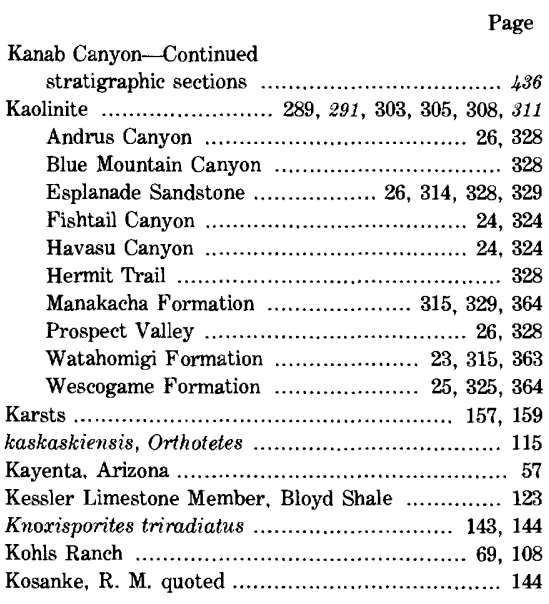

\section{$\mathbf{L}$}

La Pasada Formation, New Mexico .................... 123 Lake Mead ................................................ 31 Lake Bonneville .................................................. 363 Lake Murray Formation, Oklahoma ................... 123 Lake Point Limestone, Utah .......................... 123 Las Vegas Hinge Line ............................... 56 Lenticular bedding .................................... 256 Leptodesma sp. ........................................ 120 Lime Ridge, conodonts ................................. 84 Limestone, aphanitic ................................ 338, 341 linearis, Schwagerina ................................ 111 Lingula sp. ........................................ 16, 452 Linoproductus eastoni ................................. 122 nodosus ............ 68, 70, 80, 107, 117, 122; pl. F1 Zone .................................... 107, 122 pumilus ........................ 80, 117, 122; pl. F1 sp. ........................................ 91, 190 sp. A ...................................... 117, 121, 122 Lipan Point .............................................. 401

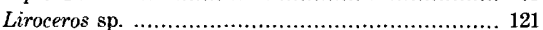
Lithology .................................................. 46 buried-valley deposits .............................. 189 Esplanade Sandstone .................................. 48 Manakacha Formation ......................... 26, 46 Watahomigi Formation ..................... 23, 46, 157 Wescogame Formation ............................... 47 Little Colorado River Gorge .............................. 401 Lovering, T. G., quoted ................................ 370 Lower Cook Inlet ......................................... 258

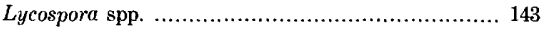

\section{M}

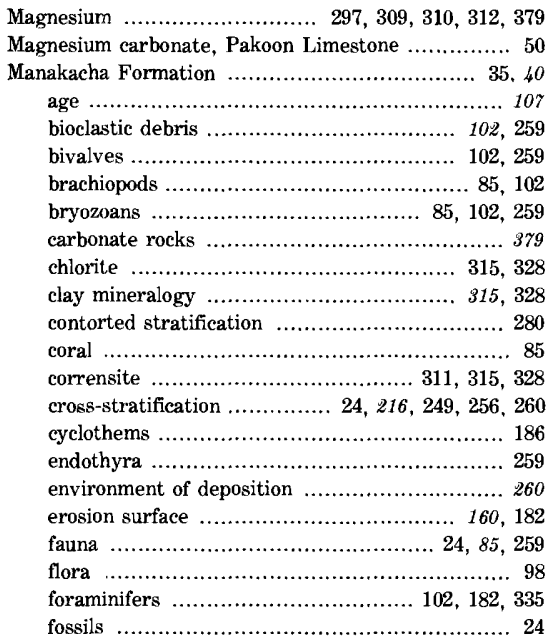

Page

anakacha Formation-Continued fusulinids ........... 24, 69, 85, 104, 182, 259 gastropods ........................................ 85 grain-size distribution ........................... 216 history $\ldots 1 . . .23$ illite ............................... 24, 315, 328, 364 insoluble residues .................................... 265 isotopic data ..................................... 36 jasper .............................. 258, 351, 367, 374 kaolinite ............................. 314, 315, 329, 364

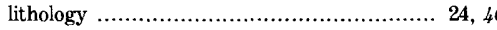
marine fauna .............................. 85, 260 paleogeography ....................................... 65 pelmatozoans ............................... 102, 259 petrography ...................................... 348

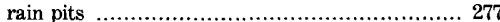
ripple marks .......................... 220, 260, 275 sandstone ............................................. 21 silica rock .......................................... 367

Manakacha Point

Manzano fossils .............................................. 53

Marble Canyon .............................................. 391 clay mineralogy ..................................... 315 erosion surface ................................. 165, 171 petrography ...................................... 355 ripple marks .............................. 236, 275 stratigraphic sections

Marcon, Jules, quoted ..........................................

Marine fauna ........................................... 77

Esplanade Sandstone ............................... 259

Pakoon Limestone

Manakacha Formation .......................... 85, 260

Pakoon Limestone ......................... 87, 183

Watahomigi Formation ............. 77, 189, 258, 260

Wescogame Formation ................... 85, 259, 261

Mazatzaland ................................................. 56 media, Endothyra ........................................ 85 meekana, Orbicubidea ................... 116, 122; pl. F1 Meekospira sp. .......................................... 121 Megaripples ......................... 247, 249, 258, 260 mercurii, Deltodus ....................................... 122

Mexican geosyncline ....................................... 56 Michelinia sp. ................................. 70, 82, 143 Micrite, defined ............................................. 11 Watahomigi Formation ....................... 258, 347 Microdoma sp. ............................... 121; pl. F4 Mierofauna, Watahomigi Formation ..................... 83 Mile 16. See House Rock Canyon.

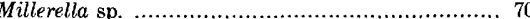
miseri, Hustedia ........................................... 70 Mississippi River ................................. 249, 256 missouriensis, Orbiculoidea ............................ 116 Moenkopi Formation, ripple marks ..................... 275 Mogollon Rim ......................................... 58 fossils .................................................. 69

Mollusks, Watahomigi Formation ....... 84, 121, 182, 347 Wescogame Formation ....................... 85, 259 Monosaccates .......................................... 143 Montmorillonite ...................... 289, 303, 310, 315 Monument Valley $\ldots \ldots \ldots \ldots \ldots \ldots \ldots \ldots . . . . . .96$

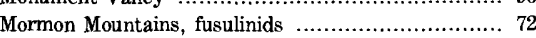
Morrow Formation, Oklahoma ........................ 144 Mountain Spring Pass, Nevada .................. 108, 160 Muav Canyon ......................................... 422

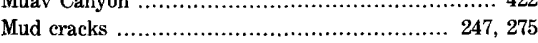
Muddy Mountains ......................................... 31

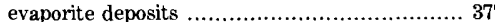
multattenuata, Syringopora ........................ 85, 111 Muscovite ..................................... 345, 355 Myalina sp. ........................... 81, 122, 479, 482 sp. A ................................... 120; pl. F4 sp. B ..................................... 122; pl. F4

\section{N}

Naco Group

Naco Formation $\ldots$

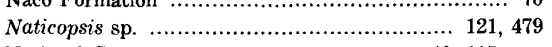
National Canyon .............................. 40, 115, 431 apharitic limestone ................................. 341
National Canyon-Continued

Page

brachiopods . . 117, 258, 363 carbonate mudstone ............................... 344 channels ............................................ 195 conglomerate .. 42, 163, 189, 191, 193, 195, 201, 202

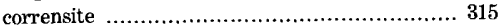
erosion surface .................... 42, 160, 163, 171 faunas ................................................. 123 gastropods .......................................... 121 Hermit Shale ......................................... 431 jasper ........................................ 200, 374 mineralogy ............................................... 345 Pakoon Limestone ................................. 49 pelecypods ................................... 120, 121 petrography ............................... 347, 351 ripple structures ............................. 213, 275 stratigraphic sections ............................. 491 trilobites ......................................... 121 Nautiloids, Watahomigi Formation .................. 82

Navajo Falls .......................................... 427 Neilsonia sp. .................................... pl. G2 Neoarchaediscus incertus .......................... 83, 107 parvus .......................................... 83, 107

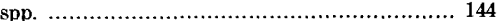
Neospirifer .......................................... 478 Neuropteris ......................................... 97 nevadensis, Rhipidomella .............................. 70 Newberry, J. S., quoted ................................ 3 newberryi, Anthracospirifer ......... 80, 117, 122; pl. F3 New Red Sandstone, Scotland ......................... 94 nitidus, Punctatisporites .................................. 143 nodosus, Linoproductus ...................... 69, 70, 80, $107,117,122 ;$ pl. F1 North Bird Spring Range, Nevada .................... 160 Nuculopsis sp. ............................... 120; pl. F4

Oak Creek, correlation with Supai Group ............... 69 occidentalis, Anthracospirifer ......................... 190 occiduus, Anthracospirifer ........................ 70, 78, 80, $107,117,121,122$, pl. F4 Oncolites ........................................... 335, 338 O'Neill Butte ................................................ 91 Ooids ............................................. 335, 338 opimus, Anthracospirifer .......................... 80, 117 Oquirrh Basin ............................................. 72

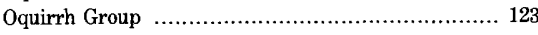
Oquirrh Mountains ........................................ 123 Orbiculoidea meekana ................... 116, 122; pl. F1 missouriensis .................................... 116 sp. ...................... 70, 80, 115, 452, 479, 480 Organ Rock Tongue ........................................ 96 Oriocrassatella sp. .......................................... 120

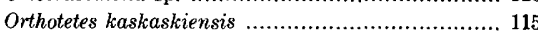
sp. ............................................... 80, 116 sp. A …................................... 116; pl. F1 Ortonella sp. ............................................... 144 Osagia sp. .................................... 181, 346 Ostracodes, buried-valley deposits .................... 144

Watahomigi Formation ...................... 346 Ouachita Mountains ......................................... 123 Ouachita trough, Oklahoma ............................... 125 ovata, Composita ......... 117, 121, 122, 144; pls. F2, G1 Ovatia sp. ........................................ pl. G2 Overbrook Sandstone Member, Springer Formation.. 144 Ozawainella sp. .............................. $72,85,111$

Pakoon Limestone $\ldots \ldots \ldots \ldots \ldots \ldots \ldots .5,26,31,42,44,49$

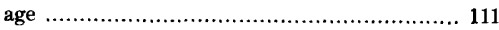

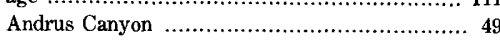
bioclastic debris ............................... 26, 104 bivalves ............................................. 26 Blue Mountain Canyon ............................ 49 brachiopods $\ldots \ldots \ldots \ldots \ldots \ldots \ldots \ldots \ldots \ldots \ldots \ldots \ldots \ldots$.
bryozoans $\ldots \ldots \ldots \ldots \ldots \ldots \ldots \ldots \ldots$ 


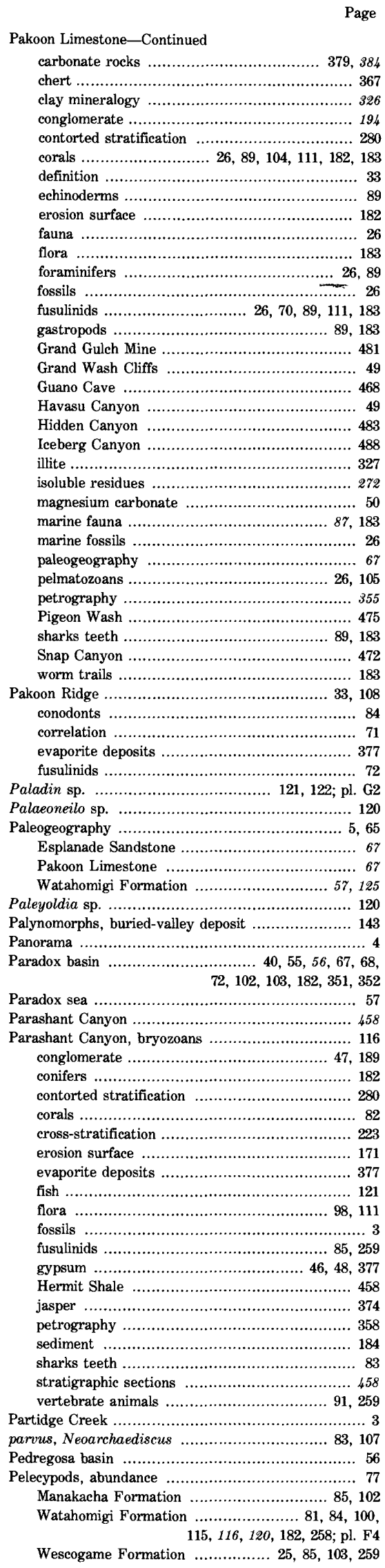

Pelmatozoans $\quad$ Page buried-valley deposits ................................... 144 Esplanade Sandstone …................................... 259, 357 Manakacha Formation ......................... 102, 259 Pakoon Limestone ............................. 26, 105 Watahomigi Formation . 23, 100, 259, 344, 346, 347 Wescogame Formation ............... 25, 103, 259, 355

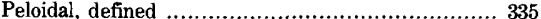
permiensis, Rivularites ...................................... 100 Permophorus sp. ............................. 82, 120; pl. F4 Petrography ………………….......................... 335 Esplanade Sandstone …............................... 355 Manakacha Formation ................................ 348 Pakoon Limestone ……………………........... 355

Wescogame Formation …............................ 352

Phestia sp. ..................................... 120; pl. F4 Phricodothyris ................................................ 478

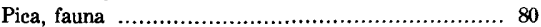
pelecypods ……........................................ 120 Watahomigi Formation ………….................. 372

Picacho Butte, grain size .................................... 229 picuris, Pulchratia ........................ 117, 122; pl. F1

Pigeon Wash …........................... 33, 40, 48, 475 accretal limestone ....................................... 338

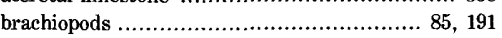
carbonate rocks ...................................... 384 conglomerate …............................... 191, 201 conglomerate $\ldots \ldots \ldots \ldots \ldots \ldots \ldots \ldots \ldots \ldots \ldots \ldots \ldots . .191,201$ grain size ................................................ 222 jasper ……........................................... 372 marine faunas ……………................. 88, 259 Pakoon Limestone ……............................... 475 petrography ..................................... 351, 355

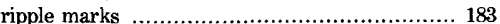
sediment ................................................... 184 shrinkage cracks ................................. 183, 276 stratigraphic sections …............................. 475 worm trails ............................................ 183

Pioche basin ............................................ 55, 72 Pisolites ……........................................ 335, 338 Piute positive element $\ldots$ planiconvexa, Crurithyris ................. 117, 122; pl. F2 Platte River ……………................... 248, 250 plicatulus, Triticites ………………………..... 72 Point Sublime …………………………........ 4 Polypora sp. ............................................... 116 Potassium .............................. 298, 301, 308, 309, 312 Potassium feldspar ............................. 291, 313, 328

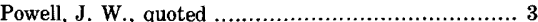
Profusulinella

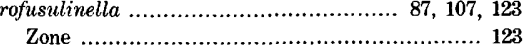
Promytilus sp. $\ldots \ldots \ldots \ldots \ldots \ldots \ldots \ldots \ldots .120,122$; pl. F4 Prospect Valley ............................................... 447

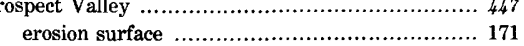
Hermit Shale ............................................... 447 insoluble residue ..................................... 272 kaolinite …………………………....... 26, 328

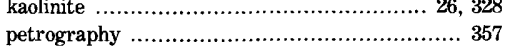
stratigraphic sections …………………..... 447

Pseudoconocardium sp. .................................. 120 Pseudoendothyra sp. .............................................. 91 Pseudoglomospira sp. ................................... 144 pseudolevalus, Punctatisporites ........................ 143 Pseudoschwagerina sp. .................... 70, 71, 89, 111
Pseudostaffella sp. ................. 69, 85, 107, 407, 413 Pulchratia picuris ............................ 117, 122; pl. F1 pumilus, Linoproductus ............... 80, 117, 122; pl. F1 Punctatisporites heterofiliferous ........................... 143

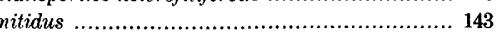

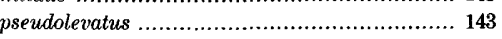
solidus ............................................ 143, 144

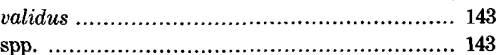
spp. ……........................................ 143 sp. ....................................... $70,190,478$

\section{Q}

quadrigatum, Glabrocingulum ........................ pl. G2 Quartermaster Canyon, buried valleys ............. 139, 145
Quartz ........................ 11, 182, 189, 291, 303, 308

Page Quartzite $\ldots a n$

Quartzite Canyon .............................................. 53 Quasiarchaediscus sp. ....................................... 144 Queantoweap Sandstone ................................. 31, 35

Queantoweap Valley ............................................ 35

Quemado-Cuchillo basin ......................................... 56

\section{$\mathrm{R}$}

Rain pits ..... 165, 171, 179, 203, 241, 247, 275, 277, 357 Esplanade Sandstone ……........................ 277 Manakacha Formation …….......................... 277 rara, Schulzospora .......................................... 143

Raticulariina campestris .................................. 105

Red beds ................................................. 3, 96

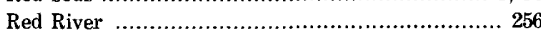

Red Wall Limestone .......................................... 3

Redwall Limestone $115,341,345,348,374,379$ Bass Trail ................................................. 421 Blue Mountain Canyon ............................... 447

Blue Spring …⿲丿................................. 399

Bunker Trail ............................................ 404

Eminence Fault ………….......................... 397

Grandview Trail ................................ 341, 407

Havasu Canyon ............................................ 431

Hermit Trail ................................................... 418

Hidden Canyon ........................................... 483

Hindu Canyon ........................................ 496

Iceberg Canyon ........................................ 492

Kaibab Trail, north …………………............... 414

Kaibab Trail, south .............................. 341, 411

National Canyon ..................................... 436

Pigeon Wash ................................................ 479

S B Canyon ................................................ 441

Separation Canyon ...................................... 496

Snap Canyon .......................................... 475

Thunder River Trail ...................................... 426

Toroweap Valley ......................................... 452

Tuckup Canyon ............................................ 444

Twentynine Mile Canyon .............................. 395 Twin Springs Canyon .................................... 468 valleys …….................................... 145, 157

Whitmore Wash .......................................457

Redwall sea ................................................. 23

Reptiles, Wescogame Formation ............................ 25

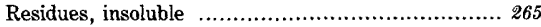

Reticulariina gonionota ..................................... 117

Recticulatisporites sp. ..................................... 143

Retispira sp. ................................................... 12

Rhipidomella nevadensis .................................... 70

Rhone River ................................................... 256 Ripple lamination …......................... 213, 256, 275 Ripple marks …….......... 179, 211, 220, 257, 275, 357 Esplanade Sandstone ……................... 236, 241 Hermit Shale ……………………………. 275 Manakacha Formation ….................. 220, 260, 275 Watahomigi Formation …........ 211, 256, 260, 275 Wescogame Formation ……........... 224, 236, 275 Rivularites permiensis ...................................... 100

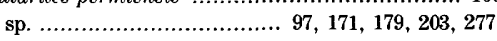
$357,412,429,439,449,480$

Roaring Springs Canyon .... robusta, Derbyia ………………….................... 117 Rocks, classification ............................................... 386 Rod Club Member, Springer Formation ................ 144 Rostroconchs, Watahomigi Formation ............. 116, 120 rugosa, Eosigmoilina ...................................... 144

$\mathrm{S}$

S B Canyon, bivalves ......................................... 259 channels ......................................193, 195, 213 conglomerate ……........ 27, 42, 163, 189, 193, 201 cross-stratification ........................... 216, 223, 234 erosion surface ........................... 160, 163, 171 
S B Canyon-Continued

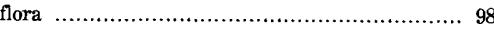
fusulinids ................................... 183, 259 Hermit Shale ......................................... 438 Redwall Limestone .................................. 441 ripple marks ............................... 237, 275 stratigraphic sections .............................. 438 vertebrate animals .............................. 91, 259 San Juan Basin ......... 5, 24, 25, 57, 215, 221, 256, 258 San Juan River Sandia sp. Sando, W. J., quoted ...................................... 143 Sandstone, Manakacha Formation ....................... 213 Watahomigi Formation ............................. 211 Wescogame Formation ................................ 221 Sandstone bodies, geometry …......................... 207 Sangre de Cristo Mountains, New Mexico ............. 115 Santa Maria Spring ......................................... 91 Schizodus amplus ........................... 120, 125; pl. F4 sp. .......................................... 81, 82, 144 sp. A ….................................. 120; pl. F4 sp. B ..................................... 120; pl. F4 Schizophoria altirostris ............. 80, 116, 122; pl. F1 sp. ..................................................... 70 Schubertella sp. ............................. 70, 89, 111 Schulzospora rara ........................................ 143 Schwagerina linearis ................................ 111 sp. ...................................... 70, 71, 89, 111 Scoyenia gracilis ..................................... 100, 180 sp. .................................................. 183 Sea urchins, Wescogame Formation ................. 103 Seed ferns ............................................... 202 Selenimyalina sp. ......................................... 120 Seligman ................................................ 492 Hermit Shale ...................................... 492 stratigraphic sections ............... 492

Separation Canyon ................................ 40, 492 accretal limestone .......................... 345, 346 cephalopods .......................................... 121 conglomerate ...................................... 193 conodonts ................................. 77, 83, 84 corrensite ..................................... 24, 315

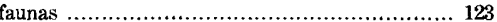

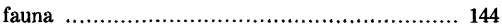

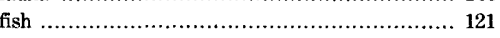
gastropods ........................................... 121

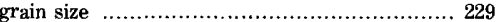
jasper ............................................... 200 pelecypods ................................. 120, 121 petrography ........................................ 355 Redwall Limestone ................................. 496 ripple marks ...................................... 275 stratigraphic sections .............................. 492 sharks teeth .......................................... 83 Separation valley ..................................... 139 Septimyalina sp. ....................................... 82 sp. A …................................ 120; pl. F4 sp. B ....................................... 120; pl. F4

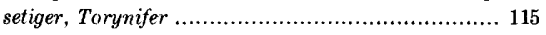
Sevier uplift ............................................. 55 Shale, defined ............................................. 10

Shansiella sp. ....... 121 Shark fossils .......................................... 181 Watahomigi Formation ............................ 83

Sharks teeth, Pakoon Limestone .................. 89, 183 Wescogame Formation …................... 85, 259 Shinumo Trail ........................................ 422 erosion surface .................................. 171

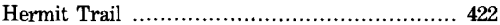
stratigraphic sections …......................... 422 Shivwitz Plateau ................................ 44, 458 gypsum ........................................... 46 Shrinkage cracks ...... 179, 182, 203, 241, 275, 276, 357

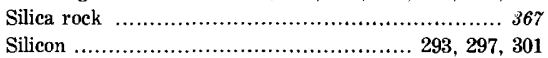
16.5 Mile Canyon, bioclasts ........................... 259 Skeletal remains ........................ 96, 346, 347, 351 Skewness, sand ..................................... 209 Smectite .................... 289, 297, $301,308,309,329$ Snap Canyon ............................... 33, 46, 48, 471
Snap Canyon-Continued accretal limestone .................................... 346

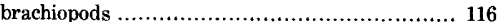
conglomerate ....................... 44, 47, 190, 201 cross-stratification ................................... 258 dolostone ............................................ 348 erosion surface .............................. 160, 171 fauna ........................................ 111, 123 Hermit Shale .................................. 471 insoluble residue ................................... 272 marine faunas ................................... 88, 259 Pakoon Limestone ................................... 472 pelecypods .......................................... 120

Redwall Limestone ................................ 475 shrinkage cracks .......................... 182, 276

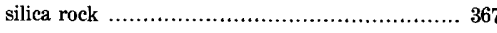
stratigraphic sections ........................... 471 warping ........................................... 145 Snap Creek, erosion channels ........................... 42

Snap Point, shrinkage cracks ............................. 276 Sodium ............................................. 309, 312 solidus, Punctatisporites ........................... 143, 144 solisortus, Auroraspora ........................... 143, 144 Sonora basin .......................................... 359 Sonoran geosyncline ...... 25, 56, 66, 67, 68, 69, 103, 22 Sonoran seas ......................................... 58, 67

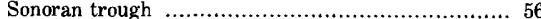
Spandelinoides sp. ..................................... 89, 111 Spencer Canyon .......................................... 492 Sphenopsids, buried-valley deposit ..................... 141 Sphenophyllum sp. ...................................... 202 Sphenotus .............................................. 82 Spirifer ...................... 435, 444, 453, 479, 480, 496 Spiriferina ........................................... 444 Springer Formation, Oklahoma ......................... 144 Staffella ................................................... 85 Stenichnus yakiensis ....................................... 92 stereon, Hadrohercos ............................. 143, 144 Straparollus (Euomphalus) sp. ......................... 121 Stratification, contorted ................................. 277 fluvial ................................................ 247

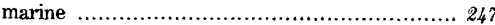

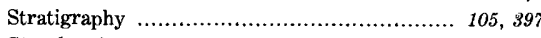
Strophomina .................................... 479, 480 Strophostylus sp. ......................................... 121 sturdevanti, Anomalopus ................................. 92 subtilita, Composita ............................... 117; pl. F3 supaiensis, Tridentichnus ............................ 92

Surprise Canyon, buried-valley deposits ............... 139 fauna ............................................... 144

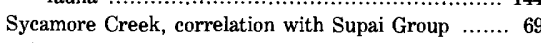
Sylvite ................................................... 378 Syringopora multattenuata ........................ 85, 111

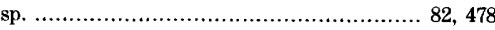

Tanner Trail. See Bunker Trail.

tanoensis, Anthracospirifer ... 80, 117, 121, 122; pl. F3 Taosia sp. .................................................. 121 teres, Endothyra ….................................... 85 terminalis, Wilkingia ........................... 120; pl. F4 Tetrapod tracks ............................................. 92 Thunder River Trail ...................................... 423 bioclasts ............................................ 259 bryozoans ........................................... 259 channels ........................................... 193 conglomerate ...................... 41, 191, 193, 202 contorted stratification ............................ 280 cross-stratification ............................... 216, 234 erosion surface ........................... 160, 171 flora .................................................... 98

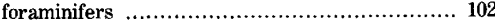
Hermit Trail ....................................... 423 rain pits .......................................... 277 Redwall Limestone ................................ 426 ripple marks .................................. 236, 275 stratigraphic sections ..............................428

Titanium ........................................ 297
Toeniopteris ................................................. 97

Tonto Creek, fossils …..................................... 69

Topocoba Trail ............................................ 426 channel-fill ........................................ 164 channels .............................................. 195 conglomerate ............................... 195, 200 cross-stratification ............................. 223, 235 erosion surface ...................................... 171

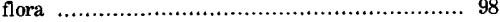

fossils .............................................. 203

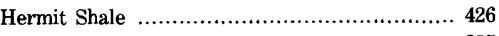
ripple marks ...................................... 275 hrinkage cracks …............................. 276 stratigraphic sections ............................... 426

Toroweap Formation ...................................... 3

Toroweap Point, corrensite .............................. 24 cross-stratification .................................... 256 evaporite deposits .............................. 377

Toroweap Valley .................................. 449, 452 brachiopods ......................... 80, 116, 191, 258 bryozoans ............................................ 82 conglomerate .......... 41, 42, 46, 163, 191, 193, 201 contorted structures ............................. 237 corals .................................................... 82 corrensite .............................................. 315 cross-stratification ............................. 235, 258 erosion surface ................... 157, 163, 169, 171 evaporite deposits ................................... 377 fauna .................................. $77,121,122$ fish .............................................. 121 fossils ......................................... 3, 115

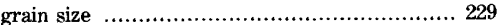
gypsum .................................. 46, 48, 377 Hermit Shale ................................... 449 illite .................................................. 327 jasper ............................................. 374 petrography ................................ 348, 357 Redwall Limestone .............................. 452 shark spine ................... 83 stratigraphic sections ........................ 449, 452 Torynifer setiger ............................... 115; pl. G1 p. ..................................................... 144 Trace Creek Shale Member, Bloyd Shale ............. 123 Tracks, amphibian ................................ 203, 247 Transgressions, sea .................................... 179 transversus, Punctospirifer ....... 80, 105, $117,121,122 ;$ pl. F3

Trilobites, abundance ....................................... 77 buried-valley deposits ............................. 144

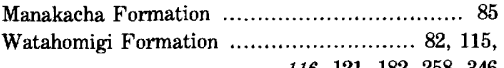
$116,121,182,258,346$

Tridentichnus supaiensis ................................ 92 triradiatus, Knoxisporites ......................... 143, 144

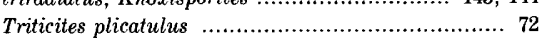

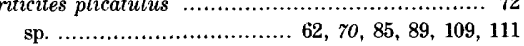
Tuckup Canyon .......................................... 442 brachiopods .................................. 258, 363 calcitic dolomite ................................... 345 channels ..................................... 193, 195 channel fill ............................................ 164

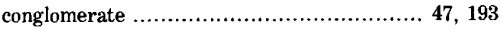
corrensite ........................................ 315 cross-stratification ........................... 223, 235

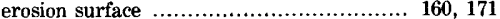
Hermit Shale ....................................... 442 petrography .................................. 348, 357 Redwall Limestone ................................ 444 stratigraphic sections .............................. 442 worm trails ....................................... 183 turbatans, Ammobatrachus ............................ 92

Twentynine Mile Canyon ................................ 391

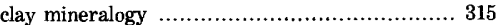
cross-stratification ......................... 224, 234, 258

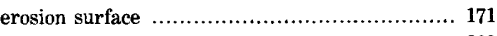

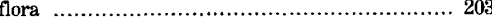
Hermit Shale .................................... 391 petrography ................................. 355,357 


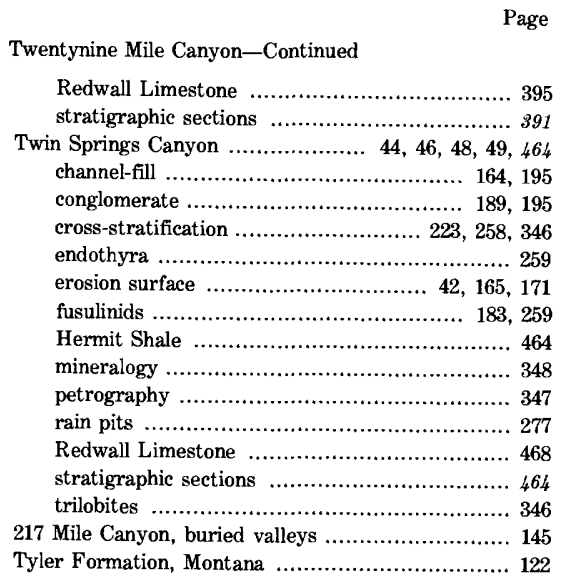

U

Uncompahgre uplift .................................... 56 Ural Mountains ........................................... 125

Utah uplift ............................................... 55

\section{V}

validus, Punctatisporites ................................. 143 Valley-fill deposits ......................................... 139 varicostatum, Diabolocera Zone .......................... 123 Vertebrate animals, Esplanade Sandstone ............... 98 Watahomigi Formation .............................. 346 Wescogame Formation .................... 25, 91, 259 Virgilian Provincial Series .................................. 194 Virgin Mountains, fusulinids ........................ 72, 108 Volvotextularia $\mathrm{sp.}$

144

\section{w}

Walchia sp. $97,163,171,179,202$ $203,241,357,412,421,459$

Wapanucka Limestone, Oklahoma .................... 123 Warping, pre-Supai ...................................... 145 Watahomigi embayment ................................... 64

Watahomigi Formation ............................... 35, 39 accretal limestone .................................. 345 age ........................................ 105, 115 bioclastic debris ........................ 23, $100,259,346$ biostratigraphy ..................................... 115 bivalves .......................................... 23, 259 brachiopods ....... $23,65,69,77,84,100,105,115$, $116,122,182,189,258,346,363$; pls. F1, F2, F3 bryozoans .. 23, $82,100,115,116,122,258,346,347$ carbonate rocks .................................. 879 cephalopods ....................................... 116, 121 chert .............................. 190, 213, 344, 367 chlorite ...................................... 23, 315 clay mineralogy ............................. 314,328 climate ................................................ 125 conglomerates ...................................... 189 conulariids ................................. 77, 82, 116 corals ..................... 70, 82, 115, 116, 125, 258 correlations ......................................... 122
Page

Watahomigi Formation-Continued

corrensite ..................... 23, 311, 315, 328, 363 crinoids ................................... 82, 100, 122 cross-bedding .......................................... 23 cross-stratification ....................... 211, 249, 260 dolostone .............................................. 348 echinoderms .............................. 82, 116, 121 environment of deposition ......................... 260 environment of deposition $\ldots \ldots \ldots \ldots \ldots \ldots \ldots \ldots \ldots .260$
erosion surfaces ............................... 157, 182 facies ............................................... 840 fauna .................................... $77,115,258$ fenestrae ........................................... 345 fish fossils ................................ 116, 121 flora .......

foraminifers $\ldots \ldots \ldots \ldots .23,70,83,84,100,144,182$, $259,335,344,346,347$ fossils ................. $3,23,46,115,182,258,346$ fusulinids $\ldots \ldots \ldots \ldots \ldots . . .23,69,105,259$ gastropods ... 80, 84, 115, 116, 120, 258, 346; pl. F4 grain sizes ......................... 211, $344,345,347$ grain types ............................. 344, 345, 347

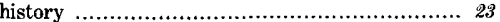
insoluble residues ......................................265 isotopic data ..................................... 863 jasper ................ 40, 46, 213, 344, 346, 367, 374 kaolinite ................. 23, 315, 363 lithology .................................. 23, 46, 157 marine fauna ........................ $77,189,258,260$ mineralogy ......................................... 344 mixed-grain limestone .............................. 347 ostracodes ........................................ 346 paleography ................................. 57, 125 pelecypods ..................... $81,84,100,115$, $116,120,182,258 ;$ pl. F4 petrography ........................................ 344 ripples ........................... 211, 256, 260, 275 rostroconchs ................................. 116, 120 sandstone ............................................... 211 silica rock .......................................... 367 trilobites ........... 82, 115, 116, 121, 182, 258, 346

Watahomigi Point ........................................... 35

Weaver, C. E., quoted .................................... 374

Wedekindellina sp. ................................... 70, 108

Wentworth scale ..................................... 10, 207

Wescogame Formation ........................... 24, 35, 40 age .................................................. 109 amphibians ................................................. 25 bioclastic debris ................................. 103, 355 bivalves ..................................... 25, 103, 259

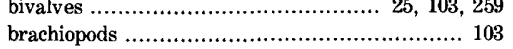
bryozoans ...................................... 108, 259

carbonate rocks $\ldots \ldots \ldots \ldots \ldots \ldots \ldots \ldots \ldots \ldots .379,384$ chert ................................................. 193 chlorite ........................................... 25, 325 clay mineralogy ............................... 324,329 cliff unit ................................................ 41

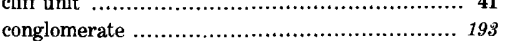
contorted stratification .............................. 280 coral .................................... 85, 111, 259

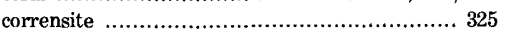

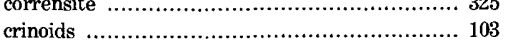
cross-stratification ................... 25, 222, 249, 261 cyclothem ............................................. 186 deposition …........................................... 24 deposition ........................................ 24 erosion surface .............................. 160, 182
Page

Wescogame Formation-Continued

$25,85,182,259$

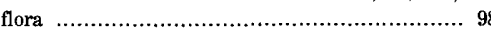
foraminifers ............................. 108, 182, 259 fossils ......................................... 25, 259 fusulinids .................. 25, 67, 85, 111, 182,259 gastropods ........................................ 25, 85 grain-size distribution ....................... 222, 261

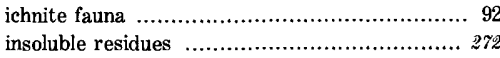
isotopic data ......................................... 368

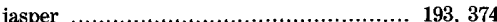
kaolinite ............................. 25, 314, 325, 364 lithology ........................................... 47 marine fauna ............................ 85, 259, 261 mollusks petrography ........................................ 852 reptiles .................................................. 25 ripple marks ............................ 224, 236, 275 sandstone .............................................221

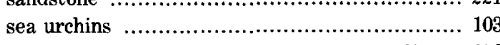
vertebrates ................................. 25, 91, 259 Wescogame Point ................................. 35

West Canyon Limestone, Utah ......................... 123

Whitmore Wash ................................ 35, 49, 203 accretal limestone ................................... 345 aphanitic limestone ................................. 341 conglomerate ........................44, 163, 189, 201 contorted bedding

contorted stratification .............................. 280 cross-stratification ............................. 256, 258 endothyra ........................................... 259 erosion surface ............................ 157, 163, 171 evaporite deposits .................................... 377 fauna ............................................... 77 foraminifers ..................................... 183, 344 fossils ............................................... 203 fusulinids .................................... 183, 259 grain size ....................................... 229 Hermit Shale ................................... 457 mineralogy .......................................... 348 pelmatozoans ....................................... 344 petrography ............................ 347, 348, 357 Redwall Limestone ..................................4457 stratigraphic sections ...................... 453, 457 See also Queantoweap Valley.

Wilkingia terminalis .............................. 120; pl. F4

Winslowoceras henbesti Ammonoid Zone .............. 123

Worm trails ............................... 179, 203, 241, 277

Esplanade Sandstone ............................. 183

Pakoon Limestone .................................. 183

Worthenia sp. ........................................... 121

\section{$\mathbf{Y}$}

Yaki Trail, flora ............................................. 97 yakiensis, Stenichnus ...................................... 92

Yeso evaporite basin ..................................... 377

Yoldia Sea, Finland ...................................... 256

Z

Zellerina sp. ............................................ 144

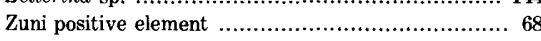

Zuni uplift .................................................. 58 